Ewely Branco Sandrin

\title{
Arte/Arquitetura/Design: \\ tecnologias atuais nas estações do metrô de São Paulo
}

São Paulo 


\section{Ewely Branco Sandrin}

\section{Arte/Arquitetura/Design: tecnologias atuais nas estações do metrô de São Paulo}

Tese apresentada à Faculdade de Arquitetura e Urbanismo da Universidade de São Paulo para obtenção do título de Doutor em Arquitetura e Urbanismo.

Área de Concentração: Design e Arquitetura

Orientador: Prof. Dr. Sérgio Régis Moreira Martins

EXEMPLAR REVISADO E ALTERADO EM RELAÇÃO À VERSÃO ORIGINAL, SOB RESPONSABILIDADE DO AUTOR E ANUÊNCIA DO ORIENTADOR.

O original se encontra disponível na sede do programa.

São Paulo, 14 de janeiro 2013.

\section{São Paulo}


AUTORIZO A REPRODUÇÃO E DIVULGAÇÃO TOTAL OU PARCIAL DESTE TRABALHO, POR QUALQUER MEIO CONVENCIONAL OU ELETRÔNICO, PARA FINS DE ESTUDO E PESQUISA, DESDE QUE CITADA A FONTE.

\section{E-MAIL AUTORA: ewelysf@hotmail.com}

Sandrin, Ewely Branco

S219a Arte/Arquitetura/Design: tecnologias atuais nas estações do metrô de São Paulo / Ewely Branco Sandrin. --São Paulo, 2012.

496 p. : il.

Tese (Doutorado - Área de Concentração: Design e Arquitetura) FAUUSP.

Orientador: Sérgio Régis Moreira Martins

1.Arte pública - São Paulo (SP) 2.Estações metroviárias - São Paulo (SP) 3.Arquitetura 4.Design 5.Intervenção ambiental

6.Tecnologias atuais 7.Avanço tecnológico I.Título

CDU 7.067.3(816.11) 
FOLHA DE APROVAÇÃO

Nome: SANDRIN, Ewely Branco

Título: Arte/Arquitetura/Design: tecnologias atuais nas estações do metrô de São Paulo

Tese apresentada à Faculdade de Arquitetura e Urbanismo da Universidade de São Paulo para obtenção do título de Doutor em Arquitetura e Urbanismo.

Aprovado em:

Banca Examinadora

Prof. Dr. Instituição

Julgamento Assinatura

Prof. Dr. Instituição

Julgamento Assinatura

Prof. Dr. Instituição

Julgamento Assinatura

Prof. Dr. Instituição

Julgamento Assinatura

Prof. Dr. Instituição

Julgamento Assinatura 
Dedico esta tese aos meus pais e ao Claudio. 


\section{AGRADECIMENTOS}

Ao Criador de todas as coisas.

Aos meus pais Marina e Reinaldo pelo apoio e compreensão de minha ausência.

Ao Prof. Dr. Claudio Tozzi pelo incentivo, apoio e conhecimento compartilhado.

Ao Prof. Dr. Sérgio Régis Moreira Martins pela orientação.

Aos amigos: Stella, Da. Rute, Peter, vô Agenor, Maria Cristina, Eliana, Ana Maria, Juliana, Nicinha, Dulce, Cássia, Ana, Bruno, Elaine.

Aos Profs. Drs.: Bruno Padovano, Carlos Zibel Costa, Cibele Haddad Taralli, Clice de Toledo Sanjar Mazzilli, Issao Minami, Maria Lucia Refinetti Rodrigues Martins, Marlene Yurgel (in memorian), Pelópidas Cypriano, Victor Knoll, Vladimir Bartalini e Waldenyr Caldas pela atenção, apoio e contribuições.

À Dra. Larissa Garcia Gomes. 
Ao Prof. Miguel Glikin.

Ao meu irmão Carlos Henrique, à minha cunhada Leila e à tia Marta.

Aos artistas: Amélia Toledo, Carlos Fajardo, Claudio Tozzi, Daniela Kutschat, Mo Toledo, Regina Silveira e Waldemar Zaidler pelas valiosas contribuições.

Ao filósofo e pesquisador de culturas urbanas Armando Silva pelas valiosas contribuições.

Aos arquitetos Luis Carlos Esteves e Thiago Pontes e ao fotógrafo João Luiz Musa pela autorização do uso de imagens.

Ao Yo Kaminagai pela atenção e autorização do uso do conteúdo de material apresentado na palestra: RATP Cultural policy and recent works, realizada no evento: Metrô, Engenho e Arte do Programa de Inteligência Corporativa da UNIMETRO do Metropolitano de São Paulo.

Aos funcionários da Companhia do Metropolitano de São Paulo: Sandra M. P. Theodózio, Ligia Catarina Fischer, Alberto Branco, Cardoso e Guilherme.

Aos usuários/espectadores/atores, monitores e técnicos de manutenção da Exposição Arte Cibernética: Acervo Itaú Cultural e dos Festivais Internacionais de Linguagem Eletrônica-FILEPAls realizados em estações da Companhia do Metropolitano de São Paulo.

Às funcionárias da secretaria e da biblioteca da pós-graduação da FAUUSP: Isa, Cristina, Diná, Ivani, Regina, Maria José, Paula e Cleide.

Aos funcionários do Departamento de Projeto e da biblioteca da graduação da FAUUSP.

À Silvia, à Dulce e à Leila pela colaboração na transcrição das entrevistas.

Ao Peter Caplan pela tradução para o inglês.

À Elaine e à Silvia pela atenção, revisão e impressão desta tese.

À Fundação de Amparo à Pesquisa do Estado de São Paulo-FAPESP pelo financiamento. 
SANDRIN, Ewely Branco. Arte/Arquitetura/Design: tecnologias atuais nas estações do metrô de São Paulo. 2012. Tese (Doutorado) - Faculdade de Arquitetura e Urbanismo, Universidade de São Paulo, São Paulo, 2012.

\section{RESUMO}

Esta tese investiga a arte nas estações da Companhia do Metropolitano de São Paulo, verifica as possibilidades de uso de tecnologias atuais e as condicionantes para propostas de intervenção ambiental, permanentes e temporárias, no espaço público em questão. A partir de repertório conceitual, histórico e técnico; de pesquisas em campo e de entrevistas realizadas com filósofo especialista em culturas urbanas; usuários/espectadores/atores, monitores e técnicos de manutenção no decorrer da Exposição Arte Cibernética: Acervo Itaú Cultural (2010) e das $1^{\text {a }}$ e $2^{\text {a }}$ edições do Festival Internacional de Linguagem Eletrônica-FILEPAl (2010 e 2011) e artistas, teve como meta comprovar a hipótese da possibilidade de aplicação e aceitação de tecnologias atuais (Diodo Emissor de Luz-LED, célula fotovoltaica, mídias eletrônica e digital, linguagem da projeção) em intervenções ambientais visando contribuir com a melhoria qualitativa dos espaços das estações futuras e em funcionamento. Para o entendimento da relevância da arte inserida no contexto da sociedade contemporânea e das formas de manifestação artística proporcionadas pelo uso de tecnologias atuais este estudo apresenta conceitos atuais de cidade, espaço público, arte pública, arte pública interativa, público e site specific. Aborda ações financiadas/cofinanciadas pelo poder público para intervenções artísticas na paisagem urbana paulistana e apresenta considerações sobre a Lei de Incentivo da Prefeitura de São Paulo. Analisa características das obras no ambiente das estações, seus significados e condicionantes. Investiga a percepção/recepção das obras tecnológicas e o comportamento social dos usuários/espectadores/atores no decorrer dos eventos mencionados. Verifica como tem sido a atuação do artista junto ao arquiteto no processo de inserção das obras de arte buscando relações com os conceitos de projeto interdisciplinar e sitespecific, e o que pensam esses profissionais a respeito desses espaços, dos significados da arte, da aplicação de tecnologias atuais, da influência de regras 
normativas na forma de criar e de atuar e possíveis medidas para que a arte se faça presente na totalidade da rede. Apresenta avanços tecnológicos que têm possibilitado novas linguagens para a criação, desenvolvimento e construção de objetos/obras para a cidade contemporânea; exemplos práticos de intervenções ambientais, com vistas à arte contemporânea, em estações de metrô do âmbito internacional; formas de atuar de algumas companhias e política cultural da Régie autonome des transports parisiens (RATP). Constata-se que, tecnicamente, é possível aplicar tecnologias atuais em intervenções ambientais temporárias e permanentes. Entretanto, condicionantes internas e externas à Companhia têm dificultado não somente a utilização dessas tecnologias, mas a presença e a permanência da arte pública no metrô e na cidade. Faz-se necessário: criar políticas públicas no campo da cultura; divulgar os benefícios da lei de incentivo para as empresas; divulgar mecanismos para os artistas e a população; rever a formação acadêmica do artista, do arquiteto e do designer, de forma que seja multidisciplinar e possibilite a prática do projeto interdisciplinar. A presença de profissional no campo do gerenciamento que tenha uma compreensão transversal das diversas disciplinas envolvidas no projeto e que delegue o posicionamento de seus autores, ainda na fase de concepção, é fundamental para que o projeto interdisciplinar aconteça. As falas dos entrevistados, o estudo técnico, a aplicação dessas tecnologias em estações do âmbito internacional e nas exposições mencionadas, a prorrogação de prazo da Exposição Arte Cibernética e a permanência das estações como espaços expositivos dos Festivais Internacionais de Linguagem Eletrônica demonstraram a aceitação das obras tecnológicas.

Palavras-chave: arte pública, estações metroviárias, arquitetura, design, intervenção ambiental, tecnologias atuais, avanço tecnológico. 
SANDRIN, Ewely Branco. Art/Architecture/Design: current technologies in the Metro of São Paulo. 2012. Thesis (Doctorate) - Faculty of Architecture and Urbanism, University of São Paulo, São Paulo, 2012.

\section{ABSTRACT}

This thesis investigates the art in the stations of the Metro Company of São Paulo and assesses the possibilities of using current technologies and their constraints, in proposals for permanent and temporary environmental intervention in the public space in question. Beginning with a conceptual, historical and technical repertoire, surveys in the field and interviews conducted with a philosopher with expertise in urban cultures, and with users / viewers / participants, monitors and maintenance technicians during the Itaú Cultural Cybernetic Art Exhibition: Collection (2010) , and the 1st and 2nd of editions of the International Festival of Electronic LanguageFILEPAI (2010 and 2011); and artists, the work was aimed at substantiating the hypothesis of the applicability and acceptance of current technologies (Light Emitting Diode-LED, photovoltaic cell, electronic and digital media, language projection) in environmental interventions, with a view to contributing to the qualitative improvement of the space in currently-operating and future stations. To understand the relevance of art inserted into the context of contemporary society and the forms of artistic expression afforded by the use of current technologies, this study presents current concepts of city, public space, public art, both interactive and site specific. It discusses actions funded/co-funded by the government for artistic interventions in the urban landscape of São Paulo and presents considerations on the Incentive Law of the municipality of São Paulo. It analyzes characteristics of works in the environment of the stations, their meanings and constraints. It investigates the perception /reception of technological projects and the social behavior of the users/viewers/participants at the events mentioned. It is demonstrated how artists have been acting with architects in the process of insertion of the artwork, seeking relationships with interdisciplinary and site-specific design concepts, and what these professionals think about these spaces, the significance of the art, of the application of current technologies, the influence of normative rules in the form of creating and 
implementing possible measures to bring about the presence of art throughout the network. Technological advances are presented that have made possible new languages for the creation, development and construction of objects/works for the contemporary city; practical examples of environmental, with a view toward contemporary art in subway stations internationally; methods of some of the companies and of the cultural politics of the Régie des transports autonome parisiens (RATP). It is ascertained that, technically, it is possible to apply current technologies in temporary and permanent environmental interventions. However, internal and external constraints on the Company have hampered the use not only of these technologies, but also the presence and continuance of public art in the city and on the subway. This makes necessary: the creation of public politics in the field of culture, promotion of the benefits of the incentive law for businesses; disseminating mechanisms for the artists and the public, and review of the academic training of the artist, architect and designer, so that it is multidisciplinary and enable the practice of interdisciplinary projects. The presence of a professional in the field of management that has a broad understanding of the various disciplines involved in the project while still in its design stage and commissions the positions of its authors is crucial to making the interdisciplinary project happen. The interviewees' statements, the technical study, the application of these technologies in the stations and in the international exhibitions mentioned, the extension of the duration of the Cybernetic Art Exhibition and maintenance of stations as exhibition spaces of the International Festivals of Electronic Language have shown acceptance of the technological works.

Keywords: public art, subway stations, architecture, design, environmental intervention, current technologies, technological advancement. 


\section{LISTA DE FIGURAS}

Figura 1: Estação Università, 2003, em aço corten...................................... 31

Figura 2: Estação Traiano, 2003, em alumínio polido................................. 31

Figura 3: Untitled Works in Concrete, 1980-1984. Donald Judd, Marfa, Texas... 32

Figura 4: Primeira Etapa do Projeto Variathions on a theme, 2006.................. 32

Figura 5: Variathions a theme, 2006. Estação Vergueiro................................ 33

Figura 6: Variathions a theme, 2006. Torre entre Vergueiro e São Joaquim....... 33

Figura 7: Variathions a theme, 2006. Estação São Joaquim............................ 33

Figura 8: Variathions a theme, 2006. Torre entre São Joaquim e Liberdade....... 33

Figura 9: Variathions a theme, 2006. Estação Liberdade.............................. 33

Figura 10: Variathions a theme, 2006. Estação São Bento............................... 33

Figura 11: Estação Vila Prudente, 2010. Cobertura em estrutura metálica e vidros autolimpantes que facilitam a manutenção.

Figura 12: Estação Vila Prudente, 2010. Estrutura metálica e concreto aparente no interior.

Figura 13: Estação Vila Prudente, 2010. Predominância do concreto aparente em seu interior e cobertura envidraçada que leva luz natural até a plataforma, 21 metros abaixo do nível da rua.

Figuras 14 e 15: Estação Butantã, 2010. Aço inox, vidro e cerâmica na fachada. Aço inox, cerâmica e concreto no interior.

Figuras 16 e 17: Entrada Estação Faria Lima, 2010. Aço inox, vidro laminado e cerâmica na fachada. Aço inox, cerâmica, concreto e painéis eletrônicos no interior.

Figuras 18, 19, 20, 21 e 22: Estação Sacomã, 2010. Aplicação de cerâmica, vidro, pintura colorida e LED.

Figuras 23, 24 e 25: Estação Alto do Ipiranga, 2007. Aplicação do LED na iluminação

Figura 26: Estação Alto do Ipiranga, 2007. Aplicação do vidro.

Figuras 27 e 28: Projeções de propaganda de filmes na parede em frente à plataforma da Estação Consolação, 2010.

Figuras 29 e 30: Painel luminoso próximo às catracas da Estação Sé, 2010......

Figuras 31, 32, 33, 34, 35 e 36: Intervenção interativa de Justin Broadbent para festa da empresa de vodka Absolut na Estação Bay do metrô de Toronto. 
Figuras 37, 38, 39 e 40: Superfícies Habitáveis de Flavio Motta no Elevado Costa e Silva, 1974.

Figura 41: Intervenção de Ricardo Ohtake, Dalto Luca e José Roberto Graciano na Rua 25 de Março..............................................................

Figura 42: Área das Intervenções Arte/Cidade I. A cidade sem janelas............. 75

Figura 43: Intervenção de Carmela Gross...................................................... 75

Figura 44: Intervenção de José Resende....................................................... 75

Figura 45: Intervenção de Anne Marie Sumner............................................... 75

Figura 46: Área das Intervenções Arte/Cidade II. A cidade e seus fluxos........... 77

Figura 47: Detector de ausências. Intervenção de Rubens Mano...................... 78

Figura 48: Vórtice. Intervenção de Regina Silveira............................................. 78

Figura 49: Área das Intervenções Arte/Cidade III. A cidade e suas histórias...... 79

Figura 50: Intervenção de Ricardo Ribenboim no Kinotrem............................... 80

Figura 51: Projeto para uma Pintura com temporal \# 6. Intervenção de Thiago Rocha Pitta, Esquina com a Av. São João e Duque de Caxias, República, São Paulo.

Figura 52: O Descanso da Sala. Intervenção de José Spaniol. Parque Burle Marx, Morumbi, São Paulo.

Figuras 53 e 54: Tamanduateí. Intervenção de Paulo Camillo Penna, Parque Dom Pedro, São Paulo.

Figura 55: Cartograffiti, Coordenado por Mauro Sergio Neri da Silva. A primeira intervenção foi inaugurada na Praça Eugene Boudin, entre a Ponte Eusébio Matoso, Av. Rebouças e a Passarela Sustentável, São Paulo.

Figuras 56 e 57: Nuvem. Intervenção de Eduardo Coimbra, Praça Charles Miller, Pacaembu, São Paulo.

Figura 58: Canteiro de Operações. Intervenção de José Resende, Rua Borges de Figueiredo, Moóca, São Paulo.

Figura 59: Clara-Clara. Intervenção de Laura Vinci, Rua Dr. Miguel Couto, Centro São Paulo.

Figura 60: Garatuja, Marcello Nitsche, 1978............................................... 92

Figura 61: Colcha de Retalhos, Claudio Tozzi, 1979...................................... 92

Figura 62: Sem título, Renina Katz, 1978................................................... 93

Figura 63: Sem título, Alfredo Ceschiatti, 1978............................................ 93

Figuras 64, 65, 66 e 67: Praça da Sé, 2011 .................................................. 95 
Figura 68: Cenas e Sonhos Latino Americanos I e II, Sérgio Ferro, 1990, inicialmente instalada na Estação Barra Funda, transferida para a Estação Vila Prudente em 2010

Figura 69: Garatuja, Marcello Nitsche, 1978. Estação Sé

Figura 70: Sem título, Alfredo Ceschiatti, 1978. Estação Sé.

Figuras 71, 72, 73, 74, 75 e 76: Descendo a Escada, Regina Silveira. Estação Brás

Figuras 77, 78, 79, 80, 81 e 82: Text Rain, Camile Utterback e Romy Achitu.

Estação Corinthans-Itaquera.

Figuras 83 e 84: Text Rain, Camile Utterback e Romy Achituv. Estação

Corinthans-Itaquera.

Figura 85 - Poema Te, Converso, de Evan Zimroth.

Figuras 86, 87, 88, 89, 90, 91, 92 e 93: OP_ERA: Sonic Dimension, Daniela Kutschat e Rejane Cantoni. Estação República.

Figuras 94, 95, 96 e 97: Reflexão \# 3, Raquel Kogan. Estação Tiradentes.

Figuras 98, 99, 100 e 101: Reflexão \# 3, Raquel Kogan. Estação Tiradentes.....

Figuras 102, 103, 104, 105, 106, 107, 108 e 109: Ultra-Nature, Miguel

Chevalier. Estação Sé

Figuras 110, 111, 112, 113, 114, 115, 116 e 117: Les Pissenlits, Edmond Couchot e Michel Bret. Estação Paraíso.

Figuras 118, 119, 120, 121, 122 e 123: PixelJunk Eden, estúdio Q-Games.

Estação Paraíso.

Figura 124: Thomas, estúdio Patrick Smith-Vectorpark. Estação

Consolação.

Figuras 125, 126, 127 e 128: Levers, estúdio Patrick Smith-Vectorpark.

Estação Consolação.

Figuras 129 e 130: Feed the Head, estúdio Patrick Smith-Vectorpark. Estação Consolação.

Figura 131: Feed the Head, estúdio Patrick Smith- Vectorpark. Estação

Consolação.

Figuras 132 e 133: Windosill, estúdio Patrick Smith-Vectorpark. Estação Trianon-MASP

Figura 134: Windosill, estúdio Patrick Smith-Vectorpark. Estação TrianonMASP

Figuras 135, 136, 137 e 138: Levers, estúdio Patrick Smith- Vectorpark. 
Figura 139: Park, estúdio Patrick Smith- Vectorpark, Estação TrianonMASP

Figuras 140, 141, 142 e 143: Hazard: the journey of life, Alexander Bruce.

Estação Vila Madalena.

Figuras 144, 145 e 146: Eufloria, Alex May \& Rudolf Kremers. Estação Vila Madalena.

Figuras 147 e 148: Every Day the Same Dream, Estação Vila Madalena.

Figura 149: Fract, Richard E. Flanagan / Phosfiend Systems. Estação Vila Madalena. Equipamento desligado

Figura 150: Fract, Richard E. Flanagan / Phosfiend Systems. Estação Vila Madalena.

Figura 151: Toys, Christoffer Hedborg. Estação Vila Madalena.

Figura 152: Anima+, Estação Trianon-MASP

Figura 153: Hybrid Moment.com, Estação Trianon-MASP

Figura 154: The Persistence of Sadness.com, Estação Trianon-MASP.

Figura 155: Jello time.com, Estação Trianon-MASP.

Figura 156: Carnal Fury.com, Estação Trianon-MASP

Figura 157: Hot Doom.com, Estação Trianon-MASP.

Figuras 158, 159, 160 e 161: Via Invisível, Soraya Braz e Fábio Oliveira Nunes

Figuras 162, 163 e 164: Suaveciclo e Vjsuave. Estação Trianon-MASP, FILE 2012.

Figura 165: Colcha de Retalhos, 1979, Claudio Tozzi

Figura 166: Movimento, 1990, Claudio Tozzi.

Figura 167: Caleidoscópio, 1999, Amelia e Mo Toledo.

Figura 168: Fiesta, 1986, Waldemar Zaidler

Figura 169: Projeto de intervenção de Carlos Fajardo para a Estação Vila Prudente

Figuras 170 e 171: Desenhos da proposta de intervenção de Waldemar Zaidler para a Estação Alto do Ipiranga, 2010.

Figuras 172 e 173: Fotos da maquete do projeto de obra permanente Tropel, de Regina Silveira, para a Estação Vila Madalena.

Figura 174: Tropel, de Regina Silveira para a 28a Bienal de São Paulo, 1998....

Figura 175: Máquinas de Ver I, videoinstalação, 1999, Daniela Kutschat e Rejane Cantoni. 
Figuras 176, 177 e 178: Escultura Palácio de Cristal e Programação de Materiais de Acabamento da Estação Cardeal Arcoverde, 1998..

Figuras 179, 180, 181 e 182: Programação cromática dos corredores da Estação Cardeal Arcoverde, 1998.

Figura 183: Programação cromática da plataforma da Estação Cardeal Arcoverde, 1998.

Figura 184: Estação Terra, 1998. Chapas de aço inox gravadas. Estação Cardeal Arcoverde, 1998

Figura 185: Estação Cidade Nova, 2010, Rio de Janeiro. Projeto arquitetônico de João Batista Martinez Correa. Programação Cromática da estrutura em arcos de Amélia e Mo Toledo

Figuras 186 e 187: Estação Cidade Nova, 2010, Rio de Janeiro. Programação Cromática da estrutura em arcos de Amélia e Mo Toledo. Piso da plataforma do Escritório Burle Marx.

Figuras 188, 189, 190 e 191: Exemplos de aplicação da Heavy Body Acrylic Colors.

Figuras 192 e 193: Sistema Munsell de Cores

Figuras 194, 195, 196, 197, 198, 199, 200, 201, 202, 203, 204, 205, 206, 207, 208, 209, 210, 211 e 212: Exemplos de aplicação Heavy Body Acrylic Iridescent Colors.

Figuras 213, 214, 215, 216, 217, 218, 219, 220, 221, 222 e 223: Exemplos de aplicação do Heavy Body Acrylic Interference Colors.

Figuras 224, 225, 226, 227, 228, 229, 230, 231, 232 e 233: Exemplos de aplicação do Fluid Acrylic Color.

Figura 234: Exemplo de aplicação do Acrylic Airbrush Colors.

Figuras 235, 236, 237, 238, 239, 240, 241, 242, 243, 244, 245, 246, 247, 248, 249, 250, 251, 252 e 253: Exemplos de aplicação do Acrylic Glazes Colours....

Figuras 254, 255, 256, 257, 258, 259, 260, 261, 262, 263, 264, 265, 266, 267 e 268: Exemplos de aplicação de Gels e Mediums.

Figura 269: Exemplo de aplicação do Self-Leveling Clear Gel. 200

Figura 270: Exemplo de aplicação do Clear Tar Gel. 200

Figuras 271, 272 e 273: Exemplos de aplicação do Soft Gel (Gloss), Soft Gel (Semi-Gloss) e Soft Gel (Matte) 200

Figuras 274, 275 e 276: Exemplos de aplicação do Regular Gel (Gloss), Regular Gel (Semi-Gloss) e Regular Gel (Matte). 
Figuras 277, 278 e 279: Exemplos de aplicação do Heavy Gel (Gloss), Heavy Gel (Semi-Gloss) e Heavy Gel (Matte).

Figuras 280, 281 e 282: Exemplos de aplicação do Extra Heavy Gel (Gloss),

Extra Heavy Gel (Semi-Gloss) e Extra Heavy Gel (Matte)

Figuras 283 e 284: Exemplos de aplicação do High Solid Gel (Gloss) e High Solid Gel (Matte)

Figura 285: Exemplo de aplicação do Clear Granular Gel..

Figuras 286, 287 e 288: Exemplos de aplicação do Fine Pumice Gel, Coarse Pumice Gel e Extra Coarse Pumice Gel.

Figura 289: Exemplo de aplicação do Fine Pumice Gel. 202

Figura 290: Exemplo de aplicação do Glass Bead Gel...... 203

Figuras 291, 292, 293 e 294: Exemplos de aplicação do Molding Paste.. 203

Figuras 295, 296, 297, 298, 299 e 300: Exemplos de aplicação da Extra Heavy Gel / Molding Paste, Fiber Paste e Crackle Paste.

Figuras 301, 302, 303, 304, 305, 306, 307, 308, 309, 310, 311 e 312 :

Exemplos de aplicação da - Light Molging Paste.

Figuras 313, 314, 315 e 316: Exemplos de aplicação do Hard Molding Paste... 205

Figuras 317 e 318: Exemplos de aplicação de Gesso and Ground.. 208

Figura 319: Exemplo de aplicação do Digital Ground White (Matte).

Figura 320: Exemplo de aplicação do Digital Ground White (Matte) or Digital Ground Clear (Gloss) or Digital Ground for Non-Porous Surfaces.

Figuras 321 e 322: Sistema steel frame (drywall) com placa cimentícia.

Figura 323: Soccer City 2010, em Joanesburgo

Figura 324: Clara Gerchman, a pesquisadora e Ivald Granato em frente ao Soccer City 2010, em Joanesburgo.

Figura 325: Detalhe das placas de GRC e das aberturas do Soccer City 2010, em Joanesburgo.

Figura 326: Cortes esquemáticos do estádio mostrando: a estrutura da cobertura, o fosso de coleta da água da chuva e o sistema de captura de imagens 3D no Soccer City 2010, em Joanesburgo

Figuras 327 e 328: Campus da Liberal Arts and Science (LAS), Doha.

Figura 329: Detalhe de fixação das placas de GRC no Campus da Liberal Arts and Science (LAS), Doha.

Figura 330: Detalhe das placas de GRC no Campus da Liberal Arts and Science (LAS), Doha. 
Figuras 331 e 332: Bridge Pavilion, Zaragoza............................................. 224

Figura 333: Bridge Pavilion, Zaragoza....................................................... 225

Figura 334: Bridge Pavilion, Zaragoza.......................................................... 225

Figuras 335 e 336: Louis Vuitton, Tokyo................................................. 226

Figuras 337 e 338: YJP Administrative Center, Tanjin................................... 226

Figuras 339, 340 e 341: Line honours, escultura em GRC............................ 227

Figuras 342, 343 e 344: Migration, escultura em GRC................................. 227

Figura 345: Célula Solar DSC............................................................. 229

Figura 346: Célula Solar Orgânica......................................................... 230

Figuras 347 e 348: À esquerda, célula solar vendida hoje no comércio. À direita, a nova célula solar da Mitsubishi que acaba de bater o recorde em eficiência.

Figura 349: Cientistas usaram pontos quânticos, nanopartículas que medem entre dois e quatro nanômetros. Em princípio, estas células solares híbridas poderão ser aplicadas como uma espécie de spray.

Figura 350: Diagrama esquemático dos elementos que capturam a luz para otimizar a conversão da luz solar em eletricidade

Figura 351: Micrografia da estrutura de fios de silício incorporados em uma matriz de polímeros.

Figura 352: Célula da IBM....................................................................... 233

Figura 353: Solar Glowing Tower, Sevilha............................................... 234

Figura 354: Sanyo Solar Ark, Japão.......................................................... 235

Figuras 355 e 356: Sanyo Solar Ark, Japão.................................................. 235

Figuras 357, 358 e 359: Estádio em Formosa, Japão..................................... 236

Figuras 360 e 361: Centro de Artes Cênicas de Seul, Coréia do Sul................. 237

Figuras 362, 363, 364, 365 e 366: Pavilhão da Suíça, projetado para a

Exposição Universal de Xangai..................................................................... 238

Figura 367: Flores solares high tech........................................................ 239

Figuras 368 e 369: Zoe Ze Spa............................................................. 239

Figura 370: Exemplos de módulos fotovoltaicos comercializados no mercado nacional.

Figura 371: Instalação em Edifício da Universidade Federal do Rio Grande do Sul. 
Figura 372: Instalação no edifício administrativo do Instituto de Eletrotécnica da Universidade de São Paulo.

Figura 373: Esquema de sistema fotovoltaico isolado.

Figura 374: Esquema de sistema fotovoltaico conectado.

Figura 375: Protótipo da Alcoa desenvolvido com caixilhos da linha Unit..

Figura 376: Estação de trem em Kyoto, no Japão.

Figuras 377 e 378: Estação de trem em Kyoto, no Japão.

Figuras 379, 380 e 381: Demonstração da dimensão de um LED

Figura 382: LEDs.

Figura 383: Telas maiores, mais brilhantes e dobráveis.

Figuras 384 e 385: COLED.

Figura 386: CN Tower, Toronto.

Figura 387: Golden Gate, Los Angeles

Figuras 388 e 389: Torraca, Itália

Figuras 390 e 391: Torraca, lamparina antiga montada com LEDs 252

Figura 392: Berlim, Alemanha 253

Figura 393: Saint-Just College, Lyon, França. 253

Figura 394: Westminster, Grã-Bretanha. 253

Figuras 395 e 396: Projeto dos lighting designers Jean Sundin e Enrique Peiniger. 254

Figura 397: Centre des Nouvelles Industries et Technologies - CNIT.............. 255

Figura 398: Centre des Nouvelles Industries et Technologies - CNIT.............. 255

Figura 399: Vidros serigrafados iluminados por linhas de LED.

Figuras 400 e 401: Os corredores que ligam o CNIT às estações de metrô e de trem

Figuras 402, 403, 404 e 405: Loja Armani Fifth Avenue.

Figuras 406, 407 e 408: Instalação luminosa: Quem tem medo do Vermelho, Azul e Verde? Bruxelas.

Figura 409: Green Pix Zero Energy Media Wall.

Figuras 410, 411 e 412: Detalhe do sistema. 260

Figura 413: Imagem pixelada.

Figura 414: WATT Club. 262

Figura 415: O piso. 
Figura 416: Sistema de molas sob o piso 262

Figura 417: Sistema de molas sob o piso. 263

Figura 418: Pista de dança equipada com pontos de LED. 263

Figura 419: Camarote 2222, Salvador. 264

Figura 420: Sustainable Dance Floor, Camarote 2222, Salvador. 265

Figuras 421 e 422: Painel Wouldn't it be nice? 266

Figura 423: Protótipo do vestido Budelle. 266

Figuras 424 e 425: Relógios com a tecnologia LED 266

Figuras 426 e 427: Componentes do Sistema Flare. 274

Figura 428: Flare - Kinetic Membrane Facade. 274

Figura 429: Flare - Kinetic Membrane Facade. 275

Figuras 430 e 431: Arranjo dos componentes do Sistema Flare. 275

Figura 432: Blinkenlights. 276

Figuras 433 e 434: Uniqua. 277

Figura 435: Grand Lisboa Casino. 278

Figuras 436, 437 e 438: Grand Lisboa Casino. 278

Figura 439: Kunsthaus Graz (2003). 279

Figura 440: NIX (2005), iluminação dinâmica utilizando iluminação casa que é tomada por um sistema centralizado, quando os serviços não estão em uso..... 280

Figura 441: Crystal Mesh. 281

Figura 442: Detalhe Crystal Mesh. 281

Figuras 443, 444 e 445: Display artístico Pixy..... 283

Figuras 446, 447, 448 e 449: Instalação You Fade to Light. 284

Figura 450: Concentricity 96. 285

Figura 451: Versão em menor escala da instalação Dune 4.2 montada, no Maastunnel e em Montevideo 286

Figura 452: Dune 4.2 286

Figura 453: Dune 4.2. 286

Figura 454: Nova - 3D lightsculpture, Estação de trem de Zurique. 287

Figuras 455 e 456: Nova - 3D lightsculpture, Estação de trem de Zurique. 288

Figuras 457 e 458: Nova - 3D lightsculpture, Estação de trem de Zurique. 288

Figura 459: Projetor DLAD-H 100, DLAD-C 35/70/150 296 
Figura 460: Projetor DLAD-HA 100, DLAD-CA 35/70/150............................... 297

Figura 461: Projetor DLAD-HFU 100 e DLAD-HGU 100.................................. 298

Figura 462: Projetor DLAD-CFU35/70/150 e DLAD-CGU35/70/150_................. 299

Figura 463: Projetor DLAD-HFW 100 e DLAD-HGW 100................................ 300

Figura 464: Projetor DLAD-HFN 100 e DLAD-HGN 100................................ 301

Figura 465: Lentes DPL50M/60M/85M/150M, D185M, DLZ120M/150M........... 302

Figura 466: Acessórios........................................................................... 303

Figura 467: Acessórios...................................................................... 304

Figura 468: Projetor Barco XLM HD30 .................................................... 305

Figura 469: Projetor Barco FLM R22+ / FLM HD20 ...................................... 305

Figura 470: Projetores Barco XLM HD30, FLM R22+ / FLM HD20 ................... 306

Figura 471: Projeto da intervenção Passagem, de Claudio Tozzi e Ubirajara

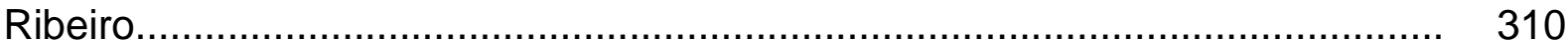

Figura 472: All Structures Are Unstable. Pavilhão da Finlândia, 2011................ 311

Figura 473: All Structures Are Unstable. Pavilhão da Finlândia, 2011............... 311

Figuras 474, 475, 476 e 477: Vistas da instalação All Structures Are Unstable. Pavilhão da Finlândia, 2011................................................................... 311

Figura 478: Bard Bridget - O Projeto Wolfsburg, 2009/2010........................... 313

Figura 479: The Ganzfeld Piece, 2011 ................................................... 313

Figura 480, 481 e 482: Bridget's Bardo.................................................. 313

Figura 483: Slow-motion shadow in colour de Olafur Eliasson......................... 314

Figura 484: Colour Shadow theatre, 2009............................................... 314

Figura 485: Colour Shadow theatre, 2009.............................................. 314

Figuras 486, 487, 488, 489, 490 e 491: Edifício Central da Estação de Trens Nyugati, em Budapeste. Vídeo Mapping com a participação do VJ Spetto......... 315

Figura 492: DR Concert Hall, 2002-2009. Copenhagen, Dinamarca. Jean

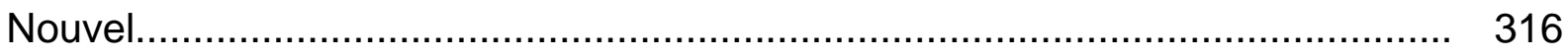

Figura 493: DR Concert Hall, 2002-2009. Detalhe da tela de revestimento.

Copenhagen, Dinamarca. Jean Nouvel

Figura 494: DR Concert Hall, 2002-2009. Copenhagen, Dinamarca. Jean Nouvel.

Figuras 495 e 496: Instalação 555 Kubic................................................... 317

Figuras 497 e 498: Instalação 555 Kubic.................................................. 318 
Figuras 499, 500, 501 e 502: Instalação Jump!

Figuras 503, 504, 505 e 506: timeLandscape - wool rhythms 2010. Juliana Mori e Matteo Sisti Sette.

Figuras 507, 508 e 509: Reações Visuais, 2011. Leandro Araújo. 320

Figura 510: The Lightning Field, 1977 321

Figura 511: The Lightning Field, 1977. 321

Figuras 512, 513, 514, 515 e 516: Elucidating Feedback, 2011. 322

Figuras 517, 518, 519 e 520: I Dance - Pista de Dança Interativa, 2011 323

Figuras 521 e 522: Parque das Ruínas, Rio de Janeiro, VideoAtaq 2010. 324

Figuras 523 e 524: O Agigantador de Pessoas, 2011 325

Figuras 525 e 526: Mapeada e Monumental, 2010. Pátio do Colégio 325

Figuras 527 e 528: Time_Frame / Tracking Imaginary Reality, Edifício Condor.. Figuras 529, 530, 531 e 532: Vídeo Mapping na fachada do SESC Belenzinho. Figuras 533 e 534: Cenografia Projetada. 325 326

Figuras 535 e 536: Projeção interativa Agigantador de Pessoas. Vídeo Guerrilha, 2011.

Figuras 537 e 538: Projeção de imagem sobre superfície grafitada (obra não interativa). Vídeo Guerrilha, 2011

Figuras 539 e 540: Projeção interativa Grafite Virtual. Vídeo Guerrilha, 2011.... 328

Figuras 541 e 542: Projeção de imagem edifício. Vídeo Guerrilha, 2011. 328

Figuras 543 e 544: Projeção de imagem edifício. Vídeo Guerrilha, 2011. 329

Figuras 545 e 546: Projeção interativa com uso de aplicativo Ipad: Touch OSC. Vídeo Guerrilha, 2011

Figuras 547 e 548: Projeção interativa com uso de sensores de movimento. Vídeo Guerrilha, 2011.

Figuras 549 e 550: Trilhos Urbanos, 2011 330

Figura 551: Videoprojeção. Fachada do Museu de Arte de São Paulo, 2011 330

Figura 552: Cindy Sherman, 2003. 338

Figuras 553 e 554: Cindy Sherman, 2003. 338

Figura 555: Ten Silhouettes, 2005. David Bachelor. 339

Figura 556: Harmonic Bridge, 2006. Bill Fontana. 340

Figura 557: Detalhe da instalação Piccadilly's Peccadilloes. 341 
Figuras 558, 559, 560 e 561: Detalhe da instalação Piccadilly's

Peccadilloes.

Figura 562: Oil Stick Work (Angelo Martinez, Richfield, Kansas) 2008.

Figura 563 : Oil Stick Work (Angelo Martinez, Richfield, Kansas) 2008.

Figura 564: Oil Stick Work (Angelo Martinez, Richfield, Kansas) 2008

Figura 565: Motion, 2005. Estação Wimbledon. Martin Barron.

Figura 566: Motion, 2005. Detalhe.

Figura 567: Priceless, 2006. Motiroti

Figura 568: Priceless, 2006. Motiroti.

Figura 569: Priceless, 2006. Motiroti.

Figura 570: Priceless, 2006. Motiroti.

Figuras 571 e 572: Wavewall, 2005, Vito Acconci.

Figura 573: Union Square in Motion.

Figura 574: Union Square in Motion.

Figura 575: Union Square in Motion.

Figura 576: Lightbox.

Figura 577: MoMA Atlantic / Pacific, na Estação de metrô Atlantic Avenue /

Pacific Street.

Figura 578: Reproduções de obras apresentadas na estação de metrô Atlantic Avenue / Pacific Street.

Figura 579: Reprodução de Claude Monet, na estação de metrô Atlantic Avenue / Pacific Street.

Figura 580: Reprodução de Jackson Pollock, na estação de metrô Atlantic Avenue / Pacific Street..

Figura 581: Scattered Light, 2010

Figura 582: Scattered Light, 2010

Figuras 583, 584, 585 e 586: Exploded View (Commuters), 2011

Figura 587: Broken Window, 2010.

Figura 588: Voices in the Subway Station, 2010. 353

Figura 589: Árvores de silício e painéis solares, 2004. 353

Figura 590: Árvores de silício e painéis solares, 2004. 353

Figura 591: Lucy in the Sky, Artista: Erwin Redl. 355

Figura 592: Reflected Loop, Jim Campbell e Klotz Werner. 
Figuras 593 e 594: Urban Archeology, Tomie Arai....................................... 356

Figura 595: Yang Ge Dance of Northeast China, Yumei Hou........................... 356

Figura 596: Arc Cycle, Catherine Wagner (título provisório).............................. 357

Figura 597: Sem título, Tom Otterness..................................................... 357

Figura 598: Arc en ciel (1978), Michael Hayden.......................................... 357

Figura 599: Arc en ciel (1978), Michael Hayden........................................... 357

Figura 600: Instalação de Roman Opalka. Estação Université Paul Sabatier. Linha B

Figura 601: Instalação de Roman Opalka. Estação Université Paul Sabatier.... 359

Figura 602: A artista Sophie Calle aplica o conceito de "transport amoureux" no Metro Toulouse DDM.

Figura 603: "transport amoureux". Sophie Calle. estação Jeanne d' Arc,

Toulouse, França 360

Figura 604: Vitrines e projeções. Estação St Germain-des-Prés... 363

Figura 605: Tela para apresentação de trabalhos culturais e publicidade.

Estação Franklin D. Roosevelt. 363

Figura 606: Fotografias. Estação Barbès. 364

Figura 607: Para marcar o bicentenário do Conservatório Nacional des Arts et Métiers, em 1994, a estação foi redesenhada pelo artista de quadrinhos belga François Schuiten. Estação Arts-et-Métiers.

Figura 608: Intervenção de Patrick Corrilon com aplicação de LED no design dos abrigos do "tramway"

Figura 609: Tunnel of Light. 365

Figura 610: Tunnel of Light . Detalhe. 365

Figuras 611 e 612: Tunnel of Light Nydalen Metro Station, Oslo. 365

Figura 613: Duality. Criado por Joachim Sauter e ART + COM. 366

Figuras 614 e 615: The Bund Sightseeing Tunnel. Vista frontal. 367

Figuras 616 e 617: The Bund Sightseeing Tunnel. Vista frontal........................ 367

Figuras 618, 619, 620, 621, 622 e 623: Excesso de publicidade. 383

Figuras 624, 625 e 626: Excesso de cores e materiais. 384

Figuras 627, 628 e 629: "Gambiarras" na iluminação e na instalação de painéis eletrônicos.

Figuras 630, 631 e 632: Fiação compromete a visibilidade das obras arquitetônicas. 
Figuras 633, 634, 635, 636, 637 e 638: Usuários das estações: Sacomã, Vila Prudente, Paraíso e República utilizando os espaços das estações como lugares de encontros, estudo, leitura, acesso à internet......

Figura 639: MULTI COLOR SP, de JP Ferreira, 2012. Concurso: Tá pintando um novo metrô 392

Figura 640: Mapa do Transporte Metropolitano, 2012. 415

Figuras 641, 642 e 643: Arte Urbana de Os Gêmeos e ISE. 418

Figura 644: Anotações em livro de registro de exposição em estação de metrô.

\section{LISTA DE GRÁFICOS}

Gráfico1: Tipos de materiais aplicados em obras permanentes e suas respectivas proporções.

Gráfico 2: Concentração de obras permanentes nas estações

Gráfico 3: Distribuição das obras permanentes nas estações

\section{LISTA DE TABELAS}

Tabela 1: Obras do acervo permanente da Companhia do Metropolitano de São Paulo.

Tabela 2: Tabela comparativa de demonstração de gastos entre lâmpadas incandescentes, fluorescentes e LEDs. 
SUMÁRIO

INTRODUÇÃO

1 CIDADE. ESPAÇO PÚBLICO. ARTE PÚBLICA. ARTE PÚBLICA

INTERATIVA PÚBLICO. SITE-SPECIFIC.

2 A ARTE E O PLANEJAMENTO. INTERVENÇÕES URBANAS:

ARTE/CIDADE I E II . ARTE NA CIDADE ......................................... 67

2.1 O PROJETO A ARTE E O PLANEJAMENTO............................................ 68

2.2 INTERVENÇÕES URBANAS: ARTE/CIDADE I E II................................... 72

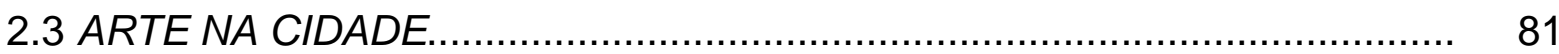

2.4 CONSIDERAÇÕES SOBRE A LEI DE INCENTIVO FISCAL PARA

PROJETOS CULTURAIS NA CIDADE DE SÃO PAULO ................................. 87

\section{A ARTE NO ESPAÇO PÚBLICO DAS ESTAÇÕES DE METRÔ DE SÃO}

PAULO

3.1 CONSIDERAÇÕES SOBRE A REESTRUTURAÇÃO E A INTERVENÇÃO VISUAL NA PRAÇA DA SÉ.

3.2 O PROJETO ARTE NO METRÔ E O PROGRAMA AÇÃO CULTURAL....... 95

3.2.1 As obras permanentes do Projeto Arte no Metrô............................... 96

3.2.2 As obras temporárias do Programa Ação Cultural.............................. 116

3.2.2.1 Exposição Arte Cibernética-Acervo Itaú Cultural (2010)....................... 117

3.2.2.2 $11^{\circ}$ e $12^{\circ}$ Festivais Internacionais de Linguagem Eletrônica: 1a e $2^{a}$ edições do FILEPAI (2010-2011)

3.2.3 Entrevistas com usuários/espectadores/atores, monitores e técnicos de manutenção no decorrer da Exposição Arte Cibernética:

Acervo Itaú Cultural e $1^{\circ}$ e $2^{\circ}$ FILEPAls.

3.2.4 Os significados da arte nas estações de metrô de São Paulo

3.2.5 Condicionantes para a aprovação de propostas de obras permanentes, exposições e eventos temporários nos espaços das estações de metrô de São Paulo

3.2.5.1 Condicionantes para apresentação de proposta de obra permanente ...

3.2.5.2 Condicionantes para apresentação de proposta de obra temporária......

4 DEPOIMENTOS DOS ARTISTAS

4.1 A ESPECIFICIDADE DAS OBRAS EM RELAÇÃO AO CONTEXTO EM QUE FORAM INSERIDAS. 
4.3 OS SIGNIFICADOS DA ARTE NOS ESPAÇOS DAS ESTAÇÕES DE

METRÔ.

4.4 A APLICAÇÃO DE TECNOLOGIAS ATUAIS EM OBRAS TEMPORÁRIAS

E PERMANENTES.

4.5 PROJETO INTERDISCIPLINAR: O QUE IMPEDE QUE ELE ACONTEÇA

NO METROPOLITANO DE SÃO PAULO?

4.6 PROJETO INTERDISCIPLINAR NAS ESTAÇÕES CARDEAL

ARCOVERDE E CIDADE NOVA NO RIO DE JANEIRO...

4.7 ATÉ QUE PONTO REGRAS NORMATIVAS INTERFEREM NO

PROCESSO DE CRIAÇÃO E NA FORMA DE ATUAR?

4.8 MEDIDAS PARA QUE TODAS AS ESTAÇÕES SEJAM CONTEMPLADAS COM OBRAS DE ARTE.

5 TECNOLOGIAS ATUAIS E SUAS POSSIBILIDADES DE APLICAÇÃO.

5.1 MATERIAIS CONVENCIONAIS

5.1.1 Tintas de Emulsão Acrílica.

5.1.1.1 Produtos da Golden Artistic Colors e aplicações.

5.1.2 Painéis Pré-fabricados de Concreto: Glass Reinforced ConcreteGRC.

5.1.2.1 Exemplos de aplicação.

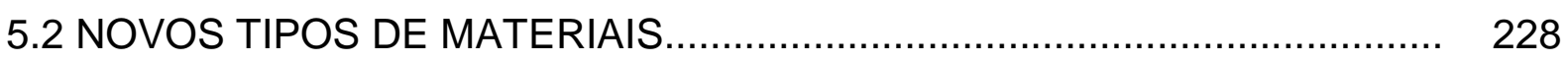

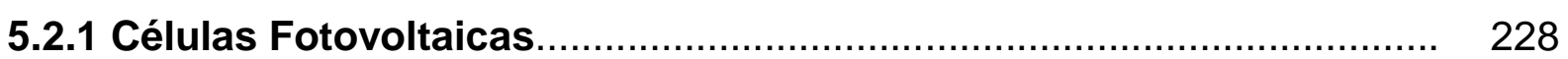

5.2.1.1 Exemplos de aplicação das Células Fotovoltaicas................................ 234

5.2.2 Diodo Emissor de Luz: Light Emitting Diode (LED)........................... 245

5.2.2.1 Exemplos de aplicação..................................................................... 250

5.2.3 Superfícies Midiáticas .............................................................. 267

5.2.3.1 Exemplos de aplicação.................................................................. 273

5.2.4 Projeções / Vídeo Mapping / Vjing ................................................... 289

5.2.4.1 Modalidades de Projeção................................................................. 292

5.2.4.2 Ferramentas para desenvolvimento e apresentação de projetos.......... 293

5.2.4.3 Exemplos de aplicação................................................................... 309

6 INTERVENÇÕES AMBIENTAIS EM ESTAÇÕES DE METRÔ NO ÂMBITO INTERNACIONAL: QUESTÕES DA ARTE CONTEMPORÂNEA..................... 335

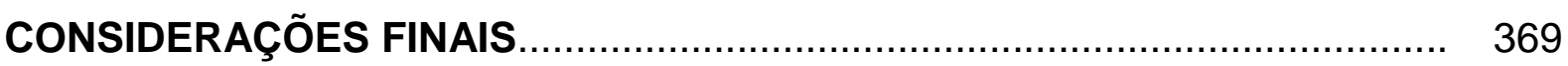

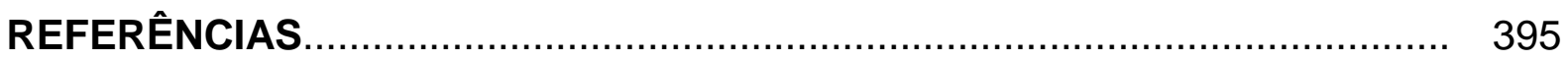

ANEXO

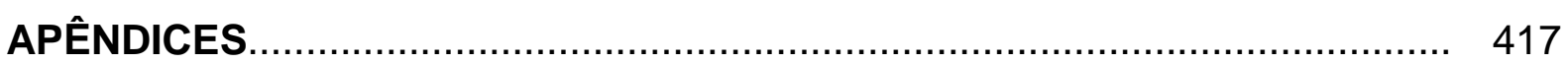




\section{INTRODUÇÃO}

\section{Objetivo Geral}

A tese objetiva investigar a arte nas estações da Companhia do Metropolitano de São Paulo, verificar as possibilidades de uso de tecnologias atuais (LED, célula fotovoltaica, mídias eletrônica e digital, videoprojeções) e as condicionantes para propostas de intervenção ambiental ${ }^{1}$ no espaço público em questão.

\section{Objetivo Específico}

Tendo em vista a situação da arte, da arquitetura e do design no século XXI, tem como meta comprovar a possibilidade de aplicação e a aceitação de tecnologias atuais em intervenções ambientais, de caráter temporário e permanente, nas estações de metrô de São Paulo visando contribuir com a melhoria qualitativa dos espaços das estações futuras e em funcionamento.

\section{Questões e Justificativa}

A complexidade de nossa "cidade polifônica" ${ }^{2}$, permite diversas publicações e pesquisas sobre suas edificações, ruas, avenidas, praças e demais espaços públicos como os das estações de metrô. A necessidade de uma solução eficaz para o transporte urbano e a franca expansão de propostas e implantações de novas

\footnotetext{
${ }^{1} \mathrm{O}$ termo "intervenção ambiental" não está relacionado ao conceito de sustentabilidade. Deve ser entendido aqui no sentido de que arte, "arquitetura e design são intervenções culturais no espaço que o qualificam e o transformam em um ambiente". Este sentido particular foi apresentado por Lucrécia Ferrara em palestra realizada em 03/05/2011, como parte da disciplina cursada no Programa de Pós-Graduação da Universidade de São Paulo: Seminários de Pesquisa em Design e Arquitetura. (informação pessoal).

2 Termo adotado pelo antropólogo Massimo Canevacci em sua obra "A Cidade Polifônica: ensaio sobre a antropologia da comunicação urbana.” São Paulo: Estúdio Nobel, 1993.
} 
linhas e, consequentemente, de novas estações reforçam a utilidade pública desta tese.

A característica atual do tema "metrô", minhas experiências nos campos da arquitetura (desenvolvimento de projetos arquitetônicos), das artes plásticas (restauro de obras de arte, participação no desenvolvimento e execução de painéis artísticos) e do design gráfico (coordenação e diagramação de livros de arte), somados ao conhecimento adquirido em disciplinas cursadas no Programa de PósGraduação da Universidade de São Paulo, no desenvolvimento dos trabalhos programados e nas disciplinas de graduação em que realizei atividades de estágio pelo Programa de Aperfeiçoamento de Ensino-PAE, possibilitaram reflexões e despertaram algumas indagações acerca da arte, da arquitetura e do design no espaço das estações do metrô de São Paulo: Haveria outras possibilidades de propostas de intervenção ambiental para as estações? Qual o significado da arte inserida nesses espaços públicos? Eles podem ser entendidos apenas como espaços destinados à passagem, como "não-lugares"? Como tem se revelado a atuação do artista plástico junto ao arquiteto no processo de inserção de obras de arte nos espaços das estações recentes? Até que ponto regras normativas influenciam nas formas de criar e de atuar do artista?

Ao pesquisar autores cujos pensamentos estivessem relacionados ao assunto, pude compreender que artes plásticas, arquitetura e design são fazeres em processo de permanente mutação, característica do próprio processo de criação e inovação, os quais sempre foram produzidos com os meios disponíveis de seu tempo.

Mudanças estruturais ocorridas nos sistemas econômico e social, a partir das últimas décadas do século $X X$, alteraram e redefiniram a prática da arte e da arquitetura (SCHULZ-DORNBURG, 2000, p.12), incluo aqui também a prática do design. Com a mundialização, o avanço da tecnologia, a forma de conceber o tempo, o espaço e o mundo em que vivemos têm se alterado. Criou-se uma nova cultura. As formas de expressão multiplicaram-se, descompartimentaram-se e estão cada vez mais aliadas a essas práticas.

Os conceitos de cidade, espaço público, arte pública e público/espectador têm passado por transformações. Os edifícios tornaram-se mais permeáveis e seus programas cada vez mais flexíveis e interativos (TOZZI, 2001). As artes plásticas expandem progressivamente seu domínio ao sair de seu habitat institucional para invadir as ruas, as praças, os edifícios, a rede virtual, as estações de metrô, o viver 
das pessoas. Há o surgimento da "Arte Pública Interativa", desenvolvida com tecnologias atuais (BARRETO, 2010, p.89-91). De acordo com o antropólogo Mássimo Canevacci,

(...) a comunicação na era digital é ainda mais importante. Seja pelo aspecto produtivo, seja pelo aspecto de valores, de comportamento, pela maneira de falar, de estabelecer uma relação com o corpo, e também com a identidade. E também a cultura. Não no sentido antropológico, não como cultura intelectual, mas cultura como estilo de vida é cada vez mais parte constitutiva da nova metrópole. (CANEVACCI, 2008) ${ }^{3}$.

"A qualidade de uma obra de arte ou de arquitetura se mede agora pelo bem que se ajusta ao usuário. O espectador é um participante ativo da mesma obra. Sua percepção da obra está irrevogavelmente vinculada à experiência sensual" (SCHULZ-DONBURG, 2000, p.12). Exige-se dele, desempenho interativo e participativo (BARRETO, 2010, p.91), o que o faz assumir o papel de "espect-ator" (CANEVACCI, 2008), em alguns casos, também de autor. Observa-se o deslocamento do interesse por obras autônomas e de autorreferência por obras com conceitos que incluem o lugar e o público/espectador que o fruirá (site specific e instalações) (SCHULZ-DONBURG, 2000, p.06; TOZZI, 2001; TOZZI, 2001, p.7). Para Rafael Cardoso, "O design tende a se afastar da materialidade e caminhar em direção à experiência, ao uso e à emoção. Cada vez mais os objetos de design serão imateriais" (CARDOSO, 2008, p.22) ${ }^{4}$.

Intervir na cidade contemporânea envolve uma série de questões: resgatar sua luz, sua cor e sua forma, sendo necessário para isso organizar seus espaços, sua poética, projetar sistemas integrados de informação (design gráfico) e de equipamentos urbanos (design de mobiliário e acessibilidade), integrar as artes plásticas ao novo modo de concebê-la (TOZZI, 2001).

Atualmente, certas obras possuem tamanha similaridade que dificulta identificar seu autor: um artista? um arquiteto? um designer? Embora a função de (re) organizar o espaço seja uma atribuição do arquiteto, há casos em que, artistas e designers também têm buscado essa (re) organização determinada não apenas pela técnica

\footnotetext{
3 CANEVACCI, Massimo. In AGUIAR, Julia. Entrevista Massimo Canevacci (entrevista realizada para a publicação Sextante - FABICO/UFRGS, sob orientação do jornalista Wladymir Ungaretti, em agosto de 2007). Publicada em 12/04/2008. Disponível em: <http://www.overmundo.com.br/banco/entrevista-com-pensadormassimo-canevacci>. Acesso em: 18/05/2010.

${ }_{4}$ CARDOSO, Rafael. Una cosa mentale. Em entrevista, Rafael Cardoso fala sobre a desmaterialização do design. Por Marco Aurélio Fiochi. Continuum Itaú Cultural, 10 mai. 2008, p. 22.
} 
(pintura ou escultura) e forma (superfície ou volume) mas também, por outros elementos que podem ser introduzidos nesse espaço: a luminosidade, a sonoridade, a reflexão, o uso do espaço negativo (escavação), a memória, o próprio deslocamento do observador (a quarta dimensão: o tempo) (SCHULZ-DONBURG, 2000; TOZZI, 2001).

Apesar das antigas discussões no esforço de definir as semelhanças entre essas disciplinas, no pensamento contemporâneo, atividades artísticas, cultura e tecnologia caminham simultaneamente. Nesse contexto, a aproximação dos limites entre artes plásticas e arquitetura (incluo o design) acontece ao pensar o espaço com atitudes e objetivos que se convergem através de uma atuação essencialmente criativa. A intervenção só se torna possível na medida em que se adote uma postura de conceber o objeto/obra através de um processo de trabalho híbrido (interdisciplinar), considerando que, cada profissional tenha uma formação ampla em informações tecnológicas e conhecimento dos valores humanos (SCHULZDONBURG, 2000, p.6; TOZZI, 2001; TOZZI, 2001, p.7).

Nesse sentido, o escultor indiano radicado em Londres, Anish Kapoor, tem vivenciado mais uma de suas experiências de colaboração com autores de projetos arquitetônicos, dessa vez, em duas estações de metrô de Nápoles-Monte Sant'Angelo, na Itália: Università e Traiano. O projeto, concebido pelo estúdio Amanda Levete Architects, teve como inspiração uma rede de túneis inacabados localizados em uma área abandonada e isolada do distrito de Traiano. A intervenção, que é elemento central para a revitalização urbana e cultural local, propõe volumes diferenciados para as entradas das estações: um em aço corten, e outro, em alumínio polido. No processo criativo do projeto, considerado uma obra de arte em si, a síntese entre finalidade e beleza foram fundamentais. (DEZEEN.COM, 2009; GUGGENHEIM-BILBAO.ES, 2010). 


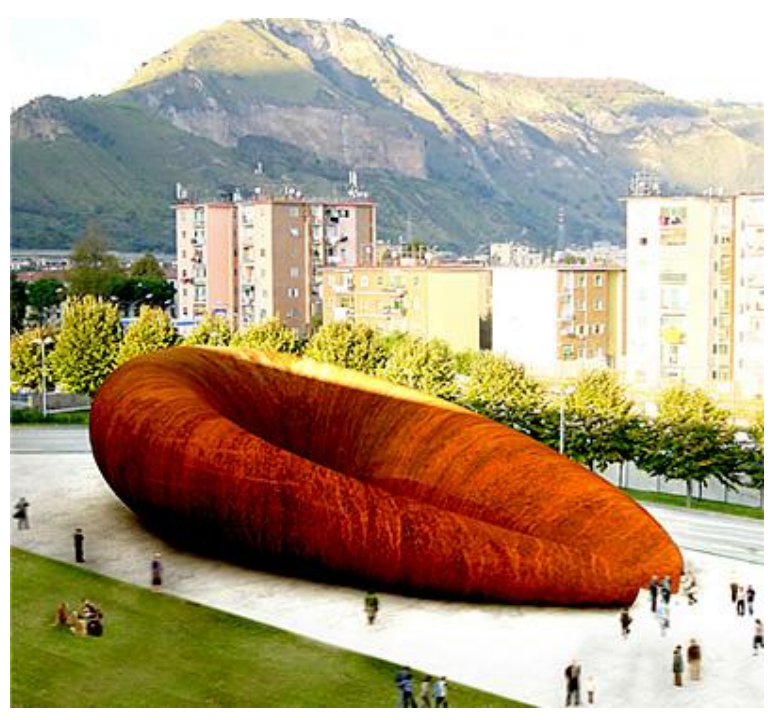

Figura 1: Estação Università, 2003, em aço bilbao.es/microsites/anish_kapoor/secciones/mas_sobre_obra/introduccion.php?idioma=en>. Acesso em 27/11/10.

Figura 2: Estação Traiano, 2003, em alumínio polido. Fonte: <http://www.guggenheimbilbao.es/microsites/anish_kapoor/secciones/mas_sobre_obra/introduccion.php?idioma=en>. Acesso em $27 / 11 / 10$.

Diferentemente de outras metrópoles, para Massimo Canevacci, a cidade de São Paulo ainda encontra-se presa à concepção modernista ou, até mesmo, minimalista, inadequadas às possibilidades que a contemporaneidade oferece (CANEVACCI, 2008). Essa característica modernista/minimalista, que corresponde à arquitetura das estações de metrô paulistanas, chamou a atenção da dupla de finlandeses: Tommi Grönlund e Petteri Nisunen, autores de trabalhos situados no limiar entre a arte e a arquitetura $^{5}$, que vieram a utilizá-las como suporte para a intervenção Variations on a theme ${ }^{6}$, na $27^{a}$ Bienal de São Paulo, em $2006 .^{7}$

\footnotetext{
${ }^{5}$ Grönlund e Nisunen são capazes de explicitar, enquanto prática, "novas afinidades" entre ambas as disciplinas, para usar a expressão de Julia Schulz-Dornburg. Conceitos como luz, som e movimento são explorados através do uso de materiais de alto padrão e de mecanismos técnicos. Na $27^{a}$ Bienal, no interior do pavilhão foram apresentadas: Antigravity Model, uma escultura de grandes dimensões, que explorava os conceitos de movimento e som, e Pattern Recognition Setup, projeto específico para o pavilhão da Bienal, que criava um tapete de luz através de uma miríade de lâmpadas LED.

${ }^{6}$ A primeira etapa do projeto Variations on a theme, foi a publicação de documentações e de variações arquitetônicas em 22 construções. Ao mesmo tempo, estas publicações ficaram disponíveis nas livrarias da Bienal e serviram como guia para encontrá-las. Na segunda etapa, foram cuidadosamente escolhidas seis torres da área central da cidade para realizar as intervenções de forma a constituir uma amostra representativa de suas variantes. $\mathrm{O}$ trecho escolhido, situado ao longo da Linha Azul, abrangeu especificamente: a Estação Vergueiro (torre de ventilação do Metrô na Rua Vergueiro, próximo ao cruzamento com a Rua Professor Antônio Prudente e o Hospital do Câncer), a Estação São Joaquim (torre de ventilação do Metrô na Avenida Liberdade, entre o cruzamento da Rua Fagundes com a Rua Barão de Iguape), a torre do Metrô na Praça 7 de Setembro, na Avenida Liberdade com a Rua da Glória e a torre da Estação São Bento. Segundo arquitetos da Companhia do Metropolitano de São Paulo, essas estruturas de concreto, projetadas pelo arquiteto carioca Marcello Frigelli, foram construídas nas décadas de 1960 e 1970, sempre muito acima do nível da rua para tornar mais cômodas as estações, evitar a entrada de poluentes e diminuir a entrada de água das chuvas no túnel. Com as novas tecnologias disponíveis, estas construções tornaram-se desnecessárias funcionalmente, o que despertou o interesse do Metrô em demolir parte delas. A torre da Estação Liberdade foi demolida no mesmo ano em que foram realizadas as intervenções. (GRÖNLUND; NISUNEN, 2006).
} 
A primeira impressão que se traça no cérebro fatigado pelo jet lag é o modernismo predominante na paisagem urbana que se abre perante os olhos, combinado com um aspecto um pouco mal cuidado e uma forte presença de vida cotidiana nela. (GRÖNLUND; NISUNEN, 2006).

Ao aproximarmos do centro os nossos olhos captam uma estranha construção de concreto. Depois outra e uma terceira. Como híbridas de um prédio e de uma escultura. Todas diferentes mas, mesmo assim, semelhantes. (...) Estas construções arquitetônicas representam algo entre um prédio e uma escultura. Como se os prédios de Oscar Niemeyer, Le Corbusier ou Louis I. Kahn tivessem sido cruzados com as esculturas em concreto que Donald Judd fez em Marfa. (GRÖNLUND; NISUNEN, 2006).

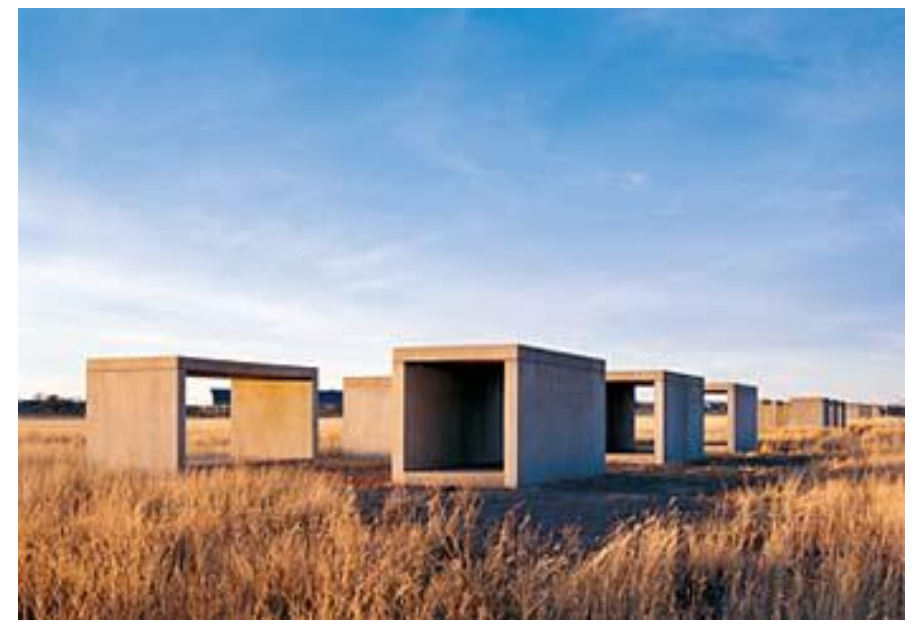

Figura 3: Untitled Works in Concrete, 1980-1984. Donald Judd, Marfa, Texas. Fonte: <http://upload.wikimedia.org/ wikipedia/commons/a/a7/Judd concrete_1.jpg >. Acesso em 24/06/12.

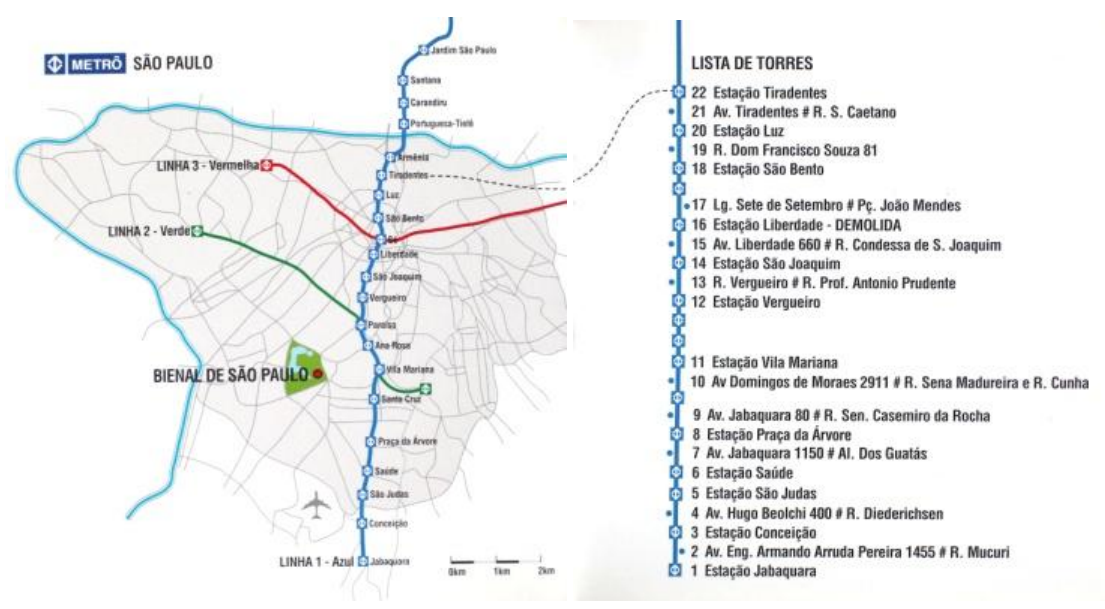

Figura 4: Primeira Etapa do Projeto Variathions on a theme, $2006 . \quad$ Fonte: GRÖNLUND, Tommi \& NISUNEN, Petteri: Catálogo: Variações sobre um tema/Variations on a theme. 27ạ Bienal de São Paulo, 2006.

\footnotetext{
${ }^{7}$ A 27a Bienal de São Paulo, sob a curadoria de Lisette Lagnado, esteve sustentada no tema "Como viver juntos", emprestado do título de um curso dado por Roland Barthes (1915-1980) no Collège de France (19761977), e na contribuição da obra e experiência de vida do artista brasileiro Hélio Oiticica (1939-1980) e seu Programa Ambiental (Programas para a Vida e Projetos Construtivos). Às propostas também foram incorporadas as ideias do artista Marcel Broodthaers (1924-1976) com a sua crítica às instituições museológicas e o uso da arte como forma de ação e crítica social e política. (DEVANEARTE.SPAWDIN.NET, 2009).
} 

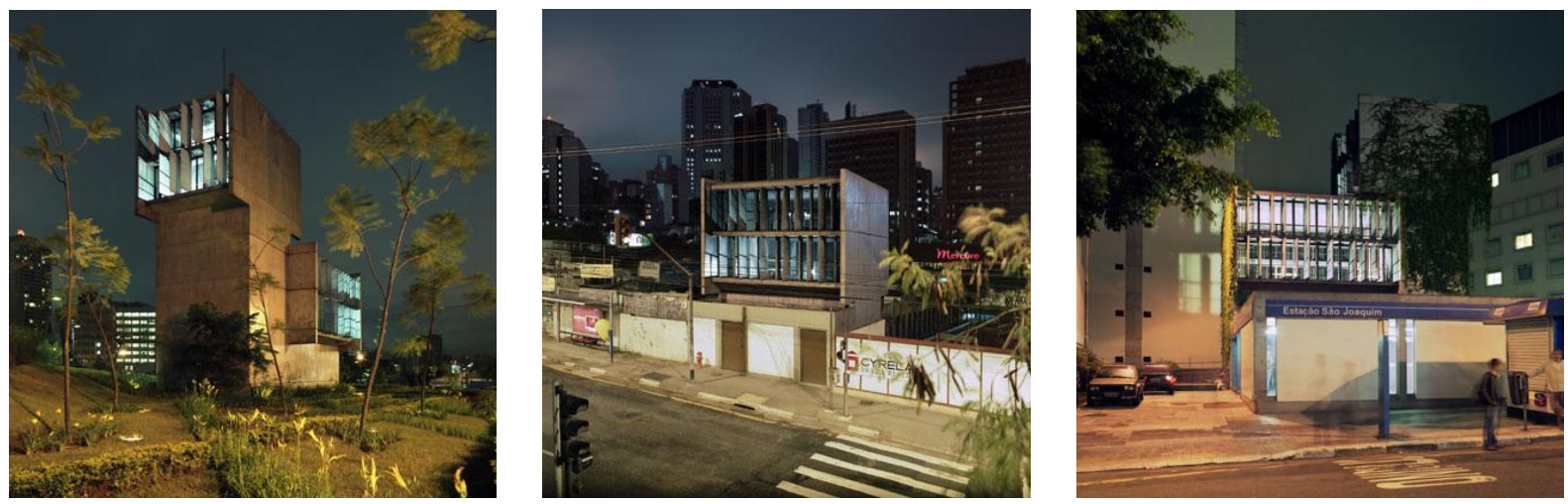

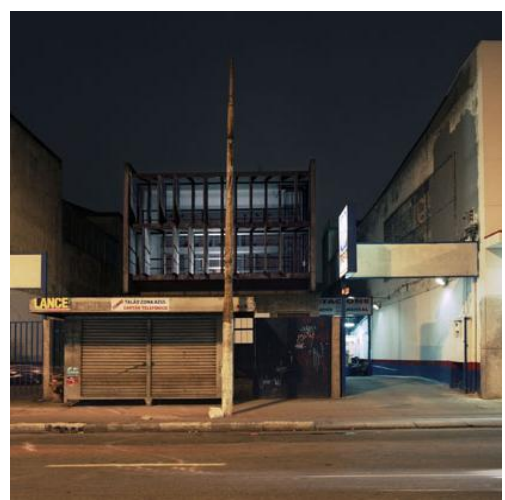

Figura 5: Variathions a theme, 2006. Estação Vergueiro. Fonte: $<$ http://g-n.fi/2006_sao_paulo.php. (C) Tommy Grönlund. Acesso em 24/06/12.

Figura 8: Variathions a theme, 2006. Torre entre São Joaquim e Liberdade. Fonte: <http://gn.fi/2006_sao_paulo.php>. (C) Tommy Grönlund. Acesso em 24/06/12.

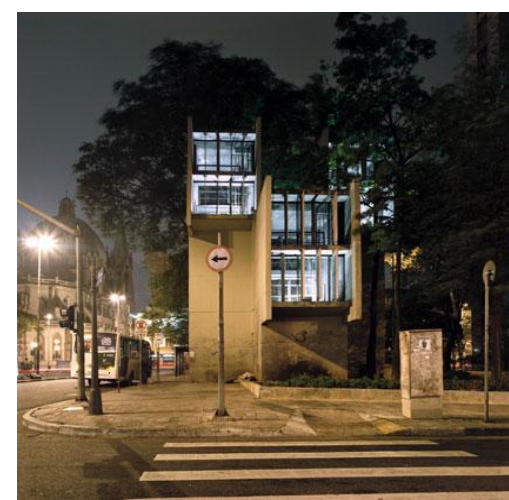

Figura 6: Variathions a theme, 2006. Torre entre Vergueiro e São Joaquim. Fonte: <http://gn.fi/2006_sao_paulo.php>. (c) Tommy Grönlund. Acesso em 24/06/12.

Figura 9: Variathions a theme, 2006. Estação Liberdade. Fonte: $<\mathrm{http}: / / g-$

n.fi/2006_sao_paulo.php>.

Tommy Grönlund. Acesso em 24/06/12.

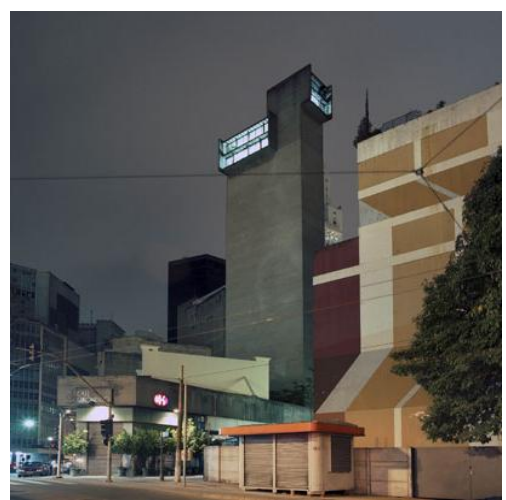

Figura 7: Variathions a theme, 2006. Estação São Joaquim. Fonte: <http://gn.fi/2006_sao_paulo.php>. (C) Tommy Grönlund. Acesso em 24/06/12.

Figura 10: Variathions a theme, 2006. Estação São Bento. Fonte: $<$ http://g-

n.fi/2006_sao_paulo.php>. (C)

Tommy Grönlund. Acesso em 24/06/12.

O objetivo da intervenção era chamar atenção para a natureza híbrida daquele "conjunto monumental de superfície" tão integrado à paisagem urbana paulistana, com a sua aparência entre arquitetura modernista e escultura de vanguarda. Elas apareceriam como "espaços surpresa" em diferentes pontos da cidade, se apropriando ou contrastando com os arredores da paisagem. A simples iluminação de seus interstícios, normalmente obscuros, chamaria a atenção de quem passasse na superfície das ruas para a estrutura subterrânea que determina a disposição das torres e contribui para que os cidadãos vivam juntos (GRÖNLUND; NISUNEN, 2006). Para alcançar tal objetivo, a luz, fundamental meio e mediador para a exploração visual, foi utilizada como instrumento. Buscava-se que as instalações interagissem com o contexto urbano e com o público através das alterações de 
iluminação ao longo do dia. Como em toda a cidade, durante o dia, as instalações permaneciam iluminadas pela luz natural e, durante a noite, pela luz artificial, adquirindo uma nova expressão, interferindo na percepção daqueles locais. A luz emitida do interior daquelas estruturas funcionais, ao atravessar os vãos entre brises e grades de ventilação, as transformaria em uma "sequência de luz" no centro da cidade. Ao ver de Yorjo Haila, Prof. Environmental Policy, University of Tampere, Finland, através dessa intervenção, as torres não eram mais meras estruturas, mas tornavam-se uma "série de transformações cíclicas" (HAILA, 2007).

As transformações pelas quais a concepção dos projetos arquitetônicos das estações de metrô têm passado ao longo dos anos é outro aspecto relevante a ser considerado na apresentação/instalação de obras artísticas. De acordo com Hatanaka, os projetos das primeiras estações estavam direcionados às questões da mobilidade e da funcionalidade. Nas 19 estações iniciais da Linha Norte-Sul, as obras de arte não faziam parte do projeto por serem entendidas pelo arquiteto Marcelo Fragelli como elementos que iriam "interferir em um espaço por ele pensado de forma completa". Apesar de ter buscado explorar as propriedades plásticas do concreto, a solução dada ao projeto de luminotécnica não contribuiu para que a intenção estética do autor se tornasse visível para o usuário, o que se refletiu também nas obras de arte, inseridas posteriormente. Para a ventilação, foram construídas as torres de concreto, mencionadas anteriormente, que partem do subsolo e alcançam espaços públicos da superfície. Nas estações projetadas por Roberto MacFadden, houve o aproveitamento da ventilação e iluminação naturais através de aberturas no nível do solo, favorecendo assim: a "interação" entre subsolo e superfície, a presença de jardins internos e uma melhor percepção do espaço e dos objetos que o habita. Nessa fase, foram inseridas as primeiras obras de arte na Estação Sé, posteriormente à construção da estação, como uma extensão do processo de reestruturação e intervenção visual realizada na Praça da Sé. Para o arquiteto, o uso do "espaço de passagem" para a colocação das obras de arte, que pensem a cidade e a sociedade, é uma atitude positiva. Atualmente, em busca de um menor consumo de energia, tem se intensificado a busca por um maior aproveitamento da iluminação e ventilação naturais na concepção dos projetos. Nos ambientes em que a luz natural não alcança, a iluminação artificial tem sido realizada com o uso de luminárias eficientes e de lâmpadas LED (HATANAKA, 2009. p.58-63). Além da luz, elemento que propicia a melhor percepção das formas 
e das cores, outra mudança a favor das obras de arte tem sido a predeterminação de espaços destinados a elas, ainda na fase de projeto. No decorrer de minhas pesquisas in loco, foi possível perceber um esforço por parte de alguns arquitetos, independentemente do resultado ser satisfatório ou não, em modificar a aparência padronizada das edificações em concreto revestindo-as, interna e externamente, com outros materiais como o aço inoxidável, a cerâmica e o vidro de forma mais intensa.

Com o objetivo de maior aproveitamento da iluminação e ventilação naturais, na Estação Vila Prudente (2010), o arquiteto Luiz Carlos Esteves fez uso de cobertura em vidro autolimpante, apoiada em estrutura metálica. Internamente, apesar do uso do aço inoxidável, do vidro, da estrutura metálica na cor branco e de pastilhas cerâmicas coloridas, ainda há a predominância do concreto aparente (MELENDEZ, 2011). Esteves explica que:

quando se fala em acabamento, o que de imediato remete a materiais de revestimento, é preciso levar em conta que, em grande parte, esses espaços já se encontram acabados após as fases de concretagem. Com efeito, e inevitavelmente, o concreto torna-se protagonista. Mais do que em qualquer outra edificação, termo que não cabe apropriadamente a uma obra subterrânea, o concreto não é uma opção construtiva, mas uma imposição. E dessa forma, com essa importância, deve ser encarado. (ESTEVES, 2011)

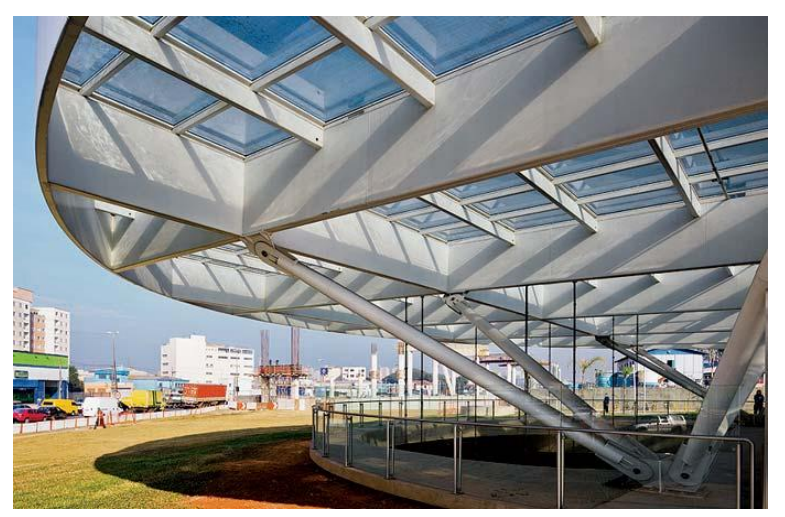

Figura 11: Estação Vila Prudente, 2010. Cobertura em estrutura metálica e vidros autolimpantes que facilitam a manutenção. Fonte: MELENDEZ, 2011. 


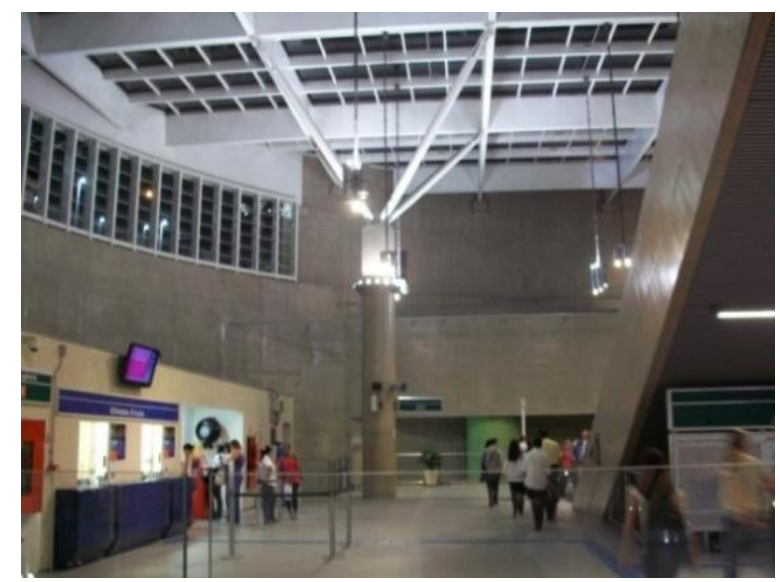

Figura 12: Estação Vila Prudente, 2010. Estrutura metálica e concreto aparente no interior. Fonte: Registro fotográfico da pesquisadora.

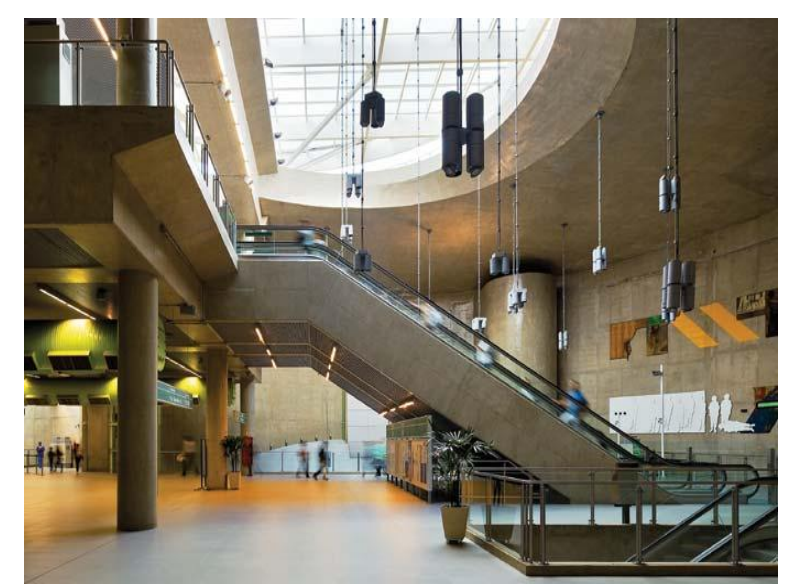

Figura 13: Estação Vila Prudente, 2010. Predominância do concreto aparente em seu interior e cobertura envidraçada que leva luz natural até a plataforma, 21 metros abaixo do nível da rua. Fonte: MELENDEZ, 2011.

As fachadas das Estações Butantã e Faria Lima, receberam aço inox, vidro laminado e cerâmicas coloridas, materiais resistentes às ações de vandalismo, de custo competitivo e que possibilitam destacar a arquitetura das estações das construções vizinhas. Os arquitetos Marc Duwe, Arno Hadlich e Eduardo Velo, da Tetraarq Projetos, responsáveis por ambos os projetos, informam que para os acabamentos das estações da Linha Amarela,

- Departamento de Arquitetura do Metrô de São Paulo elaborou diretrizes que preveem o uso de cores e materiais modernos e resistentes para que as estações se tornem marcos urbanos e não desapareçam no tecido da cidade, como aconteceu com as linhas mais antigas.(...) $\mathrm{O}$ aço e, principalmente, o aço inox, foi extensivamente utilizado nas estruturas da cobertura, revestimentos de fachada, revestimentos internos, guardacorpos, suportes para comunicação visual e mapas, no mobiliário, como bancos e lixeiras, e acabamentos de elevadores. (DUWE; HADLICH; VELO, 2010). 

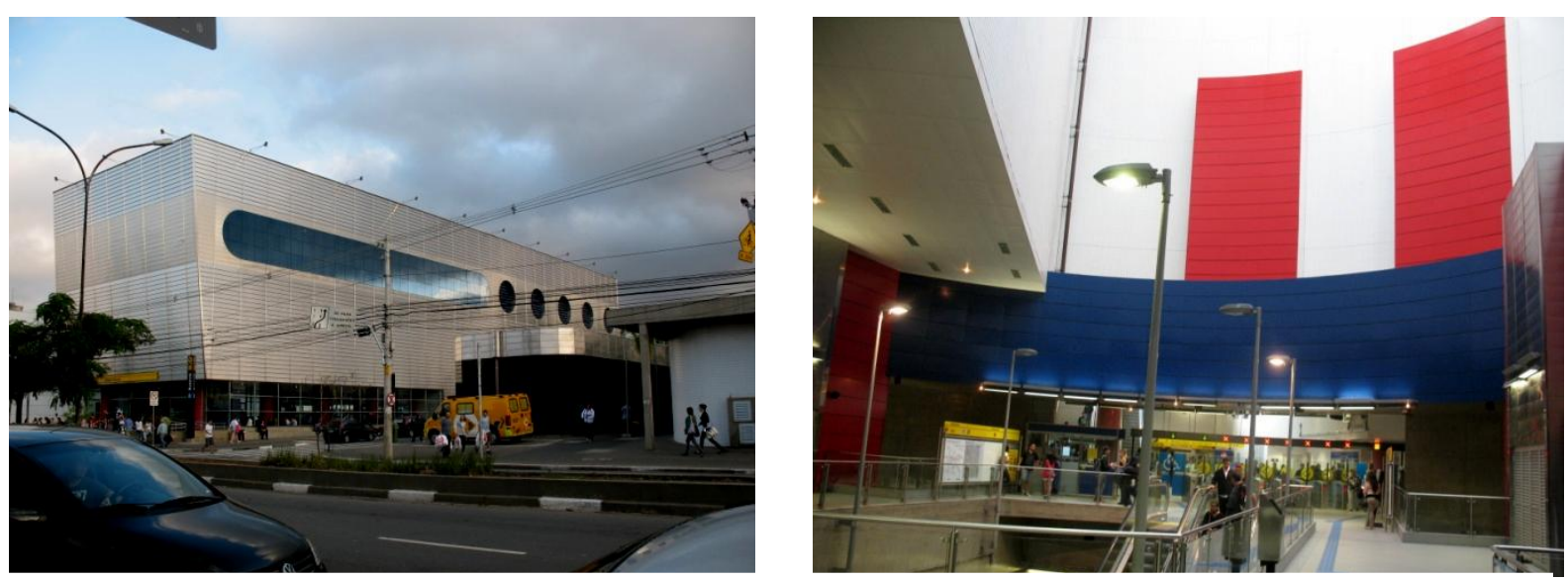

Figuras 14 e 15: Estação Butantã, 2010. Aço inox, vidro e cerâmica na fachada. Aço inox, cerâmica e concreto no interior. Fonte: Registro fotográfico da pesquisadora.
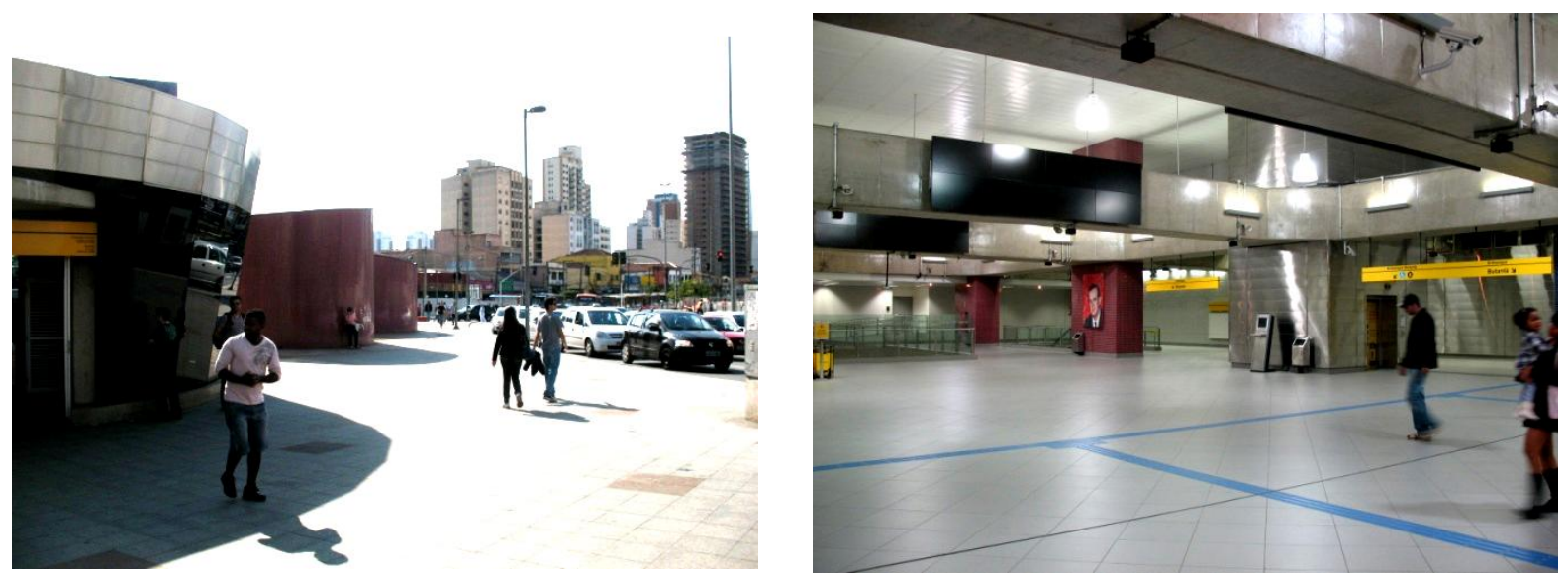

Figuras 16 e 17: Entrada Estação Faria Lima, 2010. Aço inox, vidro laminado e cerâmica na fachada. Aço inox, cerâmica, concreto e painéis eletrônicos no interior. Fonte: Registro fotográfico da pesquisadora.

Na Estação Sacomã (2010), também da Tetraarq Projetos, houve a preocupação em amenizar o aspecto negativo causado pelo predomínio do cinza no interior dos espaços com a aplicação de cerâmica em diversas cores, vidro, pintura colorida sobre a superfície de concreto e iluminação LED, direcionada para um painel decorativo localizado na área das escadas rolantes de acesso às plataformas. $O$ plano do teto da área de acesso à plataforma de embarque recebeu a aplicação de forro desenhado em uma configuração orgânica, não convencional. Externamente, o LED também foi usado para iluminar um dos volumes que compõem a fachada em concreto. 

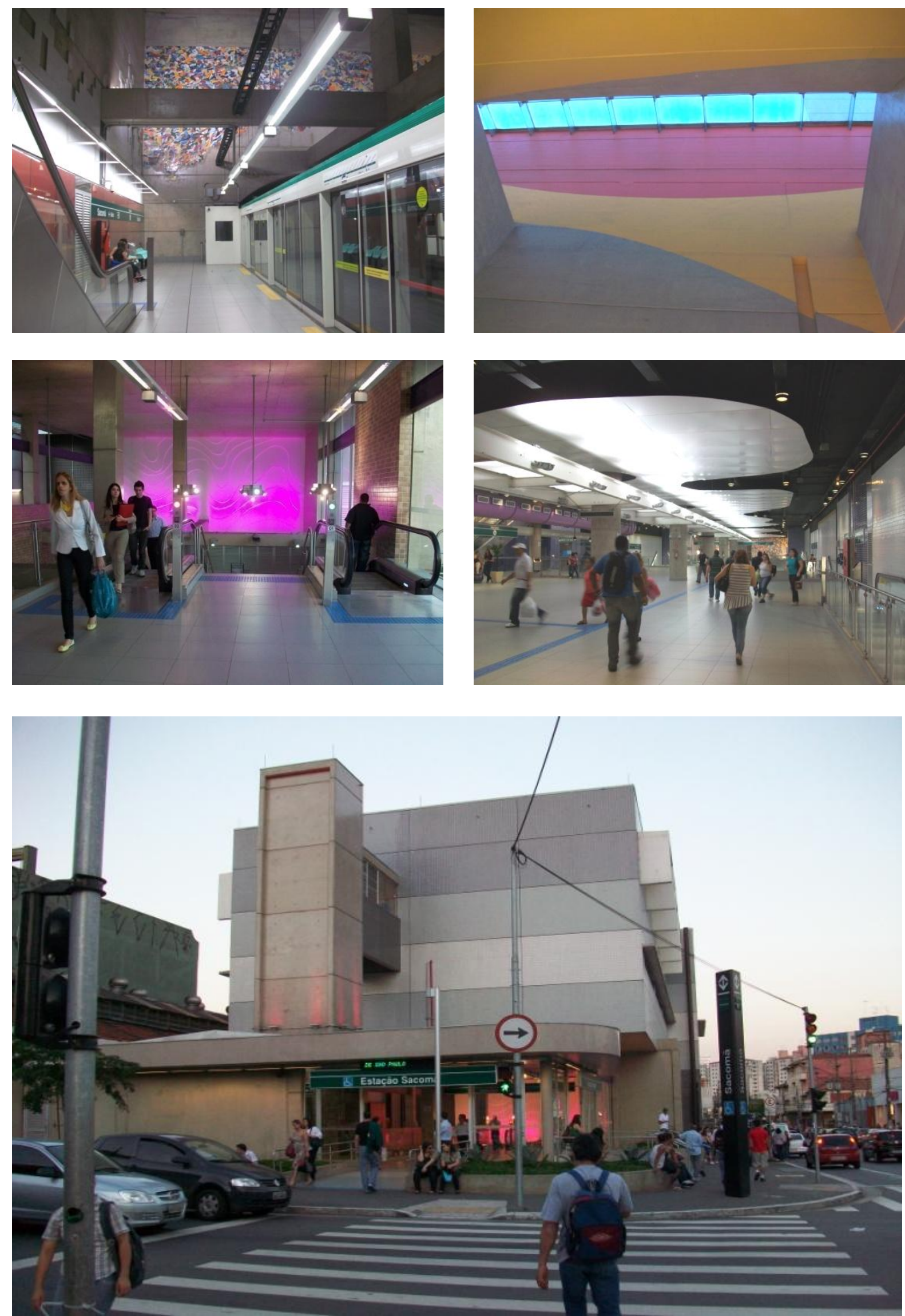

Figuras 18, 19, 20, 21 e 22: Estação Sacomã, 2010. Aplicação de cerâmica, vidro, pintura colorida e LED. Fonte: Registro fotográfico realizado pela pesquisadora. 
Na Estação Alto do Ipiranga (2007), projetada pelo arquiteto Ilvio Silva Artioli, foi aplicado o LED nas escadas rolantes, na cor branco e, na iluminação das plataformas, na cor verde, que associadas às cores amarelo dos dutos e azul da estrutura da escada que leva ao plano do piso superior, compõem as cores da bandeira brasileira, uma referência à história do bairro onde foi proclamada a Independência do Brasil. O vidro também foi aplicado em busca de maior iluminação natural e do rompimento com a linguagem do concreto.
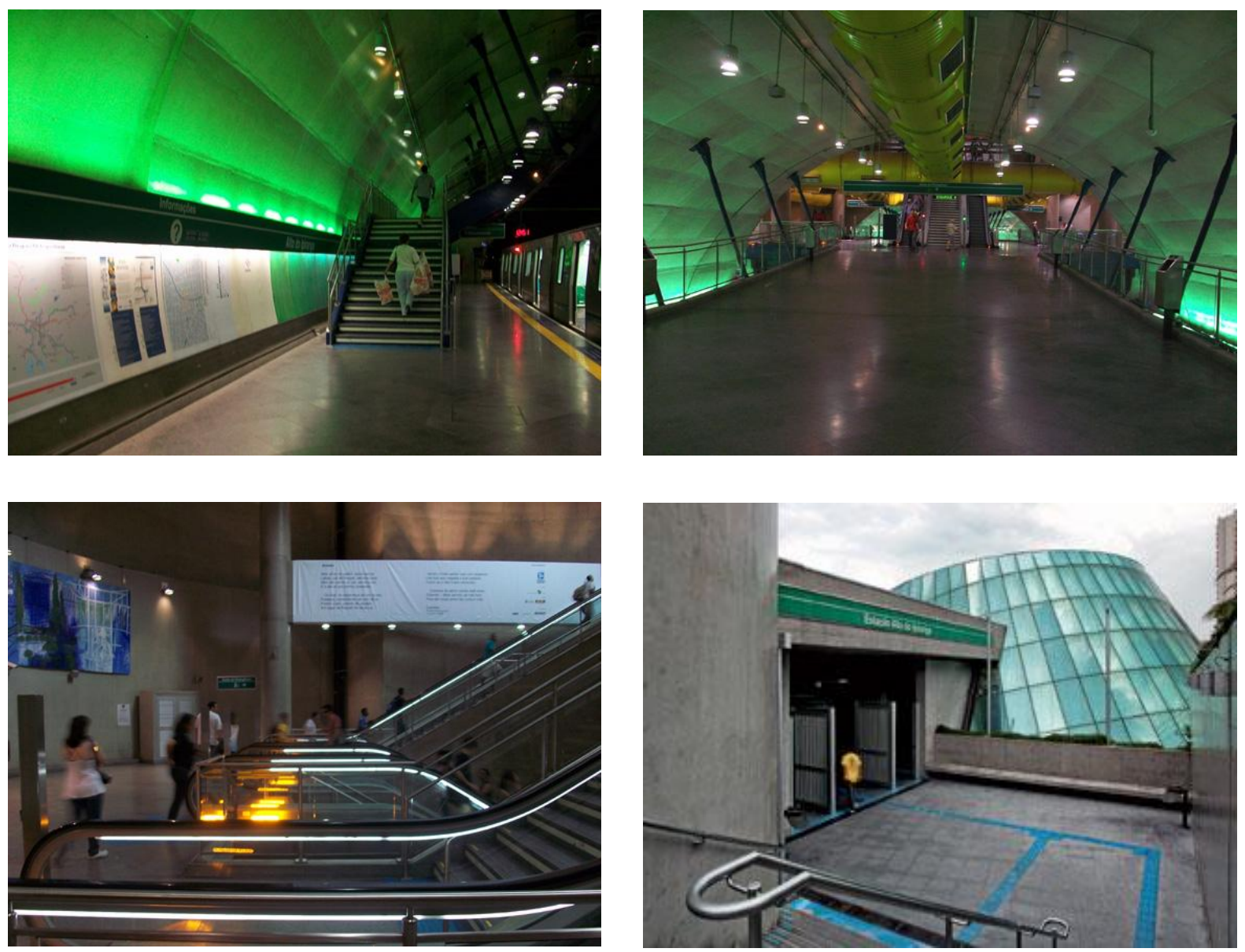

Figuras 23, 24 e 25: Estação Alto do Ipiranga, 2007. Aplicação do LED na iluminação. Fonte: Registro fotográfico realizado pela pesquisadora.

Figura 26: Estação Alto do Ipiranga, 2007. Aplicação do vidro. Fonte: MELENDEZ, 2010. 
Observa-se que na publicidade, intensamente praticada nesses espaços, profissionais têm utilizado a seu favor painéis luminosos, projeções e a interatividade para chamar a atenção dos usuários. Além dos exemplos que serão apresentados a seguir, dos metrôs de São Paulo e de Toronto, os eventos do Itaú Cultural e da FIESP/SESI (mencionados mais adiante no texto), que tiveram o apoio do Banco Itaú e do Banco Santander S.A., respectivamente, também são exemplos disso.
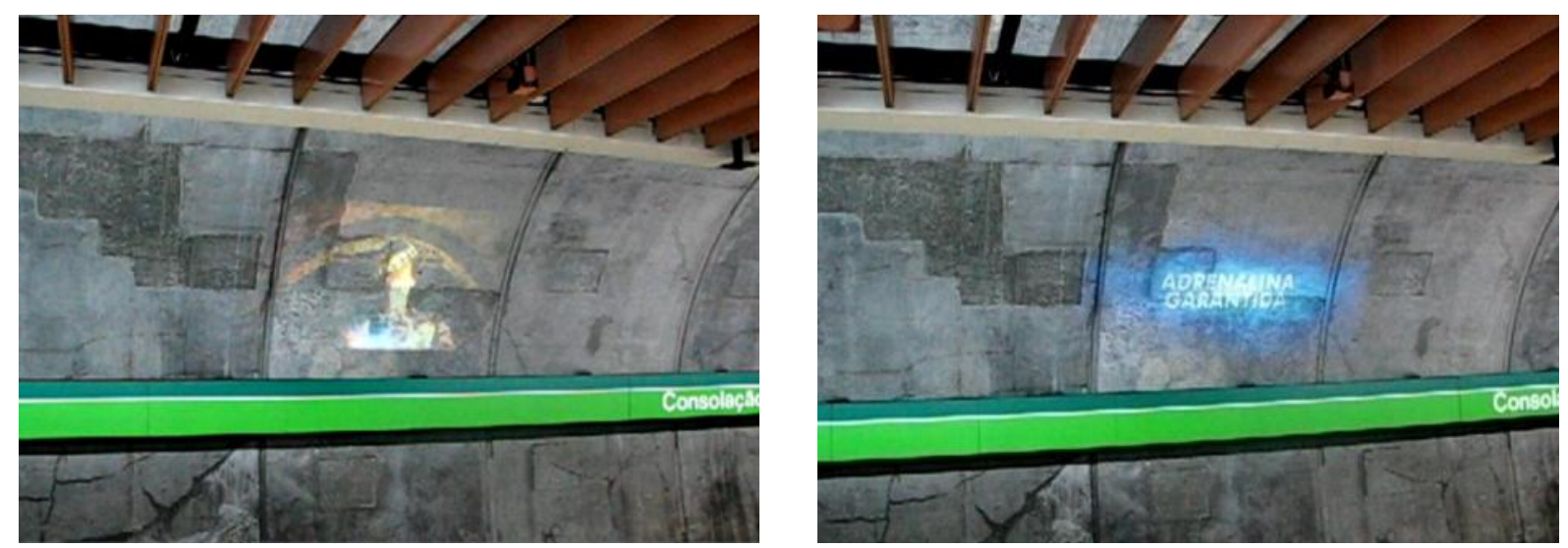

Figuras 27 e 28: Projeções de propaganda de filmes na parede em frente à plataforma da Estação Consolação, 2010. Fonte: Registro fotográfico realizado pela pesquisadora.
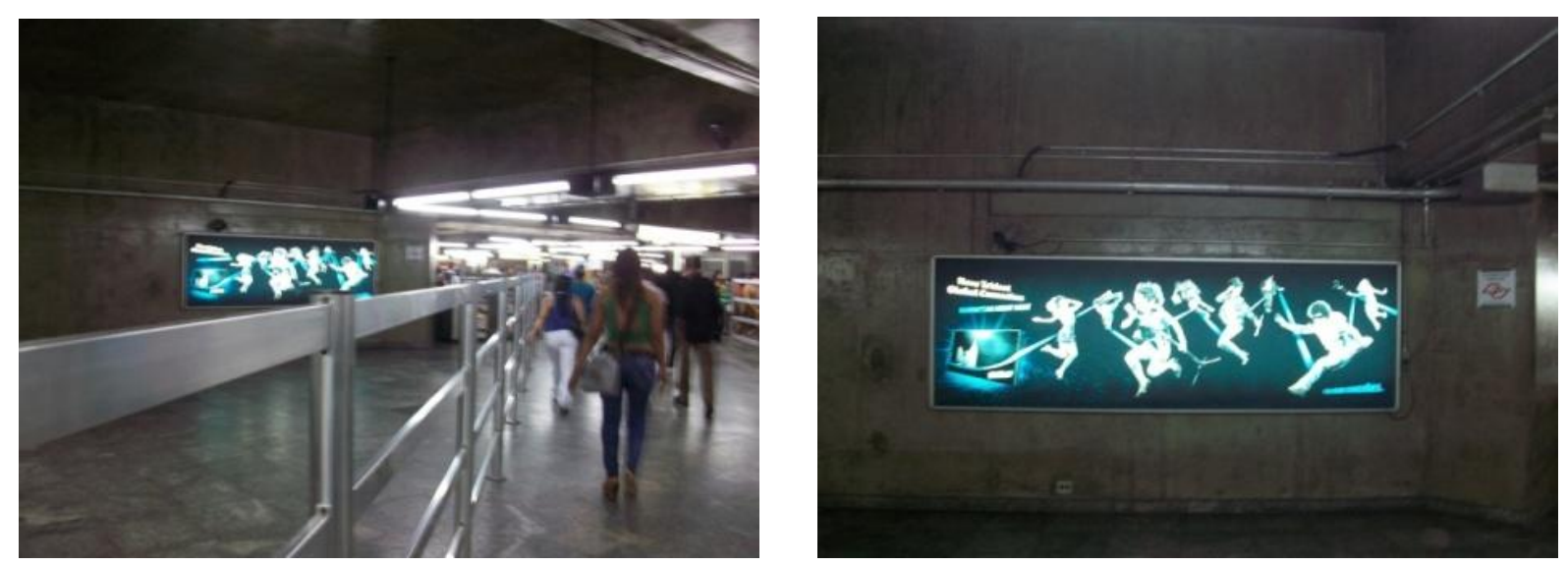

Figuras 29 e 30: Painel luminoso próximo às catracas da Estação Sé, 2010. Fonte: Registro fotográfico realizado pela pesquisadora. 

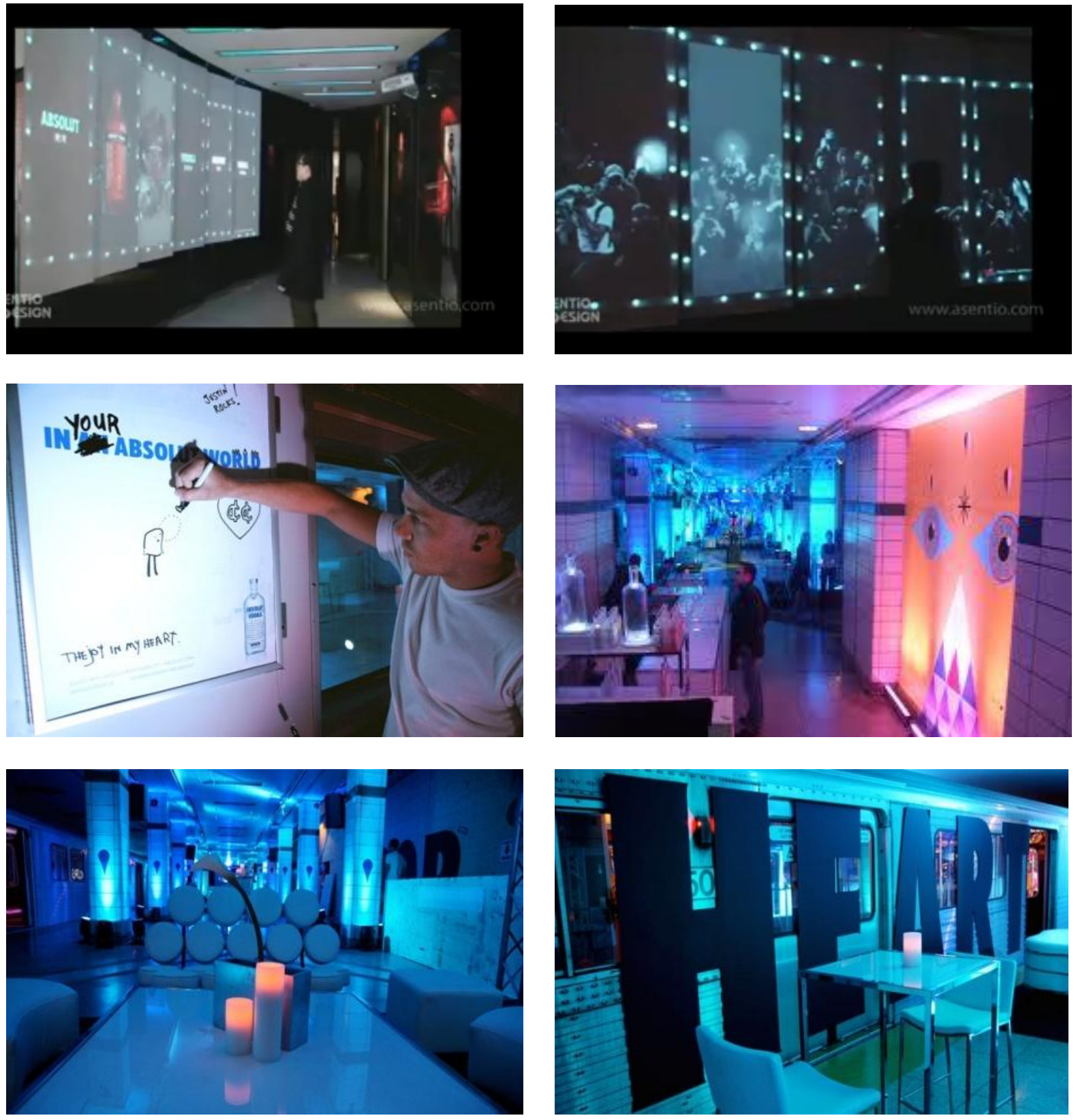

Figuras 31, 32, 33, 34, 35 e 36: Intervenção interativa de Justin Broadbent para festa da empresa de vodka Absolut na Bayção do metrô de Fonte:<http://www.blogto.com/arts/2009/08/absolut_lower_bay_subway_station/>. Acesso em 27/11/10.

Quanto à definição dos espaços das estações, são frequentemente entendidos como "espaços de passagem", como "não-lugares" (AUGÉ, 1994). No entanto, o filósofo e pesquisador de culturas urbanas, Armando Silva, os define de forma particular.

(...) o metrô é um "sítio", no sentido greco-latino, não é um "não-lugar". Lugar é uma coisa mais arquitetônica, mais relacionada ao espaço físico, enquanto que, "sítio" está relacionado à pessoa. A pessoa está ocupando 
um espaço, está fazendo um "sítio". Contemporaneamente, temos mais "sítios" que lugares. (SILVA, 2010).

Afirma Silva: o que Augé chamava de "não-lugar" é um "sítio contemporâneo".

O metrô é um "sítio contemporâneo" muito forte onde acontecem muitas coisas cidadãs. As pessoas ouvem música, há muita atenção, muito perigo, muitas coisas psicológicas estão acontecendo. É um "sítio existencial". "Não-lugares", são lugares que não têm discurso, que não são visitados ou são visitados por muito poucas pessoas, que não têm reflexão coletiva. $O$ metrô é um bom exemplo de sítio autêntico, muito urbano, de muita vida coletiva.

No decorrer dos levantamentos in loco, foi possível verificar que, realmente, não se tratam de espaços exclusivamente destinados à passagem, de "não-lugares". Pelo contrário, o comércio e a publicidade, intensamente praticados nesses espaços, comprovam isso. Algumas estações dispõem de serviço de biblioteca. Usuários marcam encontros, estudam nesses espaços.

O conjunto de informações colhidas em campo, no levantamento bibliográfico e nas pesquisas existentes sobre o tema, realizadas pelo psicólogo Ricardo Gomides Santos, pela socióloga Márcia Pinheiro e pela arquiteta Conceição Midori Hatanaka, indicavam que o diálogo entre artista plástico e arquiteto no desenvolvimento dos projetos das estações de São Paulo, até o ano de 2009, era inexistente. O Projeto Arte no Metrô e o Programa Ação Cultural também passaram por transformações, seja na composição da comissão que avalia as propostas artísticas, no tipo de trabalho aceito, no financiamento das obras. Assim, tornou-se necessário saber, junto aos artistas, como o processo tem sido realizado de fato.

Paralelamente às pesquisas de ordem teórica, histórica, técnica e de levantamento das obras do acervo permanente, ocorreram ações de parceria do Metropolitano de São Paulo com o Itaú Cultural, a Federação das Indústrias do Estado de São Paulo FIESP e o Serviço Social da Indústria - SESI, que proporcionaram aos usuários/espectadores a apreciação e a experimentação de obras interativas temporárias desenvolvidas com dispositivos tecnológicos. As instalações da Exposição Arte Cibernética- Acervo Itaú Cultural, só tinham sentido se acionadas pelo usuário/espectador/ator através do seu deslocamento, do sopro ou do acionamento de teclas. Os games do $11^{\circ}$ Festival Internacional de Linguagem

\footnotetext{
${ }^{8}$ Armando Silva em entrevista concedida à pesquisadora, 2010 (APÊNDICE A).
} 
Eletrônica-FILEPAl (2010), exigiam a interface usuário-computador através de mouses e de controles-remoto. No $12^{\circ}$ Festival Internacional de Linguagem Eletrônica-FILEPAI (2011), além de games e animações, que exigiam a mesma interface, na área externa de algumas estações, foram exibidas réplicas de uma mesma instalação acionada por celular. Tratava-se de exemplos práticos de aplicação de tecnologias atuais e de comportamento social que eram extensões de transformações culturais que o mundo contemporâneo tem vivenciado. Os trabalhos exibidos e as entrevistas realizadas com usuários/espectadores/atores, monitores e técnicos de manutenção no decorrer das exposições ${ }^{9}$, trouxeram respostas a algumas indagações iniciais e comprovaram, em parte, a hipótese levantada da possibilidade de aplicação e aceitação de tecnologias atuais em obras tecnológicas, no caso, temporárias.

Diante dos conceitos contemporâneos e da aplicação de tecnologias atuais nos projetos arquitetônicos das recentes estações do Metropolitano de São Paulo (uso de LEDs (Light Emitting Diode) na iluminação, portas automáticas nas plataformas, escadas rolantes inteligentes, esteiras rolantes, composições sem operador) e em obras artísticas temporárias da 27a Bienal de São Paulo (2006) e da Exposição Arte Cibernética (2010) e FILEPAls (2010 e 2011), porque não aplicar tais recursos contemporâneos em intervenções ambientais permanentes para os espaços das estações do Metropolitano de São Paulo?

Em busca de elementos que comprovassem a hipótese levantada em sua plenitude, e partindo do princípio de que a atividade projetual do artista não pode isolar o objeto proposto do público/espectador/usuário, do espaço em que será inserido, e tampouco, ignorar as condicionantes de projeto e as qualidades técnicas e estéticas dos produtos atuais, foram realizados estudos sobre condicionantes para propostas de intervenção nas estações, de materiais convencionais que passaram por transformações significativas: as tintas de emulsão acrílica e o glass reinforced concret (GRC) e das tecnologias contemporâneas: LED, célula fotovoltaica, mídias eletrônica e digital e linguagem da projeção, seguidos de exemplos práticos de aplicação nos campos das artes plásticas, da arquitetura e do design. Aproximando do objeto de estudo desta tese: "arte" em estações de metrô, foi realizada a pesquisa de exemplos práticos de aplicação dessas tecnologias em estações de

\footnotetext{
${ }^{9}$ As entrevistas encontram-se no APÊNDICE B.
} 
metrô do âmbito internacional. A verificação do que tem sido feito em termos de projetos artísticos, arquitetônicos e de design, abriu caminho para o conhecimento de formas de atuar e de política cultural que poderão vir a contribuir para melhor gerenciá-los e para melhor desenvolver, apresentar e instalar obras artísticas nas estações paulistanas.

\section{Estrutura e Descrição dos Capítulos}

A presente tese está estruturada em três eixos: conceitual, histórico e técnico, que irão fundamentar a hipótese da possibilidade de aplicação e da aceitação de tecnologias atuais em intervenções ambientais temporárias e permanentes no espaço público das estações de metrô de São Paulo.

No primeiro capítulo, a partir de visões de autores de diferentes campos do conhecimento, serão apresentados conceitos atuais relacionados à paisagem urbana: cidade, espaço público, público e o objeto de estudo "arte pública", objetivando o maior entendimento da importância da arte inserida no contexto da sociedade contemporânea e das formas de manifestação artística proporcionadas pelo uso de tecnologias atuais. A especificidade do lugar se insere como um dos critérios que atribui significados e qualifica a arte pública ao envolver compromissos de ordem estética, histórica, ideológica, social, política e cultural da obra.

No segundo capítulo são abordados: o Projeto a Arte e o Planejamento - COGEP, as Intervenções Urbanas: Arte Cidade I e ll e o Arte na Cidade, ações financiadas ou cofinanciadas pelo poder público da Secretaria de Cultura do Município de São Paulo e da Secretaria de Cultura do Estado de São Paulo que possibilitaram a prática de intervenções artísticas em espaços públicos e privados da paisagem urbana paulistana. Aborda também aspectos relevantes da Lei de Incentivo Fiscal da Prefeitura de São Paulo.

No terceiro capítulo são apresentadas considerações sobre o processo de reestruturação e intervenção visual na Praça da Sé, momento em que foram inseridas as primeiras obras de arte nas estações. Em seguida, parte para um breve histórico do Programa Ação Cultural e do Projeto Arte no Metrô alcançando o levantamento do acervo de obras permanentes e as obras temporárias 
desenvolvidas com tecnologias atuais, exibidas na Exposição Arte CibernéticaAcervo Itaú Cultural (2010), nas la e $2^{a}$ edições do Festival Internacional de Linguagem Eletrônica-FILEPAI (2010 e 2011) e no FILE 2012, em parcerias da Companhia do Metropolitano com instituições privadas. Aborda os significados pretendidos para a arte inserida nas estações e as condicionantes para a apresentação e execução de propostas de obras permanentes e temporárias. A partir de informações colhidas em pesquisas de campo e em entrevistas junto aos usuários/espectadores/atores, monitores e técnicos de manutenção dessas exposições temporárias são apresentadas considerações sobre a percepção/aceitação das obras, o comportamento social e os significados atribuídos a elas por parte dos usuários/espectadores/atores.

No quarto capítulo, com referência em depoimentos colhidos junto a artistas plásticos que possuem obra de sua autoria como parte do acervo permanente, que tiveram propostas aprovadas mas que não foram executadas, que pretendem apresentar propostas de intervenção, que exibiram obra desenvolvida com tecnologia atual nas exposições anteriormente mencionadas e que trabalharam de forma integrada com o arquiteto das estações Cardeal Arco Verde e Cidade Nova do Rio de Janeiro, são apresentadas considerações que auxiliam na compreensão de como tem sido de fato a atuação do artista junto ao arquiteto no processo de inserção das obras de arte no espaço arquitetônico em questão, buscando relações com os conceitos de projeto interdisciplinar e de site-specific e o que pensam esses profissionais a respeito da aplicação de tecnologias atuais em intervenções temporárias e permanentes para o metrô, do significado dessa arte, da definição desses espaços e da influência de regras normativas na forma de atuar e de criar.

No quinto capítulo, é realizado o estudo técnico de alguns materiais convencionais que passaram por evoluções significativas em função de avanços tecnológicos e de tecnologias atuais que têm possibilitado a criação, o desenvolvimento e a execução de projetos artísticos, arquitetônicos e de design para a cidade contemporânea, acompanhado de exemplos práticos de aplicação.

No sexto capítulo, retomando o objeto de estudo "arte" no contexto das estações de metrô, são apresentados exemplos de aplicação de tecnologias atuais em intervenções ambientais nos espaços públicos de estações do âmbito internacional, formas de atuar de algumas redes e política cultural da rede parisiense. 



\section{CIDADE . ESPAÇO PÚBLICO . ARTE PÚBLICA . ARTE PÚBLICA INTERATIVA PÚBLICO . SITE-SPECIFIC}

A paisagem urbana contemporânea é objeto de estudo de diversos campos do conhecimento, o que revela, em sua essência, a coexistência das dimensões: sociológicas, históricas, econômicas, políticas, antropológicas, psicológicas, estéticas, culturais, científicas e tecnológicas. Para o artista, o arquiteto e o designer, a importância dessa paisagem vem da diversidade de elementos, espaços e funções, em constante tranformação, que a constituem e das possibilidades que oferecem à reflexão e à ação. Através da apresentação de diferentes visões sobre os conceitos de cidade, espaço público, arte pública, arte pública interativa, público e site-specific, esta tese objetiva tecer um panorama interdisciplinar que possa contribuir para o entendimento da relevância do elemento arte inserido no contexto da sociedade contemporânea e das formas de manifestação artística proporcionadas pelo uso de tecnologias atuais. Os pensamentos investigados, não são considerados aqui como verdades absolutas, mas como extrações culturais que apontam para a aplicação e a aceitação dessas tecnologias em intervenções ambientais no campo ampliado das cidades contemporâneas, do qual fazem parte as estações de metrô.

As apresentações têm início adotando como recorte o conceito de cidade, o mais abrangente, ao qual estão diretamente relacionados os subsequentes. Para o antropólogo Massimo Canevacci, nos anos 1970, houve o início de um processo de transição da cidade industrial para 0 que ele denomina "metrópole comunicacional". Esse processo vem ocorrendo lentamente e tende a transformar a fábrica da produção industrial, entendida como um local que dava sentido de transformações econômicas, políticas, culturais e sociológicas da cidade, em um "policentrismo" em que o consumo, a comunicação e a cultura apresentam relevância ainda maior do que na era industrial. Afirma que, para melhor compreender a metrópole da era digital, também é necessário que nos atenhamos às mudanças nas visões contemporâneas voltadas ao urbanismo, à arquitetura, ao design, à publicidade e à arte. Em diversas localidades do mundo, têm sido desenvolvidas propostas inovadoras enquanto possibilidades de forma, 
percepção do espaço e comunicação, que se devem, em parte, ao uso de mídias eletrônicas que têm favorecido a criatividade dos profissionais. Mobilidade, fluidez e hibridização são parte da experiência cultural, corporal, e também urbanística, da metrópole contemporânea. Neste sentido, alerta que a Cidade Polifônica ${ }^{10}$ ainda encontra-se profundamente marcada pela tradição modernista ${ }^{11}$, ou seja, inadequada à realidade contemporânea. (CANEVACCI, 2008).

\begin{abstract}
Então para entender essa nova metrópole é fundamental olhar o tipo de reforma, não somente urbanística, mas de prédio, de loja, e especialmente de museus, de lugares de exposições, que tem como forma arquitetônica um tipo de desenho, mas também de lógica que é pós-euclidiana. Então, se a gente olha um pouco a grande área metropolitana do mundo, esse é um desafio que é muito estagnado. Por que no Brasil, São Paulo que é uma cidade modernista, também Porto Alegre, mas São Paulo muito mais, não consegue desenvolver um tipo de arquitetura adequada à contemporaneidade. É como se a arquitetura no Brasil fosse ainda modernista, ou minimalista às vezes. E não estivesse dentro desse fluxo de desenvolver formas inovadoras, que favoreçam um tipo de percepção, de sensorialidade, e de comunicação que outras áreas metropolitanas favorecem. Então, esse tipo de transição significa que o território não é mais como antes. Que também a etnicidade, a sexualidade, a família, a identidade, são muito mais pluralizados. Tudo é muito mais possível (...) a flexibilidade é parte constitutiva do conflito contemporâneo. (CANEVACCI, 2008).
\end{abstract}

Nelson Brissac Peixoto ${ }^{12}$ chama atenção para a consolidação das "megalópoles", cidades que alcançam grandes escalas, com proporcional complexidade, que "não se ajustam mais às formas convencionais de estrutura urbana e arquitetônica, de organização e percepção do espaço, fenômeno acentuado pelos efeitos da integração globalizada e dos novos meios de comunicação" que têm alterado

\footnotetext{
${ }^{10}$ Em A Cidade Polifônica: ensaio sobre a antropologia da comunicação urbana, publicado em 1993, Canevacci atribui o termo "Polifônica" à cidade de São Paulo no sentido de que cada um de seus fragmentos possui uma história. A interpretação da história de cada fragmento só poderia ser realizada através do estudo de cada um deles sem estabelecer uma relação dialética com a totalidade, explica o autor. (CANEVACCI, 1993).

${ }^{11}$ Como complementação a esse pensamento, citamos as palavras de José Correia Tavares de Lira:

"No Brasil, a sensação predominante nas últimas duas décadas é que os espaços de discussão de arquitetura e urbanismo tornaram-se cada vez mais escassos. Enquanto avançava a pesquisa especializada, a arquitetura parecia perder relevância cultural: sumiam público e críticos, periódicos de arquitetura convertiam-se em vitrines de escritórios e fabricantes, dissolviam-se os elos entre arquitetura, as artes e o pensamento, assim como entre reflexão e prática projetual, levando o meio profissional brasileiro à desorientação e ao conformismo mais conveniente.

É provável que este curto-circuito que se produziu depois da construção de Brasília tenha algo a ver com a forma como a modernidade arquitetônica passou a ser interpretada entre nós. Sobretudo desde o golpe militar de 1964. De um lado, a partir da exacerbação do viés produtivista da arquitetura moderna em favor da construção estatal e especulativa pesada; de outro, a partir da denúncia de sua face aparatosa e autoritária em meio à crise das promessas de desenvolvimento social e autonomia nacional. A impressão que se tem é que, com o passar dos anos, o debate da profissão chegou a um ponto de saturação tal que, enrijecidas em suas próprias convicções, nenhuma das posições em voga no país - ultra, pró, pós ou anti-modernas - tem muita coisa a nos dizer quando o assunto é o que fazer da arquitetura para além do mero consentimento com exercícios de estilo pessoal, da escola ou oportunidade." (LIRA, José Tavares Correia de. In NESBITT, Kate (org). Uma nova agenda para a arquitetura. Antologia teórica (1965-1995). São Paulo: Cosac Naify, 2006.)

${ }_{12}$ Nelson Brissac Peixoto: sociólogo, filósofo e curador.
} 
"dispositivos tradicionais de proximidade e distância e conexões entre as diferentes regiões e cidades do planeta." Locais posicionados e circunscritos passam a ser cada vez mais ilimitados, genéricos e amorfos. Locais desprovidos de história, esvaziados de suas características arquitetônicas e sociais, transfigurados em suas funções urbanas. São áreas urbanas marcadas por processos de desindustrialização, desertificação e reconstrução, e por uma reinserção altamente tensionada, através de novas vias expressas de transporte e de comunicações, transformados em manchas metropolitanas muito mais vastas. Não se tratam mais de locais, mas, de "territórios urbanos" (PEIXOTO, 2002, p.21). Sob outro ponto de vista, Lorenzo Benedetti ${ }^{13}$, vê a cidade como "interface da arte", como um "grande teatro de ação", "um imenso espaço expositivo", "uma infinita fonte de inspiração para articular novas formas e novos conceitos". Entende a cidade como cenário de um novo panorama artístico independente das estruturas tradicionais de museus e centros de arte "que se deslocam para dinâmicas globalizantes". Ela se converte em "uma alternativa ao lugar do museu, se converte no âmbito do site-specific, onde o artista se sente livre em utilizar e dar vida às partes da cidade contextualizando-as como espaço expositivo." (BENEDETTI, 2003, p. 29-31, tradução nossa). Para o autor, a cidade é o contexto adequado para criar e expor arte, é território para a prática de atitudes relacionais que podem vir a remodelar e a transformar a paisagem urbana.

A cidade é por si um contexto adequado para criar e expor arte. (...) A
cidade é um grande entrelaçamento de vidas e pessoas. Intercâmbios,
choques e fusões são leis fundamentais que vivem a cidade em seus
diversos níveis. E assim, a cidade é também território de uma série de
atitudes relacionais. Começa implantar-se a possibilidade de remodelar e
transformar a paisagem da cidade mediante a direta intervenção das
pessoas. (BENEDETTI, 2003, p. 29-31, tradução nossa).

Na concepção de Armando Silva ${ }^{14}$, temos a "cidade imaginada", interpretada como "a imagem de um mundo", definição que se complementaria se também fosse entendida como "o mundo de uma imagem que lenta e coletivamente vai sendo construída e volta a construir-se, incessantemente." A traduz como "lugar de acontecimento cultural", "cenário de um efeito imaginário", "uma densa rede

\footnotetext{
${ }^{13}$ Lorenzo Benedetti: curador.

${ }^{14}$ Armando Silva: filósofo, docente e pesquisador de culturas urbanas da Universidade Externado, Colômbia.
} 
simbólica em construção e expansão" que "se parece com seus criadores", que são feitos por ela. O que diferencia uma cidade da outra

(...) não é só sua capacidade arquitetônica que ficou para trás após o modernismo unificador em avançada crise, mas os símbolos que os seus próprios habitantes constroem para representá-la. E os símbolos mudam como mudam as fantasias que uma coletividade elabora para fazer sua urbanização de uma cidade. (SILVA, 2011, p. XXV-XXVI).

Para Claudio Tozzi ${ }^{15}$, uma característica do novo processo de pensar o espaço urbano, propõe "um modelo de gestão da cidade que estabeleça direções para seu desenvolvimento" o que estimula um "crescimento ordenado" e possibilita "novas relações com a natureza e o social". O novo modelo "abrange o conceito de espaço total, cria uma cidade nova e não somente recupera espaços já construídos. É o conflito do existente visível com o 'vir a ser' planejado, incorporando um certo grau de incerteza, de conflitos e de diversidades" que transformam a cidade em um “organismo", "em constante mutação, próprio dos processos de criação e inovação". O complexo ato de intervir na cidade inclui, dentre outras questões, integrar as artes plásticas ao novo sistema, em um "processo de trabalho interdisciplinar" que requer uma formação "ampla em informações tecnológicas e em conhecimento dos valores humanos", de forma a "abranger questões mais amplas" que o ato de criar (TOZZI, 2001).

As correlações entre eventos globais e ações locais nas cidades contemporâneas têm caracterizado a formação do espaço público de uma maneira particular. Judith Laister ${ }^{16}$ esclarece que na década de 1960, momento em que o espaço público tornou-se foco da atenção urbana e artística, o conceito de 'público' era uma referência ao legado do iluminismo cívico e transmitia a ideia de participação crítica da vida em sociedade. O conceito de 'espaço' referia-se a um espaço territorialmente concebido, encapsulado, que era de livre acesso a todas as pessoas, a qualquer momento, ao contrário dos espaços privados e institucionais. Dessa forma, o espaço público, deveria estar disponível "para todos" e ser usado "por todos" como um local para a comunicação social e para a criação. Falar em espaço público foi uma expressão política, técnica e de desenvolvimento urbano

\footnotetext{
${ }^{15}$ Claudio Tozzi: artista plástico, formado arquiteto pela Faculdade de Arquitetura e Urbanismo da Universidade de São Paulo onde atua como docente.

${ }^{16}$ Judith Laister: antropóloga da Universidade de Graz, Áustria.
} 
associada a uma dupla crítica: "por um lado, a 'transformação estrutural da esfera pública'" em que

o público foi substituído por 'relações públicas', que como um instrumento de sugestão e manipulação, suplanta os processos críticos de socialização. Por outro, a falta de hospitalidade 'de nossas cidades' em uma era de modernização e aumento da automobilização foi declarada, através do qual o espaço urbano foi degradado a um elemento funcional para o movimento. (LAISTER, 2007, p.431, tradução nossa).

Atualmente, o espaço público continua sendo negociado por estes dois caminhos. Pode ser considerado ainda "um modelo icônico democrático e um espaço de negociação para os diversos interesses da sociedade". No entanto, os fatores que influenciam a visibilidade e o estabelecimento dessas duas posições têm se multiplicado. Política, economia e tecnologia passaram por transformações (LAISTER, 2007, p.431, tradução nossa).

O espaço físico não perdeu seu significado, apesar de prognósticos influenciados por muitos - 'globalization and media-euphoria'. Pelo contrário, está novamente desfrutando atenção especial como instrumento estratégico para a representação do poder. (...) No contexto de uma 'overmodern global community', a negociação do espaço público torna-se uma questão de acesso e de exclusão, participação e distinção, centro e periferia, tanto local quanto globalmente. (LAISTER, 2007, p. 431, tradução nossa).

Para Ricardo Barreto ${ }^{17}$, o "ambiente público" não pode ser definido como o ambiente dos museus e galerias "vazio, asséptico e morto", pelo contrário, "trata-se de um ambiente pleno de vida, com múltiplos interesses e com múltiplos comportamentos". No mundo contemporâneo das megacidades, das sociedades dinâmicas, a "ambiência pública urbana" tornou-se um sistema complexo, no qual "estão inseridas milhares de variáveis, com milhares de pessoas que vivem, estudam e trabalham". Formatada pelo Estado através de "leis, regras e adestramentos comportamentais", também é um "potencial imanente de acontecimentos emergenciais" dos quais fazem parte as manifestações advindas da internet, provenientes de uma sociedade de redes virtuais, "que exige de seu usuário um desempenho interativo e participativo". (BARRETO, 2010, p. 90).

\footnotetext{
${ }^{17}$ Ricardo Barreto: filósofo, artista, organizador do I Festival Internacional de Linguagem Eletrônica-FILE.
} 
Se, por um lado, a ambiência urbana é formatada transcedentalmente pelo Estado, pelos governos, através das leis, regras e adestramentos comportamentais, mas também pelo controle e pela repressão, incluindo o mercado - através da publicidade e da produção da subjetividade, por outro lado, ela é um potencial imanente de acontecimentos emergenciais: a greve; a passeata; os grafites urbanos; a pichação; as atuais manifestações advindas da internet, mas também uma sociedade que cada vez mais vive em redes virtuais que exige de seu usuário um desempenho interativo e participativo. (BARRETO, 2010, p. 90).

Ao considerar que a arte em espaço público abrange todo o espectro de formas artísticas, Claudia Büttner ${ }^{18}$, entende que o conceito de espaço público está sujeito a uma redefinição (BÜTTNER, 2007, p.332, tradução nossa). Esta afirmação se completa com o pensamento de Armando Silva; para o filósofo e pesquisador de culturas urbanas, a arte digital, também é "arte pública porque, hoje, nós temos arte pública não somente no espaço físico mas, o espaço virtual também é parte do espaço público. No espaço público, o que mais se está fazendo é a arte digital, é a arte pública." (SILVA, 2010).

Com referência em outros autores, Vera Pallamin ${ }^{19}$, busca esclarecer a diferença entre arte em lugares públicos e Arte Pública, objeto de estudo desta tese. A arte em lugares públicos, refere-se a "trabalhos de arte comprados ou comissionados para espaços acessíveis publicamente ou de propriedade pública. É a arte tornada pública, fora de casa ou do museu" (BEARDSLEE, 1981 apud PALLAMIN, 1994, p. 24) ${ }^{20}$. A Arte Pública, por outro lado, engloba uma situação mais complexa,

envolvendo em seu papel social, convicções nem sempre compartilhadas entre seus autores e público, assim como outras preocupações em relação à trama urbana, tais como a especificidade em relação ao seu lugar de ocorrência. (...) Tem sido definida como 'uma manifestação de atividades e estratégias artísticas que tomam a idéia de público como gênese e tema de análise'. (PHILLIPS, s/d, apud PALLAMIN, 1994, p.24) 21 .

Em outros termos, sua adjetivação tem sido construída sobre os sentidos, conflitos ou situações urbanos para os quais se volta, e não em função de seu volume e audiência. (DEUTSCH, $s / d$, apud PALLAMIN, 1994, p.24) ${ }^{22}$.

\footnotetext{
${ }^{18}$ Claudia Büttner: filósofa, historiadora de arte e curadora, Berlim.

19 Vera Pallamin: arquiteta, docente da Faculdade de Arquitetura e Urbanismo da Universidade de São Paulo, coordenadora do Ateliê de Escultura da FAU-USP.

${ }^{20}$ BEARDSLEE, J., Personal Sensibilities in Public Places. Artforum, Summer, 1981, p.43.

21 PHILLIPS, P. C., Temporality and Public Art. In SENIE, H. F. ed., 'Critical issues..., s/d. p.301-3.

22 DEUTSCH, R., Public Art and its Uses. In SENIE, H. F. ed., 'Critical issues..., s/d. p.301-3.
} 
Diante das constantes transformações na paisagem urbana pública, a Arte Pública contemporânea se faz simultaneamente, de forma específica e temporária. Sem a intenção de exprimir valores eternos, de expressar um tema irrepreensível e acessível a todos, suscita controvérsias quanto à sua recepção. Pode ser instalada em lugares indiscretos, marginais e não-tradicionais. Nesse sentido, o espaço público de uma estação de metrô de New York é citado como exemplo pela autora. ${ }^{23}$

\begin{abstract}
(...) objetos duráveis expressando permanência/perpetuidade tem dado lugar a manifestações do efêmero e do surpreendente. Neste contexto, sem pontos fixos, a arte e a vida públicas vão refazendo suas texturas continuamente, movimentando-se, com isso, a própria definição de público assim como a relação de público/privado que a sustenta. Nessa trama, a Arte Pública mostra-se como sendo, ao mesmo tempo, específica e temporária. Não vigora, neste campo, a idéia de se exprimir valores eternos para uma vasta platéia, nem a expectativa de se expressar um tema irrepreensível e acessível a todos. Irreverente a esses aspectos, a Arte Pública contemporânea frequentemente suscita controvérsias no âmbito da sua recepção, permitindo-se ocorrer e se instalar em lugares indiscretos, marginais e não-tradicionais (PALLAMIN, 1994, p. 24).
\end{abstract}

Oliver Marchart ${ }^{24}$ considera que práticas artísticas públicas, em muitos casos, aspiram à relevância por grupos políticos e sociais. O adjetivo 'público' não identifica o local da intervenção, mas o tipo de intervenção (PHILLIPS, 1995 apud MARCHART, 2007, p.426) ${ }^{25}$. São práticas que devem ser julgadas, sobretudo, por seu caráter político (MARCHART, 2007, p.426, tradução nossa).

Historicamente, para Ricardo Barreto, a Arte Pública é uma prática muito antiga "que era vista inicialmente pelo público clássico pré-tecnológico, de modo teofânico: através das obras de 'arte', as divindades tornavam-se presenciais e adquiriam vida na vida das pessoas". Naquela época, como garantia da presença dos deuses, templos, estátuas e tragédias faziam parte do cotidiano dos cidadãos comuns. "A arte distribuída pela cidade era de tal maneira imanente a eles, que desconheciam o conceito de arte pública como algo separado de suas vidas". Na modernidade, com a separação entre arte e vida, a arte em geral, tornou-se meramente "estética e

\footnotetext{
${ }^{23}$ Em New York, a plataforma de metrô Spring Street (linha para Wall Street) foi alvo da intervenção produzida e financiada pelo artista Alfredo Jaar. Seu trabalho substituiu imagens de propaganda local por dois painéis fotográficos que retratavam a corrida do ouro no Brasil, em Serra Pelada, e as condições em que viviam os trabalhadores envolvidos nessa atividade. Entre os painéis, havia uma complementação feita regularmente com a inserção de posters com as cotações diárias do ouro em New York, Frankfurt, Londres e Tóquio. Naquele local, "caracterizado pelo temporário e pelo rápido deslocamento, o público foi levado a tirar suas próprias conclusões sobre a instalação (sem textos explicativos), sendo envolvido numa expressão sobre sua cumplicidade em eventos mundiais. Ressalta-se ainda, que o rápido aparecimento e desaparecimento dessa obra contribuiu para acentuar a urgência presente em seu próprio conteúdo." (PHILLIPS, s/d, apud PALLAMIN, 1994, p. 30-31).

${ }^{24}$ Oliver Marchart: professor de sociologia da Universidade de Lucerne, Suíça.

25 PHILLIPS, Patricia C. Private Acts and Public Art. In Felshin, 1995 (fn.1) p. 286.
} 
transcendente" e passou a ser exposta em galerias e museus, o que a afastou do público comum (BARRETO, 2010, p.90).

\begin{abstract}
No século $X X$, com a modernidade não representacional, a arte pública se deparou com novos desafios: levar obras abstratas e conceituais à fruição pública em geral. O desafio era trazer o grande público para as artes modernas. A arte pública moderna contemplativa, no entanto, não conseguiu, na maioria dos casos, o objetivo por ela proposto e viu, pelo contrário, o grande público se afastar ou ignorar tais manifestações, chegando em alguns casos à pura aversão (BARRETO, 2010, p.90).
\end{abstract}

Algumas obras chegaram a ser removidas pelo poder público por solicitação popular. Tal consequência,

advém de uma visão analógica dos fomentadores de arte pública contemplativa. Eles vêem o espaço público como um mero espaço vazio a ser preenchido: de um lado, por obras que originalmente foram feitas para o mercado de arte e não especificamente para ele, e de outro, por comportamentos padronizados, tais como o do cubo branco adotado pelo museu e pela galeria de arte (BARRETO, 2010, p.90).

Para Claudia Büttner, o termo arte em espaço público surge no momento em que se torna necessário para designar obras de arte criadas especialmente para 0 espaço urbano, distinguindo-as das obras de atelier da escultura moderna colocadas em parques e jardins. Em meados século XX, como mencionado anteriormente, ocorreram os primeiros esforços no sentido de situar a arte no espaço público. A questão principal era levá-la para fora do contexto do museu e, mais uma vez, fornecer-lhe uma função no domínio público. Naquele momento, "enquanto artistas aspiravam conseguir visibilidade para seu trabalho, tirar proveito da produção e novas oportunidades de exposição, políticos culturais e planejadores urbanos, estavam preocupados com a configuração estética do ambiente e de domínio público". Atualmente, é um "termo vago, mas comumente usado para a arte situada em espaços ao ar livre nas cidades e comunidades locais" (BÜTTNER, 2007, p.332, tradução nossa).

Lilian Amaral Nunes ${ }^{26}$ reforça a ideia de que "a arte como instância pública ou social está redefinindo os conceitos de arte pública e de espaço público". A partir dos anos 1980, o conceito de arte pública fica vinculado ao espaço público. Com o sistema de desenvolvimento urbano massivo e acelerado, as cidades têm sido transformadas em "espaços de proveito privado sob um controle público, criando bolsas

\footnotetext{
${ }^{26}$ Lilian Amaral Nunes: artista audiovisual, curadora.
} 
urbanas de desamparados, uma vez que o desenvolvimento e a reestruturação dos espaços urbanos têm destruído sistemas precários de sobrevivência nas grandes cidades." Nesse contexto, a arte tem assumido o "papel de elemento de coesão, considerando que aspectos de monumentalização, decoração, embelezamento do espaço público estão em declive" (NUNES, 2010, p.32).

A “'nova arte pública' surge do conflito e da opressão que geram esses novos espaços urbanos". Desde os anos 1960 e 197027, a abordagem interdisciplinar da arte tem transformado a prática em outra "mais alijada do objeto artístico", atribuindo-Ihe "dimensão política e social evidenciada, dado que se estende à prática da arte como uma prática crítica" (NUNES, 2010, p.32). Entretanto, há uma condição para que essa arte crítica aconteça:

Se ao conceito de espaço público acrescentamos o de esfera pública, na qual os cidadãos podem criar estados de opinião críticos contra o estado, o sistema ou a instituição estabelecida, neste contexto, a arte crítica convertese em elemento-chave para interferir na esfera pública, convertendo o espaço público em espaço político. É quase uma condição sine qua non que a arte pública tenha lugar fora dos espaços institucionais da arte, qual seja, 'fora do museu', para garantir sua qualidade pública e total e o livre acesso (NUNES, 2010, p. 32).

Acompanhando as redes de fluxos e lugares de Manuel Castells ${ }^{28}$, e as "massas pós-analógicas que querem se comunicar, editar seus conteúdos e produzir seus acontecimentos", está a Arte Pública Interativa. Nela,

o estético cede lugar à ludicidade/didatismo, e a interatividade substitui as epifanias, bem como os códigos da contemplação do belo e do sublime.(...) A Arte Pública Interativa do século XXI vive no mundo das epistemes digitais - cujas obras, tanto o conhecimento quanto a ludicidade, fruição com interação, são imanentes e inseparáveis (BARRETO, 2010, p.90).

Ao contrário do que ocorreu com as "epistemes transcendentes modernas", nas artes digitais, não há a distinção entre aprender e fruir-interagir ${ }^{29} 0$ que

\footnotetext{
${ }^{27}$ Nos anos 1970, as práticas artísticas foram impulsionadas a partir da "arte expandida e da hiper-realidade social, criando novas formas de implicação da arte com a sociedade, ativando disciplinas como a sociologia, a psicologia, as ciências da comunicação e outras, as quais, em interação com os processos e a sensibilidade artística têm desembocado em uma fusão de arte com realidade" (NUNES, 2010, p. 33).

${ }_{28}$ Manuel Castells: sociólogo, docente de diversas universidades, autor da trilogia "A Era da Informação: economia, sociedade e cultura (1996-2000)", sendo "Sociedade em rede", o primeiro volume.

${ }^{29}$ Para Ricardo Barreto: "Toda obra de arte sempre foi conhecimento e fruição, tanto para quem a faz como para quem a usa. Toda obra de arte implica em algum conhecimento, no mínimo que seja para sua fruição; quando isto não ocorre abre-se um hiato entre a obra e o público. Foi o que aconteceu com as epistemes transcendentes modernas, que separaram o aprender do fruir; outrora, em uma pintura representacional, a cópia podia ser comparada com o original, o que garantia a um público mais amplo algum conhecimento, logo alguma fruição. No período moderno, com a destruição da representação, exceto no cinema, o aprender se separou do fruir,
} 
"garante o retorno do público, do grande público, fora das elites, ao mundo das artes, em um volume nunca visto e que só pode ser trabalhado de forma mais eficaz no mundo contemporâneo com estratégias públicas de interação digital”. Apesar de diversas experiências nesse sentido, as cidades ainda estão despreparadas para esse novo mundo em que a inovação:

é o principal motor da economia. Inovações em que o uso de computadores e celulares está transformando as multidões em massas inteligentes e emergenciais. (...) O acoplamento cérebro-dispositivo digital está criando a ciber-inteligência e a ciber-criatividade, constituindo nas massas autoorganizações com resultados imprevisíveis. Elas estão se acelerando e tornando-se transconectivas. As emergências serão inevitáveis. (...) Caminhamos rapidamente para uma renovação urbana jamais vista: cidades inteligentes, cidades interativas, cidades emergenciais. (BARRETO, 2010, p.91).

É necessário que os governos se atentem para essa realidade. A arte pública também tem desafios para que possa compreender e absorver os novos fenômenos sociais. É preciso

criar novas interfaces tecnológicas em relação ao público e à cidade; desenvolver estratégias que possam sinergizar os acontecimentos emergenciais que brotam das sociedades contemporâneas, ao invés de tolhê-los; promover táticas públicas no intuito de sair da fase de uso da tecnologia para a fase do aprender a produzi-la, e assim ir da inclusão para a produção digital em massa (BARRETO, 2010, p.91).

Ao considerar que grande parte da população brasileira não tem acesso à rede, Massimo Canevacci fala da necessidade do Brasil contemporâneo colocar em prática uma política comunicacional que favoreça o desafio do "digital divide". A escola pública deveria ser totalmente digitalizada através de uma política de financiamento público e privado (CANEVACCI, 2008).

Com referência nas falas dos autores apresentadas anteriormente, nota-se que, inerente às transformações ocorridas nos conceitos de cidade, espaço público e arte

aprende-se na escola e frui-se no museu, na galeria, no teatro... Assim, o grande público, que não detinha os códigos, se afastou das artes modernas; elas tornaram-se desta maneira elitizadas e especializadas." (BARRETO, 2010, p.90-91). 
pública, está a transformação no conceito de públicolespectador. Embora ainda haja o público que apenas observa e ouve, atualmente, a realidade da comunicação contemporânea tem favorecido que ele "seja parte constitutiva da obra e que possa representar a sua própria história, o seu próprio conto, a sua própria imaginação. A tecnologia digital está favorecendo a criatividade, ou poderia favorecer a criatividade da pessoa, singular, e também como público" (CANEVACCI, 2008). Sendo assim, o público espectador:

vem agora a ser espect-ator, isto é, uma mistura do que participa, mas que é também ator. Espect-ator significa esse tipo de co-participação que desenvolve um tipo de atitude performática no público, um espect-ator performático. Isto é, que não é mais passivo, mas é parte constitutiva da obra. Isso é muito claro no desenvolvimento da tecnologia digital. (CANEVACCI, 2008).

O público está deixando de ser homogêneo, massificado, passando a ser pluralizado, passando a ser "multivíduos"30. "Seja pelo aspecto produtivo, seja pelo aspecto de valores, de comportamento, pela maneira de falar, de estabelecer uma relação com o corpo, e também com a identidade" (CANEVACCI, 2008).

Esse público, usuário do espaço urbano, também pode ser definido como "elemento que aciona a percepção global e contínua do contexto, que estabelece seleções e relações em um repertório contextual" através de seu uso ${ }^{31}$. (FERRARA, 1986, p.120).

Ruas, avenidas, praças, monumentos, edificações, configuram-se como uma realidade sígnica que informa sobre seu próprio objeto: isto é, o contexto. Entretanto, o elemento que aciona essa percepção global e contínua, que estabelece seleções e relações em um repertório contextual é o usuário e o uso é a sua fala, sua linguagem. (FERRARA, 1986, p.120).

\footnotetext{
${ }^{30}$ Para Canevacci, multivíduo é uma pessoa, um sujeito, que tem uma multidão de "eus" na própria subjetividade (CANEVACCI, 2008).

${ }^{31}$ Lucrecia d'Aléssio Ferrara: possui graduação em Letras Neolatinas pela Pontifícia Universidade Católica de São Paulo (1959), doutorado em Literatura Brasileira pela Pontifícia Universidade Católica de São Paulo (1964), professora livre-docente pela Faculdade de Arquitetura e Urbanismo da USP. É professora titular aposentada da FAUUSP e foi professora titular da PUCSP. Atualmente exerce a função de professora doutora junto ao programa de pós-graduação em Comunicação e Semiótica da Universidade Católica de São Paulo. Tem experiência na área de Comunicação, com ênfase em Teoria da Comunicação, atuando principalmente nos seguintes temas: comunicação, cultura, semiótica, arquitetura e design.
} 
Pode ser entendido como "objeto de desejo" (SCHULZ-DORNBURG, 2000, p.12) ${ }^{32}$, uma vez que,

(...) tanto a arte como a arquitetura têm rompido seus moldes históricos. Buscam a inspiração em nossa cotidianeidade e em nossos sonhos. Todos somos agora objetos de desejo. Se analisam nossas rotinas diárias, e a menor aventura é objeto de investigação. Se investigam nossas histórias, e se anotam nossos desejos. 0 comum tem se convertido em algo socialmente aceitável. (...) A arquitetura já não cria estruturas emblemáticas para que sejam admiradas, senão lugares para serem utilizados, sentidos e experimentados. A arte tem substituído o 'objeto' para ser contemplado pelo 'entorno' para ser sentido (...) $\mathrm{Na}$ arte e na arquitetura, a relação entre teoria e prática, entre razão e experiência física, tem sido redefinida. (SCHULZ-DORNBURG, 2000, p.12, tradução nossa).

O público/espectador contemporâneo é um participante que age e interage (BARRETO, 2010, p.90), que "se interessa pela relação entre a arte, a ciência e as tecnologias contemporâneas, que procura informação sobre o assunto e se depara com a escassez de publicações nessa área."33 (VENTURELLI, 2004, p.14). Em alguns casos, o público/espectador/ator, também assume o papel de autor.

Retomando a questão da especificidade da obra de Arte Pública em relação ao local em que está inserida, Vera Pallamin esclarece que, reflexões da crítica sobre o sentido urbano dessa arte, de caráter temporário ou permanente, envolve diretamente compromissos de ordem social, política e cultural. Sua especificidade funcionalista, está restrita "ao ponto de vista físico, sustentando-se numa cesura entre a arte e o social." Nesta versão, a obra é tratada:

(...) sob um ponto de vista instrumental em relação ao espaço urbano, sendo advogada a 'preencher' necessidades sociais. É posicionada como se estivesse acima dos conflitos sociais de que a cidade se faz. (...) É tratada de modo a 'colaborar' na resolução de problemas: pode preencher espaços, atrair expectativas ou agendar usos aos usuários. Pode também ser utilizada como amenidade empregada na valorização de certas áreas de interesse, promovendo sua integração física. Apresenta-se, aparentemente, como um 'bem' para todos. (PALLAMIN, 1994, p. 25-27).

\footnotetext{
32 Julia Schulz-Dornburg: arquiteta.

33 Suzette Venturelli: docente do Instituto de Artes da Universidade de Brasília, artista, organizadora e curadora de exposições e congressos nacionais e internacionais.
} 
Como exemplo desta prática, cita obras escultóricas de Picasso, Calder e Henry Moore, ampliadas e instaladas em espaços públicos de forma autônoma, sem qualquer preocupação com o contexto, utilizadas apenas como marco simbólico em projetos de redesenvolvimento urbano.

Nelson Brissac, aponta outras questões relacionadas ao conceito de site-specific no decorrer da história da arte. A seu ver, para que possamos entender a prática artística e arquitetônica atuais é necessário considerarmos as grandes escalas da metrópole, aliadas à perda de referências históricas e locais que elas provocam. A produção e o debate em torno dessas práticas têm sido marcados por essa questão. Nos últimos anos, "foram desenvolvidos diversos projetos para o espaço urbano, cujas relações com operações de revitalização e desenvolvimento urbano, são cada vez mais complexas e polêmicas, gerando ao mesmo tempo uma reação de fluxo, de reafirmação de autonomia da obra de arte e de retorno ao museu" (PEIXOTO, 2002, p.18). Buscando traçar uma trajetória, o autor observa que a escultura moderna passou de uma lógica do lugar histórico (monumento ou estátua) para uma forma autônoma, um objeto sem lugar, enquanto que a produção contemporânea, inversamente, incorpora aos limites externos a arquitetura e a paisagem, instaurando uma nova lógica do espaço, ou seja, um processo de expansão no campo da escultura que passou a admitir tudo o que era excluído ${ }^{34}$. Quanto ao espectador, ocorre a passagem de uma "contemplação de ambulatória de objetos autônomos", apresentados em um contexto neutro, para viver uma "experiência estética", proporcionada pelo lugar investido esteticamente. O lugar passa a ser edificações sem uso e espaços públicos, espaços de "conotação forte e imediata, capazes de proporcionar experiências com o passado e o significado social e político dos lugares." Desta forma,

(...) as relações com o lugar tornam-se um componente indissociável da obra de arte (...) uma radical alteração na questão da percepção, que passa a pressupor um observador inserido no espaço engendrado pela obra. A obra como objeto que se dilui diante da utilização do lugar como forma de experiência estética (PEIXOTO, 2002, p.18).

${ }^{34} \mathrm{Em}$ seu artigo Sculpture in the Expanded Field, 1977, Rosalind Krauss, teoriza sobre o processo de "expansão" pelo qual passou a escultura e sua inserção no ambiente: espaço construído e não-construído. 
Nos anos 1960, houve a crise dos espaços expositivos tradicionais e a questão era a crítica da autonomia da obra de arte, da escultura entendida apenas por meio das "relações estruturais internas". No final da década foram introduzidas as práticas de sítio específico, entendido como específico em um sentido formal, abstrato e estetizado, o que fez muitos desses trabalhos terem sido reapropriados pelo circuito comercial e serem expostos em museus.

O Minimalismo e as obras para sítio específico, com a valorização de experiência e deambulação, acabariam então, paradoxalmente, formatando uma pragmática baseada no espetáculo da cidade. Com a transformação da cidade no local de exibição, o mapa substitui a obra de arte, a cidade substitui o museu (PEIXOTO, 2002, p.19).

Nos anos 1970, grandes intervenções em espaços abertos (land art) colocaram questões essenciais como a articulação entre a obra e a paisagem circundante, o princípio de que todas as formas de registro são constitutivas de intervenções irredutíveis à experiência individual e à visualização. Os projetos atingiram grandes escalas. Percebe-se, hoje, um interesse em resgatar essas operações. Richard Serra e Robert Smithson radicalizam os procedimentos para o sítio específico recorrendo a escalas, métodos industriais de produção e processos de implantação em vez de simplesmente adequar ao lugar. Introduziram um olhar crítico sobre a situação urbana. Há o surgimento de operações que redefinem a especificidade do sítio ao introduzir um novo tipo de experiência espacial que leva em consideração dimensões institucionais, econômicas e políticas do espaço, enfatizando suas contradições e conflitos. O conceito de sítio estendese agora não só ao contexto estético da obra, mas também aos significados simbólico, social e político dos lugares, bem como as circunstâncias históricas nas quais obra de arte, observador e lugar estão inseridos. Ao contrário do conceito inicial de site-specific, a obra é tomada em relação à situação urbana e cultural.

No final da década de 1980, "nota-se que a procura por novos espaços para práticas artísticas torna-se uma norma. Os procedimentos da land art e dos trabalhos para site-specific 'evoluem para ocupações espalhadas pela cidade e pura utilização de redes sociais de comunicação". Há uma busca desenfreada por 
locais ainda não ocupados pela arte. A originalidade desse tipo de manifestação passa a residir, muitas vezes, mais no caráter bizarro do lugar do que na qualidade das obras apresentadas. Há o abandono da pesquisa formal em favor da contextualização das obras opondo-se ao que marcou a origem da especificidade do sítio. A prática da produção in situ, passou por uma transformação radical e qualquer coisa pode ser agrupada sob essa expressão. O curador decide o lugar e os parâmetros da operação. As obras para situ passam então a poder ser deslocadas, além de eventualmente exibidas em museus, prática que:

\begin{abstract}
corre o risco de ser na maioria dos casos mais um modo disfarçado de publicidade e política corporativa.(...)Todo um segmento da produção in situ flerta com o novo paradigma da estética comunicacional. $\mathbf{O}$ trabalho vai para o lugar. Uma orientação cada vez menos característica do modus operandi que leva em conta o lugar. 0 que resta da especificidade do sítio é agora menos definido por uma estratégia visando o lugar do que por intercâmbio de lugares, criações que se fazem na passagem de um lugar para o outro. (PEIXOTO, 2002, p.19).
\end{abstract}

Nos anos 1990, surge uma nova figura: "'o artista interventor itinerante'. Ele toma o mundo como um vasto campo para suas ações pontuais, convertendo-se em etnógrafo - paradigma da arte contemporânea. O local das transformações políticas é também o local de transformações artísticas." Os trabalhos são usados para fazer não-lugares parecerem específicos novamente restaurando-os como locais enraizados e não como espaços abstratos com o objetivo de reintroduzir valores como autenticidade e singularidade para uso de patrocinadores (mapeamento etnográfico de comunidades). Instituições podem usar obras para lugar específico no desenvolvimento econômico, recuperação social e turismo artístico convertendo os projetos em locais turísticos e as tensões são reconciliadas com a promoção cultural e política. O próprio artista se converte em turista e os curadores passam a locar "artistas etnógrafos nômades" em diferentes sítios. Passam a realizar visitas, pesquisas e encontros com especialistas, administradores e membros da comunidade para a seleção de sítio, estudo da cultura e projeto. Em princípio, a configuração in situ do projeto é 
inadequada para sua reapresentação em outro local sem alterar seu sentido, o que não impede sua disponibilização, visto que a presença do artista (performática, colaborativa, arregimentadora) torna-se a base da operação. Ele presta serviços: negocia, pesquisa, entrevista, coordena. Os projetos orientados para o lugar passam então a se alinhar com os projetos anteriores do artista executados em outros lugares.

\begin{abstract}
Não por acaso a metáfora da cartografia (itinerários, territórios) vem dominando as grandes exposições internacionais nos últimos anos. Ela implica não só uma transformação nas condições da percepção e da ocupação do espaço no mundo contemporâneo, mas também mudanças nos procedimentos de criação e da organização institucional e comercial da arte e da arquitetura (PEIXOTO, 2002, p.19-20).
\end{abstract}

Atualmente, grande parte dessa produção busca um maior engajamento no mundo externo e na vida cotidiana - a arte para lugar específico converte-se em arte comunitária. Ela está integrada diretamente às questões sociais: ecologia, sem-teto, AIDS, violência e sexualidade. Centros de vivência social: hotéis, prisões, hospitais e igrejas, são ocupados indistintamente. "Preocupações estéticas relativas à história da arte são deixadas em segundo plano". O conceito de sítio, consequentemente, também passou por transformações. Ele é

estruturado informacionalmente, em vez de espacialmente. Seu modelo não é um mapa, mas um itinerário, uma seqüência fragmentada de eventos e ações através de espaços, uma direção que só é articulada pela passagem do artista - o que corresponde ao padrão de movimento em espaços eletrônicos (cyberspaces), igualmente estruturados para serem experimentados transitivamente, um após o outro, e não como simultaneidade sincrônica. (PEIXOTO, 2002, p.20).

Estudos realizados por Miwon Kwon ${ }^{35}$ também apontam que o conceito de site specific não se limita apenas aos trabalhos realizados no final dos anos 1960 e início dos 1970, como o Tilted Arc de Richard Serra. O conceito se expande ao considerar o site também como espaço para intervenções críticas. Para Kwon, "podemos provisoriamente concluir que nas artes avançadas dos últimos 30 anos, a definição vigente de site foi transformada de uma localidade física - enraizada,

\footnotetext{
${ }^{35}$ Miwon Kwon: arquiteta, fotógrafa e pesquisadora de arte pública, Califórnia.
} 
fixa, real - para um vetor discursivo - desenraizado, fluído, virtual". (KWON, 2002, p.12, tradução nossa). O site passa por uma desterritorialização e adota estratégias "que são, ou agressivamente antivisuais - informacionais, textuais, expositivas, didáticas - ou simplesmente imateriais - gestos, eventos, performances delineadas pelo tempo" (KWON, 2002, p.7). Com referência em James Meyer, a autora fala sobre o conceito de "functional site" em que o lugar, em sua condição funcional, é entendido como um processo, uma operação que ocorre entre sites. $\mathbf{0}$ lugar é um campo de conhecimento, de troca intelectual ou de debate cultural em que são sobrepostas informações em forma de textos, fotografias, vídeos, dados, elementos físicos e objetos.

Alex Coles ${ }^{36}$, em texto publicado sobre o Programa Platform for Art / Art on the Underground, do metrô de Londres, também faz referência ao crítico James Meyer. Ao discorrer sobre a diversidade dos projetos apresentados nas estações da rede, esclarece que cada um deles pode ser interpretado como uma forma de "nutrir uma resposta contemporânea sob a forma de abordagens participativas e relacionais para a noção do que é historicamente denominada arte site-specific". Menciona Meyer como defensor da existência de duas diferentes noções de site: o literal e o funcional. $O$ primeiro se refere a um tipo de trabalho que é, literalmente, localizado em um local específico. Envolve uma forma de contemplação ótica passiva de uma composição que o espectador observa e diz respeito à arte, embora talvez de uma maneira fugaz. O segundo implica em algo que é muito mais expansivo. Envolve uma obra de arte que não é estática, que está incorporada às peças de trabalho de uma estrutura já existente, com uma finalidade específica. Este tipo de site é exemplificado com os desenhos desenvolvidos por artistas para as capas dos mapas da rede. São trabalhos disponíveis em todas as estações, que "se tornam uma parte essencial da maneira como o serviço é captado e, portanto, utilizado. Estes projetos só fazem sentido em relação ao seu contexto funcional, por sua vez, com implicações para a forma como o trabalho é experimentado. A ideia do site funcional exige uma forma bem diferenciada de contemplação que, muitas vezes, é de caráter tátil. Com os projetos das capas dos mapas, o usuário/espectador, dada a natureza da interação, inicialmente tem um papel mais ativo na relação com o trabalho que, em seguida, é tocado e levado

\footnotetext{
${ }^{36}$ Alex Coles: crítico de arte, designer e editor, Inglaterra.
} 
embora. Para Coles, no discurso da arte contemporânea, o conceito de site funcional de James Meyer corresponde à prática da "Estética Relacional" de Nicolas Bourriaud (COLES, 2007, p.21, tradução nossa) que descreve a história da arte como história da produção de relações com o mundo. Para Bourriaud, desde o início dos anos 1990, a arte vinha produzindo cada vez mais relações sociais. O local em que essas relações ocorriam tinha se deslocado do espaço privado e simbólico para o espaço real. Trabalhos de artistas como: Rirkrit Tiravanija, Phillipe Parreno, Liam Gillick, Huyghe Pierre, Angela Bulloch, Felix Gonzalez-Torres e Vanessa Beecroft, tomaram forma de reuniões, festas, jogos e outros eventos de convívio ou de cooperação. Tratava-se de "uma tentativa de criar relações entre as pessoas, acima das formas institucionais" (MÖNTMANN, 2007, p. 433, tradução nossa). Dessa forma, as convenções das ações de comportamento que transcenderam espaços expositivos modernos alteraram os papéis tradicionais de artistas, como produtores, e do público, como destinatário em que a utilização de uma obra de arte substitui a contemplação. Há o interesse do autor em encontrar uma teoria para esta nova estética, que seria necessariamente diferente da estética modernista do sublime. No lugar de objetos exibidos, apresenta um aspecto socialmente relevante dos trabalhos em que situações refletem a transição de uma sociedade de produção para uma sociedade de serviços.

Para Nina Möntmann ${ }^{37}$,

Esta estratégia afirmativa da apresentação imitativa de encontros e da freqüência de "consumption-oriented", e que são sustentadas por ações simples, é justificada por Bourriaud com a percepção pós-estruturalista que a priori não há nada fora das estruturas de poder. (MÖNTMANN, 2007, p. 433-434, tradução nossa).

A autora observa que há uma omissão na teoria de Bourriaud que reside na "estimativa falsa de transcendência institucional", uma vez que "na área artística que instiga processos relacionais (...) são quase exclusivamente encontros de confraternização com um público de arte, que acontecem dentro dos tradicionais limites institucionais." (MÖNTMANN, 2007, p. 433-434, tradução nossa).

\footnotetext{
${ }^{37}$ Nina Möntmann: curadora, crítica e escritora, Hamburgo.
} 
Apesar das particularidades nas formas de pensar dos autores, há uma convergência com relação à influência do fenômeno da globalização e dos novos meios de comunicação, possibilitados pelos avanços tecnológicos, nas formas de criar e de atuar dos profissionais da arte, da arquitetura, do urbanismo e do design contemporâneos e na forma em que nós, público/espectador/ator/autor da arte, nos comportamos, nos relacionamos e nos identificamos. 



\section{A ARTE E O PLANEJAMENTO. INTERVENÇÕES URBANAS: ARTE/CIDADE I E II . ARTE NA CIDADE}

Em países com elevado grau de desenvolvimento, grande parte das obras de arte são financiadas por programas de governos estaduais, federais e de conselhos locais: os Percent for Art, iniciados em 1930. Esses programas, de cunho social e do primado da arquitetura e do planejamento da cidade, destinam um por cento do valor de obras construídas para projetos de arte pública. Claudia Büttner afirma que nas décadas de 1960 e 1970, programas foram criados em diversos países para suportar a arte no espaço público. Nos EUA, desde 1965, o National Edowment for the Arts financiou 'Art in Public Places'. Na Alemanha, Bremen foi a primeira cidade, em 1974, a transformar um por cento para orientação do programa de arte em um modelo programático para a arte no espaço público. Outras cidades, como Hamburgo e Berlim, seguiram o exemplo. Além de monumentos, é permitido que fontes, esculturas, instalações, pinturas e objetos sejam colocados "em determinados contextos fora do arquitetônico: praças públicas, ruas, espaços verdes e fachadas" (BÜTTNER, 2007, p.332, tradução nossa). A cidade de New York, onde o turismo gerado em torno da arte e do teatro representa 6,8 bilhões de dólares anuais para a economia local, a partir de lei aprovada em 1982, passou a ter o programa Percent for Art do New York City Department of Cultural Affairs, que destina um por cento do valor de cada obra pública construída à arte pública permanente. No processo de encomenda de obras artísticas, há um sistema de júri composto por profissionais de arte, membros da comunidade e representantes municipais. Para cada encomenda é criado um novo júri. São realizadas reuniões para a compreensão do local, da comunidade e da arquitetura. Membros da comunidade são selecionados por pesquisa realizada pela equipe do programa que busca saber quem são as pessoas mais importantes da comunidade, sua situação econômica e social, e qual o grupo étnico predominante. "A seleção procura permitir que o artista participe do estágio mais primitivo possível da construção de uma obra pública. (...) Assim, arquiteto e artista podem trabalhar juntos para criar algo significativo para aquele local" (FINKELPEARL, 1995, p.71). Após a conclusão das entrevistas e seleção do artista, são solicitadas autorizações de todos os departamentos municipais competentes. Altamente 
burocrático, leva de quatro a cinco anos para ser finalizado, período necessário para projetar e construir uma obra pública em New York. O programa objetiva "levar artistas para o processo de design" (NYC.GOV, 2012).

A cidade de São Paulo, apesar de ser considerada um polo cultural, apresenta uma realidade social, econômica, política e cultural que, evidentemente, não pode ser comparada à de cidades desenvolvidas mencionadas anteriormente. Entretanto, algumas ações financiadas ou cofinanciadas pelo poder público da Secretaria Municipal de Cultura e da Secretaria de Cultura do Estado possibilitaram a prática de intervenções ambientais em espaços públicos da paisagem urbana através do projeto A Arte e o Planejamento (1974), de Intervenções Urbanas: Arte Cidade I e II (1994) e de Arte na Cidade (2010).

\subsection{O PROJETO A ARTE E O PLANEJAMENTO}

São Paulo é uma cidade onde - ao contrário do Rio, espremido entre o mar e a montanha - não há pontos de referência, e onde visitantes e mesmo moradores se perdem com frequência. São Paulo é uma cidade vista por seu habitante como um lugar cinzento e frio, com seus prédios monótonos e sem vida. São Paulo é uma cidade onde a arte está muito distanciada do público, fechada nos poucos visitados museus e galerias. Esses e outros vazios poderão ser preenchidos, segundo artistas e Prefeitura, pelo novo plano da COGEP ${ }^{38}$.

Em 15 de maio de 1974, o Jornal da Tarde anunciava, simultaneamente, a aprovação do projeto de Flavio Motta para o Elevado Costa e Silva - o Minhocão - e os primeiros testes dos computadores do metrô. Tratava-se do primeiro passo no sentido de atrair o artista plástico para a equipe de planejamento urbano da cidade de São Paulo através do projeto da Coordenadoria Geral do PlanejamentoCOGEP: A Arte e o Planejamento, anunciado na gestão do Prefeito Miguel Colassuono.

\footnotetext{
38 PREFEITURA DO MUNICÍPIO DE SÃO PAULO - COORDENADORIA GERAL DO PLANEJAMENTOCOGEP. Projeto A Arte e o Planejamento. Trecho do artigo 'Prefeitura anuncia sua mais recente ideia: pintar a cidade‘ em O Estado de São Paulo, 11/05/74, p. 43.
} 
Esboçado por João Evangelista Leão, coordenador geral de planejamento, estava voltado à pesquisa de novas formas de intervenção ou renovação urbana que possibilitariam, a baixos custos e em prazos curtos, influir na vida social e econômica da cidade. Objetivava testar a ideia de incorporar o artista plástico às equipes pluridisciplinares compostas por arquitetos, engenheiros, paisagistas, psicólogos e economistas que realizavam o planejamento geral. O profissional do campo da arte poderia, através de sua experiência e sensibilidade, ajudar a detectar as deficiências da cidade, e assim, trazer importante contribuição no desenvolvimento de projetos e propostas de tratamento do espaço urbano em seus aspectos físicos e visuais.

\footnotetext{
Os artistas foram solicitados a apresentar propostas que complementassem as preocupações do planejamento municipal e que, a partir de sua sensibilidade, ajudassem a detectar algumas deficiências da cidade em que viviam. O tratamento de novas áreas, a recuperação de áreas urbanizadas, a valorização de aspectos estético-culturais, a criação de pontos de referência, todo um quadro muito amplo que exige a contribuição do artista cujo papel na cidade do século $X X$ precisa ser revisto e reequacionado. (PREFEITURA DO MUNICÍPIO DE SÃO PAULO - COGEP, 1974, p.3).
}

As áreas onde seriam realizadas as intervenções eram indicadas pela COGEP e pelos artistas. Não havia um número estabelecido de projetos, cada artista podia apresentar uma ou várias sugestões. A seleção das propostas era realizada por uma equipe da COGEP que incluía, entre outros, Marcello Nitsche, Ricardo Ohtake e José Roberto Graciano. As obras poderiam ser pinturas nas empenas cegas dos edifícios, esculturas colocadas em praças ou qualquer outro tipo de proposta, fossem elas permanentes ou temporárias. Havia uma preocupação por parte de João Evangelista Leão, Vitor Chinaglia (engenheiro), Marcello Nitsche, Flávio Motta, e de todas as pessoas envolvidas no plano, em esclarecer que não se tratava de "enfeitar" ou de "decorar" a cidade. Outra consideração feita pelo coordenador dizia respeito à cautela na análise das sugestões apresentadas para que não fosse criado um novo tipo de poluição visual no ambiente urbano e não se caísse em uma "arte dirigida". (LEÃO, 1974, p.43).

O trabalho destinado "aos baixos do viaduto" foi um dos apresentados ao prefeito e executado naquele ano. Claudio Tozzi, Rubens Gershman, Marcello Nitsche, Gerty Saruê, Clovis Graciano, Tomoshigue Kusuno, Nicolas Vlavianos, Amélia Toledo, Maurício Fridman, e outros, também participaram do encontro. Os artistas propuseram a distribuição de esculturas e objetos ao longo das Avenidas 23 de Maio 
e Rubem Berta, que serviriam de referência e orientação para os motoristas, pinturas em paredes cegas de alguns edifícios, pinturas e murais em passagens subterrâneas para pedestres e uma festa de bandeiras no Vale do Anhangabaú. Naquela ocasião, o prefeito não garantiu que todos os projetos seriam executados, mas que esperava dar o estímulo necessário e a devida remuneração para que os artistas levassem a ideia adiante.

A proposta de Superfícies Habitáveis foi pensada como uma sucessão de painéis pintados sob o elevado. O propósito era que o passageiro, de carro ou de ônibus, passasse e visse uma sequência de formas geométricas coloridas, que seguiam um determinado ritmo, em direção ao Pico do Jaraguá, tema dos painéis. Como disse Flavio Motta:

Pensamos em pintar espaços que não existem; pensamos em converter parte da cidade numa sequência organizada, quase cinematográfica. (...) Não se trata apenas de atenuar com a tinta os eventuais erros em concreto. O fundamental é tornar a cidade um campo de relacionamento humano mais amplo, inteligível, observável, correspondendo às aspirações de desenvolvimento social. Não se trata de isolar os interesses e desorganizar o social. Cabe mostrar que a cidade resulta da intervenção humana no ambiente. (WILKE, 1976).
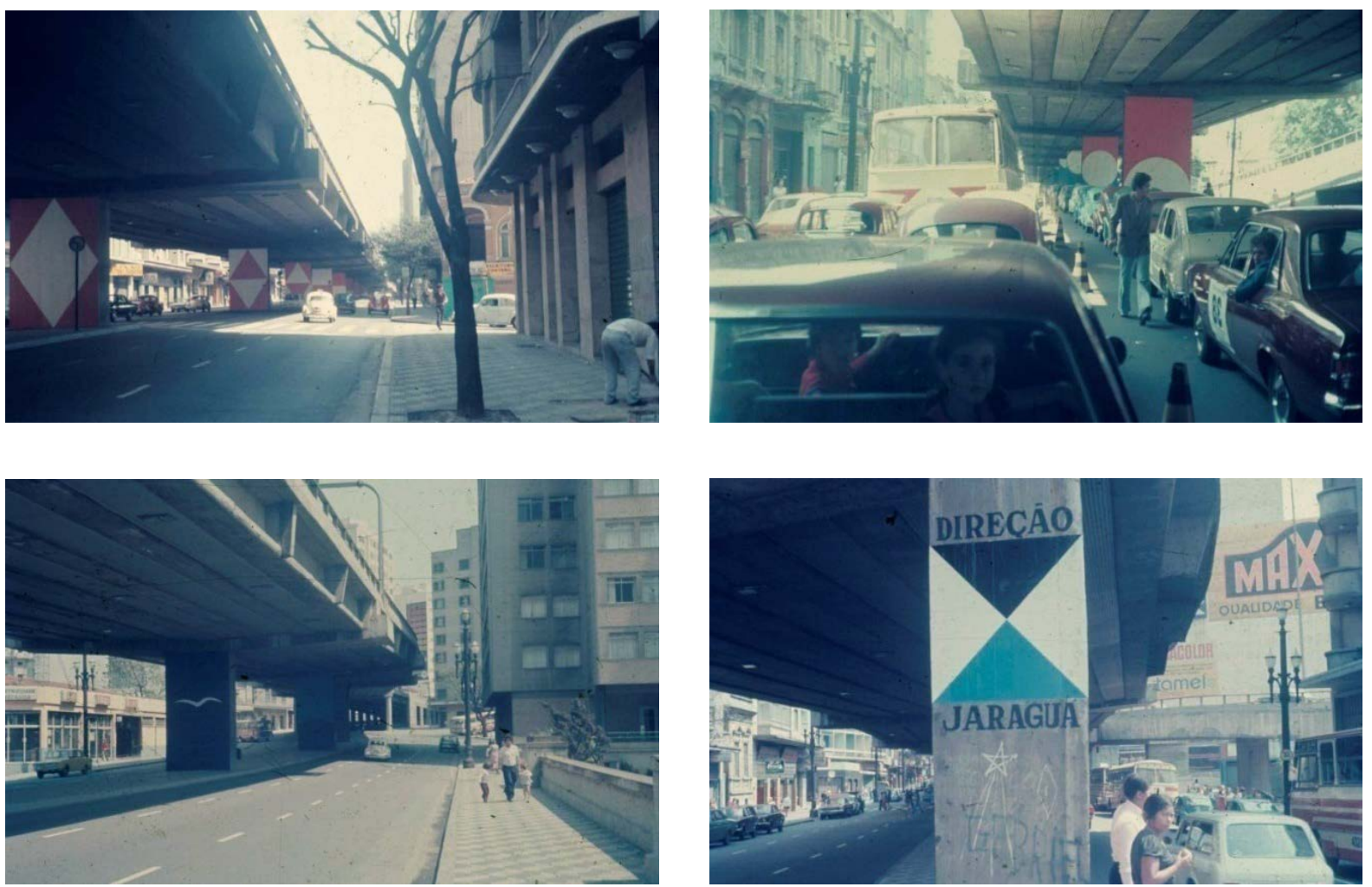

Figuras 37, 38, 39 e 40: Superfícies Habitáveis de Flavio Motta no Elevado Costa e Silva, 1974. Fonte: Acervo da Biblioteca da FAU/USP. 
O projeto de reabilitação urbana proposto por Ricardo Ohtake, Dalto de Luca e José Roberto Graciano, estava direcionado à área comercial da Rua 25 de Março. Consistia em pinturas nas superfícies cegas de edifícios com o objetivo de "reavivar valores escondidos pelo tempo ou pelo uso impróprio" (WILKE, 1976). As pinturas deveriam seguir uma unidade visual. Um dos temas abordados foi o nascer do sol, embora pudesse ser renovado a cada dois anos.

O projeto ainda propunha: a retirada de placas de todas as ruas da região para serem substituídas por faixas uniformes colocadas na cobertura dos passeios; bancas de frutas, telefones públicos e caixas de correio seriam agrupados em alguns pontos; quatro grandes marcos seriam colocados em pontos de maior movimento para fornecer informações; fios, postes e transformadores seriam remanejados para o subsolo e mobiliários urbanos seriam projetados para cada função.

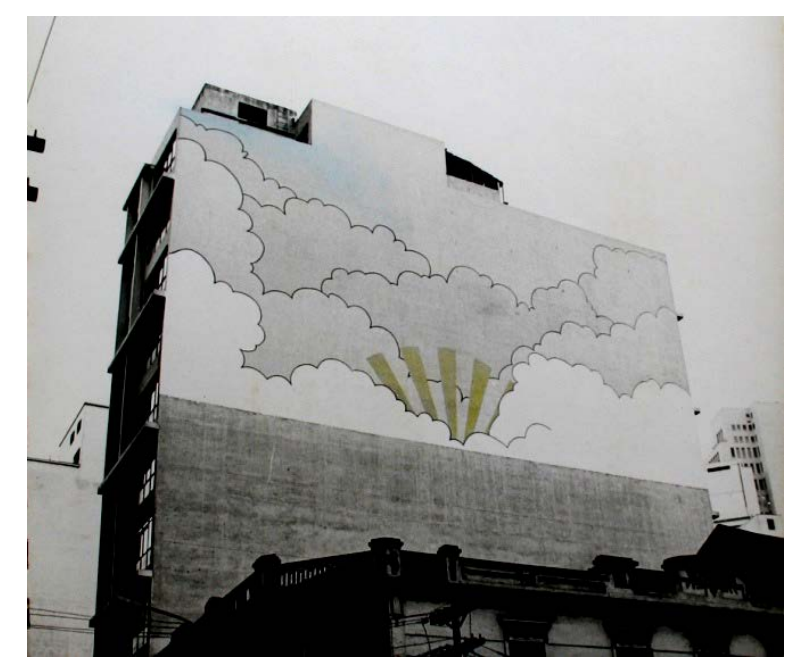

Figura 41: Intervenção de Ricardo Ohtake, Dalto Luca e José Roberto Graciano na Rua 25 de Março. Fonte: WILKE, 1976.

Apesar das diversas realizações discutidas e programadas com a participação ou a liderança de artistas, cujo significado pudesse contribuir para o aprimoramento de trabalhos planejados para a cidade, poucas propostas foram executadas sem que, contudo, houvesse a prática de uma ação integrada no processo de planejar a cidade I criar a arte. As obras foram criadas para ocupar espaços existentes. O Museu das Esculturas, parte do projeto de reestruturação urbana e intervenção visual da Praça da Sé, realizado quatro anos depois, não teve a participação de artistas na equipe da Empresa Municipal de Urbanização-EMURB e a poluição visual permaneceu como prática constante e degradante na paisagem urbana ao longo dos anos até a promulgação da Lei no 14.223 - a Lei Cidade Limpa, em vigor a partir $1^{\circ}$ de janeiro de 2007. 


\begin{abstract}
É uma inscrição num fluxo mais amplo e complexo que é a dinâmica urbana. Implica entender a cidade como algo em movimento. Não na forma de vetor progressivo, orientado, mas em várias direções. Intervir: um gesto que já está em movimento. Como surfar ou entrar em uma frequência. É um paradigma da metrópole contemporânea: uma vasta rede que existe por si, em que sempre se entra em movimento (PEIXOTO, 2002, p.12).
\end{abstract}

Arte/Cidade(s) I, II, III e IV foram projetos de intervenção urbana realizados na cidade de São Paulo, com início de suas apresentações em 1994. O primeiro evento resultou da iniciativa do curador Nelson Brissac Peixoto, convidado pela Secretaria da Cultura do Estado de São Paulo para conceber um evento cultural e midiático. A sugestão foi a de um projeto que atualizasse a discussão sobre a cidade. A proposta aconteceu no momento em que várias iniciativas reconheciam a urgência de tratar dos problemas da cidade, em particular do centro histórico, abandonado pelas grandes instituições financeiras e comerciais interessadas em áreas mais periféricas e valorizadas.

Os projetos foram concebidos para ter lugar fora do circuito institucional das galerias e dos museus, adotando como ponto de partida a metrópole contemporânea enquanto espaço complexo e dinâmico, "cenário em que arquitetura e urbanismo são continuamente redesenhados, em que se cruzam diversas linguagens e suportes". Os sites escolhidos para as intervenções foram áreas críticas da cidade, espaços diretamente relacionados aos processos de reestruturação e projetos de redesenvolvimento visando "identificar seus agentes e linhas de força e ativar sua dinâmica e diversidade". Tratava-se de "uma tentativa de novos mapas e visões da cidade." A particularidade dos Arte/Cidade(s) foi reconhecer a complexidade da intervenção na cidade como algo plural, ou seja, uma intervenção urbanística, arquitetônica, política, cultural e artística, uma vez que as ações não foram vistas isoladamente como no interior de um museu que tem suas regras próprias, mas no interior de um campo ampliado: a cidade. Para Peixoto, na metrópole, toda intervenção também é necessariamente pontual, sem pretender abranger o todo. "Predomina o princípio da ação/reação" em que cada gesto provoca "contínuas rearticulações", dando novas funções e sentidos para locais e serviços (PEIXOTO, 2002, p.12). 
Arte/Cidade não teve um perfil institucional rígido. As duas primeiras edições: $A$ cidade sem janelas e $A$ cidade e seus fluxos, ambas realizadas em 1994, contaram com o apoio de diversos órgãos governamentais e empresas privadas, uma vez que seus próprios títulos viriam a valorizar a cidade, pelo menos enquanto imagem, marketing, em uma época de crescente globalização. A partir da terceira edição, passou a ser realizado por uma entidade própria - o Grupo de Intervenção Urbana, criado em 1996, com a participação de criadores e especialistas das diversas áreas de produção e organização da cultura e da cidade. A ausência de um contexto institucional pré-estabelecido que determinasse seu formato, organização e iniciativa implicou em novas formas de atuação. A grande complexidade do projeto exigiu a mobilização de um amplo e variado número de realizadores e patrocinadores, exigiu uma atuação multi e interdisciplinar.

No cenário vigente da administração das cidades e da cultura, dominado por operações corporativas e institucionais de grande poder econômico e político, o projeto visou desenvolver repertório técnico, estético e institucional para práticas artísticas e urbanísticas não convencionais. Foram traçadas linhas gerais (conceitos, área a ser tratada) e artistas, arquitetos e especialistas convidados passaram a se reunir e a preparar seus projetos ao mesmo tempo em que eram negociadas permissões e suportes. Projetos de alto risco, em que as intervenções eram precedidas de um longo processo de preparação e divulgação para que se pudesse introduzir a ideia na comunidade e galvanizar o apoio necessário, um processo de contínua mobilização. O resultado final dependia da confluência desses subsídios.

As intervenções eram:

(...) investigativas e críticas, especulações essencialmente artísticas sobre a natureza e o destino daquelas áreas da cidade. Não visavam determinar um perfil definitivo dos lugares. Nem efetivar reformas estruturais na trama urbana, tarefa que cabe aos órgão públicos administrativos da cidade (...) se tratava de intensificar a percepção desses espaços, trazer à tona significados ocultos ou esquecidos, apontar para novas possibilidades e usos, redimensionar sua organização estrutural, sugerir novas e inusitadas configurações (PEIXOTO, 2002, p.13).

A primeira edição - A cidade sem janelas, com coordenação e curadoria de Nelson Brissac Peixoto e Agnaldo Farias, ocupou o antigo Matadouro Municipal da Vila Mariana. Na época da exposição, o espaço, desativado desde 1927 devido a 
políticas ambientalistas, estava vazio e deteriorado, o que o tornava sombrio, sem memória e, portanto, sugestivo. Quinze artistas e arquitetos trabalharam no site empregando diferentes linguagens: vídeo, escultura, performance, instalações. Neste caso, a cidade não seria o tema, mas seu suporte. Os artistas não tratariam da cidade como algo externo ao seu trabalho, mas incorporariam elementos da própria cidade à sua linguagem artística. As relações foram estabelecidas na escala do indivíduo. Não havia como apreender de uma só vez o conjunto do espaço, o que obrigava o público espectador a percorrer o labirinto formado por seu espaço compartimentado. Nas intervenções, o espaço ligou objetos e planos de diferentes dimensões.

Carmela Gross cavou o próprio lugar, mapeando todo o piso por buracos irregulares escavados no chão com proporções rigorosamente determinadas, relacionadas com os sistemas de pesos e medidas que organizam um matadouro. Seguindo o caminho de seu trabalho da série Larvas, as paredes foram cobertas com painéis em tecido que reproduziam a imagem das perfurações. Os buracos atuavam como janelas negativas que se abriam para dentro engolindo o espaço (espaço negativo), enquanto os painéis abriam "janelas", o que trazia ao site uma unidade e identidade novas. O espectador descobria que aquele espaço que parecia morto, parecia vivo. José Resende considerou a cidade como espetáculo, uma vez que os monumentos faziam parte da paisagem, mas não podiam ser vistos como espetáculo. Nos fundos do matadouro, o escultor fez uso de um dispositivo de montagem e desmontagem para compor ininterruptamente estruturas com elementos encontrados no local. A obra só poderia ser observada pelo espectador através da grade de um portão, proporcionando a experiência do voyeurismo, fantasia, violência, esforços/resistências, poesia, técnica, materiais, matérias, ritmo, som e cor. Tratavase de um estudo sobre articulações dos objetos e dos materiais. Havia uma problematização da verticalidade, uma renúncia ao impulso construtivo, uma retomada de esforço para erguer o insustentável pesado.

Anne Marie Sumner propôs uma estrutura arquitetônica composta por três telas metálicas paralelas que deixavam entrever os galpões através de suas malhas sobrepostas, mas bloqueavam a visão panorâmica do lugar. Eram elementos de diferentes comprimentos que cruzavam diagonalmente o terreno acompanhando seus desníveis. A entrada, por definição de uma área aberta de trânsito facilitado, passou a requerer um itinerário. A intervenção não podia ser compreendida de um 
só ponto de vista. Exigia um percurso que a contornasse, que possibilitasse vê-la de diferentes posições do terreno.
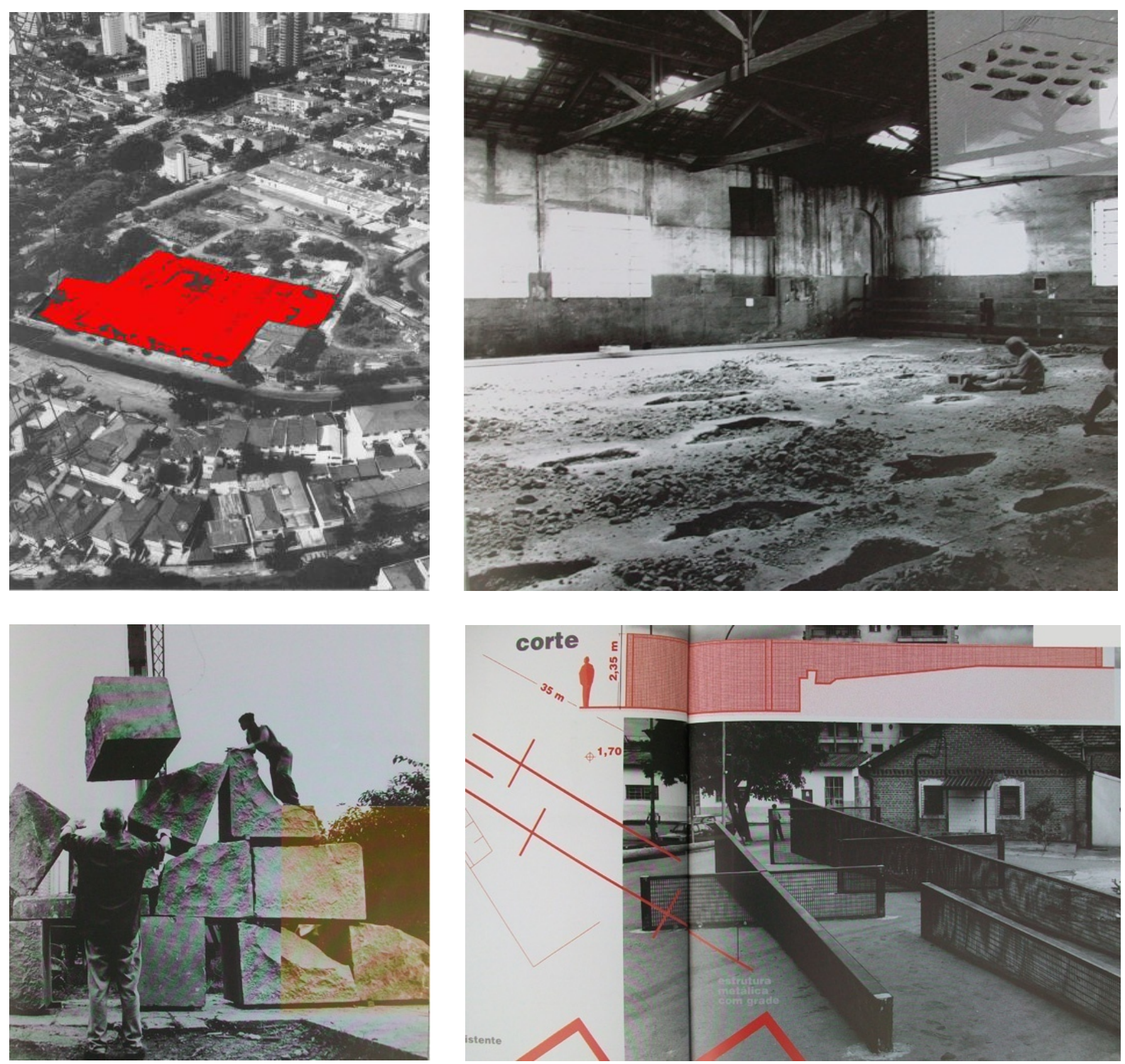

Figura 42: Área das Intervenções Arte/Cidade I. A cidade sem janelas. Fonte: PEIXOTO, 2002, p.34.

Figura 43: Intervenção de Carmela Gross. Fonte: PEIXOTO, 2002, p.45.

Figura 44: Intervenção de José Resende. Fonte: PEIXOTO, 2002, p.51.

Figura 45: Intervenção de Anne Marie Sumner. Fonte: PEIXOTO, 2002, p. 54-55.

A segunda edição - A cidade e seus fluxos, também sob coordenação e curadoria de Nelson Brissac Peixoto, teve como lugar uma área demarcada por três edifícios: Edifício Guanabara, Banco do Brasil e Eletropaulo, em torno do Viaduto do Chá, região de principal conexão entre o centro antigo e a região por onde, no início do século, se deu a expansão da cidade sobre o Vale do Anhangabaú. $O$ viaduto 
também servia de espaço para a ação de ambulantes que ali vendiam todo tipo de produtos, o que aumentou o número de pedestres e a falta de segurança. Foi ocupado o topo dos três edifícios, a área do vale e as ruas circundantes. $O$ tema foi adequado ao território adotado por se tratar de um intrincado cruzamento de multidões pedestres e motorizadas. Milhares de pessoas atravessavam o viaduto em suas atividades diárias. Ao contrário do matadouro, a cidade se apresentava totalmente viva e repleta de contradições. Os três edifícios apresentavam obras que tratavam do movimento, da luz, da leveza e da escala desmedida do lugar. Antigos dispositivos de olhar, mecanismos de comunicação, projeções, estruturas em suspensão e sistemas interativos foram instalados em toda a área, formando um universo de circulação. Alguns artistas usaram 0 espaço apenas para colocar/recolocar seus trabalhos, outros, abordaram os fluxos.

Para ir de um edifício ao outro era preciso cruzar o viaduto e percorrer lateralmente as encostas tomadas por um intrincado de ruas e jardins. Naquele lugar, havia a presença de diferentes escalas. O topo dos edifícios ficava a $50 \mathrm{~m}$ do nível da autopista, com os outros níveis intermediários do jardim e do viaduto, além dos demais edifícios mais altos, uma "complexidade urbano-arquitetônica". Havia um movimento contínuo, horizontal e vertical que dinamizava a área. Não foi criado um itinerário privilegiado, inúmeros caminhos eram possíveis. A questão foi a distância e a tensão entre os lugares, não se tinha mais o indivíduo como medida, as escalas eram outras. Participaram vinte e dois artistas e arquitetos que conceberam intervenções para esse espaço e criaram obras específicas para CD-ROM. Foi o primeiro CD-ROM criado por artistas brasileiros.

Rubens Mano apresentou a obra Detector de ausências, um dispositivo composto por dois grandes holofotes militares, de 12000 watts de potência, instalados ao lado do Viaduto do Chá. Cada cilindro foi colocado sobre torres de $13 \mathrm{~m}$ de altura erguidas a partir do piso do vale, cortando a passarela na altura da calçada. Fachos de luz paralelos, não coincidentes, de $1,5 \mathrm{~m}$ de diâmetro, atingiam o fluxo de pedestres, cujos focos traduziam a velocidade crescente da cidade, desqualificando o espaço, acarretando desterritorialização. Os feixes de luz indicavam a situação do indivíduo na metrópole: permitiam que ele fosse visto, mas também evidenciavam seu anonimato, sua precariedade. Aparecer e desaparecer transformou-se então em uma experiência contemporânea e complementar que era repetida quando o pedestre passava pelo segundo facho de luz. Ele aparecia e desaparecia como 
pessoa e como imagem, um processo que reproduzia o que ocorre continuamente no espaço/tempo da cidade, era um "processo de desterritorialização e reterritorialização" (PEIXOTO, 2002, p.87).

Regina Silveira transformou o prédio da Eletropaulo abordando uma das características mais marcantes da cidade: a verticalização. Tudo acontecia no 5을 andar do edifício. Vórtice foi uma obra site-specific, realizada com um grande desenho em perspectiva em forma de triângulo truncado, pintado em preto, sobre 60 chapas brancas de plástico rígido, totalizando 15,50m de extensão por $11 \mathrm{~m}$ de profundidade. O desenho anamórfico reproduzia as janelas da fachada da Eletropaulo, "transparentando" a estrutura arquitetônica do prédio. Havia uma inversão que forçava o espectador a olhar para baixo. Como no trabalho de Carmela Gross, as paredes e o chão abrigavam janelas insólitas que alteravam o sentido do espaço construído, porém, o espectador não era envolvido pelo espaço, o espaço arquitetônico se abria fazendo com que se perdesse bruscamente o sentido de direção e se percebesse a altura do edifício, a distância que o separava da rua. Ao descer do elevador deparava-se com um espaço virtual vertical, um abismo.

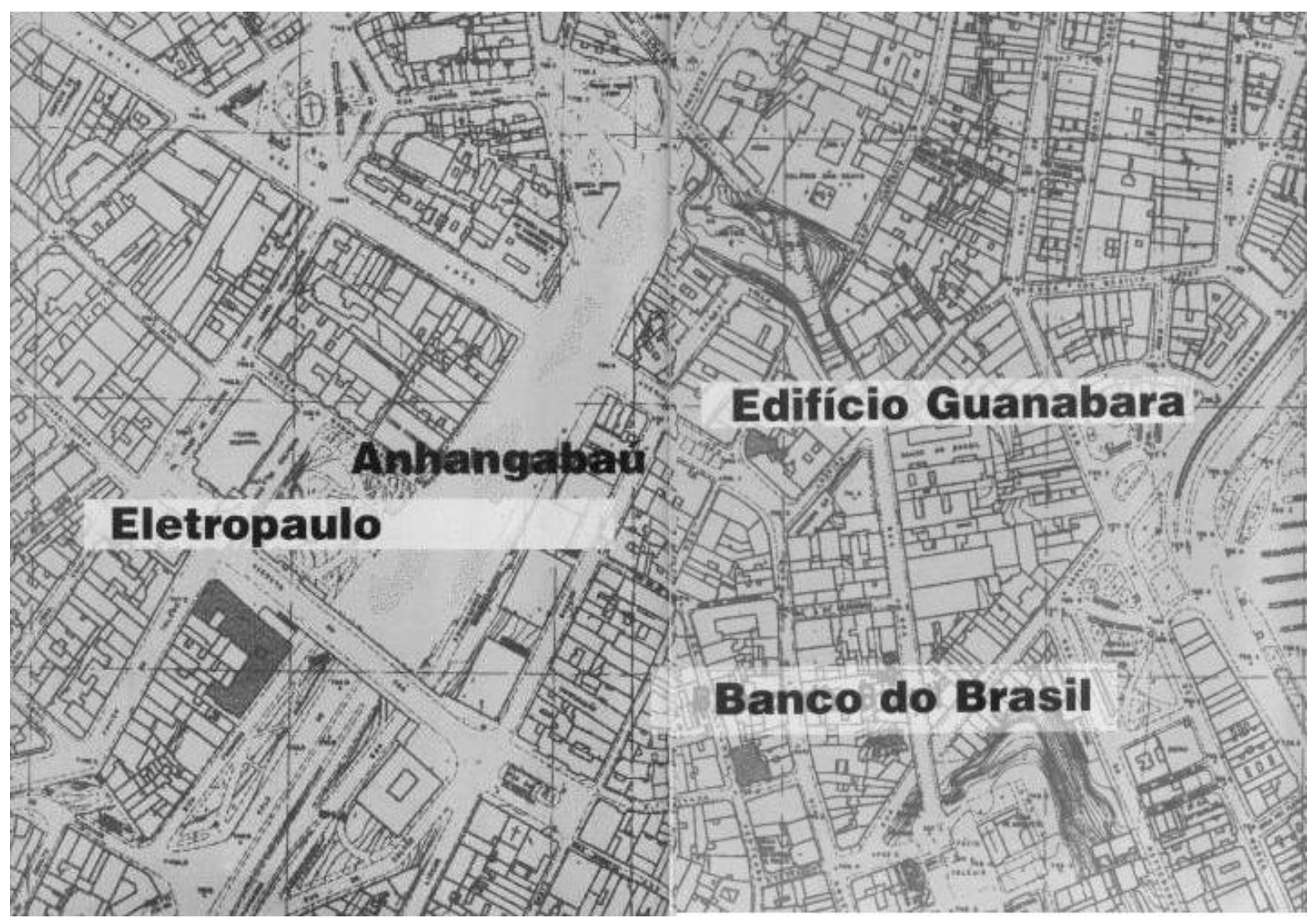

Figura 46: Área das Intervenções Arte/Cidade II. A cidade e seus fluxos. Fonte: PEIXOTO, 2002, p.56-57. 

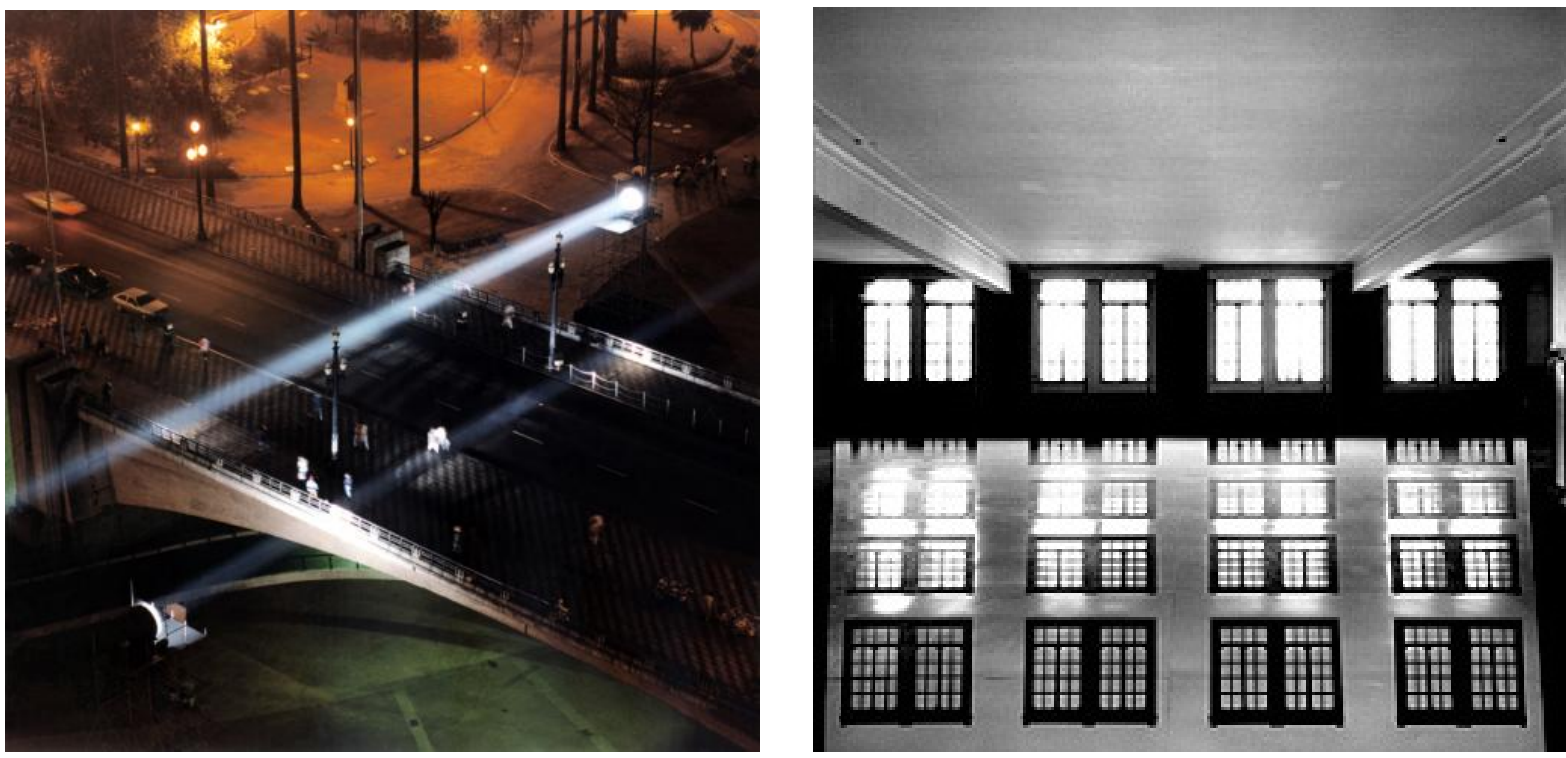

Figura 47: Detector de ausências. Intervenção de Rubens Mano. Fonte: <http://www.28bienalsaopaulo.org.br/participante/rubens-mano>. Acesso em 21/06/12.

Figura 48: Vórtice. Intervenção de Regina Silveira. Fonte: PEIXOTO, 2002, p.73.

Embora a terceira edição - $A$ cidade e suas histórias, não seja um exemplo de intervenção financiada pelo poder público, objetivo deste capítulo, teve como particularidade a escolha do site e do meio de transporte utilizado para a visitação do público/espectador. Realizada em 1997, sob coordenação e curadoria de Nelson Brissac Peixoto, adotou uma área de $5 \mathrm{~km}$ de ferrovia que ligava três sites representativos na história da cidade: a Estação da $\mathrm{Luz}^{39}$, os silos do Moinho Central e os galpões e chaminés que restavam do grande complexo industrial das Indústrias Matarazzo. Partindo da Luz, um trem reservado especialmente para a mostra levava o espectador para o Moinho Central, edifício de quatro andares e seis silos, abandonado, usado como abrigo para marginais. Em seguida, para as Indústrias Matarazzo, símbolo da industrialização de São Paulo. Espalhados pela ferrovia, estes sites não eram percebidos em sua totalidade. As intervenções voltaram-se para a grande escala desse recorte, com suas áreas inacessíveis à observação ocular e desconectadas da organização urbana da metrópole atual. Neste caso, ficou mais evidente que nas edições anteriores, o significado particular desses sites. Trinta e cinco artistas e arquitetos participaram.

\footnotetext{
${ }^{39}$ A Estação da Luz, primeira estação ferroviária de São Paulo, facilitou o crescimento industrial da cidade ao ligá-la ao Porto de Santos. Muito utilizada pelos moradores da periferia e situada em uma área que abrigou os primeiros bairros industriais e residenciais da cidade, estava bastante deteriorada e já era considerada uma região perigosa.
} 


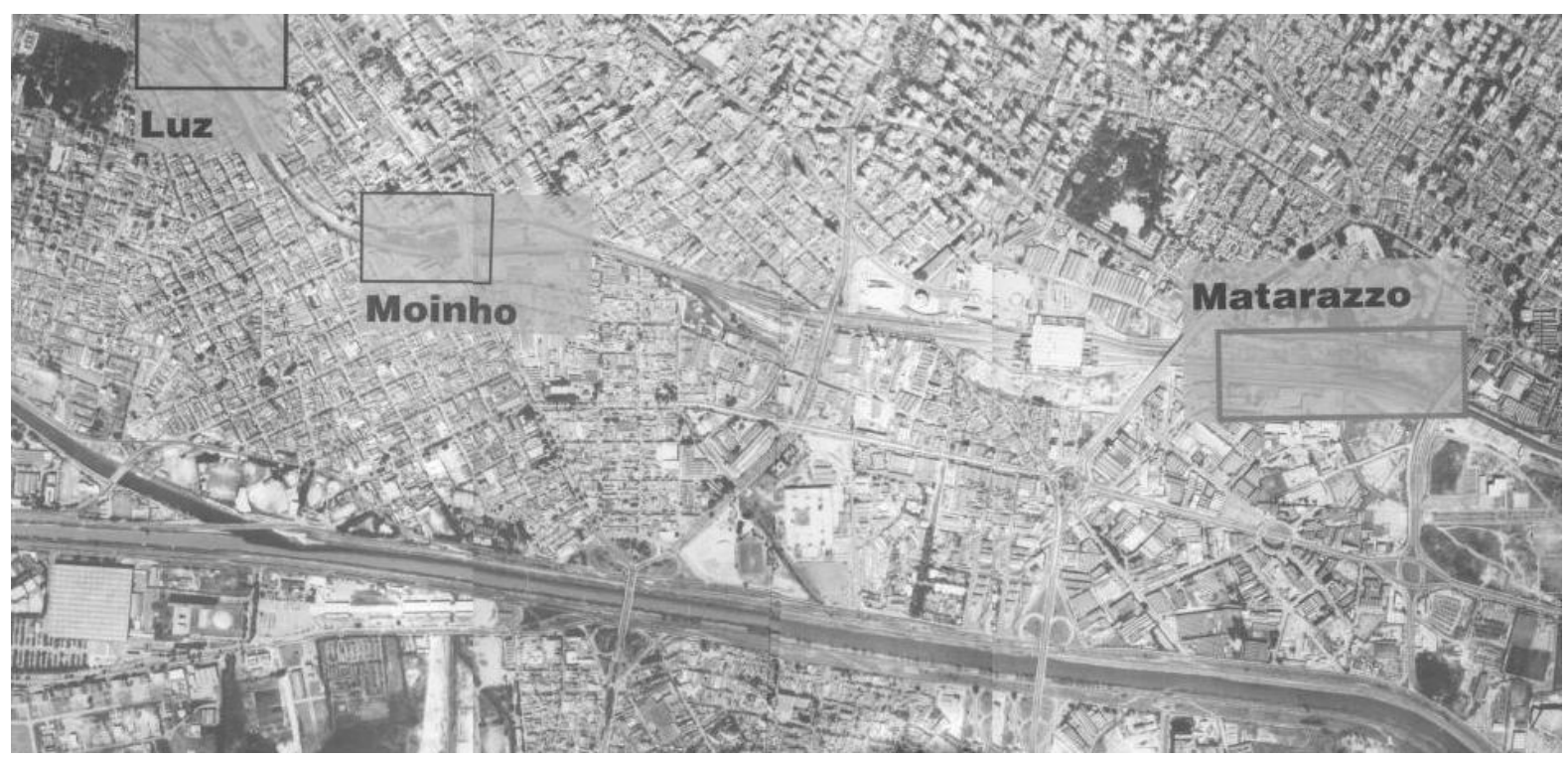

Figura 49: Área das Intervenções Arte/Cidade III. A cidade e suas histórias. Fonte: PEIXOTO, 2002, p.98-99.

Um dos trabalhos especiais desenvolvidos paralelamente aos dos artistas e arquitetos convidados foi a intervenção no trem utilizado para percorrer a área. Com referência em experiências concebidas pela vanguarda russa no período revolucionário (1919-1920) ${ }^{40}$ sua superfície externa foi pintada. A releitura do material histórico e o desenvolvimento do projeto gráfico foram realizados por Ricardo Ribenboim. O trem também funcionou como veículo de informação e educação, assim como foi no Kinotrem russo ${ }^{41}$. Através da linguagem e das tecnologias do vídeo, uma equipe fez rápidas reportagens para serem difundidas no trem e um cinejornal foi realizado nas áreas e comunidades ao longo do ramal ferroviário e nas paradas do veículo levantando discussões sobre a história e as possibilidades do documentário e do cine/telejornalismo. Faziam parte dos vídeos de curta duração exibidos no interior do trem: trailers que sintetizavam os elementos

\footnotetext{
${ }^{40}$ Segundo Lucas Bambozzi: "No início do século, o trem foi mais que um veículo de transporte. Foi um meio de comunicação. Combinado com outras técnicas de criação e difusão artísticas, o trem ganhou uma dimensão cultural mais ampla, levando ao limite o princípio do veículo de comunicação. Ambulante, o trem engendra um novo espaço cultural, articulação das cidades com os dispositivos de movimento e circulação.

$\mathrm{Na}$ antiga União Soviética, onde a implantação das novas formas de expressão foi simultânea à industrialização, surgiram várias formas de utilização de trens na criação e na difusão da arte.

No período da Revolução, entre os anos 1919 e 1920, a vanguarda artística russa usou trens para difundir entre a população a arte e novos produtos da indústria. Essas composições ferroviárias, chamadas de 'trens culturais e de instrução', tinham os vagões pintados pelo lado externo, transformando-se em exposições ambulantes através do campo e das cidades.

As composições eram preparadas nos grandes centros (Moscou, Petrogrado, Kiev) e depois percorriam todo o país. Esses veículos de propaganda faziam rápidas paradas nas cidades do interior, oferecendo a possibilidade de contato com várias artes ao mesmo tempo (cartazes, panfletos, cinema, teatro)." (BAMBOZZI, 2002, p.136137).

${ }^{41} \mathrm{O}$ projeto do Kinotrem russo, de autoria de Alexandr Medvedkin, funcionava como um estúdio cinematográfico, inteiramente equipado para produzir filmes em circunstâncias de transporte ferroviário, uma "fábrica cinematográfica móvel", que tinha como lema: "Hoje filmamos, amanhã exibimos". (BAMBOZZI, 2002, p.145).
} 
que constituíam a história e as kino-reportagens, registros em vídeo realizados pelo próprios visitantes do Arte/Cidade. Na Estação Matarazzo havia um circuito de exibição formado por vários monitores e projeções controlados por um VJ (editor/diretor de imagens). Em função da capacidade bidirecional de emissão e recepção de vídeo, o sistema também vinculou transmissões ao vivo provenientes de uma unidade móvel: a Kinokombi, que possibilitava a comunicação entre a instalação e as regiões periféricas ao evento, com a participação do público visitante e dos habitantes dos bairros próximos viabilizando um circuito interativo de intervenção em tempo real. O Projeto foi desenvolvido por Eliane Caffé, Fabiano Gullane, Lucas Bambozzi e Renato Barbieri sob coordenação geral de Lucas Bambozzi (BAMBOZZI, 2002, p.144-151).

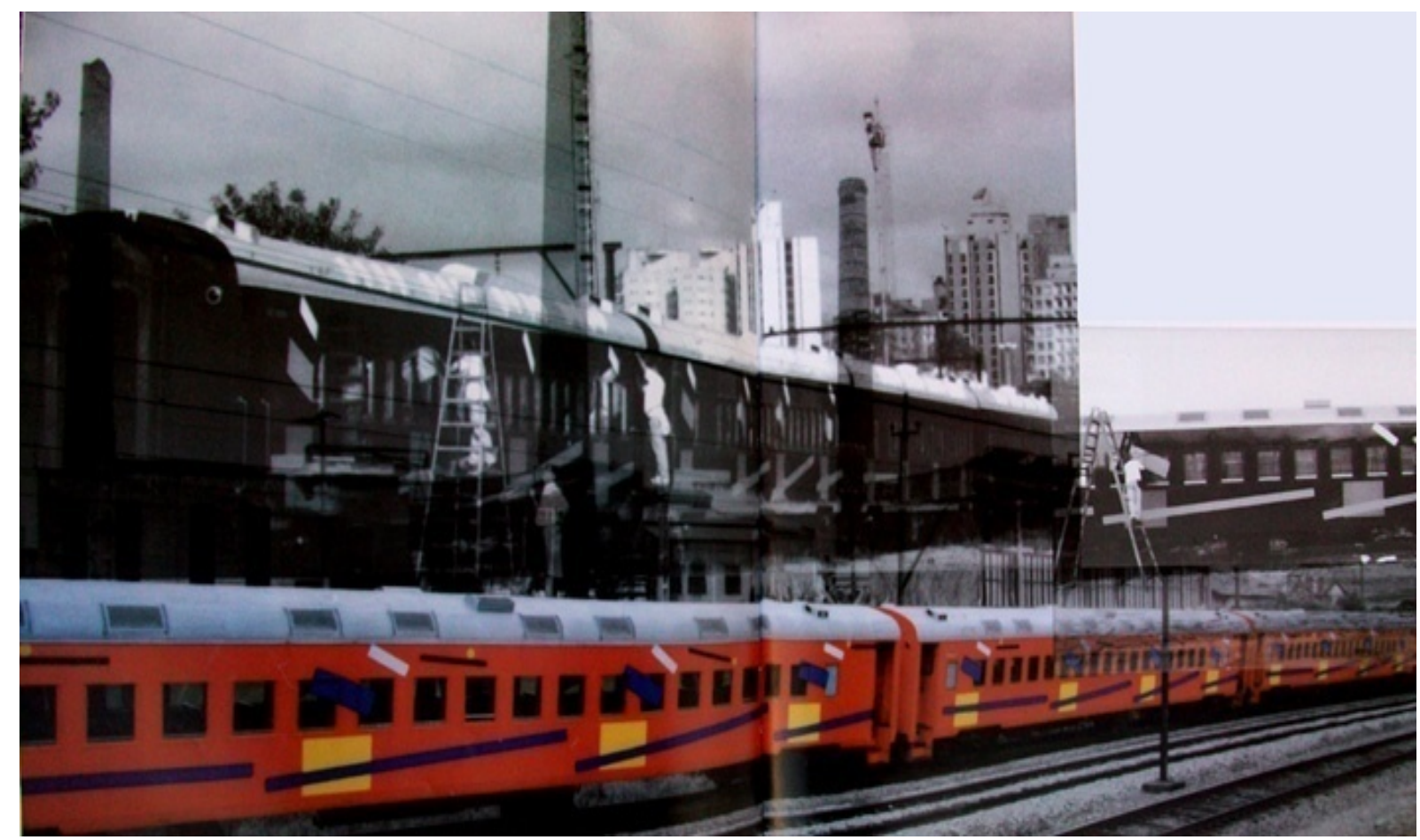

Figura 50: Intervenção de Ricardo Ribenboim no Kinotrem. Fonte: PEIXOTO, 2002, p.142-143.

Embora para alguns autores a qualidade dos trabalhos tenha sido discutível, para Peixoto, houve uma evolução de uma edição para outra. As obras passaram a estar cada vez menos relacionadas com a produção regular dos artistas e arquitetos, concebidas e realizadas em ateliers e estúdios, para voltarem-se às reflexões que levaram em consideração: o sítio, a inserção arquitetônica, a escala urbana, a complexidade das situações e os componentes sociais e políticos. 
Quanto ao resultado do impacto desses projetos na releitura dos lugares e situações da cidade e do papel que possam ter tido nas operações urbanas que estavam sendo ali implantadas:

Oportunidades não foram completamente percebidas nem aproveitadas, em parte, por causa das dificuldades - quando não existiam precedentes de práticas semelhantes - de introduzir abordagens alternativas nas negociações com as instituições e empresas que cediam os espaços, muitas vezes, interessadas em controlar e utilizar a iniciativa. (PEIXOTO, 2002, p.14).

\subsection{ARTE NA CIDADE}

(...) a abertura de espaços para a arte pública - para a arte realmente pública, aquela que se espalha pela cidade sem cobrar ingresso, sem hora marcada, sem um contexto formal específico e que colhe seu fruidor de surpresa, muitas vezes - é uma tendência global cada vez mais forte. Apoiar a arte pública é hoje, além de operação justificada em si mesma (a arte nunca necessita de pretextos externos para existir), um ato em favor de uma qualidade de vida renovada. O belo, o intrigante, o curioso, o atrevido são dimensões da vida urbana que, numa cidade como São Paulo, foram esquecidas ou raramente cultivadas. Esta iniciativa inicia o resgate de uma grande dívida da cidade consigo mesma. (COELHO, 2010).

Com a proposta de "transformar espaços livres em cenário de intervenções artísticas" (PREFEITURA.SP.GOV.BR, 2010) e o objetivo de repensar a arte pública e estimular artistas e curadores a darem sua versão atual do "monumento" no espaço urbano (edificações, parques e praças), a Secretaria Municipal de Cultura, lançou 0 edital Arte na Cidade, em 2010 (MEDEIROS, 2012; PREFEITURA.SP.GOV.BR, 2010). Direcionado às artes visuais, teve a colaboração de curadores representativos da cidade na elaboração do texto: Marcelo Araújo, diretor da Pinacoteca do Estado; Agnaldo Farias, um dos curadores da $29^{a}$ Bienal de São Paulo; Tadeu Chiarelli, diretor do Museu de Arte Contemporânea e Teixeira Coelho, curador do Museu de Arte de São Paulo Assis Chateaubriand-MASP.

As intervenções poderiam ser "temporárias ou semipermanentes (até dois anos)". Artistas, coletivos, curadores, brasileiros ou estrangeiros residentes no país poderiam participar. Em 2011, a Prefeitura copatrocinou $R$ \$1,2 milhão, com o limite de $R \$ 200$ mil por projeto. A proposta que apresentasse orçamento que excedesse o valor estipulado deveria obter os recursos complementares por meio de fontes governamentais ou privadas. 
O processo de seleção das propostas ocorreu em duas etapas. Inicialmente, uma comissão de análise composta por representantes das Secretarias Municipais da Cultura, Subprefeituras, Verde, Desenvolvimento Urbano e Empresa Municipal de Urbanização-EMURB analisou a viabilidade das propostas em relação ao local indicado. Posteriormente, três profissionais com experiência no campo das artes visuais, examinaram e selecionaram as propostas com referência no portfólio do proponente. Como critério de avaliação foram considerados: "qualidade artística, contribuição para aprimoramento da linguagem das artes visuais, amplo acesso público, compatibilidade entre o projeto e o local escolhido para o desenvolvimento e coerência entre orçamento e cronograma de execução." Após a aprovação, o projeto selecionado teve o prazo de seis meses para inaugurar a intervenção. (EDITAL PARA APRESENTAÇÃO DE PROJETOS CULTURAIS, 2010).

O período de exibição das obras tem ocorrido de forma diferenciada, apenas três delas ficarão expostas até setembro de 2013: Projeto para uma Pintura com temporal \# 6, O Descanso da Sala e Tamanduateí. Projeto para uma Pintura com temporal \# 6, de autoria de Thiago Rocha Pitta, trata-se de uma obra em progresso que tem como suporte a empena do edifício Isnard, na Avenida São João. O material utilizado é uma tinta especial, feita de óxido de ferro, que vai enferrujando e criando uma pintura espontânea. O processo de mudança é a própria obra.

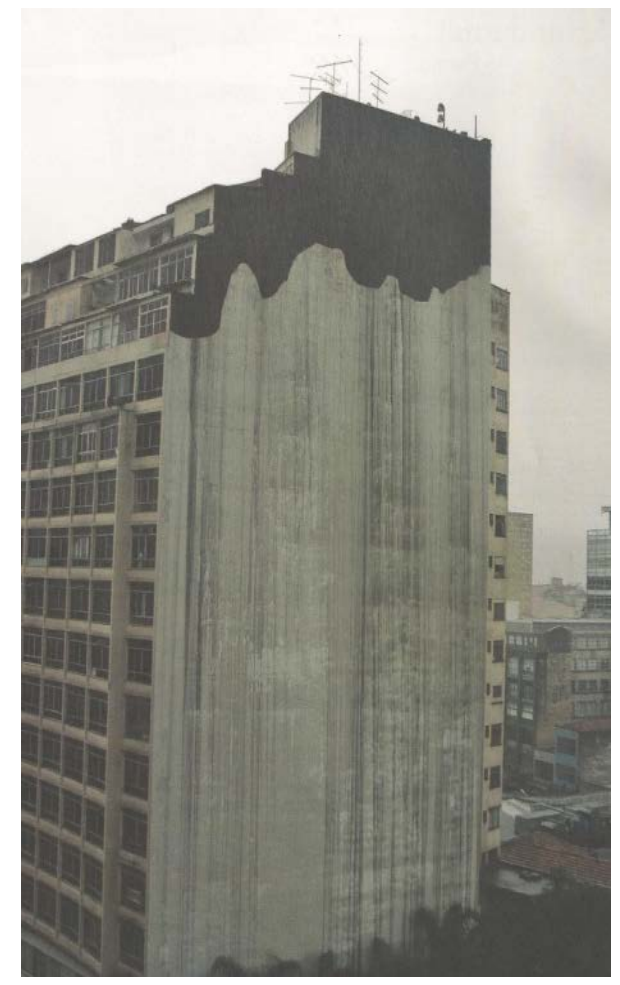

Figura 51: Projeto para uma Pintura com temporal \# 6. Intervenção de Thiago Rocha Pitta, Esquina com a Av. São João e Duque de Caxias, República, São Paulo. Fonte: CATÁLOGO ARTE NA CIDADE, 2012, p. 18. 
O Descanso da Sala, de autoria de José Spaniol, construída em aço e ferro, está instalada de ponta-cabeça, a 7 metros da superfície do lago situado no interior do Parque Burle Marx, em meio à reserva da Mata Atlântica, explorando o elemento água para o efeito de espelhamento. "Há um jogo de ilusão e escala, os objetos parecem mudar de tamanho e de distância. O lugar privado está deslocado para o espaço público, mas está inacessível; passível de certa aproximação, mas não de uso." (CATÁLOGO ARTE NA CIDADE, 2012:11) A obra é a "única que tem um caráter duplo de intervenção e monumento". (MEDEIROS, 2012).

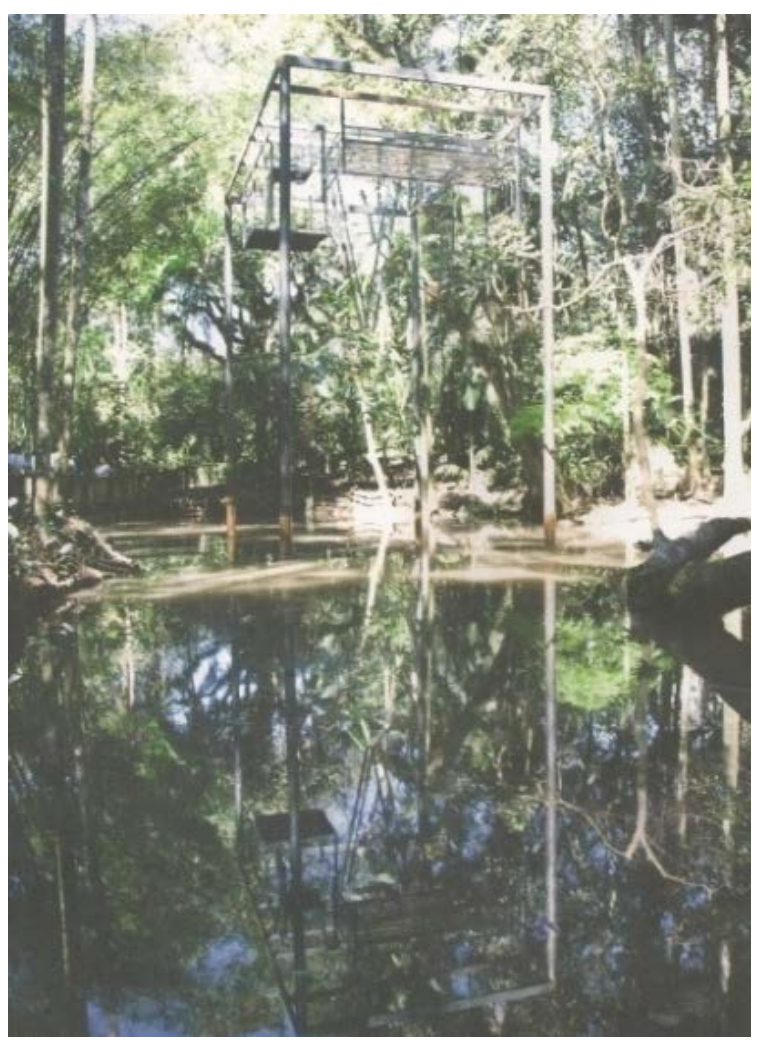

Figura 52: O Descanso da Sala. Intervenção de José Spaniol. Parque Burle Marx, Morumbi, São Paulo. Fonte: CATÁLOGO ARTE NA CIDADE, 2012, p.10.

Tamanduateí, de Paulo Camillo Penna, é uma série de colagens de imagens e palavras feitas com técnicas de xilogravura e tipografia, alusivas à passagem do dilúvio no poema As Metamorfoses, de Ovídio. O autor adota como suporte pilares de viadutos, muros de passarelas e passagens de pedestres do Parque Dom Pedro. Trata da presença do rio na cidade e traz, através de metáforas, a possibilidade de uma reflexão de sua relação com a cidade. 

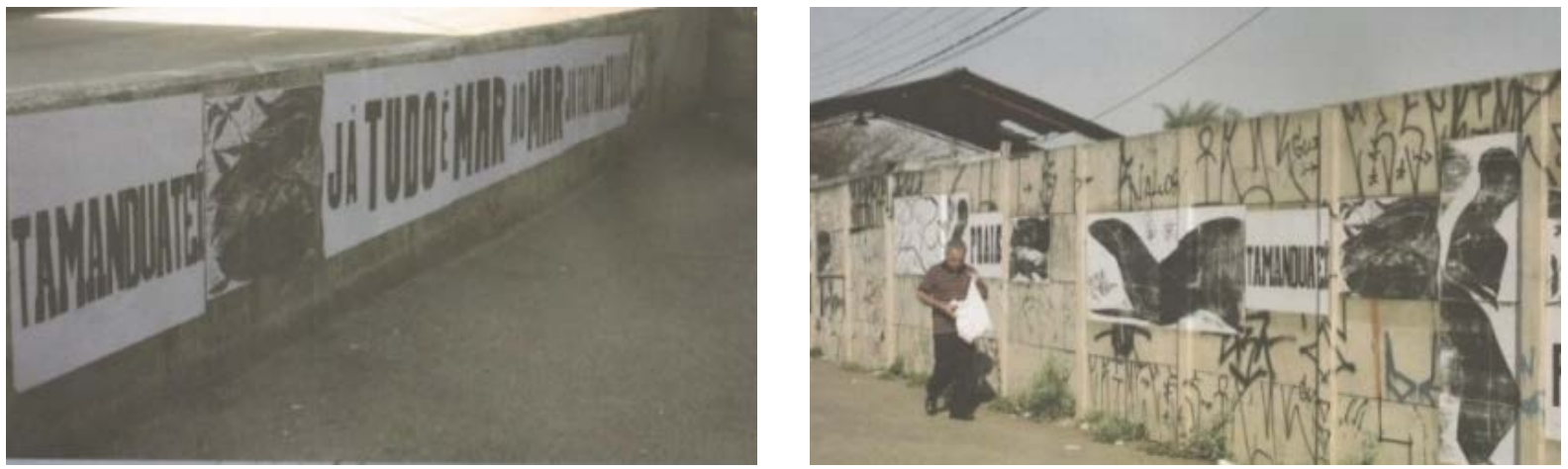

Figuras 53 e 54: Tamanduateí. Intervenção de Paulo Camillo Penna, Parque Dom Pedro, São Paulo. CATÁLOGO ARTE NA CIDADE, 2012, p.17.

Com estrutura modular, as imagens se articulam de maneiras diferentes, permitindo várias configurações. (...) De seis em seis meses, o artista refaz a colagem nos locais, assimilando a ação do tempo e das pessoas às colagens anteriores, rearticulando o trabalho com os dados trazidos pela cidade. (CATÁLOGO ARTE NA CIDADE, 2012, p. 17).

A instalação coletiva Cartograffiti, exibida inicialmente em 25 de setembro de 2011, com permanência até o final do ano de 2012, na Praça Eugene Boudin, em Pinheiros, é coordenada por Mauro Sergio Neri e conta com a participação de nove artistas: Alessandra Cestac, André Monteiro Pato, Floriana Breyer, lara Freiberg, Marcus Enivo, Paulo Ito, Rafael Sliks, Rodrigo Branco e Walter Nomura. Como metodologia serão mapeados:

(...) 21 pontos livres, degradados ou, ainda, sem perspectiva imediata de restauro ou revitalização na cidade, levando em consideração a paisagem, as áreas de proteção ambiental, seus canais e reservatórios hídricos, o fluxo nos principais corredores viários e a mobilidade urbana. Nesses pontos, 0 grupo propõe a criação de uma área de convivência, com bancos, lixeiras e murais com trabalhos dos artistas participantes. Os murais são realizados de maneira coletiva e colaborativa, a partir de uma coleta de informações na região, construindo uma identidade do local onde realizado. Toda intervenção recebe um mapa onde estão marcadas as demais áreas onde o projeto se realiza. Dessa maneira, ao mesmo tempo em que pretende mapear e definir a identidade de cada local, o projeto propõe um circuito onde se estabelece um fluxo pela cidade de São Paulo. (CATÁLOGO ARTE NA CIDADE, 2012, p.15).

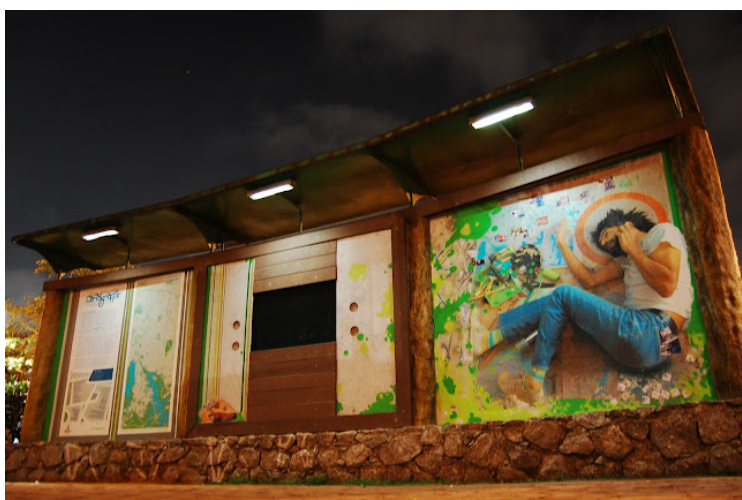

Figura 55: Cartograffiti, Coordenado por Mauro Sergio Neri da Silva. A primeira intervenção foi inaugurada na Praça Eugene Boudin, entre a Ponte Eusébio Matoso, Av. Rebouças e a Passarela Sustentável, São Paulo. Fonte: CATÁLOGO ARTE NA CIDADE, 2012, p.14. 
As obras exibidas a partir de 2012, permaneceram por um período ainda mais reduzido. Nuvem (fevereiro a março de 2012), de autoria de Eduardo Coimbra, instalada na Praça Charles Müller, no Pacaembu, era constituída por cinco caixas de luz, de aproximadamente $5 \times 5 \mathrm{~m}$, que traziam imagens de uma nuvem seccionada. As laterais das caixas, revestidas com espelhos, davam a sensação de maior leveza à estrutura e reforçavam essa ideia que a própria imagem de uma nuvem pressupõe.
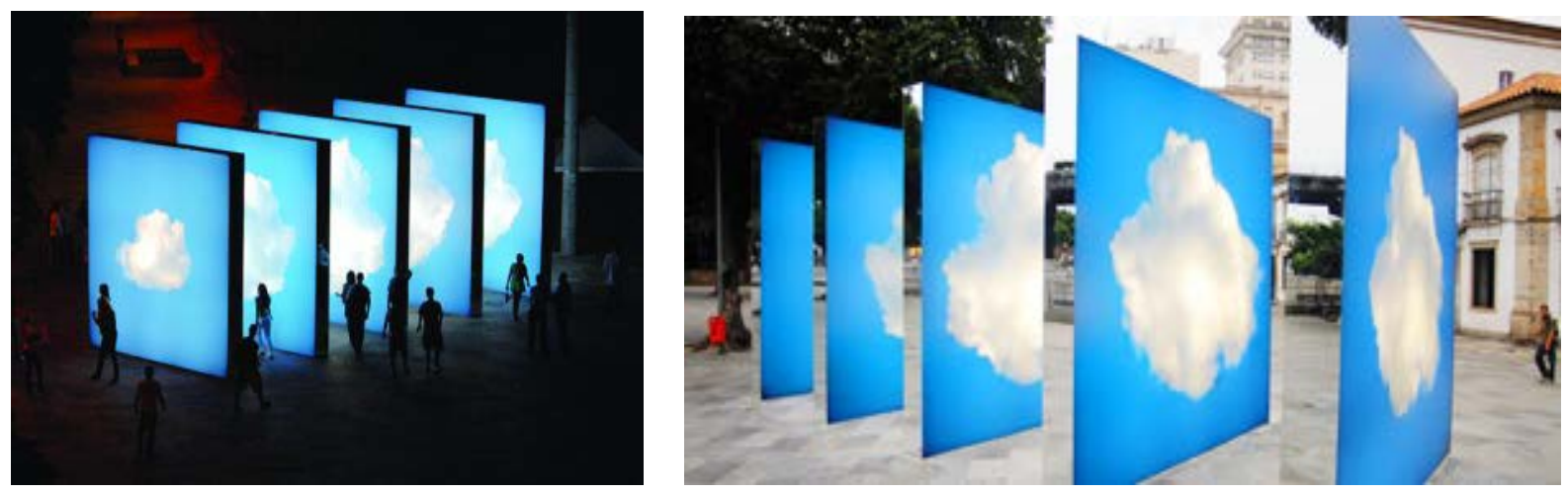

Figuras 56 e 57: Nuvem. Intervenção de Eduardo Coimbra, Praça Charles Miller, Pacaembu, São Paulo. Fonte: CATÁLOGO ARTE NA CIDADE, 2012, p. 06.

Canteiro de operações (março de 2012), de autoria de José Resende, foi idealizada para um ramal ferroviário desativado, na Rua Borges de Figueiredo, na Moóca. Sob curadoria de Nelson Brissac, teve como foco o processo de experimentação. Trilhos e vagões cargueiros semiabandonados foram usados na instalação. Vagões foram suspensos por meio de um grande volume de areia despejada em um dos lados. Com a ajuda de cabos, escavadeiras e guindastes, foi possível promover o desequilíbrio e a suspensão parcial dos resíduos. O artista pôde experimentar diferentes formas de estruturação de peças pesadas, "no limite do equilíbrio, convertendo a área num verdadeiro campo de renovação dos procedimentos e formas da arte em espaços públicos”. Por se tratar de uma área de difícil acesso e visibilidade, um galpão localizado do outro lado do ramal foi utilizado como mirante que abrigava informações sobre a região e o projeto, além de possibilitar debates sobre aspectos urbanos, patrimoniais e artísticos que envolviam a proposta. (CATÁLOGO ARTE NA CIDADE, 2012, p.8). 


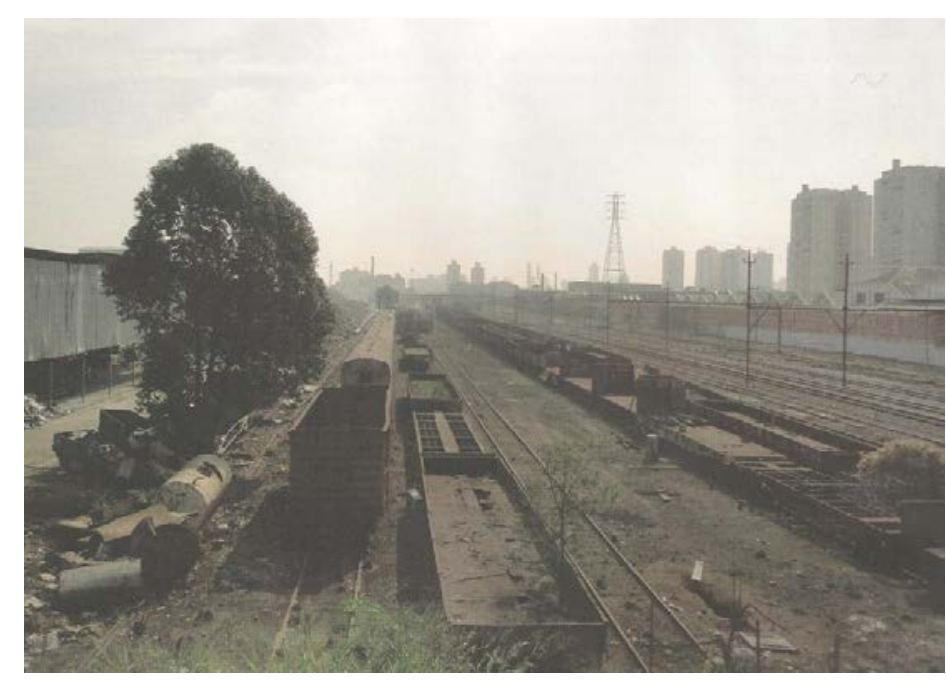

Figura 58: Canteiro de Operações. Intervenção de José Resende, Rua Borges de Figueiredo, Moóca, São Paulo. Fonte: CATÁLOGO ARTE NA CIDADE, 2012, p.8.

Em Clara-Clara (março a agosto de 2012), de autoria de Laura Vinci, a artista utilizou a luz e elementos próprios da iluminação pública da cidade. Sete redes de náilon suspensas, cada uma com sete luminárias ligadas durante 24 horas, substituíram a iluminação da Rua Dr. Miguel Couto, no Centro de São Paulo. A obra era constante, mas seu entorno se transformava de acordo com a luminosidade e as condições climáticas.

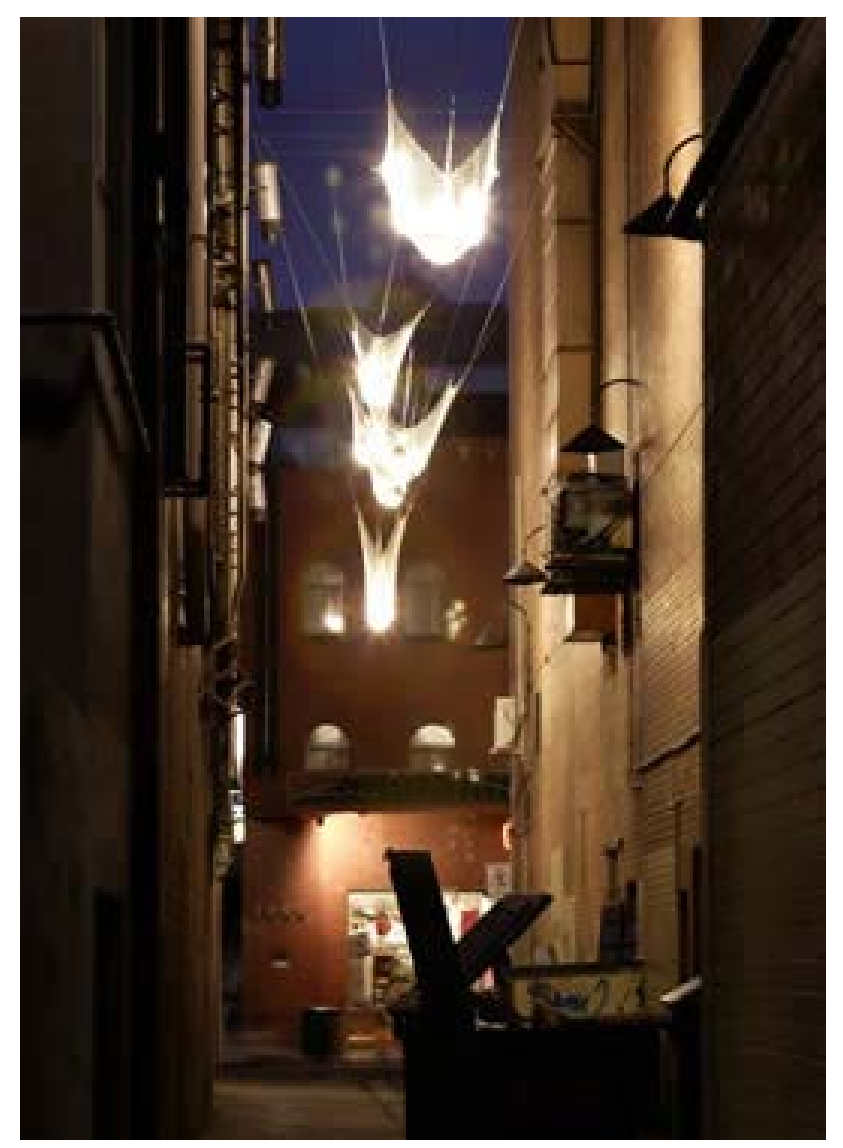

Figura 59: Clara-Clara. Intervenção de Laura Vinci, Rua Dr. Miguel Couto, Centro São Paulo. Fonte: CATÁLOGO ARTE NA CIDADE, 2012, p.12. 


\subsection{CONSIDERAÇÕES SOBRE A LEI DE INCENTIVO FISCAL PARA PROJETOS CULTURAIS NA CIDADE DE SÃO PAULO}

Em 30 de dezembro de 1990, entrou em vigor a Lei $n^{\circ} 10.923$, que regulamenta incentivos fiscais para projetos culturais no âmbito do município de São Paulo. O incentivo fiscal corresponde

ao recebimento por parte do empreendedor de qualquer projeto cultural no Município, seja através de doação, patrocínio ou investimento, de certificados expedidos pelo Poder Público. (LEI DE INCENTIVO, 1990).

Os certificados podem ser utilizados para o pagamento de impostos sobre serviços de qualquer natureza: ISS e IPTU, até o limite de $20 \%$ do valor devido a cada incidência dos tributos. Cabe à Câmara Municipal de São Paulo fixar anualmente o valor que deverá ser usado como incentivo o qual "não poderá ser inferior a $2 \%$ nem superior a $5 \%$ da receita proveniente do ISS e do IPTU" (LEI DE INCENTIVO, 1990). Em 2012, o investimento disponível deverá ser destinado à realização de projetos das áreas de música; artes cênicas (teatro, circo e dança); audiovisual (cinema, vídeo e multimídia); artes visuais (artes plásticas, artes gráficas e fotografia); literatura e bibliotecas; patrimônio histórico e acervos; registro, inventário e conservação de tradições culturais.

Quanto ao processo, após a apresentação e o preenchimento de formulário, o projeto era encaminhado para uma comissão composta por 25 membros, sendo que apenas três eram funcionários públicos e os demais indicados por entidades ou sindicatos vinculados à área da cultura. Como critério de avaliação das propostas eram consideradas: a coerência, a viabilidade técnica e, acima de tudo, orçamentária. "A lei proíbe que se entre no mérito dos projetos." (GOUVEIA, 1994, p.9).

O projeto pré-qualificado recebia uma autorização provisória com duração de 180 dias para que fosse buscado um patrocinador na área privada. No Edital de 2012, a autorização denominada "Certificado Declaratório" tem validade de 365 dias contados a partir da data do despacho (EDITAL PARA APRESENTAÇÃO DE PROJETOS CULTURAIS, 2012). O patrocinador deve fazer um adiantamento do 
valor do projeto que é passado para o artista ou produtor. As empresas podem efetuar o desconto durante 24 meses, período em que o valor é corrigido pelo mesmo índice do imposto a pagar.

A partir de 1996, o edital publicado pela comissão a cada 4 meses, passou a ser aberto no início do ano e tem se estendido até o final, como é feito na Lei Rouanet. Como critério de seleção passaram a ser considerados: o caráter cultural do projeto, os benefícios de sua produção, a extensão de seu interesse, o efeito multiplicador da produção, a participação da coletividade, o atendimento de áreas culturais com menores possibilidades de desenvolvimento com recursos próprios e o acesso das populações de baixa renda.

A partir dos critérios iniciais entende-se que a lei foi feita para incentivar projetos de arte pública, entretanto, de acordo com Gouveia, uma pequena parcela dos trabalhos realizados eram efetivamente de arte pública. Complementa que a combinação do uso de lei federal com municipal para o patrocínio de um mesmo projeto possibilitaria ao empresário desembolsar menos de $10 \%$ do valor total. Benefícios de marketing como a promoção de imagem institucional, o prestígio social e a adição de valor à marca podem ser alcançados, mas são pouco divulgados. Os recursos disponíveis são consideráveis, mas também falta divulgar esses mecanismos junto à população. (GOUVEIA, 1995, p.91).

Com referência em pesquisa realizada, Roberto Muylaert afirma que

os incentivos fiscais não são objeto de preocupação dos empresários (...) que pensam em cultura independentemente de terem ou não incentivo.

A primeira preocupação é com a adequação da ação cultural à imagem da empresa que leva em consideração a qualidade do projeto e a confiança em quem o criou. Em segundo lugar, está o retorno do investimento para a empresa. O incentivo fiscal fica em último plano. Muitos projetos que ganham direito de usar a Lei Rouanet não saem do papel. Isto se deve à falta de envolvimento do produtor cultural com a área financeira da empresa, que considera a despesa inútil, e da falta de apoio da área de marketing. Com a Lei Rouanet é possível $70 \%$ de redução fiscal nas despesas da empresa; no caso de bancos, chega a $75 \%$. Somada à Lei de Audiovisual, a dedução é de $100 \%$. Neste sentido, é necessário que o Ministério da Cultura tenha uma equipe de auditores que apresentem à área financeira das empresas que 
cultura também é um bom negócio. Uma das possibilidades seria levar a cultura para o entorno de seu próprio edifício, trazendo benefícios para elas mesmas (MUYLAERT, 1995, p.83-86). 



\section{A ARTE NO ESPAÇO PÚBLICO DAS ESTAÇÕES DE METRÔ DE SÃO PAULO}

\subsection{CONSIDERAÇÕES SOBRE A REESTRUTURAÇÃO E A INTERVENÇÃO VISUAL NA PRAÇA DA SÉ}

Para melhor compreender o contexto e o processo da inserção de obras de arte no espaço das estações de metrô de São Paulo é necessário conhecer um pouco da história de um dos espaços públicos mais representativos da cidade, cuja fisionomia é marcada por mudanças, reformas e transportes coletivos sempre presentes - a Praça da Sé - onde tudo começou (FERRARA, 1986, p.124).

Palco de significativas manifestações culturais, políticas e sindicais, a Praça da Sé, espaço público da área central da cidade, passou por sucessivas transformações ${ }^{42}$ até tornar-se a primeira superpraça do país. Particularmente, na década de 1970, com o objetivo do poder público de promover a revitalização do local, foi realizado o processo de reestruturação e intervenção visual que a reconfigurou ${ }^{43}$.

Com o projeto, pretendia-se tornar o "ambiente agradável, amplo e renovado". A transferência do centro de decisões financeiras e de comércio de alto nível para a Avenida Paulista e proximidades da Rua Augusta, fez com que o local fosse ocupado por marginais, desempregados, vendedores ambulantes, contrariando as intenções do projeto (FERRARA, 1986, p.130). Com a implantação da estação de metrô em seu subterrâneo, supunha-se a oportunidade de mudar sua aparência e utilização.

A historiadora e museóloga Radha Abramo observa que, ao contrário do que se previa, a construção da Estação Sé desencadeou a destruição da área. A praça ficou muito grande e os respiradouros do metrô causaram poluição visual no local. Por se tratar de um espaço público, diretamente ligado à história política e trabalhista da cidade e, portanto, com uma carga emotiva muito significativa, uma ampla

\footnotetext{
${ }^{42} \mathrm{Em}$ seu processo de transformação, a Sé foi "Adro de igreja colonial, eixo urbano, centro de manifestações políticas, fulcro de agigantamento urbano" para posteriormente tornar-se superpraça, característica "que Ihe roubou a antiga estrutura, a primitiva fisionomia" (FERRARA, 1986, p.124).

${ }^{43}$ No ano de 1744, "foi demolida a primeira igrejinha de São Pedro da Pedra para dar lugar a outra igreja, mais imponente". Com o desenvolvimento comercial das ruas adjacentes, o progresso cafeeiro, o início do ciclo industrial e o advento da tração elétrica, a Sé passou por diversas ampliações sem que houvesse um planejamento, o que no entender de Lucrécia, nos "permite levantar a suposição do desejo de monumentalizar São Paulo." (FERRARA, 1986, p.124).
} 
pesquisa foi realizada como ponto de partida para o projeto de reestruturação local. Durante o período de três meses, uma comissão da Empresa Municipal de Urbanização-EMURB, composta por arquitetos, engenheiros, técnicos do metrô, historiadores e críticos de arte realizou o levantamento de artistas, técnicas, programação visual e apresentação de maquetes. Na seleção das obras, que constituiriam o Museu das Esculturas, realizada por uma comissão nomeada pelo Prefeito Olavo Egydio Setubal, permaneceram artistas que "já tinham experiência com trabalhos em escala monumental e com materiais duráveis, requisitos necessários para o trabalho" (ABRAMO, 1995, p.57-58). No total, foram instaladas 15 esculturas na praça e uma no interior da estação: Aparência do Inacabado de Caciporé Torres, Diálogo de Franz Weissmann, O Espaço Cósmico de Yutaka Toyota, Condor de Bruno Giorgi, A Estética vem do Sul de Francisco Stockinger, Sombras em Mutação de Sérgio Camargo, A Lírica das Nuvens de Nicolas Vlavianos, O Voo da Liberdade de Felícia Leirner, Luz e Sombra de Ascâmio Maria Martins Monteiro, Emblema de São Paulo de Rubem Valentim, O Rigor Construtivo de José Resende, Sem Título de Mário Cravo Junior, Dinâmica das Linhas de Amilcar de Castro, Totem da Sé de Domenico Calabrone, Garatuja de Marcello Nitsche, instalada inicialmente em uma das escadas de acesso à estação de metrô e Sem título de Alfredo Ceschiatti, particularmente, a única obra do museu que apresentava característica figurativa e a única instalada no interior da estação. Ainda em 1978, a Companhia comprou e instalou dois murais na estação: Colcha de Retalhos de Claudio Tozzi e Sem título de Renina Katz. (O ESTADO DE SÃO PAULO, 1979; FERRARA, 1986, p.124-145).
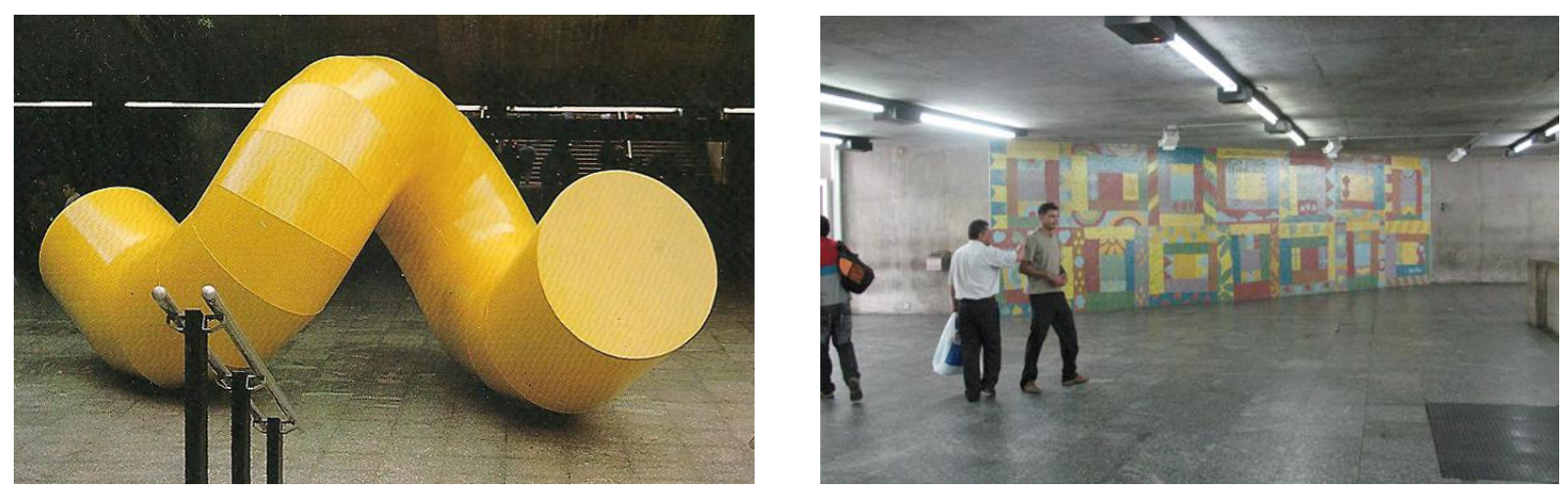

Figura 60: Garatuja, Marcello Nitsche, 1978. Fonte: COMPANHIA DO METROPOLITANO DE SÃO PAULO, 1991, p.146.

Figura 61: Colcha de Retalhos, Claudio Tozzi, 1979. Fonte: Registro fotográfico realizado pela pesquisadora. 

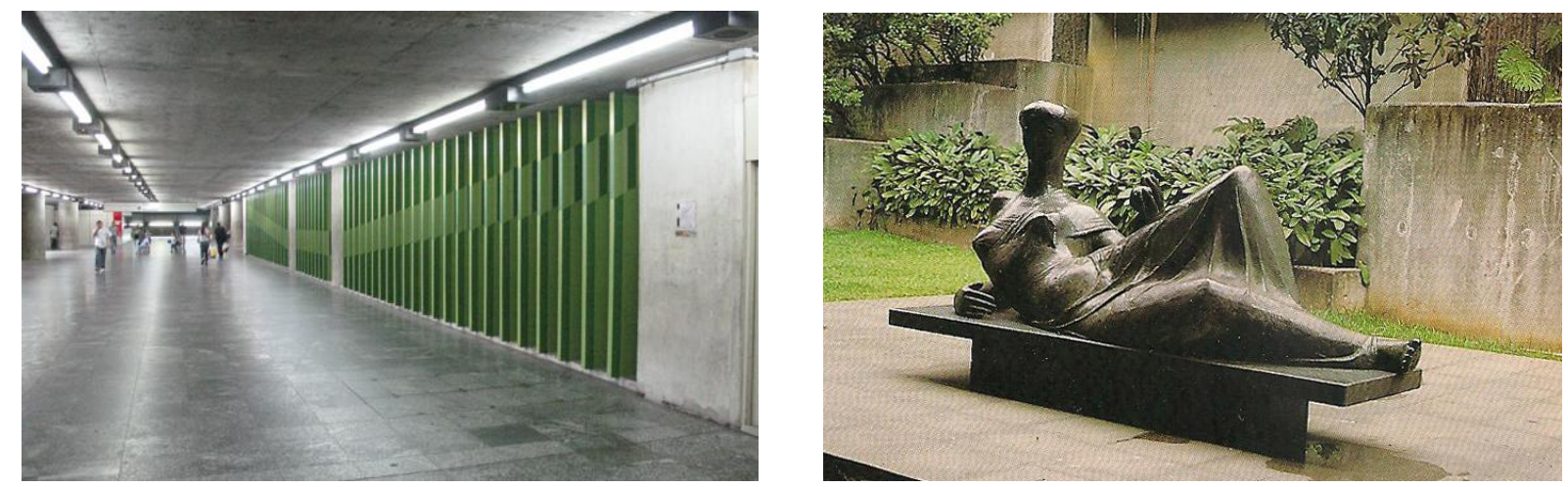

Figura 62: Sem título, Renina Katz, 1978. Fonte: Registro fotográfico realizado pela pesquisadora.

Figura 63: Sem título, Alfredo Ceschiatti, 1978. Fonte: COMPANHIA DO METROPOLITANO DE SÃO PAULO, 1991, p.146.

Amplamente divulgado pela imprensa, o projeto que exigia demolições e extenso canteiro de obras, à medida que ia sendo executado, apresentou uma grande variedade de materiais e de recursos decorativos que atribuíram um "empilhamento kitsch" (FERRARA, 1986, p.133) ao local, do qual também faziam parte as obras de arte:

(...) Piso de mosaico e granito, rosa-dos-ventos revestida de granito e mármore branco do Paraná, 110 luminárias antigas recondicionadas, 86 luminárias quase ao nível do solo, palmeiras imperiais, chorões, tipuanas em área de dois mil metros quadrados e número de 250, 150 bancos de madeira, relógio-carrilhão de quatro faces, cascata artificial, espelho d'água em cinco níveis e entre tudo 15 esculturas de artistas célebres.

A ocupação múltipla do espaço superior remanescente da estrutura subterrânea do metrô resultou numa aglomeração de ambientes e um acúmulo desordenado de elementos que não atingem o objetivo físico do projeto que era aproveitar a cobertura do metrô para decorar, definitivamente, a Praça da Sé dando-Ihe status de cartão de visita e, ao mesmo tempo, sanear o centro da cidade apagando o aspecto descuidado e periférico. Estranho destino de um projeto urbano que em lugar de estabelecer um princípio de ordem, um código que o fizesse legível e traduzível em uso, implanta redundância descontrolada e gratuita. Se o objetivo coercitivo do projeto chegasse a alcançar a intenção, seria um rígido princípio de ordem estabelecido na linguagem do centro urbano, entretanto, consciente ou inconsciente, aquele princípio coercitivo procurou esconder-se em soluções decorativas e gratuitas que redundam em empilhamento kitsch. (FERRARA, 1986, p.133). 
Espelhos d'água e cascatas, construídos em escala reduzida, não se integram ao conjunto da praça. Planos e escadas impedem o acesso e o rápido cruzamento. "O passar não se transforma em passear, em lazer", "inexequível e obstruído pela passagem incessante dos passageiros que demandam a estação do metrô ou dela saem, apesar de numerosos bancos que preenchem o limitado espaço livre remanescente da ocupação de floreiras e jardins." De acordo com Ferrara, "o espaço foi projetado para a escala do monumento e não para o uso." Obras de arte foram espalhadas pela praça como "instrumento eficaz" sem, contudo, considerar a bagagem cultural do usuário/espectador. Toda a variedade de elementos não proporcionou aos seus usuários um espaço adequado ao seu uso e que contribuísse, enquanto fonte de informações, para um público tão diversificado social e culturalmente. $O$ novo projeto propunha demolir e construir tudo novamente. Procurava fazer uma "assepsia da história, transformando o quotidiano em monumento. Uma praça novinha feita para dar a impressão de velha, tradicional, escultural" (FERRARA, 1986, p.131). Dessa forma, a concepção do projeto teve desdobramentos que, na realidade, não condiziam com as intenções de proporcionar circulação, espaço para manifestações cívicas e religiosas e para lazer. Não condiziam com o objetivo físico para aquele espaço e para aquele usuário.

(...) projetada fora da escala do usuário, a superpraça torna-se ilegível e transforma em espectador aquele que deveria ser ator; tenta envolver e extasiar, teatralmente, o usuário; porém isto não é suficiente ou é, até, um obstáculo para o uso. Aquela praça não tem nada a ver com aquele usuário; levando ao ápice o objetivo de culturação do centro urbano, a superpraça instalou um repertório intraduzível para o usuário, em uma clara manifestação de ampliação de repertório de classe social mais simples pela maratona de levar cultura. Nessa empresa a 'arte' aparece na qualidade de instrumento pretendido como eficaz: é o caso de 15 esculturas espalhadas pela praça, confundindo o espaço, indecifráveis nas suas mensagens considerando-se a taxa de informação do repertório daquele receptor. (FERRARA, 1986, p.132).

Não coube, no projeto, qualquer questão sobre o legítimo usuário da praça nos dias atuais, as características do seu padrão urbano, as possibilidades, não de elevação elitista do seu repertório, mas de diversificação da taxa de informações a que ele poderia ter acesso a partir de suas características sociais e de suas necessidades urbanas (FERRARA, 1986, p.131). 

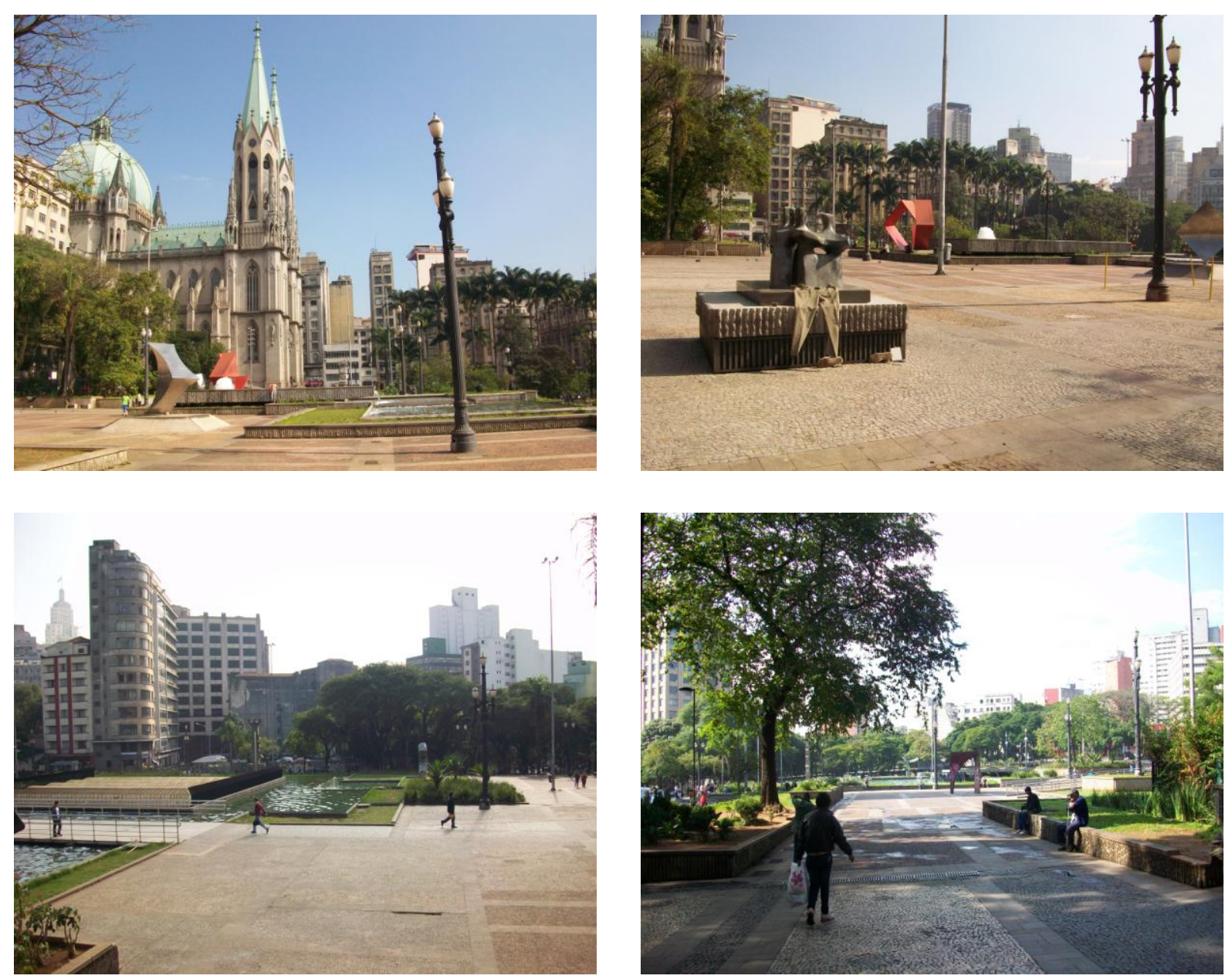

Figuras 64, 65, 66 e 67: Praça da Sé, 2011. Fonte: Registro fotográfico realizado pela pesquisadora.

Em outro texto a autora analisa a Praça da Sé como ambiente urbano, discorre sobre a poluição visual, a ilegibilidade daquele ambiente e a importância do usuário como elemento catalisador, considerando o planejador urbano, o primeiro usuário do ambiente projetado a quem compete "apreender o uso sugerido pelo contexto e plasmar, materialmente, esse uso, esse significado ambiental" (FERRARA, 1977, $s / p)$.

\subsection{O PROJETO ARTE NO METRÔ E O PROGRAMA AÇÃO CULTURAL}

A principal preocupação na concepção dos projetos do metrô sempre esteve direcionada à "escolha da Tecnologia mais moderna e adequada que pudesse responder às necessidades de um transporte de massa" para a megalópole. (GIOSA, 1994, p.7). 
A princípio, no entender da Companhia do Metropolitano, a qualidade desse meio de transporte público estaria traduzida em cuidados voltados à boa operação $\mathrm{e}$ manutenção dos trens e das instalações, segurança, rapidez, confiabilidade, regularidade, conforto (terminais de integração com outros meios de transporte), facilidade de acesso para os usuários, boa comunicação visual, limpeza, telefones, sanitários, lojas de utilidades, postos de atendimento médico, de achados e perdidos, central de informações e caixa de sugestões. No entanto, na década de 1970, o sistema já operava com deficiência em sua capacidade de oferta, principalmente na Linha Leste-Oeste. Na década de 1980 teve sua sobrecarga intensificada em função da inauguração do Terminal Rodoviário do Tietê e do aumento significativo da demanda das classes populares devido à ampliação do poder de compra proporcionado pelo Plano Cruzado (1986), que congelou o preço do bilhete. Diante das frequentes falhas, interrupções e atrasos dos trens a sensação de insegurança foi instalada e, com ela, a crescente insatisfação do usuário/consumidor (HATANAKA, 2009).

$\mathrm{Na}$ tentativa de apaziguar a relação com os usuários, a administração adotou como parte do Programa de Gerenciamento de Qualidade Total, a "arte aliada à tecnologia", entenda-se aqui a arte, em suas diversas formas de expressão, como um canal de aproximação mais intenso com o usuário, um instrumento constante de melhoria do sistema e dos serviços, um elemento cultural que serviria como "instrumento de humanização" (GIOSA, 1994, p.7). Ainda nos anos 1970 foram implantados o Projeto Arte no Metrô e o Programa Ação Cultural, ambos lançados sob responsabilidade do Departamento de Marketing e Comunicação da empresa.

\subsubsection{As obras permanentes do Projeto Arte no Metrô}

Seguindo o exemplo de estações de metrô do âmbito internacional, amplos espaços de mezaninos, jardins internos e externos, corredores de acesso às plataformas e plataformas de embarque/desembarque passaram a ser entendidos como ambientes propícios às intervenções ambientais. A inserção da arte nesses espaços ocorreu timidamente com a apresentação de concertos musicais e de algumas poucas obras plásticas instaladas. A reação positiva dos usuários, demonstrada pela aceitação, 
preservação e apreciação das obras de arte, constatada tanto por pesquisas formais realizadas pela Companhia, quanto pela observação in loco do comportamento do usuário resultou no Projeto Arte no Metrô (FREITAS, 1994, p.10). Idealizado pela historiadora e museóloga Radhá Abramo, o projeto tomou forma e consistência em 1978, com a inauguração da Estação Sé, mas somente em 1988 ganhou impulso e tornou-se prioritário.

Atualmente, a rede do Metropolitano de São Paulo possui 67 estações em funcionamento, como indicado no ANEXO I. Em 38 delas, estão distribuídas 106 obras de arte do acervo permanente da Companhia, de autoria de diversos artistas: Amélia Toledo, Alfredo Ceschiatti, Antonio Peticov, Claudio Tozzi, Cleber Machado, Gilberto Salvador, José Roberto Aguilar, Maurício Nogueira Lima, Marcello Nitsche, Maria Bonomi, Mario Gruber, Odiléia Toscano, Renina Katz, Tomie Ohtake, Waldemar Zaidler, Wesley Duke Lee, entre outros ${ }^{44}$.

A seguir, na Tabela 1, a apresentação das obras do acervo permanente, organizadas por tipo de material empregado: tintas, metais, cerâmicas, vidros e outros tipos de materiais, em ordem alfabética das estações ${ }^{45}$.

\footnotetext{
${ }^{44}$ Rubens Gerchman apresentou uma proposta de painel para ser instalado em uma das estações da linha amarela. O projeto foi aprovado pela comissão, mas devido à falta de patrocínio e ao falecimento do artista não foi levado adiante.

${ }^{45} \mathrm{~A}$ maior parte dos registros fotográficos das obras foi realizada pela autora. Devido às obras de reforma e construção das estações e à falta de equipamento adequado para o registro, algumas imagens foram extraídas dos catálogos e do site da Companhia.
} 
Tabela1: Obras do acervo permanente da Companhia do Metropolitano de São Paulo

\section{TINTAS}

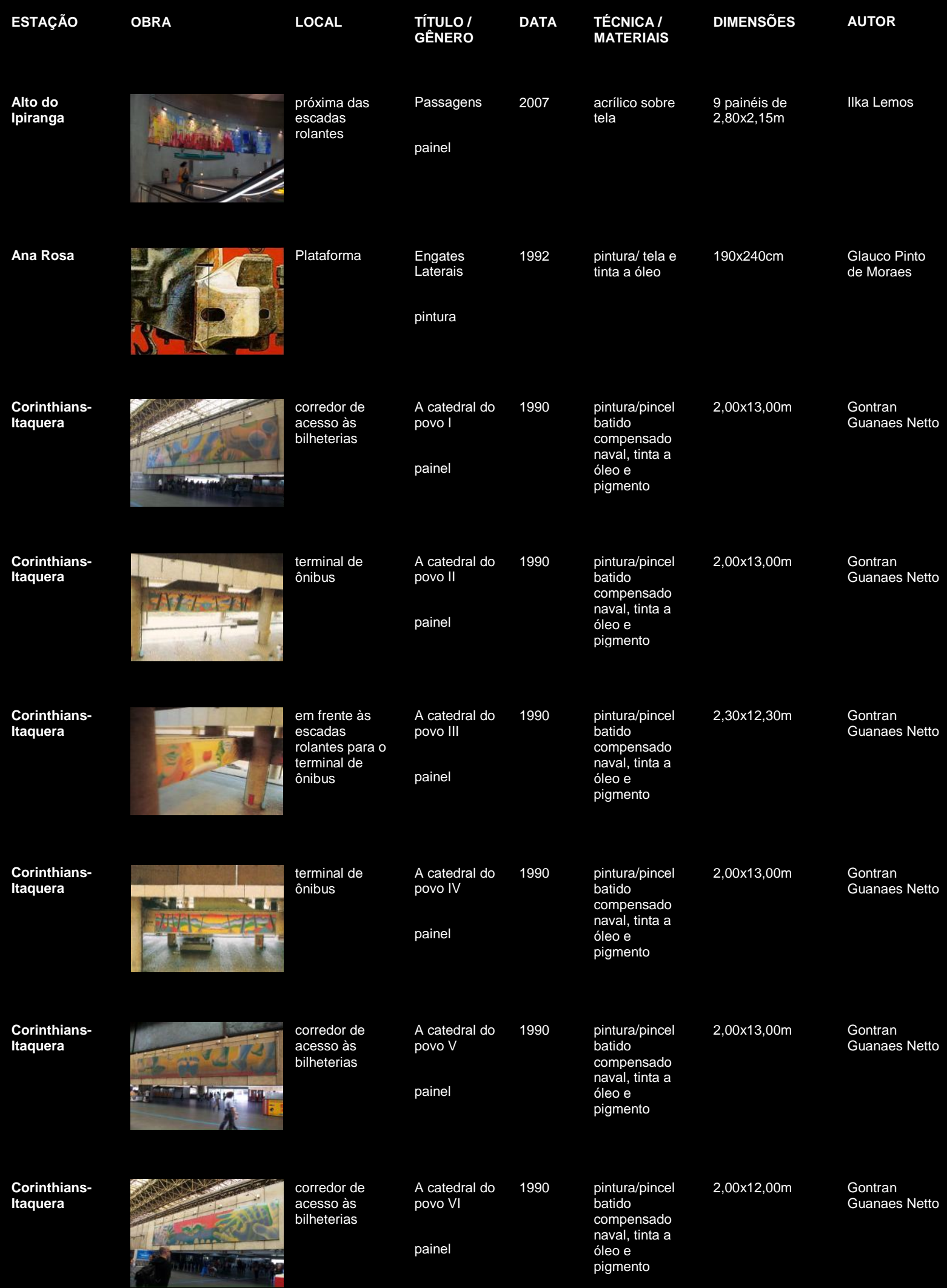




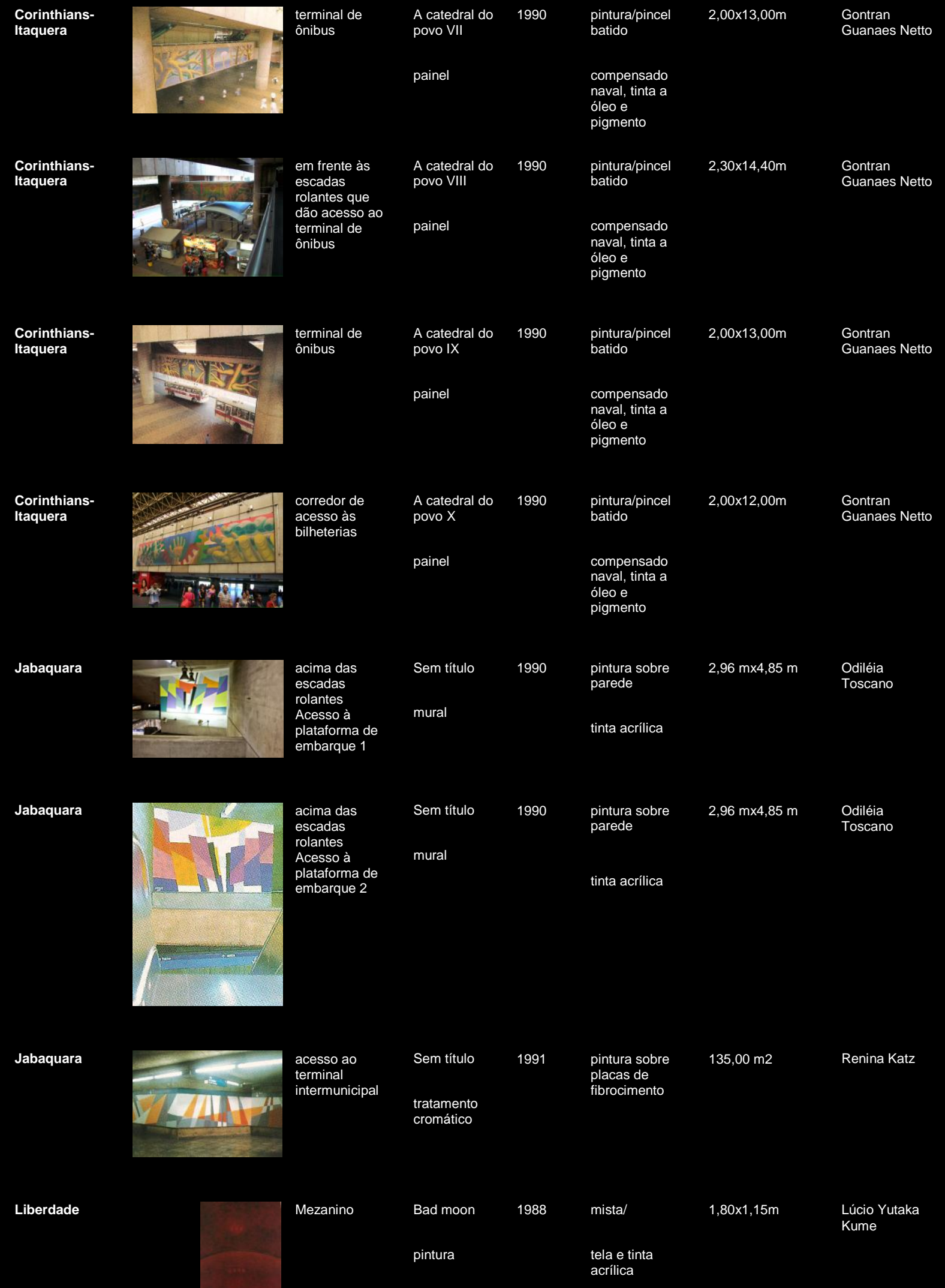


Liberdade

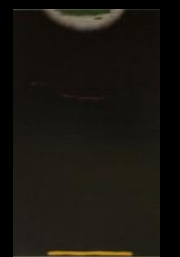

mezanino

\begin{tabular}{|c|c|c|}
\hline Momento & 1988 & pintura/ \\
\hline nintura & & tela e tinta \\
\hline
\end{tabular}

$1,80 \times 1,15 \mathrm{~m}$

Laerte Yoshiro acrílica

Liberdade

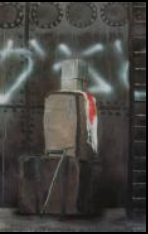

mezanino

O primeiro
imigrante a

1988

pintura/

desembarcar

tela e tinta

$1,80 \times 1,15 \mathrm{~m}$

Oscar Satio

acrílica

pintura

Liberdade

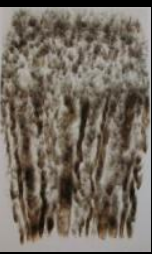

mezanino

Paralelepípe

1988

fuligem sobre

tela fixada com

$1,80 \times 1,15 \mathrm{~m}$

Mário Noboru

verniz acrílico

Ishikawa

pintura

algodão cru

tinta vinílica

querosene

Liberdade

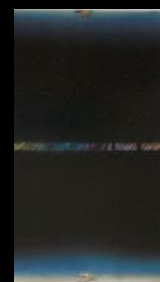

mezanino

Pós 80

1988

mista/

$1,80 \times 1,15 \mathrm{~m}$

Hironobu Kai

pintura

tinta acrílica e

tela

\begin{tabular}{|c|c|c|c|c|}
\hline $\begin{array}{l}\text { Projeto para } \\
\text { uma paixão } \\
\text { sem fim }\end{array}$ & 1988 & $\begin{array}{l}\text { bico- de-pena } \\
\text { tela, tintas } \\
\text { nanquim }\end{array}$ & $1,80 \times 1,15 \mathrm{~m}$ & $\begin{array}{l}\text { Milton } \\
\text { Terumitsu } \\
\text { Sogabe }\end{array}$ \\
\hline
\end{tabular}

desenho

nanquim

Liberdade

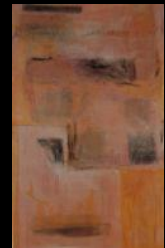

mezanino

Tempo I
pintura

1988

mista

$1,80 \times 1,15 \mathrm{~m}$

Ayao Okamoto

papel arroz,

tinta acrílica,
lápis e verniz

Liberdade

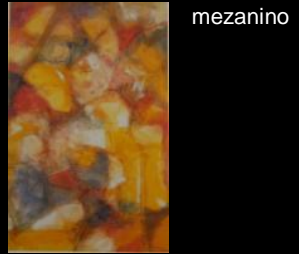

Sem título $\quad 1988 \quad$ mista

$1,80 \times 1,15 \mathrm{~m}$

Carlos

Yasoshima

pintura

papel, paste

seco e tinta

acrílica 


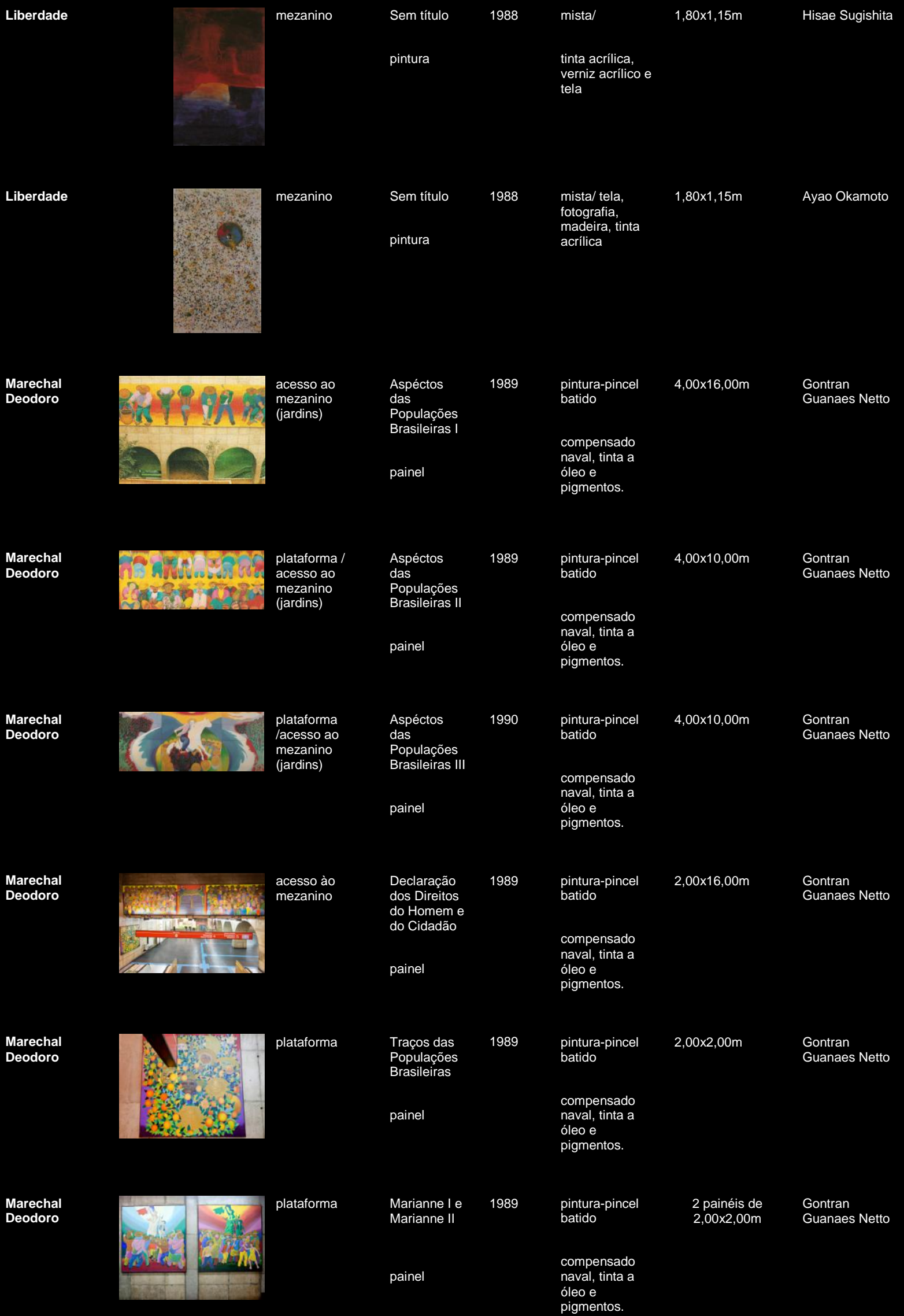




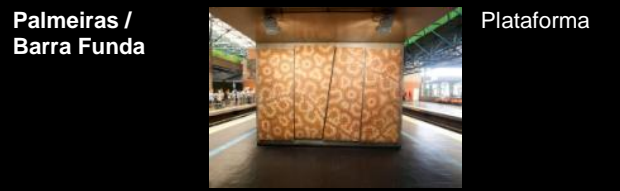

Palmeiras / Barra Funda

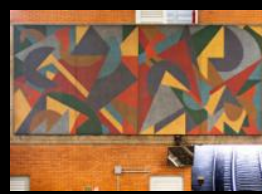

Plataforma

Movimento
painel

1990

pintura/

$3,50 \times 8,00 \mathrm{~m}$

Claudio Tozzi

tinta acrílica

sobre tela

$\begin{array}{lll}\begin{array}{l}\text { Senhores do } \\ \text { movimento }\end{array} & 1990 & \text { pintura/ } \\ \text { painel } & & \begin{array}{l}\text { tinta acrílica } \\ \text { sobre tela }\end{array}\end{array}$

Palmeiras /

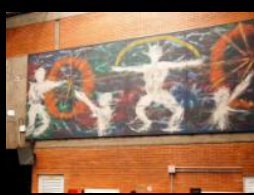

plataforma

Raios de sol

1990/ Catedral

parede acim

da escada fixa

$-1$

mural

1991

concreto/

tinta acrílica

acesso à

Catedral

Ortodoxa,

parede frontal

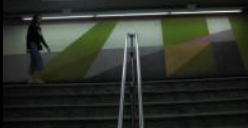

mura

1990

pintura sob

concreto/

1991

tinta acrílica

Sem título- 3 1990/

acesso

Brahma,
parede acim

das escadas

mura

1991

pintura sobre concreto/

tinta acrílica

Odiléia

Toscano $\begin{array}{ll}3,50 \times 8,00 \mathrm{~m} & \text { José Roberto } \\ \text { Aguilar }\end{array}$

$4,40 \times 4,00 \mathrm{~m} \quad$ Odiléia

Toscano

Odiléia

Toscano

Paraíso

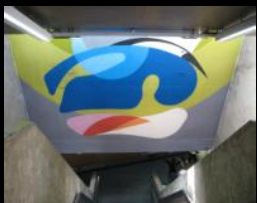

acesso ao Viaduto Santa Generosa

\section{Sen}

mura

1990/

pintura sobre concreto/

$5,85 \times 6,60 \mathrm{~m}$

Odiléia

mural

1991

tinta acrílica

Paraíso

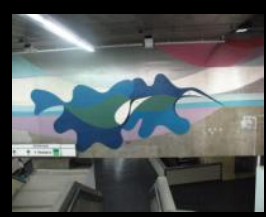

hall de acesso à plataforma

Sem título- $5 \quad 1990$

pintura sobre concreto/

$3,20 \times 33,00 \mathrm{~m}$

Odiléia

mural

1991

tinta acrílica

Sem título- 6 1990/

pintura sobre concreto/

$1,60 \times 9,90 \times 4,00 \mathrm{~m}$

mural

1991

tinta acrílica 


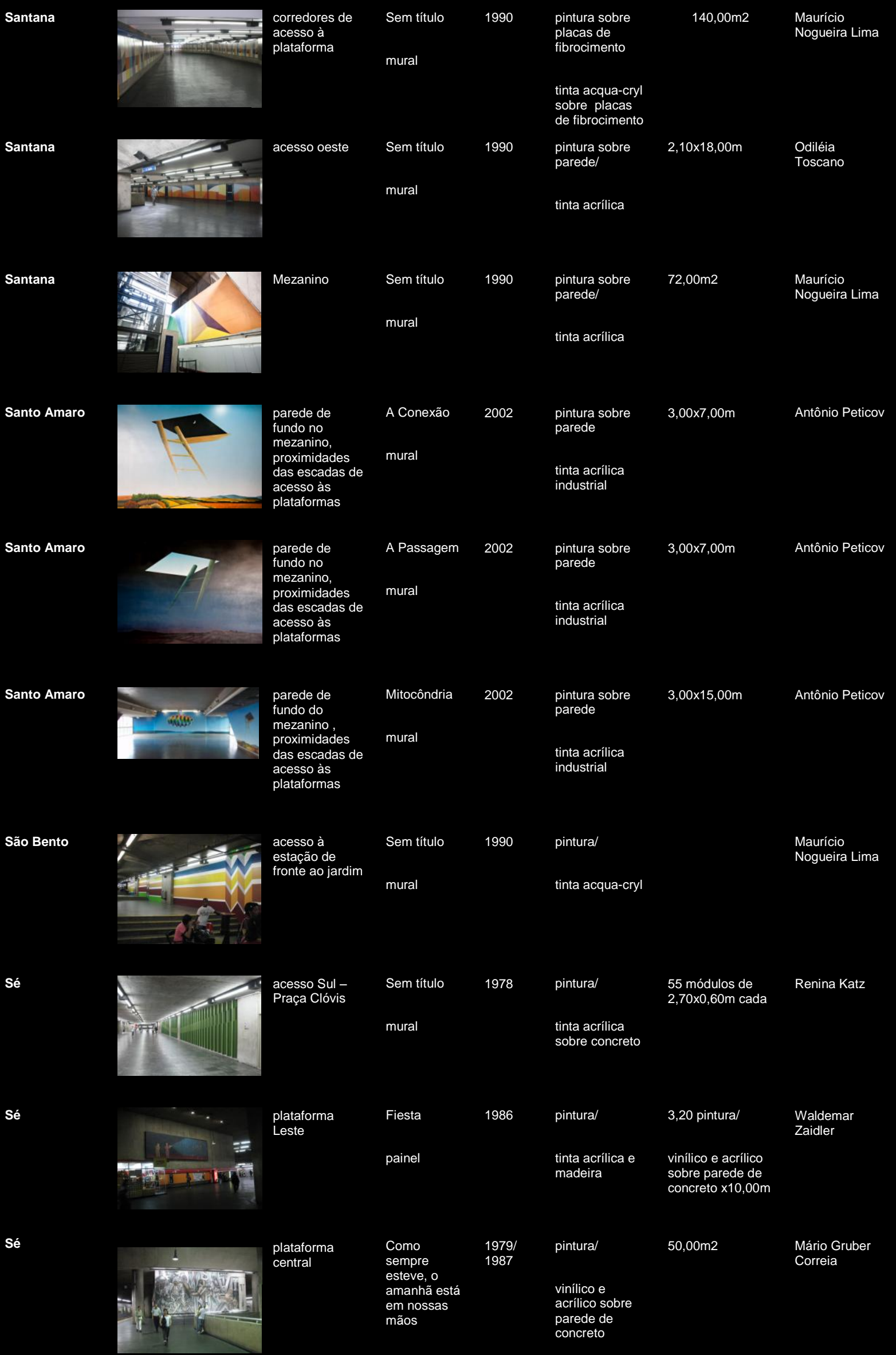




\section{METAIS}

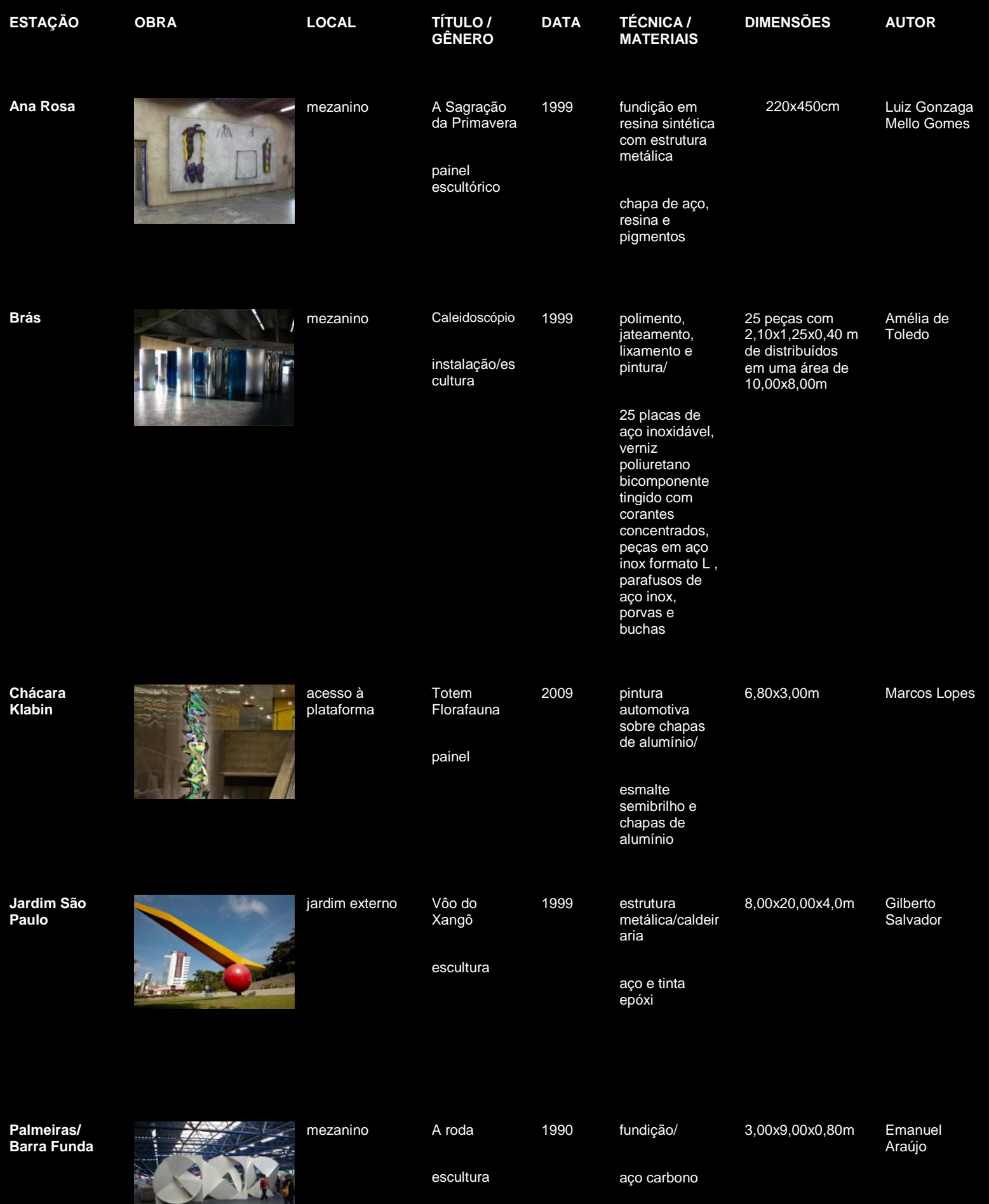


Paraíso

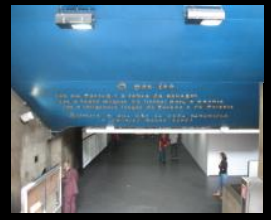

acesso à Praça

O paraíso

1995

letra bloco/

$4,00 \times 5,00 \mathrm{~m}$

Betty Milan

Generosa

poesia

chapa

galvanizada

com tinta

metálica

República

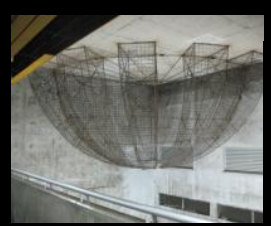

Século XXI -

1991

estrutura em ferro soldado/

$12,00 \times 3,00 \mathrm{~m}(\mathrm{a}$ direita)

Vestígios

vergalhões e

$11,20 \times 5,60 \mathrm{~m}$ (à

instalação

tela de ferro

esquerda)

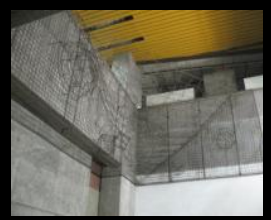

Santa Cecília

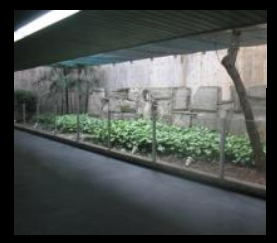

piso

intermediário

jardim interno

Trilho, ritm

e vibração

1991

fundição/

Caciporé

aço, pó de

escultura mármore $\mathrm{e}$

cimento branco

Santos-

Imigrantes

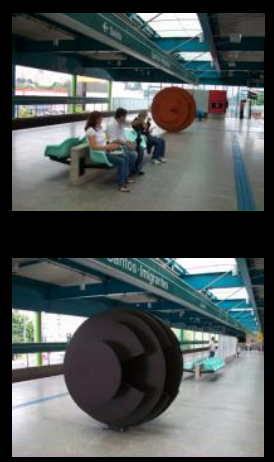

plataforma

Esfera

2009

ferro pintado

$2,00 \mathrm{~m}$ de

diâmetro

Marcos Garrot

escultura

São Bento

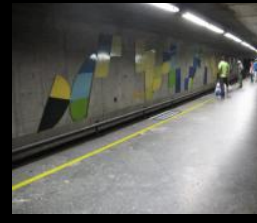

plataforma

sentido

Jabaquara-

Tucuruvi

Sem título

1990

chapas

recortadas

$350,00 \mathrm{~m} 2$

Odiléia

painel

tintas sintéticas

e acrílicas e

chapas de

metal

São Bento

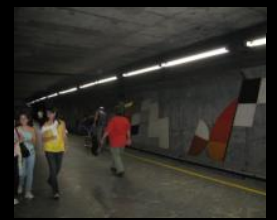

plataforma

Sem título

1990

chapas recortadas e pintadas/

$350,00 \mathrm{~m} 2$

Odiléia

tintas sintéticas

e acrílicas e

chapas de

metal 
Sé

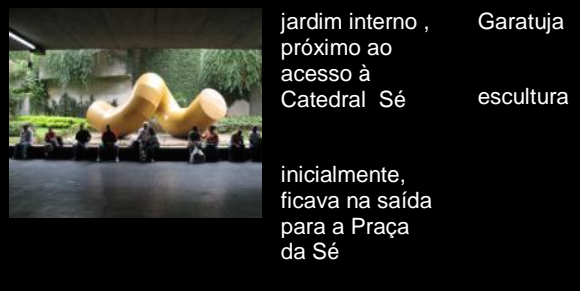

1978

pintura
poliuretan

poliuretana
sobre metal

soldado/

chapa de ferro

metalizada com

zinco - placas

de aço

vincadas e

pintura em

poliuretano

Sé

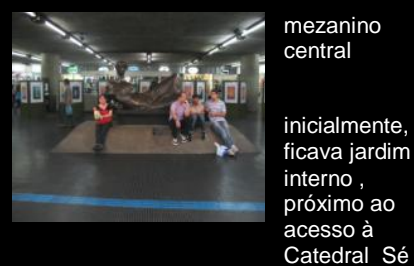

Sem título

1978

modelagem me

$1,27 \times 3,05 \times 1,00 \mathrm{~m}$

Alfredo bronze/

Ceschiatti

escultura

bronze e

granito

(pedestal)

acesso a

Sem título 1995 aço corten

$2,00 \times 1,60 \times 0,80 m$

Luis Carlos

Martinho da

escultura

Silva

Senhora de

Fátima-

Freire

(n)

Sumaré

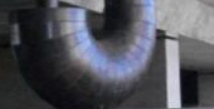

Tucuruvi

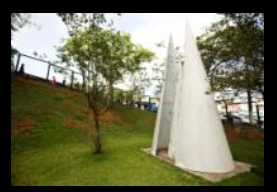

jardim externo Ogô

1999

modelação em

$7,00 \times 3,30 \mathrm{~m}$

fôrma de

madeira,

escultura

interna em aço/

aço, resina de

polietileno, tinta

epóxi

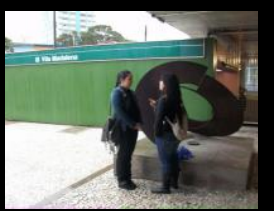

Praça Américo

Homenagem

2007

mista/

Galilei II

estrutura em

aço corten,

resina epóxi e

granalha de

aço

$2,00 \mathrm{~m}$

Cleber

Machado

escultura 


\section{CERÂMICAS}

\begin{tabular}{|c|c|c|c|c|c|c|c|}
\hline ESTAÇÃO & OBRA & LOCAL & $\begin{array}{l}\text { TÍTULO / } \\
\text { GÊNERO }\end{array}$ & DATA & $\begin{array}{l}\text { TÉCNICA / } \\
\text { MATERIAIS }\end{array}$ & DIMENSÕES & AUTOR \\
\hline Ana Rosa & & Mezanino & $\begin{array}{l}\text { Figuras } \\
\text { instalação }\end{array}$ & 1992 & $\begin{array}{l}\text { barro queimado } \\
\text { a } 1260 \text { graus/ } \\
\text { argila }\end{array}$ & $\begin{array}{l}80 \text { figuras de } \\
170 \mathrm{~cm} \text { por } 20 \mathrm{~cm} \\
\text { de diâmetro }\end{array}$ & Lygia Reinach \\
\hline Armênia & & $\begin{array}{l}\text { jardins externos } \\
\text { dos acesso à } \\
\text { estação }\end{array}$ & $\begin{array}{l}\text { Fragmentos } \\
\text { da Memória } \\
\text { instalação }\end{array}$ & 1995 & $\begin{array}{l}\text { mista/ } \\
\text { cerâmica, vidro } \\
\text { jateado, luz, } \\
\text { água e } \\
\text { paisagismo }\end{array}$ & $\begin{array}{l}2 \text { peças de } \\
3,66 \times 1,10 \times 0,20 \mathrm{~m}\end{array}$ & $\begin{array}{l}\text { Josely } \\
\text { Carvalho }\end{array}$ \\
\hline Brás & & $\begin{array}{l}\text { Praça externa } \\
\text { da estação }\end{array}$ & $\begin{array}{l}\text { Tribuna livre } \\
\text { da criança } \\
\text { painel }\end{array}$ & 1991 & $\begin{array}{l}\text { pintura sobre } \\
\text { cerâmica/ } \\
\text { cerâmica e tinta } \\
\text { específica para } \\
\text { cerâmica }\end{array}$ & $2,50 \times 9,20 \mathrm{~m}$ & $\begin{array}{l}\text { Criação } \\
\text { coletiva de } 24 \\
\text { crianças }\end{array}$ \\
\hline Brigadeiro & & $\begin{array}{l}\text { plataforma } \\
\text { sentido Ana } \\
\text { Rosa }\end{array}$ & $\begin{array}{l}\text { Cores e } \\
\text { formas } \\
\text { painel }\end{array}$ & 1991 & $\begin{array}{l}\text { pintura a } \\
\text { revolver/ } \\
\\
\text { lajota de } \\
\text { cerâmica de } \\
0,50 \times 0,50 \mathrm{~m} \text { e } \\
\text { tinta }\end{array}$ & $2,00 \times 20,00 \mathrm{~m}$ & Cícero Dias \\
\hline Brigadeiro & & $\begin{array}{l}\text { plataforma } \\
\text { sentido Clínicas }\end{array}$ & $\begin{array}{l}\text { Desacelera- } \\
\text { ção } \\
\text { painel }\end{array}$ & 1991 & $\begin{array}{l}\text { pintura a } \\
\text { revólver }\end{array}$ & $2,00 \times 20,00 \mathrm{~m}$ & $\begin{array}{l}\text { Fernando } \\
\text { Lemos }\end{array}$ \\
\hline Largo Treze & & $\begin{array}{l}\text { parede em } \\
\text { frente ao } \\
\text { mezanino de } \\
\text { acesso ao } \\
\text { terminal de } \\
\text { ônibus }\end{array}$ & $\begin{array}{l}\text { Vôo da } \\
\text { aproximação } \\
\text { painel }\end{array}$ & 2002 & $\begin{array}{l}\text { pintura e } \\
\text { esmalte em } \\
\text { cerâmica } \\
\text { queimada à } \\
\text { alta } \\
\text { temperatura. } \\
\\
\text { peças cerâmicas } \\
\text { esmaltadas }\end{array}$ & $150,00 \mathrm{~m} 2$ & $\begin{array}{l}\text { Gilberto } \\
\text { Salvador }\end{array}$ \\
\hline
\end{tabular}


Luz

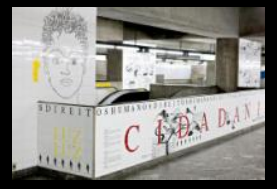

Mezanino

Inscrever os

Direitos

Humanos na

Estação Luz

2010: $1^{\text {a }}$ pintura sobre

$102 \mathrm{~m} 2$

Françoise

$\begin{array}{ll} & \\ \text { não Luz } & 2011: 2^{\mathrm{a}}\end{array}$

azulejos

Schein

$70 \mathrm{~m} 2$ para azulejos

painel

Pedro II

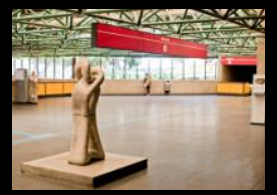

mezanino

Figuras

entrelaçadas

1992

cerâmica de

alta

temperatura

(monoqueima)/

escultura

argila

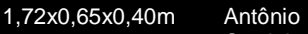

Cordeiro

Momento

Antropofágic

1990

mista/

$3,00 \times 16,50 \mathrm{~m}$

Antônio Peticov

azulejo,

ladrilho

madeira, aço e

Andrade

vinil

painel

Sacomã

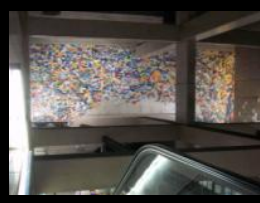

plataforma

Árvore
subterrânea
mural

São Paulo

Viva

painel

acima das

escadas
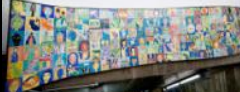

Inter-

Relação

entre 0

Campo e a

Cidade

mural

Tiradentes

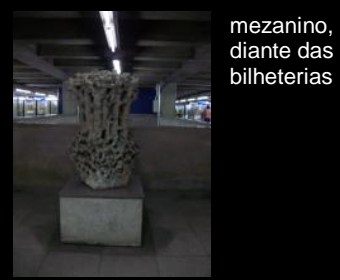

Trianon MASP

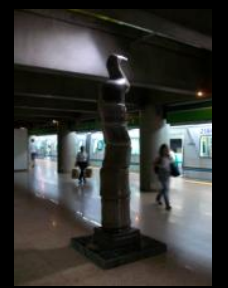

plataforma central
Sem título

escultura

2002

$\begin{array}{lll}\begin{array}{l}\text { Pássaro } \\ \text { Rocca }\end{array} & 1990 & \begin{array}{l}\text { cerâmica } \\ \text { vitrificada/ }\end{array} \\ & \\ \text { escultura } & \text { argila } \\ & & \text { vitrificada, } \\ & \text { queimada em } \\ & \text { alta } \\ & \text { temperatura }\end{array}$

barro queimado à 1350 graus/

$0,81 \times 0,79 \times 1,22 m$

Akinori Nakatani

argila
$2,80 \times 0,40 \mathrm{~m}$

Francisco Brennand
Tuchband,

Verena Matzen

e Paula

Pedrosa

Aldemir Martins

pintada em alt

cerâmica e tinta

temperatura 


\section{VIDROS}

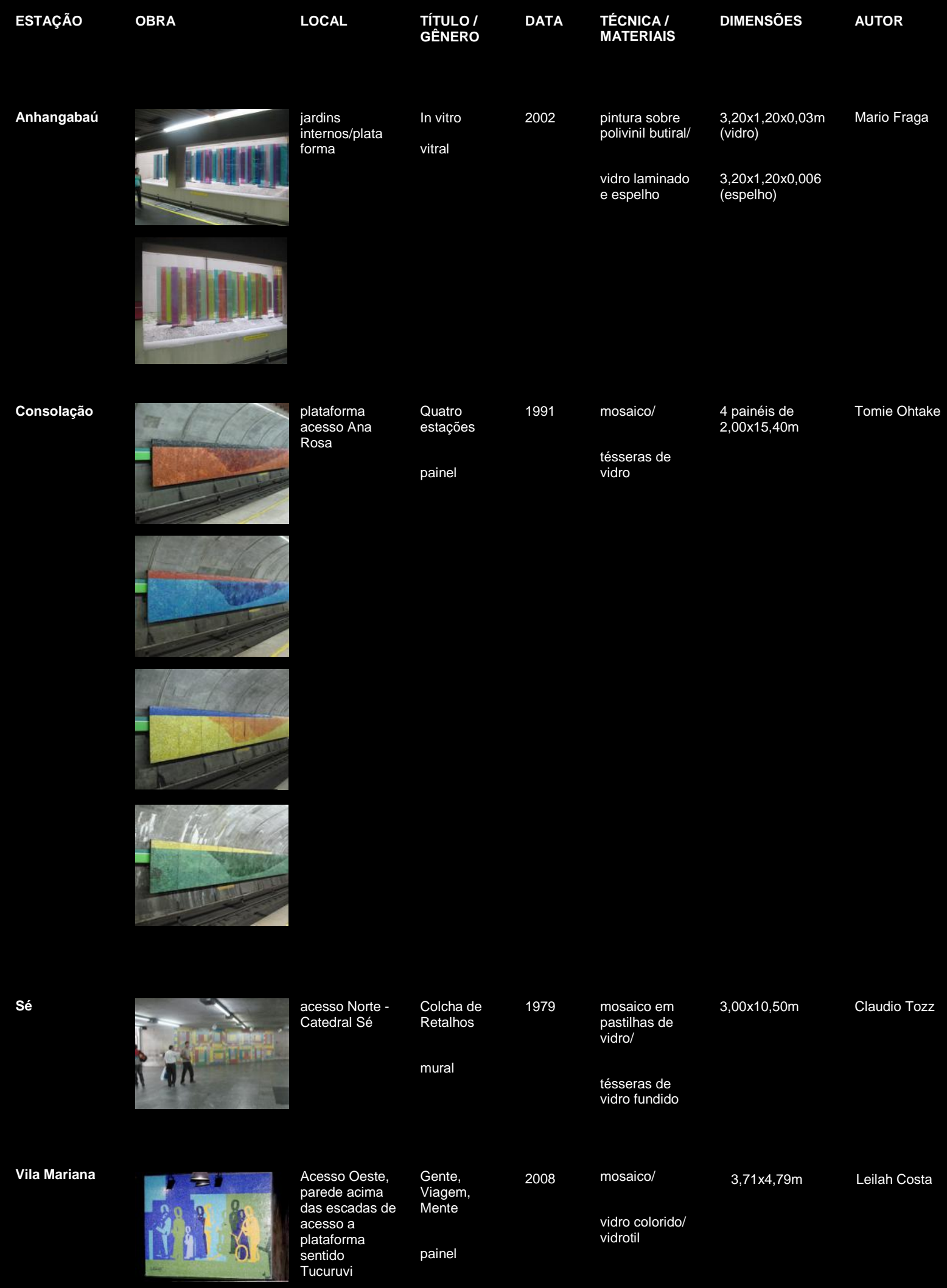


OUTROS MATERIAIS

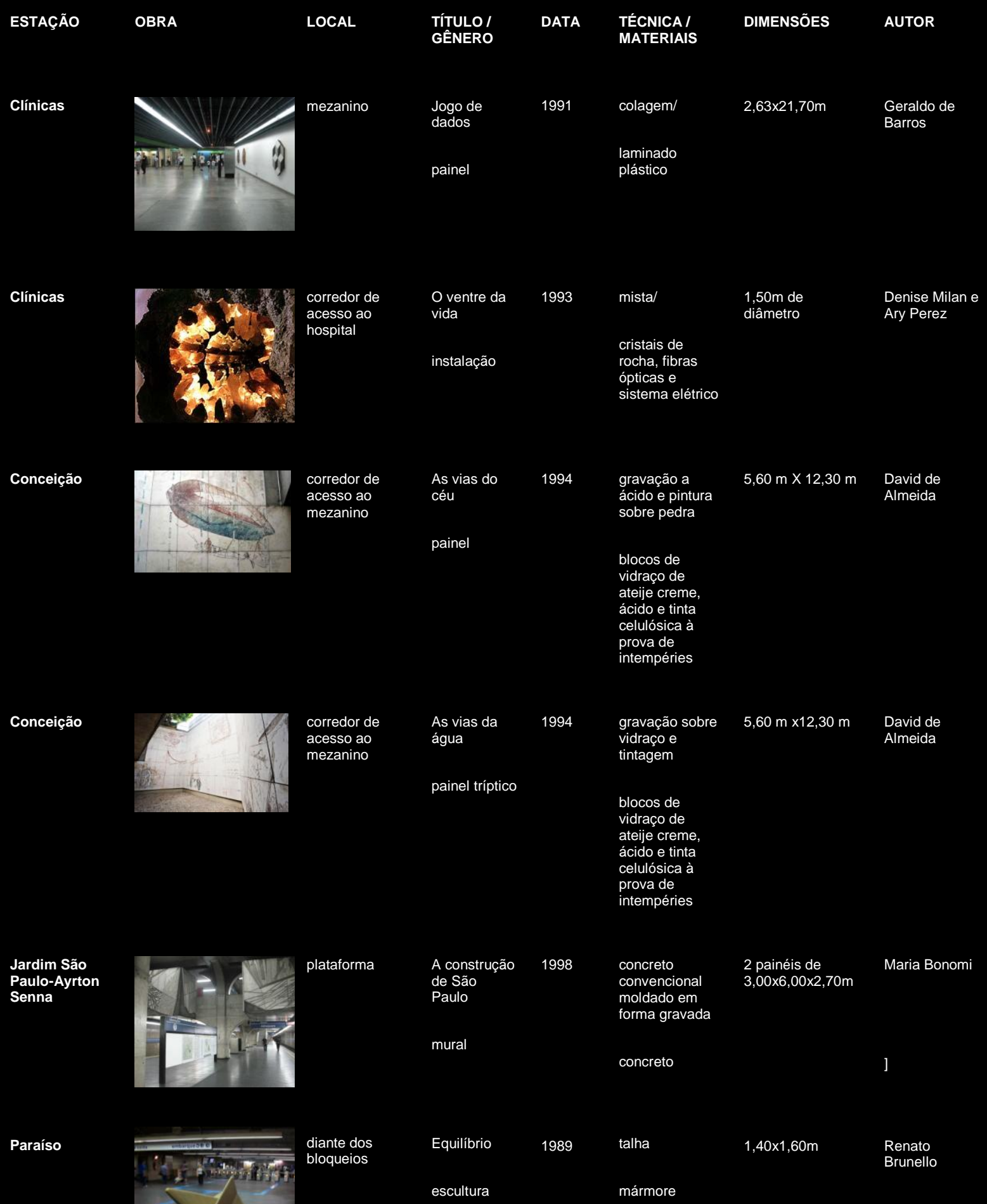


Penha

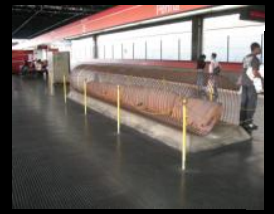

plataforma

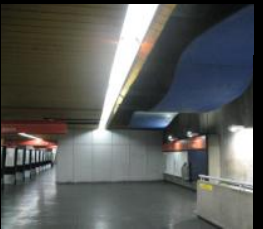

teto sobre mezanino

República

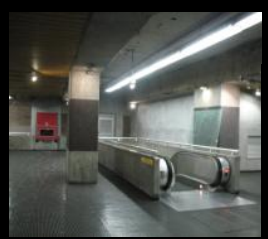

segundo

subsolo

(n)

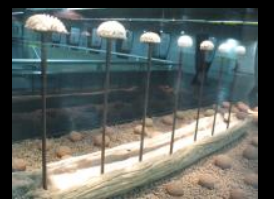

segundo
subsolo
Século XXI

Resíduos $e$

Vestígios

instalação

Estudo do

homem 1

escultura

Estudo da

mulher 1

1989

molde perdido

$1,00 \mathrm{~m}$

concreto, goma

laca, grafite,

anilina e cera

instalação de

vitrina com

naturais e

artesanais

seixos rolados,

corais

marinhos,

madeira,

hastes de

madeira e

cerâmicas

escultura

concreto, goma

laca, grafite,

anilina e cera
$1,23 \times 0,99 \times 6,00 \mathrm{~m} \quad$ Eliana Zaroni Lindenberg

ferro, espuma de poliuretano, óxido de ferro estrutura suspensa

fibra de vidro, alumínio,

madeira, resina acrílica e tinta acrílica

pintura e

materiais sobre

4 colunas com $4 \quad$ Xico Chaves faces

Xico Chaves

fibra de vidro e

sobre concreto/

minérios de

ferro (hematita,

blue dust,

hematita mole),

quartzo (areia $e$

microesferas)

pigmentos

óxido de ferro,

cobre, azurita,

filito e resina de

poliéster

$1,20 \times 4,50 \times 2,00 \mathrm{~m} \quad$ Bené Fonteles

José Guerra

$5,00 \times 2,00 \mathrm{~m} \quad$ Roberto Mícoli (a) 


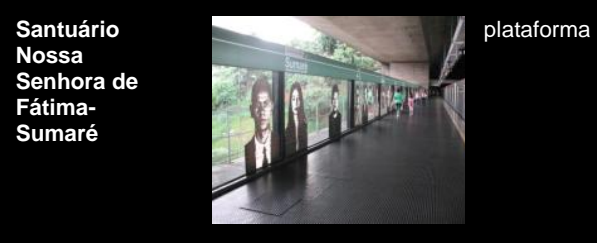

\section{Sem título \\ instalação/ poema}

Trianon MASP

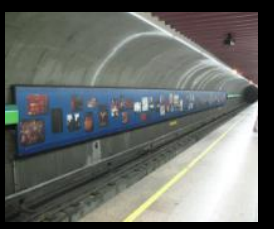

nível da

plataforma en

ambos os

sentidos

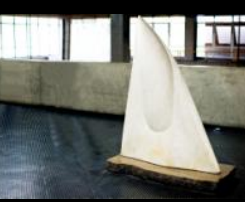

대

Mezanino

A Semente

1999

escultura

\section{Cenas e}

Sonnos

Americanos

2010

do poço Sul

inicialmente,

ficava na

passagem de

acesso ao

Memorial da

e II

América Latina

painel

na Estação

Barra Funda talha /

$1,70 \times 1,35 \times 1,40 \mathrm{~m}$

Renato

mármore

branco

digitalização de

cromo e

computação

$2,00 \times 40,00 \mathrm{~m}$

gráfica/

lona vinílica

44 painéis de

vidro,

$1,75 \times 1,25 \times 0,01 \mathrm{~m}$

cada

vidro, alumínio

inta vinílica

mista, acrílico

alquídico e óleo

$1,95 \times 26,90 \mathrm{~m}$

Sérgio Ferro
Wesley Duke

Lee
Alex Fleming sobre tela de

linho/

madeira, corda,

vidro e tinta

acrílica 
São esculturas, murais, painéis, pinturas e instalações inseridas, em sua maior parte, em espaços internos e de maior concentração de usuários/espectadores, situados após o bloqueio das catracas, ou seja, apenas quem paga pelo bilhete pode ter acesso a elas. Os materiais empregados são diversificados, convencionais, duráveis e de fácil manutenção; as tintas acrílica e a óleo são os mais utilizados, em seguida, os metais, as cerâmicas e os vidros. O concreto, o mármore e a fibra de vidro, apesar de possuírem características favoráveis, são empregados em poucos exemplares. Alguns materiais fogem a regra: os elementos naturais, a serigrafia sobre vidro e a impressão digital sobre lona vinílica. Os dois últimos são exemplares da aplicação de técnicas que representam recursos tecnológicos avançados para a época em que foram executados.
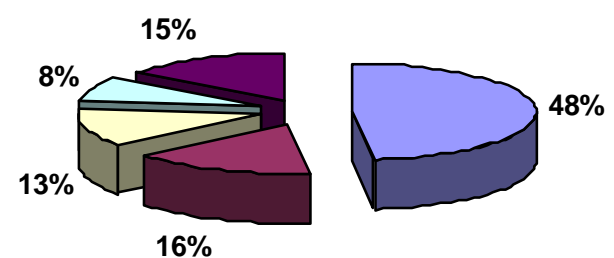

$\square$ tintas

$\square$ metais

$\square$ cerâmicas

$\square$ vidros

$\square$ outros materiais

Gráfico1: Tipos de materiais aplicados em obras permanentes e suas respectivas proporções.

Nota-se que $43 \%$ das estações em funcionamento não possuem obras permanentes, enquanto que em $16 \%$ das que possuem, há uma concentração de obras instaladas: Sé, República e Marechal Deodoro (seis obras); Paraíso (oito obras) e Corinthians-Itaquera e Liberdade (dez obras).
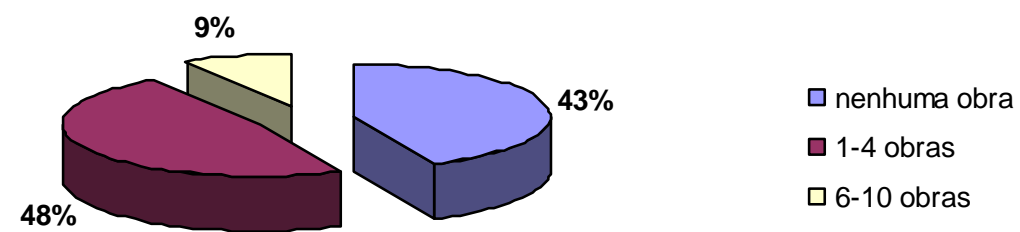

Gráfico 2: Concentração de obras permanentes nas estações 

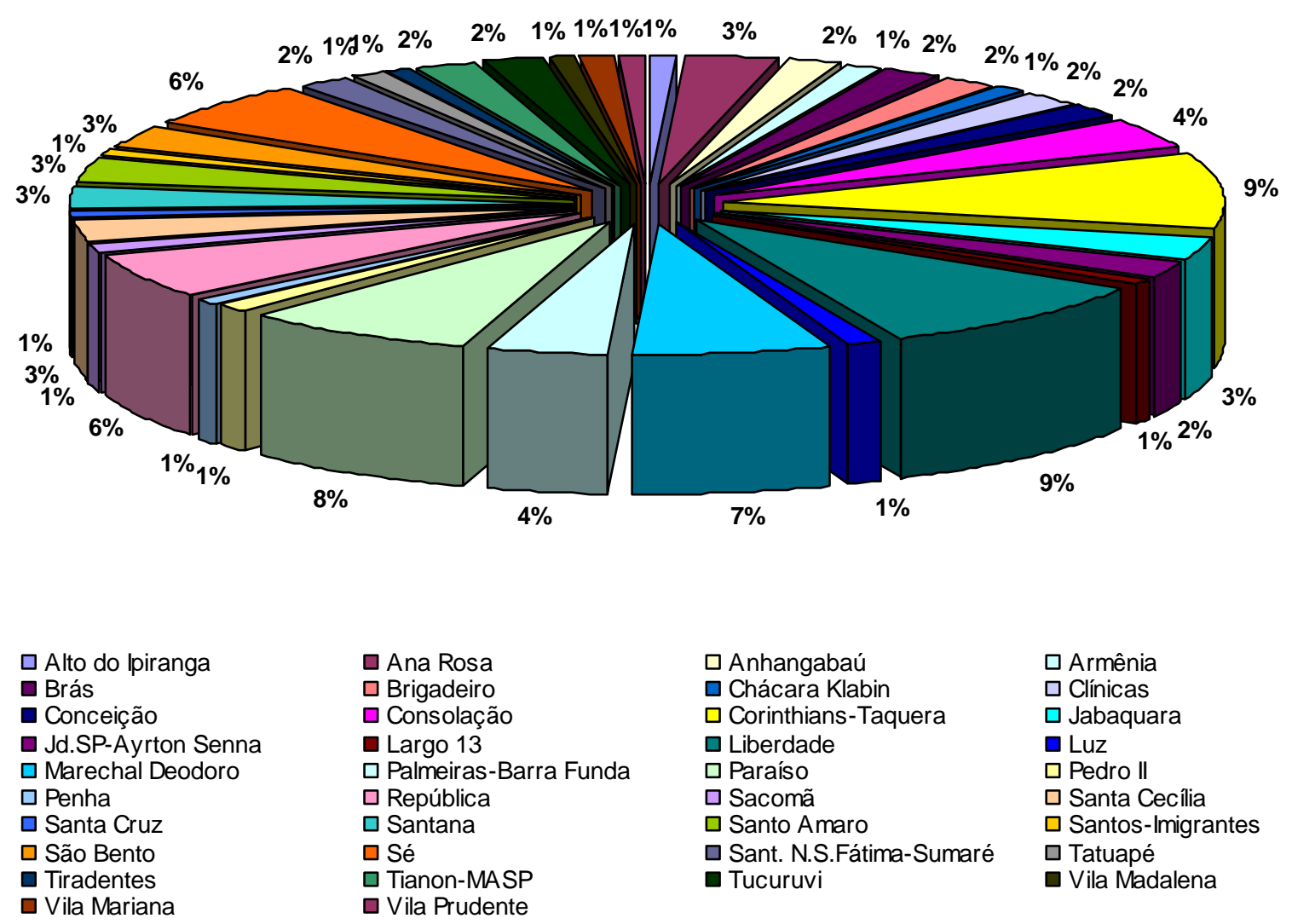

\begin{tabular}{|c|}
\hline $\begin{array}{l}\square \text { Ana Rosa } \\
\square \text { Brigadeiro } \\
\text { Consolação } \\
\square \text { Largo 13 } \\
\square \text { Palmeiras-Barra Fun } \\
\square \text { República } \\
\square \text { Santana } \\
\square \text { Sé }\end{array}$ \\
\hline
\end{tabular}

$\square$ Anhangabaú
$\square$ Chácara Klabin
$\square$ Corinthians-Taquera
$\square$ Liberdade
$\square$ Paraíso
$\square$ Sacomã
$\square$ Santo Amaro
$\square$ Sant. N.S.Fátima-Sumaré
$\square$ Tucuruvi

$\square$ Armênia

$\square$ Clínicas

$\square$ Jabaquara

- Luz

$\square$ Pedro II

$\checkmark$ Santa Cecilia

$\square$ Santos-Imigrantes

$\square$ Tatuapé

- Vila Madalena

Gráfico 3: Distribuição das obras permanentes nas estações

Nas estações que possuem obras de arte permanente, painéis informativos indicam quais são as obras instaladas, sua localização e as informações técnicas, porém, não contemplam informações sobre o autor. Em algumas estações, além do painel, há totens multimídia que apresentam as mesmas informações de forma interativa.

Quanto à especificidade das obras em relação ao lugar em que estão inseridas, o acervo abrange desde as obras totalmente desvencilhadas do contexto, vindas de ateliers, alcançando aquelas pensadas para os contextos físico, social, histórico, cultural, ecológico/ambiental e relacionadas à memória do lugar.

A recente transferência do trabalho de Sergio Ferro, Cenas e Sonhos Latino Americanos I e II (1990), para a Estação Vila Prudente, inaugurada em 2010, inicialmente instalado na Estação Barra Funda, próximo ao Memorial da América Latina, demonstra que a transitoriedade da obra em relação ao local persiste nos subterrâneos como prática comum, aceitável. Embora, formalmente e esteticamente, o trabalho tenha se encaixado de forma harmoniosa naquele espaço, é preciso ter maiores cuidados com este tipo de operação em relação ao sentido proposto pelo autor no momento da concepção da sua obra. A obra Garatuja (1978), de Marcello Nitsche, inicialmente instalada no patamar da escada de acesso ao Museu das 
Esculturas, fechado por motivos técnicos e de segurança, perdeu seu sentido ao ser transferida para o jardim interno da estação, anterior aos bloqueios das catracas, onde estava instalada a obra de Alfredo Ceschiatti. Segundo Hatanaka, a escolha do local inicial, feita pelo artista, deveu-se ao fato das obras do Museu serem instaladas "quase sempre, dentro das floreiras" o que sugeria "a conotação de pedestais, o que ele não queria". Desejava que "as pessoas passassem pela obra, por baixo, ou através dela, interagindo com a mesma no corre-corre cotidiano dos usuários do metrô" (HATANAKA, 2009, p.74). Contrariando sua concepção, o jardim desnivelado do piso interno configurado como um pedestal também barra a interação obra/espectador. A obra de Ceschiatti (1978), transferida para o mezanino central, embora não tenha sido concebida para aquele espaço específico, ganhou um segundo pedestal, o que lhe atribuiu a função de mobiliário para o descanso dos usuários.
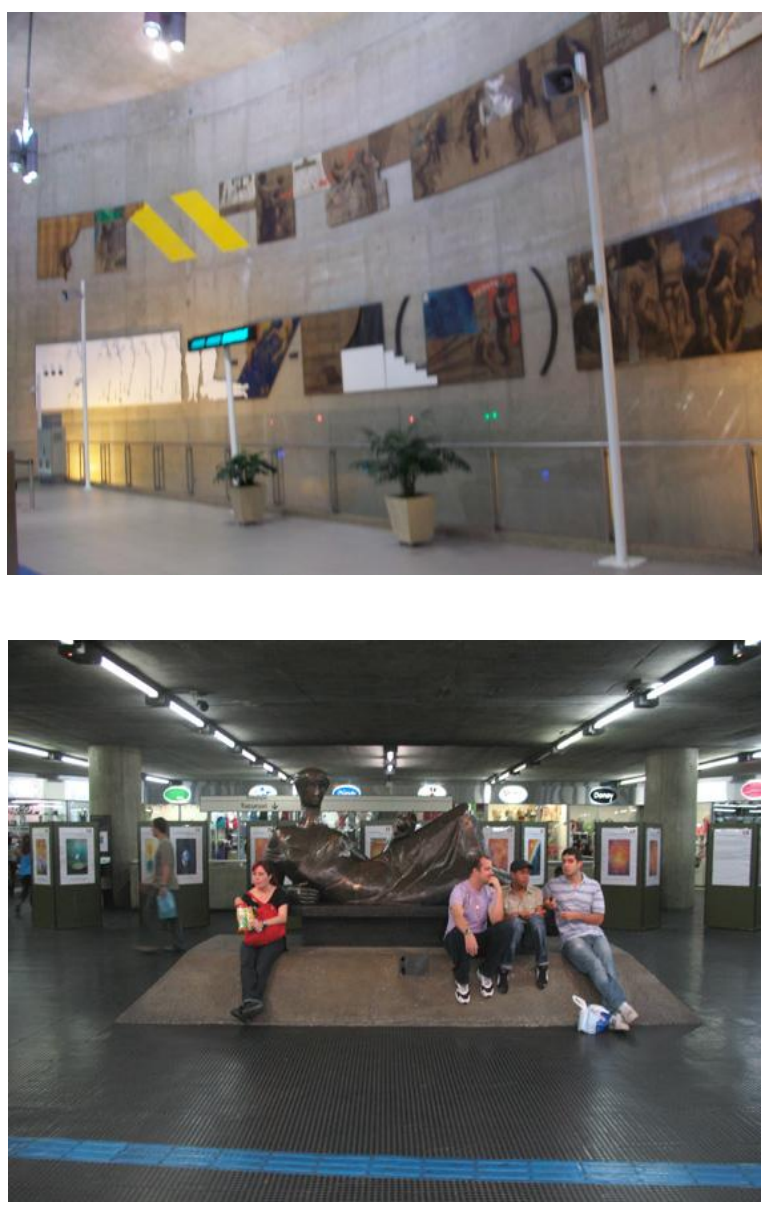

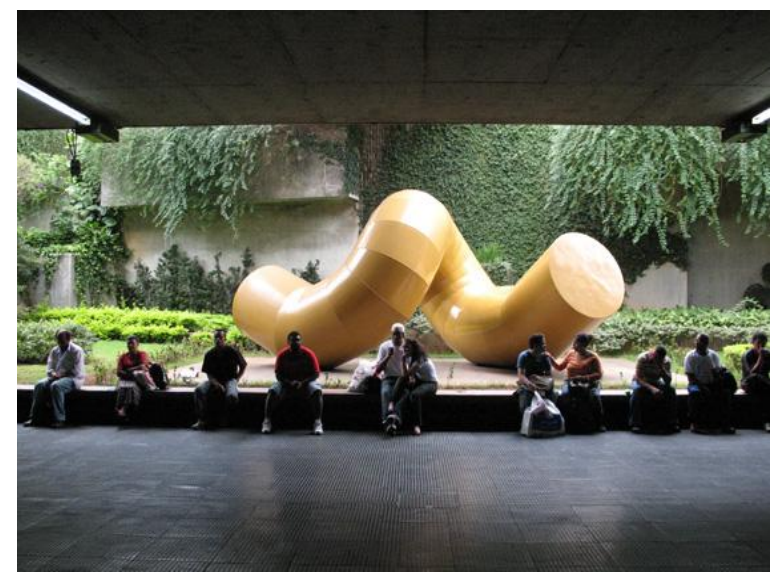

Figura 68: Cenas e Sonhos Latino Americanos I e II, Sérgio Ferro, 1990, inicialmente instalada na Estação Barra Funda, transferida para a Estação Vila Prudente em 2010. Fonte: Registro fotográfico realizado pela pesquisadora.

Figura 69: Garatuja, Marcello Nitsche, 1978. Estação Sé. Fonte: Registro fotográfico realizado pela pesquisadora.

Figura 70: Sem título, Alfredo Ceschiatti, 1978. Estação Sé. Fonte: Registro fotográfico realizado pela pesquisadora. 


\subsubsection{As obras temporárias do Programa Ação Cultural}

Diferentemente da característica do Projeto Arte no Metrô, direcionado à exposição de obras de arte permanentes, o Programa Ação Cultural, oficializado em 1986, caracteriza-se por apresentações temporárias de cunho artístico-cultural. Música, dança, teatro, cinema e oficinas culturais (Projeto Encontros) fazem parte da programação realizada em 18 estações, recentemente equipadas com telas LCD e totens multimídia interativos que trazem informações sobre arte, cultura e mapas dos arredores. Poesia (Projeto Poesia no Metrô), literatura (Projeto Embarque na leitura ${ }^{46}$, turismo (Turismetrô) ${ }^{47}$ e exposições de temáticas, de arte e de arte desenvolvida com dispositivos tecnológicos, também fazem parte do programa.

As vitrines do MASP, localizadas no interior da Estação Trianon-MASP, são espaços expositivos que através da parceria do Metropolitano com o Museu de Arte de São Paulo Assis Chateaubriand-MASP, complementam a difusão artística ao permitir ao usuário/espectador que não visitou o museu o contato com obras raras do acervo. Sob curadoria da artista Regina Silveira, obras contemporâneas têm sido expostas temporariamente nesses espaços. Galeria Virtual, disponível no site da Companhia, é outra possibilidade de acesso a exposições artísticas temporárias realizadas em parceria com outras instituições.

Todas as modalidades mencionadas possuem o seu valor enquanto prática social e cultural que merecem ser estudadas com intensidade, no entanto, esta tese adota como recorte as obras apresentadas nas estações nas exposições de arte tecnológica: Exposição Arte Cibernética-Acervo Itaú Cultural (2010), $11^{\circ}$ e $12^{\circ}$ Festivais Internacionais de Linguagem Eletrônica-FILEPAls (2010 e 2011) ${ }^{48}$, por se tratar de trabalhos que representam, claramente, transformações tecnológicas e de comportamento social que são extensões de transformações culturais que o mundo

\footnotetext{
${ }^{46}$ São quatro bibliotecas que integram o projeto Ler é Saber do Instituto Brasil Leitor-IBL, entidade que administra as bibliotecas, facilita o acesso aos livros e oferece acervos completos para empréstimos gratuitos. (METRO.SP.GOV.BR, 2012).

47 O Turismetrô resulta da parceria da Companhia do Metropolitano com a São Paulo Turismo. O programa oferece cinco roteiros que possibilitam percorrer pontos turísticos e históricos da cidade. Os percursos têm acompanhamento de guias bilíngues que contam a história local. Intervenções artísticas são realizadas por atores que interpretam diferentes personagens em determinado ponto dos trajetos. Todos os roteiros têm como ponto de partida a Estação Sé. (METRO.SP.GOV.BR, 2012).

${ }^{48}$ Tivemos a oportunidade de realizar entrevistas com usuários/espectadores/atores que interagiram com as obras expostas no decorrer das exposições.
} 
contemporâneo tem vivenciado, de forma a comprovar que é possível a aplicação e a aceitação de tecnologias atuais em intervenções temporárias no espaço das estações de metrô.

\subsubsection{Exposição Arte Cibernética-Acervo Itaú Cultural (2010)}

A arte cibernética que ocupa atualmente seis estações tem vida própria e proporciona boas surpresas a partir da interatividade com o público. (GUIADAFOLHAONLINE, 2010).

O encontro entre cultura, arte e tecnologia também pôde ser apreciado e experimentado por usuários do metrô de São Paulo através da Exposição Arte Cibernética - Acervo Itaú Cultural (2010), fruto de uma parceria entre o Instituto Itaú Cultural $^{49}$ e a Companhia do Metropolitano de São Paulo.

Entendida como a arte desenvolvida com tecnologias contemporâneas, a arte cibernética "exige uma interação constante entre o observador e a obra - ou entre os subsistemas que a compõe", ou seja, é somente através dessa interação que a obra se realiza por completo.

Apesar dos espaços das estações serem frequentados por usuários de perfis bastante diferenciados, a intenção de colocar as instalações em estações de metrô foi a de mostrar aquela manifestação artística para quem, eventualmente, nunca tivesse visitado o instituto, e assim, tivesse a oportunidade de ver a arte cibernética de uma forma diferente, em um espaço público. "Mesmo que ele não entenda isso como arte", esclareceu Marcos Cuzziol, diretor do laboratório de mídias interativas do Itaú Cultural-Itaulab. Como critério para a seleção das obras, foram levadas em conta aquelas que poderiam ser apresentadas a um grande público. "A adequação ao espaço físico do metrô também serviu como critério, já que a área de exposição teria de ser escurecida para facilitar a projeção dos trabalhos, sem que isso atrapalhasse a circulação dos passageiros." (ESTADAO.COM.BR, 2010). Monitores orientaram o público durante o horário de

\footnotetext{
${ }^{49}$ A primeira peça do acervo de arte cibernética do Itaú Cultural foi adquirida em 1997, de autoria de Regina Silveira. Atualmente, a coleção totaliza 15 obras. Segundo dados disponíveis no site do Instituto Itaú Cultural, o desenvolvimento da relação entre tecnologia, arte e cultura tem sido buscado desde sua fundação, no ano de 1987, através de iniciativas como: o programa Rumos Arte Cibernética, a Bienal Internacional de Arte e Tecnologia de São Paulo: Emoção Art.ficial e investimentos em informações e conteúdo acessível ao público na Enciclopédia Itaú Cultural de Arte e Tecnologia.
} 
funcionamento da mostra, exposta em três estações da Linha Vermelha: Brás, República e Corinthians-Itaquera e, em outras três da Linha Azul: Tiradentes, Paraíso e Sé. O período de exibição dos trabalhos, ocorrido entre 14 de abril e 23 de maio, foi prorrogado por mais uma semana.

Na Estação Brás esteve a obra Descendo a Escada (2002), de autoria da artista Regina Silveira. Tratava-se de uma projeção interativa, estruturada sobre o triedro espacial formado pelo chão e pelo ângulo de duas telas verticais, que gerava um "continuum virtual dinâmico". Elaborada com a colaboração do laboratório de mídias interativas do Itaú Cultural, é uma versão interativa da obra Escada Inexplicável 2 (1999). Com ela, o observador pôde experimentar a sensação de vertigem do movimento de descida dos degraus de uma escada virtual.
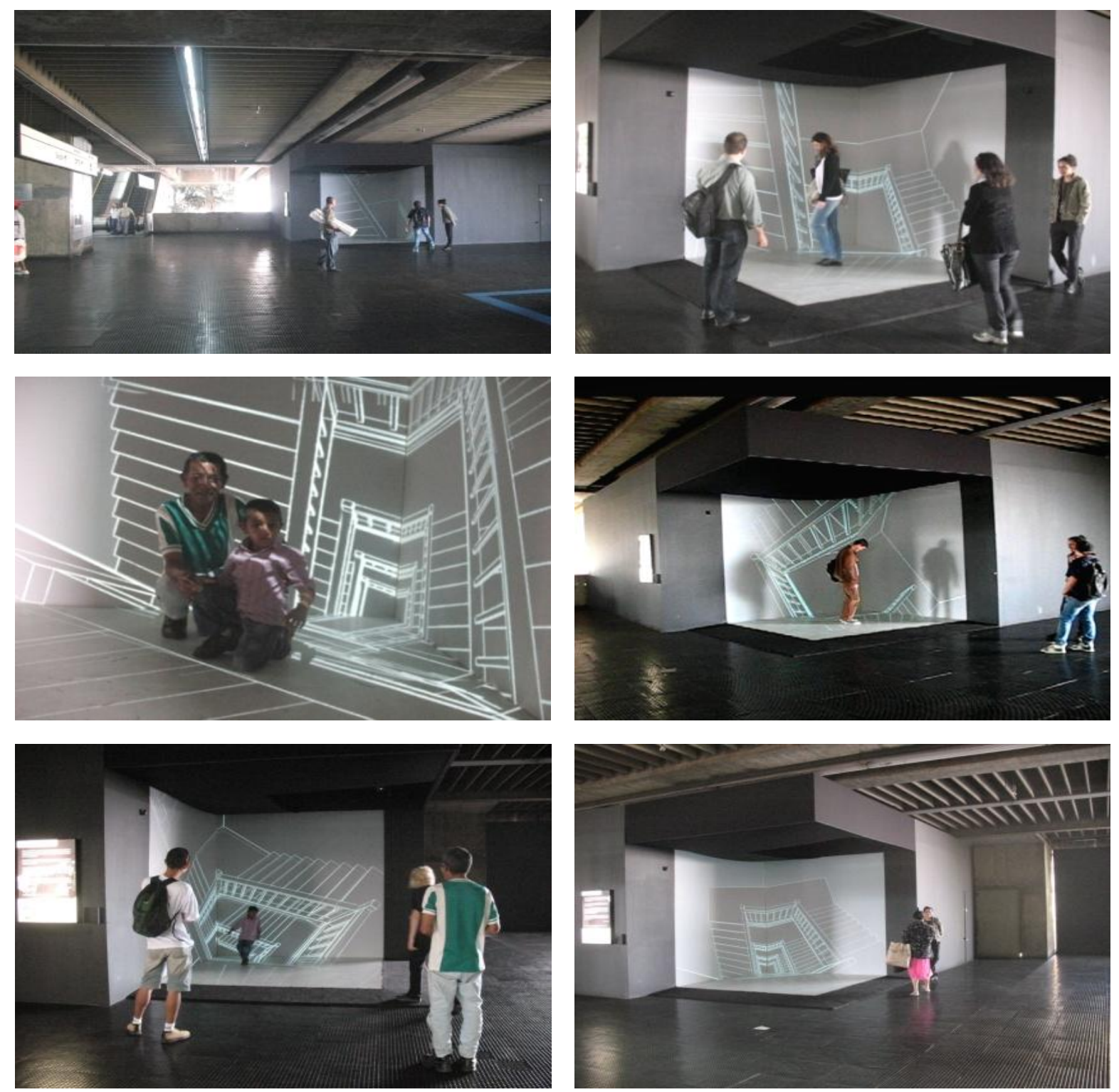

Figuras 71, 72, 73, 74, 75 e 76: Descendo a Escada, Regina Silveira. Estação Brás. Fonte: Registro fotográfico realizado pela pesquisadora. 
Text Rain (1999), de Camile Utterback e Romy Achituv, exposta na Estação Corinthians-Itaquera, assim como o próprio título sugeria, tratava-se de uma combinação de animação de chuva de letras coloridas que era desencadeada com a presença e os movimentos corporais do observador, com a projeção do observador. Com o acúmulo de letras arrastadas ao longo do comprimento de seus braços estendidos, ou da silhueta de algum objeto, era possível formar de palavras a frases. Letras e palavras não eram aleatórias, faziam parte dos versos do poema Talk, you, de Evan Zimroth, que falava sobre o corpo e a linguagem, exposto em um plano localizado a frente do plano de projeção.
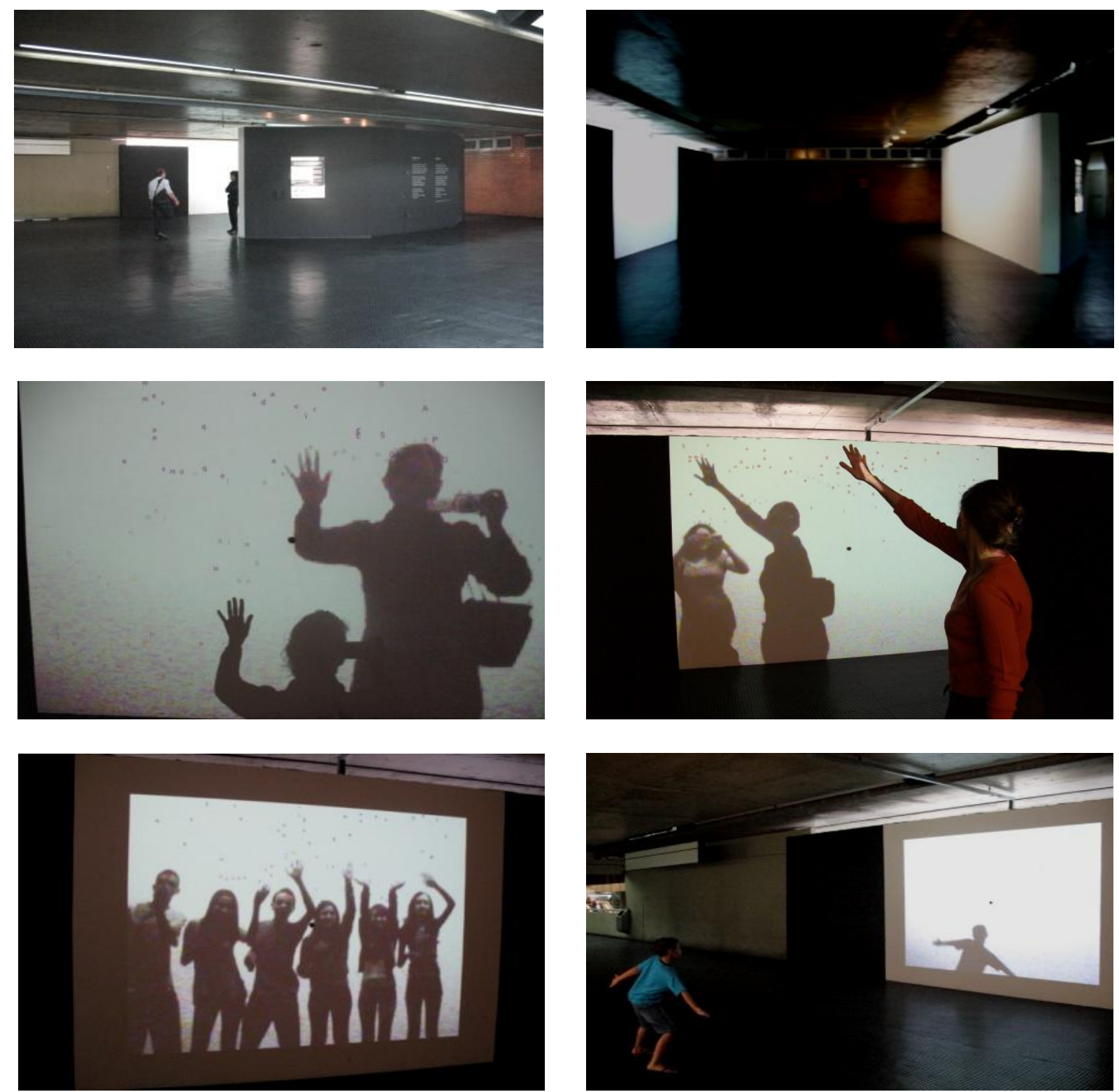

Figuras 77, 78, 79, 80, 81 e 82: Text Rain, Camile Utterback e Romy Achituv. Estação Corinthians Itaquera. Fonte: Registro fotográfico realizado pela pesquisadora e Stella Marina Rodrigues. 

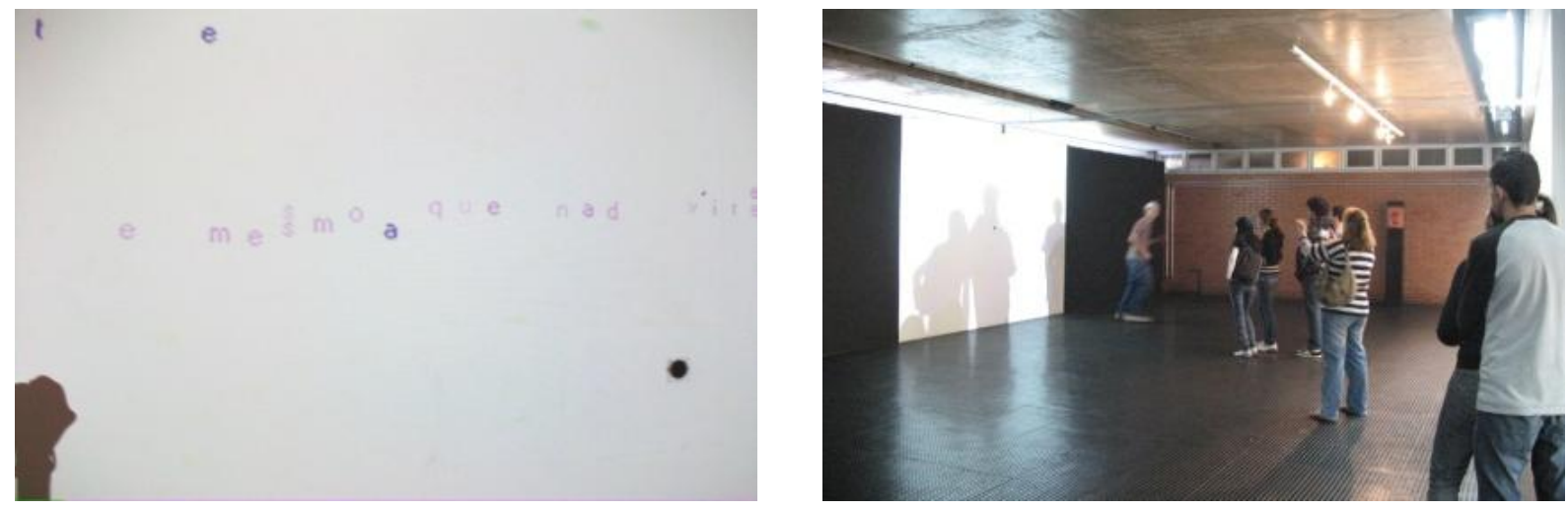

Figuras 83 e 84: Text Rain, Camile Utterback e Romy Achituv. Estação Corinthans-Itaquera. Fonte: Registro fotográfico realizado pela pesquisadora e Stella Marina Rodrigues.

\section{poema: Te, Converso}

Eu gosto de falar com você, Simplesmente conversar, Um giro-com ou - em torno Como sua meia-volta volver Para de repente me ver...

\section{autor: Evan Zimroth}

Em seu giro, cada parte Do meu corpo vira verbo. Somos o oposto

Da língua-amarrada, se

Tal antônimo existisse; tradução: Marcus Bastos
Somos sinônimos
Para o quebra-galho
Da sintaxe,
E mesmo que vire nada:
É só papo.

Figura 85: Poema Te, Converso, de Evan Zimroth.

$\mathrm{Na}$ Estação República, em forma de um cubo preto, aberto, com superfícies (4×3m cada) constituídas por centenas de linhas luminosas que lembram cordas de um instrumento musical, esteve a obra: OP_ERA: Sonic Dimension (2005). Na instalação interativa e imersiva, de autoria de Daniela Kutschat e Rejane Cantoni, cordas virtuais podiam ser tocadas pelo espectador. Afinadas com a tensão adequada, vibravam conforme a frequência de luz e som determinadas pela posição relativa e pela forma de interação do espectador/ator. A interação ocorreu de dois modos:

No primeiro modo, a interface de entrada é um conjunto de microfones que coletam sons produzidos pelos interatores. Quando um microfone captura um som, o software analisa, filtra e converte a informação em um output visual correspondente. Isto é, se o interator produz um som Fá, ele verá as frequências Fá vibrando como cordas de acordo com os postulados Pitagóricos.

No segundo modo, a interface de entrada é uma malha de sensores. Utilizada para detectar a posição do interator, esta interface permite ao sistema interpretar qualquer ação como uma força gravitacional. Quando o interator aponta para uma corda, por exemplo, além de fazer a corda correspondente vibrar, esta ação modifica a forma do espaço tempo. 0 objetivo desse projeto é pesquisar a geometria de espaços sônicos e desenvolver interfaces sônicas. (OP_ERA.COM, 2009). 

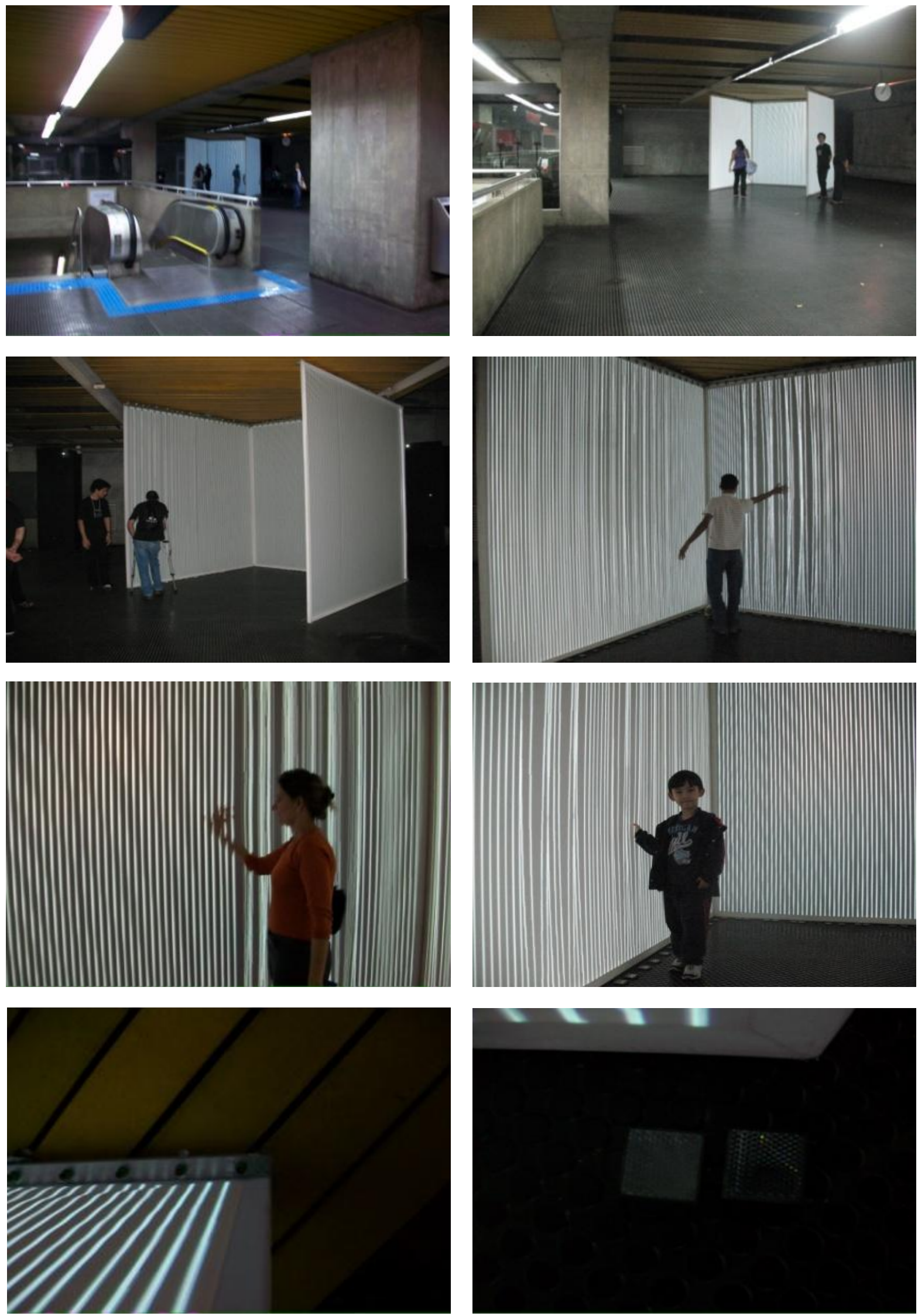

Figuras 86, 87, 88, 89, 90, 91, 92 e 93: OP_ERA: Sonic Dimension, Daniela Kutschat e Rejane Cantoni. Estação República. Fonte: Registro fotográfico realizado pela pesquisadora e Stella Marina Rodrigues. 
$\mathrm{Na}$ instalação Reflexão \#3 (2005), de Raquel Kogan, na Estação Tiradentes, imagens de diversas sequências numéricas foram projetadas sobre o plano de uma parede escura e refletidas em um espelho d'água no plano do chão. Através de um teclado que regulava a velocidade do movimento da projeção, os observadores podiam interagir com a obra. Criava-se, assim, "um movimento contínuo, mas nunca repetido, como se os números subissem de um espelho a outro, sucessivamente. (ESTADAO.COM.BR, 2010).
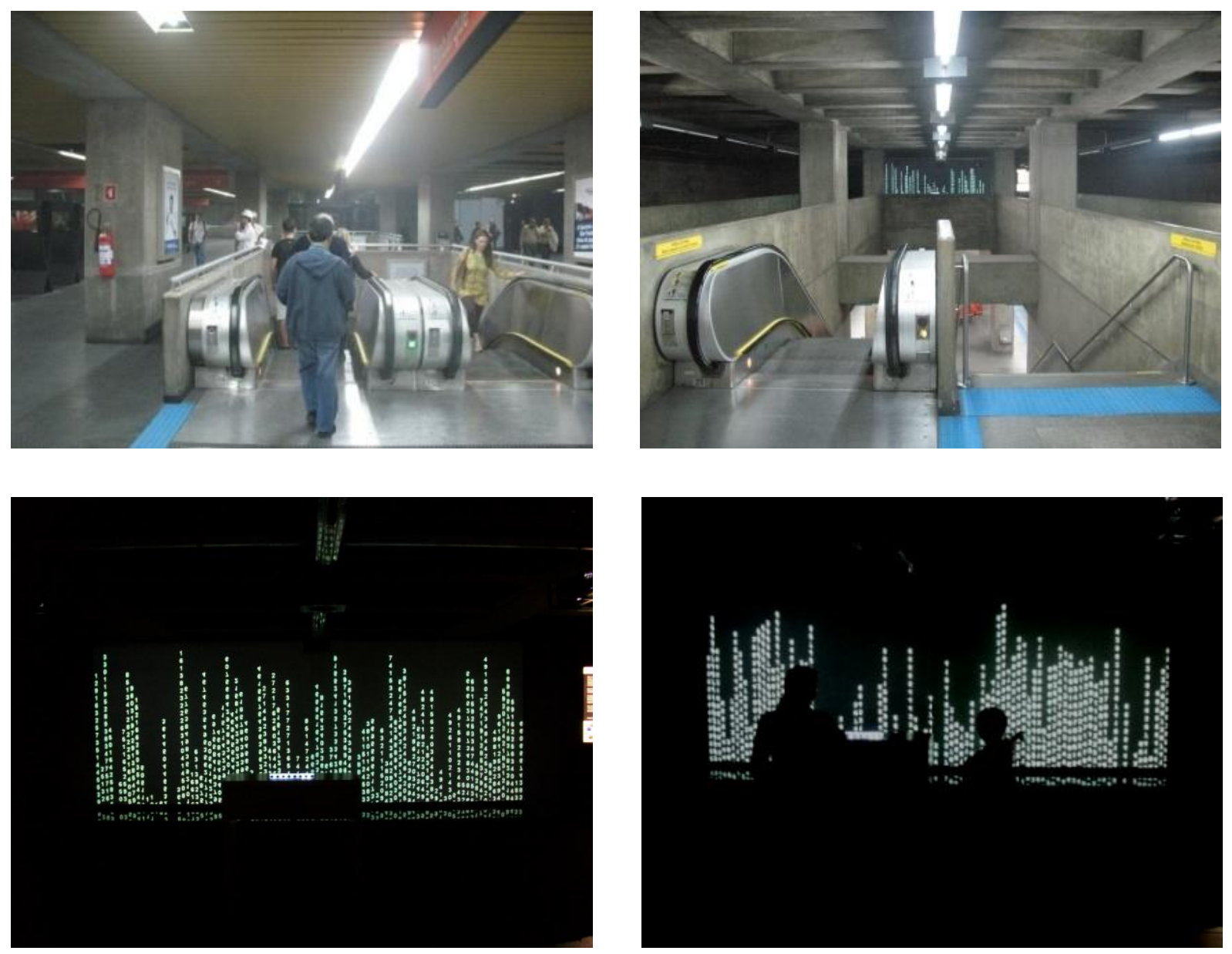

Figuras 94, 95, 96 e 97: Reflexão \# 3, Raquel Kogan. Estação Tiradentes. Registro fotográfico da pesquisadora. 

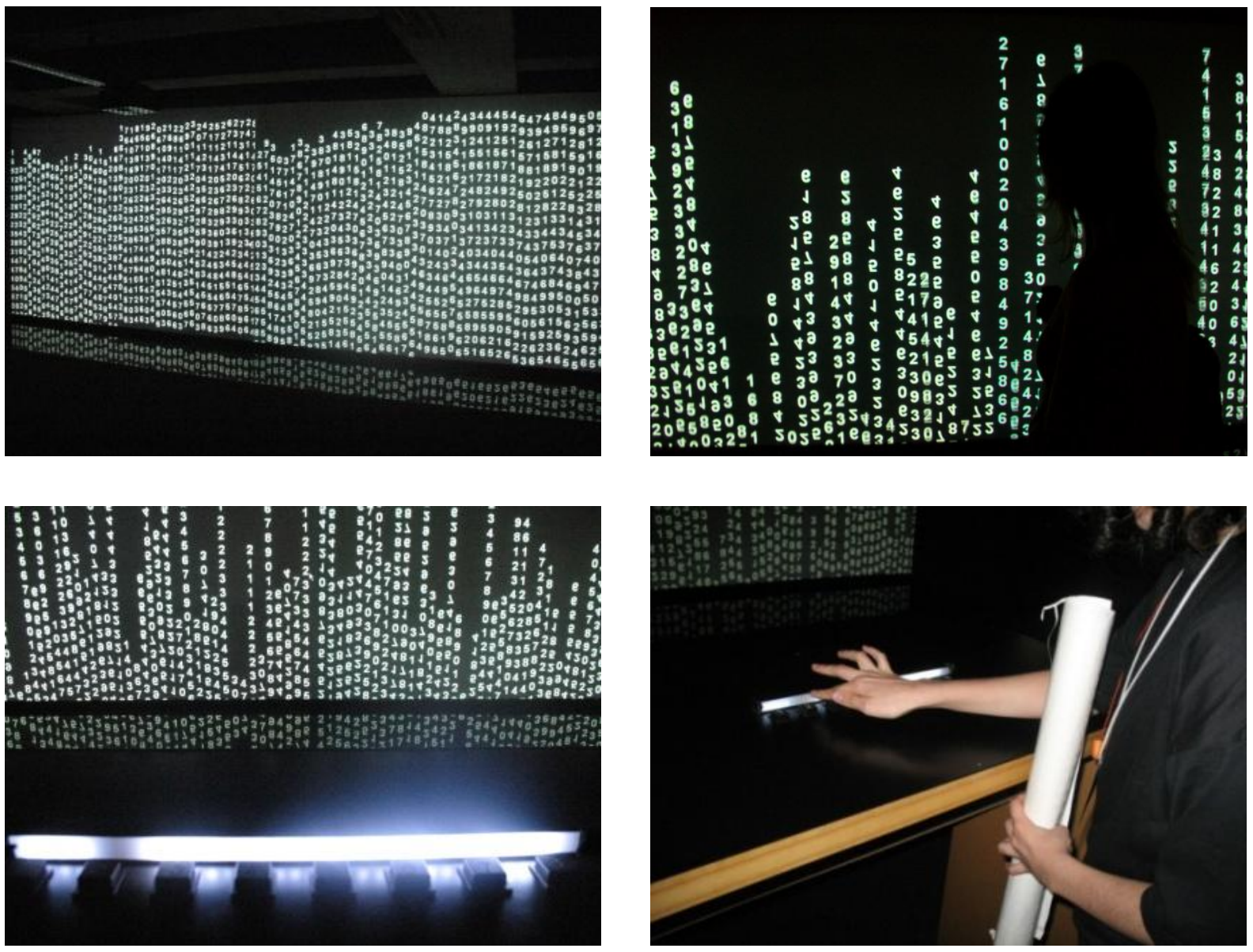

Figuras 98, 99, 100 e 101: Reflexão \# 3, Raquel Kogan. Estação Tiradentes. Fonte: Registro fotográfico da pesquisadora.

Nas Estações Sé e Paraíso, foram apresentados elementos florais que compunham, respectivamente, os jardins virtuais: Ultra-Nature (2008) e Les Pissenlits (2006). O primeiro, de autoria do artista mexicano Miguel Chevalier, era composto de seis tipos de plantas digitais coloridas, sendo que "cada uma delas evoluía de acordo com suas características genéticas e pela interação com o público que, por meio de sensores, provocava a polinização entre elas, influenciando o crescimento de novas e inesperadas florações". Essa obra já havia sido exposta em 2008, na primeira parceria do Itaú Cultural com o Metrô, durante a Bienal Internacional de Arte e Tecnologia: Emoção Art.Ficial 4.0. Les Pissenlits (2006), obra de Edmond Couchot e Michel Bret, era um jardim de dentes-de-leão, que através de um microfone, era acionado pelo sopro humano. A força e a duração do sopro determinava o movimento das sementes que desenvolviam trajetórias complexas e diferentes. 

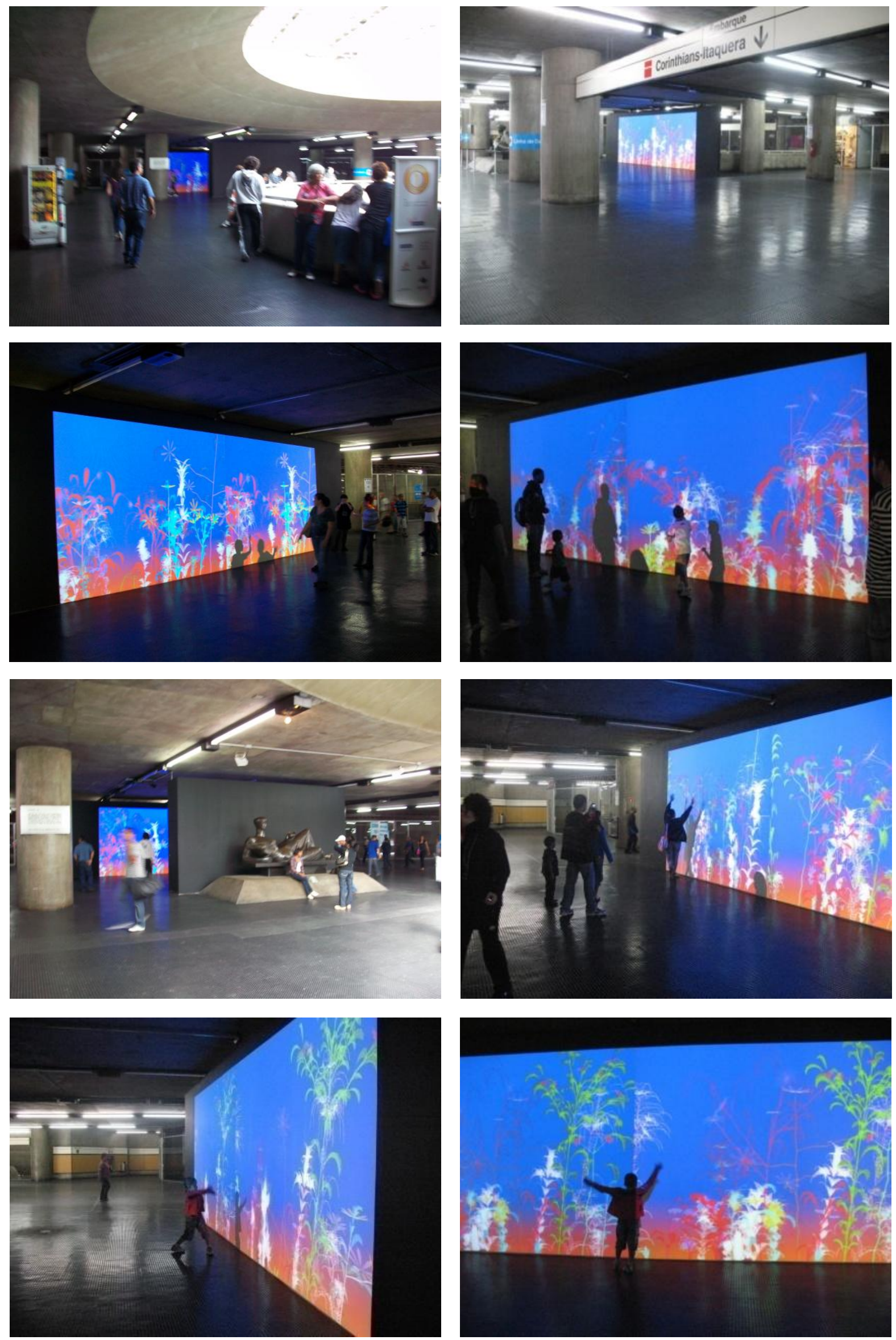

Figuras 102, 103, 104, 105, 106, 107, 108 e 109: Ultra-Nature, Miguel Chevalier. Estação Sé. Fonte: registro fotográfico realizado pela pesquisadora. 

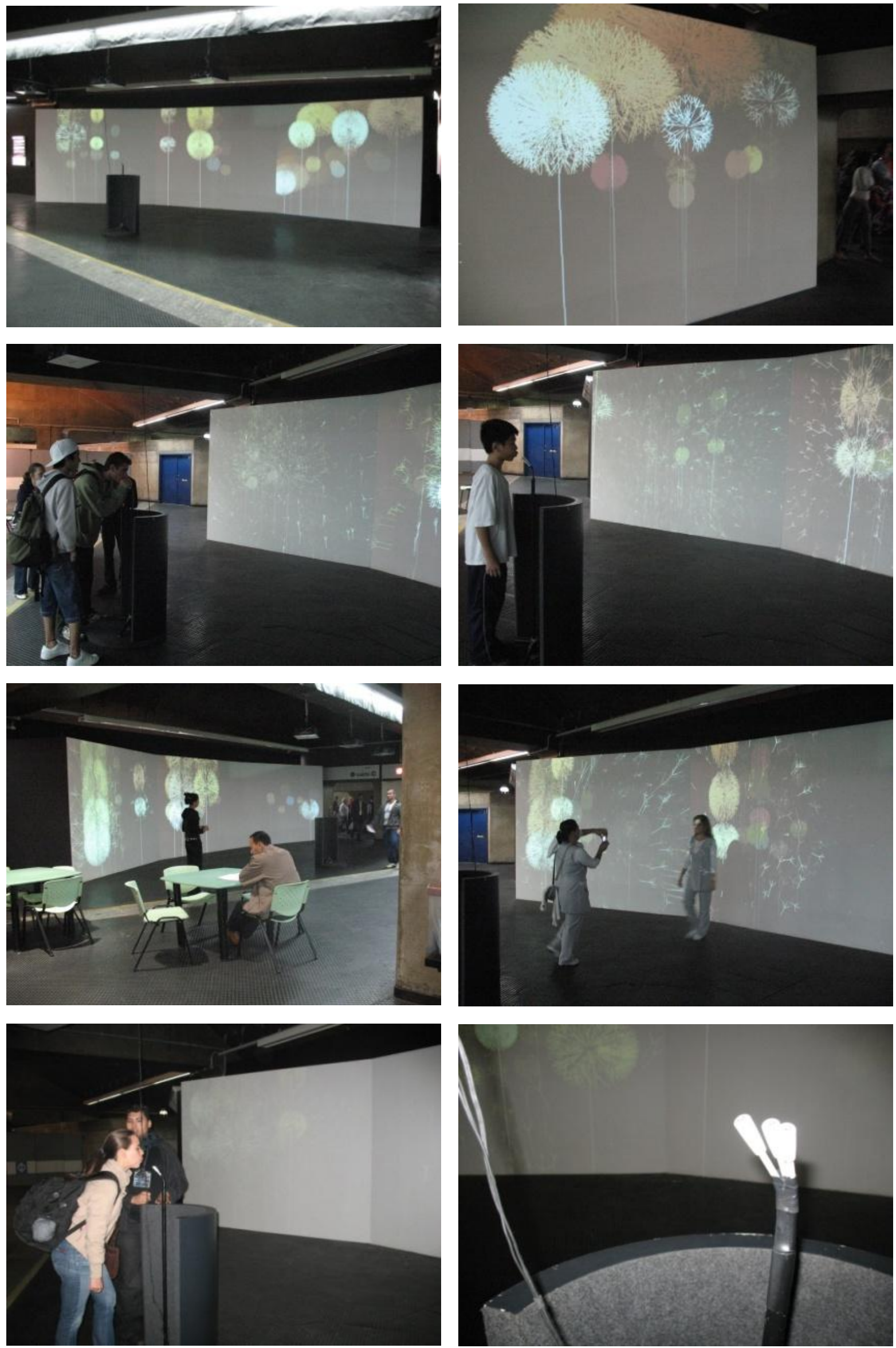

Figuras 110, 111, 112, 113, 114, 115, 116 e 117: Les Pissenlits, Edmond Couchot e Michel Bret. Estação Paraíso. Fonte: registro fotográfico realizado pela pesquisadora. 
3.2.2.2 $11^{\circ}$ e $12^{\circ}$ Festivais Internacionais de Linguagem Eletrônica: ta e $2^{a}$ edições do FILEPAI (2010-2011)

No período de 27 de julho a 29 de agosto, o Sistema FIESP (Federação das Indústrias de São Paulo), por intermédio do SESI-SP (Serviço Social da Indústria de São Paulo), com a lei de incentivo à cultura e o patrocínio do Santander, realizou - 11ํ Festival Internacional de Linguagem Eletrônica-FILE (2010), considerado o maior festival de arte e tecnologia da América Latina. Segundo a organização do evento, o FILE buscou ressaltar a importância da arte pública interativa "no sentido de compreender e absorver os novos fenômenos sociais proporcionados pela tecnologia e, desta maneira, construir estratégias que pudessem interligar-se com esses novos comportamentos de massa" (BARRETO, 2010, p.91).

Fizeram parte do evento: o FILEPRIXLUX, uma premiação de artistas do mundo todo que desenvolveram projetos inovadores de arte interativa, linguagem digital e sonoridade eletrônica; e a 1 a edição do FILEPAI (Paulista Avenida Interativa ou Arte Pública Interativa), um projeto de arte pública digital que ocupou estações de metrô e diversos espaços da Avenida Paulista. A Galeria de Arte do SESI-SP, o Teatro e o Mezanino do Centro Cultural FIESP-Ruth Cardoso, o MASP, a Fnac, o Conjunto Nacional e o Instituto Cervantes receberam a exposição com instalações interativas, games, maquinemas, trabalhos de internet, performances e workshops. Nas estações de metrô da Linha 2-Verde: Trianon-MASP e Consolação, foram instalados games em seus acessos na área externa. Na Estação Paraíso, na área próxima às plataformas. Na Estação Brigadeiro, que também fazia parte do roteiro, não foi possível a apreciação dos games devido à incidência direta dos raios solares na tela do equipamento, impossibilitando a visualização das imagens. O problema se repetiu na Estação Trianon-MASP, o que restringiu a apresentação apenas à área interna. A princípio, pretendia-se utilizar para a interface joysticks e controles, mas, de acordo com os monitores, devido à falta de uma base para os usuários apoiá-los, foram utilizados mouses e controles de computador.

Na Estação Paraíso, no período de 27 de julho a 7 de agosto, foi apresentado o game PixelJunk Eden, do estúdio Q-Games (Japão), lançado em 2008, para 0 Playstation3 e PSP. Nele, os jogadores tomavam a forma de plantas abstratas e se moviam pelo jardim. O objetivo era juntar pequenas partículas de pólen para 
transformar sementes adormecidas em sementes ativadas. As novas sementes podiam ser usadas para criar novas plantas e, assim, ganhar mais mobilidade pelo jardim. Neste caso, a iluminação da estação, localizada em uma posição inadequada em relação ao plano de projeção das imagens, diminuiu a intensidade das cores, o que prejudicou a visibilidade da imagem projetada. $\mathrm{O}$ problema poderia ter sido resolvido com o simples revestimento das luminárias, solução adotada pelo Itaú Cultural na Exposição Arte Cibernética.
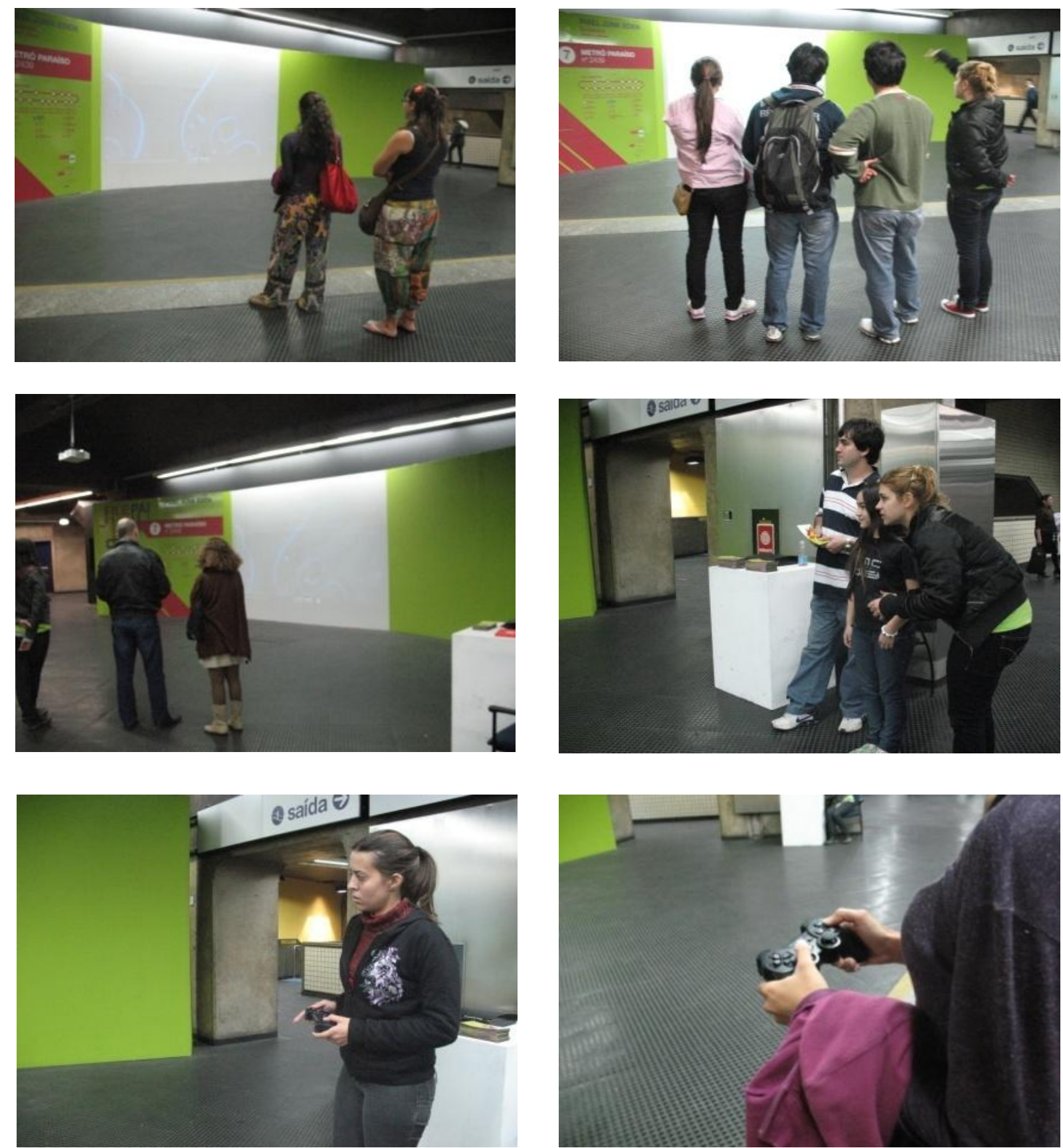

Figuras 118, 119, 120, 121, 122 e 123: PixelJunk Eden, estúdio Q-Games. Estação Paraíso. Fonte: Registro fotográfico realizado pela pesquisadora. 
Na Estação Brigadeiro, no período de 27 de julho a 7 de agosto, deveriam ter sido apresentados os games: Windosill, lançado em 2009, e Thomas, lançado em 20012005, ambos desenvolvidos pelo estúdio Patrick Smith-Vectorpark (EUA). O primeiro era uma série de salas imaginárias para destrancar e explorar (deveria ter sido instalado no Acesso C - saída rua Carlos Sampaio, lado par). O segundo, um ovo que montava um monociclo por meio de uma série de pequenas experiências (deveria ter sido instalado no Acesso C - saída rua Teixeira da Silva - Centro, lado par).

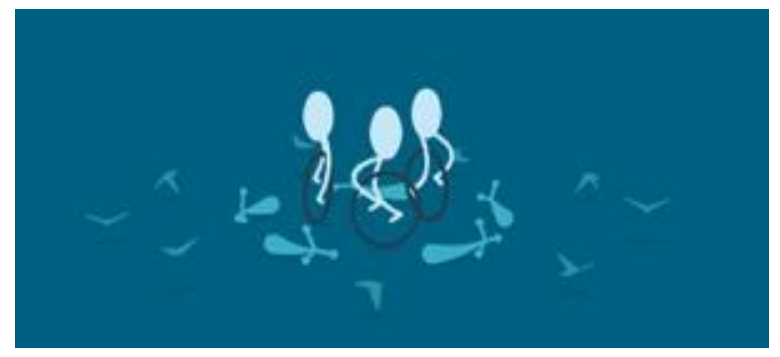

Figura 124: Thomas, estúdio Patrick Smith-Vectorpark. Estação Consolação. Fonte: CATÁLOGO FILE, 2010,

$\mathrm{Na}$ Estação Consolação, no período de 27 de julho a 7 de agosto, foram apresentados os games: Feed the Head, lançado em 2007, e Levers, lançado em 2001, ambos desenvolvidos pelo estúdio Patrick Smith-Vectorpark (Estados Unidos). O primeiro era um jogo surreal com regras que mudavam. O segundo, um jogo de equilíbrio com base na física.
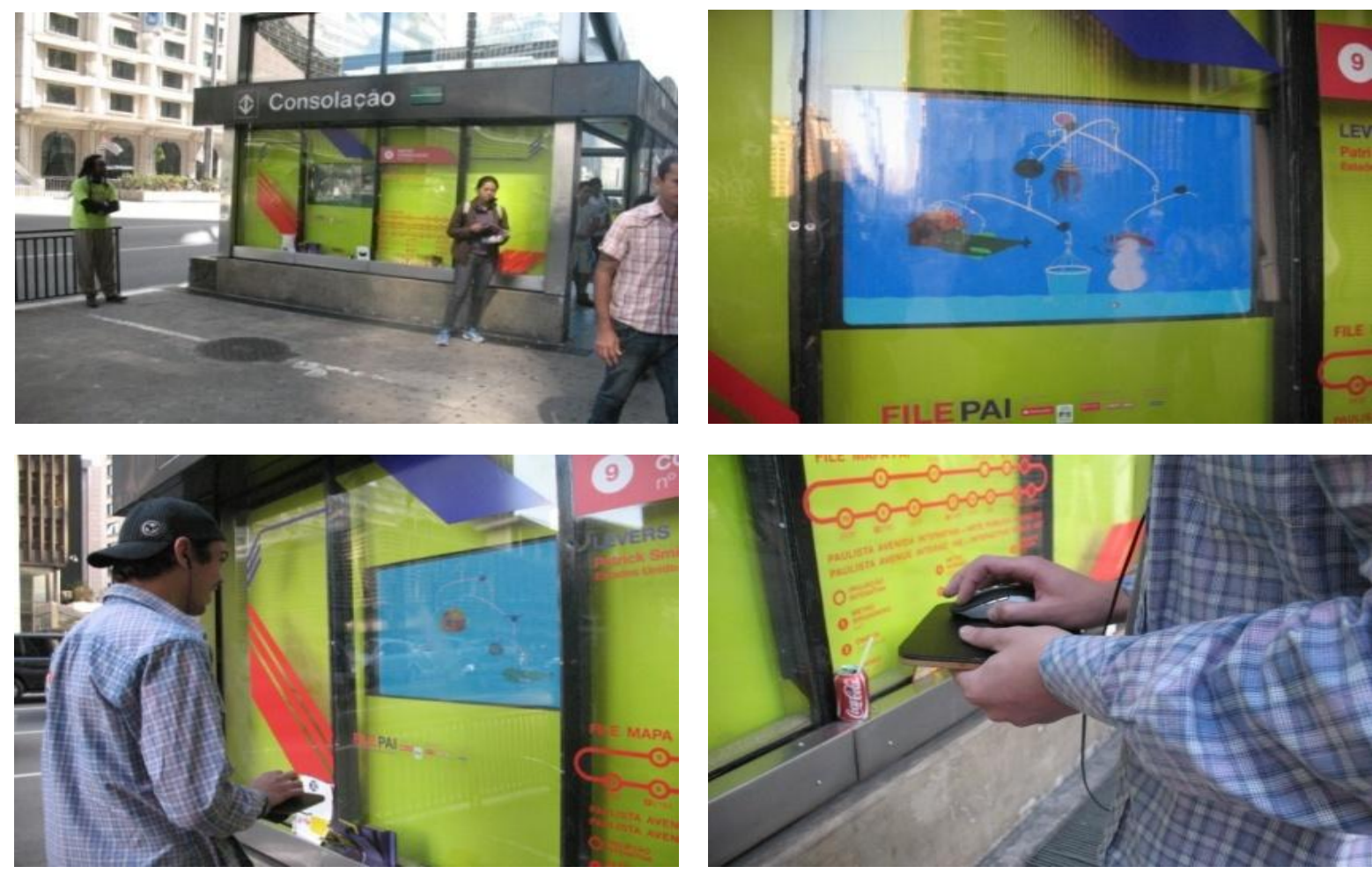

Figuras 125, 126, 127 e 128: Levers, estúdio Patrick Smith-Vectorpark. Estação Consolação. Fonte: Registro fotográfico realizado pela pesquisadora. 

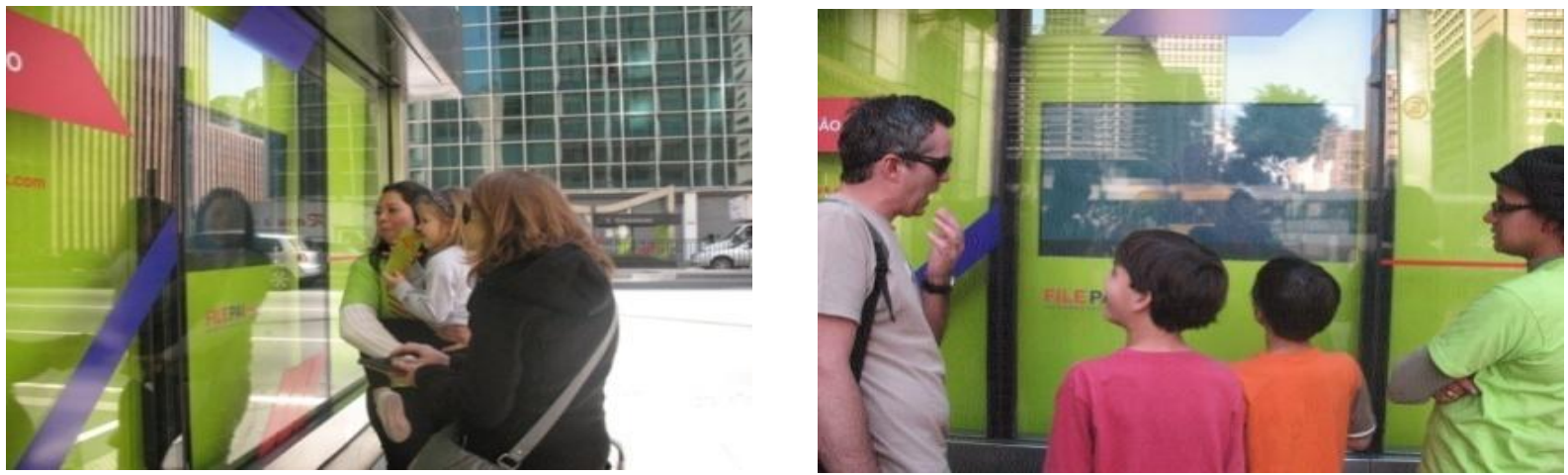

Figuras 129 e 130: Feed the Head, estúdio Patrick Smith-Vectorpark. Estação Consolação. Fonte: Registro fotográfico realizado pela pesquisadora.

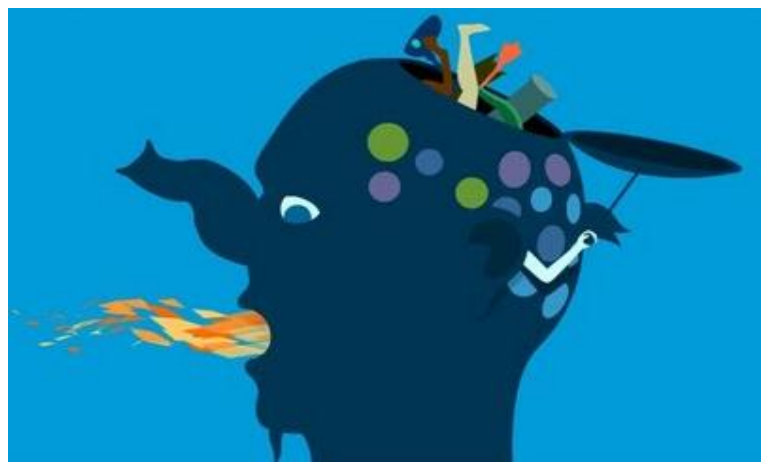

Figura 131: Feed the Head, estúdio Patrick SmithVectorpark. Estação Consolação.

Fonte: CATÁLOGO FILE SÃO PAULO, 2010, p.96.

Na Estação Trianon-MASP, no período de 27 de julho a 29 de agosto, foram apresentados os games: Windosill, lançado em 2009, e Levers, lançado em 2001, ambos desenvolvidos pelo estúdio Patrick Smith-Vectorpark (Estados Unidos) e exibidos no espaço interno, nas vitrines do MASP, situadas antes dos bloqueios das catracas. Deveria ter sido apresentado também (no Acesso A - lado par) Park, lançado em 2000, pelo mesmo estúdio. Problema técnico semelhante ao ocorrido na Estação Brigadeiro inviabilizou a apresentação.
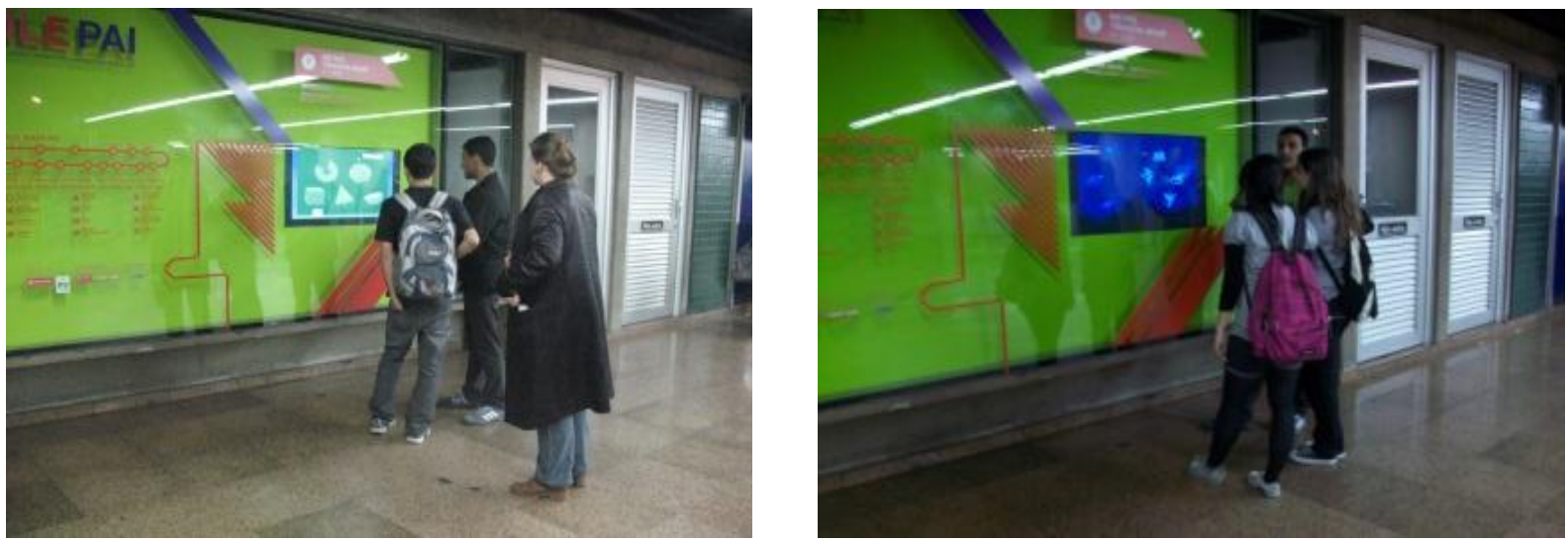

Figura 132 e 133: Windosill, estúdio Patrick Smith-Vectorpark. Estação Trianon-MASP. Fonte: Registro fotográfico realizado pela pesquisadora. 


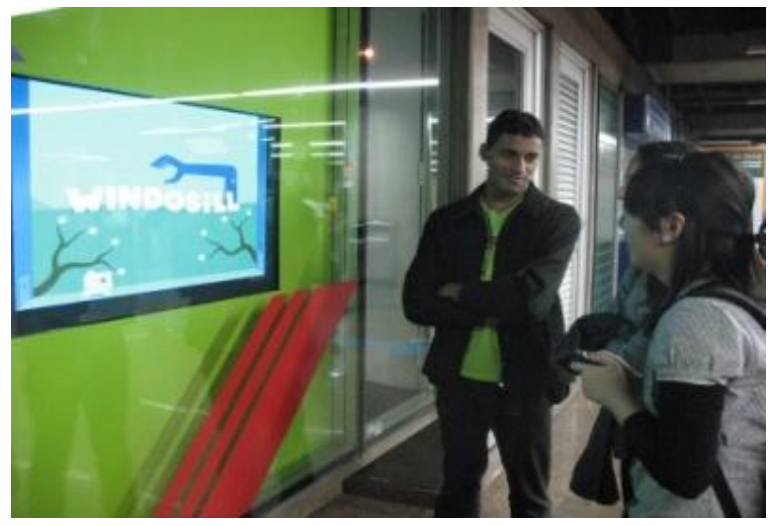

Figura 134: Windosill, estúdio Patrick SmithVectorpark. Estação Trianon-MASP. Fonte: Registro fotográfico realizado pela pesquisadora.
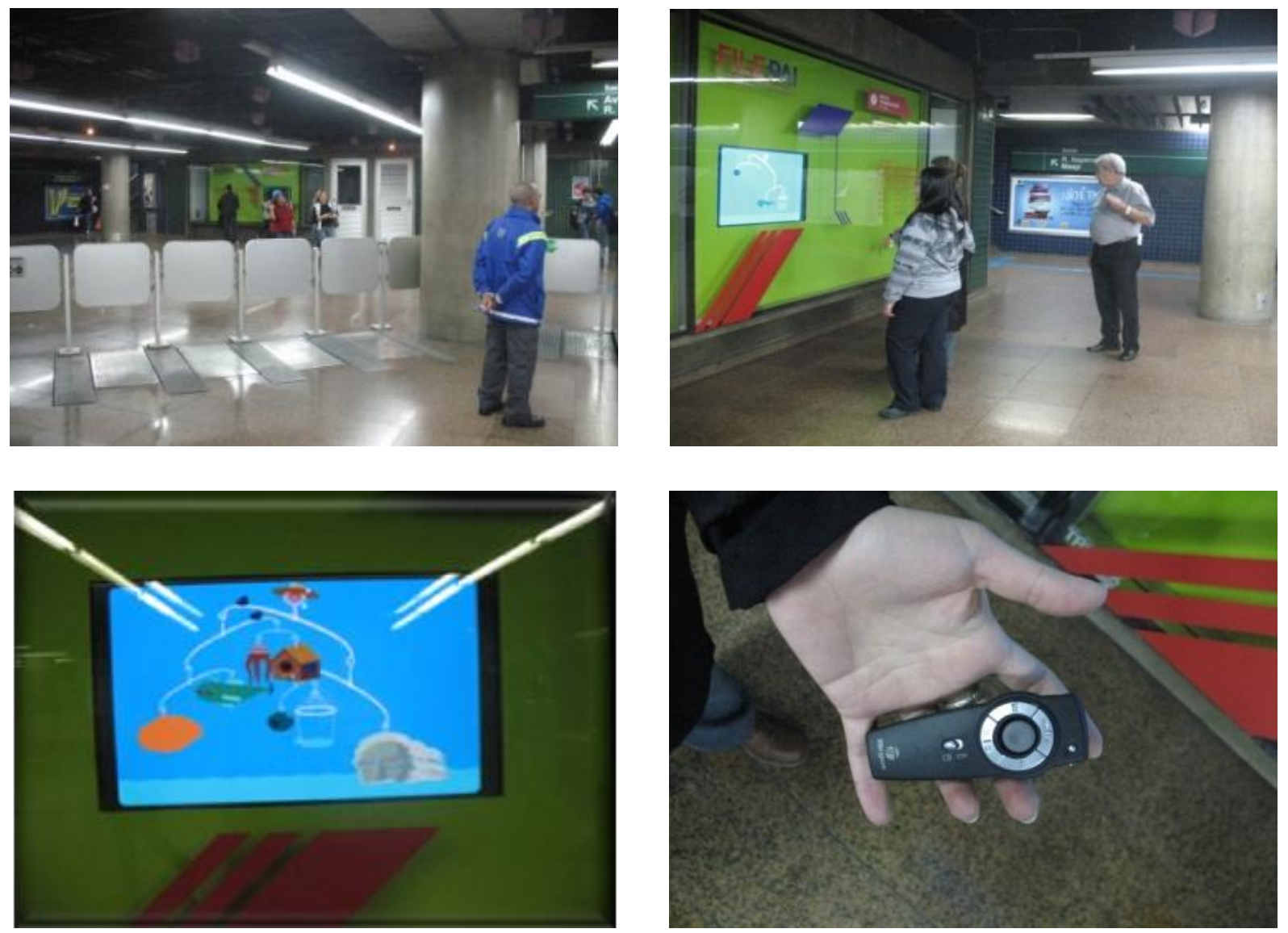

Figuras 135, 136, 137 e 138: Levers, estúdio Patrick Smith- Vectorpark. Estação Trianon-MASP. Fonte: Registro fotográfico realizado pela pesquisadora.

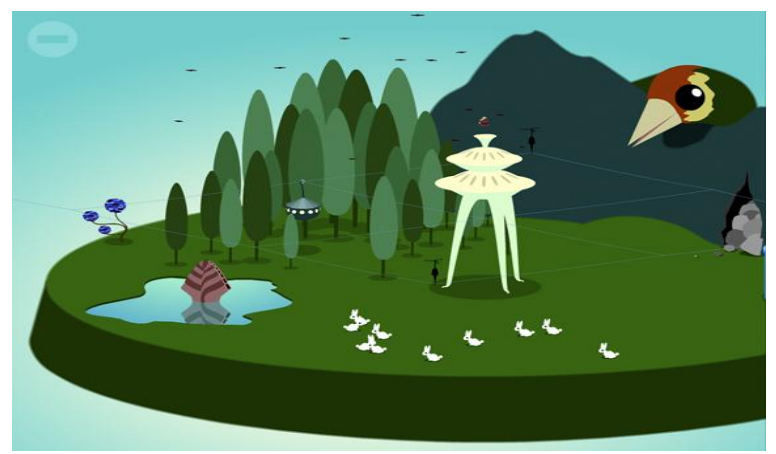

Figura 139: Park, estúdio Patrick Smith - Vectorpark. Estação Trianon-MASP: Fonte: <http://www.theindieshelter.com/vectorpark/>. Acesso em 17/06/2012. 
No período de 19 a 28 de julho de 2011, foi realizado o $12^{\circ}$ Festival Internacional de Linguagem Eletrônica-FILE, e com ele, a 2 edição do FILEPAI. Em diversos espaços da Avenida Paulista e região foram exibidos trabalhos realizados com ferramentas eletrônicas e digitais: instalações interativas, games, animações e maquinemas. No Centro Cultural São Paulo foram realizados: o FILE Symposium 2011, um espaço para discussão entre artistas, teóricos e interessados em arte e tecnologia, e o FILE Workshop. Nas estações de metrô foram exibidos games-FILE Game, animações-FILE Anima+ e réplicas de uma instalação interativa. Nessa edição, os games foram exibidos no espaço interno de uma única estação, a Estação Vila Madalena, anteriormente não utilizada como espaço expositivo. A interface obra-usuário ocorreu através do uso de teclados e mouses.
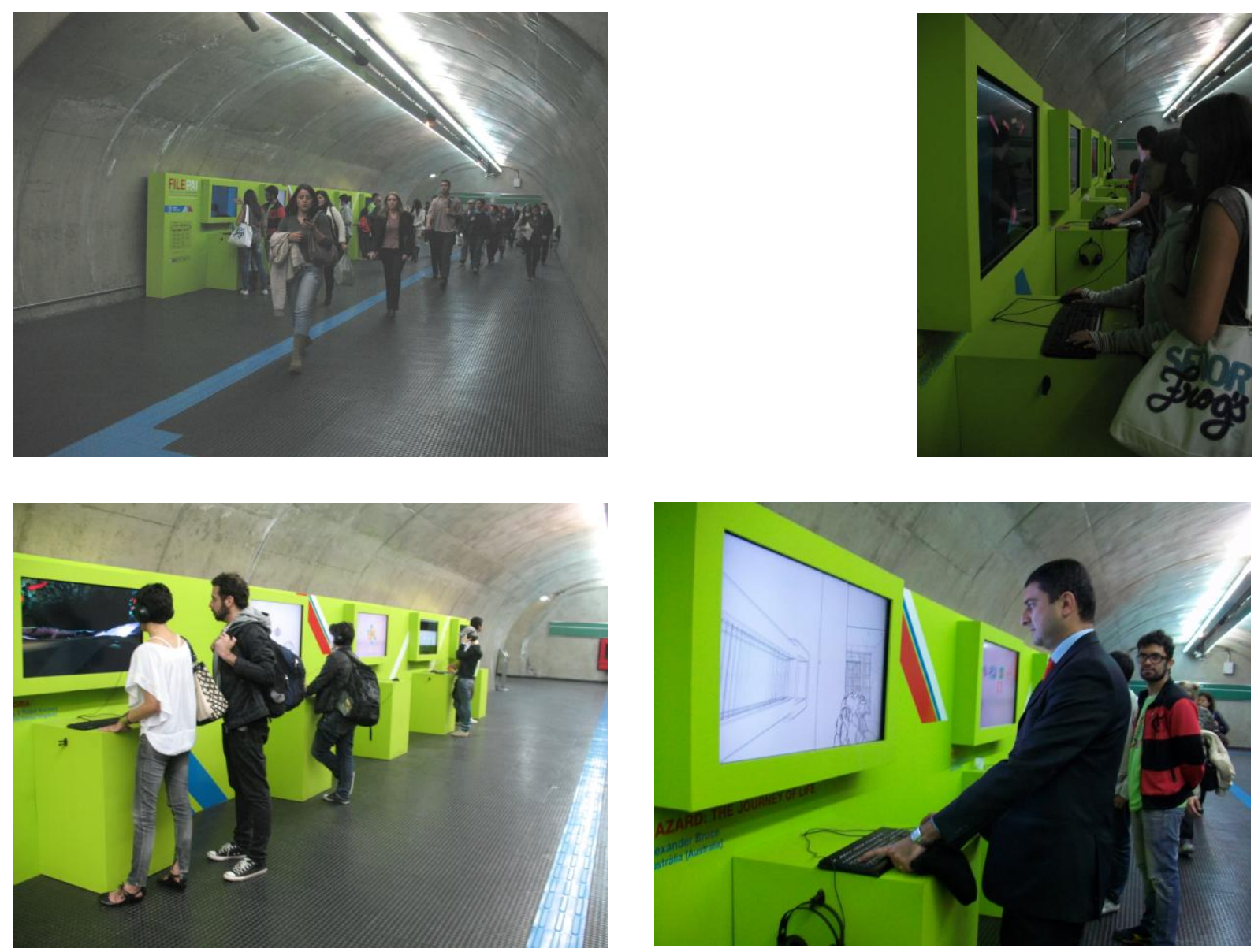

Figuras 140, 141, 142 e 143: Hazard: the journey of life, Alexander Bruce. Estação Vila Madalena. Fonte: Registro fotográfico realizado pela pesquisadora. 

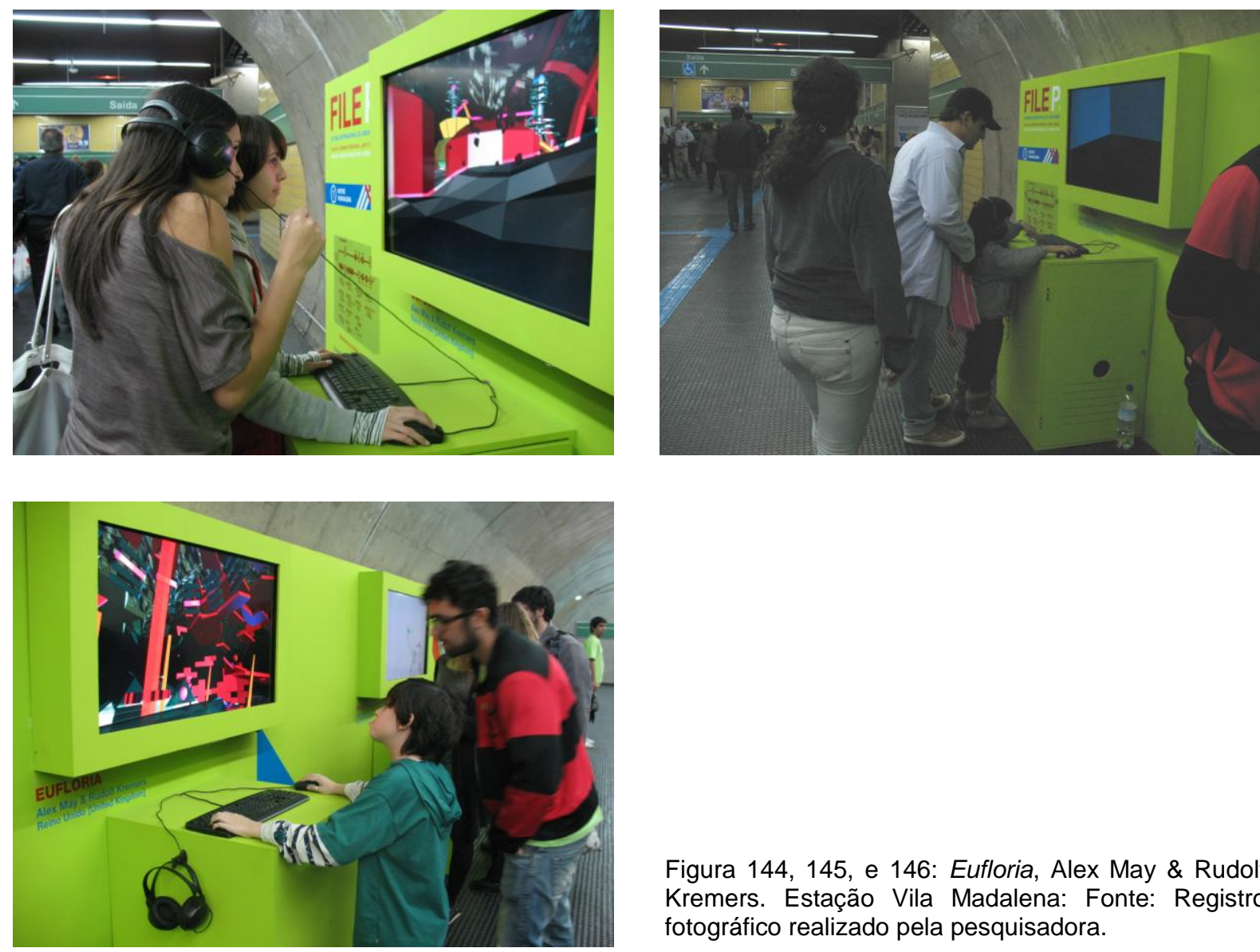

Figura 144, 145, e 146: Eufloria, Alex May \& Rudolf Kremers. Estação Vila Madalena: Fonte: Registro fotográfico realizado pela pesquisadora.
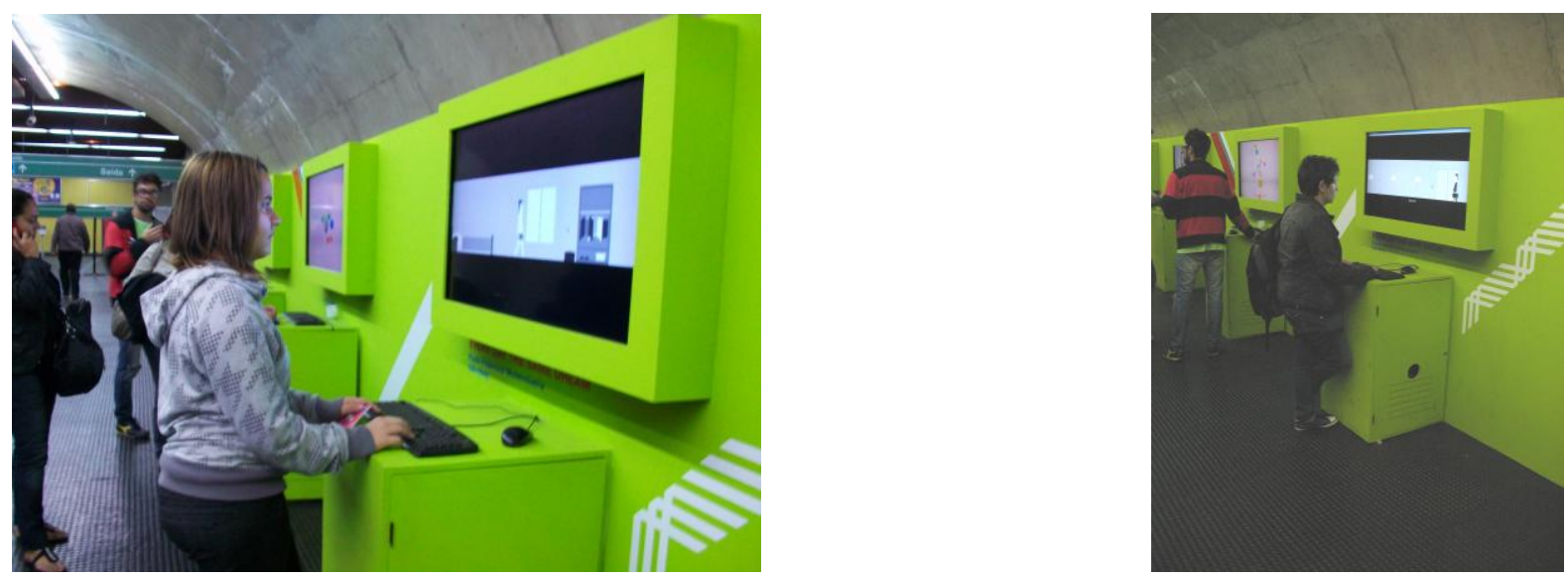

Figuras 147 e 148: Every Day the Same Dream, Estação Vila Madalena: Fonte: Registro fotográfico realizado pela pesquisadora. 

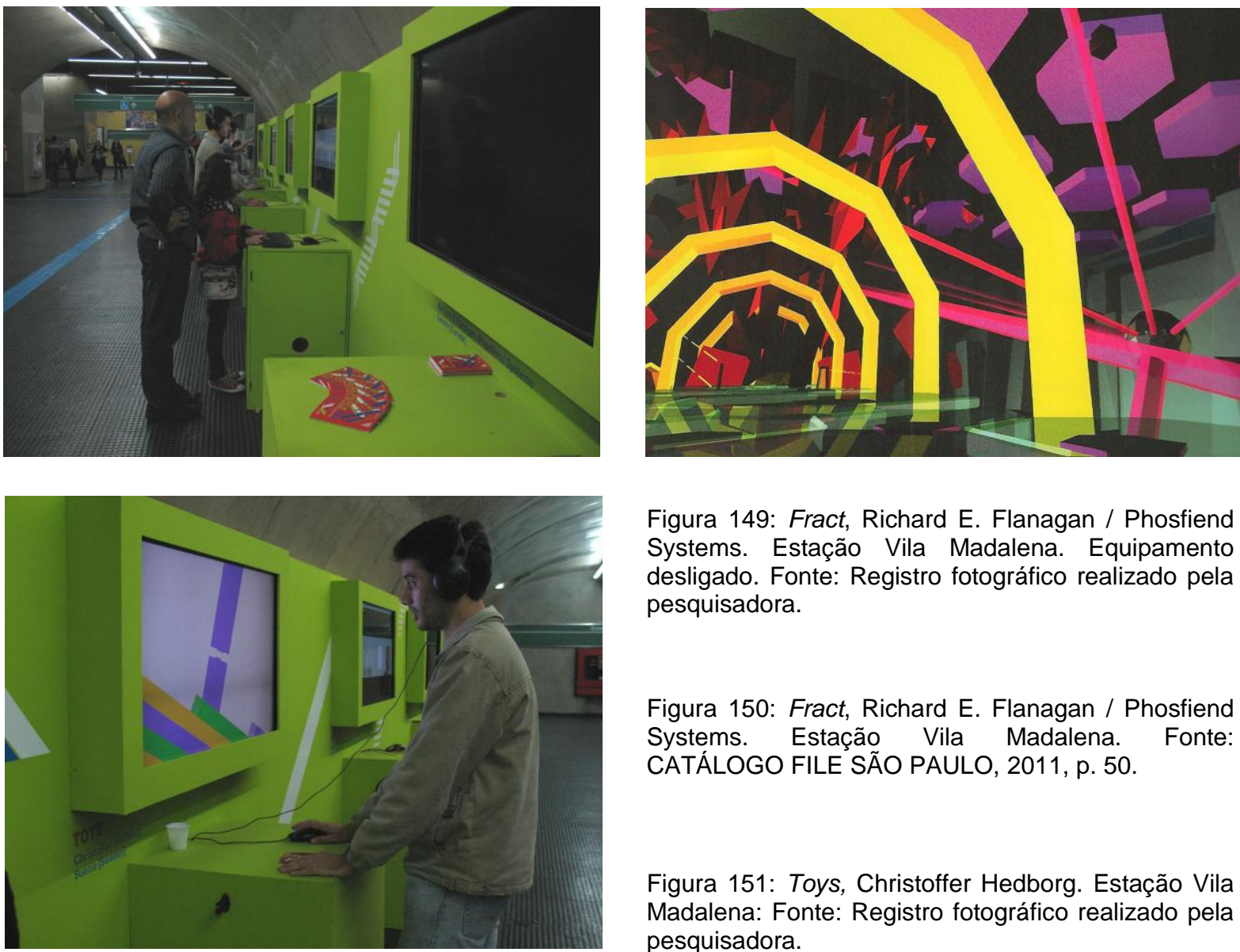

Figura 149: Fract, Richard E. Flanagan / Phosfiend Systems. Estação Vila Madalena. Equipamento desligado. Fonte: Registro fotográfico realizado pela pesquisadora.

Figura 150: Fract, Richard E. Flanagan / Phosfiend Systems. Estação Vila Madalena. Fonte: CATÁLOGO FILE SÃO PAULO, 2011, p. 50.

Figura 151: Toys, Christoffer Hedborg. Estação Vila Madalena: Fonte: Registro fotográfico realizado pela pesquisadora.

Eufloria, de autoria de Alex May \& Rudolf Kremers do Reino Unido, exibia um ambiente de exploração e conquista espacial que empregava temas de crescimento de plantas e evolução biomecânica. Permitia que o jogador explorasse um universo renderizado. A estética do jogo lembrava livros infantis como $O$ Pequeno Príncipe e era acompanhado de uma trilha ambiente de Brian Grainger. (CATÁLOGO FILE SÃO PAULO, 2011, p.40).

Every Day the Same Dream, de autoria de Paolo Pedercini/ Molleindustria da Itália, tratava da 
recusa ao trabalho e alienação. Um conto curto e triste sobre um $\mathrm{dia} /$ sonho/pesadelo. Um homem unidimensional sem rosto é preso na rotina diária. Sua libertação/condenação/despertar só acontece quando o jogador descobre todas as maneiras possíveis de subverter sua vida cotidiana. (CATÁLOGO FILE SÃO PAULO, 2011, p. 49).

Fract, de autoria de Richard E. Flanagan / Phosfiend Systems do Canadá, outro trabalho que deveria fazer parte da exposição, não estava em funcionamento no decorrer das visitas que fizemos ao local. Tratava-se de:

(...) uma aventura na primeira pessoa para Windows e Mac, na linha dos títulos Myst, mas com um viés electro. O jogador é deixado em um mundo abstrato construído sobre sons e estruturas inspiradas na música eletrônica. $\mathrm{O}$ jogador deve explorar o ambiente e encontrar pistas para ressuscitar e reviver o maquinário há muito esquecido desse mundo musical, para destravar seu mecanismo interno. (CATÁLOGO FILE SÃO PAULO, 2011, p. 50).

Hazard: the journey of life, de autoria de Alexander Bruce da Austrália, era um game "surreal de quebra-cabeças que explorava um labirinto vibrante e ilusório onde o espaço podia mudar e nada era o que parecia" (CATÁLOGO FILE SÃO PAULO, 2011, p.40). Toys, de autoria de Christoffer Hedborg da Suécia, era composto por 12 brinquedos. $O$ ângulo em que eram observados era a chave para colocá-los em ordem (CATÁLOGO FILE SÃO PAULO, 2011, p.43).

O FILE Anima+ abriu espaço para a apresentação de todos os gêneros de animações, de clássicos de grandes estúdios às produções independentes, de profissionais aos estudantes. No total, foram 406 trabalhos que demonstraram a aplicação de tecnologias atuais por animadores e novas visões do campo das linguagens digitais. As que fizeram parte do FILEPAl, ocuparam o espaço interno da Estação Trianon-MASP. Hybrid Moment.com (2009), The Persistence of Sadness.com (2010), Jello time.com (2007), Carnal Fury.com (2011) e Hot Doom.com (2009), todas de autoria de Rafaël Rozendaal, da Holanda. "Meu trabalho está espalhado sobre uma enorme quantidade de domínios. Cada um deles é título de uma obra. Em cada trabalho você vai encontrar uma versão condensada da realidade irreal, ou algo assim", explica o autor (CATÁLOGO FILE SÃO PAULO, 2011, p.160). A interface obra-usuário ocorreu através do uso de mouses. 

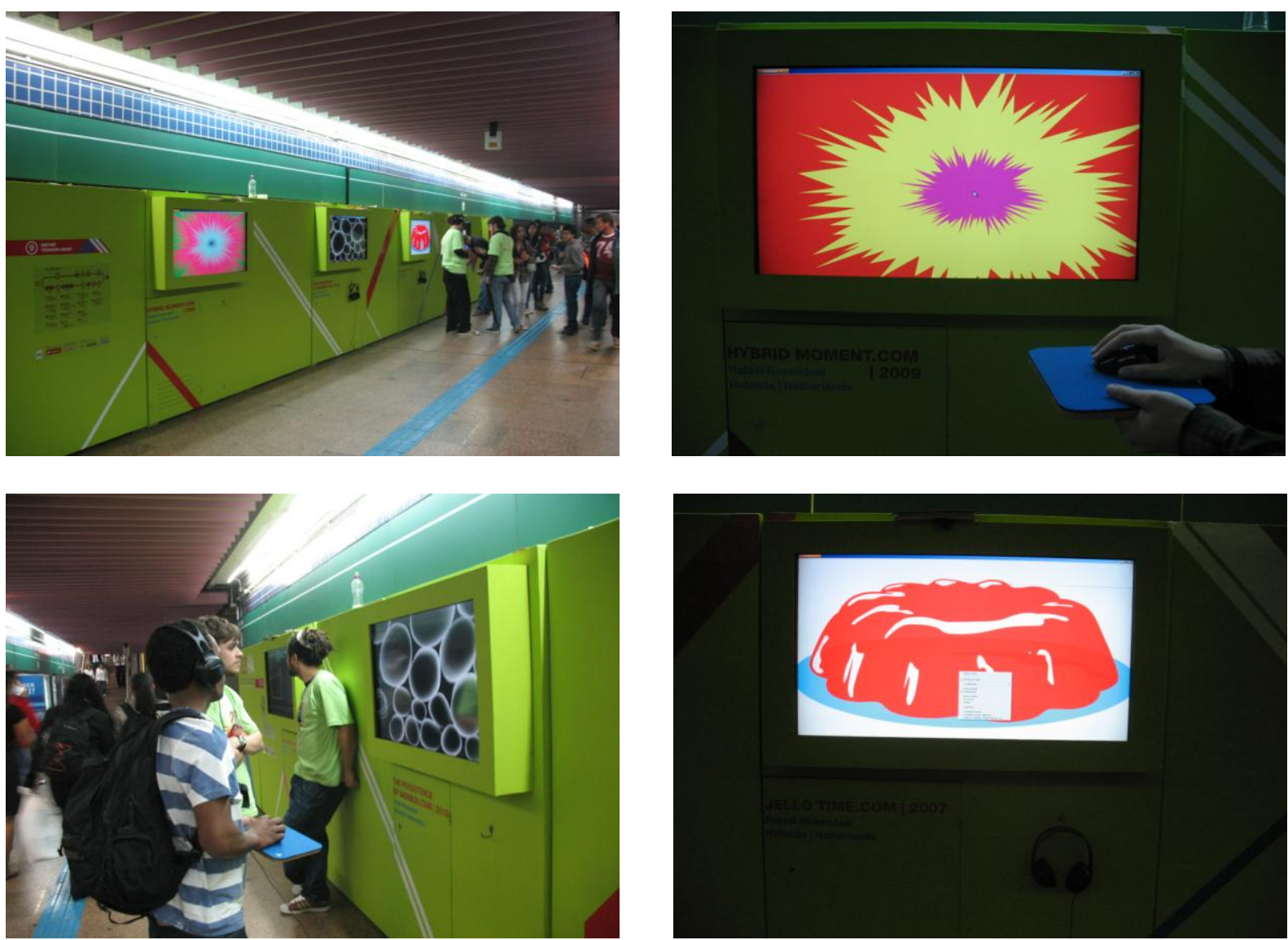

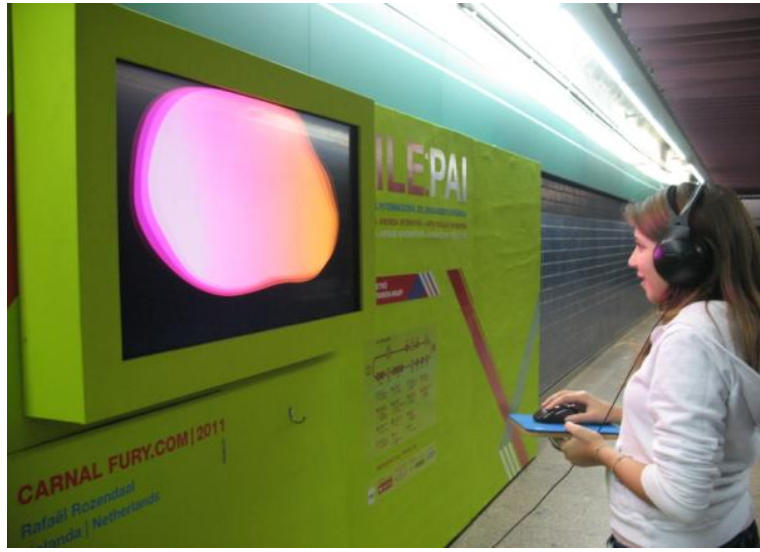

Figura 152: Anima+, Estação Trianon-MASP. Fonte: Registro fotográfico realizado pela pesquisadora.

Figura 154: The Persistence of Sadness.com, Estação Trianon-MASP. Fonte: Registro fotográfico realizado pela pesquisadora.

Figura 156: Carnal Fury.com, Estação TrianonMASP. Fonte: Registro fotográfico realizado pela pesquisadora.

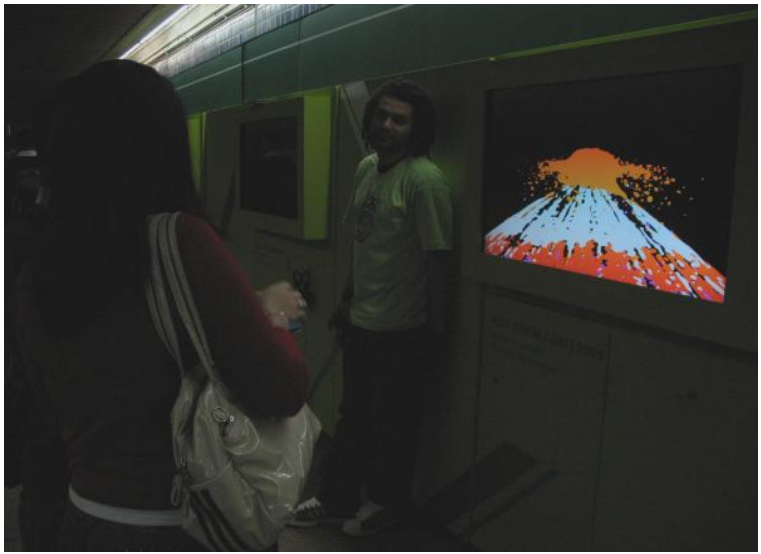

Figura 153: Hybrid Moment.com, Estação TrianonMASP. Fonte: Registro fotográfico realizado pela pesquisadora.

Figura 155: Jello time.com, Estação Trianon-MASP. Fonte: Registro fotográfico realizado pela pesquisadora.

Figura 157: Hot Doom.com, Estação Trianon-MASP. Fonte: Registro fotográfico realizado pela pesquisadora.

A instalação Via Invisível, de autoria dos brasileiros Soraya Braz e Fábio Oliveira Nunes (Fábio FON), teve réplicas exibidas na área externa das estações: Brigadeiro, 
Consolação e Trianon-MASP. Constituída de um painel revestido de vidro com pequenos sensores de radiofrequência, comumente utilizados no interior de pingentes de celulares, comercializados em lojas de bijuterias e miudezas, tornavam-se luminosos ao serem estimulados por transmissões eletromagnéticas como o uso de celulares em sua proximidade. Logo abaixo dos sensores luminosos, estava a palavra "Roaming" referindo-se, primeiramente, ao termo empregado em português para designar a transmissão de aparelhos em locais distintos da sua região de origem. Na língua inglesa, significa "viajando", mas também pode significar a esmo, vagar.

Esse sentido daquilo que não é próprio do local onde se encontra e que nos traz a incerteza da permanência e a efemeridade das circunstâncias. A composição que se forma através dos sensores iluminados é visível por alguns instantes e nos apresenta os vestígios de um corpo invisível. Essa condição efêmera que a palavra nos traz se referencia à práxis do trabalho e também à própria condição humana frente à tecnologia, em especial, às tecnologias que fazem uso da radiação eletromagnética. (CATÁLOGO FILE SÃO PAULO, 2011, p. 224).
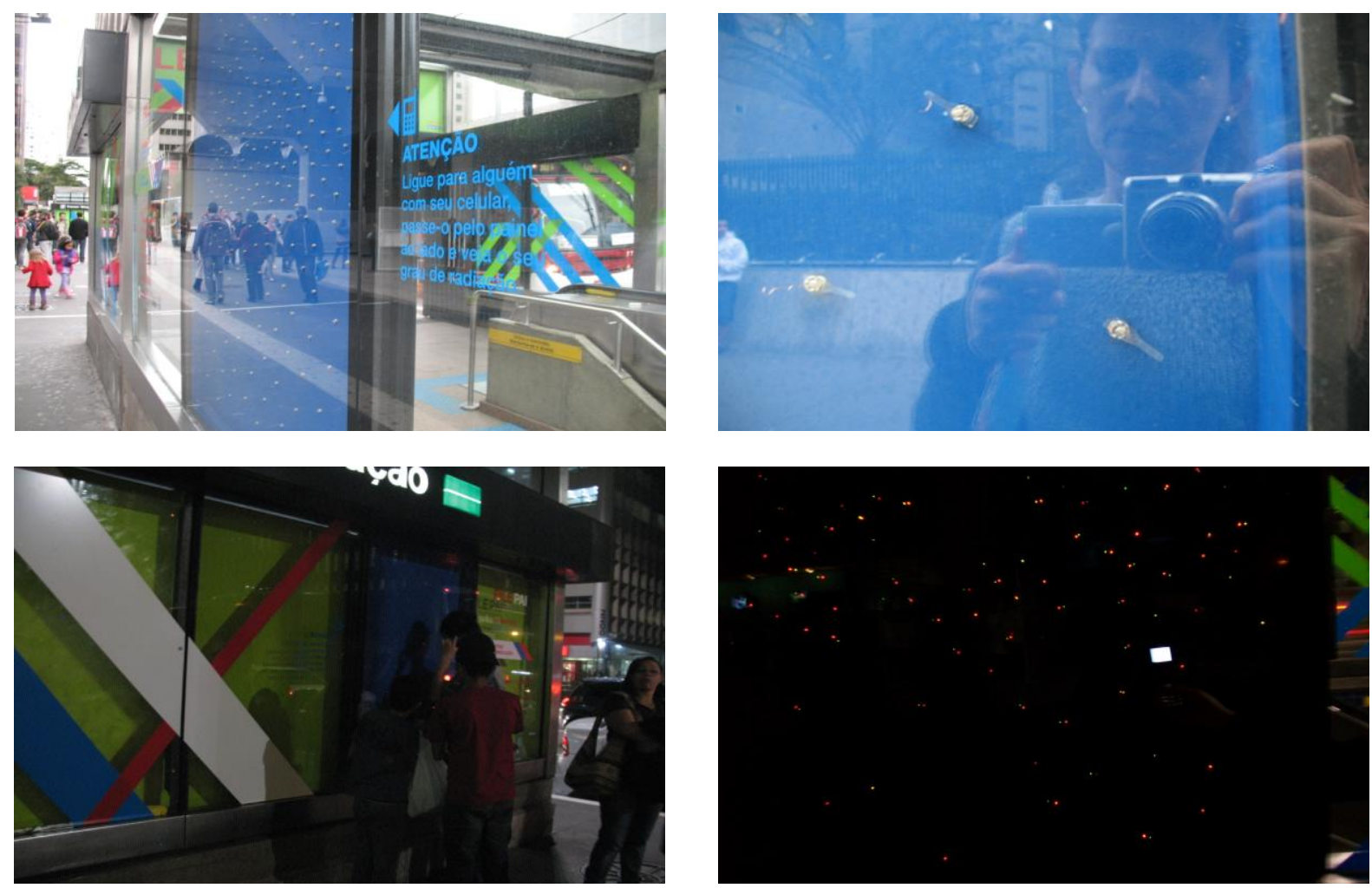

Figuras 158, 159, 160 e 161: Via Invisível, Soraya Braz e Fábio Oliveira Nunes. Fonte: Registro fotográfico realizado pela pesquisadora. 
Cabe ainda registrar que no período de 17 de julho a 19 de agosto, foi realizado o FILE 2012. O Festival englobou: FILE Instalação, Tablet, Games, Hipersônica, Maquinema e Mídia Arte. Com curadoria própria, o FILE Anima+, através de parcerias com os festivais internacionais de animação: Animated Dreams, Anifest \& Czech Institute of Animation, Be There! Corfu Animation Festival, Japan Media Arts, Kinofest (Romênia), Red Stick International Animation Festival, Sicaf e Siggrap, exibiu trabalhos na Galeria de Arte do SESI, no Teatro do SESI, no Espaço FIESP, no Museu da Imagem e do Som - MIS e no acesso às estações de metrô: TrianonMASP e Consolação onde, no período de 17 a 22 de julho, foi exibida Vjsuave, uma projeção de graffiti digital, de autoria dos artistas visuais Ygor Marotta e Cecilia Soloaga, emitida pelo Suaveciclo, uma bicicleta audiovisual (METRO.SP.GOV.BR, 2012). Para este trabalho, que unia arte de rua e videomapping, os artistas desenvolveram técnica e ferramenta para projeções em movimento. O veículo permitia projetar e captar imagens de vídeo por toda a cidade. Animações criadas quadro a quadro foram projetadas sobre superfícies reais acompanhadas de música criada por BMIND (FILEFESTIVAL.ORG, 2012). Na primeira semana foram apresentadas: Hipersônica Performance e animações, no Teatro do SESI-SP. Na Sala de Ensaio do Mezanino do SESI-SP ocorreram o FILE Workshop e Symposium.
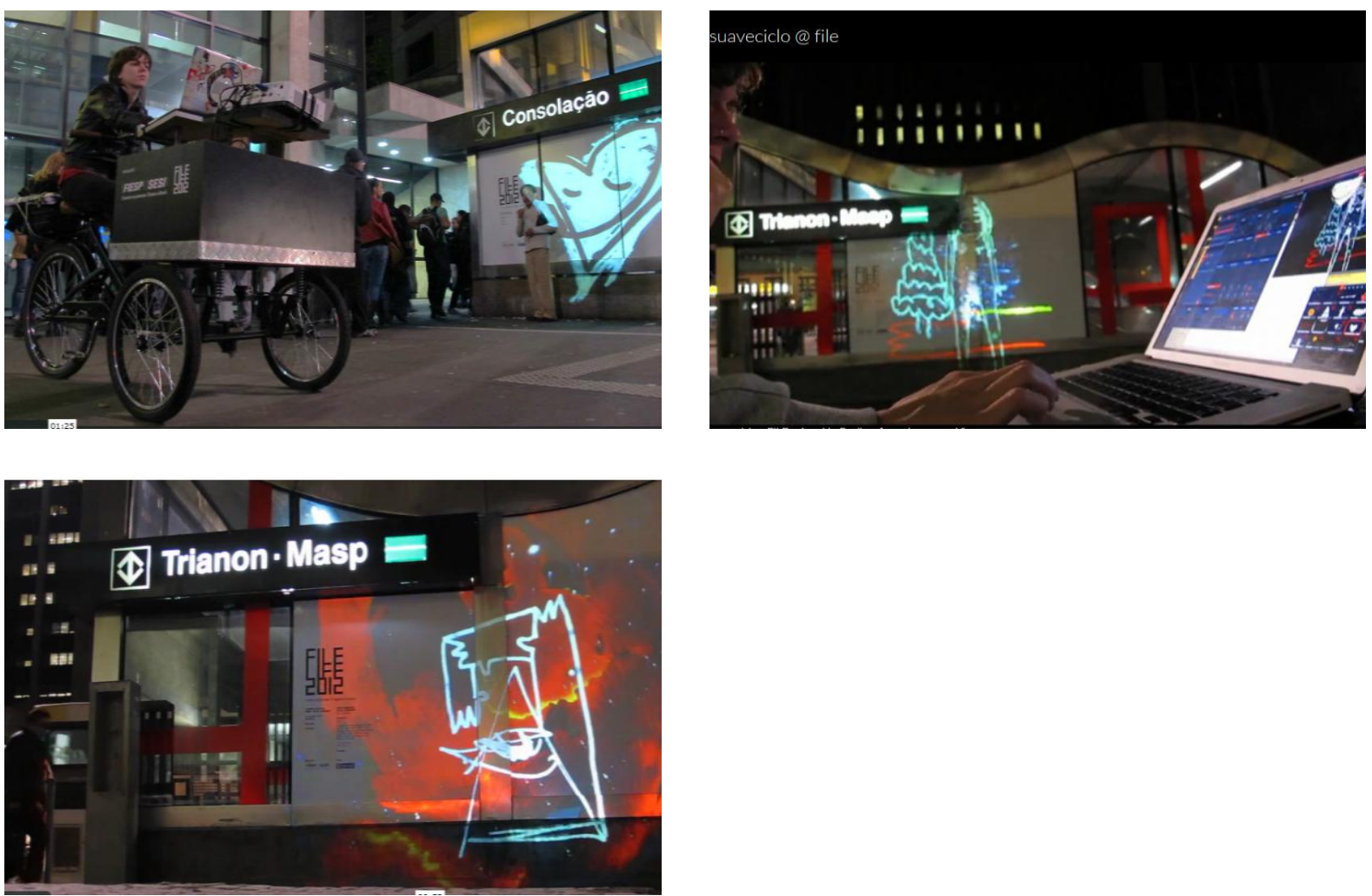

Figuras 162, 163 e 164: Suaveciclo e Vjsuave. Estação Trianon-MASP, FILE 2012. Fonte: <http://www.vjsuave.com/>. Acesso em 28/07/12. 


\subsubsection{Entrevistas com usuários/espectadores/atores, monitores e técnicos de manutenção no decorrer da Exposição Arte Cibernética: Acervo Itaú Cultural e $1^{\circ}$ e $2^{\circ}$ FILEPAIS}

Desde o início, tínhamos consciência de que a pesquisa qualitativa com usuários/espectadores/atores, monitores (a maioria deles usuários) e técnicos de manutenção das exposições deveria ter sido realizada por especialistas capazes de criar condições para examinar uma tipologia de resposta, e assim, ser dada a ela maior importância no desenvolvimento da tese.

Embora o resultado obtido seja apenas impressões do que uma pequena parcela desses usuários/espectadores/atores percebem e pensam a respeito das obras de arte expostas nas estações do metrô de São Paulo, consideramos que devam ficar aqui registradas por se tratar de informações que contribuem para confirmar a aceitação de trabalhos desenvolvidos com tecnologias atuais, apresentados nas exposições temporárias anteriormente mencionadas. Incluindo usuários, monitores e técnicos de manutenção, foram realizadas 62 entrevistas na Exposição de Arte Cibernética (2010), 34 no $1^{\circ}$ FILEPAI (2010) e 39 no 2ํ FILEPAI (2011).

As respostas dos usuários/espectadores/atores apresentaram convergências quanto ao elevado grau de receptividade dos trabalhos desenvolvidos com tecnologia atual, até mesmo pelo desconhecimento de trabalhos semelhantes (instalações). Instalações, games e animações foram entendidos como obras de arte por serem "interessantes", "divertidos", "criativos", "bonitos", "inovadores", "diferentes". Tais características, de acordo com os usuários, resultantes da "criatividade" de seus autores em busca de "expressar uma ideia", "chamaram a atenção", "atraíram", "despertaram a curiosidade em saber como funcionavam". A interatividade exigida, tornava o usuário/espectador/ator parte constituinte das obras, elemento indispensável para que se completassem. $O$ ato de interagir foi visto como uma forma de "brincar" que "traz boas sensações", "diverte", "relaxa", "desestressa", "distrai", "quebra a rotina do cotidiano", "torna o ambiente melhor", "aproxima a arte das pessoas".(USUÁRIOS/ESPECTADORES/ATORES, 2010, 2011) ${ }^{50}$.

Quanto às obras permanentes registradas em seus imaginários, na maioria dos

\footnotetext{
${ }^{50}$ Usuários/Espectadores/Atores, em entrevistas concedidas à pesquisadora, 2010, 2011 (APÊNDICE B).
} 
casos, não foram lembradas em um primeiro momento, só depois de esclarecer que estávamos questionando sobre obras que ficavam o tempo todo no espaço das estações é que algumas delas foram mencionadas. Os trabalhos citados de imediato foram os expostos em outras exposições temáticas temporárias. De acordo com um dos usuários/espectadores/atores:

Quando a obra é permanente ela passa a ser integrada, se torna cotidiano e não é percebida. Quando você passa e vê algo diferente a tua curiosidade é aguçada para ver o que é ou se tem alguém interagindo você vai também. (USUÁRIO/ESPECTADOR/ATOR, 2010).

Estas observações são muito pertinentes, considerando que nas obras permanentes do acervo são aplicados materiais convencionais comumente utilizados na própria arquitetura, no entanto, como veremos nos Capítulos 5 e 6, dependendo do tipo de tecnologia aplicada, uma obra permanente ou temporária pode assumir características diferentes ao longo de sua apresentação e se destacar no ambiente em que está inserida, mesmo que nele estejam aplicadas tecnologias semelhantes, como o LED, por exemplo, aplicado em painéis concebidos como trabalhos artísticos para serem alterados constantemente, com a possibilidade de interferência do próprio usuário/espectador.

Abramo afirma que a exposição do observador contemporâneo "à velocidade e à intersecção das imagens cinéticas, da TV e do cinema" ampliou o nível perceptível das obras de arte. A seu ver, "não se perdeu e nem se substituiu o estado de contemplação, acrescentou-se a ela a percepção fragmentada oriunda da aceleração, da multicaptação da obra de arte e de seu entorno." No espaço das estações, o fruidor não para diante das obras para contemplá-las (veremos mais adiante que não é bem assim), mas à medida em que ele realiza seu deslocamento até o trem vai "acumulando formas, cores e linhas que depois se arranjam mentalmente em correspondência à obra vista. Com esta atitude ele soma ao anterior prazer de admirar concretamente a obra o prazer maior de recriá-la abstratamente na memória" (ABRAMO, 1994, p.16). Para este tipo de fruição, algumas obras deveriam ser planejadas para serem alocadas em locais de fluxo mais acelerado, enquanto que outras, capazes de permitir uma pausa, um contato mais contemplativo, para ocuparem espaços de fluxo mais lento, ou seja, para que haja a percepção e a fruição obra de arte-usuário/espectador, em momentos distintos de seu deslocamento no interior das estações, implica em maiores cuidados 
na seleção dos artistas, dos espaços e das obras.

$\mathrm{Na}$ interpretação de Santos, a percepção e a interação com as obras de arte permanentes, variam "desde o não reconhecimento de sua existência até sua assimilação utilitária - elas existem para quebrar a rotina ou ocupar lugares vazios" (SANTOS, 2006, p.7). A percepção das obras e do próprio espaço se dá "enquanto" o usuário espera o trem, "enquanto" espera por alguém, quando "o olhar 'verificador' que não para, observa e registra todo o entorno enquanto se desloca" (...) este olhar que registra a existência de um elemento estranho ao habitual" (SANTOS, 2006, p.108-109). Estas afirmações se confirmaram, em parte, no decorrer das investigações das obras temporárias. Embora esses usuários/espectadores/atores, no seu dia-a-dia, não frequentem as estações com o objetivo de contemplar obras de arte como se estivessem em um museu ou em uma galeria, houve casos em que foram às estações especificamente para este fim, ou seja, para conhecê-las, para mostrá-las para alguém, para interagir com as obras tecnológicas temporárias apresentadas nos espaços internos e externos das estações. Muitos dos entrevistados afirmaram que não é todo mundo que tem tempo, hábito, interesse e dinheiro para frequentar galerias e museus; neste sentido, a presença da arte em espaços públicos como os do metrô "facilita o contato com a arte", "desperta o interesse", "possibilita conhecer o que está sendo feito de novo sem ter que sair da rotina".

De acordo com os monitores, as pessoas que interagiram com as obras eram as que vinham direto do trabalho, estudantes, as que estavam visitando os demais trabalhos das exposições instalados na Av. Paulista ou na galeria, mas, "o maior fluxo foi o dos usuários do metrô". A faixa etária dos usuários/espectadores/atores foi diversificada. As instalações atraíram todas as faixas, enquanto os games e animações tiveram maior atenção de crianças e jovens. Outro aspecto a ser considerado é a confirmação do retorno de usuários para rever, para interagir com as obras. Muitos, pela falta de tempo, não pararam para interagir no momento em que as viram, mas retornaram justamente para levar seus filhos. Era "como se estivessem educando uma nova geração com aquele tipo de arte"(MONITORES, 2010, 2011) ${ }^{51}$. Professores de escola de ensino médio e curso superior solicitaram aos alunos a visita à Exposição Arte Cibernética para

\footnotetext{
${ }^{51}$ Monitores em entrevistas concedidas à pesquisadora, 2010, 2011 (APÊNDICE B).
} 
que desenvolvessem trabalhos sobre as obras exibidas. Alguns idosos, apesar de não estarem acostumados com as tecnologias atuais, de desconhecerem sequer como funciona um mouse, também interagiram com os trabalhos com a ajuda de monitores que quebraram a barreira existente entre tecnologia e ação. Apesar do constrangimento causado pela dúvida se era preciso pagar para brincar, crianças de rua interagiram com games exibidos na Estação Trianon-MASP, instalados antes do bloqueio das catracas. Alguns usuários/espectadores/atores preferiram interagir com os games no ambiente das estações, apesar de estarem disponíveis na internet.

No caso da obra Via Invisível, não houve a necessidade da permanência de monitores devido ao acionamento simples, apresentado em um texto explicativo fixado ao lado da obra. As animações também tinham uma interação simples e rápida, o que exigia menos tempo e, consequentemente, não atrapalhavam o fluxo do espaço e do cotidiano dos usuários/espectadores/atores.

Nesses espaços públicos, frequentados por pessoas dos mais diversificados perfis, alguns usuários observaram que a apresentação dos games no idioma inglês foi um obstáculo para o entendimento das falas dos personagens e que a divulgação deveria ser maior. Houve também dois usuários que não se identificaram com os trabalhos, o que não impediu que fossem aceitos.

Quanto aos técnicos de manutenção: um da Exposição Arte Cibernética-Acervo Itaú Cultural (2010), e outro, do 2 FILEPAI (2011), no metrô, há o fator "tremor da estrutura", inexistente em uma galeria, o que desregulava o posicionamento dos projetores utilizados na exibição das instalações da Exposição Arte Cibernética. Os sensores de movimento saíam do lugar, o que exigiu visitas periódicas, de caráter preventivo, a cada dois dias. Na equipe técnica havia profissionais que cuidavam do áudio, vídeo, software e suporte geral. No caso dos games e animações do FILE 2011, estes requereram pouca manutenção devido aos computadores serem recentes, explicou o técnico. A equipe só era acionada quando necessário. Não houve a necessidade de visitas preventivas. Para comprovar as informações colhidas nas entrevistas, optamos por apresentar no APÊNDICE B uma amostragem do que houve de mais significativo nas falas dos usuários/espectadores/atores, monitores e técnicos de manutenção. 


\subsubsection{Os significados da arte nas estações de metrô de São Paulo}

Considerando que toda arte é social e que "o relevo dos significados das obras de arte urbana e sua concretização no domínio público dão-se em meio a espaços permeados de interdições, contradições e conflitos" (PALLAMIN, 2000, p.17, 49), iniciamos com a transcrição das palavras de Marcello Glycério Freitas, um dos coordenadores do Projeto Arte no Metrô (1994), e do texto publicado no site da Companhia do Metropolitano (2012):

O contato com a obra de arte possibilita um aflorar de sensibilidades e emoções, um momento de reflexão, uma desaceleração do cotidiano e a humanização do espaço. (...) Painéis, murais, pinturas e esculturas tornam-se o vínculo afetivo necessário para estabelecer as demais ligações empresa-usuário. Amenizam os espaços amplos, colorem 0 trajeto cinza do concreto, emocionam pelas questões colocadas, instigam a imaginação e predispõem positivamente para os serviços oferecidos. (FREITAS, 1994, p.10-11).

As artes e a cultura no Metrô são instrumentos de humanização que permanecem até hoje como os melhores canais de relacionamento com seus usuários, com a cidade e com seus visitantes. (METRO.SP.GOV.BR, 2012).

Freitas ainda afirma que foi a partir das primeiras iniciativas para amenizar a descontinuidade criada entre a Praça da Sé e a estação subterrânea que descobriuse a "monumentalidade das estações e a possibilidade de adequação da arquitetura para conter obras de arte." Em seu texto, uma sequência de observações reforçam a ideia anteriormente mencionada de estreitar relações com os usuários através da arte. $O$ elemento arte aliado à técnica e à sensibilidade poderia valorizar a arquitetura e levar aos espaços áridos do metrô maior qualidade de vida. $\mathrm{A}$ união entre obra de arte e espaço arquitetônico deveria acontecer sem que houvesse interferência na funcionalidade, na uniformidade visual, na concepção estética das estações. A exposição de obras de arte poderia significar a transmissão de "mensagens educativas através de elementos, que por sua plástica, aguçam a curiosidade, estímulo ao respeito e noção de conservação dos espaços coletivos" utilizados no cotidiano poderia recuperar a memória coletiva.

Radhá Abramo esclarece que a filosofia do projeto baseia-se nos pensamentos de 
Baruch Spinoza ${ }^{52}$ e John Ruskin ${ }^{53}$. Através de Spinoza, defende o exercício simultâneo da ética e da estética, possibilitado pela inclusão da obra de arte no mobiliário da vida cotidiana. Seria um "bom serviço social”, "uma coisa boa”, "útil”, "que traz concórdia social”, uma vez que ela é "capaz de despertar o conhecimento sensível, perceptivo, e o aspecto sensível da nossa afetividade." Através de Ruskin, defende que "toda arte é ensinamento", como elemento que exerce uma "função social educadora" (ABRAMO, 1994, p.16). De modo geral, é possível constatar que a arte inserida nas estações do Metropolitano representa essa diversidade de significados e outros mais, explícitos e implícitos.

Partindo para alguns exemplos práticos, a intervenção realizada na Praça da Sé, que culminou no Museu de Esculturas e no Projeto Arte no Metrô, também alcançou o entorno da estação com o objetivo de realizar um "saneamento social". Uma pesquisa com a população local apontava um número significativo de crianças que dormiam e viviam de maneira precária. A partir desse dado foi elaborado um programa que as envolvia no projeto como guias da população que transitava pela praça, o que implicou no fornecimento de roupas que as distinguia das outras e no pagamento de meio salário mínimo. Outro trabalho com meninos de rua envolveu a Secretaria da Criança, artistas e outros setores em um projeto de arte urbana. Inicialmente, 137 crianças, número reduzido para 37, aprenderam a trabalhar com alguns materiais juntamente com professores, na rua. O material produzido foi transformado por Gilberto Dacahe, dono da Cerâmica Aruã, em um painel cerâmico instalado na área externa da Estação Brás (ABRAMO, 1995, p.59-60). Ainda na Estação Sé, Claudio Tozzi, autor do painel Colcha de Retalhos, em uma forma particular de atuação, valorizou o usuário incluindo-o no processo de seleção de uma dentre as três propostas desenvolvidas pelo artista: astronauta, "transeunte do espaço celeste" deslocado para o espaço subterrâneo; silhuetas de transeuntes, "que significavam o andar das pessoas que por lá passavam"; e colcha de retalhos, "uma reelaboração do que se faz nas periferias da cidade com sobras de tecidos". O resultado da pesquisa demonstrou a identificação do usuário/espectador com algo que ele mesmo produzia, e ainda produz (TOZZI, 2012) ${ }^{54}$. O trabalho cinético de Renina Katz teve a particularidade de resolver um problema de ordem estética

\footnotetext{
52 Filósofo, nascido em Amsterdam (1632-1677), autor de "Ethic", considerado seu mais importante trabalho.

${ }^{53}$ Escritor, crítico de arte, crítico social, poeta e desenhista, nascido em Londres (1819-1900), autor de ensaios sobre arte e arquitetura.

${ }^{54}$ Claudio Tozzi em entrevista concedida à pesquisadora, 2012 (APÊNDICE C).
} 
ao intervir em um brise, elemento arquitetônico que, originalmente, apenas permitiria a saída do ar. Na Estação Liberdade, localizada em tradicional bairro de imigrantes japoneses, que em comemoração aos 80 anos da imigração, abriga pinturas de artistas da mesma origem; na Estação Armênia, a escultura Memorial Armênia, de Josely Carvalho, foi inaugurada em 1995, ano em que foi relembrado os 80 anos do genocídio armênio, assim como, na Estação República, na região de Pinheiros, local da antiga trilha dos Tupiniquins, em que todas as estações apresentam obras de artistas brasileiros com essa temática, os trabalhos recuperam a memória coletiva (FREITAS, 1994, p.10-11). Na Estação Marechal Deodoro, Gontran Guanaes, ainda no gênero de memorial pelos 200 anos da Declaração dos Direitos Humanos, cobriu as paredes com imagens educativas da Revolução Francesa contendo a inscrição dos trinta artigos dos Direitos Humanos em contraposição às imagens de boias-frias brasileiros, pintados na ação contínua do trabalho do campo. Durante a execução das obras, usuários e residentes do bairro solicitaram-Ihe instruções, o que culminou na montagem de um atelier de pintura improvisado. Na Estação Trianon-MASP, o painel Um Espelho Mágico da Pintura no Brasil, de autoria de Wesley Duke Lee, apresenta uma mostra do acervo do Museu de Arte de São Paulo Assis Chateaubriand-MASP, impressa em lona vinílica. A obra tem uma identidade com o entorno da estação, com o museu situado logo acima, na superfície. Como mencionado anteriormente, há também vitrines deste museu, situadas no interior da estação, utilizadas para apresentação de exposições temporárias de obras do acervo e de obras contemporâneas. De acordo com informações transmitidas por Paulo Klein, na Estação Tiradentes, objetiva-se que seja feito algo semelhante com o Museu de Artes Sacras (KLEIN, 2012) ${ }^{55}$. Na recém-inaugurada Estação Sacomã, em homenagem a um Jequitibá-Rosa transplantado pelo Metrô para a Praça Padre Lourenço Barendse, próxima à estação, foi instalado o mural Árvore Subterrânea, executado com resíduos cerâmicos reaproveitados. Inspirado na diversidade ambiental existente na região, seu autor buscou "resgatar a ideia de reciclagem e

\footnotetext{
${ }^{55}$ Estas informações foram registradas pela pesquisadora em 24 de agosto de 2012, no decorrer do evento: Metrô, Engenho e Arte, realizado pelo primeiro Programa de Inteligência Corporativa-PIC da Universidade Corporativa do Metrô-UNIMETRO com o objetivo de mostrar a trajetória de como a arte foi introduzida no metrô de São Paulo e em outras localidades do mundo. Transmitido simultaneamente pelo site da Companhia e pelo site de Tecnologias para Escolas do Governo (www.escolasdegoverno.gov.br) contou com a presença dos palestrantes: Françoise Schein (arquiteta, urbanista e artista); Yo Kaminagai ("délégué à la conception" da Companhia de metrô e ônibus de Paris: Régie autonome des transports parisiens-RATP); Paulo Klein (jornalista, crítico de arte e curador) e Jair Ribeiro de Souza (chefe do Departamento de Soluções e Serviços de Tecnologia da Informação do Metrô de São Paulo).
} 
de otimização de recursos" (METRO.SP.GOV.BR, 2010). Embora pertença à Companhia Paulista de Trens Metropolitanos-CPTM e não ao Metropolitano, na Estação Luz, situada na galeria de conexão linhas A, B, D, E e F da CPTM com as linhas 1, 3 e 4 do Metrô, está a obra Epopeia Paulista, de autoria de Maria Bonomi, realizada em homenagem ao migrante nordestino. Para a execução da proposta foi empregada a linguagem da gravura aplicada em placas de concreto. Na composição das peças, foram utilizados objetos esquecidos na seção de Achados e Perdidos, formas abstratas e imagens da literatura de cordel. Baixos e altos-relevos, pensados para serem tocados por deficientes visuais, foram executados pela artista, cinco auxiliares e cerca de três mil colaboradores (MENGOZZI, 2004). A obra executada de forma coletiva remete à memória da estação e dos usuários, ao imaginário, à inclusão social. Outra experiência de caráter colaborativo realizada na Estação Sé, ainda em processo de elaboração e execução, tem sido desenvolvida pela artista francesa Françoise Schein. A partir de trabalhos realizados sobre o tema "Direitos Humanos" nos metrôs de Paris, New York, Bruxelas e Lisboa, desenvolveu um kit pedagógico para ensinar o assunto em escolas. Nesse material didático, alunos fazem ilustrações sobre cada artigo apresentado, posteriormente reproduzidas em cerâmicas que compõem painéis artísticos instalados nos espaços públicos das estações. A metodologia foi utilizada em Berlim, Estocolmo e no Rio de Janeiro, onde trabalhou em favelas com o apoio da Comunidade Europeia, criou uma microempresa de azulejos e recebeu uma encomenda do metrô local para intervir em uma torre de ventilação da Estação Siqueira Campos. Em São Paulo, o trabalho também tem sido desenvolvido com jovens e crianças de bairros desfavorecidos e apresenta as vertentes artística e cultural, ao levar em consideração o potencial histórico e cultural da região da Estação da Luz do Metrô e os temas principais dos Direitos Humanos; educativa, com oficinas de arte e técnica de pintura sobre azulejos desenvolvidas com jovens de escolas públicas e com estudantes de escolas de arte; social/sociológica, com a mobilização social e a reflexão em torno dos Diretos Humanos, que tem resultado na produção de uma obra de arte pública permanente que chama a atenção para o espaço público em que está inserida, promovendo discussões sobre as fronteiras urbanas, sociais e culturais da cidade. $O$ projeto resulta da parceria com: Association Inscrire (Paris), Associação Danyann: Aprender e Evoluir (São Paulo), Atelier Azulejarial (Rio de Janeiro), Instituto Brasil Leitor (São Paulo), Comissão Municipal de Direitos Humanos da Cidade de São 
Paulo-CMDHSP, Museu da Língua Portuguesa e Secretaria Municipal de Educação e do patrocínio de empresas privadas. Até o momento, foi realizado vinte e cinco por cento do projeto total, com a participação de 60 alunos (SCHEIN, 2012 ${ }^{56}$; FOLHETO AÇÃO INSCREVER ESTAÇÃO LUZ DO METRÔ, 2012). No site da instituição são

expostos desenhos e aquarelas de Diana Dorothea Danon que, desde os anos 1970, documenta a história da intervenção do metrô na cidade paulistana. Como mencionado anteriormente, as obras temporárias tecnológicas foram exibidas nos espaços de algumas estações com o objetivo de apresentar manifestações artísticas contemporâneas para quem não tivesse visitado os espaços institucionais do Itaú Cultural e da FIESP e para ressaltar a importância da arte pública interativa, buscando compreender e absorver os fenômenos proporcionados pela aplicação de tecnologias atuais.

Sob o ponto de vista de Santos, nos discursos de Freitas e Abramo ainda há o resguardo de um "caráter utilitarista" para as obras. Não é levado em consideração que uma obra pode gerar discórdia, e nem por isso seria ruim (SANTOS, 2006, p.65). O conceito de Arte Pública descrito pelos coordenadores do projeto está diretamente relacionado:

(...) às intenções do Metropolitano em criar novas formas de contato com o usuário, que então demonstrava vivo descontentamento com os serviços prestados pela companhia, algo refletido nas pesquisas de opinião e explícito nas atitudes de enfrentamento em plataformas e trens. Na fala destes autores, manifestam-se construções ideológicas que visam encobrir as origens do projeto - quais sejam: o desgaste da relação com os usuários, não mais cooptados pelo sentido primeiro de modernidade e civilidade representado pelo metrô; a intenção de reintroduzir na convivência institucional esta civilidade cordata e passiva, agora beneficiada pela inclusão de um elemento bom no metrô: as obras de arte contemporâneas. É uma variação da modernidade dos espaços inicialmente empreendida pela tecnologia e arquitetura, que levará compulsoriamente os paulistanos a se modernizar. Como expresso de maneira canhestra por Freitas (1995, p. 13), a arte inseriria a contemporaneidade à cidade e aos cidadãos. Daí ser identificada como tecnologia é fácil de ser entendido (SANTOS, 2006, p. 69).

O alcance do projeto não se restringiria apenas aos seus usuários, mas a toda a comunidade beneficiada pela imagem corporativa da empresa, vista positivamente na vida sociocultural da cidade. Políticas de intercâmbio de obras e de comunicação social com outras companhias de metrô trariam dividendos ${ }^{57}$. Para os artistas, é

\footnotetext{
${ }^{56}$ Informações registradas pela pesquisadora, em 24 de agosto de 2012, no decorrer do evento: Metrô, Engenho e Arte.

${ }^{57}$ Em 1993, a arquitetura das estações e a Arte no Metrô foram premiadas na $V$ Bienal Internacional de Arquitetura, em Buenos Aires. Em 1994, foi estabelecido o primeiro intercâmbio cultural entre o Metropolitano de São Paulo e o de Lisboa com a inserção da obra Brasil-Portugal: 500 anos - a Chegança, de autoria do artista
} 
significativo ter seus trabalhos expostos para um público mais amplo do que o alcançado nos ambientes de museus e galerias. Entendidas como elementos que chamam a atenção dos usuários no interior das estações, as obras de arte passaram a despertar o interesse de empresas privadas. Investir em obras de arte significaria investir em publicidade ${ }^{58}$. A entrada de novos recursos na Companhia, aumentada com a exploração comercial dos espaços, gerou modificações na imagem da instituição, também melhorada em função da expansão da Linha 2-Verde, reforçada pelas campanhas de marketing do Governo Estadual. O serviço de clipping da Companhia, em 1989, indicou o Projeto Arte no Metrô como o principal responsável pelo aumento de publicações na mídia impressa sobre a empresa. Tornou-se um movimento irreversível que tem influenciado estações em construção (SANTOS, 2006, p.64).

\subsubsection{Condicionantes para a aprovação de propostas de obras permanentes, exposições e eventos temporários nos espaços das estações de metrô de São Paulo}

Assim como a arquitetura de espaços públicos, a arte pública envolve preocupações de ordem histórica, social e de eficácia junto ao público, mas também está submetida a condicionantes econômicas, físicas, construtivas, tecnológicas, de uso ao longo do tempo, de normas preestabelecidas, de propósitos políticos.

Com referência no material publicado pesquisado, em entrevista realizada com técnico de manutenção da Exposição Arte Cibernética (APÊNDICE B), nos depoimentos dos artistas e nos regulamentos disponíveis no site da companhia, discorreremos sobre as condicionantes para a apresentação e execução de propostas de obras de arte permanentes e temporárias nas estações.

brasileiro Luis Ventura, na Estação Restauradores, em Lisboa, e das obras As Vias da Água e As Vias do Céu, de autoria do artista português David de Almeida, na Estação Conceição. As companhias dos metrôs de Caracas, São Francisco, New York, Buenos Aires e Paris também mantêm contato com o Metrô de São Paulo "através do intercâmbio de obras de arte envolvendo a participação dos próprios artistas, de estágios de profissionais de comunicação no Metrô de São Paulo e de exposições itinerantes sobre o projeto arte no metrô." (FREITAS, 1994, p.12).

58 Conceição Midori Hatanaka reforça essa ideia ao afirmar que há uma parceria de patrocínio de empresas privadas que, através de leis de incentivo, adquiriam as obras, estrategicamente, em troca de uma publicidade que atingiria milhões de usuários que circulam pelas estações diariamente (HATANAKA, 2009, p. 51). 
3.2.5.1 Condicionantes para apresentação de proposta de obra permanente

Iniciamos a apresentação de condicionantes para obras permanentes do Projeto Arte no Metrô a partir de considerações feitas pela idealizadora: Radhá Abramo. Em seu entendimento, a obra de arte no espaço das estações de metrô deve ser considerada um "objeto durável", característica que aceita todo tipo de proposta, exceto as de "caráter efêmero", posto que, nela houve um investimento de custos e de mão de obra. "A transitoriedade, portanto, não reside nos subterrâneos, só é permitida a transitoriedade dos usuários." Nesse sentido, há uma série de "prerrogativas, quesitos fundamentais que orientam a sua criação, execução e instalação." Por se tratar, em grande parte, de espaços subterrâneos, amplos e previstos para receber uma quantidade crescente de usuários, sua escala deve ser proporcional ao espaço em que será inserida, "deve ser monumental". Os materiais devem ser "formes e facilitadores de conservação" para atribuir estabilidade e durabilidade. "O suporte e a instalação das obras merecem tratamento particular, preventivo e rigor técnico". Em muitos casos, é necessária a elaboração de maquetes para uma "melhor visualização da proposta" e "melhor adequação da obra ao espaço destinado" (ABRAMO, 1994, p.19). O "efeito pistão" (ABRAMO, 1995, p.155) e a trepidação (TÉCNICO DE MANUTENÇÃO, 2010; TOZZI, 2012) ${ }^{59}$ provocados pelo deslocamento do ar à medida em que as composições se movimentam no interior das estações, são variações que também devem ser levadas em conta na infraestrutura da obra.

Consideramos que, somadas ao tipo de material e à escala empregados, estão a localização e a iluminação adequadas, condicionantes que contribuem para a melhor visualização e percepção de cores e formas. Entretanto, a disponibilidade de recursos financeiros para a aquisição e a manutenção da obra, é condicionante de primeira ordem, que determina sua presença e permanência.

Quanto ao processo de seleção dos artistas e das obras de arte a serem instaladas nas estações, inicialmente, foi instituída uma Comissão Consultiva multidisciplinar que realizava o trabalho a partir de critérios técnicos. Renovada a cada dois anos, contava com profissionais de diferentes áreas: antropólogos, arqueólogos, historiadores, arquitetos, artistas conceituados, técnicos do acervo cultural do

\footnotetext{
59 Técnico de manutenção em entrevista concedida à pesquisadora, 2010 (APÊNDICE B) e Claudio Tozzi em entrevista concedida à pesquisadora, 2012 (APÊNDICE C).
} 
Governo e representantes dos usuários. Os profissionais eram incumbidos de estudar as estações, indicar e receber sugestões de projetos de autores que, uma vez aprovados, passavam a fazer parte do Banco de Arte do Departamento de Marketing Institucional do Metrô, aguardando o calendário, a vez da execução e da instalação das obras nas estações, um processo lento, tendo em vista o curso do tempo necessário às escavações e à construção dos subterrâneos (ABRAMO, 1994, p.19). Era realizado concurso fechado e a apresentação dos trabalhos em nível de projeto (ABRAMO, 1995, p.60). De acordo com Tozzi (2012) ${ }^{60}$, na Estação Sé, primeira a receber obras de arte, houve um projeto curatorial feito por Radhá Abramo, que incluía a locação das obras e o diálogo entre elas envolvendo a área externa da Praça da Sé e diversas áreas internas da estação. Posteriormente, o local de instalação era decidido, em comum acordo entre arquitetos e projetistas responsáveis pelas estações, sem a orientação de um curador. Desta forma, "como as obras de arte não faziam parte dos projetos de arquitetura e planejamento destes espaços, elas nem sempre encontravam um ambiente propício para sua implantação." (HATANAKA, 2009, p.51). Atualmente, os novos projetos preveem o local para a instalação das peças (FREITAS, 1994, p.11). Inicialmente, a iluminação era a mesma utilizada nas estações e o financiamento das obras era feito pela Companhia.

Em 2012, passou a ser publicado no site da Companhia o regulamento para apresentação de projetos de obras de arte permanente que, de acordo com o texto, tem como objetivo:

(...) divulgar os espaços com vocação para a instalação de Obras de Arte permanente nas estações em fase de projeto, para o chamamento de interessados em encaminhar propostas de Obra de Arte para comporem o acervo de arte permanente do Metrô. Pretende-se, com isso, minimizar as interferências geradas com implantação de Obras de Arte após a inauguração das futuras estações e compatibilizar a proposta artística com o conjunto de projetos arquitetônico e complementares que envolvem a construção e o funcionamento das estações de Metrô. (REGULAMENTO PARA APRESENTAÇÃO DE PROJETOS DE OBRAS DE ARTE PERMANENTE, 2012).

Plantas com a indicação de espaços predeterminados para a instalação de obras de arte em estações em construção (Adolfo Pinheiro e Moema) foram disponibilizadas. No processo seletivo, as propostas são avaliadas pela Comissão Consultiva de Arte-CCA, composta por representantes de instituições públicas e

\footnotetext{
${ }^{60}$ Claudio Tozzi em entrevista concedida à pesquisadora, 2012 (APÊNDICE C).
} 
privadas, ligadas à arte e à cultura e por integrantes da Companhia do Metrô que avaliam "a pertinência do artista e da obra para compor o acervo". Posteriormente, as propostas são reavaliadas pela Companhia a partir de aspectos técnicos e operacionais que envolvem segurança, circulação dos usuários, manutenção, durabilidade e interferências visuais.

Quanto à apresentação dos projetos, é permitida apenas uma proposta por artista. $\mathrm{O}$ projeto deve ser inédito e encaminhado de forma a permitir o seu perfeito entendimento, juntamente com carta de manifestação de interesse, justificativa da proposta, currículo resumido e dados para contato com o artista. Poderão ser aceitas mais de uma solicitação para o mesmo espaço, desde que sejam de autores diferentes. Há uma data limite para que as solicitações sejam postadas, enquanto que, as reuniões da Comissão não têm data definida, ocorrem no prazo de um ano a partir da data limite. Após o processo de aprovação, deverão ser entregues: projeto executivo; projetos de iluminação e de reforço estrutural, quando a obra assim requerer; memorial descritivo com a indicação de materiais utilizados na confecção e fixação da obra e das empresas contratadas para a execução e implantação; cronograma físico-financeiro, com a previsão da execução, prazos e gastos a serem executados nas diversas fases do projeto e relatório técnico para a realização da limpeza e manutenção da obra indicando produtos e materiais que podem ser utilizados com as respectivas proporções, formas e periodicidades desejáveis de aplicação. Os projetos complementares deverão ser entregues no máximo em seis meses contados a partir da liberação oficial do projeto. A instalação da obra artística deverá ser compatibilizada com o cronograma da obra arquitetônica da estação, porém, com a seguinte ressalva:

Os projetos das estações poderão sofrer alterações de prazos ou até mesmo do projeto arquitetônico em função dos prazos e objetivos políticos da Companhia. Nesses casos, o Metrô disponibilizará um novo espaço para o artista. (REGULAMENTO PARA APRESENTAÇÃO DE PROJETOS DE OBRAS DE ARTE PERMANENTE, 2012).

Quanto aos recursos:

Todos os custos gerados para a confecção, instalação e finalização da obra de arte, bem como reforços estruturais quando necessários ao suporte da obra, deverão ser integralmente cobertos pelo artista ou pela iniciativa privada, sob a forma de apoio cultural. (REGULAMENTO PARA APRESENTAÇÃO DE PROJETOS DE OBRAS DE ARTE PERMANENTE, 2012). 
Todo tipo de material de divulgação da iniciativa deve "ter suas artes finais, obrigatoriamente, encaminhadas para o conhecimento e aprovação prévia do Departamento de Marketing Corporativo do Metrô". (REGULAMENTO PARA APRESENTAÇÃO DE PROJETOS DE OBRAS DE ARTE PERMANENTE, 2012).

O Metrô fica incumbido unicamente de acompanhar e orientar tecnicamente 0 processo de implantação definitiva da obra, fornecer a carta de interesse no recebimento do projeto para que o artista solicite leis de incentivo fiscal e/ou busque patrocínio e de providenciar o modelo do Instrumento Particular de Doação da obra para preenchimento e assinatura do artista.

\subsubsection{Condicionantes para apresentação de proposta de obra temporária}

Assim como as obras do Projeto Arte no Metrô, de caráter permanente, eventos e exposições de artes visuais do Programa Ação Cultural, de caráter temporário, são submetidos a regras e a procedimentos para aprovação de suas propostas pelo Departamento de Marketing Corporativo e pela Coordenadoria de Ação Cultural da Companhia do Metropolitano de São Paulo.

Consta do regulamento, que devem ser entendidos como Eventos: "acontecimentos (espetáculos, comemorações, solenidades etc.) programados pelo Departamento de Marketing e pela Coordenadoria"; como Exposições de Artes Visuais: "instalações, montagens, apresentações de fotos, objetos e quaisquer outros materiais similares organizados para visitação pública em espaços predeterminados nas estações". As exposições permanecem, em média, por 20 dias em uma mesma estação, podendo ser estendidas para outras estações por igual período, caso haja interesse do Departamento de Marketing e da Coordenadoria (REGULAMENTO PARA APRESENTAÇÃO DE EXPOSIÇÕES E EVENTOS, 2012).

As propostas podem ser enviadas ao longo do ano para que sejam cadastradas no sistema e analisadas no prazo estabelecido de três meses. Podem participar do Programa Ação Cultural pessoas físicas ou jurídicas, artistas ou seus representantes legais e instituições na qualidade de proponentes. A proposta deve ser encaminhada acompanhada da ficha de inscrição e termo de compromisso assinado; sinopse do projeto, currículo do proponente, incluindo artistas ou entidades que venham a ser por ele representados, limitando-se ao âmbito artístico; material de projetos 
anteriores; fotos para divulgação; descrição e justificativa de todas as atividades a serem desenvolvidas, sendo vedada a comercialização ou promoção de produtos de qualquer natureza; projeto contendo a descrição e as especificações de todos os materiais e infraestrutura necessários. Quando se tratar de exposições, deve ser incluído CD com imagens que irão compor a mostra, representativas do conteúdo em sua totalidade, "para que não haja dúvida sobre o tema a ser exibido". No caso de eventos musicais, apresentações de dança, teatro, performances ou exposições que contemplem a execução de música ao vivo ou mecânica, deve ser incluído release do(s) artista(s), material gravado, repertório, mapa de palco e roteiro musical do ECAD preenchido e assinado (REGULAMENTO PARA APRESENTAÇÃO DE EXPOSIÇÕES E EVENTOS, 2012).

A análise para aprovação é realizada pela equipe da Coordenadoria de Ação Cultural. No processo de avaliação são considerados: a adequação do projeto ao espaço físico das estações, respeitando-se critérios de segurança e operação do Metrô de São Paulo, bem como normas estabelecidas pelo Departamento de Marketing Corporativo do Metrô; a qualificação do projeto (originalidade, qualidade técnica e contemporaneidade da proposta); o grau de expectativa e de interesse do público (projeto inédito, atratividade do tema); a perspectiva de contribuição ao enriquecimento sociocultural da comunidade; a adequação à imagem institucional do Metrô de São Paulo e à política cultural do Departamento de Marketing e Comunicação. A curadoria das exposições é atribuição do Departamento de Marketing. Caso o artista tenha um curador este deverá trabalhar em parceria com a curadoria do Metrô, "que em última instância é a responsável pela apresentação dos projetos nas estações." (REGULAMENTO PARA APRESENTAÇÃO DE EXPOSIÇÕES E EVENTOS, 2012).

A cessão de espaços destinados às atividades culturais é gratuita. Plantas das estações com a indicação dos espaços destinados para o desenvolvimento de atividades culturais são disponibilizadas no site. Leiaute, diagramação visual e legenda devem, preferencialmente, seguir a padronização estabelecida pela Companhia. Cartaz de abertura, fechamento e apresentação é fornecido pelo Metrô. Contato, logomarcas de patrocinadores e/ou apoiadores são informações que devem ser inseridas em cartaz impresso pelo proponente, obedecendo ao formato padronizado e devendo ser enviado para aprovação. Para exposições que atendam ao padrão determinado, são fornecidos expositores. Em mostras que utilizarem seus 
próprios expositores, a estrutura deverá ser em alumínio, madeira ou outro material resistente, com acabamento padronizado e deverá passar por processo de aprovação. Gastos, custos e despesas decorrentes do projeto, proteção das obras, equipe e material de apoio, montagem e desmontagem, são de responsabilidade do proponente/organizador. As atividades são supervisionadas por um membro da equipe do Departamento de Marketing Corporativo do Metrô de São Paulo.

Quando houver iluminação/sonorização, deverá ser compatível com a disponibilidade de carga nas estações (1200W-10A-110V). Quando a proposta apresentar outro tipo de necessidade, será submetida à análise do Departamento de Engenharia do Metrô sendo para isso necessária visita técnica aos espaços agendada com a Engenharia do Metrô e técnico especializado, contratado pelo proponente, e o croqui do projeto elétrico elaborado conforme especificações técnicas fornecidas pela Engenharia do Metrô. Não haverá possibilidade de utilização de infraestrutura hidráulica. As estruturas e/ou cenários não poderão obstruir as obras de arte permanente, os painéis de comunicação visual, publicitários ou informativos. Não poderão interferir no acesso aos equipamentos de segurança da estação. É proibida a utilização de equipamentos sonoros que prejudiquem a operação do sistema, em especial o public address (P.A.): mensagens de segurança e informativos, dirigidos aos usuários do Metrô, via rádio/caixas acústicas.

A agenda é divulgada mensalmente, por meio de cartazes afixados nos espaços institucionais, em todas as estações e prédios da Companhia do Metrô; comunicação eletrônica interna por meio da intranet (Metrô Click), voltada para os funcionários da Companhia; comunicação eletrônica externa (newsletter), enviada para os usuários cadastrados; Site do Metrô (www.metro.sp.gov.br) e assessoria de imprensa. Nessas mídias, os apoiadores são mencionados por escrito, não havendo espaços para logomarcas. Todo tipo de divulgação deve ser autorizada previamente pelo Departamento, sendo obrigatória a presença das "logomarcas da Companhia do Metrô, da Secretaria dos Transportes Metropolitanos e do Governo do Estado de São Paulo, de acordo com padrões exigidos pelo Metrô de São Paulo" (REGULAMENTO PARA APRESENTAÇÃO DE EXPOSIÇÕES E EVENTOS, 2012). De modo geral, a burocracia e a preocupação com a imagem da instituição e, consequentemente, do Governo do Estado, são evidentes em ambos os regulamentos. 



\section{DEPOIMENTOS DOS ARTISTAS}

Com referência em depoimentos colhidos junto aos artistas, autores de propostas e/ou de obras de caráter permanente e temporário para estações de metrô de São Paulo, serão apresentadas considerações a respeito da especificidade das obras em relação ao contexto em que foram inseridas; da definição atribuída a esses espaços; do significado dessa arte; de como tem sido a atuação desses profissionais junto aos arquitetos que projetam as estações; de até que ponto regras normativas interferem no processo de criação e na forma de atuar; do que pensam sobre a aplicação de tecnologias atuais em obras temporárias e permanentes; e de quais medidas poderiam ser tomadas para que obras sejam instaladas na totalidade das estações da rede metropolitana.

Foram realizadas sete entrevistas que englobam profissionais da arte em situações diversas: autores de obras do acervo permanente da Companhia (Amélia e Mo Toledo, Claudio Tozzi, Waldemar Zaidler); que tiveram projetos de obra permanente aprovados pela comissão em todas as etapas, porém, não foram executados (Carlos Fajardo e Regina Silveira), que apresentou proposta de obra permanente, mas no decorrer do processo, optou por não levar o projeto adiante (Waldemar Zaidler); autoras de obras desenvolvidas com tecnologia atual exibidas na Exposição Arte Cibernética: Acervo Itaú Cultural (Regina Silveira e Daniela Kutschat) e autores de projetos cromáticos para estações da Companhia do Metrô do Rio de Janeiro desenvolvidos de forma integrada com os projetos arquitetônicos de autoria do arquiteto paulista João Batista Martinez Correa (Amélia e Mo Toledo).

\subsection{A ESPECIFICIDADE DAS OBRAS EM RELAÇÃO AO CONTEXTO EM QUE FORAM INSERIDAS}

As obras dos profissionais entrevistados assumem características diferenciadas em relação ao contexto de sua inserção. Na categoria de obras permanentes do acervo, Colcha de Retalhos, de autoria de Claudio Tozzi, como visto no Capítulo 3, foi uma proposta escolhida pelo público da Estação Sé dentre as três apresentadas pelo 
artista: astronauta, silhuetas e colcha de retalhos, desenvolvida especificamente para o espaço predeterminado pelos arquitetos do metrô, à convite de Radhá Abramo. Através de elementos pesquisados e apropriados da produção popular das colchas, desenvolveu imagens gráficas para pertencerem à iconografia do painel, adequadas às cores de tesselas de vidro existentes, elaborando o projeto final com detalhes da estrutura visual e solução cromática para ser produzido. Sob a orientação do artista, foi executado por uma equipe dirigida pelo mestre italiano Severino Faro, especialista em mosaicos da indústria Vidrotil. O projeto do painel Movimento foi um dos cinco apresentados por artistas convidados em um concurso para o Palácio dos Bandeirantes para substituir o painel de Portinari. Na ocasião da inauguração da exposição, o Governador e a comissão de arte decidiram que os quatro projetos iriam para outros espaços públicos, no caso, o da Estação Barra Funda, já que não havia obras de arte previstas para ela. Foi um projeto "feito meio de última hora e com materiais não tão adequados para o espaço: tinta acrílica sobre tela colada em madeira revestida com verniz acrílico, processo que resiste ao tempo, mas que precisa de uma manutenção maior" (TOZZI, 2012) ${ }^{61}$. Caleidoscópio, de Amélia e Mo Toledo, faz parte de uma série de múltiplos de aço calandrado e pintado que começaram a desenvolver nos anos 1980. Na versão para a Estação Brás usou o aço inox com o objetivo de chamar as pessoas "pelo próprio reflexo, pelo movimento" (AMÉLIA TOLEDO, 2012) ${ }^{62}$. Fiesta, de Waldemar Zaidler, executado com tinta acrílica e madeira, foi concebido para a $18^{a}$ Bienal Internacional de São Paulo, ao longo do ano de 1985. O painel, que seria destruído, foi doado pelo autor para a Companhia do metrô no momento em que estava iniciando o acervo. Trata-se da síntese de "uma quantidade muito grande das mesmas imagens que estavam nele espalhadas pela cidade, convergindo para a Bienal." "Apesar de não ter sido feito para aquele espaço específico, ele traz uma série de características da arte pública, da intervenção pública, da arte de intervenção propriamente dita" que o diferencia de um trabalho "concebido em ateliê e, simplesmente, transposto." Para Zaidler, naquele momento, ainda não estava incorporada a ideia de site específico para a Companhia. "Gostaram do trabalho, acharam que iria bem, escolheram um lugar eles próprios", no caso, a Estação Sé

\footnotetext{
${ }^{61}$ Claudio Tozzi em entrevista concedida à pesquisadora, 2012 (APÊNDICE C).

62 Amélia Toledo em entrevista concedida à pesquisadora, 2012 (APÊNDICE C).
} 
(ZAIDLER, 2012) ${ }^{63}$. Todas as obras foram inseridas em estações já construídas.
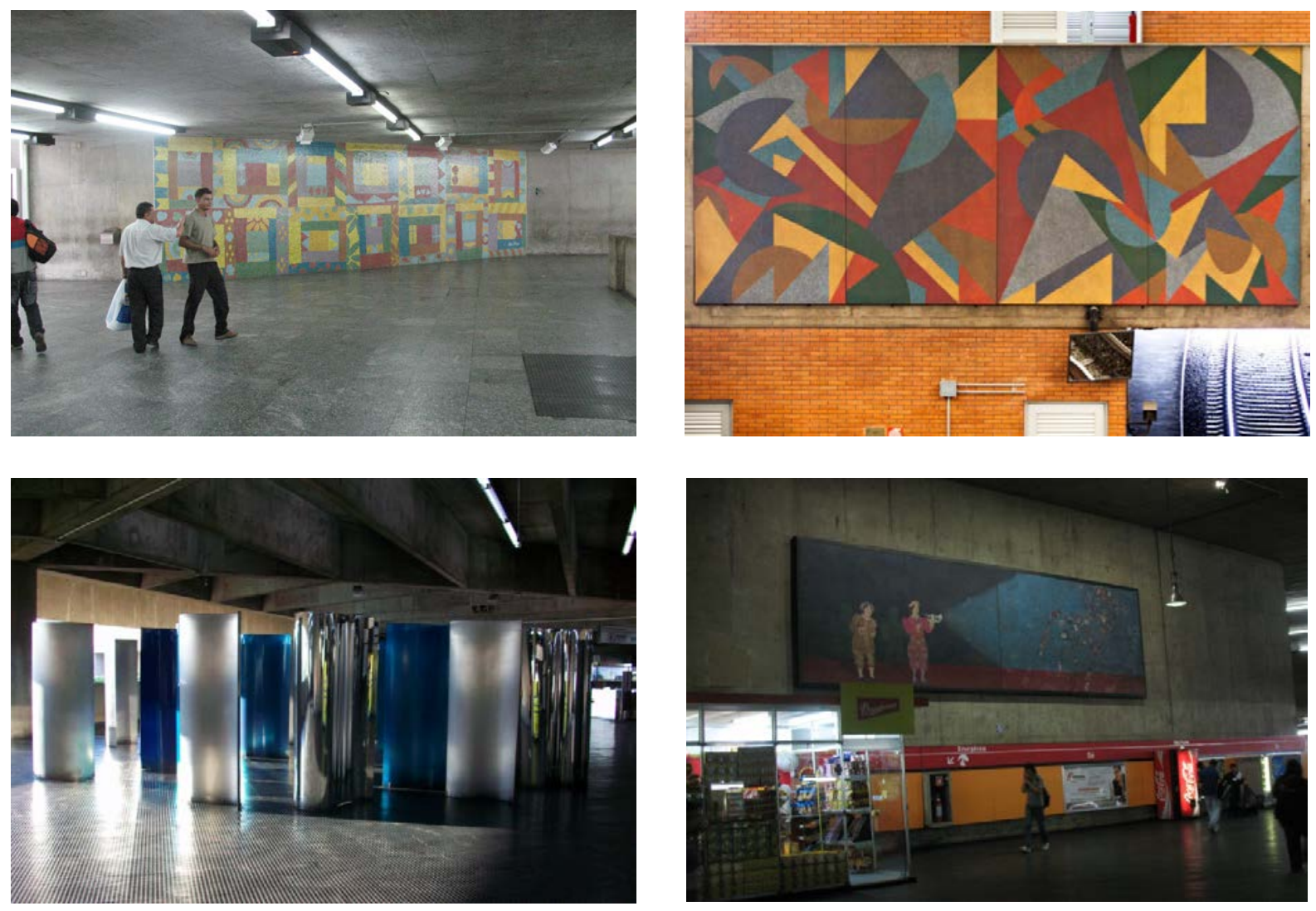

Figura 165: Colcha de Retalhos, 1979, Claudio Tozzi. Fonte: Registro fotográfico realizado pela pesquisadora.

Figura 166: Movimento, 1990, Claudio Tozzi. Fonte: Registro fotográfico realizado pela pesquisadora.

Figura 168: Fiesta, 1986, Waldemar Zaidler. Fonte:

Figura 167: Caleidoscópio, 1999, Amélia e Mo Toledo. Fonte: Registro fotográfico realizado pela pesquisadora.

Houve duas propostas de obras permanentes elaboradas para estações inauguradas recentemente que não foram executadas: uma de Carlos Fajardo, e outra, de Waldemar Zaidler, ambas site specific. Carlos Fajardo, comissionado para apresentar sua proposta, em comum acordo com o arquiteto que projetou a Estação Vila Prudente, escolheu uma parede voltada para as escadas rolantes que guardava um grande duto de ventilação, para instalar um painel espelhado, amarelo, de aproximadamente $4 \times 24 \mathrm{~m}$. Trata-se de uma área ricamente envidraçada, em seu fechamento lateral e na cobertura, que ofereceria uma situação favorável em que os raios solares não comprometeriam a obra. A ideia foi de desenvolver "um trabalho que se mimetizava com o ambiente e que, por contraste, refletia todo o entorno e, principalmente, os passantes que utilizariam os trens dessa estação". Apesar de ter

\footnotetext{
${ }^{63}$ Waldemar Zaidler em entrevista concedida à pesquisadora, 2012 (APÊNDICE C).
} 
sido aprovada em todas as etapas do processo e de não ter sido solicitada a busca de patrocínio não foi levada adiante, de acordo com o autor, "talvez, por ter enfrentado a misteriosa burocracia que acabou por inviabilizar sua execução" (FAJARDO, 2012) ${ }^{64}$.

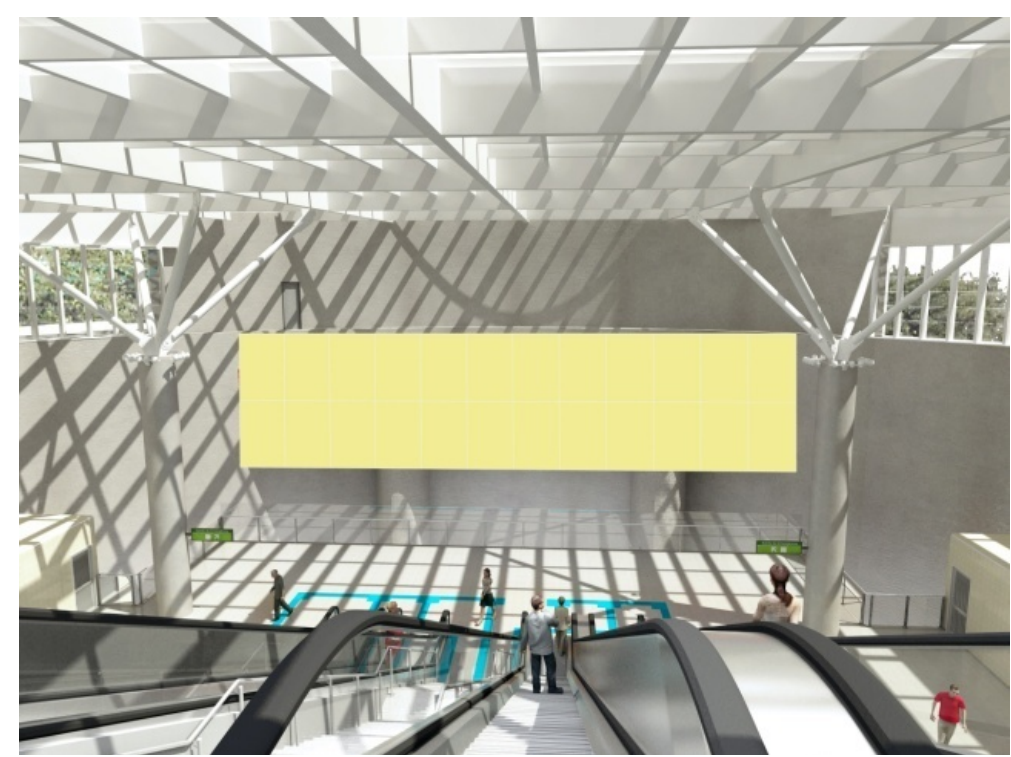

Figura 169: Projeto de intervenção de Carlos Fajardo para a Estação Vila Prudente. Imagem da maquete eletrônica de autoria de Luiz Esteves Arquitetura, agosto de 2010.

No caso de Waldemar Zaidler, também houve um pedido para que apresentasse uma proposta de intervenção para a Estação Alto do Ipiranga. Rizoma do Ipiranga, tratava-se de uma instalação em estrutura atirantada, pensada para ser instalada próxima às escadas rolantes.

A ideia seria atirantar. Isso em função do espaço. Uma coisa bem..., aí sim, total site específico, inclusive, inspirado na estrutura total daquele pudim, no posicionamento das escadas rolantes e tudo. Seria uma série de elementos, de barras atirantadas numa estrutura que ficaria na própria estrutura, inclusive, mimetizada com a estrutura da cobertura, seguindo a mesma linguagem, o mesmo padrão, o mesmo tudo. Essas barras seriam independentes, mas elas se tocariam fazendo com que houvesse um movimento rizomático mesmo. Todo mundo tocando em todo mundo e, cada um, fazendo seu movimento em função desses toques e tudo girando ao mesmo tempo. Ligando essas barras, que foi isso o que eles imputaram, em alguns momentos, ligando a barra A pendurada no ponto A1, lá no teto, ligando com a barra $B$ pendurada no ponto B1, lá no teto. Até de uma maneira articulada teriam imagens que se remeteriam à ideia do Grito do Ipiranga. Daí de um ideário que eu tava compondo na época, e que, não o caso de apresentar esse ideário, mas que iria desde Almeida Junior até todo o outro lado da história, a caganeira do D. Pedro, ou seja, eu iria botar uma farra ali, mesmo. Alguma coisa com imagens recortadas em algum material $X$. Como é que chama isso? Rígido. Na verdade, seriam os positivos dos estênceis.

\footnotetext{
${ }^{64}$ Carlos Fajardo em entrevista concedida à pesquisadora, 2012 (APÊNDICE C).
} 
(...) Projetariam sombras nos espaços mais escuros (...) Sombra porquê é um espaço fisicamente iluminado, inclusive, naturalmente iluminado. Mas, quando não pela luz do dia, com luz artificial e daria pra fazer fotos. Enfim, daria pra fazer com que o trabalho realmente se expandisse em termos de ambiência, pra outros níveis da estrutura. Pra outros andares da coisa.

Seria interessante, contemporâneo e com zero de tecnologia, de não dar dor de cabeça pra eles, o que é pior. Porque eu até bolei, sabe, um jeito que essa estrutura descia e tinha uma articulação que ficava ao alcance da mão pra fazer a limpeza das peças com uma vassoura, de seis em seis meses, pra tirar o pó. Não depende de nada. Não tem peso. Não depende de nada. Nada. É uma coisa que tem movimento, mas é um movimento iniciado pela corrente de ar ou por um desequilíbrio proposital de uma peça que fique ali, num pêndulo, ou até por um sensorzinho que quando o negócio para, dá uma empurradinha, sabe. Plim! Uma coisinha já é o suficiente pra detonar todo o movimento, questão sonora, questão de iluminação, som e um chamado para essa representação ainda que o Rizoma não esteja presente, ou seja, não seja representável, mas uma representação da ideia. Principalmente na época que eu fiz essa proposta eu estava tentando entender um pouquinho - não entendi até hoje e nunca vou entender, não faz mal, mas estava inspirado por essa coisa. Então, rolou desse jeito. (ZAIDLER, 2012).
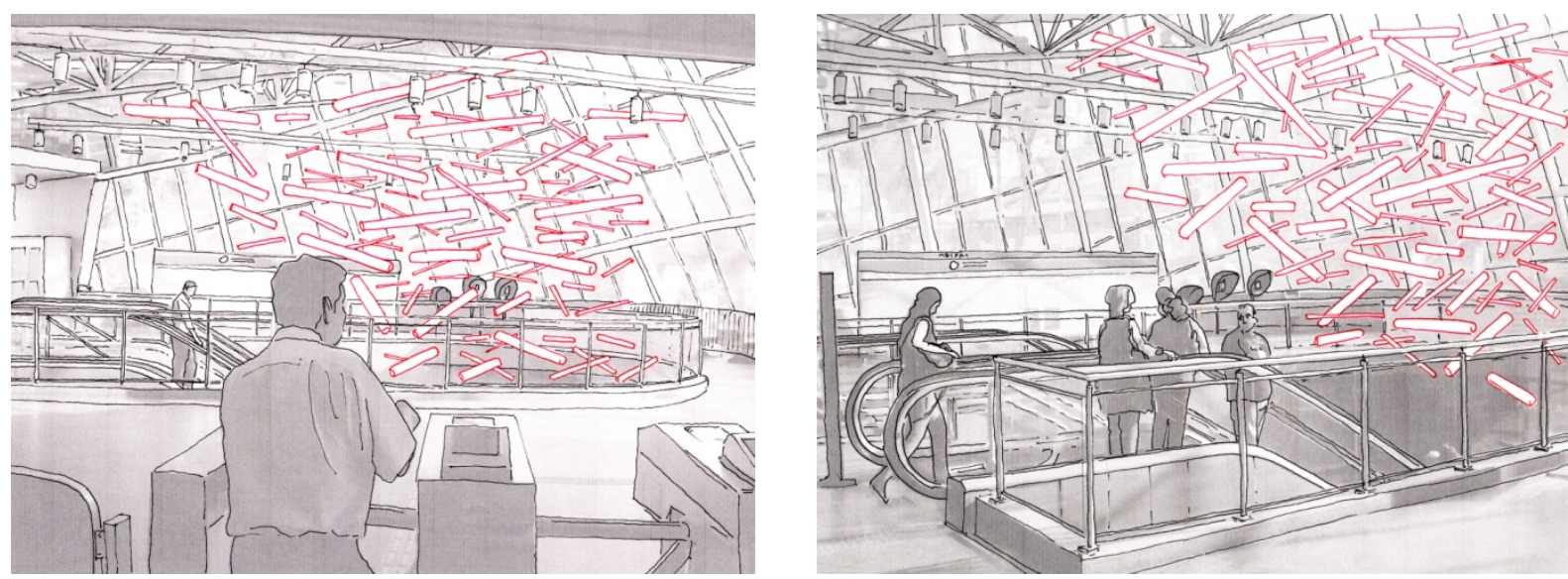

Figuras 170 e 171: Desenhos da proposta de intervenção de Waldemar Zaidler para a Estação Alto do Ipiranga, 2010. Desenhos do artista.

No entanto, no momento em que apresentou a proposta não tinha conhecimento que, caso fosse aceita, teria que

correr atrás da realização disso, conseguir dinheiro, conseguir patrocínio, conseguir tudo, e ainda por cima, convencer uma coisa chamada manutenção das questões da tecnologia que é o seguinte: Ah! pode por, mas quem manda se o trabalho, a linguagem, quem manda na tecnologia é o departamento de manutenção. (...) Olha que casamento perfeito: arte com manutenção. (...) o trabalho foi muito bem aceito, gostaram bastante, mas começaram a pedir um determinado tipo de detalhamento que indicava duas coisas: uma, a questão da manutenção que eu já falei e, outra, a questão de censura à palavra, e essa, eles queriam saber exatamente como seriam as imagens. (ZAIDLER, 2012). 
Foi dado um prazo para que fosse feita a retificação do projeto, mas o artista optou por não levá-lo adiante.

Em situação oposta, Regina Silveira, pretende executar um projeto desenvolvido há mais de dez anos para a Estação Vila Madalena. A proposta da obra permanente Tropel, desde o início aprovada pelo metrô, foi concebida especificamente para o contexto a que se destina. A ideia é aplicar a obra feita na fachada da $28^{a}$ Bienal de São Paulo, em 1998, "como motivo gráfico para ocupar o paredão em cima das catracas, por sua afinidade com os grafites tão celebrados da Vila Madalena", no entanto, como disse a autora:

sou eu quem tem que conseguir... Uma longa história, com diversos proponentes nas inscrições para benefícios das leis de incentivo, muitas justificativas, muitas idas e voltas a Brasília e outras comissões, que um dia contarei em detalhes, se houver oportunidade e se este projeto for feito. (SILVEIRA, 2012) ${ }^{65}$.
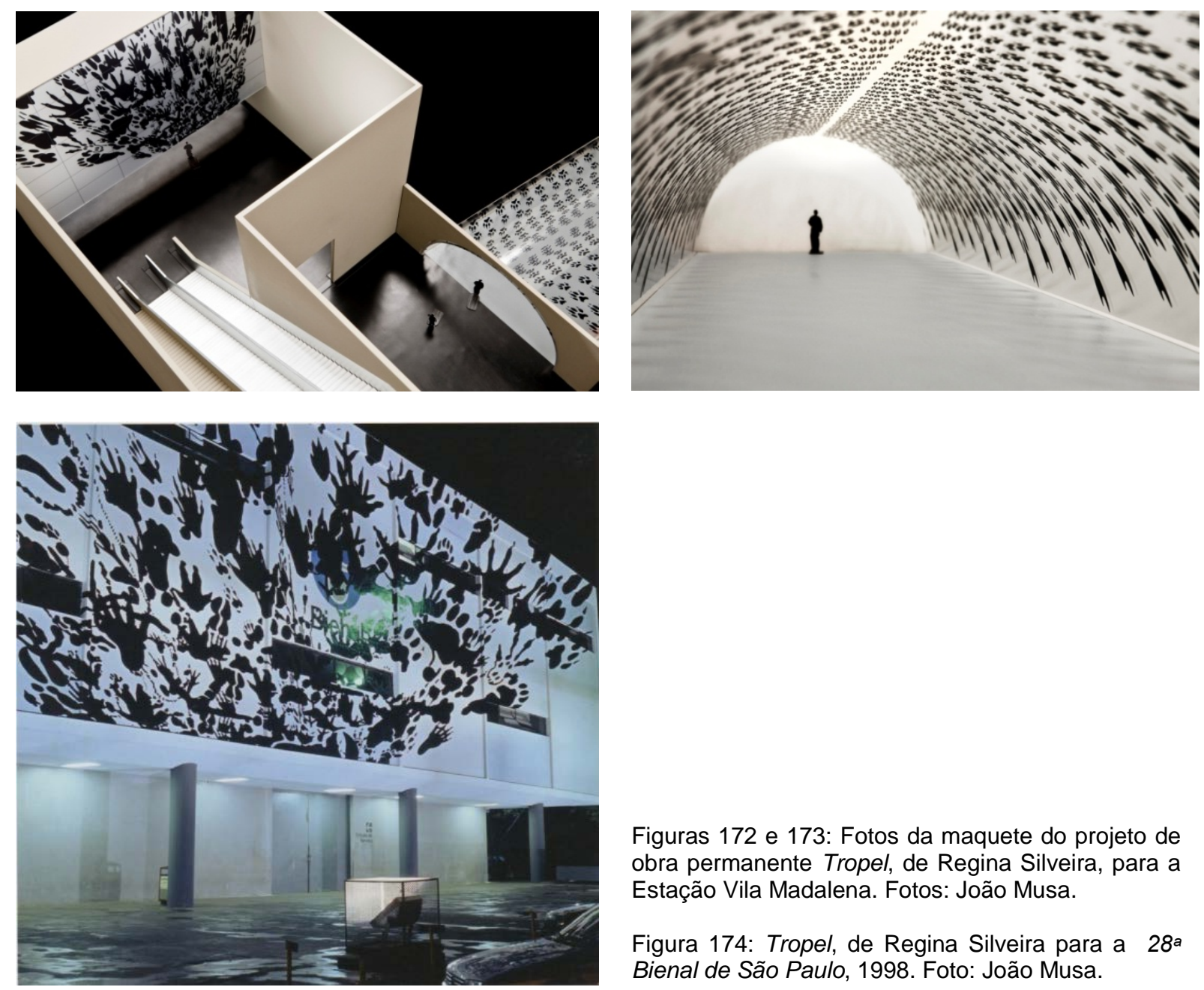

Figuras 172 e 173: Fotos da maquete do projeto de obra permanente Tropel, de Regina Silveira, para a Estação Vila Madalena. Fotos: João Musa.

Figura 174: Tropel, de Regina Silveira para a $28^{a}$ Bienal de São Paulo, 1998. Foto: João Musa.

\footnotetext{
${ }^{65}$ Regina Silveira em entrevista concedida à pesquisadora, 2012 (APÊNDICE C).
} 
Com o passar do tempo, foi incluída no projeto a ocupação do túnel. A técnica em vinil adesivo da proposta inicial "ficou muito mais enxuta e atualizada, pelas possibilidades abertas pelo uso de chapas de alumínio composto recortadas a laser, para reproduzir um rebaixamento com resultados gráficos similares." A artista também assumiu a curadoria das exposições temporárias realizadas nas vitrines da EstaçãoTrianon-MASP, "com a intenção de dar uma orientação mais definida para o uso daquele equipamento em espaço público". Em uma ação coordenada entre o MASP e o Metrô, busca-se promover o uso desses espaços por artistas que se disponham a utilizá-los para intervenções específicas "e não como vitrines convencionais, para apreciar quadros emoldurados..." (SILVEIRA, 2012). Ainda na categoria de obras temporárias, teve a obra Descendo a Escada, exibida na Exposição Arte Cibernética: Acervo Itaú Cultural, na Estação Brás.

Daniela Kutschat, em coautoria com Rejane Cantoni, desenvolveu OP_ERA Sonic Dimension, trabalho exibido na Exposição Arte Cibernética: Acervo Itaú Cultural, na Estação República, e a videoinstalação Máquinas de Ver I (1999), exposta duas vezes no Paço das Artes, a qual pretende expor na Estação Sé, site de onde foram captadas as imagens que compõem a videoinstalação executada com dois projetores e dois DVDs em loop. De acordo com a autora,

o trabalho foi feito na Estação Sé, porque nós queríamos o ponto zero da cidade, e a Estação Sé tem uma configuração muito interessante porque ela tem uma plataforma na qual se pode estar vendo os trens chegando da zona Norte de um lado, e trens chegando da zona Sul, do outro, de espaços opostos. E essa questão do espaço oposto e de você olhar para frente e para trás ao mesmo tempo, que era a grande questão desse trabalho, a melhor forma e o melhor lugar para fazer isso, seria justamente esse lugar. A gente escolheu a dedo o lugar para desenvolver esse trabalho. (KUTSCHAT, 2012) ${ }^{66}$.

${ }^{66}$ Daniela Kutschat em entrevista concedida à pesquisadora, 2012 (APÊNDICE C). 


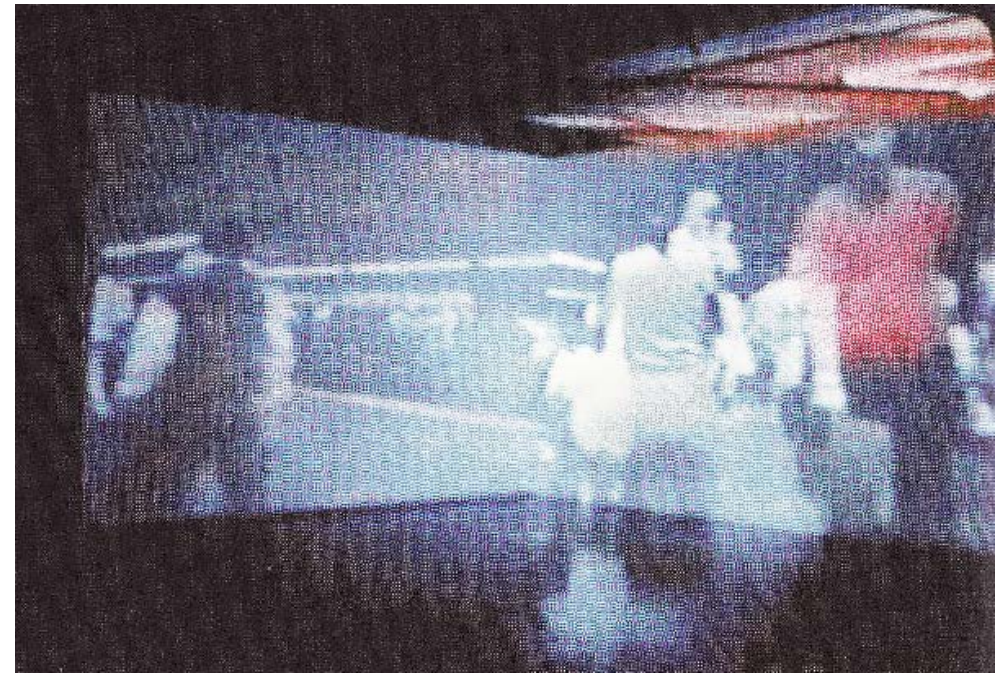

Figura 175: Máquinas de Ver I, videoinstalação, 1999. Autoras: Daniela Kutschat e Rejane Cantoni. Foto: João Caldas.

\subsection{ESTAÇÕES DE METRÔ: ESPAÇOS DE PASSAGEM? NÃO-LUGARES?}

De maneira sintetizada, Regina Silveira define os espaços das estações como "secos e limpos", "passagens despersonalizadas, para trânsito rápido, olhares indiferentes", características interpretadas como "um desafio para o artista" (SILVEIRA, 2012). Para Amélia Toledo, "são um campo de percurso de pedestres e ao mesmo tempo estágios desse percurso. Locais de pedestres que convivem com o piso, com as paredes, com o teto" (AMÉLIA TOLEDO, 2012). Carlos Fajardo, com referência no livro "Invenção do cotidiano", de Michel de Certeau, entende que lugares como: metrôs, supermercados, estações de trem, aeroportos, "são o que a gente pode dizer que 'o espaço é um lugar praticado', assim, a rua, geometricamente definida por um urbanismo, é transformada em espaço pelos pedestres" (FAJARDO, 2012). Waldemar Zaidler analisa os espaços das estações através de duas vertentes arquitetônicas diretamente ligadas "a um encaminhamento político de como são feitas as coisas":

Uma concepção de estação, de espaço interno da estação que privilegia, ou que procura privilegiar, a pessoa na questão do usuário não só do ponto de vista prático mas também do ponto de vista monumental. A estação do Metrô, no seu espaço interno, como uma coisa que agrega ao cotidiano da cidade um valor de uma monumentalidade, um valor de mudar mesmo, de tentar ser um lugar, de tentar ser um marco, 
considerando todos os não lugares que a gente já sabe, os Marc Augé do mundo, sem desprezar isso, mas é uma tentativa. Outro, é uma (...) monumentalidade externa, não também no sentido de um lugar que marca o ponto do metrô. Aliás, é muito curioso porque o metrô, num monte de lugar, no mundo inteiro, é da terra pra baixo, você tem uma entradinha e pimba. Aqui, tá virando, não consigo entender no sentido prático porque, mas tá virando um negócio de edifícios, um do lado do outro. Você pega uma EstaçãoFradique. Que é aquele prédio em cima da Fradique? Eu não sei, uma coisa de vai saber, manutenção, coisa técnica do metrô. Tá, tudo bem, mas tem outro logo ali, são muito próximos, não dá pra entender o que que significa aquele, com o perdão da palavra, cagalhão que fizeram aqui perto da USP, na Vital Brasil. Para que um troço daquele tamanho pra fora? Quer dizer, isso tem um significado. É um tipo de edificação que não dá pra entender o sentido, a necessidade, a não ser privilegiar politicamente uma relação externa, e nessas, a gente vê o espaço interno, na minha avaliação, muito menos trabalhado do ponto de vista do usuário no que se refere aos materiais, no que se refere à própria arquitetura, ao desenho das peças, ao design dos equipamentos e tudo. Estações mais recentes, como essa que fizeram na Consolação, que chama Paulista e a que fica ao lado da Paulista, que chamam Consolação, que tem na sua lateral uma vitrine da Casas Pernambucanas ou coisa que o valha. Ah! mas tudo bem, como é que chama isso, de lei, de legislação, de Cidade Limpa, só existe essa conversa porque levantaram aquela coisa com o revestimento que a mais pobre das padarias recusaria, com aquela pastilha hidráulica que sei lá que diabo, uma coisa primária, uma coisa demente, uma coisa assim sem nenhum cuidado: olha, é pro povo mesmo, puta, faz lá mesmo meu, tudo bem, faz grandão que é pra todo mundo ver que fez, a sensação que eu tenho, não tô dizendo que seja isso, mas acho que a representação desses edifícios, desses espaços, dessas duas vertentes, uma delas representa isso. Outra delas, que se encontra nas estações mais antigas, e em algumas mais recentes também, como me agrada muito a do Alto do Ipiranga, por exemplo, é uma estação pra baixo, ela tem uma entrada arquitetonicamente concebida, com design bonito, uma estrutura legal. Parece um pudim. (...) Ali, uma coisa de luz, de claridade, ou seja, uma bela recepção, um ponto importante, mas que, simplesmente, recebe as pessoas, tem uma preocupação interessante. Lá dentro, tem espaços generosos abaixo da terra, espaços generosos com o usuário não só no sentido de caber o usuário, coisa que na Praça da Sé já não acontece, não cabe, o usuário não cabe lá dentro, isso é um horror mas daí também é uma questão de dimensionamento, de fazer outras opções. Não é o espaço em si, é simplesmente um espaço que ficou pra trás. É um monte de gente a mais pra nenhum espaço a mais, entupiu. Natural, isso não é culpa do espaço, é culpa de quem não fez mais espaço, outros espaços, outras alternativas com o crescimento da demanda da população, dos usuários, do número de usuários. Então, tem essas duas vertentes dos espaços internos do metrô: uma que tenta tratar o usuário como gente, e eu acho que é essa a vertente que insiste, não importa de que maneira, se equivocada, se correta, se às vezes sim, às vezes não, mas insiste para que tenha, por exemplo, a questão da arte que procura tratar a própria arquitetura como arte e, a outra vertente, que quer colocar lojinha, que quer colocar muambódromo oficial, que quer colocar o shopping center, que quer fazer coisas pra fora, coisas que tudo bem, é prático juntar pontos de venda num lugar de grande circulação. Não sei, pra muita gente não. Eu não sou urbanista, tem muito urbanista que fala que não, não sei, eu não entro no mérito, mas eu tendo a acreditar mais na Jane Jacobs. Jane Jacobs, por exemplo, fala que não tem nada que concentrar as coisas ali. Tem que diversificar, tem que deixar na rua mesmo. Tudo bem, pensamento lá de 1960, mas muito atual.(ZAIDLER, 2012). 
Na avaliação de Waldemar Zaidler, não se tratam de espaços de passagem, não se tratam de não-lugares.

A questão do espaço não é uma questão inerente ao espaço. É uma troca e que envolve o ser vivente naquele espaço. A ontologia do espaço é dividida com o ser que nele vive. $O$ espaço de passagem tá muito mais ligado a uma questão da ambiência, que é revelada nesse espaço, e a ambiência depende de quem tá ali. Então, qualquer espaço é espaço de passagem e nenhum espaço é espaço de passagem.

(...) os lugares não são ou deixam de ser, existe aí uma relação, por isso é importante a gente tratar da questão da arte pública, a questão dos ativadores desse espaço, e aí, mais uma vez, a questão da tecnologia. Tecnologia voltando um pouco, a tecnologia não ativa coisa nenhuma. Ela é utilizada pra fazer com que uma ideia seja percebida, por quem tá ali passando e que possa detonar, possa ativar, possa funcionar como gatilho de uma percepção diferente daquele lugar que não é não-lugar, não é um lugar de passagem. Não sei, pra mim, eu funciono assim. Eu sou bem sincero e verdadeiro nessa coisa, sabe. Acho que existe essa concepção do não-lugar etc. etc., mas é uma coisa analítica, é uma coisa que sim, que deve ser considerada, deve ser pensada, na hora que se cai a ficha desse fenômeno, dessa possibilidade e aí você assume uma posição, uma postura política em relação à essa possibilidade e aí, como artista, como arquiteto, como seja lá o que for, performer, o diabo que for, você vai fazer ali algum tipo de intervenção porque, politicamente, você não quer que aquele espaço continue sendo um espaço. Você quer transformar ele num lugar e pra isso precisa um estímulo, só como uma ajudazinha porque o espaço pra virar lugar, ele prescinde desse estímulo. (ZAIDLER, 2012).

O artista acredita que há uma disputa em que a "vertente da lojinha" está ganhando, diferentemente do momento em que desenvolveu sua proposta de intervenção para duas torres de respiração do metrô, no Largo São Francisco, como trabalho de conclusão do curso da Faculdade de Arquitetura e Urbanismo, na FAUUSP, o que o levou a aproximar-se da instituição e, posteriormente, a doar o painel Fiesta. Atualmente, admite não se identificar com o metrô como se identificou no passado.

Para Daniela Kutschat, dependendo da estação e do horário, podem ser considerados espaços de passagem.

Mas existem estações que permitem alguns cantos mais voltados para exposições, e as pessoas acabam percorrendo esse espaço de outra forma, elas acabam parando, olhando um pouco, voltando depois, elas se relacionam de uma outra forma com o espaço. (KUTSCHAT, 2012).

Quanto ao conceito de não-lugar, a artista tem um posicionamento particular, diretamente relacionado à mobilidade proporcionada pelas tecnologias contemporâneas: 
Eu acho esse conceito bem interessante, mas eu penso muito numa questão que tem a ver com as tecnologias contemporâneas que é a questão da mobilidade. Eu acho que quando a gente tem essas tecnologias, esses dispositivos móveis, quanto mais a gente tem isso, mais essa relação de espaço e "não lugar" pode ser pensada de uma outra forma. Isso pode se expandir, na verdade, para outros espaços que não foram definidos por ele como "não lugares". Eu acho que a relação das pessoas com esses espaços que foram definidos como "não lugares" já está um pouco alterada através dessas tecnologias que estão incorporadas no corpo mesmo. Então, você está em todo lugar, a todo tempo. É uma coisa que eu estou pensando agora, você que estabelece o espaço, ou seja, é através da sua relação com ele.

(...) quando alguém está num lugar, num espaço físico, se conecta ali e começa a se conectar com outros e tal, é como se ela estivesse criando esse espaço. Eu gosto muito da ideia de fluxos, eu acho que a gente vive em fluxos mesmo, cada vez mais. Até pensar a casa da gente, a gente tende pensar de outro jeito. O escritório da gente já não é aquele escritório. $E$ esses espaços tipo hotel, aeroporto, eles acabam quase que presentificando um pouco fisicamente essa relação que a gente tem mesmo de conexão que não é tão palpável, que não é tão visível, mas que é existente, a gente faz isso, a gente abre o laptop, está na rede, "pluft"! Outro dia, eu estava mandando um e-mail dos Estados Unidos e aí o Google me perguntou: "É você mesma? Você está mandando um e-mail de um lugar que você não costuma mandar e-mail". Quer dizer, ele me localizou, mas, na verdade, as pessoas para as quais eu estava mandando e-mail, eu podia estar aqui, podia estar lá, podia estar em qualquer outro lugar, o importante é a conexão que está sendo feita e o espaço que se constrói. (KUTSCHAT, 2012).

De modo geral, avalia positivamente o funcionamento do metrô paulistano, mas observa que apresenta deficiências na própria comunicação que poderiam ser solucionadas com a distribuição de mapinhas de bolso para melhor orientar os usuários.

\subsection{OS SIGNIFICADOS DA ARTE NOS ESPAÇOS DAS ESTAÇÕES DE METRÔ}

Diante da amplitude de significados que a arte pública pode alcançar no espaço das estações de metrô, para Amélia Toledo (2012), a arte é um "estímulo para a imaginação das pessoas, um campo de viagem espiritual". Para Claudio Tozzi (2012), o espaço de uma estação deve significar um "elemento de desenho da cidade", "um símbolo para a cidade".

É muito importante que a arte não fique restrita aos espaços privados e que o desenho da cidade seja constituído também de obras. Se você vai a 
Berlim, por exemplo, todos os edifícios, todas as construções mais recentes, o próprio espaço urbano da cidade, tem uma série de intervenções que estabelecem um novo desenho para cidade. O metrô também tem que ter esse significado. Uma estação não pode ser simplesmente um local onde você vai tomar um trem mas que você sinta como um elemento de desenho da cidade. A Estação Sumaré, por exemplo, é muito bonita porque integra uma avenida que passa acima, uma avenida que passa abaixo e cria um espaço de relação entre as duas avenidas. Da estação se tem a transparência visual para o vale da Av. Sumaré que, antes, era um rio. Tem o significado da própria obra da estação ser um símbolo para a cidade. Incorpora a topografia do espaço e estabelece a ligação simbólica de duas vias urbanas que se cruzam em planos diferentes. Todas poderiam ser assim.(TOZZI, 2012).

Waldemar Zaidler (2012) aborda a arte pública de forma mais abrangente, como um fenômeno que apresenta dimensões estéticas, filosóficas, de fazer, de causar reflexões e convidar, além da dimensão política, que demonstra uma preocupação com os "cidadãos que merecem todo tipo de cuidado que a cidade possa oferecer" sendo a arte "um desses cuidados fundamentais".

\begin{abstract}
Eu não vejo o significado da arte no metrô, diferentemente do que eu vejo em qualquer outro espaço público. Trata-se de espaço público e de arte pública. A arte pública tem duas funções básicas que são na verdade, inclusive, uma só. Eu, analiticamente, vejo dois grandes lados que é o lado digamos estético, filosófico, que é isso que eu acabei de falar, de fazer, de causar reflexões e convidar, eu vejo muito assim. (...) Essa é uma das... eu não gosto de falar função porque não é função, é um dos lados do fenômeno, e outro, é político. Acho que esse lado é um lado até mais objetivo, menos difícil de ser mais óbvio em relação ao outro que eu falei, ele é mais óbvio, ele é um lado que demonstra uma preocupação. É um tratamento de cidadãos como cidadãos. Cidadãos que merecem todo tipo de cuidado que a cidade possa oferecer, então, a arte é mais um deles, mais um desses cuidados fundamentais. (ZAIDLER, 2012).
\end{abstract}

Daniela Kutschat (2012) entende a intervenção artística nesses sites, inseridos em uma cidade como São Paulo, frequentados por um grande número de pessoas, como "um desafio perceptivo e cognitivo" que pode proporcionar aos seus usuários/espectadores uma experiência transformadora que ative a sensibilidade, a percepção e a compreensão do mundo.

É você passar ou estar em algum lugar, ser capturado por algo estranho, que é essa proposta artística, a intervenção artística, talvez ficar em algum estado de surpresa, silêncio, não entendimento, curiosidade, depois voltar para o mundo de uma outra forma, com essa experiência, e eu acho isso fundamental. Principalmente, numa cidade como São Paulo que é uma cidade que engole a gente, ela tem um volume, e uma dimensão, e uma quantidade de pessoas, e uma correria, uma dinâmica muito dela também, que acaba fazendo muitas vezes com que a 
gente automatize muitos processos e procedimentos do cotidiano, e quando você tem uma intervenção, uma proposta dessas numa estação de metrô, que é um lugar de um fluxo de milhões de pessoas, milhares em cada estação, faz essa pessoa ter uma experiência que caia fora dessa moldura. E essa experiência pode ser transformadora, ativa a sensibilidade. Ativa a percepção e talvez a compreensão do mundo. Acho isso importantíssimo. (KUTSCHAT, 2012).

\subsection{A APLICAÇÃO DE TECNOLOGIAS ATUAIS EM OBRAS TEMPORÁRIAS E PERMANENTES}

Amélia Toledo, com a experiência de ter realizado uma animação projetada sobre espelho, refletida sobre o espectador, afirma que quando encontra "pessoas com essas afinidades, o trabalho de parceria se desenvolve naturalmente e as técnicas se colocam a serviço das ideias propostas". Nesse sentido, pensa que é "legal" aplicar tecnologias atuais em obras temporárias e permanentes nas estações. Mo Toledo, compartilha dessa opinião. Pretende criar um projeto usando novas mídias e tecnologias que envolva, talvez, mais de uma estação de São Paulo, em parceria com profissionais que trabalhem com som e mídias visuais. Apesar de admitir não saber ao certo o que irá propor e nem se será possível, acredita que pode pensar nisso e procurar o caminho para realizar.

Claudio Tozzi (2012), diante da marcante diversidade de técnicas e de materiais empregados em sua produção, entende que o artista deve ter conhecimento de tecnologias atuais e incorporá-las ao seu trabalho. Menciona o projeto de passagem de nível da Paulista desenvolvido com Ubirajara Ribeiro, que será apresentado no Capítulo 5, em que foi trabalhado o sistema de luzes cruzadas na qual o próprio espectador fundia sua imagem com outra imagem pré-pintada sobre uma parede. "A relação de ângulos de luz criava uma nova escala para a imagem em movimento que era quase uma projeção do transeunte que se fundia com a imagem pintada." Criava-se "uma unidade, uma relação entre a pintura e o espaço, o transeunte, o usuário, e tudo o que acontecia naquele espaço através da luz." A mesma ideia foi aplicada na proposta das silhuetas que apresentou para a Estação Sé, juntamente com a da Colcha de Retalhos. Cita como exemplo de aplicação dos recursos: luz, projeção e reflexão, em função de um espaço predeterminado, os trabalhos de 
Olafur Eliasson e Anish Kapoor. A seu ver, a "interação entre a arte e a tecnologia e o conhecimento do artista de todos esses processos é muito importante para se criar uma obra de arte que seja contemporânea." No caso das estações,

É muito importante que as obras tenham essa linguagem contemporânea, que o metrô proponha também não só a aplicação de materiais ou de tinta sobre uma superfície pré-existente mas que se construa espaços onde se use uma tecnologia bastante contemporânea. É o mesmo pensamento que você tem que ter em todas as épocas! (TOZZI, 2012).

Chama atenção para os fatores da vibração e do deslocamento de ar ocasionados pelo movimento dos trens (trepidação e efeito pistão, respectivamente, mencionados no Capítulo 3), condicionantes que exigem pensar não apenas nos materiais e suas tecnologias, mas também, nos encaixes, fixações e características físicas da obra, para que haja pouca manutenção e maior resistência à exposição pública. Afirmou que além das técnicas que pesquisa há décadas: tintas e resinas acrílicas, materiais siderúrgicos, placas variadas, fibras, concreto e outras, gostaria de fazer um novo trabalho para o metrô em que experimente linguagens contemporâneas incorporando novas tecnologias, como o vidro que muda de cor, as células fotovoltaicas, o LED, de forma que o trabalho seja uma relação entre sua "obra de pintura" e "uma obra de tecnologia apropriada a esses espaços urbanos". (TOZZI, 2012)

A artista multimídia Regina Silveira também se mostra favorável à aplicação de tecnologias atuais em intervenções temporárias e permanentes nas estações. Acredita que

\begin{abstract}
Possivelmente essas tecnologias atuais, que já estão na "família" daquelas utilizadas para a comunicação dentro das estações do metrô, poderiam até proporcionar uma implantação mais fácil de obras artísticas - permanentes ou não - mais afinadas com as condições oferecidas pelo ambiente e pela situação de passagem e apreensão rápida, por parte dos usuários do Metrô. Talvez elas tenham mais capacidade, especialmente quando aplicadas a intervenções ambientais, de ocupar escalas maiores com menor fisicalidade e mesmo - considerada a comunicação onipresente - de se constituírem como ruído capaz de criar uma espécie de "pausa" ou mudança temporária - nas percepções banais do cotidiano. Mas tudo depende da qualidade da arte, como sempre... o uso das novas tecnologias por si só não assegura o estatuto da arte - que para ser arte tem que ficar na contramão e no avesso da comunicação...(SILVEIRA, 2012).
\end{abstract}

Aproximando deste pensamento, para Waldemar Zaidler (2012), o uso de qualquer tecnologia é bem vindo desde que favoreça a concepção do trabalho artístico, ou 
seja, desde que seja aplicada como um meio, como "uma interface entre o conhecimento e a materialidade das coisas". Apesar de respeitar quem a use como um fim, entende que o resultado do trabalho não pode ser entendido como arte. Admite que, no "sentido de fruição, de proporcionar maneiras de se perceber diferentes, de proporcionar diferentes relações do ponto de vista de prazer, de proximidade, de tato", pode ser avaliada positivamente, mas, "a priori, não é a tecnologia". Outra questão relevante apontada pelo artista é o posicionamento dos encomendadores que a veem como "impeditivo" para a realização do trabalho em função da manutenção, uma vez que, "nenhuma tecnologia prescinde de manutenção".

(...) colocam a questão da tecnologia na frente, tanto pra determinar o que eles querem, quanto pra determinar o que eles não querem. Se envolve determinado grau de manutenção, com uma periodicidade ou com um tipo específico então já não pode, ou seja, tá colocando a questão da tecnologia como um impeditivo pra fazer um trabalho que naquela tecnologia alcançaria a plenitude da sua linguagem. A tecnologia é consequência. Tecnologia, no meu entendimento, em qualquer área do conhecimento, é uma interface entre o conhecimento e a materialidade das coisas, só isso. No mundo real, só faz essa interface e só serve pra isso. Se você tira essa função de interface e coloca ela como um fim, tudo bem, pra quem gosta de tecnologia e quer estudar esse tal desenvolvimento, tecnologia, maravilhoso. Graças a Deus que existe gente que pensa assim, e que faz isso, mas não é arte, não se aproxima da arte, não tem picas a ver com a arte, a coisa em si, que fique claro. (ZAIDLER, 2012).

Por outro lado, para Daniela Kutschat (2012), "pensar a cidade como uma superfície de comunicação é uma tendência" que tem levado designers, artistas e arquitetos a criar fachadas e vitrines interativas, através da aplicação de tecnologias contemporâneas, em que a fluidez substitui a rigidez arquitetônica. Há também trabalhos não interativos, como as intervenções de Jenny Holzer, em que o elemento luz é "material básico de trabalho". Observa que a maior parte dos exemplos desse tipo de trabalho não estão em São Paulo, no Brasil. Isto se deve à necessidade de ampla infraestrutura, o que implica no aluguel de equipamentos, e de conhecimento e familiarização com as tecnologias para que sejam melhor exploradas as possibilidades estéticas e de linguagem.

Ainda com o objetivo de verificar a possibilidade de aplicação das tecnologias aplicadas nas obras temporárias Descendo a Escada e OPERA_Sonic Dimension em obras permanentes, questionamos as autoras sobre o custo e a frequência de 
manutenção exigida em função do efeito pistão e da trepidação. De acordo com as informações transmitidas à Regina Silveira por Marcos Cuzziol, quem acompanhou o processo de instalação e manutenção durante todo o período da Exposição Arte Cibernética: Acervo Itaú Cultural:

\begin{abstract}
...A tecnologia utilizada não tem custo especialmente elevado - a maior diferença de um PC de uso normal é a placa de vídeo com saídas independentes para os três projetores. As exigências de manutenção também não foram muito diferentes das de um ambiente mais controlado. Lembro apenas que foi necessário ajustar o sensor de presença algumas vezes, mas isso se deveu muito mais ao volume de público que ao ambiente em si. Entretanto, outras obras, que ficaram mais próximas às plataformas, apresentaram defeitos nos cabos de vídeo devido a vibração e exigiram estrutura reforçada nas telas de projeção para suportarem os constantes deslocamentos de ar. (SILVEIRA, 2012) ${ }^{67}$.
\end{abstract}

Regina afirma que a iniciativa do Itaú Cultural de exibir obras da sua coleção de arte e tecnologia dentro de estações do metrô

foi um sucesso, a interatividade das obras colaborou para atrair o público - que muitas vezes pode gastar um pequeno tempo a mais dentro da estação. $E$ os espaços mais escuros do percursos internos ganharam uma mágica que antes não tinham...

Foi temporária, ainda bem, porque assim a mostra guardou o máximo do seu poder de surpreender, sem muito desgaste de manutenção. Uma iniciativa para manter ou dar sequência, sem dúvida. (SILVEIRA, 2012).

Daniela Kutschat (2012) esclareceu que, apesar do custo da tecnologia aplicada na obra OPERA_Sonic Dimension ter sido elevado, de ter exigido maiores cuidados, não em função da trepidação e do efeito pistão, mas da própria sensibilidade do equipamento que era desrregulado com 0 simples toque dos usuários/espectadores/atores na tela, e das discussões acerca da preservação, da manutenção e da pertinência desse tipo de trabalho, acredita que seja possível a aplicação de tecnologias atuais, no caso, projeções e sensores de movimento acompanhados do desenvolvimento de hardware e software, em obras permanentes nas estações, desde que, logicamente, se tenha verba para a realização do projeto e que haja um acervo com " $X$ dispositivos, que são daquela época, e eles têm que funcionar, pra você poder fazer com que o trabalho funcione, ou seja, você vai fazer quase que uma arqueologia de equipamento." Explica que:

\footnotetext{
${ }^{67}$ Marcos Cuzziol em resposta a Regina Silveira em entrevista concedida à pesquisadora, 2012 (APÊNDICE C).
} 
Para a gente implementar o projeto, em 2005, porque é o mesmo projeto, a gente teve que desenvolver tecnologia. Então, a gente desenvolveu desde hardware até toda a instalação em si, todo o projeto mesmo da instalação, a programação, um software dedicado. A gente teve apoio de uma empresa de sistemas de controle, a gente teve que comprar uma quantidade de sensores específicos que poderiam funcionar naquele espaço, naquela proposta, e tudo isso teve um custo elevadíssimo. O que acontece: normalmente, a gente idealiza o projeto, essa idealização do projeto já é fazendo uma pesquisa sobre tecnologias, sobre possibilidades, elabora um orçamento, e aí a gente manda para editais específicos. Uma vez contemplado no edital, você recebe a verba específica para a realização do projeto.

(...) Tivemos monitores que ficavam direto junto com a obra, porque nossa obra é supersensível, ela tem sensores que têm que ser calibrados (...) No caso, lá, a trepidação teve menos problemas do que a altura do espaço, ele era um pouco baixo, e a manipulação das pessoas. Porque, $O$ trabalho, você não precisava tocar nas telas, você só se aproximava das telas e você ia produzindo sons, mas as pessoas colocavam as mãos na tela, e quando colocavam elas, às vezes, as deslocavam. O monitor ficava lá inclusive conversando com as pessoas, a gente teve um feedback.

A gente procurou desenvolver uma tecnologia que era ligar o botão, deixar ligado, e aquilo funcionar sem problemas. E quando a gente foi pra Alemanha, eu acho que aquilo ficou quase 4 meses, e aquilo foi ligado apenas uma vez, nunca foi desligado. Então, a gente conseguiu realmente um estado da arte também no sentido de robustez do projeto que foi bem interessante. Agora, tem uma questão aí, que é como guardar esses trabalhos, como fazer a manutenção deles, porque as tecnologias também elas vão mudando, e se é pertinente atualizá-las tecnologicamente. Essas são questões mesmo que o pessoal da área de arte e tecnologia discute muito, e, inclusive, os museus também discutem. Por exemplo, esse museu que adquiriu a obra, a adquiriu pela questão de que a gente tinha desenvolvido software, que foi entregue junto, que a gente tinha desenvolvido toda a parte tecnológica, e que nós tínhamos uma possibilidade de manutenção que eles dominavam. Tudo isso foi pensando. Inclusive a elaboração desse contrato de venda foi uma coisa complexa, por que o que você está vendendo?

A autoria continua sendo sua, você continua sendo o autor. Mas você está vendendo software, você está vendendo a instalação, a tecnologia. Eles podem mudar de repente, daqui 5 anos eles poderiam dizer: "Ah, mas esses sensores estão desatualizados. Vamos trocar por uma tecnologia melhor?"

Esse problema é o que o pessoal do vídeo também tem, porque se você compra o vídeo você está comprando o quê? A cópia ou o original? O original vai durar um certo tempo, e pra você reproduzir a obra você precisa dos equipamentos também. Você tem que ter os equipamentos também, você não pode ter só o vídeo, você tem que ter o equipamento de projeção. Essas coisas são questões mesmo que são muito debatidas, o quanto os trabalhos já não podem ser vistos. Uma série de trabalhos que eu realizei na década de 90 que hoje não rodam mais, porque não é mais aquele sistema operacional, aquele computador, aquela porta de entrada. Então, cadê esses trabalhos? Eles só existem na documentação. (KUTSCHAT, 2012). 
Outro aspecto significativo mencionado pela artista é transformação a qual o profissional da arte contemporâneo tem vivenciado em sua forma de atuar. Atualmente,

passa muito tempo elaborando projetos, fazendo a própria produção do projeto. Então, ele é na verdade, um executivo, ele tem que ser um empreendedor, ele tem que correr atrás dos editais, às vezes ele precisa do selo de algum órgão pra ele poder entrar com o projeto. Então, por exemplo, se você já tiver aprovado no MINC o seu projeto isso já te ajuda... Ele tem que, realmente, ser muito empreendedor, tem que desenvolver várias habilidades e qualidades bastante administrativas. Aquela visão de artista que idealiza e pronto, eu acho que não é assim. Não é isso que eu vejo com meus colegas, não é isso que eu vivo, e é complexo. (KUTSCHAT, 2012).

\subsection{PROJETO INTERDISCIPLINAR: O QUE IMPEDE QUE ELE ACONTEÇA NO METROPOLITANO DE SÃO PAULO?}

Os depoimentos revelam que os artistas se mostram abertos à atuação integrada com arquitetos e demais profissionais envolvidos no processo de criação, desenvolvimento e implantação da obra artística.

Claudio Tozzi, em sua tese de doutorado e em artigo publicado (2001), defende "propostas que determinem a intersecção de campos interdisciplinares e resultem na criação de ambientes integrados e na articulação espacial que propõe o diálogo e a síntese no fazer do arquiteto e do artista plástico."

Enquanto o arquiteto tende, em sua obra, a uma realização estável, a intervenção do artista é algo que é acrescentado à identidade local. É ponto de partida do confronto com o espaço físico, que modifica a realidade, a "redefine", confere-lhe novos atributos: ao interpretar, a relê poeticamente. São inúmeros os exemplos e as situações em que o trabalho do artista em relação à arquitetura consiste simplesmente no "decorar" parcialmente uma determinada parte do espaço, sem considerar o ambiente em sua totalidade, se concentrando num detalhe particular e ignorando o todo.

Tal fato ocorre em todos os períodos da história, inclusive nos dias de hoje, mas devido à superficialidade de sua proposta, não nos interessa considerar.(TOZZI, 2012).

Para tanto, é preciso

(...) repensar a formação acadêmica do artista plástico. É necessário que ele tenha um conhecimento mais amplo da escala e da estrutura 
dos espaços urbanos e dos edifícios. Deve ter uma formação e conhecimento técnico de materiais, incluindo o processo de execução, fixação da obra, interferências e utilizar a linguagem do vídeo, do cinema, da mídia eletrônica e outros elementos que trabalham com a projeção e reflexão da luz com vários materiais que são integrados e determinam a solução da obra.

\begin{abstract}
Muitos artistas têm uma formação semelhante à do arquiteto. Nos projetos de Olafur Eliasson e Anish Kapoor, essa integração está presente. No mundo inteiro se faz isso. Os grandes escritórios de arquitetura também têm a participação de artistas plásticos. Algumas intervenções que os arquitetos fazem são muito associadas às artes plásticas como, por exemplo, em New York, a intervenção em linha de trem abandonada de Diller Scofidio. Então, hoje, o artista, o arquiteto, o designer, o comunicador visual, ele tem uma questão a resolver: a cidade, o espaço urbano. Essa integração, é muito interessante quando se dá no ato de projetar. (TOZZI, 2012).
\end{abstract}

No caso do metrô de São Paulo, quando foi convidado para fazer o painel Colcha de Retalhos, a estação já estava pronta. Não trabalhou de forma integrada com o arquiteto, mas houve uma integração através de um projeto curatorial, feito por Radhá Abramo, que incluía a locação das obras e o diálogo entre elas envolvendo a área externa: a Praça da Sé e diversas áreas internas da estação. Havia uma comissão que tentava fazer essa ponte. Atualmente, desconhece o processo interno, mas afirma que há alguns projetos em que a relação artista/arquiteto tem se dado pelo menos em um diálogo de materiais que serão utilizados. "Seria muito bom que a partir do processo de projeto de uma estação o artista desenvolvesse em conjunto com o arquiteto intervenções espaciais já pensando em soluções de materiais." (TOZZI, 2012).

Para Waldemar Zaidler, arte, arquitetura e design são disciplinas que "não podem acontecer de modo separado, em momentos diferentes ou sob a batuta de algum maestro." A seu ver, houve

um lapso modernista que interrompeu essa prática, mas que, na verdade, sempre foi assim antes e está voltando cada vez mais a ser. (...) A arquitetura, a arte, tem que sair realmente de uma concepção múltipla, polifônica, conversada, entrosada", (...) "é uma tendência que deveria caminhar para existir". (ZAIDLER, 2012).

Seguindo nesta direção, Carlos Fajardo, após ter sido comissionado para desenvolver a proposta de intervenção para a Estação Vila Prudente, se aproximou do arquiteto Luis Carlos Esteves no momento em que a estação estava sendo construída por compreender que 
Projetos dessa magnitude exigem essa atuação integrada. São projetos que, geralmente, envolvem uma integração com a arquitetura, exigem um acompanhamento técnico de engenharia e têm que ter um cuidado imenso da parte de todos os envolvidos com o usuário final. Num certo sentido, esse procedimento é imposto a esse usuário. Não se trata de uma obra de arte colocada em um lugar público de visitação como um museu, mas um lugar de uso público indiferenciado. (FAJARDO, 2012).

Daniela Kutschat, que tem trabalhado com outros artistas em uma relação de coautoria ou de colaboração no desenvolvimento de projetos, também pensa que no caso das estações de metrô

\begin{abstract}
trabalhar integradamente com o arquiteto é fundamental, porque você está lidando com uma quantidade de pessoas que é inacreditável, são muitas pessoas e, às vezes, você tem uma intenção, e essa intenção ela não se concretiza na mente, na sensação, no outro. Então, nesse sentido, eu acho que meu trabalho se aproxima bastante do Design, porque eu fico pensando voltado às pessoas que vão receber o trabalho. E aí, quando o trabalho é no metrô, eu acho que você tem que ter uma clareza sobre em que lugar que você vai instalar o seu trabalho, qual vai ser o fluxo que vai ter naquele espaço, qual a iluminação, como que ele se relaciona inclusive com as outras coisas que estão presentes no espaço. Todos esses elementos são fundamentais e aí você não tem que trabalhar talvez só com o arquiteto, você tem que trabalhar com uma grande quantidade de pessoas, inclusive com alguém da área de gerência mesmo do metrô, da estação, para fazer esses acordos mesmo; a instalação é uma intervenção, ela estará intervindo no espaço anterior, e é isso o que a gente quer. Inclusive, saber quais são as limitações, porque às vezes a gente parte, o artista parte do ideal, ele quer implementar o ideal, o que está na cabeça dele, o que vai para o projeto dele, o que está no desenho dele, ele quer implementar aquilo. Agora, às vezes, o contexto, principalmente o contexto público como o metrô, não permite isso. Então, como que ele vai fazer uma adaptação, se uma adaptação for possível, para ele também conseguir realizar o próprio trabalho. (KUTSCHAT, 2012).
\end{abstract}

De modo particular, Regina Silveira (2012) entende que a atuação integrada não é uma obrigatoriedade, mas "pode ser essencial, especialmente quando a proposta envolve o ambiente - há muitos conhecimentos e dados envolvidos que o artista sozinho não domina - a colaboração interdisciplinar é sempre um enriquecimento". No desenvolvimento da proposta de obra permanente Tropel, criada para a Estação Vila Madalena, não esteve com o autor do projeto arquitetônico, mas se associou ao arquiteto Ronald Monreal, profissional que colaborou na concepção de estratégias, materiais e técnicas de execução e que esteve presente em todas as reuniões com o metrô. 
Amélia Toledo, entende que arte e design "é tudo uma coisa só". Afirmou que os projetos que realizou juntamente com João Batista Martinez Correa, arquiteto que projetou a Estação Cardeal Arcoverde do metrô do Rio de Janeiro, a convite do próprio arquiteto, "foi feito muito entrosado com o projeto arquitetônico". Perguntei a ela o que impede que este tipo de atuação aconteça em São Paulo. A seu ver, "não há impedimentos", "mas depende de ser apreciado, e depois aprovado, por algumas instâncias, do arquiteto (ou do escritório de arquitetura) aos engenheiros, em alguns casos, até o governador do Estado participa dessa decisão" (AMÉLIA TOLEDO, 2012). Para o artista Mo Toledo, que trabalha juntamente com Amélia na concepção, desenvolvimento e execução das propostas,

Tem um problema inicial. Em geral, os arquitetos não gostam de artista. Gostam de arte, mas não são muito chegados ao processo de criação da arte. Ou eles se colocam como sendo os próprios artistas. O Oscar Niemeyer é um que faz da obra dele uma escultura. Ele dava o encargo de fazer arte pro Atos Bulcão de uma maneira legal. Fizeram coisas bonitas, integradas, juntos, mas é muito raro você ver trabalho integrado bem feito de obra de arte com arquitetura porque os arquitetos não costumam ter essa abertura, essa disponibilidade. (MO TOLEDO, 2012) ${ }^{68}$.

\subsection{PROJETO INTERDISCIPLINAR NAS ESTAÇÕES CARDEAL ARCOVERDE E CIDADE NOVA NO RIO DE JANEIRO}

A convite do arquiteto João Batista Martinez Corrêa, autor dos projetos das estações Cardeal Arco Verde (1998) e Cidade Nova (2010) do metrô do Rio de Janeiro, Amélia e Mo Toledo, em uma ação integrada com o arquiteto, ainda na fase de projeto, desenvolveram propostas de programação cromática e de materiais de acabamento para os sites. A primeira intervenção partiu do exterior em direção ao interior da estação escavada sob uma montanha. No centro de um espelho d'água, localizado em uma praça externa, foi instalada a escultura: Palácio de Cristal (1998),

\footnotetext{
${ }^{68}$ De acordo com Mo Toledo, em entrevista concedida à pesquisadora, o arquiteto João Batista Martinez Correa: "tinha o desafio do percurso que era complicado porque a pessoa embarcava e tinha que percorrer um longo trecho no subterrâneo, em Copacabana, que é um bairro todo colorido, símbolo de beleza, e a pessoa ia chegar deprimida por ter atravessado um túnel cinza? Quando o João Batista viu a exposição da Amélia, a primeira que eu fiz a montagem, no MASP, ele percebeu que ela era a pessoa que poderia resolver essa questão e ele procurou a gente justamente por isso" (APÊNDICE C).
} 


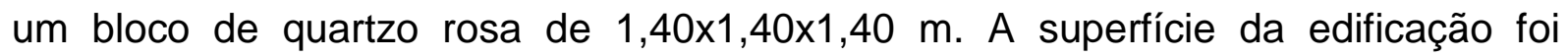
revestida de pastilhas de vidro em cores que variam do azul ao violeta, como um prolongamento do rosa da escultura. Dando continuidade ao violeta da fachada, próximo à escada de acesso ao primeiro subsolo, arcos de aço revestem as paredes do túnel, iluminados indiretamente, pintados de forma a prosseguir o ritmo cromático com o uso de vermelhos, laranjas e amarelos. No segundo subsolo, as cores utilizadas vão dos amarelos, aos verdes e lilases. O trabalho de revestimento do piso da estação: Paisagem Subterrânea (1998), é composto por placas de mais de noventa variedades de granitos brasileiros. Na plataforma de desembarque, há um painel de aço inoxidável de doze metros de extensão, que funciona como portas de acesso à área de serviço: Estação Terra (1998), mostrando a América do Sul, com bichos e crianças, desenvolvido com o apoio da Andrade Gutierrez. Desta forma, a estação configura-se como uma pintura/escultura que passa por dentro da terra. $O$ projeto levou quatro anos para ser finalizado. Foram mais de seiscentos metros lineares de paredes e pisos (FARIAS, 2004, p.280). Para Agnaldo Farias, a obra oferece ao público uma "experiência espacial", mas também "experiências sensoriais relacionadas ao tempo, à matéria e à cor." (FARIAS, 2004, p.227).

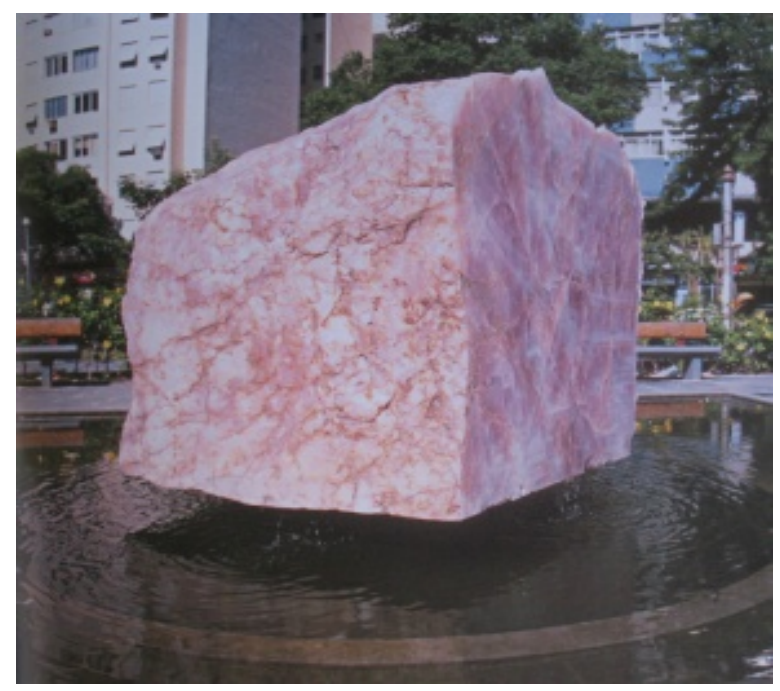

Figuras 176, 177 e 178: Escultura Palácio de Cristal e Programação de Materiais de Acabamento da Estação Cardeal Arcoverde, 1998. Fotos de Fernando Chaves. Fonte: FARIAS, 2004, p. 229-230.
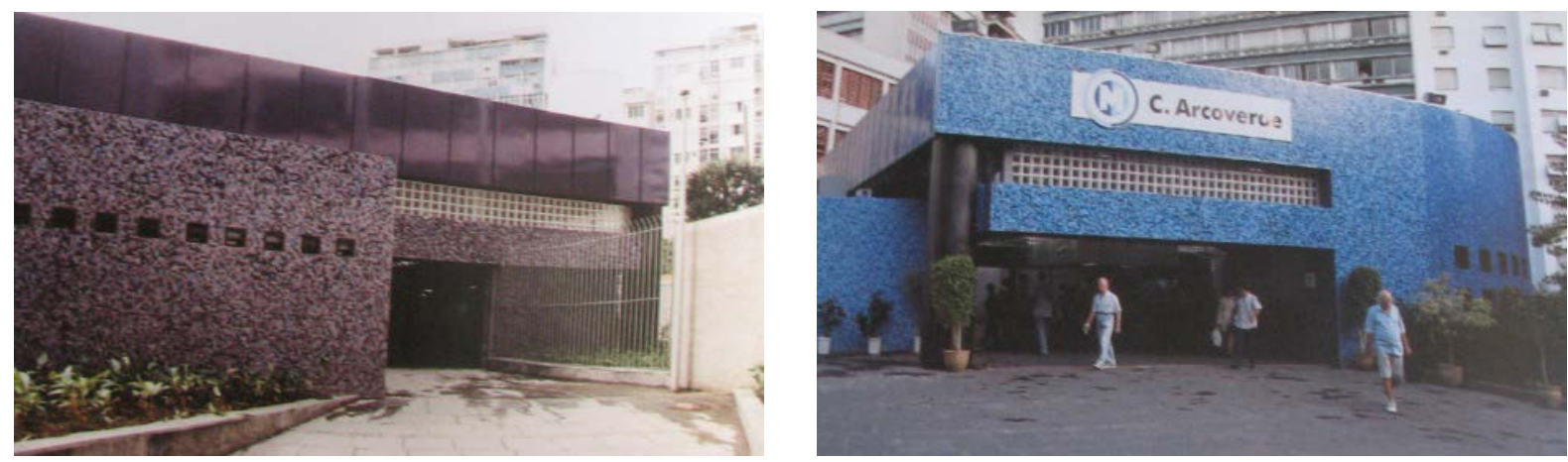

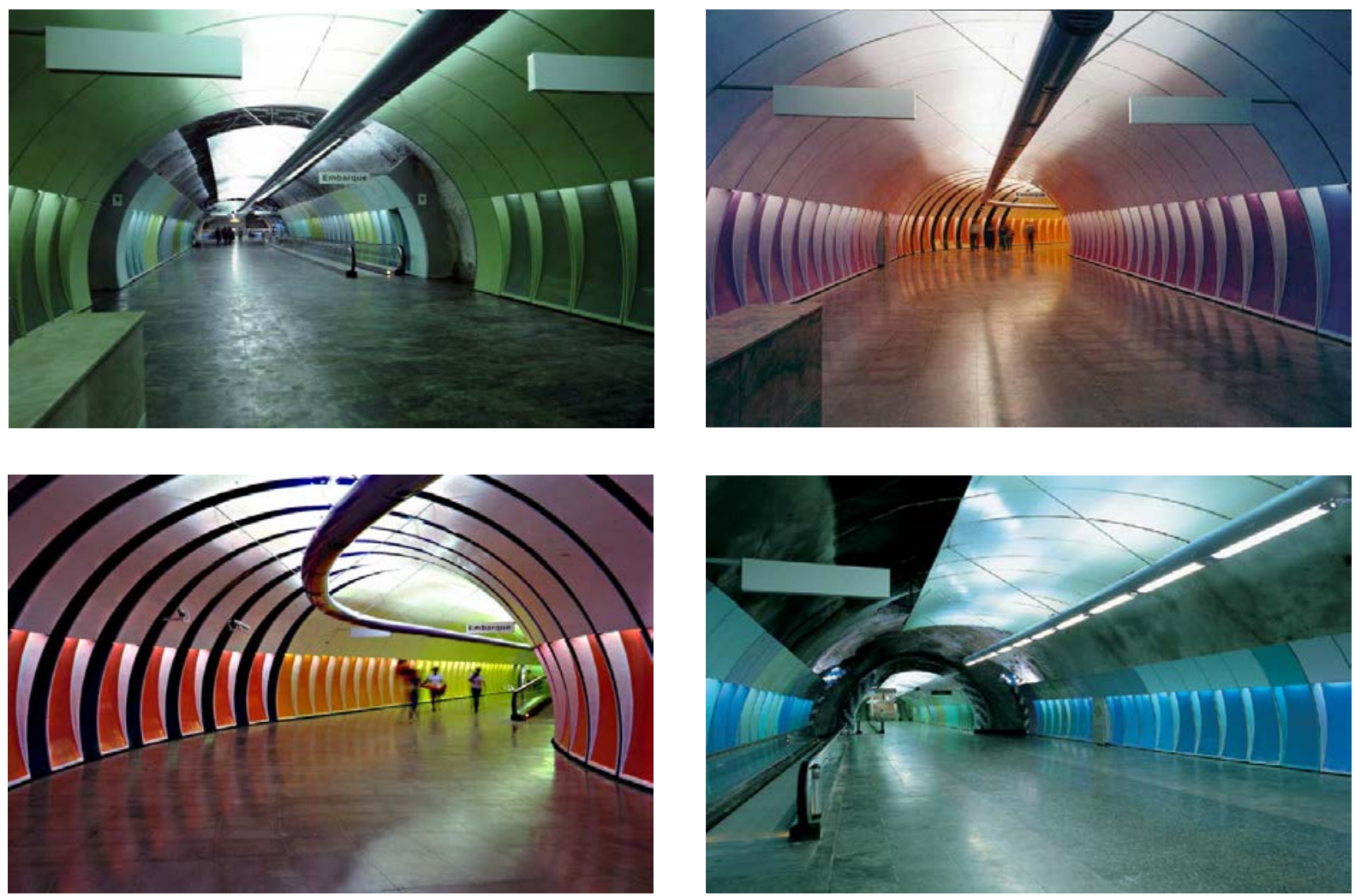

Figura 179, 180, 181 e 182: Programação cromática dos corredores da Estação Cardeal Arcoverde, 1998. Fonte: <http://Améliatoledo.com/category/instalacoes/>. Acesso em 05/07/12.
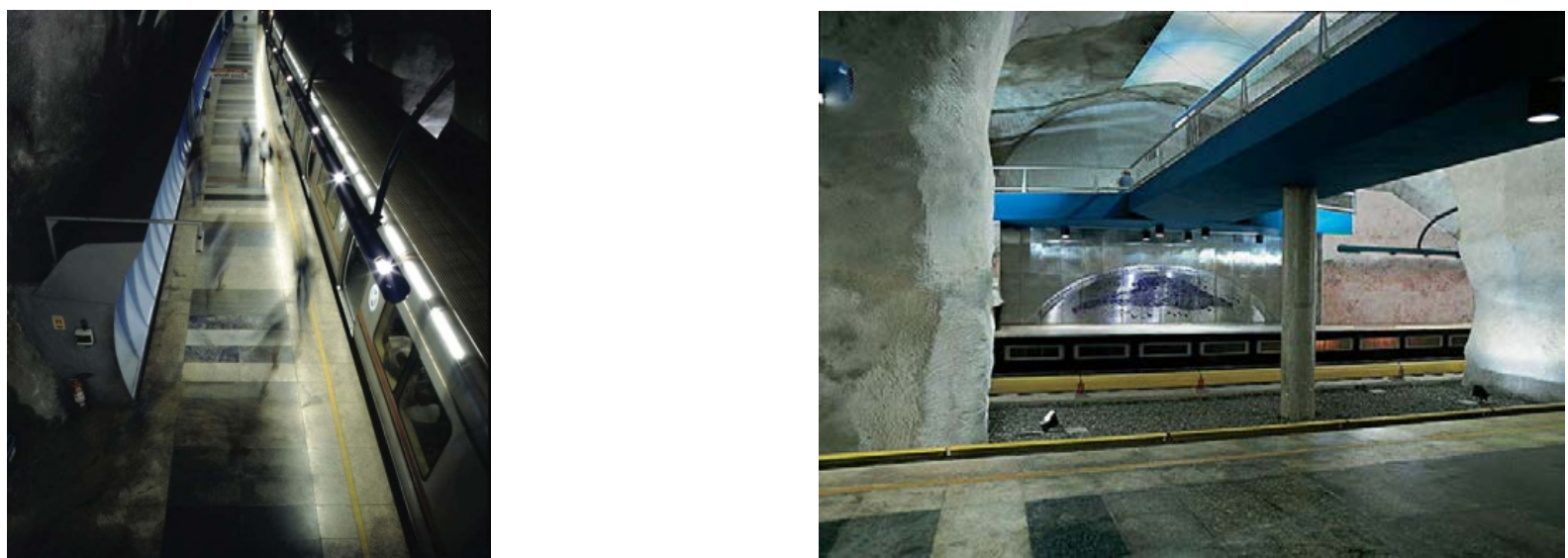

Figura 183: Programação cromática da plataforma da Estação Cardeal Arcoverde, 1998. Fonte: <http://Améliatoledo.com/category/instalacoes/>. Acesso em 05/07/12.

Figura 184: Estação Terra, 1998. Chapas de aço inox gravadas. Estação Cardeal Arcoverde, 1998. Foto de Fernando Chaves. Fonte: FARIAS, 2004, p.234.

A proposta foi apresenta à Companhia do Metrô do Rio de Janeiro como parte do projeto arquitetônico,

a Promon, que era a empresa onde o João trabalhava, era a responsável e já tinha ganhado a concorrência pra fazer. Entrar em 
concorrência nesse tipo de coisa é o mesmo que dizer perdeu, entendeu? Vão ver que tem artista no meio e vão dizer que aquilo é bobagem, que aquilo é perda de tempo, que é dinheiro jogado fora quando não tem nem dinheiro, tanto que eles nos pagaram sem ter dinheiro. A gente fez, vamos dizer, quase que por preço simbólico. A gente faz por esporte, é gostoso fazer este tipo de projeto. Dá um trabalhão mas o trabalho vai ficar pro público, as pessoas vão ver o que no dia a dia delas nunca podem ter dentro das suas casas. Pelo menos, elas têm onde ver arte na hora que estiverem no caminho de casa pro trabalho e não ver só uma cidade detonada.(MO TOLEDO, 2012).

Devido ao custo da escultura da entrada e do aço inox aplicado no acabamento do painel ter sido acima do orçamento da obra o projeto também teve patrocínio da Lei de Incentivo (AMÉLIA TOLEDO, 2012). Outro fato relevante apontado pelos artistas é a falta de conservação pela qual a fonte/escultura tem passado.

(...) há o problema de conservação, porque a gente fez aquela fonte na praça, e a fonte é uma terra de ninguém. Ela é meio do Parques e Jardins (prefeitura), meio da companhia que administra o metrô, mas é território e obra do Governo do Estado. Afinal, ninguém cuida de nada, fica tudo caindo aos pedaços. Então, é um negócio muito complicado. A parte interna do metrô tem um responsável pra cuidar que é quem administra o funcionamento do metrô, então, o responsável tem que deixar ali limpinho, trocar o que caiu, etc.(MO TOLEDO, 2012).

A segunda intervenção, para a Estação Cidade Nova (2010), uma ponte pênsil sobre a Av. Presidente Vargas, em que foram indicados: a cor dourada da estrutura, as cores das telhas, os tons da pintura dos ambientes e um projeto de piso que foi descartado.

A Amélia, primeiro fez uma proposta na cor verde aí, um dia, ela sonhou que seria dourado. Eu falei com o João. O João achou a ideia muito bonita e começamos a tentar fazer os convencimentos. Muitos políticos, não é uma turma fácil de conversar, mas eles acabaram aprovando. Por outro lado foi pena porque a Amélia fez um projeto para um piso lindo, azul, de um granilite que ia ser feito com metal. la ser uma coisa linda mesmo, e aí o pessoal do Burle Marx ficou com ciúmes e aí fizeram eles o piso, que deve ter ficado uma porcaria, eu não fui lá ver. Aí colocaram no jornal: escritório do Burle Marx... aí bota o nosso projeto dourado lá como se fosse obra deles, pode?

(...) O projeto do piso era uma brincadeira com o mar, todo com ondas, brincando com aquelas ondas do Burle Marx, mas com aquela ideia de onda do mar, da cor do mar, com azuis, com verdes, uma coisa mais sofisticada, mexendo com o fluxo de onde as pessoas estão vindo, pra onde elas estão indo, quando elas circulam. Então, tudo isso são coisas que a gente faz brincadeiras com o material que está sendo usado, como ele está sendo colocado e aquilo que ele vai simbolizar. A cor simboliza. (MO TOLEDO, 2012). 


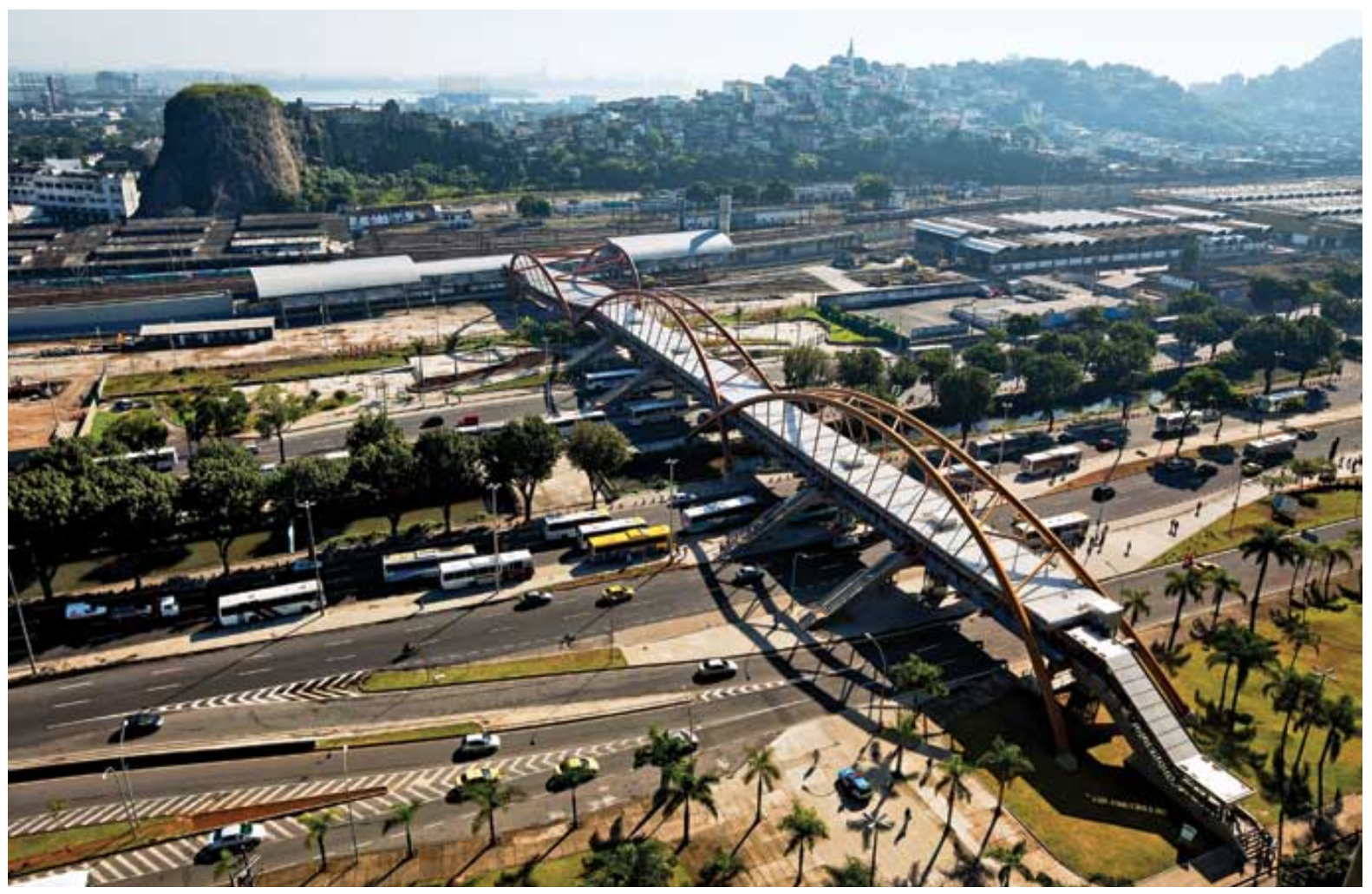

Figura 185: Estação Cidade Nova, 2010, Rio de Janeiro. Projeto arquitetônico de João Batista Martinez Correa. Programação Cromática da estrutura em arcos de Amélia e Mo Toledo. Foto de Nelson Kon. Fonte: <http://www.arcoweb.com.br/arquitetura/jbmc-arquitetura-urbanismo-passarela-estacao-14-12-2011.html>. Acesso em 11/07/12.
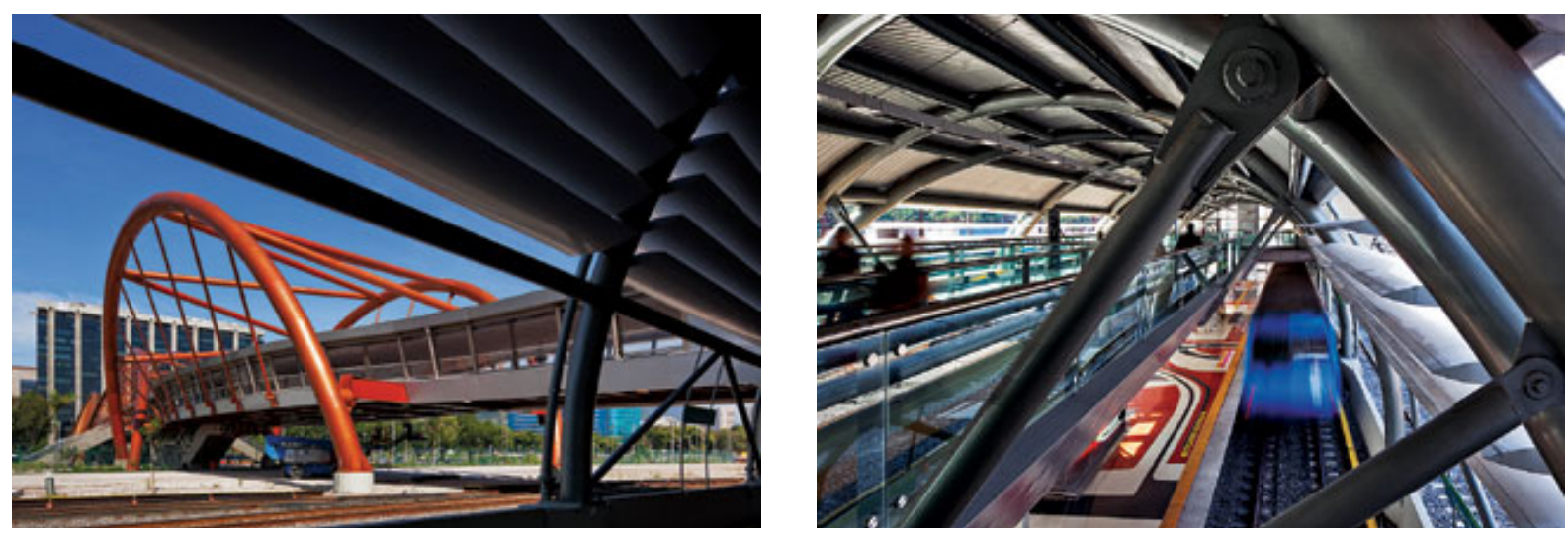

Figuras 186 e 187: Estação Cidade Nova, 2010, Rio de janeiro. Programação Cromática da estrutura em arcos de Amélia e Mo Toledo. Piso da plataforma do Escritório Burle Marx. Fotos de Nelson Kon. Fonte:< http://www.arcoweb.com.br/arquitetura/jbmc-arquitetura-urbanismo-passarela-estacao-14-12-2011.html>. Acesso em $11 / 07 / 12$

De acordo com Amélia, João Batista tem desenvolvido outros projetos, em seu próprio escritório, para estações do Rio de Janeiro "mas o pessoal de lá quer tomar conta dos projetos". Afirma que, sempre é chamada "para palpitar nos projetos quando há essa abertura por parte dos governos, mas isso é muito raro".(AMÉLIA TOLEDO, 2012). 


\subsection{ATÉ QUE PONTO REGRAS NORMATIVAS INTERFEREM NO PROCESSO DE CRIAÇÃO E NA FORMA DE ATUAR?}

Para Waldemar Zaidler, a questão das regras normativas é "um dos lados do fazer

artístico", "da burocracia do fazer", "super importante", que influencia no trabalho em uma série de questões, dentre elas, a escolha da tecnologia aplicada, mas tudo isso, "não tem nada a ver com arte". Como artista, arquiteto, designer, pesquisador, encara essa "tranqueirada" toda se tiver a ver com sua ideia artística:

(...) é uma parte da questão prática que entra no dia a dia, na coisa que tem muito pouco a ver com arte, pra não falar, nada a ver com arte. Eu gosto muito, são coisas assim, que fazem parte do fazer artístico, que possibilitam na verdade a concretização das obras de arte dentro de um determinado âmbito. Quando se trata de arte pública, é um âmbito muito restrito, principalmente depois de um movimento que começou já há uns quarenta anos atrás, cinquenta anos atrás, do qual eu fiz parte. Eu ainda faço, de uma certa maneira, que é ignorar esse tipo de encomendador e perceber que existem outros encomendadores pra questão da arte pública que não passam por essas coisas, então, da mesma maneira que existem outros circuitos de arte a serem explorados além das galerias, além dos museus, enfim, as coisas vão se multiplicando. Eu acho que esse fazer, num determinado momento, a sua intenção do trabalho, o trabalho tem sentido dentro daquele âmbito, daquela instância de encomenda, de instituição, enfim, que ocupa esse lugar determinado dentro do campo vastíssimo da arte pública, aí, não há esforços a serem medidos. Pra mim é assim, da mesma maneira que eu não tinha medo de polícia que me impedisse pichar, entendeu, é da mesma maneira que não tive medo de encarar um monte de careca de terno atrás duma mesa na hora de fazer um mundaréu de painéis que eu fiz em espaços, em instituições como o SESC ou coisas desse naipe, porque eu achava que, naquele momento, valia a pena fazer e então eu fui às últimas consequências e fiz. São coisas do fazer.(ZAIDLER, 2012)

Daniela Kutschat entende que, "não só regras normativas, mas as próprias limitações que as tecnologias e os materiais impõem", influenciam o tempo todo. Alerta que "a pesquisa de materiais é fundamental no trabalho, principalmente na arte e tecnologia". Explica que,

às vezes, você idealiza uma coisa, e quando você vai para a prática, realizar aquilo, com aquele material, com aquela tecnologia, você percebe que aquilo não funciona bem daquele jeito que você idealizou. Por isso que a pesquisa de materiais é tão fundamental no trabalho, principalmente na arte e tecnologia. A gente tem que conhecer muito bem o que é possível fazer e com o que é possível fazer. A mesma coisa acontece com as regras normativas dos espaços. Então, você tem restrições. Por exemplo, o próprio espaço tem restrições. A gente já teve esse problema da altura que nos era dada não ser suficiente para podermos implementar o projeto do jeito que a gente precisava e queria. Então, o projeto sofreu adaptações. Elas estão influenciando, influenciam o tempo inteiro. Às vezes, você tem um trabalho, e alguém te convida a apresentar este trabalho num espaço. Na maior parte das vezes os trabalhos que eu realizei já eram 
conectados ao espaço, ou seja, a gente mandava uma proposta para realização num determinado espaço. Então, quem julgava a proposta, já julgava sabendo quais eram os requisitos que nós tínhamos, mas, às vezes, vem o seguinte, você faz a exposição num lugar, alguém vê a exposição e quer levar para outro lugar, que tem outras condições físicas, outro espaço físico e tal, e aí o projeto, às vezes, não pode sofrer alterações e adaptações, mas na maior parte das vezes é possível fazer isso. (KUTSCHAT, 2012).

Regina Silveira, diz sentir-se à vontade com limites e parâmetros dos espaços e regras, os quais devem ser entendidos como "balizas para a criação", como uma "charada" que "leva a imaginação para outros caminhos".

(...) em qualquer projeto que envolva espaços públicos e ambientes com funções, eles não devem ser entendidos como barreiras restritivas, mas como balizas para a criação. Penso que as regras podem funcionar para compor a invenção do artista com uma espécie de charada a resolver - em muitos casos isto pode ser bem interessante, leva a imaginação para novos caminhos.(SILVEIRA, 2012).

\subsection{MEDIDAS PARA QUE TODAS AS ESTAÇÕES SEJAM CONTEMPLADAS COM OBRAS DE ARTE}

No estudo das obras de arte apresentado no Capítulo 3, é apontado um desequilíbrio na distribuição de obras permanentes instaladas nas estações da rede do metropolitano marcado pela concentração em poucas estações e pela ausência em praticamente metade delas.

Essa realidade pode estar relacionada, em parte, ao "estilo de divulgação do que já foi feito", à ausência do "encontro entre as pessoas que estão trabalhando agora com os artistas que são competentes para esse trabalho" e com aqueles que nunca fizeram este tipo de trabalho, mas que "podem ter essa capacidade", ao "pouco estímulo à criação artística para obras permanentes para âmbito público". Foram poucas as pessoas que tiveram iniciativas criativas que possibilitassem viabilizar projetos. (AMÉLIA TOLEDO, 2012).

Para Claudio Tozzi, "é necessário fazer um planejamento integrado", ou seja,

Ao se pensar o sistema viário da cidade e estações de metrô, o projeto deve ser ampliado para que se receba locações e intervenções visuais nos espaços a serem construídos. $O$ projeto integrado permite determinar o uso do lugar: a locação de obras permanentes e espaços destinados as transitórias.(...) tem que pensar o metrô como um 
sistema viário da cidade. Tem linhas que cruzam o espaço aberto, tem estações que são submersas em eixos da cidade. Tudo isso tem que ser pensado para que se faça também um projeto de intervenção visual no metrô. Esse pensamento conjunto, esse conceito inicial de pensar o espaço como um todo vai resultar em soluções mais específicas, mais adequadas para o metrô. (TOZZI, 2012).

Para Carlos Fajardo (2012), "uma medida seria tornar obrigatório nos lugares públicos a instalação de objetos de arte. Isso é uma prática rara aqui em São Paulo, mas que ocorreu de uma forma intensa pelo menos uma vez, na Praça da Sé."

Regina Silveira (2012) descreve sobre a ausência de uma "comissão regular para resolver a questão da arte no metrô" e a falta de "verba para as realizações permanentes". O projeto pode ser proposto e aceito, mas só se torna válido se aprovado pelas leis de incentivo, se tiver um proponente, um produtor e um patrocinador, sendo o artista encarregado de "chegar com tudo para a execução". Pressupondo que a forma de agir da companhia em relação às obras efêmeras e às intervenções seja semelhante à adotada para as obras permanentes ou para as vitrinas do MASP, em que é fornecido apenas o suporte técnico para as montagens, de forma básica e lenta, mas que funciona, entende que "a medida ou o caminho é este mesmo, não há lugar para amadorismo ou improvisações”.

Para Waldemar Zaidler (2012), não há o que ser feito em relação a isso, "não é uma questão do metrô". Na cidade de São Paulo, "as questões das políticas públicas em relação às questões visuais, particularmente, a questão da arte na cidade engatinham". Cita a Lei Cidade Limpa como um avanço que teve reflexos positivos, mas que ainda está "totalmente desvinculado de qualquer tipo de conhecimento, de qualquer tipo de pesquisa, de qualquer tipo de reflexão mais aprofundada", o que considera "historicamente compreensível porquê é uma coisa que não existia, nunca existiu". Nesse sentido, acredita que é necessário que haja "uma atuação política em relação a como é a exigência de criação, manutenção e evolução de políticas públicas que tratem da arte". "A questão da concentração é um reflexo político de como as coisas são encaminhadas na cidade e o Metrô não foge à regra". A companhia poderia ter iniciativas, assim como as do Banco do Brasil e do Itaú, para criar mecanismos que facilitassem a intervenção artística de forma "mais móvel”, "ágil”, "barata no sentido de exequível”, "dinâmica", "partindo de concepções mais contemporâneas". Menciona como exemplo válido a instalação 
de pianos nas estações, o que poderia ser feito com outros instrumentos, além de outras coisas, como oficinas de instrumentos para se fazer bate-lata, performances, mas esse tipo de iniciativa depende de ganhar força política.

Reconhece que a inserção do comércio, de serviços públicos e da farmácia popular são importantes, mas, assim como a arquitetura das estações, poderiam ser melhor resolvidos. Da maneira como têm sido feitos "É fazer força pra transformar o lugar, o espaço num lugar de passagem, isso sim é fazer força, é dar todo estímulo pra que o lugar seja transformado num ponto de consumo". Neste sentido, a própria arquitetura dá sinais de que não é para ter arte nesses espaços. Fazer uso de ladrilhos, colocar prédios para cima são questões que "marcam politicamente a existência do Metrô" enquanto "lá dentro, as pessoas que nem sardinha em lata, passando por lojinhas, (...) é uma coisa que passa por política pública, por um monte de questões que são totalmente externas à arte, à arquitetura.(...) É questão de cultura, é questão do campo da cultura mesmo, questão política dentro do campo da cultura."

Para Daniela Kutschat (2012), também é "uma questão de política cultural" em que a Secretaria Estadual de Cultura deveria "entender inclusive que a estação de metrô pode ser o espaço da arte, e que pode conter em si esse valor, porque a arte é um patrimônio cultural mesmo". Outras possibilidades seriam "abrir concursos para artistas e arquitetos", "promover mostras", "fazer uma agenda de exposições". Sugere a apresentação de performances e de outras formas de arte que "criassem a cultura de frequentar o espaço não como do ir e vir, mas como espaço mesmo de estar e de ter uma experiência", (...) "teria que ter alguém na secretaria pensando que isso é importante e que isso pode, inclusive, dar uma identidade para a estação, criar um circuito cultural de estação em estação, que é uma coisa que o Arte Cibernética tentou fazer, um circuito naquele espaço".

No geral, os artistas desconhecem qual o procedimento para apresentar obras de arte temporárias e permanentes nas estações. 



\section{TECNOLOGIAS ATUAIS E SUAS POSSIBILIDADES DE APLICAÇÃO}

A concepção e a realização de projetos artísticos, arquitetônicos e de design estão diretamente relacionadas aos tipos de materiais $e$, consequentemente, às tecnologias neles aplicadas. O desenvolvimento tecnológico no setor de materiais utilizados na execução de trabalhos desses profissionais vem acompanhando uma série de mudanças ocorridas nos últimos anos, em grande parte, devido ao processo de globalização mundial que atinge todos os setores da atividade produtiva. Nesse contexto, propriedades como beleza, qualidade, durabilidade, leveza, agilidade e facilidade de manutenção são determinantes no desenvolvimento de produtos convencionais como a tinta acrílica e o concreto, por exemplo, bem como os fatores sustentabilidade e interatividade, possibilitados aos profissionais contemporâneos, com o surgimento das tecnologias atuais: LED (diodo emissor de luz), célula fotovoltaica e mídias eletrônica e digital. A linguagem da projeção, utilizada desde os anos 1960, também faz parte do estudo por ter evoluído significativamente em função de avanços tecnológicos.

Diante da diversidade de materiais e tecnologias disponíveis no mercado, neste capítulo, pretendemos através da apresentação de alguns deles, atualmente explorados nos campos profissionais e acadêmicos mencionados, contribuir para o conhecimento de suas possibilidades de aplicação, para a compreensão da influência de nossa cultura em seu desenvolvimento e seus desdobramentos em uma nova linguagem, a interativa.

\subsection{MATERIAIS CONVENCIONAIS}

\subsubsection{Tintas de Emulsão Acrílica}

A necessidade de uma tinta resistente aos rigores da exposição ao ar livre foi o ponto de partida para que os muralistas mexicanos ${ }^{69}$ iniciassem estudos para 0

69 De acordo com dados publicados no site: <http//www.itaucultural.org.br>, "o termo refere-se à pintura mexicana da primeira metade do século XX, de feitio realista e caráter monumental. $\mathrm{A}$ adesão dos pintores aos 
desenvolvimento das cores artísticas. Experiências com emulsões acrílicas de polímero foram realizadas até o momento em que conseguiram criar tintas com maior permanência, facilidade de aplicação, estabilidade e brilho. "Essas tintas acrílicas poderiam ser diluídas em água e ofereciam durabilidade e conservação de cor excepcionais quando aplicadas em suportes de gesso e cimento expostos ao calor extremo, à luz solar e às chuvas intensas." (TOZZI, 2001, p.125).

Com o desenvolvimento da resina acrílica em forma de emulsão, adequada para o uso como um veículo de tinta, iniciaram-se diversas pesquisas voltadas ao refinamento do polímero e à formulação da tinta. A tinta acrílica de látex, usada na pintura de edificações, foi um dos frutos dessas pesquisas. "Os fornecedores de materiais artísticos combinaram os avanços na tecnologia, resultados desse esforço, com sua perícia na preparação de tintas para artes plásticas e, desenvolveram um meio que permitiu novas perspectivas para o artista profissional." (TOZZI, 2001, p.125).

Atualmente, a tinta acrílica é um material que pode ser aplicado em diversos suportes que abrangem desde a tradicional tela aos wall paint criados na arquitetura, possibilitando a "integração do fazer do artista plástico ao trabalho do arquiteto". Diversificados efeitos de pintura podem ser alcançados com a adição de meios acrílicos (mediums), vernizes, géis, pastas de modelagem e gesso acrílico. As lojas de produtos artísticos oferecem o produto produzido por diversos fabricantes: Golden, Liquitex, Acrycolor, Windsor e Newton, Amsterdan, Reves, Galeria, Holbein, Mameri, Lukas, Aquatec, Hyplar, Shiva, Acrilex etc. (TOZZI, 2001, p.123).

Em oposição às tintas látex, as tintas acrílicas artísticas são formuladas apenas com pigmento e aglutinante, sem adição de cargas ou diluentes. O objetivo é conseguir cores mais intensas no lugar de cores opacas. A maioria dessas tintas são formuladas com $100 \%$ de polímeros acrílicos que proporcionam maior durabilidade e

murais de grandes dimensões liga-se diretamente ao contexto social e político do país, marcado pela Revolução Mexicana de 1910-1920. Após 30 anos de ditadura militar, o movimento revolucionário - ancorado na aliança entre camponeses e setores urbanos, entre eles, intelectuais e artistas - projeta uma nação moderna e democrática, cujos alicerces repousam no legado das antigas civilizações pré-colombianas e na instituição de um Ministério da Cultura, dirigido pelo escritor José Vasconcelos. A política cultural do novo ministério tem como eixos o combate ao analfabetismo e a renovação cultural. O programa de pinturas de murais, narrando a história do país e exaltando o fervor revolucionário do povo, adquire lugar destacado no projeto educativo e cultural do período. Nos termos de Diego Rivera (1886-1957), um dos principais expoentes do muralismo mexicano, a arte "é uma arma", um instrumento revolucionário de luta contra a opressão. Os muralistas retomam de perto a produção gráfica de José Guadalupe Posada (1852-1913), engajada na crítica à ditadura militar de Porfírio Días (1876-1911)".Disponível em: <http://www.itaucultural.org.br/aplicExternas/enciclopedia_IC/index.cfm?fuseaction=termos_texto\&cd_verbete=31 90>. Acesso em: 05/03/2010. 
permanência. Em geral, os grandes fabricantes de materiais artísticos produzem uma linha completa de tintas acrílicas de polímero, as quais apresentam como propriedades: excelente durabilidade da película de tinta exposta em ambientes internos e externos; possibilidade da produção dos efeitos opaco e transparente no revestimento; secagem rápida, que diminui o tempo de finalização da pintura e possibilita que as telas sejam enroladas no dia seguinte da finalização do trabalho sem formar blocos ou manchas; boa adesão e adaptação a todos os tipos de superfícies não oleaginosas sem se desprender; boa flexibilidade, que evita craquelamentos e possibilita que as telas possam ser enroladas sem que haja danos à película; boa permanência, devido sua resistência às substâncias químicas e ao tempo (amarelamento e escurecimento); compatibilidade entre cores; boas características da cor, ou seja, não há mudança na cor do estado úmido para o estado seco; fácil aplicação e limpeza devido ao sistema de emulsão aquosa poder ser diluído em água.

Para que as cores artísticas sequem e transformem-se em uma película de tinta insolúvel em água, existem dois tipos de polímeros acrílicos: emulsão e solução.

\begin{abstract}
As emulsões acrílicas Rhoplex (AC-22, AC-33 e AC-34) consistem em pequenas esferas de polímero acrílico diluídas em água. As emulsões não modificadas têm aparência e consistência leitosas. Quando são espalhadas em películas e estão em processo de secagem, a água evapora e as partículas de polímero aglutinam-se para formar películas de polímero inodoras, incolores e transparentes. ${ }^{70}$ (TOZZI, 2001, p.127).
\end{abstract}

As três emulsões apresentam adesão, capacidade de aderência do pigmento e estabilidade mecânica excelentes. São usadas como bases para tintas tipo látex para a pintura de interiores e exteriores de edificações e como aglutinante em formulações para preparação de telas. A primeira a ser aplicada na arte foi a AC-33, e ainda é a mais importante. A AC-34, semelhante à AC-33, é destinada a suportes externos de madeira, enquanto que a AC-22, a mais recente, oferece melhores propriedades de fluição e veladura, porém, não é resistente ao ar livre. Quanto aos polímeros acrílicos em forma de solução, como os "Rohm e Haas Acryloid B-72 (40\% de sólidos resinosos em toluol) e Acryloid F-10 (40\% de sólidos resinosos em redutor mineral/Amsco F, 9:1)", são diluídos em solvente forte. A solução Acryloid B-

\footnotetext{
${ }^{70}$ Devido à especificidade técnica do assunto, as anotações ao longo do texto referentes às definições, às composições e aos processos de fabricação e aplicação dos produtos serão reproduzidas na forma como são apresentadas no material de referência.
} 
67MT, compatível com o óleo de linhaça, pode ser usada como meio de pintura das tintas a óleo à base de água, enquanto que a Acryloid B-67MT, a Acryloid-10 e a Acryloid B-72 como veículos de verniz de aparência clara. Na preparação das tintas acrílicas, seja com polímero de emulsão ou de solução, também poderão ser adicionados pelo fabricante: pigmentos, dispersantes, espessantes, agentes umectantes, dilatadores, conservantes, além de outros componentes específicos de cada fórmula. ${ }^{71}$ (TOZZI, 2001, p.127, 132).

Devido à preferência dos artistas pelas tintas solúveis em água, ou seja, tintas de polímero constituídas de veículo de emulsão, essas são encontradas em maior quantidade no mercado. Os veículos de solução de polímero passaram a ser usados na produção das tintas a óleo, diluíveis em aguarrás e solventes minerais, embora já exista a tinta a óleo à base de água.

Nos trabalhos artísticos em que é enfatizada interação das cores, a boa dispersão de pigmento e a intensidade da cor são propriedades indispensáveis, no entanto, é necessário que sejam tomados os devidos cuidados na dosagem de dispersante adicionada ao pigmento para que sejam evitados a floculação quando outros ingredientes forem adicionados, o desequilíbrio na uniformidade da cor e a instabilidade da tinta. Essa dosagem varia de acordo com o tipo e o fabricante do pigmento.

Para uma grande variedade de pigmentos, o Temol 731 (25\%) é um dispersante eficiente. Quando houver dificuldade em umidificar o pigmento, deve ser adicionado à sua trituração um agente umectante - o Triton CF-10, produto que apresenta característica de umedecimento eficiente combinada com propriedades de baixa espumação.

Para aqueles exemplos em que o pigmento reativo como, por exemplo, o silicato de chumbo básico ou o óxido de zinco for usado, o Tamol 850 (30\%) demonstra qualidade superior de dispersante. Mas, é relativamente fraco para dispersar pigmentos orgânicos. A necessidade de dispersante de pigmentos reativos pode ser calculada ao se usar o método de concentração-agregação ${ }^{72}$ (...), substituindo a titulação de $10 \%$ de sólidos

\footnotetext{
71 Para o amolecimento e a remoção de películas secas insolúveis em água devem ser usados solventes especiais como o cloreto de metileno. (TOZZI, 2001, p.129).

$72 \mathrm{O}$ teste de concentração-agregação, desenvolvido por técnicos de laboratórios de pesquisa de diversos fabricantes, consiste em determinar a necessidade máxima de dispersante de qualquer pigmento ou combinação de pigmentos. "Neste método, 50 gramas de pigmento seco são misturadas com água suficiente para formar uma pasta firme e ligeiramente úmida. Um dispersante em solução aquosa (uma solução 10\% de sólidos de 1:1) é então adicionado à pasta em quantidades pequenas, misturando-se cuidadosamente. Quando a massa do pigmento tornar-se fluida o bastante para que as ondulações da superfície desapareçam apenas com a suave agitação do recipiente, o pigmento estará desfloculado.

Uma pequena porção do sistema de pigmento (aproximadamente $1 \mathrm{ml}$ ) é então removida e colocada em um recipiente de vidro para observação. Um espessante iônico como o Acrysol GS é adicionado a esta porção. A
} 
de Tamol 731 e Triton CF-10 por uma solução aquosa de Tamol 850 em 5\% de sólidos. Os melhores resultados são obtidos ao se adicionar quatro gotas de $5 \%$ de agente umectante Triton X-120 ao pigmento após a água inicial. (TOZZI, 2001, p.127).

Uma questão a ser considerada, é a possível estocagem da tinta por longos períodos, pré e pós-venda, o que requer do fabricante uma verificação da estabilidade de dispersão do pigmento da tinta acabada através de testes de estabilidade de congelamento-descongelamento e de aquecimento.

Quanto à relação pigmento-aglutinante ${ }^{73}$, cada pigmento ou cada combinação deles exige um aglutinante específico. A necessidade de aglutinante de pigmentos diferentes varia muito e depende da capacidade de pigmento-aglutinante do veículo de emulsão usado, do número de partículas, da forma, das características, da área de superfície e da curva de distribuição de tamanho da partícula de pigmento. Essa variedade de fatores invalida a adoção simplesmente do volume de pigmento para se chegar a um valor, ou seja, o processo é totalmente empírico.

A formulação de tintas líquidas de emulsão acrílica ou as cores de tubo exigem cuidados na seleção de pigmentos que sejam resistentes à alcalinidade. Uma forma de verificação é testar uma mistura de pigmento e água aplicada em uma nova superfície com alto conteúdo de cal antes de usá-lo em uma formulação. Se não houver mudança visível na coloração após 24 horas, o pigmento pode ser considerado resistente à alcalinidade.

Agentes antiespumantes também são necessários para minimizar a formação de espuma durante a aplicação das tintas de emulsão. $O$ tipo e a quantidade de agente depende tanto do tipo de veículo da emulsão de polímero usado quanto das propriedades do sistema inteiro. O nível varia entre $0,05 \%$ e 0,20\% e sua eficiência é ampliada ao

dividir o agente anti-espumante, incorporando metade na trituração com um anti-espumante e a outra metade, enquanto o sistema descansa, com um desespumante. Alguns dos agentes disponíveis são: Balab 748, Colloid 600, Foamicide 581 B e Nopco 1497V, NDW ou NXZ. Para a maioria dos

quantidade adicionada não é predeterminada, mas é conveniente usar de 2 a 3 gotas de uma solução de Acrysol GS diluída em água, na proporção de 6ํำ da pasta sólida.

Esta quantidade de aditivo iônico é suficiente para causar floculação visível ou até mesmo a transformação da tinta em uma 'matéria gelatinosa', se a quantidade de dispersante usada não foi suficiente.

Se ocorrer floculação na amostra do teste, dispersante adicional deve ser acrescentado na dispersão do pigmento principal. Outra pequena porção deve ser removida e testada da mesma maneira. O procedimento é repetido até que a alíquota não seja floculada pelo espessador. (...) Pode-se calcular a necessidade de dispersante do pigmento em questão a partir da quantidade total de dispersante usada." (TOZZI, 2001, p.126127).

${ }^{73}$ Essa relação refere-se à quantidade mínima de veículo necessária para formar uma quantidade contínua de aglutinante e para unir todas as partículas de pigmento firmemente na película de tinta seca. 
pintores, a espumação é considerada um problema porque quando a tinta seca com as bolhas de espuma forma-se uma espécie de crateras na película, no entanto, há profissionais que tiram partido disso e até mesmo intensificam 0 efeito com a adição em pequena quantidade de agentes umectantes como o Triton X-100. (TOZZI, 2001, p.129).

Para aumentar a viscosidade dos sistemas de tinta que contenham emulsões acrílicas e para que as cores de tubo de emulsão de polímero tenham uma determinada consistência, existem os espessantes poliacrílicos Acrysol GS e Acrysol ASE-60. O primeiro é uma "solução aquosa de 12,5\% de poliacrílico de sódio que proporciona composições de textura macia com excelente viscosidade quando usado com veículos de emulsão Rhoplex". O segundo,

é um espessante de baixa viscosidade de emulsão acrílica e ligação cruzada que contém ácido. Quando o Acrysol ASE-60 é diluído em água e neutralizado com uma base, cada partícula de polímero dilata-se e a emulsão torna-se altamente viscosa (...). Nas emulsões acrílicas, ele pode ser incorporado diretamente no sistema sem diluição ou neutralização para aprimorar a consistência. (TOZZI, 2001, p.129).

Agentes espessantes como o hidroxietil celulose, o metilcelulose e o carboximetil celulose também podem ser adicionados em pequenas quantidades às tintas de emulsão acrílica.

A secagem rápida é uma das vantagens da tinta de emulsão acrílica em relação à tinta a óleo, que pode levar meses para secar. Em alguns trabalhos, é necessário que esse tempo seja aumentado para que 0 artista possa trabalhar e misturar as cores livremente sem que a tinta do pincel, da paleta e da tela sequem rapidamente. Para esse fim são usados o etileno glicol e o propileno glicol como agentes provocadores de umidade que retardam a secagem. O propileno glicol é o mais indicado por razões de economia e de melhor secagem sob condições de alta umidade. ${ }^{74}$

Os fungos são outro problema que pode aparecer nas emulsões. Eles se proliferam rapidamente em meio às impurezas da superfície da tinta ou até mesmo quando essas impurezas são introduzidas acidentalmente no processo de fabricação. Como prevenção, deve ser usado um conservante na formulação da solução aquosa da tinta a fim de evitar "crescimento microbiológico no recipiente ou na superfície pintada (...). Sais de mercúrio de fenila são uma opção, mas muitos compostos de

\footnotetext{
${ }^{74}$ Ao contrário de muitos látex de polímero, a Rhoplex AC-22 pode receber grandes quantidades de propileno glicol permitindo a formulação de tintas com tempos de secagem maiores. (TOZZI, 2001, p.129).
} 
mercúrio são sensíveis ao sulfeto de hidrogênio e reagem com ele para produzir desbotamento preto ou marrom na película da tinta". Quadros pendurados em paredes de residências estão expostos ao sulfeto de hidrogênio proveniente da fumaça vinda da cozinha e as tintas de emulsão aplicadas ao ar livre também podem estar expostas a esse sulfeto, proveniente de operações industriais. Sendo assim, é prudente que sejam utilizados conservantes orgânicos como o Nicon P e o óxido de estanho tributil que "não apresentam mercúrio em sua composição e são resistentes ao bolor e à coloração do sulfeto quando usados em níveis de aproximadamente $1 \%$ nas formulações de tinta de emulsão Rhoplex." (TOZZI, 2001, p.131).

Películas de tinta mais firmes e com menos gomos podem ser obtidas quando em sua fórmula forem aumentados os níveis de pigmento ou incorporadas às emulsões acrílicas (Rholpex AC-22, AC-33 ou AC-34) pequenas quantidades de polímeros mais firmes, o que implica na necessidade de ajuste na proporção da concentração de dispersante. Os polímeros Rholpex também podem ser usados na fabricação de meio incolor de polímero acrílico, usado para dar transferência em vernizes, ou funcionar como um verniz de acabamento final. As emulsões de polímeros mais firmes, como a Rholpex AC-61 e a Rholpex AC-73, podem ser usadas como veladuras de verniz translúcido sobre pinturas, sem modificação do polímero, entretanto, "eles precisam de coalescentes, como por exemplo, Cellosolve butílico para formar película em temperatura ambiente." O meio sem brilho ou matte, pode ser preparado através da "tribulação de um agente como a sílica coloidal com veículos de emulsão Rhoplex AC-22, AC-33 e AC-34. O agente fornece massa de aparelhar suficiente para inibir a gomosidade própria da superfície que caracteriza as películas de aglutinante não modificado." (TOZZI, 2001, p.132).

\subsubsection{Produtos da Golden Artistic Colors e aplicações}

Para melhor demonstrar os avanços da indústria de cores artísticas de emulsão acrílica e o alcance de suas possíveis aplicações, passaremos a descrever sobre os produtos da indústria norte-americana Golden Artistic Colors, voltada à fabricação e ao desenvolvimento de pesquisas que abarcam grande variedade de tintas acrílicas e de demais produtos, como: géis, pastas de modelar, esmaltes, mediums, 
polímeros, aditivos, gessos e vernizes. Os materiais produzidos constituem um sistema acrílico único, em que todos são compatíveis entre si, o que possibilita ao artista, ao arquiteto e ao designer profissional uma infinidade de combinações e de possibilidades de aplicação que podem produzir resultados inovadores.

Encontram-se disponíveis no mercado as linhas: Heavy Body Acrylic Colors; Matte Acrylic Colors, Fluid Acrylic Colors, Matte Fluids, OPEN Acrylics, Acrylic Airbrush Color, Acrylic Glazes Colors, Fluorescent Acrylics, Phosphorescent Green, Géis and Mediums, Molding Pastes, Special Purpose Acrylic Polymers, Aditives, Gessos and Grounds, Varnishes, além de produtos exclusivos e de produtos fornecidos exclusivamente para uso profissional.

1 - HEAVY BODY ACRYLIC COLORS: foi a primeira linha de produtos lançada pela empresa em 1980. É a linha original de tintas acrílicas, lisa e com consistência espessa. É mais flexível quando seca, permitindo uma aplicação mais grossa, o que reduz o risco da pintura quebrar. Nela, há a maior variedade de pigmentos originais puros em um veículo de emulsão 100\% acrílica. Apresenta excelente permanência e resistência à luz. Não apresenta cargas, extensores, opacificantes, toners ou corantes adicionados. Cada cor é formulada de modo diferente, dependendo da natureza do pigmento. No caso das cores que toleram mais pigmento (carga) apresentam um acabamento fosco, enquanto as que são mais reativas e não aceitam carga elevada de pigmento são mais brilhantes, com tendência à transparência. Não contém aditivos, fazendo com que cada cor apresente um brilho diferente. A linha totaliza 102 cores.
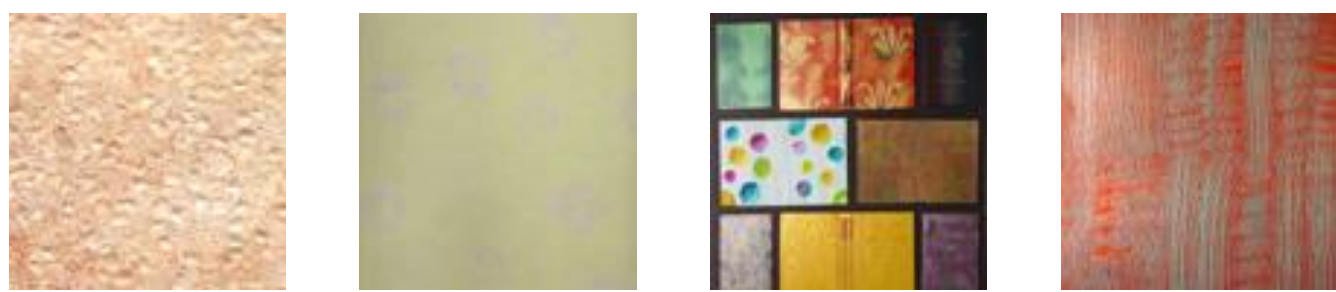

Figuras 188, 189, 190 e 191: Exemplos de aplicação da Heavy Body Acrylic Colors. Fonte: <http://www.goldenpaints.com/technicaldata/techniques/library/index.php>. Acesso em 18/03/2010. 
Heavy Body Acrylic Neutral Grays: são cinzas neutros formulados de acordo com o Sistema Munsell de Cores ${ }^{75}$.

\begin{abstract}
Eles são Achromatic, significando que eles não têm tonalidades distinguíveis ou chroma, mas valor apenas. (...) Branco e preto representam os dois extremos de valor. Misturá-los em conjunto, produzem um cinza; se é ou não é um cinza neutro depende dos pigmentos utilizados. Na maioria dos casos, um verdadeiro neutro não será produzido, que provavelmente vai mudar no sentido de uma direção de hue e / ou chroma (ou seja mais quentes ou frios). Os cinzas foram ajustados para ficar absolutamente neutros. (GOLDENPAINTS.COM, 2010, tradução nossa).
\end{abstract}

Os cinzas neutros (black bone e branco de titânio) são usados para criar estudos sem chroma ou matiz. Para estudos monocromáticos, pode ser adicionada a eles qualquer cor. ${ }^{76}$
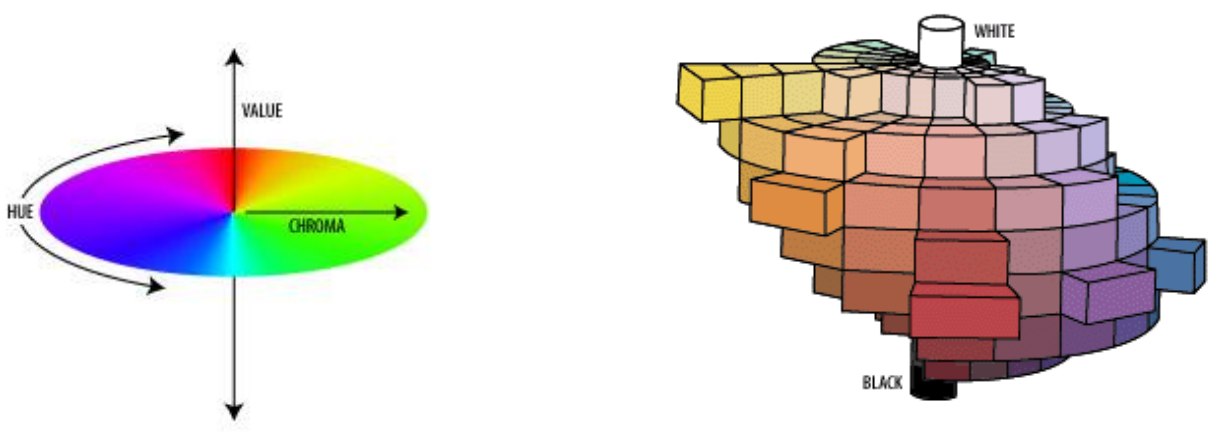

Figuras 192 e 193: Sistema Munsell de Cores. Fonte: $<$ http://dba.med.sc.edu/price/irf/Adobe_tg/models/munsell.html>. Acesso em $27 / 03 / 2010$.

Heavy Body Acrylic Hues: é uma recriação dos pigmentos, usados por centenas de anos nas paletas de grandes artistas, os quais foram considerados perigosos ou vulneráveis aos efeitos da luz e do clima. Aquelas cores foram recriadas com resistência à luz, segurança na utilização e permanência.

Heavy Body Acrylic Iridescent Colors: é um dos produtos mais recentes, os quais oferecem reflexivas variações metálicas. Propriedades reflexivas são reproduzidas sinteticamente: a nacarada ou a perolada, qualidades encontradas em escamas de peixe ou o pó de asa de uma borboleta, e as qualidades: brilhante e reflexiva,

\footnotetext{
${ }^{75}$ O Sistema Munsell de Cores, desenvolvido pelo artista norte-americano Albert Henry Munsell foi publicado em 1915 e é internacionalmente utilizado para a especificação de cores (colorimetria). A definição das cores estão baseadas em componentes do sistema denominados: matiz, valor e croma. TECHNICAL GUIDES. The Munsell Color System. 2000. Disponível em: <http://dba.med.sc.edu/price/irf/Adobe_tg/models/munsell.html>. Acesso em $27 / 03 / 2010$.

${ }^{76}$ Segundo dados publicados no catálogo e no site do fabricante, quando diversas cores são adicionadas na mesma proporção do mesmo cinza neutro, serão produzidas cores com valores semelhantes.
} 
encontradas em certos metais e minerais. As cores iridescentes "grosseiras" são versões de partículas maiores de pigmento. Essa linha pode ser preparada em três grupos de composição química:

Grupo I: Essas cores são derivadas de plaquetas de mica. Em seguida, são revestidos com uma camada muito fina de dióxido de titânio. Refração e reflexão da luz nas camadas de dióxido de titânio produzem várias cores e efeitos perolados. Grupo I inclui o pigmento iridescente Pearl (finos e grossos).

Grupo II: Essas cores também são derivadas de plaquetas de mica, mas um revestimento de óxido de ferro faz com que os pigmentos Grupo II possuam tonalidades, além de qualidades peroladas. Este grupo inclui iridescente Gold (finos e grossos), iridescente de cobre e cobre Light (finos e grossos), e iridescente Bronze.

Grupo III: Um terceiro grupo é composto por corantes reflexivos que não se encaixam nas descrições acima, incluindo os pigmentos altamente metálicos. Este grupo inclui Stainless Steel (finos e grossos), óxido de ferro micáceo, e Mica Flakes (todas as variedades). (GOLDENPAINTS.COM, 2010 tradução nossa).
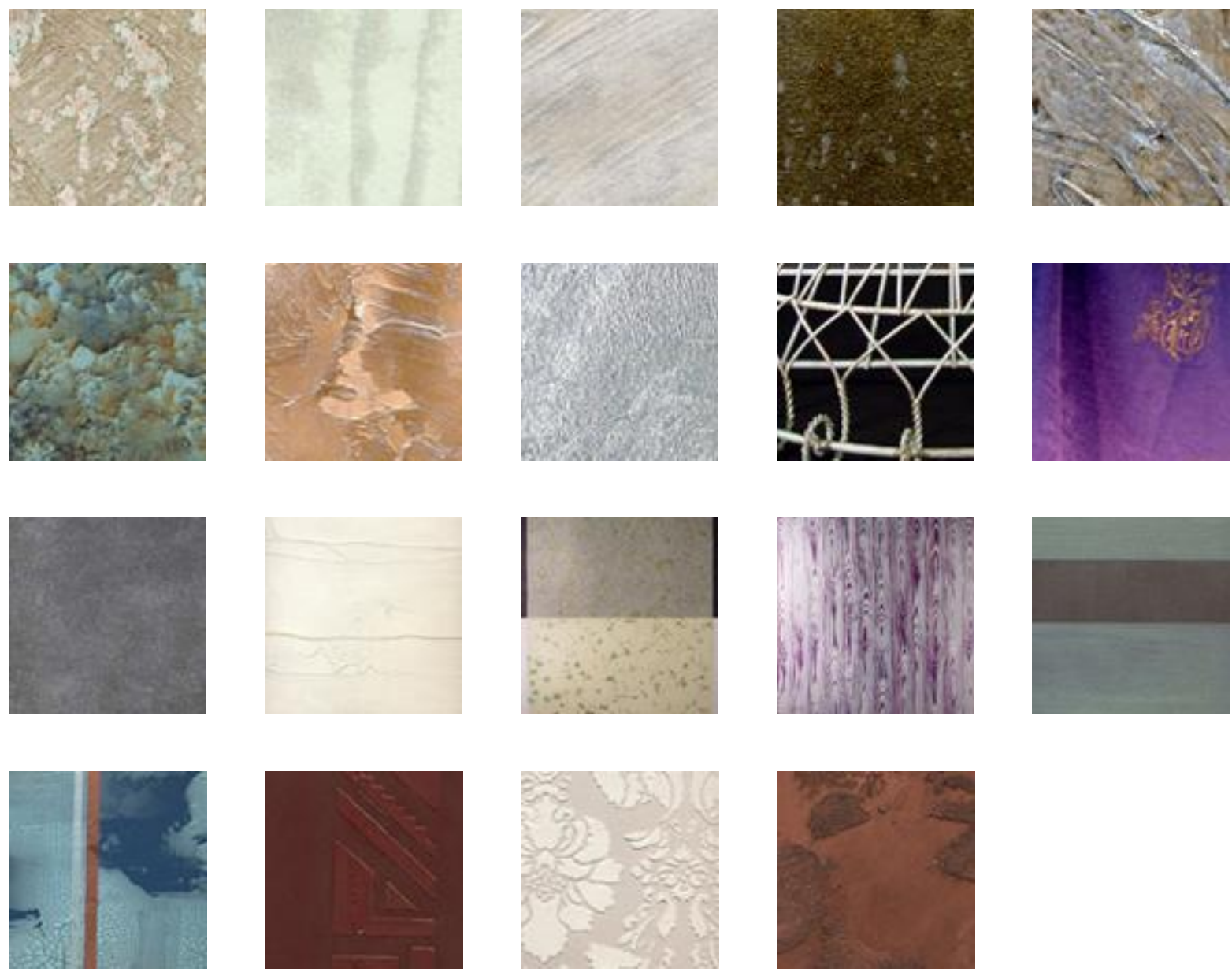

Figuras 194, 195, 196, 197, 198, 199, 200, 201, 202, 203, 204, 205, 206, 207, 208, 209, 210, 211 e 212 :

Exemplos de aplicação Heavy Body Acrylic Iridescent Colors. Fonte:

<http://www.goldenpaints.com/technicaldata/techniques/library/index.php>. Acesso em: 18/03/2010. 
Heavy Body Acrylic Interference Colors: são cores em que, quando vistas a partir de perspectivas diferentes, percebe-se um efeito chamado "flip de cores de interferência" que ocorre entre uma cor opalescente brilhante e seu complemento. "Quando aplicado sobre superfícies brancas ou claras, a cor de interferência é menos óbvia e o efeito 'flip' é mais evidente. Quando aplicado sobre superfícies escuras ou preto, a cor de interferência é mais evidente e o efeito 'flip' é menos evidente. A maioria das cores estão disponíveis em duas variedades: grosso e fino. Eles oferecem uma gama de propriedades de reflexão e interação com a luz." Essas cores são relativamente transparentes. (GOLDENPAINTS.COM, 2010).
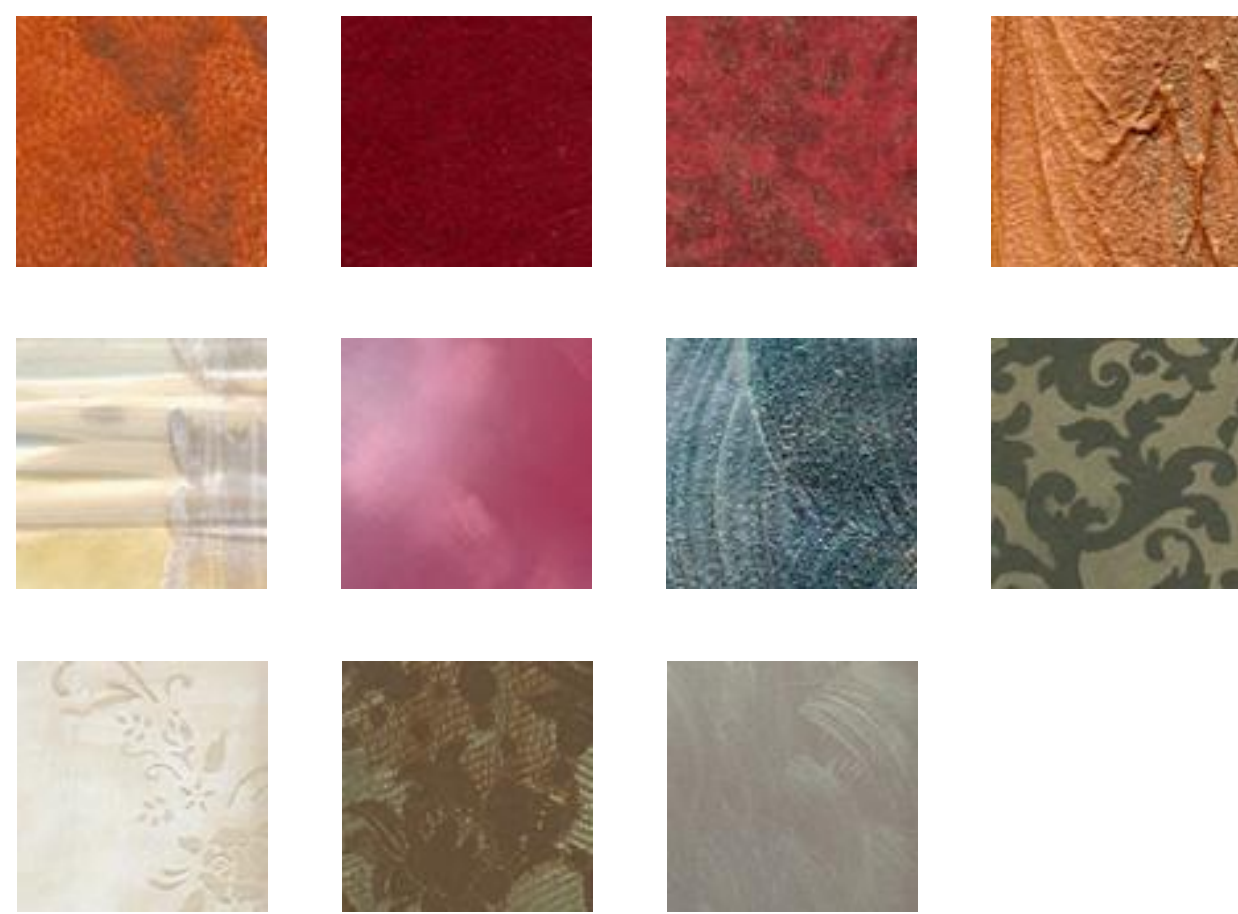

Figuras 213, 214, 215, 216, 217, 218, 219, 220, 221, 222 e 223 : Exemplos de aplicação do Heavy Body Acrylic Interference Colors. Fonte:

<http://www.goldenpaints.com/technicaldata/techniques/library/index.php>. Acesso em 18/03/2010.

2 - MATTE ACRYLIC COLORS: fornecem um acabamento uniforme e apagado em uma grande variedade de cores de pigmentos concentrados. Quando adicionado o Matte Medium à tinta acrílica será produzida uma superfície fosca, combinação que sempre diminuirá o brilho e reduzirá a intensidade da cor. "Para evitar essa perda de força de cor, Matte Acrylics são formulados com um agente de esteira e um nível de pigmento comparável ao Golden Heavy Body Acrylic." (GOLDENPAINTS.COM, 2010). 
3 - FLUID ACRYLIC COLOR: apresenta uma fórmula similar aos produtos da linha Heavy Body Acrylics, a diferença está no ponto de viscosidade ou consistência em que a tinta é finalizada. A carga de pigmento ou a intensidade de cor também são semelhantes à linha Heavy Body.

Os Acrílicos Fluidos contém níveis elevados de pigmentos suspensos em um veículo de polímeros acrílicos. O resultado oferece uma dispersão fina, tingimento de alta resistência, durabilidade, flexibilidade e boa aderência. São ideais para pulverização, escova, coloração, e podem ser misturados facilmente com géis, mediums, gessos e fundos. Quando mesclados com Airbrush Medium tornam-se aplicáveis em spray, através do uso de aerógrafos. No que se refere à Fluid Interference Colors, o que a difere da linha Heavy Body é a adição às cores de interferência padrão de outras três cores chamadas "Color Travel Interference" (verde-azul, verde-laranja, violeta-verde) que mudam dramaticamente quando observadas de ângulos diferentes, revelando tons múltiplos entre dois pontos do espectro. (GOLDEN, 2009, tradução nossa).
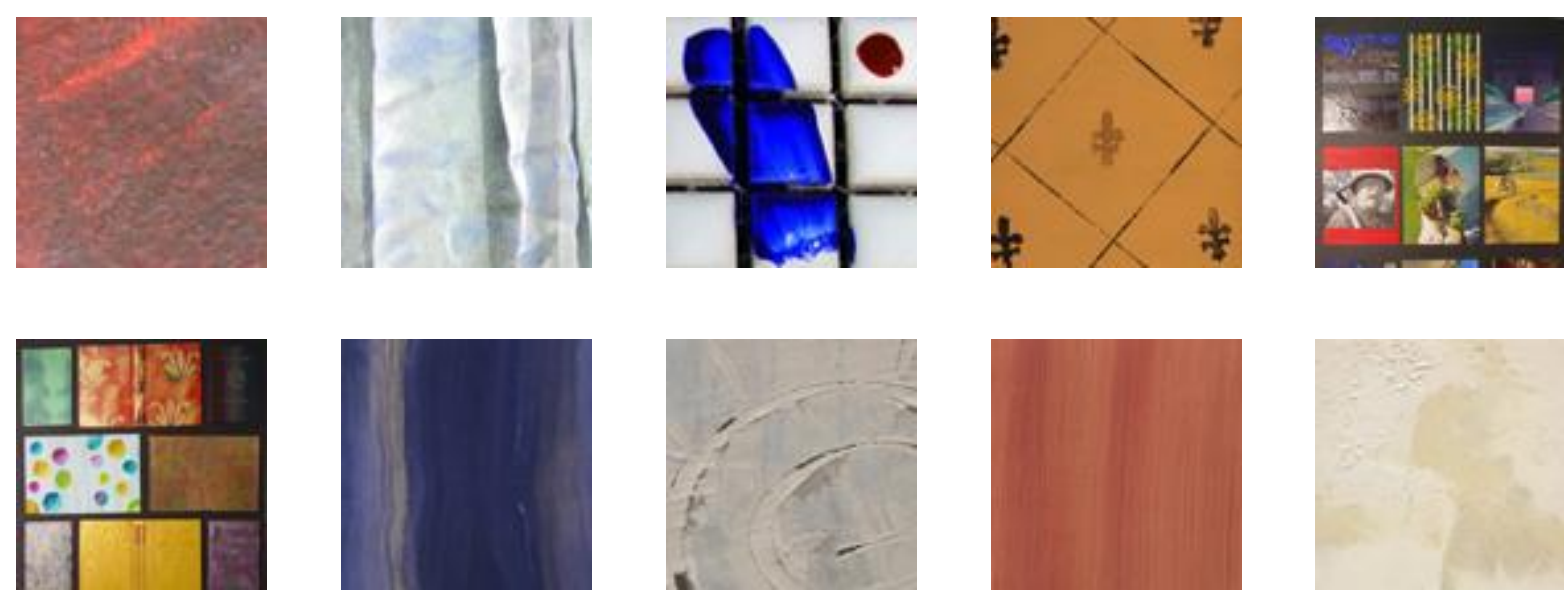

Figuras: 224, 225, 226, 227, 228, 229, 230, 231, 232 e 233: Exemplos de aplicação do Fluid Acrylic Color. Fonte:< http://www.goldenpaints.com/technicaldata/techniques/library/index.php>. Acesso em 18/03/2010.

4 - MATTE FLUIDS: são mais espessos que os Fluid Acrylics, porém, são produzidos para que possam se autonivelar, de modo que as películas fiquem mais uniformes, sem a necessidade de pinceladas. São pouco brilhantes e mais opacos que os fluidos em geral, o que torna sua aplicação ideal para técnicas tradicionais como a têmpera e o guache.

5 - OPEN ACRYLICS: é uma linha nova de cores e mediums, para artistas profissionais, desenvolvida com características únicas que aumentam drasticamente a gama de técnicas disponíveis. São formulados com um ótimo equilíbrio de carga de pigmento e uma dispersão de polímeros acrílicos de 100\% para produzir um 
conjunto de características amplas de trabalho e uma versatilidade que permite explorar uma ampla gama de técnicas voltadas à pintura de retratos e de paisagens que requerem técnica para suavizar, matizar, envernizar e criar pequenos detalhes. São resistentes à criação de nata por permanecerem molhados na paleta por longos períodos, o que permite que sejam usados diretamente do tubo em pinturas ao ar livre, monoimpressos e estampas serigráficas. Podem ser mesclados com outros Golden Acrylic Colors, mediums e géis, com o tempo de trabalho das misturas proporcionalmente reduzido. Para obter o máximo tempo de trabalho dos OPEN Acrylics, recomenda-se o uso de mediums e diluentes OPEN.

6 - ACRYLIC AIRBRUSH COLORS: linha dedicada ao sistema de pintura aplicada por aerógrafo, pincel e caneta técnica. Preserva a intensidade, a pureza e a resistência à descoloração das linhas Heavy Body. Oferece a capacidade de criar cores opacas de alta intensidade para fins de ilustração e de arte. As cores são formuladas para que sua aplicação seja livre de aglutinamentos, com o uso de emulsão de polímero acrílico de $100 \%$ incorporando apenas os pigmentos mais resistentes à luz disponíveis, o que proporciona permanência e desempenho excepcionais.

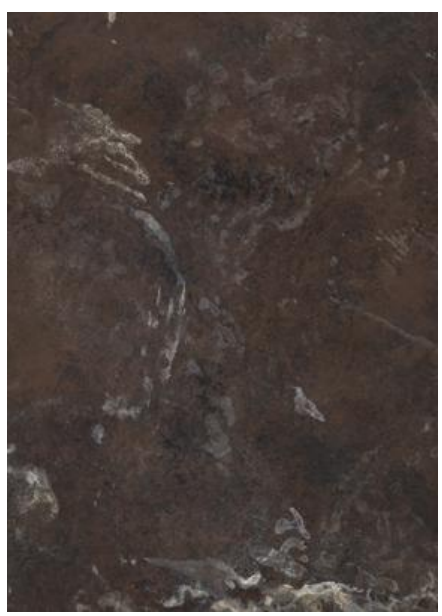

Figura 234: Exemplo de aplicação do Acrylic Airbrush Colors. Fonte: <http://www.goldenpaints.com/technicaldata/techniques/library/index.php>. Acesso em 18/03/2010.

Airbrush Titanium White: formulado para maximizar a opacidade e manter a qualidade da pulverização e da integridade do filme. Isso resulta no branco mais opaco. As demais cores são formuladas para atingir a força máxima da cor o que resulta em cores com diferentes níveis de opacidade em função da natureza do pigmento. 
Airbrush Transparente Extender: pode ser adicionado ao Airbrush Colors para produzir cores mais transparentes sem comprometer a integridade do filme e a permanência. Ao diminuir a carga de pigmento, adicionando o Extender, aumenta a durabilidade do filme e a performance do equipamento.

7 - ACRYLIC GLAZES COLOURS: os glazes ou esmaltes são mesclas de cores de secagem lenta. Suas propriedades são diferentes dos acrílicos comuns de secagem rápida, com o objetivo de permitir ao artista um maior tempo para a aplicação de películas de esmalte e para a harmonização das cores. São 40 opções de cores, incluindo as metálicas, nacaradas e opalinas, que podem ser mescladas entre si. São usados em artes decorativas e em obras de arte. Nas artes decorativas, podem ser aplicados em paredes, tetos, vidraças, madeiras e mobiliário.
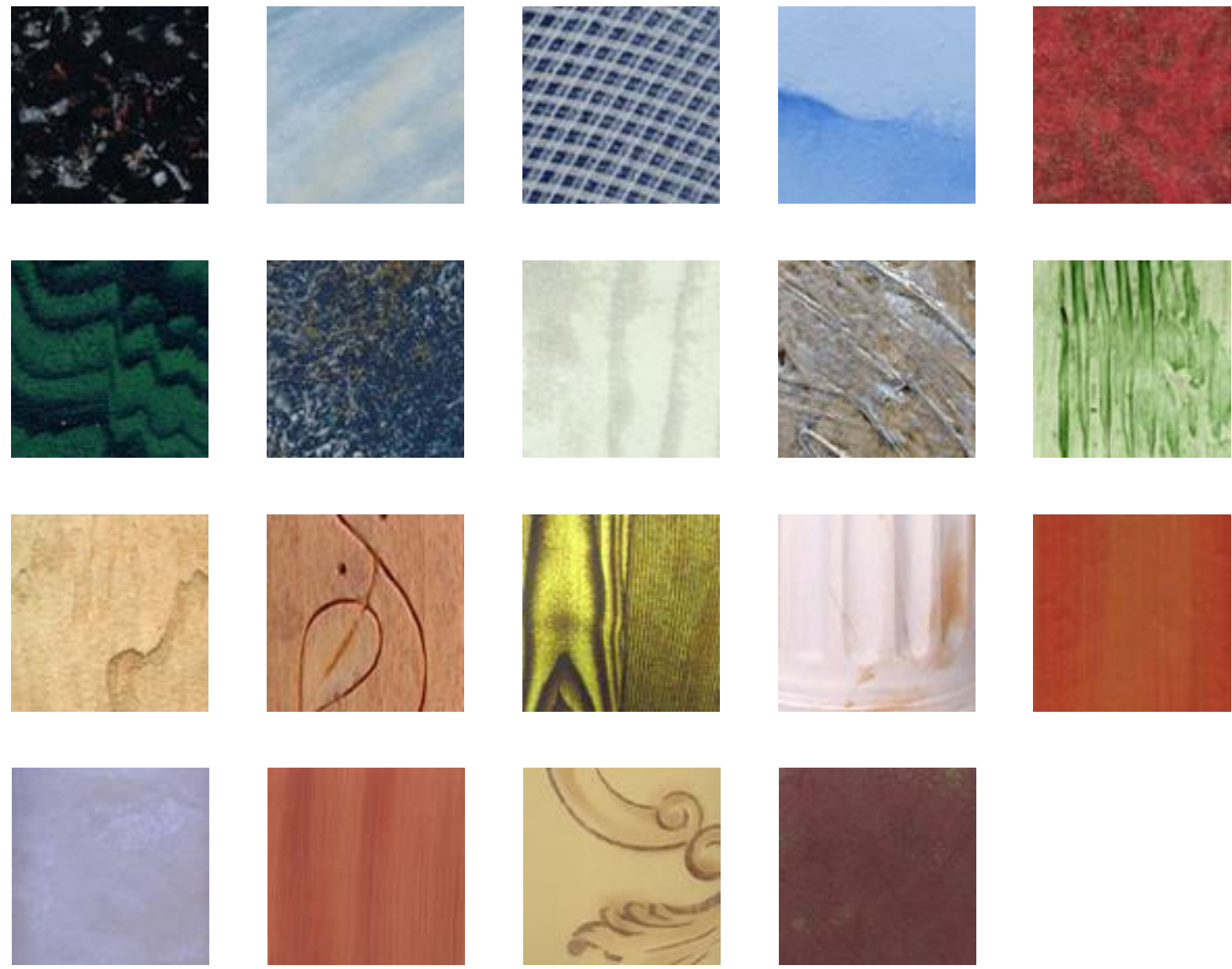

Figuras: 235, 236, 237, 238, 239, 240, 241, 242, 243, 244, 245, 246, 247, 248, 249, 250, 251, 252 e 253 : Exemplos de aplicação do Acrylic Glazes Colours. Fonte:

<http://www.goldenpaints.com/technicaldata/techniques/library/index.php>. Acesso em 18/03/2010. 
8 - FLUORESCENT ACRYLIC COLOR: as cores são intensas e brilhantes, produzidas a partir de corantes rodeados por uma camada de polímero. Por serem muito transparentes, uma maior intensidade pode ser alcançada se for aplicada sobre superfície branca brilhante. Não são resistentes à descoloração. Para uma maior permanência, deve ser aplicado um acabamento de verniz MSA com UVLS (Estabilizador de Luz Ultravioleta), embora haja uma redução do brilho fluorescente.

9 - PHOSPHORESCENT GREEN ACRYLIC COLOR: é um meio acrílico à base de água que pode ser aplicado em diversas superfícies. Formulado com um pigmento único, caracteriza-se por sua capacidade de absorver e armazenar a luz natural e artificial. Quando a fonte de luz é removida, um brilho esverdeado é emitido por até 15 minutos. É possível que seja mesclado com produtos fluorescentes para obter uma variedade de cores fosforescentes, no entanto, haverá uma redução do brilho. Não é resistente à descoloração.

10 - GELS and MEDIUMS: apresentam uma ampla variedade de consistências, transparências e acabamentos. Podem ser usados para criar esmaltes, prorrogar o tempo de pinturas, criar texturas, ajustar o brilho e como agente aglutinante para colagens. Não é recomendada a aplicação em imagens.
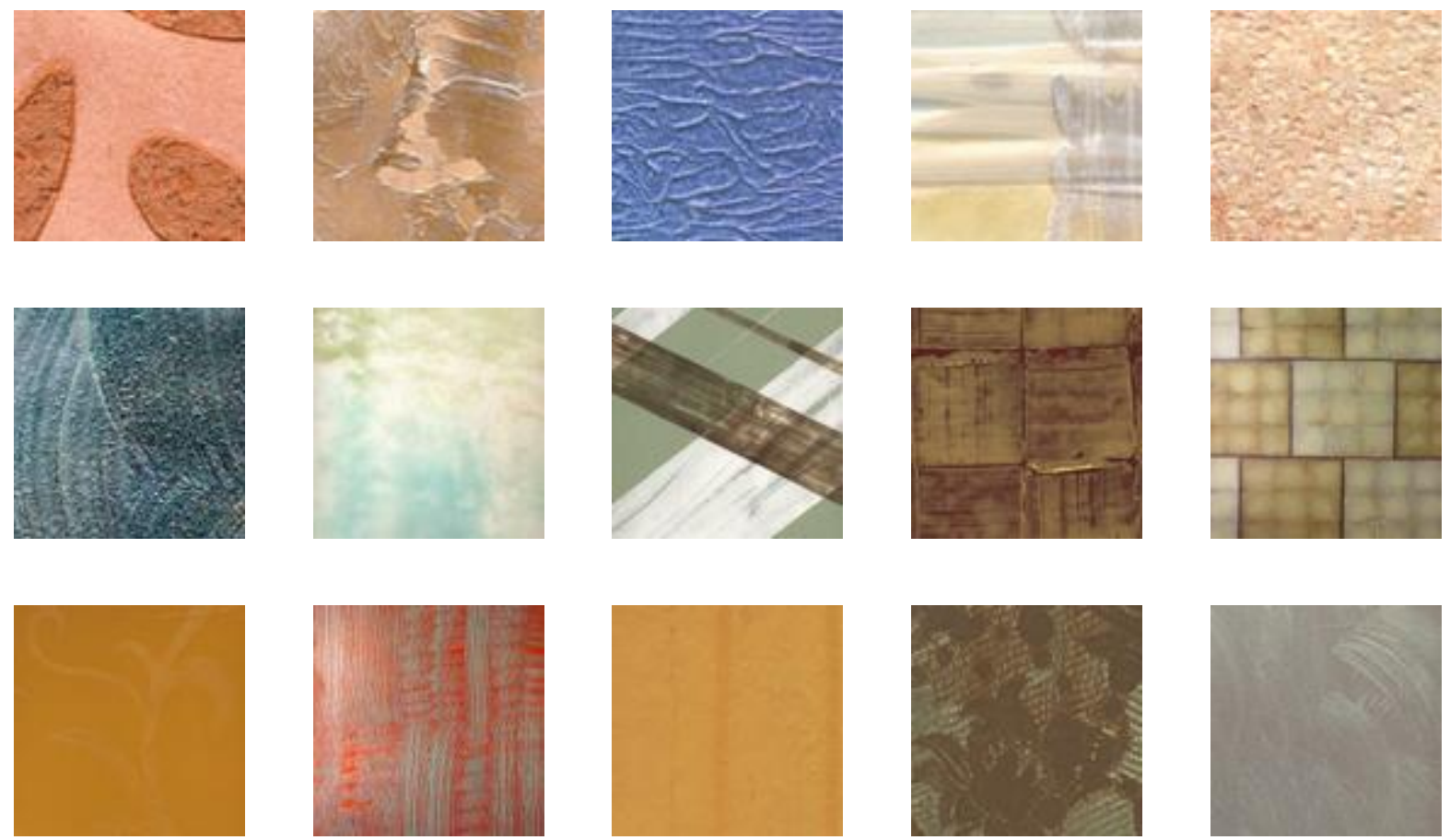

Figuras 254, 255, 256, 257, 258, 259, 260, 261, 262, 263, 264, 265, 266, 267 e 268: Exemplos de aplicação de Gels e Mediums.

Fonte: <http://www.goldenpaints.com/technicaldata/techniques/library/index.php>. Acesso em 18/03/2010. 
Self-Leveling Clear Gel: é o mais fino de todos, desenvolvido para criar uma película uniforme de alta claridade. Quando seco, produz uma película flexível e de alto brilho, ao mesmo tempo transparente e nivelada.

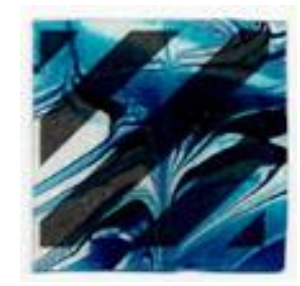

Figura 269: Exemplo de aplicação do Self-Leveling Clear Gel. Fonte: <http://www.goldenpaints.com/technicaldata/techniques/library/index.php>. Acesso em 18/03/2010.

Clear Tar Gel: projetado para produzir a consistência do fio de alcatrão, mas sem cor. É útil para produzir linhas detalhadas ou para ser espalhado sobre superfícies através de espátulas ou de outras ferramentas do artista. Combina com todas as cores acrílicas, particularmente as Fluid Acrylics. A mistura deve descansar um pouco para que as bolhas de espuma emerjam à superfície.

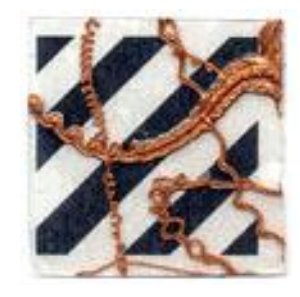

Figura 270: Exemplo de aplicação do Clear Tar Gel. Fonte:

<http://www.goldenpaints.com/technicaldata/techniques/library/index.php>. Acesso em 18/03/2010.

Soft Gels: são mais finos do que as cores da Heavy Body Acrylics. Quando são misturadas com uma pequena quantidade de cor, produzem um esmalte brilhante. Podem ser usados como uma base para uma mistura úmida de cor e funciona como uma goma para colagens. O Soft Gel tipo Gloss pode ser diluído em água e aplicado com um pincel como camada permanente e não removível de isolamento antes de aplicar a camada final de verniz removível. Eles são translúcidos quando secos.
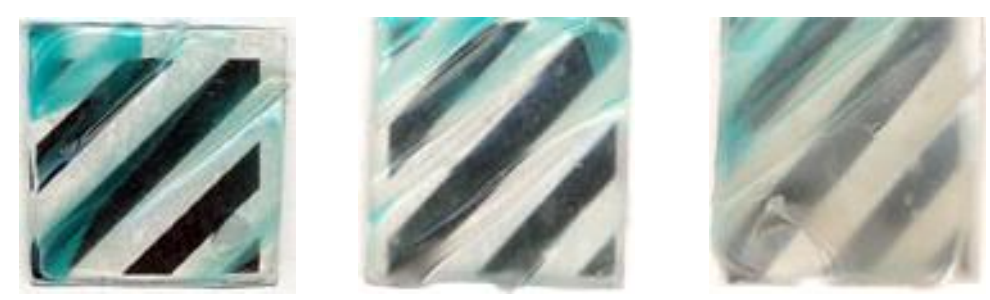

Figuras 271, 272 e 273: Exemplos de aplicação do Soft Gel (Gloss), Soft Gel (Semi-Gloss) e Soft Gel (Matte). Fonte: <http://www.goldenpaints.com/technica Idata/techniques/library/index.php>. Acesso em 18/03/2010. 
Regular Gels: são cremosos, como os Heavy Body Acrylics e ideais para a ampliação da pintura e para regular a transparência sem alterar a consistência dos Heavy Body. São úteis para efeitos de aplicação de esmalte em obras de enchimento e ficam translúcidos quando secos.
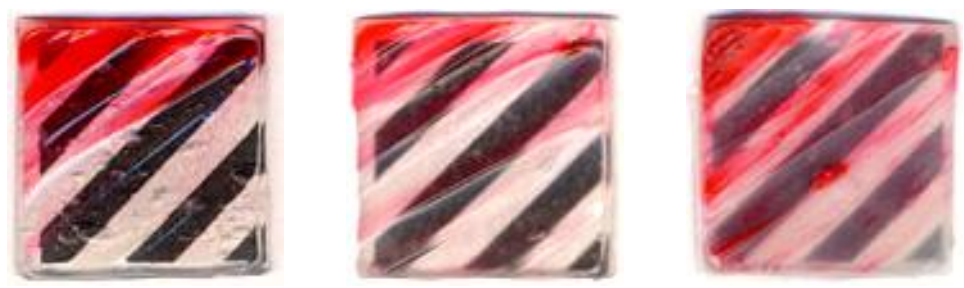

Figuras 274, 275 e 276: Exemplos de aplicação do Regular Gel (Gloss), Regular Gel (Semi-Gloss) e Regular Gel (Matte). Fonte: $<$ http://www.goldenpaints.com/technicald ata/techniques/library/index.php>. Acesso em 18/03/2010.

Heavy Gels: são mais grossos do que os Heavy Body Acrylics. Podem ser combinados com outras cores para aumentar a espessura. São excelentes para a realização de picos criados com a pintura e ficam translúcidos quando secos.
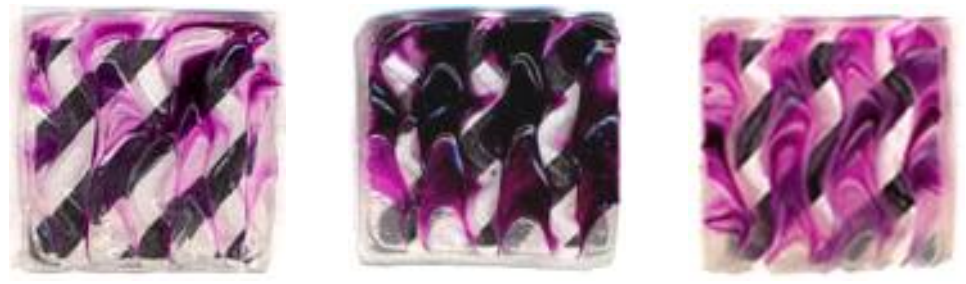

Figuras 277, 278 e 279: Exemplos de aplicação do Heavy Gel (Gloss), Heavy Gel (Semi-Gloss) e Heavy Gel (Matte). Fonte:

$<$ http://www.goldenpaints.com/technicald ata/techniques/library/index.php>. Acesso em 18/03/2010.

Extra Heavy Gels: juntamente com os High Solid Gels é o mais denso de todos, com uma textura mais densa que a dos Heavy Gels. São excelentes para a manutenção de topos e ficam translúcidos quando secos.
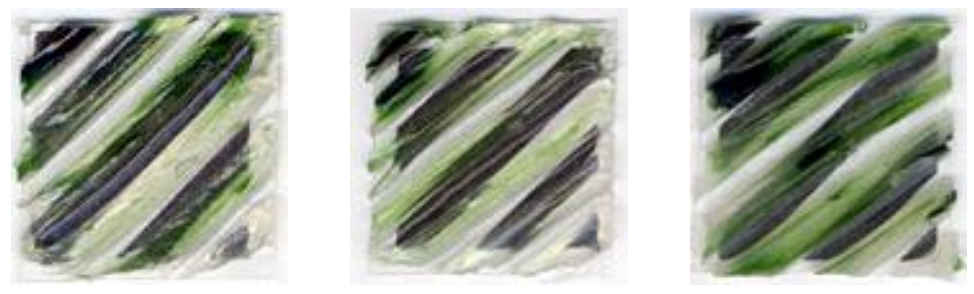

Figuras 280, 281 e 282: Exemplos de aplicação do Extra Heavy Gel (Gloss), Extra Heavy Gel (Semi-Gloss) e Extra Heavy Gel (Matte). Fonte: $<$ http://www.goldenpaints.com/technica Idata/techniques/library/index.php >. Acesso em 18/03/2010.

High Solid Gel: a espessura é semelhante à dos Extra Heavy Gels porque eles contêm menos água e maior quantidade de sólidos acrílicos e encolhem menos que os outros. Combinam bem com outras cores e retêm as pinceladas quando secos. Esse recurso é aplicado quando o artista deseja que uma pintura em tinta acrílica se comporte como pinturas a óleo. Na secagem, os High Solid Gloss são muito brilhantes, enquanto os High Solid Matte produzem um acabamento opaco, com consistência parecida com a cera. 

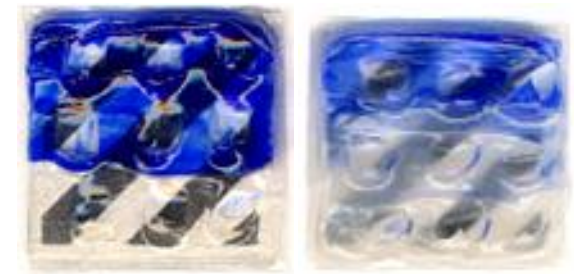

Figuras 283 e 284: Exemplos de aplicação do High Solid Gel (Gloss) e High Solid Gel (Matte). Fonte: <http://www.goldenpaints.com/technicaldata/techniques/library/index .php>. Acesso em 18/03/2010.

Clear Granular Gel: feito de acrílicos sólidos granulares e transparentes, tem uma excelente claridade e durabilidade. Oferece consistência e resistência semelhantes ao Extra Coarse Pumice Gel. Como o Clear Granular é translúcido quando seco, pode ser usado para ampliar a pintura e adicionar textura sem alterar a cor.

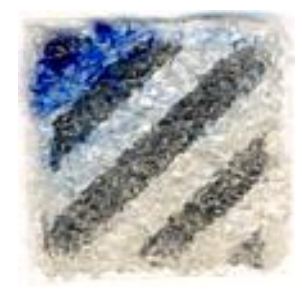

Figura 285: Exemplo de aplicação do Clear Granular Gel. Fonte: <http://www.goldenpaints.com/technicaldata/techniques/library/index.php>. Acesso em 18/03/2010.

Fine Pumice Gels: oferece diversos níveis de texturas grossas que secam produzindo películas duras. Para aumentar a flexibilidade e a aderência, recomendase que sejam misturados com outros géis ou mediums. Combinam bem com cores acrílicas. O Fine Pumice $\mathrm{Gel}$ é usado para criar superfícies finas com textura e também é útil como base para pinturas em pastel. O Coarse Pumice Gel (Gel de Pedra Pomes Grosso) e o Extra Coarse Pumice Gel (Gel de Pedra Pomes Extra Grosso) produzem texturas granulares mais grossas semelhantes ao cimento.
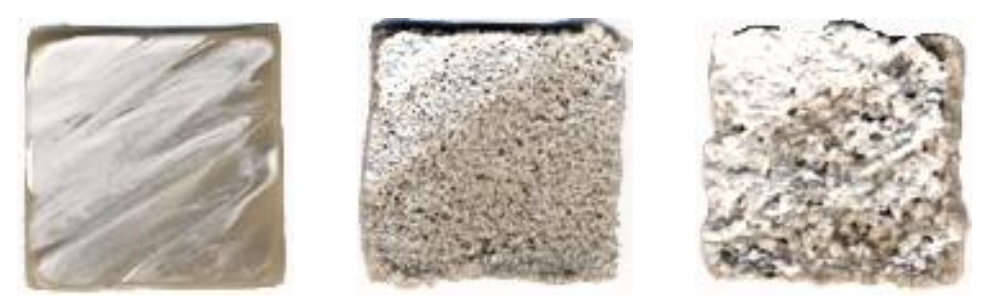

Figuras 286, 287 e 288: Exemplos de aplicação do Fine Pumice Gel, Coarse Pumice Gel e Extra Coarse Pumice Gel. Fonte: $<$ http://www.goldenpaints.com/technica Idata/techniques/library/index.php>. Acesso em 18/03/2010.

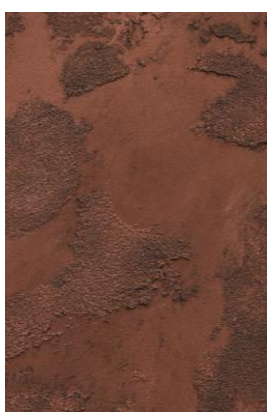

Figura 289: Exemplo de aplicação do Fine Pumice Gel. Fonte: <http://www.goldenpaints.com/technicaldata/techniques/library/index.php>. Acesso em 18/03/2010. 
Glass Bead Gels: são feitos com contas de vidro especiais que oferecem um efeito visual único. São mais visíveis em películas finas, as quais permitem que as contas de vidro se iluminem contra um fundo de cor.

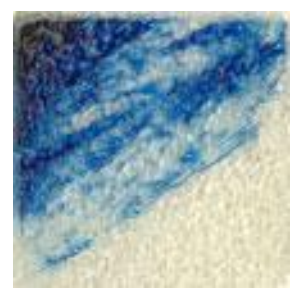

Figura 290: Exemplo de aplicação do Glass Bead Gel. Fonte: $<$ http://www.goldenpaints.com/technicaldata/techniques/library/index.php>. Acesso em 18/03/2010.

Gel Topcoat w/UVLS: é uma capa final, não removível, de polímero acrílico à base de água, muito útil para proteger impressos, papéis e outros materiais contra os efeitos daninhos dos raios ultravioleta do sol.

11 - MOLDING PASTE: ao secar produz uma camada dura e opaca, mas continua sendo flexível, porém, mais rígida que os géis. Retém os topos com muita firmeza para criar superfícies de muita textura.
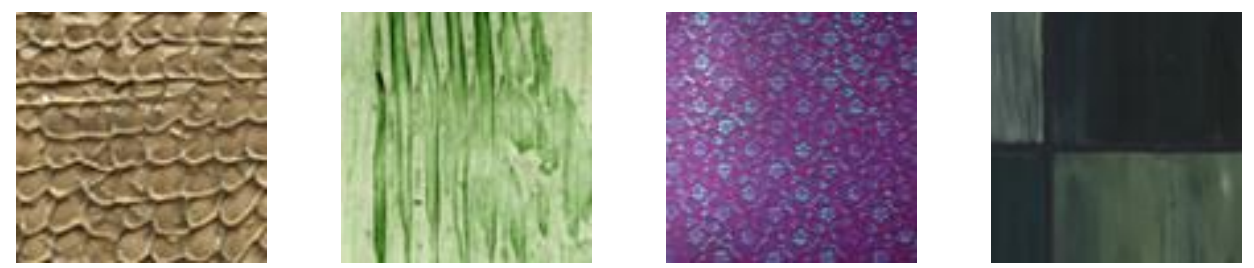

Figuras 291, 292, 293 e 294: Exemplos de aplicação do Molding Paste. Fonte: <http://www.goldenpaints.com/technicaldata/techniques/library/index.php>. Acesso em $18 / 03 / 2010$.

Extra Heavy Gel / Molding Paste: é uma mescla de Extra Heavy Gel e argila para produzir, quando seco, um acabamento acetinado semiopaco. Combina com outras cores e é ideal para aumentar a viscosidade e adicionar camadas para aumentar a espessura da superfície.

Fiber Paste: proporciona uma película áspera com aparência de papel feito à mão. Se espalhada com uma espátula molhada pode alcançar uma superfície lisa. Quando seca, a cor é branca e altamente absorvente. Ideal para aguadas de pintura acrílica.

Crackle Paste: consistente e opaca, foi desenvolvida para criar rachaduras e fissuras quando seca. O tamanho e a extensão do efeito craquelado depende da espessura da camada aplicada e das condições ambientais. 

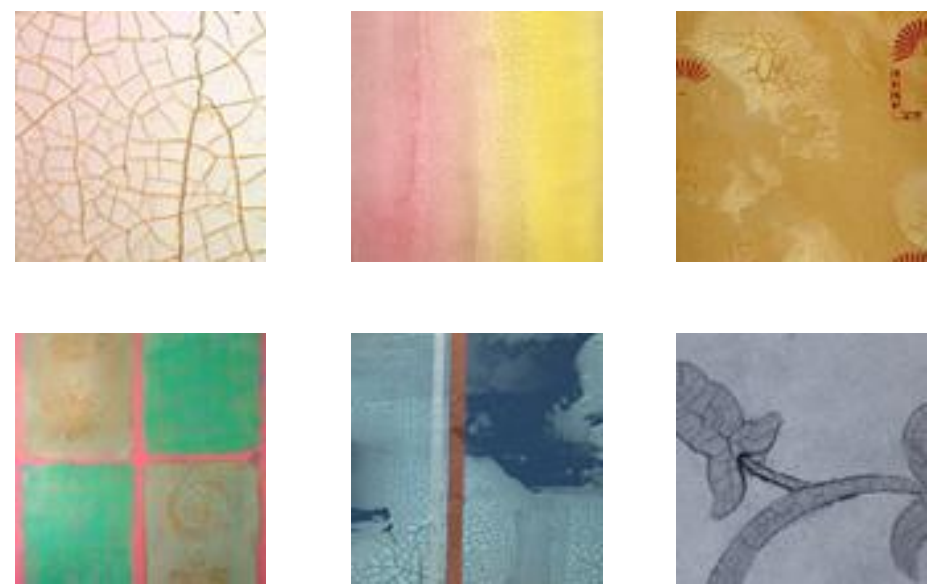

Figuras 295, 296, 297, 298, 299 e 300: Exemplos de aplicação da Extra Heavy Gel / Molding Paste, Fiber Paste e Crackle Paste. Fonte: <http://www.goldenpaints.com/technicaldata/techniques/library/in dex.php>. Acesso em 18/03/2010.

Light Molging Paste: apresenta reduções de peso significativas quando aplicada em espessas camadas de acrílico. Quando seca, seu aspecto é opaco. É mais suave que a Molding Paste e é extremamente flexível. Pode ser usada para reter topos e criar superfícies com muita textura.
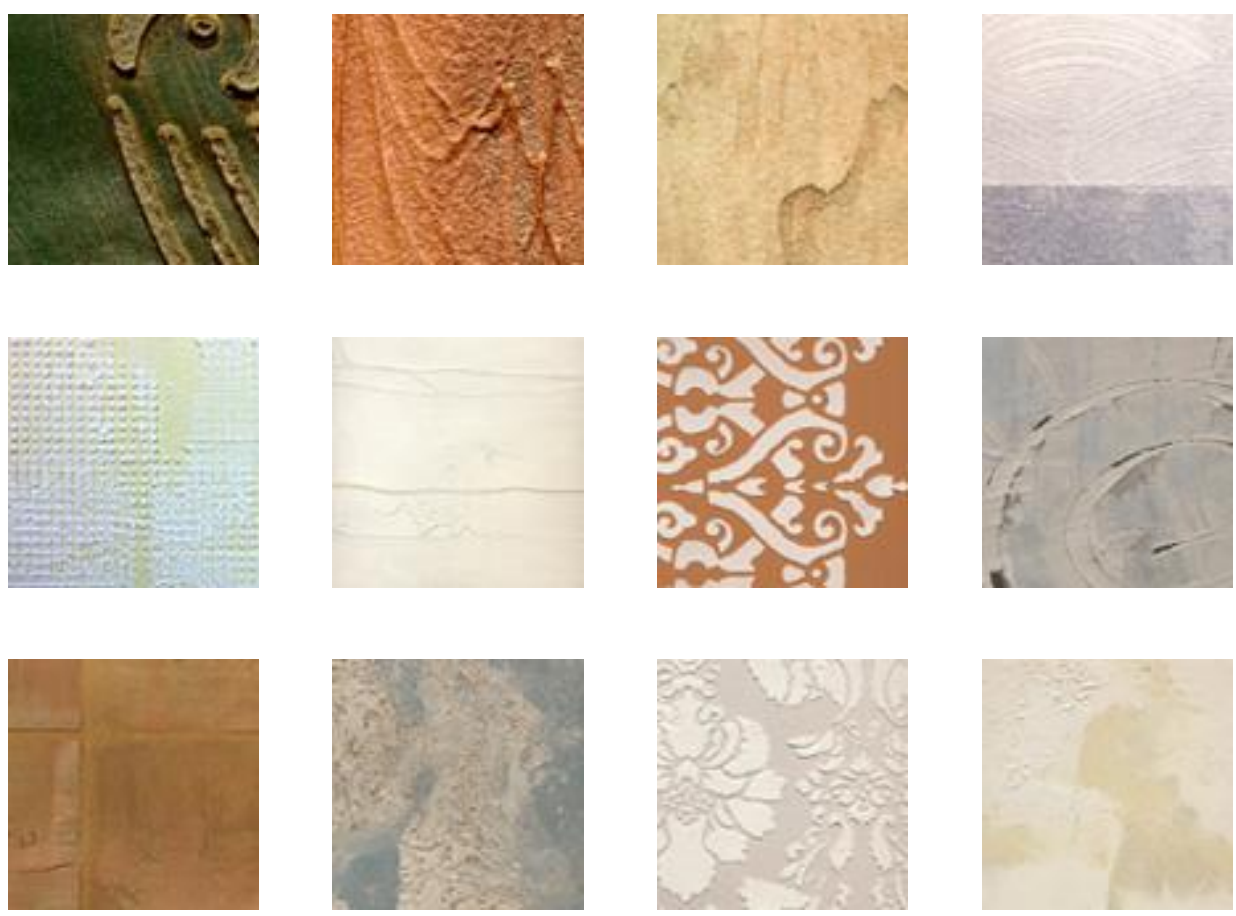

Figuras 301, 302, 303, 304, 305, 306, 307, 308, 309, 310, 311 e 312: Exemplos de aplicação da - Light Molging Paste. Fonte: <http://www.goldenpaints.com/technicaldata/techniques/library/index.php>. Acesso em 18/03/2010. 
Hard Molding Paste: proporciona um acabamento opaco, a mais dura de todas. Combina com as cores acrílicas e é ideal para acabamentos duros e duráveis sobre superfícies lisas ou com texturas. Quando seca, a dura película pode ser talhada a mão ou com tornos elétricos.
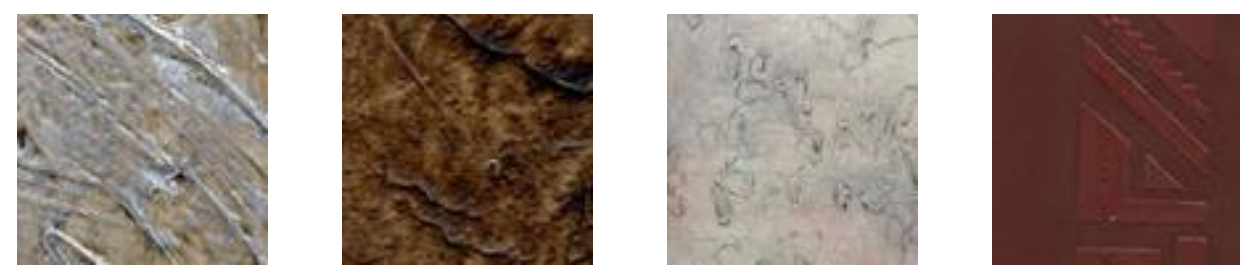

Figuras: 313, 314, 315 e 316: Exemplos de aplicação do Hard Molding Paste. Fonte: <http://www.goldenpaints.com/technicaldata/techniques/library/index.php>. Acesso em 18/03/2010.

Coarse Molding Paste: espessa e de cor branco quente, translúcida quando espalhada em uma camada fina. Quando seca, cria uma superfície dura e rígida, porém, flexível como uma folha de lixa fina. A película seca aceita mediums secos e úmidos.

\section{2 - MEDIUMS:}

Polimer Medium Gloss: meio líquido de uso geral, muito útil para criar esmaltes, estender cores, realçar o brilho e a translucidez e aumentar a integridade da película.

Fluid Matte Medium: líquido, útil para estender cores, reduzir o brilho e aumentar a integridade da película. É particularmente útil na combinação com os Fluid Acrylics para reduzir o brilho sem alterar a consistência das cores.

Matte Medium: é um meio variável, de uso geral, útil para estender a cor, reduzir o brilho e aumentar a integridade da película. Também pode ser usado no lugar do gesso para criar um fundo claro sobre a tela.

Super Loaded Matte Medium: é um meio variável com altos níveis de agente fosco. É usado para uma maior redução do brilho quando mesclado com outras cores acrílicas. Também pode ser usado no lugar do gesso para criar um fundo sobre a tela. 
Airbrush Medium: desenvolvido para modificar a consistência dos Fluid Acrylics e permitir seu uso no aerógrafo, reduzindo significativamente o aglutinamento durante a pulverização. Também pode ser usado para aguar outros produtos acrílicos como os Iridescente / Interference Acrylics e o gesso, para que possam ser aplicados com o pulverizador. Não foi desenvolvido para ser mesclado com os Airbrush Colors, com os quais devem ser usados o Airbrush Transparent Extend.

Acrylic Glazing Liquid: é um meio que pode ser mesclado com cores acrílicas para aplicações interiores sobre paredes e mobiliários. A secagem é lenta o suficiente para a aplicação de uma grande variedade de esmaltes. É excelente como meio de harmonização quando aplicado em obras de arte. Está disponível nas versões brilhante e acetinado.

13 - SPECIAL PURPOSE ACRYLIC POLIMERS: podem ser misturados com tintas acrílicas para estender a tinta, regular a transparência, criar esmaltes, obter brilho, reduzir a viscosidade ou melhorar a aderência e integridade da película. Podem ser usados também para vários efeitos de superfícies. Ao contrário dos outros Golden Mediums e Géis, os polímeros acrílicos GAC têm uma quantidade mínima de espessantes, niveladores, antiespumantes e surfactantes para garantir a boa formação da película.

GAC 100: é o polímero acrílico universal usado para estender e diluir cores, além de aumentar a flexibilidade e a integridade da película. Umedece os sólidos mais facilmente que os outros polímeros e é útil para mesclar tintas. Também são ideais para evitar a descoloração induzida por suportes (Support Induced Discoloration SID);

GAC 200: polímero acrílico endurecedor de película, é o mais duro e menos flexível. Ideal para combinações com tintas acrílicas para aumentar a dureza da película e reduzir a pegajosidade. Pode ser mesclado com tintas acrílicas quando se deseja aderi-las a superfícies não porosas como o vidro e o plástico. Quando seco, apresenta um acabamento transparente e com alto brilho. 
GAC 400: polímero acrílico para endurecer telas de modo que telas de algodão e linho tornem-se formas sem suportes.

GAC 500: polímero acrílico para aplicações autoniveladoras, produzindo um equilíbrio entre a dureza e a flexibilidade da película. Quando seco, apresenta alto brilho e boa transparência. É usado para aumentar a resistência ao desgaste e reduzir a pegajosidade da película seca. Pode ser usado como isolante em aplicações com aerógrafo, mesclando com o Airbrush Transparent Extender.

GAC 700: polímero para aumentar a claridade e transparência da película. Quando seco produz uma película de alto brilho e de dureza moderada.

GAC 800: polímero acrílico redutor de aglutinamento. Quando seco, apresenta bom brilho e flexibilidade, porém, a claridade é moderada. É ideal para melhorar a adesão em superfícies calcárias.

GAC 900: polímero acrílico para produzir peças de vestuário com cores acrílicas para pinturas aplicadas com aerógrafos, pincel ou serigrafia. Se o calor for forjado devidamente engendra suficiente estabilidade e suavidade para que a peça possa ser lavada a mão ou na máquina. ${ }^{77}$

\section{4 - ADITIVOS:}

Retarder: é um aditivo que estende o tempo de secagem da pintura acrílica. Ideal para a técnica de wet-in-wet e para estender o tempo em que a tinta da paleta permanece fresca. Não descascam.

Acrylic Flow Release: usado para reduzir a tensão superficial da água dentro da emulsão acrílica, aumentando o caráter escorregadio e fluido da tinta. Ideal para fazer pinturas sobre superfícies porosas. Não é apropriado para menores de idade.

\section{5 - MEDIUMS E ADITIVOS GOLDEN OPEN ACRYLICS:}

OPEN Acrylic Gel: apresenta a mesma consistência das cores e é usado para

\footnotetext{
${ }^{77}$ O fabricante alerta que quando o GAC 900 é aplicado, a ventilação deve ser adequada devido o processo de forjar o calor liberar pequenas quantidades de formaldeído, o que também torna seu uso inapropriado para crianças.
} 
prolongar o alcance da tinta mantendo ao mesmo tempo as propriedades de trabalho das mesmas.

OPEN Acrylic Medium: formulado para obter menor viscosidade, é usado para prolongar o alcance da tinta e manter suas propriedades quando se deseja uma mescla mais fluida aumentando o fluxo da mesma.

OPEN Thinner: não contém aderentes e é usado não só para diluir a consistência das mesclas de tinta sem alterar o tempo de trabalho, mas também para manter e ajustar as propriedades de trabalho das cores sobre a paleta sem ter que fazer uso de água e nem de paletas umedecidas.

16 - GESSOS and GROUNDS: o gesso pode ser pensado como uma ponte entre o suporte e a tinta. Fornece uma superfície que adere a tinta, o que aumenta a vida útil da obra. É formulado para ser flexível e é altamente pigmentado para cobertura opaca; o ground acrílico e o ground absorvente fornecem superfícies propícias para receber, respectivamente, a técnica de pastel e a técnica de aquarela e outros produtos.

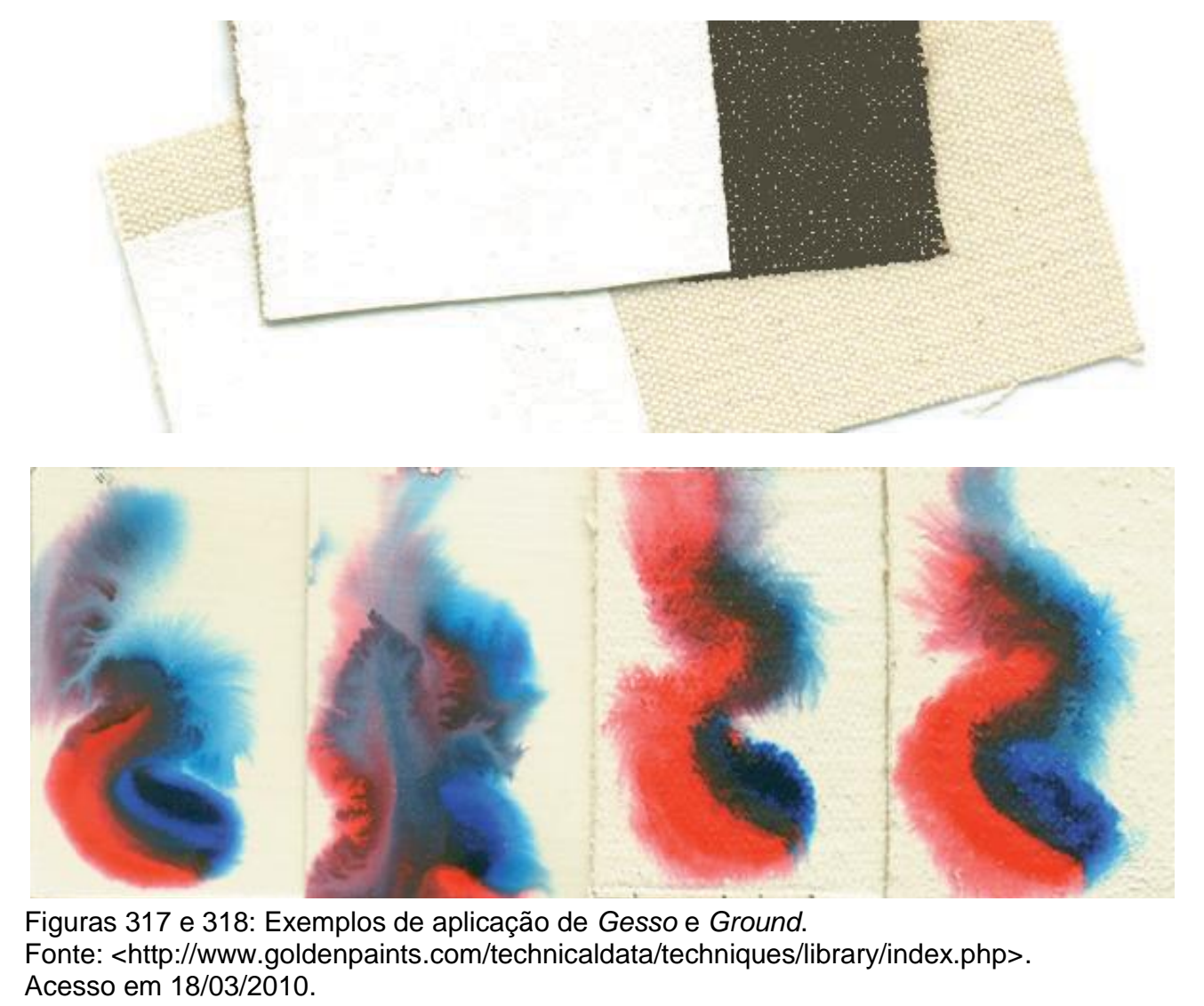


White and Black Gessos: são fundos líquidos prontos para serem aplicados. Foram formulados para aplicação em qualquer superfície usada para pintura. São flexíveis e podem ser aplicados em camadas finas para conformar superfícies de diferentes texturas. Quando o trabalho for óleo sobre gesso, devem ser aplicadas ao menos três camadas do produto.

Sandable Hard Gesso: formulado com 100\% de emulsão de polímeros acrílicos, pode ser lixado para fornecer superfícies que são ainda mais suaves que as criadas utilizando gesso regular.

Absorvente Ground: é um meio líquido de revestimento acrílico que, quando seco, produz uma superfície porosa parecida com papel. Quando aplicado sobre tela engessada, permite efeitos semelhantes à aquarela. É resistente à descoloração, permanente e flexível.

Acrylic Ground for Pastels: é um fundo para a preparação de telas e outros suportes para a aplicação da técnica de pastel. A textura é semelhante à dos papéis especiais para pastel ou giz. Para aumentar sua granulosidade, acrescenta-se o Fine ou o Coarse Pumice Gel. Pode ser mesclado com cores acrílicas.

Silverpoint / Drawing Ground: é um líquido acrílico utilizado para a preparação de suportes para a elaboração de desenhos. Destina-se à realização de linhas finas e pormenorizadas sobre um fundo permanente, flexível e impermeável à luz. É ideal para o uso de estiletes de metal ou de outras ferramentas de desenho.

Digital Ground White (Matte): fundo branco semiopaco adequado para impressão em uma grande variedade de superfícies porosas e não porosas. Ideal para a impressão de tintas de secagem rápida voltado aos trabalhos de arte digital. 


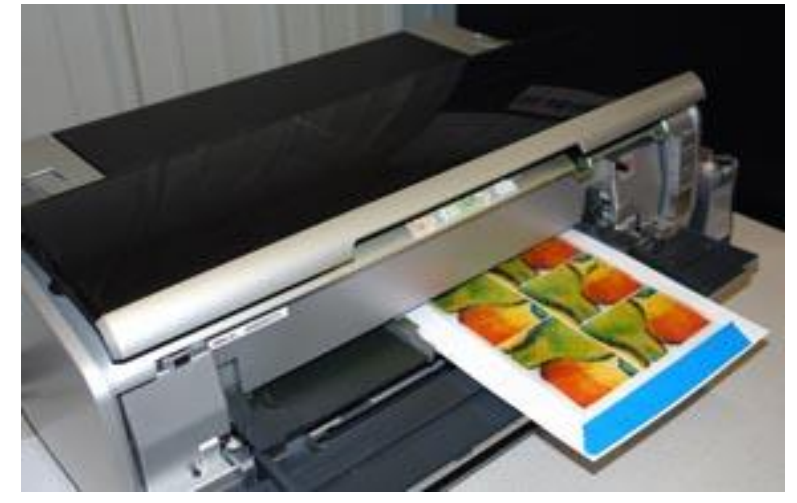

Figura 319: Exemplo de aplicação do Digital Ground White (Matte). Fonte: $<$ http://www.goldenpaints.com/technicaldata/techn iques/library/index.php>. Acesso em 18/03/2010.

Digital Ground Clear (Gloss): fundo transparente e semibrilhante destinado à superfícies porosas onde se deseja visualizar com clareza os materiais de base. Toda a modificação da impressora é feita pelo usuário. Pode afetar o desempenho do equipamento e anular sua garantia.

Digital Ground for Non Porous Surfaces: fundo brilhante para cobrir superfícies não porosas como o plástico e o metal, quando se deseja claridade. Toda a modificação da impressora é feita pelo usuário e pode afetar o desempenho do equipamento e anular sua garantia.

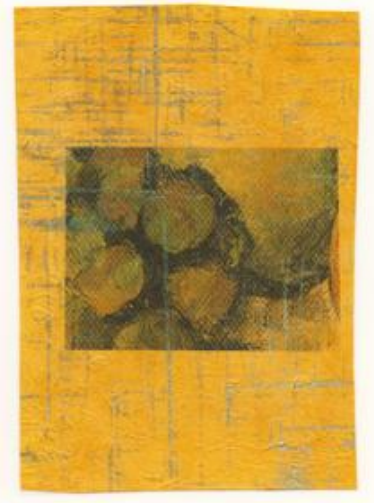

Figura 320: Exemplo de aplicação do Digital Ground White (Matte) or Digital Ground Clear (Gloss) or Digital Ground for Non-Porous Surfaces. Fonte: <http://www.goldenpaints.com/technicaldata/techniques/library/index.php>. Acesso em 18/03/2010.

\section{7 - VERNIZES}

Acrylic Polymer Varnishe: é um verniz acrílico à base de água com UVLS (Estabilizante de Luz Ultravioleta) que seca produzindo uma película de proteção flexível e resistente à poeira da superfície. É usado como selante final sobre tinta acrílica. Deve ser diluído antes de usar devido à formulação mais espessa em 
relação aos demais vernizes disponíveis no mercado. Estão disponíveis nas versões: brilhante, fosco ou acetinado. É indicado somente para uso em ambientes internos. Pode ser removido com amônia para fins de restauração. Não deve ser usado por menores de idade.

MSA (Mineral Spirit Acrylic) Varnish: com URLS, é um sistema de resina acrílica à base de alcoois minerais que produz uma película mais resistente e menos permeável que a dos vernizes de emulsões acrílicas à base de água. Pode ser aplicado em superfícies pintadas com tinta acrílica, a óleo ou alquídica. Reduz a penetração de impurezas e de desgaste da superfície ao produzir uma película extremamente lisa. Quando seco, é removível com alcoois minerais. Recomenda-se o uso no interior e no exterior. Está disponível nas versões: brilhante, fosco e acetinado. Não deve ser usado por menores de idade.

Archival Varnish MSA Aerosol W/URLS: formulado com resina 100\% de polímeros acrílicos reversíveis à base de solventes. O verniz padrão MSA é reduzido com o uso de acetona de secagem rápida, o que possibilita a produção de um produto de fácil pulverização. Se aplicado corretamente, produz uma película lisa com claridade excelente tanto no estado úmido como seco. É resistente às mudanças de aparência e permanece flexível. Está disponível nas versões: brilhante, fosco e acetinado. É removível para fins de restauração. Não deve ser usado por menores de idade.

\section{8 - PRODUTOS EXCLUSIVOS:}

High Load Acrylic: produto de formulação exclusiva com alta carga de pigmentos em comparação às tintas acrílicas tradicionais. A cor é intensa e a consistência é parecida com a do gesso. Quando seco, produz um acabamento fosco e aveludado, suscetível ao desgaste. É ideal para ser usado como fundo ou quando se deseja uma cor mais espessa e opaca. Possui um grande poder de tingimento e é resistente à descoloração.

Acrylic Modifier for Plaster: emulsão com 100\% de polímeros acrílicos, especialmente desenvolvido para ser aplicado no gesso com o objetivo de diminuir as fissuras e, ao mesmo tempo, manter a resistência à tração. 
MSA (Mineral Spirit Acrylic) Gel: quando seco produz uma película semirrígida de flexibilidade limitada, com excelente resistência às impurezas e ao desgaste, com durabilidade exterior excepcional. Depois de seco, continua sendo solúvel em alcoois minerais. Pode ser usado para modificar as cores do MSA ou para ser mesclado com tintas a óleo à base de linhaça para reduzir o tempo de secagem. Não deve ser usado por menores de idade.

Hard MSA (Mineral Spirit Acrylic) Varnish w/URLS: sistema acrílico à base de alcoois minerais. Quando seco, produz um acabamento rígido, não flexível, com excelente resistência às impurezas e ao desgaste, com uma durabilidade exterior excepcional. O sistema URLS proporciona à superfície uma excelente proteção contra os raios ultravioleta. Está disponível nas versões: brilhante, fosco e acetinado. Não deve ser usado por menores de idade.

Paste Paints and Paste Gels: possuem uma consistência extremamente viscosa. Foram desenvolvidos para serem mais espessos que as tintas acrílicas regulares. Devem ser aplicados com espátula ou planos. Podem ser alcançados efeitos encáusticos com o uso de meio durável e permanente. Podem ser aplicados em camadas e ainda serem cortados ou talhados com uma faca. Para produzir uma variedade de texturas exclusivas, a tinta em pasta pode ser usada com gel em pasta e outros acrílicos.

Silk Screen Fabric Gel: é um meio que deve forjar o calor. Para produzir tintas serigráficas para tecidos com uma grande capacidade de lavagem, devem ser misturadas em partes iguais de tinta. Para tintas mais grossas deve ser usada Heavy Body Acrylics, enquanto que para as misturas mais leves Fluid Acrylics. O gel produz um mínimo de aglutinamento na tela. Depois da película seca, é forjado o calor e as pinturas resultantes são suaves ao toque e resistentes às rachaduras, mesmo quando lavadas.

Liquid Thickener (Long Rheology): polímero alcalino inflável desenvolvido para dar maior espessura aos produtos acrílicos à base de água e uma consistência curta e amanteigada. Seu potencial e estabilidade como coagulante são sensíveis ao pH, 
porque o sistema de engrossar deve permanecer alcalino (pH 8.0-9.5), condição caracterizada por um odor levemente amoníaco.

Liquid Thickener (Short Rheology): polímero alcalino inflável desenvolvido para dar maior espessura aos produtos acrílicos à base de água e uma consistência larga, filamentosa e resinosa. Seu potencial e estabilidade como espessante depende do $\mathrm{pH}$, porque o sistema de engrossar deve permanecer alcalino $(\mathrm{pH} 8.0$ 9.5), condição caracterizada por um odor levemente amoníaco.

Universal Dispersant: proporciona uma melhor dispersão e estabilidade para uma grande variedade de pigmentos e extensores de tintas acrílicas à base de água. Tipicamente, os pigmentos apresentam uma repulsão inerente à água, por isso são difíceis de misturar. Esse dispersante contém surfactantes capazes de umedecer e estabilizar as superfícies dos pigmentos, permitindo que os sistemas de pigmentos à base de água se mesclem com maior facilidade e desenvolvam um maior número de cores.

Defoamer for Fluid Acrylics: produto à base de petróleo que ajuda a reduzir a produção de espuma nos meios fluidos acrílicos ou nas mesclas de tintas. Não deve ser usado por menores de idade.

Defoamer for Heavy Body Acrylics: produto à base de petróleo que ajuda a reduzir a produção de espuma nos meios Heavy Body. Não deve ser usado por menores de idade.

Porcelain Restoration Glaze: meio removível, à base de água, usado para restaurar porcelanas. Quando seco, produz uma película dura que pode ser lixada e polida até obter o brilho desejado. É fácil de ser diluído e aplicado com aerógrafo. São mesclados com as cores de aerógrafo para harmonizá-los com as cores do esmalte submetido à cocção. Está disponível nas versões: brilhante e fosco.

19 - PRODUTOS APENAS PARA USO PROFISSIONAL: são adquiridos apenas sob encomenda. Quando enviados ao cliente, são acompanhados por instruções de 
segurança (Material Safety Data Sheets - MSDN). Crianças não devem usar nem tocar nesses produtos.

MSA (Mineral Spirit Acrylic) Colors: cores produzidas a partir de um sistema de resina acrílica à base de alcoois minerais. Secam rapidamente para formar películas mais duráveis, resistentes à água e aos raios ultravioleta e apresentam uma excelente resistência química aos ácidos e às substâncias alcalinas. Todos os pigmentos são escolhidos por sua grande claridade e permanência de cor de cada classe química. São úteis para a arte da conservação e para harmonizar a tinta dentro de algo já pintado. São solúveis em alcoois minerais e podem ser mesclados com tintas a óleo e alquídica.

Stoddard Solvent: é o mesmo solvente usado para fazer os vernizes MSA. Feito à base de alcoois minerais muito puros e pode ser mesclado apenas com tinta a óleo e com os produtos: MSA Varnish, MSA Conservation Colors e MSA Gel. Deve ser usado com proteção e com a devida ventilação.

Stop-Out Varnish for Intaglio Printmaking: é um líquido negro que substitui totalmente os vernizes Stop-Out tradicionais tóxicos feitos à base de asfalto e laca. Tem sido desenvolvido por impressores dedicados à gravura. É ideal para todo trabalho de impressão em entalhe sobre pranchas de metal em que são usados o cloreto de ferro ou em gravuras tipo Edinburg Etch.

\subsubsection{Painéis Pré-fabricados de Concreto: Glass Reinforced Concrete-GRC}

Como solução para a vedação vertical interna e externa, a qual exige elevados níveis de qualidade e produtividade, além da redução de perdas, foram lançados no mercado painéis pré-fabricados feitos com GRC-Glass Reforced Concrete (inicialmente conhecidos como Glass Reforce Cement). Trata-se de uma matriz cimentícia reforçada com fibras de vidro resistentes a álcalis. O material alia a elevada compressão das argamassas e concretos com a resistência ao impacto e à flexão através do reforço de fibras. Considerando tais características, é possível 
produzir componentes de pequena espessura, portanto, mais leves e fáceis de serem transportados, armazenados, manuseados e instalados. A flexibilidade de formas, texturas e cores o torna uma alternativa não apenas para a racionalização da construção de edifícios, mas também para a confecção de painéis artísticos e esculturas.

De acordo com o artigo publicado pela engenheira Claudia Teresinha de Andrade Oliveira, o material passou a ser sistematicamente pesquisado em 1960, a partir da experiência da indústria de plásticos reforçados. Foi estudado como um potencial substituto do cimento amianto, cujo uso estava sendo proibido na Europa, contudo, a indústria do GRC começou a crescer efetivamente na década de 1970. Com a constante evolução dos materiais e das técnicas de produção foi consolidado o emprego de pré-fabricados, presentes no mercado internacional da construção civil 28 anos antes do surgimento do GRC.

Segundo dados do manual técnico do National Precast Concrete Association Austrália-NPCAA (1999), os materiais básicos constituintes dos componentes leves de GRC são: cimento Portland, areia, aditivos (superplastificantes, polímeros geralmente de base acrílica), adições minerais (basicamente adições com atividade pozolânica) e as fibras de vidro álcali-resistentes (propriedade que o difere dos demais produtos existentes, uma vez que o vidro comum pode ser atacado pelo meio alcalino da solução de íons de sódio e de potássio presentes na pasta endurecida de cimento Portland). Quanto à relação água/cimento, deve ser a mais baixa possível $(0,33)$ para garantir a hidratação do cimento e obter a trabalhabilidade adequada. Devido a essa baixa relação, os componentes devem, após a moldagem, ser submetidos a um processo criterioso de cura, etapa crítica na produção dos componentes que afeta todas as propriedades do material ao longo do tempo. Quanto ao teor de cimento e areia varia entre 1:0,5 e 1:1. (OLIVEIRA, 2002, p.79, 81).

Estão disponíveis no mercado três tipos de painéis produzidos pela indústria internacional, os quais são classificados em: painéis simples tipo casca, painéis tipo sanduíche e painéis enrijecidos por estrutura metálica, cujas descrições são reproduzidas $^{78}$ a seguir:

\footnotetext{
${ }^{78}$ Devido à especificidade técnica do assunto, as anotações referentes aos tipos de painel, tipos de acabamento e métodos de produção serão reproduzidas na forma como são apresentadas no material de referência.
} 
PAINÉIS SIMPLES TIPO CASCA (single skin): o tipo mais leve, e provavelmente 0 mais barato, é um paramento externo tipo casca. Normalmente é usado para vãos de até $1 \mathrm{~m}$ e com espessura de 10 a $15 \mathrm{~mm}$; não é muito suscetível às variações de umidade e gradientes de temperatura; nesse tipo de painel é sempre desejável o enrijecimento dos bordos e das faces por meios de nervuras ou insertes metálicos que permitem a sua fixação à estrutura do edifício;

PAINÉIS TIPO SANDUÍCHE (sandwich panel): o material de isolamento (poliestireno, poliuretano, ou um concreto leve com poliestireno) é incorporado ao painel ainda na fase de produção. É importante ter cuidado em especificar o material de enchimento do núcleo, pois em razão de diferenças entre a deformação das cascas e do núcleo surgem tensões de cisalhamento na união rígida entre a casca e o núcleo e conseqüente fissuração do GRC, a movimentação entre os elementos do painel é decorrente do gradiente térmico, movimentação de umidade e retração por secagem. Devem ser evitados materiais de enchimento de elevado módulo de elasticidade, painéis de grandes dimensões (limite de $\sim 3 \mathrm{~m}$ );

PAINÉIS ENRIJECIDOS POR UMA ESTRUTURA METÁLICA LEVE (stud frame): o painel de GRC é reforçado com uma estrutura metálica leve, incorporada ao painel na fase de projeção das placas de GRC. É a forma mais usada em painéis de fachada. (OLIVEIRA, 2002, p.83).

\section{É possível produzir os painéis com a face externa acabada, seja para efeito estético}

ou para reproduzir outros componentes para as obras de reconstituição de fachadas antigas, construções históricas e até mesmo obras de arte. O produto pode apresentar textura superficial, tratamento superficial, pigmentação e revestimento rígido. A seguir, a descrição:

TEXTURA SUPERFICIAL: possibilidade de obtenção de alguns detalhes e formas com baixo e alto relevo na face exposta dos painéis; alguns elementos feitos geralmente com outros materiais (borracha, por exemplo) são colocados na face interna do molde antes da aplicação do GRC em estado fresco; após o desmolde, esses elementos não devem ficar aderidos à superfície do painel; é a alternativa de acabamento mais econômica; deve-se tomar cuidado para evitar a falta de uniformidade e a fissuração superficial da pasta de cimento que reveste o painel;

TRATAMENTO SUPERFICIAL: remoção da pasta em torno dos agregados feita quimicamente, por meio de retardadores de pega do cimento ou ácido diluído; ou ainda pode ser feita mecanicamente com abrasivos, escovas, jato de areia ou polimento; o resultado são os diferentes graus de exposição dos agregados formando diferentes texturas;

PIGMENTAÇÃO: a cor do painel é normalmente alterada pela aplicação de uma mistura de acabamento pigmentada ou pelo uso de agregados coloridos expostos na face do painel; os pigmentos utilizados devem ser estáveis em alta temperatura e frente à radiação ultravioleta, resistentes aos meios alcalinos, inertes com o cimento, não solúveis em água e não afetar a porosidade superficial do painel; é desejável que a mistura de acabamento tenha propriedades semelhantes à do GRC para minimizar os problemas de movimentação diferencial, retração etc.; 
REVESTIMENTO RíGIDO: o uso de placas de granito, terracota e cerâmica requer o emprego de barreiras de aderência, ou seja, elementos que permitem a movimentação independente da camada de GRC e do revestimento em razão da diferença entre coeficientes de dilatação térmica dos materiais; requer também o uso de ancoragens flexíveis que minimizem as tensões geradas no GRC devido à movimentação diferencial dos revestimentos. (OLIVEIRA, 2002, p.83-84).

O produto pode ter suas propriedades alteradas de acordo com o método de produção e dosagens o que possibilita seu uso na substituição de materiais tradicionais da construção civil em diversas aplicações. Pode ser usado em

(...) situações que explorem a leveza e a facilidade de moldagem dos componentes nas mais diversas formas e seções, na produção de componentes decorativos, brises, chapas planas e corrugadas, cenários de parques temáticos, mobiliário urbano, silos, tubulações de grandes dimensões, barreiras anti-ruído, pisos elevados, caixilhos, fôrmas permanentes para concreto armado e protendido entre outros, (OLIVEIRA, 2002, p.78-79).

incluindo-se obras de arte. Uma outra variação dos componentes de GRC tem sido os monoblocos tridimensionais, usados em estações retransmissoras dos sistemas de telefonia celular, em banheiros e cozinhas com todas as instalações e acabamentos incorporados. Esses monoblocos não apresentam juntas de ligação e são reforçados com mantas tecidas de fibras de vidro (OLIVEIRA, 2002, p. 78-79).

Os componentes de GRC são produzidos a partir de métodos de produção adaptados da indústria de plásticos reforçados ou do cimento-amianto, ou seja, por projeção direta (spray-up), pré-mistura (premix), adensamento mecânico, por projeção direta (spray-suction) ou processo manual.

PROJEÇÃO DIRETA (spray-up): pode ser mecanizada ou manual, as fibras são picadas a partir de um rolo de fibra contínua (roving) e projetadas simultaneamente com a argamassa (misturada a parte) contra um molde; a projeção é feita por uma pistola com bicos ejetores distintos (um para a argamassa e outro para as fibras); as fibras podem ser incorporadas à matriz no bico de injeção ou diretamente no molde; a compactação das camadas é feita pelo meio;

PRÉ-MISTURA (premix): as fibras são incorporadas à argamassa em um misturador mecânico e, em seguida, a moldagem propriamente dita é realizada por: injeção em molde fechado; extrusão; projeção da mistura contra um molde aberto (spraymix);

ADENSAMENTO MECÂNICO: vibração ou prensagem em molde aberto;

PROJEÇÃO INDIRETA (spray-suction): fibras contínuas são projetadas juntamente com a matriz sobre o molde aberto revestido com papel filtro; a 
água em excesso é retirada por sucção; pode ser combinado o uso de fibras picadas;

PROCESSO MANUAL (hand lay-up): processo de laminação no qual o compósito em estado fresco é aplicado manualmente em camadas sucessivas sobre o molde e reforçada com feixes contínuos ou mantas; é uma técnica empregada na produção de componentes pequenos e de geometria complexa. (OLIVEIRA, 2002, p.80).

Novos métodos de produção surgiram da combinação entre esses métodos tradicionais "que têm como diferencial o uso híbrido de fibras picadas, fibras contínuas e mantas tecidas e não-tecidas de fibra de vidro." A quantidade de fibra incorporada depende do método de produção. Os métodos mais usados são o de projeção direta e o de pré-mistura, o que possibilita "incorporar fibras de vidro picadas em teores de 5\% e 3-3,5\% em massa com relação à massa de argamassa (m/m), respectivamente." (OLIVEIRA, 2002, p.80-81).

Segundo dados publicados pela empresa portuguesa Glasscrete, por se tratar de um produto de cimento em que as armaduras metálicas são substituídas por fibras de vidro não corrosíveis, a manutenção ao longo de sua vida útil é baixa. (GLASSCRETE.PT, 2010).

No Brasil, ainda em grande parte, as edificações são construídas em alvenaria revestida de argamassa, sistema que apresenta elevado desperdício, baixa produtividade e intenso uso de mão de obra. Segundo Gisele Cichinell, em artigo publicado no site da Revista Téchne, estão disponíveis no mercado placas cimentícias cuja constituição pode resultar da mistura de cimento Portland com agregados, adições ou aditivos e reforçada com fibras, fios, filamentos ou telas, as quais apresentam alta resistência e durabilidade. Dentre as placas disponíveis estão: as Placas com cimento Portland, constituídas por agregados leves e reforçadas com telas de fibra de vidro nas superfícies, as CRFS (Cimento Reforçado com Fios Sintéticos) constituídas de cimento Portland, agregados naturais, celulose e fios sintéticos e as GRC ou GRFC (Glass Fiber Reinforced Concrete) constituídas de cimento Portland, agregados e fibras de vidro resistentes a álcalis dispersos na matriz. Elas podem ser aplicadas em fechamentos externos e internos de estruturas pré-fabricadas ou convencionais, pisos, forros e shafts, no entanto, devido à "lenta difusão do conceito de fast construction, vem ocasionando um certo desconhecimento técnico do produto, principalmente quando o assunto é sua aplicação." (CICHINELL, 2007). 
Mais adiante em seu artigo, nos informa que, através da ação conjunta entre a Escola Politécnica da USP (Universidade de São Paulo) pelo Programa de Tecnologia para Habitação (Habitare/Finep) e em parceira com professores da FZEA (Faculdade de Zootecnia e Engenharia de Alimentos), EESC (Escola de Engenharia de São Carlos) e várias empresas do setor, uma série de tecnologias para placas moduladas têm sido estudadas em uma pesquisa que objetiva desenvolver painéis cimentícios de alta durabilidade e bom desempenho para serem aplicados em edifícios habitacionais e comerciais construídos com a técnica steel frame. Segundo Vanderley Moacyr John, coordenador do projeto: "O foco é o desenvolvimento de um produto de excelente desempenho, ecoeficiente, com alta tecnologia e de baixo custo". Outra particularidade é que, no desenvolvimento dos materiais, será aplicada a tecnologia FGM (Functionaly Graded Materials) que permitirá variar as propriedades dos produtos conforme as especificidades de cada projeto.
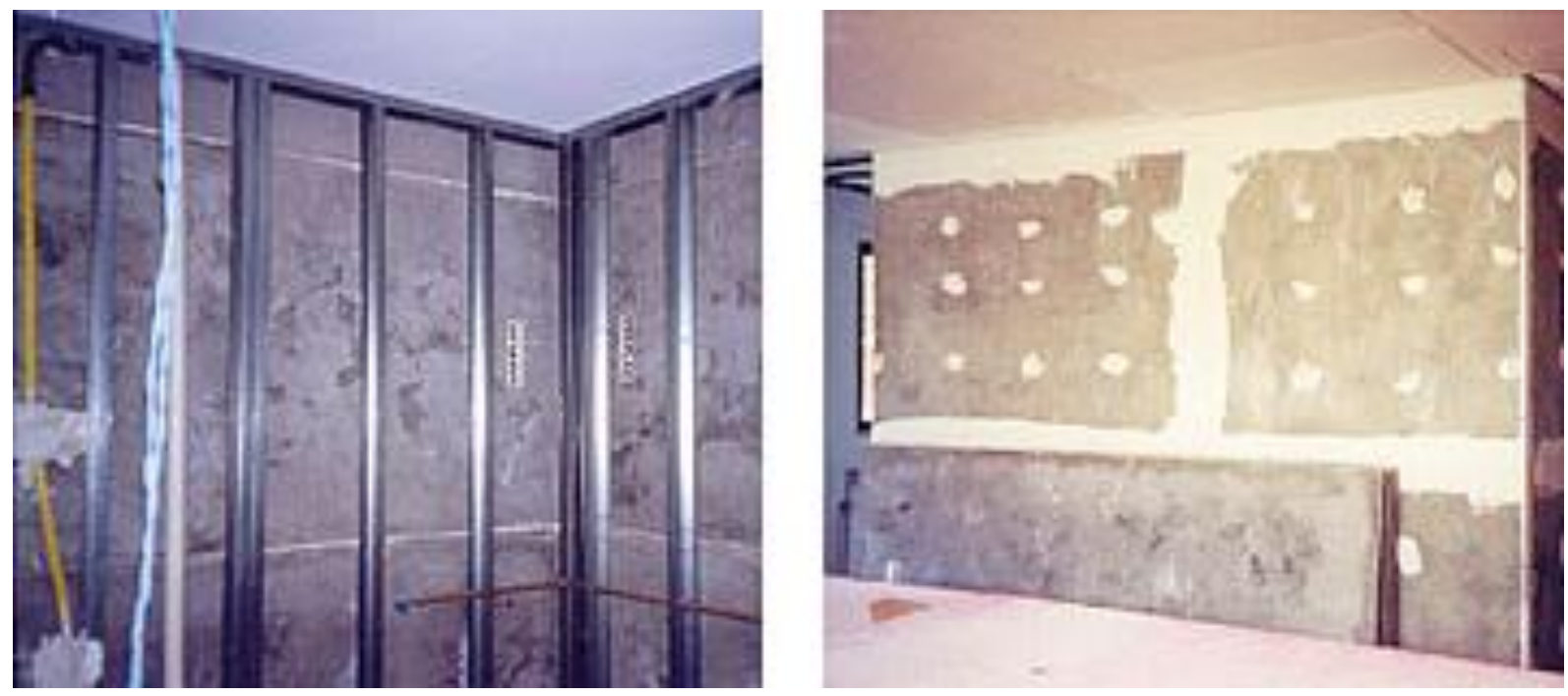

Figuras 321 e 322: Sistema steel frame (drywall) com placa cimentícia.

Fonte: <http://www.revistatechne.com.br/engenharia-civil/128/artigo66600-1.asp>. Acesso em: 12/02/2010.

No mesmo artigo, o professor Wanderley Moacyr John afirma: “(...) a solução é bastante competitiva, sobretudo quando comparada aos painéis de concreto arquitetônico, os pré-fabricados GRC (Glass Reinforced Concrete), ainda são caros. (CICHINELL, 2007). 


\subsubsection{Exemplos de aplicação}

$\mathrm{Na}$ fachada do principal palco da Copa do Mundo de 2010, localizado nas proximidades do bairro Soweto, em Joanesburgo: o Soccer City $2010^{79}$, foram empregados painéis de GRC com $13 \mathrm{~mm}$ de espessura, altamente duráveis e resistentes ao fogo. Sua forma, que remete à calabaça, um tipo de vaso artesanal africano, foi realçada através do uso de painéis de diversas cores. A pigmentação é da linha Bayferrox, fabricada pela empresa Lanxess.

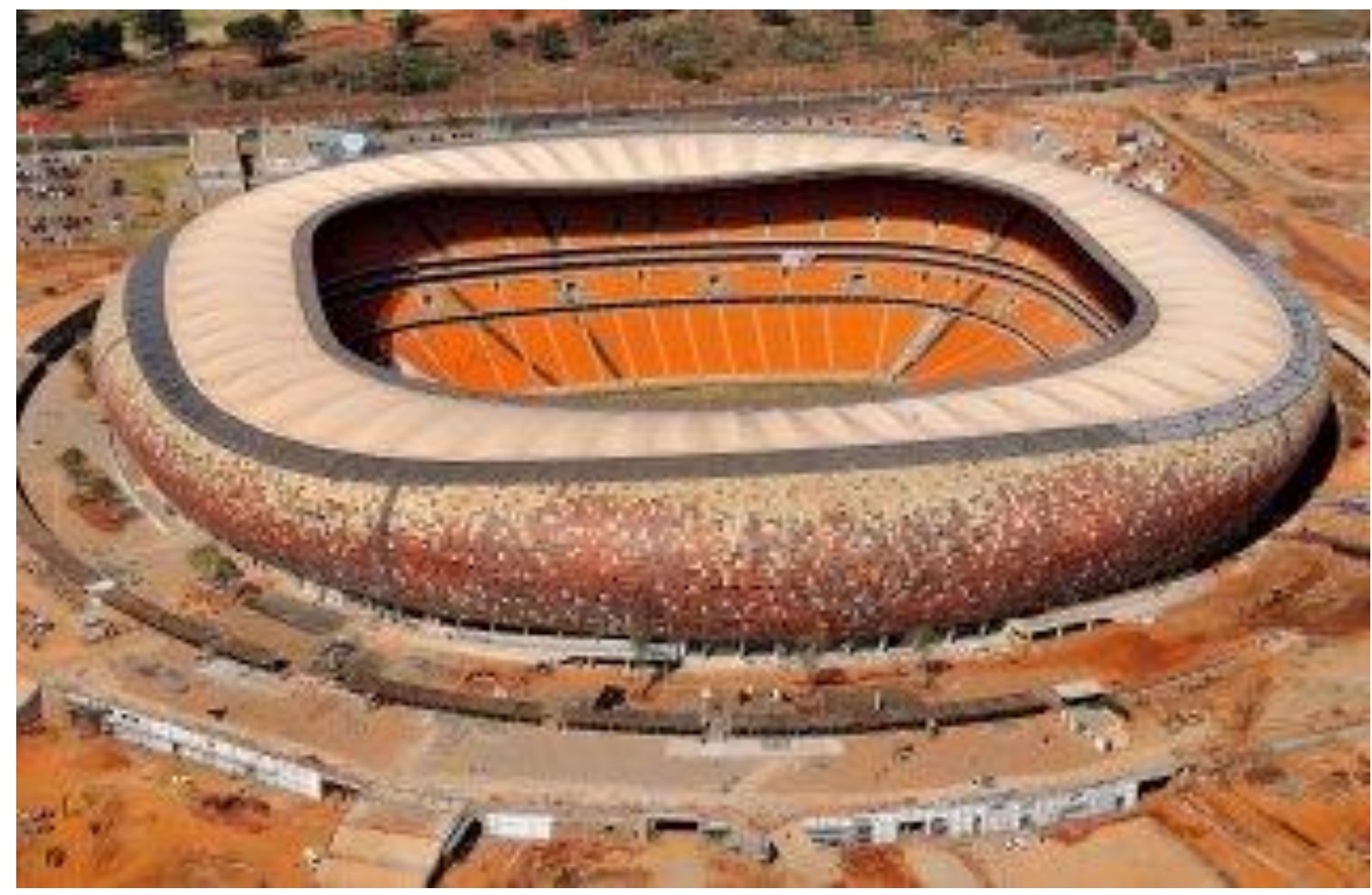

Figura 323: Soccer City 2010, em Joanesburgo. Fonte: <http://www.revistatechne.com.br/engenhariacivil/128/artigo66600-1.asp>. Acesso em 12/02/2010.

\footnotetext{
${ }^{79} \mathrm{O}$ espaço que abriga cerca de 90 mil torcedores e chega a alcançar 60 metros de altura e 300 metros de comprimento, tomou lugar do antigo Estádio FNB, construído em 1987. O terreno em que foi construído guarda histórias.

"O gigante de concreto está estrategicamente localizado em uma área que separa Johanesburgo do bairro negro de Soweto. Um lugar que acolhia escombros da época da corrida pela extração de ouro, no fim do século 19, e serviu, ao fim, para também distanciar as duas raças. 'O apartheid tinha uma dimensão espacial. Criava, até mesmo, barreiras físicas', recorda Sibongile Mazibuko, coordenador de projetos da Copa em Johanesburgo. Hoje, ao menos, unirá o país.

(...)

"Foi no terreno do atual Soccer City que Mandela fez seu primeiro discurso assim que saiu da prisão, em 1990. Três anos depois, milhares de pessoas estiveram no antigo FNB para o funeral do ativista Chris Hani. O local também traz boas lembranças quando o assunto é futebol: lá, a África do Sul conseguiu seu título de maior expressão, a Copa das Nações Africanas de 1996. Para homenagear o FNB, parte da arquibancada oeste do estádio foi mantida no Soccer City." (O ESTADO DE SÃO PAULO, 2010).
} 

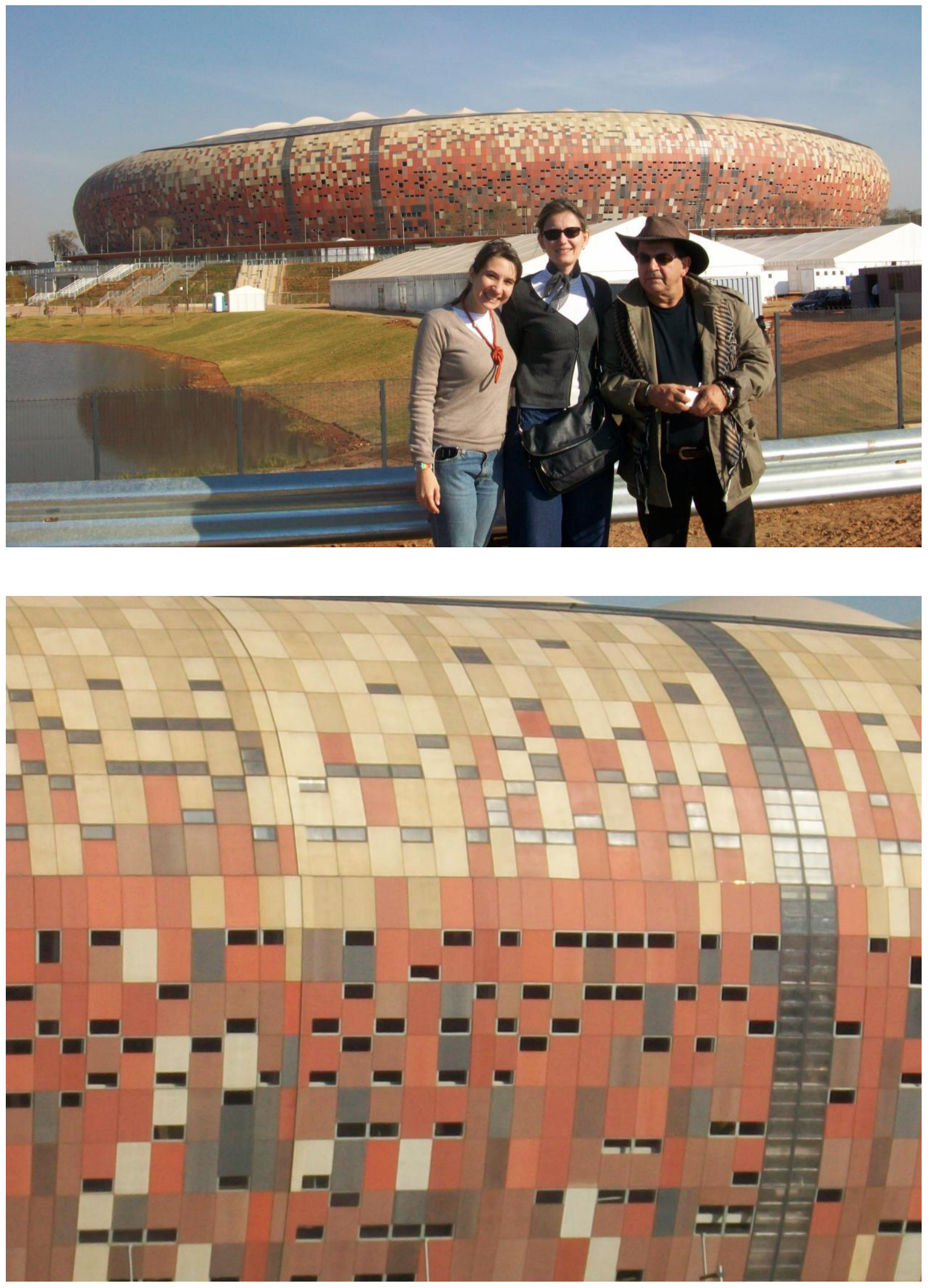

Figura 324: Clara Gerchman, a pesquisadora e Ivald Granato em frente ao Soccer City 2010, em Joanesburgo. Fonte: foto de Antonio Peticov.

Figura 325: Detalhe das placas de GRC e das aberturas do Soccer City 2010, em Joanesburgo. Fonte: Registro fotográfico da pesquisadora. 
A construção apresenta ainda como soluções inovadoras de projeto: a estrutura da cobertura composta por policarbonato transparente e membrana de teflon; fosso de coleta e reserva de água da chuva para irrigar o gramado e um sistema de "câmeras gêmeas" para a captura de imagens 3D. "O Brasil foi um dos países contemplados terá partidas transmitidas em cinemas, mas com ingressos vendidos apenas para empresas." (O ESTADO DE SÃO PAULO, 2010).

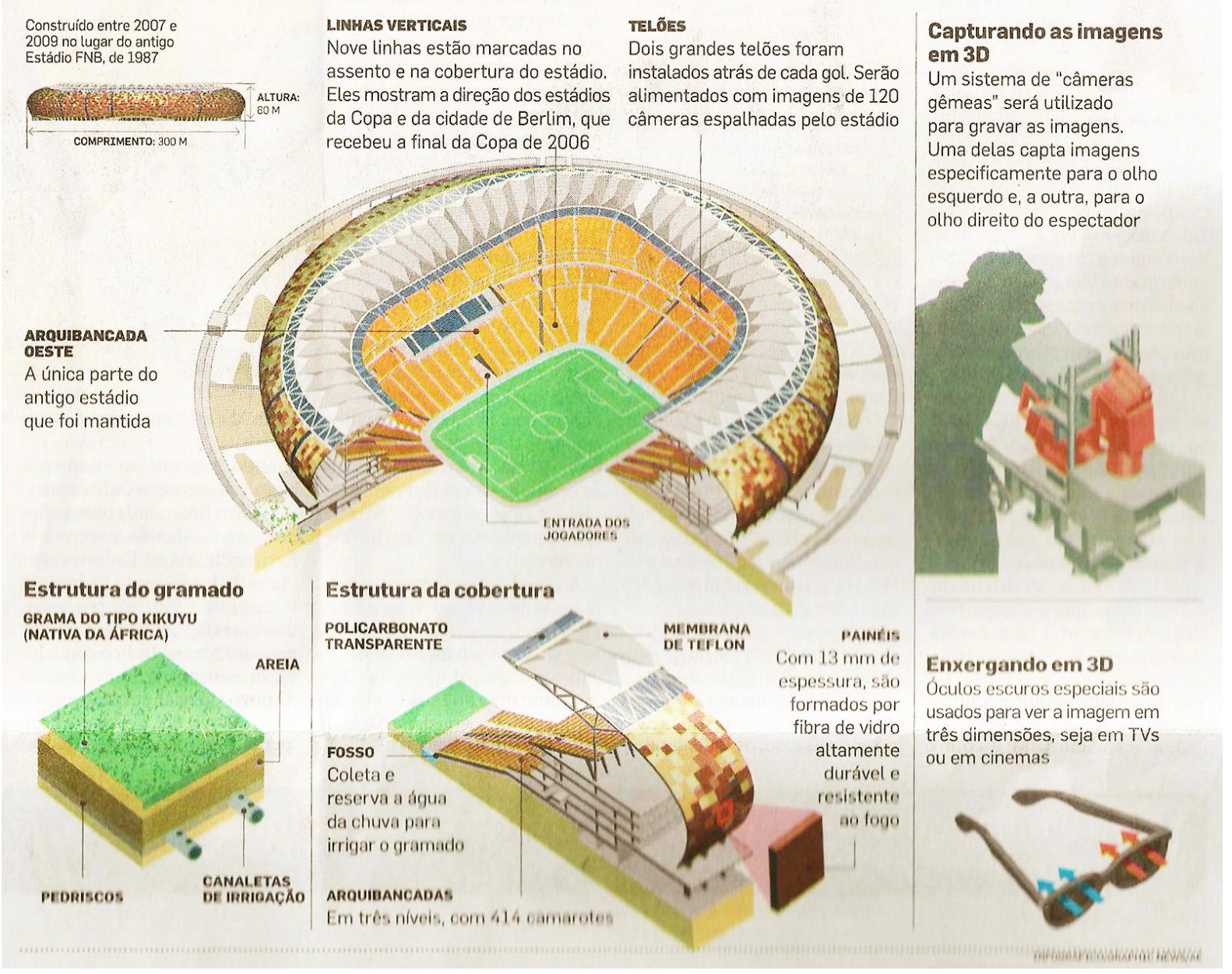

Figura 326: Cortes esquemáticos do estádio mostrando: a estrutura da cobertura, o fosso de coleta da água da chuva e o sistema de captura de imagens 3D no Soccer City 2010, em Joanesburgo. Fonte: O ESTADO DE SÃO PAULO, 11 de junho de 2010.

No edifício do Education City Campus da Liberal Arts and Science (LAS), em Doha, Qatar, o arquiteto Arata Isozaki, realizou estudos intensivos em busca de elementos essenciais da cultura islâmica, os quais foram introduzidos através de novas interpretações de padrões geométricos derivados dos tradicionais mosaicos árabes. A solução foi monocromática. 

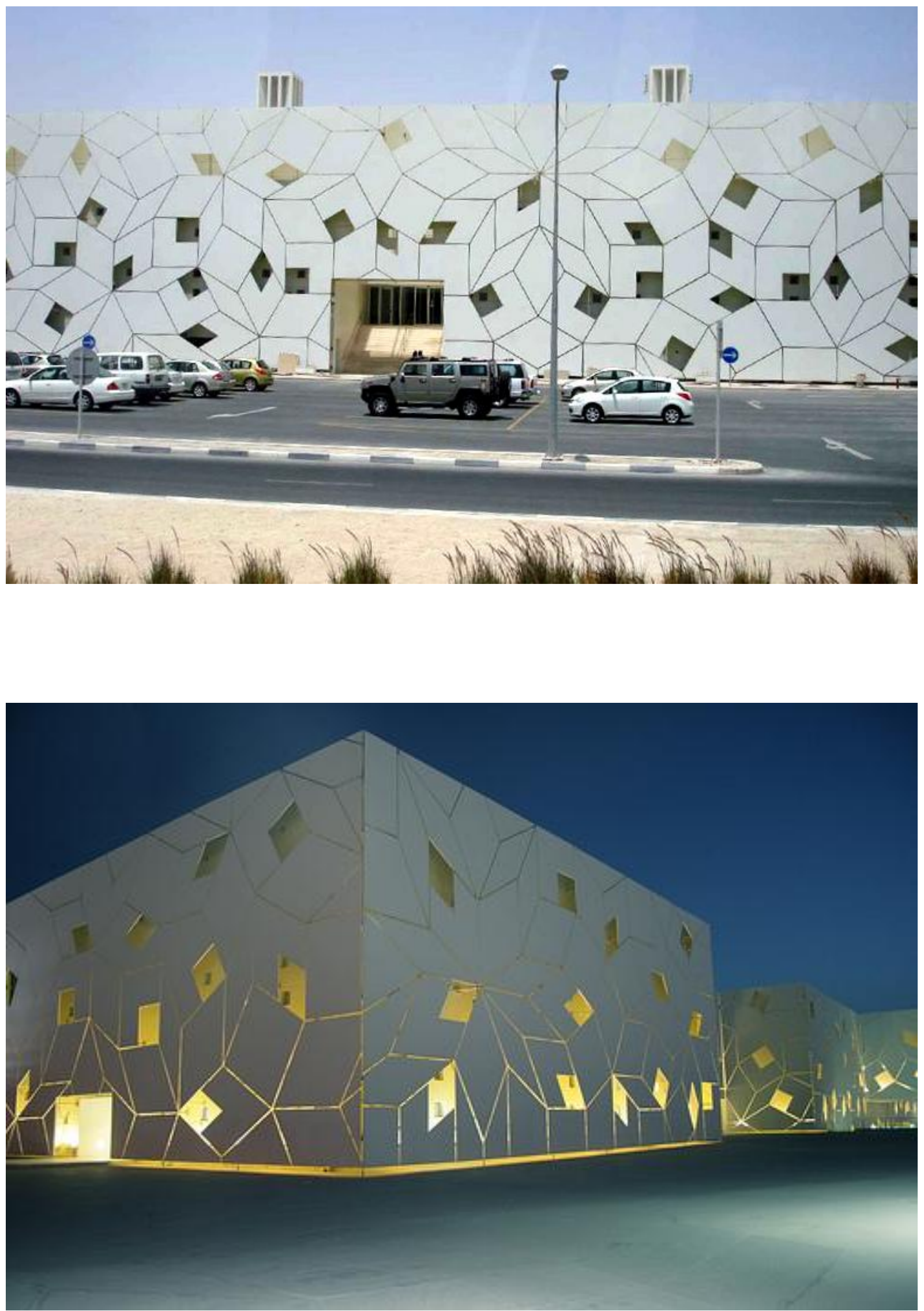

Figuras 327 e 328: Campus da Liberal Arts and Science (LAS), Doha. Fonte:< http://www.archpeace2.blogspot.com/2010/02/architectural-aspirations-of-emerging.html árabes>. Acesso em 28/03/2010. 

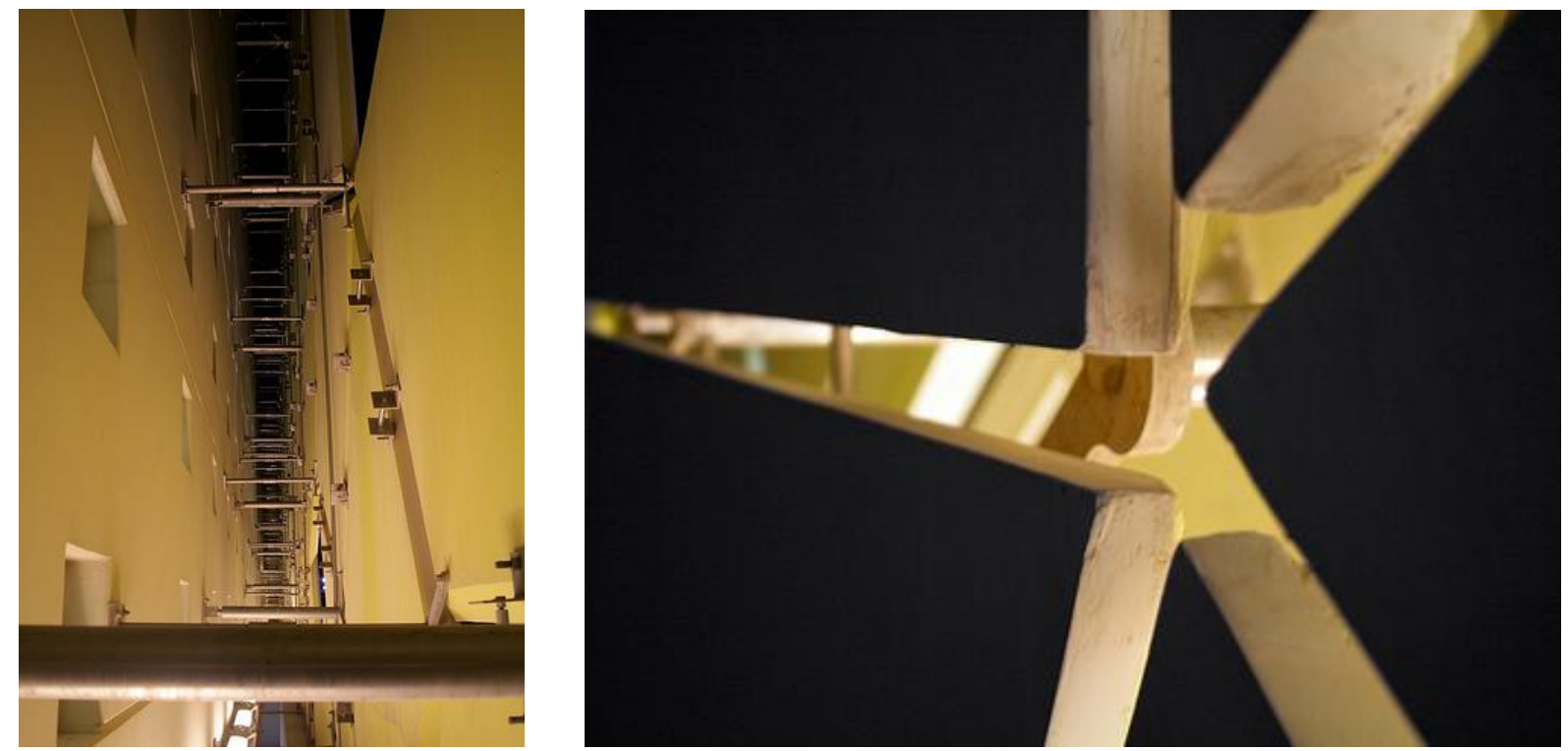

Figura 329: Detalhe de fixação das placas de GRC no Campus da Liberal Arts and Science (LAS), Doha. Fonte: <http://www.flickr.com/photos/50451021@N00/3428342530/>. Acesso em 28/02/2010.

Figura 330: Detalhe das placas de GRC no Campus da Liberal Arts and Science (LAS), Doha.

Fonte: < http://www.flickr.com/photos/albinoflea/3427538695/in/photostream>/.Acesso em 28/02/2010.

Nas superfícies externas do Bridge Pavilion projetado por Zaha Hadid para a Expo 2008, em Zaragoza, na Espanha, foram aplicadas 29.000 placas triangulares de GRC em três tonalidades de cinza.
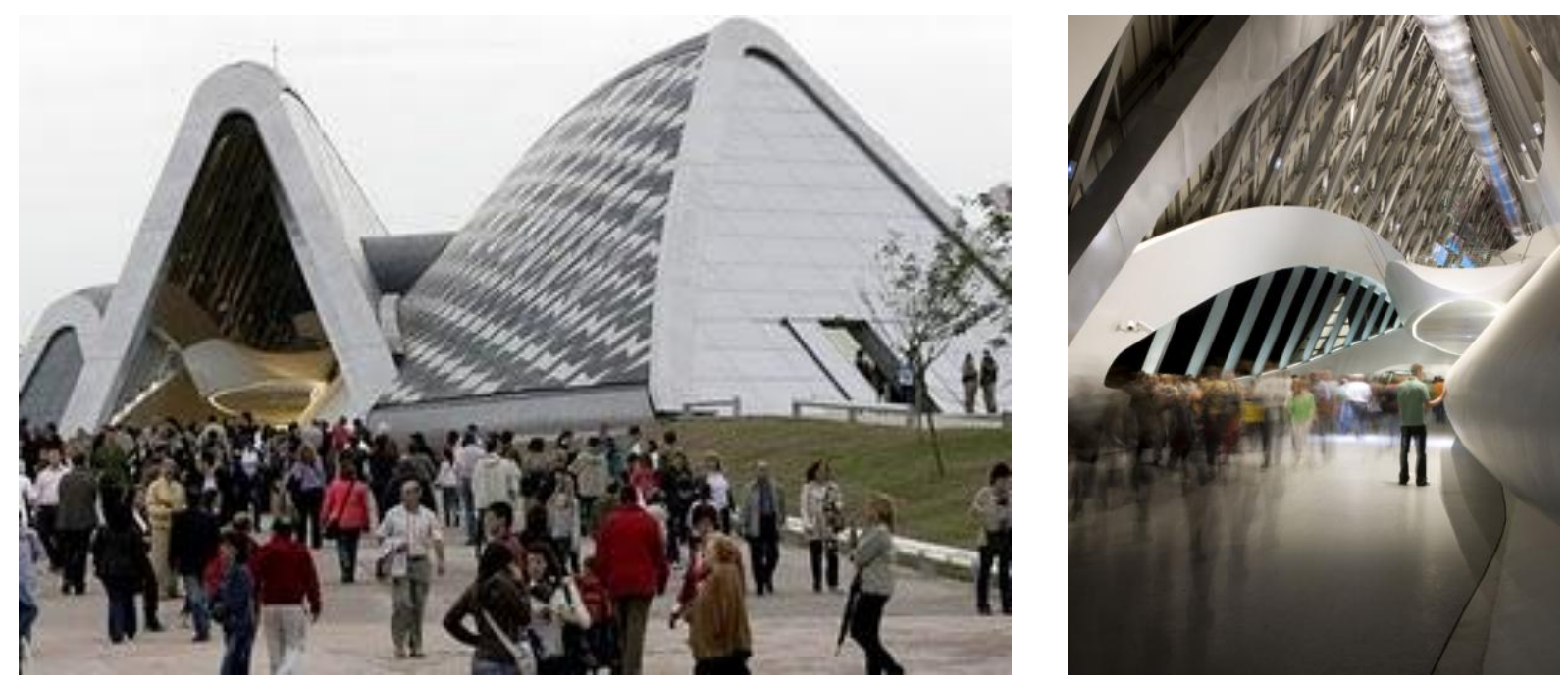

Figuras 331 e 332: Bridge Pavilion, Zaragoza. Fonte: <http://beautifulbuildings.blogspot.com/2009/06/bridgepavilion-zaragoza-spain.html>.Acesso em 12/02/2010. 

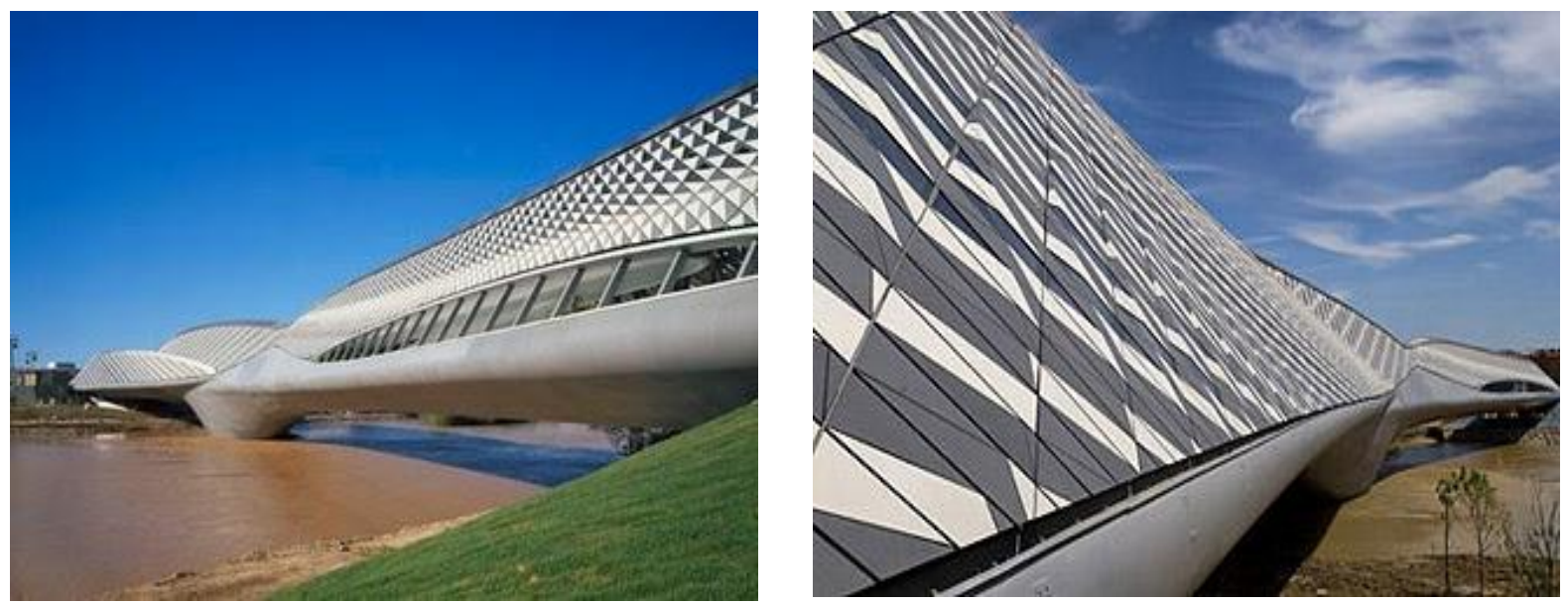

Figura 333: Bridge Pavilion, Zaragoza. Fonte: <http://www.google.com.br/imgres>? $?^{80}$. Acesso em 06/09/2010.

Figura 334: Bridge Pavilion, Zaragoza. Fonte: <http://www.google.com.br/imgres>? ${ }^{81}$. Acesso em 06/09/2010.

Os profissionais da grife Louis Vuitton também apostaram nessa tecnologia em uma de suas lojas: a Ginza Namiki Store, em Tokyo, projetada por Jun Aoki \& Associates, Louis Vuitton Malletier e Higo Design, em 2004.

80

<http://www.google.com.br/imgres?imgurl=http://www.archhis.com/bldg/images/03538001.jpg\&imgrefurl=http://w ww.archhis.com/highlight/an00.cfm\%3Fhy\%3D09\%26hm\%3D02\&usg=_Ho2L12Ms4lfdRzAhN_Zgt_vikz8=\&h=2 $20 \& \mathrm{w}=320 \& \mathrm{sz}=38 \& \mathrm{hl}=\mathrm{pt}-$

BR\&start=128\&zoom=1\&tbnid= TGUO9st31 FsdM:\&tbnh=128\&tbnw=189\&prev=/images\%3Fq\%3Dbrigge\%2Bpa vilion,\%2Bzaha\%2Bhadid\%26um\%3D1\%26hl\%3Dpt-. AcesoBR\%26sa\%3DN\%26rlz\%3D1R2SNNT ptBR\%26biw\%3D1345\%26bih\%3D555\%26tbs\%3Disch:10\%2C2515\&um=1\&itbs=1\&iact=hc\&vpx=1063\&vpy=284\& dur $=422 \&$ hovh $=176 \&$ hovw $=256 \&$ tx $=122 \&$ ty $=184 \&$ ei=qJGFTOa9AsOclgfs $4-$

ZZ1

<http://www.google.com.br/imgres?imgurl=http://static.worldarchitecturenews.com/news_images/10062_3_zara\% 2520photo\%25205big.jpg\&imgrefurl=http://www.worldarchitecturenews.com/index.php\%3Ffuseaction\%3Dwanap pln.projectview\%26upload_id\%3D10062\&usg $=$ _Fz_VwZCUZBJxjRP2NMDHejSaT14=\&h=1354\&w $=1000 \& s z=18$ $2 \&$ hl=pt-

BR\&start=21\&zoom=1\&tbnid=ePjTWItQ64wafM:\&tbnh=123\&tbnw=98\&prev=/images\%3Fq\%3Dbrigge\%2Bpavilio n,\%2Bzaha\%2Bhadid\%26um\%3D1\%26hl\%3Dpt-BR\%26sa\%3DN\%26rlz\%3D1R2SNNT_pt-

BR\%26biw\%3D1345\%26bih\%3D555\%26tbs\%3Disch:11\%2C155\&um=1\&itbs=1\&iact=hc\&vpx=119\&vpy=199\&du $\mathrm{r}=375 \&$ hovh=261\&hovw=193\&tx=110\&ty=212\&ei=pending\&oei=_ZCFTLWXD8Oblgfs9tyWDg\&esq=2\&page=2\&n $\mathrm{dsp}=22 \& v e d=1 \mathrm{t}: 429, \mathrm{r}: 0, \mathrm{~s}: 21 \& \mathrm{biw}=1345 \& \mathrm{bih}=555>$. 

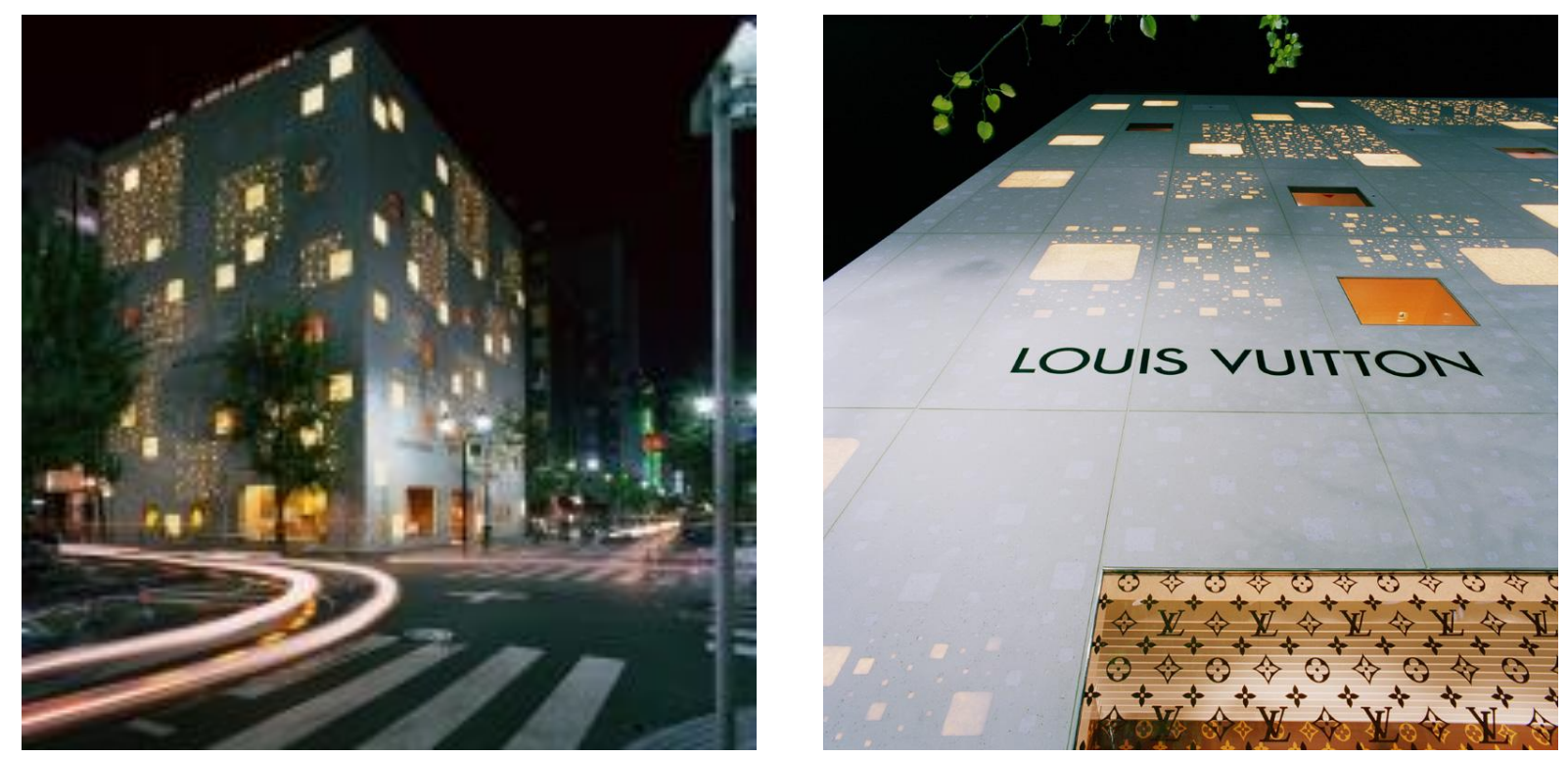

Figuras 335 e 336: Louis Vuitton, Tokyo. Fonte: <http://jimmycohrssen.com/work/index. php\%3F/archives/louisvuitton-ginza-namiki/\&usg >. Acesso em 28/02/2010.

No edifício YJP Administrative Center, Tanjin, China, projetado por HHDFUN, houve uma solução diferenciada pelo uso de peças de GRC com formas e dimensões diversificadas que dão um efeito tridimensional à fachada.
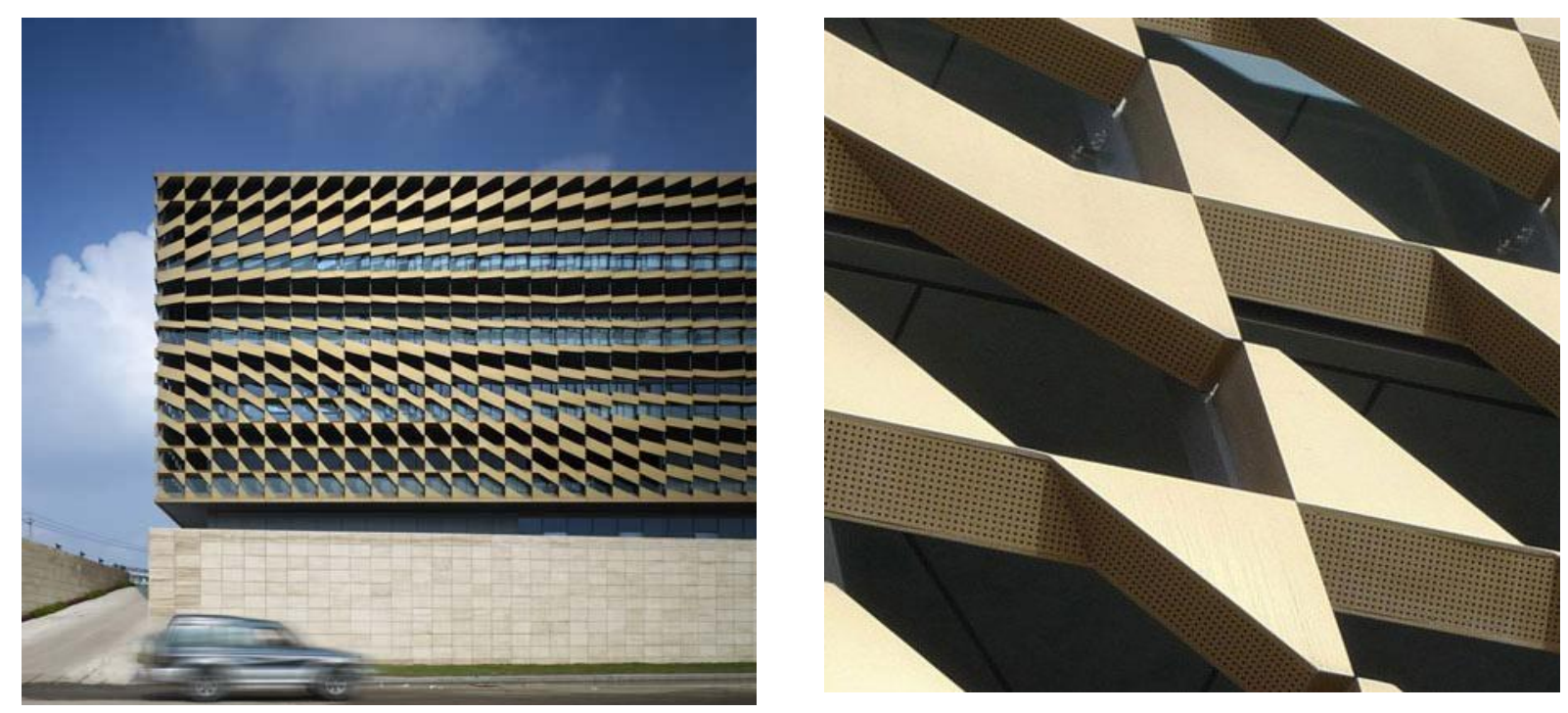

Figuras 337 e 338: YJP Administrative Center, Tanjin. Fontes:

<http://www. http://www.archinect.com/forum/threads.php?id=95192_0_42_0_C162>. Acesso em 15/02/2010. <http://www.google.com.br/imgres ${ }^{82}$. Acesso em 29/02/2010.

82

<http://www.google.com.br/imgres?imgurl=http://static.dezeen.com/uploads/2010/01/dzn_YJP-AdministrativeCenter-by-HHD_FUN031.jpg\&imgrefurl=http://www.dezeen.com/2010/01/11/yjp-administrative-center-byhhd_fun/comment-page-1/\&usg =_NX2zThkEiQEubzKFM_zgea1lz7s=\&h=450\&w=450\&sz=46\&hl=ptBR\&start=0\&zoom =1\&tbnid=ENFzGilOMnZ58M:\&tbnh=121\&tbnw=121\&prev=/images\%3Fq\%3D\%2522YJP\%2B Administrative\%2Bcenter\%2522\%26um\%3D1\%26hl\%3Dpt-BR\%26sa\%3DN\%26rlz\%3D1R2SNNT_ptBR\%26biw\%3D1345\%26bih\%3D516\%26tbs\%3Disch:1\&um=1\&itbs=1\&iact=rc\&dur=405\&ei=9pyFTL2LKsH6lweh ztSxDg\&oei=9pyFTL2LKsH6lwehztSxDg\&esq=1\&page=1\&ndsp=24\&ved=1t:429,r:4,s:0\&tx=69\&ty=77 archinect.com/forum/threads.php?id=95192_0_42_0_C162>. Acesso em 29/02/2010. 
Line honours e Migration são esculturas de autoria de Helen Lempriere. Line honours, foi desenvolvida para Bondi Beach, em Sydney. Migration, para o Nacional Sculpture Award 2006, ambas em 2006.
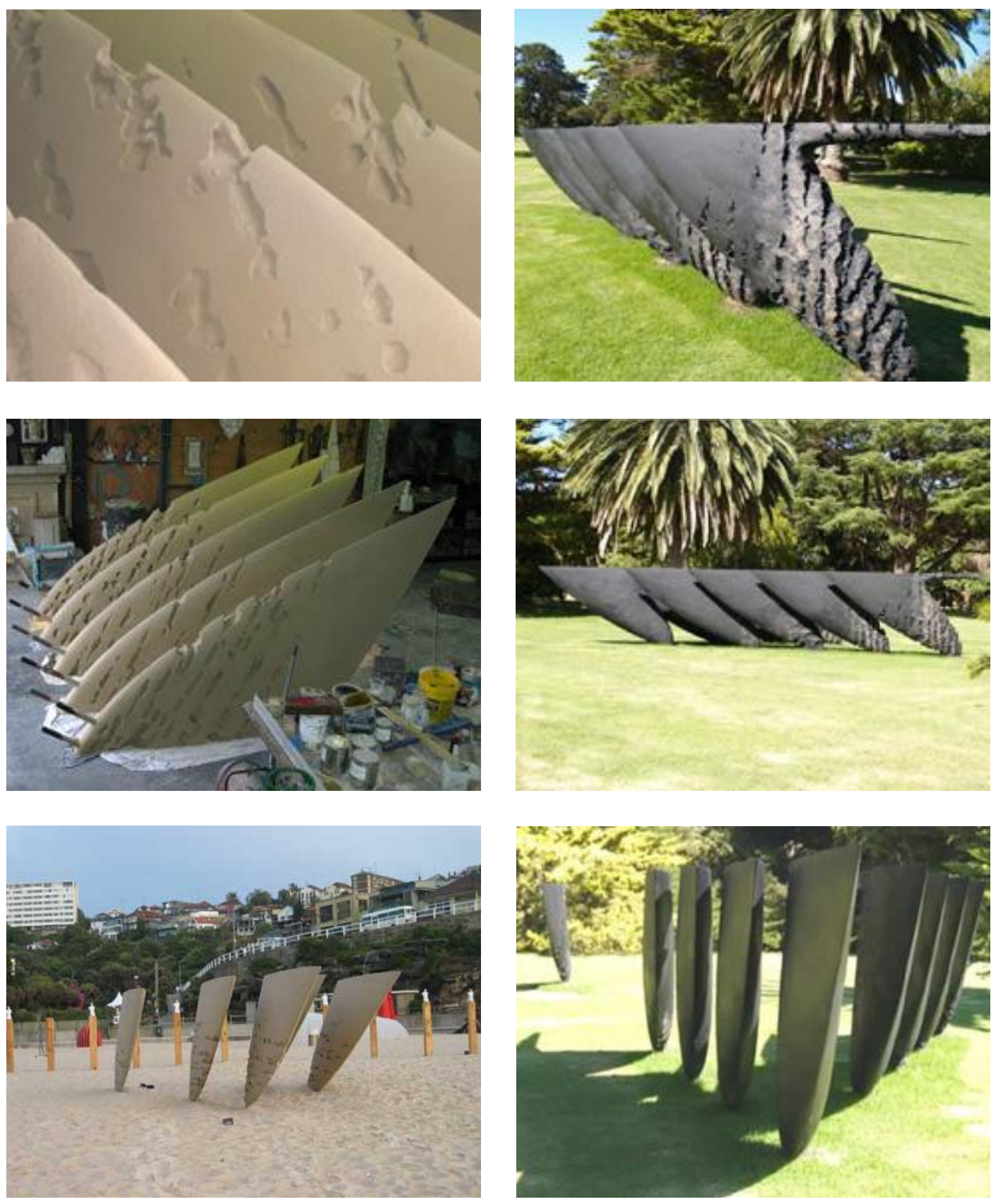

Figuras 339, 340 e 341: Line honours, escultura em GRC. Fonte:

$<\mathrm{http}: / /$ www.artservice.com.au/Sculpture_Awards_pg2.html>. Acesso em 17/02/10.

Figuras 342, 343 e 344: Migration, escultura em GRC. Fonte: <http:// www.artservice.com.au/Sculpture_Awards_pg2.html> Acesso em 17/02/10. 
5.2 NOVOS TIPOS DE MATERIAIS

\subsubsection{Células Fotovoltaicas ${ }^{83}$}

Em artigo publicado no site Inovação Tecnológica, em 19 de fevereiro de 2010, "A cada hora, a Terra recebe mais energia da luz do Sol do que o planeta inteiro consome em um ano. Ainda assim, a energia solar fornece menos de $0,1 \%$ da eletricidade consumida no mundo." (INOVACAOTECNOLOGICA.COM.BR, 2010).

Assim como a própria palavra indica, a célula ou módulo fotovoltaico (foto=luz e voltaica=eletricidade) é aquela que converte a luz do Sol diretamente em eletricidade. Inicialmente, as células solares eram usadas em calculadoras e em satélites ${ }^{84}$; hoje, podem ser aplicadas com finalidades diversas que vão desde 0 abastecimento de edificações a aplicações no campo da biomedicina.

De acordo com Scott Aldous, em artigo publicado no site Ambiente/HowStuffWork, em abril de 2000, elas são feitas de materiais chamados semicondutores, como é o caso do silício, que absorvem a luz que atinge a célula, ou seja, a energia solar é transferida para o semicondutor. Aldous explica que:

A energia arranca os elétrons fracamente ligados, permitindo que eles possam fluir livremente. As células FV também possuem um ou mais campos elétricos que forçam os elétrons livres, pela absorção da luz, a fluirem em um certo sentido. Esse fluxo de elétrons é uma corrente; e pondo contatos de metal na parte superior e na parte inferior da célula, podemos drenar esta corrente para usá-la externamente. (SCOTT ALDOUS, 2008).

Para o funcionamento do sistema, é necessário que o telhado tenha uma orientação ou ângulo de inclinação igual à latitude da área, portanto, adequado para o aproveitamento da energia solar. Aldous complementa com outras informações que

\footnotetext{
83 Temos conhecimento que, ao longo do tempo, esse sistema amplamente utilizado em diversos países da Europa, ainda tem sido alvo de diversas pesquisas. No entanto, devido ao grande volume de artigos publicados, selecionamos alguns dentre os mais recentes a partir dos quais buscaremos mostrar algumas das conquistas alcançadas.

${ }^{84}$ Em artigo publicado no site da PINIWEB.COM, Paulo Kiss afirma que, na década de 1950, época em que tinha início a corrida espacial, os centros de tecnologia espacial dos Estados Unidos e da então União Soviética necessitavam encontrar uma forma alternativa de energia que fosse capaz de alimentar instrumentos de navegação e de operação de satélites. "A busca culminaria com o desenvolvimento da chamada energia fotovoltaica. A oportunidade de testar o invento surgiu com o lançamento do satélite Vanguard 1. Graças à persistência de alguns cientistas, o programa espacial americano permitiu instalar no satélite pequenos painéis para testar a conversão da luz solar em energia elétrica. Com isso, em vez de alguns meses, como era previsto, o satélite operou durante seis anos. (KISS, 1999).
} 
devem ser consideradas: o painel não deve ser colocado em área sombreada; sua produção de eletricidade é variável porque depende do clima, assim como sua demanda também pode variar; o custo e a manutenção são elevados porque o sistema requer baterias para o armazenamento de energia, controlador de carga e inversor que converta corrente direta para corrente alternada (quando não vier embutido).

Em novembro de 2004, o site Inovação Tecnológica, publicou artigo que divulgava a descoberta da célula fotoeletroquímica (Dye-sensitized Solar Cell - DSC) ${ }^{85}$ a qual, sensibilizada por corante, era capaz de transformar energia solar em eletricidade, assim como as células fotovoltaicas. As células produzidas até então eram capazes de gerar 0,5 volt, o que exigia a montagem de painéis com várias delas para que fossem atingidas tensões e potências úteis, enquanto que a nova tecnologia, apresentada pela empresa japonesa Peccell Technologies, poderia gerar 4 volts.

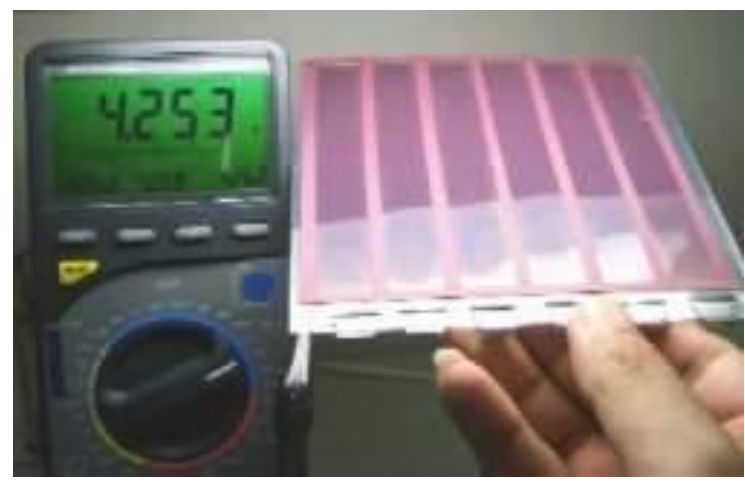

Figura 345: Célula Solar DSC.

Fonte: INOVACAOTECNOLOGICA.COM.BR Nova célula fotovoltaica DSC gera até 4 volts. 16/09/2004

Disponível

em

$<$ http://www.inovacaotecnologica.com.br/noticias/notici a.php?artigo $=010115040916 \#>$. Acesso em 21/02/2010.

A célula solar DSC, apresentava eletrodos feitos com uma pasta especial de óxido de titânio composta por partículas que mediam entre 10 e 500 nanômetros. Com a diminuição do tamanho das partículas, aumentou extraordinariamente a área do material, a quantidade de corante sensível à luz e, consequentemente, a quantidade muito maior de fótons capturados, o que permitiu o aumento na tensão gerada pela célula, ou seja, "um fluxo de elétrons excitados, resultantes da absorção da luz do sol pelo corante, é levado aos eletrodos feitos de partículas semicondutoras, inclusive de óxido de titânio, causando uma força eletromotora - a conversão de fótons para elétrons." (INOVACAOTECNOLOGICA.COM.BR, 2004).

85 De acordo com o site Inovação Tecnológica, a pesquisa das células DSC foi coordenada pelo professor Tsumoto Miyasaka, da Universidade de Yokohama no Japão. 
O produto seria um dos tipos de célula fotovoltaica de menor custo que poderia substituir as tradicionalmente produzidas com silício. Por serem feitos de um filme plástico, os painéis solares poderiam "(...) ser produzidos em qualquer formato e cor, podendo ser integrados facilmente a projetos arquitetônicos ou aparelhos eletrônicos portáteis". (INOVACAOTECNOLOGICA.COM.BR, 2004).

Mais tarde, foram desenvolvidas as células solares orgânicas, flexíveis e fabricadas por um processo semelhante ao de impressão a jato de tinta, as quais apresentavam como principais vantagens: o custo inferior em relação às tradicionais feitas de silício; a flexibilidade das placas que anteriormente eram rígidas e a proximidade da transparência, o que estendia sua aplicação em vidros de janelas quase sem perda da iluminação natural. Apesar de tudo, a durabilidade dos filmes flexíveis e sua eficiência eram baixas. Em agosto de 2009, foram anunciadas pesquisas voltadas às células solares orgânicas com alta eficiência e durabilidade. (INOVACAOTECNOLOGICA.COM.BR, 2009).

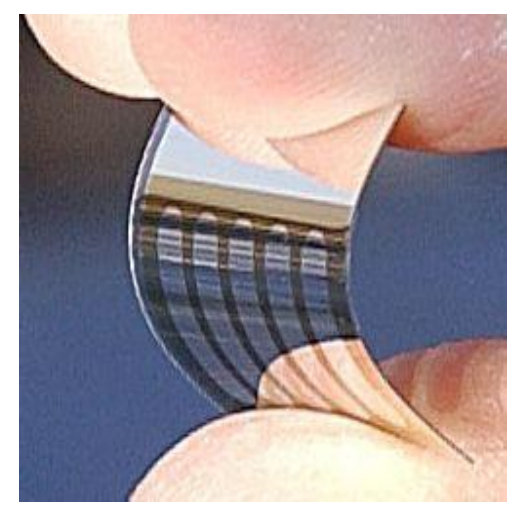

Figura 346: Célula Solar Orgânica. Fonte: INOVACAOTECNOLOGICA.COM.BR Células solares ganham em eficiência e durabilidade. 20/08/2009. Disponível em <http://www.inovacaotecnologica.com.br/noticias/noticia.php?artigo=cel ulas-solares-organicas-ganham-eficiencia-durabilidade\&id=\#>. Acesso em 21/02/2010.

Em 2010, foi inventado um novo tipo de célula solar de altíssima eficiência e as células fotovoltaicas em produção comercial bateram recordes na conversão da luz do Sol em eletricidade. (INOVACAOTECNOLOGICA.COM.BR, 2010).

As células solares fotovoltaicas, anunciadas pela empresa japonesa Mitsubishi, são feitas de silício policristalino. O primeiro recorde foi marcado pela elevação da eficiência na conversão fotoelétrica com a capacidade de converter a luz solar em eletricidade para 19,3\% através do uso de pastilhas de silício policristalino de 100 centímetros quadrados. As células policristalinas são construídas sobre pastilhas e medem 15×15×200 micrômetros de espessura. 

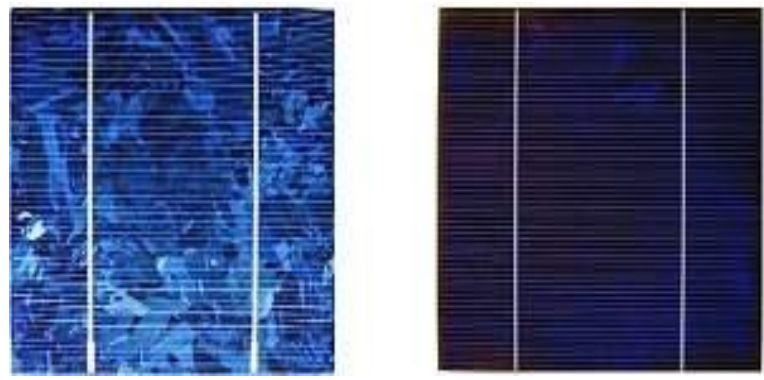

Figuras 347 e 348: À esquerda, célula solar vendida hoje no comércio. À direita, a nova célula solar da Mitsubishi que acaba de bater o recorde em eficiência.

Fonte: INOVACAOTECNOLOGICA.COM.BR. Células solares ganham em eficiência e durabilidade. 20/08/2009. Disponível

$<$ http://www.inovacaotecnologica.com.br/noticias/noticia.php?a rtigo=celulas-solares-organicas-ganham-eficiencia-

durabilidade\&id=\#>. Acesso em 21/02/2010.

segundo recorde foi alcançado com o uso da "mesma tecnologia de redução das perdas resistivas no interior das células, mas usando células ultrafinas, medindo 15x15×100 micrômetros de espessura, que alcançaram uma eficiência de 18,1\%". Essas novas células solares são tão finas que começaram a competir com as células orgânicas quanto à flexibilidade. Elas utilizam apenas 1\% do silício necessário para fabricar uma célula fotovoltaica tradicional. Apesar de sua eficiência ser ligeiramente menor, é compensada pela grande redução nos custos de produção. (INOVACAO TECNOLOGICA.COM.BR, 2010).

Outra novidade são as células solares híbridas desenvolvidas por uma equipe da Universidade de Freiburg, na Alemanha. Na prática, trata-se de uma técnica em que as células são formadas por uma camada de nanopartículas inorgânicas e um polímero orgânico. "De um ponto de vista teórico, a técnica poderá ser usada em vários tipos de nanopartículas, permitindo a construção de estruturas muito precisas." (INOVACAOTECNOLOGICA.COM.BR, 2010).

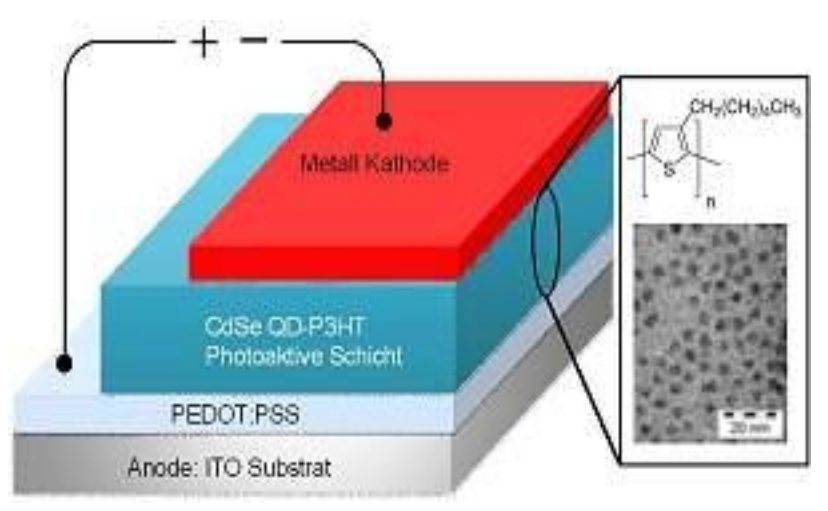

Figura 349: Cientistas usaram pontos quânticos, nanopartículas que medem entre dois e quatro nanômetros. Em princípio, estas células solares híbridas poderão ser aplicadas como uma espécie de spray. Fonte: INOVACAOTECNOLOGICA. COM.BR. Células solares ganham em eficiência e durabilidade. 20/08/2009. Disponível em <http://www.inovacaotecnologica.com.br/noticias/no ticia.php?artigo=celulas-solares-organicas-ganhameficiencia-durabilidade\&id=\#>. Acesso em 21/02/2010. 
Devido à possibilidade de serem fabricadas por técnica de impressão sobre plástico, as células solares orgânicas são muito promissoras pelo seu baixo custo. Sua eficiência que era de $1 \%$, com a nova técnica, alcançou $1,8 \%{ }^{86}$

Na pesquisa, foram usados pontos quânticos, nanopartículas que medem entre dois e quatro nanômetros. A princípio, essas células solares híbridas poderão ser aplicadas como uma espécie de spray sobre as superfícies.

A célula solar de nanofios, pesquisada pelo Instituto de Tecnologia da Califórnia, nos Estados Unidos, é outra novidade que ainda está sendo desenvolvida em laboratório.
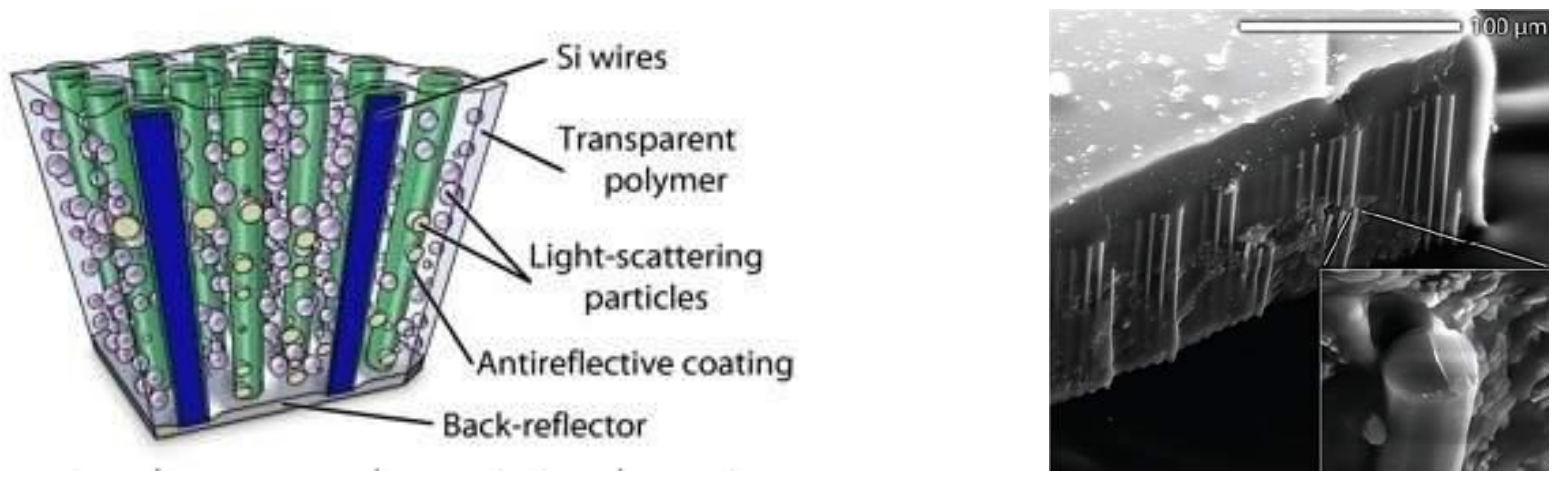

Figura 350: Diagrama esquemático dos elementos que capturam a luz para otimizar a conversão da luz solar em eletricidade (imagem: Caltech/ Michael Kelzenberg). Fonte: INOVACAOTECNOLOGICA.COM.BR. Células solares ganham em eficiência e durabilidade. 20/08/2009. Disponível em

$<$ http://www.inovacaotecnologica.com.br/noticias/noticia.php?artigo=celulas-solares-organicas-ganhameficiencia-durabilidade\&id=\#>. Acesso em 21/02/2010.

Figura 351: Micrografia da estrutura de fios de silício incorporados em uma matriz de polímeros. (Imagem: Kelzenberg et al./Nature Materials). Fonte: INOVACAOTECNOLOGICA. COM.BR. Células solares ganham em eficiência e durabilidade. 20/08/2009. Disponível em

<http://www.inovacaotecnologica.com.br/noticias/noticia.php?artigo=celulas-solareso-organicas-ganhameficiencia-durabilidade\&id=\#>. Acesso em 21/02/2010.

A nova célula solar é flexível como as células solares orgânicas, gasta uma quantidade do caro silício cristalino menor do que as células solares de película fina e, mais importante de tudo, possui uma eficiência na conversão fótons-elétrons que fica entre 90 e $100 \%$. (INOVACAO TECNOLOGICA.COM.BR, 2010).

Considerando que cada fio de silício mede entre 30 e 100 micrômetros de comprimento e 1 micrômetro de diâmetro, como são postos lado a lado, a espessura

${ }^{86}$ O mesmo texto apresenta a seguinte complementação: "O recorde atual de eficiência entre as células solares orgânicas puras é de $7 \% "$. 
total da célula solar é a mesma dos fios, ou seja, 100 vezes mais fina que a célula solar "ultra fina" da Mitsubishi.

Quanto à sua composição, apenas $2 \%$ da nova célula é feita de silício, enquanto que os 98\% restantes são compostos por polímeros, o que a enquadra na categoria das células orgânicas (que possuem carbono em sua composição). Em laboratório elas possuem 1 centímetro quadrado, mas para que sejam comercializáveis, devem chegar a uma área pelo menos 100 vezes maiores.

A IBM também anunciou um novo tipo de célula solar: a célula solar da IBM, em que a camada principal que absorve luz para a conversão em eletricidade é composta exclusivamente por elementos de baixo custo: cobre, estanho e zinco, mais enxofre e/ou selênio. Apresenta um rendimento de $9,6 \%$, o que supera as células solares orgânicas puras.

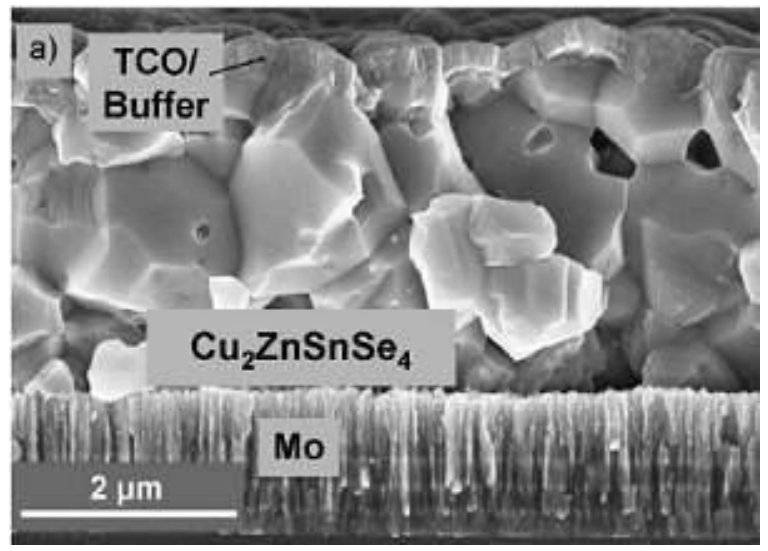

Figura 352: Célula da IBM. Fonte: INOVACAOTECNOLOGICA.COM.BR. Células solares ganham em eficiência e durabilidade. 20/08/2009. Disponível em $<$ http://www.inovacaotecnologica.com.br/noticias/noti cia.php?artigo=celulas-solares-organicas-ganhameficiencia-durabilidade\&id=\#>. Acesso em $21 / 02 / 2010$

Ela pode ser enquadrada na categoria de células solares de película fina. "Foi criada utilizando um conjunto de técnicas de manipulação de nanopartículas e de processamento em meio líquido que é muito mais barato de se fazer industrialmente do que os métodos atuais de deposição a vácuo." As células solares de película fina disponíveis atualmente são feitas principalmente de compostos químicos caros, como o seleneto de gálio-índio-cobre ou o telureto de cádmio. "Outros pesquisadores já haviam criado células solares sem estes elementos, atingindo 
rendimento de até $6,7 \%$ - 40\% menos do que o agora obtido." (INOVACAO TECNOLOGICA.COM.BR, 2009).

\subsubsection{Exemplos de aplicação das Células Fotovoltaicas}

O Solar Glowing Tower, é um monumento à energia renovável construído em Sevilha, na Espanha. A torre de 40 andares é iluminada por 600 espelhos ajustados para refletir a luz solar em placas solares localizadas no topo da torre. Com o sistema, é gerada energia suficiente para abastecer 6.000 casas. Pretende-se que com a instalação de milhares de espelhos seja possível fornecer energia para 600.000 pessoas. (BLOG.BOLA.INFO, 2008).

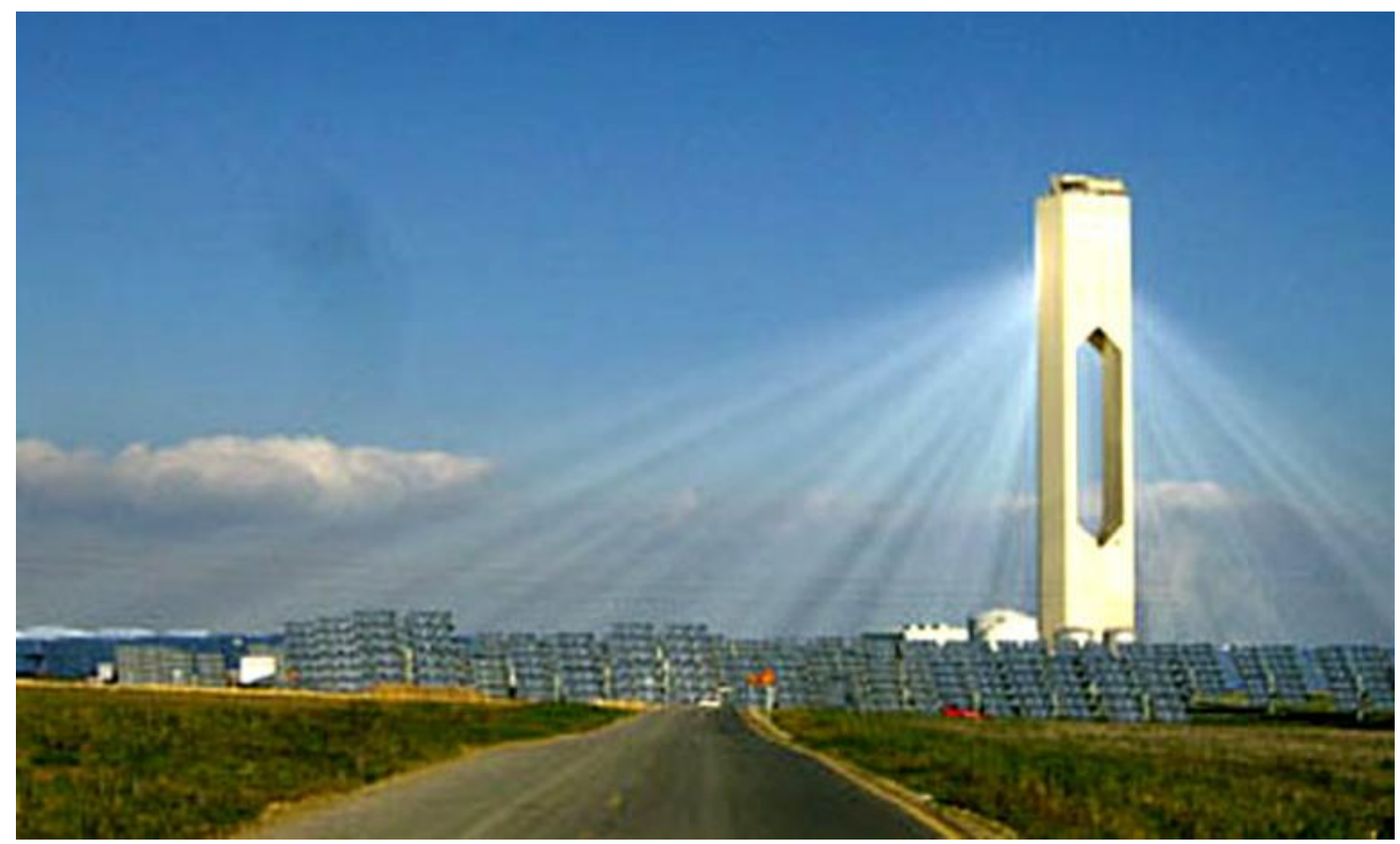

Figura 353: Solar Glowing Tower, Sevilha. Fonte: <http://blog.bola.info/2008/06/20/arquitetura-top-10iniciativas-green/>. Acesso em 21/02/2010.

O Museu da Energia Solar, conhecido como Sanyo Solar Ark, no Japão, construído pela Kajima Corporation, apresenta uma fachada em forma de asa, com 315 metros de envergadura e altura que varia de 32 metros (no centro) a 37 metros (nas laterais), completamente coberta por células fotovoltaicas. Somente um pequeno 
núcleo apoiado no solo, que constitui o espaço do museu, é habitável. São aproximadamente 5.000 painéis de células fotovoltaicas que produzem 630 Kilowatts de energia, tornando-o autossuficiente. Nessa fachada ainda foram incorporados 72.200 LEDs. No espaço do museu são apresentadas exposições multimídia, há um laboratório de energia solar - Solar Lab e salas para eventos voltados a questões ambientais.
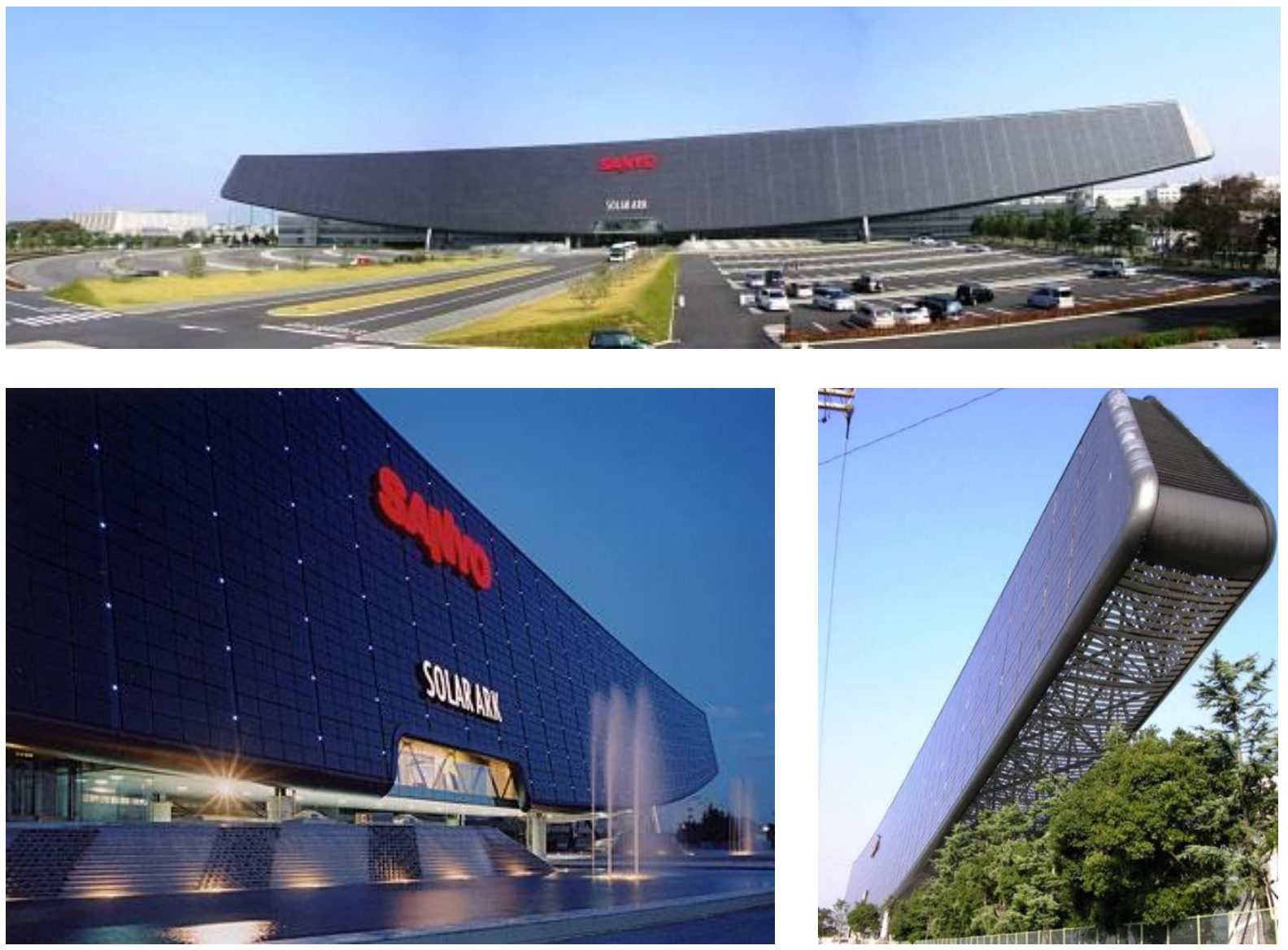

Figura 354: Sanyo Solar Ark, Japão. Fonte: <http://lafora.com.br/2009/02/arquitetura-ou-midia-exterior/>. Acesso em 28/03/2010.

Figuras 355 e 356: Sanyo Solar Ark, Japão. Fonte:

<http://inventorspot.com/articles/sanyos_solar_ark_combines_practi_9758>. Acesso em 28/03/2010. 
O Estádio em Formosa, no Japão, projetado por Toyo Ito, foi o primeiro construído com energia totalmente proveniente da energia solar. A cobertura composta de 8.844 painéis solares, pode gerar anualmente 1.14 GWh de energia. Quando o espaço não está sendo utilizado, $80 \%$ da energia gerada fica à disposição da vizinhança.
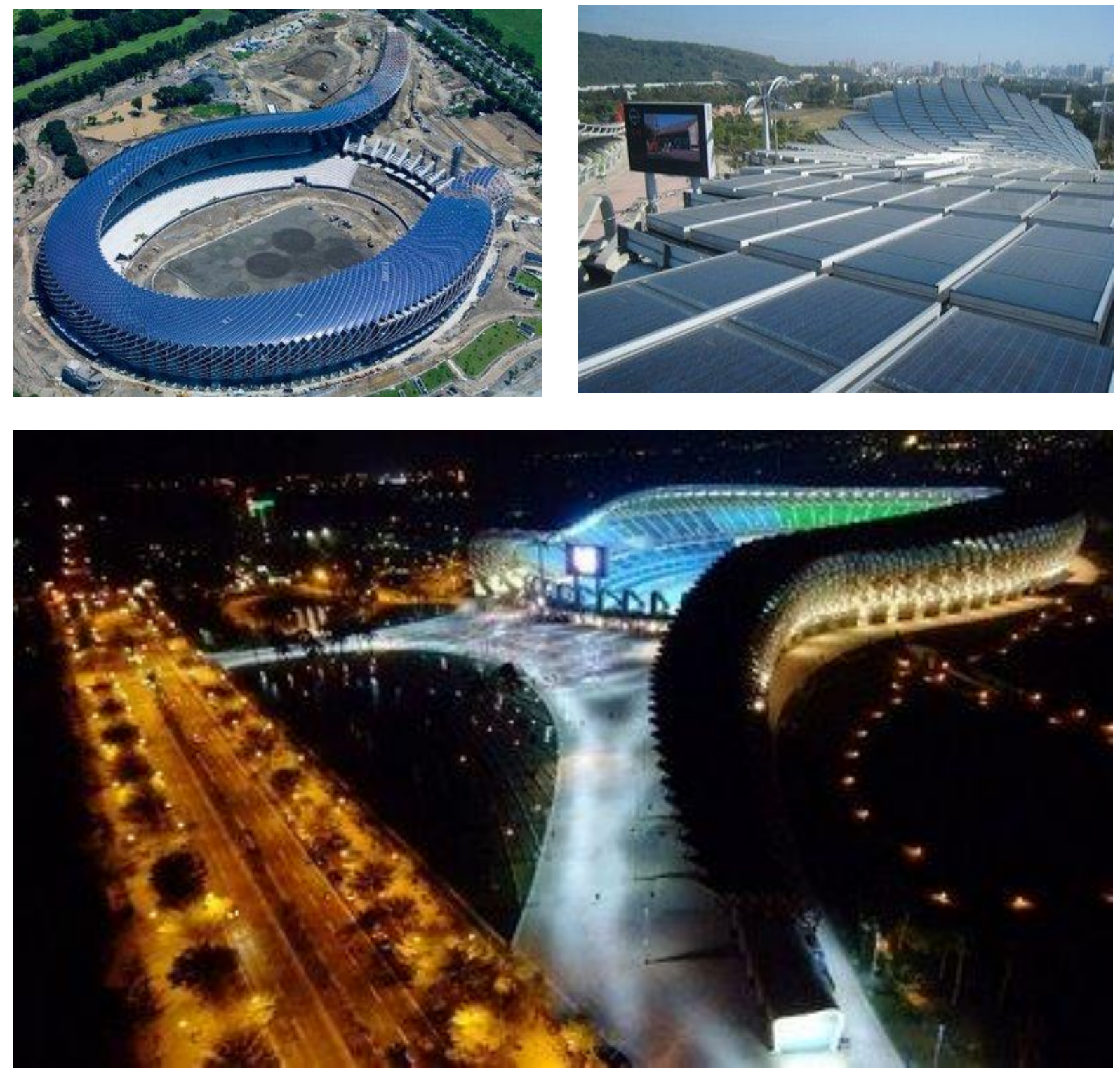

Figuras 357, 358 e 359: Estádio em Formosa, Japão. Fonte: <http://domescobar.blogspot.com/2009_05_01_archive.html>. Acesso em 28/03/2010.

O projeto vencedor do concurso realizado em 2009, para o Centro de Artes Cênicas de Seul, na Coréia do Sul, foi concebido com o objetivo de adequar-se ao meio ambiente. O edifício apresenta células fotovoltaicas integradas ao prédio em um sistema de aproveitamento de energia solar, iluminação e ventilação naturais. 

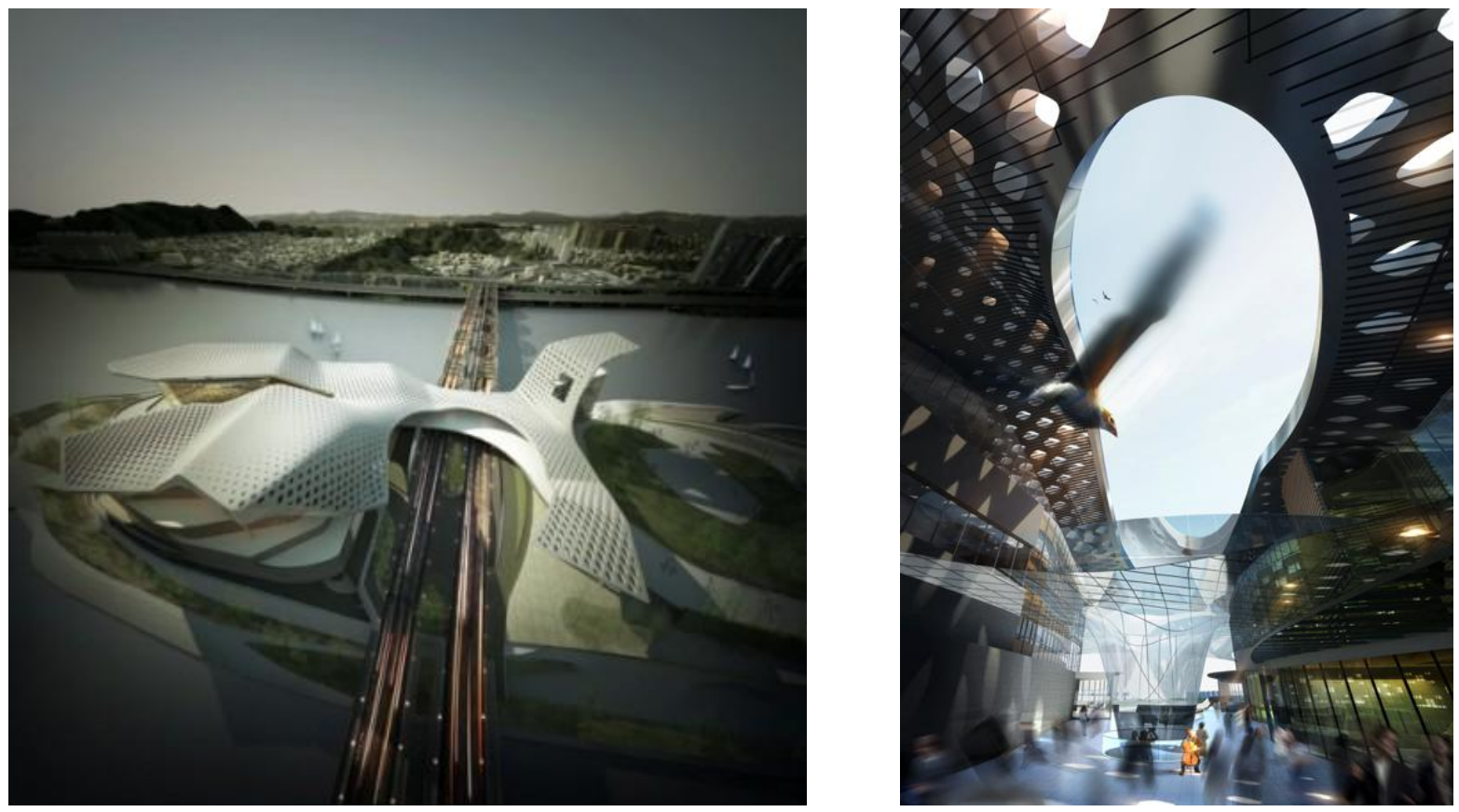

Figuras 360 e 361: Centro de Artes Cênicas de Seul, Coréia do Sul. Fonte: $<$ http://arquitetogeek.wordpress.com/category/edificacoes/>. Acesso em 21/02/2010.

O Pavilhão da Suíça, projetado para a Exposição Universal de Xangai, inaugurada em abril de 2010, foi criado pelo atelier Buchner Brundler Architects e teve inspiração o conceito sustentável do Yin e Yang.

Seu exterior é composto por uma fibra de soja biodegradável que se decompõe duas semanas após ser coberto com terra. Incorporando células fotovoltaicas, a 'cortina' transmite uma aparência de floresta que permite iluminar o interior muito tempo após o sol se pôr. O pavilhão de 4000 metros quadrados teve um custo de 18,52 milhões de dólares, e tem um sistema de teleférico na sua cobertura, que permite levar os visitantes a um prado florido. (GMCASQUEIRO.COM, 2010). 


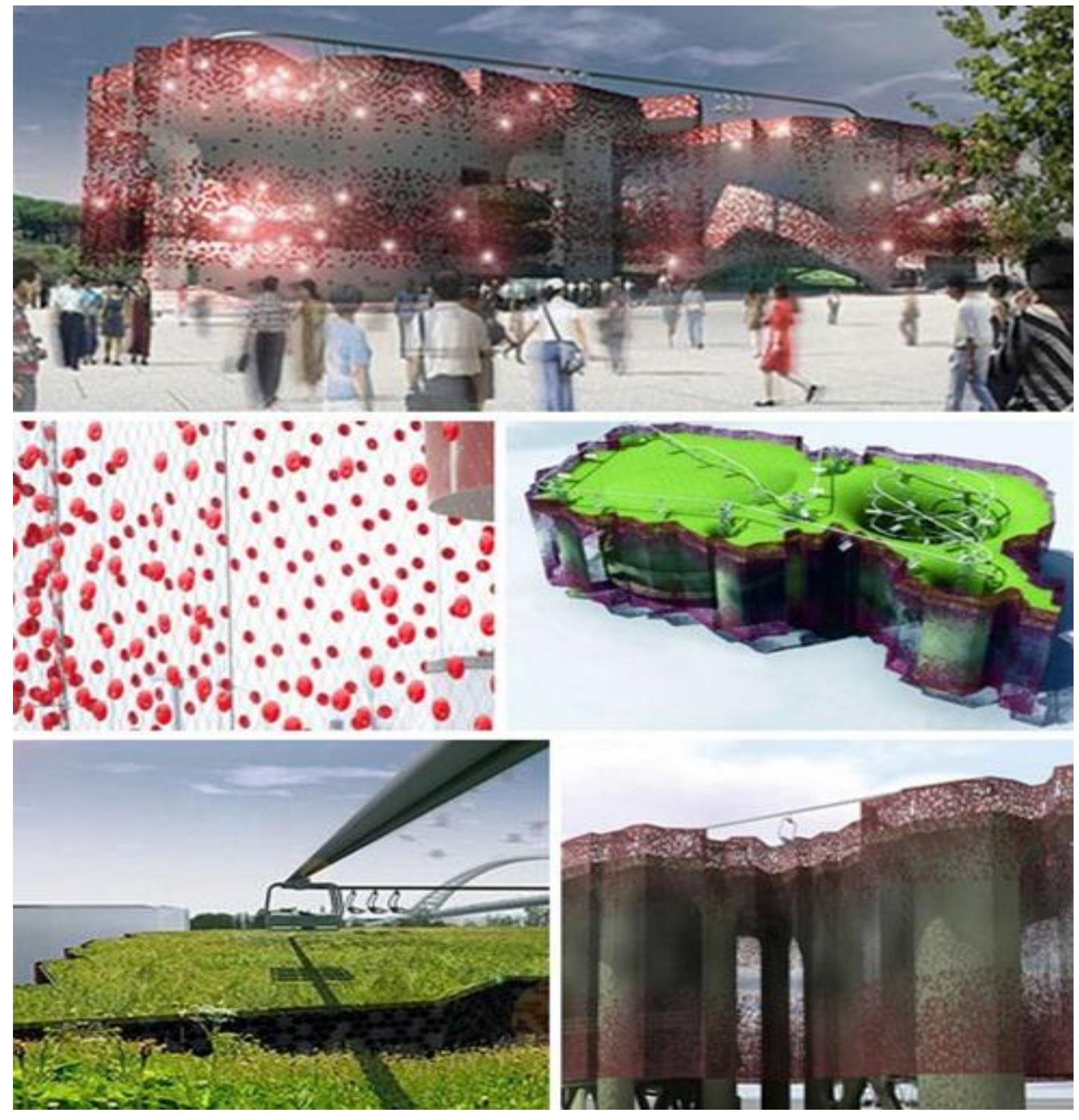

Figuras: 362, 363, 364, 365 e 366: Pavilhão da Suíça, projetado para a Exposição Universal de Xangai. Fonte: <http://gmcasqueiro.com/blog/2010/04/shanghai-expo-2010-15-projectos-arquitectnicos-de-cortar-a-respirao/>. Acesso em 23/05/2010.

Flores solares high tech foram criadas, em 2009, como estratégia de marketing do carro hibrido Prius da Toyota. Elas têm 5,5 metros de altura e funcionam como carregadores de celulares, tocadores de MP3, baterias de laptop e para conectar à internet. As pétalas são equipadas com células fotovoltaicas que absorvem os raios solares e transmitem a energia para a base em forma de corrente de 110 volts. A base comporta até dez pessoas das 8 às 21 horas todos os dias. Boston, New York, Chicago, Seattle, São Francisco e Los Angeles foram as cidades que as receberam. 


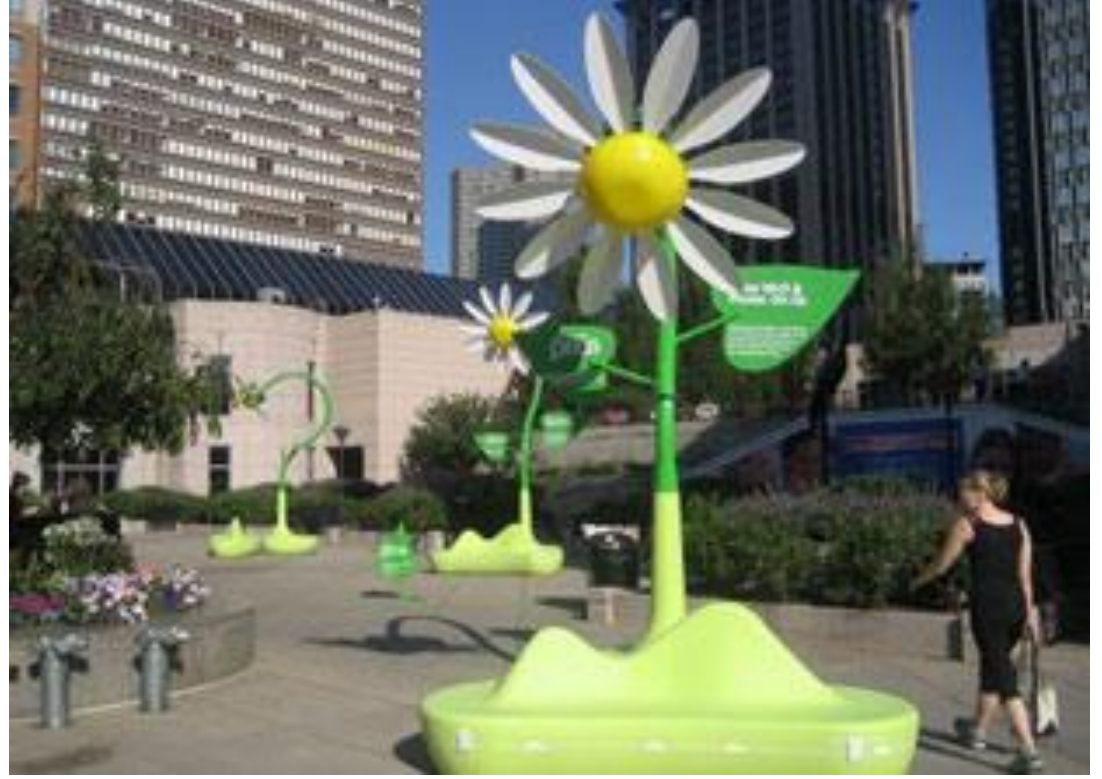

Figura 367: Flores solares high tech. $<$ http://epocanegocios.globo.co $\mathrm{m} /$ Revista/Common/1,,EMI834 83-16382,00.html>. Acesso em $21 / 02 / 2010$

Zoe Ze Spa, novo carro conceito da Renault tem o teto móvel coberto por células fotovoltaicas inteligentes que recarregam parte da energia gasta pelo veículo e asseguram proteção contra o frio e o calor. Desenvolvido em parceria com a Biotherm, o produto deve ser lançado em 2012.
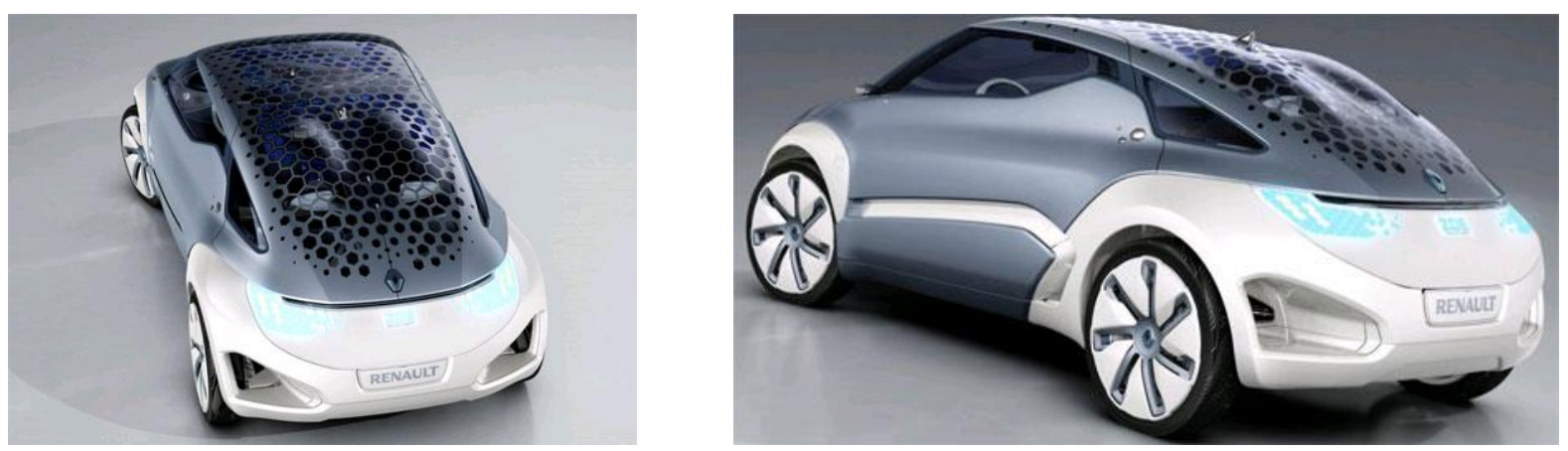

Figuras 368 e 369: Zoe Ze Spa. Fonte: <http://www.284brasil.com.br/blog/?tag=carros>. Acesso em 21/02/2010.

No Brasil, em função da bem sucedida experiência de alguns países europeus e da crescente crise energética mundial, têm sido dado os primeiros passos em direção ao uso dessa fonte de energia renovável e limpa. Ainda que lentamente, o meio acadêmico tem realizado pesquisas e incentivado projetos com o uso da energia fotovoltaica, enquanto que, no mercado ainda são considerados "objetos de desejo". (ARCOWEB.COM.BR, 2009). 


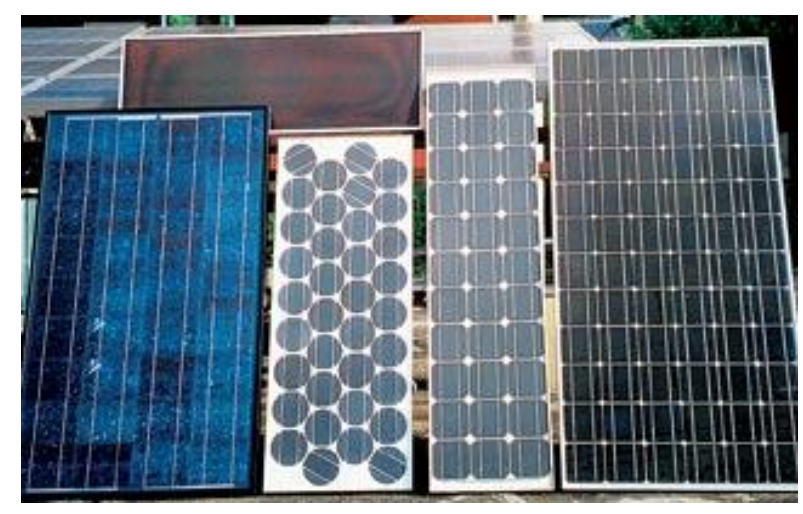

Figura 370: Exemplos de módulos fotovoltaicos comercializados no mercado nacional.

Fonte:

$<$ http://www.arcoweb.com.br/tecnologia/energia-

fotovoltaica-na-arquitetura-no-brasil-19-062009.html >. Acesso em 21/02/2010.

A tecnologia pesquisada há alguns anos pelo Laboratório de Energia Solar da Universidade Federal de Santa Catarina (Labsolar/UFSC) tem sido aplicada no desenvolvimento de projetos de Estádios Solares e Aeroportos Solares, como é o caso do novo terminal de passageiros de Florianópolis, através de parcerias com o Instituto de Energias Alternativas da América Latina (IDEAL) e com a Empresa Brasileira de Infraestrutura Aeroportuária (Infraero). Em 2009, foi assinado um convênio de transferência tecnológica entre Brasil e Alemanha na área energética.

No prédio do edifício administrativo do Instituto de Eletrotécnica da Universidade de São Paulo, foram aplicados em 120 metros quadrados de sua fachada painéis fotovoltaicos com potência nominal de 12 quilowatts, sistema que produz

em média, $50 \%$ das necessidades energéticas da edificação, cuja demanda nos dias de semana é de 100 quilowatts-hora. Aos sábados e domingos, o excedente é injetado na rede elétrica. Integrados na fachada como elementos construtivos, os módulos fotovoltaicos produzem energia, reduzem a carga térmica do prédio e também funcionam como brises. (ARCOWEB.COM.BR, 2009).
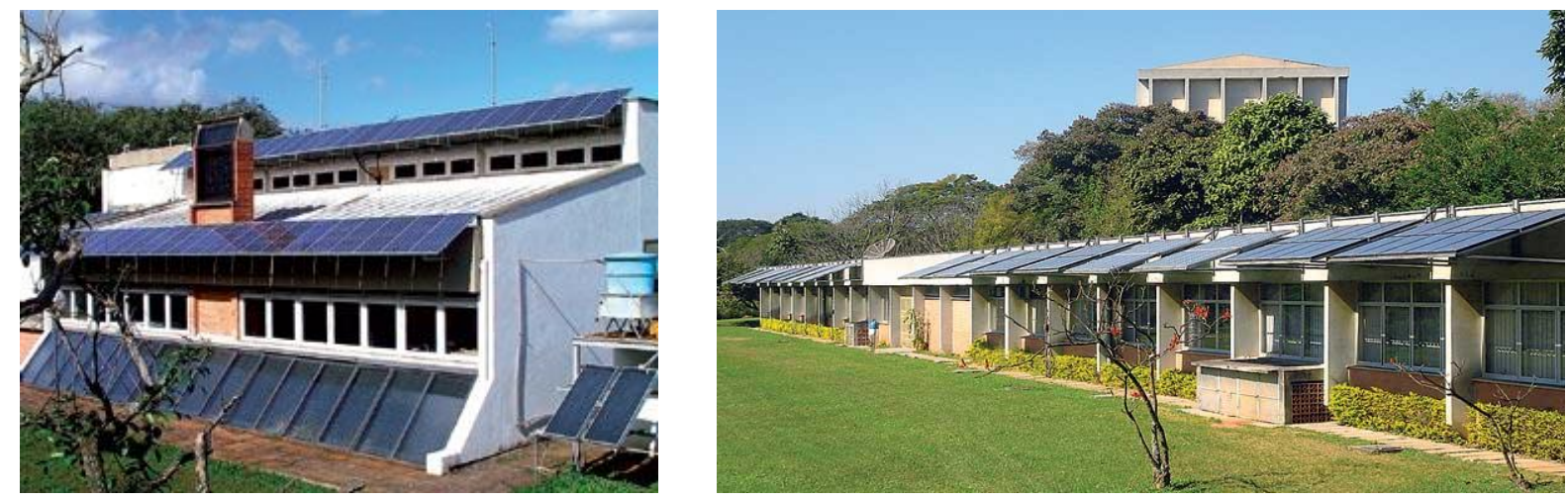

Figura 371: Instalação em Edifício da Universidade Federal do Rio Grande do Sul. Fonte: <http://www.arcoweb.com.br/tecnologia/energia-fotovoltaica-na-arquitetura-no-brasil-19-06-2009.html>. Acesso em 21/02/2010.

Figura 372: Instalação no edifício administrativo do Instituto de Eletrotécnica da Universidade de São Paulo. Fonte: <http://www.arcoweb.com.br/tecnologia/energia-fotovoltaica-na-arquitetura-no-brasil-19-06-2009.html>. Acesso em 21/02/2010. 
Quanto ao funcionamento,

O sistema conectado à rede (on-grid) não permite acúmulo de energia em bateria - se não for consumida, a eletricidade é automaticamente devolvida à rede. Nos países onde essa tecnologia é bem desenvolvida, o ponto de conexão da energia fotovoltaica ocorre antes do contador, fora da instalação da residência. Dessa forma, não há redução do consumo do ponto de vista da concessionária, mas o proprietário do sistema recebe uma tarifa prêmio por quilowatt-hora produzido com 0 sistema solar. (ARCOWEB.COM.BR, 2009).
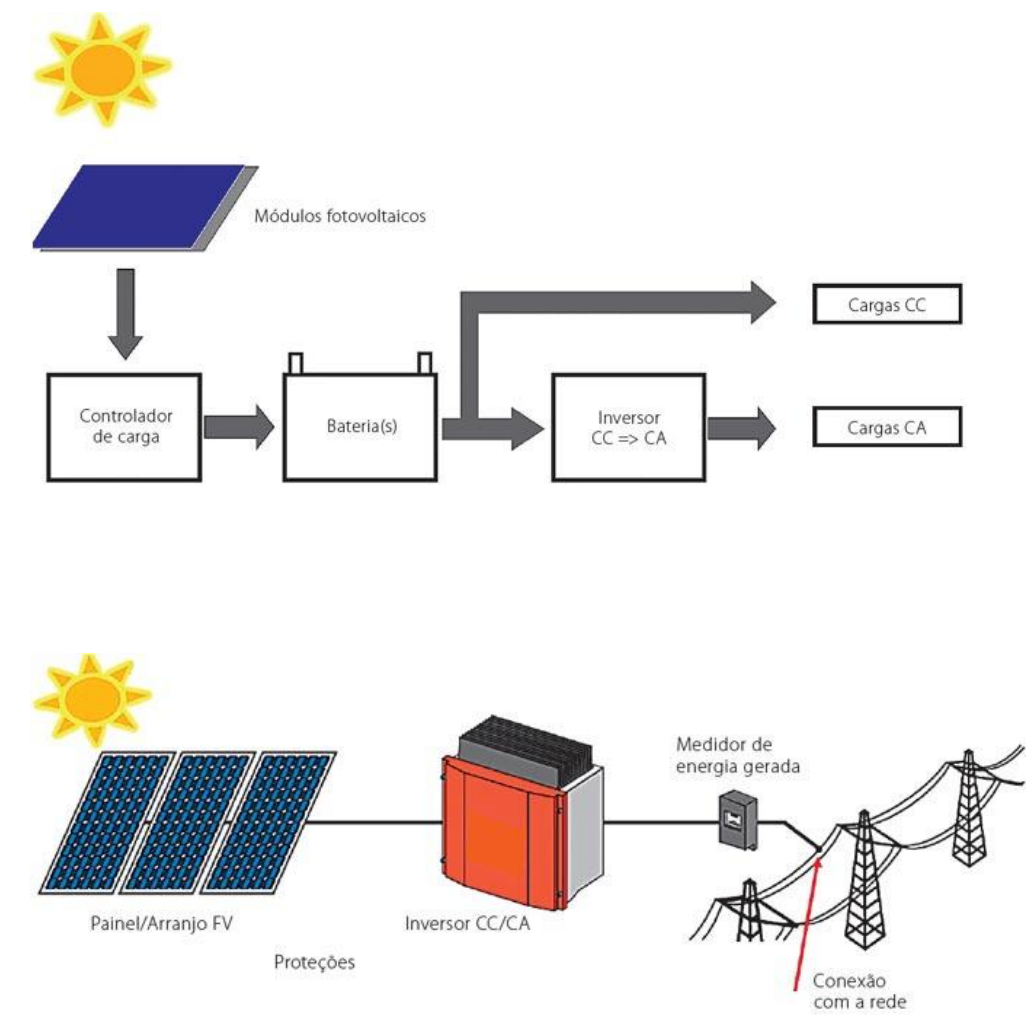

Figura 373: Esquema de sistema fotovoltaico isolado. Fonte:< http://www.arcoweb.com.br/tecnol ogia/energia-fotovoltaica-naarquitetura-no-brasil-19-062009.html >. Acesso em 21/02/2010.

Como não há demanda de mercado para a aplicação de painéis fotovoltaicos em edificações, o que existe no mercado brasileiro são produtos importados, como é o caso da empresa alemã Schüco. A Alcoa, empresa que também produz sistemas de fachadas, lançou na II Feira de Esquadrias, Ferragens e Componentes - Fesqua de 2008, em São Paulo, um protótipo de caixilhos com sistema fotovoltaico. A coordenadora de novos produtos da empresa, Cíntia Figueiredo, afirmou em entrevista ao Jornal O Estado de São Paulo, que essa é uma solução muito usada na Europa como opção de energia limpa e ecologicamente correta. "O painel é uma placa de vidro onde são colocadas as células ligadas por fios. Por trás é colocado outro vidro, que pode receber um revestimento de cobertura." O sistema é voltado para edificações com parede-cortina que, geralmente, têm estrutura de alumínio. A 
proposta é que os painéis fotovoltaicos sejam usados como vedação, sendo assim, exige que sua aplicação seja definida ainda na fase de projeto. "O ideal é usar essa instalação na face norte e com possibilidade de instalação dos painéis com alguma inclinação. Isso vai ajudar na absorção. (...) Na face externa, a estética é pela combinação dos desenhos das células". Não foram definidos o custo de uma fachada e nem a quantidade de energia que poderá produzir o produto. (O ESTADO DE SÃO PAULO, 2008).

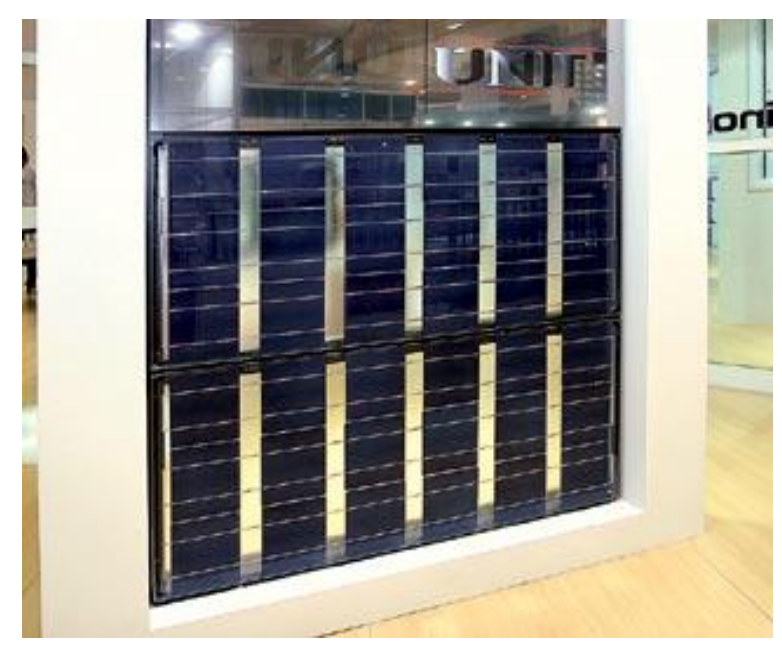

Figura 375: Protótipo da Alcoa desenvolvido com caixilhos da linha Unit. Fonte: <http://www.arcoweb.com.br/tecnologia/energiafotovoltaica-na-arquitetura-no-brasil-19-062009.html>. Acesso em 21/02/2010.

Segundo Bruno Topel, diretor da empresa Heliodinâmica, pioneira nessa tecnologia no Brasil,

O mercado brasileiro ainda está por descobrir a energia fotovoltaica. Tratase de um dos investimentos mais rentáveis e a durabilidade das placas fotovoltaicas é de 25 anos, pelo menos. Essa empresa fabrica placas que chegam aos $14 \mathrm{Wp}$ as quais são usadas no setor de telecomunicações e naqueles locais desprovidos de rede elétrica. Em algumas rodovias de São Paulo há painéis em funcionamento, para os sistemas de controle de tráfego, instalados em postes com cerca de seis metros de altura. (ARCOWEB.COM.BR, 2009)

Valentina N. Figuerola, em artigo publicado na Edição Especial Pini 60 anos, afirma que já existem estudos voltados ao emprego de células fotovoltaicas em placas cerâmicas, o que poderá contribuir para a eficiência energética dos edifícios. A nova tecnologia está sendo desenvolvida pelo professor e pesquisador Arturo Salomoni do Centro Cerâmico de Bolonha, na Itália, e foi divulgada na feira Revestir realizada em São Paulo, em março de 2008. As cerâmicas fotovoltaicas foram concebidas para serem instaladas em fachadas ventiladas, ou seja, com juntas abertas e com a fixação das placas em uma estrutura metálica fixada no edifício, de modo que o vão 
entre os componentes cerâmicos e a vedação favoreça a circulação por efeito chaminé, e assim, haja uma melhora no desempenho térmico das edificações. Esse tipo de sistema construtivo, muito conhecido na Europa, ainda não é aplicado no Brasil, onde a fixação dos componentes cerâmicos ainda são feitas com argamassa. Outra pesquisa em desenvolvimento pelo Instituto de Tecnologia Cerâmica - ITC, na Espanha, são cerâmicas que poderão incorporar além das células fotovoltaicas placas fototérmicas, capazes de coletar o calor para aquecer um fluido de calefação de um edifício. (FIGUEROLA, 2008)

Em 10 de junho de 2010, tivemos a oportunidade de assistir à palestra: Integração Fotovoltaica em Edifícios, no Instituto de Arquitetos do Brasil - IAB, em São Paulo, apresentada por Teodosio Del Caño, representante da empresa espanhola ONYX Solar, especializada em realizar integração fotovoltaica em edifícios através do sistema BIPV capaz de converter fachadas, coberturas e janelas de edifícios em estações de geração de energia de alto rendimento. De uma maneira geral, a empresa dedica-se:

(...) ao estudo e posta no funcionamento de medidas de eficiência energética e tecnologias sustentáveis para a readaptação de moradias existentes e a criação de novos edifícios ecoeficientes e que surge com a filosofia de disponibilizar soluções únicas e inteligentes de integração arquitetônica combinando a otimização do isolamento térmico com a geração fotovoltaica. (ONYX SOLAR, 2010, tradução nossa)

A integração fotovoltaica pode ser alcançada com a aplicação de placas de vidro laminado e de vidro isolante térmico e acústico. O vidro laminado está disponível em diferentes tecnologias, cores, espessuras e tamanhos. Embora possa ser aplicado como piso para baixo tráfego de pessoas, suas principais aplicações têm sido em fachadas e em coberturas ventiladas fotovoltaicas, para as quais a empresa desenvolve produtos e serviços suplementares com o objetivo de proporcionar maior facilidade de instalação em qualquer tipo de edificação; desta maneira, há a possibilidade de adaptar os vidros à forma, à localização, às necessidades econômicas e estéticas de cada cliente. Diante da variedade de produtos fotovoltaicos e de diversas tecnologias disponíveis, a empresa oferece uma solução única e inteligente para a integração das mesmas, levando sempre em conta as características de cada projeto. Entre as soluções estão: 
a-SI: rendimento ótimo sob condições de irradiação difusa, estável desde o ponto de vista térmico e esteticamente atraente, o que favorece a perfeita integração nos edifícios;

CIS/CIGS: melhor rendimento em qualquer condição de irradiação, disponível em diversas cores;

CRISTALINO: uma solução ideal para sistemas BIPV com um alto potencial de geração de energia elétrica. (ONYX SOLAR, 2010, tradução nossa)

Quanto ao vidro isolante térmico e acústico, encontra-se disponível em diferentes tamanhos e espessuras e é formado por dois ou mais vidros fotovoltaicos separados por uma câmara de ar. Para que haja uma integração em janelas e paredes-cortina, a caixa de conexões fica oculta atrás da estrutura. Sua característica semitransparente, não impede a visão para o exterior do edifício. Caño nos informou que a tecnologia pode ser aplicada em edificações sujeitas a trepidações, assim como estações de trem e de metrô. Citou como exemplo prático a Estação de Kyoto, no Japão.

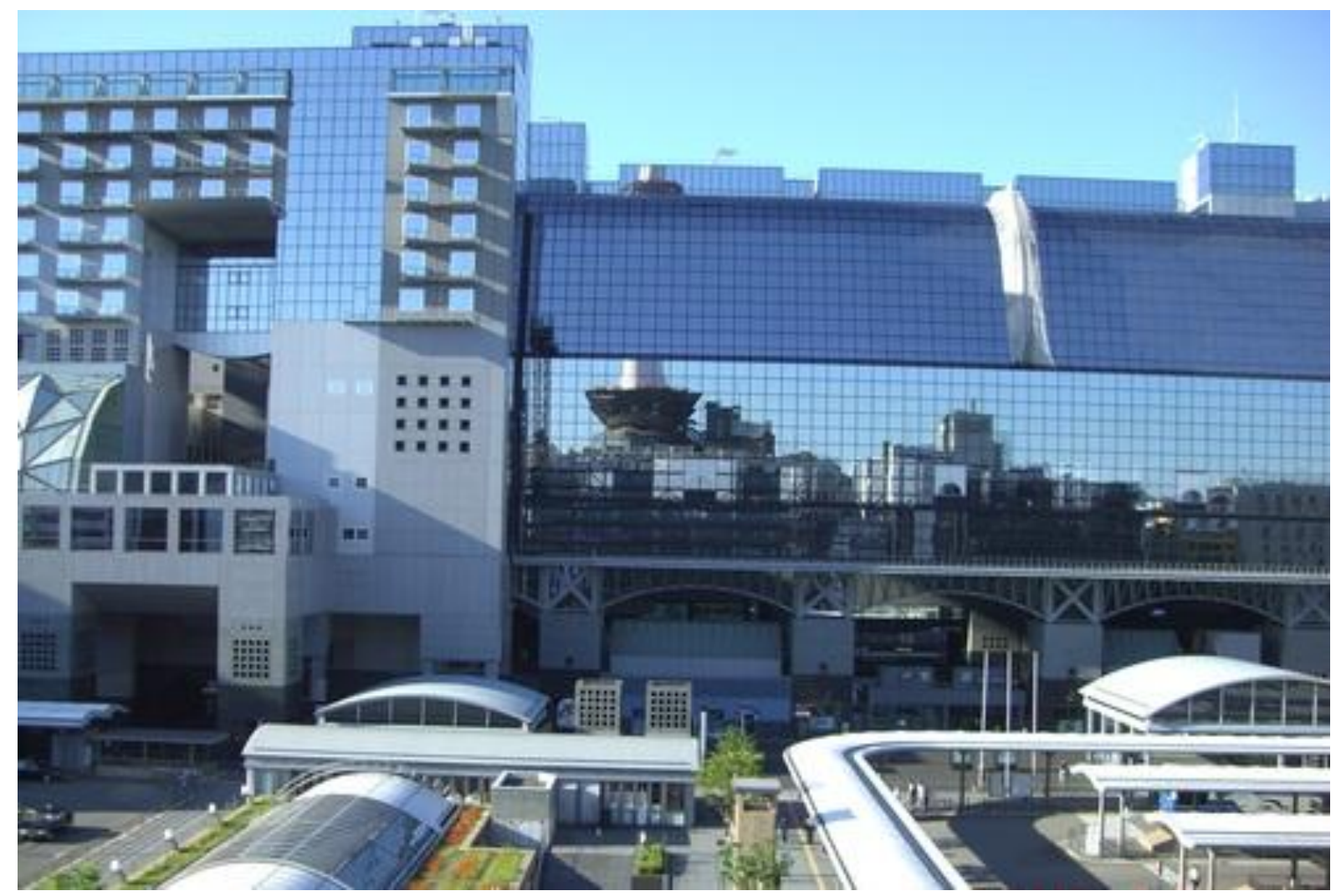

Figura 376: Estação de trem em Kyoto, no Japão. Foto: Juan José Marquez. Uploaded on September 4, 2007. Fonte: <http/www.panoramio.com/photos/original/4409921.jpg >. Acesso em 13/06/2010. 

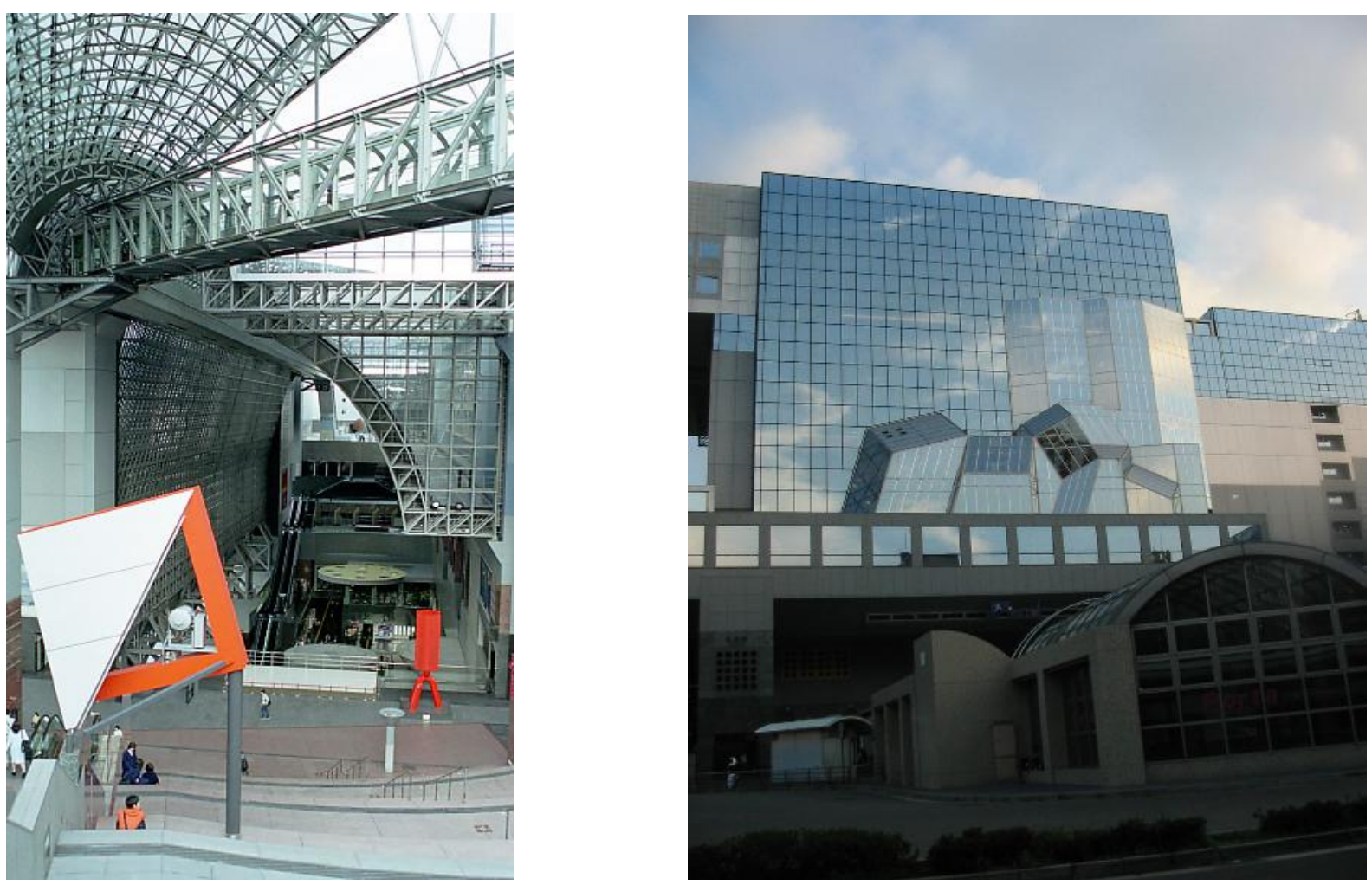

Figuras 377 e 378: Estação de trem em Kyoto, no Japão. Fonte:<http://www.google.com.br/imgres $>$ ? $^{87}$ Acesso em 06/09/2010.

\subsubsection{Diodo Emissor de Luz: Light Emitting Diode (LED)}

De acordo com dados publicados recentemente na revista Veja, o desconhecido físico sueco Svante Arrhenius, em 1896, já havia nos alertado que estaríamos sujeitos a sérias consequências climáticas caso continuássemos a emitir dióxido de carbono no ritmo em que se fazia desde 1750, com a Revolução Industrial. Para Arrhenius, era previsível a elevação da temperatura média da Terra como resultado do efeito estufa. Seu raciocínio pouco foi considerado até que novas evidências científicas surgiram. Nos anos 1960, surgiu a "idéia romântica, utópica e alternativa de preservação da natureza". Atualmente, embora timidamente, essa ideia "ajudou a

87

<http://www.google.com.br/imgres?imgurl=http://www.johnharveyphoto.com/Japan/Kyoto\%2520Day\% 25202/KyotoTrainStationLg.jpg\&imgrefurl=http://www.johnharveyphoto.com/Japan/Kyoto\%2520Day\% 25202/KyotoTrainStation. $h t m l \& u s g=\_c k E L a E 09 m z D K K U K I b M k Q U 4 \mid k J 0 k=\& h=1500 \& w=854 \& s z=392$ \&hl=pt-

BR\&start=0\&zoom=1\&tbnid=EP5LaCQvoWjf0M:\&tbnh=120\&tbnw=68\&prev=/images\%3Fq\%3Dtrain\% 2Bstation,\%2Bkyoto\%26um\%3D1\%26hl\%3Dpt-BR\%26rlz\%3D1R2SNNT_pt-

BR\%26biw\%3D1345\%26bih\%3D516\%26tbs\%3Disch:1\&um=1\&itbs=1\&iact=hc\&vpx=569\&vpy=16\&du

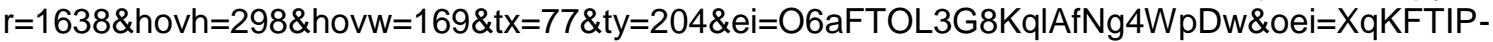

HsOBIAfhv42IDg\&esq=6\&page $=1$ \&ndsp $=24 \& v e d=1 \mathrm{t}: 429, \mathrm{r}: 3, \mathrm{~s}: 0>$. 
transformar os processos de produção industrial e moldou o perfil dos líderes empresariais que conduzem o capitalismo no século XXI." (VEJA, 2009, p. 215).

Segundo o artigo, no ano de 2010, o lançamento de alguns produtos, ideias e posturas estarão começando a delinear com maior clareza o cotidiano baseado na "economia limpa". Entre as inovações tecnológicas está uma nova forma de emissão de luz: o LED (Diodo Emissor de Luz ou Light Emitting Diode), que veio para substituir as lâmpadas fluorescentes e incandescentes. "Nessa tecnologia, um semicondutor semelhante ao usado nos microcomputadores, quando atravessado por energia, emite luminosidade." Essas lâmpadas convertem até $40 \%$ da energia consumida em luz, o que reduz o desperdício e beneficia o meio ambiente. "Se a metade de toda a iluminação mundial fosse convertida à tecnologia LED até 2025, seria possível economizar 120 gigawatts de eletricidade. Isso reduziria a emissão de dióxido de carbono em 350 milhões de toneladas por ano." (VEJA, 2009, p. 220).
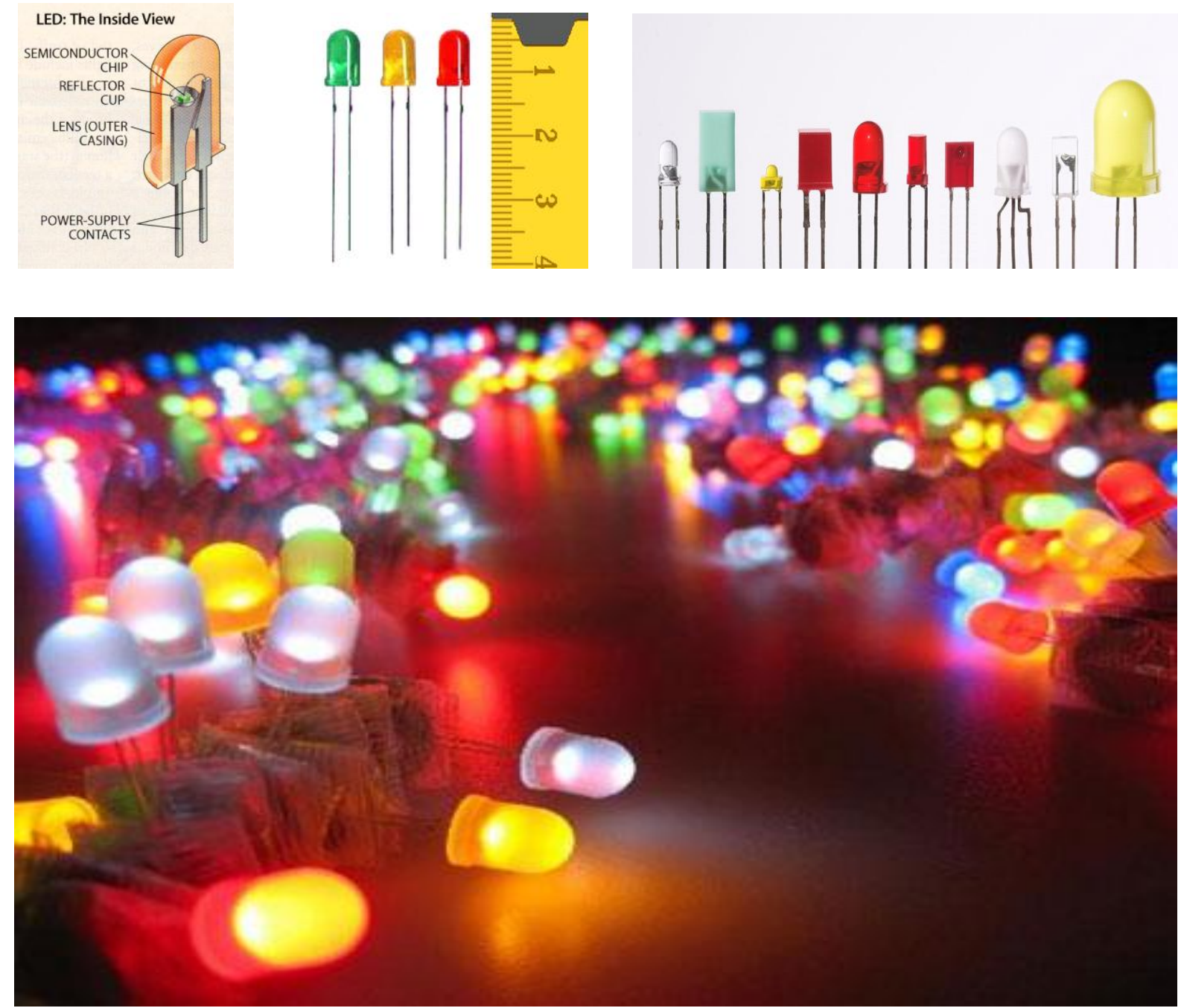

Figura 379, 380 e 381: Demonstração da dimensão de um LED. Fonte: <http:/www.eletr.ufpr.br/mehl/LED/LED>. Acesso em 14/02/2010.

Figuras 382: LEDs. Fonte: <http:www.autoblog.jrmania.com.br/.../06/led_resistor.jpg>. Acesso em 14/02/2010. 
Para melhor esclarecer os benefícios desse novo produto do ecodesign, segue uma tabela que demonstra gastos estimados ao longo de cinco anos para uma residência com vinte pontos de luz e utilização média de dez lâmpadas acesas durante seis horas.

Tabela 02: Tabela comparativa de demonstração de gastos entre lâmpadas incandescentes, fluorescentes e LEDs. Fonte: Revista Veja, 30 de dezembro de 2009, p. 220.

\begin{tabular}{llll}
\hline & INCANDESCENTE & FLUORESCENTE & LED \\
\hline investimento inicial com lâmpadas & $\mathrm{r} \$ 36$ & $\mathrm{r} \$ 700$ (com reatores) & $\mathrm{r} \$ 1500$ \\
potência média de consumo das lâmpadas & $60 \mathrm{w}$ & $18 \mathrm{w}$ & $8 \mathrm{w}$ \\
consumo de energia & $6480 \mathrm{kwh}$ & $1994 \mathrm{kwh}$ & $1080 \mathrm{kwh}$ \\
lâmpadas trocadas & 110 & 14 & Zero \\
gasto com energia & $\mathrm{r} \$ 2628$ & $\mathrm{r} \$ 778$ & $\mathrm{r} \$ 345$ \\
gasto com lâmpadas & $\mathrm{r} \$ 195$ & $\mathrm{r} \$ 140$ & Zero \\
Total & $\mathrm{r} \$ 2859$ & $\mathrm{r} \$ 1618$ & $\mathrm{r} \$ 1845$ \\
\hline
\end{tabular}

A empresa alemã de iluminação Osram, conduziu um estudo sobre o processo de produção da lâmpada de LED que envolveu desde a manufatura ao acender da luz e descobriu que a energia utilizada é um quinto da compacta fluorescente. A Philips, lançou um modelo de LED com soquete e luminosidade equivalentes aos de uma lâmpada incandescente de 60 watts.

Os LEDs apresentam ângulos de emissão de luz que vão de 5a a 180․ Quanto maior for o ângulo, maior será a área iluminada e menor será a intensidade da luz no foco. Quanto aos tipos, podem ser classificados em: normais (2V), super brilho (3V) e super LEDs que trabalham em valores diferenciados de voltagem e necessitam de dissipador de calor.

Nos super brilho temos os LEDs Ultravioleta que emitem uma luz (que o olho humano não capta) que ilumina ambientes escuros. Normalmente, são usados em conjunto com câmeras de segurança ou filmadoras. Temos também os infravermelhos usados em controles remoto, celulares, etc. Eles também são LEDs, parecidos com os ultravioleta, que emitem impulsos de luz sincronizada para os receptores (...). E também não podemos esquecer dos úteis LEDs tricolores que são compostos por uma espécie de "dual-led" interno, onde é possível fazer a combinação de cores e se obter uma nova ou ainda usar as cores puras, sem a necessidade da troca do diodo. Lembrando que esta variação de cor ocorre graças às mudanças de corrente de energia que o LED recebe. (AUTOBLOG.JRMANIA.COM.BR, 2008) 
Em junho de 2009, foi publicado no site Inovação da Universidade de CampinasUNICAMP, um texto baseado em artigo publicado no New York Times, em 30 de maio de 2009, o qual aborda o início do uso do LED para iluminar residências e ruas, tecnologia que reduz radicalmente emissões. Amplamente utilizada em painéis ao ar livre e em semáforos, a reportagem relata que estão em andamento experiências voltadas à substituição de lâmpadas incandescentes e fluorescentes por LEDs. Nos Estados Unidos, a iluminação responde a $60 \%$ do consumo de energia do país. Com base em cálculos, em 20 anos, a transição para lâmpadas de LEDs corresponderia à redução de mais de $50 \%$ nas emissões. Segundo relatório da consultoria MCKinsey and Company, essa conversão é entendida como "potencialmente a mais efetiva do ponto de vista de custo de um grupo de medidas simples para enfrentar o aquecimento global usando tecnologias já existentes." (INOVACAOUNICAMP.BR, 2009).

De forma inversa às características negativas das lâmpadas fluorescentes que consomem alto índice de energia, têm pouca durabilidade e contêm o mercúrio como um de seus componentes, o que ocasiona problemas relacionados ao descarte, a nova tecnologia é duas vezes mais eficiente em relação às fluorescentes, apresenta longa durabilidade e não possui elementos tóxicos, o que a isenta de tais problemas. Apesar das grandes vantagens, o custo ainda é um problema para aquisição do produto por consumidores domésticos. $O$ interesse comercial em produzir lâmpadas a um custo mais baixo pode trazer outro problema. Devido aos diodos serem "minúsculos sanduíches de dois materiais diferentes que emitem luz quando elétrons saltam de um para o outro" essas lâmpadas devem ser cuidadosamente desenhadas para que não se corra o risco do calor danificá-las e reduzir seu tempo de vida "de décadas para meses". (INOVACAOUNICAMP.BR, 2009).

$\mathrm{O}$ artigo ainda aponta uma outra questão a ser considerada, é que a luz fornecida é unidirecional, enquanto as lâmpadas convencionais emitem luz em todas as direções. Os LEDs são indicados para iluminar ruas a partir de uma certa altura, mas não são uma boa solução para serem usados em um abajur, por exemplo. Sua implantação em municípios deve ser realizada com certa cautela para que sejam evitados "desapontamento ou desastres". (INOVACAOUNICAMP.BR, 2009).

Mais adiante, afirma que avanços científicos têm solucionado alguns desses problemas. O preço está caindo e a qualidade da luz tem se aproximado à necessária para iluminar residências e ruas. Tem se buscado a substituição da 
safira, utilizada como matéria prima, por pastilhas de silício, muito mais baratas. Os primeiros LEDs só emitiam luz verde ou vermelha, hoje, já é possível fabricá-los com emissão de luz azul, os quais "podem ser manipulados para simular a luz de lâmpadas incandescentes." (INOVACAOUNICAMP.BR, 2009).

Avançando no estudo, pudemos perceber o quão intensas têm sido as pesquisas nesse campo. Os dados que haviam sido publicados em junho de 2009 já estavam ultrapassados. Um ano depois, o site Inovação Tecnológica publicou que, após os LEDs inorgânicos tradicionais, foram lançados no mercado os LEDs orgânicos (OLEDs), os quais possibilitaram a fabricação em rápida e larga escala devido à possibilidade da deposição dos materiais emissores de luz ser feita sobre um material plástico utilizando um processo similar ao de impressão a jato de tinta. No entanto, superando os LEDs orgânicos, foi desenvolvida uma pesquisa pela equipe do professor John Rogers, da Universidade de Ilinois, nos Estados Unidos, que produziu LEDs inorgânicos minúsculos e ultrafinos que podem ser fabricados em conjunto em larga escala. Segundo Rogers, "o objetivo é casar algumas das vantagens da tecnologia dos LEDs inorgânicos com a escalabilidade, a facilidade de produção e a resolução dos LEDs orgânicos." (INOVACAOTECNOLOGICA.COM.BR, 2009).

Os LEDs tradicionais, compostos por semicondutores inorgânicos e sem o carbono, têm suas vantagens por apresentarem uma maior vida útil, brilho superior, maior robustez e confiabilidade, enquanto os OLEDs, que levam carbono em sua composição, apresentam outras vantagens por serem fabricados em "substratos flexíveis e em conjuntos densos e interconectados, o que torna possível sua instalação em superfícies irregulares, na forma de tetos ou paredes totalmente iluminadas e até em janelas semitransparentes." Essas folhas finas e flexíveis de LEDs impressos, além de possibilitar seu uso para iluminação, painéis de instrumentos, painéis de telas e monitores, também podem ser muito úteis nos campos da biomedicina e da biotecnologia, afirma Rogers. 


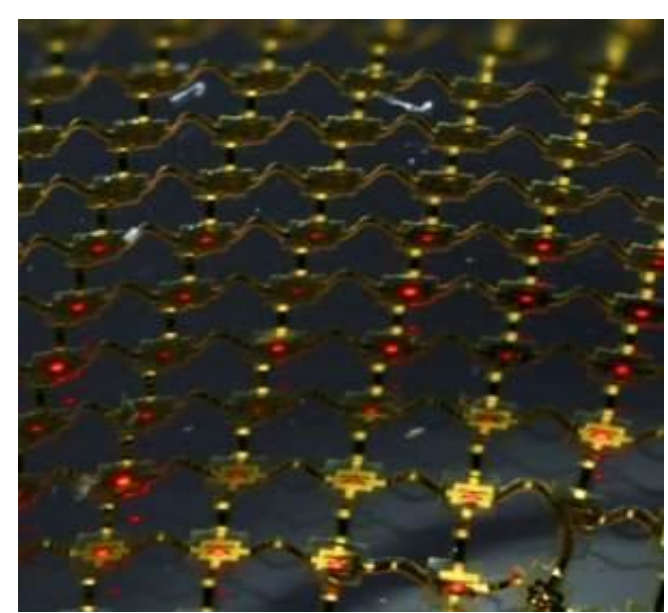

Figura 383: Telas maiores, mais brilhantes e dobráveis. Fonte:

$<$ http://www.inovacaotecnologica.com.br/noticias/noticia.p $\mathrm{hp}$ ?artigo=leds-ultrafinos-abrem-novas-possibilidades-

iluminacao-telas-dobraveis\&id=010115090825>. Acesso em 13/02/2010.

Em 2011, foram criados os COLEDs (Cavity Organic Light-Emitting Diode), projetados pela equipe do Dr. Yijan Shi, do Instituto SRI, nos Estados Unidos, entidade de pesquisa sem fins lucrativos. "São novos LEDs orgânicos que utilizam cavidades ópticas, espelhos paralelos e contrapostos que evitam a fuga de fótons para outros pontos que não a direção de saída do dispositivo, por onde a luz é emitida." (INOVACAOUNICAMP.BR, 2009).
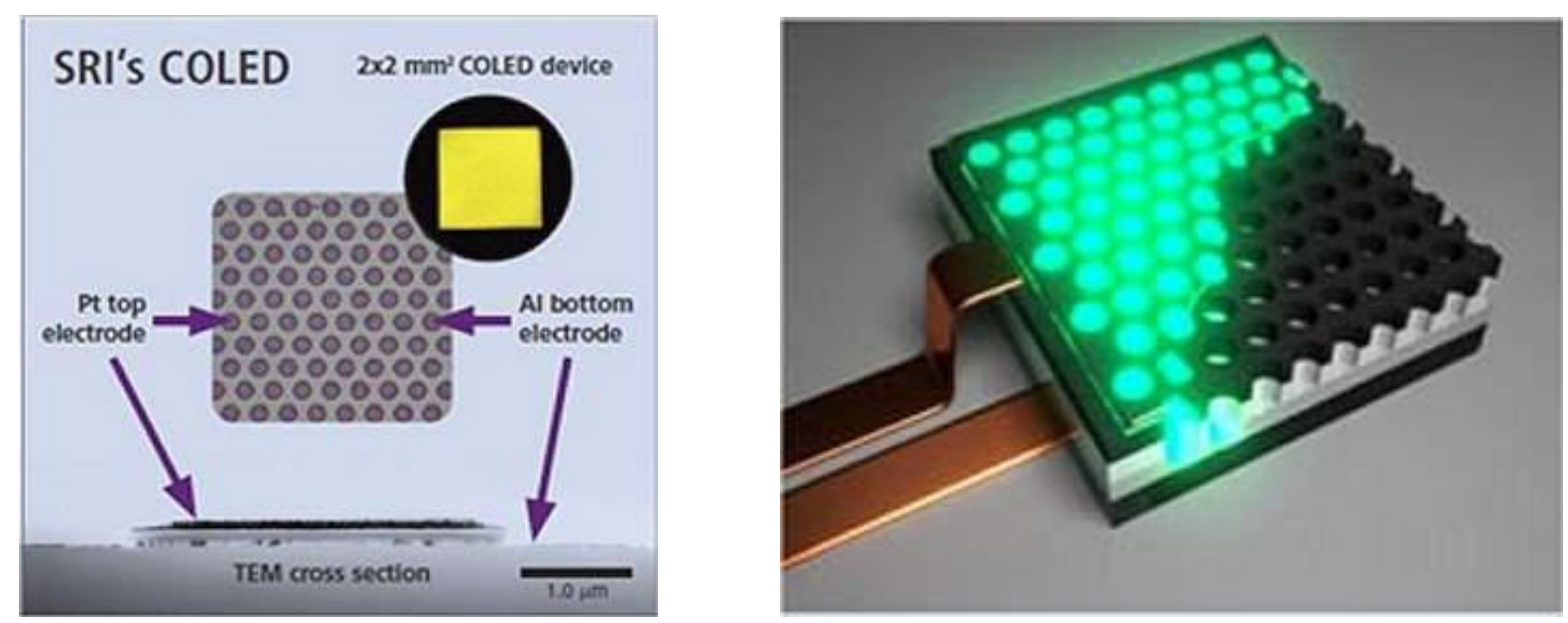

Figuras 384 e 385: COLED. Fonte:< http://www.inovacaotecnologica.com.br/noticias/noticia.php?artigo=coledled-organico-cavidade-optica-bate-todos-recordes\&id=010115090811 >. Acesso em 14/02/2010.

\subsubsection{Exemplos de aplicação}

Em termos práticos, o processo de conversão da iluminação convencional de lâmpadas incandescentes e fluorescentes para o sistema de LEDs foi iniciado em 
Toronto (Canadá), Ann Arbour (EUA), Tianjin (China) e em três grandes cidades da Califórnia: Los Angeles, com 140 mil lâmpadas de rua; San Jose, com 62 mil lâmpadas e São Francisco, com 30 mil. A primeira a adotar a tecnologia foi Ann Arbour (INOVACAOUNICAMP.BR, 2009), no entanto, o pequeno vilarejo medieval de Torraca (na Itália), habitado por 1200 habitantes e com 700 ruas, foi o primeiro lugar no mundo a ter um sistema de iluminação totalmente realizado com a nova tecnologia, o que a tornou conhecida como "ícone de sustentabilidade". (VEJA, 2009 , p. 221). O mecanismo gerou uma economia de $65 \%$, uma redução dos custos de manutenção em 50\% e 90\% da poluição luminosa.
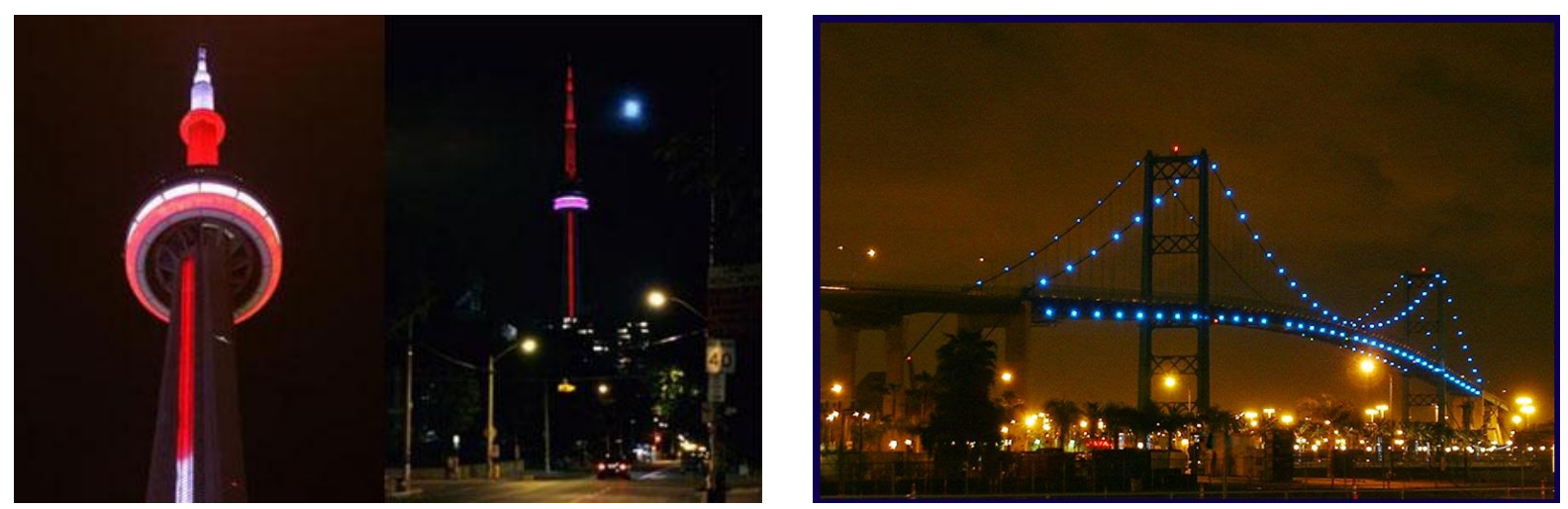

Figura 386: CN Tower, Toronto. Fonte:< http://www.engadget.com/2007/06/29/torontos-cn-tower-gets-lit-up-withleds/>. Acesso em 13/02/2010.

Figura 387: Golden Gate, Los Angeles. Fonte:< http://www.trekearth.com/gallery/photo148306.htm>. Acesso em $13 / 02 / 2010$.

No caso de Ann Arbour, pelo fato da luz dos LEDs ser modulável

elas foram programadas (...) para se tornarem mais brilhantes quando alguém passasse por baixo de uma lâmpada ou para piscar do lado de fora de uma casa para guiar paramédicos em uma emergência. Na cidade de Raleigh (EUA), outra cidade que instalou LEDs em alguns lugares, os moradores aprovaram a mudança pelo fato de sua luz unidirecional não incomodá-los no interior de suas residências. Em Torraca, para que não fosse perdido o "romantismo" de seu cenário medieval, foram colocadas algumas lamparinas antigas montadas com LEDs. (INOVACAOUNICAMP.BR, 2009). 

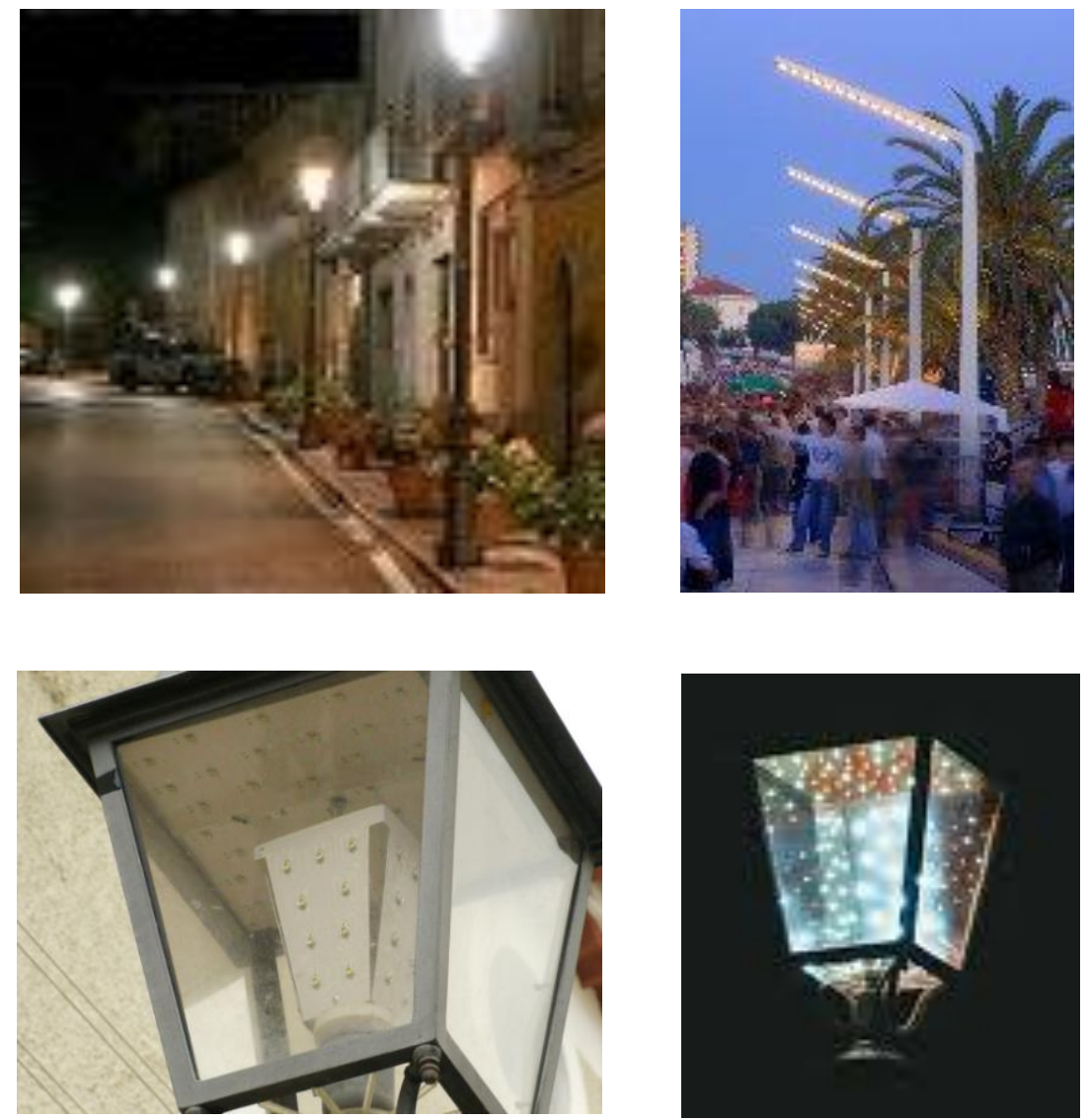

\begin{abstract}
Figuras 388 e 389: Torraca, Itália.
Fonte: <http://images.google.com.br >. Acesso em 13/02/2010.

Fonte: <http://nonsolobotte.blogspot.com/2008/03/torraca-sillumina-

dimmenso.html>. Acesso em 13/02/2010.
\end{abstract}

Figuras 390 e 391: Torraca, lamparina antiga montada com LEDs.

Fonte: <http:/www.cityledlighting.com/torraca/impianto.htm> . Acesso em 13/02/2010.

Com o objetivo de prestar reconhecimento às cidades onde foram implementados sistemas de iluminação urbana sustentável, a Lighting Urban Community International (LUCI) juntamente com a empresa belga Schéder, criaram o prêmio Auroralia. O primeiro lugar ficou para Berlim, com um plano de iluminação urbana que consiste na redução de consumo de energia (entre 30\% e 50\%) através da substituição de luminárias equipadas com lâmpadas de mercúrio por outras de alta performance que diminuem o consumo de energia e os custos de manutenção. $O$ plano deve estar concluído em 2012. O segundo lugar, para Lyon, com o projeto de lighting design para a construção histórica do Saint-Just College, criada pelo escritório Les Eclairgistes Associés, no qual há uma valorização das características arquitetônicas do edifício como marco da cidade, ao mesmo tempo em que cria uma ambiência para seus habitantes. Há a escolha de variações cromáticas dinâmicas de 
acordo com as diferentes estações e eventos locais e o uso de luminárias e tecnologias de baixo consumo de energia associadas a $40 \mathrm{~m}^{2}$ de painéis fotovoltaicos instalados no telhado do edifício. O terceiro lugar ficou para Westminster, cidade que entre os anos de 2007 e 2009, realizou o plano de iluminação Westbourne Green Regeneration, proposta que abordou de forma coordenada o paisagismo e a iluminação de ruas e passeios públicos. Para reduzir custos, as colunas existentes foram preservadas e foram instaladas luminárias com tecnologia mais avançada com o objetivo de economizar energia e proporcionar altos níveis de iluminação, uma combinação de luminárias de alta performance equipadas com LEDs e sistemas de gerenciamento remoto de dimerização. Com esse projeto, houve uma economia anual de 72 mil KWh no consumo de energia e uma redução de 31 toneladas por ano na emissão de CO2. Espera-se, com a divulgação dos projetos premiados, incentivar outras localidades a adotá-los. ( $L+D$ INTERNACIONAL LIGHTING MAGAZINE, 2010, p.38).
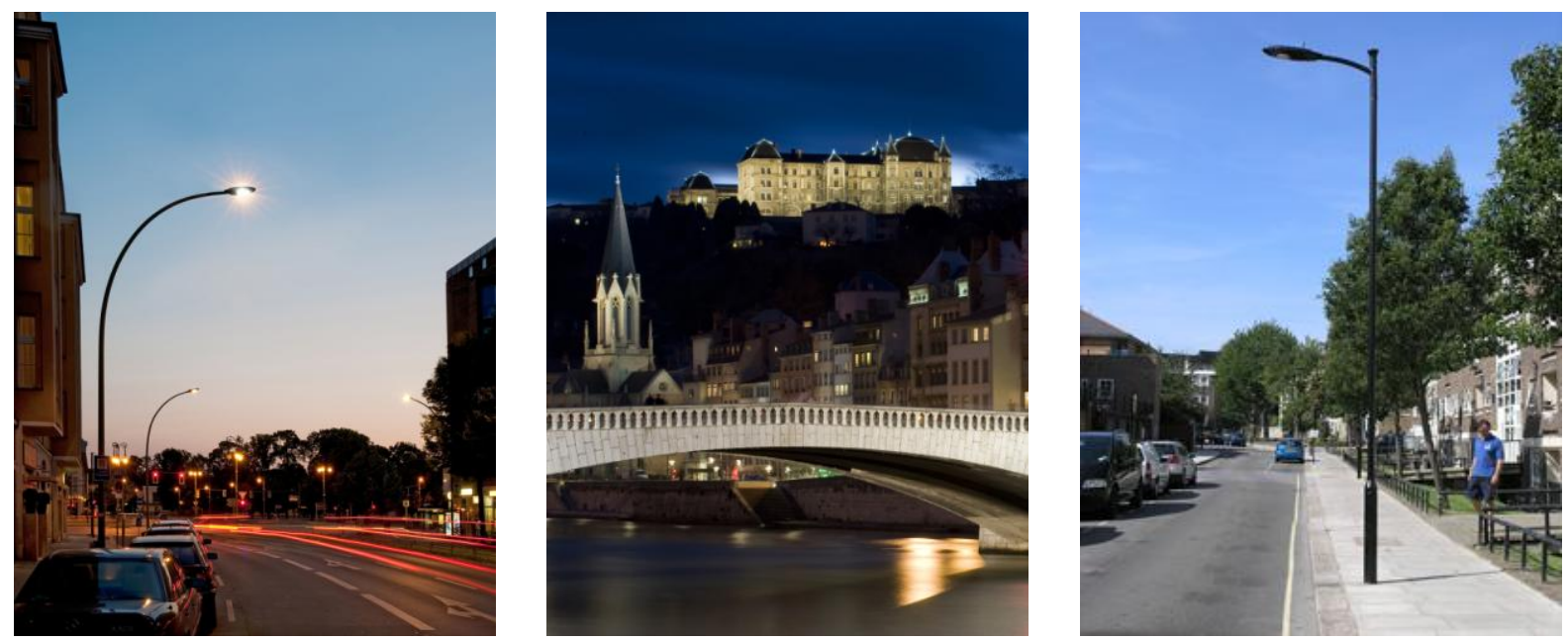

Figura 392: Berlim, Alemanha. Fonte : <http://www.auroralia.org/auroralia.asp?Lang=6>. Acesso em 05/04/2010.

Figura 393: Saint-Just College, Lyon, França. Fonte :<http://www.auroralia.org/auroralia.asp?Lang=6>. Acesso em 05/04/2010.

Figura 394: Westminster, Grã-Bretanha. Fonte : <http://www.auroralia.org/auroralia.asp?Lang=6>. Acesso em 05/04/2010.

Na segunda edição do Professional Lighting Designers' Convention (PLDC), realizado em Londres, no ano de 2009, também foram apresentados diversos projetos de iluminação urbana. Dentre eles, estava o projeto dos lighting designers Jean Sundin e Enrique Peiniger, que propuseram para as ruas de New York 
luminárias para serem montadas com LEDs. Segundo os autores, a prefeitura da cidade confirmou que o produto será integrado ao catálogo de iluminação viária do Departamento de Transportes e os primeiros protótipos seriam implantados até 0 final do ano de 2010. (L+D INTERNACIONAL LIGHTING MAGAZINE, 2010, p.40).
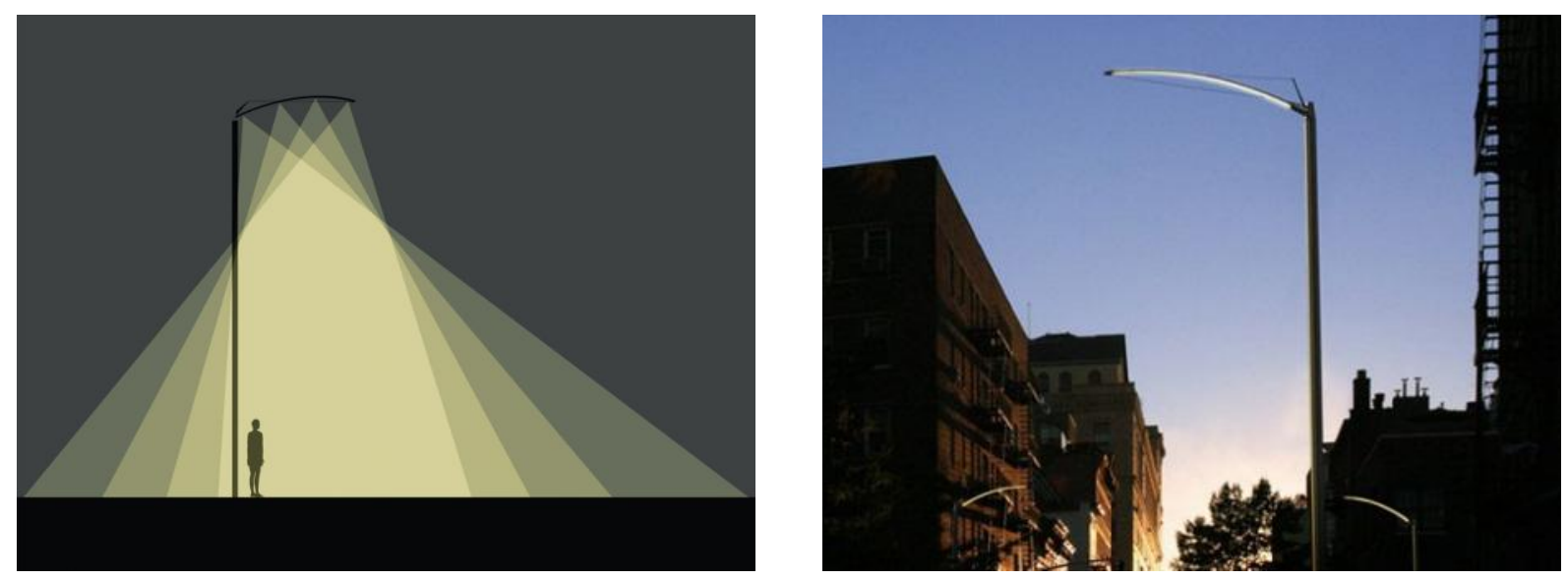

Figuras 395 e 396: Projeto dos lighting designers Jean Sundin e Enrique Peiniger, que propuseram para as ruas de New York luminárias para serem montadas com LEDs. Fontes:

<http://www.architectmagazine.com/lmages/tmp108B.tmp_tcm20-193181.jpg >. Acesso em 05/04/2010.

<http://www.gearfuse.com/tag/eco/>. Acesso em 05/04/2010.

Como um dos exemplos de aplicação do LED em escala reduzida - a dos edifícios, podemos citar o Centre des Nouvelles Industries et Technologies (Centro de Novas Indústrias e Tecnologias) - CNIT, localizado em La Défense, Paris, reinaugurado em outubro de 2009, com nova proposta arquitetônica ${ }^{88}$ de Jean Luc Couchon e Cuno Brullman, e de iluminação, de autoria do lighting designer Louis Clair. Dentre os diversos elementos e soluções propostos na nova iluminação, internamente, foram criados painéis de vidro serigrafado especialmente desenvolvidos para captar a luz branca proveniente de 600 tubos de LED (6.000K). Esses painéis, "criam uma atmosfera mágica para os visitantes que povoam o espaço destinado ao público" e para iluminá-los foram embutidos tubos fluorescentes (T5, 21W, 3.000K) no piso térreo da praça central. Para as áreas elevadas, foi desenvolvido um equipamento especial constituído de "pequenos discos de inox de $12 \mathrm{~cm}$ de diâmetro com seis LEDs traseiros (1W, 4.000K) que criam um efeito 'negativo', onde não se pode identificar a fonte de luz e, portanto, pode-se observar o ambiente sem ofuscamento." Para realçar os corredores que ligam o CNIT às estações de metrô e de trem foram projetados túneis fortemente iluminados por lâmpadas LEDs RGB,

\footnotetext{
${ }^{88}$ O projeto original é de Jean Prouvé, renomado arquiteto e designer francês.
} 
cujas luzes multicoloridas são filtradas e uniformizadas pelos painéis de vidro fosco que revestem os túneis. Foram criados diferentes cenários, programados por um sistema autônomo de iluminação, e o efeito gerado oferece aos visitantes uma experiência de dinamismo, ludicidade e cor. (BECHARA, 2010, p.52).
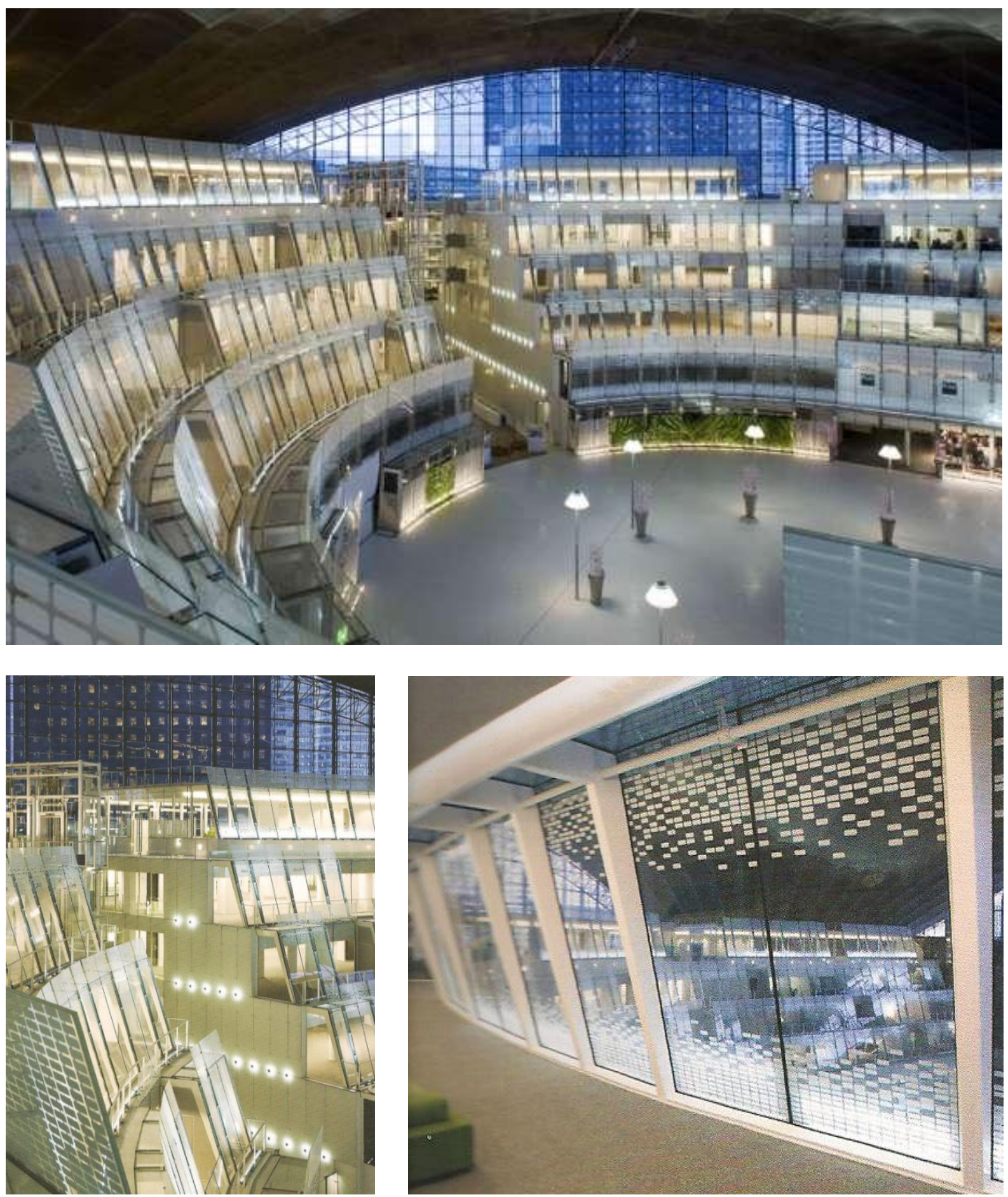

Figura 397: Centre des Nouvelles Industries et Technologies (Centro de Novas Indústrias e Tecnologias) - CNIT, localizado em La Défense, Paris. Fonte: BECHARA, 2010, p. 52.

Figura 398: Centre des Nouvelles Industries et Technologies (Centro de Novas Indústrias e Tecnologias) - CNIT, localizado em La Défense, Paris. Fonte: BECHARA, 2010, p. 52.

Figura 399: Vidros serigrafados iluminados por linhas de LED. Fonte: BECHARA, 2010, p. 51. 


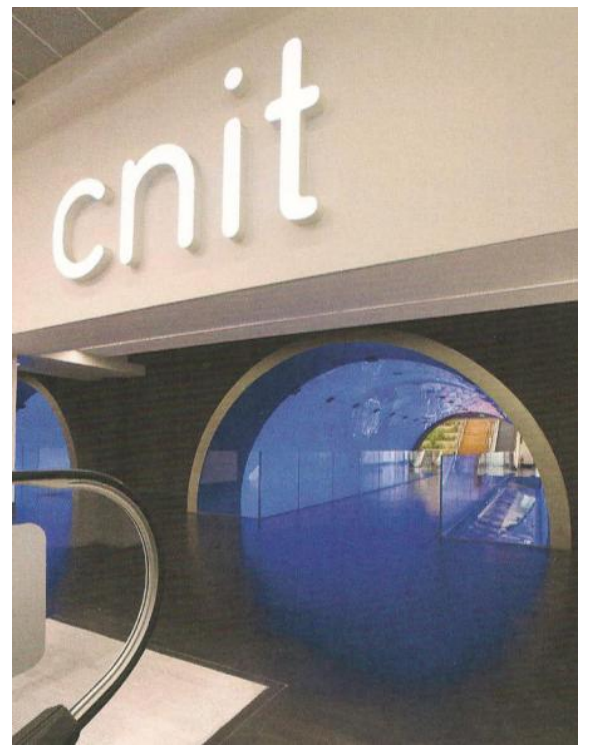

Figuras 400 e 401: Os corredores que ligam o CNIT às estações de metrô e de trem foram projetados túneis fortemente iluminados por lâmpadas LEDs RGB. Fonte: BECHARA, 2010, p. 51.

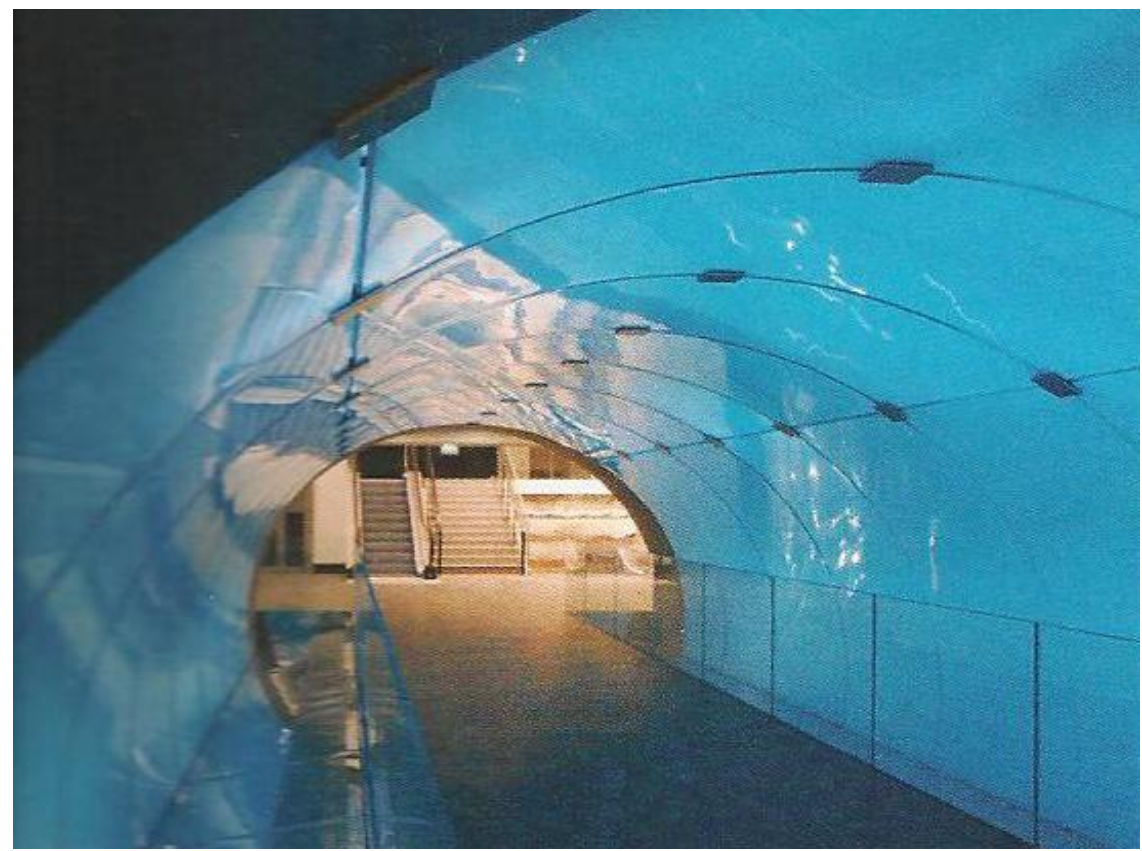

No projeto da loja Armani Fifth Avenue, de autoria do arquiteto Massimiliano Fuksas e dos lighting designers do escritório Speirs \& Major Associates, devido ao curto prazo e à tradição do uso de painéis luminosos no local, optaram pelo uso de barras de LEDs distribuídas de forma variável de acordo com o comprimento do edifício com o objetivo de "criar uma imagem de impacto em uma das esquinas com intensidade decrescente ao longo da fachada. Esta abordagem cuidadosamente planejada impediu que as barras verticais comprometessem a transparência da caixa de vidro". (NAKAMURA, 2010, p. 81). 

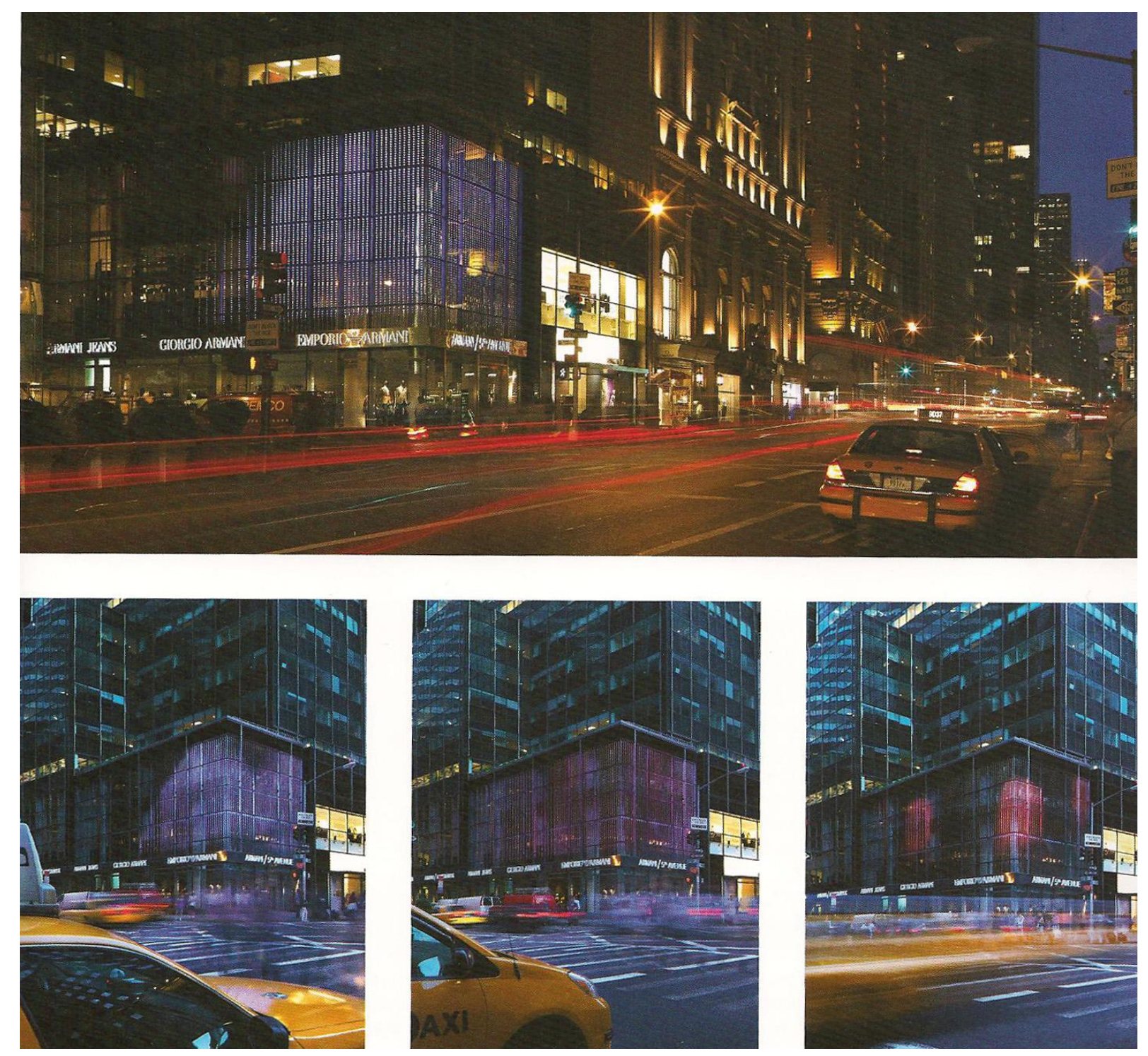

Figuras 402, 403, 404 e 405: Loja Armani Fifth Avenue. Fotos: Allan Toft. Fonte: NAKAMURA, 2010, p. 81.

A instalação luminosa: Quem tem medo do Vermelho, Azul e Verde? idealizada em 2007 por arquitetos do LAb[au], contribuiu ainda mais para que terceiro edifício mais alto de Bruxelas: o Dexia Tower, construído em 2005 e projetado por arquitetos do Philippe Samyn \& Partners, se tornasse um marco arquitetônico da capital. Entre as 6.000 janelas que compõem a fachada do edifício, 4.200 são iluminadas com barras de LEDs (aproximadamente 220.000), cada uma com um microprocessador que controla um conjunto de LEDs verdes, vermelhos e azuis, que combinados, podem produzir uma infinita paleta de cores e proporcionar efeitos dinâmicos. Além de efeitos visuais artísticos, o painel também transmite informações meteorológicas através de dados provenientes do Royal Meteorological Institute of Belgium, os quais são convertidos

por uma central de computação. 

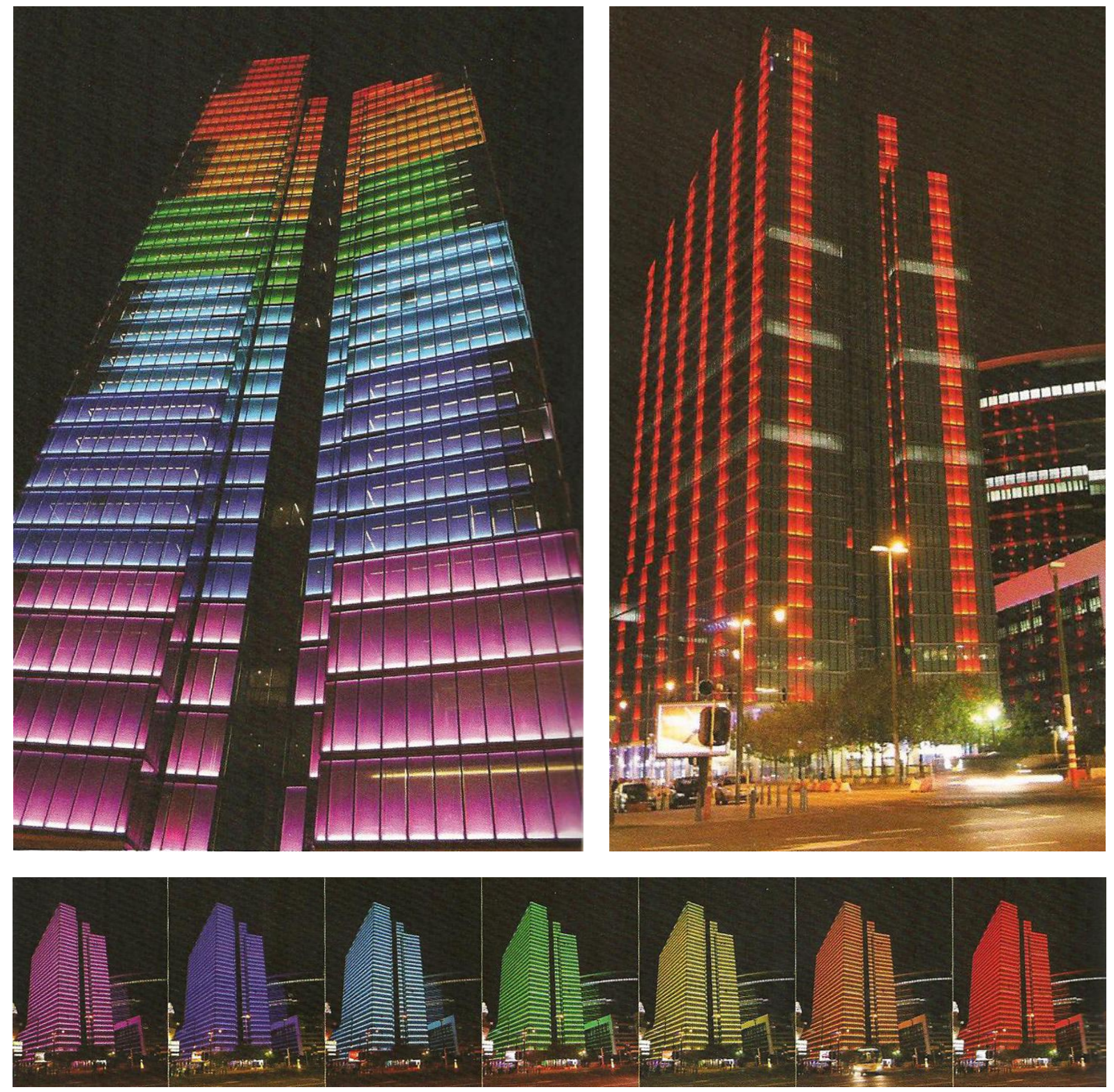

Figuras 406, 407 e 408: Instalação luminosa: Quem tem medo do Vermelho, Azul e Verde?, Bruxelas. Fotos: Divulgação LAb[au]. Fonte: NAKAMURA, 2010, p. 84.

O uso do LED também pode estar associado a outros sistemas, como células fotovoltaicas, mídia eletrônica e digital (que será estudado mais profundamente no próximo item) e molas aliadas a microchips. Como exemplos de tecnologia aliada à arquitetura, à arte e à sustentabilidade é possível citar uma infinidade de obras contemporâneas.

No GreenPix Zero Energy Media Wall (em Pequim), por exemplo, foi desenvolvida uma nova tecnologia para laminar células fotovoltaicas em cortina de vidro. Para isso, o arquiteto Simone Giostra e o escritório ARUP (projeto de iluminação), responsáveis pelo projeto, tiveram o suporte das empresas alemãs Schueco e Sun 
Way e supervisionaram a produção dos primeiros painéis da empresa chinesa Sun Tech. Trata-se de uma grande media wall, construída na fachada frontal do edifício do centro de entretenimento Xicui, em Pequim. O painel projetado, um dos maiores displays de LEDs coloridos do mundo e o primeiro sistema fotovoltaico integrado a uma cortina de vidro na China, é constituído de 2.292 LEDs RGB (comparável a um monitor de $2.200 \mathrm{~m}^{2}$ ) e representa uma forma inovadora de integração entre tecnologia e arquitetura conhecida mundialmente como a mediatecture.

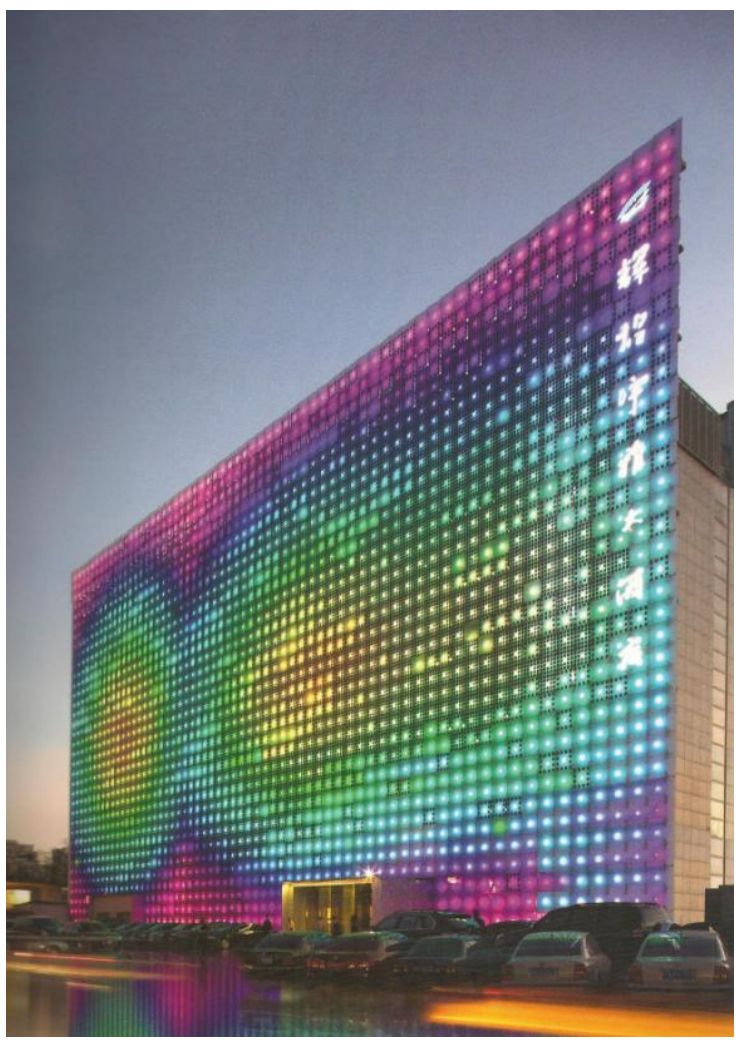

Figura 409: Green Pix Zero Energy Media Wall. Fonte: Nakamura, 2010, p. 79.

O fechamento do edifício é uma cortina de vidro de aproximadamente $2.000 \mathrm{~m}^{2}$, construída dentro de exigências antissísmicas, transformada em um espaço de exibições de instalações audiovisuais. São 2.292 pontos de luz RGB integrados a um sistema de geração de energia fotovoltaica que o transforma em um "sistema orgânico auto-suficiente que armazena energia solar ao longo do dia para utilizá-la na iluminação da tela durante a noite totalizando um ciclo climático de 24 horas." (L+D INTERNACIONAL LIGHTING MAGAZINE, 2008, p. 22). 

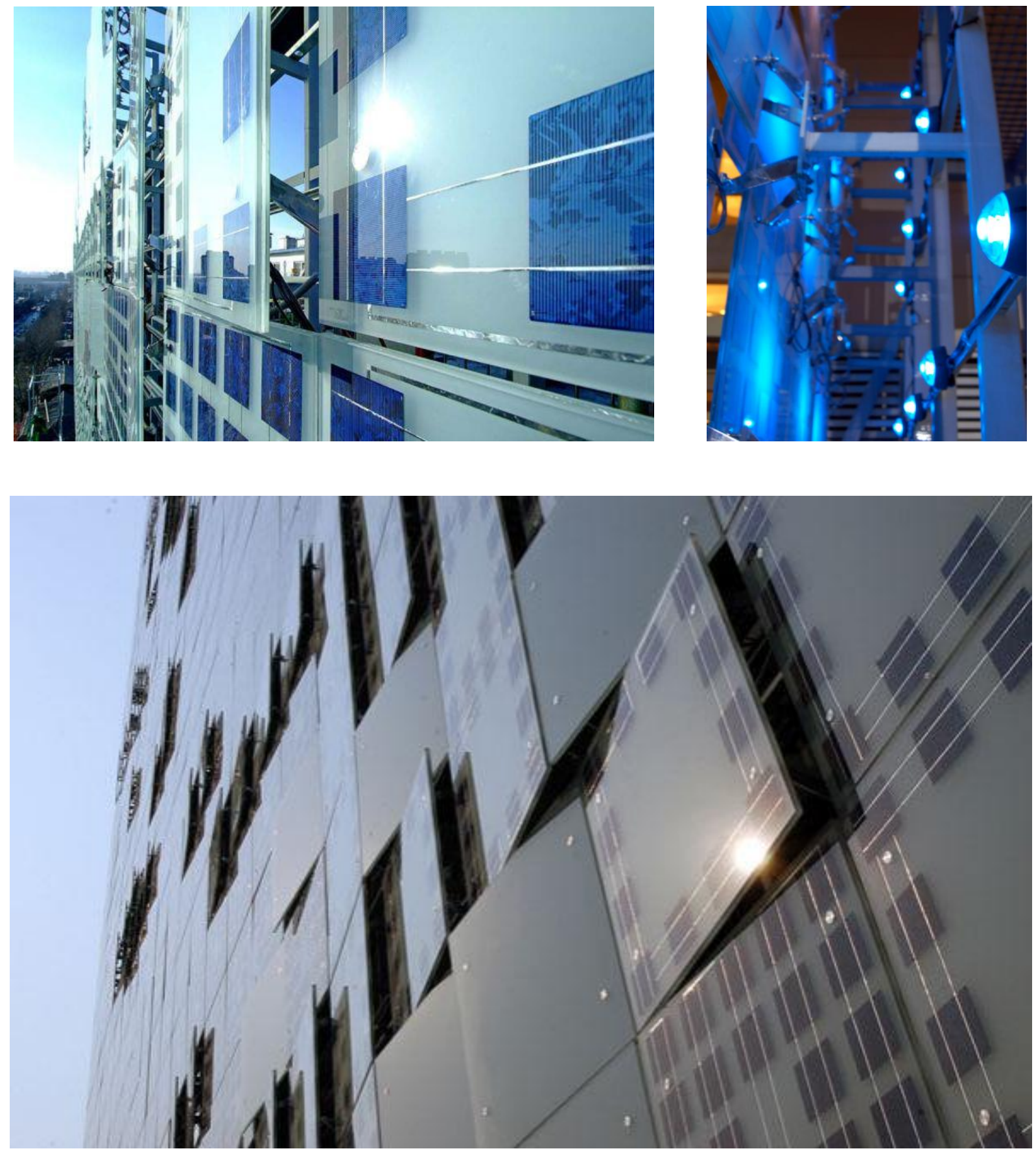

Figuras 410, 411 e 412: Detalhe do sistema. Fonte: <http:// www.edutp.com.br> . Acesso em 13/02/2010.

Para que houvesse economia energética optou-se por uma tela em baixa resolução e o painel LED só consome a energia por ele produzida. Como diz Giostra:

A imagem gerada, portanto, terá duas leituras: pixelada de perto, nítida e precisa quando vista de longe, o que aconteceria na maior parte das vezes, já que, como o edifício está situado em uma importante avenida de Pequim, a maioria das pessoas irá visualizar o painel do interior de seus carros. ( $L+D$ INTERNACIONAL LIGHTING MAGAZINE, 2008, p.23). 


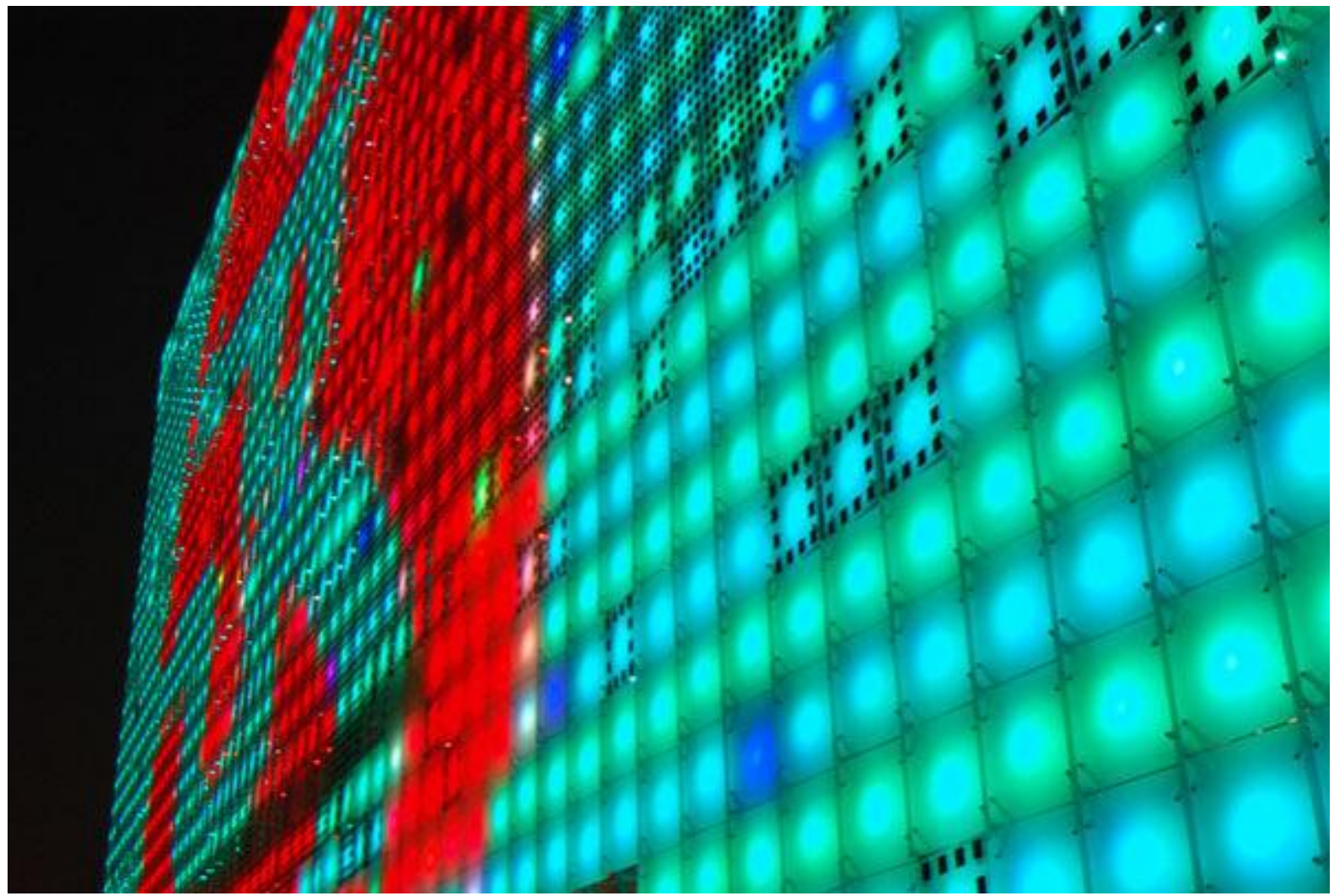

Figura 413: Imagem pixelada. Fonte: <http: www.edutp.com.br> . Acesso 13/02/2010.

Para evitar reflexos na superfície do painel, há uma combinação de três tipos de painéis texturizados: vidros de baixa, média e alta transparência. "A arquitetura tirou partido da volumetria proporcionada pela movimentação das placas que se ajustam de acordo com as placas de iluminação." (NAKAMURA, 2010, p.80).

O GreenPix Zero Energy Media Wall, "funciona como um ecrã de televisão gigante" onde poderiam ser exibidos desde anúncios publicitários a cinema. No entanto, diferentemente do que ocorre com os demais painéis de grandes dimensões utilizados para publicidade, este tem caráter exclusivamente artístico. Para Giostra, "este media wall vai dar à cidade de Pequim seu primeiro edifício dedicado à arte digital, ao mesmo tempo oferecendo o exemplo mais radical da aplicação da tecnologia fotovoltaica a todo o fechamento de um edifício feito até hoje." Em sua inauguração, em 2008, foram apresentadas diversas instalações em vídeo e performances executadas por artistas europeus, americanos e chineses. $(L+D$ INTERNACIONAL LIGHTING MAGAZINE, 2008, p.23).

O holandês WATT Club, apresenta soluções que o tornaram conhecido como o primeiro Dance Club sustentável do mundo. 
Construído com materiais recicláveis reaproveitados, utiliza sistemas de economia e reaproveitamento de água e converte o impacto das pisadas em energia elétrica utilizada para iluminar o próprio piso da pista de dança equipado com pontos de LED. O sistema é constituído por molas e microchips que captam os movimentos dos usuários e passam para um gerador que armazena eletricidade. Pretende-se, futuramente, conseguir usar a energia produzida pelo piso em outros sistemas. $(L+D$ INTERNACIONAL LIGHTING MAGAZINE, 2008, p. 32).

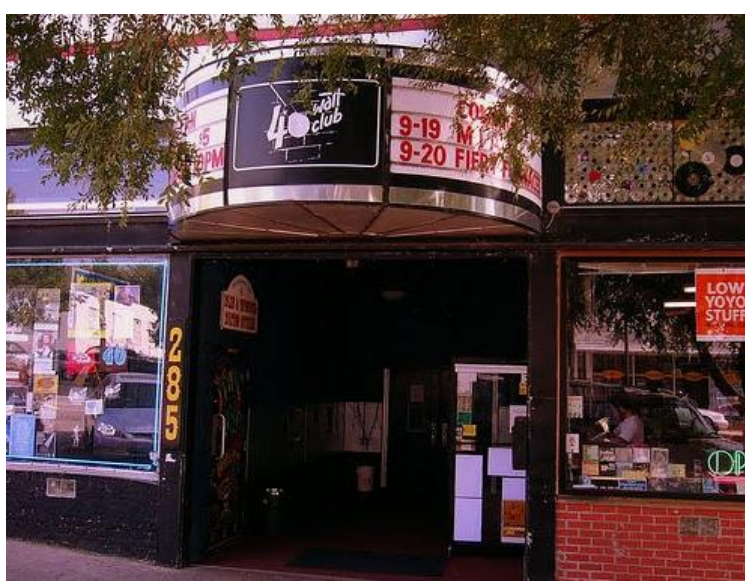

Figura 414: WATT Club. Fonte: $<$ http://www.google.com.br/imgres>? 89 . Acesso em 06/09/2010.

Figura 415: O piso. Fonte: <http://www.google.com.br>. Acesso em 06/09/2010.

Figura 416: Sistema de molas sob o piso. Fonte: $<$ http://www.google.com.br/imgres $>?^{90}$ Acesso em 06/09/2010.
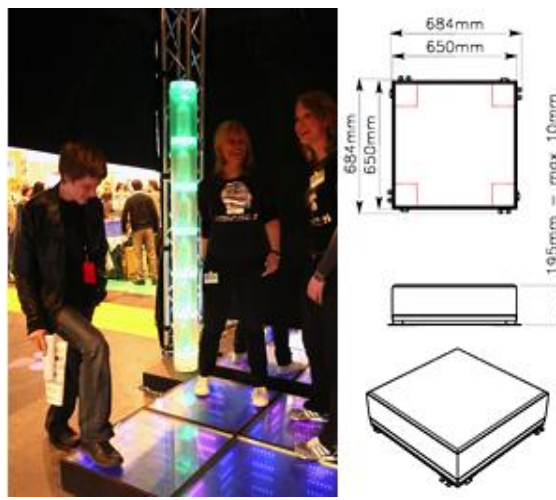

Energy Generated:

$10 W_{\text {continuos }}$ output at $18 V D C$ for
adults dancing on the module or

$20 W_{\text {continuos }}$ output at $18 \mathrm{VDDC}$ for adults jumping on the module

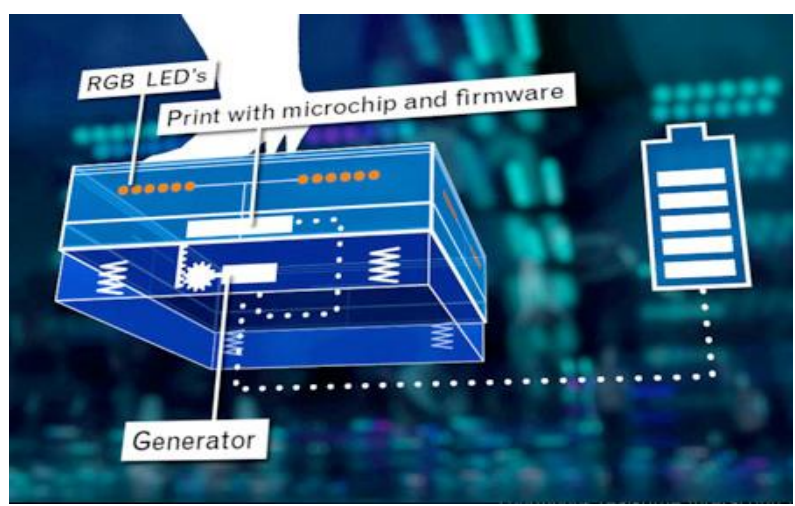

${ }^{89}<$ http://www.google.com.br/imgres?imgurl=http://4.bp.blogspot.com/_G47ydZTmxIA/S7jdGdPAt8I/AAAAAAAAB VU/IPIDw2eRDS0/s1600/40\%2BWATT\%2BCLUB.jpg\&imgrefurl=http://vagonalternativo.blogspot.com/2010/04/re m-tourist-guide-of-athens-georgia.html\&usg=_J_RmouUryfSp83V5eHGd5W-

$\mathrm{Mdq} 8=\& \mathrm{~h}=375 \& \mathrm{w}=500 \& \mathrm{sz}=59 \& \mathrm{hl}=\mathrm{pt}-\mathrm{BR} \& \mathrm{start}=\overline{2} 1 \& \mathrm{zoom}=0 \& \mathrm{tbnid}=\mathrm{fep} \mathrm{T}$ -

bgUO5msnM:\&tbnh=98\&tbnw=130\&prev=/images\%3Fq\%3Dfloor\%2Bwatt\%2Bclub\%26um\%3D1\%26hl\%3DptBR\%26rlz\%3D1R2SNNT pt-.

BR\%26biw\%3D1345\%26bih\%3D516\%26tbs\%3Disch:10\%2C225\&um=1\&itbs=1\&iact=hc\&vpx=947\&vpy=321\&du $r=4820$ \&hovh=98\&hovw $=130 \& \mathrm{tx}=122 \& \mathrm{ty}=74 \& \mathrm{ei}=\mathrm{DLKFTLu1BMP} 6 \mathrm{lwfK5MGEDg} \&$ oe $i=h K y F T P m m P M O B I A f h v 42 \mathrm{I}$ Dg\&esq=4\&page=2\&ndsp=26\&ved=1t:429,r:6,s:21\&biw=1345\&bih=516>. Acesso em: 06/09/2010.

<http://www.google.com.br/imgres?imgurl=http://www.greenbiz.com/sites/default/files/inline/100413-sdcfig1.jpg\&imgrefurl=http://www.greenbiz.com/news/2010/04/13/french-city-use-sneaky-sidewaks-generatepower\&usg = CRFRvz3JGlifWE8Zm_I_HI5nZro=\&h=307\&w=448\&sz=83\&hl=pt-

BR\&start=450\&zoom=1\&tbnid=_CVkNJiJDN8NRM:\&tbnh=101\&tbnw=141\&prev=/images\%3Fq\%3Dfloor\%2Bwatt \%2Bclub\%26um\%3D1\%26hl\%3Dpt-BR\%26rlz\%3D1R2SNNT_pt-

BR\%26biw\%3D1345\%26bih\%3D516\%26tbs\%3Disch:10\%2C7347\&um=1\&itbs=1\&iact=hc\&vpx=103\&vpy=92\&du $r=7909 \&$ hovh $=186 \&$ hovw $=271 \& \mathrm{tx}=168 \& \mathrm{ty}=87 \& \mathrm{e}=\mathrm{i}$ 7CFTI3QJ8Gclgf36MjFDg\&oei=hKyFTPmmPMOBIAfhv42IDg \&esq $=23$ \&page $=19 \&$ ndsp $=26 \&$ ved $=1 \mathrm{t}: 429, \mathrm{r}: 9, \mathrm{~s}: 450 \& \mathrm{biw}=1345 \& \mathrm{bih}=516>$. 


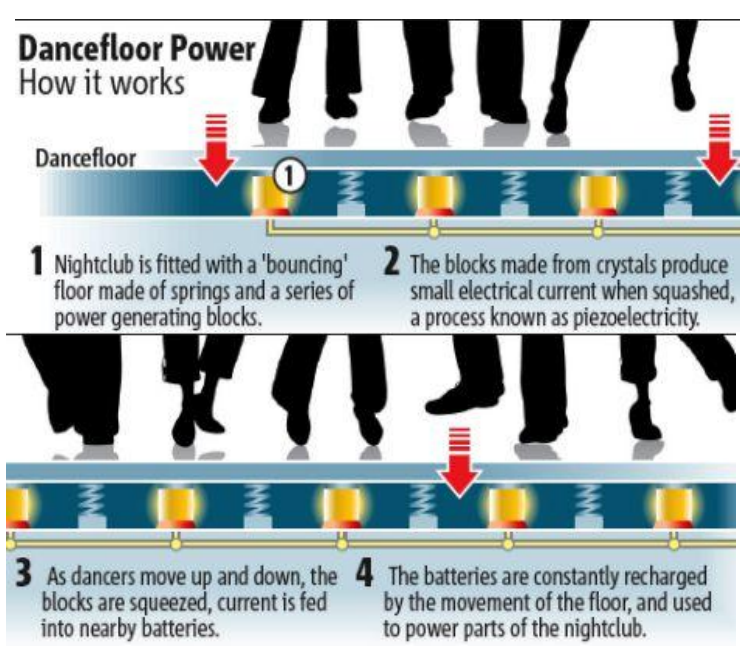

Figura 417: Sistema de molas sob o piso. Fonte: $<$ http://writer.dek-d.com/dek-

$\mathrm{d} /$ writer/viewlongc . php?id=418999\& chapter=54> Acesso em 03/04/2010.

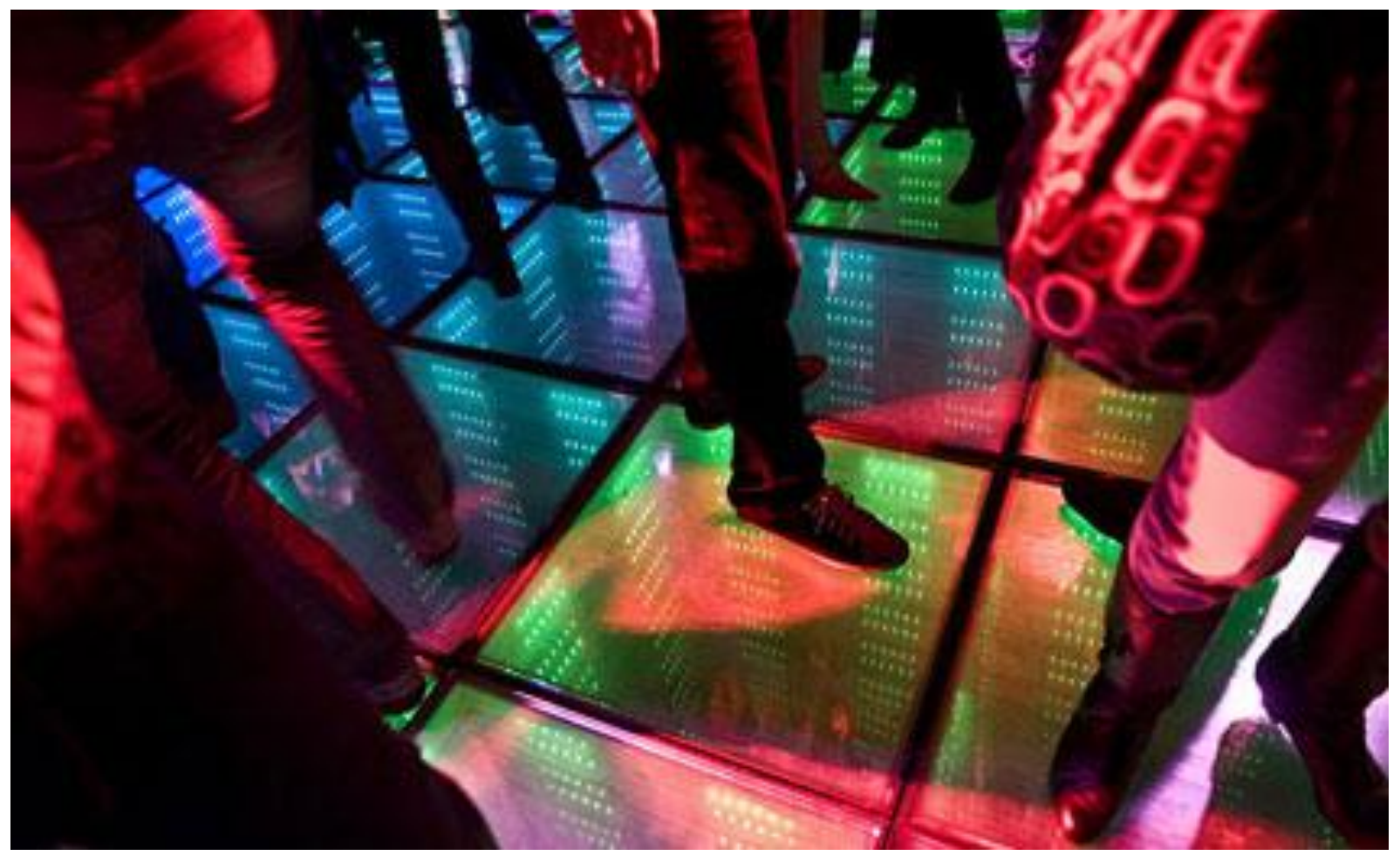

Figura 418: Pista de dança equipada com pontos de LED. Fonte: <http://www.ecodesenvolvimento.org.br/ecodtv/Sustainable\%20Dance\%20Club.flv/video_view>. Acesso em 03/04/2010.

No carnaval de 2010, a pista de dança sustentável também se tornou realidade em Salvador. A empresa LG, presente no evento desde 2001, inovou com a pista construída dentro da boate do concorrido Camarote Expresso 2222, promovido por Flora Gil. Foi uma oportunidade de interagir e de mostrar sua marca para os 
milhares de turistas que visitaram a cidade durante os dias de festa. ${ }^{91}$ (ECODESENVOLVIMENTO.ORG.BR, 2010).

O grande destaque foi a Sustainable Dance Floor, uma das maiores novidades no mundo do entretenimento sustentável. A pista de dança gera energia com o balanço das pessoas sobre o piso, energia que é utilizada para iluminar a própria pista. A combinação de técnicas modernas e de design arrojado possibilitam uma nova proposta de diversão: fazer o que se gosta e de maneira sustentável. O Expresso e a LG trouxeram a pista para o camarote com o objetivo de despertar a curiosidade e provocar a reflexão sobre tecnologia, sustentabilidade e inovação. (EXPRESSO2222.COM.BR, 2010).

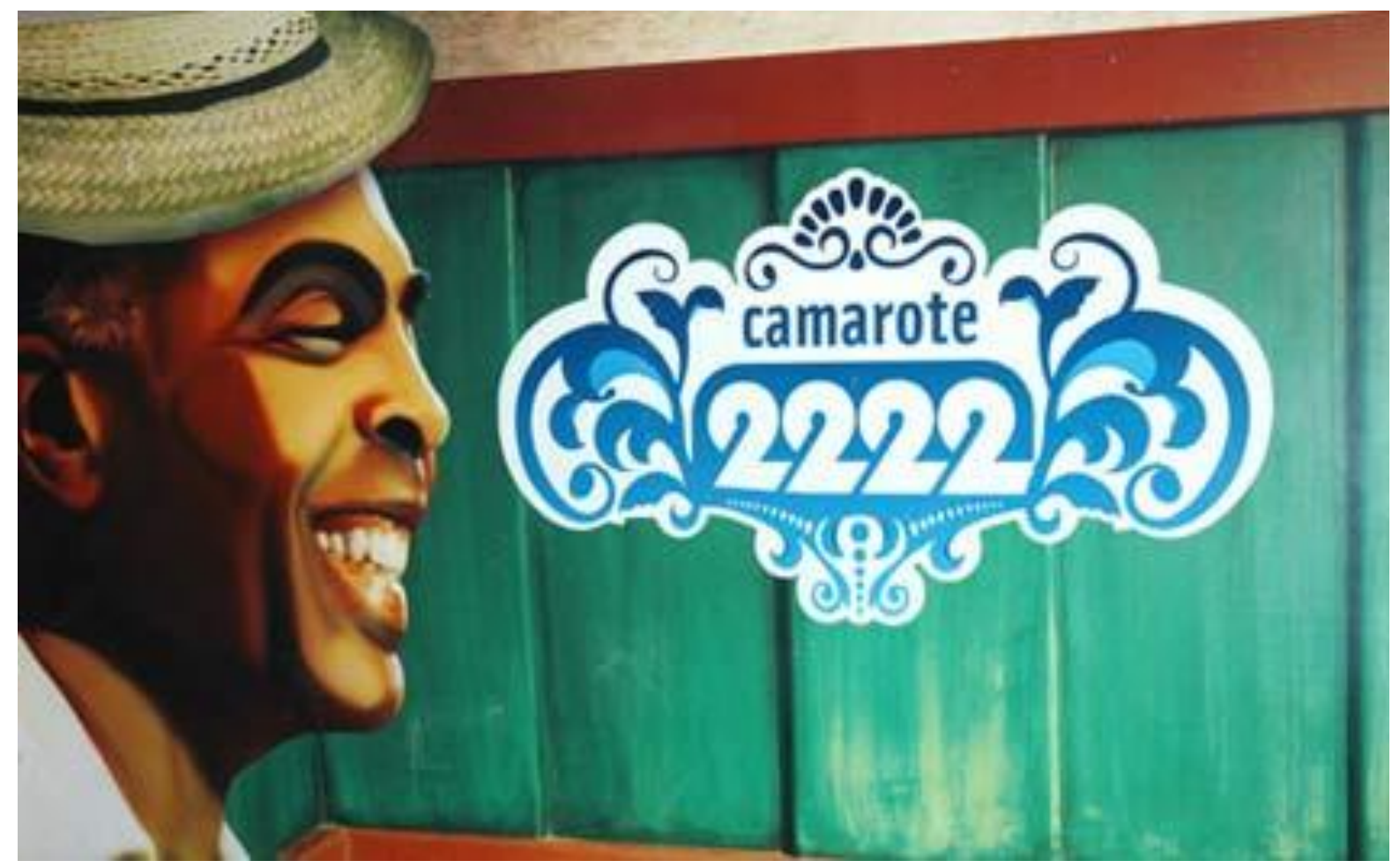

Figura 419: Camarote 2222, Salvador. Fonte:<http://www.ecodesenvolvimento.org.br/noticias/camaroteexpresso-2222-traz-sustentabilidade-para>. Acesso em 13/02/2010.

\footnotetext{
${ }^{91}$ Segundo o publicado no site ecodesenvolvimento.org.br, "A proposta de transformar a festa popular em um difusor de bons hábitos veio da produtora Flora, que teve a ideia de usar como tema o verso "Transformai as velhas formas do viver' da música Tempo Rei, criada pelo compositor baiano."
} 


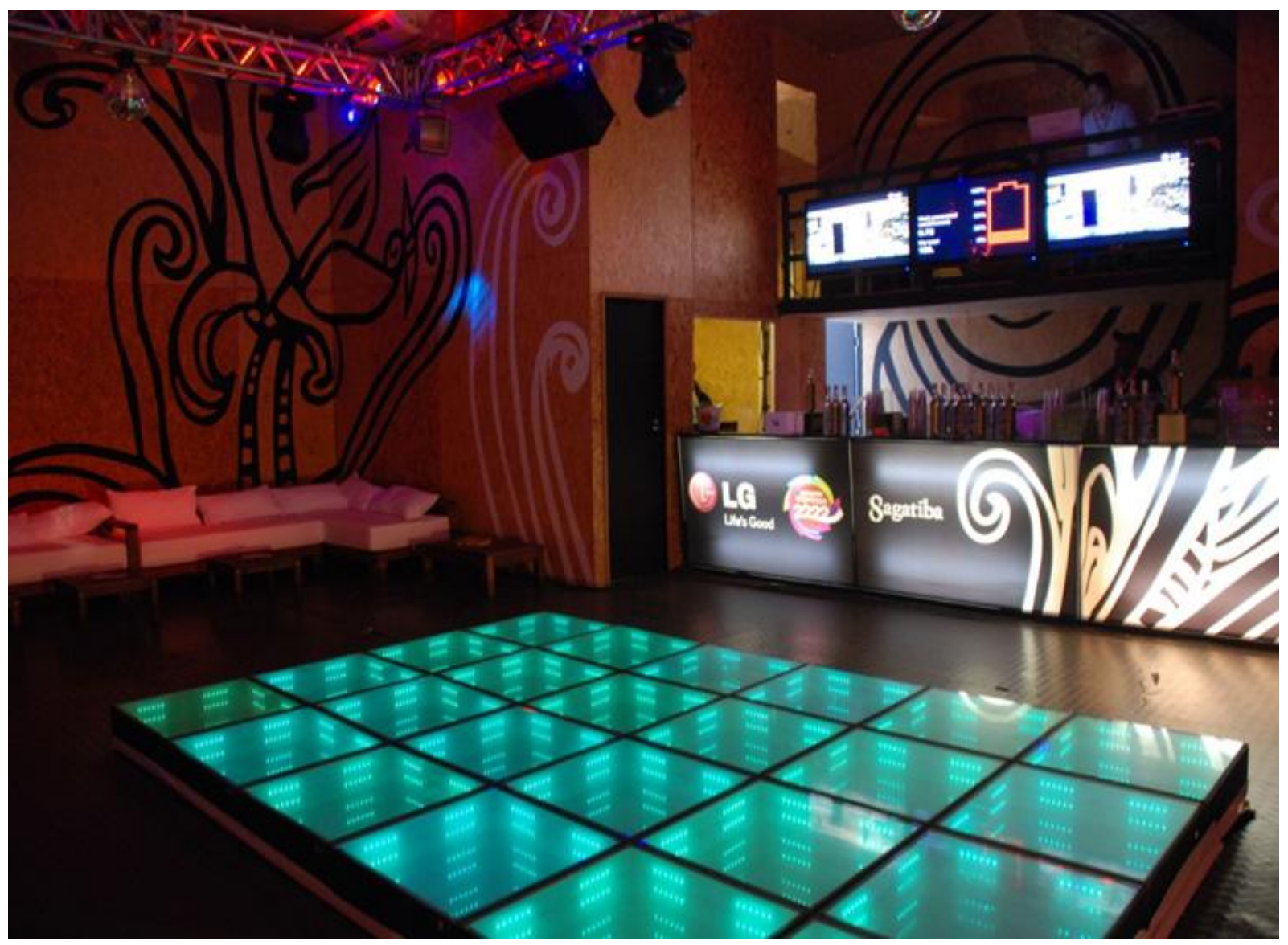

Figura 420: Sustainable Dance Floor, Camarote 2222, Salvador. Fonte: <http://www.expresso2222.com.br/pos_venda/energia.php>. Acesso em 12/09/2010.

Assim como no WATT Club, os blocos que formam a pista movimentam-se verticalmente na medida em que as pessoas dançam sobre eles. "Cada pessoa é capaz de produzir de 5 a 20 watts dependendo do peso e da atividade sobre o piso. A energia gerada vai acender as luzes dos blocos, criando uma interação com os convidados." (BLOGLGLE.COM.BR, 2010).

Como complementação, seguem outros exemplos da aplicação do LED na arte e no design de moda e de relógios. O painel "Wouldn't it be nice?”, trabalho de Daniel De'Sure, resultou de um projeto de animação em que uma parede coberta por LEDs apresenta um texto que se altera seguindo uma programação. 

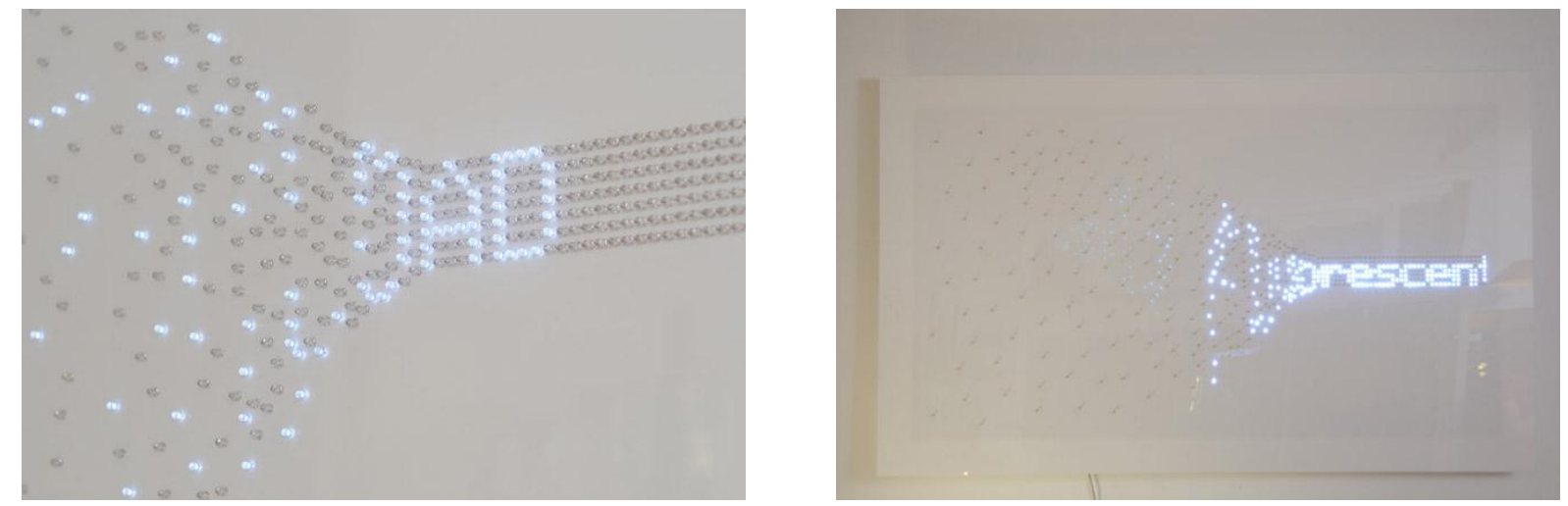

Figuras 421 e 422: Painel Wouldn't it be nice? Fonte: <http://www.todayandtomorrow.net/2009/03/30/wouldnt-itbe-nice/>. Acesso em 24/02/2010.

O Projeto PELE, desenvolvido pelo programa de investigação da Philips Design, investigou novas tendências e mudanças sociais na área de 'emotional sensing' e demonstrou a possibilidade da forma eletrônica ser incorporada a tecidos e ao vestuário para expressar emoções. Dentre os protótipos está o vestido 'Bubelle'. A peça é cercada por uma bolha que ao ser soprada reage "inflamando uma constelação particular de LEDs minúsculos. (...) O projeto de pesquisa PELE desafia a noção de que nossas vidas são automaticamente melhores porque são mais digitais. Ele olha para os fenômenos mais 'analógicos', como emocional de detecção e explora tecnologias que são 'sensíveis' ao invés de 'inteligentes'." (SCIENCE \& TECHNOLOGY NEWS, 2006, tradução nossa).

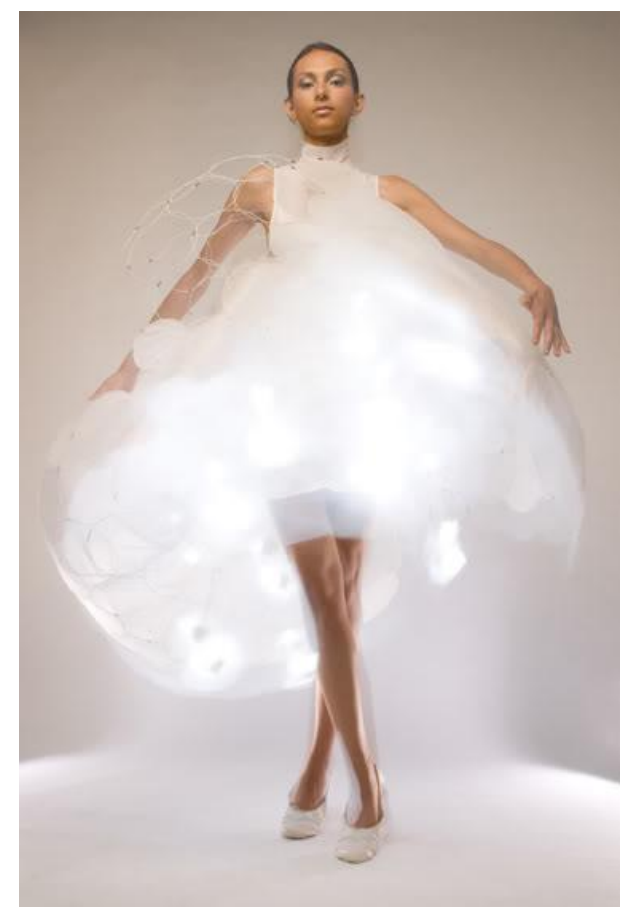

Figura 423: Protótipo do vestido Budelle.

Fonte: SCIENCE \& TECHNOLOGY NEWS. O futuro da moda é bem iluminado com o Projeto PELE. 21/09/2006. Disponível <http://www.impactlab.com/20069/09/21/the-future-offashion-is-well-lit-with-project-skinq>. Acesso 24/02/2010.

Figuras 424 e 425: Relógios com a tecnologia LED. Fonte: $<$ http://forums.coolest-

gadgets.com/showthread.php?t=30781 >. Acesso em 24/02/2010.
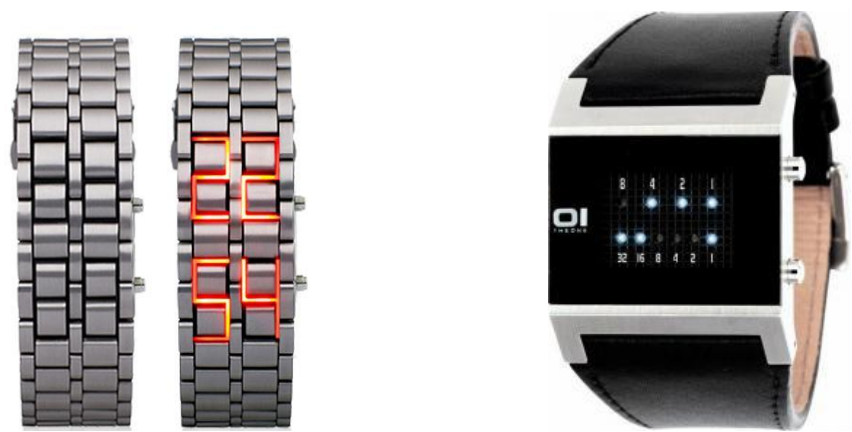


\subsubsection{Superfícies Midiáticas}

Com a globalização, o avanço da tecnologia, a forma de conceber o tempo, o espaço, o mundo em que vivemos têm se alterado. Criou-se uma nova cultura. Nossas vidas estão sendo invadidas pela mídia digital. As formas de expressão multiplicaram-se, descompartimentaram-se e estão cada vez mais aliadas aos fazeres da arte, da arquitetura e do design. A história desse fazer tecnológico, que alia ciência e tecnologia aos campos de atuação mencionados, faz-se na multiplicação de ângulos de percepção, na inserção do corpo nesse universo (interfaces entre homem e máquina) e na escolha de pontos de vista cada vez mais impensáveis, ou seja, na busca de sentido para o mundo em todas as suas formas e complexidades, através da experimentação.

Embora os recursos de mídia como letreiros luminosos e telas de animação já tenham sido aplicados excessivamente na Times Square, em New York, e na Fremont, em Las Vegas, atualmente, uma nova geração de profissionais da arquitetura, do lighting design e da arte têm visualizado a relação entre arquitetura e mídia sob uma nova perspectiva. Essa nova abordagem substitui o conceito de fachada como suporte para a publicidade pelo conceito de integração entre arte, arquitetura, design, mídia e tecnologia da informação.

Segundo o arquiteto austríaco Gernot Tscherteu, diretor da exposição Media Facades Festival Berlin 2008, e coordenador de um grupo de pesquisa interdisciplinar que estuda o tema fachadas mídia, desde o ano de 1997, "os meios de comunicação e a arquitetura não devem representar dois níveis de significado, mas formar um sistema comum de referência." (NAKAMURA, 2010, p.78).

Para o pesquisador, as fachadas mídia representam uma nova ligação entre o espaço digital, a arquitetura e o espaço urbano que:

(...) apela não só aos usuários individuais, como no caso de um computador pessoal, mas também a grupos inteiros ou mesmo para um conjunto da população urbana e que, além disso, também permite a 'resposta', ou seja, para interagir com uma fachada ou para projetar seu conteúdo. Neste caso, um potencial poderoso para a concepção e afetividade é criado envolvendo uma série de chances e riscos que são difíceis de estimar e que exigem uma discussão aprofundada. Os produtores e os usuários dessas fachadas mídia também enfrentam uma série de desafios, e vão precisar de tempo 
para parecer totalmente diferenciados na evolução de um discurso que está apenas tomando forma. (TSCHERTEU; LEEB, 2008, tradução nossa).

Mais adiante em seu texto, afirmou que há uma variedade de características técnicas que influenciam significativamante sobre "a experiência visual, mas também sobre a interatividade e o valor do 'urbano' da arquitetura de mídia." (TSCHERTEU; LEEB, 2008, tradução nossa) Nos projetos de media architecture, variadas linguagens e suportes tecnológicos podem ser explorados. Elas podem trabalhar com a luz solar ou ambiente para criar efeitos de superfície e informações de imagem, como é o caso da obra Flare, descrita a seguir. Pode haver a emissão de luz nessas fachadas, através das tecnologias do LED ${ }^{92}$, da lâmpada fluorescente e outras disponíveis no mercado, além de diferentes métodos para mover mecanicamente as peças através de ar comprimido ou de energia eólica. Além das fontes de luz, também são de fundamental importância os softwares e os equipamentos de controle para que haja uma operação adequada e a permissão do recebimento de sinais externos como vídeo e áudio, de forma integrada. A produção de energia local é outra questão imprescindível que tem tornado tendência a incorporação de células fotovoltaicas como geradoras de energia para o funcionamento desses sistemas, como é o caso do GreenPix, na China (apresentado no item anterior - LED). Para o designer Guinter Parschalk, o custo dos recursos de mídia não é o problema porque tendem a ser barateados, 0 desafio é "saber o que fazer com eles", ou seja, é preciso que o profissional saiba equacionar, ainda na fase de projeto, questões relacionadas à resolução, ao brilho, à manutenção e à intrusão de displays em áreas internas dos edifícios, sem contar os desafios a serem superados quanto ao enquadramento das fachadas midiáticas às restrições urbanísticas para não gerar poluição luminosa. Tscherteu afirma que pesquisas são necessárias para descobrir em quais circunstâncias essa tecnologia pode ser aplicada sem afetar os usuários do edifício. Dificuldades surgem acerca dessas questões, devido à concepção dessas fachadas acontecer, na maioria dos casos, após a concepção da arquitetura, ou até mesmo, após a construção dos edifícios. É preciso que fachada e arquitetura sejam concebidas de forma integrada para

\footnotetext{
92 O LED tem sido a tecnologia mais utilizada em fachadas mídia devido à densidade de luz singular e por ser a única capaz de criar telas brilhantes o suficiente para competir com a luz do sol. (NAKAMURA, 2010, p. 78).
} 
que haja um melhor resultado estético, maior facilidade de instalação e manutenção dos dispositivos e redução dos custos. (NAKAMURA, 2010,p. 78).

A imagem criada pela fachada mídia apresenta como propriedades: a resolução, a difusão, a distância do observador, o brilho e a quantidade de cor (colour depth). A resolução está relacionada à quantidade de pixels que compõe a imagem. Essa quantidade pode variar muito, visto que, "um maior número de pixels não significa necessariamente melhor qualidade da imagem (...) mas definitivamente uma maior resolução permite imagens mais nítidas e mais detalhadas, se necessário, como é o caso do: Blinkenlights (144 pixels), Uniqa (160.000 pixels) e do Grand Lisboa (mais de um milhão de pixe/s)". (TSCHERTEU; LEEB, 2008, tradução nossa).

Ainda de acordo com o autor, a difusão tem relação com o tamanho dos pixels (pixel pitch) e a localização deles que têm um grande efeito sobre o observador. Fontes de luz milimétricas como os LEDs podem ser transformadas em pixels maiores "por meio de difusão de superfícies". A luminosidade ou o poder de luz de uma lâmpada está disperso em uma área maior, através da difusão, mas a sua luminosidade ou a densidade da luz é assim reduzida." Há uma relação direta entre a distância do observador, o tamanho dos pixels e a difusão. Quanto maior a distância entre os pixels, maior deve ser a distância do observador para que possa ter uma visualização total da imagem.

As técnicas mencionadas podem variar em função do brilho. Dentre os monitores ativos, "apenas o LED é brilhante o suficiente para persistir na luz direta. No entanto, algumas fachadas cinéticas como Flare aproveitam habilmente a luz solar." Uma questão a ser considerada são os problemas que, durante a noite, o brilho intenso pode trazer aos moradores e ao tráfego.

A quantidade de cores (colour depht) também varia de acordo com a tecnologia aplicada. No caso dos edifícios: BIX, SPOTS, Blinkenlights ou Chanel em Tóquio há uma redução de cores, enquanto naqueles em que a tecnologia do LED é aplicada, permite-se a produção de espaços com grande variedade de cores, que chegam aos milhões delas.

Tscherteu e Leeb reforçam que, para que uma intervenção possa ser considerada uma arquitetura de mídia, é fundamental que haja uma integração construtiva entre a fachada (ou o interior do edifício) e a tela, de modo a fundirem-se em algo novo. A unidade de exibição também pode ser reforçada pelo conteúdo personalizado para aquele edifício em que será aplicado, o que possibilitará uma 
comunicação. O conteúdo da projeção exposta na fachada pode ter uma relação com a identidade corporativa da empresa, com o uso e a forma do edifício, e assim produzir um forte efeito publicitário na medida em que se "transforma em um marco", torna-se "uma parte da percepção urbana cotidiana" das pessoas.

Certamente todas as formas de projeção das fachadas de mídia - seja para fins publicitários ou uma projeção puramente artística - exige muita perícia e experiência, por que, como visto acima, são tão diferentes os efeitos de tela, comuns em muitos aspectos (resolução, pixel pitch e brilho), e requer muita sensibilidade para a arquitetura e o espaço urbano. (TSCHERTEU; LEEB, 2008, tradução nossa).

Quanto ao "conceito de comunicação" não pode incluir apenas a fachada, mas também a iluminação da sala e, assim,

alcançar a partir da superfície as profundezas do edifício de modo que os processos comunicativos possam evoluir, na superfície do edifício, mas também no interior, na esfera pública em torno do edifício e, finalmente, também - espacialmente irrestrita - em mídia eletrônica. (TSCHERTEU; LEEB, 2008, tradução nossa).

Quanto à temporalidade, a princípio, instalações de fachadas mídia concebidas para serem permanentes, apresentam um resultado melhor em função de um conceito, planejamento e dinheiro aplicados. No entanto, como exceção à regra, exemplificando fachadas mídia bem sucedidas, projetadas e instaladas em edifícios já construídos, temos: o UNIQA, o Blinkenlights, algumas fachadas de concertos e eventos como a dos Jogos Atlânticos e também as de conteúdo artístico como SPOTS.

Outro aspecto da integração é a dimensionalidade. Dificilmente, as exibições são feitas ocupando as três dimensões do edifício, o que traria desconforto ao usuário, no entanto, existem casos que, no momento em que o morador está ausente, a projeção para o interior do edifício é possível de ser explorada por um período de dias do ano e de horas limitados. Até então, temos as '2,5 D', ou seja, projeções 2,5D. São aquelas que não se restringem apenas a uma superfície, mas a um fluxo em torno das bordas ou se estendem a superfícies esféricas (UNIQA e Grand Lisboa) proporcionando projeções e impressionantes efeitos espaciais, como é o caso de Nova-3D, uma instalação no interior da estação ferroviária de Zurique. 
A incidência de luz e o consumo de energia são pontos em que as fachadas mídia podem entrar em conflito com outras funções do edifício. Há situações em que os componentes dessas fachadas cobrem parte do edifício, o que torna a incidência de luz insuficiente para atingir os ambientes internos, ou até mesmo, inexistente. Nesse sentido, a redução da saída de luz e a existência de peças que maximizem a sua luminosidade são questões que têm sido solucionadas com o uso de LEDs integrados às tampas de cobertura e às grelhas de proteção solar. Ainda há casos em que existe "um conflito lógico entre o desempenho da luz transmitida e a resolução ou o pixel pitch, também nesses casos, onde a tomada de iluminação está integrada à fachada." Para que seja alcançada uma maior resolução ou para reduzir a distância entre as linhas de pixels,

a grade de fachada tem que ser ajustada em conformidade, ou, alternativamente, a grelhas de proteção solar ou a componentes similares que devem ser colocados na frente da fachada, o que necessariamente prejudica o desempenho da luz do dia. Soluções têm sido possíveis através da utilização de componentes que são colocados para a frente e espaçados com soquetes de iluminação integrada, que também apresentam uma imagem de alta qualidade. (TSCHERTEU; LEEB, 2008, tradução nossa).

Em linhas gerais, todo projeto bem sucedido deve partir do princípio de que é fundamental que o usuário receba luz suficiente e tenha uma visão desobstruída.

A imagem pode ser transparente, não transparente, como no caso do Chanel, edifício em Tóquio, onde os filmes do edifício foram utilizados como camada de difusão. Obviamente, um dos objetivos do designer, neste caso, foi dissolver os soquetes de iluminação individual em áreas de iluminação usando Privalite de vidro, e, assim, criar efeitos de imagem que se assemelham fortemente ao tecido. $O$ efeito magnífico da imagem, neste caso realmente é às custas dos ocupantes, que não podem ver claramente o exterior durante a operação. A camada de difusão, além disso, tem o efeito que uma parte da luz é refletida no interior do edifício como a luz dispersa.

A arquitetura de mídia também pode proporcionar um elevado potencial de identificação para com seu usuário, ou seja, estamos falando da mídia interativa. No Blinkenlights, em Berlim, foram dadas aos usuários diferentes possibilidades de se comunicar com o edifício em si, ou com outros habitantes de Berlim. Por um lado, vídeos com animações simples ou mensagens de texto do usuário podem ser enviados para a fachada (...). Por outro lado, pode-se jogar Pong através de interfaces de telefone celular. (TSCHERTEU; LEEB, 2008, tradução nossa). 
A operação é executada automaticamente a partir de uma lista predefinida de animações. Pode-se interromper o programa via celular,

\begin{abstract}
(...) a fim de jogar Pong isoladamente ou em conjunto, ou ativar uma carta de amor previamente carregada. Rendering poderia ser temporalmente programada através da apresentação de uma chave de ativação via telefone celular, para que a mensagem servisse perfeitamente a um momento romântico com alguém amado. É óbvio que, por muitos momentos pessoais como estes, onde uma auto desempenha o papel principal na fachada de mídia, uma forma particular de intensa identificação é estabelecida. São experiências únicas, que permanecem em nossa memória e estão estreitamente associadas a um determinado lugar. $O$ website de acesso público ao software desempenhou um papel importante na formação de uma comunidade em torno do Blinkenlights. Os usuários faziam parte da concepção do meio e tinham as ferramentas à sua disposição, com as quais poderiam criar concretas e significativas mensagens. Eles transformaram-se em criadores ativos de conteúdo de mídia e Blinkenlights foi aceito como suporte desses documentos. TSCHERTEU; LEEB, 2008, tradução nossa).
\end{abstract}

Com o crescente desenvolvimento dos meios de consumo gerados na WEB 2.0 e com o boom de redes sociais como o MySpace e o Facebook, no pensar de Susa Pop, Gerente de Projeto e Diretora de Seleções do Media Facades Festival Berlin 2008, pode-se supor que há

(...) um grande potencial para aplicações que criam redes sociais em torno da arquitetura de mídia, e que assim vão levar a maior penetração do espaço físico e virtual. Aqui, novos formatos de mídia serão criados, o que pressupõe um elevado nível de interdisciplinaridade por parte dos designers que tenham a possibilidade de produzir em muitas experiências urbanas inovadoras. (WAGNER, 2008)

O evento Media Facades Festival Europe 2010 também refletiu sobre a crescente presença de grandes infraestruturas digitais com elementos visuais em espaços públicos para investigar sua função comunicativa no ambiente urbano. Nessa edição foram exploradas as possibilidades de rede de telas urbanas e fachadas de mídia via internet e as novas tecnologias europeias: "'eventos conjuntos de Radiodifusão' (...) As fachadas de mídia serão transformadas em fases locais e abrirão uma janela global para os processos culturais e sociais em toda a Europa." Pretende-se que, a longo prazo, o evento torne-se 
(...) um catalisador para a criação de uma estrutura sustentável e transportável, onde artistas, profissionais da cultura, organizações de arte, instituições culturais, organismos governamentais, empresas privadas e comerciais, meios de comunicação social e o público em geral, de dentro e fora da Europa, possam interagir, através do desenvolvimento de um novo formato de comunicação cultural no espaço público. (MEDIAFACADES.EU, 2010, tradução nossa).

\begin{abstract}
Diante da crise energética, um fato que não podemos deixar de considerar é o elevado consumo de energia que esse tipo de fachada requer. Mais uma vez, os LEDs são muito eficazes, mas dependendo do número utilizado, seus níveis de consumo também podem ser elevados. Quanto maiores forem a área, o brilho e a densidade de pixels, maior será o consumo de energia. É necessário que se considere a relação custo benefício do sistema a ser aplicado,
\end{abstract}

(...) o que é justificável para a sociedade, e não simplesmente o que uma grande empresa pode pagar. (...) Além disso, deve-se ter claramente em mente que, além da operação, outras fases do ciclo de vida de um monitor também tem que ser incluído em um balanço ecológico, como a produção e eliminação. (WAGNER, 2008).

\title{
5.2.3.1 Exemplos de aplicação
}

A primeira tecnologia mencionada: o Flare, é um sistema modular para criar dinâmicas simples em fachadas ou em qualquer superfície de parede. O sistema consiste em um número de corpos metálicos inclináveis, chamados "flocos", ligados individualmente a cilindros pneumáticos e é controlado por um computador que pode formar diversos tipos de animação de superfície. "Sistemas de sensores dentro e fora do edifício comunicam a atividade de construções diretamente para o sistema Flare que atua como as construções da linha lateral." Trata-se de uma "membrana permeável cinética" que atua como uma "pele viva" que permite um edifício se expressar, comunicar e interagir com seu meio ambiente". (MEDIAARCHITECTURE.ORG, 2008). 

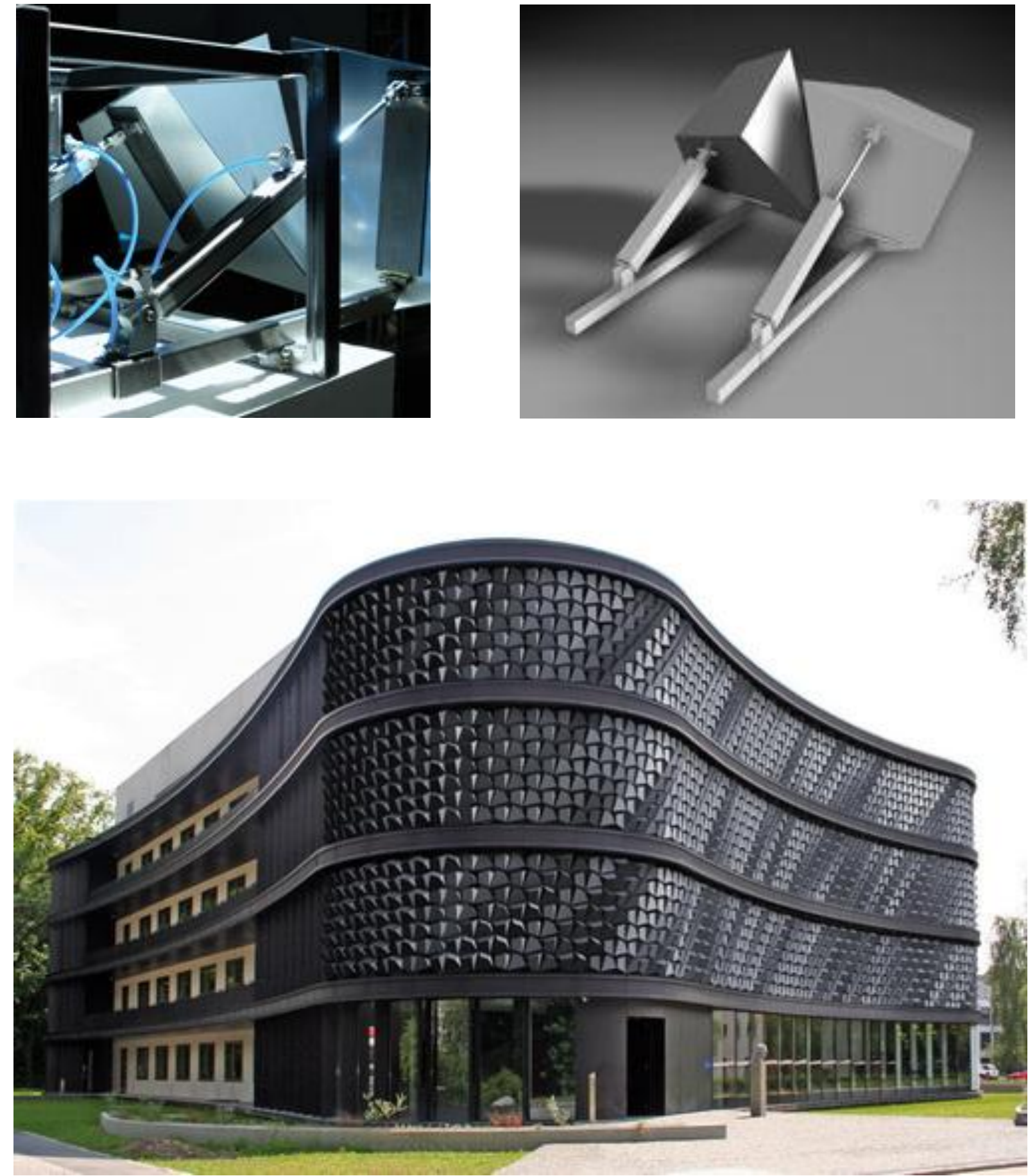

Figuras 426 e 427: Componentes do Sistema Flare. Fonte:< http://www.flare-facade.com/>. Acesso em 10/03/2010.

Figura 428: Flare - Kinetic Membrane Facade Fonte: <http://www.mediaarchitecture.org/mediafacades2008/exhibition/basics>. Acesso em 25/02/2010. 

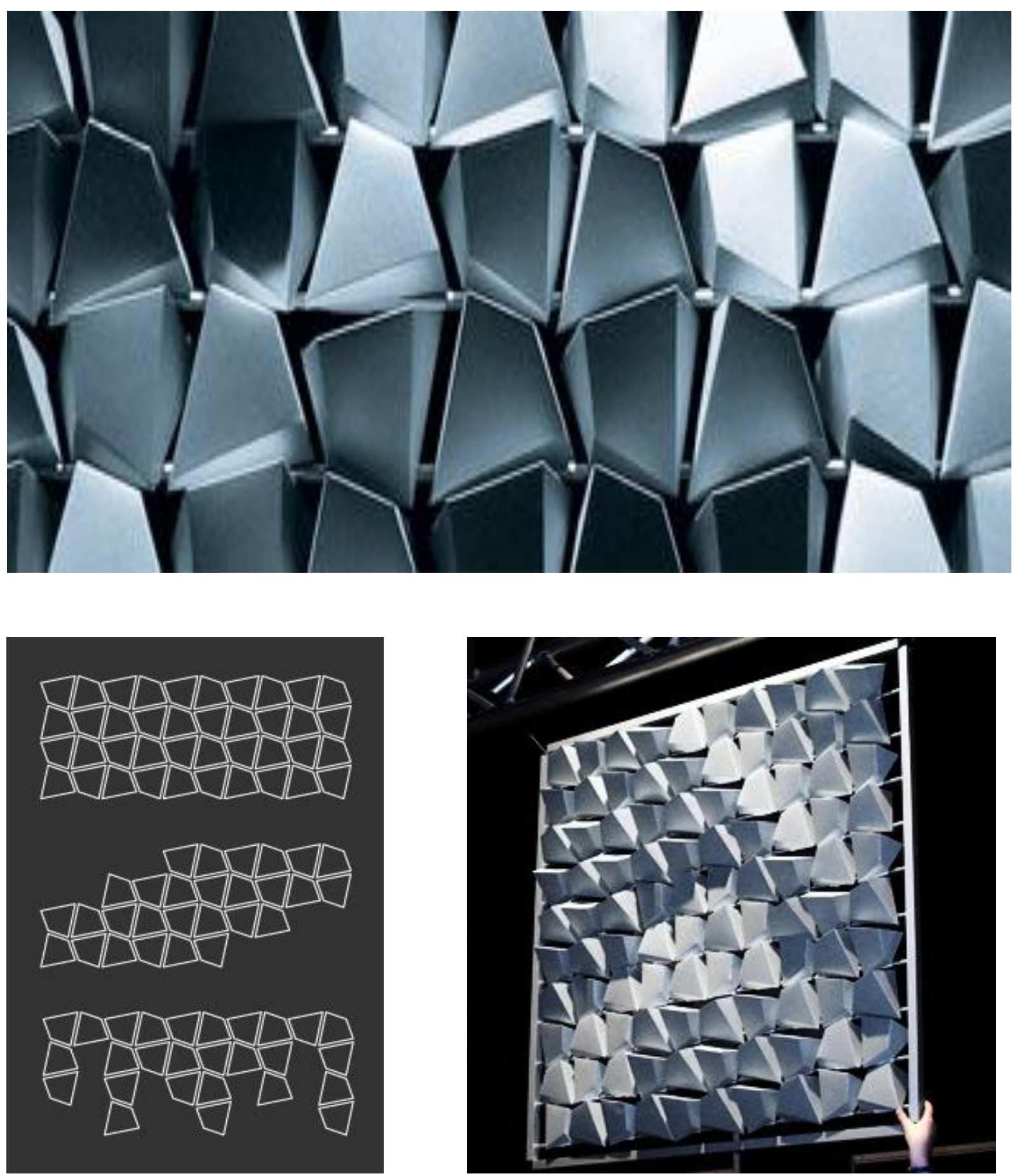

Figura 429: Flare - Kinetic Membrane Facade. Fonte:< http://www.flare-facade.com/> . Acesso em 10/03/2010.

Figuras 430 e 431: Arranjo dos componentes do Sistema Flare.

Fonte:< http://www.flare-facade.com/>. Acesso em 10/03/2010.

Fonte:< http://www.mediaarchitecture.org/mediafacades2008/exhibition/basics>. Acesso em 25/02/2010.

O Blinking Lights, realizado no ano de 2001, em Berlim, foi uma animação criada por Djenia Beliaikin, na qual foram aplicadas 144 lâmpadas halógenas simples, controladas pelo "Blinkenpaint 2.4, um software de fonte aberta pela CCC". Também dedicado ao público e voltado à interação, não é um exemplo típico de fachada 
mídia devido ao excesso de luzes halógenas brilhantes aplicadas por trás de uma camada de difusão, o que "só parece fazer sentido em edifícios que estão vazios." (MEDIAARCHITECTURE, 2008, tradução nossa)

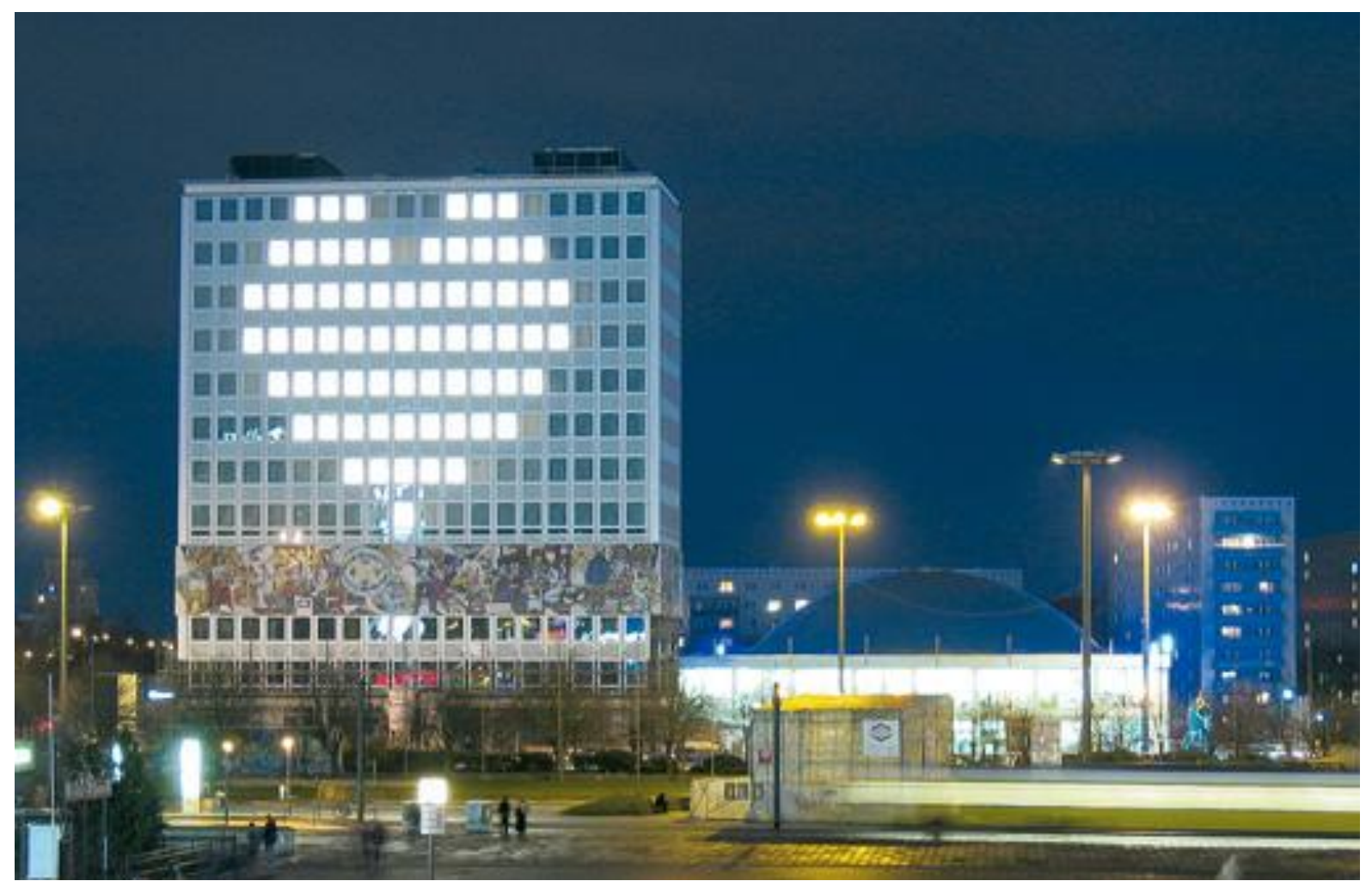

Figura 432: Blinkenlights. Fonte: <http:// www.mediaarchitecture.org/mediafacades2008/exhibition/basics>. Acesso em 25/02/2010.

A nova sede da empresa Uniqua Insurance Company, em Viena, possui sua fachada composta por duas camadas de vidro e, entre elas, módulos de LED. O espaçamento entre os vidros coincide com a grade. A resolução não é alta, mas suficiente para a exibição de imagens de fotografias as quais só podem ser exibidas durante a noite. A técnica foi feita por Licht kunst Licht e Barco e o conteúdo artístico pela Mader Stublic Wiermann. 

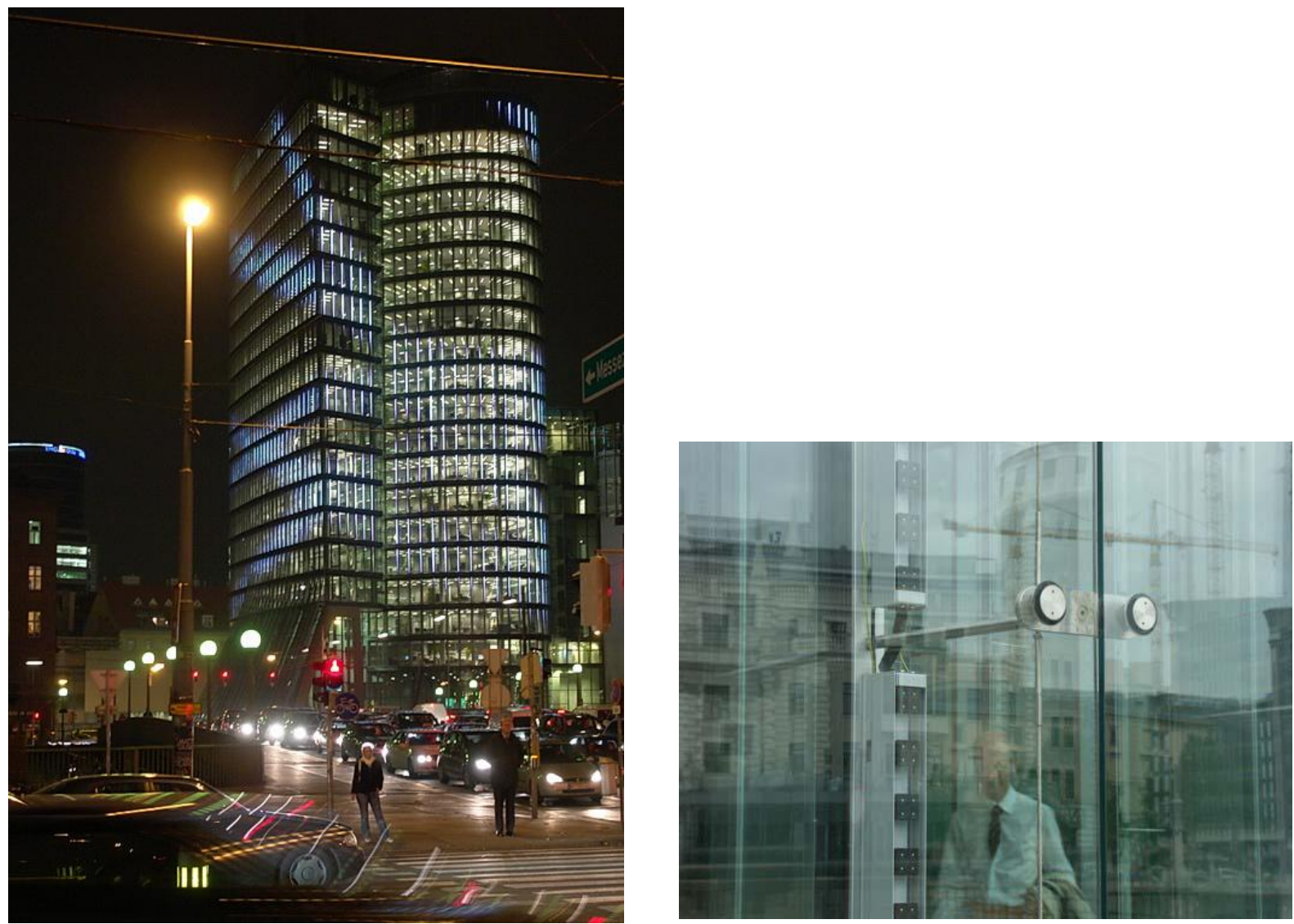

Figuras 433 e 434: Uniqua. Fonte: $<$ http://

www.mediaarchitecture.org/mediafacades2008/exhibition/basics>. Acesso em 25/02/2010

O Grand Lisboa Casino é um edifício de 52 andares construído em Macau. "O design distinto e icônico da arquitetura (...) foi inspirado no símbolo Lótus de Macau, combinado com a extravagância de cocares de plumas de dançarinos brasileiros e o requinte de um ovo de Fabergé ${ }^{93}$. À noite, a base é um caleidoscópio de cores" devido à aplicação de 1,2 milhões de LEDs em sua superfície. A iluminação e o sistema de vídeo foram projetados pela empresa Magic Monkey.

\footnotetext{
93 Os chamados "Ovos Fabergé" são obras-primas da joalharia produzidas pelo joalheiro Peter Carl Fabergé no período de 1885 a 1917 para os czares da Rússia. Eram peças elaboradas com esmalte, metais e pedras preciosas nas quais "escondiam surpresas e miniaturas e eram encomendados e oferecidos na Páscoa entre os membros da família imperial." A perfeição com que os ovos de Páscoa eram feitos despertou o interesse de colecionadores. Disponível em: <http://pt.wikipedia.org/wiki/Ovo_Faberg\%C3\%A9>. Acesso em 25/02/2010.
} 


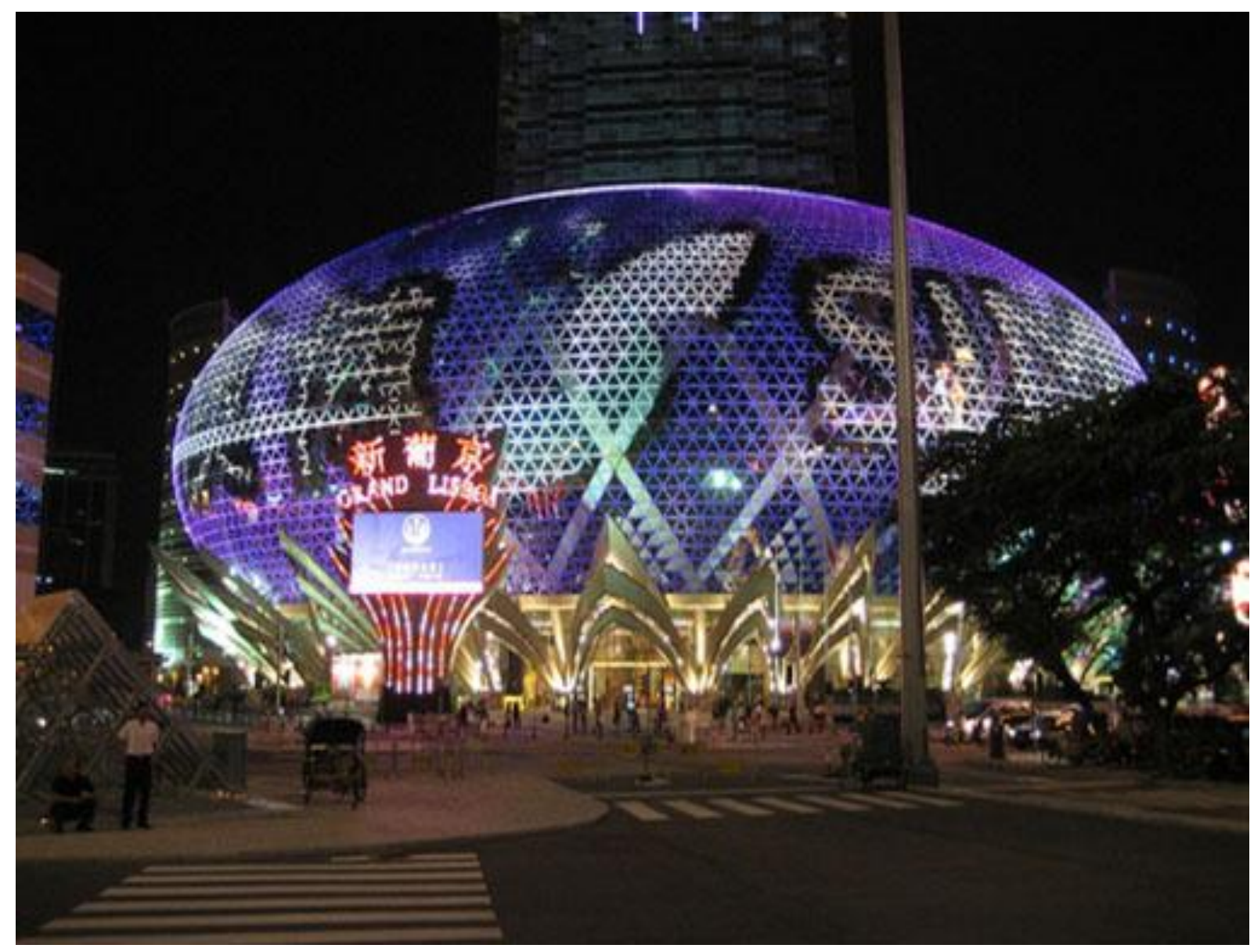

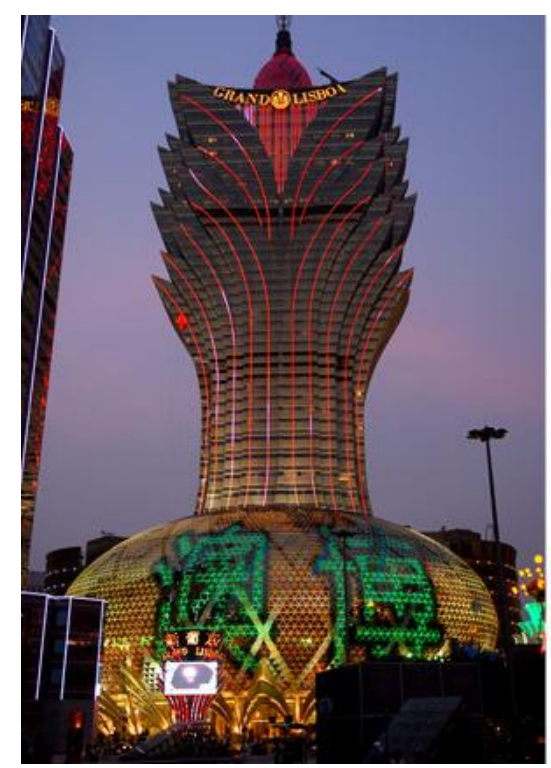

Figura

435:

Grand

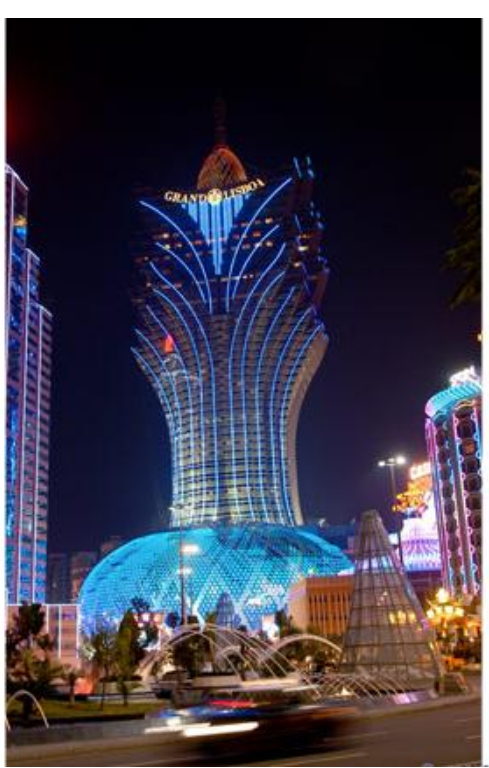

Lisboa

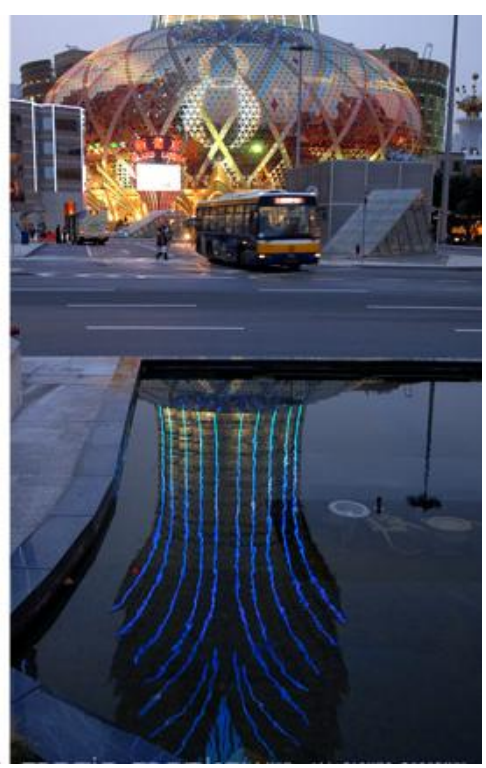

Fonte:

www.mediaarchitecture.org/mediafacades2008/exhibition/basics >. Acesso em 25/02/2010.

Figuras 436, 437 e 438: Grand Lisboa Casino. Fonte: <http://www.magicmonkey.net/en/projects/grandlisboa>. Acesso em 28/03/2010.

Em entrevista à revista Enlightermagazine, Jan Edler, arquiteto responsável por projetos dos mais conhecidos da arquitetura dinâmica como o Spots em Berlim, na 
Alemanha e Kunsthaus Graz, na Áustria ${ }^{94}$, revela que seu trabalho encontra-se “em algum lugar na fronteira entre arte e arquitetura" (EDLER, 2009). Em Graz, projetado por Peter Cook \& Colin Fournier, foram criados espaços e objetos que respondem às necessidades e demandas individuais, sociais e ambientais. (CARNEIRO, 2010).

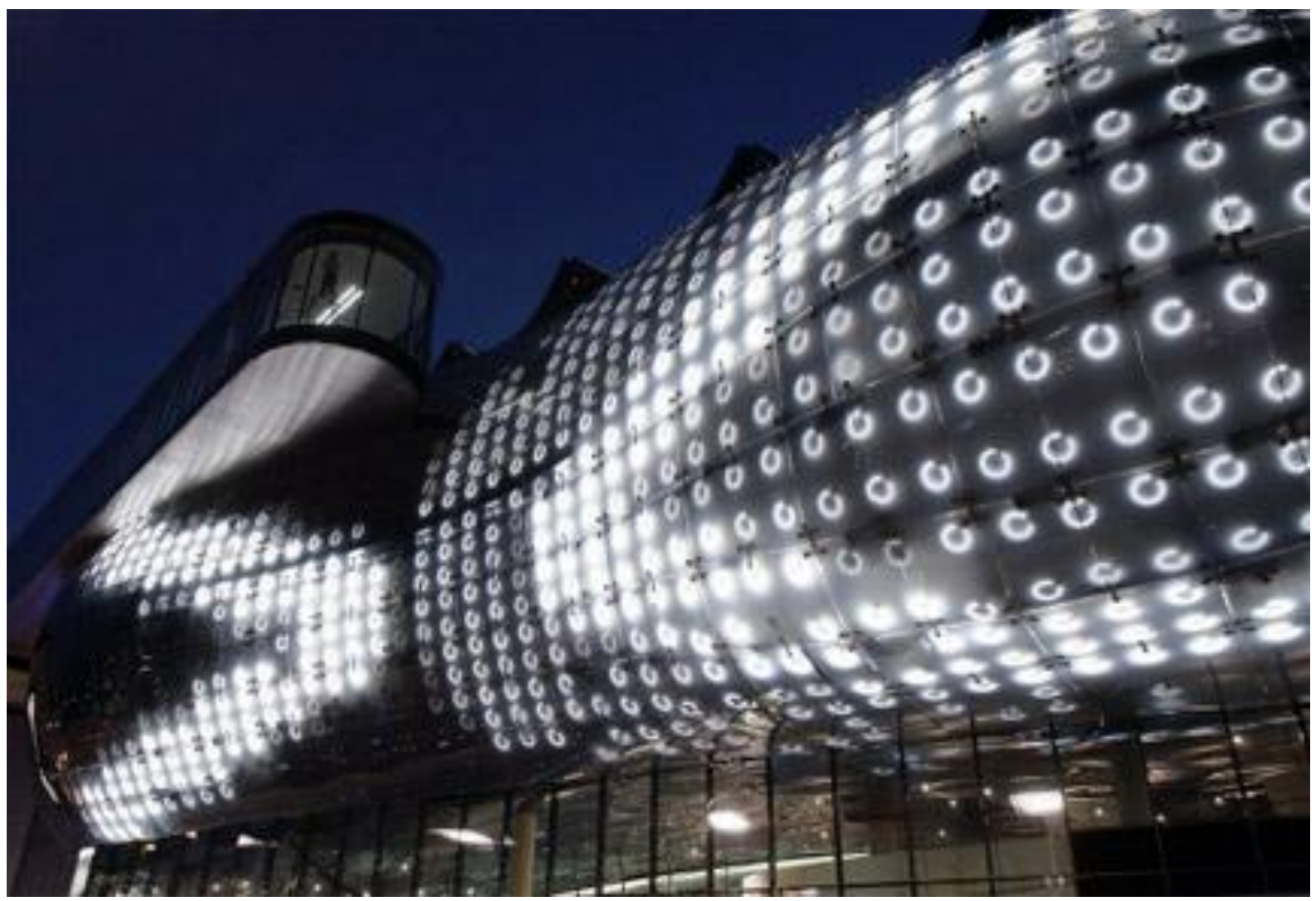

Figura 439: Kunsthaus Graz (2003). Projeto de Peter Cook \& Colin Fournier. Iluminação de fachada. Fonte: EDLER, 2009.

Para Jan, o termo "arquitetura de mídia" ainda não tem uma definição, é algo que está sendo criado. O arquiteto espera que, ao longo do tempo, fiquemos "longe da ideia geral de uma televisão transferida para o espaço urbano, apesar de que hoje a indústria da mídia é a influência predominante nestes tipos de projeto." A seu ver, não se trata de uma nova arquitetura mas "de um alargamento do entendimento do que a arquitetura deve incorporar hoje", de "como lidar com os fenômenos que os arquitetos têm de incorporar aos seus projetos" a fim de ficar em dia com a tecnologia de seu tempo. "A tecnologia de exibição está nos dando a

94 Jan Edler realiza seus projetos pela empresa Realities: United - RU, fundada e dirigida por seu irmão Tim Edler, também arquiteto. 
possibilidade de alterar pelo menos a superfície, o que pode levar a ideias de estruturas que poderiam mudar também fisicamente." (EDLER, 2009).

Um de seus projetos que se encaixa na categoria de arquitetura dinâmica é o projeto NIX, desenvolvido para o edifício do Banco Central Europeu (BCE) em Frankfurt, na Alemanha. Nele, o objetivo era explorar a terceira dimensão, de modo que todas as superfícies do volume do edifício fossem campo de intervenção e

todo o edifício, poderia se tornar uma obra de arte abstrata. A idéia de usar a iluminação de células individuais do Office para criar algo dinâmico que se estende por todo o edifício está realmente em coesão com a filosofia geral da ESB que é 'trazer elementos individuais em conjunto para criar um valor acrescentado'. (EDLER, 2009)

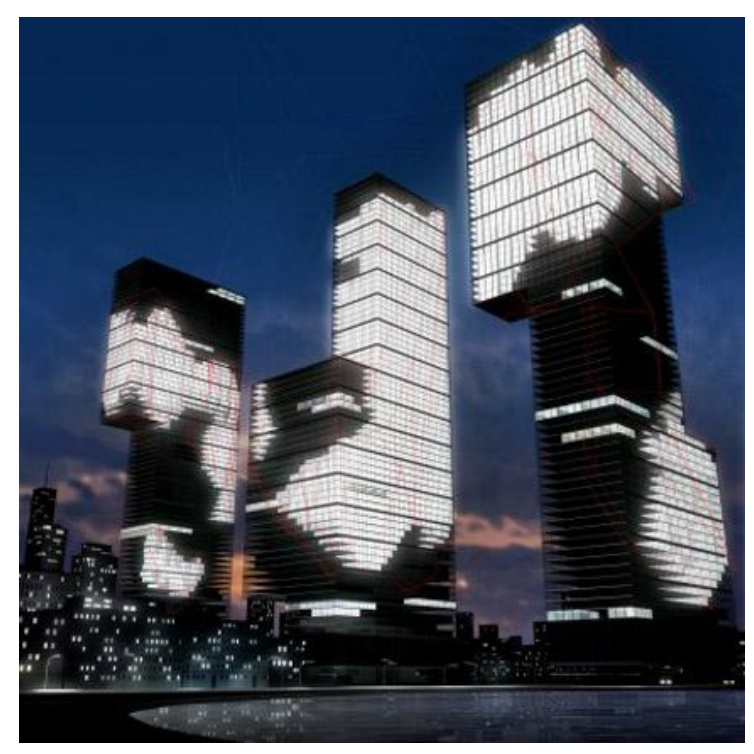

Figura 440: NIX (2005), iluminação dinâmica utilizando iluminação casa que é tomada por um sistema centralizado, quando os serviços não estão em uso. Fonte: EDLER, 2009.

Outro projeto desenvolvido pelo Realities United, em parceria com o WOHA Architects, foi o Crystal Mesh (Malha de Cristal), painel aplicado na fachada do Iluma Shopping Center, em Cingapura. Considerada uma das maiores fachadas mídia permanente do mundo, totaliza uma área superior a 5 mil metros quadrados cobertos por 3 mil módulos de peças geométricas de policarbonato estampado que formam uma espécie de mosaico monocromático e remetem à angulação de diamantes. Neste caso, cerca de $2 / 3$ das peças foram eletrificadas e equipadas com número variável de lâmpadas fluorescentes compactas (entre uma e sete) controladas individualmente por software específico. Devido à irregularidade na disposição das peças, a superfície iluminada foi dividida em diferentes resoluções, criando efeitos visuais mais dinâmicos. 

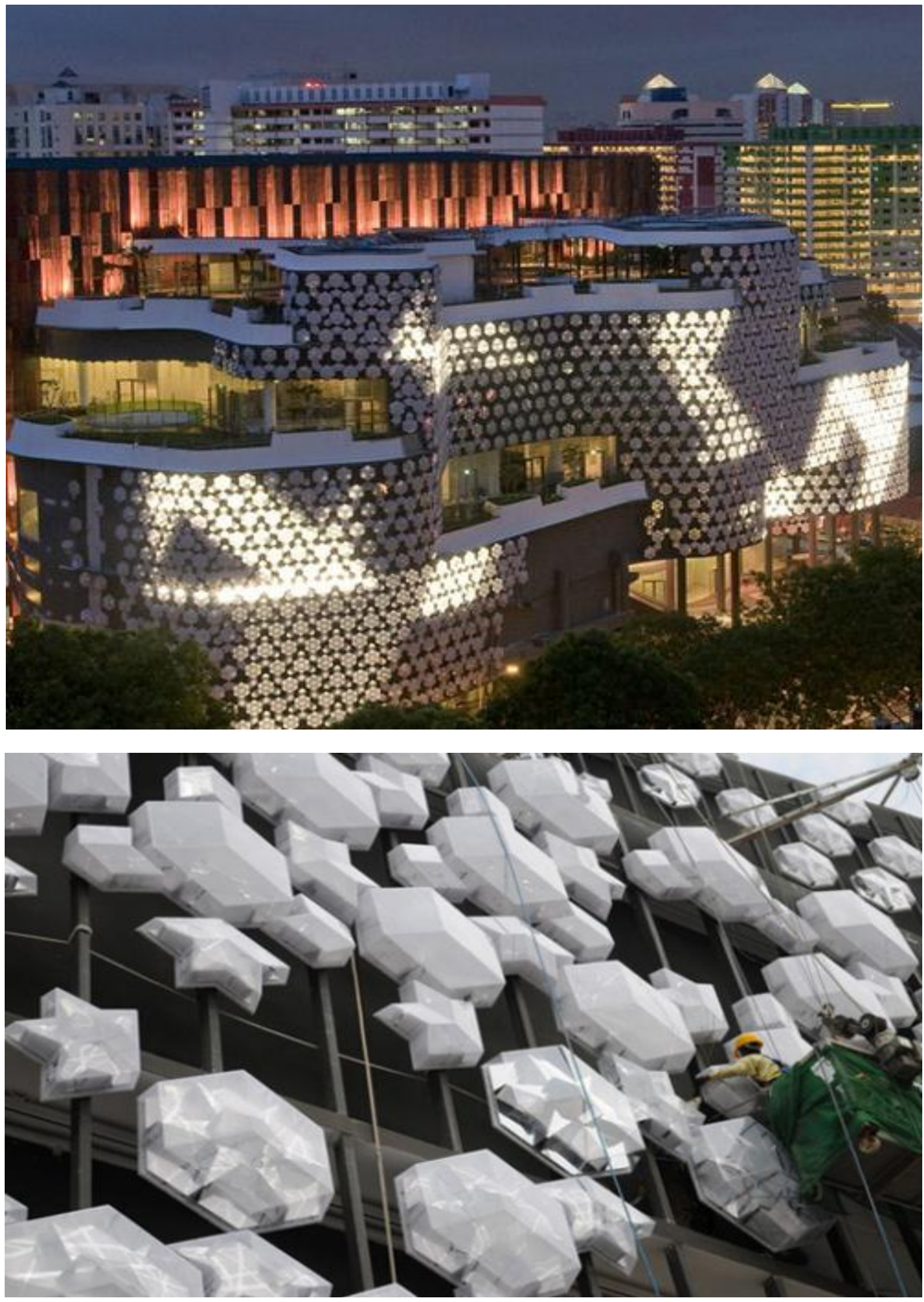

Figura 441: Crystal Mesh.Fonte:< http://www.flickr.com/photos/journal-du-design/3899990952/>. Acesso em 23/05/2010.

Figura 442: Detalhe Crystal Mesh.Fonte: <http://www.bestofremodeling.com/assets/borblog_artic>. Acesso em 23/05/2010. 
O profissional nos alerta quanto a alguns problemas presentes no decorrer de um projeto de arquitetura de mídia. $O$ primeiro deles é que, na maioria dos projetos, não há a opção de explorar diferentes possibilidades, porque eles já estão predefinidos para um campo específico, o da publicidade. Uma situação que contraria esse padrão foi o projeto da instituição de arte em Graz (Kunsthaus Graz), em que o cliente não sabia que estaria recebendo "uma fachada que poderia se comunicar com o mundo exterior e, consequentemente, não houve pressão comercial por trás do projeto."

Também é real que

(...) a tecnologia está quase lá, mas não é tão simples como parece. Essa é a razão pela qual não a temos em toda parte hoje. Se você tiver a chance de incorporar esta tecnologia para a construção, numa fase muito inicial do processo de projeto é relativamente barata, por isso não está adicionando um monte de dinheiro extra. (EDLER, 2009).

\section{É necessário que se tenha a tecnologia disponível no mercado e que,} fundamentalmente, haja uma comunicação entre os profissionais envolvidos no projeto (engenharia elétrica, construção de sistemas de automação, sistemas de segurança, engenheiros de dados de distribuição), pessoas que na maioria das vezes, "não estão acostumadas a ter um designer para vir e dizer a eles o que fazer."

Um outro problema de ordem prática está relacionado à pré-visualização da ideia. No caso do NIX, foi necessário desenvolver um software especial de renderização. (EDLER, 2009).

Pixy é um display artístico criado pelo coletivo francês e canadense Experientia Electrica, uma coprodução entre Videographer (Montreal) e Arcadi (França). Nele, o pixel é transformado em um "objeto fixo a serviço de um espaço modular". A imagem, em baixa resolução, pode ser manipulada e distorcida. "Cada pixel da imagem é um elemento físico autônomo feito de papel eletroluminescente, que pode ser movido". A estrutura Pixy não é limitada a duas dimensões, ela pode ser colocada em um volume e tornar-se um objeto com um potencial interativo. Por poder tornar-se um volume, nos permite manipular o espaço em benefício das imagens de vídeos escolhidos. (MEDIAARCHITECTURE, 2008). 

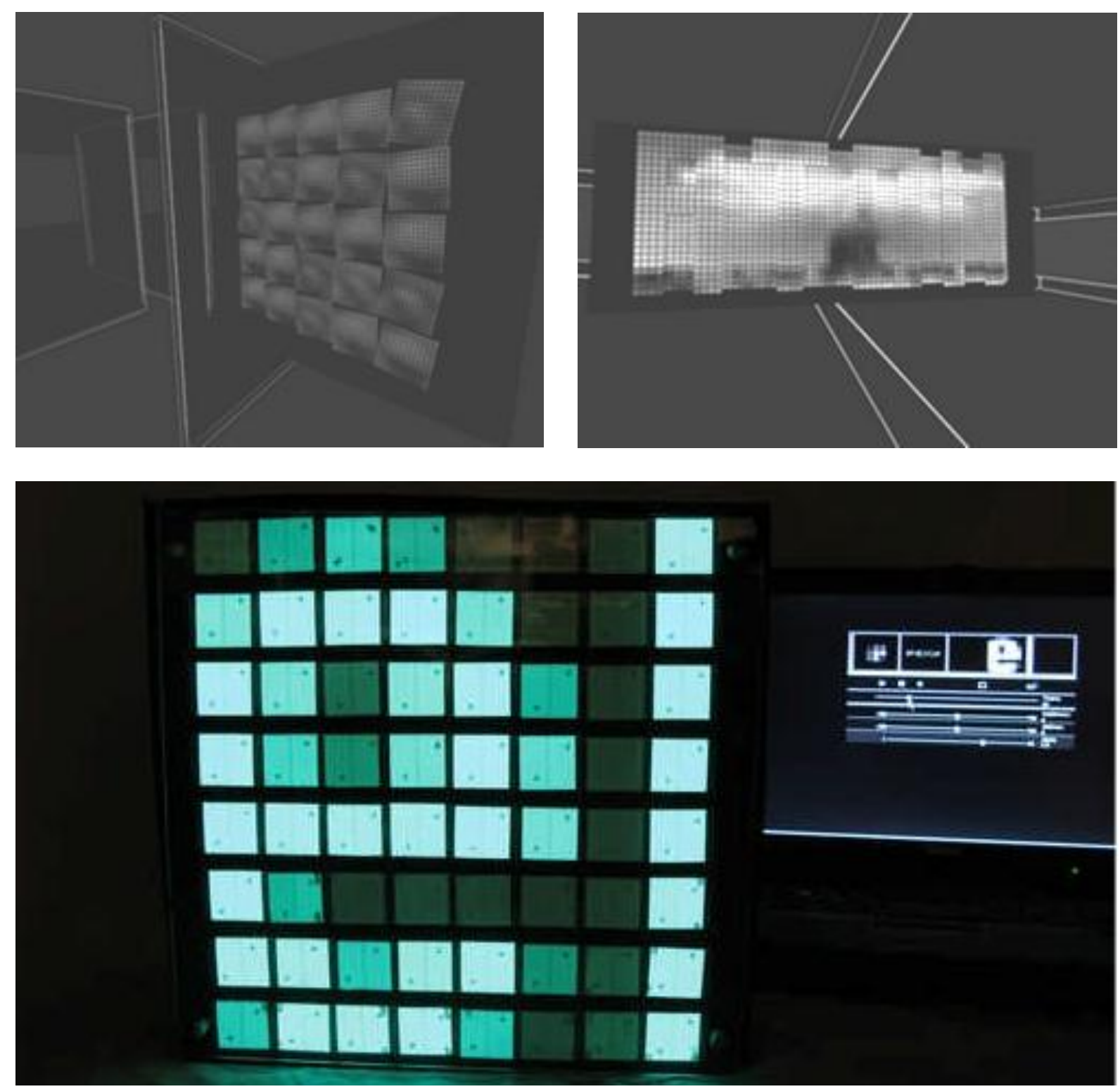

Figuras 443, 444 e 445: Display artístico Pixy. Fonte: <http:// www.mediaarchitecture.org/mediafacades2008/exhibition/basics>. Acesso em 25/02/2010.

A instalação You Fade to Light foi criada para a Philips, por designers do escritório rAndom International: Stuart Wood, Flo Orkrass e Hannes Koch, profissionais que "trabalham exclusivamente com produtos que transitam entre a arte, o design e a tecnologia". O ponto central da proposta é a interação do espectador/usuário com a obra. O painel de $128 \times 274 \mathrm{~cm}$, que totaliza $150 \mathrm{Kg}$, foi construído com 1.024 OLEDs, os quais refletem os movimentos do usuário em uma superfície de vidro ultrafino $(2 \mathrm{~mm})$ extremamente reflexiva. Com o auxílio de um software especialmente desenvolvido, o dispositivo reconhece os movimentos e os transforma em luz com um consumo de aproximadamente 800W/h. (L+D INTERNACIONAL LIGHTING MAGAZINE, 2010, p.24). 
A instalação tem obtido reações positivas por todos os lugares nos quais é exibida tendo sido, inclusive, incorporada ao acervo do museu internacional de design Neue Sammlung, em Munique, na Alemanha, e atraído a atenção não apenas de empresas e veículos especializados em design e iluminação, mas também de colecionadores de arte contemporânea. ( $L+D$ INTERNACIONAL LIGHTING MAGAZINE, 2010, p.24).
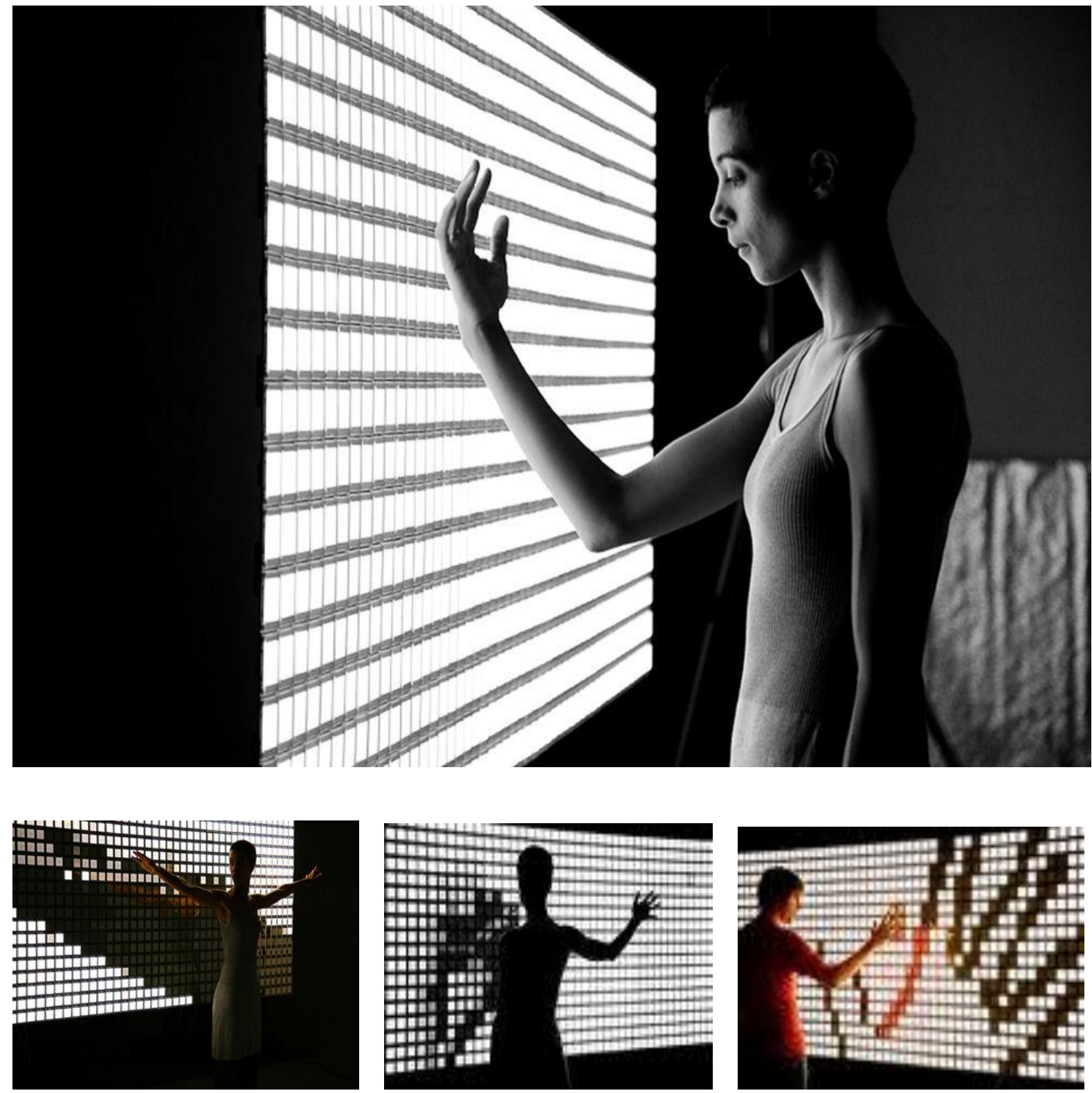

Figuras 446, 447, 448 e 449: Instalação You Fade to Light. Fonte:

$<$ http://www.worldarchitecturenews.com/index.php?fusea>. Acesso em 03/04/2010.

Fonte: <http://artnews.org/gallery.php?i=675\&exi=19351>. Acesso em 03/04/2010. 
O artista norte-americano Joshua Kirsch, criou uma série de três esculturas interativas denominadas Concentricity. Cada obra possui uma manivela branca iluminada que abriga um ímã para acionar interruptores reed (interruptores elétricos ativados por campos eletromagnéticos) localizados no centro da estrutura. Através desses interruptores, LEDs são acesos ou apagados conforme o movimento realizado pelo usuário. Todos os elementos eletrônicos que compõem as esculturas são, propositalmente, expostos e tratados como matéria escultórica que complementa os demais. A obra Concentricity 96, é composta por 96 LEDs vermelhos, que ficam acesos permanentemente, e 96 LEDs brancos que, quando a manivela é acionada, interagem com a estrutura pantográfica em alumínio produzindo estampas na parede.

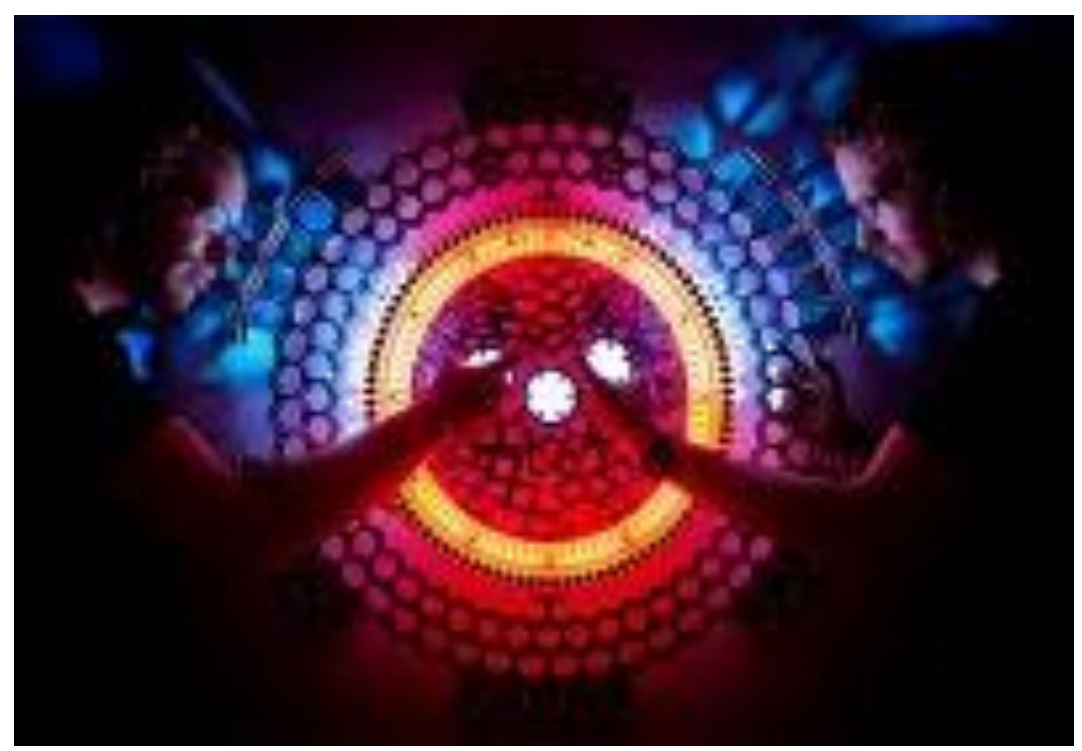

Figura 450: Concentricity 96.

Fonte: <http://ficuslot.blogspot.com/2009_10_01_archive.html>. Acesso em 03/04/2010.

Recentemente, às margens do Rio Maas, em Rotterdam, foi construída pelo designer holandês Daan Roosegaarde, a paisagem interativa: Dune 4.2. A instalação, de caráter permanente, é um híbrido entre natureza e tecnologia 
construída com fibras óticas e LEDs que acendem de acordo com os sons e os movimentos dos espectadores que por ela passam. Com 60 metros de extensão, a obra montada ao ar livre, utiliza apenas aproximadamente 60W. Versões em menor escala foram montadas no Maastunnel, em Montevideo, e no Museu Victorio \& Albert, em Londres, para a exposição Decode: digital sensations.
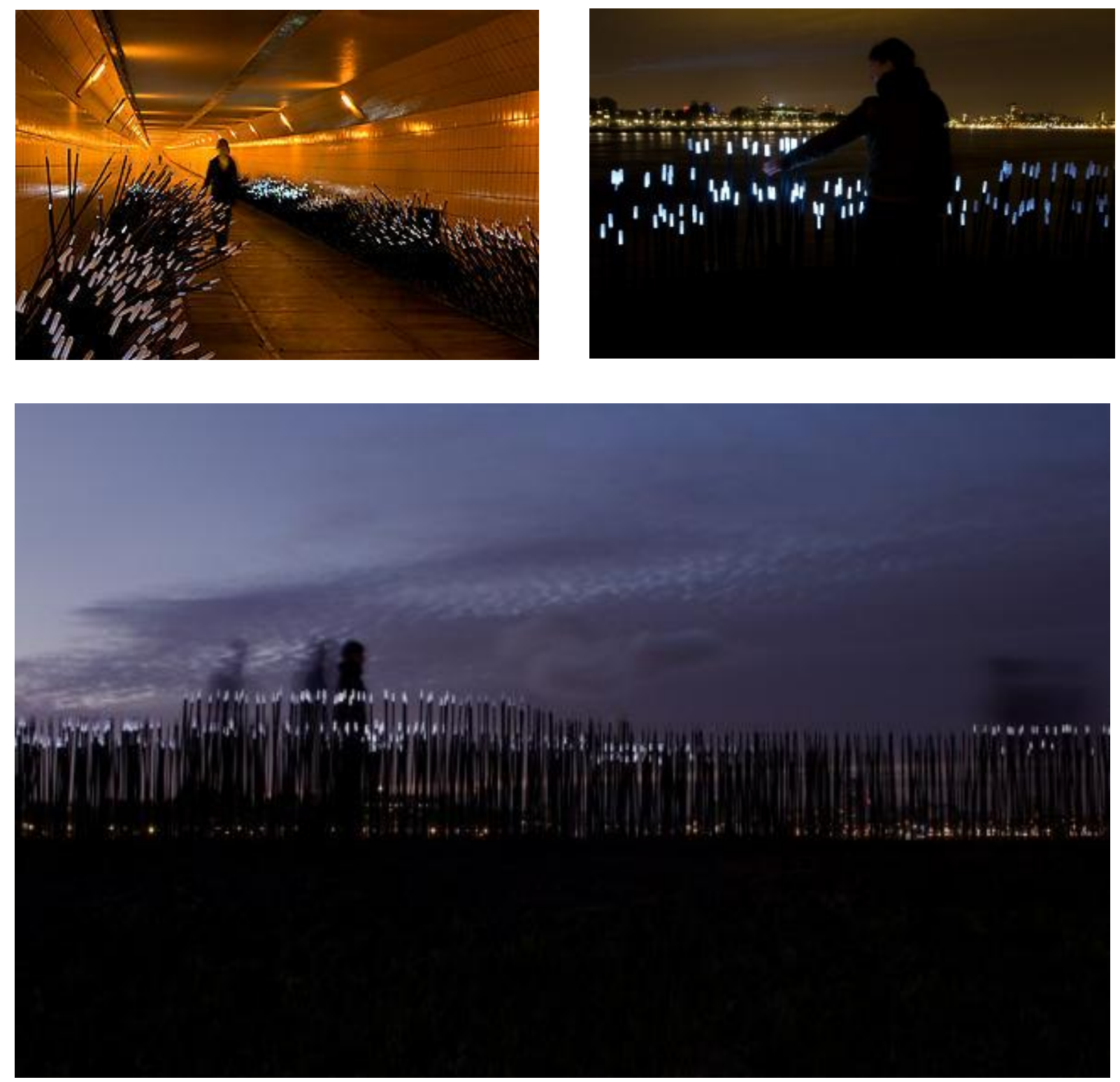

Figura 451: Versão em menor escala da instalação Dune 4.2 montada, no Maastunnel e em Montevideo. Fonte: <http://www. plusmood.com/2009/12/dune-4-2-daan-roosegaarde/> . Acesso em 03/04/2010.

Figura 452: Dune 4.2. Fonte: <http://www.mediamatic.net/id/13171>. Acesso em 03/04/2010.

Figura 453: Dune 4.2. Fonte: <http://www. plusmood.com/2009/12/dune-4-2-daan-roosegaarde/>. Acesso em 03/04/2010. 
Nova - 3D lightsculpture é um display de LEDs projetado para os 150 anos do Jubileu da Universidade ETH de Zurique. O paralelepípedo de seis toneladas é composto por 25.000 luzes que podem ser acesas em mais de 16 milhões de cores. Instalado em uma estação de Zurique, pode apresentar, além de imagens abstratas, sequências de imagens fotográficas e cinematográficas. A exibição de imagens é renovada em uma sequência de 25 ciclos por segundo. Uma instalação de visualização gráfica interativa também faz parte do projeto. Há um display touchscreen translúcido com um Flash-like GUI para controlar o que o display 3D de LED exibe; nele é possível que o usuário da estação desenhe no display em tempo real. A ideia do projeto pertence a Horao $\mathrm{GmbH}$; o desenvolvimento do sistema global de técnicos e o hardware vem do ETH Supercomputing Sistem AG. O software foi desenvolvido no Laboratório de Computação Gráfica da ETH Zurique.

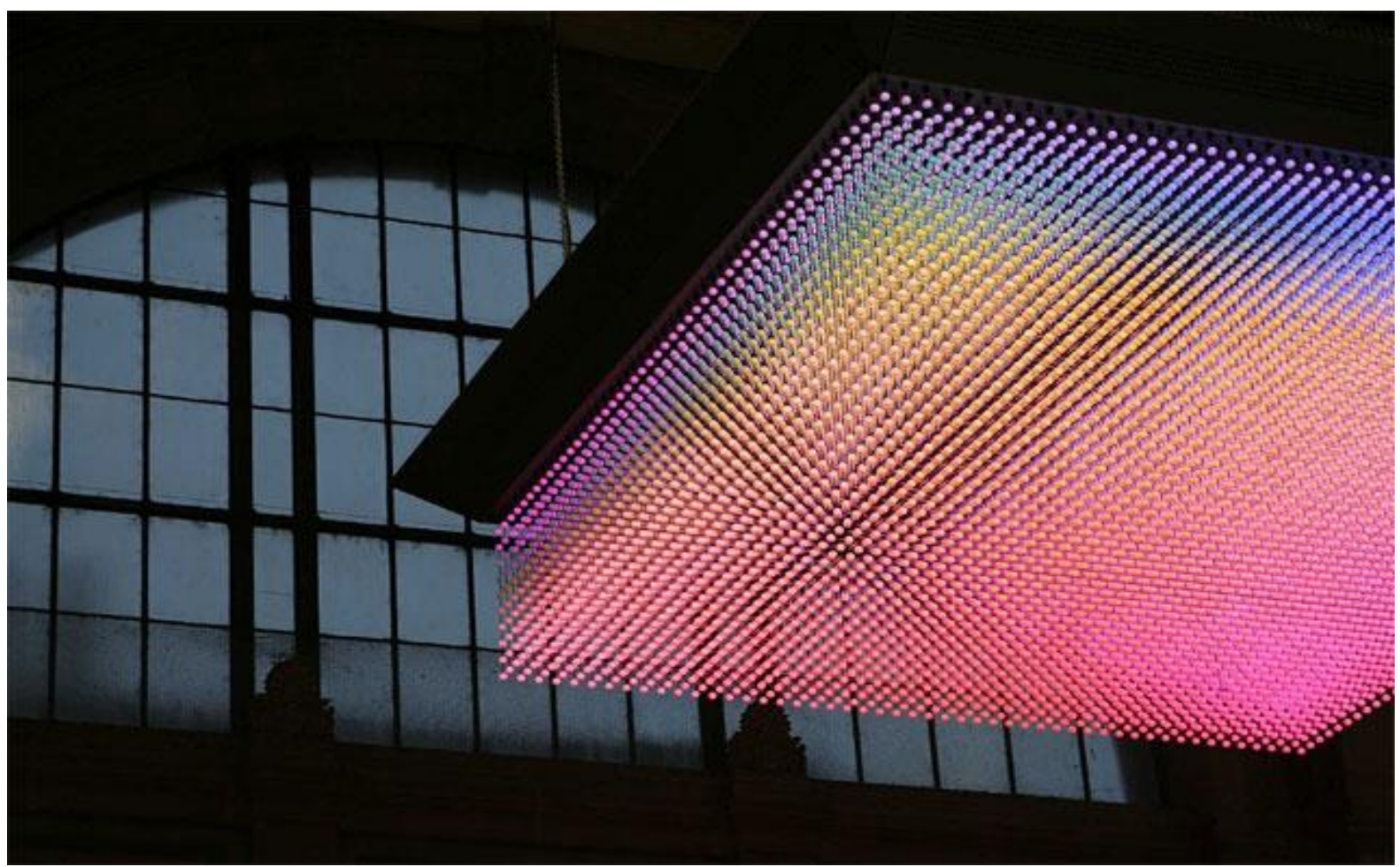

Figura 454: Nova - $3 D$ lightsculpture, Estação de trem de Zurique. Fonte: <http://www.todayandtomorrow.net/2008/04/29/nova-3d-led-display/> . Acesso em 11/03/2010. 

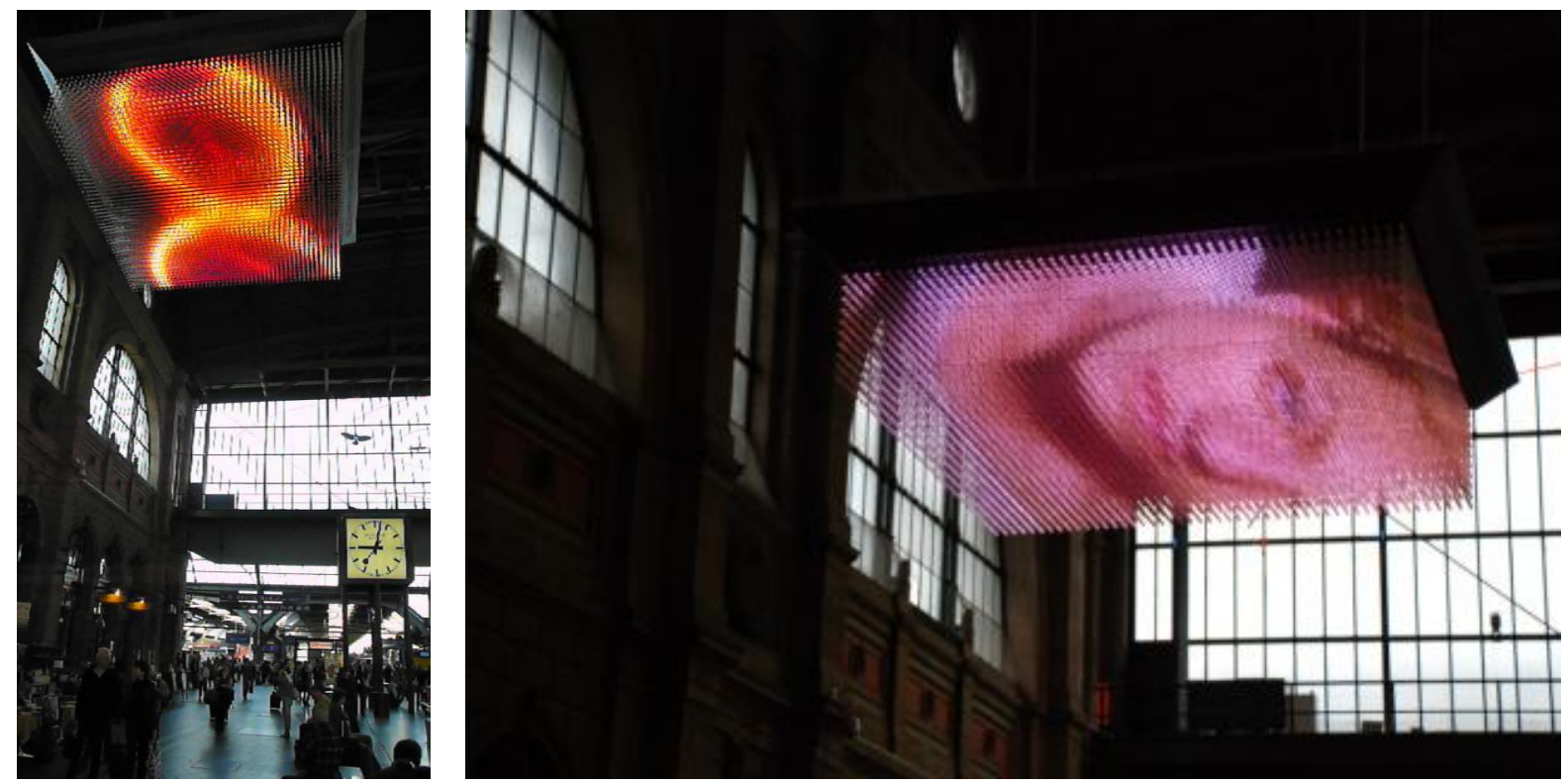

Figuras 455 e 456: Nova - $3 D$ lightsculpture, Estação de trem de Zurique. Fonte: <http://nait5.files. wordpress.com/2009/10/imagen-23.png?w=460\&h=308>. Acesso em 11/03/2010.
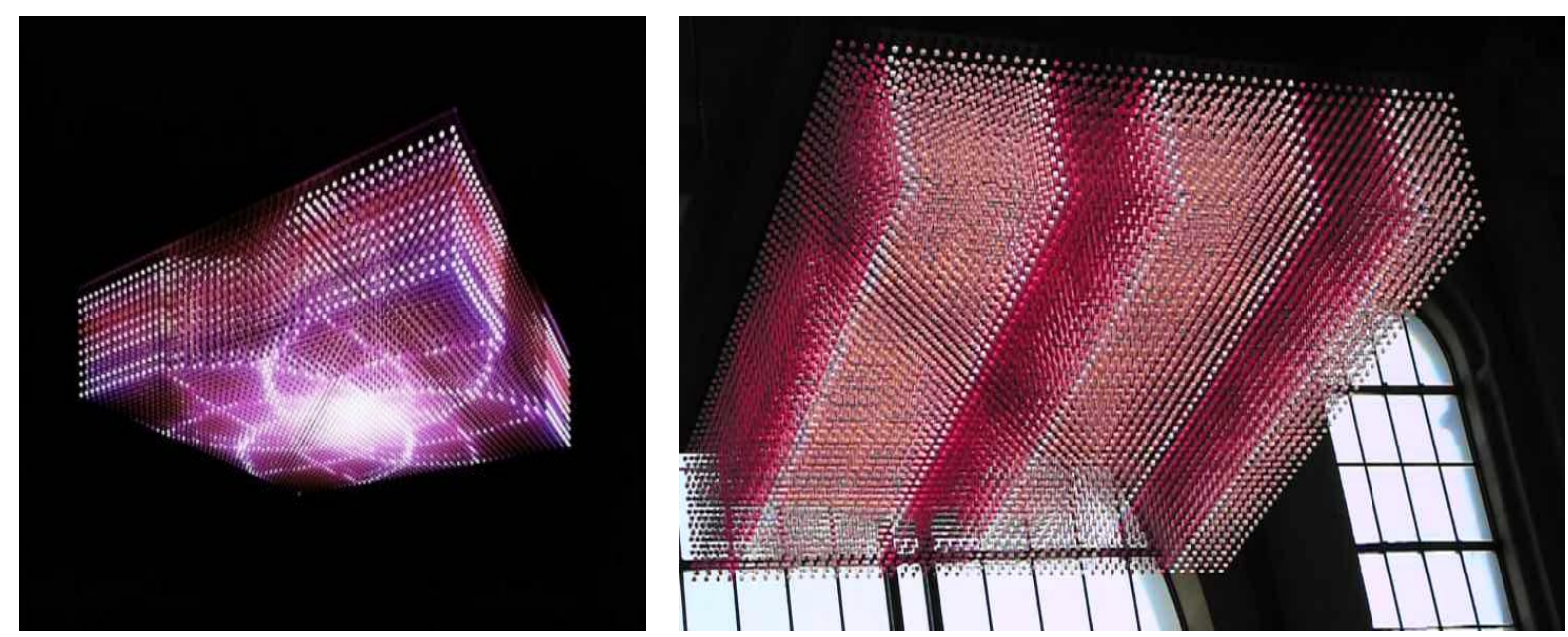

Figuras 457 e 458: Nova - 3D lightsculpture, Estação de trem de Zurique. Fonte: <http://nait5.files.wordpress.com/2009/10/imagen-23.png?w=460\&h=308>. Acesso em 11/03/2010. 


\subsubsection{Projeções / Video Mapping / Vjing}

A projeção, uma das linguagens exploradas na década 1960, passou por transformações significativas ao longo dos últimos anos. Naquela década, "havia por parte do artista uma grande preocupação estética voltada para o conceito da obra e o contexto de sua apresentação". A arte cinética, a pop art, o minimalismo e a arte conceitual, foram as formas artísticas predominantes. Nas artes plásticas,

o ilusionismo dá lugar a um tipo de produção extremamente simples na atitude do artista, que refletia uma atitude artística cada vez mais marcada pela abolição entre a arte e o cotidiano. Nesse contexto, a mídia de massa predominante era a televisão, cujo mundo era bastante distanciado do mundo da arte. (RUSH, 2000, p.79 apud VENTURELLI, 2004, p.41) ${ }^{95}$.

Os primeiros videoartistas acreditavam que para ter uma relação crítica com a sociedade televisiva era necessário, antes de tudo, "participar televisualmente". A imagem animada que, anteriormente, era vista no cinema, passou a fazer parte do cotidiano das pessoas. Ao longo do século XX, foi criada uma hierarquia das mídias: em primeiro lugar estava o cinema, seguido da televisão, do vídeo e das imagens de computador. No entanto, essa hierarquia perdeu o sentido à medida que todas as mídias foram se fundindo com a descoberta da tecnologia digital. Os fatores determinantes para o uso da técnica do vídeo por artistas foram a espontaneidade e a captura do instante, assim como, os temas relacionados ao tempo e à memória. Nam June Paik foi o primeiro artista a utilizá-la, seguido de Dan Grahan, Bruce Nauman, Joan Jonas e John Baldessari. Paralelamente, outras vertentes e temáticas surgiram. Alguns trabalhos tiveram origem nas performances de artistas conceituais e minimalistas. Ana Mandieta, Cris Burden, Peter Campus e Bruce Neuman gravavam suas performances e ações. A poética da técnica também foi explorada no cinema, no filme "200 Motels" (1971), de Frank Zappa, uma fusão de cinema e televisão denominada videoarte. Jean-Luc Godard, em 1968, rompeu com o cinema tradicional propondo a fusão de diferentes mídias. Nos 1970, um dos fundadores da arte sociológica, o teórico e artista francês Hervé Fischer,

\footnotetext{
${ }^{95} \mathrm{RUSH}$, Michael. Les nouveaux medias dans l'art. Paris: Thames\&Hudson, 2000, p. 79.
} 
enfatizava a importância do uso das novas tecnologias como um meio para a crítica social pela arte. Dizia que, ao contrário dos que aplicavam seu talento de artista para tornar estética a produção televisiva e lhe arrancar efeitos lumino-cinéticos novos, os artistas da arte sociológica se esforçavam para utilizar a câmera de vídeo como um revelador crítico dos ritos sociais, dos gestos e comportamentos da vida cotidiana, como um aparelho para dinamizar, acelerar processos e comunicação. Assim, a câmera passa a ser um olho que interroga, um olho que vigia e que incomoda a pessoa olhada, colocando-a em contraste com as suas atitudes estereotipadas apreendidas no contexto social. (FISCHER, 1977, p.138-153 apud VENTURELLI, 2004, p.44-45) ${ }^{96}$.

Nos anos 1980 e 1990, os trabalhos de vídeo "traduzem narrações pessoais, numa busca de identidade cultural, sexual e de liberdade política", nas obras de Denis Oppenheim, Jacques Nyst, Nil Yalter, Shigeko Kubota, Kuntrel Thierry, Mariejo Lafontaine, Lea Lublin, Pierrick Sorin, Idea General, Fischli e Weiis, Bruch Vom, Robert Cahen, Robert Smithson, Steina Vsulka, Robert Fillou, Jacques Monory e Hans Richter. Bill Viola, um dos artistas mais reconhecidos na atualidade, considera em seus trabalhos "processos introspectivos, o eu físico e psicológico". (VENTURELLI, 2004, p.46).

José Luiz Sampaio ${ }^{97}$, afirma que na década de 1960,

(...) em eventos musicais, os artistas visuais utilizavam slides, bolas de espelhos e projeções de luzes sobre fumaça para criar ambientes e novas experiências. Em São Francisco, entre 1965 e 1966 os liquid light shows eram produzidos por coletivos de artistas visuais. Entre os vários grupos, o Joshua Light Show e o Brotherhood of Light destacam-se pelos efeitos visuais que acompanharam os concertos dos Grateful Dead. Estes efeitos visuais com luz e cor foram fortemente estimulados pela geração Beat e alimentados pela 'expansão da consciência' em volta das experiências com ácidos, próprias da época. (SAMPAIO, 2011).

No Brasil, nos anos 1970, foram realizadas algumas experimentações, intensificadas nos anos 1980. Os primeiros trabalhos experimentais com o uso do super-8 e do vídeo foram realizados por: Carlos Zilio, Nitsche, Anna Bella Geiger, Claudio Tozzi, Flávio Império, Antonio Dias, Fernando Cocchiarale, Ivens Machado, José Roberto Aguilar, Leticia Parente, Mary Dritschel, Paulo Brusky, Paulo Herkenhoff, Regina Silveira, Regina Vater, Roberto Sandoval, Sonia Andrade e outros. Para Sheila

\footnotetext{
${ }_{97}^{96}$ FISCHER, Hervé. Théorie de l'art sociologique. Paris: Casterman, 1977.

97 José Luiz Sampaio é videoartista, diretor de arte e foi professor do curso: Arte e Tecnologia: Video Mapping, realizado na Escola São Paulo, em janeiro de 2011. Ao longo do texto, serão indicadas: anotações realizadas pela pesquisadora no decorrer do curso e autores do material de apoio: POEIRA, Daniel; SANTANA, Luciano Costa Nascimento de. e WWW.PROJECTORCENTRAL.COM.
} 
Leirner, o contato mais profundo com a videoarte aconteceu em 1975, na Bienal de São Paulo. A crítica de arte, entende que a videoarte:

(...) cobre quatro interesses relacionados à principal propriedade do vídeo, o tempo. O primeiro interesse leva para uma consciência diferente do tempo, principalmente para o espectador; o segundo está voltado para a própria técnica do vídeo e suas múltiplas possibilidades de edição de imagem, que se complementa com a música; o terceiro é que o vídeo facilita a criatividade e a espontaneidade por meio de estímulos previamente registrados e da observação de eventos contínuos e, finalmente, o último interesse é a possibilidade que ele tem para a criação das instalações e dos vídeos objetos, cujo modo de apresentação pode estabelecer a simultaneidade entre o real e o seu simulacro. (LEINER, 1982, p.69 apud VENTURELLI, 2004, p.46) ${ }^{98}$.

No início das décadas de 1980 e 1990, Rafael França foi pioneiro na videoinstalação no Brasil. Otávio Donasci apresenta suas videocriaturas, atores vestidos com uma TV sobre a cabeça. O grupo Corpos Informáticos, da Universidade de Brasília, criou uma "linguagem videográfica e espetáculos-performance que implicavam em constantes reformulações que provocavam novos trabalhos e oportunidades de experimentação." (VENTURELLI, 2004, p.48-49).

Atualmente, o rápido processo de desenvolvimento tecnológico, tanto em softwares como em hardwares, juntamente com a maior acessibilidade aos equipamentos, são fatores que têm contribuído para a evolução e, consequentemente, para a prática cada vez mais frequente de videoprojeções e videoinstalações que buscam criar ambientes e proporcionar novas experiências para os usuários/espectadores do espaço urbano e do espaço institucional das galerias e museus.

Na Bienal de Veneza de 2011, por exemplo, Vesa-Pekka Rannikko e James Turrel, apresentaram trabalhos que exploravam a relação luz/espectador/obra através do uso de projeções. No Brasil, são diversas as iniciativas direcionadas a esta prática. O Museu da Imagem e do Som-MIS de São Paulo, instituição da Secretaria da Cultura do Estado, sob curadoria de Daniela Buosso, realizou a exposição Perceptum Mutantis, com obras de artistas argentinos e brasileiros patrocinada pela Fundação Telefônica, no Programa Arte e Tecnologia, apoiada pela Lei de Incentivo à Cultura. Os trabalhos exibidos foram desenvolvidos com dispositivos fílmicos e maquínicos, em diferentes níveis de interatividade: sistemas táteis, circuitos de conexão e projeções interativas que estimulavam a participação do espectador junto a máquinas de ler, ao cinema panorâmico, às videoprojeções e às videoinstalações.

\footnotetext{
${ }^{98}$ LEIRNER, Sheila. Arte como medida. São Paulo: Perspectiva, 1982.
} 
Eventos como: $11^{\circ}$ e $12^{\circ}$ Festivais Internacionais de Linguagens Eletrônicas FILEPAIs da FIESP/SESI, Rumos da Arte Cibernética do Itaú Cultural, Virada Cultural e Vídeo Guerrilha de São Paulo e VídeoAtaq do Rio de Janeiro, são exemplos significativos de aplicação de projeções em suas mais variadas formas: nos planos bidimensional e tridimensional, interativas ou não.

Na concepção estética de suas obras, Jean Nouvel também utiliza de modalidades expressivas contemporâneas provenientes das artes plásticas, da produção industrial, da ciência, do cinema e da fotografia. O arquiteto "suscita do espectador sensações buscadas no projeto através do emprego de imagens hiper-realistas" De acordo com Casamonti, artistas de "Joseph Beuys a Walter de Maria, de Donald Judd a Richard Serra, de Frederico Fellini a Win Wenders, influenciaram o seu modo de observar a realidade, restituída sempre com uma evidente insistência narrativa." (CASAMONTI, 2011, p.12-13).

\subsubsection{Modalidades de Projeção}

Além da forma tradicional da simples projeção de luz ou exibição de uma imagem, a linguagem da projeção assumiu outras modalidades contemporâneas de processos de criação e exibição: o VJing e o Video Mapping. O VJing (experiência da live image) trata-se de uma performance visual que, através de recursos tecnológicos, criação e manipulação de imagem, acontece em tempo real, de forma integrada com música ou som. Aplicado em concertos, discotecas, festivais de música, galerias e museus, muitas vezes está combinada com práticas performáticas que podem incluir músicos, atores, Vjs (video-jockeys), bailarinos.

Outros videoartistas, exploram o Video Mapping, também conhecido por 3D Mapping ou Videomapeamento Arquitetônico. Inovador e revolucionário, tem sido utilizado por $V j s$ no mapeamento de vídeo a partir da arquitetura de um local específico. Com o auxílio de softwares especiais e de projetores de alta potência é possível projetar e manipular imagens. A partir de uma imagem que será projetada, pode-se mapear pontos de luz de um ou mais projetores, tornando possível adequar imagens do conteúdo de vídeo a qualquer tipo de suporte: bi ou tridimensional. Janelas, portas, arestas, podem ser transformadas em telas de projeção. (SAMPAIO, 2011). O 
processo é "influenciado pela topografia e pelo trabalho de sonares". (ALBUQUERQUE, 2010).

Diferentemente do trabalho de projeções de imagens sintonizadas com o som de um $D J$, de acordo com Spetto, os projetos de Video Mapping apresentam uma estrutura complexa, multidisciplinar, que pode envolver, além do $\mathrm{VJ}$ : fotógrafos, arquitetos, diretores de arte e, ocasionalmente, atores e figurantes. Os projetores também são mais pesados. Assim como em um projeto arquitetônico, quanto maior a metragem quadrada da projeção, maior o custo. Quando o alvo de intervenção for um edifício ou um monumento público, faz-se necessária a autorização de autoridades, o que implica em maior complexidade e custo do projeto. No entanto, é crescente o envolvimento do poder público com esse tipo de trabalho por ser considerado uma forma de homenagear e renovar ícones do espaço público. (ALBUQUERQUE, 2010).

5.2.4.2 Ferramentas para desenvolvimento e apresentação de projetos ${ }^{99}$

Como já mencionado anteriormente, o mercado dispõe de uma diversidade de projetores, softwares e hardwares, que possibilitam e auxiliam no desenvolvimento e apresentação de projetos que façam uso de projeções.

Diante da grande variedade de projetores disponíveis, para facilitar a escolha, é necessário que sejam considerados os fatores: resolução, brilho, peso e custo. A resolução é um indicador do número de pixels que o projetor usa para criar a imagem; quanto maior o número de pixels, maior a resolução. A melhor resolução é aquela compatível com a resolução do computador que será usado. Há projetores com resoluções diferenciadas: SVGA (800x600), XGA (1024x768), WXGA (1280x800), SXGA + (1400x1050) e UXGA (1600x1200), esta última é aplicada em apresentações que exigem maiores detalhes, informações e uma ampla variedade de equipamentos de informática. Quanto ao brilho, os projetores vêm em uma ampla gama de saídas de luz, que são medidas em "ANSI lumens", ou apenas, "lumens". Quanto maior o valor de lumens, maior o brilho. No entanto, nem sempre o mais

\footnotetext{
${ }^{99}$ Por se tratar de informações técnicas muito específicas, no texto que segue, serão realizadas transcrições de trechos do material de referência.
} 
brilhante é o ideal, depende do uso pretendido. Atualmente, os projetores podem ser agrupados por ANSI lúmen de saída da seguinte forma: inferior a 2000 lumens, 2000-3000 lumens, 3000-4500 lumens e 4500-12.000 lumens ou mais. Estes últimos são usados para uma variedade de aplicações, em locais de grandes dimensões, incluindo: salas de reuniões, salas de conferência, salas de treinamento, auditórios, igrejas, shows, boates, e assim por diante. O peso é um fator importante no caso do equipamento ter que ser transportado para locais diferentes. O custo está diretamente relacionado aos fatores: resolução e brilho, quanto maiores forem, maior será o valor do equipamento (PROJECTORCENTRAL.COM, 2011). De acordo com a proporção da projeção que se pretende realizar, não é possível executá-la com projetores domésticos. Nesse caso, o custo elevado do equipamento trouxe para o mercado empresas especializadas no serviço de aluguel.

Diversos artistas fazem uso de equipamentos da empresa DLAD Lights (Dedolight Architectural and Display Lights). Especializada em instrumentos de precisão seletiva de iluminação, particularmente adequados para museus, galerias de arte, exposição de produtos, desenvolveu equipamentos especiais de projeção de imagens, luz e sombra.

Para a projeção de imagens, dispõe de sistemas que podem ser utilizados em diferentes tarefas: Steel gobo, Glass gobo (em três variações de cor), Slide projection e Invisible lighting - visible detail.

Steel gobo: existem mais de 300 padrões ready-made de luz e sombra disponíveis. Imagens em preto e branco sem escalas de cinza. Padrões customizados podem ser entregues rapidamente.

Glass gobo: preto e branco - escalas de cinza também são possíveis: disponível com padrões de alta resolução da grade.

Glass gobo: única cor - muitas vezes usado para projetar logotipos, texto ou símbolos.

Glass gobo: multicolour - usando um processo de fotolitografia, separações de cores são transferidas para quatro camadas extremamente finas de vidro, gravado e depois combinados. Em alta resolução.

Slide projection: um sistema de projeção que utiliza calor, refletindo filtros dicróicos e ventilador.

Depende da fonte de luz utilizada (saída de luz / calor). As lâminas têm uma vida útil limitada e podem ter que ser trocadas ocasionalmente. A vida de um slide também depende de sua densidade / transmissão e as cores predominantes.

Invisible lighting - visible detail: por exemplo, uma estátua de free-standing pode ser iluminada com quatro fontes de luz, para que a impressão ideal de 
sua plasticidade possa ser alcançada. Mesmo quando os visitantes andam completamente em torno da estátua, eles não vão tomar conhecimento de qualquer fonte de

luz. Por máscaras de sombra, que levam em consideração a colocação exata de cada fonte de luz, ângulo de incidência e de perspectiva - apenas o objeto em si será aceso sem sombras visíveis ou outros efeitos de luz. (CATÁLOGO DLAD LIGHTS, 2009, p.13, tradução nossa)

Através destes sistemas, é possível solucionar problemas de aberração cromática, halo, distorção, baixa resolução, baixo contraste e distribuição desigual de luz.

Para ocasiões em que bordas de luz e sombra devem ser fornecidas com a máxima precisão, desenvolveu obturadores com enquadramento (máscaras de sombra móveis) que permitem luz muito mais limpa e bordas de sombra ajustáveis, sem aberrações de cor, halo ou distorção. Para o ajuste perfeito da distância e tamanho do objeto com a eficiência de luz ideal, oferece projeções ópticas diferentes, incluindo lentes zoom. 
FOCUSING LIGHTS

\section{DLAD-H100}

Precision focusing light for halogen lamps

Patented Double Aspheric optical system

Extreme high focusing range

Precision beam, no stray light

Lamps:

Halogen, long-life (4000h). $3000 \mathrm{~K}$

100W/12V GY6.35 4000h 1800 lumen

$75 \mathrm{~W} / 12 \mathrm{~V}$ GY6.35 4000h 1450 lumen

$50 \mathrm{~W} / 12 \mathrm{~V}$ GY6.35 4000h 910 lumen

$35 \mathrm{~W} / 12 \mathrm{~V}$ GY6.35 4000h 600 lumen

20W/12V GY6.35 4000h 320 lumen

\section{DLAD-C35}

Precision focusing light for long-life ceramic lamp

$35 \mathrm{~W}$ ceramic lamp

available as WDL G12 - $3000 \mathrm{~K}, 3300$ lumen

available as NDL G12 -approx. 4000 K. 3100 lumen

\section{DLAD-C70}

Precision focusing light head Double Aspheric optics

For long-life ceramic lamps $70 \mathrm{~W}$

available as WDL G12-3000 K, 6700 lumen

available as NDL G12 - approx. 4000 K, 6500 lumen

\section{DLAD-C150}

Precision focusing light

For long-life ceramic lamps $150 \mathrm{~W}$

available as WDL G12 - approx. $3000 \mathrm{~K}, 14500$ lumen

available as NDL G12 - approx. $4000 \mathrm{~K}, 13700$ lumen

BA-DAY $150 \mathrm{~W}$, approx. $5600 \mathrm{~K}, 13000$ lumen
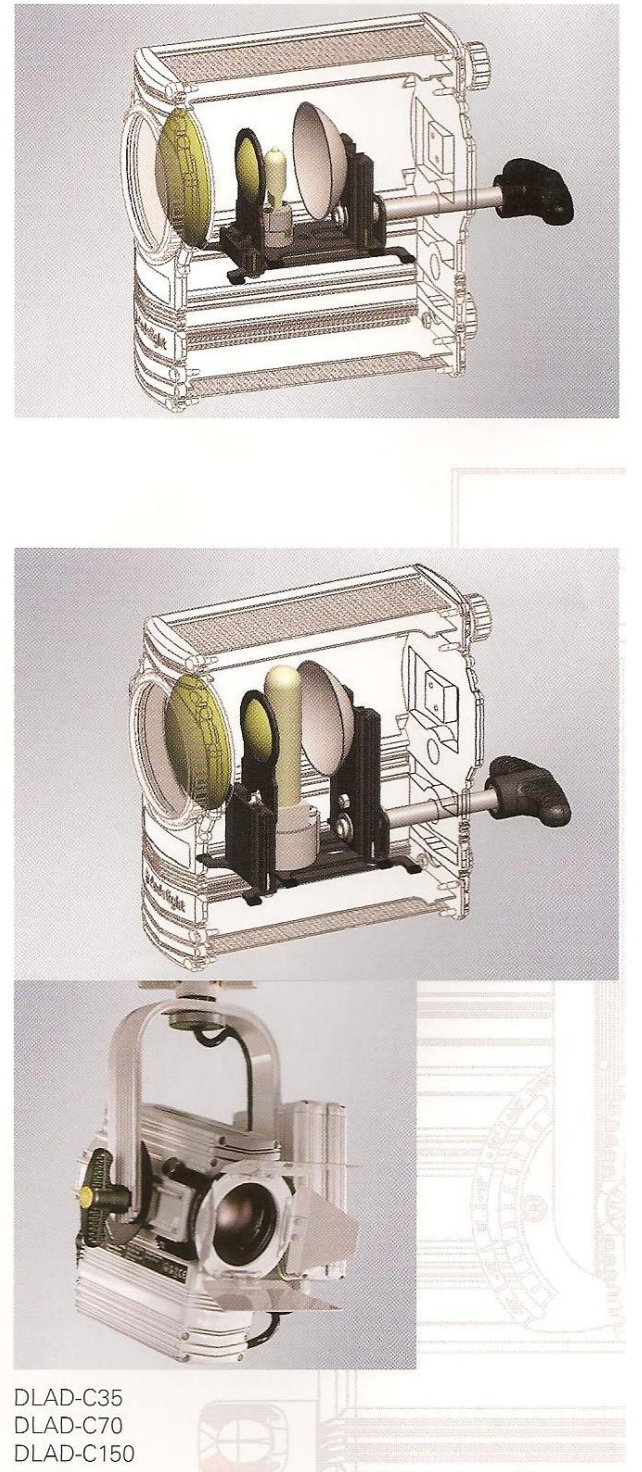

Figura 459: Projetor DLAD-H 100, DLAD-C 35/70/150. Fonte: CATÁLOGO DLAD LIGHTS, 2009 , p. 14. 

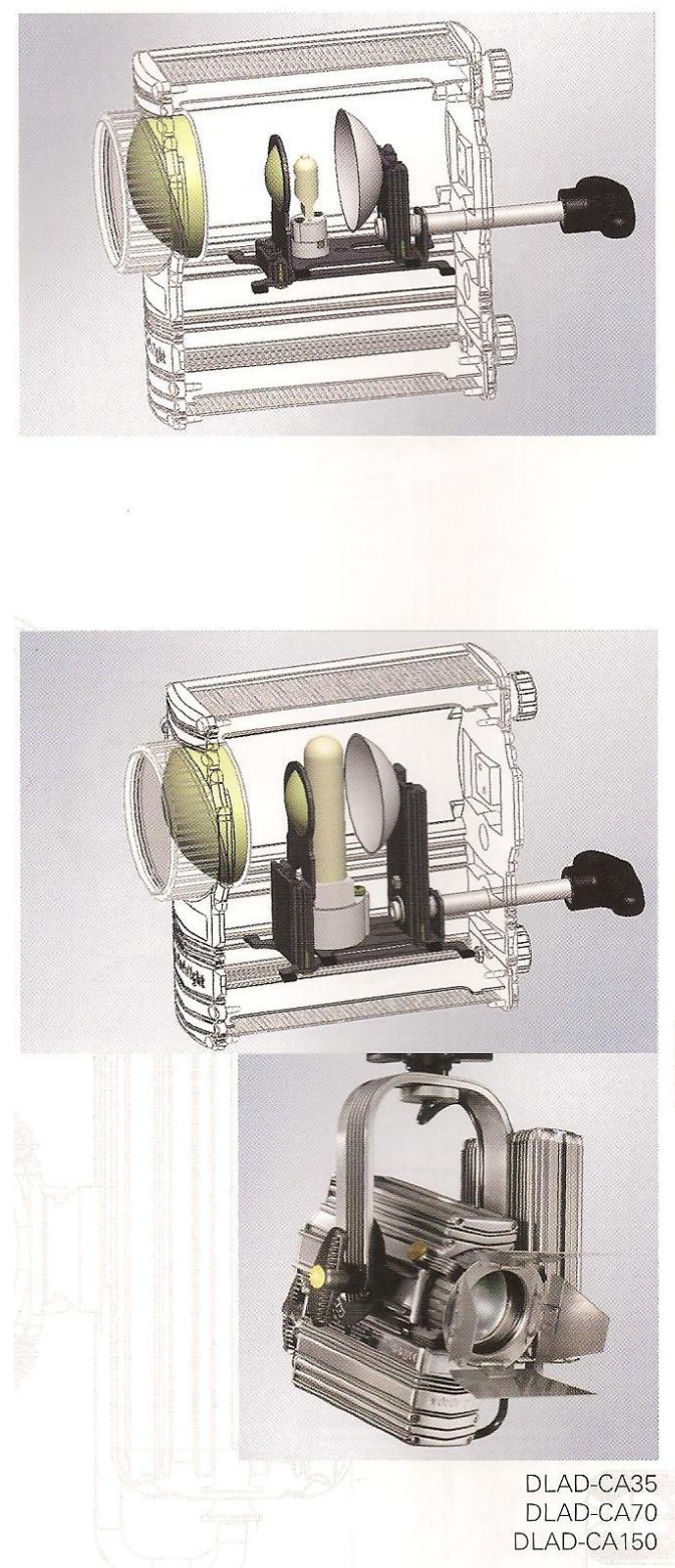

\section{DLAD-HA100}

Focusing light head

Patented Double Aspheric optics

Patented optics for asymmetric light distribution functional through entire focusing range

For halogen lamps

Lamps:

Halogen, long-life (4000h), $3000 \mathrm{~K}$

100W/12V GY6.35 4000h 1800 lumen

$75 \mathrm{~W} / 12 \mathrm{~V}$ GY6.35 4000h 1450 lumen

$50 \mathrm{~W} / 12 \mathrm{~V}$ GY6.35 4000h 910 lumen

35W/12V GY6.35 4000h 600 lumen

20W/12V GY6.35 4000h 320 lumen

\section{DLAD-CA35}

\section{Focusing light head}

Patented Double Aspheric optics

Patented optics for asymmetric light distribution

functional through entire focusing range

For ceramic lamps $35 \mathrm{~W}$

available as WDL G12 - 3000 K, 3300 lumen

available as NDL G12 - approx. 4000 K, 3100 lumen

\section{DLAD-CA70}

Focusing light head

Patented Double Aspheric optics

Patented optics for asymmetric light distribution functional through entire focusing range

For ceramic lamps $70 \mathrm{~W}$

available as WDL G12 - 3000 K, 6700 lumen

available as NDL G12 - approx. 4000 K, 6500 lumen

\section{DLAD-CA150}

Focusing light head

Patented Double Aspheric optics

Patented optics for asymmetric light distribution functional through entire focusing range

For ceramic lamps $150 \mathrm{~W}$

available as WDL G12 - approx. 3000 K, 14500 lumen available as NDL G12 - approx. 4000 K, 13700 lumen

Figura 460: Projetor DLAD-HA 100, DLAD-CA 35/70/150. Fonte: CATÁLOGO DLAD LIGHTS, 2009 , p. 15. 


\section{PROJECTION UNIVERSAL}

DEDOLIGHT ARCHITECTURAL and DISPLAY LIGHTS with combination:

- for Projection Attachment/Imager for light framing (versions $\mathrm{F}$ )

- for projections of shadow patterns from Gobo or Iris (version G - requires Gobo holder for Gobo)

\section{DLAD-HFU100}

Light head for combination with Projection Attachment/lmager

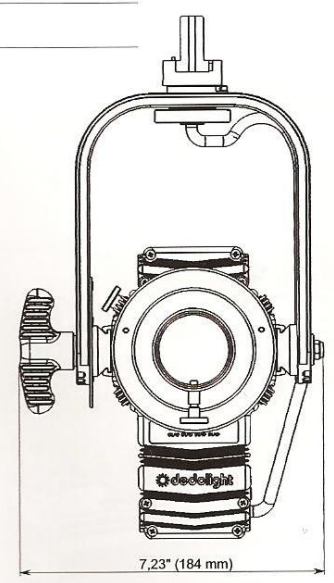

Universal version accepts all seven different lenses

Works with halogen lamps:

Halogen, long-life (4000h), $3000 \mathrm{~K}$

100W/12V GY6.35 4000h 1800 lumen

$75 \mathrm{~W} / 12 \mathrm{~V}$ GY6.35 4000h 1450 lumen

$50 \mathrm{~W} / 12 \mathrm{~V}$ GY6.35 4000h 910 lumen

$35 \mathrm{~W} / 12 \mathrm{~V}$ GY6.35 4000h 600 lumen

20W/12V GY6.35 4000h 320 lumen

This version, DLAD-HFU100, works with integrated framing shutters for light framings.

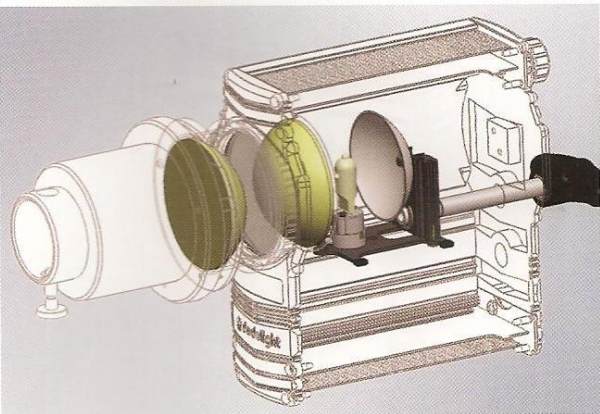

Same light in combination with Projection Attachment/ Imager but for universal receptacle for Gobos or Iris

Works with halogen lamps:

Halogen, long-life (4000h), $3000 \mathrm{~K}$

$100 \mathrm{~W} / 12 \mathrm{~V}$ GY6.35 4000h 1800 lumen

$75 \mathrm{~W} / 12 \mathrm{~V}$ GY6.35 4000h 1450 lumen

$50 \mathrm{~W} / 12 \mathrm{~V}$ GY6.35 4000h 910 lumen

35W/12V GY6.35 4000h 600 lumen

20W/12V GY6.35 4000h 320 lumen
DLAD-HFU100 DLAD-HGU100

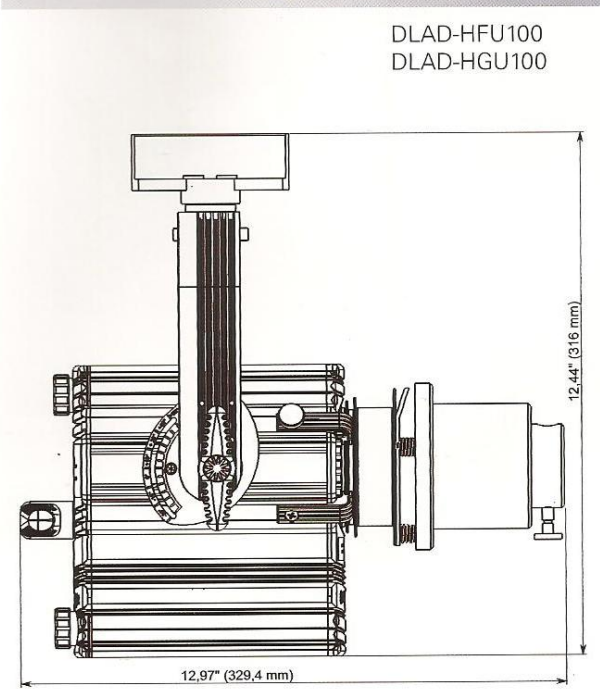

$12,97^{(}(329,4 \mathrm{~mm})$

See page 20 for interchangeable lenses for projection attachment/imager

Figura 461: DLAD-HFU 100 e DLAD-HGU 100. Fonte: CATÁLOGO DLAD LIGHTS, 2009, p. 16. 


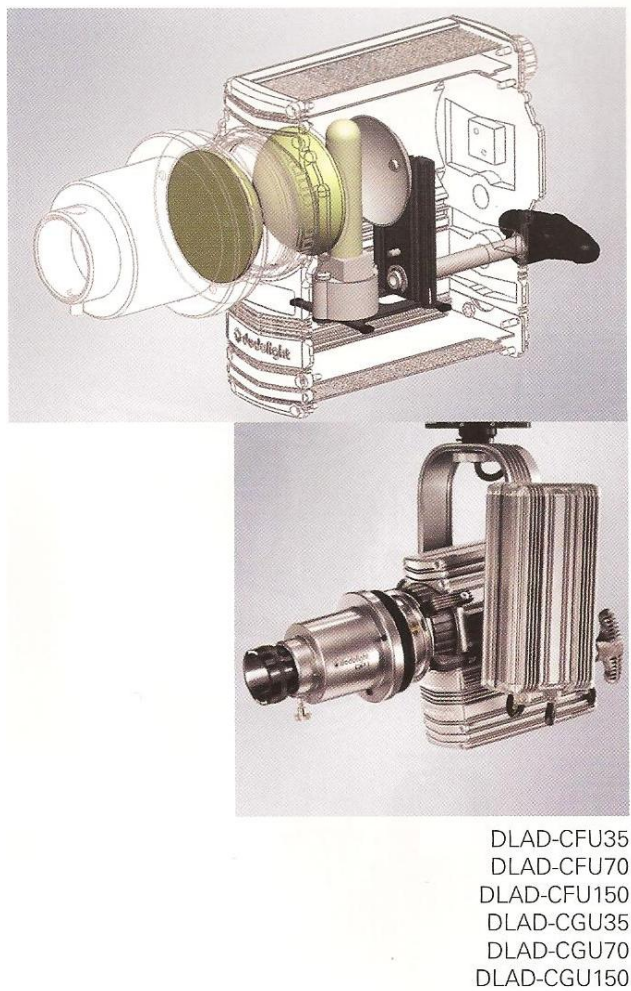

\section{DLAD-CGU150}

Light head for combination with Projection Attachment/ Imager with receptacle for Gobos and Iris and framing shutters for light framings

For ceramic lamps $150 \mathrm{~W}$

available as WDL G12 - approx. 3000 K, 14500 lumen available as NDL G12 - approx. 4000 K, 13700 lumen BA-DAY 150W, approx. $5600 \mathrm{~K}, 13000$ lumen

\section{DLAD-CFU35}

Light head for combination with Projection Attachment/ Imager for shadow projection and shaping

For ceramic lamp $35 \mathrm{~W}$

available as WDL G12 - 3000 K, 3300 lumen

available as NDL G12 - approx. 4000 K, 3100 lumen

\section{DLAD-CFU70}

Light head for combination with Projection Attachment Imager

For ceramic lamps $70 \mathrm{~W}$

available as WDL G12-3000 K, 6700 lumen

available as NDL G12 - approx. 4000 K, 6500 lumen

\section{DLAD-CFU150}

Light head for combination with Projection Attachment/ Imager with framing shutters for light framings

For ceramic lamps $150 \mathrm{~W}$

available as WDL G12 - approx 3000 K 14500 lumen available as NDL G12 - approx. 4000 K, 13700 lumen BA-DAY 150W, approx. $5600 \mathrm{~K}, 13000$ lumen

\section{DLAD-CGU35}

Light head for combination with Projection Attachment/ Imager with receptacle for Gobos and Iris

For ceramic lamp $35 \mathrm{~W}$

available as WDL G12 - 3000 K, 3300 lumen

available as NDL G12 - approx. 4000 K, 3100 lumen

\section{DLAD-CGU70}

Light head for combination with Projection Attachment/ Imager with receptacle for Gobos and Iris

For ceramic lamps $70 \mathrm{~W}$

available as WDL G12 - $3000 \mathrm{~K}$, 6700 lumen

available as NDL G12 - approx. 4000 K, 6500 lumen

BA-DAY $150 \mathrm{~W}$, approx. $5600 \mathrm{~K}, 13000$ lumen

Figura 462: Projetor DLAD-HFW 100 e DLAD-HGW 100. Fonte: CATÁLOGO DLAD LIGHTS, 2009, p. 18. 
PROJECTION HALOGEN HIGH OUTPUT

\section{HALOGEN LIGHTS 12V}

For combination with Projection Attachment/Imager

Highest light efficiency by use of deep reflector

Patented double sided Aspheric lens system

\section{DLAD-HFW100}

Built-in framing shutters for light framing

Works with wide-angle lenses $50 \mathrm{~mm}, 60 \mathrm{~mm}, 85 \mathrm{~mm}$ as well as zoom lenses $70-120 \mathrm{~mm}$ and $85-150 \mathrm{~mm}$

Works with halogen lamps:

Halogen, long-life (4000h), $3000 \mathrm{~K}$

100W/12V GY6.35 4000h 1800 lumen

$75 \mathrm{~W} / 12 \mathrm{~V}$ GY6.35 4000h 1450 lumen

$50 \mathrm{~W} / 12 \mathrm{~V}$ GY6.35 4000h 910 lumen

$35 \mathrm{~W} / 12 \mathrm{~V}$ GY6.35 4000h 600 lumen

20W/12V GY6.35 4000h 320 lumen

\section{DLAD-HGW100}

Built-in gobo slot for light framing

Works with wide-angle lenses $50 \mathrm{~mm}, 60 \mathrm{~mm}, 85 \mathrm{~mm}$

Will also work with zoom lenses $70-120 \mathrm{~mm}$ and

85-150mm

With Projection Attachment/ Imager for use with Gobos or Iris

Works with halogen lamps:

Halogen, long-life (4000h), $3000 \mathrm{~K}$

100W/12V GY6.35 4000h 1800 lumen

$75 \mathrm{~W} / 12 \mathrm{~V}$ GY6.35 $4000 \mathrm{~h} 1450$ lumen

$50 \mathrm{~W} / 12 \mathrm{~V}$ GY6.35 4000h 910 lumen

$35 \mathrm{~W} / 12 \mathrm{~V}$ GY6.35 4000h 600 lumen

20W/12V GY6.35 4000h 320 lumen
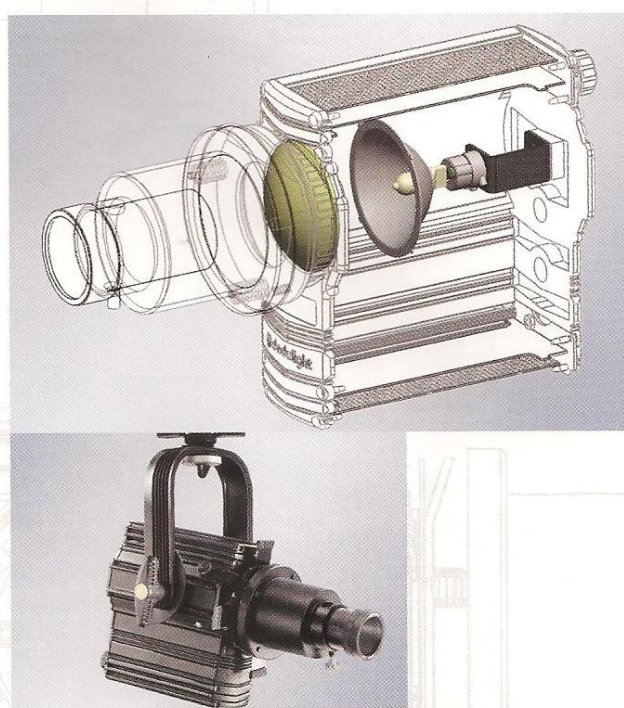

DLAD-HFW100

DLAD-HGW100

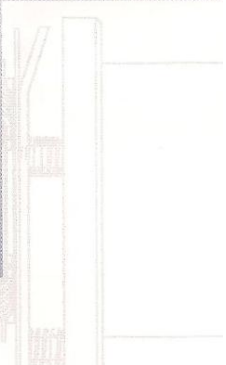

See page 20 for interchangeable lenses for projection attachment/image

Figura 463: Projetor DLAD-HFW 100 e DLAD-HGW 100. Fonte: CATÁLOGO DLAD LIGHTS, 2009, p. 18. 


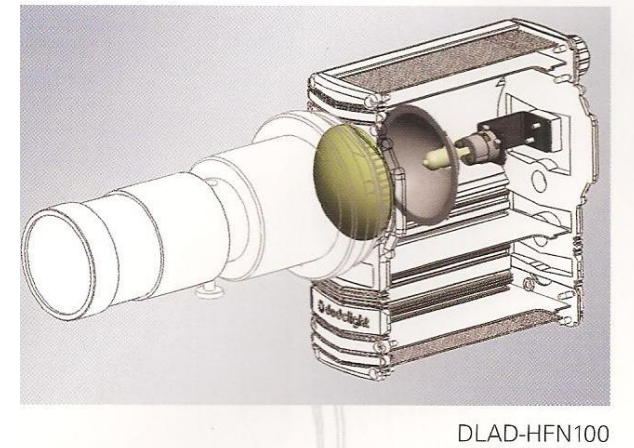

DLAD-HGN100

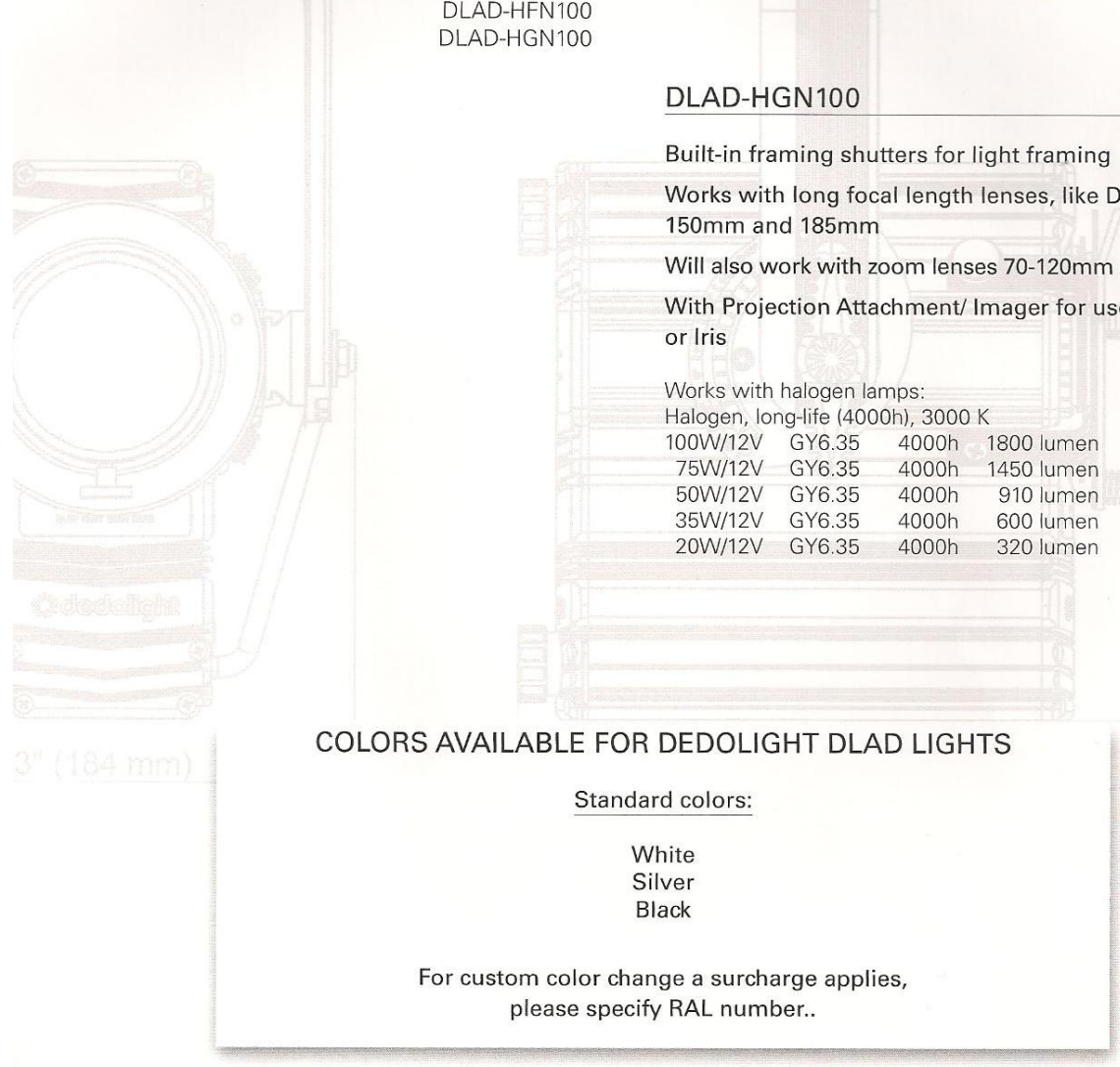

* See page 20 for interchangeable lenses for projection attachment/imager

Built-in framing shutters for light framing

Works with long focal length lenses, like Dedolight

lens $150 \mathrm{~mm}$ and $185 \mathrm{~mm}$

Also works with zoom lenses $70-120 \mathrm{~mm}$ and

$85-150 \mathrm{~mm}$

Works with halogen lamps:

Halogen, long-life (4000h), $3000 \mathrm{~K}$

100W/12V GY6.35 4000h 1800 lumen

$75 \mathrm{~W} / 12 \mathrm{~V}$ GY6.35 4000h 1450 lumen

$50 \mathrm{~W} / 12 \mathrm{~V}$ GY6.35 4000h 910 lumen

$35 \mathrm{~W} / 12 \mathrm{~V}$ GY6.35 $4000 \mathrm{~h} 600$ lumen

\begin{tabular}{ll|ll}
$35 \mathrm{~W} / 12 \mathrm{~V}$ & $\mathrm{GY} 6.35$ & $4000 \mathrm{~h}$ & 600 lumen \\
$20 \mathrm{~W} / 12 \mathrm{~V}$ & $\mathrm{GY} 6.35$ & $4000 \mathrm{~h}$ & 320 lumen
\end{tabular}

\section{DLAD-HGN10}

Works with long focal length lenses, like Dedolight lens $150 \mathrm{~mm}$ and $185 \mathrm{~mm}$

列 $85-150 \mathrm{~mm}$

Works with halogen lamps:

H/12V GY6.35 - 4000h 1800 lumen

(1450lumen

75W/10 lumen

5W/12V GY6.35 4000h 600 lume

OW/12V GY6.35 4000h 320 lumen

\section{COLORS AVAILABLE FOR DEDOLIGHT DLAD LIGHTS}

White

Black

please specify RAL number.

\section{DLAD-HFN100}

Figura 464: Projetor DLAD-HFN 100 e DLAD-HGN 100. Fonte: CATÁLOGO DLAD LIGHTS, 2009, p. 19. 


\section{INTERCHANGEABLE LENSES}

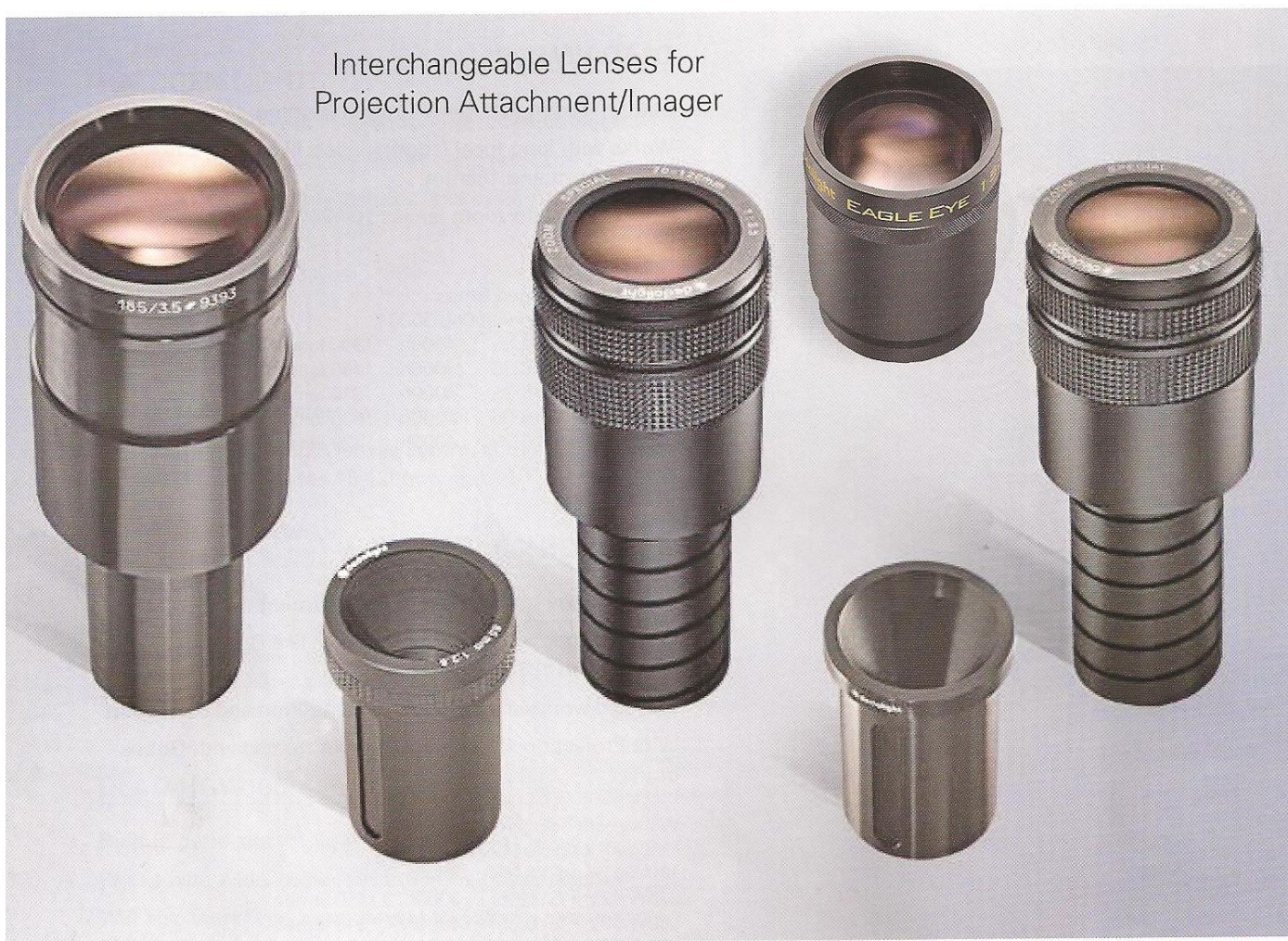

DPL50M

$50 \mathrm{~mm}$ lens f 2.8

DPL60M

$60 \mathrm{~mm}$ lens $\mathrm{f} 2.4$

DPL85M

$85 \mathrm{~mm}$ lens $\mathrm{f} 2.8$

DPL150M

$150 \mathrm{~mm}$ lens eagle eye $\mathrm{f} 2.2$

\section{D185M}

$185 \mathrm{~mm}$ lens $\mathrm{f} 3.5$

\section{DLZ120M}

70-120mm zoom lens f3.5

DPLZ150M

85-150mm zoom lens f3.5

Figura 465: Lentes DPL50M/60M/85M/150M, D185M, DLZ120M/150M. Fonte: CATÁLOGO DLAD LIGHTS, 2009, p. 20. 


\section{ACCESSORIES}

\section{DBD-8 / DBD-8W}

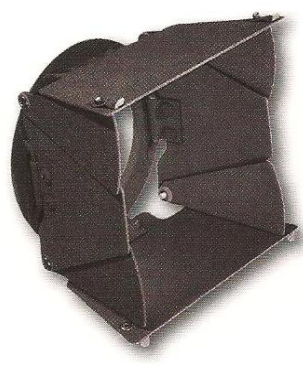

8-leaf barn door

Small leaves have two helper leaves to eliminate unwanted light exit

\section{DBD 2}
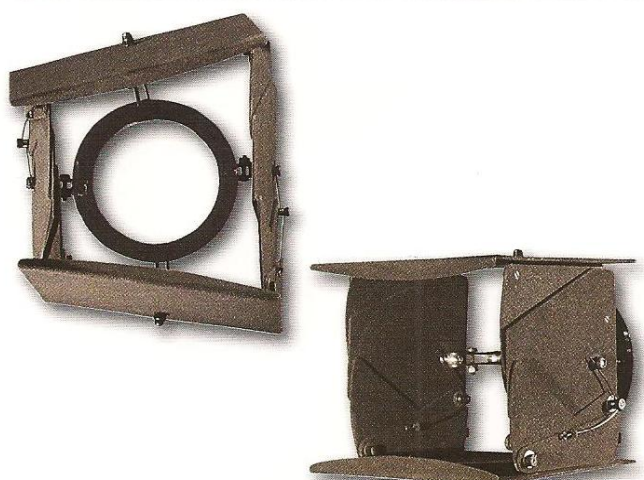

Super museum barn door

A 12-leaf barn door designed for precision work. A unique patented system, which allows individual rotation of each main leaf to create trapezoidal shapes when lighting rectangular objects from off-axis angle. Both smaller leaves are fitted with four spring-loaded helper leaves to make sure that no unwanted light escapes.

\section{DLWA / DLWAW}
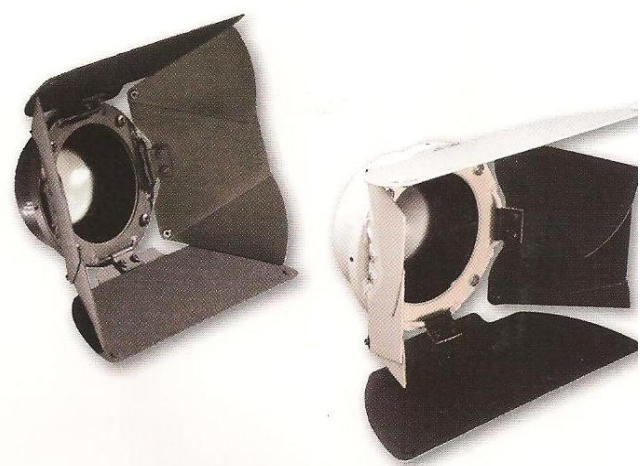

Optical wide-angle attachment with special negative lens - widens exit angle to maximum - with integrated 8-leaf barn door for precision control

\section{DGRADF 0.3 \\ DGRADF 0.6 \\ DGRADF 0.9}

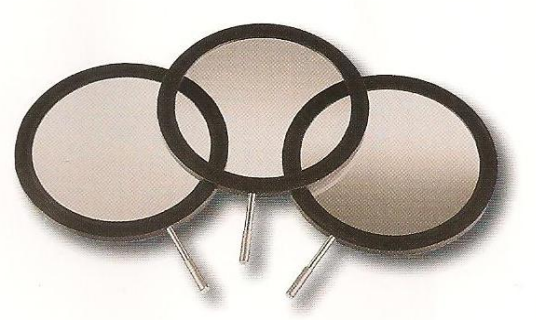

Graduated neutral grey glass filters with dichroic coating Soft edge transition from clear glass to neutral grey

Available in three densities:

ND03 - transition at densest part 50 percent

ND06 - transition at densest part 25 percent

ND09 - transition at densest part 12.5 percent

Great help in smoothing light distribution when lighting from an angle.

Figura 466: Acessórios. Fonte: CATÁLOGO DLAD LIGHTS, 2009, p. 22. 
DFCOL-2

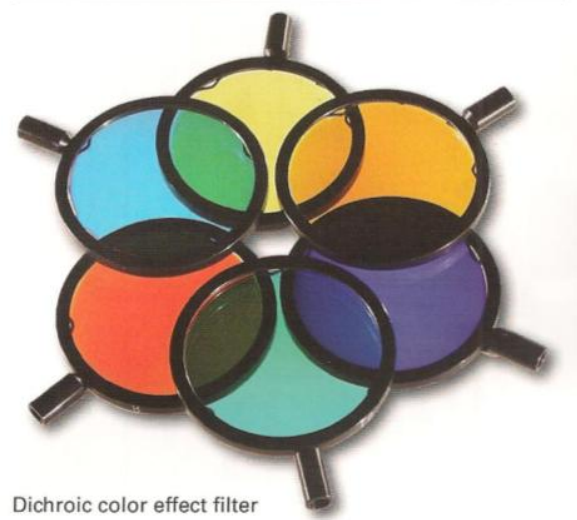

Available in the following colors:

Red

Red Magenta

Full Orange

Yellow Orange

Yellow

Light Green

Full Green

Turquoise

Medium Blue

Purple

$$
\begin{aligned}
& \text { DFCOL2R } \\
& \text { DFCOL2RM } \\
& \text { DFCOL2FO } \\
& \text { DFCOL2O } \\
& \text { DFCOL2Y } \\
& \text { DFCOL2LG } \\
& \text { DFCOL2FG } \\
& \text { DFCOL2T } \\
& \text { DFCOL2LB } \\
& \text { DFCOL2MB } \\
& \text { DFCOL2P }
\end{aligned}
$$

DPGH

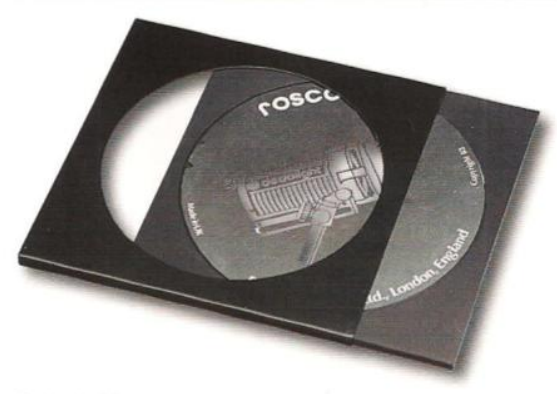

Gobo holder
DPGGH

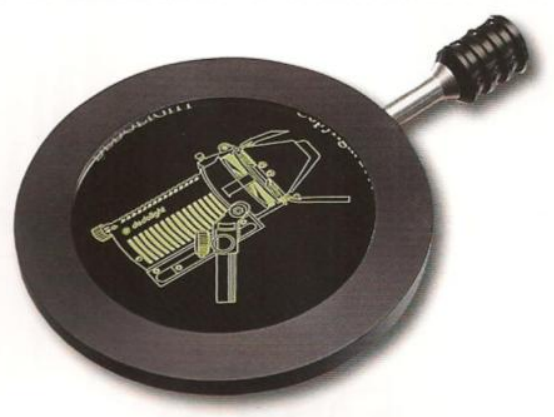

Glass Gobo holder for size M Gobos

DPG

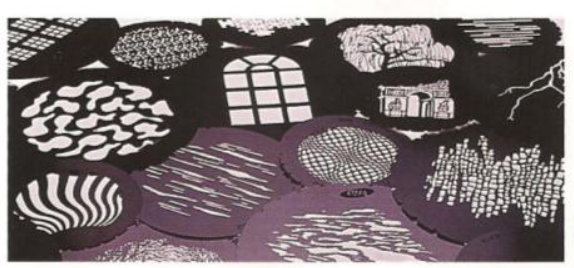

Steel Gobo size M

DPIR

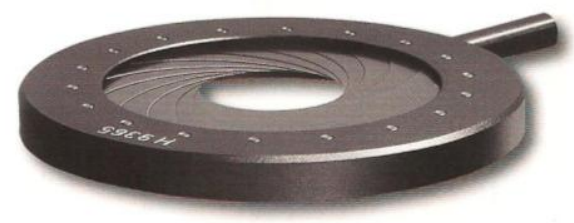

Full metal Iris, allowing the creation of almost perfectly round images and varying sizes
18 leaves

Figura 467: Acessórios. Fonte: CATÁLOGO DLAD LIGHTS, 2009, p. 23. 
No caso de exibição de projeções em lugares mais amplos, a Barco é um exemplo de empresa de tecnologia global, que projeta e desenvolve soluções de visualização para uma variedade de mercados profissionais, dentre eles: mídia e entretenimento, infraestrutura e serviços públicos de trânsito, transporte e defesa, segurança e educação. Dispõe de uma variedade de hardwares e softwares que podem ser usados de maneira integrada, no entanto, serão apresentados apenas exemplos de projetores de maior alcance. (BARCO.COM, 2011, p.24).

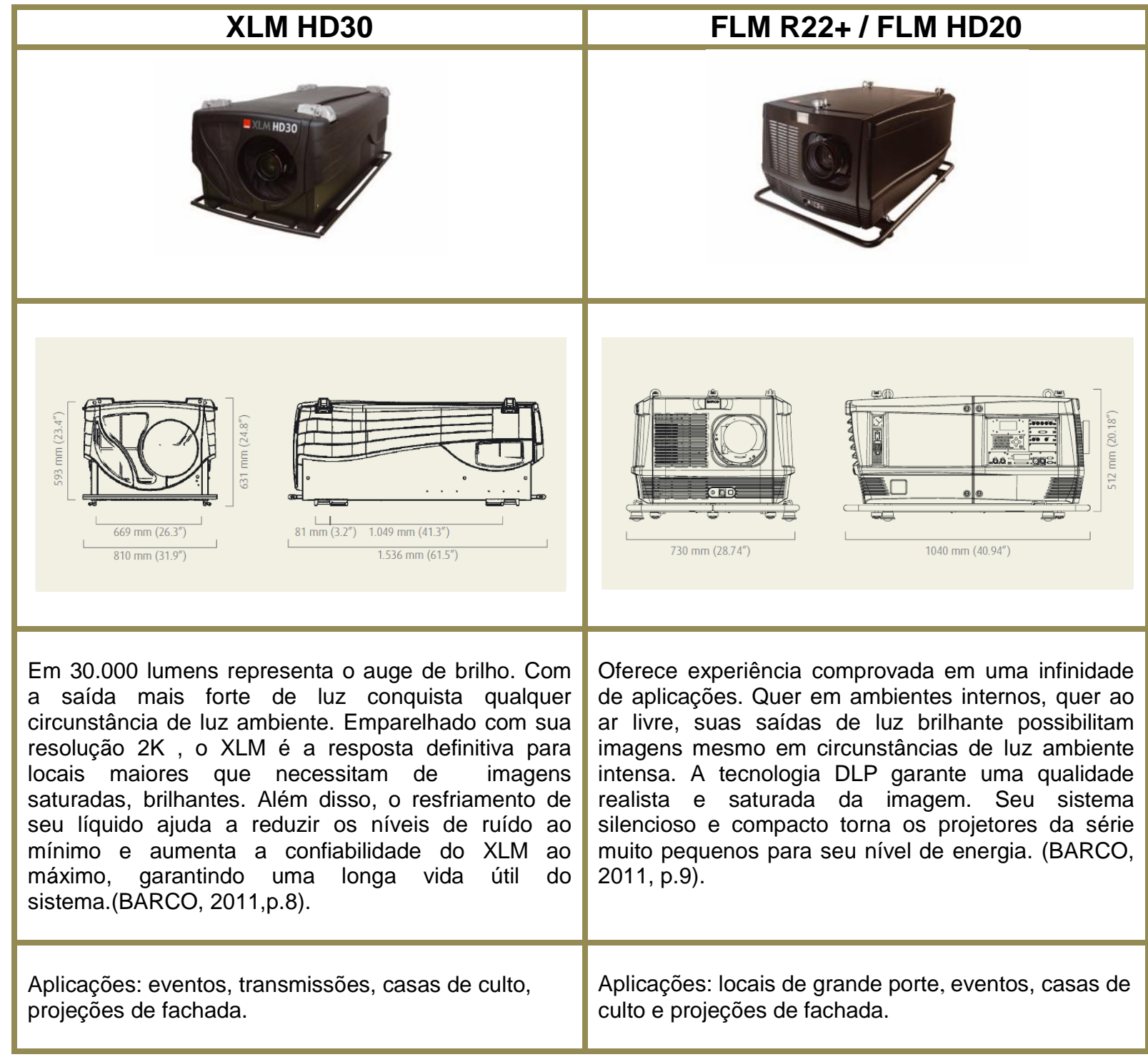

Figura 468: $\quad$ Projetor $\quad$ Barco $\quad$ XLM $\quad$ FD30. <http://www.barco.com/downloads/media_entertainment/Catalogs/Proj-IP_Product_Catalog.pdf>, p.8. Acesso em 01/10/2011.

Figura 469: Projetor Barco FLM R22+ / FLM HD20. Fonte: <http://www.barco.com/downloads/media_entertainment/Catalogs/Proj-IP_Product_Catalog.pdf, p.9>. Acesso em 01/10/2011. 


\begin{tabular}{|c|c|c|c|c|}
\hline & \\
\hline & & XLM HD30 & FLM R22+ & FLM HD2O \\
\hline \multirow{9}{*}{$\frac{\frac{\pi}{6}}{\frac{5}{b}}$} & Projector type & HD 3-chip DLP digital projector & SXGA+ 3-chip OLP digital projector & HD 3-chip DLP digital projector \\
\hline & Technology & $1.2^{\prime \prime} \mathrm{DMD}^{\mathrm{m}} \times 3$ & $0.95^{\prime \prime}$ DMD ${ }^{m} \times 3$ & $0.95^{\prime \prime} \mathrm{DMD}^{\mathrm{mm}} \times 3$ \\
\hline & Resolution (pixels) & $2,048 \times 1,080$ & $1,400 \times 1,050$ & $1,920 \times 1,080$ \\
\hline & Brightness • center lumens & 32,000 & 22,000 & 20,000 \\
\hline & - ANSI lumens & 30,000 & 21,000 & 19,000 \\
\hline & Contrast ratio (normal) & $2,000-2,800: 1$ (full field) & $1,700-2,200: 1$ (full field) & $2,100-2,700: 1$ (full field) \\
\hline & Brightness uniformity & $80 \%$ & $90 \%$ & $90 \%$ \\
\hline & Aspect ratio & $16: 9$ & $4: 3$ & $16: 9$ \\
\hline & Edge blending/warping & $\begin{array}{c}\text { horizontal and vertical edge } \\
\text { blending }\end{array}$ & $\begin{array}{c}\text { horizontal and vertical edge } \\
\text { blending }\end{array}$ & $\begin{array}{c}\text { horizontal and vertical edge } \\
\text { blending }\end{array}$ \\
\hline \multirow{5}{*}{$\begin{array}{l}\frac{3}{3} \\
\frac{8}{3} \\
\frac{10}{6}\end{array}$} & Lenses range & $\begin{array}{c}1: 1 ; 1.45-1.8: 1 ; 1.8-2.4: 1 ; \\
2.2-3.0: 1 ; 2.8-5.5: 1 ; 5.5-8.5: 1\end{array}$ & $\begin{array}{c}0.73: 1 ; 1.2: 1 ; 1,25-1.6: 1 ; \\
1.5-2.0: 1 ; 2.0-2.8: 1 ; 2.8-4.5: 1 \\
\quad 4.5-7.5: ; 7.5-11.2: 1^{\text {mitas }}\end{array}$ & $\begin{array}{c}0.73: 1 ; 1.2: 1 ; 1,25-1.6: 1 \\
1.5-2.0: 1 ; 2.0-2.8: 1 ; 2.8-4.5: 1 \\
4.5-7.5: ; 7.5-11.2: 1^{* n+\infty}\end{array}$ \\
\hline & Optical lens shift & $\begin{array}{c}\text { Vert }-10 \%+110 \% ; \text { Hor }+/-50 \% \text { on } \\
\text { zoom lenses }\end{array}$ & $\begin{array}{c}\text { Vert }-10 \%+110 \% \text {; Hor }+/-50 \% \text { on } \\
\text { zoom lenses }\end{array}$ & $\begin{array}{c}\text { Vert }-10 \%+110 \% ; \text { Hor }+/-30 \% \text { on } \\
\text { zoom lenses }\end{array}$ \\
\hline & Color correction & P7 & P7 & P7 \\
\hline & Lamps & $6.3 \mathrm{~kW}$ Xenon & $3 \mathrm{kw}$ Xenon & $3 \mathrm{~kW}$ Xenon \\
\hline & Lamp life (typical/maximum) & $1,000 \mathrm{Hrs}$ & $1,000 \mathrm{Hrs}$ & $1,000 \mathrm{Hrs}$ \\
\hline \multirow{5}{*}{ 约 } & Sealed DLP core & Standard & Standard & Standard \\
\hline & Optical dowser & Standard & Standard & Standard \\
\hline & Advanced Picture in Picture & Four sources simultaneously & Two sources simultaneously & Two sources simultaneously \\
\hline & Orientation & $\begin{array}{l}\text { table/ceiling/side (portrait)" } \\
\text { vertical }\end{array}$ & $\begin{array}{l}\text { table/ceiling/side (portrait)" } \\
\text { vertical }\end{array}$ & $\begin{array}{l}\text { table/ceiling/side (portrait)" } \\
\text { vertical }\end{array}$ \\
\hline & others & $\begin{array}{l}\text { Can be controlled by DMX512 } \\
\text { console (optional). } \\
30 \text { optional }\end{array}$ & $\begin{array}{c}\text { Can be controlled by DMX512 } \\
\text { console (optional), warping, } 30 \\
\text { optional }\end{array}$ & $\begin{array}{c}\text { Can be controlled by DMX512 } \\
\text { console (optionai), Warping, 3D } \\
\text { optional }\end{array}$ \\
\hline \multirow{6}{*}{$\frac{3}{8}$} & Standard inputs & $\begin{array}{c}\text { OVI; SDI/HDSDI } \\
\text { RGB; SOI; HOSOI; OVI }\end{array}$ & $\begin{array}{l}\text { DVI (HDCP); SDI/HDSDI } \\
1 \times 5 \text {-BNC (RGBHV, RGBS/RGSB) } \\
\text { Composite video; S-Video; VGA }\end{array}$ & $\begin{array}{l}\text { DVI (HOCP); SDI/HOSOI } \\
1 \times 5 \text {-BNC (RGBHV, RGBS/RGSB) } \\
\text { Composite video; S-Video }\end{array}$ \\
\hline & Optional inputs & $\mathrm{RGB} ; 2 \times \mathrm{SDI} / \mathrm{HDSDI}$, DVI & $\begin{array}{c}\text { OVI (HOCP); SOI/ HOSDI } \\
\text { 5-BNC RGBHV (RGBS/RGSB, YUV } \\
\text { CS/SOY, Composite Video, S-Video) }\end{array}$ & $\begin{array}{c}\text { DVI (HDCP); SDI/ HDSDI } \\
\text { 5-BNC RGBHV (RGBS/RGSB, YUV } \\
\text { CS/SOY, Composite Video, S-Video) }\end{array}$ \\
\hline & Input resolution & From NISC up to $2,048 \times 1,080$ & $\begin{array}{l}\text { From NISC up to UXGA }(1,600 \times \\
1,200) \text { incl. HD }(1,920 \times 1,080)\end{array}$ & $\begin{array}{l}\text { From NISC up to UXGA }(1,600 \times \\
1,200) \text { ind. HD }(1,920 \times 1,080)\end{array}$ \\
\hline & Software tools & Projection Toolset & Projection Toolset & Projection Toolset \\
\hline & Control & $X L R$ wired + IR; RS232/422 & XLR wired + IR; RS232/422 & XLR wired + IR; RS232/422 \\
\hline & Network & $2 \times 10 / 100$ Base-T, Rf- 45 connection & $10 / 100$ Base-T, RJ-45 connection & 10/100 Base-T, RJ-45 connection \\
\hline \multirow{6}{*}{ एँ } & Power consumption & $8,000 \mathrm{~W}$ & $3,500 \mathrm{~W}$ & $3,700 \mathrm{~W}$ \\
\hline & Operating noise level (typ) & $67 d B(A)$ & $56 \mathrm{~dB}(\mathrm{~A})$ & $58 \mathrm{~dB}(\mathrm{~A})$ \\
\hline & Dimensions $(W \times L \times H)$ & $810 \times 1,563 \times 631 \mathrm{~mm}$ & $707 \times 1,025 \times 548 \mathrm{~mm}$ & $707 \times 1,025 \times 548 \mathrm{~mm}$ \\
\hline & Weight & $180 \mathrm{~kg}$ & $99 \mathrm{~kg}$ & $99 \mathrm{~kg}$ \\
\hline & Certification & $\begin{array}{l}\text { Compliant with UL1950 and EN60950 } \\
\text { complies with FCC rules \& regulations, } \\
\text { part } 15 \text { Class A and CE ENS5022 Class } \\
\text { A, RoHS }\end{array}$ & $\begin{array}{l}\text { Compliant with UL1950 and EN60950 } \\
\text { complies with FCC rules \& regulations, } \\
\text { part } 15 \text { Class A and CE ENSSO22 Class } \\
\text { A, RoHS }\end{array}$ & $\begin{array}{l}\text { Compliant with UL } 1950 \text { and EN60950 } \\
\text { complies with FCC rules \& regulations, } \\
\text { part } 15 \text { Class A and CE EN55022 Class } \\
\text { A, RoHS }\end{array}$ \\
\hline & Warranty & 2 years $^{\text {sin }}$ & 2 years $^{\text {tw" }}$ & 2 years $^{\mathrm{sin}}$ \\
\hline & $\begin{array}{l}\text { sition - portrait } \\
\text { mount) }\end{array}$ & $\begin{array}{l}\text { uch as: vertical } \\
\text { (most common, either ceiling }\end{array}$ & $\begin{array}{l}\Rightarrow \quad \text { Worranty inciudes labor, ports } \\
\text { Lens throw for } S X+\text { chip }\end{array}$ & gine \\
\hline
\end{tabular}

Figura 470: Projetores Barco XLM HD30, FLM R22+ / FLM HD20. Fonte: <http://www.barco.com/downloads/media_entertainment/Catalogs/Proj-IP_Product_Catalog.pdf.>, p.12. Acesso em 01/10/2011. 
Para o trabalho de vídeo ao vivo podem ser utilizadas imagens prontas ou produzidas pelo próprio VJ. Quando se trata de material original, criado pelo próprio artista, é possível produzi-lo através do uso de um computador, uma câmera e uma parede pintada com tinta especial para Chroma-key. Outra forma de produção é através do uso de softwares de criação de gráficos. O Flash da Macromedia é um programa que possibilita a criação de animações em duas dimensões. O 3D Studio Max é uma ferramenta de criação de gráficos e animações em três dimensões, mais complexo para ser operado por envolver mais variáveis. Há também softwares denominados "eye-candies", que "geram animações que estimulam a retina, de forma que prendem a atenção como doce para uma criança - daí o nome eyecandy, que ao pé da letra seria 'doce para os olhos' ". (SANTANA, 2005, p.54).

Após a produção ou seleção de imagens prontas, parte-se para a etapa de préprodução (etapa opcional), momento em que as imagens são editadas para adequálas à performance. Dentre os softwares de edição de vídeo,

o 'Adobe Premiere Pro', para 'Windows XP' e o 'Final Cut HD', para 'Mac OS' são os mais populares. Além do básico, recortar e colar, é possível inserir caracteres, aplicar efeitos de correção de cor, brilho e contraste.

Existem ainda programas para a finalização de vídeo como o 'Adobe After Effects' e o 'Combustion', ambos disponíveis para Windows e 'Mac OS'. Com esses programas pode-se fazer manipulações mais complexas nas imagens, como animar figuras estáticas, aplicar chroma-key, efeitos mais complexos de cor e distorção, criar composições em um só quadro, efeitos de iluminação, entre outros. (SANTANA, 2005, p.55-56).

Para a manipulação de vídeo ao vivo há uma série de interfaces baseadas em softwares e em hardwares. As baseadas em softwares são compostas por computador (preferencialmente portátil), software para VJing e controladores $M I D I^{100}$.

\footnotetext{
O computador deve ter capacidade de processamento e memória suficiente para rodar o software escolhido, os números variam com o software. Porém, é imprescindível que a placa de vídeo do computador tenha duas saídas de vídeo, de forma que no monitor do computador seja visualizada a interface de manipulação do software e que na segunda saída seja enviada a imagem desejada. (...) Alguns softwares para Vjs já possuem um controlador MIDI próprio, como é o caso do Resolume. A última versão do software Arkaos, a $3.5 \mathrm{DMX}$, permite que o software se comunique com

${ }^{100}$ Segundo Santana, "MIDI é uma sigla para Musical Instrument Digital Interface. Trata-se de uma tecnologia de comunicação entre um computador e uma interface de controle, que no caso o VJ permite que a imagem seja 'tocada' e manipulada com um instrumento musical digital. Existem controladores MIDI com teclas de piano, com botões giratórios ou deslizantes e até na forma de um toca-discos. O design varia de acordo com a intenção de aplicação e com o software para o qual a interface foi desenhada. Para utilizar a interface MIDI o usuário deve conectá-la no computador e configurar o software para que ele responda da forma desejada ao acionamento de cada botão."(SANTANA, 2005, p.58).
} 
qualquer mesa de controle de iluminação baseada na tecnologia DMX. Assim, o VJ conecta o seu computador à mesa de iluminação DMX por uma porta MIDI, podendo disparar imagens e aplicar efeitos com a dinâmica e a lógica de um iluminador de shows; manipular simultaneamente a projeção e a iluminação em um espetáculo ou em uma festa; além de poder em um só dispositivo de controle manipular mais de um computador, que mandam sinais independente para os respectivos projetores. De qualquer forma a interface de controle ideal é subjetiva, varia com o software e com o VJ que vai utilizá-la. O importante é que os controladores MIDI proporcionam uma interação maior entre o VJ e o software, ao permitir que as imagens sejam manipuladas como um instrumento musical, dando mais agilidade e liberdade às performances ao vivo. (SANTANA, 2005, p. 57-58)

\section{O Programa Resolume, desenvolvido para Windows,}

é basicamente um mixer de vídeo, onde se cria bancos com até 25 imagens, das quais até três podem ser misturadas simultaneamente, em camadas que seguem padrões definidos de transparência ou formatos de divisão de tela. Essas imagens podem ser vídeos, arquivos em Flash ou a imagem ao vivo de uma câmera conectada ao computador. É possível aplicar um efeito ao vivo em cada imagem do banco e também até três efeitos simultâneos em toda a composição. (SANTANA, 2005, p. 58-59)

\section{O Arkaos, funciona tanto em PC quanto em Mac, além disso,}

Uma das principais vantagens do Arkaos sobre o Resolume é a possibilidade de tocar o som presente nos arquivos de vídeo, viabilizando assim uma apresentação audiovisual e não apenas uma performance de vídeo ao vivo. A interface do Arkaos é mais intuitiva que a do Resolume, se apresentando como um teclado de piano. Para cada tecla é associado um vídeo, um som ou um efeito que é disparado pelo teclado do computador ou por um teclado MIDI. Assim o Arkaos se aproxima do conceito de 'tocar' a imagem e o som digital como um instrumento musical. Outra vantagem é que não há limites de camadas e nem de efeitos simultâneos, desde que o computador tenha um bom processador e bastante memória. (SANTANA, 2005, p. 59-60).

Apesar de todas as vantagens do uso de softwares na manipulação de vídeos, ainda há profissionais que optam pela manipulação baseada em hardwares como: mixer, câmera de vídeo, videocassete, DVD e outros aparelhos. Ao contrário dos softwares, que têm custo relativamente baixo para um resultado satisfatório, os hardwares são mais caros. No entanto, há uma questão importante a ser considerada:

a maior parte dos softwares para Vjs trabalha com vídeos comprimidos ou em baixa resolução, o que melhora o desempenho dos programas, mas compromete a qualidade. Já os sistemas baseados em hardware não têm perda de qualidade nenhuma. (...) O cérebro desses sistemas é o mixer ou switcher, que vai permitir que as imagens de diversas fontes sejam misturadas. O mixer Edirol V4, por exemplo, foi desenvolvido especialmente para Vjs, trazendo além das funções básicas de corte, efeitos digitais 
aplicados em tempo real, a possibilidade de fazer samples de vídeo em tempo real, possui um tamanho compacto e uma boa relação custo/benefício se comparado a outros mixers de vídeo. O tocador de DVD DVJX-1 da Pioneer é o sonho de consumo de muitos Vjs. Esse aparelho foi desenvolvido especialmente para performances audiovisuais ao vivo, permitindo que se toque a imagem e o som de DVDs, que seja manipulada a velocidade, que seja feito scratches, loops e samples ao vivo, entre outras funções. O Kaos Pad da Korg, é um processador de efeitos digitais de imagem e som. São 100 efeitos de imagem e 100 efeitos de som que podem ser aplicados em qualquer fonte audiovisual em tempo real, sendo possível manipular os parâmetros que geram o efeito para conseguir resultados diferenciados. Há ainda a possibilidade de conectar câmeras de vídeo ao mixer, o que agrada ao público que gosta de se ver nas telas e ainda permite a criação de imagens ao vivo. (SANTANA, 2005, p. 60-61).

$\mathrm{Na}$ edição e processamento de vídeo digital para a técnica de Video Mapping, é fundamental que o profissional tenha familiaridade com os softwares: Adobe After Effects e Modul8 e com o codec: Quicktime. Os programas gráficos: Adobe Photoshop, Autocad, Adobe Illustrator, Corel Draw, também são muito úteis. ${ }^{101}$ O programa Sony Vegas, assim como o After Effects, é um software de edição e processamento de vídeo digital que já traz em si opções e presets que facilitam a criação e a manipulação de vídeo digital nos mais variados formatos e sistemas de cor. No processo de composição do After Effects, é possível definir altura e largura do vídeo e a ordem das linhas (POEIRA, 2007, p.12). O Modul8 é um software desenvolvido para o desempenho e vídeo em tempo real. É uma ferramenta extremamente ágil, flexível e fácil de usar. (MODUL8.CH, 2011).

\subsubsection{Exemplos de aplicação}

Ainda na década de 1960, os artistas plásticos Claudio Tozzi e Ubirajara Ribeiro, apresentaram o projeto de ambientação: Passagem, criado para uma passagem de pedestres localizada na Rua da Consolação com a Av. Paulista, em São Paulo. Como visto no Capítulo 4, o trabalho pretendia trazer para o suporte da intervenção, a reprodução de imagens dos transeuntes. Com o objetivo de causar o efeito de multiplicação de imagens e do próprio espaço urbano, propunha a aplicação de

\footnotetext{
${ }^{101}$ Informações anotadas pela pesquisadora no decorrer do curso: Arte e Tecnologia: Video Mapping, realizado por José Luiz Sampaio, na Escola São Paulo, em janeiro de 2011.
} 
material reflexivo e de projeção de luzes coloridas que intensificariam tal efeito. Nas palavras de Ubirajara Ribeiro:

A formulação do projeto é levar para as paredes os mesmos elementos que se encontram em trânsito, criando com o uso de material reflexivo uma multiplicação de imagens e de espaço, fundindo o real com o irreal, cujo efeito será reforçado pela iluminação colorida. Dando um ar de espetáculo, de vitrine.

Poderia se pensar num recurso também apropriado - um labirinto - onde os passantes a cada vez tentariam alcançar a saída, quebrando a monotonia desse frio passar. (WILKE, 1976).

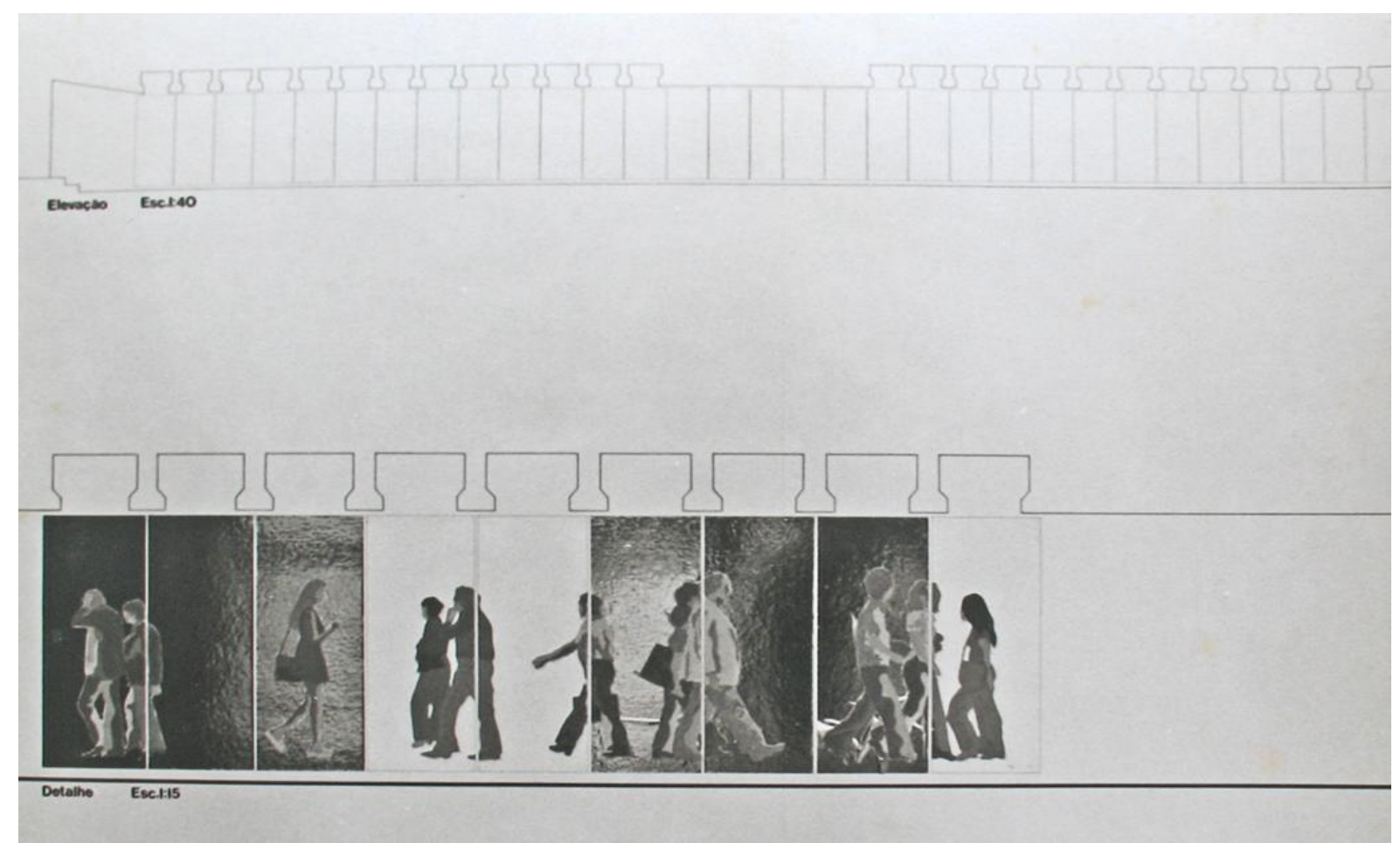

Figura 471: Projeto da intervenção Passagem, de Claudio Tozzi e Ubirajara Ribeiro. Fonte: WILKE, 1976.

Vesa-Pekka Rannikko criou uma série de obras site-specific que "ofuscam as fronteiras entre espectador habitual, obras de arte e espaço." O ponto de partida de seu projeto, desenvolvido para a Bienal, foi o Pavilhão Finlandês ${ }^{102}$. O artista explora a própria arquitetura a partir da fachada ao propor uma construção nova, que coloca para trás o edifício original, fazendo com que aquela estrutura familiar passasse a ser vista de uma outra maneira. No espaço interno, foram projetados três vídeos, imagens em três camadas, em que o artista comenta a sua própria obra e métodos. A disposição das projeções dão ao espectador a ilusão de perspectiva. Na parede,

\footnotetext{
102 O Pavilhão foi desenhado por Alvar Aalto, em 1956. Construído em madeira, no Giardini, para a exposição de finlandeses, foi concebido para ser uma estrutura temporária. Devido aos elogios e atenção recebidos permanece no local há mais de 50 anos.
} 
que serve de suporte para as projeções, há a ideia de uma exposição fictícia de quadros. A sala é como se fosse uma falsa estrutura: "uma fase que se define ao longo do tempo com a mudança de seu conteúdo" (CATALOGHI BIENNALE DI VENEZIA, 2011, p.410, tradução nossa). Rannikko trabalha "subvertendo as regras da perspectiva, explorando a fronteira entre bidimensional e tridimensional, transformando imagem em objeto e o espaço de trabalho em uma imagem". (FEOLA, 2011, tradução nossa).
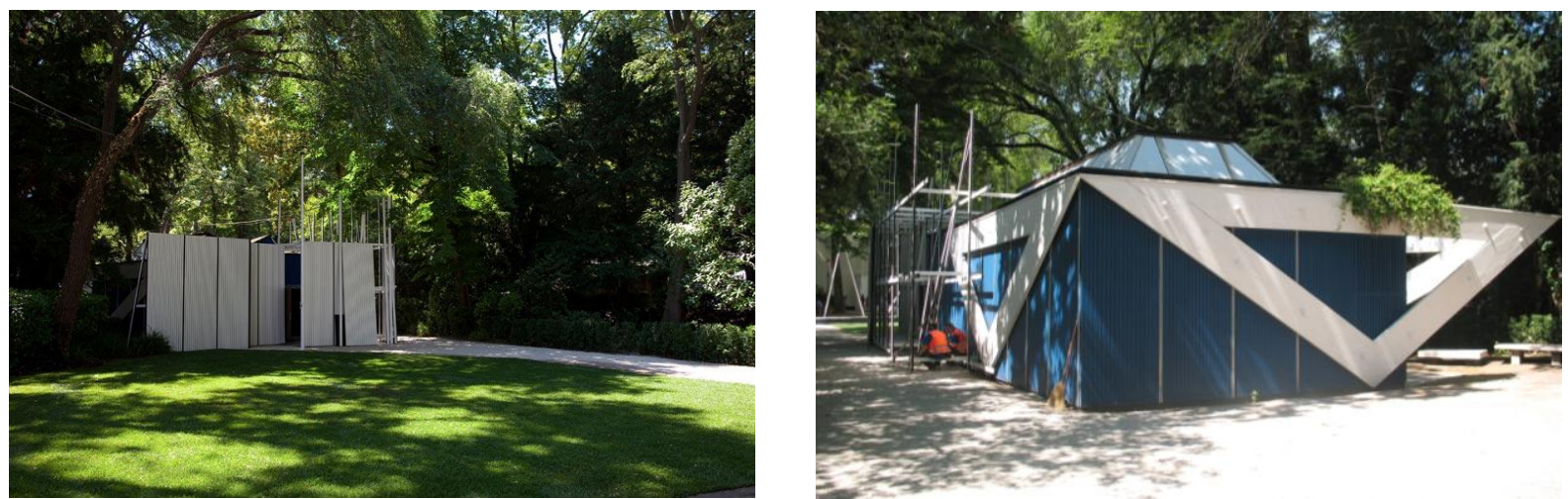

Figura 472: All Structures Are Unstable. Pavilhão da Finlândia, 2011. Fonte: <http://www.thisistomorrow.info/viewArticle.aspx?artld=810>. Acesso em 14/06/2011. Crédito: Vesa-Pekka Rannikko.

Figura 473: All Structures Are Unstable. Pavilhão da Finlândia. 2011. Fonte: Registro fotográfico de Claudio Tozzi. Veneza, junho de 2011.
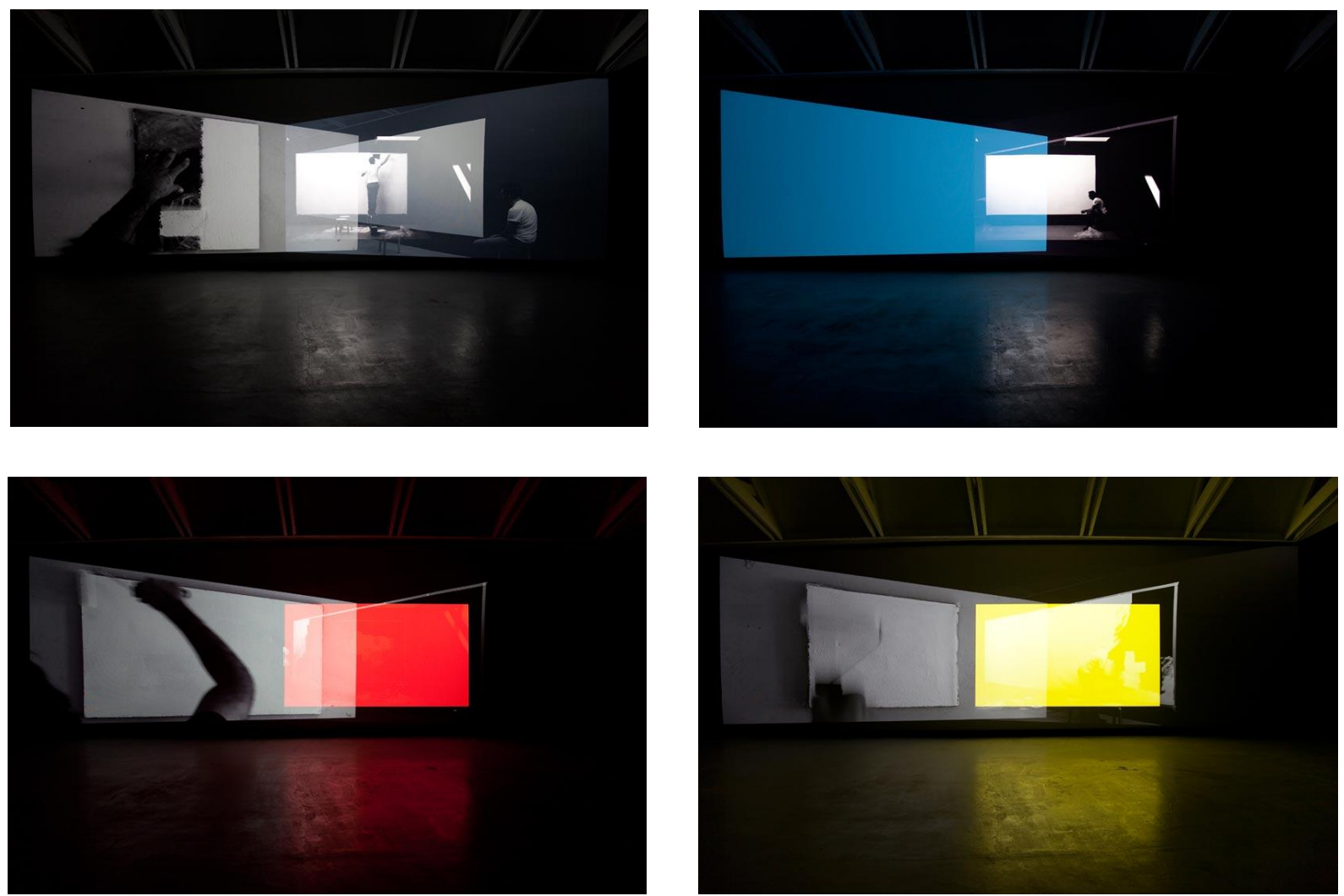

Figura 474, 475, 476 e 477: Vistas da instalação All Structures Are Unstable. Pavilhão da Finlândia. 2011. Fonte: <http://www.thisistomorrow.info/viewArticle.aspx?artld=819. Acesso em 14/06/2011>. Crédito: Eva Maria Ohtonen. 
Ao longo dos últimos quarenta anos, James Turrell criou ambientes e instalações de luz, transformando o elemento luz em um material artístico que pode ser comprimido, derramado, modelado e espessado. Os espectadores de suas obras são convidados a lidar com a luz de uma maneira nova: caminhando, banhando-se, percebendo-a de olhos fechados. O interesse pelas propriedades da luz, como sugere o artista, foi inspirada, em parte, pela religião Quaker e sua "pura, rígida apresentação do sublime". Lembra de sua avó que o encorajava a "entrar e aceitar a luz." Como disse Turrell: "Eu gosto de trabalhar com a luz e utilizá-la de modo que se possa perceber fisicamente como a presença da luz ocupa espaço." (CATALOGHI BIENNALE DI VENEZIA, 2011, p.285, tradução nossa).

Para o trabalho - The Ganzfeld Piece, criado especificamente para a Bienal, dois espaços vazios, conectados um ao outro, foram gradualmente inundados por uma luz em constante mudança de cor. Em vez de iluminar as características do espaço, ilumina a escuridão de forma gradual, produzindo uma superfície na qual todos os elementos arquitetônicos são dissolvidos em uma cor na parede. "O trabalho desafia nossas noções do que é realmente presente, criando uma chama estética ou espiritual de Turrell 'ver para sentir'. 'A luz', disse o artista, 'não precisará revelar mais nada: ela própria é uma revelação'." A obra foi exibida no Pavilhão Principal da Exposição Internacional do Curador: ILLUMInazioni. (CATALOGHI BIENNALE DI VENEZIA, 2011, p.285, tradução nossa).

Bridget's Bardo, instalação ambiente criada pelo light artist para o interior do museu Kunstmuseum-Wolfburg, na Alemanha, tinha $700 \mathrm{~m}^{2}, 11 \mathrm{~m}$ de altura e atingia o teto envidraçado do local. Com ela, objetivava-se criar um "espaço dentro de um espaço". A construção era composta por duas câmaras interconectadas: Viewing Space e Sensing Space, completamente vazias e preenchidas com luz colorida que mudava constantemente e lentamente. (L+D INTERNATIONAL LIGHTING MAGAZINE, 2010, p.20, tradução nossa). 

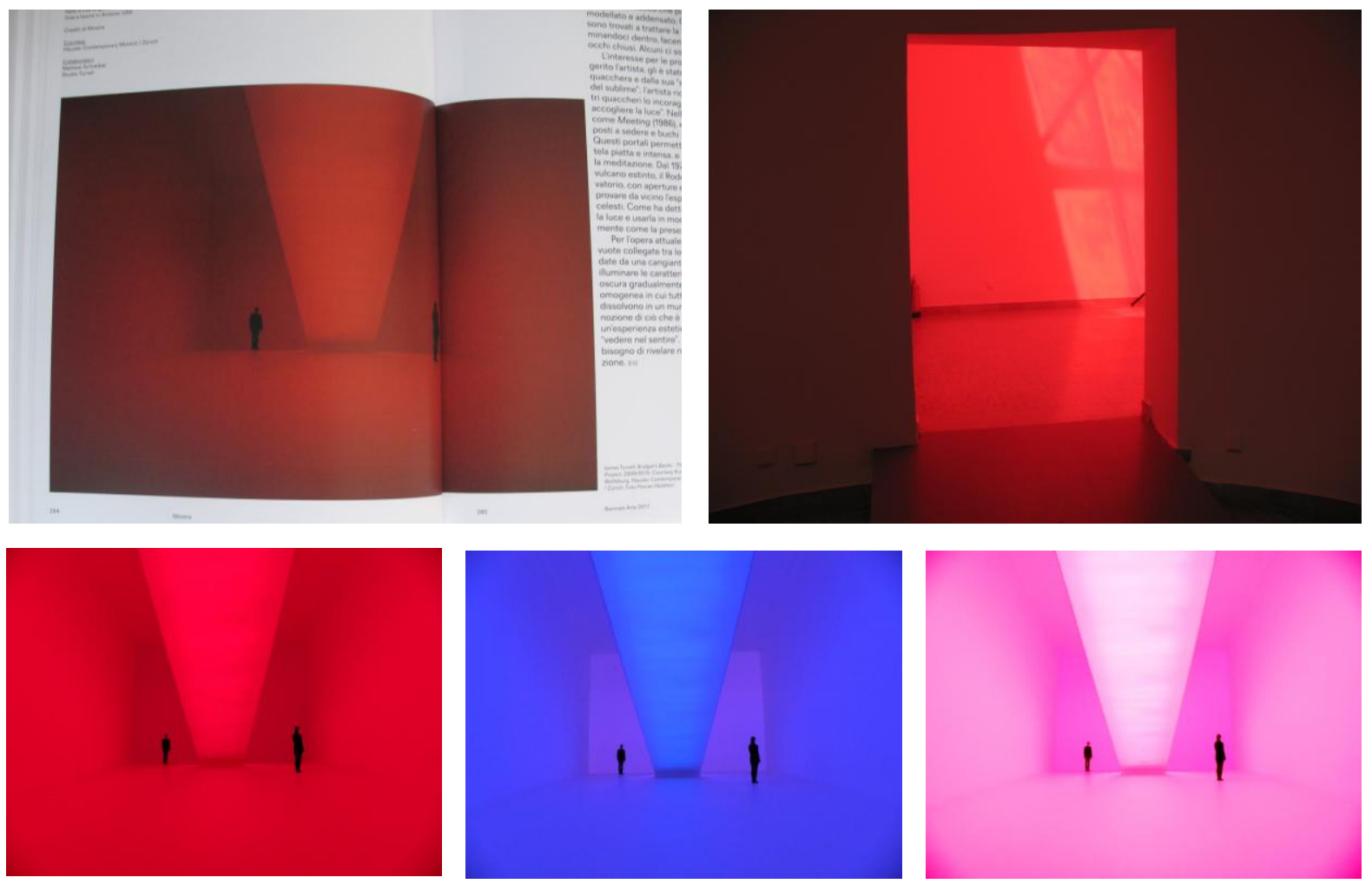

Figura 478: Bard Bridget - O Projeto Wolfsburg, 2009/2010. Cortesia Kunstmuseum Wolfsburg, Munique Contemporânea Häusler, Zürich. Foto Holzherr Florian. Fonte: CATALOGHI BIENNALE DI VENEZIA 2011 , p. 284-285.

Figura 479: The Ganzfeld Piece, 2011. Fonte: Registro fotográfico de Claudio Tozzi. Veneza, junho de 2011.

Figura 480,481 e 482: Bridget's Bardo. Fonte: <http://www.Kunstmuseum-wolfburg.de>. Acesso em 03/04/2010.

$\mathrm{Na}$ obra Slow-motion shadow in colour, Olafur Eliasson decompôs a sombra do espectador em sucessivas projeções de silhuetas coloridas, solução que proporcionava a sensação de movimento. Para alcançar o efeito desejado, foram usadas lâmpadas $\mathrm{HMI}^{103}$ e filtros de vidro nas cores: azul, verde, magenta, laranja, vermelho e amarelo. A intenção da exposição era fazer um trabalho envolvente $e$ relevante no espaço do museu adaptado para trazer a instituição para a vida. Salas e corredores foram transformados através do uso da luz, espelhos, sombras, cores, vento e nevoeiro. Eliasson "repropõe o museu de arte, não apenas como uma facilidade para visualizar a arte em um contexto afastado da sociedade mas, como

\footnotetext{
${ }^{103}$ As lâmpadas HMI proporcionam elevado índice de reprodução de cores e elevada eficiência luminosa de até $100 \mathrm{~lm} / \mathrm{W}$. Possuem uma temperatura de cor do tipo luz do dia de $6.000 \mathrm{~K}$ e permitem o reacendimento, mesmo quando aquecidas. A maioria das lâmpadas HMl é utilizada em filmagens cinematográficas e em estúdios de televisão, onde a qualidade da luz é imprescindível. As lâmpadas HMl estão disponíveis em duas versões: single ended (bipino) e double ended (bilateral). As lâmpadas HMl bipino possuem um bulbo externo, que as torna menos sensíveis às influências ambientais. Elas possuem temperatura de cor de $6.000 \mathrm{~K}$, elevado índice de reprodução de cor superior a 90 e excelente estabilidade de cor. Todas as lâmpadas HMI permitem o reacendimento mesmo quando aquecidas e podem ser dimerizadas.(OSRAM.COM.BR, 2010).
} 
um espaço público com potencial para engajar profundamente na sociedade e no ambiente urbano." Buscou fazer "sua arte acessível e interativa, criando um diálogo e uma relação com o espectador." (KANAZAWA21.JP, 2009, tradução nossa).

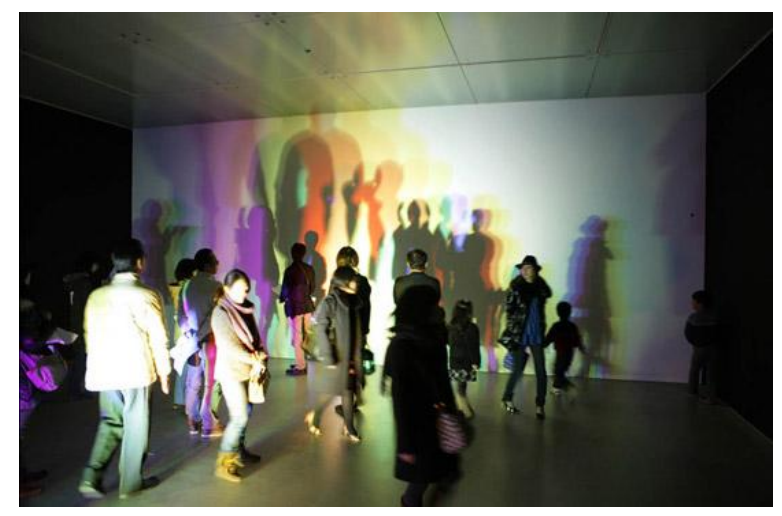

Figura 483: Slow-motion shadow in colour de Olafur Eliasson. 2009. Exposição individual: Your chance encounter (O Encontro Casual) no 21st Century Museum of Contemporary Art, Japão.

Fonte:

<http://www.kanazawa21.jp/data_list.php?g=79\&d=1\&l $\mathrm{ng}=\mathrm{e}>$. Imagem do Estúdio Olafur Eliasson. Acesso em 06/04/2010.

A obra Colour Shadow é outro exemplo de interação espectador/luz/obra, composta por borracha, aço inoxidável, aço, madeira, prisma de vidro, lâmpadas HMI e filtros coloridos. (KANAZAWA21.JP, 2009; DESIGNBOOM.COM, 2011).
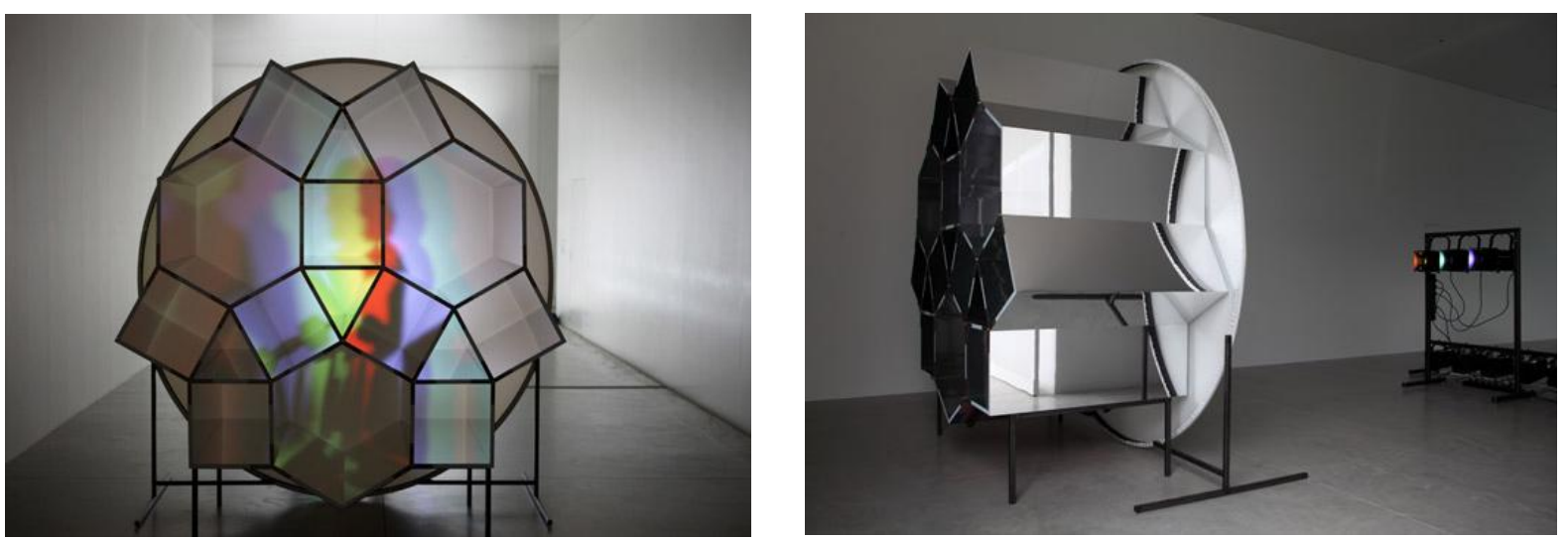

Figura 484: Colour Shadow theatre, 2009. Exposição individual: Your chance encounter (O Encontro Casual), 21st Century Museum of Contemporary Art, Japão. Fonte:

<http://www.kanazawa21.jp/data_list.php?g=79\&d=1\&lng=e>. Imagem do Estúdio Olafur Eliasson. Acesso em 06/04/2010.<http://www.designboom.com/weblog/cat/10/view/9467/olafur-eliasson-your-chanceencounter.html>. Acesso em 22/08/2011.

Figura 485: Colour Shadow theatre, 2009. Exposição individual: Your chance encounter (O Encontro Casual), 21st Century Museum of Contemporary Art, Japão. Fonte: <http://www.kanazawa21.jp/data_list.php?g=79\&d=1\&lng=e>. Imagem do Estúdio Olafur Eliasson. Acesso em 06/04/2010. 
O Edifício Central da Estação de Trem Nyugati, em Budapeste, serviu de suporte para intervenção do grupo de Vjs Cinetrip. Um software processou o mapeamento de elementos tridimensionais da construção. Posteriormente, as imagens mapeadas foram estrategicamente combinadas com imagens bidimensionais pré-gravadas, criando ilusões gigantescas. O liveset contou com a participação do VJ Spetto e do $V J$ e programador Roger $S$, que desenvolveu um gerador de texturas arquitetônicas chamado MotoLED. (CONEXOESTECNOLOGICAS.ORG.BR, 2010).
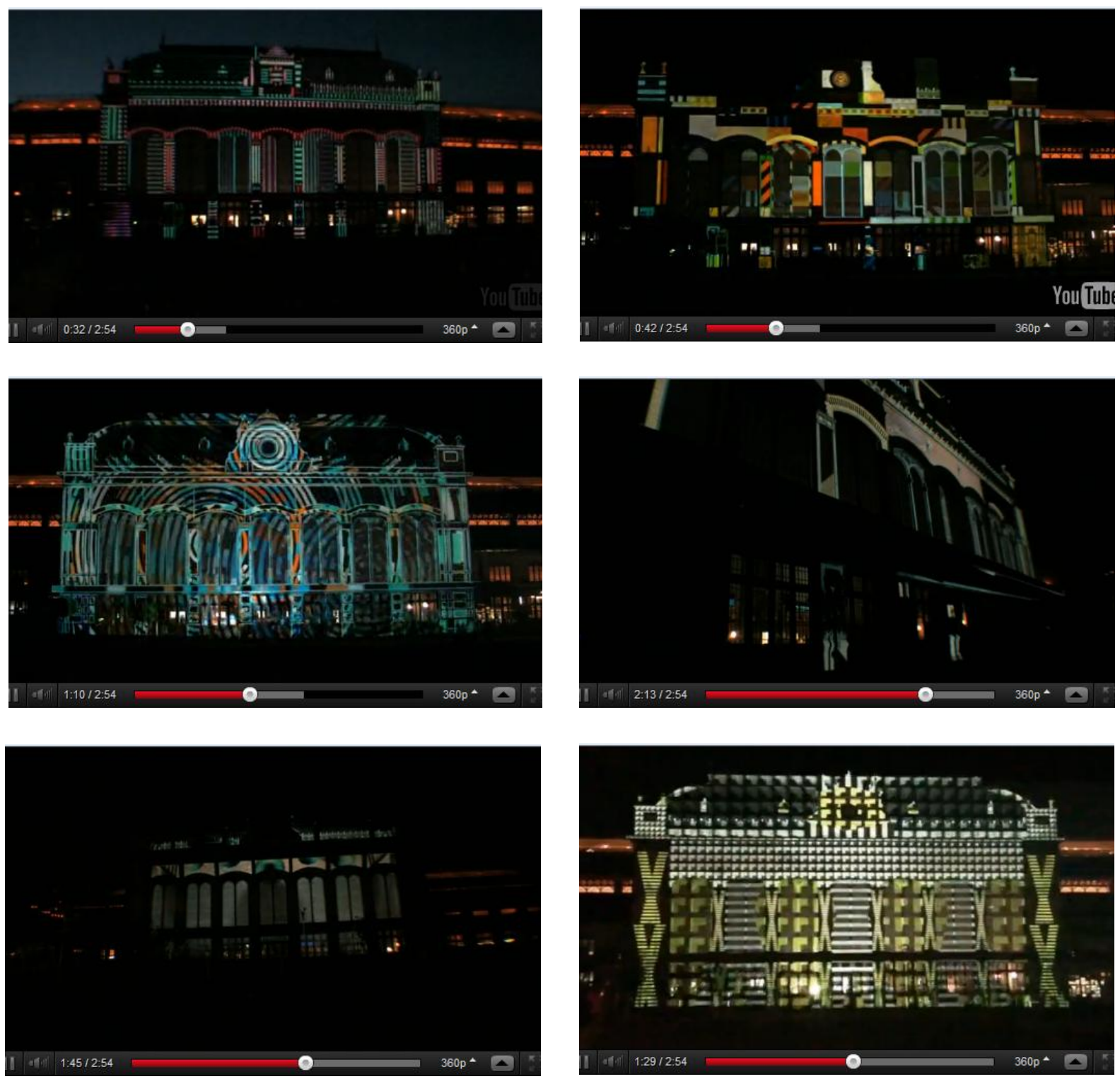

Figura 486, 487, 488, 489, 490 e 491: Edifício Central da Estação de Trens Nyugati, em Budapeste. Video Mapping com a participação do VJ Spetto. 2010. Fonte:< http://conexoestecnologicas.org.br/?p=1159>. Acesso em ?8/0.9/?011.

O Auditório Danish Radio (2002-2009), projeto de Nouvel, encerra uma série de volumes em uma caixa retangular de 45 metros de altura, revestido por uma tela 
azul transparente. O edifício permanece em constante mudança, de acordo com as condições de iluminação e da hora do dia, que ora escondem, ora revelam o que há no interior. Durante a noite, imagens são projetadas sobre uma tela azul. (ARCSPACE.COM, 2009).
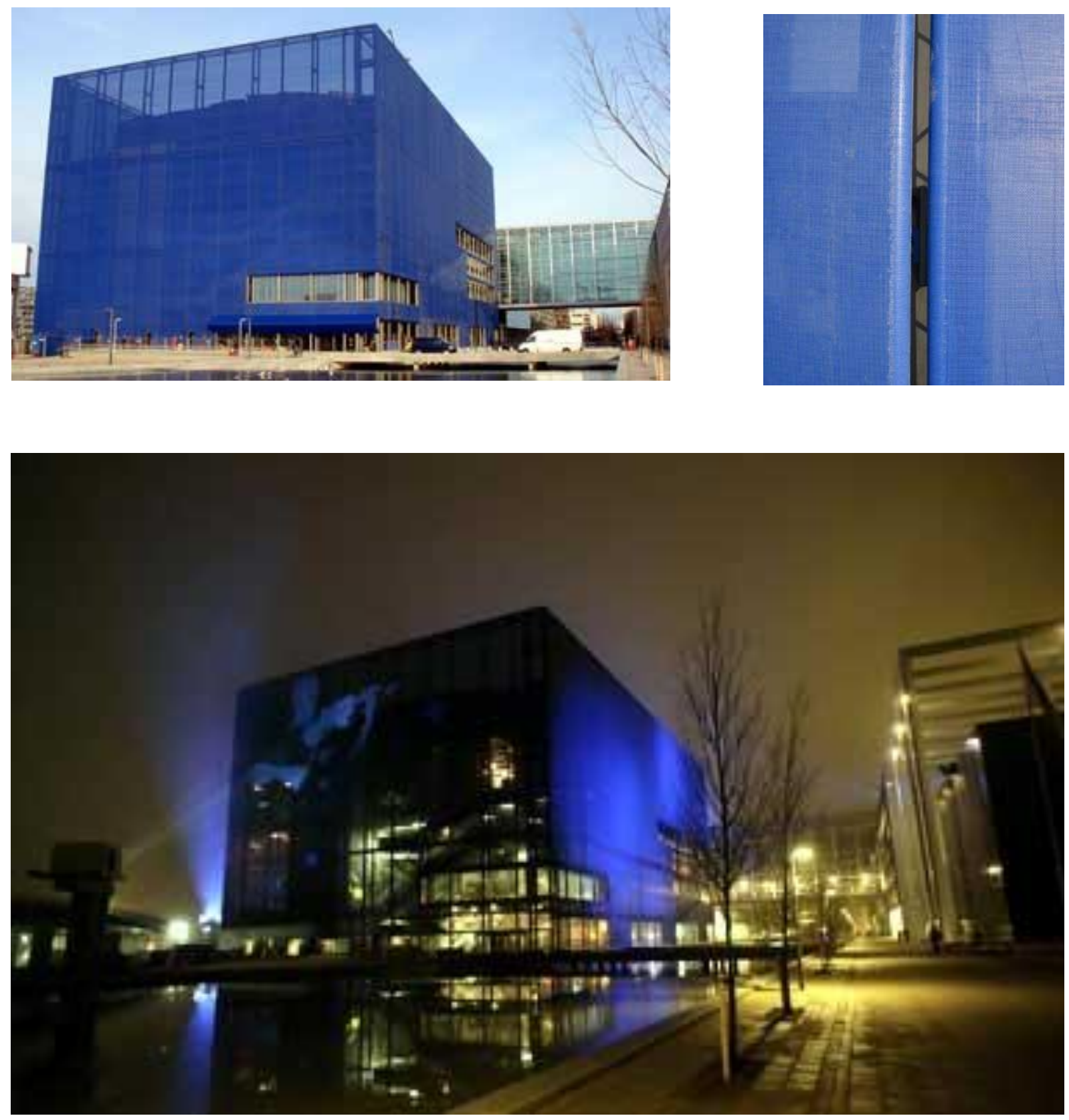

Figura 492: DR Concert Hall, 2002-2009. Copenhagen, Dinamarca. Jean Nouvel. Foto: arcspace.com. Fonte: <http://www.arcspace.com/architects/nouvel/dk_concert/dk_concert.html>. Publicado em 21 de janeiro de 2009. Acesso em 03/11/2011.

Figura 493: DR Concert Hall, 2002-2009 Detalhe da tela de revestimento. Copenhagen, Dinamarca. Jean Nouvel. Foto: arcspace. Fonte: <http://www.arcspace.com/architects/nouvel/dk_concert/dk_concert.html>. Publicado em 21 de janeiro de 2009. Acesso em 03/11/2011.

Figura 494: DR Concert Hall, 2002-2009. Copenhagen, Dinamarca. Jean Nouvel. Foto: Bjarne Bergius Hermansen. Fonte: <http://www.arcspace.com/architects/nouvel/dk_concert/dk_concert.html>. Publicado em 21 de janeiro de 2009. Acesso em 03/11/2011. 
Em Bremen, na Alemanha, a equipe URBANSCREEN, reúne oito artistas colaboradores de diferentes disciplinas, como arquitetura, música, cenografia e media art para desenvolver projetos de projeções em superfícies urbanas de grande escala. A concepção das instalações site-specific é realizada em uma abordagem interdisciplinar que tem como foco principal levar para estruturas existentes ou inerentes à arquitetura o contexto temático e dos arredores.

\begin{abstract}
Através de uma encenação arquitetônica, são examinadas a intersecção do conceito do site, a localização e a aparência. Procedimentos específicos são adaptados ao local de projeção de forma que Ihes permita interligar várias mídias, tais como: imagens geradas por computador, iluminação artificial e dança - para caracterizar a arquitetura e os níveis versáteis do que pode ser experimentado no próprio edifício. (URBANSCREEN.COM, 2010, tradução nossa).
\end{abstract}

Como exemplos de instalações apresentadas por Urbanscreen estão: 555 Kubic e Jump!. A concepção do projeto 555 Kubic, desenvolvida por Urbanscreen.com (produção), Daniel Rossa (direção de arte), Thorsen Bauer (diretor técnico), David Starmann (3D design), Wiese Jonas (desenho de som) e mediaserver mxwendler.net, baseou-se na deriva de sua arquitetura. "A ideia básica da narrativa foi dissolver e romper a arquitetura rigorosa da OM Ungers 'Galerie der Gegenwart". A superfície sólida da fachada torna-se permeável através de diferentes interpretações da concepção, da geometria e da estética expressa através de gráficos e movimentos. "A situação evolui para a reflexividade - que descreve a constituição e a percepção dos espaços deste local por meio do próprio edifício". (URBANSCREEN, 2010, tradução nossa).
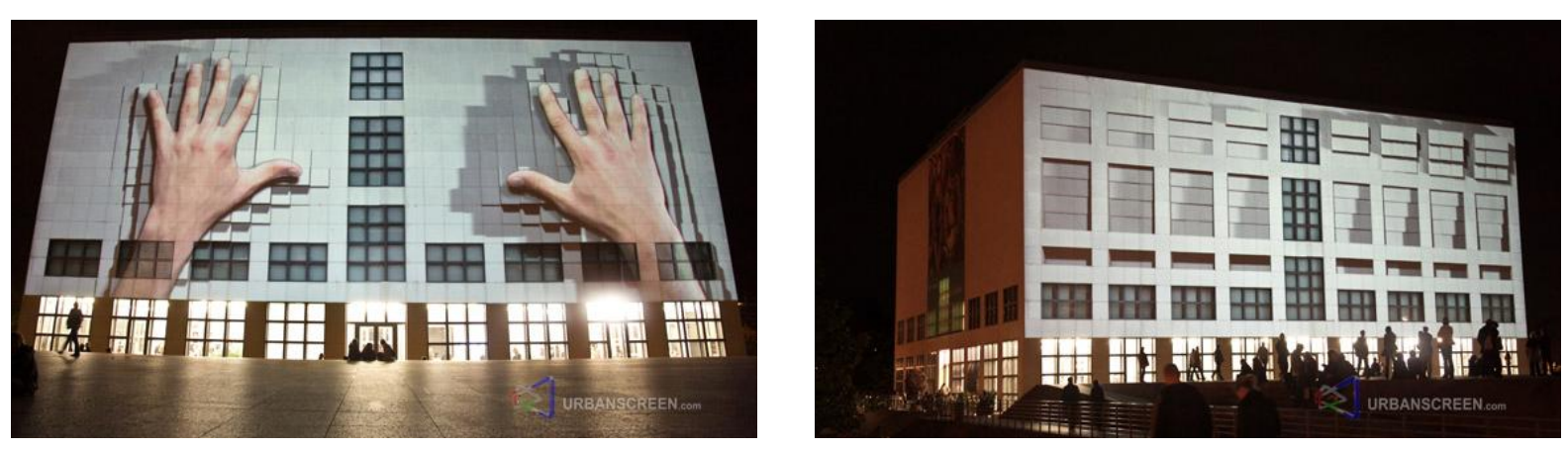

Figuras 495 e 496: Instalação 555 Kubic. Fonte: <http://www.urbanscreen.com/usc/41>. Acesso em $23 / 05 / 2010$ 

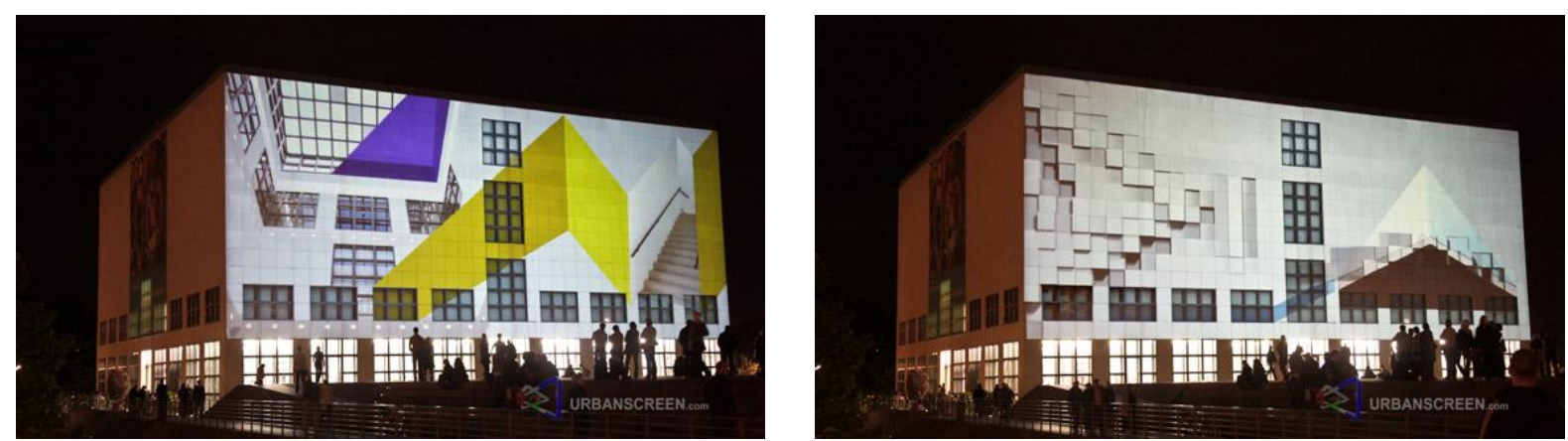

Figuras 497 e 498 : Instalação 555 Kubic. Fonte: <http://www.urbanscreen.com/usc/41>. Acesso em 23/05/2010.

Jump! foi realizada no Banco Alemão Sparda-Bank, no evento Viertelfest Bremen. Projeções transformaram a superfície da fachada do edifício em um trampolim e em uma parede de escalada. Seus autores foram os artistas: o B-Boys e Tobo do Novo Circo. "Por detrás destas janelas que você não consegue encontrar descanso, mas uma aventura, desde os dias da infância... quando você ainda era capaz de escalar, saltar e quase voar." (URBANSCREEN, 2010, tradução nossa).
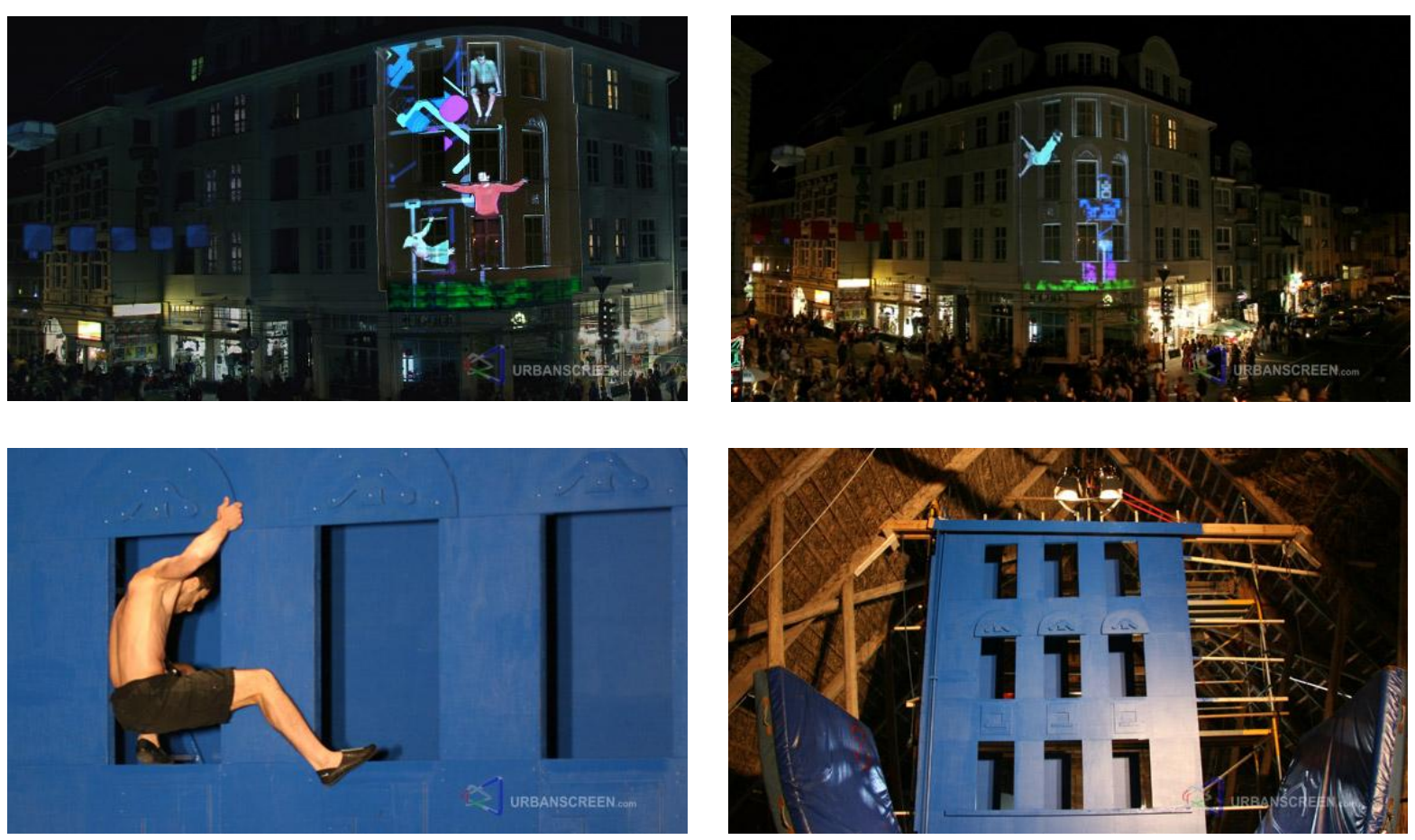

Figuras 499, 500, 501 e 502: Instalação Jump! Fonte: <http://www.urbanscreen.com/usc/41>. Acesso em 23/05/2010. 
A instalação audiovisual interativa: timeLandscape - wool rhythms 2010, de Juliana Mori e Matteo Sisti Sette, é parte da série timeLandscape, realizada em 2009/2010. Os recursos que possibilitaram que os artistas realizassem a obra foram diversos: vídeo, áudio, projetor, alto-falantes, patch (PD-Gem), sensor, máquina têxtil e loop. Com dimensões e duração variáveis,

uma paisagem documentada a partir de múltiplas possibilidades temporais é re(composta) em tempo real a partir da interação com um objeto físico. Desenvolvida em Biella, Itália, região pioneira na industrialização têxtil, lida com a percepção cíclica do tempo e a interferência humana, linear, nestes ciclos (...) reúne natureza e artefato, conectando uma máquina de fabricação de lã à projeção em vídeo do ciclo de um dia em um panorama montanhoso. Ao girar a manivela, o homem gira a máquina. Através de um sensor acoplado, a velocidade de rotação é calculada e serve de parâmetro para a mistura de fragmentos de áudio e vídeo em tempo real, criando paisagens que respondem ao ritmo e velocidade de cada interator. (CATÁLOGO FILE SÃO PAULO, 2011, p.27).
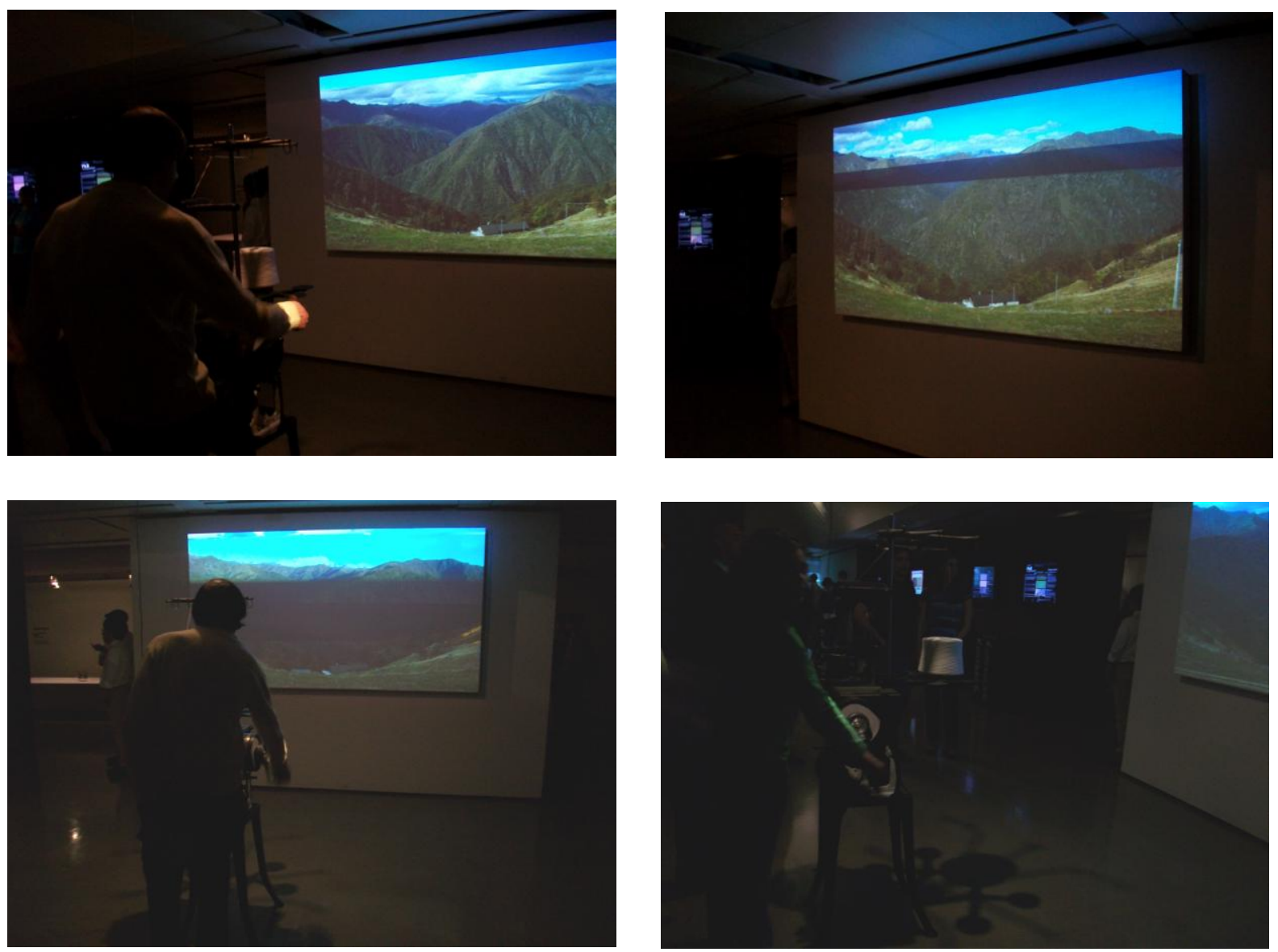

Figura 503, 504, 505 e 506: timeLandscape - wool rhythms 2010. Juliana Mori e Matteo Sisti Sette. Fonte: Registro fotográfico realizado pela pesquisadora no Festival Internacional de Linguagens Eletrônicas - FILE 2011. 
A instalação Reações Visuais, de Leandro Araújo, acontece por meio de um software de análise espectral sonora que transforma ruídos da cidade em imagens digitais da Mata Atlântica. "Em termos técnicos, ondas sonoras podem ser captadas e representadas visualmente por diferentes métodos, como uma operação matemática que decompõe o sinal em suas frequências constituintes." (ITAUCULTURAL.ORG.BR, 2011). As imagens são projetadas em três telas justapostas em ângulo e refletidas em um espelho d’água.

Nesta instalação, representações de matas e florestas são geradas a partir da análise espectral do som captado em tempo real por um microfone instalado do lado de fora desta galeria. A cada intervalo de tempo o som é decomposto em espectros de frequência, cuja densidade é representada pela transparência do pixel na imagem. O conjunto de linhas forma a imagem de vegetação que é um reflexo do som captado na rua neste momento. (ITAUCULTURAL.ORG.BR, 2011) ${ }^{104}$.
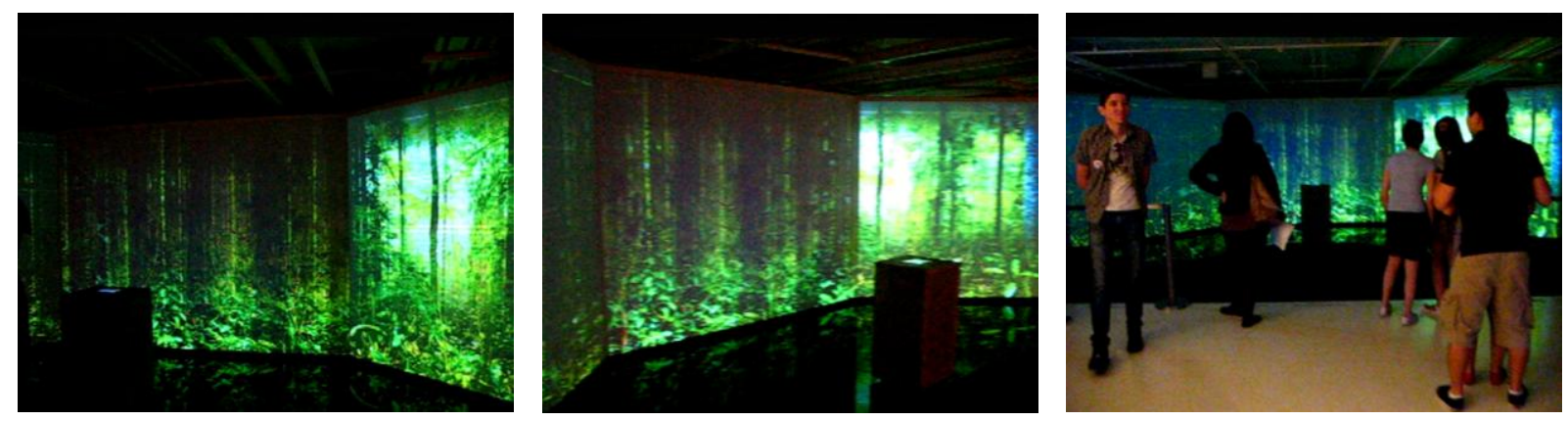

Figura 507, 508 e 509: Reações Visuais, 2011. Leandro Araújo. Fonte: Registro fotográfico realizado pela pesquisadora na exposição Rumos da Arte Cibernética 2011, Itaú Cultural.

A relação obra / espaço construído / espaço natural existente, presente nas obras: timeLandscape - wool rhythms e Reações Visuais, foi explorada por Walter De Maria em The Lightning Field, quando se apropriou de uma planície no alto das montanhas do Novo México para instalar 400 postes de aço inoxidável distribuídos em uma malha retangular de 1 milha por $1 \mathrm{Km}$ de extensão. A altura de cada poste variava de acordo com a topografia do terreno criando um plano horizontal.

104 Dados extraídos pela pesquisadora do vídeo explicativo apresentado no decorrer da exposição Rumos da Arte Cibernética 2011, no Itaú Cultural. 

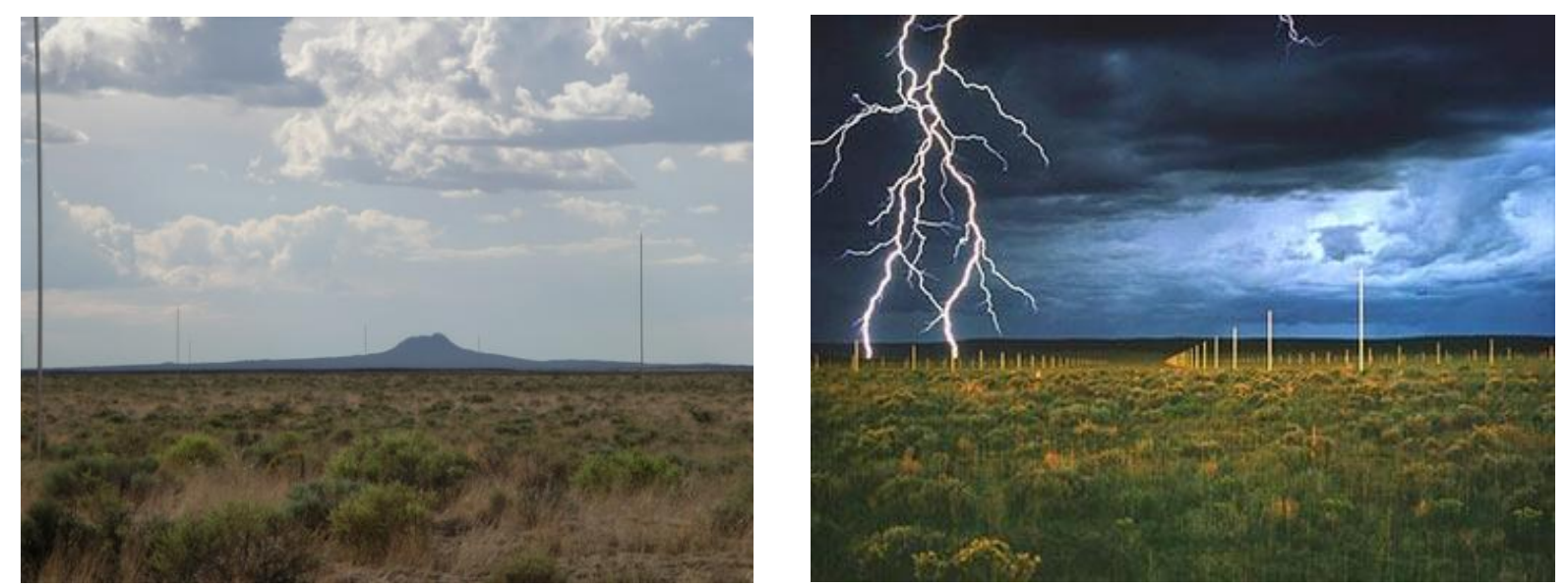

Figura 510: The Lightning Field, 1977, de Walter De Maria, nos planaltos do Novo México. Fonte: $<$ http://ui.uncc.edu/story/land-art>. Acesso em 11/10/11.

Figura 511: The Lightning Field, 1977, de Walter De Maria, nos planaltos do Novo México. Fonte: <http://www.filefestival.org/site_2007/filescript_pop.asp?cd_pagina=311\&id=2\&cd_materia=466>. Acesso em 13/10/2011.

A instalação Elucidating Feedback (2011) de Ben Jack, apresenta uma forma de interatividade particular, "controlada mentalmente sobre a criatividade inerente ao ato de observar". Parte da ideia de que: "Quanto mais olhamos, mais vemos; quanto mais vemos mais olhamos." A partir de uma projeção inicial, que se faz presente para ser observada e iniciar todo o processo, responde com projeções diferenciadas de acordo com o nível de atenção prestada pelo espectador. Quanto maior a atenção, mais ordem é refletida no vídeo e no áudio. Isso é possível através da "realimentação neurológica obtida pela interação entre o usuário e o dispositivo $\mathrm{BCl}$ (interface computador-mente). O mindset (o dispositivo de $\mathrm{BCl}$ ) lê suas ondas cerebrais e isso altera como a instalação cria forma a partir da estática". É formado um loop de realimentação entre a atenção do usuário e as projeções apresentadas em três planos. (CATÁLOGO FILE SÃO PAULO, 2011, p.19-20). 

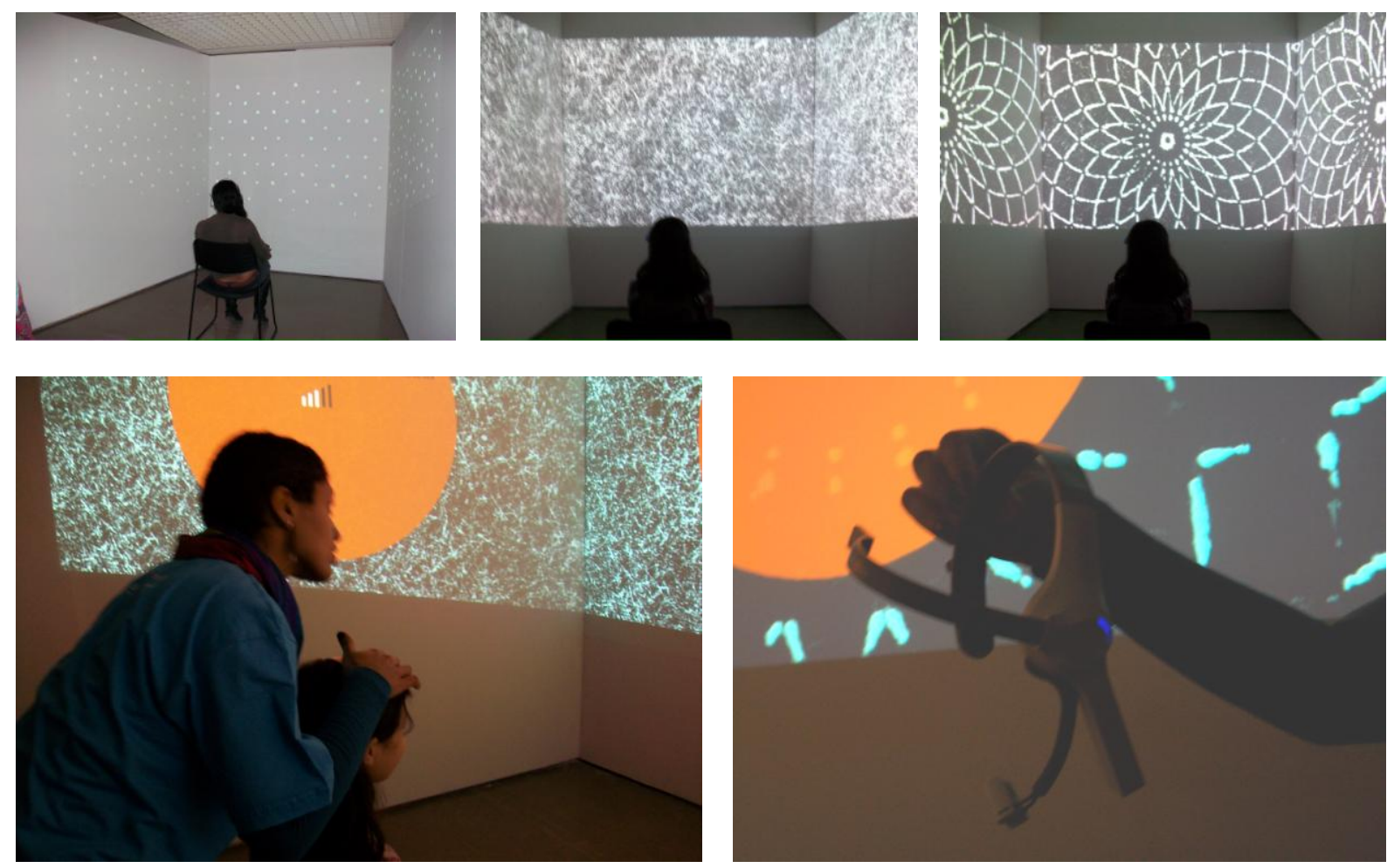

Figuras 512, 513, 514, 515 e 516: Elucidating Feedback, 2011. Ben Jack. Fonte: Registro fotográfico realizado pela pesquisadora no Festival Internacional de Linguagem Eletrônica - FILE 2011.

Leandro Trindade, em sua obra: I Dance - Pista de Dança Interativa, faz uso de sensores de movimento instalados no ambiente da pista de dança que captam os movimentos dos interatores. "Sequências de efeitos, formas e cores são alteradas por meio de um software desenvolvido pelo próprio artista e também por webcams modificadas, datashows de curto disparo e iluminadores infravermelhos." (ITAUCULTURAL.ORG.BR, 2011). As imagens exibidas na parede, em telas LCD, são as mesmas projetadas no plano do piso, porém, adequadas a outra proporção. Segundo o artista, "a velocidade das pessoas também pode permitir diversas coisas". O algoritmo usado para o processamento de imagem é o Lucas Kanade. "Ele faz um processamento de triangulação de pontos de alto contraste."105

\footnotetext{
${ }^{105}$ Dados extraídos pela pesquisadora do vídeo explicativo apresentado no decorrer da exposição.
} 

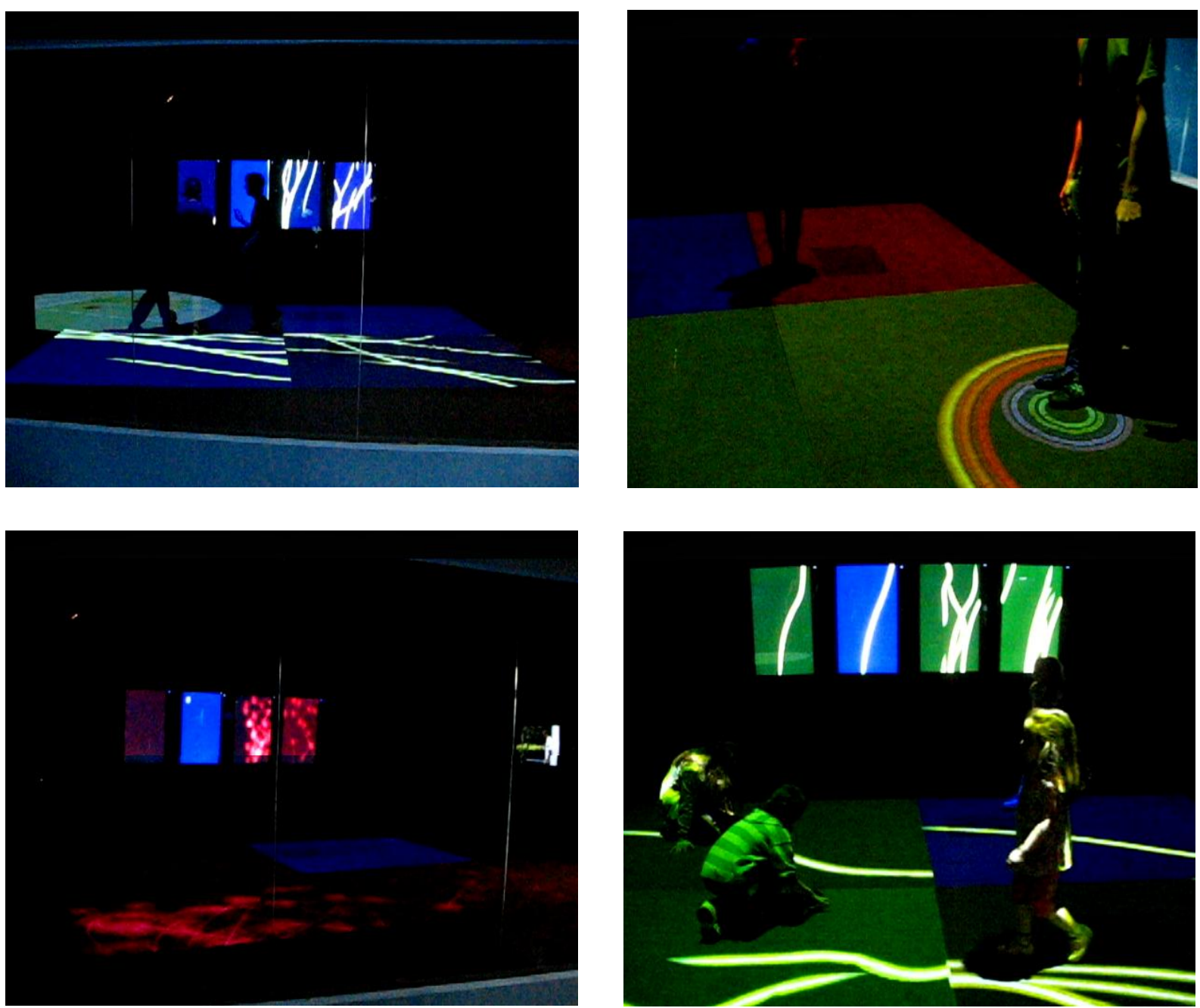

Figura 517, 518, 519 e 520: I Dance - Pista de Dança Interativa, 2011. Leandro Trindade. Fonte: Registro fotográfico realizado pela pesquisadora na exposição Rumos da Arte Cibernética 2011, Itaú Cultural.

Em 2010, o evento Video Ataq, buscou associar a arte de novas mídias a outras formas já consolidadas como a música e a poesia em espaço público, reutilizando as ruínas de uma construção do Parque das Ruínas, no Rio de Janeiro (explorada em 2009), como suporte para exibições. Ao longo dos três dias de evento foram ministradas oficinas práticas de Vjing e de Video Mapping. Dentre os professores estavam: Spetto, Laki Lazslo, Alexis, Bóris Eldestein, Ilan Katin e outros. A projeção foi o ponto alto, como explica o VJ e diretor Jodele Lascher, curador da mostra:

O video mapping vai ser a estrela do evento. Serão 20 minutos de uma grande experiência audiovisual envolvendo a fachada do parque. É como se fosse um cinema expandido e sensorial. (ALBUQUERQUE, 2010) 

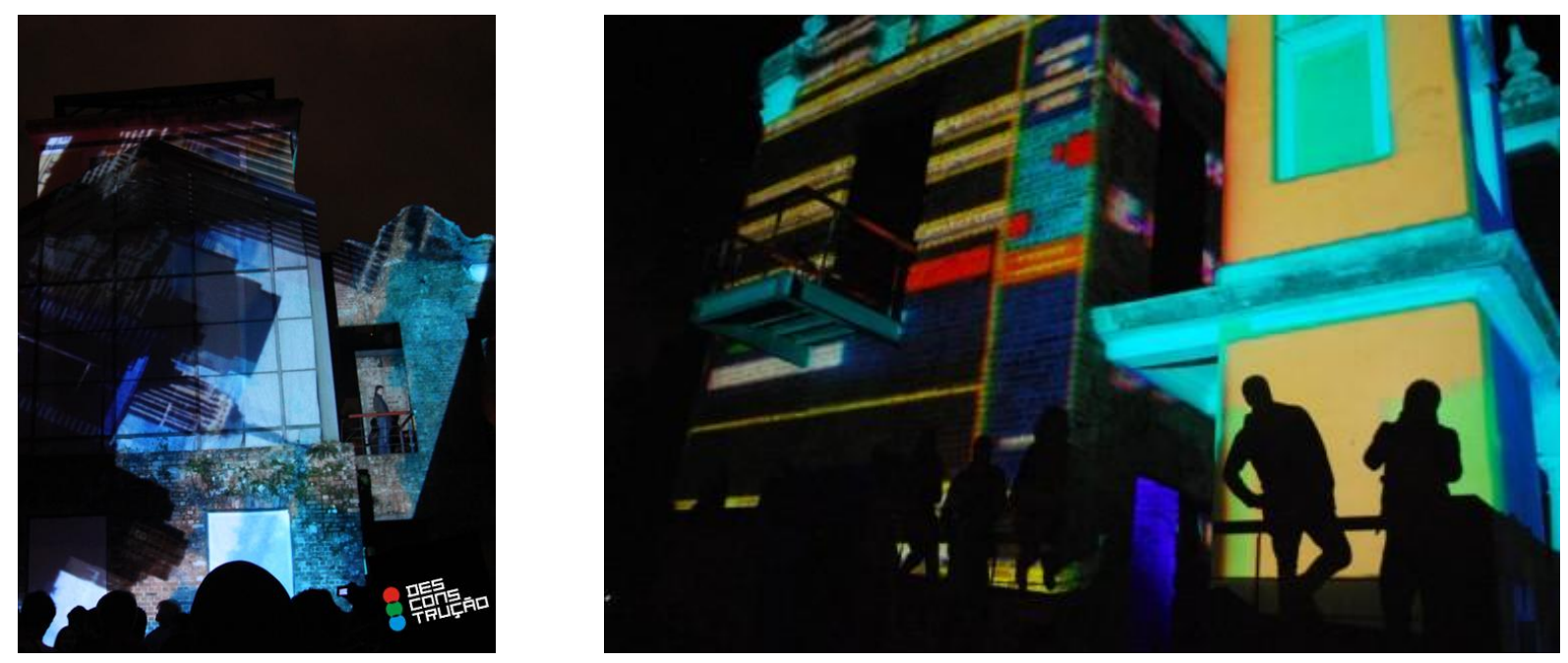

Figuras 521 e 522: Parque das Ruínas, Rio de Janeiro, VideoAtaq 2010. Fonte: <http://www.desconstrucao.com.br/2010/08/video-ataq-desconstrucao-apresenta-video-mapping-no-parque-dasruinas-rio-de-janeiro-2/>. Acesso em 28/09/2011.

No decorrer da Virada Cultural 2011, em São Paulo, a produtora de projeções Visualfarm, do VJ Alexis Anastasiou, realizou intervenções visuais em edifícios da cidade. Foram quatro técnicas de megaprojeções de imagens: o Agigantador de Pessoas, no Banespão: Instalação interativa, em que um mini estúdio escuro foi montado na rua, em frente ao prédio, para servir de palco para a captação e transmissão simultânea da imagem das pessoas, de forma que elas pudessem se ver com estatura gigantesca na fachada do histórico edifício. No Pátio do Colégio, local onde houve a comemoração do centenário da Orquestra Sinfônica Municipal com a Ópera Pagliacci, foram exibidas uma cenografia projetiva e a projeção Mapeada e Monumental. Com a proposta de "remixar" a fachada de $1.000 \mathrm{~m}^{2}$, esta última foi uma reapresentação da projeção realizada na edição de 2010 da Virada Cultural, um acervo de pinturas e gravuras do século XIX de artistas como JeanBaptiste Debret, Benedito Calixto e Thomas Ender. O Sesc Belenzinho também foi suporte para projeção mapeada. Em comemoração ao Ano da Holanda no Brasil, foi apresentado o projeto Time_Frame / Tracking Imaginary Reality, na empena do Edifício Condor, em frente à Faculdade de Direito do Largo São Francisco. A organização da Virada Cultural, em parceria com o Projeto Time Frame e o Consulado da Holanda, convidou doze artistas daquele país, sob a curadoria de Miguel Petchkovsky, para a instalação Holanda Monumental. (VISUALFARM.COM.BR, 2011). 

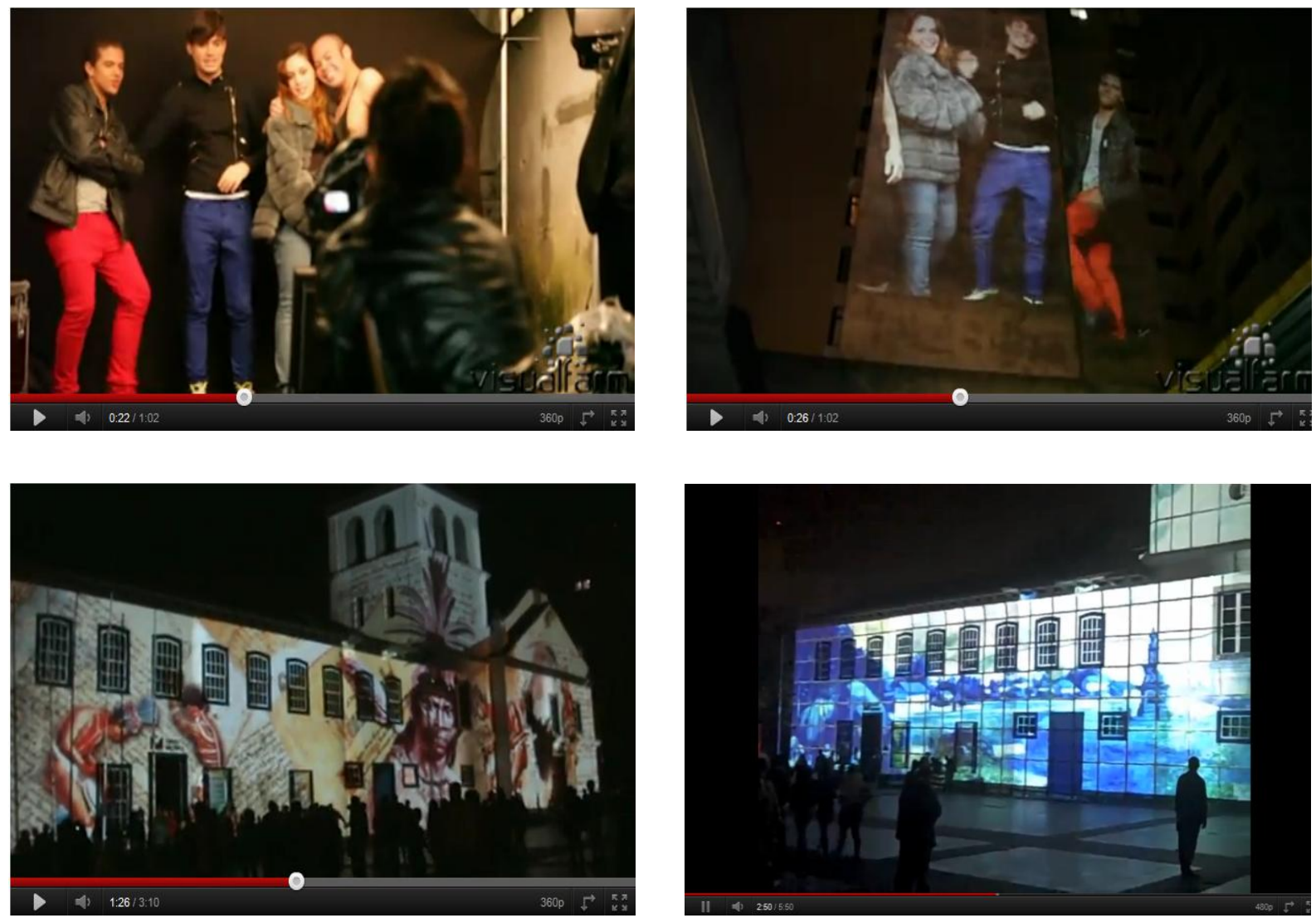

Figuras 523 e 524: O Agigantador de Pessoas, 2011. Visualfarm: novas linguagens visuais. Enviado em 22/01/2011. Fonte: <http://www.youtube.com/watch?v=thEMaB7pJ64>. Acesso em 03/10/2011.

Figuras 525 e 526: Mapeada e Monumental, 2010. Pátio do Colégio. Visualfarm: novas linguagens visuais. Fonte: <http://www.youtube.com/watch?v=clxxQbkdpME\&NR=1>. Enviado em 16/05/2010 por Jorge Folpes. Acesso em 27/09/2011.
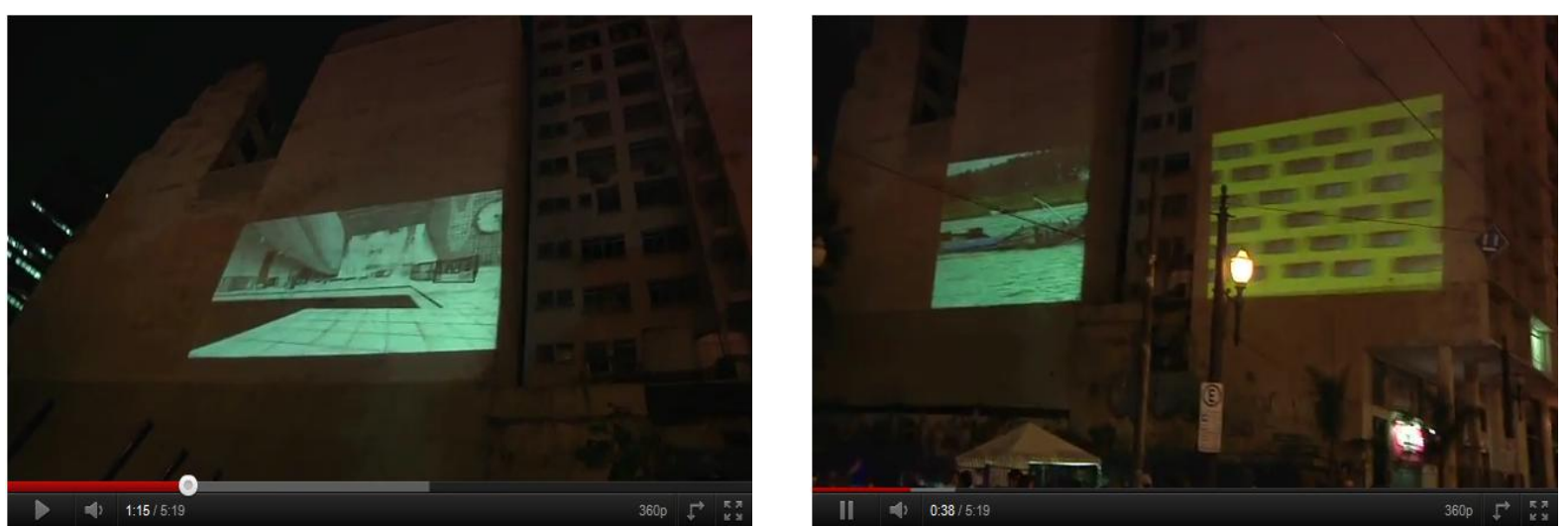

Figura 527 e 528: Time_Frame / Tracking Imaginary Reality, Edifício Condor, 2011. Visualfarm: novas linguagens visuais. Fonte: <http://www.youtube.com/watch?v=aM7-bj_quig>. Acesso em 03/10/2011. Enviado por porcpigao em 28/04/2011. 

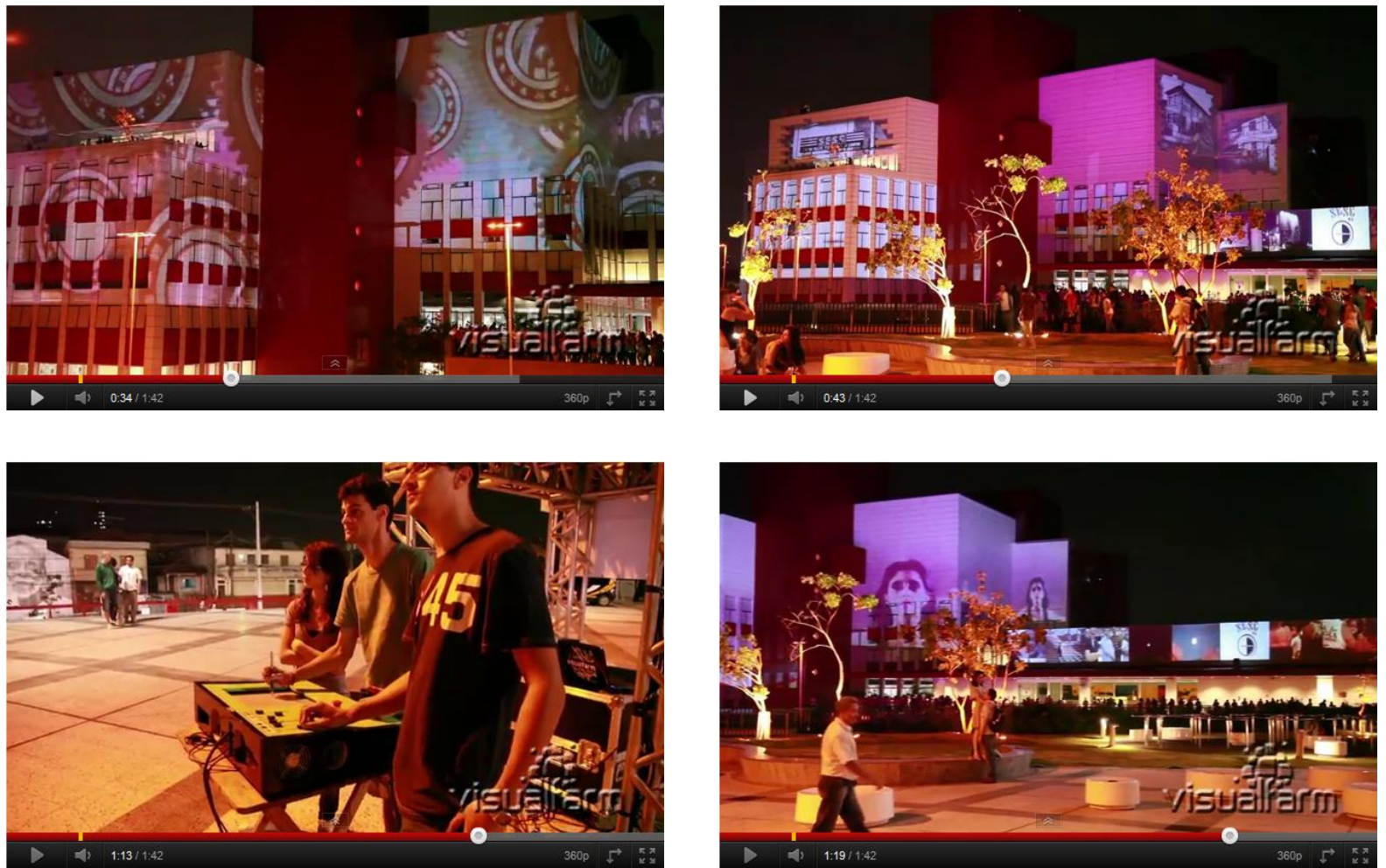

Figuras 529, 530, 531 e 532: Video Mapping na fachada do SESC Belenzinho. Visualfarm: novas linguagens visuais. Fonte: <http://www.youtube.com/watch?v=BPMdAGgOiu4>. Enviado por visualfarm em 16/05/2011. Acesso em 03/10/2011.
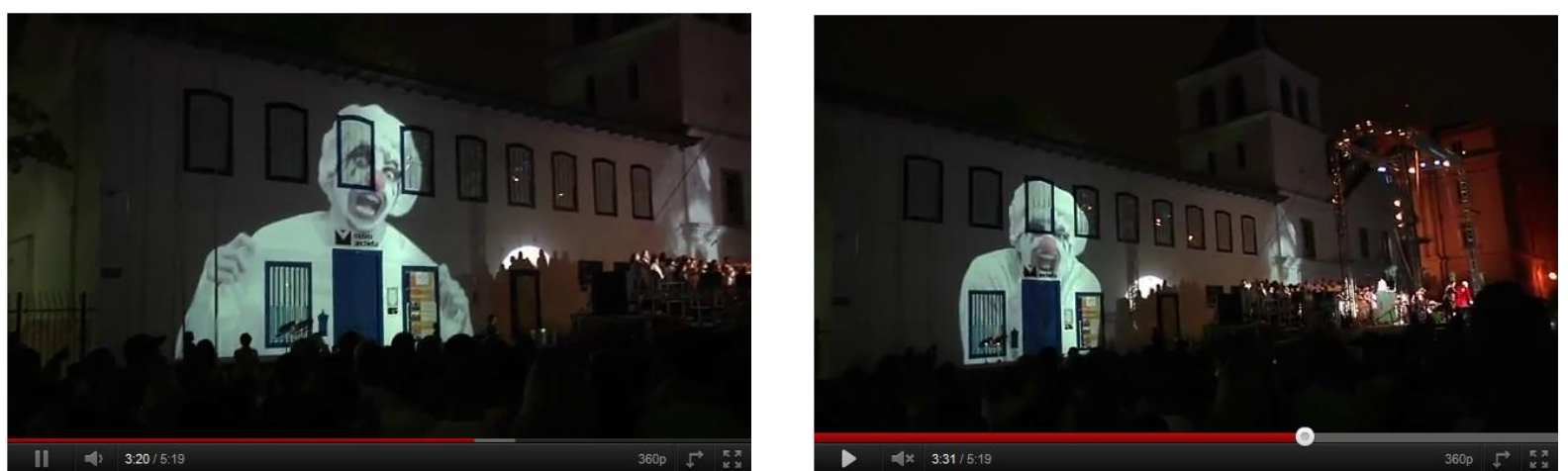

Figuras 533 e 534: Cenografia Projetada. Visualfarm: novas linguagens visuais. Fonte: <http://www.youtube.com/watch?v=aM7-bj_quig>. Enviado por porcpigao em 28/04/2011. Acesso em 03/10/2011.

No período de 17 a 20 de novembro de 2011, foi realizada a segunda edição do evento Vídeo Guerrilha, projeto proposto pela agência publicitária We e produzido pela Visualfarm, com o patrocínio da empresa Calvin Klein. ${ }^{106}$ A ação visou estimular a prática de intervenções urbanas no espaço público através da exibição de projeções de imagens, quatro delas interativas, com o uso de sensores de

\footnotetext{
${ }^{106}$ Em artigo publicado na Folha de São Paulo, por Edison Veiga: "Para marcar a parceria da CK One com o projeto, a We criou uma ação publicitária que será veiculada entre as projeções. Nela, será enfatizado o icônico visual da fragrância unissex $C K$ One, que inspirou a criação da nova marca para o estilo de vida de homens e mulheres contemporâneos nas linhas de jeanswear, underwear e swimwear." (VEIGA, 2011)
} 
movimento, câmeras de vídeo, sistema touch screen, caneta digital, aliados a tablets e a aplicativos específicos. Os trabalhos, de autoria de diversos videoartistas, em sua maior parte, adotaram como suporte superfícies de fachadas de edificações da Rua Augusta, em São Paulo, incitando a participação do público, conforme Anastasiou expressou:

Queremos que o público participe mesmo. Os interessados vão poder brincar com luzes como se estivessem jogando videogame. (...) Serão muitas as instalações interativas. (VEIGA, 2011)

Monitoras do evento, informaram que, além do Agigantador de Pessoas (mencionado anteriormente no evento Virada Cultural de 2011), outros três trabalhos interativos, exibidos no estacionamento de um supermercado, foram criados com o auxílio de aplicativo interativo do Ipad, o programa Touch OSC, que possibilitou a interação do público com imagens projetadas, em sistema randômico, alteradas a cada 30 segundos; sensor de movimento que projetava imagens em infravermelho; tablet integrado ao software Grafite Virtual, em que o público podia criar seu "grafite", através de uma caneta digital, em que desenhos e mensagens eram projetadas, simultaneamente, em escala ampliada ${ }^{107}$.
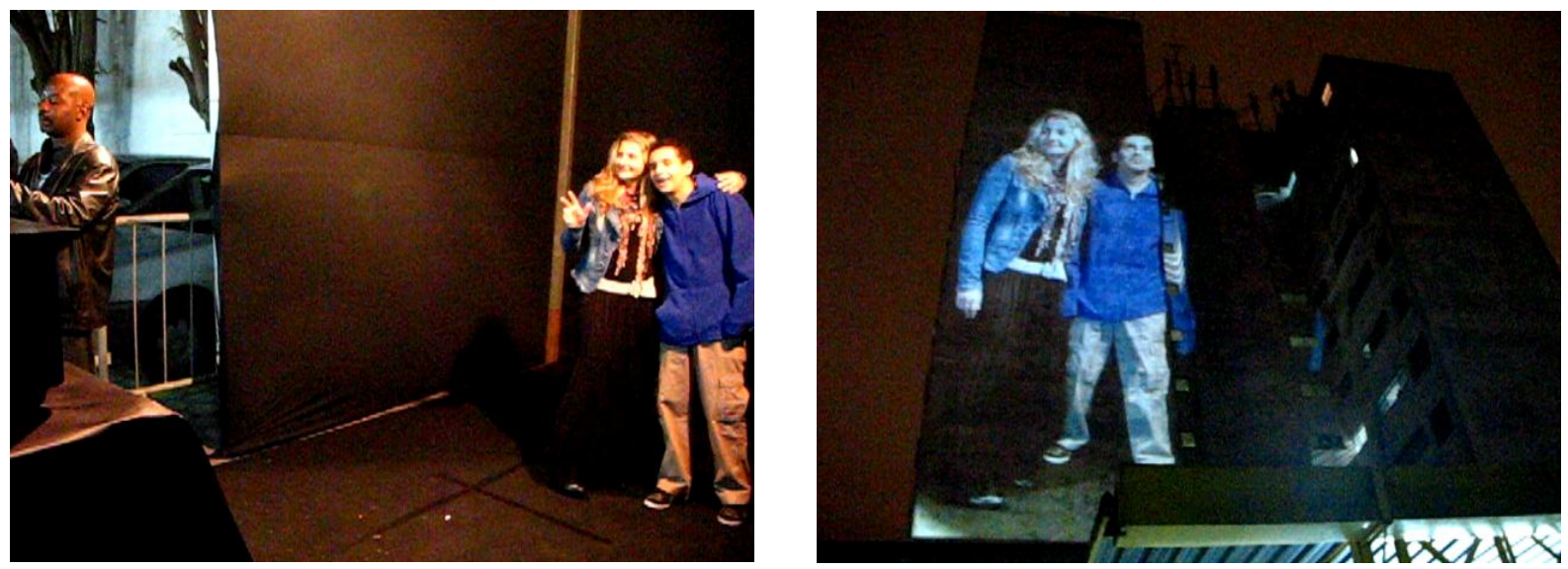

Figuras 535 e 536: Projeção interativa Agigantador de Pessoas. Vídeo Guerrilha, 2011. Fonte: Registro fotográfico realizado pela pesquisadora.

\footnotetext{
${ }^{107}$ Informação verbal concedida à pesquisadora no decorrer do evento Video Guerrilha, 2011.
} 

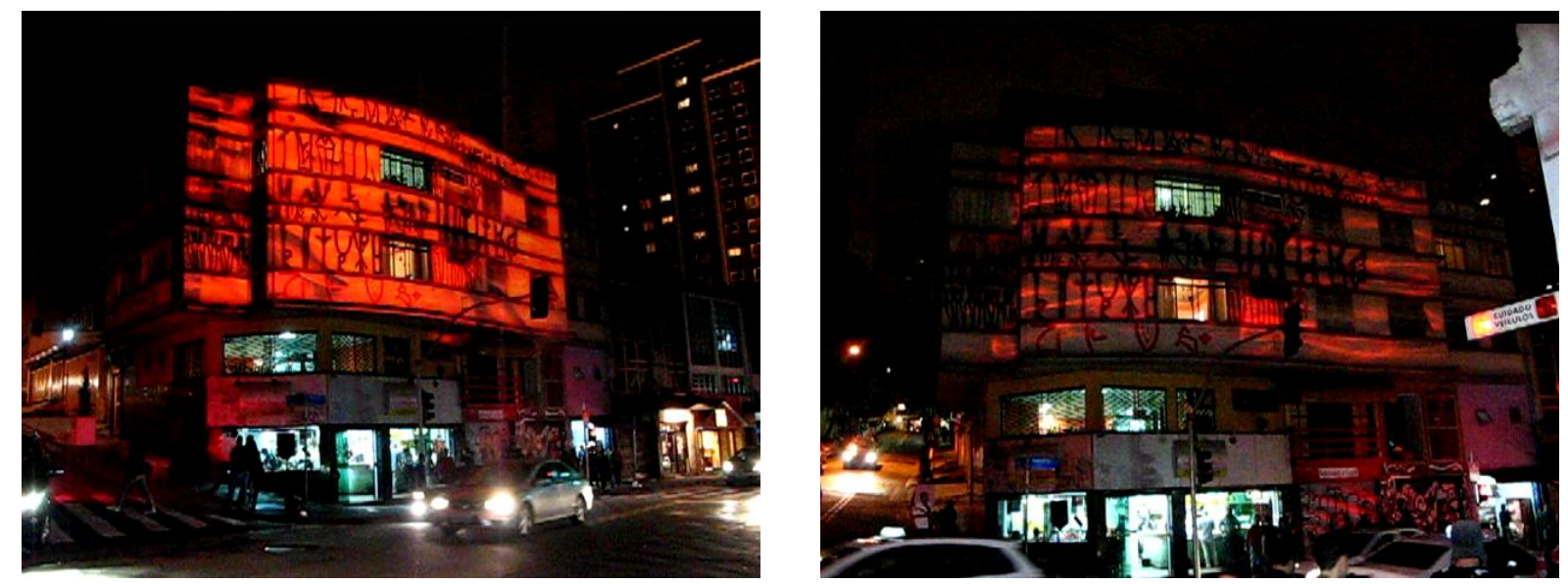

Figuras 537 e 538: Projeção de imagem sobre superfície grafitada (obra não interativa). Vídeo Guerrilha, 2011. Fonte: Registro fotográfico realizado pela pesquisadora.
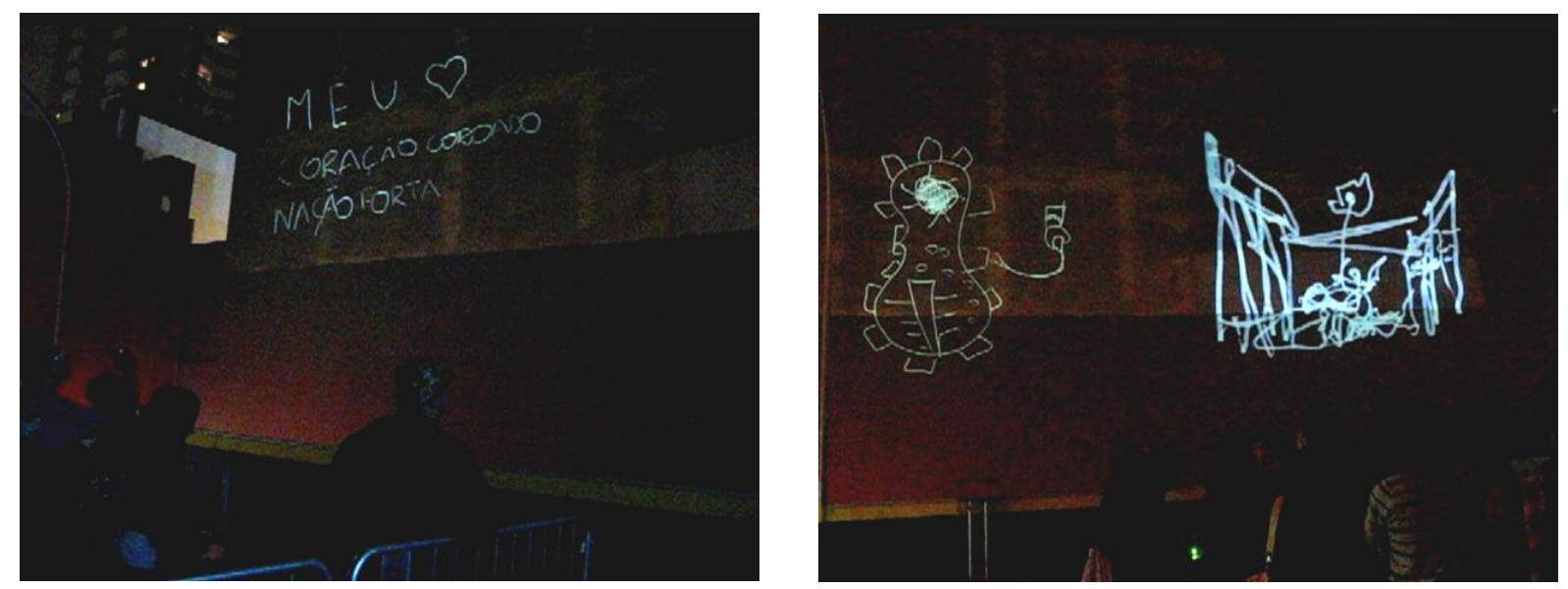

Figuras 539 e 540: Projeção interativa Grafite Virtual. Vídeo Guerrilha, 2011. Fonte: Registro fotográfico realizado pela pesquisadora.
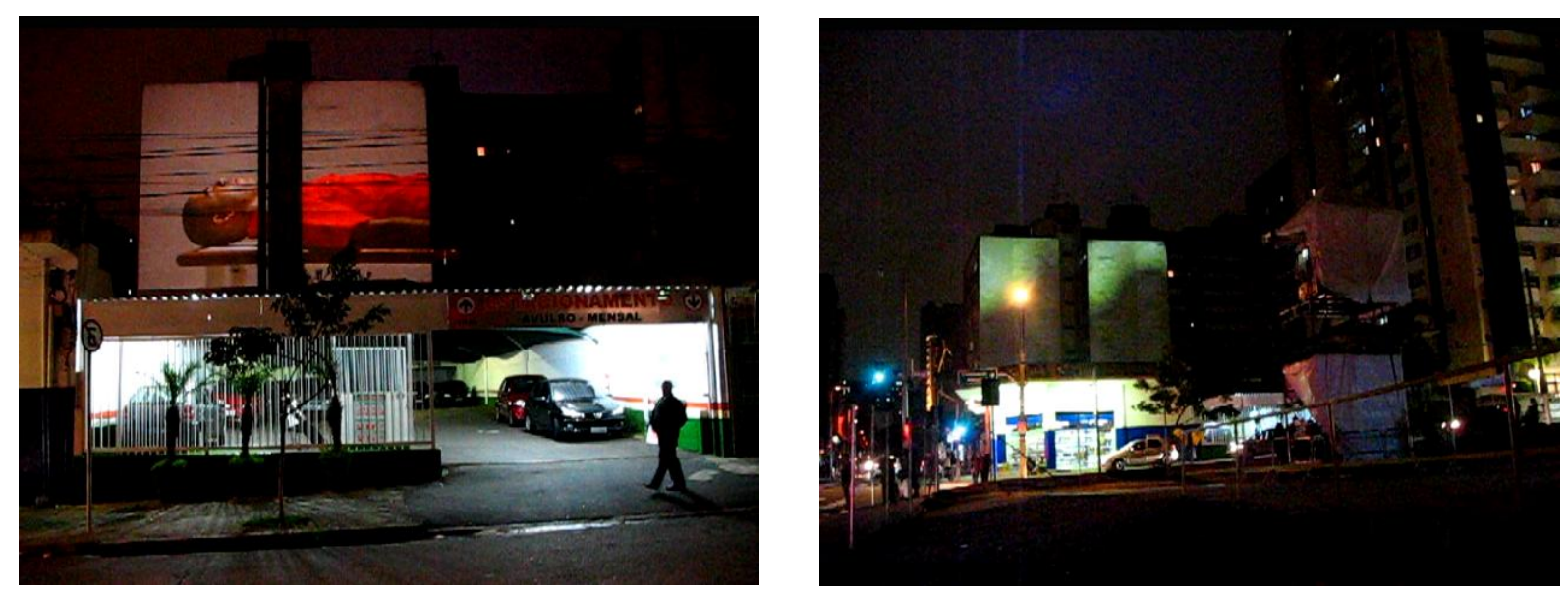

Figuras 541 e 542: Projeção de imagem edifício. Vídeo Guerrilha, 2011. Fonte: Registro fotográfico realizado pela pesquisadora. 

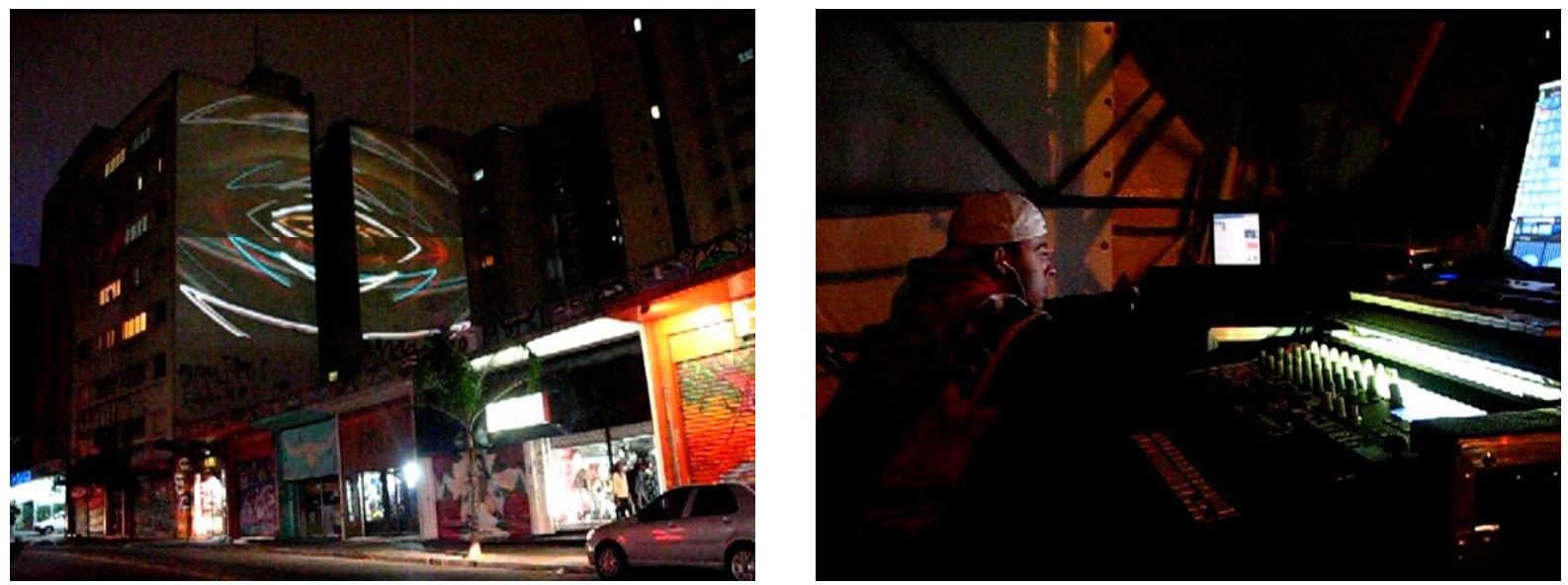

Figuras 543 e 544: Projeção de imagem edifício. Vídeo Guerrilha, 2011. Fonte: Registro fotográfico realizado pela pesquisadora.
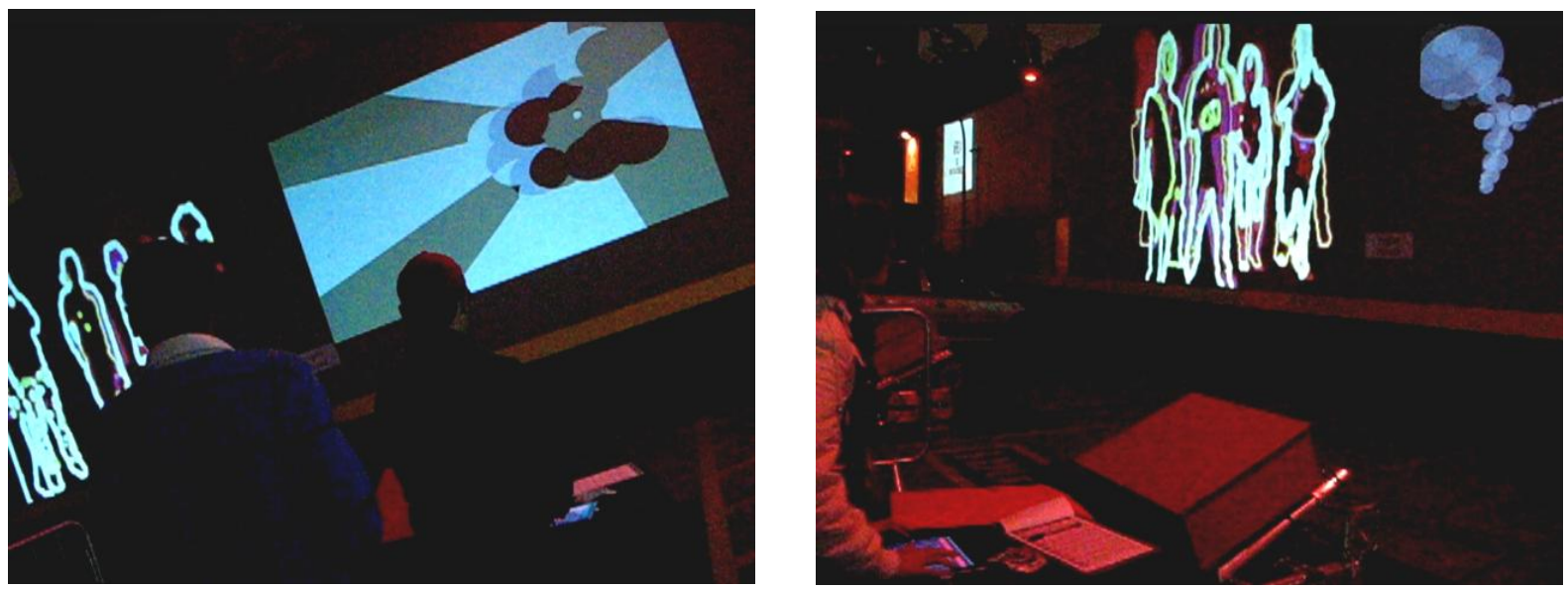

Figuras 545 e 546: Projeção interativa com uso de aplicativo Ipad: Touch OSC. Vídeo Guerrilha, 2011. Fonte: Registro fotográfico realizado pela pesquisadora.
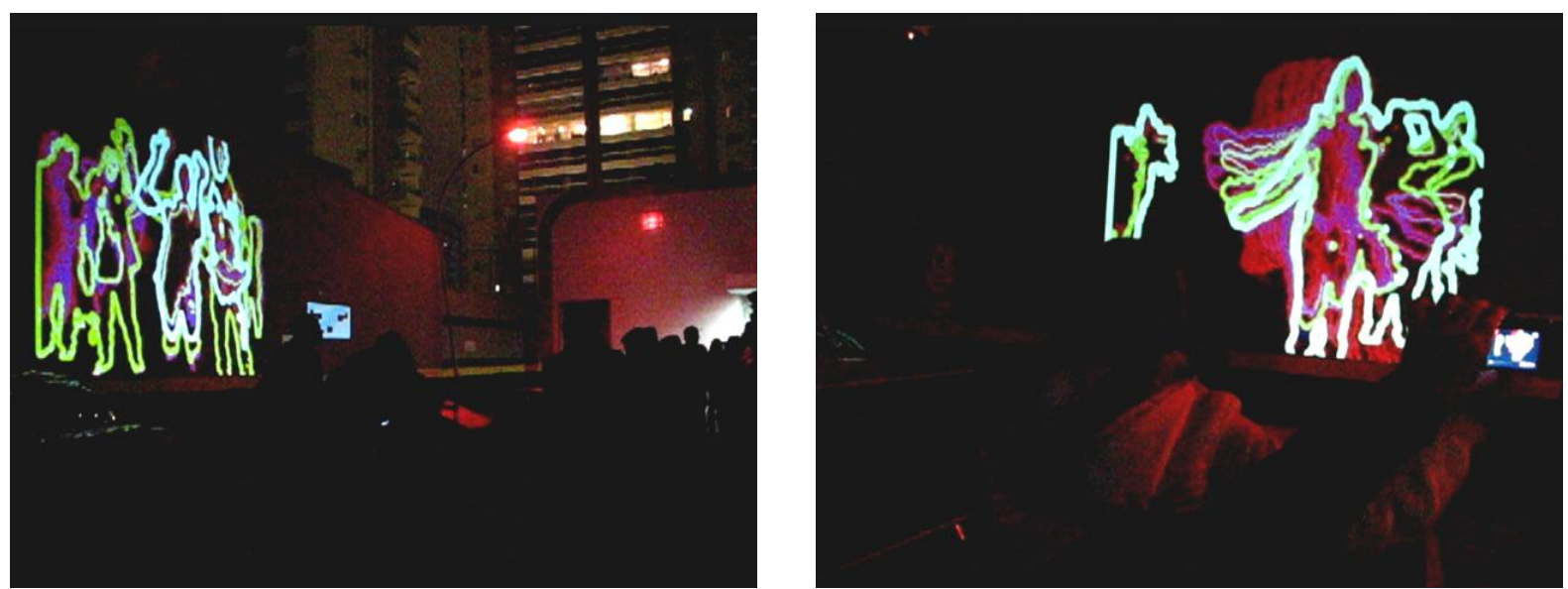

Figuras 547 e 548: Projeção interativa com uso de sensores de movimento. Vídeo Guerrilha, 2011. Fonte: Registro fotográfico realizado pela pesquisadora. 
Em Perceptum Mutantis (2011), exibida no Museu da Imagem e do Som de São Paulo, André Parente e Pedro Parente exibiram a instalação interativa: Trilhos Urbanos. O trabalho consistia em uma série de imagens fixas e panorâmicas gravadas a partir da janela de trens. À medida que os espectadores se deslocavam diante dessas imagens, provocavam uma anamorfose resultante do deslocamento da janela. Foi desenvolvida com uma versão específica do software Corisco.
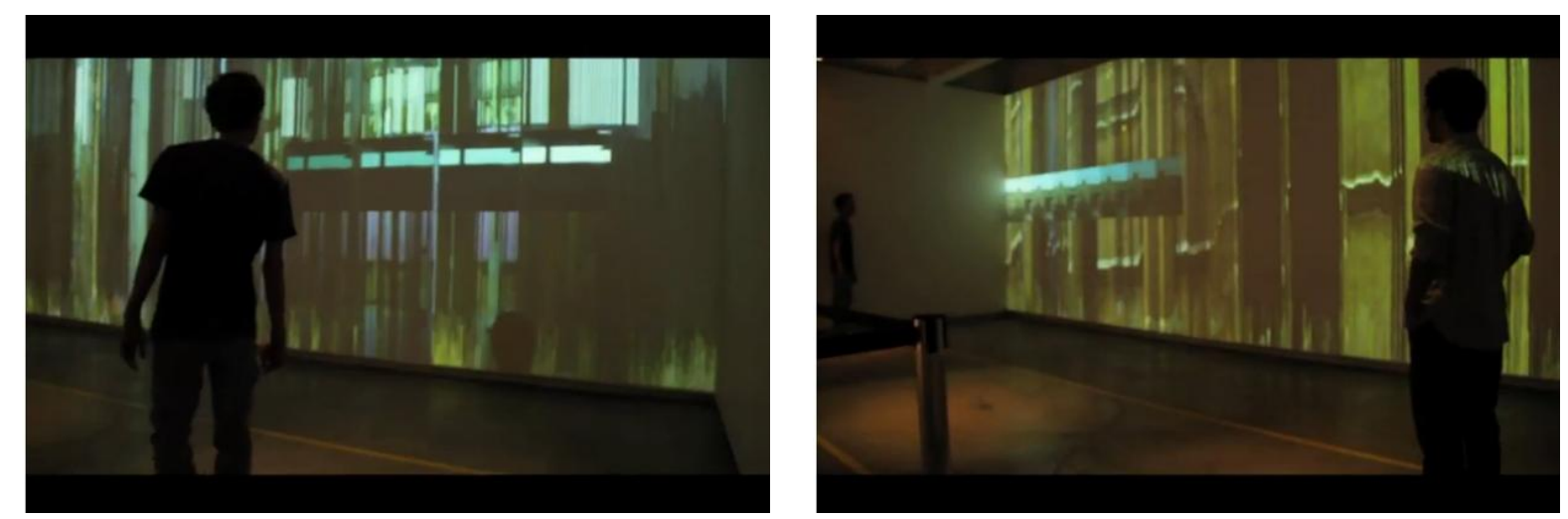

Figuras 549 e 550: Trilhos Urbanos, 2011. André Parente e Pedro Parente. Perceptum Mutantis, Museu da Imagem e do Som de São Paulo. Fonte: <http://vimeo.com/26044592>. Por André Parente. Acesso em $14 / 10 / 2011$

Em 2011, publicitários fizeram uso da técnica para a campanha de lançamento da série Planeta Humano, do Discovery Channel. O suporte para a exibição foi a fachada do Museu de Arte de São Paulo-MASP. A intervenção urbana foi produzida pelo estúdio Bijari. (CUEVA, 2011).

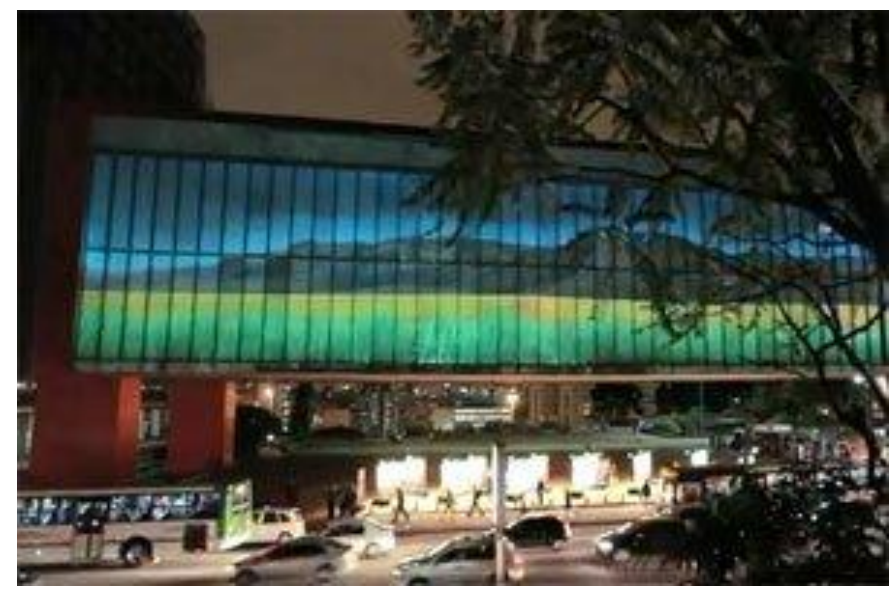

Figura 551: Videoprojeção. Fachada do Museu de Arte de São Paulo, 2011.

Fonte:<http://www.mangacom.com.br/site/at ualidades/acao-faz-parte-de-campanha-delancamento-da-producao-planeta-

humano.php>. Publicado em 10/05/2011 por Claudia L. Ramires Cueva. Acesso em 28/09/2011. 
Com referência em textos de diversos autores, BAMBOZZI, BASTOS e MINELLI, apresentam considerações em relação à realidade do audiovisual na era da portabilidade. A combinação de redes sem fio e aparelhos portáteis como os PDAs $^{108}$ e os telefones celulares, têm possibilitado que as linguagens audiovisuais passem por transformações ainda mais intensas, "textos, imagens e sons tornaramse ubíquos":

\begin{abstract}
Sons e imagens em movimento passam a fazer parte do cotidiano 'individual', intensificando um processo de audiovisualização da cultura que remonta aos anos 1980, com o aparecimento do videocassete e a crescente proliferação de tecnologias mais acessíveis de captura, transmissão e recepção de imagens. Esse processo leva à popularização de aparelhos de TV em espaços públicos, mas também à invasão de bancos, metrôs e universidades por câmeras de vigilância. No estágio atual, telefones celulares, iPods e os chamados sistemas locativos aproximam do corpo dados e imagens antes mais ligados ao espaço da cidade. De forma análoga, a produção individual ganha possibilidade de distribuição nos novos contornos públicos que se formam nas redes. Existem aspectos positivos e negativos nesse processo, no qual a democratização da mídia está próxima da vigilância e do cerceamento de liberdades individuais. (BAMBOZZI; BASTOS; MINELLI, 2010, p.21).
\end{abstract}

Em 1980, Robert Adrian utilizou “o I.P.Sharp” ('caixa postal' eletrônica, depois chamada de ARTEX), primeiro veículo que possibilitou o intercâmbio de informações à distância entre artistas através de sistemas de comunicação. Naquele mesmo ano, Paulo Bruscky (Recife) e Roberto Sandoval (São Paulo) foram os primeiros artistas a se comunicar via fax no Brasil. Carmela Gross, Leonora de Barros, Leon Ferrari, Mario Ramiro, Omar Khouri, Paulo Miranda, Paulo Laminski, Régis Bonvicino e Roberto Sandoval participaram do projeto Arte pelo Telefone (1982), no Museu da Imagem e do Som-MIS, coordenado por Julio Plaza, no qual foram exploradas as possibilidades criativas do videotexto. Em 1985, A exposição Arte: Novos Meios/Multimeios - Brasil 70/80, realizada em São Paulo, reuniu os projetos: FacSimilarte, de Paulo Bruscky e Roberto Sandoval, e Arte/Vídeo-texto, de Julio Plaza, com a participação de Alex Flemming, Alice Ruiz, Augusto de Campos, Carmela

\footnotetext{
108 "PDA (Personal Digital Assistant ou Assistente Pessoal Digital). Aparelhos portáteis que surgiram como formas sofisticadas de agenda e, conforme evoluíram, tornaram-se pequenos computadores de bolso. Permitem que seus usuários, a qualquer momento e em qualquer lugar, acessem e alterem as informações que armazenam. Geralmente, os PDAs comportam a instalação de softwares para a edição de texto, planilhas de cálculo e outros de uso cotidiano." (BAMBOZZI; BASTOS; MINELLI, 2010, p. 221).
} 
Gross, Leon Ferrari, Leonora de Barros, M. José Palo, Lucia Santanella, Monica Costa, Nina Moraes, Omar Khouri, Paulo Leminski e Paulo Miranda. Em Intercities: São Paulo/Pittsburgh (1988) foi promovido o intercâmbio de imagens via slow-scan. $O$ evento foi realizado pelo Instituto de Pesquisas em Arte e Tecnologia-IPAT, coordenado por Arthur Matuck em colaboração com Paulo Laurentiz, e pelo Digital Art Exchange-DAX da Universidade de Carnegie-Mellon, coordenado por Bruce Breland, em Pittsburgh. No ano seguinte, foram realizados: o Faxarte l, em intercâmbio entre a Escola de Comunicações e Artes-USP e o Instituto de ArtesUNICAMP, e o Faxarte II. O primeiro, coordenado por Arthur Matuck e Paulo Laurentiz, o segundo, por Arthur Matuck, Shirley Miki e Gilberto Prado com a participação de: Anna Barros, Lucia Fonseca, Marco do Valle, Milton Sogabe, Paulo Laurentiz, Rejane Cantoni e Regina Silveira. Em 1990, Sandra Kogut construiu Vídeo Cabines São Caixas Pretas. Tratavam-se de cabines para serem montadas em espaços públicos do Rio de Janeiro, onde o espectador podia fazer o que desejasse na frente da câmera. As cabines foram montadas em Tóquio, Paris, New York, Dakar e Moscou. As imagens registradas foram inseridas no vídeo Parabolic People onde a artista fez uso da "colagem e superposição simultânea de imagens para fazer um ensaio antropológico sobre as formas de comunicação planetária permitidas pelas redes de televisão." Em 1997, foram realizadas: a exposição Arte Suporte Computador, na Casa das Rosas, com curadoria de Lucas Bambozzi, onde foram apresentados trabalhos para a internet e a performance Time Capsule de autoria de Eduardo Kac e o Kino Trem, mencionado no Capítulo 2, como parte do projeto Intervenções Urbanas: Arte/Cidade III em que foi promovida a comunicação bilateral, móvel e ao vivo entre espaços expositivos e bairros próximos ao local do evento. Na exposição [re]distributions (2001), sob curadoria de Patrick Lichty, Giselle Beiguelman apresentou Wop Art, um dos primeiros trabalhos brasileiros concebidos para celular explorando a tecnologia WAP. O uso de celulares na produção artística também é explorada em Life Goes Mobile (2004), em São Paulo, com a participação de duVa, Lucia Koch, Helga Stein, Giselle Beiguelman, Spetto, Angelo Palumboe Izo Levin. Em 2006, iniciam os primeiros festivais de arte em mídias móveis: arte.mov, em Belo Horizonte, e Mobilefest, em São Paulo. (BAMBOZZI; BASTOS; MINELLI, 2010, p. 13-18).

Para os autores, na "cultura sem fio", aparelhos portáteis funcionam como "itens de consumo fashion, pequenas centrais de produção multimídia, como ferramentas de 
acesso e gerenciamento de informação ou como código, circulam por todo canto, nas mais variadas camadas sociais", inclusive do Brasil ${ }^{109}$. O avanço da portabilidade tem diminuído substancialmente os custos para a criação de filmes e vídeos, o que tem ampliado a produção doméstica. Associado a isso, a internet possui canais como o Vimeo, You Tube e Blinkx, que disponibilizam novas formas de indexação, interação e reedição. O site Ubuweb, tem uma área para filmes e vídeos. "O Archive.org, é um acervo de trabalhos de televisão, filmes educativos e vídeos independentes, todos em domínio público ou com licença open source." São trabalhos com perfil diferenciado daqueles dos circuitos tradicionais do cinema e da TV, apresentados em pequenas telas, com a possibilidade de serem visualizados em lugares claros, ruidosos, entrópicos, que não substituem as telas amplas, os ambientes escuros e imersivos tradicionais, no entanto, não deixam de ser relevantes por se tratar de uma alternativa ao modelo fechado das redes de TV. (BAMBOZZI; BASTOS; MINELLI, 2010, p. 21-29)

\footnotetext{
${ }^{109}$ De acordo com Bambozzi, Bastos e Minelli (2010, p.29): “(...) com a consolidação gradual das tecnologias 3D e a popularização dos smartphones e de aparelhos mais robustos, com capacidade efetivamente multimídia, o uso do celular como plataforma de navegação na internet torna-se recorrente. Em alguns países (caso do Brasil e de Angola), esse fator representa, aliás, uma possibilidade de oferecer acesso a camadas da população que dificilmente conseguiriam conectar-se à rede por meio de computadores pessoais. $O$ preço do celular é mais acessível. E o Brasil nunca superou por completo problemas de infraestrutura de telefonia e algumas defasagens tecnológicas decorrentes das reservas de mercado instituídas no país durante os anos de 1980. Ironicamente, em vez de políticas públicas, é o sucesso de um produto como o telefone celular que parece equalizar um pouco esse problema."
} 



\section{INTERVENÇÕES AMBIENTAIS EM ESTAÇÕES DE METRÔ NO ÂMBITO INTERNACIONAL: QUESTÕES DA ARTE CONTEMPORÂNEA}

Neste capítulo, direcionado à aplicação de tecnologias atuais em intervenções ambientais em estações de metrô do âmbito internacional, apresentaremos exemplos de aplicação do LED, da célula fotovoltaica, das mídias eletrônica e digital e da linguagem da projeção. A fotografia, embora não tenha sido abordada no estudo do capítulo 5 , será exemplificada por estar sendo intensamente aplicada em trabalhos de arte contemporânea apresentados em exposições nacionais e internacionais.

Adotamos como ponto de partida considerações sobre o Programa Art on the Underground, da Companhia de metrô de Londres: a London Underground-LU, totalmente direcionado às questões da arte contemporânea, alcançando exemplos práticos de intervenções na rede londrina e de outras localidades. Considerações a respeito das formas de atuar e de política cultural também serão realizadas, em especial, a adotada pelo Groupe RATP - Companhia de metrô, bonde e ônibus de Paris, pela inovadora "engenharia cultural" desenvolvida para ser aplicada desde a fase de concepção dos projetos de arquitetura, design e arte nas estações.

Reconhecida mundialmente, a London Underground-LU, tem sido um dos clientes mais consistentes no setor da arte pública e serve de referência para quase todos os outros sistemas ferroviários urbanos. É considerada pelo presidente do painel consultivo do Programa Platform for Art-PFA: Tim O'Toole, como "a própria vida da cidade de Londres". (DILLON, 2007, p.6, tradução nossa).

Segundo Coles, a história do programa "é apoiada na convicção de ir além dos limites da arte para o domínio do design para criar uma experiência visual integrada para o espectador." Dirigida, inicialmente, por Frank Pick, restringia-se aos elementos gráficos de sinalização. A partir de 1920, Pick começou a empregar artistas como Edward McKnight Kauffer, Man Ray, Paul Nash e Graham Sutherland na concepção de cartazes, o designer gráfico Edward Johnston na criação do estilo tipográfico da companhia, Harry Back no desenho do mapa da rede, incluindo arquitetos como Charles Holden para projetar as estações. "O resultado foi uma perfeita identidade visual, muitas vezes, referida como 'design total'." (COLES, 2007, 


\section{p.23-24, tradução nossa)}

Com início em 2000, o PFA, conhecido a partir de 2007 por Art on the Underground, é considerado "um canal através do qual a nova arte está sendo produzida para continuar uma conexão cultural contemporânea entre a LU e um contexto mais amplo". Com a visão de entregar um programa de nível mundial de projetos de arte contemporânea para o contexto do metrô de Londres, permanece com a incorporação integrada de áreas distintas de programação, as quais se enquadram em duas vertentes que, frequentemente, se sobrepõem: os grandes projetos de arte contemporânea e os projetos comunitários voltados à arte, ambos de caráter temporário. Este modo particular de atuar está diretamente relacionado às discussões recentes em torno da história da arte pública e comunitária.

Conceitualmente, ao considerar que o "movimento em direção da arte relacional, situada e mediada, tem a complexidade de um site para incluir sua história, sua população e sua função, bem como suas características físicas", (DILLON, 2007, p.10, tradução nossa)

(...) o desenvolvimento do programa e a abordagem de cada projeto são apoiados na compreensão de como a arte contemporânea evoluiu para se envolver com tal contexto. A localização da arte fora da galeria leva a uma reconsideração dos parâmetros que a definem, novas possibilidades de pensar sobre a relação entre arte e arquitetura, e as particularidades de outros contextos mais amplos são abertas. Neste sentido, as estratégias de curadoria buscam assegurar um envolvimento continuado com a crítica de arte contemporânea. (DILLON, 2007, p.15, tradução nossa)

Para Alex Coles:

A escolha do trabalho é um importante precursor do programa mas a história da arte site-specific com sua dimensão relacional contemporânea também é crucial. (...) O projeto não é nada se não for site-specific, uma vez que responde a um mandato específico destinado a uma finalidade específica. (COLES, 2007, p.23-24, tradução nossa).

A avaliação dos trabalhos é realizada em reuniões com membros da LU, da Transport For London, da Greater London Authority, de profissionais de arte, do prefeito e de outras organizações e agências como o Arts Council of England. Cada projeto gera um conjunto de desafios para negociar e, consequentemente, uma quantidade considerável de comissões temporárias ao longo da rede. Esse extenso e complexo espaço, regulamentado e gerido por uma organização 
exigente, dificulta para os artistas a oportunidade de desenvolver e de expor sua arte. Questões de comunicação, flexibilidade, segurança e conteúdo são consideradas de fundamental importância. Os suportes para apresentação de trabalhos encomendados são os mais diversificados: plataformas fora de uso, janelas vazias, mapas do metrô, trens, painéis, paredes vazias, folhetos, posters, cartões. As exposições de artistas internacionais e os projetos comunitários, envolvem a participação de funcionários da LU, usuários e partes interessadas. Parcerias são fundamentais para o sucesso de muitos projetos e permitem a criação de um complexo de obras novas.

Atualmente, a rede tem passado pelo maior programa de investimento voltado à sua modernização. Como parte integrante desse programa, serão desenvolvidas obras de arte permanentes que

\begin{abstract}
vão sustentar um elemento cultural importante dentro desse processo (...) contribuindo para o desenvolvimento da sua distinta identidade cultural, melhorando a qualidade das viagens e engajando seus passageiros para estabelecer um forte senso de propriedade compartilhada. O processo de produção de novas obras de arte permanente, irá compartilhar os mesmos ideais de excelência e de reflexão da arte contemporânea dos projetos temporários. A diferença será na criação de novos marcos que pontuem e melhorem as viagens de milhões de pessoas. Estas áreas distintas da programação servirão para atingir os mesmos objetivos gerais, para trazer a grande arte para 0 público viajante e fazer contribuições significativas aos bens culturais de Londres para um legado duradouro. (DILLON, 2007, p.15, tradução nossa)
\end{abstract}

De modo geral, o PFA busca centrar-se em projetos que tenham uma variedade de formatos e que envolva uma grande diversidade de pessoas. Os usuários são incentivados a se envolver com o programa de diversas formas: através de oportunidades para participar de negociações com artistas e eventos, respondendo aos projetos e enviando sugestões para o site do PFA. (DILLON, 2007, p.13).

A parceria com galerias e museus é prática comum no programa de arte local. Em uma ação conjunta da Billboard Commission do metrô de Londres com a Serpentine Gallery, no ano de 2003, foi apresentado na Estação Gloucester Road o trabalho de Cindy Sherman. A exposição na estação ocorreu simultaneamente à exposição da artista na galeria. Segundo o site do metrô, foi a primeira experiência com o "objetivo fundamental de fazer links com galerias e outras instituições culturais". O trabalho, concebido e produzido em colaboração com a galeria, foi inserido em uma 
plataforma desativada que ocupa toda a extensão da estação, o que exigiu uma produção de arte em que a escala foi fator fundamental para que a obra causasse impacto. Dez fotografias ampliadas da própria artista disfarçada foram colocadas sobre um fundo cinza. Tratava-se de versões de obras produzidas no período de 1983 a $2000^{110}$. Segundo o curador Tamsin Dillon, o diálogo entre artista, galeria e público e a resposta da mídia ao projeto de arte no metrô foram fundamentais para que o programa se fortalecesse e ganhasse reputação. (DILLON, 2007, p.10-11).
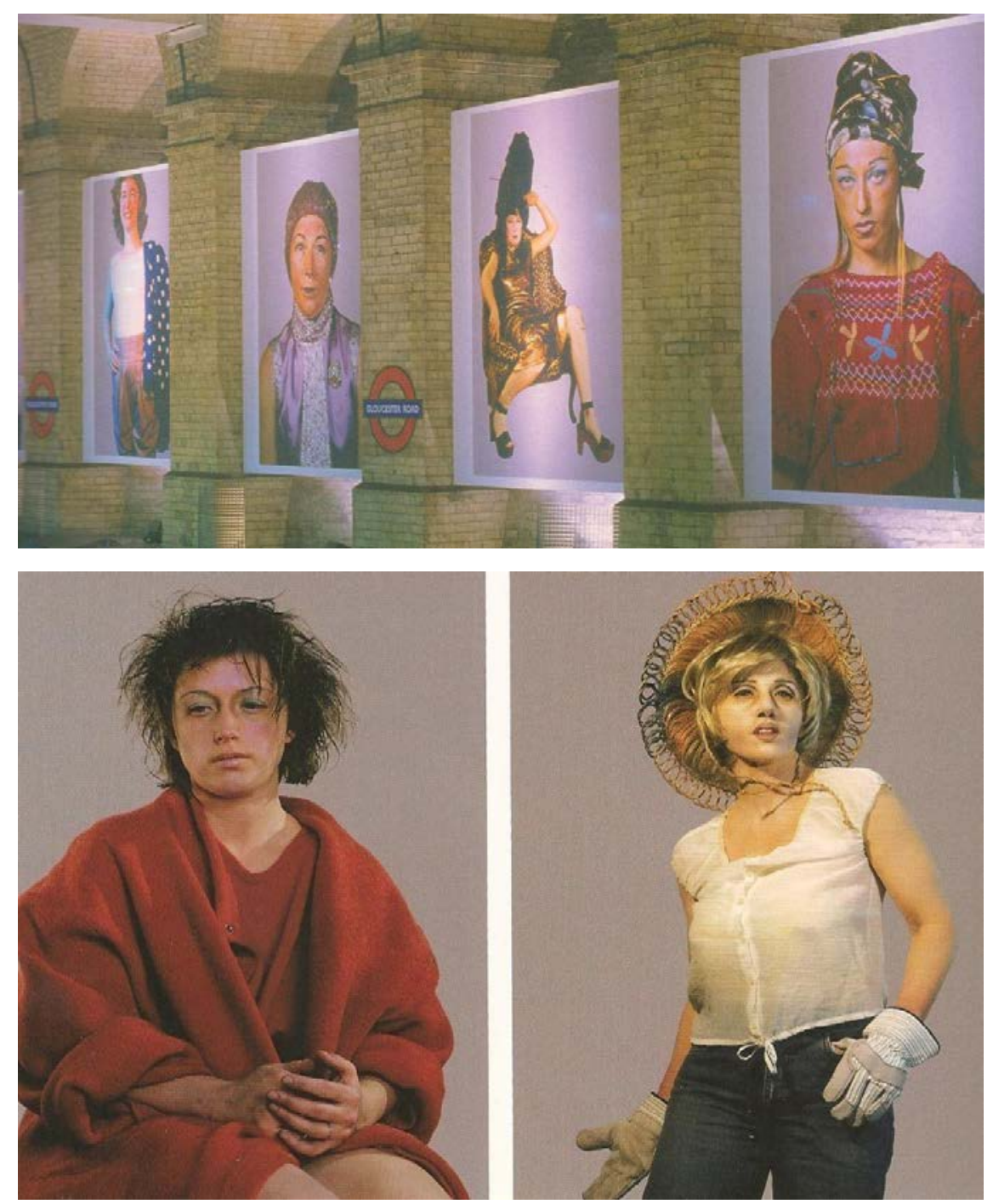

Figura 552: Cindy Sherman, 2003. Fonte: DILLON, 2007, p.81.

Figuras 553 e 554: Cindy Sherman, 2003. Fonte: DILLON, 2007, p.80.

\footnotetext{
${ }^{110}$ Desde meados dos anos 1970, Sherman atua como diretora, fotógrafa e atriz para criar imagens provocativas e intrigantes. "A adoção de uma série de papéis e disfarces, explora e expõe imagens bem definidas e os estereótipos das mulheres na sociedade ocidental ao longo da história." (ART.TFL.GOV.UK, 2003, tradução nossa).
} 
Para a execução de Ten Silhouettes (2005), David Bachelor também adotou como site a plataforma desativada da Estação Gloucester Road. Nichos em forma de arco abrigaram dez estruturas de aço reciclado e alumínio, suspensas e iluminadas por trás. Silhuetas escuras, de diferentes tamanhos e formas, envoltas por um halo de cor, preencheram os nichos. Parte dessas estruturas foram confeccionadas a partir da sucata da própria rede de metrô. $O$ trabalho foi uma extensão da produção do artista que, ao longo de dez anos, analisou cores características e materiais associados ao ambiente urbano. (DILLON, 2007, p.71).

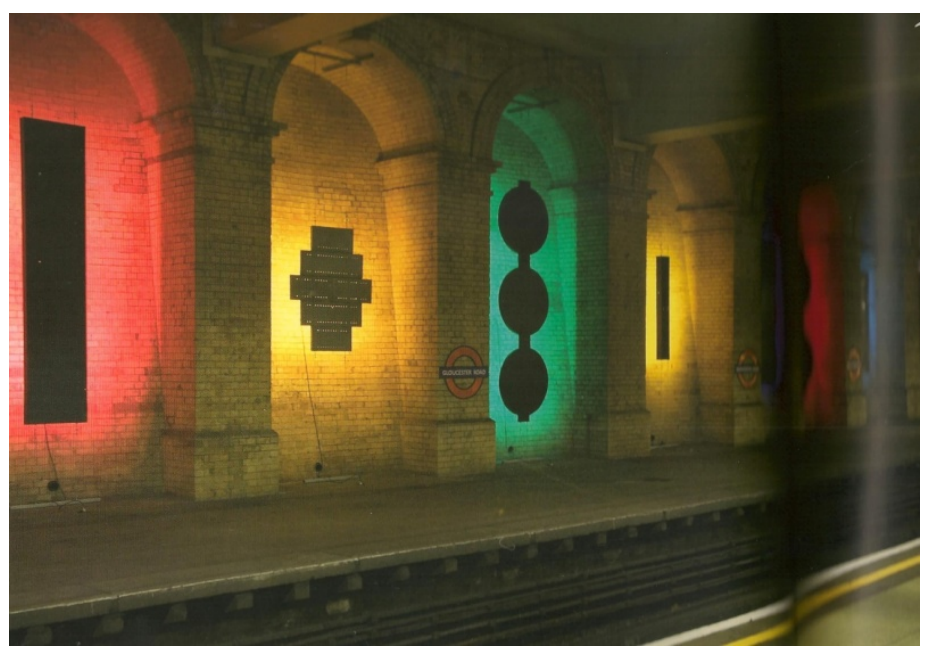

Figura 555: Ten Silhouettes, 2005. David Bachelor. Fonte: DILLON, 2007, p.71-72.

Bill Fontana ${ }^{111}$, em Harmonic Bridge (2006), explorou o elemento som através de uma rede de dispositivos de gravação chamados acelerômetros, colocados em diversos pontos da ponte Millenium de Londres. Vibrações dos peões e das condições meteorológicas locais foram registradas e transmitidas, simultaneamente, no saguão intermediário da Estação Southwark e na Tate Modern Turbine Hall, revelando a musicalidade presente na estrutura. Uma "escultura acústica" que reproduzia sons em alto-falantes, especialmente projetados. (DILLON, 2007, p.125, tradução nossa).

\footnotetext{
${ }^{111}$ Bill Fontana é conhecido internacionalmente por suas experiências pioneiras em arte sonora. $\mathrm{O}$ artista tem interesse em "usar o ambiente urbano como uma fonte viva de informação musical, e no potencial de suas qualidades de evocar imagens visuais na mente do ouvinte." Desde 1970, desenvolve instalações sonoras sitespecific. (DILLON, 2007, p.125, tradução nossa).
} 


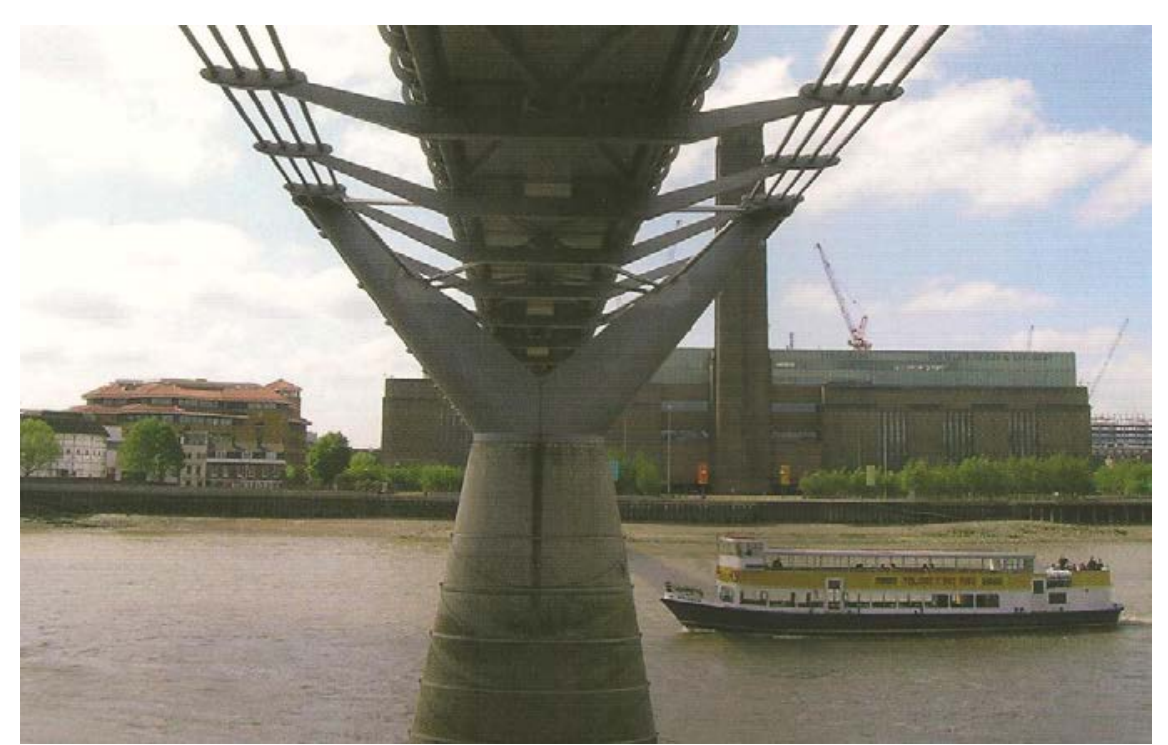

Figura 556: Harmonic Bridge, 2006. Bill Fontana. Fonte: DILLON, 2007, p.125 (imagem cedida pelo artista)

No Projeto Thin Cities ${ }^{112}$ (2007), desenvolvido para comemorar os 100 anos da Linha Piccadilly, Rut Blees Luxemburgo foi contratada para produzir fotografias. $O$ trabalho resultou na série: Piccadilly's Peccadilloes. Tratava-se de registros de detalhes das fachadas de doze estações clássicas desenhadas por Charles Holden. Cada imagem focalizava fragmentos refletidos em superfícies molhadas de poças d'água. Desta forma, a artista buscou "momentos em que camadas de história são reveladas na forma arquitetônica" (DILLON, 2007, p.109). As imagens foram exibidas em vinte e quatro impressões, em grande escala, que circundaram a bilheteria da Estação Heathrow Terminal 4. A artista reforça que o trabalho não se tratava de uma concepção de site literal ou funcional, mas de uma ficção. (DILLON, 2007, p.37, tradução nossa).

\footnotetext{
112 O centenário da linha Piccadilly levou a uma nova iniciativa importante: Thin Cities, para os quais artistas emergentes e de renome internacional foram contratados para fazer trabalhos ao longo da linha durante 0 ano. Este ambicioso projeto foi concebido para ser realizado em grande escala, o que exigiu a entrada de uma equipe temporária maior. Gavin Wade, foi o curador convidado para integrar a equipe. O ponto de partida foi o livro de Italo Calvino: Cidades Invisíveis. Foi aprovado um tema coerente para o projeto e mais de 20 novas obras foram encomendadas e apresentadas na linha, em 2007. (DILLON, 2007, p.12).
} 


\section{Segundo Rut Blees Luxemburg:}

I wanted to develop a project that might approach the complexity of the site itself and I felt that ficcion was a strong way of dealing with this. Foregrounding fiction would, I hope, begin to set out the very different ways that people who use the line could perceive the same connected world... I see Calvino's fiction of Marco Polo's storytelling as a way of both romanticizing the journey of a Piccadilly line traveler - as an explorer - and of potentially highlighting a sense of how you as an individual impress upon any given situation your own fiction of the world.

So Wade's conception of the notion of the site is neither literal or functional: it is fictional. (DILLON, 2007, p.37).

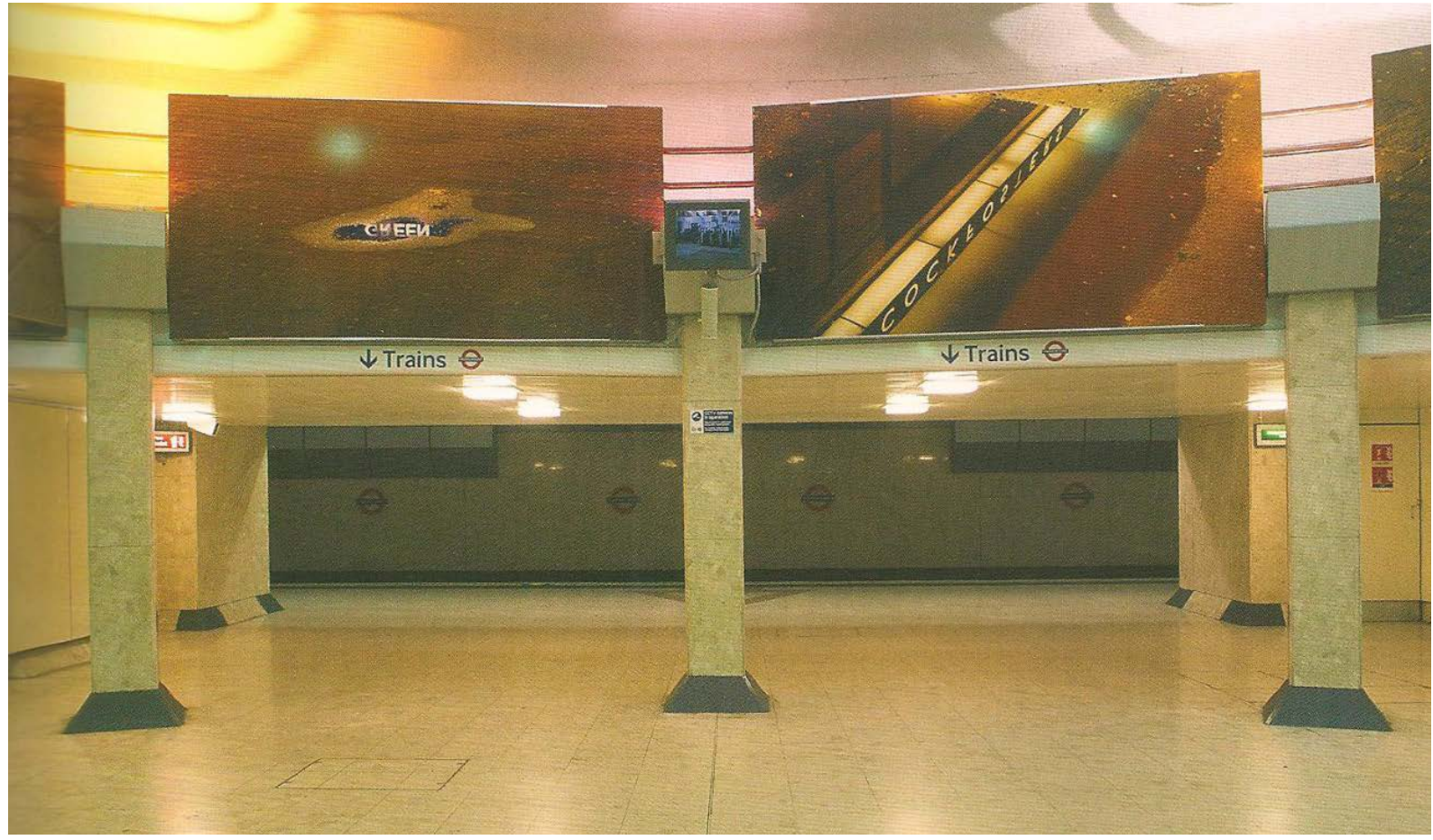

Figura 557: Detalhe da instalação Piccadilly's Peccadilloes, no Heathrow Terminal 4, 2007. Rut Blees Luxemburg. Foto de Andy Keate. Fonte: DILLON, 2007, p. 37. 

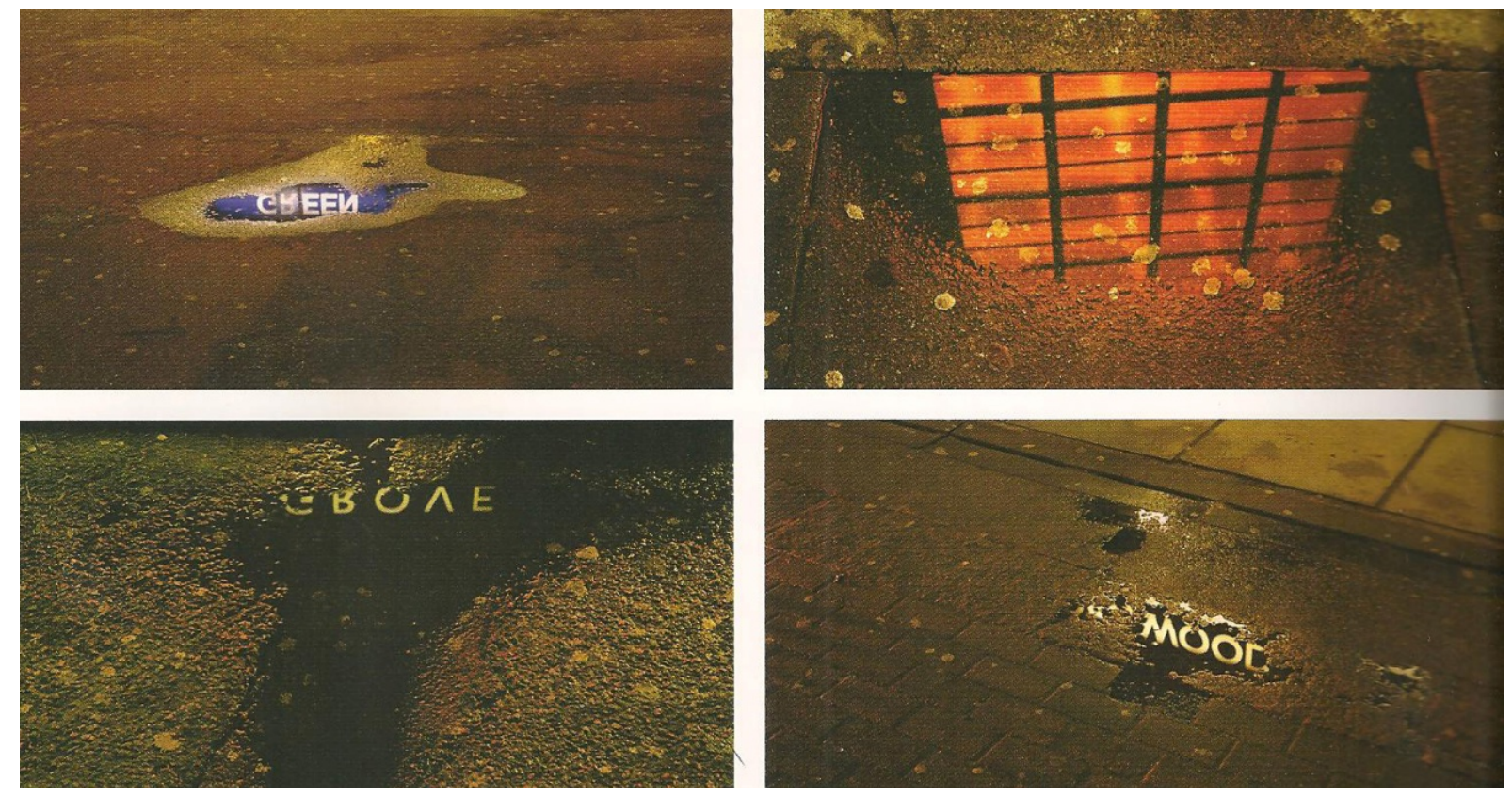

Figura 558, 559 ,560 e 561: Detalhe da instalação Piccadilly’s Peccadilloes, no Heathrow Terminal 4, 2007. Rut Blees Luxemburg. Fotos de Rut Blees Luxemburg e da London Underground. Fonte: DILLON, 2007, p.38.

Sob curadoria de Sally Shaw, a projeção digital Oil Stick Work (Angelo Martinez/Richfield, Kansas) ${ }^{113}$, de 2008, foi um dos trabalhos de arte contemporânea encomendados pelo Programa Art on the Underground ao artista irlandês John Gerrard, para a Estação Canary Wharf, da Linha Jubilee. A obra, criada para se desenvolver em tempo real, durante o período de 30 anos, apresenta a vista de um silo industrial de grãos, situado em um campo aberto. Também faz parte da obra uma figura humana digitalmente reconfigurada no trabalho: Angelo Martinez. Ele chega para trabalhar todos os dias ao amanhecer e parte ao pôr do sol. Sua tarefa diária é pintar um metro quadrado na fachada do silo com uma oil stick. Ao longo dos 30 anos, irá pintar o prédio inteiro de preto até formar uma silhueta no centro da paisagem. (E-FLUX.COM, 2010) Para sua construção, a partir de fotografias digitais e topografias coletadas de uma paisagem existente, mapeadas e reconstruídas em 3D, foi usado um software personalizado de design de games que possibilita a projeção da imagem em um movimento complexo (ART.TFL.GOV.UK, 2010). Para sua exibição, foi instalada uma superfície de $12 \mathrm{~m} x$ 8m. O trabalho foi patrocinado por Eventos XL. (APENGINE.ORG, 2010).

\footnotetext{
113 Instalado sob o vasto complexo financeiro de Canary Wharf, "oferece uma partida em uma paisagem que incentiva uma meditação sobre o trabalho, materiais e tempo. Visitantes e passageiros são convidados pelo Arte no Metrô a testemunhar o progresso gradual e diário do trabalho ao longo do ano em que está instalado na estação." (E-FLUX.COM, 2010, tradução nossa).
} 

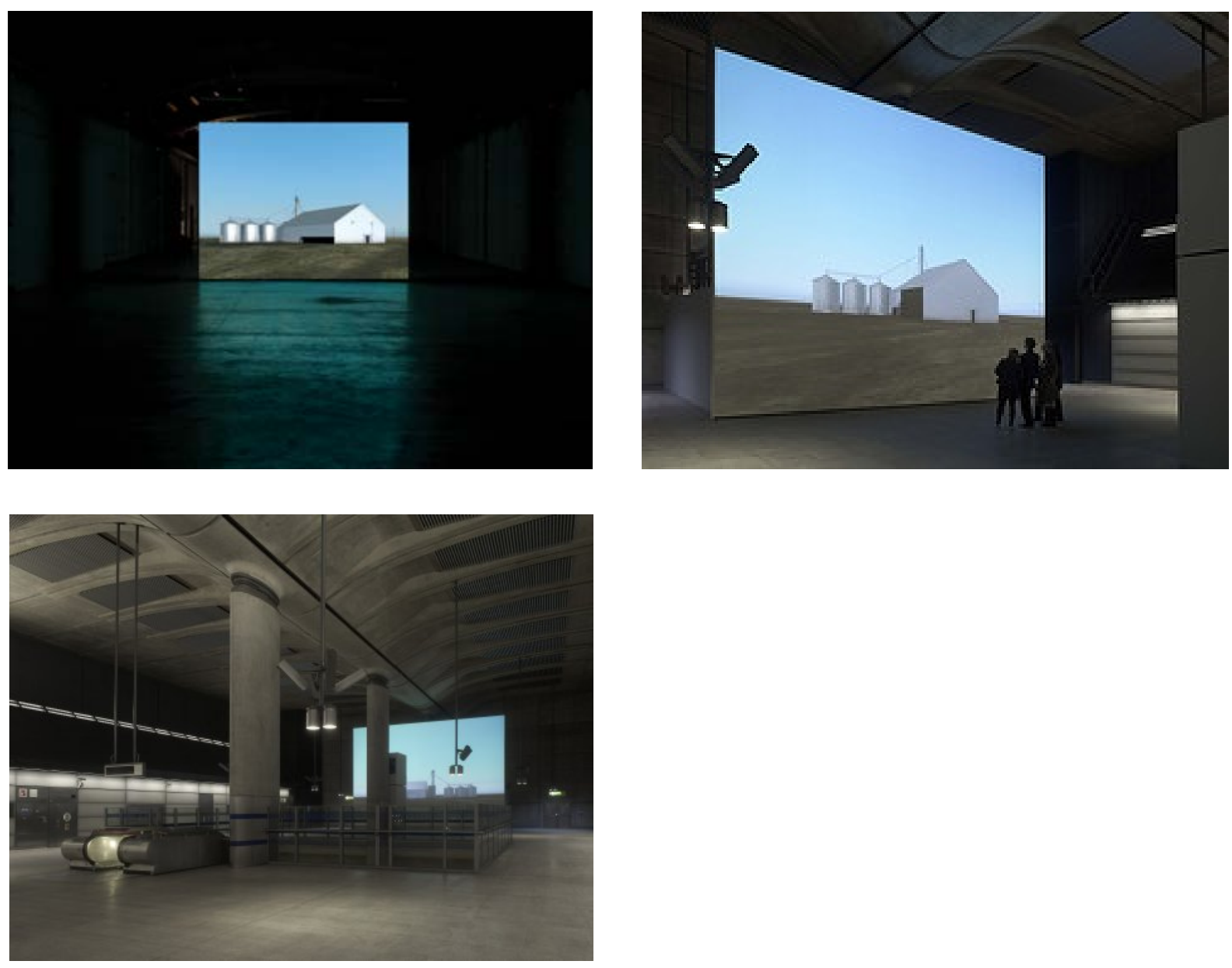

Figura 562: Oil Stick Work (Angelo Martinez, Richfield, Kansas) 2008. John Gerrard. Estação Canary Wharf. Fonte: <http://www.tfl.gov.uk / arte>. Postado em 11/05/2010. Acesso em 07/09/2011.

Figura 563 : Oil Stick Work (Angelo Martinez, Richfield, Kansas) 2008. John Gerrard. Estação Canary Wharf. Foto de Andy Keate. Galeria de Art on the Underground. Fonte: em: <http://www.flickr.com/photos/aotu/with/5267837153/>. Postado em 17/12/2010. Acesso em 11/09/2011.

Figura 564: Oil Stick Work (Angelo Martinez, Richfield, Kansas) 2008. John Gerrard. Estação Canary Wharf. Foto de Andy Keate. Galeria de Art on the Underground. Fonte: <http://www.flickr.com/photos/aotu/with/5267837153/>. Postado em 17/12/2010. Acesso em 11/09/2011.

Como exemplo de obras temporárias resultantes de projetos comunitários desenvolvidos em parceria com colégios e com funcionários da rede estão: Motion e Priceless, respectivamente. Motion (2005), de autoria de Martin Barron, aluno da escola de arte Wimbledon College of Art, tratava-se de uma reprodução fotográfica, em escala ampliada, de uma imagem desconstruída. A instalação, que respondeu ao tema "movimento", ocupou os espaços vazios da janela de uma unidade de varejo envolvendo a frente e a lateral da Estação Wimbledon. 

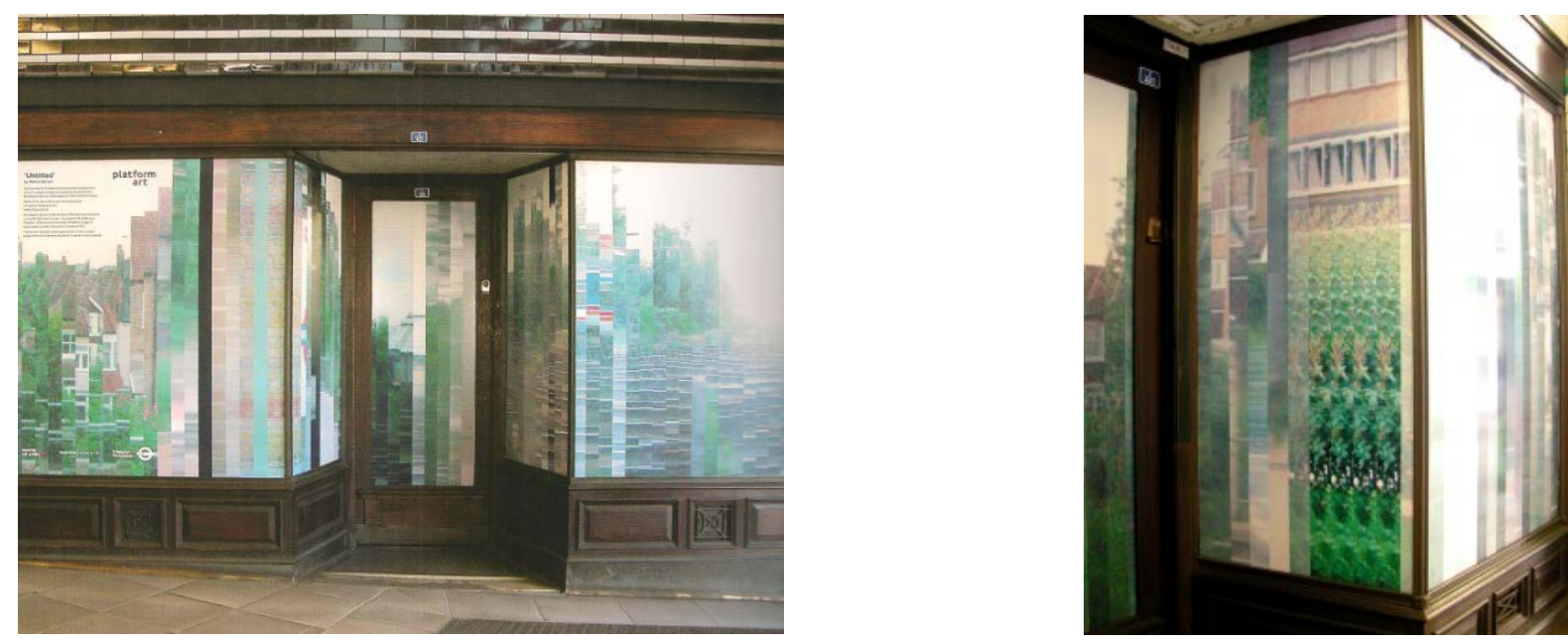

Figura 565: Motion, 2005. Estação Wimbledon. Martin Barron. Fonte: DILLON, 2007, p.156.

Figura 566: Motion, 2005. Detalhe. Fonte: <http://art.tfl.gov.uk/project/1293/\#1>. Acesso em 26/05/12.

Priceless (2006), foi uma iniciativa liderada pela Serpentine Gallery, em parceria com - Exhibition Road Cultural Group-ERCG e com o grupo de artistas Motiroti. ${ }^{114} \mathrm{O}$ trabalho, realizado na Estação South Kensington, com a participação de funcionários do metrô, foi exibido como parte de um programa de grande escala, desenvolvido dentro das organizações do ERCG, que incluiu outras instituições: Goethe Institute de Londres, Imperial College, Museum of Natural History, Royal of Art College, Royal Geographical Society, Royal Parks, Serpentine Gallery e Science Museum and V\&A. A ideia foi explorar as redes sociais e as conexões pessoais da equipe do metrô. As informações dos participantes, gravadas pelos artistas em vídeo, som e textos, foram traduzidas em uma série de cartazes e mapas, distribuídos em paredes e piso.

\footnotetext{
${ }^{114}$ Motiroti é um grupo de artistas, fundado por Ali Khan Zaidi e Keith, que suporta grupos existentes de pequeno e grande porte para criar projetos de arte personalizada que "excitam a imaginação, examinam os valores culturais e precipitam mudanças". O grupo Incentiva e apoia o trabalho de novos artistas e "amplia os limites da nova tecnologia". (DILLON, 2007, p.152, tradução nossa).
} 

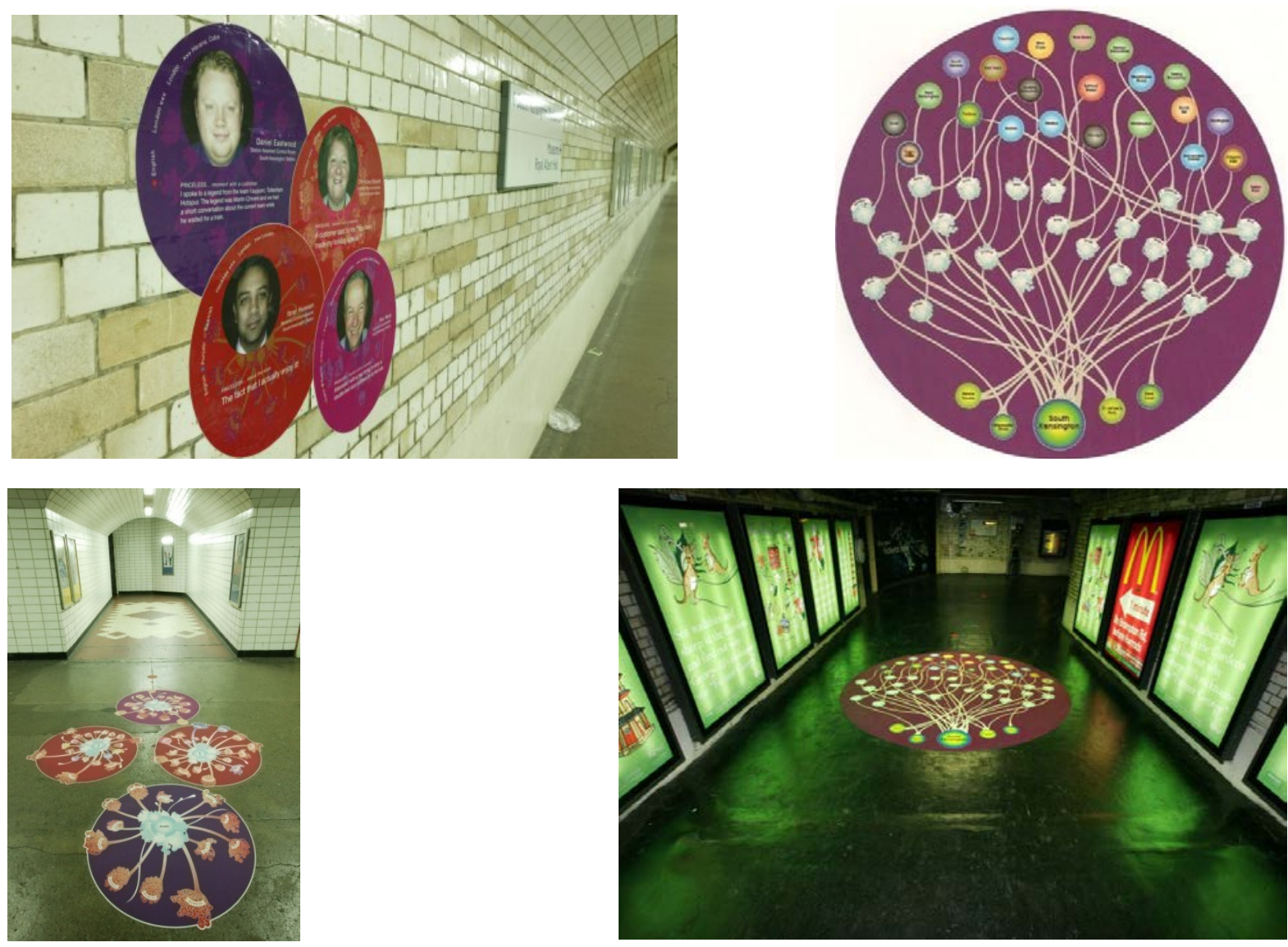

Figura 567: Priceless, 2006. Motiroti. Fonte: <http://art.tfl.gov.uk/project/1277/\#15>. Acesso em 26/05/12. Figura 568: Priceless, 2006. Motiroti. Fonte: DILLON, 2007, p.152.

Figura 569: Priceless, 2006. Motiroti. Fonte: <http://art.tfl.gov.uk/project/1277/\#15>. Acesso em 26/05/12. Figura 570: Priceless, 2006. Motiroti. Fonte: <http://art.tfl.gov.uk/project/1277/\#15>. Acesso em 26/05/12.

Em New York, na década de 1980, juntamente com o programa de reabilitação das centenárias estações de metrô e de trens urbanos foi criado o programa de arte pública: MTA (Metropolitan Transportation Authority) Arts for Transit commissions, para supervisionar a seleção de artistas e a instalação de obras de arte permanente. Parte dos fundos aplicados na renovação e no restauro das estações são direcionados à instalação de obras de arte permanente, à preservação das obras mais antigas e à introdução de trabalhos de design como posters (Transit Poster Program, 1998) e cartões (Transit Card Program, 1999) ${ }^{115}$. O programa também engloba o Music Under New York e o Lightbox Project.

\footnotetext{
${ }^{115}$ Os posters são exibidos aleatoriamente no espaço publicitário não usado nas plataformas ao longo das 468 estações de metrô. Os cartões são exibidos no interior dos vagões. Ambos são disponibilizados para venda nas lojas do New York Transit Museum. (MTA.INFO, 2012).
} 
O processo de análise e seleção dos artistas é realizado por profissionais das artes visuais e por representantes da comunidade. Gestores do programa realizam, constantemente, pesquisas para identificar os artistas a serem considerados e, posteriormente, convidados. Registros do Percent for Art Slide Registry of the City's Department of Cultural Affairs são utilizados no processo de identificação. Arquitetos e engenheiros determinam os parâmetros e o local em que a obra artística poderá ser incorporada, seguindo a programação de renovação da estação. Os projetos são desenvolvidos a partir do envolvimento da vizinhança com a história da arquitetura e do design no contexto de cada estação. Os materiais utilizados são diversificados: mosaico de vidro, cerâmica, metais, vidro facetado e mixed-media sculpture. Paredes, portas, praças e a própria arquitetura servem como suporte para as intervenções. (MTA.INFO, 2012).

Em uma ação integrada entre profissionais da arquitetura e das artes visuais, no projeto de renovação da Estação West 8th Street-New York Aquarium, o arquiteto Jim McConnell da Daniel Frankfurt, teve como colaborador o artista Vito Acconci. A partir de elementos de referência locais adotados pelo arquiteto: o histórico Coney Island Boardwalk, a montanha-russa Cyclone, o aquário ao lado da estação e as praias, Acconci desenvolveu para a fachada a proposta da Wavewall (2005), em que os novos para-brisas possibilitam a visão do Oceano Atlântico. Na concepção do artista: "Os tubos de aço normalmente horizontais e verticais dos para-brisas e painéis foram transformados em uma forma mais sinuosa que evoca a noção de uma onda, ou do movimento do Cyclone ou do metrô em si." (MTA.INFO, 2012, tradução nossa). 


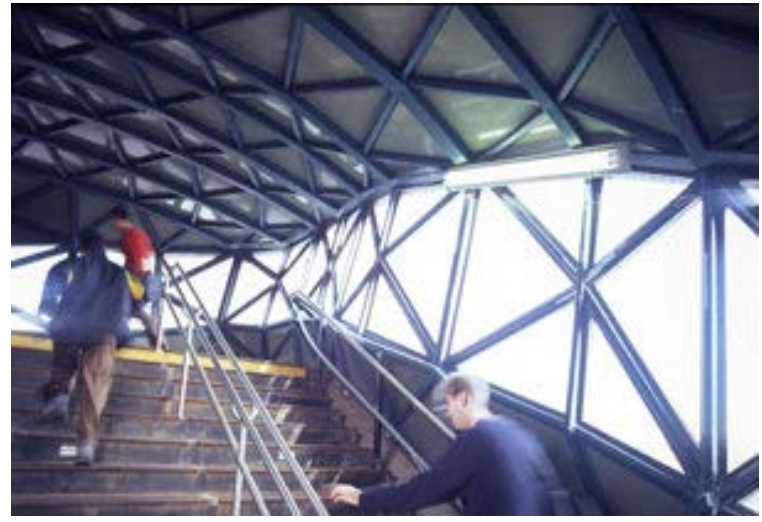

Figuras 571 e 572 : Wavewall, http://mta info/mta/aft/permanentart/permart html?agency=nyct\&/i 17/05/2012.

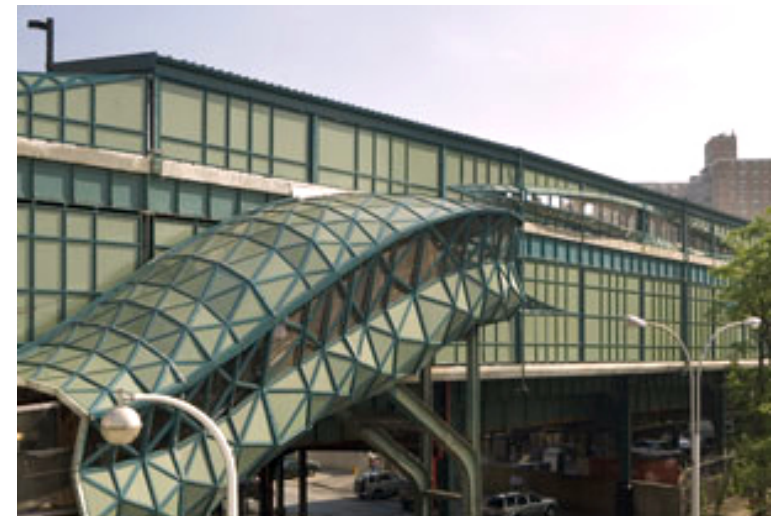

2005, Vito $=21>$. Acesso em

Exposições temporárias também são realizadas nas estações através de parcerias com outras instituições. Union Square in Motion foi uma instalação de arte interativa que exibiu nove conjuntos de imagens abstratas e orgânicas, com temas criados por seis estudantes da Parsons The New School of Design: Jeanne Kelly, Hilal Koyuncu, Rose Maison, Umut Ozover, Josefina Santos e Vigília Aqi, sob orientação de Anezka Sebek e Josué Spodek. A obra, que só pode ser visualizada com o movimento dos usuários/espectadores, aparece através de um zootrópio digital onde uma série de imagens fixas, que diferem umas das outras de maneira sutil, criam a aparência de uma animação quando vistas por um espectador em movimento. Instalada em janelas de uma área não paga da estação, é considerada uma forma digitalizada da tecnologia utilizada na obra Masstransiscope, um mural animado pelo movimento dos comboios, de autoria do videoartista Bill Band, instalada em 1980 em um túnel de metrô de New York como um projeto de arte pública permanente, que após 20 anos de abandono foi restaurada pelo MTA Arts for Transit. (MTA.INFO, 2012; KENNEDY, 2008, tradução nossa). 

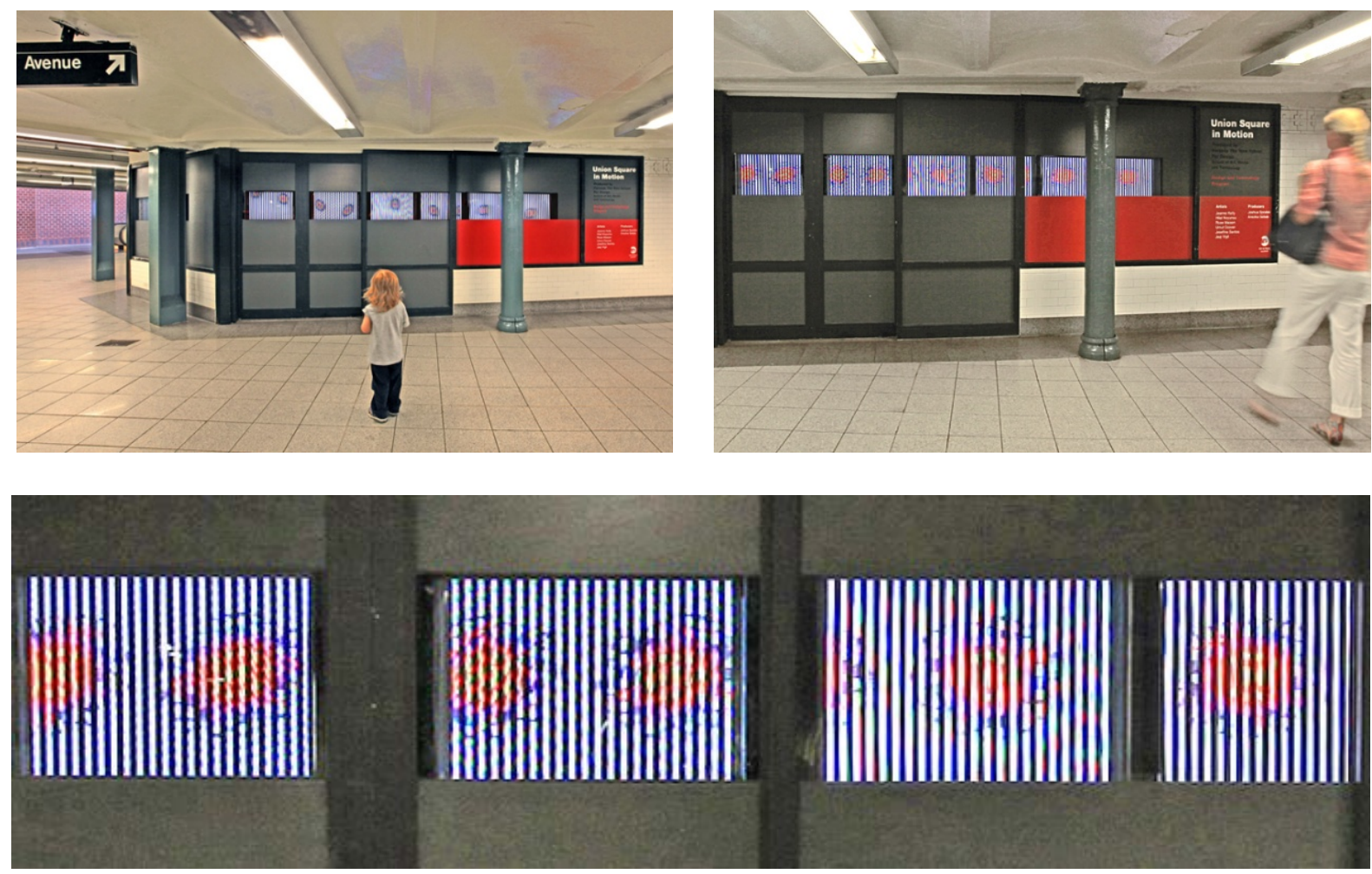

Figura 573: Union Square in Motion. Fonte:<http://mta.info/mta/aft/lightbox/lightbox.html?station=5\&img=1>. Acesso em 17/05/2012.

Figura 574: Union Square in Motion. Fonte:<http://mta.info/mta/aft/lightbox/lightbox.html?station=5\&img=3>. Acesso em 17/05/2012.

Figura 575: Union Square in Motion. Fonte: <http://mta.info/mta/aft/lightbox/lightbox.html?station=5\&img=5>. Acesso em 17/05/2012.

Em março de 2009, o Museum of Art Modern-MoMA exibiu a reprodução em escala ampliada de seu acervo de arte moderna e contemporânea na Estação Atlantic Avenue/Pacific Street, no Brooklyn. A instalação MoMA Atlantic/Pacific, teve como objetivo "ampliar a conscientização do acervo do MoMA e transmitir os benefícios acessíveis de adesão a locais públicos de New York." Foram aproximadamente 58 reproduções de imagens icônicas que incluíram trabalhos do campo das artes plásticas, da arquitetura, do design e 'media works'"116. (ARTKNOWLEDGENEWS.COM, 2011, tradução nossa). Mesas de luz iluminadas por dentro, de aproximadamente $45 \times 66$ polegadas: as lightbox, foram utilizadas para expor as reproduções fotográficas.

\footnotetext{
${ }^{116}$ Dentre as reproduções exibidas estavam: Les Demoiselles d'Avignon (Pablo Picasso), A Noite Estrelada (Vincent van Gogh), Nuvens refletidas sobre a água da lagoa Lily (Claude Monet), Roda de bicicleta (Marcel Duchamp), latas de Sopa Campbell (Andy Warhol). Cartazes de desenhos de Ed Ruscha, fotografias de Cindy Sherman, Nan Goldin, Andreas Gursky. Desenhos arquitetônicos de Frank Lloyd Wright e Mies van der Rohe, objetos de design de Charles e Ray Eames e William Morris. "Media works" de Doug Aitken, Pipilotti Rist, e Bruce Nauman. (ARTKNOWLEDGENEWS.COM, 2011).
} 


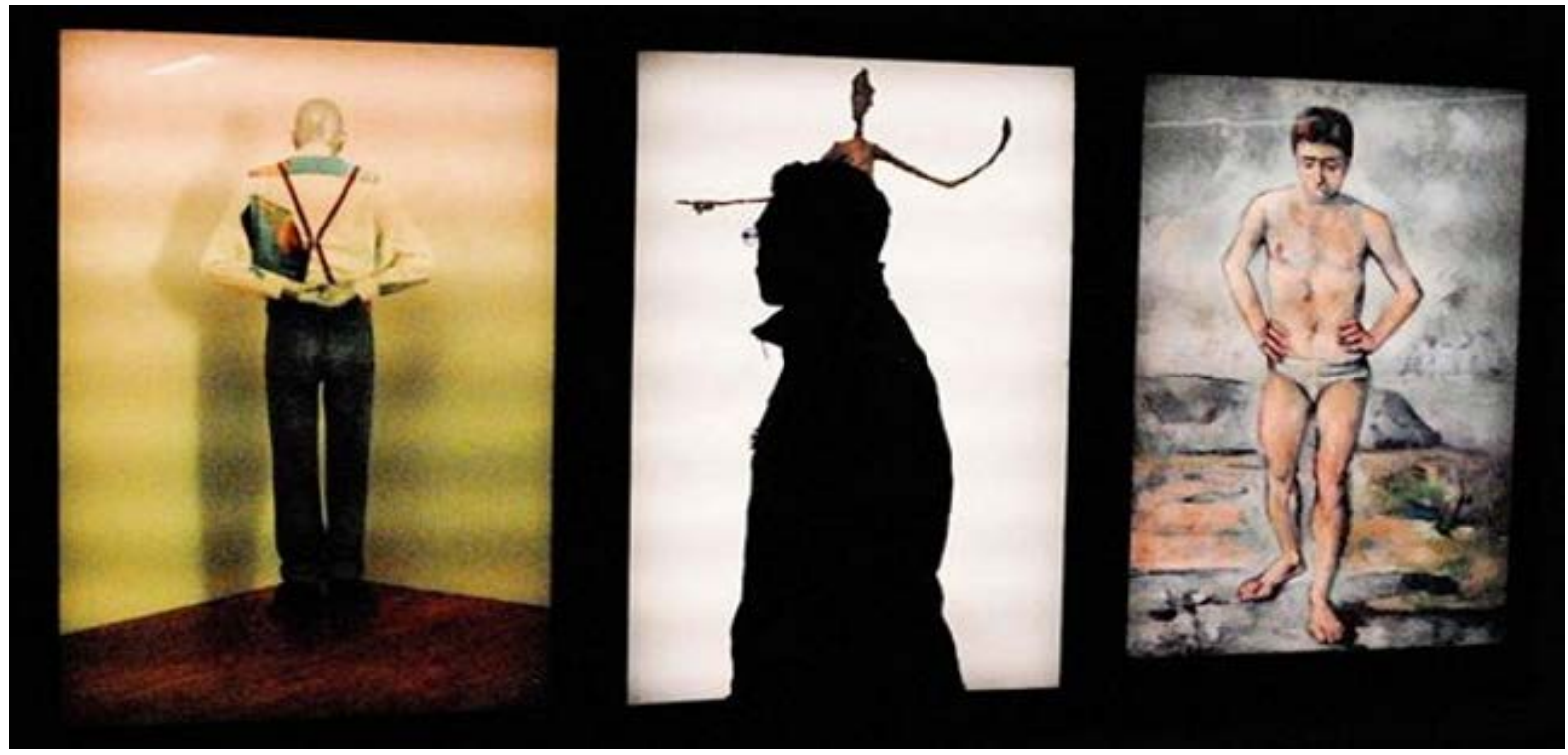

Figura 576: Lightbox. Fonte: MoMA Displays Iconic Reproductions at NYC Subway Station. Fonte: $<$ http://www.artknowledgenews.com/momaatlanticpacificprojecthtml.html>. Escrito por Ricky Vermont domingo 27 fevereiro, 2011. Foto de Jeff Baxter, 2008. The Museum of Art Modern. Acesso em 28/08/2011.
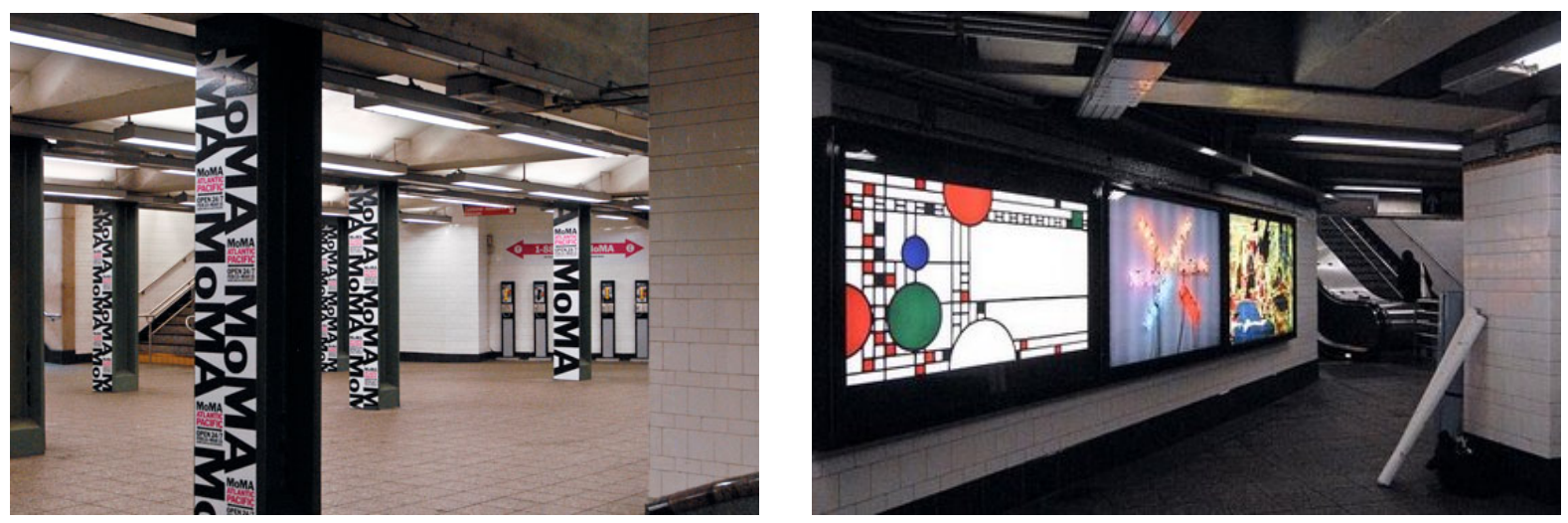

Figura 577: MoMA Atlantic / Pacific, na Estação de metrô Atlantic Avenue / Pacific Street, Brooklyn. Fonte:: <http://www.monoscope.com/2009/02/moma_atlantic_pacific.html>. Foto de Jeff Paxter. Acesso em 04/09/2011.

Figura 578: Reproduções de obras apresentadas na Estação de metrô Atlantic Avenue / Pacific Street, no Brooklyn, como parte da MoMA Atlantic / Pacific. Fonte: <http://daily.publicadcampaign.com/2009/02/momaatlanticpacific-project.html>. Foto de Jordan Seiler. Postado em 20/02/2009. Acesso em 04/09/2011. 

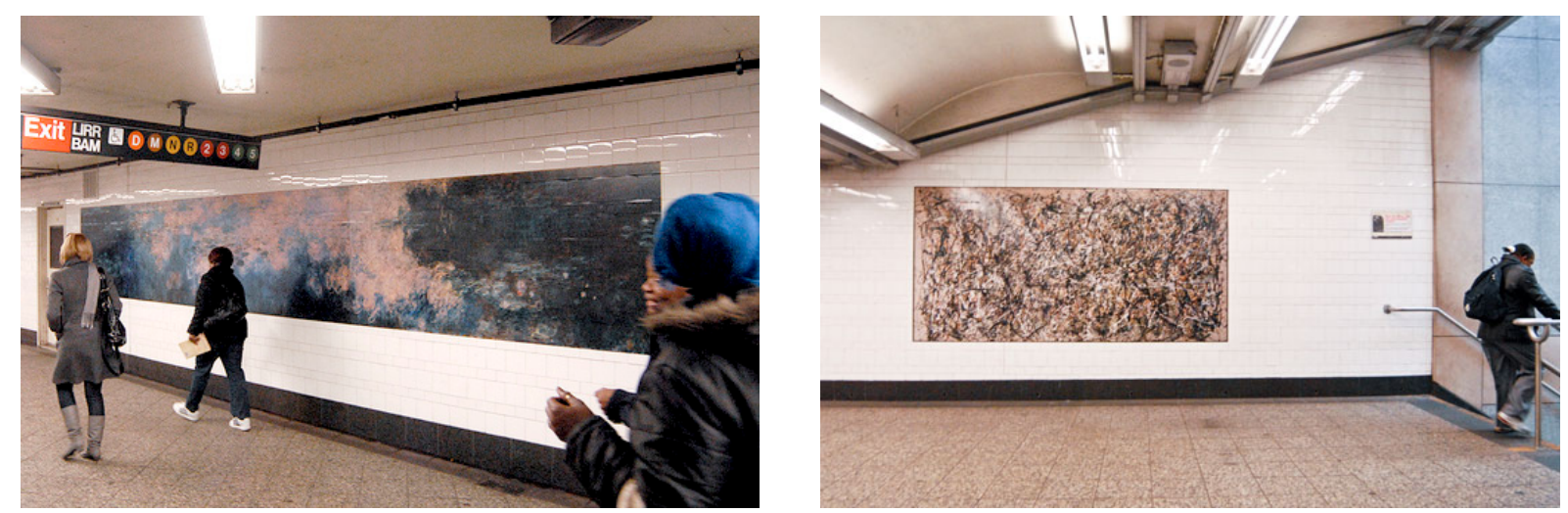

Figura 579: Reprodução de Claude Monet, na Estação de metrô Atlantic Avenue / Pacific Street, no Brooklyn, como parte da MoMA Atlantic / Pacific. <http://www.designboom.com/weblog/cat/10/view/5507/moma-atlantic-pacific.html>. Foto de Jeff Baxter. Publicado em 19/02/2011. Acesso em 04/09/2011.

Figura 580: Reprodução de Jackson Pollock, na Estação de metrô Atlantic Avenue / Pacific Street, no Brooklyn, como parte da MoMA Atlantic / Pacific. Fonte: <http://www.designboom.com/weblog/cat/10/view/5507/momaatlantic-pacific.html>. Foto de Jeff Baxter. Publicado em 19/02/2011. Acesso em 04/09/2011.

A exposição foi acompanhada por lançamento de website personalizado do projeto (www.moma.org/atlanticpacific), que incluía mapa e guia para as obras de arte; comentários em áudio de obras selecionadas e informações sobre o MoMA que podiam ser acessadas por um número de telefone toll-free (888-939-MoMA) e folheto, distribuído gratuitamente no nível da rua, que incluía um cupom para livre acesso ao museu ou um desconto na adesão. O projeto, concebido por Doug Jaeger, CEO, Founder, thehappycorp global, projetado por Julia Hoffmann, diretora de criação do Department of Advertising and Graphic Design do museu, é parte de uma série de iniciativas inovadoras recomendadas pelo comitê de marketing consultivo estabelecido pelo museu, em janeiro de 2008. Ficou conhecido como uma "station domination" da campanha. (ARTKNOWLEDGENEWS.COM, 2011, tradução nossa).

Em 2011, como parte do Programa de Arte Madison Square Park Conservancy (2011), foi apresentada no Madison Square Park, localizado sobre uma estação de metrô, a instalação site-specific: Scattered Light, de autoria do artista midiático Jim Campbell ${ }^{117}$. Composta por três instalações de luz, incorporava elementos de programação de computadores e alta tecnologia

\footnotetext{
117 Jim Campbell, é matemático e engenheiro. "Em 1992, criou uma das primeiras obras públicas permanentes de vídeo interativo, em Phoenix, Arizona. Ministrou aulas sobre arte interativa em muitas instituições em todo o mundo, incluindo o MoMa, de Nova York. Como engenheiro, detém quase 20 patentes na área de processamento de imagem de vídeo. Uma monografia de sua obra, Material Light, foi publicada pela Editora Hatje Cantz, em 2010." (<http://www.emocaoartficial.org.br/pt/artistas-e-obras/emocao-art-ficial-6-0/>. Acesso em 13/06/12).
} 
(MADISONSQUAREPARK.ORG, 2011). O artista abordou o elemento luz como elemento escultural e o conceito atual de pixilated image-making. A maior das três obras, também chamada Scattered Light, foi instalada no centro da Lawn Oval Madison Square Park. Aproximadamente 2.000 LEDs envoltos em bulbos de lâmpadas convencionais foram suspensos por uma estrutura de apoio de 80 metros de comprimento, por 20 metros de altura, por 16 metros de largura. As lâmpadas LED, programadas para piscar em luz difusa, criavam a ilusão de imagens figurativas que exploravam e refletiam a experiência humana em meio à paisagem urbana, criando a aparência de "sombras humanas gigantes atravessando uma matriz 3D de luzes flutuantes". À medida que o observador se deslocava, o ponto de vista alterava e as figuras de luz começavam a se tornar abstratas, alcançando "as fronteiras entre imagem e objeto" (MADISONSQUAREPARK.ORG, 2011, tradução nossa). O projeto também contou com recursos públicos do Department of Cultural Affairs of New York City, em parceria com o Conselho da Cidade. O suporte para a obra Scattered Light, foi fornecido por Bryce Wolkowitz Gallery, The Wall Street Journal, Time Out New York, o Ace Hotel New York, a Delta Air Lines e da Andy Warhol Foundation for the Arts Visual. As lâmpadas de Scattered Light foram doadas pelo Technologies Halco Lighting. (MADISONSQUAREPARK.ORG, 2011, tradução nossa).
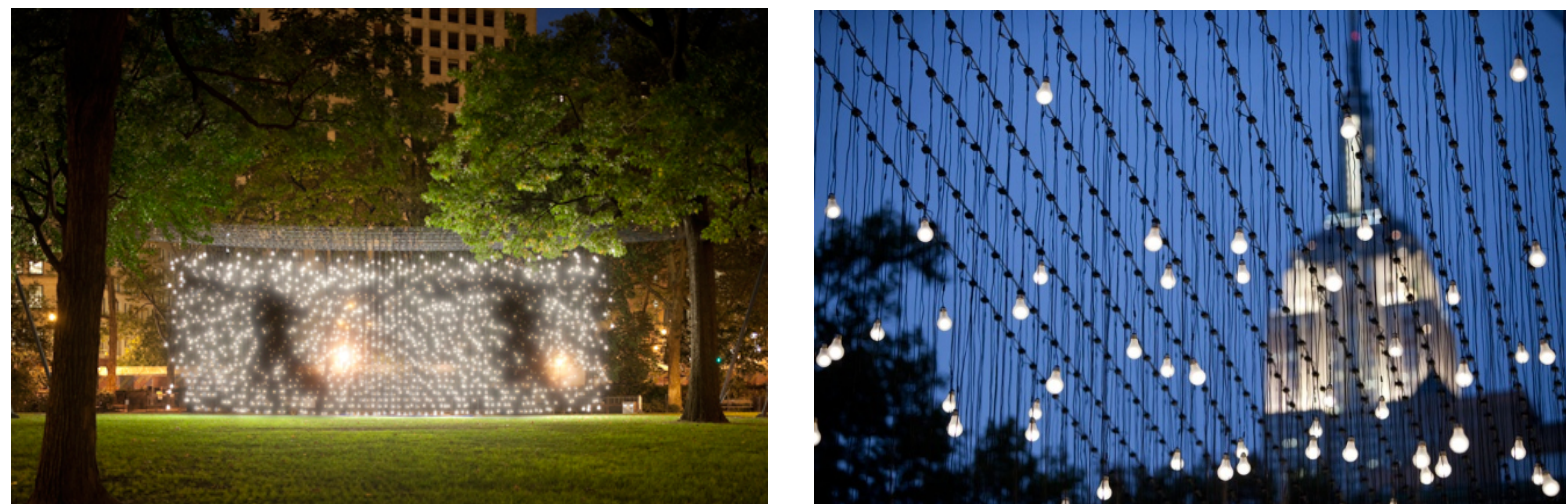

Figura 581: Scattered Light, 2010. Jim Campbell. Madison Square Park, New York. Credit: Courtesy Madison Square Park Conservancy/Copyright James Ewing. Fonte:< http://www.madisonsquarepark.org/things-todo/calendar/jim-campbell-scattered-light>. Acesso em 06/09/2011.

Figura 582: Scattered Light, 2010. Jim Campbell. at Madison Square Park, New York. Credit: Courtesy Madison Square Park Conservancy/Copyright James $\quad$ Ewing. <http://www.artdaily.org/index.asp?int_sec=2\&int_new=42037>. Acesso em 28/08/2011. 
Na Bienal Internacional de Arte e Tecnologia: Emoção art.ficial 6 (2012), Campbell apresentou trabalho semelhante: Exploded View (Commuters), 2011. A obra expandia uma imagem, plana e bidimensional, em uma matriz escultórica de mais de mil LEDs brancos. A partir de um determinado ponto de vista, o piscar das luzes aparentemente aleatório, revelava silhuetas de pessoas em movimento no espaço urbano.
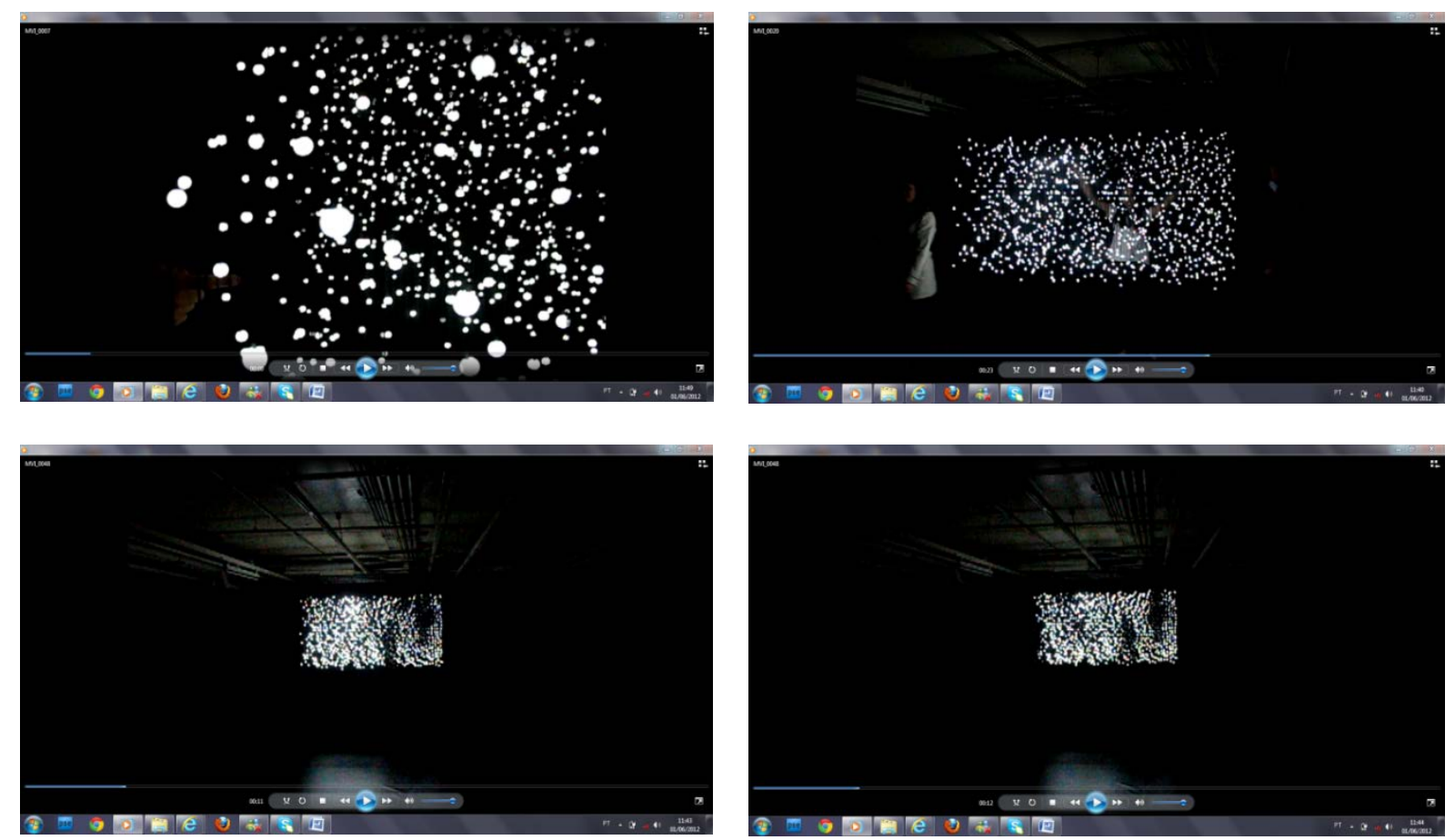

Figuras 583, 584, 585 e 586: Exploded View (Commuters), 2011. Fonte: Registro fotográfico realizado pela pesquisadora.

Na obra Broken Window, instalada próxima à entrada principal da Madison Square Park, um conjunto de LEDs envoltos por uma parede de tijolos de vidro (70"x 70"x 10") criava imagens iluminadas que pareciam "deslizar através do plano de vidro, refletindo os movimentos da cidade em torno deles e ecoando a poesia estética da instalação Scattered Light." (MADISONSQUAREPARK.ORG, 2011).

$\mathrm{Na}$ lateral leste da Madison Avenue, entre as ruas 24 e 25, esteve a obra: Voices in the Subway Station. Eram "18 tijolos de vidro (14"x 22") iluminados por baixo por LEDs, especificamente programados para pulsar em intervalos de tempo designados para criar uma orquestra visual de vozes individuais no contexto de conversas sobrepostas e acontecimentos do metrô". Juntos, os pulsos coordenados criaram uma "onda visual de luz simbólica dos sons" que marcava "a progressão do estrondo na chegada de trens do metrô e as viagens, levando os 
sons dos passageiros com eles." (ARTDAILY.ORG, 2011), (MADISONSQUAREPARK.ORG, 2011, tradução nossa).
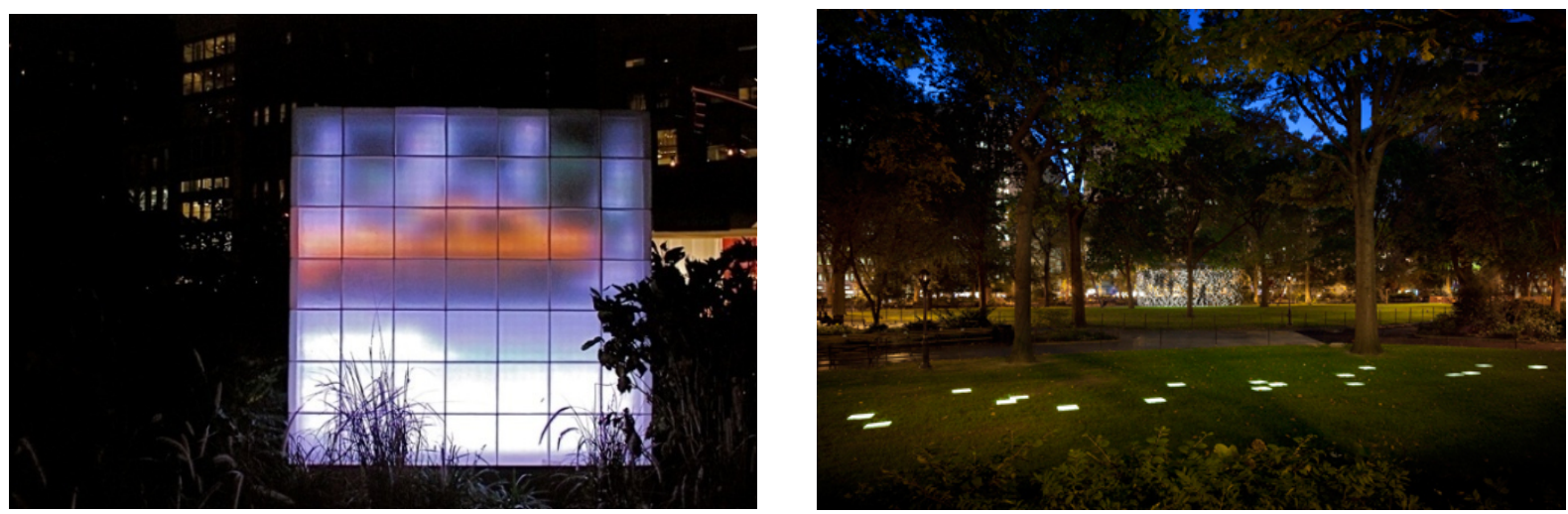

Figura 587: Broken Window, 2010. Jim Campbell. Fonte: <http://nyclovesnyc.blogspot.com/2010/11/new-mediaartist-jim-campbells-broken.html>. Postado por Noel YC em 12/11/2010. Acesso em 07/09/2011.

Figura 588: Voices in the Subway Station, 2010. Jim Campbell. Credit: Courtesy Madison Square Park Conservancy/Copyright James Ewing. Fonte: <http://www.artdaily.org/index.asp?int_sec=2\&int new=42037>. Acesso em 28/08/2011.

Ainda nos Estados Unidos, em Portland, na área externa da Estação Interstate/Rose Quarter, da MAX Light Rail, três faixas de circulação de veículos foram iluminadas por árvores metálicas de silício alimentadas por um sistema de painéis solares acoplados à sua estrutura. Bancos metálicos, instalados próximos às bases das árvores, também fazem parte da proposta do artista plástico Brian Borrello.
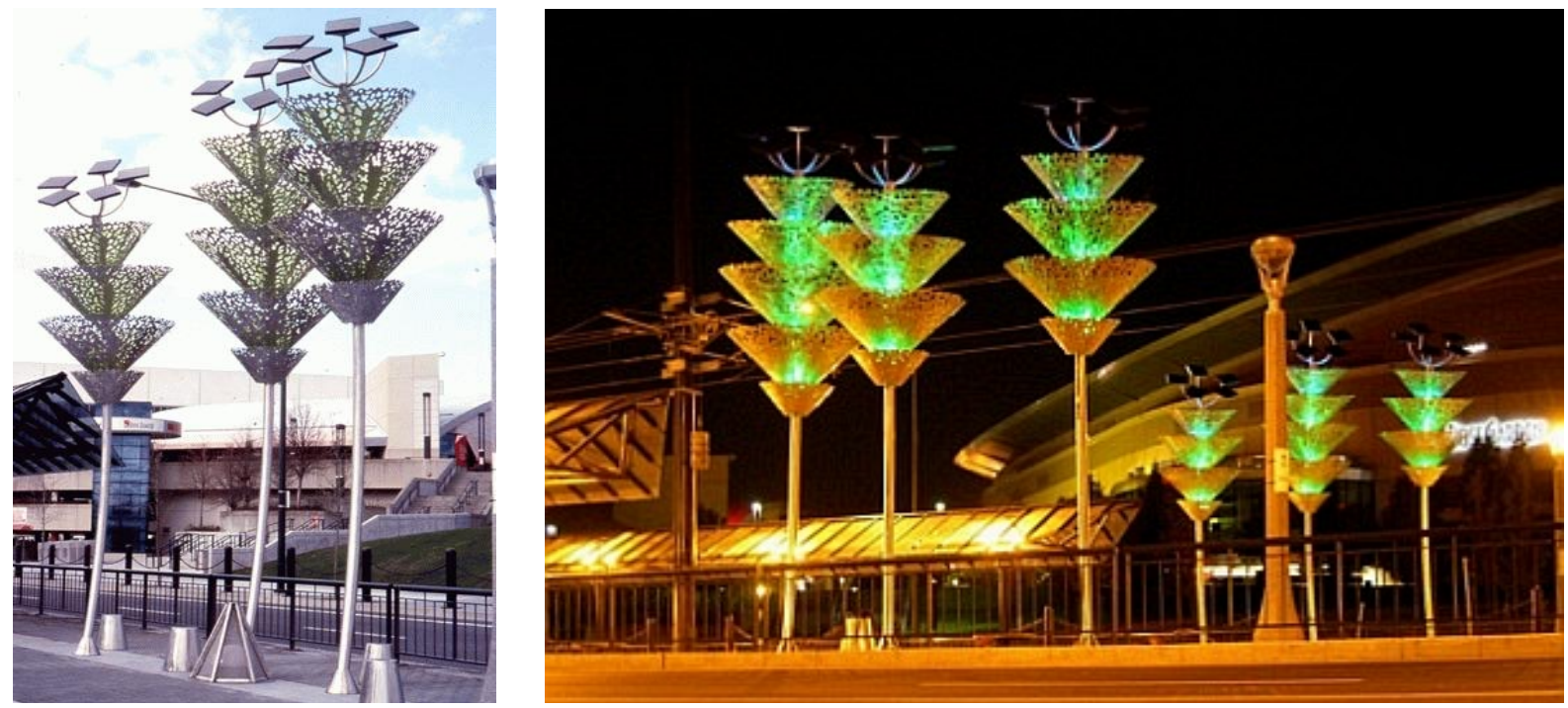

Figura 589: Árvores de silício e painéis solares, 2004. Brian Borrello. Interstate/Rose Quarter station. Fonte: <http://www.lope.ca/artrenewable/index.html> .Acesso em 23/10/2011.

Figura 590: Árvores de silício e painéis solares, 2004. Brian Borrello. Interstate/Rose Quarter station. Fonte: $<$ http://mic-ro.com/metro/metrocity.html?city=Portland>. Foto de trimet.org. Acesso em 23/10/2011. 
Em 2010, em São Francisco, a Art Commission of San Francisco anunciou os vencedores de seis propostas artísticas escolhidas para o Central Subway Public Art Program. Para cada uma das três estações: Market Street, Chinatown e Moscone, foram encomendados dois tipos de trabalhos permanentes: um landmark artwork (marco) e um wayfinding artwork. O projeto marco, serviria como identidade para a estação e estaria localizado em uma área de destaque: na entrada ou na extensão de grandes paredes. O projeto wayfinding artwork, se estenderia por dois ou três níveis da estação, "oferecendo uma referência visual para pedestres em movimento na estação". (SFARTSCOMMISSION.ORG, 2010, tradução nossa). Para a Estação Market Street, a obra marco: Lucy in the Sky, de Erwin Redl, irá ocupar todo o teto do saguão principal, com centenas de elementos translúcidos, de 10"x10", alinhados em uma grade de linhas em diagonal. Cada "pixel de luz" será iluminado por LEDs RGB que farão com que pequenos painéis mudem constantemente de cor proporcionando "um espetáculo para os usuários em trânsito". As unidades de luz serão controladas por computador e exibirão padrões simples e animações. Como wayfinding artwork, foi escolhido o trabalho da dupla: Jim Campbell e Klotz Werner. A instalação Reflected Loop, "circunscreverá seções dos níveis de afluência e da plataforma para criar um circuito de unificação dos reflexos de luz e do ambiente ao longo da estação". Discos de aço inoxidável, altamente polidos, com dimensões e espaçamentos variáveis, serão sustentados por finas hastes do mesmo material pintadas em cores diferentes. $\mathrm{Na}$ superfície dos discos, que refletem o usuário e a própria arquitetura local, há textos e imagens em baixa resolução. (CENTRALSUBWAYBLOG.COM, 2010; SFARTSCOMMISSION.ORG, 2010, tradução nossa). 

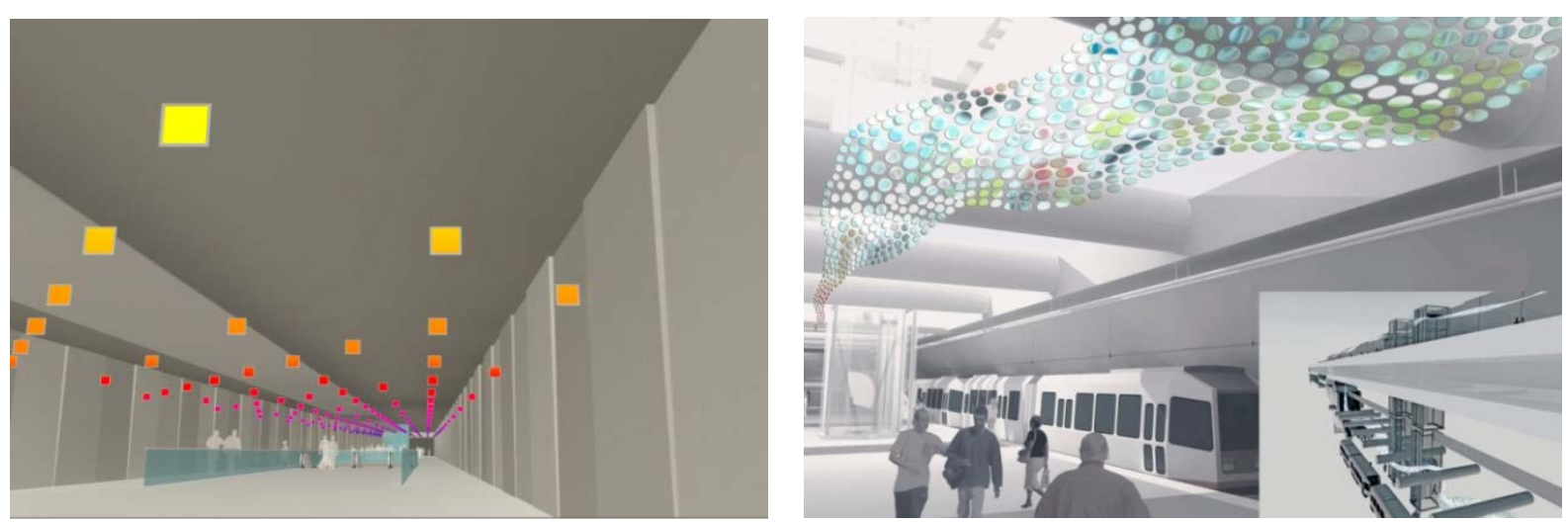

Figura 591: Lucy in the Sky, Artista: Erwin Redl. Fonte: <http://www.sfartscommission.org/pubartcollection/pubartpress-releases/2010/07/30/central-subway-public-art-program-winners-announced/>. Publicado em 30/07/2010. Acesso em 08/09/2011.

Figura 592: Reflected Loop, Jim Campbell e Klotz Werner Fonte: $<$ http://www.sfartscommission.org/pubartcollection/pubart-press-releases/2010/07/30/central-subway-public-artprogram-winners-announced/>. Publicado em 30/07/2010. Acesso em 08/09/2011.

Para a Estação Chinatown, foi escolhida como obra marco: Yang Ge Dance of Northeast China, de Yu Mei Hou. A instalação tem como referência a arte do corte de papel, prática tradicional chinesa. Através dos "cortes", busca representar uma dança folclórica popular ao ar livre das províncias do nordeste da China. A dança folclórica é uma forma de contar histórias. A obra inclui imagens de lendas populares, bem como cenas da vida cotidiana. O trabalho de Tomie Arai: Urban Archeology, que ilustra a história da arte circundante em elementos de vidro para construção, foi escolhido como wayfinding. São projetos desenvolvidos para os elevadores que ligam as plataformas às bilheterias. (CENTRALSUBWAYBLOG.COM, 2010). 

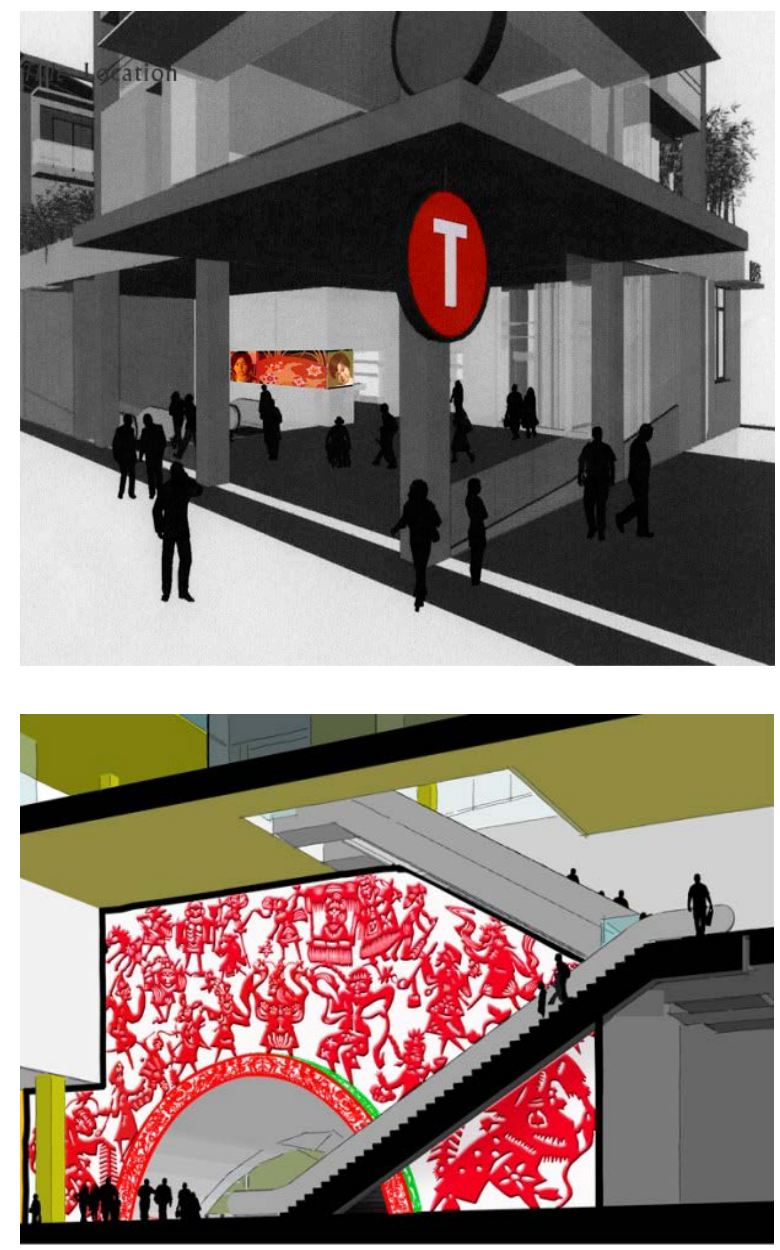

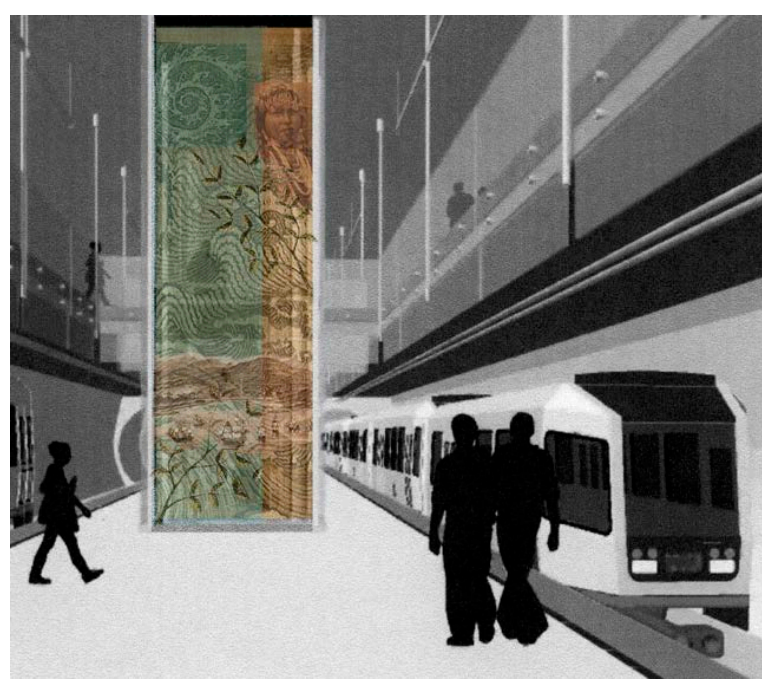

Figuras 593 e 594: Urban Archeology, Tomie Arai. Fonte:<http://www.sfartscommission.org/pubartcollec tion/pubart-press-releases/2010/07/30/central-

subway-public-art-program-winners-announced/>. Publicado em 30/07/2010. Acesso em 08/09/2011.

Figura 595: Yang Ge Dance of Northeast China, Yumei Hou. Fonte: <http://www.sfartscommission.org/pubartcollection/pu bart-press-releases/2010/07/30/central-subwaypublic-art-program-winners-announced/>. Publicado em 30/07/2010. Acesso em 08/09/2011.

Na Estação Moscone, a artista local Catherine Wagner, transformou registros fotográficos realizados por ela no final de 1970, no decorrer da construção do Moscone Center, "em desenhos fotografados em grande escala vistos como relevos esculturais", que serão exibidos no espaço das catracas até o dos elevadores. As imagens serão jateadas e gravadas a laser, em pedra cinza ou em painel de metal, ligeiramente recuada das paredes. Como wayfinding, Otterness Tom, criará "uma série de vinhetas humorísticas esculturais com seus personagens em bronze", que serão colocados em diversos espaços da estação, incluindo os bancos das plataformas. (CENTRALSUBWAYBLOG.COM, 2010; SFARTSCOMMISSION.ORG, 2010). 

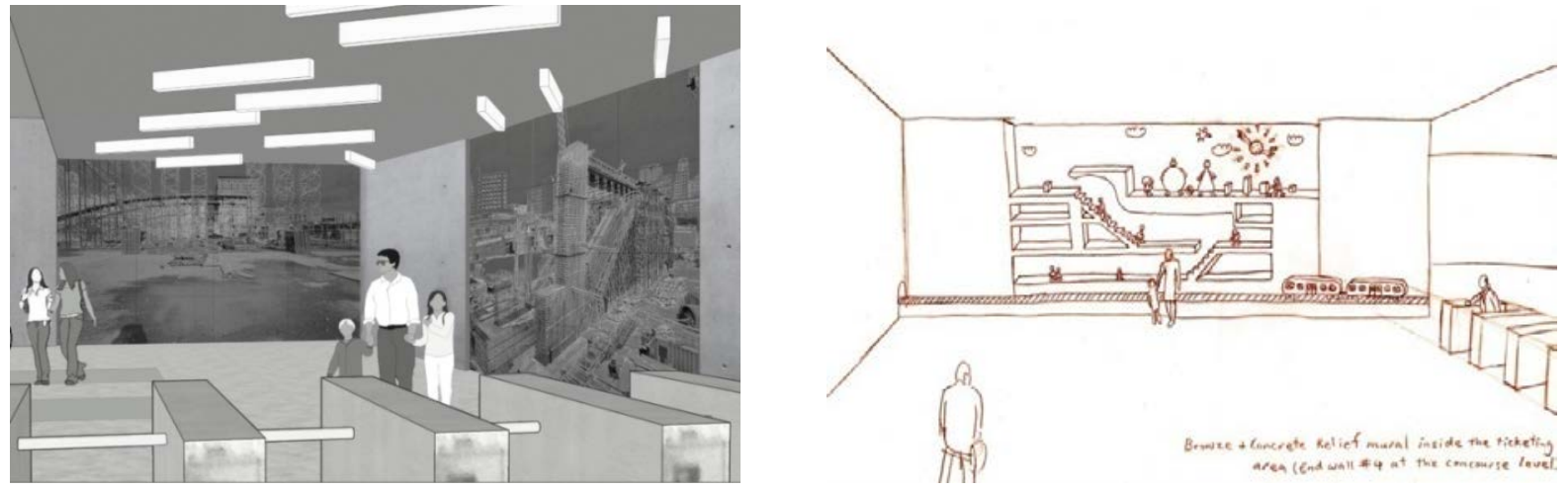

Figura 596: Arc Cycle (título provisório), Catherine Wagner.

Fonte: $\quad<h t t p: / / w w w . s f a r t s c o m m i s s i o n . o r g / p u b a r t c o l l e c t i o n / p u b a r t-p r e s s-r e l e a s e s / 2010 / 07 / 30 / c e n t r a l-s u b w a y-$ public-art-program-winners-announced/>. Publicado em 30/07/2010. Acesso em 08/09/2011.

Figura 597: Sem título, Tom Otterness.

Fonte: <http/www.sfartscommission.org/pubartcollection/pubart-press-releases/2010/07/30/central-subway-publicart-program-winners-announced/>. Publicado em 30/07/2010. Acesso em 08/09/2011.

No Canadá, em Toronto, na Estação Yorkdale, da Linha Spadina, a obra Arc em ciel (1978) de Michael Hayden é considerada uma "metáfora visual impressionante de velocidade e de movimento". A instalação de luz, com 570 metros de comprimento, foi concebida de forma a fazer parte da estrutura em aço inoxidável perfurado que cobre a estação, integrando-se totalmente à arquitetura. Suas luzes pulsavam as cores do espectro, sincronizadas com as chegadas e partidas dos trens. Em 1990, foi removida por falta de fundos para a manutenção. (ERICKSON, 2010, tradução nossa).
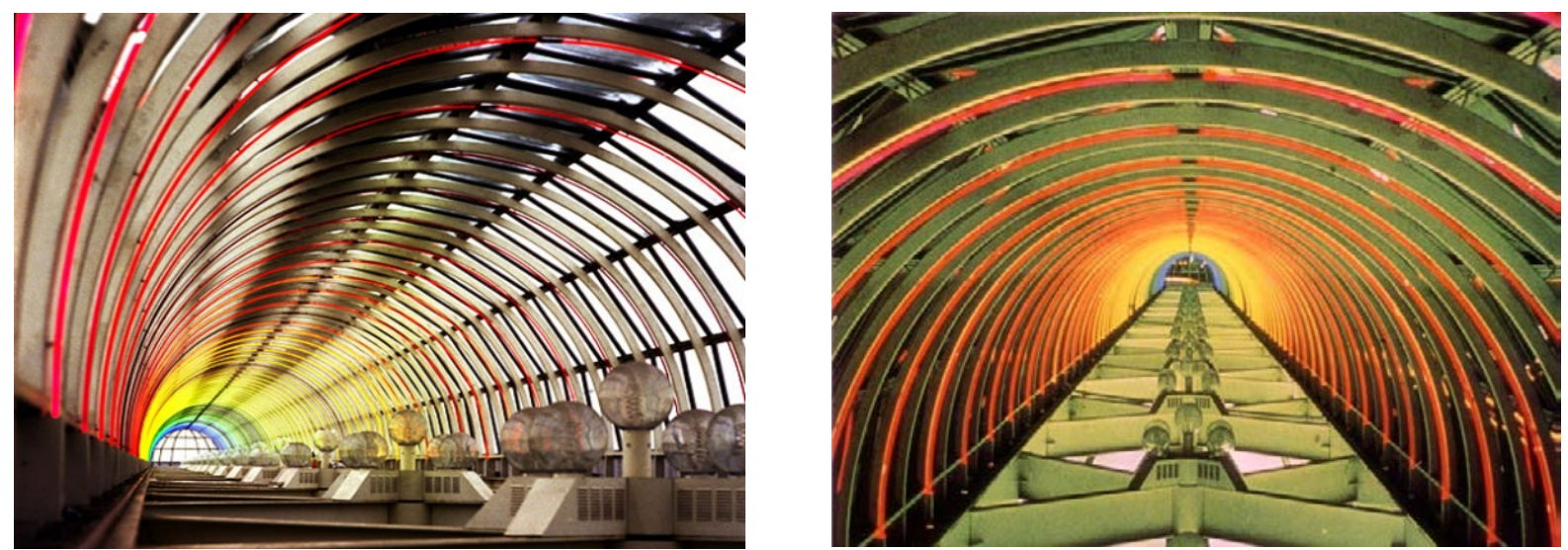

Figura 598: Arc en ciel (1978), Michael Hayden, Estação Yorkdale. Foto de Michel Proulx. Fonte: $<$ http://www.blogto.com/arts/2010/11/michael_haydens_arc_en_ciel_might_return_to_yorkdale_station/>. Postado por Derek Flack em 04/11/2010. Acesso em 08/09/2011.

Figura 599: Arc en ciel (1978), Michael Hayden, Estação Yorkdale. Art and architecture on the Spadina subway. Arthur Erickson. Publicado em 28/10/10. Fonte: <http://robertmoffatt115.wordpress.com/page/3/>. Acesso em 11/09/2011. 
Segundo Derek Flack, a instalação poderá voltar a funcionar. Embora não haja uma confirmação por escrito de compromisso financeiro, a proposta de restauração da obra foi aprovada como parte de uma negociação que envolveu a expansão do Centro Comercial Yorkdale. O desenvolvedor da Oxford Properties concordou em pagar por ela.

Não se trata apenas de uma reinstalação ou restauração, afinal, não é certo que transformadores e interfaces que controlavam as luzes do projeto original ainda estejam guardados na estação. 0 ideal seria fazer uso de tecnologias atuais. De acordo com Derek Flack:

Resurrecting the piece won't, however, be merely a matter of re-installation or restoration. The artist isn't even sure if the TTC has the original transformers and interfaces that once controlled the lights when trains arrived at the station. And beyond this, it's also been over 30 years since Arc en ciel was built, and there have obviously been many technological advancements since that time that he'd like to take advantage of. (FLACK, 2010)

Outro aspecto a ser considerado é o processo de execução, originalmente trabalhoso. Tubos de vapor de mercúrio foram pintados de cores diferentes para criar o efeito de arco-íris. Neste sentido, a disponibilidade da tecnologia LED e das cores RGB facilitaria o processo, permitiria uma variedade maior de cores e a obra permaneceria muito similar. Para Flack,

\begin{abstract}
The original work was crafted out of mercury vapor tubes, which were then painted different colours to create the rainbow effect referred to in the title of the piece. But with the advent of LED technology and RGB colour, it's no longer necessary to go through such a labourious process. Not only that, the use of LED lights would allow the artist to display a far wider range of colour in the new version of Arc en ciel.
\end{abstract}

But, referring to installation photographs of the original, Hayden says that the new version "will look strikingly similar to how it did in 1978. (FLACK, 2010)

Ao Sul da França, o metrô VAL driverless, em Toulouse, possui obras de arte em todas as estações. Em algumas bilheterias está disponibilizado o folheto: Galeries Art d' (MIC-RO.COM, 2008). Para a linha B do metrô de Toulouse, artistas criaram trabalhos no âmbito de contratos públicos. No concurso público, "os artistas foram associados às estações desde a sua concepção arquitetônica". Os materiais recomendados nas especificações fornecidas para os participantes foram o vidro e a luz (PHOTOGRAPHIE.COM, 2007). Dentre os 
artistas selecionados estavam: Roman Opalka ${ }^{118}$ e Sophie Calle.

Na Estação Universitá Paul Sabatier, foi exibida a obra de Roman Opalka, uma instalação de luz em que uma pirâmide de números, que iam de um a oito, foi projetada em uma das paredes da parte de trás da estação, voltada para a Universidade de Matemática, diante das catracas.

Ela parece flutuar no ar. No limite do número 7 atravessa uma linha horizontal. Quando se aproxima da obra, o espectador um pouco curioso pode contar com a sua sombra." (...) " 'Opalka queria focar tanto a pirâmide de números quanto destacar um trilho de luz poderosa, esta linha enigmática do espaço-tempo de uma vida', diz o folheto anexado à parede.(LIBETOULOUSE.FR, 2011, tradução nossa)
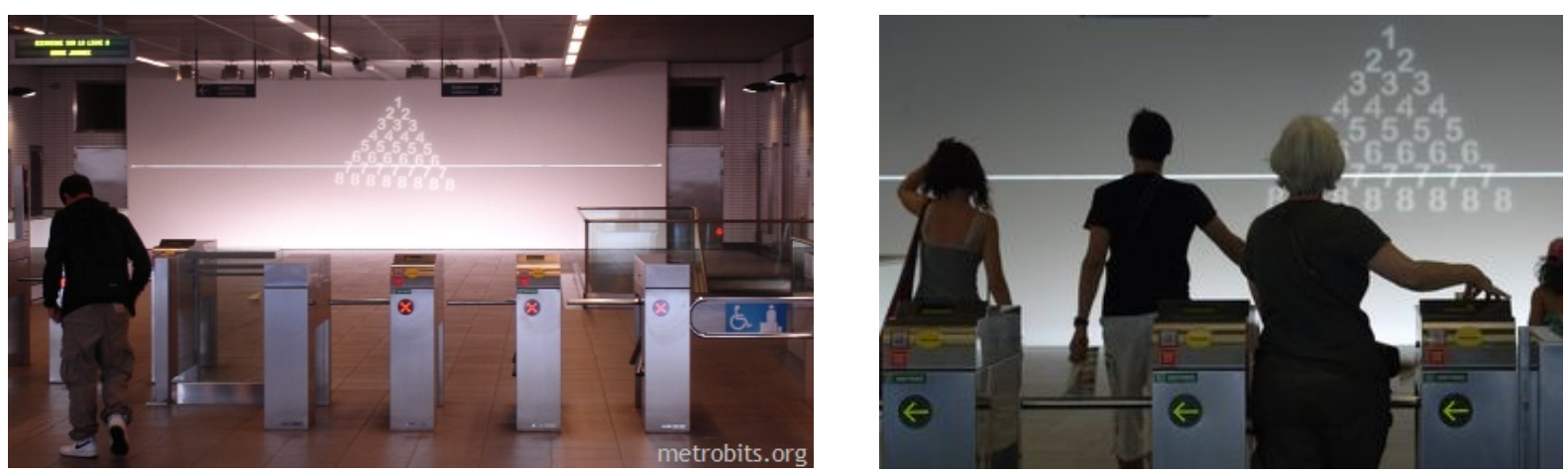

Figura 600: Instalação de Roman Opalka. Estação Université Paul Sabatier. Linha B. Foto: M. Rohde (2008). Fonte: <http://mic-ro.com/metro/phototour.html?city=Toulouse>. Acesso em 28/08/2011.

Figura 601: Instalação de Roman Opalka. Estação Université Paul Sabatier. Foto: Julien Dromas. Fonte: <http://www.libetoulouse.fr/2007/2011/08/-roman-opalka-arrête-de-compter-à-79-ans.html>. Publicado por J-M.E em 08/08/2011. Acesso em 29/08/2011.

Sophie Calle, apropriou-se do conceito "transport amoureux" (transporte no amor) para ser aplicado na Estação Jeanne d' Arc. As regras do jogo foram exibidas ao redor da estação:

Você regularmente conhece um estranho em uma plataforma do metrô e nunca se atreve a falar. (...) Quer saber quem estava lendo um livro amarelo, um que usava um casaco vermelho, que você lamenta a oportunidade perdida por constrangimento, medo, ou porquê não se prestava no momento. Então deixe uma mensagem. (LADEPECHE.FR, 2007, tradução nossa).

\footnotetext{
${ }^{118}$ Artista contemporâneo que, desde 1965, pintou em suas telas números em ordem crescente, de cima para baixo, "para gravar a faixa de tempo reversível" em busca do "constante infinito". (LIBETOULOUSE.FR, 2011).
} 
Ao acessar o site www.transport-amoureux.vu, os usuários da linha declamavam o seu amor. Mensagens inventadas pela artista, ou listadas na imprensa, se misturaram com as enviadas pelos usuários. A memória do computador, responsável por exibir as mensagens de texto, tinha um número limitado a 150. As mensagens mais antigas, desapareciam automaticamente. Um moderador excluía aquelas consideradas obscenas ou racistas. Desta forma, "a espera por passageiros do metrô se refletiu no processo artístico", "telas foram instaladas na plataforma e no átrio da estação", diz a artista. (LADEPECHE.FR, 2007, tradução nossa).
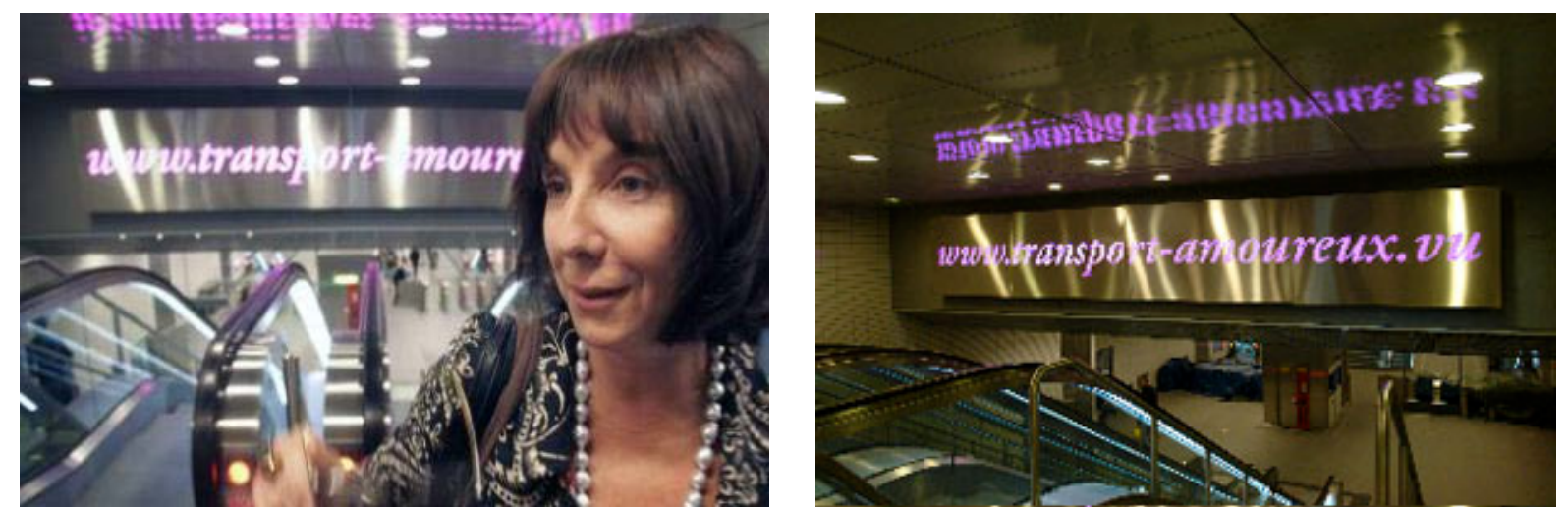

Figura 602: A artista Sophie Calle aplica o conceito de "transport amoureux" no Metro Toulouse DDM.Fonte: <http://blog.retrouve-moi.fr/>. Publicado em 19/02/2008. Acesso em 29/08/2011.

Figura 603: "transport amoureux". Sophie Calle. Estação Jeanne d'Arc, Toulouse, França. Fonte: <http://blog.retrouve-moi.fr/>. Publicado em 19/02/2008. Acesso em 29/08/2011.

Em Paris, a política cultural e os trabalhos recentemente realizados na tradicional Companhia de metrô, bonde e ônibus local: a Groupe RATP (Régie autonome des transports parisiens), explicitam a preocupação com a forma de atuar dos profissionais envolvidos desde a fase de concepção dos projetos e com a aplicação de tecnologias atuais em intervenções no espaço das estações. De acordo com Yo Kaminagai ${ }^{119}$, ex-diretor do departamento de design da RATP e atual diretor da plataforma de design e cultura da União Internacional de Transportes Públicos-UITP, para que problemas fossem minimizados foi criada uma nova função profissional na companhia: a de "délégué à la conception", hoje, ocupada por ele, que trabalha ao lado do diretor dos projetos para posicionar os designers, arquitetos e artistas no início dos projetos. Observa que problemas ocorriam porque essas disciplinas não eram bem integradas aos projetos

\footnotetext{
${ }^{119}$ Yo Kaminagai foi diretor da RATP durante 20 anos.
} 
técnicos. A seu ver, não há a possibilidade de fazer um bom trabalho artístico se não for oferecido um "espaço correto".

Fabricar um espaço é o trabalho dos arquitetos e dos designers.

(...) Bem fazer a combinação entre o objetivo de ambientação da estação e colocar um bom projeto de arte é uma coisa muito importante que deve ser feita por uma sorte de curadoria especial que nós chamamos de "engenharia cultural" que existe no departamento de comunicação há 20 anos. (KAMINAGAI, 2012).

Na programação de uma nova estação, ou de uma nova linha, há métodos que devem ser rigorosamente adotados. Quando é decidido que o projeto cultural fará parte do projeto dos espaços, quatro assuntos devem ser tratados no mesmo nível: a ligação entre a obra e o espaço; a ligação entre a obra e o público; a ligação entre a obra e os atores institucionais que a financiam e a ligação entre a obra e o artista.

Considerando a extensão do patrimônio parisiense, afirma que a questão política é importante, mas a manutenção das obras ao longo de décadas também é relevante. Nesse sentido, "amplos projetos culturais clássicos" como a preservação da forma de abóbada branca, que remete a um céu artificial branco, conceito adotado em 1900 quando não havia luz e que "faz parte do DNA do metrô de Paris" é colocada em prática. Há também uma estratégia de preservação que inclui a política de design global, como é o caso da recente Linha 14, a primeira completamente automática, realizada em 1998, em que todos os materiais, componentes e espaços são combinados. Como resultado de uma "reação do mundo cultural francês" à destruição das entradas do metrô pela própria companhia, nos anos 1950 e 1970, as 86 restantes foram tombadas pelo Ministro da Cultura. Quando possível, performances e concertos são apresentados por serem considerados ações que dão vida à imagem da RATP. Outro projeto cultural são as "estações culturais, que não são obras de arte, mas obras espaciais", a exemplo da reprodução do trabalho do artista de quadrinhos belga François Schuiten na Estação Arts-et-Métiers. (KAMINAGAI, 2012).

"Novos princípios de ação cultural" têm sido aplicados quando se deseja responder a funções normais por um caminho especial utilizando artistas. Cita como exemplo, a intervenção de Patrick Corrilon no design dos abrigos do "tramway" em que faz uso do LED na sinalização adotando uma estratégia de cores 
diferenciadas, de estação para estação, que ficam mais claras à medida em que um trem chega. Outro princípio considerado muito importante é o de "colocar coisas que possam mudar porque todas as obras de arte são interessantes, mas, em uma cidade como Paris, uma coisa que parece interessante um dia, vinte anos depois, talvez pareça antiga e não poderá ser deslocada, proibida." Para tanto, foram feitos projetos com telas na Estação Europe, com programas, produtos, com muitos parceiros dentro da Europa e de outros países, ou canais de televisão. $\mathrm{Na}$ Estação Franklin D. Roosevelt, está sendo utilizado outro tipo de tela em que, $\mathbf{2 0} \%$ do tempo são exibidas obras artísticas e $\mathbf{8 0} \%$ do tempo publicidade. Tratase de uma "experimentação que é uma mistura" que irá durar de 2 a 3 anos. Se for bem aceita pelo público se tornará permanente, caso contrário, devido ao custo, o lado cultural será abandonado. Nessa estação também foram apresentadas vitrines e projeções. A Estação St. Germain Des-Prés, por exemplo, é dedicada à criação. A cada três meses, é apresentado um conteúdo produzido por um parceiro público ou privado qualificado que, neste caso, realiza a própria curadoria. A Estação Louxembourg, foi dedicada ao desenvolvimento sustentável. No ano 2000 foi aceito um conteúdo da revista Courrier International, colocado sobre a parede, para que o público pudesse ler durante a espera do metrô. Posteriormente, para o ano do Brasil na França, foi dedicada às favelas. Na linha 14, com o Galliera Museum, há vitrines onde são expostos trabalhos de alunos de escolas de arte ou de Festival de Histórias em Quadrinhos. A fotografia também foi exibida em espaços da arquitetura histórica e demonstraram resultado duplamente positivo: as fotos e a redescoberta da arquitetura e do patrimônio. Detalhes visíveis como a marca metrô, e invisíveis, como o porquê do nome das estações, são explicados em 500 painéis culturais espalhados pelas estações. Quatro estações fechadas para a guerra, em 1939, e que não foram reativadas são utilizadas para projetos culturais e publicitários. Para fazer a promoção do patrimônio, anualmente, são realizados os "dias do patrimônio" com o objetivo de promover a imagem do metrô. (KAMINAGAI, 2012)

Quanto às estratégias culturais, assim como na maior parte dos metrôs, tem como objetivos: 
metrôs e o projeto artístico é um problema; 2. Alimentar o orgulho e o sentimento de pertencimento para os clientes e a população em geral; 3. Os projetos culturais são instrumentos de cooperação entre o mundo do transporte e autoridades locais; 4. Alimentar a marca e a identidade cultural da empresa de transporte e da cidade. (KAMINAGAI, 2012).

O orçamento para projetos culturais fazia parte do plano de investimento da RATP. Atualmente, o princípio é dividir o financiamento entre uma parte pública e patrocinadores.
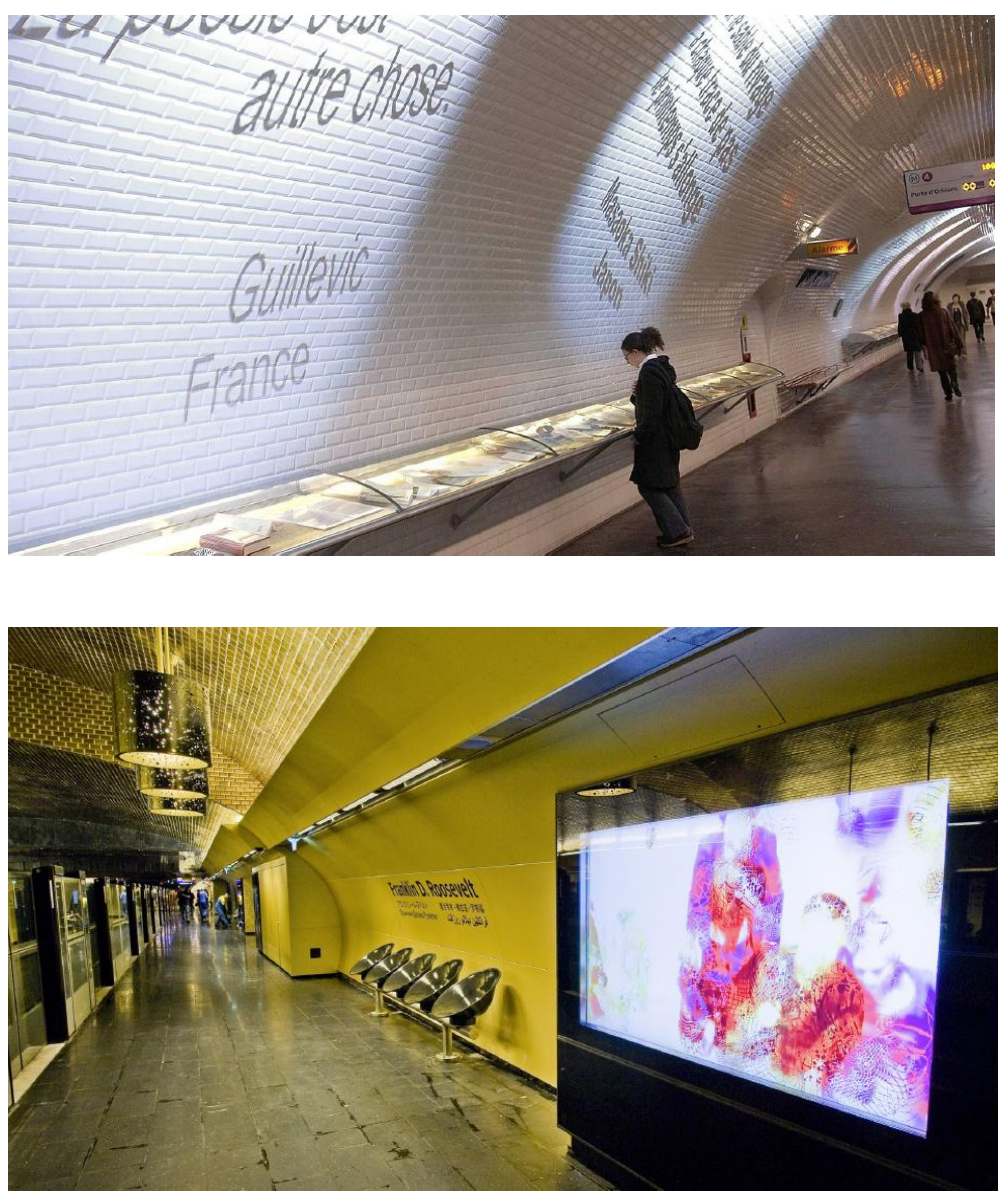

Figura 604: Vitrines e projeções. Estação St Germain-des-Prés. Fonte: Imagem extraída da apresentação RATP Cultural policy and recent works, de Yo Kaminagai, no evento Metrô, Engenho e Arte, realizado na Companhia do Metropolitano de São Paulo em 24 agosto de 2012.

Figura 605: Tela para apresentação de trabalhos culturais e publicidade. Estação Franklin D. Roosevelt. Fonte: Imagem extraída da apresentação RATP Cultural policy and recent works, de Yo Kaminagai, no evento Metrô, Engenho e Arte, realizado na Companhia do Metropolitano de São Paulo em 24 agosto de 2012. 

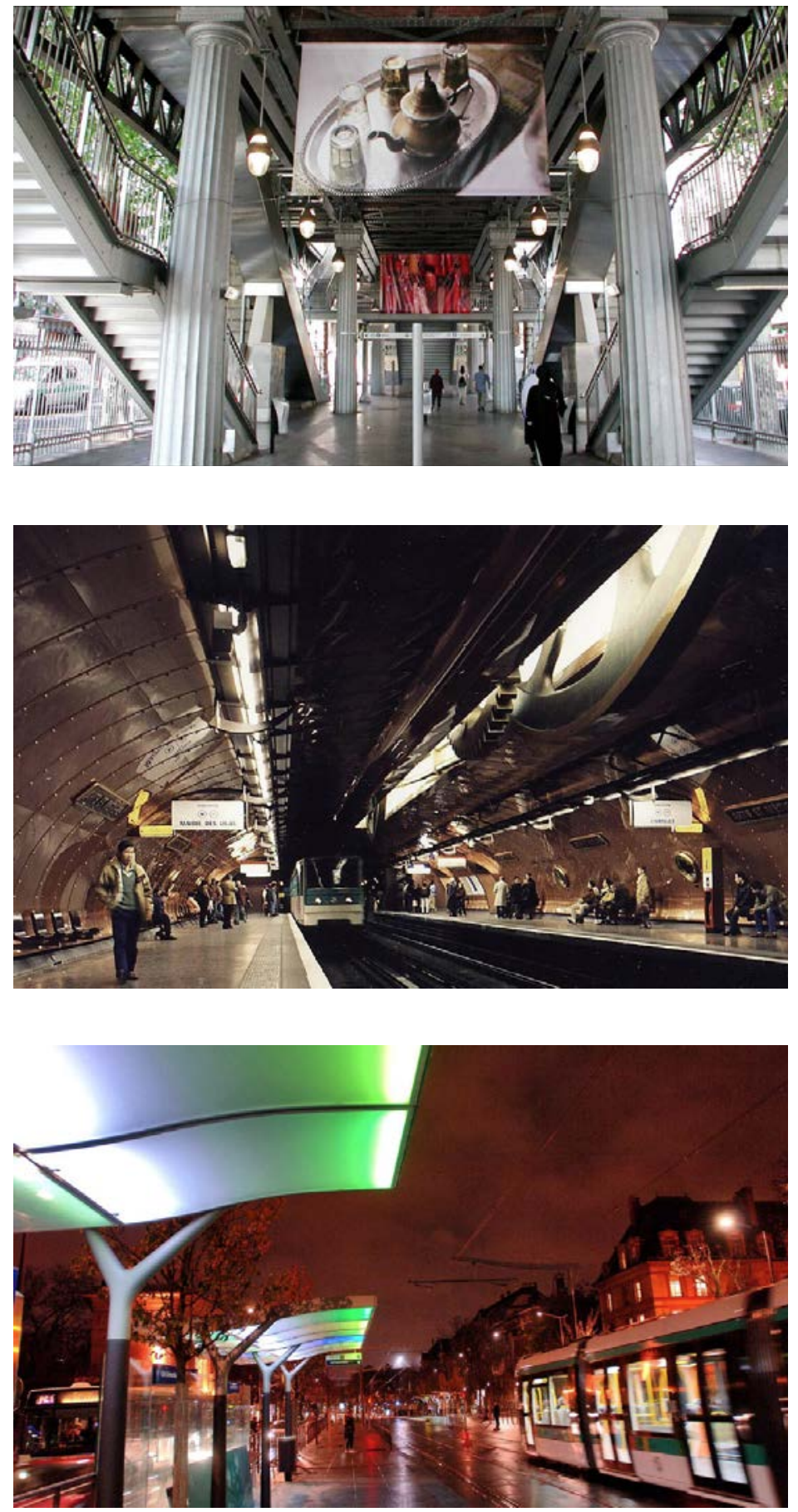

Figura 606: Fotografias. Estação Barbès. Fonte: Imagem extraída da apresentação RATP Cultural policy and recent works, de Yo Kaminagai, no evento Metrô, Engenho e Arte, realizado na Companhia do Metropolitano de São Paulo em 24 agosto de 2012.

Figura 607: Para marcar o bicentenário do Conservatório Nacional des Arts et Métiers, em 1994, a estação foi redesenhada pelo artista de quadrinhos belga François Schuiten. Estação Arts et Métiers. Fonte: Imagem extraída da apresentação RATP Cultural policy and recent works, de Yo Kaminagai, no evento Metrô, Engenho e Arte, realizado na Companhia do Metropolitano de São Paulo em 24 agosto de 2012.

Figura 608: Intervenção de Patrick Corrilon com aplicação de LED no design dos abrigos do "tramway". Fonte: Imagem extraída da apresentação RATP Cultural policy and recent works, de Yo Kaminagai, no evento Metrô, Engenho e Arte, realizado na Companhia do Metropolitano de São Paulo em 24 agosto de 2012.

Na Estação Nydalen, em Oslo, Noruega, projetada pelo arquiteto Kristin Jarmund, está a instalação interativa: Tunnel of Light, localizada no túnel que abriga escadas rolantes que ligam o nível do solo ao da plataforma dos trens. O sistema é composto 
por luz e som, totalizando 44 alto-falantes e 1600 tubos de luz CCL, integrados a uma superfície de vidro translúcido de 27 metros de comprimento. Luz e som variam de acordo com 0 fluxo dos usuários $\mathrm{e}$ dos trens. (PERFORMATIVE.WORDPRESS.COM, 2007; EN.WIKIPEDIA.ORG, 2008).

O tema do trabalho está relacionado às "diferentes experiências de viajar no tempo e lugar" (EN.WIKIPEDIA.ORG, 2008). O projeto da instalação foi iniciado pelo arquiteto Kristin. Um grupo de artistas trabalhou durante dois anos e meio no desenvolvimento do conceito multimídia. O sistema de iluminação foi desenvolvido por Per Age Lysa do Intravision System, o software que mescla som e cor, por Yngve Sandboe e a música, composta por Bjarne Kvinnsland. (EN.WIKIPEDIA.ORG, 2008; NORDICDESIGNBLOG.COM, 2006).
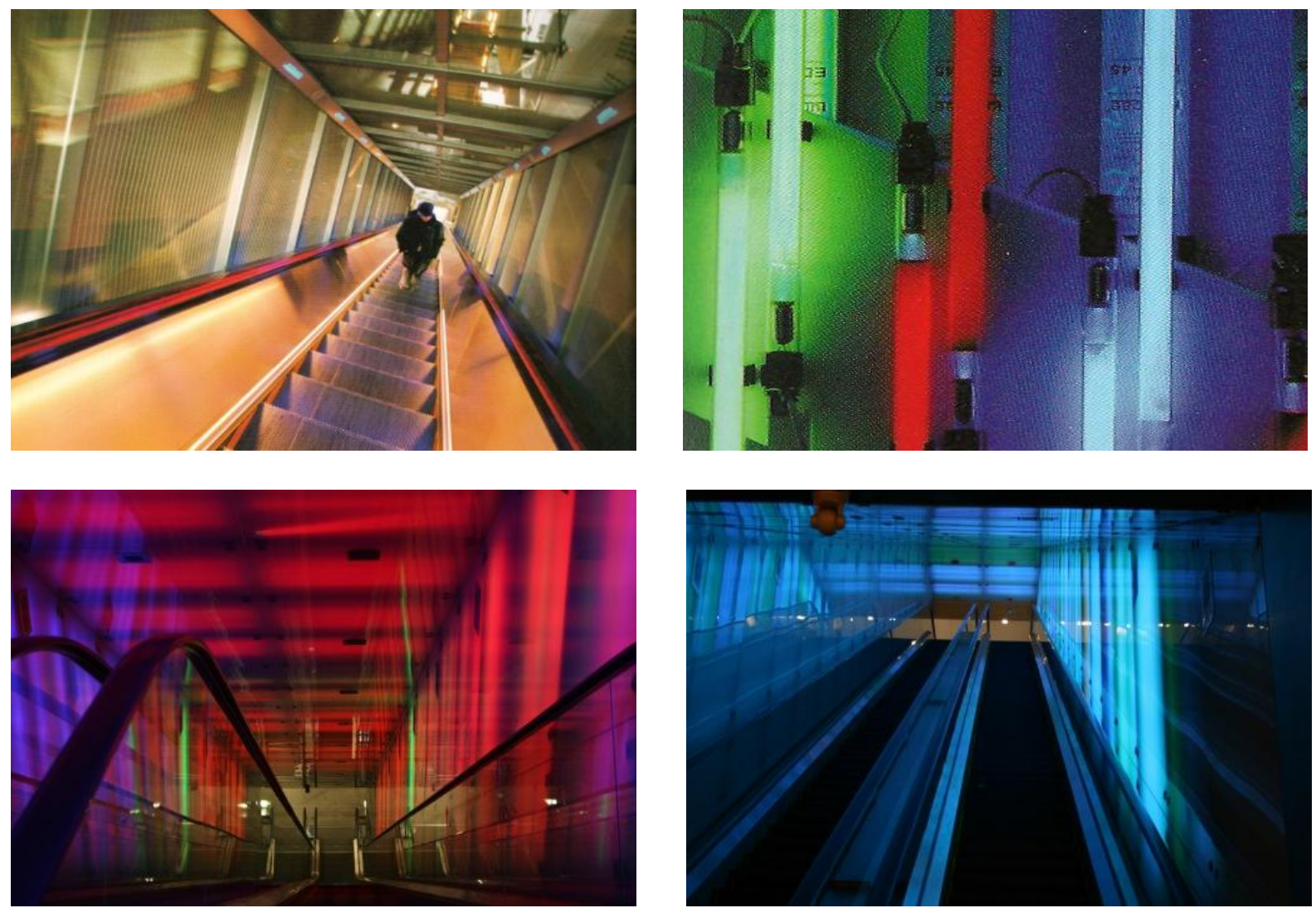

Figura 609: Tunnel of Light. Fonte: BENNETT, 2005, p.146.

Figura 610: Tunnel of Light . Detalhe. Fonte: BENNETT, 2005, p.147

Figuras 611 e 612: Tunnel of Light Nydalen, Metro Station, Oslo. Fonte: <http://performative.wordpress.com/2007/01/. Fotos de Bo Stjerne Thomsen>. Postadas em 21/01/2007. Acesso em 28/08/2011. 
Às margens de um lago artificial, localizado na saída da Estação de metrô Osaki, em Tóquio, no Japão, Joachim Sautere e ART+COM, exibiram Duality, um sistema de piso interativo composto por LEDs cobertos por vidros translúcidos que difundiam a luz emitida. À medida em que os usuários circulavam sobre a superfície, provocavam a exibição de ondas virtuais em tempo real. Quando atingiam as bordas do plano, eram estendidas para o lago como ondulações reais. Desta forma, foi possível explorar as dualidades: líquido/sólido, real/virtual, água/ondas de luz, ponto de partida do projeto. (KATIELEVITT.WORDPRESS.COM, 2007)

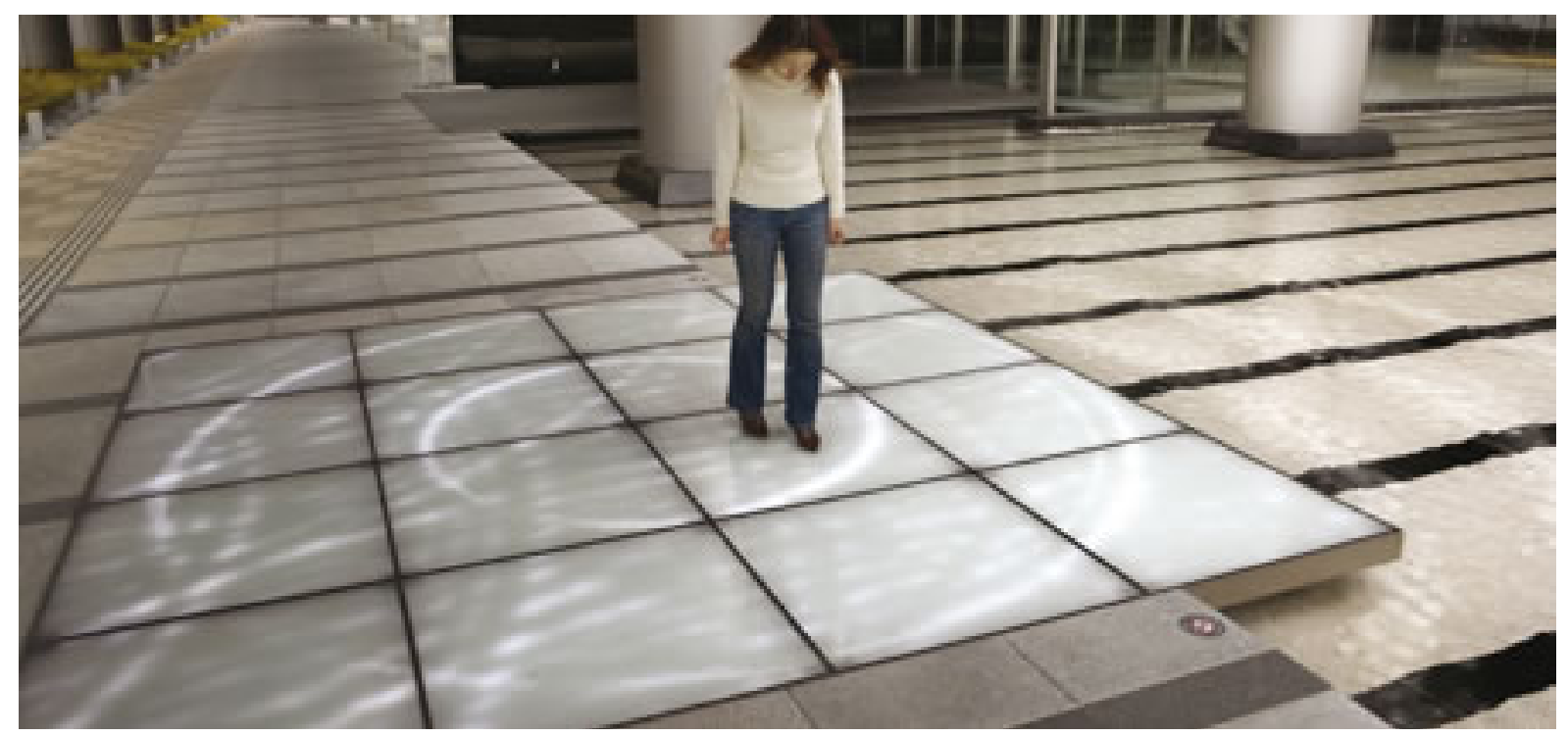

Figura 613: Duality. Criado por Joachim Sauter e ART + COM.

Fonte: Public Art that Emphasizes New Media Triangulation [From www.interactivearchitecture.org]. Publicado em 16/10/2007. Disponível em: <http://katielevitt.wordpress.com/category/more-things-design/page/3/>. Acesso em 08/09/2011.

No site oficial das Olimpíadas de Beijing foi declarado que o sistema de metrô de Shangai (China) estava "prestes a se tornar uma experiência de arte em movimento" (EN.BEIJING2008.CN, 2008). Neste sentido, o The Bund Sightseeing Tunnel, de aproximadamente 650 metros de comprimento, que liga os dois lados do rio Huangpu, é um exemplo prático de aplicação de tecnologia de ponta. A superfície de suas paredes foi transformada em um cenário composto por "imagens, padrões e pontos de vista sobre pessoas, história, cultura, ciência e tecnologia". (JOURNEYTEC.COM, 2010; SCENERY.CULTURAL-CHINA.COM, 2011). 

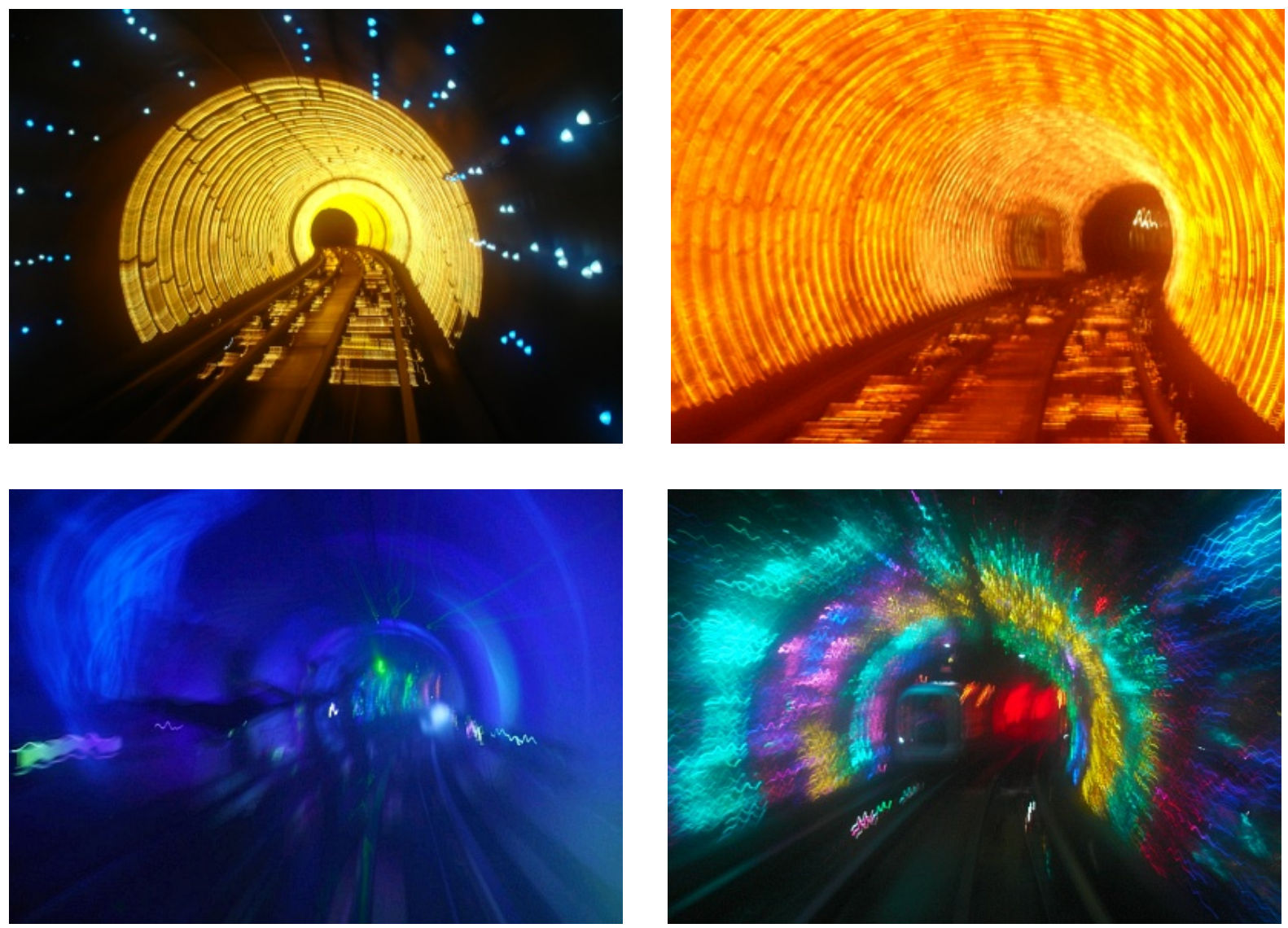

Figuras 614 e 615: The Bund Sightseeing Tunnel. Vista frontal. Fonte: Top 10 Subway Stations of the World. Fonte: <http://www.journeyetc.com/travel-ideas/top-10-subway-stations-of-the-world/>. Acesso em 27/11/10.

Figuras 616 e 617: The Bund Sightseeing Tunnel. Vista frontal. Fonte: Top 10 Subway Stations of the World. Fonte: <http://www.journeyetc.com/travel-ideas/top-10-subway-stations-of-the-world/>. Acesso em 27/11/10.

Embora as publicações existentes sobre intervenções ambientais em estações de metrô sejam em número restrito, as anotações apresentadas certamente contribuem para traçar um panorama dos tipos de manifestações artísticas contemporâneas e de formas de atuar e de política cultural realizadas em redes metropolitanas do âmbito internacional. As informações colhidas comprovam que, apesar das diversas condicionantes de ordem econômica, física, construtiva, tecnológica, de uso ao longo do tempo, de normas pré-estabelecidas e de propósitos políticos, é tecnicamente possível e socialmente aceito o uso de tecnologias atuais em obras temporárias e permanentes nesses ambientes. 



\section{CONSIDERAÇÕES FINAIS}

\section{A ARTE PÚBLICA NA CIDADE CONTEMPORÂNEA}

No panorama atual das reflexões apresentadas no Capítulo 1, nota-se que a paisagem urbana tem sido abordada de modo a expressar as singularidades de seu tempo. A cidade contemporânea: "metrópole comunicacional" (CANEVACCI, 2008) ${ }^{120}$, “megalópole" (PEIXOTO, 2002, p.21), “megacidade” (BARRETO, 2010, p.90), "interface da arte" (BENEDETTI, 2003, p.29), "organismo em constante mutação" (TOZZI, 2001), "imaginada" que "se parece com seus criadores" que são feitos por ela (SILVA, 2011, p.XXIII), é entendida como palco e reflexo de mudanças sociais, econômicas, políticas, culturais e tecnológicas. É cenário para a apresentação de propostas inovadoras enquanto possibilidades de forma, de percepção do espaço e de comunicação que se devem, em parte, às mídias eletrônica e digital. É "território para a prática de atitudes relacionais" (BENEDETTI, 2003, p.29-31), que podem transformar a paisagem urbana, e tem sido transformada em "espaço de proveito privado sob um controle público" (NUNES, 2010, p.32). Intervir na cidade contemporânea também implica em integrar as artes plásticas através de um processo de trabalho híbrido, interdisciplinar (TOZZI, 2001, 2012 ${ }^{121}$ ). A cidade de São Paulo encontra-se profundamente marcada pela tradição modernista/minimalista, portanto, inadequada à realidade contemporânea, fora do "fluxo de desenvolver formas inovadoras, que favoreçam um tipo de percepção, de sensorialidade e de comunicação que outras áreas metropolitanas oferecem". (CANEVACCI, 2008).

O espaço público, diferentemente dos espaços privados e institucionais de galerias e museus, é um ambiente de intensa vida coletiva, de múltiplos interesses e comportamentos (BARRETO, 2010, p. 90). Pode ser usado como "instrumento estratégico para a representação do poder" (LAISTER, 2007, p.431). Ao abranger todo espectro de formas artísticas, seu conceito está sujeito a uma redefinição. (BÜTTNER, 2007, p.332). Pode ser definido como físico e virtual, uma vez que o

\footnotetext{
120 CANEVACCI, Massimo. In AGUIAR, Julia. Entrevista Massimo Canevacci (entrevista realizada para a publicação Sextante - FABICO/UFRGS, sob orientação do jornalista Wladymir Ungaretti, em agosto de 2007). Publicada em 12/04/2008. Disponível em: <http://www.overmundo.com.br/banco/entrevista-com-pensadormassimo-canevacci>. Acesso em: 18/05/2010

${ }_{121}$ Claudio Tozzi em entrevista concedida à pesquisadora, 2012 (APÊNDICE C).
} 
espaço virtual também faz parte do espaço público (SILVA, 2010) ${ }^{122}$. De contornos indefiníveis, possibilita a interação, a participação e a criação de um novo tipo de sujeito, múltiplo e ativo (CANEVACCI, 2008).

Falar em arte pública implica, diretamente, em noções relacionadas à cidade e ao público. Ela tem sido apresentada sob diversas formas e a interpretação do seu papel, no contexto da sociedade contemporânea, é um campo extenso e elástico. Diferentemente do termo "arte em lugares públicos", referente às obras compradas ou comissionadas para espaços acessíveis publicamente ou de propriedade pública (BEARDSLEE, 1981, p.43 apud PALLAMIN, 1994, p.24) ${ }^{123}$, exige atenção ao local (site) em que será inserida e às relações sociais, históricas, políticas e culturais que, continuamente, trabalham na formação do ambiente, o que possibilita que também assuma dimensão crítica. $\mathrm{Na}$ arte pública contemporânea, não há a intenção de exprimir valores eternos e de expressar um tema irrepreensível e acessível a todos. Pode "ocorrer e se instalar em locais indiscretos, marginais e não-tradicionais", como as estações de metrô. Do ponto de vista físico, ela também pode assumir uma especificidade funcionalista, sustentada na cesura entre a arte e o social ao preencher espaços vazios, ao atrair expectativas ou agendar usos aos usuários, ao ser utilizada na valorização de certas áreas de interesse, aparentando ser um "bem para todos" (PALLAMIN, 1994). Tem sido considerada um "termo vago", comumente usado para a arte inserida em espaços ao ar livre nas cidades e comunidades locais (BÜTTNER, 2007, p.332) e sua prática deve ser julgada por seu caráter político (MARCHART, 2007, p.426). No contexto da sociedade de redes de fluxos e lugares, tem-se também uma expansão do conceito de site. Sua definição "foi transformada de uma localidade física - enraizada, fixa, real - para um vetor discursivo desenraizado, fluído, virtual" (KWON, 2002, p.12). Há o surgimento do conceito de arte pública interativa em que conhecimento e ludicidade, fruição com interação, "são imanentes e inseparáveis" (BARRETO, 2010, p.91). O conceito de público/espectador também tem sido transformado. Somando-se àquele que observa e ouve, está o público definido como "elemento que aciona a percepção global e contínua do contexto, que estabelece seleções e relações em um repertório contextual" através de seu uso (FERRARA, 1986, p.120), entendido como "objeto de desejo" (SCHULZ-DORNBURG, 2000, p.12) "para viver uma experiência estética"

\footnotetext{
${ }_{122}$ Armando Silva em entrevista concedida à pesquisadora, 2010 (APÊNDICE A).

123 BEARDSLEE, J., Personal Sensibilities in Public Places. Artforum, Summer, 1981, p.43.
} 
(PEIXOTO, 2002, p.18), que "se interessa pela relação entre a arte, a ciência e as tecnologias contemporâneas, que procura informação sobre o assunto e depara com a escassez de publicações nessa área" (VENTURELLI, 2004, p.14). Participante que age e interage (BARRETO, 2010, p.90). Progressivamente, a identidade de um trabalho artístico contemporâneo, no ambiente público ou privado/institucional, tem dependido da saída da esfera exclusiva de seu autor em direção ao outro (PALLAMIN, 1994), em direção ao público/usuário/espectador/ator/autor. Sua existência social e cultural confirma-se a partir desse momento. Dessa forma, podemos reafirmar que a "atividade artística não constitui uma essência imutável, mas um jogo cujas formas, modalidades e funções evoluem conforme as épocas e os contextos sociais" (BOURRIAUD, 2009, p.14). A qualidade de seu produto "depende da trajetória que descreve na paisagem cultural" (BOURRIAUD, 2009, p.42) e é mensurada "pelo bem que se ajusta ao usuário. O espectador é um participante ativo da obra. Sua percepção da obra está irrevogavelmente vinculada à experiência sensual." (SCHULZ-DONBURG, 2000, p.12).

\section{TECNOLOGIAS ATUAIS E SUAS POSSIBILIDADES DE APLICAÇÃO}

No Capítulo 5 é possível observar a semelhança entre os trabalhos propostos por artistas, arquitetos e designers contemporâneos. O artista tem ampliado seu vocabulário de trabalho tradicional e tem começado a criar interiores, ambientes, instalações e estruturas configuradoras de espaço. Suas metodologias e ferramentas têm se adaptado às novas necessidades e suas fontes de referência têm incluído a ciência, a biologia, a construção, a iluminação, a decoração, o som, a moda, o cinema e a informática (SCHULZ-DORNBURG, 2000, p.12; TOZZI, 2001). O conceito de integração entre arte, arquitetura, design, mídia e tecnologia da informação tem representado uma nova ligação entre o espaço digital, a arquitetura e o espaço urbano que pode envolver grupos de usuários e permite a interação. $\mathrm{O}$ conteúdo exposto pode ser exclusivamente artístico e/ou estar relacionado com a identidade corporativa da empresa, com o uso e a forma do edifício, e assim, produzir um forte efeito publicitário ao tornar-se um marco que passa a fazer parte da percepção urbana cotidiana. No entanto, produtores e usuários enfrentam uma série de desafios a serem superados em um discurso que está tomando forma. Em 
um projeto de arquitetura de mídia há questões relevantes a serem consideradas: a disponibilidade da tecnologia, o custo, o consumo de energia, o conhecimento de questões relacionadas à técnica e às restrições urbanísticas para não gerar poluição luminosa e não afetar o usuário. Pesquisas têm sido realizadas constantemente em busca da redução de custos e de aprimoramentos quanto à eficiência, aplicação, produção e descarte das tecnologias do LED, da célula fotovoltaica e das mídias eletrônica e digital. No caso do LED, o custo tem diminuído (INOVACAOUNICAMP.BR, 2009), a célula fotovoltaica está por ser descoberta pelo mercado brasileiro como um dos investimentos mais rentáveis (ARCOWEB.COM, 2009) e os recursos de mídia tendem a ser barateados; o desafio é "saber o que fazer com eles" (NAKAMURA, 2010, p.78). A hibridização de linguagens e de suportes tecnológicos aplicados em uma única obra de forma integrada tem atribuído às edificações uma nova pele, até mesmo sensível ao toque de nossas mãos. Podem constituir sistemas autossuficientes de armazenamento de energia solar durante o dia para ser utilizada durante a noite, a exemplo do GreenPix Zero Energy Media Wall. Sistemas de molas e microships instalados no piso podem captar movimentos dos usuários que são transferidos para um gerador que armazena eletricidade para alimentar sistemas de iluminação da edificação, como no WATT Club. Com o crescente desenvolvimento dos meios de consumo gerados na $W E B$, o boom de redes sociais, os novos formatos de mídia que serão criados e a portabilidade de aparelhos sem fio como os celulares, supõe-se um grande potencial para aplicações que criem redes sociais em torno da arquitetura de mídia, as quais levarão à maior penetração dos espaços físico e virtual, o que implica também na redução de custos para o acesso à rede e na criação de filmes e vídeos domésticos. Instalações concebidas para serem permanentes apresentam melhores resultados em função do conceito, planejamento e investimento aplicados (TSCHERTEU; LEEB, 2008, tradução nossa). Se as tecnologias forem incorporadas ao projeto ainda na fase de concepção tornam-se relativamente baratas. É fundamental que haja uma comunicação entre os profissionais envolvidos e que seja feita a prévisualização da ideia (EDLER, 2009). 
TECNOLOGIAS ATUAIS EM INTERVENÇÕES AMBIENTAIS EM ESTAÇÕES DE METRÔ DO ÂMBITO INTERNACIONAL

No estudo de intervenções ambientais em estações de metrô de Londres, New York, Toronto, Shangai, Portland, São Francisco, Toulouse, Tóquio, Olslo e Paris, apresentado no Capítulo 6, foi possível observar que a extensão, somada à complexidade desses espaços regulamentados e geridos por uma organização rígida, dificulta a oportunidade dos artistas desenvolverem e exporem seus trabalhos. Apesar das diversas condicionantes de ordem econômica, física, construtiva, tecnológica, de uso ao longo do tempo, de normas pré-estabelecidas e de propósitos políticos, às quais a arte pública está submetida, tem sido tecnicamente possível e socialmente aceito o uso das tecnologias atuais: LED, célula fotovoltaica, mídias eletrônica e digital, incluindo projeções e fotografias, em obras temporárias e permanentes, nesses ambientes. Os trabalhos têm sido em grande parte site-specific, também executados com materiais convencionais (metais, vidro, sucata). Os elementos água, som e luz fazem parte de propostas de intervenção. Em alguns casos, há a hibridização de materiais e linguagens. A interatividade ocorre em dois níveis - com o usuário/espectador/ator e/ou com o ambiente. Nota-se desta forma uma correspondência com os trabalhos desenvolvidos por artistas, arquitetos e designers contemporâneos apresentados no Capítulo 5. Intervenções em forma de instalações, equipamento urbano, projeções, fotografias, cartazes, mapas da rede, são apresentados/instalados em plataformas, bilheterias, próximos às catracas, túnel, escada rolante, entorno das estações, na própria arquitetura. Outra particularidade é o uso de tecnologias atuais para 0 restauro e a execução de releituras de obras antigas.

Artistas reconhecidos internacionalmente são convidados para participar dos programas de arte das redes. Concursos são realizados para apresentação de propostas de intervenção em espaços internos e no entorno das estações. Artistas, arquitetos e designers atuam de forma integrada desde a fase de concepção do projeto arquitetônico. Há a presença do curador(es) e de comissão(ões) temporária(s) ou permanente(s), composta(s) por membros diversificados: profissionais das artes visuais, representantes da comunidade, usuários, prefeitura, organizações e conselhos locais, que analisam artistas e propostas. Exposições de artistas internacionais e projetos comunitários, uma das derivações da arte 
contemporânea, envolvem a participação de usuários, estudantes, membros das comunidades locais e funcionários da rede de metrô. Redes sociais, constituintes do espaço público virtual, exploradas em práticas artísticas interativas, foram traduzidas e apresentadas na forma física de cartazes e mapas instalados em paredes e pisos. Folhetos sobre as obras de arte apresentadas nas estações são distribuídos nas bilheterias. Painéis culturais que informam aos usuários sobre diversos aspectos da estação/linha em que estão inseridos são instalados em plataformas, escadas. Trabalhos são encomendados e, totalmente ou parcialmente, financiados pelo poder público. Em New York e Toulouse, por exemplo, parte dos recursos aplicados na restauração ou na construção das estações, $1 \%$ e $0,5 \%$ respectivamente, é destinada à instalação de trabalhos artísticos permanentes, de design e à restauração de trabalhos antigos. Em Paris, o financiamento era realizado pela Companhia, atualmente, uma parte do financiamento é pública e outra é privada. Parcerias são fundamentais para a realização dos projetos, sendo marcante o apoio de galerias e museus. O espaço público das estações é explorado como uma extensão desses espaços institucionais privados em que trabalhos são apresentados em ambos, simultaneamente, como estratégia de marketing em busca de um público diversificado e mais amplo, característica que tem despertado o interesse de publicitários.

Como parte da "engenharia cultural" da rede parisiense, está o profissional que desempenha a função inédita de "délégué à la conception", quem gerencia e delega o posicionamento dos profissionais das diversas disciplinas ainda na fase de concepção dos projetos. As relações entre obra/espaço, obra/público, obra/financiadores, obra/artista são tratadas com o mesmo grau de importância. Preocupações com a seleção das obras e dos artistas, a curadoria, a manutenção, a preservação, o design total, a informação cultural e a aplicação de tecnologias atuais são constantes na busca de satisfazer os usuários/espectadores/consumidores, alimentar o sentimento de pertencimento da população, realizar projetos culturais que sejam instrumentos de cooperação entre a rede de transporte e autoridades locais e de alimentar a marca e a identidade cultural da empresa e da cidade. (KAMINAGAI, 2012). 


\section{A ARTE PÚBLICA NA CIDADE DE SÃO PAULO}

$\mathrm{Na}$ cidade de São Paulo, em ações financiadas ou cofinanciadas pelo poder público: A Arte e o Planejamento, Intervenções Urbanas: Arte Cidade I e Il e Arte na Cidade, apresentadas no Capítulo 2, há correspondências com os conceitos atuais de cidade, espaço público, arte pública, arte pública interativa e site specific apresentados no Capítulo 1. Trabalhos foram desenvolvidos, em sua maior parte, especificamente para o contexto em que foram inseridos. As exposições demonstraram que a arte, ao longo de décadas, vem sendo utilizada pelos poderes público e privado como elemento funcional que valoriza a cidade enquanto imagem e marketing. Intervenções artísticas e urbanísticas, de caráter permanente e temporário, adotaram como cenário e/ou suporte espaços convencionais e não convencionais da paisagem urbana. Partiram da escala do espectador, alcançaram maiores proporções e retornaram para a escala inicial. Os Arte/Cidade(s) nasceram com o propósito de ser eventos culturais midiáticos, o que implicou no uso de tecnologias atuais e de linguagens diversas. Luz, água (reflexão), som, escavação e o próprio tempo também foram recursos empregados como parte constitutiva de algumas obras. Alguns trabalhos possuem (ainda há trabalhos do Arte na Cidade em exposição) um ciclo para que sejam concluídos interagindo com o ambiente, enquanto outros requereram a ação dos espectadores/atores ou propunha espaços de convivência para a exibição de murais desenvolvidos de forma coletiva/colaborativa aproximando-se do conceito da "estética relacional" de Nicolas Bourriaud. Os processos de criação dos artistas e arquitetos participantes não estiveram integrados aos dos arquitetos e planejadores urbanos dos sites, os trabalhos foram desenvolvidos para espaços pré-existentes. A ausência de um contexto institucional pré-estabelecido que determinasse o formato, a organização e a iniciativa do Arte/Cidade III implicou na mobilização de um amplo e variado número de realizadores e patrocinadores e exigiu dos profissionais uma atuação multi e interdisciplinar.

O incentivo fiscal para projetos culturais no município ainda é pouco utilizado em decorrência da restrita divulgação dos benefícios de marketing para as empresas e da ausência de divulgação do mecanismo para os artistas e a população. A combinação do uso de lei federal com municipal para o patrocínio de um mesmo projeto possibilitaria ao empresário desembolsar menos de $10 \%$ do valor total 
(GOUVEIA, 1995, p.91). Outra questão relevante é que a Lei Municipal de Incentivo Fiscal, que apoia projetos de artes visuais e audiovisuais, dentre outros, não contempla projetos apresentados por escolas, o que dificulta a participação de estudantes.

Muitos projetos aprovados pela Lei Rouanet, que possibilita 70\% de redução fiscal, no caso de bancos chega a $75 \%$ e, se somada à Lei de Audiovisual, a dedução é de $100 \%$, não são executados devido a falta de envolvimento do produtor cultural com a área financeira das empresas, que considera a cultura uma despesa inútil, e a falta de apoio da própria área de marketing. É necessário que auditores do Ministério da Cultura esclareçam que cultura também é um negócio que traz benefícios. (MUYLAERT, 1995, p.83-86).

\section{A ARTE PÚBLICA NAS ESTAÇÕES DE METRÔ DE SÃO PAULO}

No Capítulo 3, nota-se que na produção artística nas estações de metrô de São Paulo, ao longo de décadas, a arte permanente esteve enquadrada no conceito de "arte em espaço público" por se tratar, inicialmente, de obras compradas ou comissionadas para os espaços públicos das estações. Sob o ponto de vista físico, enquadra-se no conceito de "arte pública" ao assumir caráter funcionalista, como "instrumento eficaz" para apaziguar a relação da instituição com o seu usuário, melhorar o aspecto cinza e estar instalada/apresentada em um espaço nãoconvencional. Entretanto, não alcança as dimensões crítica e política em sua plenitude, impossibilitada, em parte, pelas restrições quanto ao tema proposto pelo artista em uma instituição dirigida pelo Estado. Parece persistir na ideia de exprimir valores eternos para uma vasta plateia com a expectativa de expressar um tema irrepreensível e acessível a todos, ou seja, na contramão da arte contemporânea, que suscita controvérsias no âmbito de sua recepção. Assim como em outros lugares públicos, ainda pode significar "um aflorar de sensibilidades e emoções, um momento de reflexão, uma desaceleração do cotidiano e a humanização do espaço." Quando aliada à técnica, à sensibilidade e à prática projetual adequadas pode valorizar a arquitetura e levar maior qualidade de vida aos seus usuários/espectadores. Possibilita transmitir "mensagens educativas através de elementos, que por sua plástica, aguçam a curiosidade, estímulo ao respeito e 
noção de conservação dos espaços coletivos" utilizados no cotidiano. Pode "recuperar a memória coletiva", (FREITAS, 1994, p.10-11) "resgatar a ideia de reciclagem e de otimização de recursos" (METRO.SP.GOV.BR, 2010), "beneficiar a comunidade pela imagem corporativa da empresa vista positivamente na vida sociocultural da cidade". Através de políticas de intercâmbio de obras e de comunicação social com outras companhias de metrô "traz dividendos". Para os artistas, significa expor seus trabalhos para um público mais amplo do alcançado nos museus e galerias (SANTOS, 2006, p.64).

O acervo é composto por uma diversidade de gêneros artísticos: esculturas, murais, painéis, pinturas e instalações inseridas, em sua maior parte, em espaços internos e de maior concentração de usuários/espectadores, situados após o bloqueio das catracas. Os materiais empregados têm sido convencionais, duráveis e de fácil manutenção como rege a filosofia inicial do Projeto Arte no Metrô: tintas, metais, cerâmicas, vidro, concreto, mármore, fibra de vidro, elementos naturais, serigrafia sobre vidro e impressão digital sobre lona vinílica. Apenas $57 \%$ das estações em funcionamento possuem obras permanentes, distribuídas de forma desequilibrada, concentradas em seis estações. Quanto à especificidade das obras em relação ao contexto em que estão inseridas, abrange desde as totalmente desvencilhadas, vindas dos ateliers, alcançando as concebidas para os contextos físico, social, histórico, cultural, ecológico/ambiental e relacionadas à memória do lugar. Os trabalhos de Marcello Nitsche e de Sérgio Ferro, transferidos dos locais para onde foram concebidos, perderam seu sentido original. $O$ trabalho de Alfredo Ceschiatti passou a ser utilizado como mobiliário para descanso dos usuários. Em todas as estações que possuem obras de arte permanente, painéis informativos indicam as obras instaladas na estação, sua localização e informações técnicas, porém, não são dadas informações sobre o autor. Em algumas delas, também há totens multimídia que apresentam as mesmas informações de forma interativa.

\section{TECNOLOGIAS ATUAIS EM INTERVENÇÕES AMBIENTAIS NAS ESTAÇÕES DE METRÔ DE SÃO PAULO}

Por iniciativa de instituições privadas, a Arte Pública Interativa, de caráter temporário, alcançou os espaços de algumas estações através de parcerias com o 
Itaú Cultural e a FIESP significando uma forma de apresentar manifestações artísticas contemporâneas para quem não tivesse visitado esses espaços institucionais, de ressaltar a importância dessa nova vertente da arte pública contemporânea em busca de compreender e absorver os fenômenos culturais proporcionados pela aplicação de tecnologias atuais que requerem a interação público/obra e de promover as instituições envolvidas. Apresentadas em forma de instalações, games e animações, foram acionadas por dispositivos diversos: sensor de movimento, mouse, controle remoto, sopro e celular. Na Exposição Arte Cibernética-Acervo Itaú Cultural (2010) e nas duas edições do FILEPAI (2010 e 2011), os trabalhos apresentados não foram criados especificamente para 0 contexto das estações do Metropolitano; no caso dos games, animações e da instalação Via Invisível, para alcançar o espaço público virtual das culturas digital e sem fio. Apesar do "efeito pistão", da trepidação e de problemas referentes à iluminação e à localização inadequadas que vieram a comprometer a visibilidade e apresentação de alguns trabalhos (FILEPAl 2010), os quais poderiam ter sido evitados se tivesse havido uma ação integrada e planejada, foi demonstrado que através de parcerias e do apoio de Leis de Incentivo e patrocínio é possível que tecnologias atuais sejam aplicadas em trabalhos temporários nas estações. Recursos diversificados que incluem a aplicação de tecnologias atuais, materiais e virtuais, têm sido utilizados por publicitários de forma estratégica, por se tratar de elementos "diferentes", que causam maior impacto no usuário/consumidor.

Na pesquisa qualitativa, realizada junto aos usuários/espectadores/atores ${ }^{124}$, houve a aceitação de instalações, games e animações, desenvolvidos com tecnologias atuais, entendidos por eles como obras de arte: "diferentes", "interessantes", "divertidas", "criativas", "bonitas", "inovadoras", que "chamaram a atenção", "atraíram", "despertaram a curiosidade em saber como funcionavam". A interatividade exigida, que os tornava parte constituinte das obras, foi vista como uma forma de "brincar" que "traz boas sensações", "diverte", "relaxa", "desestressa", "distrai", "quebra a rotina do cotidiano", "torna o ambiente melhor", "aproxima a arte das pessoas". Houve casos em que foram às estações especificamente para conhecê-las, mostrá-las para alguém, para interagir novamente com as obras tecnológicas temporárias apresentadas nos espaços internos e externos das

\footnotetext{
${ }^{124}$ Usuários/espectadores/atores em entrevistas concedidas à pesquisadora no decorrer da Exposição de Arte Cibernética e nos FILEPAI(s), 2010 e 2011 (APÊNDICE B).
} 
estações. Como afirmaram muitos dos entrevistados, não é todo mundo que tem tempo, hábito, interesse e dinheiro para frequentar galerias e museus, neste sentido, a presença da arte em espaços públicos como os do metrô "facilita o contato com a arte", "desperta o interesse", "possibilita conhecer o que está sendo feito de novo sem ter que sair da rotina". O idioma inglês utilizado nos trabalhos apresentados por artistas internacionais foi indicado como um fator que dificultou o entendimento das falas dos personagens dos games.

De acordo com as observações dos monitores ${ }^{125}$, o maior fluxo de pessoas que interagiu com as obras "foi o dos usuários do metrô". As instalações atraíram todas as faixas etárias, enquanto que os games e as animações tiveram maior atenção de crianças e jovens. O retorno de usuários para rever, apresentar e interagir foi reafirmado. Muitos, pela falta de tempo, não pararam para interagir no momento em que as viram, mas retornaram justamente para levar seus filhos, "como se estivessem educando uma nova geração com aquele tipo de arte". Alunos de escola de ensino médio e de curso superior visitaram a Exposição Arte Cibernética para desenvolverem trabalhos solicitados pelos professores. Idosos, apesar de não estarem acostumados com as tecnologias atuais, interagiram com a ajuda de monitores. Crianças de rua tiveram a oportunidade de interagir com games exibidos na Estação Trianon-MASP, instalados antes do bloqueio das catracas. Houve também a preferência de alguns usuários por interagir com games e animações no ambiente das estações, apesar de estarem disponíveis na internet. Para Regina Silveira, a Exposição Arte Cibernética "foi um sucesso e a interatividade das obras contribuiu para atrair o público que muitas vezes pode permanecer por um período de tempo maior na estação" (SILVEIRA, 2012) ${ }^{126}$. A prorrogação do prazo da exposição, a manutenção requerida pelas obras que fizeram parte dela em função do volume de interatores (SILVEIRA, 2012) e a permanência desses espaços no roteiro dos eventos do FILE são fatos significativos nos quais está implícita a aceitação do público/usuário/espectador/ator. A exemplo das exposições do FILEPAI, áreas anteriores às catracas e externas às estações também deveriam ser utilizadas como espaços expositivos para que os trabalhos fossem apreciados não somente pelos usuários do metrô, que pagam pelo bilhete, mas também pelos demais cidadãos.

\footnotetext{
${ }^{125}$ Monitores em entrevistas concedidas à pesquisadora no decorrer da Exposição de Arte Cibernética e nos FILEPAI(s), 2010 e 2011 (APÊNDICE B).

${ }^{126}$ Regina Silveira em entrevista concedida à pesquisadora, 2012 (APÊNDICE C).
} 
Condicionantes de ordem econômica, física, construtiva, tecnológica, de uso ao longo do tempo, de normas pré-estabelecidas, de propósitos políticos influenciam na apresentação e instalação das obras de caráter temporário e permanente. $\mathrm{Na}$ filosofia do Projeto Arte no Metrô, a escala deve ser "monumental", os materiais "formes e facilitadores de conservação" para proporcionar estabilidade e durabilidade, o suporte e a instalação das obras devem receber "tratamento particular, preventivo e rigor técnico". Em muitos casos, é necessária a elaboração de maquetes para "melhor visualização da proposta" e "melhor adequação da obra ao espaço destinado" (ABRAMO, 1994, p.19). O "efeito pistão" e a trepidação são fenômenos que devem ser levados em conta na infraestrutura da obra (ABRAMO, 1995, p.155; TÉCNICO DE MANUTENÇÃO, 2010 ${ }^{127}$; TOZZI, 2012). A localização e a iluminação devem ser adequadas para a melhor visualização e percepção de cores e formas, no entanto, a disponibilidade de recursos financeiros é condicionante de primeira ordem, determinante de sua presença e permanência.

Inicialmente, havia uma Comissão Consultiva multidisciplinar que incluía em sua composição artistas e representantes dos usuários a qual, a partir de critérios técnicos, realizava a seleção de artistas e obras (ABRAMO, 1994, p.19) através de concurso fechado e a apresentação dos trabalhos era em nível de projeto (ABRAMO, 1995, p.60). Para a Estação Sé, Radhá Abramo realizou um projeto curatorial que envolvia a área externa da Praça da Sé e diversas áreas internas da estação (TOZZI, 2012). Posteriormente, arquitetos e projetistas responsáveis pelas estações passaram a decidir o local de instalação das obras sem a orientação de um curador. A iluminação era a mesma utilizada nas estações e o financiamento era feito pela Companhia.

Nos regulamentos para apresentação e execução de obras permanentes e temporárias, publicados recentemente no site da instituição, é possível observar progressos e retrocessos em relação à forma inicial de atuar da Companhia. A disponibilização do regulamento para apresentação de obras permanentes acompanhado de peças gráficas com a indicação dos espaços "com vocação" para recebê-las, a mencionada preocupação com elementos que possam vir a interferir na visibilidade das obras e a predeterminação de relatório técnico que oriente a manutenção e a preservação são avanços que merecem ser destacados. Em

${ }_{127}$ Técnico de manutenção da Exposição Arte Cibernética: Acervo Itaú Cultural em entrevista concedida à pesquisadora, 2010 (APÊNDICE B). 
contrapartida, a não disponibilização de espaços e peças gráficas de estações em funcionamento, principalmente daquelas que não possuem obra artística instalada; a ausência de representantes da comunidade local e de usuários no corpo da Comissão Consultiva; a ausência de um curador que harmonize as obras artísticas no espaço arquitetônico; a avaliação da "pertinência da obra" que não deixa explícito a que se refere, mas que, de acordo com depoimento apresentado no Capítulo 4, inclui a restrição ao tema e a falta de financiamento por parte do metrô indicam retrocessos que têm implicado na não execução de propostas aprovadas, apresentadas por artistas convidados/comissionados.

A disponibilização dos espaços predeterminados pelo arquiteto das estações em construção para a intervenção artística é uma iniciativa válida, mas que poderia ter resultados mais significativos enquanto criação, inovação e redução de custos, não somente para a obra artística, mas também para a obra arquitetônica, se fossem criadas e desenvolvidas de forma planejada e integrada com o artista e demais profissionais envolvidos ainda na fase de concepção dos projetos, assim como indicam as falas apresentadas nos Capítulos 1, 2, 4, 5 e 6. Não é mencionado o tipo de material a ser aplicado.

A especificidade da obra em relação ao lugar, como assinalado anteriormente, aparenta não ser um aspecto da arte pública considerado relevante pela Companhia. Trabalhos sem relação alguma com o espaço, com o contexto, são instalados nas estações. $O$ deslocamento de alguns deles demonstram a permanência da transitoriedade das obras no subterrâneo, o que corresponde ao que acontece nos espaços públicos da superfície. Isto se deve, inicialmente, à própria concepção da obra arquitetônica em que os espaços não eram pensados para receber obras de arte. No entanto, tende a permanecer com o conteúdo do regulamento que ignora esse aspecto como um dos critérios na seleção das propostas artísticas e explicita a possibilidade do artista ter de transferir a obra do lugar disponibilizado em função de possíveis mudanças no projeto arquitetônico e de interesses políticos da Companhia, uma contradição à filosofia do Projeto Arte no Metrô, caracterizada pelo desperdício de mão de obra e de recursos financeiros investidos não somente na obra pública artística, mas também arquitetônica, e pelo desrespeito ao trabalho do artista.

No regulamento para apresentação de obras temporárias, a cessão gratuita dos espaços, que favorece a acessibilidade aos proponentes; a multiplicidade de canais 
utilizados na divulgação dos eventos e exposições, que informa usuários e funcionários e a preocupação com que as obras permanentes não sejam obstruídas por painéis de comunicação visual, publicitários e informativos são ações positivas. Critérios de avaliação das propostas relacionados à adequação do projeto ao espaço físico das estações, à qualificação do projeto quanto à originalidade, técnica e contemporaneidade da proposta são considerações que apontam para a especificidade física da obra e para a aceitação da aplicação de tecnologias atuais em intervenções ambientais temporárias. Por outro lado, restrições quanto ao uso da infraestrutura hidráulica, ao tema proposto e a ausência de um curador são aspectos negativos que, em parte, também são indicados no regulamento para obras permanentes.

A burocracia e a preocupação com a imagem da instituição e, consequentemente, do Governo do Estado, são explícitos em ambos os regulamentos, sendo que a ausência de financiamento público tem sido declaradamente o maior empecilho para que a arte se faça presente e permaneça nos espaços das estações de metrô e da paisagem urbana paulistana.

A interdisciplinaridade artista/arquiteto que projetou a estação, com exceção da aproximação do artista Carlos Fajardo e do arquiteto Luis Carlos Esteves enquanto a Estação Vila Prudente estava sendo construída, continua sendo inexistente nas estações mais recentes. É certo que Renina Katz (Sé) e Maurício Nogueira Lima (São Bento), mesmo que não tenham vivenciado a experiência do trabalho integrado com 0 arquiteto, tiveram a oportunidade de realizar obras específicas integradas à forma arquitetônica que contribuíram para tornar os espaços ambientes agradáveis, exceções possibilitadas pela sensibilidade e experiência profissional dos artistas e pelo uso de material convencional: a tinta acrílica. No entanto, quando se pretende aplicar tecnologias atuais, o projeto interdisciplinar é fundamental.

O uso dos espaços públicos das estações para interesses privados e políticos tem gerado ao longo dos anos um "empilhamento" que se estende para além do kitch, alcançando o caótico. Quiosques comerciais, informes publicitários, elementos de comunicação visual, instalações elétricas, vigas metálicas e o excesso de materiais e de cores aplicadas no interior e no exterior das estações antigas e recentes têm se sobreposto e, ao mesmo tempo, competido com as obras de arte permanentes e temporárias. Uma concentração de elementos que polui 0 ambiente e que compromete a visibilidade e a legibilidade do usuário/espectador. Nas estações da 
Linha Amarela, operada em regime de concessão pelo Consórcio Via Quatro ${ }^{128}$, as obras de arte inexistem. Se existissem, possivelmente, passariam despercebidas em meio à concentração de cores, de materiais, do comércio e de painéis publicitários em um mesmo espaço, em especial, o das plataformas de embarque e desembarque. A provável falta de "planejamento integrado" (TOZZI, 2012) tem resultado em "gambiarras" na instalação da iluminação e de painéis eletrônicos no interior das estações e na permanência de fiações em estado precário como parte da paisagem circundante, elementos que interferem na qualidade e na visualização das obras arquitetônicas recém-inauguradas.
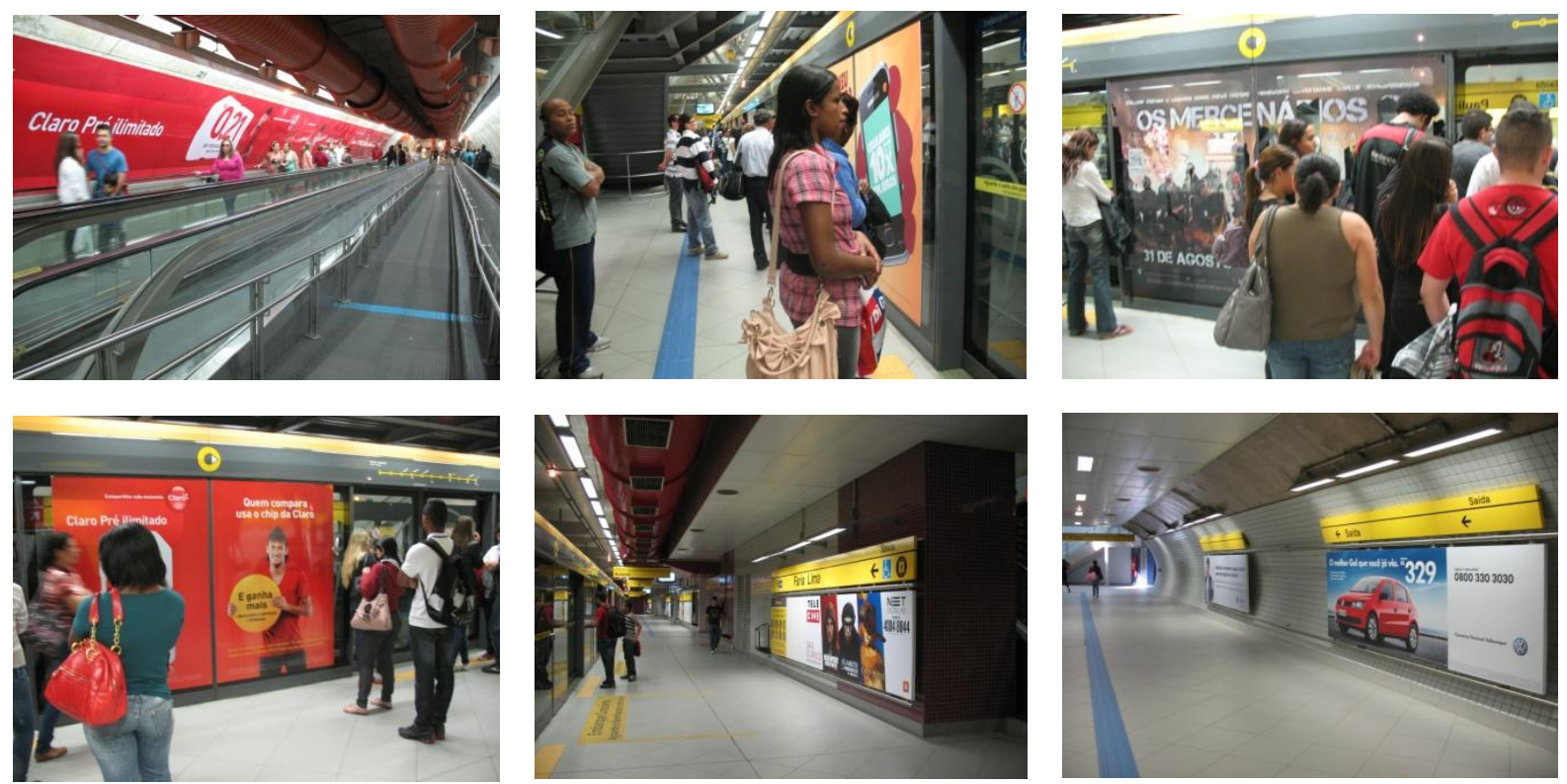

Figuras 618, 619, 620, 621, 622 e 623: Excesso de publicidade. Fonte: Registro fotográfico realizado pela pesquisadora.

\footnotetext{
128 ViaQuatro é uma empresa pertencente a Companhia de Concessões Rodoviárias, que tem sido a responsável pela operação e manutenção da Linha 4 do Metrô de São Paulo (Linha Amarela), por um contrato de concessão de 30 anos através de uma parceria público-privada com o governo do Estado de São Paulo. (PT.WIKIPEDIA.ORG, 2012).
} 

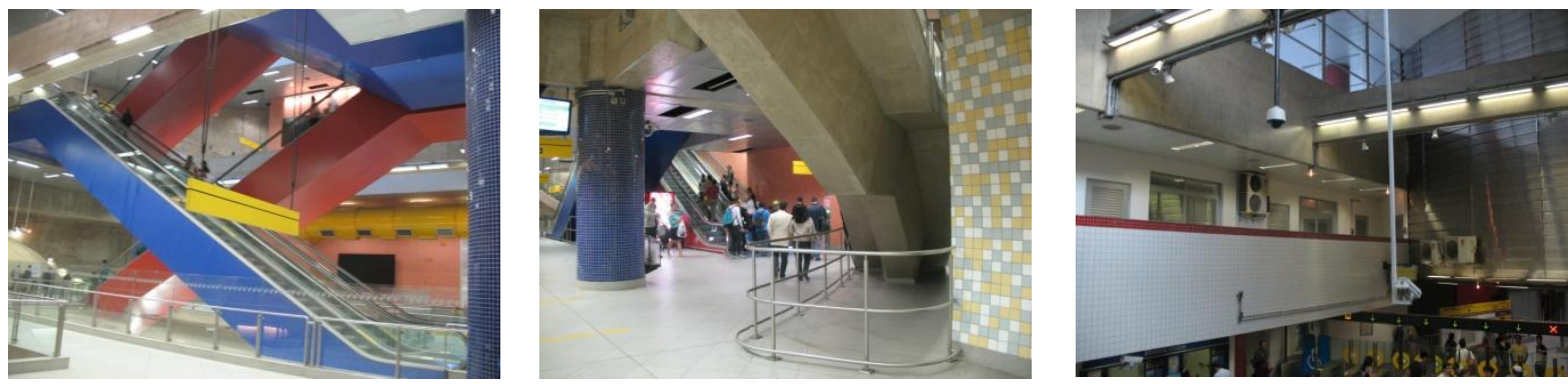

Figuras 624, 625 e 626: Excesso de cores e materiais. Fonte: Registro fotográfico realizado pela pesquisadora.
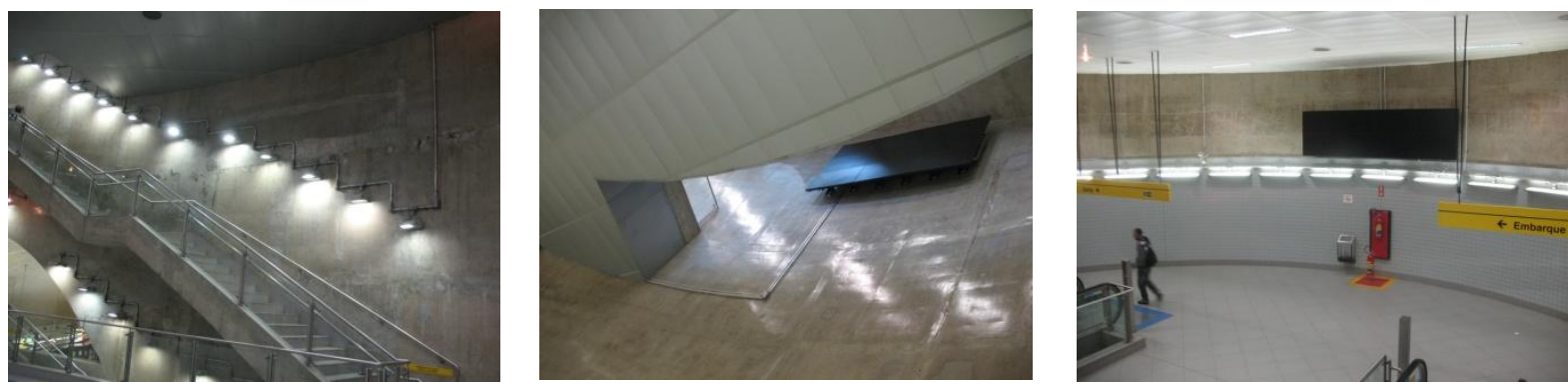

Figuras 627, 628 e 629: "Gambiarras" na iluminação e na instalação de painéis eletrônicos. Fonte: Registro fotográfico realizado pela pesquisadora.
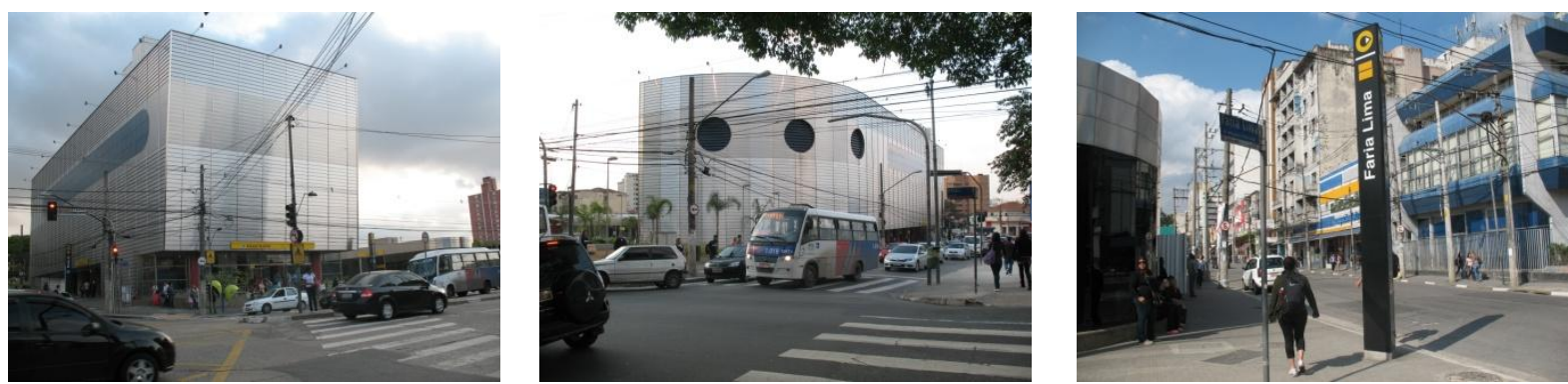

Figuras 630, 631 e 632: Fiação compromete a visibilidade das obras arquitetônicas. Fonte: Registro fotográfico realizado pela pesquisadora.

Nos depoimentos dos artistas, apresentados no Capítulo 4, a arte nesses espaços pode significar um "estímulo para a imaginação das pessoas, um campo de viagem espiritual" (AMÉLIA TOLEDO, 2012) ${ }^{129}$; um "elemento de desenho da cidade", "um símbolo para a cidade" (TOZZI, 2012); um fenômeno que apresenta dimensões estéticas, filosóficas, de fazer, de causar reflexões e convidar, além da dimensão política, um dos "cuidados fundamentais" para com os cidadãos (ZAIDLER, 2012) ${ }^{130}$; "um desafio perceptivo e cognitivo" que pode proporcionar aos seus usuários/espectadores/atores uma "experiência transformadora que ativa a sensibilidade, a percepção e a compreensão do mundo" (KUTSCHAT, 2012) ${ }^{131}$.

\footnotetext{
${ }^{129}$ Amélia Toledo em entrevista concedida à pesquisadora, 2012. (APÊNDICE C)

${ }^{130}$ Waldemar Zaidler entrevista concedida à pesquisadora, 2012. (APÊNDICE C)

131 Daniela Kutschat em entrevista concedida à pesquisadora, 2012. (APÊNDICE C)
} 
Os espaços das estações do metrô de São Paulo foram definidos de diversas formas, porém, em nenhum momento como não-lugares. São espaços "secos e limpos", "passagens despersonalizadas, para trânsito rápido, olhares indiferentes", características interpretadas como "um desafio para o artista" (SILVEIRA, 2012); "campo de percurso de pedestres e ao mesmo tempo estágios desse percurso" (AMÉLIA TOLEDO, 2012); "lugares praticados" (FAJARDO, 2012) ${ }^{132}$. São espaços resultantes de "um encaminhamento político de como são feitas as coisas", não se trata de espaços de passagem, não se trata de não-lugares, uma vez que "a questão do espaço não é uma questão inerente ao espaço. É uma troca e que envolve o ser vivente naquele espaço", ou seja, "qualquer espaço é espaço de passagem e nenhum espaço é espaço de passagem". Uma das questões a considerar é a tecnologia, que pode ser utilizada para que uma ideia seja percebida pelo usuário, funcionando "como gatilho de uma percepção diferente daquele lugar que não é não-lugar, não é um lugar de passagem." O espaço para virar lugar prescinde de estímulo (ZAIDLER, 2012). Dependendo da estação e do horário, podem ser consideradas espaços de passagem. Se possuem espaços expositivos, há uma outra relação do usuário/espectador com o espaço, deixando de ser espaço de passagem. Diante da mobilidade proporcionada pelas tecnologias atuais, a "relação das pessoas com esses espaços que foram definidos como 'não lugares' já está um pouco alterada através dessas tecnologias que estão incorporadas ao corpo". É possível estarmos em todo lugar, a todo tempo, ou seja, somos nós que estabelecemos o espaço através de nossa relação com ele (KUTSCHAT, 2012). Este entendimento dos artistas corresponde, em parte, ao de Armando Silva, para quem o metrô é um "sítio contemporâneo" que está relacionado à pessoa. Contemporaneamente, temos mais "sítios" que lugares. "Não-lugares", são lugares que não têm discurso, que não são visitados ou são visitados por muito poucas pessoas, que não têm reflexão coletiva, características que não correspondem ao metrô, "um bom exemplo de sítio autêntico, muito urbano, de muita vida coletiva". (SILVA, 2010) .

Registros de usuários realizando atividades diversas demonstram que não se trata de não-lugares e de espaços exclusivamente de passagem. O comércio e a publicidade, intensamente praticados nesses espaços, a Exposição Arte Cibernética e os FILEs, contribuem para comprovar isso.

\footnotetext{
${ }^{132}$ Carlos Fajardo em entrevista concedida à pesquisadora, 2012. (APÊNDICE C)
} 

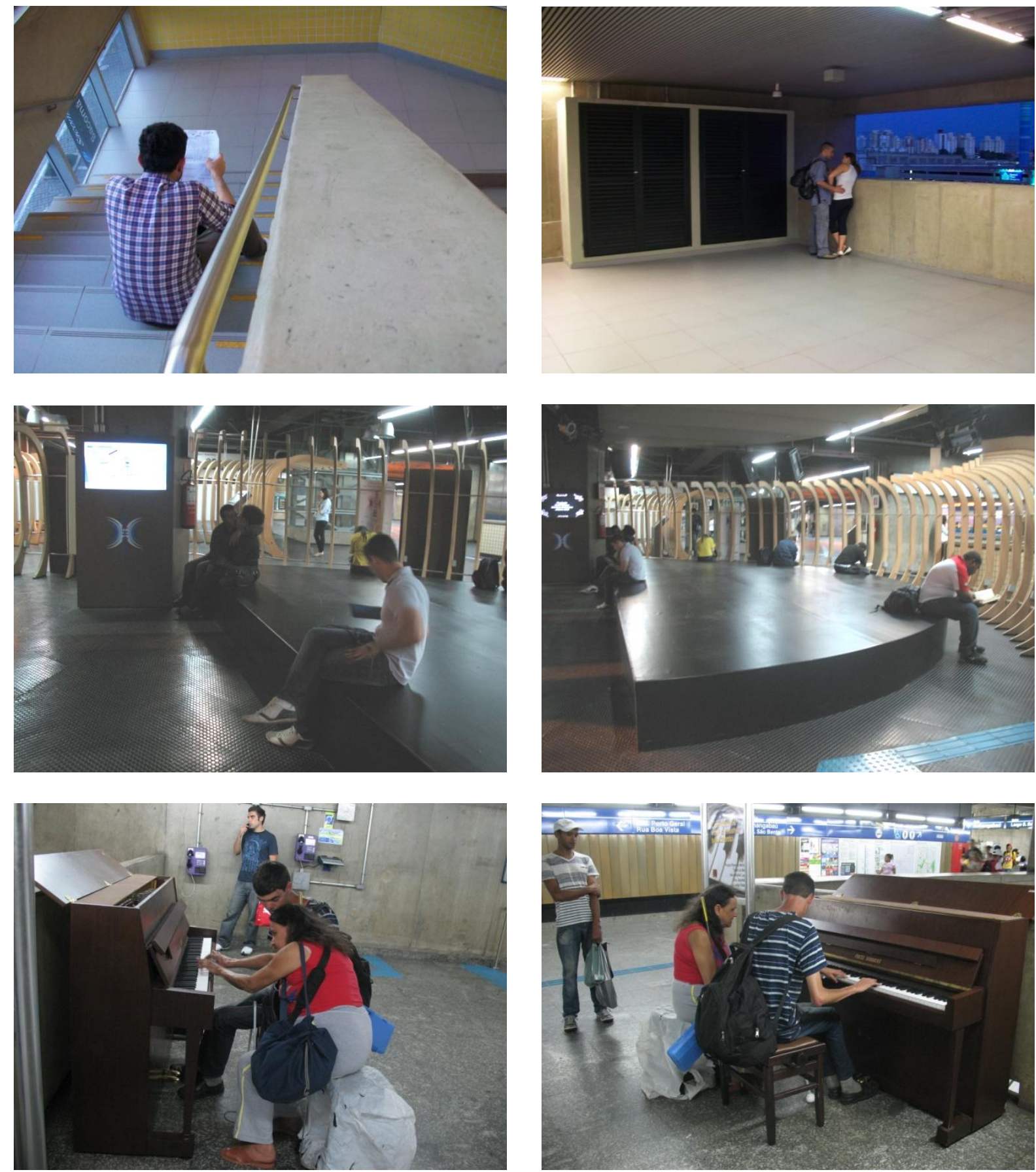

Figuras 633, 634, 635, 636, 637 e 638: Usuários das estações Sacomã, Vila Prudente, Paraíso e República utilizando os espaços das estações como lugares de encontros, estudo, leitura, acesso à internet. Uma deficiente visual ensina outro deficiente a tocar piano. Fonte: Registro fotográfico realizado pela pesquisadora.

A interação entre arte e tecnologia, em obras temporárias e permanentes, é vista de maneira positiva. Alguns dos artistas aplicam tecnologias atuais em seus trabalhos; outros pretendem aplicá-las até mesmo associadas a materiais convencionais, apesar da tecnologia por si só não ser entendida como arte por parte deles. A 
aplicação do LED, da célula fotovoltaica, das mídias eletrônica e digital e da linguagem da projeção é "mais afinada com as condições oferecidas pelo ambiente e pela situação de passagem e apreensão rápida" e poderiam facilitar a implantação de obras artísticas temporárias e permanentes. As intervenções ambientais poderiam ocupar "escalas maiores", com "menor fisicalidade" e, "mesmo considerada a comunicação onipresente - de se constituírem como ruído capaz de criar uma espécie de 'pausa' ou mudança temporária - nas percepções banais do cotidiano. Mas tudo depende da qualidade da arte" (SILVEIRA, 2012). O uso de qualquer tecnologia é bem-vindo desde que favoreça a concepção do trabalho artístico, ou seja, desde que seja aplicada como um meio, como "uma interface entre o conhecimento e a materialidade das coisas". No "sentido de fruição, de proporcionar diferentes maneiras de se perceber, diferentes relações de prazer, de proximidade, de tato, pode ser avaliada positivamente". Tecnologias atuais são vistas por alguns encomendadores, como é o caso do metrô, como "impeditivo" para a realização do trabalho em função da manutenção (ZAIDLER, 2012). "Pensar a cidade como uma superfície de comunicação é 'uma tendência' que tem levado designers, artistas e arquitetos a criarem fachadas e vitrines interativas, através da aplicação de tecnologias contemporâneas, em que a fluidez substitui a rigidez arquitetônica". Há também trabalhos não interativos, em que o elemento luz é "material básico de trabalho". A maior parte dos exemplos desse tipo de trabalho não está no Brasil devido à necessidade de ampla infraestrutura, o que implica no aluguel de equipamentos e de conhecimento e familiarização com as tecnologias para que sejam mais bem exploradas as possibilidades estéticas e de linguagem. (KUTSCHAT, 2012). Descendo a Escada e as demais obras da Exposição Arte Cibernética, com exceção de OPERA_Sonic Dimension, não tiveram custo especialmente elevado e as exigências de manutenção foram semelhantes às de um ambiente mais controlado. Ajustes foram necessários, em sua maior parte, pelo volume de público e menos pelas condicionantes do ambiente em si. As obras instaladas próximas às plataformas apresentaram defeitos nos cabos de vídeo devido à vibração e exigiram estrutura reforçada nas telas de projeção para suportarem os constantes deslocamentos de ar. (SILVEIRA, 2012). OPERA_Sonic Dimension teve custo elevado e exigiu maiores cuidados, em função da própria sensibilidade do equipamento que era desregulado com o simples toque dos usuários/espectadores/atores na tela e não em função da trepidação e do "efeito 
pistão". Apesar das discussões quanto à preservação, manutenção e pertinência desse tipo de trabalho, é possível a aplicação de tecnologias atuais, no caso, projeções e sensores de movimento acompanhados do desenvolvimento de hardware e software, em obras permanentes nas estações desde que, logicamente, haja recursos financeiros para a realização do projeto e um acervo de dispositivos da época. (KUTSCHAT, 2012).

Quanto à forma de atuar, todos se mostraram abertos à atuação integrada com arquitetos e demais profissionais envolvidos no processo de criação, desenvolvimento e implantação da obra artística nesses espaços de intenso fluxo de pessoas e que, portanto, exige o conhecimento de uma diversidade de elementos, o que implica em trabalhar inclusive com profissionais da área de gerenciamento. (KUTSCHAT, 2012). Entretanto, para que este tipo de atuação aconteça é necessário "repensar a formação acadêmica do artista plástico" a qual deveria abranger conhecimentos mais amplos quanto à escala, à estrutura dos espaços urbanos e dos edifícios, às condicionantes do espaço, às linguagens contemporâneas e outros materiais e elementos que são integrados e que determinam a solução da obra (encaixes e fixação). (TOZZI, 2012).

Para Amélia e Mo Toledo que, a convite do arquiteto João Batista Martinez Corrêa, autor dos projetos das estações Cardeal Arco Verde (1998) e Cidade Nova (2010) do metrô do Rio de Janeiro, vivenciaram a experiência do trabalho integrado na criação e desenvolvimento de programação cromática e de materiais de acabamento para os sites, ainda na fase do projeto arquitetônico, no metrô de São Paulo, não há impedimentos para que o projeto interdisciplinar aconteça, mas "depende de ser apreciado, e depois aprovado, por algumas instâncias, do arquiteto (ou do escritório de arquitetura) aos engenheiros, em alguns casos, até o governador do Estado participa dessa decisão" (AMÉLIA TOLEDO, 2012). A arte ainda é vista como "bobagem", "dinheiro jogado fora" e "os arquitetos não costumam ter essa abertura, essa disponibilidade" para a atuação integrada (MO TOLEDO, 2012) ${ }^{133}$.

A questão das regras normativas é "um dos lados do fazer artístico", "da burocracia do fazer", que influencia no trabalho em uma série de questões, dentre elas, a escolha da tecnologia aplicada, mas tudo isso, "não tem nada a ver com arte" (ZAIDLER, 2012). Não apenas regras normativas, mas as próprias limitações que 0 espaço, as tecnologias e os materiais impõem influenciam constantemente. Nesse

\footnotetext{
${ }^{133}$ Mo Toledo em entrevista concedida à pesquisadora, 2012. (APÊNDICE C)
} 
sentido, é preciso "conhecer muito bem o que é possível fazer e com o que é possível fazer" (KUTSCHAT, 2012). Limites e parâmetros do espaço e de regras devem ser entendidos como "balizas para a criação". (SILVEIRA, 2012).

O desequilíbrio na distribuição de obras permanentes instaladas nas estações da rede do Metropolitano marcado pela concentração em seis estações e pela ausência em praticamente metade delas pode estar relacionado, em parte, ao "estilo de divulgação do que já foi feito", à ausência do "encontro entre as pessoas que estão trabalhando agora com os artistas que são competentes para esse trabalho" e com aqueles que nunca fizeram este tipo de trabalho mas que "podem ter essa capacidade", ao "pouco estímulo à criação artística para obras permanentes para âmbito público" e ao número restrito de pessoas com iniciativas criativas que possibilitem viabilizar os projetos (AMÉLIA TOLEDO, 2012). Ao pensar o sistema viário e as estações de metrô, é necessário que haja um "planejamento integrado" de forma que o projeto seja ampliado para receber locações e intervenções visuais nos espaços a serem construídos (TOZZI, 2012). A instalação de objetos de arte deveria se tornar obrigatória em espaços públicos. (FAJARDO, 2012). Em uma abordagem mais ampla, a má distribuição da arte nas estações "não é uma questão do metrô". Na cidade de São Paulo, "as questões das políticas públicas em relação às questões visuais, particularmente, a questão da arte na cidade engatinham". A Lei Cidade Limpa foi um avanço que teve reflexos positivos, mas que ainda está "totalmente desvinculado de qualquer tipo de conhecimento, de qualquer tipo de pesquisa, de qualquer tipo de reflexão mais aprofundada", realidade "historicamente compreensível por que é uma coisa que não existia, nunca existiu”. Nesse sentido, se faz necessário "uma atuação política em relação a como é a exigência de criação, manutenção e evolução de políticas públicas que tratem da arte". "A questão da concentração é um reflexo político de como as coisas são encaminhadas na cidade e o Metrô não foge à regra". A Companhia poderia ter iniciativas para criar mecanismos que facilitassem a intervenção artística de forma mais "móvel", "ágil", "barata", "dinâmica", "partindo de concepções mais contemporâneas", a exemplo da instalação de pianos nas estações o que poderia ser feito com outros instrumentos, além de oficinas de instrumentos, performances, mas esse tipo de iniciativa depende de ganhar força política. A inserção do comércio, de serviços públicos e da farmácia popular é importante, porém, assim como a arquitetura das estações, poderiam ser melhor resolvidos. Da maneira como têm sido feitos "É fazer força para 
transformar o lugar, o espaço num lugar de passagem, (...) é dar todo estímulo para que o lugar seja transformado num ponto de consumo". "A própria arquitetura dá sinais de que não é para ter arte nesses espaços". Fazer uso de ladrilhos, colocar prédios para cima são questões que "marcam politicamente a existência do Metrô" enquanto "lá dentro, as pessoas que nem sardinha em lata, passando por lojinhas, (...) é uma coisa que passa por política pública, por um monte de questões que são totalmente externas à arte, à arquitetura. (...) É questão política dentro do campo da cultura". (ZAIDLER, 2012). Para Daniela Kutschat, também é "uma questão de política cultural" em que a Secretaria Estadual de Cultura deveria "entender inclusive que a estação de metrô pode ser o espaço da arte, e que pode conter em si esse valor, porque a arte é um patrimônio cultural". Outras possibilidades seriam "abrir concursos para artistas e arquitetos", "promover mostras", "fazer uma agenda de exposições". Sugeriu a apresentação de formas de arte que "criassem a cultura de frequentar o espaço não como do ir e vir, mas como espaço mesmo de estar e de ter uma experiência", (...) "teria que ter alguém na secretaria pensando que isso é importante e que isso pode, inclusive, dar uma identidade para a estação, criar um circuito cultural de estação em estação, que é uma coisa que o Arte Cibernética tentou fazer, um circuito naquele espaço". Outro aspecto relevante que o profissional da arte contemporâneo tem vivenciado é a transformação em sua forma de atuar. Ele não é apenas idealizador de seu trabalho. Na prática, o processo é complexo. Tem que ser executivo, empreendedor e desenvolver várias habilidades e qualidades administrativas. A artista chama atenção para deficiências na própria comunicação que poderiam ser solucionadas com a distribuição de mapas de bolso para melhor orientar os usuários (KUTSCHAT, 2012). E por que não possibilitar que mapas sejam elaborados também por artistas, assim como no metrô de Londres?

Todos os artistas desconheciam os regulamentos atuais para apresentar/instalar obras de arte temporárias e permanentes nas estações.

Como indicado nos Capítulos 3 e 6, em agosto de 2012, foi realizado o evento Metrô, Engenho e Arte, o Primeiro Seminário de Arte no Metrô de São Paulo, revelando um posicionamento da Companhia em busca do conhecimento do que tem sido feito em uma das mais tradicionais redes de transporte metroviário: o metrô de Paris. Na ocasião, foram apresentadas experiências que, se consideradas com a seriedade que merecem, poderão contribuir para a solução de pelo menos parte dos problemas referentes à arte, à arquitetura e ao design existentes no Metropolitano, a 
começar pela "engenharia cultural" requerida para o gerenciamento de projetos dessa magnitude. De acordo com Kaminagai, a arte inserida no sistema do metrô deve ser escolhida e mantida por profissionais especializados no assunto, que ainda são em número restrito. É muito importante que sejam realizados encontros com esses especialistas. O financiamento público de projetos culturais é "muito difícil" em diversos países ${ }^{134}$. É impossível realizá-los apenas oferecendo o espaço, é necessário que seja oferecido ao menos uma parte dos recursos. Trata-se de uma questão complexa que, juntamente com o técnico, o artístico e o legal, faz parte da "engenharia cultural" desses espaços. Apesar do Programa Percent for Art fazer parte da legislação francesa, não é aplicado em estações do metrô de Paris, uma vez que " $1 \%$ do custo de uma estação, de um túnel, seria demais". Nesse sentido, "a escolha dos projetos deve ser muito bem feita para que esse momento difícil possa ser um momento de facilitação de outros financiamentos." Em projetos de estações de bonde, conhecido na França por tramway, em que o objetivo tem sido "fabricar a cidade, não apenas o mobiliário urbano" pode servir como referência para possíveis soluções de projetos futuros para estações de metrô paulistanas no sentido de incluir a reconstrução da paisagem urbana circundante como parte do projeto ${ }^{135}$. Talvez, o ponto chave para resultados satisfatórios no metrô parisiense esteja no entendimento de que as estações de metrô "não são receptáculos mas recursos, e quando se pensa um espaço como recurso, um recurso tem valores culturais, econômicos, funcionais, que você deve guardar ou fazer aumentar esse valor." (KAMINAGAI, 2012).

Apesar das restrições quanto aos participantes, o concurso Tá pintando um novo metrô foi outra iniciativa positiva por parte da Companhia em busca de nova forma de atuar, possibilitada por tecnologia atual. Através da apropriação do espaço público virtual foram apresentadas propostas de estampas para os trens que irão operar no prolongamento da Linha 2-Verde em monotrilho (Vila Prudente - Cidade Tiradentes). Qualquer pessoa poderia participar com exceção de propostas "com mais de um autor (coletivas) ou de empresas (pessoas jurídicas)" e de funcionários do metrô. Uma comissão julgadora, "formada por profissionais da área de design, propaganda e comunicação e por representantes da SECOM do Estado de São

\footnotetext{
${ }^{134}$ De acordo com a arquiteta e artista plástica Françoise Schein: "Na Europa e nos Estados Unidos, geralmente, os fundos vêm totalmente do metrô. No Brasil, é questão de fiscalização e fundos a procurar pelos artistas, um processo bastante complicado. O resultado disso é que só a elite pode fazer, e isso não é democracia." (SCHEIN, 2012).

${ }_{35}$ Até $\mathrm{o}$ ano de 2014 serão construídas nove linhas de bonde em toda a região parisiense.
} 
Paulo, do Metrô e da Bombardier" pré-selecionou 20 trabalhos, dentre os quais um foi selecionado por voto popular via internet. MULTI COLOR SP, do designer JP Ferreira. Foram "128164 acessos somando 70959 votos". (TAPINTANDOUMNOVOMETRO.COM.BR, 2012).

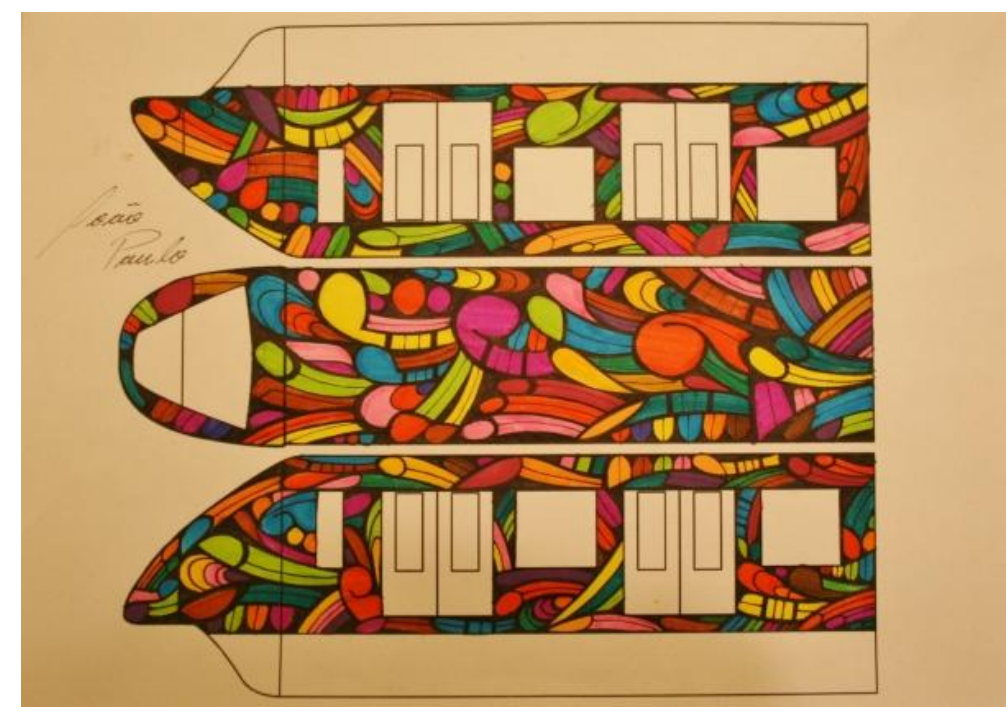

Figura 639: MULTI COLOR SP, de JP Ferreira, 2012. Concurso: Tá pintando um novo metrô. Fonte: <http://www.tapintandoumnovometro. com.br/main.php?g_ct=principalVota cao>. Acesso em 10/10/2012.

A partir das informações colhidas nesta pesquisa foi possível constatar que é tecnicamente possível e socialmente aceita a aplicação de tecnologias atuais em intervenções ambientais temporárias e permanentes nas estações de metrô de São Paulo, no entanto, condicionantes internas e externas à Companhia têm dificultado não somente a utilização dessas tecnologias, mas a presença e a permanência da arte pública no metrô e na cidade. Regulamentos falhos, burocracia, concentração de elementos, ausência de financiamento público e privado e de profissionais especializados que atuem de forma integrada e planejada são fatos diretamente relacionados a questões mais amplas: ausência de políticas públicas no campo da cultura, ausência de divulgação dos benefícios da lei de incentivo para as empresas, ausência da divulgação dos mecanismos para os artistas e para a população e ausência de uma formação profissional multidisciplinar do artista, do arquiteto e do designer, amplas em conhecimentos humanos e informações técnicas e que possibilitem a prática do projeto interdisciplinar, ponto de partida para que haja melhores resultados estético e funcional, maior facilidade de instalação e manutenção e redução de custos, principalmente, quando se pretende aplicar tecnologias atuais. 
Diante da complexidade desses espaços, outra questão fundamental a ser considerada para que o projeto interdisciplinar aconteça é a presença de profissional no campo de gerenciamento que tenha conhecimentos amplos que possibilitem uma compreensão transversal das diversas disciplinas envolvidas no projeto, de uma estação ou de uma linha, que seja capaz de delegar o posicionamento dos autores dos projetos de arte, arquitetura, design e complementares ainda na fase de concepção. (KAMINAGAI, 2012).

Colocar em prática novas formas de criar e de produzir arte, arquitetura e design, adequadas ao usuário/espectador contemporâneo, ativo e interativo, a partir de tecnologias atuais e de ações integradas e planejadas traria benefícios para os usuários/espectadores/atores, a instituição, os financiadores, os autores dos projetos, a população, a cidade. É necessário que se tenha este pensamento como parte de uma "engenharia cultural" que atenda aos espaços do metrô, ainda vinculados à tradição modernista.

Certamente, é difícil avaliar sem o distanciamento do tempo o grau de relevância que os trabalhos expostos na Exposição Arte Cibernética: Acervo Itaú Cultural e nos FILEs terão no cenário da arte contemporânea. Significativos, senão enquanto tentativas de aproximar o público do que está sendo produzido na cultura contemporânea, enquanto início de um percurso rumo a fazeres artísticos, arquitetônicos e de design que apliquem tecnologias atuais também como meio em processos de criação e produção que alcancem resultados ainda mais inovadores enquanto forma de conhecimento, seja para quem produz o trabalho, seja para quem o observa ou interage com ele. Resultados ainda mais comoventes, sustentáveis e significativos para a história da arte, da arquitetura e do design contemporâneos em constante mutação. 



\section{REFERÊNCIAS}

ABRAMO, Radhá. A filosofia do projeto Arte no Metrô. In: Companhia do Metropolitano de São Paulo. Arte no Metrô. São Paulo: Alter Market, 1994.

ABRAMO, Radhá. Praça da Sé, Cidade Universitária, Metrô. In: Seminários de Arte Pública (I) - SESC. São Paulo: SESC, 1995.

ALBUQUERQUE, Carlos. O 'video mapping', inovadora técnica que ajuda a criar ilusões óticas ao ar livre, em 3D, vai ganhar mostra no Rio. Publicada em 07 jun. 2010, 11h45m. Disponível em: <http://oglobo.globo.com/cultura/mat/2010/06/07/ovideo-mapping-inovadora-tecnica-que-ajuda-criar-ilusoes-oticas-ao-ar-livre-em-3dvai-ganhar-mostra-no-rio-916799331.asp>. Acesso em 27 ago. 2011.

ANASTASIOU, Alex. In VEIGA, Edson. Festival de grafite digital vai colorir noites da Augusta. Folha de São Paulo. Caderno 1, p. 10. 16 nov. 2011.

ANJOS, Moacir. Local/global: arte em trânsito. Rio de Janeiro: Jorge Zahar Ed., 2005.

APENGINE.ORG. John Gerrard at Canary Wharf underground station. Publicado em 25 mai. 2010. Disponível em: <http://www.apengine.org/2010/05/john-gerrard-atcanary-wharf-underground-station>. Acesso em 07 set. 2011.

ARCHER, Michael. Arte Contemporânea: uma história concisa.Tradução Alexandre Krug, Valter Lellis Siqueira. São Paulo: Martins Fontes, 2001.

ARCSPACE.COM. The architecture dematerializes and becomes a matter of light and surface effects. Publicado em 21 jan. 2009. Disponível em: $<\mathrm{http}: / /$ www.arcspace.com/architects/nouvel/dk_concert/dk_concert.html>. Acesso em 03 nov. 2011.

ARCOWEB.COM.BR. ENERGIA FOTOVOLTAICA NA ARQUITETURA. No Brasil, o meio acadêmico sai na frente não apenas na pesquisa, como também na implantação de projetos com uso de energia fotovoltaica. Disponível em: <http://www.arcoweb.com.br/tecnologia/energia-fotovoltaica-na-arquitetura-no-brasil19-06-2009.html>. Acesso em 21 jan. 2010.

ARQUITETURA \& AÇO. Edição 24 - Dezembro/2010. Disponível em: <http://www.metalica.com.br/aco-inox-para-as-modernas-estacoes-paulistanas>. Acesso em 27 out. 2011.

ARTDAILY.ORG. Site-Specific Public Art Installation By Pioneering New Media Artist Jim Campbell. Disponível em: $<$ http://www.artdaily.org/index.asp?int_sec=2\&int_new=42037>. Acesso em 28 ago. 2011. 
. Voices in the Subway Station, 2010. Jim Campbell. Madison Square Park, New York. Credit: Courtesy Madison Square Park Conservancy/Copyright James Ewing. Disponível em: $<$ http://www.artdaily.org/index.asp?int_sec=2\&int_new=42037>. Acesso em 28 ago. 2011.

ARTE BRASILEIRA. Interfaces para a Contemporaneidade. MAC USP. São Paulo, 2005/2006.

ARTE CONTEMPORÂNEA E SUAS INTERFACES. São Paulo: MAC USP, 2006.

ARTKNOWLEDGENEWS.COM. MoMA Displays Iconic Reproductions at NYC Subway Station. Disponível em: <http://www.artknowledgenews.com/momaatlanticpacificprojecthtml.html>. Escrito por Ricky Vermont, 27 fev. 2011. Foto de Jeff Baxter, 2008 The Museum of Art Modern. Acesso em 28 ago. 2011.

ARTSERVICES.COM.AU. Sculpture Awards. Disponível em: <http://www.artservices.com.au/Sculpture_Awards_pg2.html>. Acesso em $16 \mathrm{fev}$. 2010.

ART.TFL.GOV.UK. Transport for London. Art on the Underground: John Gerrard Oil Stick Work Art on the Underground and artist John Gerrard have now switched off Oil Stick Work at Canary Wharf Underground station. Publicado em 13 mai. 2010. Disponível em: $<$ http//www.art.tfl.gov.uk/participate/resources/\&usg=ALkJrhjtKK6HiMSJMLARTCaye nNzg19luA>. Acesso em 07 set 2011.

AUGÉ, Marc. Não-Lugares: Introdução a uma Antropologia da Supermodernidade. Campinas: Papirus, 1994.

AUTOBLOG.JRMANIA.COM.BR. Faça você mesmo: LEDS. Disponível em: <http://autoblog.jrmania.com.br/index.php/tecnologia/faca-voce-mesmoleds/\#commentsAUTOBLOG 24/06/08)>. Acesso em 14 fev. 2010.

BARCO.COM. Products: Projectors. Disponível em: $<$ http//www.barco.com/downloads/media_entertainment/Catalogs/ProjIP_Product_Catalog.pdf>. Acesso em 01 out. 2011.

BAMBOZZI, Lucas. O trem. In Intervenções urbanas: Arte/Cidade/Nelson Brissac Peixoto. São Paulo: Editora SENAC São Paulo, 2002, p.122-153.

BAMBOZZI, Lucas; BASTOS, Marcus; MINELLI, Rodrigo. Mediações, tecnologia e espaço público: panorama crítico da arte em mídias móveis. São Paulo: Conrad Editora do Brasil, 2010.

BARRETO, Ricardo. In FILE São Paulo: PAl: PRIX LUX= File São Paulo 2010: PAl: PRIX LUX / [concepção editorial Ricardo Barreto, Paula Perissimoto]. São Paulo: FILE, 2010, p.88-91. 
Festival Internacional de Linguagem Eletrônica: FilePAl: Arte Pública Interativa. Disponível em: <http://www.filepai.org/sobre.aspx>. Acesso em 01 ago. 2010.

BARTALINI, Wladimir. Arte e Paisagem: Uma união instável e sempre renovada. In Paisagem e ambiente: ensaios. Universidade de São Paulo, Faculdade de Arquitetura e Urbanismo. São Paulo: FAU, n.27, 2010.

BASBAUM, Ricardo. Arte contemporânea: texturas, dicções, ficções, estratégias. Rio de Janeiro: Editora Rios Ambiciosos, 2001.

BEAUTIFULBUILDINGS.BLOGSPOT.COM. Bridge Pavilion Zaragoza Spain. Disponível em: <http://beautifulbuildings.blogspot.com/2009/06/bridge-pavilionzaragoza-spain.html>. Acesso em 12 fev. 2010.

BECHARA, Márcia. L+D INTERNACIONAL LIGHTING MAGAZINE. Especial Fachadas Midiáticas: CNIT: novas luzes no coração de La Défense. Editora Lumière: São Paulo, número 27, março/abril 2010, p. 49-52.

BENEDETTI, Lorenzo. La ciudad como interfaz del arte. In La ciudad radiante. Achille Bonito Oliva. Centre Cultural Bancaixa, Valencia: Skira, 2003, p. 29-31.

BENNET, David. Metro Die Geschichte der Untergrundbahn. Die englischsprachige Originalausgabe erschien im Jahr 2004 unter dem Titel Metro bei Mitchell Beazley / Octopus Publishing Group Ltd., London. Copyright (c) Octopus Publishing Group Ltd., 2004. First published in Germany by transpress Verlag. Published in Great Britain by Octopus Publishing Group Ltd. Auflage, 2005.

BLOG.BOLA.INFO. Arquitetura top 10 iniciativas green. Disponível em: $<$ http://blog.bola.info/2008/06/20/arquitetura-top-10-iniciativas-green/>. Acesso em 21 fev. 2010.

BOURRIAUD, Nicolas. Estética Relacional. Trad. Denise Bottmann. Coleção Todas as Artes. São Paulo: Martins, 2009.

. Pós-produção: como a arte reprograma o mundo contemporâneo. Trad. Denise Bottmann. Coleção Todas as Artes. São Paulo: Martins, 2009.

BÜTTNER, Claudia. Art in Public Space. In Sculpture Projects Muenster 07. Muenster, 2007, p. 332-333.

CANEVACCI, Massimo. A Cidade Polifônica: ensaio sobre a antropologia da comunicação urbana. São Paulo: Estúdio Nobel, 1993.

In AGUIAR, Julia. Entrevista Massimo Canevacci (entrevista realizada para a publicação Sextante - FABICO/UFRGS, sob orientação do jornalista Wladymir Ungaretti, em agosto de 2007. Publicada em 12 abr. 2008. Disponível em $<$ http://www.overmundo.com.br/banco/entrevista-com-pensador-massimocanevacci>. Acesso 18 mai. 2010. 
CAÑO, Teodosio Del. Onyx Solar. Palestra: Integração Fotovoltaica em Edifícios. Instituto de Arquitetos do Brasil - IAB. Local: São Paulo, 10 jun. 2010.

CANONGIA, LIGIA. O legado dos anos 60 e 70. Rio de Janeiro: Jorge Zahar Ed., 2005.

CARDOSO, Rafael. Una cosa mentale: Em entrevista, Rafael Cardoso fala sobre a desmaterialização do design. Por Marco Aurélio Fiochi. Continuum Itaú Cultural, 10 mai. 2008, p. 22.

CARNEIRO, Gabriela. Arquitetura Interativa. Seminário apresentado no 8 Simpósio Internacional de Artemídia e Cultura Digital - Acta Media 8. In-pacto: processos criativos nas artes: o tradicional e o contemporâneo. São Paulo. FAU-USP. Agosto de 2010. Informação verbal.

CASAMONTI, Marco; NOUVEL, Jean. Trad. Marcos Maffei. 1 ed. São Paulo: Folha de São Paulo, 2011, p.12-14, 58.

CATÁlOGO ARTE NA CIDADE. Prefeitura do Município de São Paulo. 2012.

CATÁlOGO COMPANHIA DO METROPOLITANO DE SÃO PAULO. O Metrô de São Paulo. 1987-1991: tecnologia e humanização. São Paulo: Alter Market, 1991.

. Os trilhos da modernidade: a Linha 5 do Metrô de São Paulo. São Paulo: Editora Gráficos Burti, 2003.

CATÁLOGO DLAD LIGHTS. Dedolight Architectural and Display Lights. Precision Lighting for Museum, Gallery and Display, 2009, p. 16-20, 22-23.

CATÁlogO FILE SÃO PAULO. FILE São Paulo: PAl: PRIX LUX= File São Paulo 2010: PAI: PRIX LUX / [concepção editorial Ricardo Barreto, Paula Perissimoto]. São Paulo: FILE, 2010, p. 88-91.

. Catálogo File São Paulo 2011: Festival Internacional de Linguagem $\overline{\text { Eletrônica }}=$ FILE 2011: Eletronic Language International Festival / [concepção editorial Paula Perissimotto e Ricardo Barreto; tradução Luiz Roberto M. Gonçalves, Cícero Inácio da Silva]. São Paulo, 2011.

CATALOGHI BIENNALE DI VENEZIA. 54 Esposizione Internazionale d'Arte: ILLUMInazioni. 2011 Fondazione La Biennale di Venezia Ca'Giustinian San Marco 1364/a 30124 Venezia. Realizzazione editoriale Marsilio Editori.

CENTRALSUBWAYBLOG.COM. Central Subway Public Art Program Winners Announced!.

em:

<http://www.sfartscommission.org/pubartcollection/pubart-press-

releases/2010/07/30/central-subway-public-art-program-winners-announced/>.

Publicado em: 30 jul. 2010. Acesso em: 08 set. 2011.

CICHINELL, Gisele. Chapas cimentícias: parede ou vedação. Téchne. Reportagem. Editora Pini. São Paulo, n.128, nov 2007. Disponível em: 
<http://www.revistatechne.com.br/engenharia-civil/128/artigo66600-1.asp>. Acesso em 12 fev. 2010.

COELHO, Teixeira. In Prefeitura lança edital "Arte na Cidade" para incentivar projetos de artes visuais: Secretaria Municipal de Cultura lança novo edital, focado em artes visuais ao ar livre, com inscrições abertas a partir de 8 de junho. Publicado em 08 jun. $2010 . \quad$ Disponível em: $<$ http://www.prefeitura.sp.gov.br/cidade/secretarias/cultura/noticias/?p=7835>. Acesso em 15 jun. 2012.

COLES, Alex. A Platform for site-specificity in Platform for Art: Art on the Underground. Edited by Tamsin Dillon. London: Black Dog Publishing Limited, 2007, p. 17-61.

CONEXOESTECNOLOGICAS.ORG.BR. Video Mapping. Disponível em: <http://conexoestecnologicas.org.br/?p=1159>. Acesso em 28 set. 2011.

COSTA, Carlos Zibel. Além das formas: Introdução ao pensamento contemporâneo no design, nas artes e na arquitetura. São Paulo: Annablume, 2010.

CUEVA, Claudia L. R. Ação faz parte de campanha de lançamento da produção Planeta Humano. Disponível em: <http://www.mangacom.com.br/site/atualidades/acao-faz-parte-de-campanha-delancamento-da-producao-planeta-humano.php>. Publicado em 10 mai. 2011. Acesso em 28 set. 2011.

DESIGNBOOM.COM. Olafur Eliasson: your chance encounter. Disponível em: $<$ http://www.designboom.com/weblog/cat/10/view/9467/olafur-eliasson-your-chanceencounter.html>. Acesso em 22 ago.2011.

DEVANEARTE.SPAWDIN.NET. As inovações da 27ª Bienal de São Paulo: "Como viver junto". Disponível em: <http://www.devanearte.spawdin.net/bienal.html>. Acesso em 06 jun. 2009.

DEZEEN.COM. Dezeen design magazine. Monte St. Angelo Subway Station by Amanda Levete and Anish Kapoor. Posted on Friday, November 20th, 2009 at 12:30 pm by Rose Etherington. Disponível em: <http://www.dezeen.com/2009/11/20/monte-st-angelo-subway-station-by-amandalevete-architects-and-anish-kapoor/> . Acesso em 27 nov. 2010.

DILLON, Tamsin. Platform for Art: Art on the Underground. London, UK:Black Dog Publishing Limited, 2007.

DIREITOSFUNDAMENTAISNAESCOLA.BLOGSPOT.COM.BR. Inscrever os Direitos Fundamentais na Sala de Aula. Disponível no site: http://direitosfundamentaisnaescola.blogspot.com.br/2012/03/artista-francoiseschein-fala-sobre-o.html. Acesso em 20/08/2012.

DOMESCOBAR.BLOGSPOT.COM. Ecoarquitetura: O maior estádio do mundo totalmente movido a energia solar para Jogos em Formosa em 2009. Disponível em: 
$<$ http://domescobar.blogspot.com.br/2009/05/o-maior-estadio-do-mundototalmente.html>. Acesso em 28 mar. 2010.

DUARTE, Paulo Sérgio. Anos 60: transformações da arte no Brasil. Rio de Janeiro: Campos Gerais Edição e Comunicação Visual, 1998.

DUWE, Marc; HADLICH, Arno; VELO, Eduardo. Aço inox para as modernas estações paulistanas. In Arquitetura \& Aço. Edição 24 - Dezembro/2010. Disponível em: <http://www.metalica.com.br/aco-inox-para-as-modernas-estacoes-paulistanas>. Acesso em 27 out. 2011.

ECODESENVOLVIMENTO.ORG.BR. Camarote Expresso 2222 traz sustentabilidade para Carnaval da Bahia. Disponível em: <http://www.ecodesenvolvimento.org.br/noticias/camarote-expresso-2222-trazsustentabilidade-para>. Acesso em 13 fev. 2010.

EDITAL PARA APRESENTAÇÃO DE PROJETOS CULTURAIS - 2012. Disponível em: <http://www.prefeitura.sp.gov.br/cidade/upload/edital2012_1335372222.pdf>. Acesso em 07 jun. 2012.

EDLER, Jan. Changing the Night, Interview with Jan Edler from Realities:United. 14 abr. 2009. Disponível em: <http://www.enlightermagazine.com/interviews/jan-edler>. Acesso em 25 fev. 2010.

E-FLUX.COM. Art on the Underground: Oil Stick Work. John Gerrard. 14 May 2010 14 May 2011. Canary Wharf Underground station. Postado em 10 mai. 2010. Disponível em: <http://www.e-flux.com/shows/view/8110>. Acesso em: 07/09/2011.

EMOCAOART.FICIAL.ORG.BR. Artistas e obras Emoção Art.ficial 6. Disponível em: $<\mathrm{http}: / /$ www.emocaoartficial.org.br/pt/artistas-e-obras/emocao-art-ficial-6-0/>. Acesso em 01 mai. 2012.

Simpósio Internacional Emoção Art.ficial 6.0. Disponível em:

<http://www.emocaoartficial.org.br/pt/programacao/simposio/http://www.emocaoartfic ial.org.br/pt/programacao/simposio>. Acesso em 08 jul. 2012

EN.BEIJING2008.CN. Shanghai Metro set to become a moving art experience. Disponível em: <http://en.beijing2008.cn/news/olympiccities/shanghai/n214190100.shtml>. Acesso em 04 set. 2011.

EN.WIKIPEDIA.ORG. Nydalen (station). Disponível em: $<$ http://en.wikipedia.org/wiki/Nydalen_(station)>. Publicado em 2008. Acesso em 01 set. 2011.

EPOCANEGOCIOS.GLOBO.COM. Flores carregam celular com energia solar. Publicado em: 21 jul. 2009. Disponível em: <http://epocanegocios.globo.com/Revista/Common/1, EMI83483-16382,00.html>. Acesso em 21 fev. 2010. 
ERICKSON, Arthur. Art and architecture on the Spadina subway. Publicado em 28 out. 2010. Disponível em: <http://robertmoffatt115.wordpress.com/page/3/>. Acesso em 11 set. 2011.

ESTADAO.COM.BR. Metrô-SP expõe arte cibernética em estações. Disponível em: $<$ http://www.estadao.com.br/noticias/arteelazer,metro-de-sp-expoe-obras-de-artecibernetica-em-estacoes,539193,0.htm >. Publicado em 16 abr. 2010. Acesso em 01 mai. 2010.

ESTEVES, Luiz Carlos. O desafio da perenidade. Publicado originalmente em: PROJETODESIGN, Edição 377, Julho de 2011. Disponível em: <http://www.arcoweb.com.br/arquitetura/luiz-esteves-arquitetura-estacao-vilaprudente16-09-2011.html.> Acesso em: 27 nov. 2011.

EXPRESSO2222.COM.BR. Expresso 2222. Disponível em: <http://www.expresso2222.com.br/pos_venda/energia.php>. Acesso em 12 set. 2010.

FARIAS, Agnaldo. Amelia Toledo: as naturezas do artifício. São Paulo: W11, 2004.

FEOLA, Sara. Finnish Pavilion. Vesa-Pekka Rannikko - And All Structures Are Unstable. Postado por curamagazine em 13 jun. 2011. Venice Biennale 2011. Disponível em: <http://www.curamagazine.com/en/?p=3139>. Acesso em 16 jun. 2011.

FERRARA, Lucrécia d'Aléssio. Revista Através no 1. São Paulo: Duas Cidades, 1977. 1986, p.124-145.

A Estratégia dos Signos. São Paulo: Editora Perspectiva, 2ª edição,

FIGUEROLA, Valentina N. Especial Pini 60 anos: Futuro da Cerâmica: novas gerações de revestimentos cerâmicos prometem contribuir para a eficiência energética dos edifícios. abr.2008. Disponível em: <http://www.revistaau.com.br/arquitetura-urbanismo/169/especial-pini-60-anosfuturo-da-ceramica-77735-1.asp>. Acesso em 24 fev. 2010.

FILEFESTIVAL.ORG. FILE $S P$ 2012. Disponível em: $<$ http://filefestival.org/site_2007/pagina_conteudo_livre.asp?a1=308\&a2=308\&id=1 > . Acesso em 21 jul. 2012.

Lightning Field: Walter de Maria. Disponível em: <http://www.filefestival.org/site_2007/filescript_pop.asp?cd_pagina=311\&id=2\&cd_m ateria=466> . Acesso em 13 out. 2011.

FILE.ORG.BR. FILE - Electronic Language International Festival. Disponível em: $<$ http://www.file.org.br>. Acesso em 05 ago. 2010.

FINKELPEARL, Tom. Financiamento de Arte Pública em Nova York. Seminários de Arte Pública (I). SESC. São Paulo, 1995, p. 70-80. 
FLACK, Derek. Arc Michael Hayden en ciel might return to Yorkdale Station. Disponível em: <http://www.blogto.com/arts/2010/11/michael_haydens_arc_en_ciel_might_return_to _yorkdale_station/>. Publicado em 04 out.2010. Acesso em 09 set. 2011.

FOLHETO AÇÃO INSCREVER ESTAÇÃO LUZ DO METRÔ. Ação inscrever estação luz do metrô - primeira fase 2011. Françoise Schein: Estação Luz. São Paulo. Brasil. Arte no Metrô. 2012.

FREITAS, Marcello Glycério de. Arte nos subterrâneos do metrô de São Paulo. In: Companhia do Metropolitano de São Paulo. Arte no Metrô. São Paulo: Alter Market, 1994.

FREITAS, Sicília Calado. Arte, Cidade e Sociedade: dimensões da arte pública no contexto urbano. In Intervenções: artes visuais em debate/Universidade Federal da Paraíba. Revista do Departamento de Artes Visuais da UFPB (Ano 1, №1). João Pessoa, 2006.

FUREGATTI, Sylvia. Arte no espaço urbano: contribuições de Richard Serra e Christo Javacheff na formação do discurso da Arte Pública atual. Dissertação de Mestrado em Arquitetura e Urbanismo. Faculdade de Arquitetura e Urbanismo da Universidade de São Paulo. São Paulo, 2002.

GIOSA, Celso. Apresentação. In: Companhia do Metropolitano de São Paulo. Arte no Metrô. São Paulo: Alter Market, 1994.

O Metrô de São Paulo. 1987-1991: tecnologia e humanização.In Companhia do Metropolitano de São Paulo. São Paulo: Alter Market, 1991.

$\begin{array}{lrr}\text { GLASSCRETE.PT. } & \text { Glasscrete. } & \text { Disponível } \\ \text { <http://www.glasscrete.pt/pdf/glasscrete.pdf>. Acesso em } 10 \text { fev. } 2010 .\end{array}$

GMCASQUEIRO.COM. Shangai Expo 2010: 15 Projectos Arquitectonicos de cortar a respirao. Disponível em: <http://gmcasqueiro.com/blog/2010/04/shanghai-expo2010-15-projectos-arquitectnicos-de-cortar-a-respirao/>. Acesso em 23 mai. 2010.

GOLDENPAINTS.COM. Materials and Resources. Disponível em: <http:// www.goldenpaints.com>. Acesso em 10 mar. 2010.

GOLDEN. Materials and Resources: Meaningful Technical Support for Artists. New York, 2009.

Palestra de representantes da GOLDEN, realizada na loja de materiais artísticos Pintar, São Paulo, 2010 (informação verbal).

GOUVEIA, Maria Alice Machado. Financiamentos privados e incentivos no Brasil. Seminários de Arte Pública (I). SESC. São Paulo, 1995, p. 87-91.

GREENPIX.ORG. The Zero Energy Media Wall by Simone Giostra \& Partners and Arup. Disponível em: <http://greenpix.org>. Acesso em 13 fev. 2010. 
GRÖNLUND, Tommi; NISUNEN, Petteri: Catálogo: Variações sobre um tema. 27ª Bienal de São Paulo, 2006.

GUIDA ALLA BIENNALE DI VENEZIA, 2011.

GUIADAFOLHAONLINE. Arte cibernética ocupa estações do metrô paulistano. Disponível em: <http://guia.folha.com.br/exposicoes/ult10048u726050.shtml>. Publicado em 27 abr. 2010. Acesso em 01 mai. 2010.

GUGGENHEIM-BILBAO.ES. Anish Kapoor-More about the artist's work : Urban Projects. Disponível em: <http://www.guggenheimbilbao.es/microsites/anish_kapoor/secciones/mas_sobre_obra/introduccion.php?idio ma=en>. Acesso em 27 nov. 2010.

HAILA, Yorjo. Second Nature. On Innovatiness in Art Projects. Framework the finish art review. 6/2007. Disponível em: <http://www.framework.fi/6_2007/features/artikkelit/haila.html>. Acesso em 06 jun. 2009.

HATANAKA, Conceição M. Arte no Metrô: obras de arte no espaço público do Metrô de São Paulo. Dissertação de Mestrado em Arquitetura e Urbanismo. Universidade São Judas. São Paulo, 2009.

INOVACAOTECNOLOGICA.COM.BR. Células solares ganham em eficiência e durabilidade. 20 ago. 2009.2 Disponível em: $<$ http://www.inovacaotecnologica.com.br/noticias/noticia.php?artigo=celulas-solaresorganicas-ganham-eficiencia-durabilidade\&id=\#>. Acesso em 21 fev. 2010.

. Dois recordes mundiais e duas novas células solares. 19 fev. 2010. Online. Disponível em: <http:// www.inovacaotecnologica.com.br/noticias/noticia.php?artigo=dois-recordesmundiais-duas-novas-celulas-solares>. Acesso $21 \mathrm{fev} .2010$.

. Nova célula fotovoltaica DSC gera até 4 volts. 16 set. 2004. Disponível em:

<http://www.inovacaotecnologica.com.br/noticias/noticia.php?artigo=010115040916\# >. Acesso em 21 fev. 2010.

INOVACAOUNICAMP.BR. The New York Times, 30 de maio de 2009: Diodos emissores de luz, os LEDs, começam a ser utilizados para iluminar casas e ruas; tecnologia traz corte radical de emissões. Publicada em 8 jun. 2009. <http://www.inovacao.unicamp.br/report/leituras/index.php?cod=542>. Acesso em 12 fev. 2012.

ITAUCULTURAL.COM.BR. mos_texto\&cd_verbete=3190>. Acesso em: 05/03/2010. 
Rumos Arte Cibernética: Mostra reúne obras que trabalham a interação

com o público. Disponível em: $<h t t p / / w w w . i t a u c u l t u r a l . o r g . b r / i n d e x . c f m ? c d \_m a t e r i a=1595 \& c d \_p a g i n a=2841>$. Acesso em 02 out. 2011.

JIMMYCOHRSSEN.COM. Louis Vuitton Ginza Namiki. Disponível em: <http://www.jimmycohrssen.com/work/index.php\%3F/archives/louis-vuitton-ginzanamiki/\&usg >. Acesso em 15 fev. 2010.

JOURNEYTEC.COM. Top 10 Subway Stations of the World. Disponível em: $<$ http://www.journeyetc.com/travel-ideas/top-10-subway-stations-of-the-world/>.

Acesso em 27 nov. 2010.

KAMINAGAI, Yo. RATP Cultural policy and recent works. Palestra realizada no evento: Metrô, Engenho e Arte do Programa de Inteligência Corporativa da UNIMETRO do Metropolitano de São Paulo. Agosto de 2012.

KANAZAWA21.JP. Olafur Eliasson "Your chance encounter", 2009. Disponível em: <http://www.kanazawa21.jp/data_list.php?g=79\&d=1\&lng=e>. Imagem do Estúdio Olafur Eliasson. Acesso em 06 abr. 2010.

KATIELEVITT.WORDPRESS.COM. Duality. Criado por Joachim Sauter e ART + COM. Fonte: Public Art that Emphasizes New Media Triangulation [From www.interactivearchitecture.org]. Publicado em 16 out 2007. Disponível em: $<$ http://katielevitt.wordpress.com/category/more-things-design/page/3/>. Acesso em 08 set. 2011.

KATHYDALWOOD.COM. Architectural Friezes, plaster \& concrete tileswall sculptures. Disponível em: <http://www.kathydalwood.com>. Acesso em $16 \mathrm{fev}$. 2010.

KENNEDY, Randy. Attention Passengers! To Your Right, This Trip Is About to Become Trippy. The New York Times. Publicado em 31 dez. 2008. Disponível em: <http://www.nytimes.com/2009/01/01/arts/design/01zoet.html?_r=2>. Acesso em 17 mai. 2012.

KISS, Paulo. A fonte da eternidade: energia solar fotovoltaica painéis. Publicado em 01 jul. 1999. Disponível no site: <http://www.piniweb.com.br/construcao/noticias/afonte-da-eternidade-85191-1.asp>. Acesso em 12 jun. 2010.

KLEIN, Paulo. Arte no Metrô de São Paulo: Novas Demandas. Palestra realizada no evento: Metrô, Engenho e Arte do Programa de Inteligência Corporativa da UNIMETRO do Metropolitano de São Paulo. Agosto de 2012.

KRAUSS, Rosalind. A escultura no campo ampliado. Trad. Elizabeth Carbone Baez. In The Anti-Aesthetic - Essays on Post Modern Culture. Washington: Bay Press, 1984.

KRISCENSKI, Ali. SOLAR ARK: World's Most Stunning Solar Building | Inhabitat Sustainable Design Innovation, Eco Architecture, Green Building. Publicado por Ali 
Kriscenski em 14 jan. 2008. Disponível em <http://www.inhabitat.com/2008/01/14/solar-ark-worlds-most-stunning-solarbuilding/>. Acesso em 12 jun. 2010.

KWON, Miwon. One place after another: site specific art and locational identity. Cambridge/London: MIT Press, 2002.

LADEPECHE.FR. L'artiste Sophie Calle applique le concept du "transport amoureux" au métro toulousain. Disponível em: <http://www.ladepeche.fr/article/2007/06/29/20458-L-artiste-Sophie-Calle-appliquele-concept-du-transport-amoureux-au-metro-toulousain.html>. Postado em 29 jun. 2007, 03:32h LA DEPECHE DU MIDI. Acesso em 29 set.2011.

LAFORA.COM.BR. Arquitetura ou mídia exterior? Disponível em: $<$ http://lafora.com.br/2009/02/arquitetura-ou-midia-exterior/s. Acesso em 28 mar. 2010.

LAISTER, Judith. Public Space in Sculpture Projects Muenster 07. 2007, p. 431.

L+D INTERNACIONAL LIGHTING MAGAZINE. Tecnologia + arte + sustentabilidade. Editora Lumière. Número 20, 2008, p. 22-23.

p. 32-33.

. Tecnologia + arte + sustentabilidade. Editora Lumière. Número 20, 2008,

. Especial Fachadas Midiáticas: Iluminação Urbana Sustentável. Editora Lumière: São Paulo. Número 27. março/abril 2010, p. 38.

. Especial Fachadas Midiáticas: PDLC 2009: Refletindo sobre a cultura da luz. Editora Lumière: São Paulo. Número 27, março/abril 2010, p. 40.

Especial Fachadas Midiáticas: Iluminação Urbana Sustentável. Editora Lumière: São Paulo. Número 27, março/abril, 2010, p. 20.

. Especial Fachadas Midiáticas: Arte, luz e interação. Editora Lumière: São Paulo. Número 27, março/abril, 2010, p. 24.

Especial Fachadas Midiáticas: Iluminação Urbana Sustentável. Editora Lumière: São Paulo. Número 27, março/abril, 2010, p. 38.

LEÃO, J. Evangelista. Projeto A Arte e o Planejamento. Prefeitura do Município de São Paulo - Coordenadoria Geral do Planejamento-COGEP., 1974, p. 43.

LEI CIDADE LIMPA. Disponível no site: <http://www3.prefeitura.sp.gov.br/cadlem/secretarias/negocios_juridicos/cadlem/inte gra.asp?alt=27092006L 142230000>. Acesso em 02 abr. 2012.

LEI DE INCENTIVO - Lei Municipal $n^{\circ}$ 10.923/90. Disponível no site: $<$ http://www.prefeitura.sp.gov.br/cidade/secretarias/cultura/lei_de_incentivo/index.ph 
$p ? p=7>$. Acesso em 07 jun. 2012.

LEI DE INCENTIVO 2012. Disponível em: $<$ http://www.prefeitura.sp.gov.br/cidade/secretarias/cultura/lei_de_incentivo/index.ph $p ? p=7>$. Acesso em 07 jun. 2012.

LIBETOULOUSE.FR. Roman Opalka arrête de compter à 79 ans. Disponível em: <http://www.libetoulouse.fr/2007/2011/08/-roman-opalka-arrête-de-compter-à-79ans.html>. Publicado por J-M.E em 08 ago. 2011. Acesso em 29 ago. 2011.

LIRA, José Tavares Correia de. In NESBITT, Kate (org). Uma nova agenda para a arquitetura. Antologia teórica (1965-1995). São Paulo: Cosac Naify, 2006.

MACFADDEN, Roberto. Arte Pública \& Arquitetura. In Seminários de Arte Pública (I) - SESC. São Paulo: SESC, 1995, p. 97.

MACIEL, Katia; PARENTE, André. Redes sensoriais: arte, ciência, tecnologia. Rio de Janeiro: Contra Capa Livraria, 2003.

MACHADO, Arlindo. Arte e mídia. Rio de Janeiro: Jorge Zahar Ed., 2007.

MADISONSQUAREPARK.ORG. Jim Campbell: Light Scattered. Disponível em: $<$ http://www.madisonsquarepark.org/things-to-do/calendar/jim-campbell-scatteredlight>. Acesso em 06 set. 2011.

MAGALHÃES, Fábio. Coleção Arte de Bolso: Claudio Tozzi. Catálogo. São Paulo: Companhia Editora Nacional e Lazuli Editora, 2007.

MARCHART, Oliver. Public Art in Sculpture Projects Muenster 07. Muenster. 2007, p. 426.

MARTINS, Sérgio R. M. Artistas quase arquitetos. Arquitetos quase artistas. Tese de Livre Docência. Faculdade de Arquitetura e Urbanismo da Universidade de São Paulo. São Paulo, 2010.

MEDEIROS, Jotabê. São Paulo reinventa monumentos: Em março, obras de José Resende, Laura Vinci e Eduardo Coimbra intervêm no dia a dia da Pauliceia. $O$ Estado de São Paulo. Caderno 2 D3, 10 jan. 2012.

MEDIAARCHITECTURE.ORG. Media Facades 2008. Disponível em: $<$ http://www.mediaarchitecture.org/mediafacades2008/exhibition/basics>. Acesso em 25 fev. 2010.

NOVA - 3D Lightsculpture, Zurique. Posted: May 14, 2007 at 10:09 am by Wolfgang Leeb. Disponível em: <http://www.mediaarchitecture.org/nova-3dlichtskskulptur-

zurich/\&prev=/search\%3Fq\%3DMediaarchitecture.org,\%2BGernot\%2BTscherteu\%2

BDI\%2BWolfgang\%2BLeeb\%26hl\%3Dpt-

BR\%26sa\%3DG\%26rlz\%3D1G1SNNT_PT- 
BRBR365\&rurl=translate.google.com.br\&usg=ALkJrhid7SCsITMj2ddMwiwBHgi9Ms3TQ>. Acesso em 25 fev. 2010.

MEDIAFACADES.EU. Media Facades Festival 2010. Disponível em: <http://www.mediafacades.eu/>. Acesso em 23 mai. 2010.

MELENDEZ, Adilson. Estação Alto do Ipiranga do metrô, São Paulo. Publicada originalmente em PROJETODESIGN. Edição 365. Julho de 2010. Disponível em: $<$ http://www.arcoweb.com.br/arquitetura/ilvio-silva-artioli-estacao-metro-13-092010.html>. Acesso em 23 set. 2012.

. Contraponto de vidro à aspereza do entorno. Publicada originalmente em PROJETODESIGN. Edição 377. Julho de 2011. Disponível no site: <http://www.arcoweb.com.br/arquitetura/luiz-esteves-arquitetura-estacao-vilaprudente16-09-2011.html>. Acesso em 27 out. 2011.

MENGOZZI, Frederico. Epopeia em concreto: Maria Bonomi inaugura na Estação da Luz, em São Paulo, uma das maiores obras de arte do país. Publicado pela Revista Época, Editora Globo, 22 nov. 2004. Disponível em: <http://revistaepoca.globo.com/Epoca/0EPT865363-1661,00.html>. Acesso em 21 mar. 2012.

METRO.SP.GOV.BR. Bicicleta Audiovisual é destaque da $13^{\underline{a}}$ edição do FILE nas estações Trianon-MASP e Consolação do metrô. Disponível em: <http://www.metro.sp.gov.br/noticias/bicicleta-audiovisual-e-destaque-da-13a-edicaodo-file-nas-estacoes-trianonmasp-e-consolacao-do-m.fss>. Acesso em 21 jul. 2012.

Cultura e Lazer: Ação Cultural. Disponível em: <http://www.metro.sp.gov.br/cultura/acaocultural>. Acesso em 03 ago. 2009.

Cultura e Lazer: Ação Cultural. Disponível em: <http://www.metro.sp.gov.br/cultura/acaocultural>. Acesso em 25 jan. 2012.

- Cultura e Lazer: Arte no Metrô. <http://www.metro.sp.gov.br/culturalazer/arte-metro/arte-metro.aspx>. Acesso em 10 fev. 2009.

- Cultura e Lazer: Arte no Metrô. <http://www.metro.sp.gov.br/culturalazer/arte-metro/arte-metro.aspx>. Acesso em 10 fev. 2012.

Embarque na Leitura. Disponível em: <http://www.metro.sp.gov.br/cultura-lazer/embarque-leitura/index.aspx>. Acesso em 25 jan. 2012.

Turismetrô. Disponível em: http://www.metro.sp.gov.br/culturalazer/turismetro/o-que-e.aspx. Acesso em 25/01/2012.

MIC-RO.COM. Metro Arts and Architecture. Disponível em: <http://micro.com/metro/metrocity.html?city=Portland>. Foto de trimet.org. Acesso em 23 out. 2011. 
$\begin{array}{lrrrr} & \begin{array}{c}\text { Toulousse } \\ \text { Rohde }\end{array} & \text { Gallery: } & \text { Université Paul Sabatier. } & \text { Linha B. Foto: } \\ \text { M. } & \text { (2008). } & \text { Disponível } & \text { em: } & <\text { http://mic- }\end{array}$ ro.com/metro/phototour.html?city=Toulouse >. Acesso em 28 ago. 2011.

MODUL8.CH. Modul8. Disponível em: <http://www.modul8.ch/>. Acesso em 01 out. 2011.

MÖNTMANN, Nina. Relational Aesthetics in Sculpture Projects Muenster 07. Muenster, 2007, p. 433-434.

MTA.INFO. Arts for Transit: West 8th Street-New York Aquarium-Vito Acconci (Acconci Studio). Disponível em: <http://mta.info/mta/aft/permanentart/permart.html?agency=n\&line=Q\&station=21\&art ist=1\&img=4\&xdev=2280 $>$. Acesso em 17 mai. 2012 .

MUYLAERT, Roberto. Incentivos Fiscais: quem carrega o carrinho? Seminários de Arte Pública (I). SESC. São Paulo, 1995, p.81-86.

NAKAMURA, Juliana. Luz e movimento na arquitetura. $L+D$ INTERNACIONAL LIGHTING MAGAZINE: Especial Fachadas Midiáticas. Editora Lumière: São Paulo. Número 27, março/abril 2010, p. 78 - 85.

NORDICDESIGNBLOG.COM. The Tunnel of Light. Disponível em: <http://www.nordicdesignblog.com/?s=nydalen>. Publicado por Igor Polyakov em 13 jun. 2006. Acesso em 28 ago. 2011.

NUNES, Lilian do Amaral. Derivações da Arte Pública Contemporânea. Tese de Doutorado. Escola de Comunicações e Artes da Universidade de São Paulo, 2010, p.31-46.

NYC.GOV. Percent for Art. Disponível em: <http://www.nyc.gov/html/dcla/html/panyc/panyc.shtml>. Acesso em 27 mai. 2012.

O ESTADO DE SÃO PAULO. Plano é preencher seus vazios. 11 mai. 1974, p. 19. . Edição 25 jan. 1979.

Alcoa lança fachada de células fotovoltaicas. Caderno Construção. Tecnologia. 3 out. 2008.

Esportes. Palco principal, enfim, está pronto: Soccer City, que teve atraso no cronograma e estouro no orçamento, abrigará o jogo inaugural e a final da Copa. 11 jun. 2010.

OLIVEIRA, Claudia Terezinha de Andrade. Painéis pré-fabricados de GRC para vedação vertical de edificações. Cadernos Técnicos - AUT / Universidade de São Paulo, Faculdade de Arquitetura e Urbanismo, Departamento de Tecnologia da Arquitetura. - n.10 (2002) - São Paulo: FAU, 2002, p. 73-90. 
OLIVEIRA, Kleber Adriano Silva. O ponto e o pixel: novas mídias, novas linguagens. Dissertação de Mestrado em Arquitetura e Urbanismo. Faculdade de Arquitetura e Urbanismo da Universidade de São Paulo. São Paulo, 2006.

ONYX SOLAR. Corporate Brochure Bipv Bureau, 2010.

OP_ERA.COM. OP_ERA: Sonic Dimension. Disponível em: <http://www.opera.com/index_port.htm>. Acesso em 31 mai. 2012.

OSRAM.COM.BR. Lâmpadas de multivapores metálicos. Disponível em: <http://www.osram.com.br/osram_br/Profissional/Display_Optic/Entretenimento/Lam padas_de_multivapores_metalicos/HMI_HTI_HSR/index.html>. Acesso em 06 abr. 2010.

PALLAMIN, Vera. Arte Urbana: aspectos contemporâneos. Sinopses. São Paulo, n.22, p. 24-32, dez. 1994.

Arte urbana: São Paulo: Região Central (1945-1998): obras de caráter temporário e permanente. São Paulo: Anablume FAPESP, 2000.

PASQUALI, Lanussi. O sentido da produção e a relação entre o público e o trabalho artístico. In Intervenções: artes visuais em debate/Universidade Federal da Paraíba. Revista do Departamento de Artes Visuais da UFPB (Ano 1, no1). João Pessoa, 2006.

PEIXOTO, Nelson Brissac. Intervenções urbanas: Arte/Cidade. São Paulo: Editora SENAC São Paulo, 2002.

PINHEIRO, Márcia Barone. Vivência de modernidade no urbano paulista - o metrô de São Paulo: representações e apropriações pelo usuário. Dissertação de Mestrado em Arquitetura e Urbanismo. Faculdade de Arquitetura e Urbanismo da Universidade de São Paulo. São Paulo, 1992.

PERFORMATIVE.WORDPRESS.COM. Performative Environments: Tunnel of Light - Nydalen, Metro Station, Oslo. Disponível em: $<$ http://performative.wordpress.com/2007/01/>. Postado em 21 jan. 2007. Acesso em 28 ago. 2011.

PHOTOGRAPHIE.COM. Commande publique pour la ligne B du métro de Toulouse / Art contemporain. Publicado por Claudine Colin Comunicação em 03 set. 2007. Disponível em: <http://www.photographie.com/?pubid=104067>. Publicado em 03 set. 2007. Acesso em 29 ago. 2011.

POEIRA, Daniel. Guia de formatos de tela e resoluções de vídeo digital. $1^{\text {a }}$ Ed. Universidade Federal de Minas Gerais. Escola de Belas Artes. Departamento de Fotografia, Teatro e Cinema. Composto e redigido por Daniel Leal Werneck em 07 ago. 2007.

PREFEITURA DO MUNICÍPIO DE SÃO PAULO - COORDENADORIA GERAL DO PLANEJAMENTO-COGEP. Projeto A Arte e o Planejamento, São Paulo, 1974. 
PREFEITURA.SP.GOV.BR. 'Arte na Cidade' inaugura duas novas obras. Edital lançado pela Secretaria Municipal de Cultura lança intervenções de Laura Vinci e Eduardo Coimbra; Obras de José Spaniol, Mauro Sergio Neri, Paulo Camillo Penna e Thiago Rocha Pitta já estão em cartaz pela cidade. Publicado em 05 mar. 2012. Disponível em: <http://www.prefeitura.sp.gov.br/cidade/secretarias/cultura/noticias/?p=10179>. Acesso em 14 abr. 2012.

. Prefeitura lança edital "Arte na Cidade" para incentivar projetos de artes visuais: Secretaria Municipal de Cultura lança novo edital, focado em artes visuais ao ar livre, com inscrições abertas a partir de 8 de junho. Publicado em 08 jun. $2010 . \quad$ Disponível em: <http://www.prefeitura.sp.gov.br/cidade/secretarias/cultura/noticias/?p=7835>.

Acesso em 15 jun. 2012.

- Prefeitura anuncia sua mais recente idéia: pintar a cidade. In O Estado de São Paulo, 11 mai. 1974, p. 43.

PROJECTORCENTRAL.COM. Projectors. Disponível em: <http://www.projectorcentral.com/buyers3.htm>. Acesso em 01/10/2011.

PT.WIKIPEDIA.ORG. Via Quatro. Disponível em: <http://pt.wikipedia.org/wiki/ViaQuatro>. Acesso em 30 set. 2012.

PUCSP.BR. Arte/Cidade. Disponível em: <http://www.pucsp.br/artecidade/>. Acesso em 12 mai. 2009.

REGULAMENTO PARA APRESENTAÇÃO DE PROJETOS DE OBRAS DE ARTE PERMANENTE. Disponível em: <http://www.metro.sp.gov.br/cultura-lazer/artemetro/como-participar.aspx>. Acesso em 12 mar. 2012.

REGULAMENTO PARA APRESENTAÇÃO DE EXPOSIÇÕES E EVENTOS. Disponível em: <http://www.metro.sp.gov.br/cultura-lazer/exposicoeseventos/index.aspx>. Acesso em 12 mar. 2012.

SAMPAIO, José Luiz. Arte e Tecnologia: Video Mapping. Curso Escola São Paulo. Jan. 2011. Material disponibilizado pelo autor para a pesquisadora no final do curso.

SAMPAIO, Paulo. Arte Virtual anima o metrô: Instalações em seis estações da cidade ajudam a tornar mais curiosa a espera pelos trens. O Estado de São Paulo. 21 abr. 2010.

SANDRIN, Ewely B.; VISCONTI, Jacopo C. A Intervenção Invisível. Seminário apresentado na Disciplina AUP5844: Cultura Contemporânea: estudos em artes, design e arquitetura da Pós-Graduação da FAUUSP, 2009.

SANTANA, Luciano Costa Nascimento de. VJ- vídeo ao vivo. Monografia de Graduação - Bacharel em Comunicação Social com habilitação em Cinema e Vídeo. Faculdade de Tecnologia e Ciências - FTC, sob a orientação do Professor Danillo Silva Barata, Salvador, 2005. 
SANTOS, Ivan Lubarino Piccoli dos. Mídia eletrônica e agenciamentos de significados para a arquitetura e design. Tese de Doutorado em Arquitetura e Urbanismo. Faculdade de Arquitetura e Urbanismo da Universidade de São Paulo. São Paulo, 2010.

SANTOS, Ricardo Gomides. Obras de Arte no Metrô de São Paulo: um estudo junto aos seus usuários. Dissertação de Mestrado em Psicologia da Universidade de São Paulo. São Paulo, 2006.

SCENERY.CULTURAL-CHINA.COM. Bund Sightseeing Tunnel. Disponível em: $<$ http://scenery.cultural-china.com/en/148Scenery4126.html>. Acesso em 23 out. 2011.

SCIENCE \& TECHNOLOGY NEWS. The Future of Fashion is Well Lit with Project Science \& Technology News. Publicado em 21 set. 2006. Disponível em: $<$ http://www.impactlab.com/2006/09/21/the-future-of-fashion-is-well-lit-with-projectskin/> . Acesso em 24 fev. 2010.

SCHEIN, Françoise. Por que a arte nos metrôs é fundamental? Palestra realizada no evento: Metrô, Engenho e Arte do Programa de Inteligência Corporativa da UNIMETRO do Metropolitano de São Paulo. Ago. 2012.

SCHINEIDER, Veronica. FILE PAI: Avenida Paulista se transforma em grande exposição interativa. Disponível em: <http://www.onne.com.br/materias/homem/14060/file_pai>. Acesso em 06 ago. 2010.

SCHULZ-DORNBURG, Julia. Arte y arquitectura: nuevas afinidades. Barcelona: Gustavo Gilli, 2000.

SCIENCE \& TECHNOLOGY NEWS. O futuro da moda é bem iluminado com o Projeto PELE. Publicado em: 21 ago. 2006. Disponível em $<$ http://www.impactlab.com/2006/09/21/the-future-of-fashion-is-well-lit-with-projectskin/ >. Acesso em 24 fev. 2010.

SCOTT ALDOUS. HowStuffWorks - Como funcionam as células solares. Publicado em 01 abr. 2000 (atualizado em 27 jun. 2008). Disponível em: <http://ambiente.hsw.uol.com.br/celulas-solares2.htm>. Acesso em 21 fev. 2010.

SEMINÁRIO DE ARTE PÚBLICA. Um breve histórico sobre arte Pública na Cidade de São Paulo. SESC SÃO PAULO, 1995 (autor desconhecido).

SFARTSCOMMISSION.ORG. Central Subway Public Art Program Winners Announced! Disponível em: <http://www.sfartscommission.org/pubartcollection/pubart-pressreleases/2010/07/30/central-subway-public-art-program-winners-announced/>. Publicado em 30 jul. 2010. Acesso em 08 set. 2011.

SILVA, Armando. Imaginários urbanos. Coleção estudos, 173/dirigida por J. Guinsburg. 1a reimp. da 1. ed. de 2001. São Paulo: Perspectiva, 2011, p. XXIII-XXIX. 
SPANGHERO, Maira. Daniela Kutschat e Rejane Cantoni. Publicado em 03 mar. 2009. Disponível no site: <http://www.cibercultura.org.br/tikiwiki/tikiindex.php?page=Daniela+Kutschat+e+Rejane+Cantoni . Acesso em 30 mai. 2012.

STM.SP.GOV.BR. Obras da Bienal ocupam espaços no Metrô de São Paulo. Publicado em 07 nov. 2006. Disponível em: <http://www.stm.sp.gov.br/index.php?option=com_content\&view=article\&id=418:n40 $0 \&$ catid=1: noticias\&ltemid=95>. Acesso em 07 jun. 2009.

STRÖM, Marianne. A Arte Pública nos espaços subterrâneos dos metrôs: Arte pública no metrô de Estocolmo. Seminários de Arte Pública (II) SESC. São Paulo, 1998.

TAPINTANDOUMNOVOMETRO.COM.BR. Regulamento do Concurso Tá pintando um novo metrô. Disponível em:

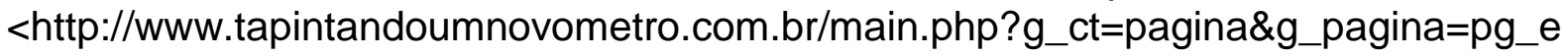
dital>. Acesso em 10 out. 2012.

TASSINARI, Alberto. O espaço moderno. São Paulo: Cosac \& Naify Edições, 2001.

TECHNICAL GUIDES. The Munsell Color System. 2000. Disponível em: $<\mathrm{http}: / / \mathrm{dba}$.med.sc.edu/price/irf/Adobe_tg/models/munsell.html>. Acesso em 27 mar. 2010.

TODAYANDTOMORROW.NET. Wouldn't it be nice? Publicado em 30 mar.2009. Disponível em: <http://www.todayandtomorrow.net/2009/03/30/wouldnt-it-be-nice/>. Acesso em 24 fev. 2010.

TOZZI, Claudio. O processo de construção da imagem e sua aplicação, relação com o espaço urbano: arte no lugar da arquitetura no fazer de um artista plástico /arquiteto. Tese em Arquitetura e Urbanismo. Faculdade de Arquitetura e Urbanismo da Universidade de São Paulo. 2001.

. Tese: Tozzi propõe arte e arquitetura integradas. Entrevista a Fabio Cypriano, Folha de São Paulo. llustrada. 24 fev. 2001.

Por uma fusão de arquitetura e artes plásticas. O Estado de São Paulo. Caderno 2, 16 dez. 2011.

TSCHERTEU, Gernot; LEEB, Wolfgang. Media Fachadas: termos e conceitos fundamentais. Publicado em: 26 jan. 2008. Disponível em: <http:// www.mediaarchitecture.org/mediafacades2008/exhibition/basics>. Acesso em 25/02/2010.

URBANSCREEN.COM. Jump! Disponível em: <http://www.urbanscreen.com/usc/41>. Acesso em 23 mai. 2010. 
VEIGA, Edson. Festival de grafite digital vai colorir noites da Augusta. Folha de São Paulo. Caderno 1, p.10, 16 nov. 2011.

VENTURELLI, Suzete. Arte: espaço_tempo_imagem. Brasília: Editora Universidade de Brasília, 2004.

VEJA. Ecodesign: a reinvenção da luz. São Paulo: Editora Abril. 30 dez. 2009, p. $215-221$.

VIMEO.COM. Trilhos Urbanos. Por André Parente. Disponível em: <http://vimeo.com/26044592>. Acesso em 14 out. 2011.

VISUALFARM.COM.BR. Projetos de arte-mídia da visualfarm transformam pontos históricos de São Paulo. Disponível em: http://www.visualfarm.com.br/blog/?p=419. Acesso em 28 set. 2011.

VJSUAVE.COM. Suaveciclo - FILE - Avenida Paulista from vjsuave on Vimeo. Disponível em: <http://www.vjsuave.com/>. Acesso em 28/07/12.

WAGNER, Felipe. Festival de Fachadas-Mediáticas Berlin 2008. Publicado por soleundurraga em 03 nov. 2008. Disponível em: $<$ http://www.plataformaarquitectura.cl/2008/11/03/festival-de-fachadas-mediaticasberlin-2008/>. Acesso em 25 fev. 2010.

WILKE, Regina Cunha. Intervenções visuais no espaço urbano a propósito de modelos. Monografia apresentada na Faculdade de Arquitetura da Universidade de São Paulo. São Paulo. 1976.

\section{Entrevistas:}

FAJARDO, Carlos. Carlos Fajardo. Depoimento. [19 jun 2012]. Entrevistadora Ewely Branco Sandrin. Local: residência do artista. Declarações gravadas pela pesquisadora.

KUTSCHAT, Daniela. Daniela Kutschat. Depoimento [02 ago 2012]. Entrevistadora Ewely Branco Sandrin. Local: Laboratório LabVisual da Faculdade de Arquitetura e Urbanismo da Universidade de São Paulo. Declarações gravadas pela pesquisadora.

MONITOR. Depoimentos de monitores no decorrer da Exposição Arte CibernéticaAcervo Itaú Cultural, realizada em parceira com o Itaú Cultural [período de 17 abril a 23 maio, prorrogada até 30 maio de 2010] e das pa e $2^{2}$ edições do FILEPAl, integrantes do $11^{\circ}$ e $12^{\circ}$ Festivais Internacionais de Linguagem Eletrônica-FILE, realizados em parceria com a FIESP e o SESI [períodos de 27 julho a 07 agosto de 2010 e de 19 a 28 de julho de 2011 respectivamente]. Entrevistadora Ewely Branco Sandrin. Local: Estações do Metropolitano de São Paulo. Declarações gravadas pela pesquisadora. 
SILVA, Armando. Armando Silva. Depoimento [09 abr 2010]. Entrevistadora Ewely Branco Sandrin. Local: Museu de Arte Contemporânea da USP-MACUSP Ibirapuera. Declarações gravadas pela pesquisadora.

SILVEIRA, Regina. Depoimento concedido via correio eletrônico [12 jul 2012]. Entrevistadora Ewely Branco Sandrin.

TÉCNICO DE MANUTENÇÃO. Depoimentos de técnicos de manutenção no decorrer da Exposição Arte Cibernética-Acervo Itaú Cultural, realizada em parceira com o Itaú Cultural [período de 17 abril a 23 maio, prorrogada até 30 maio de 2010] e das 1 ae $2^{\mathrm{a}}$ edições do FILEPAl, integrantes do $11^{\circ}$ e $12^{\circ}$ Festivais Internacionais de Linguagem Eletrônica-FILE, realizados em parceria com a FIESP e o SESI [períodos de 27 julho a 07 agosto de 2010 e de 19 a 28 de julho de 2011 respectivamente]. Entrevistadora Ewely Branco Sandrin. Local: Estações do Metropolitano de São Paulo. Declarações gravadas pela pesquisadora.

TOLEDO, Amélia. Amélia Toledo. Depoimento [27 jun 2012]. Entrevistadora Ewely Branco Sandrin. Local: residência/atelier da artista. Declarações gravadas pela pesquisadora.

TOLEDO, Mo. Mo Toledo. Depoimento [09 jul 2012]. Entrevistadora Ewely Branco Sandrin. Local: residência/atelier do artista. Declarações gravadas pela pesquisadora.

TOZZI, Claudio. Claudio Tozzi. Depoimento [12 set 2012]. Entrevistadora Ewely Branco Sandrin. Local: residência/atelier do artista. Declarações gravadas pela pesquisadora.

USUÁRIO/ESPECTADOR/ATOR. Depoimentos de usuários/espectadores/atores do metrô de São Paulo no decorrer da Exposição Arte Cibernética-Acervo Itaú Cultural, realizada em parceira com o Itaú Cultural [período de 17 abril a 23 maio, prorrogada até 30 maio de 2010] e das 1 a e $2^{a}$ edições do FILEPAl, integrantes do $11^{\circ}$ e $12^{\circ}$ Festivais Internacionais de Linguagem Eletrônica-FILE, realizados em parceria com a FIESP e o SESI [períodos de 27 julho a 07 agosto de 2010 e de 19 a 28 de julho de 2011, respectivamente]. Entrevistadora Ewely Branco Sandrin. Declarações gravadas pela pesquisadora.

ZAIDLER, Waldemar. Waldemar Zaidler. Depoimento [15 jun 2012]. Entrevistadora Ewely Branco Sandrin. Local: Faculdade de Arquitetura e Urbanismo da Universidade de São Paulo. Declarações gravadas pela pesquisadora. 


\section{ANEXO I}

\section{Mapa do Transporte Metropolitano}

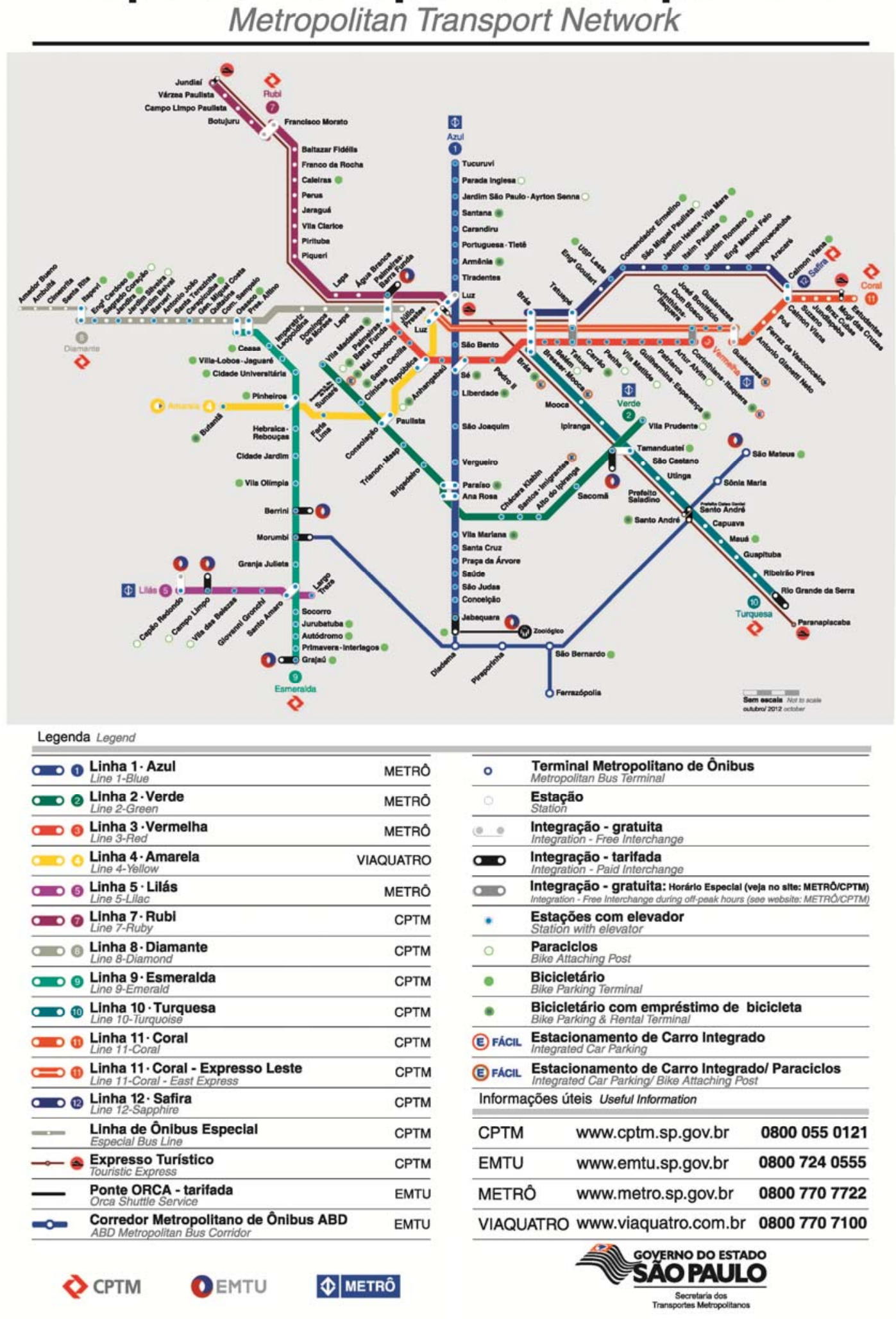

Figura 640: Mapa do Transporte Metropolitano, 2012. Fonte:

<http://www.metro.sp.gov.br/pdf/mapa-da-rede-metro.pdf>. Acesso em: 28.10.2012 


\section{APÊNDICE A}

\section{Entrevista com Armando Silva}

Local: Museu de Arte Contemporânea da USP - MACUSP Ibirapuera

Data da realização: 09 de abril de 2010

Armando Silva é Doutor em Filosofia e Literatura Comparada pela Universidade da Califórnia. É autor de dezesseis livros, dentre eles: Imaginários Urbanos, Family Photo Album (vencedor do Prêmio de melhor tese de doutorado das universidades da Califórnia-UMI, 1996), Urban Imaginaries from Latin America. Diretor do Projeto Imaginários Urbanos e editor da série visual Cidades Imaginadas. Participou da Documenta 11 em Kassel, Alemanha (2002), Bienal de São Paulo (2002), Bienal de Veneza (2006). Em 2007, a Fundación Antoni Tàpies de Barcelona exibiu uma retrospectiva completa de sua obra. Em 2008, o Museu de Arte Moderna de Bogotá (MAMBO) exibiu arquivos urbanos visuais de 22 cidades do mundo, com distintos coordenadores, em formatos impressos, audiovisuais e digitais. Em 2009, a Oficina de Divulgación Cultural da Universidad Nacional e o Banco de La República montaram uma exposição de seus arquivos cidadãos, organizados pela Fundación Antoni Tàpies de Barcelona. É membro do Conselho Editorial de revistas como: Diálogos de La Comunicación da Federación Latinoamericana de Faculdades de Comunicatión; Ciudades, no México, The Journal of Culture and The Unconscious, em São Francisco e Alambre, revista eletrônica de Buenos Aires. É Pesquisador e Professor Emérito da Universidad Nacional de Colombia e professor e pesquisador da Faculdade de Ciências Humanas da Universidad Externado de Colombia. É professor convidado em universidades da América e Europa. Em 1990, foi convidado pelo PROLAM da Universidade de São Paulo para iniciar seus estudos sobre culturas urbanas em São Paulo. Em 2010, organizou a Exposição Cidades Imaginadas Iberoamericanas, com curadoria de Lisbeth Rebollo Gonçalves, realizada no MAC USP Ibirapuera, no período compreendido entre 08 abril e 30 maio.

Pesquisadora: Começou a desenvolver seus estudos sobre culturas urbanas em 1990, em São Paulo. Neles, estariam incluídas obras de arte de alguma estação do metrô da cidade ou de outras cidades iberoamericanas?

Armando: Sim, em New York. Eu estava morando lá entre os anos de 1978 e 79. Lembro-me bem, que havia muitas pinturas grafites de um pessoal de Porto Rico. Era o início de um grafite que não era contestatório, era ideológico. A parte revolucionária desse grafite era que não falava de nada, era somente imagem. Era mais político, usava a imagem como uma estratégia política. Por isso, foi um grafite muito revolucionário por se tratar de uma ruptura entre o grafite ideológico e o estético. Era uma ruptura com maio de 68. Era uma imagem muito forte, era uma 
coisa muito territorial. Tinha muitas qualidades para ser grafite. Não era um grafite de arte como se faz hoje, que em lugar de se fazer arte na galeria, se faz na rua.

Depois aqui, em 90, trabalhei com a cidade. Só me lembro que na estação Consolação havia um grupo que estava fazendo música e, ao mesmo tempo, pintava a estação do metrô. Era o que chamo de "grafite rock", um fenômeno que também encontrei em Bogotá. Em Paris, em 1987, na estação Nation, se fazia a mesma coisa. Era uma arte muito mais familiar ao grafite que a arte de hoje que, historicamente, estão nas galerias mas agora estão no metrô.

Pesquisadora: Afirma que nem tudo o que está nos muros é grafite e que um grafite não tem que estar em um muro das ruas. Sei que são apenas imagens, mas o que poderia dizer a respeito da obra dos Gêmeos e ISE na conexão das estações de trem e metrô da Luz? E sobre anotações feitas por usuários do metrô em um livro de registro de uma exposição de fotografias exposta dentro da estação? Seriam grafites? Seriam grafite estético e grafite contestatório, respectivamente?
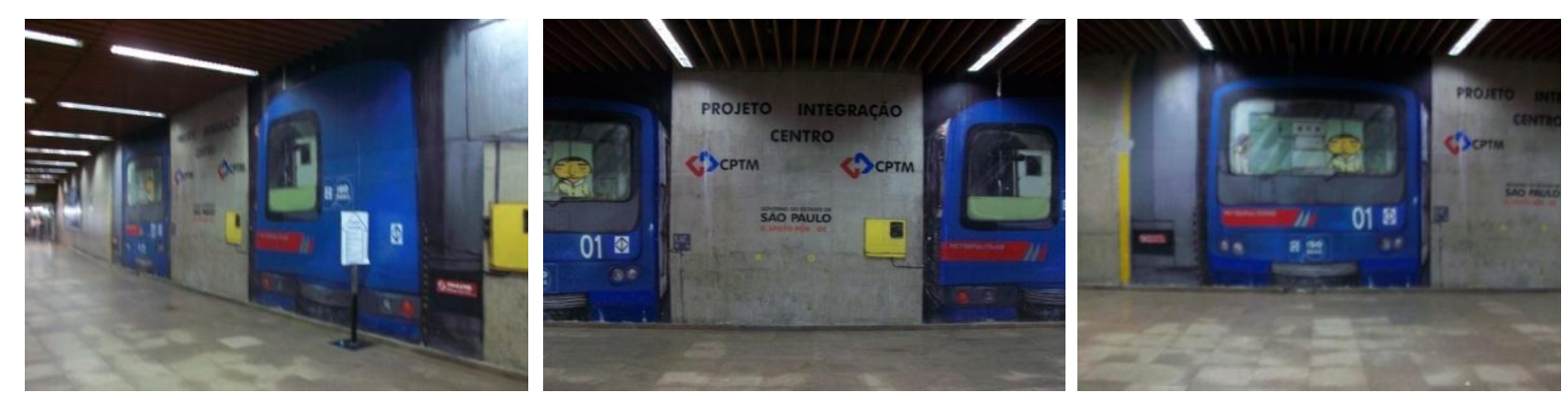

Figuras 641, 642 e 643: Arte Urbana de Os Gêmeos e ISE. Fonte: Registro fotográfico da pesquisadora.
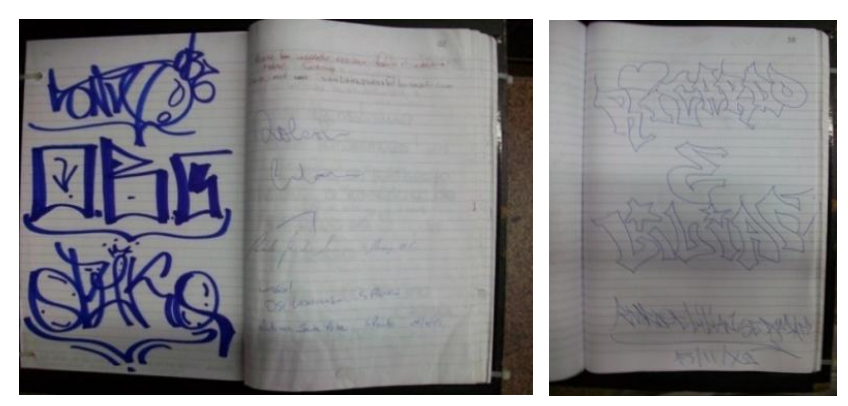

Figura 644: Anotações em livro de registro de exposição em estação de metrô. Fonte: Registro fotográfico da pesquisadora.

Armando: No meu ponto de vista, grafite é uma coisa muito mais revolucionária, mais contra situações estabelecidas, contra o sistema, então, é sempre político. Pode ser que alguns grafiteiros usem a estética, mas precisa de uma dimensão política para entrar em meu sistema de grafite. No Brasil, a pichação é mais como um jogo de palavras, geralmente, com as iniciais dos nomes das pessoas. Chamo isso de "grafite pobre" porque está fazendo uma coisa proibida, mas é uma situação muito mais narcisista, feita por tribos. Por isso, que nem tudo é grafite porque grafite é um sistema muito poderoso que completa "valências". A pichação é um grafite degradado, pobre. 
O caso dos Gêmeos é uma situação contemporânea que estou falando muito mais de arte urbana. Pode ser que os gêmeos, agora, estejam no limite entre grafite e arte urbana. Os Gêmeos cercaram muito mais a arte urbana. A classificação do grafite é uma coisa muito dinâmica. Pode ser que, hoje, eles sejam mais artistas urbanos que grafiteiros. Não por fazer desenhos ou imagens pela cidade, não por isso são necessariamente grafites. A cidade tem muitas imagens que não são necessariamente grafites. Temos três gêneros no espaço público: grafite, arte urbana, arte pública e, uma outra situação que convive também com o espaço público, que são os imaginários urbanos. Então, são quatro ações, porque vêm de pessoas que têm uma formação ou um intento, em todo caso, ou estético ou político. Essa é minha sugestão que posso dar pelo que estou vendo nas imagens que você me mostra.

Pesquisadora: Como você definiria o espaço urbano (público) de uma estação de metrô? Se enquadraria no que você chama de "lugar contemporâneo" ? Por quê?

Armando: Sim, "não-lugar" não, sítio. O metrô é um "sítio", no sentido greco-latino, não é um "não-lugar". Lugar é uma coisa mais arquitetônica, mais relacionado ao espaço físico, enquanto que, "sítio" está relacionado à pessoa. A pessoa está ocupando um espaço, está fazendo um "sítio". Contemporaneamente, temos mais sítios que lugares. Para mim, o que Augé chamava de "não-lugar" é um "sítio contemporâneo". O metrô é um "sítio contemporâneo" muito forte onde acontecem muitas coisas cidadãs. As pessoas ouvem música, há muita atenção, muito perigo, muitas coisas psicológicas estão acontecendo. É um "sítio existencial". "Nãolugares", para mim, são lugares que não têm discurso, que não são visitados ou são visitados por muito poucas pessoas, que não têm reflexão coletiva. O metrô é um bom exemplo de sítio autêntico, muito urbano, de muita vida coletiva.

Falo que Urbanismo não é do espaço físico, é a pessoa que está fazendo o urbanismo, está ligado aos cidadãos, não ao espaço físico. Minha teoria está ligada aos cidadãos. Naturalmente, que imaginários são invisíveis, mas têm corpo dentro de um objeto. Têm um corpo porque estão fazendo um sítio, como por exemplo, as Ruas Consolação e Augusta. É uma situação muito antropológica, de imaginário, de efemeridade, de trânsito.

Pesquisadora: A seu ver, qual o significado da arte: para o espaço arquitetônico do metrô de São Paulo e para seus usuários?

Armando: Para a Arquitetura, naturalmente, é parte da arquitetura, da geografia, do sítio. Para os usuários, é parte do gozo, do prazer estético. O grafite é uma outra coisa, é algo que está pegando o lugar à força. O que se está fazendo no metrô não é a força, é legal, é parte de uma arquitetura, de um desenho que é permitido, que é institucional. Mesmo que o grafite não seja institucional também dá prazer. Não é grafite é arte urbana.

Muitas cidades estão fazendo arte para ir contra o grafite, é uma medida política. Colocar a arte nos espaços é uma forma de prevenir o grafite. É uma ação política para defender-se da resposta dos grafiteiros.

Na Bienal de São Paulo, mais interessante que a ideia foi a ação dos grafiteiros. $O$ grafite entrou em um espaço branco, limpo, ideologicamente burguês. É uma estética que entra e rompe. É um autêntico grafite.

Pesquisadora: Em entrevista publicada no catálogo da exposição "Cidades Imaginadas Iberoamericanas", realizada no Museu de Arte Contemporânea da USP - 
MACUSP Ibirapuera, você afirmou que Arte Pública é a produzida por artistas enquanto que os imaginários são ações de cidadãos. E a arte digital (criada por um artista, arquiteto ou designer) diretamente relacionada à tecnologia, à interatividade, em alguns casos, à afetividade, em que o espectador também assume o papel de autor, o que seria?

Armando: Acho que é arte pública porque, hoje, nós temos arte pública não somente espaço físico mas espaço virtual também é parte do espaço público. Hoje, no espaço público, o que mais se está fazendo é a arte digital, é arte pública. Vou trocar a pergunta: Qual a diferença entre virtual e imaginário? Virtual é uma técnica como escrita, fotografia, muito poderosa, marca a contemporaneidade. O imaginário não é uma técnica, é ontológico, é do pensamento, é a maneira como estou pensando o mundo, são coisas muito distintas. Hoje, temos muitos imaginários que têm origem em técnicas digitais, mas nem todos os imaginários são digitais, são uma epistemologia ou estética ao mesmo tempo. Como penso o mundo segundo meus sentimentos. Virtual é uma na técnica de produzir imaginários. Pode ser que no espaço público, também dentro do espaço digital, nós temos escrituras muito privadas, não públicas. Como a Internet, escrevo somente para você e para mim, ou usos sexuais, eróticos entre duas pessoas. Facebook é muito mais comunitário.

Eu tenho um livro que fala sobre arquivos cidadãos chamado "Urbanismos cidadãos" em que falo que temos três tipos de arquivos cidadãos: íntimo (como álbum de família), comunitário (facebook), público (cidades imaginadas, como trabalho público de arte digital). Então, as mesmas coisas que são íntimas ou públicas da cidade real são a mesma coisa para arquivos digitais, que podem ser públicos ou não públicos. Hoje, falo que grafite não é público. A diferença é que um é digital e outro é físico. Facebook não é público, é comunitário, mas se escrevo para você, é um arquivo privado de você para mim. Como a vida erótica é privada, mas também pode ser pública. Quando falamos de digital não é necessariamente público, uma parte é pública, outra não. 


\section{APÊNDICE B}

Entrevistas com os usuários/espectadores/atores do metrô de São Paulo, monitores e técnicos de manutenção, no decorrer da Exposição Arte Cibernética-Acervo Itaú Cultural, realizada em parceira com o Itaú Cultural no período de 17 abril a 23 maio, prorrogada até 30 maio de 2010 , e das pe $2^{a}$ edições do FILEPAl, integrantes do $11^{\circ}$ e 12을 Festivais Internacionais de Linguagem Eletrônica-FILE, realizados em parceria com a FIESP e o SESI nos períodos de 27 julho a 07 agosto de 2010 e de 19 a 28 de julho de 2011, respectivamente.

Questões:

1- Dados do entrevistado: nome, idade, atuação profissional.

2- O que você achou deste trabalho?

3- Você já tinha visto este tipo de trabalho em algum outro lugar?

4- Acha que pode ser considerado uma obra de arte?

5-Você costuma usar o metrô com frequência? Tem alguma obra de arte permanente que você se lembre que esteja exposta nesta ou em outra estação?

6- O que você pensa sobre a presença de obras de arte nas estações de metrô?

EXPOSIÇÃO ARTE CIBERNÉTICA - ACERVO ITAÚ CULTURAL (2010)

\section{Estação Brás}

Obra: Descendo a Escada (2002)

Autor: Regina Silveira

usuário/espectador/ator: Rogério, estudante de engenharia de produção, 30 anos

Pesquisadora: O que você achou deste trabalho?

Rogério: Eu gostei.

Pesquisadora: Você considera este tipo de trabalho uma obra de arte?

Rogério: Essa é uma obra de arte que interage com as pessoas e isso é raro. Você vai no MASP, por exemplo, tem aqueles quadros magníficos. Olha que bonito, o cara desenhou isso, fez aquilo, tal, o quê ele queria passá com isso? Você pega e descobre a história escondida dentro do quadro. No caso dessa obra de arte, você pega e interage com ela. Ela pega e responde prá você. Isso te faz sentir bem. 
Estação Corinthians-Itaquera

Obra: Text Rain (1999)

Autores: Camile Utterback e Romy Achitu

usuárias/espectadoras/atoras: Maria Helena, 44 anos, auxiliar de creche infantil (mãe) / Juliana, 14 anos, estudante do ensino médio (filha)

Pesquisadora: Você é professora deles?

Maria Helena: Não, eu sô a mãe de uma delas. Eles cursam o segundo ano do ensino médio e a professora de artes pediu prá eles um trabalho baseado nas obras das exposições, então eu trouxe eles, né.

Pesquisadora: O que você achou deste trabalho?

Maria Helena: Achei muito interessante, muito interessante mesmo aquelas letras se mexendo.

Pesquisadora: Você já tinha visto este tipo de trabalho em algum outro lugar? Maria Helena: Não, eu nunca tinha visto. Agora nós vamos vê nas outras estações.

Pesquisadora: $\mathrm{O}$ que você pensa sobre a presença deste tipo de trabalho nas estações do metrô?

Maria Helena: Ah, é importante sim né. Assim as pessoas têm acesso à cultura.

Pesquisadora: Acha que pode ser considerado uma obra de arte?

Maria Helena: Eu acho sim.

usuária/espectadora/atora 24: Cristina, 35 anos, professora (mãe) / Guilherme, 6 anos (filho)

Pesquisadora: Ele é seu filho?

Cristina: $E^{\text {. }}$

Pesquisadora: Qual o nome dele?

Cristina: Guilherme.

Pesquisadora: Quantos anos ele tem?

Cristina: Seis.

Pesquisadora: É a primeira vez que ele vê este trabalho?

Cristina: Não. Toda vez que a gente acaba saindo ele pede prá pará aqui.

Pesquisadora: Você o levou para ver nas outras estações?

Cristina: Não, só nessa aqui mesmo, é nosso caminho. Ele já veio o caminho inteiro perguntando: será que as letras tão lá mãe? Na hora que ele tava descendo a escada ele viu e veio correndo.

Monitora: Denise

Pesquisadora: Quantas pessoas costumam vir para visitar esta obra? 
Denise: Então, aqui em Itaquera, a média é de 300 a 400 pessoas por dia, inclusive aos finais de semana. Geralmente, sábado aumenta um pouco mais, não é todo sábado, varia bastante.

Pesquisadora: Qual a faixa etária das pessoas?

Denise: Todas as faixas etárias vêm. Todas as faixas etárias. Idosos, crianças se divertem mais, né. Mas tem bastante idoso, adolescente, adulto, todo mundo.

Pesquisadora: E qual é o período do dia, que horário, que as pessoas costumam vir?

Denise: Após o meio dia até a hora que acaba a exposição. Tanto nos finais de semana quanto durante a semana.

\section{Estação Paraíso \\ Obra: Les Pissenlits (2006) \\ Autores: Edmond Couchot e Michel Bret}

\section{usuário/espectador/ator: Francisco Igor, 17 anos, estudante e auxiliar administrativo.}

Pesquisadora: O que você achou deste trabalho?

Francisco: Muito interessante, bem divertido, é uma coisa assim que você não vê todo dia, em qualquer lugar.

Pesquisadora: Você já tinha visto este tipo de trabalho em algum outro lugar?

Francisco: Não, eu nunca tinha visto.

Pesquisadora: Esta é a primeira vez que você para para observá-lo?

Francisco: Eu tive que passá um dia desses na estação Paraíso e vi. Até tive curiosidade mas como eu tava na correria não parei. Mais aí eu vi naquelas telinha do metrô daí eu aproveitei prá passá hoje.

Pesquisadora: $O$ que você pensa sobre a presença deste tipo de trabalho nas estações do metrô?

Francisco: Eu acho divertido porquê, tipo, de final de semana mesmo, tem crianças que param prá olhá. Tipo, os pais não querem vê mais as crianças têm a curiosidade de sabê o que é. Elas chamam os pais, perturbam os pais prá pará. Bem divertido mesmo.

Pesquisadora: Você costuma usar muito o metrô? Tem alguma obra de arte que você se lembre que esteja exposta nesta ou em outra estação?

Francisco: Costumo. Então, geralmente, quando eu uso o metrô é quando eu tô trabalhando, então eu sempre tô na correria mas sempre quando tem alguma exposição que dá pra mim dá uma olhada eu páro e dô uma olhada. A última vez que eu vi foi na República. Tinha uns quadros só que eu não prestei atenção no quê que era porquê eu não tive tempo de pará prá olhá. Mas eu vi que tem uns quadros, umas exposições lá.

Pesquisadora: E obras que ficam o tempo todo ali você nunca percebeu? 
Francisco: Não, eu nunca dei uma olhada. Tem uma na Praça da Sé também, uma estátua. Não lembro o nome dela, não me recordo muito bem mais é uma pessoa deitada, eu acho, mais tem uma estátua lá.

Pesquisadora: Acha que esta obra pode ser considerada uma obra de arte?

Francisco: Considero porque são pessoas que se dedicam para fazer isso, pessoas que tipo, deixam de trabalhar em uma outra coisa para se dedicar prá isso, prá mostrá prá outras pessoas.

\section{Monitora: Mariana}

Pesquisadora: Quantas pessoas costumam vir interagir com esta obra por dia? Mariana: Bom aqui, varia muito, né. Na semana... vem 50 pessoas. De sábado vem bem mais, vem 100, 180, varia muito.

Pesquisadora: Em que horário elas costumam vir?

Mariana: Durante a semana é mais das 18:00 às 19:00 horas, assim, que é horário de pico, né. Sábado é o dia inteiro. Domingo também.

Pesquisadora: Qual a faixa etária das pessoas?

Mariana: Varia muito.

\section{Estação República}

Obra: OP_ERA: Sonic Dimension

Autoras: Daniela Kutschat e Rejane Cantoni

\section{usuários/espectadores/atores: Jorge, 55 anos, administrador / Valter Seden, 52 anos, diretor de teatro.}

Pesquisadora: O que vocês acharam deste trabalho?

Jorge: É ótimo interagir com isso aí, é sensacional.

Pesquisadora: Vocês já tinham visto este tipo de trabalho em algum outro lugar? Jorge: Não, eu nunca tinha visto. Hoje, ele estava me falando, então eu disse: Vamos passar lá prá nós vermos.

Pesquisadora: Vocês viram as outras também?

Jorge: Não. Aonde tem mais? É que não utilizamos o metrô né, só assim, eventualmente, aos finais de semana.

Pesquisadora: Vocês consideram importante ter este tipo de trabalho exposto nas estações do metrô? Por quê?

Valter: Prá mim é, porquê eu tô fazendo um trabalho teatral em que eu uso telão. Isso aqui me deu uma outra visão prá eu poder usar no meu trabalho.

Pesquisadora: Vocês costumam usar muito o metrô? Tem alguma obra de arte que vocês se lembrem que esteja exposta nesta ou em outra estação? 
Jorge: Sim. Eu geralmente, passo aqui pela República porquê nós moramos aqui próximo, né. Então, eventualmente, quando eu passo por aqui sempre tem alguma exposição. Agora assim, de você interagir, é a primeira vez que eu tô tendo contato. É que às vezes, você passa correndo também e você não se atém. Você para, olha, e fala: depois eu volto. Outro dia nós voltamos prá ver uma que estava exposta, o figurino, acho que foi de uma minissérie que passou na televisão e quando nós voltamos prá ver não estava mais.

Valter: É, era o figurino de uma novela que tinha acabado, é isso.

Pesquisadora: Mas e aquelas obras permanentes, que ficam o tempo todo expostas nas estações?

Jorge: Quando é permanente, ela passa a ser integrada. Aí se torna cotidiano aquilo e você não percebe. Agora, quando você passa e nota algo diferente, principalmente aqui que tá movendo, a tua curiosidade é aguçada, realmente. Você vai entrar prá ver o quê que é, ou você vai perceber que tem alguém interagindo e você vai interagir também.

Valter: É verdade. Eu acho que aí na Santa Cecília, tem muita poesia. Esses dias, inclusive, tá tendo pinturas lá. E a gente às vezes passa. De repente, um dia eu tava esperando uma pessoa lá e comecei a ler as poesias. Essas fixas, você não vê, acaba passando, mas é que essa é inovadora, e é uma coisa que coincidiu com o meu trabalho. Eu vou fazer um espetáculo de teatro: o humano integrado com os telões, né, de filmagem. Então, as pessoas contracenam. Como acontece aqui, você mexe o chão, a imagem, com a imagem travada.

Pesquisadora: E qual o nome da peça? Quem sabe eu vá assisti-la!

Valter: Claro, "E se Deus fosse um de nós".

usuários/espectadores/atores: Estudantes do segundo ano de jornalismo. Estavam pesquisando o metrô para fazer um trabalho fotográfico para a faculdade.

Kely, 21 anos / Fabiana, 20 anos / Aline, 20 anos

Pesquisadora: $\mathrm{O}$ quê vocês acharam deste trabalho?

Fabiana: Ah, eu gostei. Achei bem interessante.

Kely: Eu acho que chama a atenção, é diferente.

Aline: Muitas vezes as pessoas passam e não prestam atenção, não veem, mais quando tem assim uma obra diferenciada todo mundo para. Então, assim, na maioria das vezes, no dia a dia das pessoas, o metrô é só o metrô.

Pesquisadora: Vocês costumam usar muito o metrô?

Kely: Eu uso.

Aline: Eu mais ou menos.

Fabiana: Quando eu vou fazer trabalho.

Pesquisadora: E você que usa mais, tem alguma obra de arte que você se lembre que esteja exposta nesta ou em outra estação?

Kely: Ah, no metrô Clínicas. Sempre tem. Eles sempre mudam. Sempre eles colocam o tema do mês. Como foi o dia das mães, eles colocaram várias mulheres assim, sabe, querendo mostrar as diferentes mulheres que tem. No metrô Itaquera, 
tem aqueles murais que sempre tão lá, são pinturas. Tem também as poesias que eles colocaram no metrô.

Pesquisadora: Vocês já tinham visto este tipo de trabalho em algum outro lugar?

Kely: No Museu da Língua Portuguesa eles usam trabalhos assim.

Aline: Mais é um pouco diferente.

Fabiana: É, lá tem letras.

Pesquisadora: $O$ que vocês pensam sobre a presença deste tipo de trabalho nas estações do metrô?

Kely: Eu acho importante, é mais uma questão cultural, né. As pessoas precisam mais de cultura.

Fabiana: Eu acho assim, eu passo poco no metrô mais eu vejo que tem esculturas, tem arames torcidos que também são esculturas que a gente acaba vendo rapidinho. Aqui não, aqui você interage com a obra, eu acho que isso é muito mais interessante. Eu acho muito importante por causa disso, à medida que eu posso interferir na sua obra é como se ela agregasse prá mim e eu faço parte. Eu acho que falta isso pras pessoas, essa falta cultura da arte. De repente, sabê olhá, que não é só um telão, é muito mais do que isso. A pessoa teve uma ideia. Alguém trabalhou prá fazê isso. E aqui é um lugar estressante. Durante a semana, muita gente passando, sê tá cansada vindo do trabalho, indo prá escola, muita gente passando. Acho que não dá prá você pará. Eu acho que a vida não é só isso. Você para e distrai, brinca um pouco.

Pesquisadora: Acha que pode ser considerado uma obra de arte?

Kely: É uma obra de arte, com certeza.

Fabiana: É uma obra de arte.

Aline: Olha, em parte sim, a gente tem que ver se já existe alguém que já fez alguma coisa parecida, né. A princípio, é muito bonito, realmente, prá mim, é. Mas depende do meu ponto de vista, entendeu. Eu acho que é muito bonito, inovador. Só que depende do ponto de vista. Muita gente pode nem ligar.

Fabiana: Eu acho que deveria ser divulgado mais. Geralmente, essas obras do metrô são vistas só por quem passa no metrô, na TV não passa, passa mais coisas inúteis como novela, essas coisas. Agora, o quê tá acontecendo culturalmente em São Paulo, não passa nada. No caso, uma obra dessa, eu nunca saberia se não tivesse vindo aqui.

\section{usuários/espectadores/atores: Fabiana, 34 anos, assistente administrativa / Jorge, 30 anos, comerciante}

Pesquisadora: O quê vocês acharam deste trabalho?

Fabiana: Muito bacana, interessante, assim, busca a gente prá vim tocá, aguça a nossa criatividade.

Jorge: Busca novos sons, vai um pouco mais pra música também, prá instrumentos musicais.

Pesquisadora: Vocês já tinham visto este tipo de trabalho em algum outro lugar? Fabiana: Não, primeira vez. 
Jorge: Também não.

Pesquisadora: Vocês consideram este tipo de trabalho uma obra de arte?

Fabiana: Eu considero, porquê atrai assim o pensamento, aguça a sua criatividade e as pessoas passam aqui, todos admiram, querem tocá.

Jorge: Eu acho que a curiosidade é o que mais chama a atenção das pessoas, aí eles vém prá conhecê e identificá alguma coisa.

Fabiana: Uma obra de arte moderna agora, né.

Pesquisadora: Você costuma usar muito o metrô? Tem alguma obra de arte que você se lembre que esteja exposta nesta ou em outra estação?

Fabiana: Todos os dias.

Jorge: Eu menos, mais fim de semana.

Fabiana: Tem uma só que não me lembro a estação. Aquela que tem todas aquelas fotos da linha verde. A Sumaré. Tem várias fotos, e aquilo eu acho muito interessante também. Muito bacana você passá e vê.

Jorge: Lá no fim não tem uns arcos na platarforma.

Pesquisadora: Você considera importante ter este tipo de trabalho exposto nas estações do metrô? Por quê?

Fabiana: Eu acho que sim porquê como eu passo aqui todos os dias, eu vi e hoje trouxe ele prá conhecê, é muito interessante. Ali também eu gosto muito de lê. Tem sempre algumas figuras diferentes, ensina sobre flores, pássaros. É sempre cultura.

\section{Técnico de manutenção do Itaú Cultural / usuário/espectador/ator: Santos}

Pesquisadora: Essas obras têm muita manutenção?

Santos: No metrô têm.

Pesquisadora: Por quê?

Santos: Porque a gente tem fatores no metrô que a gente não tem numa galeria, né.

Pesquisadora: Quais, por exemplo?

Santos: Tremor, a gente não sente, mas a obra parada trepida demais. No caso, os projetores, a gente sempre tem que tá ajustando porque eles saem do lugar. A obra em si treme, então os sensores saem do lugar. A cada dois dias a gente passa aqui.

Pesquisadora: A cada dois dias? Tudo isso?

Santos: É uma preventiva, né. A cada dois dias a gente passa prá vê se tá precisando de alguma coisa. No geral, são eles que ligam, os monitores.

Sabe aonde a gente tava tendo mais problema? No Brás, porque o projetor tá travado no trilho assim. Mas agora não tem tido mais.

Pesquisadora: Você só cuida do áudio e imagem?

Santos: É, mas tem uma outra equipe grande que cuida do software, e tem uma pessoa que dá suporte no geral, né.

Pesquisadora: Fica caro para manter este tipo de trabalho?

Santos: O custo eu não sei. Eu acho que poderia sê mais divulgado. É legal assim porque não ficô só centralizado, isso é mais legal né. 
Pesquisadora: E você costuma usar muito o metrô?

Santos: Não, porque assim, eu moro na Zona Sul, e não tem linha de metrô em Santo Amaro. Mas eu uso mesmo por causa da empresa né.

Pesquisadora: Mas assim, nessas poucas vezes que você usa o metrô, você lembra de algum outro tipo de arte que fica exposta nas estações?

Santos: Na Sé não tem como você não repará na estátua né, no piso principal. Mais é na Sé mesmo. Sempre tem alguma música, alguma mostra. Acho que na Penha também tem uma obra, é, uns ferros com... que parece um vórtice assim, esse é legal.

Pesquisadora: $\mathrm{O}$ que você pensa sobre a presença desse tipo de trabalho nas estações, tanto desse tipo interativo quanto do outro?

Santos: Você tem que levar a arte prá todo mundo. Não adianta ficar numa galeria só. Isso é do acervo do Itaú mas não adianta ficá lá e expor uma vez a cada dois anos e depois ficá guardado. Tem que rodá mesmo.

\section{usuária/espectadora/atora: Ana Luisa, 4 anos}

Pesquisadora: Qual é o seu nome?

Ana Luisa: Ana Luisa.

Pesquisadora: Quantos aninhos você tem?

Ana Luisa: Quatro.

Pesquisadora: Você gostou de brincar aqui?

Ana Luisa indica com a cabeça que sim.

Pesquisadora: O que você achou? Você gostou?

Ana Luisa: Legal.

Pesquisadora: É a primeira vez que você vem aqui?

Ana Luisa indica com a cabeça que sim.

\section{Monitor: Leandro}

Pesquisadora: Você poderia me dizer quantas pessoas costumam vir interagir com esta obra por dia?

Leandro: No começo era mais. Em média 900 pessoas por dia.

Pesquisadora: Isso tanto durante a semana quanto aos finais de semana?

Leandro: Isso.

Pesquisadora: Em que horário elas costumam vir mais?

Leandro: Mais a tarde, por volta das 17:00, 18:00 horas.

Pesquisadora: Durante a semana? E aos finais de Semana?

Leandro: Durante o final de semana. No final de semana, qualquer horário, não tem horário, não tem pico. 
Pesquisadora: Qual a faixa etária das pessoas?

Leandro: Normalmente vem gente mais jovem. Acho que por conta da frequências dos bares aqui em volta, né, da Galeria do Rock... Aqui tem muitas empresas de operadores de telemarketing, então é um pessoal mais jovem que passa por aqui e usa a estação.

\section{Estação Sé \\ Obra: Ultra-Nature (2008) \\ Autor: Miguel Chevalier}

\section{usuárias/espectadoras/atoras: Andréia, 32 anos, telemarketing (mãe) / Bárbara, 14 anos, estudante (filha)}

Pesquisadora: $O$ que vocês acharam deste trabalho?

Bárbara: Ah, eu achei bem bacana. Poderiam inventar mais coisas assim, mais legal, mais criativa prá gente podê tá explorando né.

Pesquisadora: Vocês já tinham visto este tipo de trabalho em algum outro lugar? Andréia: Não é a segunda vez que eu venho ver esta obra.

Pesquisadora: Vocês chegaram a ver as outras?

Andréia: Não.

Pesquisadora: Vocês costumam usar muito o metrô? Tem alguma obra de arte que vocês se lembrem que esteja exposta nesta ou em outra estação?

Andréia: Eu uso. No Brás eu sempre vejo, aquelas pinturas. Como é que chama?

Pesquisadora: Aquelas que são fixas?

Andréia: Isso. De teatro também. Cantos. Eu acho legal.

Pesquisadora: Acha que pode ser considerada uma obra de arte?

Bárbara: Eu acho assim porque as pessoas andam muito estressadas então prá desestressá assim, ficam brincando assim, interagindo.

Andréia: Vê alguma coisa bacana, diferente, legal né, desestressa um pouco.

usuários/espectadores/atores: Márcia, 31 anos, metalúrgica / Julio, 30 anos, permutação

Pesquisadora: O que vocês acharam deste trabalho?

Márcia: Ah, eu achei legal. Interessante.

Júlio: Interessante.

Pesquisadora: Vocês já tinham visto este tipo de trabalho em algum outro lugar? Márcia: É a primeira vez.

Pesquisadora: Vocês costumam usar muito o metrô? Tem alguma obra de arte, daquelas que ficam ali o tempo todo, fixas, que vocês se lembrem que esteja exposta nesta ou em outra estação?

Márcia: Às vezes só, é muito difícil usar. 
Júlio: Como a gente mora no $A B C$, a gente vem prá cá só quando tem algum compromisso.

Márcia: Eu lembro de uma exposição, acho que era sobre São Paulo, mas acho que não era aqui não.

Pesquisadora: $\mathrm{O}$ que vocês pensam sobre a presença deste tipo de trabalho nas estações do metrô?

Márcia: Ah, eu acho importante. A gente tá sempre na correria né, aí a gente para um poco prá vê, brincá um poco.

Júlio: Até estranho um poco também.

usuários/espectadores/atores: Nice, 59 anos, arquiteta / Mauricio, 60 anos, publicitário

Pesquisadora: O que vocês acharam deste trabalho?

Nice: Achei bonito.

Maurício: Legal.

Pesquisadora: Vocês já tinham visto este tipo de trabalho em algum outro lugar?

Nice: Não.

Maurício: Talvez no museu da Língua Portuguesa. Ele tem uma interação mais é diferente.

Pesquisadora: $\mathrm{O}$ que vocês pensam sobre a presença deste tipo de trabalho nas estações do metrô?

Maurício: Acho importante.

Nice: Acho, então, aliás eu vim prá cá, saí do trem e até perguntei prá ele: Que obra de arte será que tem, que exposição? Porquê sempre a gente lembra que tem alguma coisa na Sé, né.

Pesquisadora: Você costuma usar muito o metrô? Tem alguma obra de arte que você se lembre que esteja exposta nesta ou em outra estação?

Nice: Eu uso, mais lá pros lados da Paulista.

Maurício: Tem uns murais aí.

Nice: Paraíso, Ana Rosa, não sei.

Maurício: Fotografia aqui tem sempre.

Nice: Aquelas poesias nas paredes.

usuários/espectadores/atores: Valderes, ajudante geral, 28 anos (mãe) / Douglas, 8 anos (filho)

Pesquisadora: O que vocês acharam deste trabalho?

Valderes: Muito bom, né. Não sei nem como explicar, é uma coisa tão bonita que eu...

\section{usuário/espectador/ator: Francisco, 70 anos}

Pesquisadora: O que o Senhor achou deste trabalho?

Francisco: Choro de alegria. 
Pesquisadora: O Senhor já tinha visto este tipo de trabalho em algum outro lugar?

Francisco: É uma das melhores, das mais belas artes que eu já vi.

Pesquisadora: O senhor costuma usar o metrô? Tem alguma obra de arte que vocês se lembrem que esteja exposta nesta ou em outra estação?

Francisco: Uso. Não lembro porque eu passo às carreiras.

Olhe, eu tive um pensamento de trazer uns coitadinhos que nunca viram isso aí, e outras pessoas.

\section{usuária/espectadora/atora: Maria Luisa, 1 ano e dois meses, interage com a obra da estação Sé.}

\section{Monitora: Regina}

Pesquisadora: Qual a quantidade de pessoas que tem vindo visitar esta obra? Regina: Isso é relativo. Geralmente, em média, é em torno de 2000 pessoas. 2000 a 2500 pessoas.

Pesquisadora: Por dia?

Regina: Por dia. Por exemplo, no primeiro período, às vezes dá 1500, no segundo período 1600 em média.

Pesquisadora: Esse primeiro período é das 9:00 às 15:00, né?

Regina: das 9:00 às 14:45. Depois das 14:45 às 21:15.

Pesquisadora: E aos finais de semana?

Regina: É o mesmo fluxo.

Pesquisadora: E são todas as faixas etárias?

Regina: Todas as faixas etárias. É bem diversificado. Na Virada Cultural deu quase 3000 pessoas, só no período da tarde. 2866 pessoas visitaram a exposição, só aqui na Sé.

\section{Monitora: Mariana}

Pesquisadora: Quantas pessoas já visitaram esta obra?

Mariana: Bom, hoje, especificamente, das 9:00 até as 13:30hs, vieram 698 pessoas.

Pesquisadora: mas de quando começou até agora? Vocês tem uma ideia?

Mariana: Ah, sempre é contado, mais como cada dia eu tô numa estação, aí praticamente eu só sei do dia mesmo.

Pesquisadora: Quais são os dias e horário que as pessoas costumam vir?

Mariana: É mais durante a semana, de segunda a sexta. Mais a tarde, das 16:00 às 19:00 horas, o movimento é bem maior. 
Estação Tiradentes

Obra: Reflexão \#3 (2005)

Autora: Raquel Kogan

usuária/espectadora/atora: Cícera, 44 anos, coordenadora pedagógica.

Pesquisadora: O que você achou deste trabalho?

Cícera: Esse, particularmente, eu não compreendi.

Pesquisadora: Você viu outros?

Cícera: Outros do metrô, já sim. Vários. Da Raquel não.

Porquê quando você vê lá do fundo, parece que são prédios da cidade de São Paulo. Parece a cidade de São Paulo se movimentando, quando você vê de longe. Mas se aproxima não, aí é uma sequência numérica.

Pesquisadora: $\mathrm{O}$ que você pensa sobre a presença deste tipo de trabalho nas estações do metrô?

Cícera: Importante, sem dúvida nenhuma porque aí disperta né as pessoas para irem visitar os museus. Estimula a visita.

Pesquisadora: Você costuma usar muito o metrô? Tem alguma obra de arte que você se lembre que esteja exposta nesta ou em outra estação?

Cícera: Uso. No metrô Sumaré tem várias obras de arte. No Vila Madalena...

Pesquisadora: Você lembra de alguma assim, em específico?

Cícera: Eu não lembro o nome do artista mas eu lembro de uma que me chamou muito a atenção que ele trabalhou com o corpo humano. Parecia um esqueleto.

usuárias/espectadoras/atoras: Aline, 20 anos, faz secretariado executivo e trabalha para empresa que cuida dos eventos culturais junto com a Secretaria da Cultura / Juliana, 20 anos, operadora de telemarketing.

Pesquisadora: $O$ que vocês acharam deste trabalho?

Aline: Ah, achei bem interessante, assim, bem diferente de muita coisa que eu já vi. Então, na verdade eu nunca tinha visto né, então prá mim eu não sei muito o sentido dele. É legal de ouvir, ver, uma coisa diferente, uma coisa nova.

Pesquisadora: Vocês acham que pode ser considerado uma obra de arte?

Aline: Com certeza.

Juliana: Com certeza.

Pesquisadora: Vocês já viram as outras obras desse tipo expostas no metrô? Juliana: Vimos. Nossa, maravilhoso!

Aline: Eu só vi a que tá no Paraíso, que a gente assopra e a flor voa, que eu gostei muito. As outras eu não vi ainda.

Juliana: A gente tá indo agora vê. Tem outra na Sé que a gente manipula a flor. É muito legal também. 
Pesquisadora: $O$ que você pensa sobre a presença deste tipo de trabalho nas estações do metrô?

Aline: Nossa, eu acho importante porque é uma coisa muito diferente né, chama muito a atenção mesmo.

Pesquisadora: Vocês costumam usar muito o metrô? Tem alguma obra de arte que vocês se lembrem que esteja exposta nesta ou em outra estação?

Juliana: Todos os dias, quatro vezes ao dia.

Aline: Ah, eu lembro mas não sei qual a estação... É tipo uma escultura que a gente sempre passa e olha, não dá muita atenção prá ela mais ela tá lá.

Pesquisadora: Como que é essa escultura?

Aline: Ah, eu não sei é tipo metade de uma pessoa assim. Não sei quem é o autor nem a época. Eu nunca cheguei perto do quadradinho lá prá ver, mais é uma escultura de mármore.

\section{1ํFESTIVAL INTERNACIONAL DE LINGUAGEM ELETRÔNICA - FILEPAI 2010}

\section{Estação Paraíso}

\section{usuária/espectadora/atora: Gabriela, 21 anos, estudante de Gestão Ambiental na USP}

Pesquisadora: Você veio exclusivamente para ver este trabalho?

Gabriela: Não, foi sem querer que eu passei. Eu sabia que ele estava em diversos pontos da cidade mais eu vi as letras assim aqui e eu vim atrás prá vê o quê é que era.

Pesquisadora: Você considera isso uma obra de arte?

Gabriela: Sim, eu considero sim.

Pesquisadora: Você usa muito o metrô?

Gabriela: Bastante, sempre.

Pesquisadora: Você se lembra de alguma obra permanente exposta em alguma estação?

Gabriela: A que mais me chama a atenção na Ana Rosa. Porque sempre tem exposições lá, mas aí são temporárias, né, mas permanente... Eu sei que tem uma que são uns bonecos de barro... Não lembro qual estação que era da linha vermelha. Acho que fica em um dos canteiros de jardim.

Pesquisadora: Você acha que é importante ter obras de arte nas estações de metrô? Gabriela: Muito.

Pesquisadora: Por quê você acha?

Gabriela: Ah, porque é um lugar que todo mundo passa e eles não tem tempo de ir visitá algum museu ou coisa do tipo, ou não tem dinheiro talvez prá pagá a entrada e o metrô é um lugar que todo mundo vai, todo mundo tem acesso e, no meio do caminho, você pode pará, dá uma interagida com a obra, olhá, apreciá e depois 
voltá pro seu caminho normal. Eu acho gostoso, assim, esse break durante a rotina tão dura assim do dia a dia de São Paulo.

\section{usuária/espectadora/atora: Mara, 24 anos, estudante da Alemanha}

Pesquisadora: o que você achou desse trabalho?

Mara: Legal, uma coisa nova, eu nunca vi.

Pesquisadora: Nem na Alemanha você viu?

Mara: Porquê eu não uso muito metrô na Alemanha, eu moro em uma cidade pequena.

Pesquisadora: Você considera este trabalho uma obra de arte?

Mara: Sim, é um tipo de arte.

Pesquisadora: $\mathrm{O}$ que você pensa sobre a presença deste tipo de arte nas estações de metrô?

Mara: Acho importante. Porque aqui no metrô tudo é muito rápido. As pessoas só correm de um lado prá outro. Acho que a arte tira um pouco da correria da vida. Passa um pouco mais de tranquilidade. As pessoas podem parar e ver a arte, pensar um pouco em outras coisas que não só a vida cotidiana.

usuários/espectadores/atores: Idenir, 45 anos, ajudante administrativa de hospital, mãe de Breno, 10 anos e Igor, 9 anos

Pesquisador: A senhora costuma usar o metrô?

Idenir: Uso bastante o metrô. Eles não.

Pesquisadora: A senhora considera este tipo de trabalho uma obra de arte? Idenir: Prá mim sim. Tudo que atrai...

Pesquisadora: A senhora lembra de alguma obra de arte, pintura, escultura, que fica o tempo todo em alguma estação?

Idenir: Eles gostaram daquela que anda assim, com aquelas cores, na Sé. Teve duas vezes.

Pesquisadora: Ah, aquela da outra exposição Arte Cibernética? Idenir: É, eles adoraram.

Pesquisadora: Mas a senhora lembra de alguma daquelas que ficam o tempo todo na estação?

Idenir: Lembro de uma exposição de quadros de animais na Praça da República parece.

Pesquisadora: O que você achou?

Igor: Legal.

Pesquisadora: Você brinca com isso em casa?

Igor: Já. 
Pesquisadora: A senhora acha importante ter obras de arte nas estações de metrô? Idenir: Acho importante porque tira um pouco o stress, tem muita violência.

\section{usuária/espectadora/atora: Carine, 25 anos, funcionária pública}

Pesquisadora: o que você achou?

Carine: Bem interessante. É interativo, né.

Pesquisadora: Você considera este tipo de trabalho uma obra de arte?

Carine: De certa forma. Hoje do que o mundo disponibiliza, né. De certa forma... ela é virtual, né. Eu acredito mais em outro tipo de arte mas...

Pesquisadora: Você costuma usar o metrô?

Carine: Costumo.

Pesquisadora: Você lembra de alguma obra de arte que fica o tempo todo em alguma estação?

Carine: Lembro de uma que teve na Estação MASP que tinha umas pinturas. Talvez estes poemas, que eles tão colocando, né, nas estações.

Pesquisadora: $\mathrm{O}$ que você pensa sobre a presença deste tipo de arte nas estações de metrô?

Carine: Ah, importante com certeza. Porque traz a cultura, né, pro povo paulista mesmo. Porque acaba circulando. Em nossa vida agitada a gente não consegue tê tempo prá tê contato com esse tipo de cultura. E a gente tendo esse contato em estações de metrô que é aonde a gente transita, né, muito. Acho que seria bom evoluí essa parte de transmissão de cultura nas estações de metrô, de trem.

\section{usuário/espectador/ator: Rogério, bancário, 47 anos}

Pesquisadora: O que você achou deste trabalho?

Rogério: É uma coisa nova prá gente. Nós tamo vivendo no mundo digital, né. Eu acho que é diferente.

Pesquisadora: Você considera este tipo de trabalho uma obra de arte?

Rogério: É uma obra de arte sim, mexe com a população. É uma arte sim. É uma obra de arte não daquela que a gente costuma vê, por isso que se não para aqui e acredita que é uma obra de arte. Ela é diferente.

Pesquisadora: Você se lembra de alguma obra permanente de alguma estação? Rogério: Essas que ficam o tempo todo não vai chamar a atenção porque se passa todo dia, entendeu. Se você passa todo dia ela deixa de se uma obra de arte, ela não mexe com você.

\section{Monitora: não quis se identificar.}

Pesquisadora: Este tipo de trabalho exige muita manutenção?

Monitora: Não tem manutenção. Mas apesar da obra estar exposta em um ambiente interno, um problema sério foi a iluminação artificial do ambiente. Partes do desenho não eram visualizadas pelo observador devido à incidência direta das luzes das 
lâmpadas. A produção do evento deveria ter ido tampar as lâmpadas para que houvesse um maior contraste nas cores das imagens.

\section{Estação Consolação}

usuária/espectadora/atora: Cristiane, 44 anos, trabalha no Tribunal - Poder Judiciário

Pesquisadora: Você costuma usar o metrô?

Cristiane: Uso todos os dias.

Pesquisadora: Você considera este trabalho uma obra de arte?

Cristiane: Sim, eu considero uma obra de arte. Obra de arte voltada pra computação, assim.

Pesquisadora: $O$ que você pensa sobre a presença de obras de arte nas estações de metrô?

Cristiane: Eu acho importante porque ajuda, assim..., as pessoas a interagirem, a ter cultura, a ter um pouco de distração...

Pesquisadora: Como você usa bastante, você sabe que tem umas obras permanentes nas estações?

Cristiane: Sei.

Pesquisadora: Você lembra de alguma?

Cristiane: Sei que tem na estação Sé, tem na... Sumaré que tem umas pinturas. Na Sé são uns quadros que tem lá de fotografias que eu vi lá e no jornal, que são temporárias.

Na Tatuapé tem umas permanentes de poesias. Na Vila Madalena também tem poesia.

\section{usuária/espectadora/atora: Fátima, 38 anos, administradora, de Atibaia}

Pesquisadora: Quando você vem prá cá você costuma usar o metrô?

Fátima: Sim, eu uso bastante.

Pesquisadora: O que você pensa sobre a presença de obras de arte nas estações de metrô ?

Fátima: Eu acho importante, só que a vida corrida do paulistano é difícil ele para prá. Então, quando é de olho você olha..., tá passando e vê. Agora, quando você para, você precisa de um tempo prá para e mexe com uma obra de arte interativa. Pro paulistano é difícil pelo pouco de tempo que ele tem.

Pesquisadora: Você lembra de alguma obra de arte permanente de alguma estação que você costuma usar?

Fátima: Então, na Sé tem quadros. Na Estação. São Pinturas. Mas isso também é novidade, então, talvez, isso também vá pegá, né. É interessante. 
Pesquisadora: Quantas pessoas costumam vir interagir com a obra por dia?

Bruna: Costuma vir mais durante a semana, o pessoal vem na hora do almoço, tem aquele agito da galera que trabalha na Paulista. No período das 9:30 às 15:00 horas. Durante a semana umas 8 a 9 pessoas e, no final de semana, umas 5 pessoas.

Pesquisadora: Você considera este trabalho uma obra de arte?

Bruna: Considero por conta do estilo.

Pesquisadora: Você costuma usar o metrô?

Bruna: Uso bastante o metrô.

Pesquisadora: Você lembra de alguma obra de arte permanente de alguma estação?

Bruna: Eu não lembro o nome do artista. É lá no Anahangabaú, chama In vitro, são duas obras de arte que ficam num vão quando você tá passando no trem que são vitrais que tão sobrepostos, são bem bonitos.

Pesquisadora: O que você pensa sobre a presença de obras de arte nas estações de metrô ?

Bruna: Eu acho super importante porque tem gente que não sabe que essa coisa cultural tá disponível a eles, que eles podem ir aos museus e tal, e isso faz uma aproximação , né. Prá quem tem esse receio de ir visitá é como se a obra de arte fosse até o passageiro, né. A maioria do povo usa o transporte público como meio de transporte, então, acaba tendo esse contato mais fácil, certo?

\section{usuários/espectadores/atores: Márcio, arquiteto (tio) / Lucas, 9 anos (sobrinho) / Felipe (sobrinho), 8 anos.}

Pesquisadora: O que vocês acharam deste trabalho?

Lucas: Legal.

Felipe: Legal.

Pesquisadora: Vocês já tinham visto este tipo de trabalho em algum outro lugar?

Felipe: Não tinha visto nada parecido antes mais a gente conhece joguinhos de computador de vários sites.

Pesquisadora: Acha que pode ser considerado uma obra de arte?

Márcio: Tudo que usa alguma criatividade, é um pouco inusitado, tem alguma diferença do que a gente vê normalmente, acho que é arte. Vem da criatividade de alguém. Foi feito para ser diferente, né. Acho que é mais ou menos isso.

\section{Monitor / usuário/espectador/ator: Rogério, 37 anos}

Pesquisadora: As pessoas tem vindo interagir bastante com esse trabalho? Rogério: Tem por ser um espaço público, por ser um espaço de bastante movimento também, principalmente durante a semana, né, as pessoas trabalham e vem nas suas horas de folga, entrada, meio de almoço, final de expediente. 
Pesquisadora: Por dia quantas pessoas costumam vir?

Rogério: Ah, umas 50- 60 que se aproximam, no meu período. Muita gente para e olha. Mas acho que chega a isso sim. 40-50, e não é exagero não, pela quantidade de gente que passa.

Pesquisadora: Você costuma usar o metrô?

Rogério: Agora eu vou voltar a usar o metrô porquê eu voltei a trabalhar em São Paulo. Eu moro no $A B C$, né.

Pesquisadora: Nesse tempo que você usou você lembra de alguma obra de arte permanente?

Rogério: Não, permanente eu não lembro mas eu sempre fui muito às atividades que estavam divulgadas. Tem uma agenda lá. Eu vou muito a essa. E não só exposições mas a culturais. Eu sempre olho muito. Olho por todas as paredes.

As da Liberdade tem toda uma temática voltada à colônia japonesa, então, elas chamam muito a atenção. Até porque elas ficam ao lado, assim, então acho que é meio complemento, assim.

A proposta do FILE é desenvolver trabalhos artísticos a partir da tecnologia, né. É lógico que eles acabam se aproximando de outros formatos, né, como jogo, por exemplo, né, mais antes de tudo é uma obra de arte. São obras de arte que são apresentadas no FILE como um todo. Algumas se aproximam da música, se aproximam dos vídeos, essa dos games, mais, acima de tudo são obras de arte. A princípio é obra de arte desenvolvida com tecnologia. $\dot{E}$ arte digital que se chama, né.

Pesquisadora: O que você pensa sobre a presença de obras de arte nas estações de metrô?

Rogério: É importante, claro, é o lugar de todo dia, né. A gente até fez uma discussão durante nossa formação que é essa questão da tecnologia, né. A princípio fica restrita a alguns poucos e ao mesmo tempo tá nas mãos de todo mundo, né. Você vai ao banco e tá lá com o digital, e fazendo um paralelo, né. Tinha até uma pergunta lá, tipo, arte tradicional e arte contemporânea, né. E eu acho que isso é muito cultura popular, de ir à rua, de estar onde o público, o povo está, então fazendo até esse diálogo, né. E a gente até conversou que o que hoje é o contemporâneo, que é prá poucos, daqui a um tempo outra coisa vai ser contemporânea e o de hoje vai passá a ser tradicional. É um processo. E eu achei muito legal o FILE, que já tem 10 anos pensá nisso né. Já acontece há 10 anos em lugares fechados, principalmente na galeria da Paulista e em outros espaços a Casa das Caldeiras e essa vez tê vindo aqui prá rua, né. Muita gente veio aqui, se interessou e provavelmente foi até à galeria prá vê as outras obras. Muito bacana esse evento a iniciativa de atrair outros públicos.

Pesquisadora: Qual a faixa etária das pessoas que interagem?

Rogério: Então, muito jovem por conta ter um aspecto de jogo e de ser jogo também, adultos também, idosos pararam, olharam, mas pintô aquela coisa de não saber mexê, ou ter medo, ter algum receio da tecnologia, não estar acostumado à tecnologia. Na verdade quem mais se apropriou da coisa é quem mais tem facilidade. Daí os jovens já nasceram com o mouse na mão e não deixam nem eu explicar, né. Os jovens vêm, é uma questão de prática mesmo, assim né. Acho que tem esse distanciamento por conta do não utilizar, né. 


\section{Estação Trianon-MASP}

\section{Monitores (2): (não quiseram se identificar)}

As pessoas voltam. Elas sabem que tem os jogos na internet mas elas querem jogar aqui. Porque tem todo um outro ambiente, né. Muitas pessoas jogam aqui, por ser de passagem as pessoas apressadas pro trabalho ou pra ir ou pra voltar a estudar... também quando as pessoas estão esperando algum amigo e não tem o que fazê esperando a outra pessoa chegar.

Ninguém fica constrangido, só quando tem dúvida se tem que pagá. Criança de rua tem esse problema. É recriminado de olhá mas aí eles acabam jogando. Você tem que ir na insistência. Pode jogar, não tem problema. Ele jogou os dois. Falei que tinha mais dez jogos lá na exposição prá ele ir lá e ele foi. Isso é legal porque você acaba dando acesso pro público que se sente constrangido de entrá nesses ambientes, mesmo que saiba que é de graça ele fala: mais eu sou pobre, não vô entrá.

Durante a semana o horário que as pessoas mais jogam é o das saídas dos colégios, horário de almoço e horário de pico.

\section{2ํFESTIVAL INTERNACIONAL DE LINGUAGEM ELETRÔNICA - FILEPAI 2011}

\section{Estação Vila Madalena - Games}

\section{usuária/espectadora/atora: Helen, 24 anos, estuda história da arte}

Pesquisadora: Você costuma usar bastante o metrô?

Helen: Então, eu moro em Curitiba mas quando venho a SP utilizo muito o metrô.

Pesquisadora: $\mathrm{O}$ que você pensa sobre a exposição de obras de arte nas estações? Helen: Eu acho bem interessante porque deixa mais próximo a arte da população. Muitas vezes tem um preconceito pensando que não pode frequentar tais ambientes, tais museus porque acha que não tem capacidade de entendê. Aí fica aquele pré-conceito, ah eu não entendo arte por isso eu não vô. Aproxima a arte das pessoas.

Pesquisadora: $O$ que você achou destes trabalhos?

Helen: Assim... aí auxilia na socialização, explicando a ideia, o conceito. Eu acho interessante.

Pesquisadora: Você considera este tipo de trabalho uma obra de arte?

Helen: Sim, considero. Eu não sei se o restante das pessoas iria entendê como obra de arte né.

Eu acho que tem todo um conceito que foi pensado, foi trabalhado. E aí, a partir do momento que a pessoa tenta passá a tua ideia seja através da tecnologia seja através das técnicas das belas artes, eu acho que isso é considerado arte. Que aí tem aquela discussão né, o que é arte?, O que é artesanato, o que é design, essas linhas muito tênues que aí se fica né, ops! O que eu faço agora? É considerado arte ou não? Porque realmente é uma coisa que a gente pega e fica em dúvida. 


\section{usuária/espectadora/atora: Rosimeire, 24 anos, financiária}

Pesquisadora: Você usa bastante o metrô?

Rosimeire: Uso, prá trabalhá só.

Pesquisadora: O que você pensa sobra a presença de obras de arte nas estações? Rosimeire: Eu acho interessante porque às vezes você não tem muito tempo prá $i$ ao museu, numa exposição, então você acaba conhecendo os artistas, suas obras, né, o que vem acontecendo sem tê que saí da sua rotina porque realmente é difícil né, geralmente atualmente você tem que escolhê ah, o que eu vô fazê? $E$ os museus acabam ficando em segundo plano, então é interessante.

Pesquisadora: Você lembra de alguma obra de arte dessas que ficam o tempo inteiro na estação?

Rosimeire: Ah, agora eu não lembro viu.

Pesquisadora: E o que você achou deste trabalho que você estava interagindo?

Helen: Achei super interessante a forma de conhecê o artista, o que vem sendo lançado. Aqui, no caso, é game, talvez tenha outras mais, em outros lugares. Eu achei importante, legal.

Pesquisadora: Você considera este tipo de trabalho uma obra de arte?

Rosimeire: Considero.

Pesquisadora: Por quê?

Rosimeire: Porque tudo que você faz com a sua mão, com seus pensamentos, inventando, tudo o que você cria eu considero uma obra de arte.

usuários/espectadores/atores: Taís, 21 anos, estuda administração / Miler, microempresário

Pesquisadora: Vocês usam bastante o metrô?

Miler: Eu bem poco porqué na cidade de onde eu venho não tem, é mais ela.

Taís: É, eu uso de vez em quando. Como eu não trabalho é mais prá ir prá faculdade, é bem rápido.

Pesquisadora: $O$ que vocês pensam sobre a presença de obras de arte nas estações?

Taís: Eu acho legal porque nem todo mundo tem acesso a isso, né. Estando no metrô é mais fácil prás pessoas que não conhecem, não tem muito interesse por isso geralmente vê no metrô, para, dá uma olhada, e a partir disso pode começá a se interessá.

Miler: Eu acho que embeleza também né um poco o metrô, né. E busca o interesse realmente das pessoas que não tem tanto acesso, ou não conhece, ou nunca procuraram sabê, né o que é a arte. Eu acho que acaba levando as pessoas né.

Pesquisadora: Vocês lembram de alguma obra de arte dessas que ficam o tempo todo na estação?

Miler: Olha pelas que eu passo não tem. Eu vô da Guilhermina até o Carrão não tem, mais eu já vi sim em algumas outras estações eu não me recordo qual mas já vi 
sim. Eu vi uma que era tipo um monte de circulo no chão assim. Ela era redonda né. Eu não lembro qual era a estação. É diferente e faz com que a gente até se enterta um pouco durante a viagem né. É muito legal.

Pesquisadora: O que vocês acharam destes trabalhos? Eu percebi que vocês interagiram com vários.

Taís: É bem interessante.

Pesquisadora: Vocês consideram esse tipo de trabalho uma obra de arte?

Miler: Eu sim, porque é uma forma de interagi também né, uma forma de mexê com a criatividade da pessoa que tá jogando, que tá buscando e vendo também que tem algumas coisas né.

Monitores / usuários/espectadores/atores: Diego, 27 anos, história da arte e trabalha com cinema e educação / Fábia, 19 anos, estuda design

Pesquisadora: Vocês costumam usar o metrô?

Diego: Bastante.

Pesquisadora: $O$ que vocês pensam sobre a presença de obras de arte nas estações?

Diego: Eu acho bastante importante porque não é todo mundo que vai pruma galeria né. Não é todo mundo que tem esse hábito, né. A partir do momento que você disponibiliza alguma obra de arte no espaço público que as pessoas circulam seja lá por qual razão, você possibilita o contato da arte com essas pessoas, eu acho bastante válido isso e necessário.

Pesquisadora: Vocês lembram de alguma obra de arte dessas que ficam o tempo todo na estação?

Diego: Eu lembro de algumas, né. De algumas pinturas. Na Consolação sê tá na plataforma, do lado oposto, né, no muro tem.

Pesquisadora: Vocês consideram este tipo de trabalho uma obra de arte?

Diego: Hummm. Tá difícil. Pode ser.

Fábia: É complicado porque a gente tá meio acostumado com aquela arte meio clássica. Essa arte junto de tecnologia é difícil de absorvê agora, mais depois que você começa a tê mais contato, começa a observá, que essas obras tentam dizer algo a respeito da nossa vida e faz a gente pensá sobre o que a gente faz ou deixa de fazê, acho que a partir desse ponto sim, posso considerá uma obra de arte. Porque ás vezes as pessoas perguntam: ah, mais o que tá tendo aqui ? A gente responde: ah são games, games não convencionais. Mais a gente não que vê game a gente qué vê obra de arte.

Pesquisadora: Mas assim, no geral, é lógico, tem casos de pessoas que não se interessam, é natural, mas no período que vocês tem ficado aqui, as pessoas tem vindo interagir?

Fábia: Tem. O que eu vejo mais são os pais trazendo os filhos. Eles trazem os filhos e vêm justamente pra isso, depois vão leva os filhos pra outro lugar, como se tivessem já educando uma nova geração já com esse tipo de arte ou, passam por 
aqui quanto tão indo pro trabalho ou indo pra casa e pegam e dizem: ah, eu não tenho tempo agora mais acho que meu filho vai gostá. E acaba voltando.

Pesquisadora: Vocês tem uma ideia de quantas pessoas tem vindo por dia para interagir?

Diego: Por dia a gente não tem como dizê. Varia bastante. A gente tá aqui no período da manhã mais uma média bem grosseira pelo menos até as 15:00horas, umas vinte pessoas. Mais eu sei que a tarde, o fluxo é muito maior, pelos monitores, né. Eles já falaram pra gente. É no horário de pico, entre umas 17:00 e 19:00 horas. Fábia: É porque no horário de pico é que essa plataforma funciona.

Pesquisadora: E assim, a faixa de idade das pessoas?

Fábia: Nossa, varia muito.

Diego: Varia bastante, né.

Fábia: Vem desde criança até um cara bem mais velho assim, que para pra sabê o que é. Às vezes, ele nem sabe mexê mais qué sabê o que é. Aí a gente fala, não, você consegue. Tem alguns que vão.

\section{Monitor: Maurício}

Pesquisadora: Quantas pessoas mais ou menos você acha que acaba vindo pra interagir?

Maurício: Ah, entre trinta, cinquenta.

Pesquisadora: De que faixa de idade?

Maurício: Das mais variadas. A ultima vez eu atendi um senhor que devia ter mais ou menos uns 80, 90 anos. Ele nem sabia pra que que servia o mouse. Foi nesse joguinho aqui mesmo. A partir do momento em que ele percebeu que ele poderia controlar o personagem aí ele não queria saí mais. Então, eu acho que, a gente tá falando de arte, né, de arte eletrônica tal, então acredito que tenha sido um meio que possibilitô a ele conhecê um pouquinho mais. Eu acho que quebrou uma espécie de barreira entre o que a gente poderia possibilitá e a ação dele, bem legal. Tem muita criança, tem muito adolescente tal, são dos mais diversos tipos.

\section{usuário/espectador/ator: Vagner, 39 anos, call center}

Pesquisadora: Você costuma usar bastante o metrô? Vagner: Costumo.

Pesquisadora: O que você pensa sobre a presença de obras de arte nas estações? Vagner: Muito legal.

Pesquisadora: Por quê?

Vagner: Porque é um local que a gente passa e tem uma interação, tem uma mudança na sua rotina.

Pesquisadora: E das estações que você costuma usar, você lembra de alguma obra de arte que fica na estação, não precisa me dar nome?

Vagner: Das que eu passo, principalmente lá na Trianon-MASP que tem aquela que fica lá no meio da plataforma. Aquele pássaro. 
Pesquisadora: E esse trabalho que você ta interagindo, o que você achou dele? Vagner: Achei muito legal, quebra um pouco a rotina de passá, transforma o ambiente num ambiente melhor, né.

Pesquisadora: Você considera este tipo de trabalho uma obra de arte? Vagner: Considero.

\section{usuário/espectador/ator: Ricardo, 40 anos, eventos}

Pesquisadora: Você costuma usar bastante o metrô? Ricardo: Uso todos os dias.

Pesquisadora: $O$ quê você pensa sobre a presença de obras de arte nas estações? Ricardo: Eu acho muito legal, e essa coisa de interagi, tem que interagi, porque a arte é prá mexê, isso é legal. Nesse caso é eletrônico, né, a interatividade tamém, eu acho bem legal, o ideal é mexê na arte, fica mais sociável, acho que é o objetivo, né.

Pesquisadora: Dessas que ficam o tempo todo nas estações, o que você pensa? Você lembra de alguma? Não Precisa me dar título nada, só me descrever mais ou menos.

Ricardo: Pouco. A gente vê em paredes né, tipo painel algumas coisas assim mais falta mexê, né, interagi. Como dança, um grafiti, uma performance.

Pesquisadora: Você interagiu com várias, né. O que você achou ?

Ricardo: Eu não conheço o FILE, né. Mais acho que dá prá se diverti um pouco né, relaxá um pouco.

\section{usuário/espectador/ator: André, 30 anos, publicitário}

Pesquisadora: Você costuma usar bastante o metrô?

André: Uso.

Pesquisadora: $O$ que você pensa sobre a presença de obras de arte nas estações? André: Acho que é legal. No Paraíso eu já vi. Aqui tem bastante exposição de coisas no bloqueio ali. Nas Clínicas tem muita coisa legal, parece que tá parado ninguém vê, mais a pessoa encontra, para cinco, dez minutinhos e tem acesso a arte de forma mais fácil. Eu acho válida a iniciativa. Eu acho que já é tradicional do metrô isso, não?

Pesquisadora: Dessas que você lembra são temporárias?

André: São temporárias.

Pesquisadora: Permanente você não lembra de nenhuma? Não precisa me dar título.

André: Não.

Pesquisadora: E o tipo de trabalho que você estava interagindo, você considera uma obra de arte?

André: Sim. Por quê não? Obra de arte não precisa ser estática. Acho que se os artistas que eu considero artistas que são mais antigos tivessem a esse nível de 
interatividade a gente tava: agora é arte. Daqui a cinquenta anos a gente vai falá: olha, era arte e o pessoal nem sabia.

\section{usuários/espectadores/atores: Vili, 39 anos, bailarino / Julia, 12 anos}

Pesquisadora: $O$ quê vocês acharam destes trabalhos?

Vili: Ah, legal. Eu acho que é super importante esse tipo de arte mesmo num lugar de tanto acesso como o metrô, né. É super simples assim, acho que são interações simples mais eu acho que já serve pra despertá a atenção das pessoas pra esse tipo de arte, né, eletrônica, é muito bacana.

Julia: Ah, gostei, é legal, é engraçado.

Pesquisadora: Você já tinha interagido com algum trabalho parecido ou não?

Julia: Parecido não.

Vili: Ela já foi no ano passado no FILE, eu levei ela.

\section{Usuários: mãe, filho e sobrinho adolescentes}

Pesquisadora: $O$ quê vocês pensam sobre a presença de obras de arte nas estações?

Mãe: Ah, eu acho que é legal né, que é bonito também né, sei lá. Eu acho válido assim.

Pesquisadora: E o quê vocês acharam destes trabalhos que vocês estão interagindo?

Filho: É legal porque, num sei, achei legal.

Mãe: É uma diversão, né.

Pesquisadora: Vocês já tinham visto algum parecido?

Filho: Não, eu nunca tinha vindo prá cá. Eu desci sempre em outras estações, eu nunca vim aqui nessa estação.

Pesquisadora: Mais este tipo de jogo você nunca tinha visto em outro lugar?

Filho: Não.

Pesquisadora: E você?

Sobrinho: Tamém não.

Pesquisadora: Eu ouvi vocês falando que não tava conseguindo levar adiante porque estava em inglês, eu entendi direito?

Sobrinho: $\dot{E}$.

Pesquisadora: E vocês foram ver, tem lá na estação MASP? Vocês viram alguma coisa?

Filho: Não.

Pesquisadora: Não é joguinho, é animação né, mas lá também tem.

Mãe: Não. Inclusive, até quando chegố perto da estação eu falei vamo descê aqui prá gente i no MASP né, mais eles não quiseram, quiseram vim até o final né. Mais eu não sabia que tinha. 
Pesquisadora: Você trouxe os dois exclusivamente pra isso?

Mãe: Não, prá conhecê a Estação Vila Prudente mesmo. Como eu mora na Vila Ema, né eu já andei algumas vezes mais o meu filho não conhecia. Mais eu falei, vô levá ele prá conhecê a estação e vô até o final né prá conhecê mesmo.

\section{usuário/espectador/ator: Ricardo, 30 anos, professor de matemática}

Pesquisadora: Você usa bastante o metrô?

Ricardo: Então, não uso mais agora. Eu sô um ex-paulistano. Eu moro no nordeste. Sempre que eu venho eu uso.

Pesquisadora: Você lembra de alguma obra de arte destas que ficam o tempo todo nas estações?

Ricardo: Eu lembro de algumas assim que ficavam aqui nesse metrô mesmo, na Ana Rosa eu acho, algumas. Mais eram mais mesmo de pinturas eu acho ou desenhos assim, o tempo todo eu não lembro de nenhuma.

Pesquisadora: O que você acha de ter obras de arte nas estações?

Ricardo: Eu acho importante pra divulgá mas também, por exemplo, essas outras eu achava falta de algum contexto pra quem entrô no assunto, enfim, nem sei se é necessário isso.

Pesquisadora: Essas que você lembrou?

Ricardo: É, as outras, eu lembro que eu via uma arte e falava: Pô, nem todo mundo que frequenta o metrô consegue percebê alguma coisa numa arte, num desenho, etc e tal, se ele não tem alguns pré-requisitos prá podê...

Pesquisadora: E o quê você achou deste trabalho aí que você tava interagindo? Você considera uma obra de arte?

Ricardo: Então, eu não sei a definição precisa de obra de arte. É... eu não considerava isso uma obra de arte, prá mim era um jogo de interação entre eu e a máquina, né.

Pesquisadora: E o quê você achou deste trabalho?

Ricardo: $O$ que eu achei? Eu joguei pra distração mesmo, pra me interagi com o jogo. Eu sô professor de matemática e esse jogo em particular mexe com formas e aí eu tentei brincá com essas formas assim. Nada mais além disso.

\section{Monitor / usuário/espectador/ator: Geraldo, 28 anos, trabalha com vídeo}

Pesquisadora: Você usa bastante o metrô no deu dia-a-dia?

Geraldo: Todo dia.

Pesquisadora: E o quê você pensa obre a presença de obras de arte nas estações? Geraldo: Ah, eu acho indispensável porque esse lugar é muito claustrofóbico, muito acinzentado, né. Acho indispensável.

Pesquisadora: E das estações que você costuma usar, você lembra de alguma obra permanente, que fica ali o tempo todo? Não precisa me dar nome. 
Geraldo: Eu lembro do Jabaquara porque quando sê ta descendo a escada rolante sê se depara de frente com uma.

Pesquisadora: E estes trabalhos aqui, você considera uma obra de arte?

Geraldo: Também. Um misto de obra de arte com entretenimento.

Pesquisadora: Por quê você acha que pode ser considerada uma obra de arte?

Geraldo: Porque não tem um apelo comercial os jogos aqui. São mais sugestões de tendências eletrônicas.

Pesquisadora: O pessoal tem vindo interagir com estes trabalhos?

Geraldo: Sim. Não tanto quanto o fluxo aqui do horário de pico, por exemplo, mais sim, tem vindo sim.

Pesquisadora: Quantas pessoas mais ou menos?

Geraldo: Ah, então, é uma pergunta difícil porqueeu sô meio ruim de número, mais sei lá, acho que a cada saída do metrô aqui no horário de pico, vô fazê uma média assim. Acho que de cada 10 pessoas, 2 param. É engraçado que tem gente que acho que tá tão condicionada com esse cinza gritante do metrô que mesmo com esse painel gigante parece que passa reto, parece que nem vê, mesmo com essa poluição visual aqui em movimento eletrônico. Talvez tamém porque sei lá tem tamém tem arte eletrônica em todo lugar. Mais é engraçado no metrô, isso me chamô a atenção.

Pesquisadora: Você me falo que a cada saída umas duas pessoas, são quantas saídas mais ou menos?

Geraldo: Eu acho que o horário de pico aqui é das cinco e meia e vai até as sete. E é saída de dois em dois minutos.

Pesquisadora: Poxa, então, umas cem pessoas pelo menos param aqui no horário de pico.

Geraldo: Umas cem pessoas sim.

Pesquisadora: E que faixa de idade costuma vir interagir?

Geraldo: É engraçado você falô isso agora, eu me lembro muito de pessoas acima dos 50 anos assim. É bastante. Bastante. E tamém criança, depois seguido de jovem, adolescente e adulto.

\section{usuários/espectadores/atores: Sônia, 50 anos, professora / sobrinho Juliano, 9 anos}

Pesquisadora: Você costuma usar bastante o metrô?

Sônia: Sim, costumo usar no final de semana, sexta, sábado e domingo.

Pesquisadora: O que você pensa sobre a presença e obras de arte nas estações?

Sônia: Ah, eu acho fundamental, inclusive é curioso quando você vê uma obra de arte que tava em algum lugar que não era metrô e agora vem pro metrô o acesso das pessoas é muito maior, todo mundo fica interessado. Fica interessado, tira foto. Eu acho fundamental. 
Pesquisadora: E dessas estações que você costuma usar, tem alguma obra e arte que fica o tempo todo ali, que você lembre? Não precisa me dar nome.

Sônia: Não, porque eu acho que é mais itinerante. A não ser o MASP, né, que você tem uma reprodução das obras que tão no MASP, aquela é constante, mais, no Sacomã onde eu pego é itinerante, fica variando. Tem exposições, mais varia. Não tem uma que fica fixa.

Pesquisadora: E o quê você pensa sobre este tipo de trabalho, você considera uma obra de arte?

Sônia: É, na verdade, eu não tenho muita afinidade com esse tipo de arte que se chama de arte eletrônica não. Não é algo que me atrai muito. Mais pra nova geração eu acho que é fundamental porque eles já entram em contato com a questão estética mesmo, a questão de arte abstrata. Pra eles já é um jogo mais também é uma maneira de tê contato com estas variações estéticas, propostas estéticas diferentes, eu acho. Mas pra mim não, não me atrai muito, eu prefiro a arte clássico. Eu parei em Picasso.

usuários/espectadores/atores: Mariana, 26 anos, gerente de produto / Renato, 18 anos, técnico de informática e estudante

Pesquisadora: Vocês usam bastante o metrô?

Renato: Todos os dias.

Mariana: Todos os dias.

Pesquisadora: O quê vocês pensam da presença de obras de arte nas estações?

Renato: É bom.

Mariana: Eu gosto principalmente daquelas exposições que ficam desenhos, fotografia. Geralmente fica aqui né no corredor da Vila Madalena. Eu gosto bastante.

Pesquisadora: Dessas que ficam o tempo todo na estação vocês não lembram de nenhuma? Não precisa me dar nome, só descrever.

Mariana: Não lembro.

Pesquisadora: O quê vocês acharam deste trabalho que vocês estavam interagindo, vocês consideram uma obra de arte?

Mariana: Sim, eu considero só que eu acho que é mal divulgado, né. Porque você passa por aqui e não sabe muito bem o que é, mais é legal.

Renato: Fica num canto meio excluído, parece meio escondido.

Mariana: $E$, falta um poco de divulgação mais a ideia é muito legal. Eu até peguei o caderninho pra olhá e tem bastante coisa prá cidade inteira né. Pelos nossos metrôs também.

usuários/espectadores/atores: Natália, 27 anos, estudante de história da moda / Fernando, 33 anos, direção de arte

Pesquisadora: Vocês usam bastante o metrô?

Natália: Sim, muito.

Fernando: Sim. 
Pesquisadora: $O$ que vocês pensam sobre a presença de obras de arte nas estações?

Natália: Eu gostei certo. Eu acho que geralmente é mal aproveitado o espaço. Num sei, eu acho que tem que sê bem pensada a disposição. Eu gosto de exposição interativa assim, é interessante chama pessoas, mais às vezes são obras que não são interessantes pro público do metrô.

Fernando: E às vezes o local que tão expostas. Por exemplo, na saída aqui, é um local que eu não acho ideal pra colocá a exposição. Aqui tá muito amoadinho num canto e não consegue valorizá a obra ali. Acho que dependendo do espaço sim. Eu acho que tipo, as frases que são colocadas acho incrível sabe, simpático. Mas acho que as peças que são expostas aqui, da forma que são expostas não. Essa aqui é impossível a gente pará prá vê da forma que ela tá montada.

Mariana: Eu até acho melhor essas que são expostas aqui do que, por exemplo, aquelas obras que tem na Consolação, no Trianon, que uma parede atrás da plataforma do metrô. É muito longe, você não consegue vê direito. A imagem tá ali , você não tem informação sobre as pessoas que fizeram a obra.

Fernando: Vira um cenário.

Mariana: É, acaba só uma decoração.

\section{usuários/espectadores/atores: Mãe: 45 anos, trabalha em agência de viagens / Marcos (filho), 8 anos.}

Pesquisadora: o que você achou destes joguinhos que você estava interagindo?

Marcos: Hum..., legais. Mais, esse daí, esse que ele tá jogando parece que a gente... eu acho que a gente tava em outro mundo aqui. Naquele parece mais um labirinto, no outro, é... um cubo, naquele outro trabalho eu não entendi muito direito. Mãe: Cada noite ele para aqui.

Pesquisadora: É? Vocês vieram aqui várias vezes já?

Mãe: É, a gente passa aqui sempre né, então, aí as vezes ou tá ocupado ou não tá funcionando daí cada vez é aquilo, ele vai vendo um.

Pesquisadora: Então você gostou muito mesmo?

Mãe: Gostou.

Pesquisadora: Então você usa bastante mesmo o metrô?

Mãe: Uso.

Pesquisadora: $\mathrm{O}$ que você acha de ter obra de arte nas estações?

Mãe: Eu acho fantástico. Porque eu acho que muitas pessoas não tem oportunidade, não tem acesso a esse tipo de informação, e no metrô passa vários tipos de pessoas. Então é uma oportunidade também prá quem não tem o acesso com facilidade.

Pesquisadora: E dessas obras assim que ficam o tempo todo nas estações você lembra de alguma? Não precisa me dar o nome.

Mãe: Ah, dos quadros que tem.

Pesquisadora: E este trabalho você considera uma obra de arte? 
Mãe: Considero. Não sei se é mais... se bem que eu não sô nenhuma entendida do assunto.

Monitor / usuário/espectador/ator: Maurício, 44 anos, professor de história.

Pesquisadora: Você usa muito o metrô?

Maurício: Uso, uso muito.

Pesquisadora: E o quê você pensa sobre a presença de obras de arte nas estações?

Maurício: Eu acho que qualquer espaço público no qual você possa tá utilizando alguma forma de arte, de linguagem artística, é sempre bem vindo. Eu acho que, principalmente, numa cidade como São Paulo, que tem vários bairros que são carentes desse tipo de proposta. Então, eu acho que como o metrô é um meio assim de locomoção de massa então é sempre bom você tá tendo essa possibilidade de abri ao público a arte de uma forma geral. Performances, visuais, música, acho bastante interessante.

Pesquisadora: Das estações que você usa, você lembra de alguma obra de arte permanente de alguma estação?

Maurício: Ah, na Estação Sé, tem no espaço da Vergueiro se eu não me engano, acho que tinha na Paraíso, aqui mesmo nessa linha, na Sumaré tem tamém e tal. Acho que na Consolação tamém. Tem várias que tem é... principalmente pinturas. Tem outra tamém eu acho que eu já falei. Eu acho que é na Paraíso, na Pedro Segundo tem tamém, e vai por aí afora.

Pesquisadora: E este tipo de trabalho que tá sendo exposto no FILE, você considera obra de arte?

Maurício: Bom, se eu achá que arte é algo em aberto e não definido pra uma determinada época ou pra um determinado contexto, eu acho que a proposta do FILE de relacioná ou de apresentá arte com tecnologias das mais diversas é absolutamente válida. Então, eu acho que a tecnologia que o grande barato do FILE eu acho que é esse, você mostrá pro público que a tecnologia pode tá a serviço da construção de meios artísticos, de temáticas e reflexões, de interatividade e por aí afora.

Pesquisadora: E aqui, o período que você fica que é durante a tarde, né, tem tido uma quantidade considerável de pessoas que tenha interagido?

Maurício: Principalmente no período da tarde.

\section{Estação Trianon-MASP - Animações}

\section{Técnico de manutenção: Gilberto}

Pesquisadora: Esse tipo de trabalho tem dado muita manutenção, ou não?

Gilberto: Não, porque na verdade, os computadores em si, são máquinas recentes, então dá menos problema. Agora, vai daonde você coloca o seu trabalho pra apresenta. Máquinas mais recentes, menos possibilidade de problemas. Máquinas mais arcaicas, mais possibilidades de problemas. Num geral, como temos vários 
trabalhos espalhados por aí, temos tido pouca solicitação assim pra resolvê problemas.

Pesquisadora: É você e mais alguém ou só você que tá cuidando disso?

Gilberto: Não, tem toda uma equipe, tem mais de quinze pessoas espalhadas por aí, né. A gente ta dentro do teatro, na galeria e em algumas estações. Tem um grupo de pessoas na verdade, né.

Pesquisadora: Tem um período pra vocês darem uma olhada ou é à medida que tem necessidade?

Gilberto: É à medida que tem necessidade. Por exemplo, nessa semana inicial, que pode dá mais um problema ou outro, daí fica dois técnicos full time, né. A gente tem dois lá dentro do teatro e aí eu tô andando pra vê como é que tão as coisas por aí, mas, não tem um tempo pra tá se passando.

Pesquisadora: E você costuma usar o metrô?

Gilberto: Não, ultimamente eu tenho usado muito poco.

Pesquisadora: E o que você acha este tipo de trabalho aqui?

Gilberto: $\dot{E}$ arte que tá sendo apresentada pra pessoas que muitas das que passam aqui não tem nem noção do que é isso. Então, é uma forma de atraí o público né pra mais próximo da arte, certo. Esse trabalho é incentivador porque disperta a imaginação, a curiosidade das pessoas e daí pode sê muito divertido, entendeu. $A$ medida que eu conheço, eu gosto, eu começo a me aprofundá um pouco eu tenho a possibilidade de desenvolvê algo dentro de mim que eu nem conhecia. E ao passo que isso não é trazido pras ruas fica no anonimato, então, com certeza, é de uma valia muito importante pros usuários do metrô né.

\section{Monitores: Giovani e Juvenal}

Pesquisadora: Eu preciso saber de vocês como que está sendo a receptividade destes trabalhos. As pessoas tem vindo muito, não tem, que horário que elas costumam vir?

Giovani: Então, tem o pessoal que vem pra cá, né, que vem direto do trabalho, que tá vindo de outros trabalhos que tão espalhados pela Paulista ou da galeria, como aqui ta muito próximo, o pessoal vem direto pra cá, tem esse fluxo de pessoas tamém mais, o fluxo maior é o fluxo de passagem né, que é o pessoal que tá indo pro metrô, então esse que é o fluxo maior. O horário que se intensifica é o horário de pico né. Entre 17:00 e 19:00 horas, 19:30 assim. Passa bastante gente.

Pesquisadora: Passa e interage ou passa e nem dá bola?

Giovani: Ah, tem uma galera que passa apressada mais passa olhando assim bastante curioso, tem o pessoal que interage, tem o que passa curioso mais não qué pará, tem o que para olha, não dá atenção e vai embora, tem de tudo né. Tá na Av. Paulista, uma avenida multicultural né. Tem todo tipo de gente.

Pesquisadora: Dos que interagem, vocês tem uma ideia mais ou menos de quantas pessoas tem vindo?

Giovani: Nossa, não faço ideia, é muita gente, é muita gente. 
Pesquisadora: Mais de cinquenta, mais de cem?

Giovani: Mais de cem.

Pesquisadora: Que faixa de idade?

Juvenal: Todas. A gente vê a criança no caso que vem com a mãe já da exposição, as pessoas mais velhas que tão vindo do trabalho, e vai da pessoa tamém né. Tem pessoas que se interessam, param e gostam. Tem pessoas que param pra interagi e acabam não se interessando muito.

Giovani: É o pessoal que mais interage são os jovens mesmo, isso não tem dúvida né. O pessoal com uma idade mais avançada fica meio com medo, meio retraído de mexê, num sei. Mais passa de tudo aqui né, é passagem do metrô né.

Juvenal: Então, tem uma interação justamente pela escolha da obra né. Porque a obra ela não é uma obra muito complexa e nem uma obra que exige muito tempo. $A$ interação é um pouco mais simples e ela é rápida, você não precisa ficá nem meio minuto pra entendê o trabalho, menos de um minuto. Então, ele propõe uma coisa nova e ao mesmo tempo não atrapalha o fluxo, assim. O fluxo do espaço, do cotidiano da pessoa.

Giovani: Tem pessoas que já conhecem o festival, que frequentaram o ano passado ou já viram, ou ouviu falá na televisão. A divulgação muito grande tamém disso aí acho que facilita bastante. Aí tem a galera que veio nos anos anteriores e procura né. Então tá sempre de passagem por aqui aí vê e lembra né que veio o ano passado e aí para pra interagi esse ano tamém.

Pesquisadora: Você tava falando que as obras que estão do lado de fora das estações elas não tem tido necessidade de um monitor, né.

Giovani: Não, essas especificamente, porque a obra em si ela funciona o tempo intero, funciona através do celular das pessoas, ela capta a radiação, então, essa obra em si não tava precisando de um monitor. Porque as pessoas paravam e já entendiam o funcionamento dela. Tinha explicação, as pessoas podiam lê e já brincavam, olhava, e o monitor tava ali meio que desnecessariamente assim, então eles acabaram saindo dali, então nos dois primeiros dias eles ficaram. Tanto que até eu fiquei lá.

Pesquisadora: E o quê você achou, o que você percebeu? As pessoas paravam mesmo pra interagir?

Giovani: Muitos paravam porque achavam diferente, né. Então, nossa, que interessante, quê que é isso, olhava brilhando e aí parava pra lê, mais tanto fora quanto dentro do metrô as pessoas na maioria elas estão na correria sempre né. Então, param, até olham, mais às vezes, não sei a novela... parece mais interessante sabe, chegá em casa do que pará pra prestá atenção.

Pesquisadora: Na semana passada eu vim e tava tendo uma boa aceitação não tava?

Giovani: Não, ela é super bem aceita, tô dizendo assim, pela maioria das pessoas, mas muitos gostam, né. 
Pesquisadora: Agora que nós estamos no penúltimo dia, na segunda semana já, você poderia me dizer mais ou menos quantas pessoas acabam vindo interagir por dia?

Giovani: Na verdade, as pessoas, a maioria delas que passaram aqui, são algumas que disseram: nossa, eu já vi isso daqui a alguns dias aqui e já que eu não tive tempo de pará, o quê que é? A maioria delas, que tavam no fluxo do dia-a-dia falaram isso. E outras vieram porque justamente tavam olhando o festival , tavam vendo as outras obras então elas vieram de passagem mesmo. Eu não sei te dizê meu porque a gente acaba perdendo meio a noção. Umas cinquenta pessoas.

Pesquisadora: Por período?

Giovani: Até agora. Tem duas horas e meia que eu tô aqui. Para bastante gente. Para bastante pessoas assim. Cinquenta contando o pai, a mãe, o filho porque todos eles acabam interagindo.

Pesquisadora: São pessoas que passam por aqui ou são pessoas que vem especificamente pra fazer isso?

Giovani: Então, hoje, agora que tá tendo o final do festival na Paulista, vai continuá só na galeria, a maioria, acaba sendo pra vir mesmo, mais tem uns gato pingado assim que vem, que tá passando assim.

Pesquisadora: Você acha que funciona?

Giovani: Eu acho que funciona porquê muita gente experimenta coisas que eu acho que nunca experimentariam na vida. Então, dependendo do que tá aqui sendo exposto, é interessante sempre tê assim sabe proporcioná prás pessoas que elas saiam desse clichê de sempre , e justamente, desse clichê de galeria.

\section{Monitor: Cassiano}

Pesquisadora: Hoje nós estamos na véspera do final da exposição e o Giovani tava me dizendo que diminuiu bem a quantidade de pessoas que tem vindo interagir. Você também percebeu isso?

Cassiano: Sim. É que aqui é um lugar de passagem né, e o horário que a gente fica, é tipo horário de saída assim do trabalho, o pessoal passa meio correndo. Aí, como o pessoal passa todos dias, vê sempre a mesma coisa, é comum mesmo, tanto que as obras, a interatividade com cada uma é bem simples e não gasta muito tempo em cada trabalho. Então a pessoa interagiu um dia, ela já interage com todos, já saca como que é todos os trabalhos. Acho que é comum mesmo a pessoa não pará mais.

\section{usuário/espectador/ator: Jeremias, 20 anos, assistente de câmera de vídeo.}

Pesquisadora: Eu vi você interagindo com três obras. Você usa bastante o metrô? Jeremias: Demais, na verdade, eu uso mais de fim de semana porque eu trampo e prá i pro job eu vô de trem né, mais metrô, bastante assim eu não consigo me locomovê sem metrô.

Pesquisadora: $\mathrm{O}$ que você acha da presença de obras de arte nas estações de metrô? 
Jeremias: Hum, bom é difícil falá isso porquêe é a primeira vez que eu paro pra vê uma exposição. Eu vejo diversas exposições na Corinthians-Itaquera, Artur Avim, na Sé, o piano em Santana. Eu acho isso interessante mais pra falá a verdade é a primeira vez que eu paro assim, que eu me lembro, prá vê uma obra no metrô.

Pesquisadora: Dessas obras que ficam tempo todo em alguma estação você lembra de alguma? Não precisa me dizer o nome, mas você lembra mais ou menos como ela é?

Jeremias: Tem uma na Ana Rosa, tem umas esculturas assim, mais fica bem longe do público né. Tem umas estátuas ali que eu achei bem bacana. Teve um dia que eu tava esperando um amigo ele atrasô por uma hora então eu fiquei bizoiando ela.

Pesquisadora: E estas obras que você estava interagindo, o que você achou? Jeremias: Achei interessante, achei a imagem interessante, que é difícil vê uma imagem assim no cotidiano e trazê um som tamém. Eu gosto bastante de senti sensações diferentes. Por exemplo, aquela ali eu achei bem interessante, achei um poco psicodélico assim. Eu tava até falando um poco com o Giovani, se tivesse um poco o som de Violeta de Outono, Pink Floyd, uma coisa bem estranha de guitarra assim ficaria bacana. Mais eu achei legal.

Pesquisadora: Você considera este tipo de trabalho uma obra de arte?

Jeremias: Nossa, é difícil defini o que é uma obra de arte. Mais eu achei belo, eu acho que pra mim é uma obra de arte sim porque me tocô sabe. Porque me levô a pensá em outras coisas, me trouxe sensações, achei bacana.

usuários/espectadores/atores: Tiele, 23 anos, estuda administração / Bruno, 20 anos, trabalha na reitoria da UNESP.

Pesquisadora: Vocês usam bastante o metrô?

Tiele: Sim, usamos.

Pesquisadora: $O$ que vocês pensam sobre a presença de obras de arte nas estações?

Bruno: Interessante.

Tiele: Legal prá todo público vê, qualquer pessoa que passa pode interagi.

Bruno: E é um local onde tem bastante gente né. É um local onde pode se bem difundida.

Pesquisadora: Das estações que vocês usam vocês lembram de alguma obra de arte que fica o tempo todo naquela estação? Não precisa me dizer o nome só mais ou menos como ela é.

Tiele: Não.

Pesquisadora: $O$ que vocês acharam deste trabalho?

Tiele: É legal porque é uma coisa diferente né que o pessoal pode tá clicando.

Pesquisadora: Vocês consideram este tipo de trabalho uma obra de arte?

Tiele: Sim.

Bruno: Porque a arte pode ser expressa de diversas maneiras.

Tiele: É o jeito que a pessoa utilizô pra expressá alguma coisa. 


\section{usuária/espectadora/atora: Ana Paula, 24 anos, bancária}

Pesquisadora: O que você achou deste trabalho?

Ana Paula: Super legal, bem interessante, chama bastante a atenção, aqui de noite principalmente né que a gente vê as luzinhas piscantes.

Pesquisadora: Você considera este tipo de trabalho uma obra de arte? Por quê?

Ana Paula: Com certeza. Não sei, porque eu acho que o artista quis mostrá alguma coisa. O ponto de vista dele tem que sê considerado né. Por isso que eu acho legal, hoje em dia obra de arte não é só um quadro que a gente vê dentro de uma galeria. As pessoas tem que considerá tudo que o artista faz. Se ele acha que é um modo de se expressá, eu acho bacana. Arte é tudo o que você se expressa.

Pesquisadora: Você usa bastante o metrô?

Ana Paula: Bastante.

Pesquisadora: E você chegou a ver as obras que tem lá dentro?

Ana Paula: Não vi todas ainda.

Pesquisadora: Mas você viu?

Ana Paula: Algumas.

Pesquisadora: E o quê você achou?

Ana Paula: Bem bacana, eu quero vê as outras agora. Espero que dê tempo de vê até o fim.

Pesquisadora: Essas que estão no metrô ficam expostas até amanhã.

Ana Paula: Já? Vô vê se eu consigo vê antes de terminá porque todas vez que tem, tem pelo menos uma vez por ano essas né, eu tento sempre vê.

Pesquisadora: E o que você pensa da presença de obra de arte nas estações de metrô?

Ana Paula: Ah, eu acho fantástico porque dá oportunidade pra todo mundo vê, as vezes a gente não tem tempo pra pará pra vê, prá i no MASP ou sei lá em qualquer lugar onde tenha essas exposições. Quando tem em lugar público a gente curte bastante.

Pesquisadora: Das estações que você usa você lembra de alguma obra dessas que ficam o tempo inteiro na estação? Não precisa me dar o nome.

Ana Paula: Tem aquela instalação que tem aquelas madeiras, acho que é na Ana Rosa ou na Santa Cruz, que tem várias obras de arte dentro que você faz intercurso, tem vários quadros assim que eu acho bem legal, e tem essas que ficam nas plataformas mesmo que eu acho bem bacana, essas são as que eu lembro.

\section{usuárias/espectadoras/atoras: Diná, 35 anos, autônoma / Débora, 43 anos, auxiliar técnica da Getúlio Vargas}

Pesquisadora: Eu vi vocês duas interagindo com este trabalho, o que vocês acharam dele?

Diná: Na verdade ela que comentô que você tinha que falá no celular pra podê acendê as luzes. Eu tava fazendo esse teste e a gente percebeu que tava 
acendendo só algumas luzes aí a gente falô será que é só isso mesmo? A gente pôde interagi com esse painel mais não acendeu todas as luzes que eu imaginava que acendia.

Pesquisadora: Vocês consideram este trabalho uma obra de arte?

Débora: Sim porque é uma coisa diferente né.

Diná: Eu acho que é arte pela ideia que a pessoa teve né. Ela teve a ideia de colocá pontinhos, as luzes pra chamá atenção da gente pra radiação solar então eu acho que é uma obra de arte porque ao mesmo tempo que tá interagindo com a gente, que tá ensinando, é uma coisa diferente ainda mais num local de metrô. É uma obra de arte.

Pesquisadora: Vocês usam bastante o metrô?

Débora: Uso, eu trabalho aqui na Paulista, todo dia.

Pesquisadora: E você viu as obras que tem aí dentro?

Débora: Não.

\section{usuários/espectadores/atores: Vitor, 20 anos, estudante / Vinícius, 14 anos, estudante / Fábio, 11 anos, estudante}

Pesquisadora: $\mathrm{O}$ que vocês acharam deste trabalho?

Vitor: Ah, então, esse eu tava curioso pra vê né porque ficam falando que sê tem que mantê longe o celular do corpo, sempre aqueles avisos. Eu vim vê o que acontece, confirmá, se realmente nessa obra a radiação é meio preocupante até. $\mathrm{Meu}$, as luzes ficaram locas e eu ando com isso o dia intero com o celular no meu corpo, durmo com ele, fico ligando. Eu acho interessante. Essa aqui principalmente.

Pesquisadora: Você considera este trabalho uma obra de arte?

Vitor: Eu acho bem difícil definir assim o quê que é arte. Eu nem gosto de defini. Eu acho que sim, na verdade. Recentemente, assim o que a pessoa falá é arte tá sendo arte, então, se eles dizem que é arte eu quero aceitá que é arte.

Pesquisadora: E você usa bastante o metrô?

Vitor: Bastante.

Pesquisadora: $O$ que você pensa sobre a presença de obras de arte nas estações?

Vitor: Ah, eu acho importante prá elas tarem fora tamém só de museu. É um movimento que acontece bastante agora, tá no metrô, tá na rua. Eu acho bacana.

Pesquisadora: Das estações que você usa, você lembra de alguma obra de arte dessas que ficam o tempo inteiro na estação? Não precisa me dá o nome, me fala mais ou menos como que é.

Vitor: Por exemplo, a do Sumaré, do Alex Fleming? Eu lembro bastante do Sumaré, do Trianon, eu lembro vagamente assim.

Pesquisadora: E vocês, o que vocês acharam deste trabalho? Vocês também interagiram ou não?

Vinícius: Eu não, eu esqueci meu celular.

Pesquisadora: Você quer usar o meu prá ligar pra ele? Você também não brincou?

Fábio: Não. 


\section{APÊNDICE C - ENTREVISTAS COM OS ARTISTAS}

\section{Entrevista Amélia Toledo}

Local: Residência/Atelier da artista

Data da realização: 27 de junho de 2012

Pesquisadora: Como parte do acervo permanente da Companhia do Metropolitano de São Paulo está a sua obra, Caleidoscópio, instalada na Estação Brás. O trabalho foi concebido especificamente para o contexto, para o espaço da estação?

Amélia Toledo: Aquela série eu comecei a fazer em várias dimensões e escalas diferentes, faz parte de uma série de múltiplos de aço calandrado e pintado que eu comecei quando voltei a morar em São Paulo, nos anos 1980, com ajuda da minha amiga Maina Junqueira, recebi o incentivo de uma bolsa (Bolsa Vitae) para desenvolver os primeiros protótipos.

A versão do trabalho da estação Brás é para incluir também o reflexo das pessoas. Elas são chamadas pelo próprio reflexo, pelo movimento. Esses projetos que fiz para espaços públicos foram todos feitos junto com o Mo, meu filho.

Pesquisadora: O de lá do Rio. Esse daqui de São Paulo, é de autoria da senhora somente?

Amélia Toledo: Olha, nós trabalhamos sempre juntos nesses grandes projetos. Até hoje, todos são feitos em conjunto, quer dizer, tem os parques, tem o parque aqui da Vila Maria, tem o do Ibirapuera que nós fizemos juntos, entendeu? E são espaços públicos, né? $O$ arquiteto que projetou esses parques, o Sergio Marin, nos chamou pra fazer um trabalho de arte e nos deu inteira liberdade e apoio logístico; as obras foram feitas com apoio de leis de incentivo à cultura, em geral usadas para eventos passageiros, mas eventualmente empregadas para obras que se incorporam em definitivo à paisagem da cidade.

Pesquisadora: Como foi o processo para apresentação e execução da proposta de intervenção?

Amélia Toledo: Fui convidada pela Companhia do Metrô de São Paulo, na época coordenada pelo Marcelo Glicério de Freitas, e apresentamos a ideia inicial, aprovada por eles; a seguir apresentamos uma proposta detalhada para a Lei de Incentivo à Cultura do MINC e tivemos a sorte de encontrar patrocínio.

Pesquisadora: Esse trabalho que a senhora fez aqui pra São Paulo foi desenvolvido de forma integrada com o arquiteto ou não, foi um trabalho colocado depois da obra já construída?

Amélia Toledo: Ah, foi depois da obra. Foi escolhido por mim porque eu trabalhei muito com arquitetura, minha vida foi muito isso. Eu trabalhei a partir dos 17 anos no escritório do Villanova Artigas, trabalhei até os 20 por aí.

Pesquisadora: Tem realizado outras experiências juntamente com João Batista Martinez Correa? 
Amélia Toledo: O João é uma pessoa muito modesta, muito quieto, ele não faz onda em cima do que ele faz sabe, e agora ele tá fazendo outros projetos lá de outras estações porque ele tem uma experiência muito grande. Mas o pessoal de lá quer tomar conta dos projetos, [risos] sabe como é? Fizemos juntos a cor dourada de uma ponte pênsil sobre a av Presidente Vargas, indicamos cores de telhas e os tons de pintura dos ambientes, mas o projeto do piso, que eu gostava tanto, foi descartado.

Pesquisadora: E a senhora está desenvolvendo algum outro trabalho integrado com ele?

Amélia Toledo: Ele sempre me chama para palpitar nos projetos quando há essa abertura por parte dos governos, mas isso é muito raro.

Pesquisadora: Na época em que a senhora fez o trabalho para a Estação Brás, o metrô ainda pagava pelas obras ?

Amélia Toledo: O "Caleidoscópio" foi feito com apoio da lei de incentivo federal, não foi patrocinado pelo Metrô, mas quando a proposta foi aprovada, recebi um pagamento pelo trabalho inicial.

Pesquisadora: $O$ que pensa sobre a atuação integrada (projeto interdisciplinar) no processo de desenvolvimento de propostas artísticas, arquitetônicas e de design para as estações de metrô?

Amélia Toledo: Acho que tudo é uma coisa só, né? Não tem essa de artística e de designer. Eu não sei, eu tenho participado de alguns projetos em conjunto com arquitetos. Esse projeto que eu fiz com o João Batista lá para a estação Arcoverde e o daqui foi feito com liberdade completa e o arquiteto fez o projeto de paisagismo em torno. O lá do Rio foi feito muito entrosado com o projeto arquitetônico.

Pesquisadora: $O$ que impede de que se atue dessa forma integrada aqui nas estações de metrô de São Paulo?

Amélia Toledo: Não há impedimentos, mas depende de ser apreciado, e depois aprovado, por algumas instâncias, do arquiteto (ou do escritório de arquitetura) aos engenheiros, em alguns casos até o governador do estado participa dessa decisão.

Pesquisadora: Na Estação Cardeal Arcoverde, além daquela escultura maravilhosa que tem na praça, a senhora fez o projeto cromático, que vem naquele ritmo todo das cores pro interior da estação, e tem também um painel metálico. Aquele painel também fez parte do mesmo projeto, é tudo integrado?

Amélia Toledo: Aqueles painéis de aço inox são portas de acesso às áreas de serviço. $O$ aço inox é o material de acabamento que propusemos, mas o custo foi fora do orçamento da obra, teve patrocínio pela lei de incentivo; aliás a escultura da entrada também. O piso foi projetado por nós e fazia parte da obra em si. As cores do percurso foram escolhidas por mim com ajuda da Ana Lucia, mãe da minha neta e nossa sócia na Tria Design naquele tempo. O Mo fez a coordenação e, com orientação do Edson Elito, meu ex aluno, redigiu os documentos técnicos para a formalização do projeto. A gente procurou colocar todas as pedras azuis por exemplo, que existem, azuladas, arroxeadas, e tal, que existem no nosso subsolo e, do outro lado, são as pedras que dão pro vermelho. Agora, o lago da praça secou por falta de cuidado na conservação. 
Pesquisadora: O que pensa sobre o uso de tecnologias atuais (LED, célula fotovoltaica, mídia eletrônica, vídeo-projeções) em intervenções ambientais, não só temporárias mas também permanentes, para estações de metrô de São Paulo?

Amélia Toledo: Fiz um trabalho que é uma projeção de uma animação feita a partir de pedras e da iluminação, que é projetada no espelho. As pessoas se deitam ali embaixo e recebem a imagem projetada do espelho por cima delas, ao mesmo tempo que elas se vêem no espelho, mergulhadas na pedra. E agora, estou fazendo uns projetos novos, não sei se é o caso de estar dando ao público, que alguém vem e copia a ideia, eu vou mais dentro da minha viagem espiritual e da prática, que é trazida por pessoas que compreendem meu trabalho. Quando encontro as pessoas com essas afinidades, o trabalho de parceria se desenvolve naturalmente $e$ as técnicas se colocam a serviço das ideias propostas.

Pesquisadora: Esse trabalho que a senhora fez com projeção de luz, esse tipo de técnica, o que a senhora pensa sobre o uso dela em intervenções ambientais nas estações de metrô?

Amélia Toledo: Acho que é legal também.

Pesquisadora: Como a senhora definiria o espaço das estações de metrô de São Paulo?

Amélia Toledo: Como definir? Elas são um campo de percurso de pedestres e ao mesmo tempo estágios desse percurso, né? Locais de pedestres que convivem com o piso, com as paredes, com o teto e o projeto do João dessa estação do Rio, da estação Arcoverde, é uma coisa linda né, orgânica assim. Ela tem a ver com isso que ela é, não quer imitar outra coisa, não quer imitar a Arquitetura Moderna.

Pesquisadora: Qual o significado da arte inserida nas estações de metrô de São Paulo?

Amélia Toledo: Acho que é um estímulo para a imaginação das pessoas, um campo de viagem espiritual, digamos, também, basicamente. E o contato com maneiras muito simples de trabalhar, porque são processos muito elementares, né. Uma chapa de aço, a curvatura feita numa máquina, e a pintura ou acabamento que receberam conforme o caso.

Pesquisadora: Pretende apresentar outra proposta de intervenção para o metrô de São Paulo? Fale sobre a proposta.

Amélia Toledo: Se me chamarem, eu faço! Enquanto eu estou lúcida, ainda dá pra trabalhar. Eu acredito que apesar dos 85 anos, ainda estou bastante lúcida e ligada à prática, quer dizer, capacitada para projetar e tal. Não sei até que ponto, até quando vou aguentar a parte física do percurso.

Pesquisadora: A partir de dados colhidos em pesquisa foi possível observar que $40 \%$ das estações não possuem obras permanentes, enquanto em outras, há uma concentração de obras instaladas. Qual medida poderia ser tomada para mudar esta realidade?

Amélia Toledo: Não sei, talvez seja o estilo da divulgação do que já foi feito, em parte, o encontro entre as pessoas que estão trabalhando agora com os artistas que são competentes pra esse trabalho, que possam ser artistas também que nunca fizeram mas que podem ter essa capacidade. Acho que existe muito pouco estímulo à criação artística para obras permanentes para âmbito público. Você vê, todos 
esses projetos foram viabilizados por poucas pessoas que tiveram iniciativas mais criativas.

\section{Entrevista com Mo Toledo}

Local: Residência/Atelier do artista

Data da realização: 09 de julho de 2012

Pesquisadora: Gostaria que você falasse um pouco do seu trabalho com Amélia. Mo: O meu trabalho com ela tem sido, tanto na montagem das exposições da obra dela, como quando a gente faz qualquer intervenção no espaço público, trazer todos os olhares possíveis, não só o meu e o dela. Eu pergunto para muitas pessoas o que elas acham daquela ideia. E na hora de fazer, propriamente, a Amélia faz o projeto, ela diz: "olha, essas pedras vão aqui, isso aqui vai ali", aí eu monto. Sou o coordenador da montagem da obra, propriamente, primeiro porque eu não sou da idade dela, que fica cansada, no meio daquela coisa, de caminhão, bota obra, fumaça, guindaste... e segundo, que eu tenho mais agilidade e liberdade de dizer: ah põe daqui, tira dali, põe ali, faz isso, faz aquilo. A mamãe gosta muito do que está projetado, do que ela pensou anteriormente. Ela fica querendo que aquilo fique igual ao que ela pensou, coisa que é impossível de acontecer. Você pensou uma coisa mas o que vai ser feito é outra. A pedra não é aquilo que você imaginou, o espaço é mais ou menos o que você pensou, mas ali, na hora, você vai ter que ver. Ah, é melhor botar essa, trocar aquela, distâncias, volumes, profundidades, muitas variáveis, fazem parte da minha profissão de pintor de paisagens.

Pesquisadora: $O$ que pensa sobre a atuação integrada (projeto interdisciplinar) no processo de desenvolvimento de propostas artísticas, arquitetônicas e de design para as estações de metrô?

Mo: Tem um problema inicial, em geral, os arquitetos não gostam de artista. Gostam de arte, mas não são muito chegados ao processo de criação da arte. Ou eles se colocam como sendo os próprios artistas. O Oscar Niemeyer é um que faz da obra dele uma escultura. Ele dava o encargo de fazer arte pro Atos Bulcão de uma maneira legal. Fizeram coisas bonitas, integradas, juntos, mas é muito raro você ver trabalho integrado bem feito de obra de arte com arquitetura porque os arquitetos não costumam ter essa abertura, essa disponibilidade; o João Batista foi o primeiro que se mostrou muito aberto. Ele tinha o desafio do percurso que era complicado porque a pessoa embarcava e tinha que percorrer um longo trecho no subterrâneo, em Copacabana, que é um bairro todo colorido, símbolo de beleza, e a pessoa ia chegar deprimida por ter atravessado um túnel cinza? Quando o João Batista viu a exposição da Amélia, a primeira que eu fiz a montagem, no MASP, ele percebeu que ela era a pessoa que poderia resolver essa questão e ele procurou a gente justamente por isso. Ele falou: "Amélia, eu tenho estes desafios no projeto". Aí a Amélia começou a ter mil ideias e eu fui aos poucos entendendo o que deveríamos fazer e, com ajuda do Edson Elito, arquiteto que foi aluno da Amélia na fac de arquitetura, explicando pra ela, fazendo o meio de campo, que é esse o trabalho que 
eu faço de verdade. O trabalho todo é concebido pela Amélia. Agora, ela acha que fui eu que fiz. Em parte, porque eu vou muitas vezes questionando e dizendo não, isso não. Teve só duas coisas que eu fiz, que foram de minha autoria, mas que nem pesa muito lá dentro daquilo tudo porque o bonito daquilo é aquilo tudo mesmo. É a programação do piso, das cores, e isso é uma sensibilidade que ela tem, excepcional, que nem dando a volta ao mundo se pode achar outro artista que tenha essa capacidade. Ela é a pessoa que sabe olhar pro negócio e dizer: "ah isso é isso", e revela a coisa do jeito que a coisa é em si, entra em contato com a "essência dos materiais". Ela não usa o material no sentido de representar como tantos outros artistas fazemos.

Pesquisadora: Como foi o processo lá no Rio?

Mo: A princípio o João Batista Martinez chamou a gente pra fazer a proposta. $A$ gente apresentou a proposta pra Companhia do Metrô porque a Promon, que era a empresa onde o João trabalhava, era a responsável e já tinha ganhado a concorrência pra fazer. Entrar em concorrência nesse tipo de coisa é o mesmo que dizer perdeu, entendeu? Vão ver que tem artista no meio e vão dizer que aquilo é bobagem, que aquilo é perda de tempo, que é dinheiro jogado fora quando não tem nem dinheiro, tanto que eles nos pagaram sem ter dinheiro. A gente fez, vamos dizer, quase que por preço simbólico. A gente faz por esporte, é gostoso fazer este tipo de projeto. Dá um trabalhão mas o trabalho vai ficar pro público, as pessoas vão ver o que no dia a dia delas nunca podem ter dentro das suas casas. Pelo menos, elas têm onde ver arte na hora que estiverem no caminho de casa pro trabalho e não ver só uma cidade detonada. Agora, há o problema de conservação, porque a gente fez aquela fonte na praça, e a fonte é uma terra de ninguém. Ela é meio do Parques e Jardins (prefeitura), meio da companhia que administra o metrô mas é território e obra do Governo do Estado. Afinal ninguém cuida de nada, fica tudo caindo aos pedaços. Então, é um negócio muito complicado. A parte interna do metrô tem um responsável pra cuidar que é quem administra o funcionamento do metrô, então, o responsável tem que deixar ali limpinho, trocar o que caiu, etc.

Pesquisadora: Então vocês não tiveram problemas com regras normativas do metrô para fazer a proposta, ela ficou como sendo parte do projeto arquitetônico mesmo? Mo: Fizemos o projeto executivo da etapa de acabamento e, claro, seguimos rigorosamente todas as regras normativas e até criamos novos designs para favorecer na prática o que as regras indicam em termos teóricos.

Pesquisadora: Você e a Amélia desenvolveram algum outro projeto de estação de metrô com o João Batista?

Mo: Sim, a Estação Cidade Nova, uma ponte estaiada que cruza por cima da av Presidente Vargas, é projeto do escritório do João, ele tem feito vários projetos de estações no Rio. A Usiminas disse que era difícil fazer. Pintar de dourado era muito complicado quando, na verdade, é praticamente a mesma coisa, entendeu? Era quase a mesma dificuldade da pintura que seria feita de qualquer outra cor. E era um desafio para eles, talvez tenham feito para poderem mostrar a qualidade do que eles fazem, seja como for, ficou bonita, uma estação super especial porque aquele lugar, da av Presidente Vargas, é muito detonado. A Amélia tinha feito um projeto de piso para essa travessia e para essa estação toda que é uma integração entre metrô e trem, mas infelizmente o projeto dela foi atropelado. 
Pesquisadora: Essa proposta veio depois do projeto pronto ou foi integrada igual a da Estação Arcoverde?

Mo: Foi integrada igual à outra. O João falou que queria que a gente fizesse a proposta. A Amélia, primeiro fez uma proposta na cor verde aí, um dia, ela sonhou que seria dourado. Eu falei com o João. O João achou a ideia muito bonita $e$ começamos a tentar fazer os convencimentos. Muitos políticos, não é uma turma fácil de conversar, mas eles acabaram aprovando. Por outro lado foi pena porque a Amélia fez um projeto para um piso lindo, azul, de um granilite que ia ser feito com metal. la ser uma coisa linda mesmo, e aí o pessoal do Burle Marx ficou com ciúmes e aí fizeram eles o piso, que deve ter ficado uma porcaria, eu não fui lá ver. Aí colocaram no jornal: escritório do Burle Marx... aí bota o nosso projeto dourado lá como se fosse obra deles, pode?

O trabalho da Amélia é muito integrado com a ideia do construtivo, ela tem essa coisa realmente verdadeira dentro do trabalho dela. Pode chamar a obra dela de qualquer coisa menos de abstrato. O nome que ela gosta é concreto. É o inverso da palavra abstrato. É concreto porque se refere às coisas em si, como elas são mesmo. Ou construtivo. Não busca a partir das coisas fazer representações, mas sim, fazer com que a coisa se represente. Então, o metal, por exemplo, se ele precisa ser pintado, tem sentido que ele seja pintado com uma cor metálica. A cor metálica dá ao metal um aspecto de metal. Então, faz sentido em alguns casos, em outros, eventualmente não, mas podendo o metal ter a cor de metal, a tinta dá a ele essa propriedade. As cores que ela mandou pintar os módulos de corredores e tal, são cores da ideia de uma pintura meio em movimento, uma pintura para quem está em movimento. Então usou a tinta como uma taturana pintora. É, a primeira palavra que ela usou era uma espécie de lagarta que ia deixando cores no rastro. A primeira imagem da proposta pro metrô do Rio era uma lagarta.

Nessa ponte da Estação Cidade Nova, as bases onde as coisas se estruturam, elas têm "cores de base". A gente sempre pensa dessa forma: o que é base tem cor de base, o que é lá encima tem que ter cor etérea, cor que a pessoa sinta que está olhando para alguma coisa distante, a cor do teto é para liberar, cores claras, as paredes dos corredores precisam de variações, tudo isso é um jogo de proximidade, de alegria, de tudo junto. Então, cada elemento desse, que vai estar no caminho, ele simboliza alguma coisa. Essa da Cidade Nova, a gente fez toda a estrutura coberta de pedra, mesmo que seja a pedra como acabamento, pra dar a impressão que é de pedra, pesada. É a parte fundamental da construção. Se é para parecer alguma coisa, é para parecer o que é.

O projeto do piso era uma brincadeira com o mar, todo com ondas, brincando com aquelas ondas do Burle Marx, mas com aquela ideia de onda do mar, da cor do mar, com azuis, com verdes, uma coisa mais sofisticada, mexendo com o fluxo de onde as pessoas estão vindo, pra onde elas estão indo, quando elas circulam. Então, tudo isso são coisas que a gente faz brincadeiras com o material que está sendo usado, como ele está sendo colocado e aquilo que ele vai simbolizar. A cor simboliza. $O$ azul tem uma sensação de água. Os vermelhos tem cores de intensidade.

Pesquisadora: Essa forma de arco foi proposta pelo do arquiteto ou por vocês? Mo: o projeto de arquitetura é do João. A gente só faz a parte cromática. A forma é do projeto dele. O projeto ganhou prêmios em bienais internacionais, um projeto bonito, interessante, porque em lugares degradados da cidade é muito importante se fazer obras bonitas. Ali, em Copacabana, era super caído, o lugar onde foi feita a 
estação. Aquela região era esquisita. Daí construiu a estaçãoe ficou bonita, mudou totalmente.

Pesquisadora: $O$ que pensa sobre o uso de tecnologias atuais (LED, célula fotovoltaica, mídia eletrônica, vídeo-projeções) em intervenções ambientais, não só temporárias mas também permanentes, para estações de metrô de São Paulo?

Mo: Eu estou pensando em criar um projeto usando novas mídias e tecnologias prá fazer algum trabalho envolvendo talvez mais do que uma estação, um percurso, uma linha, ainda não sei o que nem se é possível. Vou procurar parceiros que já trabalham com som e com as mídias visuais.

Pesquisadora: Mas isso você está pensando para uma estação aqui de São Paulo ou lá do Rio?

Mo: Aqui de São Paulo. A Companhia do metrô de São Paulo é muito bem organizada, acho que a gente pode pensar nisso e procurar o caminho para realizar.

Pesquisadora: Você pensa como uma obra permanente?

Mo: É, fazer uma obra que fique vivendo dentro do metrô que traga brincadeira pro passeio das pessoas, a lgum tipo de coisa lúdica, enfim, alguma coisa que traga um sentido de pensar, de refletir. Eu não sei ainda o que é, mas eu vou começar a conversar.

\section{Entrevista Carlos Fajardo}

Local: Residência do artista

Data da realização: 19 de junho de 2012

Pesquisadora: Parece-me que grande parte de seu trabalho se relaciona com o espaço, com o lugar, produzindo um objeto não tautológico mas especular, utilizando o reflexo do espelho e trabalhando com a duplicação do espaço, criando um espaço reverso. Congela o tempo no espaço. Em alguns trabalhos também faz uso do elemento luz em cores diferenciadas. Gostaria que descrevesse o processo mental de criação de sua obra.

Carlos Fajardo: A ideia de usar uma imagem dentro de outra imagem é algo que surgiu no meu trabalho desde o seu início. A pintura já implica nessa relação, entretanto, na pintura, sempre surge em primeiro plano a ideia de representação de algo ausente, algo que me desagrada e me distancia muito do objeto pictórico. $O$ primeiro trabalho que pensa uma imagem dentro da outra que eu realizei é um dos meus trabalhos mais antigos, de 1966: um cubo de acrílico dentro do qual eu inscrevi, através de desenho nas bordas da superfície desse cubo, um outro cubo achatado que, entretanto, só se realiza visualmente de forma virtual. Talvez esse trabalho se irradia na minha atuação de várias maneiras, sendo que, a atual envolve espelhos.

Pesquisadora: $O$ que pensa sobre o uso de tecnologias atuais (LED, célula fotovoltaica, mídia eletrônica, videoprojeções) em intervenções ambientais, não só temporárias mas também permanentes, para estações de metrô de São Paulo? 
Carlos Fajardo: Eu fui comissionado para realizar um trabalho para o metrô Vila Prudente. Na verdade, não usava tecnologias atuais mas ele estava situado em um espaço que utiliza muito dessas tecnologias. Era um grande painel amarelo, espelhado, que ocupava uma área estratégica do espaço do metrô, de cerca de 24 $m$ de comprimento por $4 m$ de altura, em frente a escada rolante que vencia uma altura muito grande. Ele refletia desde o teto feito de vidro, que via o céu, como os túneis de baixo em que passavam os trens do metrô, como os passantes que olhavam meu trabalho, que viam essas duas instâncias não só diretamente como através das imagens refletidas pelo trabalho. O trabalho não usava nenhuma tecnologia avançada, porém, ele espelhava todas as possibilidades utilizadas nesse enorme "lugar praticado".

Pesquisadora: $O$ trabalho foi concebido especificamente para o espaço da estação? Carlos Fajardo: Sim. Após ter havido a indicação de uma comissão para esse projeto, entrei em contato com o arquiteto que tinha feito o desenho da estação, então, em construção, Luis Carlos Esteves. Nesse grande espaço, havia uma parede que guardava um grande duto de ventilação e que tinha em sua face, voltada para as escadarias, exatamente essa área que seria ocupada pelo meu trabalho. Essa área, era ricamente envidraçada por um grande cilindro de vidro e pelo teto. Eu desenvolvi um trabalho que se mimetizava com o ambiente e que, por contraste, refletia todo o entorno e, principalmente, os passantes que utilizariam os trens dessa estação.

Pesquisadora: Como que foi o processo para você apresentar essa proposta, já que ela não foi executada?

Carlos Fajardo: O trabalho foi aprovado nos vários níveis em que ele foi apresentado. Ele não foi executado, talvez, por ter enfrentado a misteriosa burocracia que acabou por inviabilizar sua execução.

Pesquisadora: $O$ que pensa sobre a atuação integrada (projeto interdisciplinar) no processo de desenvolvimento de propostas artísticas, arquitetônicas e de design para as estações?

Carlos Fajardo: Projetos dessa magnitude exigem essa atuação integrada. São projetos que, geralmente, envolvem uma integração com a arquitetura, exigem um acompanhamento técnico de engenharia e têm que ter um cuidado imenso da parte de todos os envolvidos com o usuário final. Num certo sentido, esse procedimento é imposto a esse usuário. Não se trata de uma obra de arte colocada em um lugar público de visitação como um museu, mas um lugar de uso público indiferenciado.

Pesquisadora: Até que ponto regras normativas influenciam no projeto e na forma de atuar do artista?

Carlos Fajardo: No meu caso, não me foi solicitada a busca de patrocínio, e se o fosse, eu não faria. Porque não julgo esse ser o papel de um artista ao qual a instituição solicita um projeto.

Pesquisadora: Como definiria o espaço das estações de metrô de São Paulo? Como espaços exclusivamente de passagem, como não-lugares?

Carlos Fajardo: No livro "Invenção do cotidiano", Michel de Certeau, diz uma coisa muito interessante a respeito desses lugares como: metrôs, supermercados, estações de trem, aeroportos, são o que a gente pode dizer que "o espaço é um 
lugar praticado", assim, a rua, geometricamente definida por um urbanismo, é transformada em espaço pelos pedestres.

Pesquisadora: A partir de dados colhidos em pesquisa foi possível observar que $40 \%$ das estações não possuem obras permanentes, enquanto em outras, há uma concentração de obras instaladas. Qual medida poderia ser tomada para mudar esta realidade?

Carlos Fajardo: Uma medida seria tornar obrigatório nos lugares públicos a instalação de objetos de arte. Isso é uma prática rara aqui em São Paulo, mas ocorreu de uma forma intensa pelo menos uma vez, na Praça da Sé.

\section{Entrevista Claudio Tozzi}

Local: Residência/Atelier do artista

Data da realização: 12 de setembro de 2012

Pesquisadora: Ao longo de sua trajetória desenvolveu propostas de intervenção artística para diversos espaços da paisagem urbana paulistana, dentre eles, os espaços das estações Sé e Barra Funda do metrô, onde estão instaladas as obras Colcha de Retalhos e Movimento, respectivamente. Esses trabalhos foram concebidos especificamente para o espaço das estações?

Claudio Tozzi: No meu trabalho, desde o início, pretendia fazer uma arte que não ficasse restrita a um espaço privado mas que pertencesse a um lugar mais amplo que é a cidade. Levávamos nossa arte aos espaços de entidades de classe atingindo um público mais amplo. Na época, o público de artes plásticas não era tão amplo quanto o formado hoje pelos museus, exposições coletivas e galerias. Fiz várias tentativas de fazer esta proposta para a cidade. A primeira delas foi fazer uma Zebra, na Praça da República. É um painel de 8x8m, pintado em poliuretano sobre folha de zinco, com uma durabilidade excepcional. Está lá até hoje. Esse painel é a reprodução de um quadro que estava pintando no atelier: uma Zebra, alusão humorística à proliferação de loterias esportivas. O termo "deu zebra" tinha uma conotação de um certo humor inesperado: apostei "num e deu outro". Achei que essa imagem iria interferir. O trabalho foi concluído em 1971. Foi uma atitude espontânea de interferir na cidade. Procurei um colecionador da época (Milton Guper) que possibilitou a execução do trabalho.

Em 79, convidado por Radhá Abramo, a participar de seu projeto de intervir nos espaços públicos e estações de metrô, realizei o painel Colcha de Retalhos. Radhá convidou vários artistas para realizar trabalhos na praça e dentro das estações. Esse projeto iniciou-se na Praça da Sé. O meu processo de trabalho foi fazer uma pesquisa valorizando a questão do usuário: quem usava aquela estação. O metrô de São Paulo era recente. Apresentei três soluções para aquele espaço que me foi determinado pelos arquitetos do metrô. Fiz uma colcha de retalhos, um astronauta e silhuetas que significavam o andar das pessoas que por lá passavam. A proposta do astronauta era pegar um transeunte do espaço celeste e deslocá-lo para o espaço subterrâneo, "do céu à terra". As silhuetas tinham a mesma escala de quem circulava na estação. Era uma pintura sobre o suporte de concreto e projeções através de imagens em movimento que se fundiam com a imagem pintada utilizando naquela época técnica muito presente em trabalhos de arte contemporânea: a 
projeção. A "colcha de retalhos" era uma reelaboração do que se faz nas periferias da cidade com sobras de tecidos: um trabalho de criação popular. A escolha através do voto foi muito semelhante ao processo de criação de um "coletivo" dos dias de hoje. Fizemos três maquetes que foram expostas no local durante aproximadamente 4 ou 5 dias. O painel que ganhou por uma grande quantidade de votos foi a Colcha de Retalhos. A partir de então, desenvolvi um trabalho específico para aquele lugar baseado em pesquisas que realizava no atelier para a série Colcha de retalhos, exposta na Galeria Paulo Figueiredo em 1981. Através de elementos pesquisados e apropriados de produção popular das colchas, desenvolvi imagens gráficas para pertencerem à iconografia do painel, já adequadas às cores das tesselas de vidro existentes elaborando o projeto final com detalhes da estrutura visual e solução cromática para ser produzido. Sob minha orientação, foi executado por uma equipe dirigida pelo mestre italiano Severino Faro, especialista em mosaicos da indústria Vidrotil. Em outro período, retomei esse trabalho, um pouco mais abstrato, que é a série fragmentos. Foi construído no processo tradicional de mesa, com a imagem invertida, onde as pastilhas foram coladas e depois invertidas e aplicadas na parede de concreto. Foi utilizada uma massa especial italiana bastante elástica para compensar a diferença de coeficiente de dilatação do concreto e do vidro (da ordem de dez a menos três e dez a menos cinco). Colcha de Retalhos foi financiada pelo metrô.

O painel da Barra Funda, já foi uma situação totalmente diferente. Houve um concurso no Palácio dos Bandeirantes para se fazer um painel em substituição ao existente de Portinari. Foram convidados cinco artistas para apresentar um projeto. Logo após a inauguração da exposição, o Governador e a comissão de arte, decidiu que os outros quatro artistas fizessem painéis em outros espaços. Como não havia obras de arte previstas para a Estação Barra Funda, ele falou: "Vamos colocar esses painéis na Estação Barra Funda". Então, foi um projeto assim feito meio de ultima hora e com materiais não tão adequados para o espaço: tinta acrílica sobre tela colada em madeira revestida com verniz acrílico, processo que resiste ao tempo mas que precisa de uma manutenção maior.

Pesquisadora: No processo de desenvolvimento de seus trabalhos atuou de forma integrada com o arquiteto que projetou as estações?

Claudio Tozzi: No caso, a estação já estava pronta, mas houve um projeto de integração, que foi feito pela Radhá Abramo, onde ela fez a curadoria incluindo a locação das obras e o diálogo entre elas. Envolvia a parte externa da Praça da Sé e diversas áreas internas da estação. Então, de certa forma, existiu um projeto curatorial, não onde o artista trabalhou diretamente com o arquiteto mas uma interação através da curadoria.

Pesquisadora: Em artigo publicado em 2001 e em sua tese de doutorado, você fala da importância da ação integrada entre artistas e arquitetos. O que pensa sobre este tipo de atuação (projeto interdisciplinar) no processo de desenvolvimento de propostas artísticas, arquitetônicas e de design para as estações?

Claudio Tozzi: É preciso repensar a formação acadêmica do artista plástico. É necessário que ele tenha um conhecimento mais amplo da escala e da estrutura dos espaços urbanos e dos edifícios. Deve ter uma formação e conhecimento técnico de materiais, incluindo o processo de execução, fixação da obra, interferências e utilizar a linguagem do vídeo, do cinema, da mídia eletrônica e outros elementos que 
trabalham com a projeção e reflexão da luz com vários materiais que são integrados e determinam a solução da obra. Nesse artigo, eu proponho exatamente essa integração que, hoje, ocorre em todos os projetos. Enquanto o arquiteto tende, em sua obra, a uma realização estável, a intervenção do artista é algo que é acrescentado à identidade local. É ponto de partida do confronto com o espaço físico, que modifica a realidade, a "redefine", confere-Ihe novos atributos: ao interpretar, a relê poeticamente. São inúmeros os exemplos e as situações em que o trabalho do artista em relação à arquitetura consiste simplesmente no "decorar" parcialmente uma determinada parte do espaço, sem considerar o ambiente em sua totalidade, se concentrando num detalhe particular e ignorando o todo.

Tal fato ocorre em todos os períodos da história, inclusive nos dias de hoje, mas devido à superficialidade de sua proposta, não nos interessa considerar. Interessamnos propostas que determinem a intersecção de campos interdisciplinares $e$ resultem na criação de ambientes integrados e na articulação espacial que propõe o diálogo e a síntese no fazer do arquiteto e do artista plástico.

Muitos artistas têm uma formação semelhante à do arquiteto. Nos projetos de Olafur Eliasson e Anish Kapoor essa integração está presente. No mundo inteiro se faz isso. Os grandes escritórios de arquitetura também têm a participação de artistas plásticos. Algumas intervenções que os arquitetos fazem são muito associadas às artes plásticas como, por exemplo, em New York, a intervenção em linha de trem abandonada de Diller Scofidio. Então, hoje, o artista, o arquiteto, o designer, o comunicador visual, ele tem uma questão a resolver: a cidade, o espaço urbano. Essa integração, é muito interessante quando se dá no ato de projetar.

Pesquisadora: Então, o que impede que esta forma de atuação aconteça no metrô de São Paulo?

Claudio Tozzi: Eu não sei o processo interno. Antes, havia uma comissão que tentava fazer essa ponte e parece que tem alguns projetos integrados dessa relação do artista com o arquiteto, pelo menos um diálogo de materiais que ele vai utilizar. Seria muito bom que a partir do processo de projeto de uma estação o artista desenvolvesse em conjunto com o arquiteto intervenções espaciais já pensando em soluções de materiais.

Pesquisadora: A diversidade de técnicas e de materiais empregados é uma característica marcante em sua produção. Na década de 60 desenvolveu uma proposta de intervenção urbana para a COGEP, juntamente com Ubirajara Ribeiro, onde indicavam o uso do elemento luz como parte constituinte da obra. Nos anos 80 , realizou um trabalho de projeção de luz na fachada do Estádio do Pacaembu. 0 que pensa sobre o uso de tecnologias atuais (LED, célula fotovoltaica, mídia eletrônica e digital, videoprojeções) em intervenções ambientais, não só temporárias mas também permanentes, para estações de metrô de São Paulo?

Claudio Tozzi: Eu acho que é a mesma questão quando eu trabalhei a Zebra. Era uma atitude de vanguarda. Era uma época de pintura a óleo, tintas, uma pintura de cavalete, e você propõe uma ruptura de um suporte e trabalha com placas de zinco, tinta de poliuretano, e verniz que também se utilizava em aviões, resina de poliuretano super elaborada que resiste ao vento, às temperaturas.

No painel da COGEP e, principalmente, na série Multidões, que realizei em 1968, as imagens utilizadas eram retiradas de fotografias por mim realizadas, ou resultado de pesquisa iconográfica em jornais e revistas da época. Existia o tempo de execução, 
como intervalo entre a ocorrência e o quadro. As imagens eram reveladas e tratadas em laboratório por processo de solarização e alto contraste, criando efeitos semelhantes ao que um programa de computação gráfica realiza hoje. A imagem era reduzida a seus elementos essenciais, através do desenho em papel vegetal translúcido superposto à foto, alterando sua escala original e reduzindo suas relações de claro-escuro, de modo a tornar a imagem impregnada de emoção, pela alteração de seus contornos e tratamento de seus traços. A elaboração da imagem no ateliê nos remetia a um código específico, que refletia o momento social e político, ao mesmo tempo que estabelecia um distanciamento entre o fato real e a imagem da pintura. Partia-se da geração espontânea da imagem, através da foto, para uma intencionalidade discursiva no quadro. As figuras eram tratadas como elementos que estabeleciam um diálogo visual entre si, e através da ampliação das imagens para as dimensões da escala humana o espectador se fundia com as figuras, ao se aproximar do quadro-objeto. Assim, a série Multidões foi realizada através de gestos e linhas agitadas que refletiam os movimentos bruscos da ação na cena representada. Já a série Astronautas tem por base linhas mais fluidas, que simbolizam o caminhar do homem na ausência de gravidade.

Hoje, por exemplo, eu acho que o artista tem que ter o conhecimento de toda essa tecnologia e tem que incorporar ao trabalho. Aqui em São Paulo já se faz várias experiências. No metrô de São Paulo, foram feitas uma série de obras em que, mesmo de caráter temporário, se utilizava uma tecnologia e até uma participação do espectador. É muito importante a incorporação da linguagem da arte à toda essa tecnologia. Quando eu fiz o projeto da passagem de nível aqui da Paulista com o Bira, a gente trabalhou um sistema de luzes cruzadas onde o próprio espectador fundia sua imagem com uma imagem pré-pintada sobre uma parede. Toda a relação de ângulo de luz criava uma nova escala para a imagem em movimento que era quase uma projeção do transeunte que se fundia com a imagem pintada. Você criava uma unidade, uma relação entre a pintura e o espaço, o transeunte, 0 usuário, e tudo o que acontecia naquele espaço através da luz. Hoje, os artistas fazem muito esses trabalhos, principalmente, o Olafur e o Anish Kapoor, que já citei. Eles trabalham muito com a luz, com a projeção, com a reflexão, mas sempre em função de um espaço predeterminado. Essa interação entre a arte e a tecnologia e o conhecimento do artista de todos esses processos é muito importante para se criar uma obra de arte que seja contemporânea. Essa questão sempre vai existir. Desde o primeiro trabalho, a Zebra, que já propunha uma tecnologia bastante avançada em relação à resistência ao tempo e todo o trabalho que se faz hoje utilizando um ferramental técnico muito grande que envolve luz, LED, som, envolve até o movimento das pessoas que pode determinar a criação de um espaço. Em várias exposições, aqui em São Paulo e no mundo, a gente vê toda essa tecnologia como linguagem das artes plásticas. É muito importante que as obras tenham essa linguagem contemporânea, que o metrô proponha também não só a aplicação de materiais ou de tinta sobre uma superfície preexistente mas que se construa espaços onde se use uma tecnologia bastante contemporânea. É o mesmo pensamento que você tem que ter em todas as épocas!

Uma questão muito importante para o artista intervir no metrô é a relação matéria / tecnologia. É necessário que o artista conheça os diversos materiais e suas tecnologias para a elaboração de um projeto. Alguns fatores externos como a vibração e o deslocamento de ar, causados pela locomoção do metrô, são importantes para a criação de uma obra que exija pouca manutenção. É preciso pensar nos materiais, seus encaixes, suas fixações e suas características físicas 
para que se tenha uma obra de pouca manutenção e que resista ‘a exposição pública.

Pesquisadora: Qual o significado da arte inserida nas estações de metrô de São Paulo?

Claudio Tozzi: É muito importante que a arte não fique restrita aos espaços privados e que o desenho da cidade seja constituído também de obras. Se você vai a Berlim, por exemplo, todos os edifícios, todas as construções mais recentes, o próprio espaço urbano da cidade, tem uma série de intervenções que estabelecem um novo desenho para cidade. O metrô também tem que ter esse significado. Uma estação não pode ser simplesmente um local onde você vai tomar um trem mas que você sinta como um elemento de desenho da cidade. A Estação Sumaré, por exemplo, é muito bonita porque integra uma avenida que passa acima, uma avenida que passa abaixo e cria um espaço de relação entre as duas avenidas. Da estação se tem a transparência visual para o vale da Av. Sumaré que, antes, era um rio. Tem o significado da própria obra da estação ser um símbolo para a cidade. Incorpora a topografia do espaço e estabelece a ligação simbólica de duas vias urbanas que se cruzam em planos diferentes. Todas poderiam ser assim. Ao criar obras para 0 metrô, o artista amplia seu vocabulário tradicional de trabalho e começa a criar ambientes, instalações e estruturas configuradoras do espaço. Sua metodologia e seu fazer se adaptam ‘as novas necessidades e suas fontes de referência se tornam amplas, incluindo a economia, a ciência, a construção, a iluminação, a cenografia, a dança, o som, o cinema e a informática.

São inúmeras as experiências de caráter ambiental, com intervenções sobre a complexidade do espaço realizadas por artistas, tendo como proposta redesenhar os espaços em sua entidade física e metafórica no âmbito das linguagens contemporâneas.

Essa unidade de ação e pensamento, da arquitetura e da "pintura" pode determinar uma arte única (resolvendo as questões entre uma e outra) onde sua essência não se constitua em elementos isolados e sobrepostos, mas se concretizem em uma expressão unitária.

A partir de então, as artes plásticas percorrem um caminho de recuperação da superfície que a contém. Transgride. Sua existência transcende a representação e acontece no meio circundante tornando-se "massas de cor", "pinturas objetos", "land art", "performances", "instalações" e se tornam linguagens que se integram e se fundem com a arquitetura, com o ambiente, com a cidade, com a paisagem urbana $e$ com a natureza.

Pesquisadora: Pretende apresentar outra proposta de intervenção para o metrô de São Paulo? Fale sobre a proposta.

Claudio Tozzi: Além das técnicas que pesquiso `a várias décadas, de tintas e resinas acrílicas, materiais siderúrgicos, placas variadas, fibras, concreto etc., gostaria de fazer um novo trabalho e experimentar linguagens contemporâneas incorporando novas tecnologias. Fazer um trabalho que utilize processos que a gente vê em obras públicas no exterior, trabalhar com vidro que muda de cor, com células fotovoltaicas, com LEDs, fazer um trabalho que seja uma relação entre minha obra de pintura e uma obra de tecnologia apropriada a esses espaços urbanos. 
Pesquisadora: A partir de dados colhidos em pesquisa foi possível observar que $40 \%$ das estações não possuem obras permanentes, enquanto em outras, há uma concentração de obras instaladas. Qual medida poderia ser tomada para mudar esta realidade?

Claudio Tozzi: É necessário fazer um planejamento integrado. Ao se pensar o sistema viário da cidade e estações de metrô, o projeto deve ser ampliado para que se receba locações e intervenções visuais nos espaços a serem construídos. 0 projeto integrado permite determinar o uso do lugar: a locação de obras permanentes e espaços destinados ‘as transitórias. Um exemplo dessa atuação é o projeto que realizei no complexo das Avenidas Bandeirantes e 23 de Maio abrangendo não somente empenas de viadutos, mas tratando o espaço como parte da cidade, criando um código de significados e interação através de formas e soluções cromáticas. Para aprofundar essa questão, tem que pensar o metrô como um sistema viário da cidade. Tem linhas que cruzam o espaço aberto, tem estações que são submersas em eixos da cidade. Tudo isso tem que ser pensado para que se faça também um projeto de intervenção visual no metrô. Esse pensamento conjunto, esse conceito inicial de pensar o espaço como um todo vai resultar em soluções mais específicas, mais adequadas para o metrô.

\section{Entrevista com Daniela Kutschat}

Local: Laboratório LabVisual da Faculdade de Arquitetura e Urbanismo da Universidade de São Paulo

Data da realização: 02 de agosto de 2012

Pesquisadora: Sua experiência na área das artes interativas, design de informação e sistemas digitais tem possibilitado que desenvolva pesquisas e proposições sensoriais e cognitivas a partir do corpo espaço e que investigue a aplicação de tecnologia em informação de comunicação ao corpo, ao objeto, ao ambiente e à cidade. O que pensa sobre o uso de tecnologias atuais (LED, célula fotovoltaica, mídias digitas e eletrônicas, incluindo videoprojeções) em intervenções ambientas não só temporárias, mas também permanentes para as estações de metrô de São Paulo?

Daniela Kutschat: Pensar a cidade como uma superfície de comunicação é uma tendência. Muitos designers, arquitetos e artistas também utilizam a cidade como a superfície de comunicação e utilizam de tecnologias contemporâneas: fachadas que são inclusive interativas e vitrines interativas. Ela se apresenta um pouco como uma possibilidade de se pensar a arquitetura como uma coisa fluida, e não rígida. Então, nesse sentido eu acho bem interessante. Antes das superfícies interativas há exemplos que eu prezo muito, que eu acho muito interessantes que são, por exemplo, as intervenções que a Jenny Holzer fez e faz, com aquelas frases e projeções mesmo em alguns edifícios pela cidade. Esse tipo de intervenção eu acho bastante interessante e uma característica é justamente o uso da luz como material básico de trabalho. Há mais exemplos fora, do que em São Paulo.

Pesquisadora: Você mencionou que em São Paulo, no Brasil, isso não tem sido muito aplicado, esse tipo de tecnologia. Você acha que isso se deve a quê? Ao custo dessa tecnologia? 
Daniela Kutschat: Na verdade você precisa de uma infraestrutura bastante grande, normalmente, você tem que alugar os equipamentos e você tem que conhecer e se familiarizar bastante com as tecnologias de Video Mapping. A gente vê, por exemplo, na Virada Cultural, houve intervenções assim, há intervenções que são feitas de projeções, mas elas são menos frequentes e às vezes elas são até alternativas, são grupos alternativos que fazem isso, e que são mais da área das artes interativas e artes videográficas, digamos assim. Em grandes eventos, a prefeitura contrata empresas para fazerem projeções em alguns espaços públicos e em alguns edifícios na cidade. Muitas vezes, essas projeções, no meu entender, elas não trazem o potencial que poderiam trazer, ou seja, às vezes, os conteúdos são um pouco banais. Elas não exploram as possibilidades que poderiam ser exploradas, em termos mesmo de linguagem, de estética. Eu acho que isso é uma coisa que faz a gente pensar um pouco.

Pesquisadora: Uma das derivações do trabalho $O P \_E R A$, que desenvolveu juntamente com Rejane Cantoni, o OP ERA Sonic Dimension, foi exibido na Exposição Arte Cibernética: Acervo Itaú Cultural, na Estação República. Na vídeo instalação Maquinas de Ver 1 foram utilizadas imagens de uma estação de metrô. Você pretende apresentar alguma proposta de intervenção para o metrô de São Paulo?

Daniela Kutschat: Olha, eu acharia muito interessante. Inclusive, eu acharia bem interessante expor esse trabalho Máquinas de Ver 1 na própria estação de metrô onde foi produzida.

Pesquisadora: É isso o que eu ia te perguntar, onde foi exposto?

Daniela Kutschat: Máquinas de Ver 1 foi exposto duas vezes no Paço das Artes. A primeira vez, foi numa temporada de projetos, os artistas mandam, em novembro normalmente são as chamadas, e os artistas enviam suas propostas e um comitê, um júri, seleciona as propostas que vão ser contempladas pro ano seguinte. 0 projeto e foi selecionado, e a gente o desenvolveu em 2000. Em 2004, Máquinas de Ver 1 foi exposto de novo, numa exposição que foi curada pelo Arlindo Machado e pela Christine Mello, que chamava "Entre o Público e o Privado". A discussão lá era trabalhar justamente essas fronteiras do publico e o privado, da privacidade, então tinham vários trabalhos que lidavam com esse tema.

Pesquisadora: Eu cortei, desculpe, o que você estava falando, que você pretende expor este trabalho na estação de onde foram extraídas as imagens. E qual estação que foi?

Daniela Kutschat: Então, o trabalho foi feito na Estação Sé, porque nós queríamos o ponto zero da cidade, e a estação Sé tem uma configuração muito interessante porque ela tem uma plataforma na qual se pode estar vendo os trens chegando da zona Norte de um lado, e trens chegando da zona Sul, do outro, de espaços opostos. E essa questão do espaço oposto e de você olhar para frente e para trás ao mesmo tempo, que era a grande questão desse trabalho, a melhor forma e o melhor lugar para fazer isso, seria justamente esse lugar. A gente escolheu a dedo o lugar para desenvolver esse trabalho.

Pesquisadora: No processo de desenvolvimento de grande parte dos seus trabalhos atua de forma integrada com Rejane Cantoni e outros profissionais. O que pensa 
sobre a atuação integrada (projeto interdisciplinar) no processo de desenvolvimento de propostas artísticas, arquitetônicas e de design para estações?

Daniela Kutschat: O processo, por exemplo, com a Rejane Cantoni, foi de coautoria, então a gente concebia junto os projetos, a gente sentava, a gente fazia "Brainstorm", a gente tinha uma meta, na verdade a gente tinha uma pesquisa de fundo, a partir da qual a gente então desenvolveu essas várias possibilidades desse projeto grande chamado OP_ERA. Aquilo foi um trabalho de coautoria. Eu trabalhei já com outros artistas numa relação de colaboração, que funciona de outro jeito. Mas, por exemplo, em projetos para estação de metrô, eu acho que trabalhar integradamente com o arquiteto é fundamental, porque você está lidando com uma quantidade de pessoas que é inacreditável, são muitas pessoas, e às vezes você tem uma intenção, e essa intenção ela não se concretiza na mente, na sensação, no outro. Então, nesse sentido, eu acho que meu trabalho se aproxima bastante do Design, porque eu fico pensando voltado às pessoas que vão receber o trabalho. $E$ aí, quando o trabalho é no metrô, eu acho que você tem que ter uma clareza sobre em que lugar que você vai instalar o seu trabalho, qual vai ser o fluxo que vai ter naquele espaço, qual a iluminação, como que ele se relaciona inclusive com as outras coisas que estão presentes no espaço. Todos esses elementos são fundamentais e ai você não tem que trabalhar talvez só com o arquiteto, você tem que trabalhar com uma grande quantidade de pessoas, inclusive com alguém da área de gerência mesmo do metrô, da estação, para fazer esses acordos mesmo; a instalação é uma intervenção, ela estará intervindo no espaço anterior, e é isso o que a gente quer. Inclusive, saber quais são as limitações, porque às vezes a gente parte, o artista parte do ideal, ele quer implementar o ideal, o que está na cabeça dele, o que vai para o projeto dele, o que está no desenho dele, ele quer implementar aquilo. Agora, às vezes, o contexto, principalmente o contexto público como o metrô, não permite isso. Então, como que ele vai fazer uma adaptação, se uma adaptação for possível, para ele também conseguir realizar o próprio trabalho.

Pesquisadora: Até que ponto regras normativas influenciam no projeto e na forma de atuar do artista?

Daniela Kutschat: O tempo todo. Não são só as regras normativas, as próprias limitações que as tecnologias e os matérias te impõem. Então, às vezes, você idealiza uma coisa, e quando você vai para a prática, realizar aquilo, com aquele material, com aquela tecnologia, você percebe que aquilo não funciona bem daquele jeito que você idealizou. Por isso que a pesquisa de materiais é tão fundamental no trabalho, principalmente na arte e tecnologia. A gente tem que conhecer muito bem o que é possível fazer e com o que é possível fazer. A mesma coisa acontece com as regras normativas dos espaços. Então, você tem restrições. Por exemplo, o próprio espaço tem restrições. A gente já teve esse problema da altura que nos era dada não ser suficiente para podermos implementar o projeto do jeito que a gente precisava e queria. Então, o projeto sofreu adaptações. Elas estão influenciando, influenciam o tempo inteiro. Às vezes, você tem um trabalho, e alguém te convida a apresentar este trabalho num espaço. Na maior parte das vezes os trabalhos que eu realizei já eram conectados ao espaço, ou seja, a gente mandava uma proposta para realização num determinado espaço. Então, quem julgava a proposta, já julgava sabendo quais eram os requisitos que nós tínhamos, mas, às vezes, vem o seguinte, você faz a exposição num lugar, alguém vê a exposição e quer levar para outro lugar, que tem outras condições físicas, outro 
espaço físico e tal, e aí o projeto, às vezes, não pode sofrer alterações e adaptações, mas na maior parte das vezes é possível fazer isso.

Pesquisadora: Como você definiria os espaços das estações de metrô de São Paulo? Você os vê como espaços exclusivamente de passagem?

Daniela Kutschat: Depende muito da estação e da hora. Na verdade, eu fico bastante fascinada com o metrô de São Paulo porque eu acho que ele funciona muito bem e ele é muito bem projetado e eu acho que eu até tenho uma relação afetiva com ele. Eu acho que é um sistema de transporte que funciona, é um espaço no qual você consegue se encontrar de uma forma bastante simples. Tem algumas deficiências, uma das deficiências que eu vejo é a própria comunicação, eles deveriam ter mapinhas que poderíamos carregar no bolso para nos orientarmos, coisas assim. Depende do horário, é espaço de passagem sim. Mas existem estações que permitem alguns cantos mais voltados para exposições, e as pessoas acabam percorrendo esse espaço de outra forma, elas acabam parando, olhando um pouco, voltando depois, elas se relacionam de uma outra forma com o espaço.

Pesquisadora: Você disse que algumas estações você entende como sendo espaços de passagem. Esse entendimento seu de espaços de passagem ele também diria respeito ao conceito de "não lugar", ou não?

Daniela Kutschat: Eu acho esse conceito bem interessante, mas eu penso muito numa questão que tem a ver com as tecnologias contemporâneas que é a questão da mobilidade. Eu acho que quando a gente tem essas tecnologias, esses dispositivos móveis, quanto mais a gente tem isso, mais essa relação de espaço e "não-lugar" pode ser pensada de uma outra forma. Isso pode se expandir, na verdade, para outros espaços que não foram definidos por ele como "não lugares". Eu acho que a relação das pessoas com esses espaços que foram definidos como "não lugares" já está um pouco alterada através dessas tecnologias que estão incorporadas no corpo mesmo. Então, você está em todo lugar, a todo tempo. É uma coisa que eu estou pensando agora, você que estabelece o espaço, ou seja, é através da sua relação com ele.

Pesquisadora: Com a mídia digital, não tem um lugar, ao mesmo tempo você está em todos.

Daniela Kutschat: É, eu penso bem por aí. Eu penso que quando alguém está num lugar, num espaço físico, se conecta ali e começa a se conectar com outros e tal, é como se ela estivesse criando esse espaço. Eu gosto muito da ideia de fluxos, eu acho que a gente vive em fluxos mesmo, cada vez mais. Até pensar a casa da gente, a gente tende pensar de outro jeito. O escritório da gente já não é aquele escritório. $E$ esses espaços tipo hotel, aeroporto, eles acabam quase que presentificando um pouco fisicamente essa relação que a gente tem mesmo de conexão que não é tão palpável, que não é tão visível, mas que é existente, a gente faz isso, a gente abre o laptop, está na rede, "pluft"! Outro dia, eu estava mandando um e-mail dos Estados Unidos e aí o Google me perguntou: "É você mesma? Você está mandando um e-mail de um lugar que você não costuma mandar e-mail". Quer dizer, ele me localizou, mas, na verdade, as pessoas para as quais eu estava mandando e-mail, eu podia estar aqui, podia estar lá, podia estar em qualquer outro lugar, o importante é a conexão que está sendo feita e o espaço que se constrói. 
Pesquisadora: Qual o significado da arte inserida nas estações de metrô de São Paulo para você?

Daniela Kutschat: Eu acho que é um grande desafio perceptivo, mas eu acho que essa também é a força da proposta artística, ser um desafio perceptivo e cognitivo. É você passar ou estar em algum lugar, ser capturado por algo estranho, que é essa proposta artística, a intervenção artística, talvez ficar em algum estado de surpresa, silêncio, não entendimento, curiosidade, depois voltar para o mundo de uma outra forma, com essa experiência, e eu acho isso fundamental. Principalmente, numa cidade como São Paulo que é uma cidade que engole a gente, ela tem um volume, e uma dimensão, e uma quantidade de pessoas, e uma correria, uma dinâmica muito dela também, que acaba fazendo muitas vezes com que a gente automatize muitos processos e procedimentos do cotidiano, e quando você tem uma intervenção, uma proposta dessas numa estação de metrô, que é um lugar de um fluxo de milhões de pessoas, milhares em cada estação, faz essa pessoa ter uma experiência que caia fora dessa moldura. E essa experiência pode ser transformadora, ativa a sensibilidade. Ativa a percepção e talvez a compreensão do mundo. Acho isso importantíssimo.

Pesquisadora: A partir de dados colhidos em pesquisa foi possível observar que $40 \%$ das estações não possuem obras permanentes, enquanto que, em outras há uma concentração de obras instaladas. Qual medida poderia ser tomada para mudar essa realidade?

Daniela Kutschat: acho que é uma questão de política cultural, é uma medida mesmo da Secretaria Estadual de Cultura, entender inclusive que a estação de metrô pode ser o espaço da arte, e que pode conter em si esse valor, porque a arte é um patrimônio cultural mesmo. Talvez abrir para concursos, abrir concursos para artistas e arquitetos, ou promover mostras, ou seja, fazer uma agenda, uma agenda de exposições, uma agenda de mostras. Nada impediria também que houvesse artes como, por exemplo, a performance. Coisas que, talvez, nem fossem permanentes, mas que criassem a cultura de frequentar o espaço não como do ir vir, mas como espaço mesmo de estar e de ter uma experiência. E também acho que esse tipo de coisa seria possível fazer, teria que ter alguém na secretaria pensando que isso é importante e que isso pode, inclusive, dar uma identidade para a estação, criar um circuito cultural de estação em estação, que é uma coisa que o Arte Cibernética tentou fazer, um circuito naquele espaço.

Pesquisadora: O tipo de tecnologia aplicada no Arte Cibernética teve custo elevado? Daniela Kutschat: Muito. Para a gente implementar o projeto, em 2005, porque é o mesmo projeto, a gente teve que desenvolver tecnologia. Então, a gente desenvolveu desde hardware até toda a instalação em si, todo o projeto mesmo da instalação, a programação, um software dedicado. A gente teve apoio de uma empresa de sistemas de controle, a gente teve que comprar uma quantidade de sensores específicos que poderiam funcionar naquele espaço, naquela proposta, e tudo isso teve um custo elevadíssimo. O que acontece: normalmente, a gente idealiza o projeto, essa idealização do projeto já é fazendo uma pesquisa sobre tecnologias, sobre possibilidades, elabora um orçamento, e aí a gente manda para editais específicos. Uma vez contemplado no edital, você recebe a verba específica para a realização do projeto. 
Pesquisadora: Edital tipo esse da prefeitura, você diz, essa Lei de Incentivo?

Daniela Kutschat: Por exemplo, tinham os editais do Itaú Cultural que eram aqueles Rumos, tinha não, tem. Depois tinha o edital que era o Prêmio Sérgio Motta. Fora do Brasil tinham outros editais. A gente mandou para um edital da Universidade da Califórnia, dentro dessa Universidade tinha um centro de arte e tecnologia o Beall Center for Art and Technology. E eles tinham um edital anual de bolsa de desenvolvimento de projeto e residência. E a gente foi então contemplado com esse projeto e recebeu então uma verba pra gente implementar o projeto e expor lá na Califórnia. Com isso, a gente conseguiu desenvolver o projeto. Esse projeto fez tanto sucesso que ele foi comprado por duas instituições. Então, a gente tem uma edição de três cópias: uma é nossa, outra é do ZKM, na Alemanha, que é um centro para arte e tecnologias de mídia que é um dos mais renomados centros do mundo, e foi comprado também pelo Itaú Cultural, e essa versão que foi comprada pelo Itaú Cultural, participou da exposição Arte Cibernética.

Pesquisadora: Considerando que nas estações você tem o efeito pistão em função do deslocamento das composições e da trepidação da estrutura, teve muita manutenção?

Daniela Kutschat: Tivemos monitores que ficavam direto junto com a obra, porque nossa obra é supersensível, ela tem sensores que têm ser calibrados, então se tem alguma coisa assim... No caso, lá, a trepidação teve menos problemas do que a altura do espaço, ele era um pouco baixo, e a manipulação das pessoas. Porque, o trabalho, você não precisava tocar nas telas, você só se aproximava das telas e você ia produzindo sons, mas as pessoas colocavam as mãos na tela, e quando colocavam elas, às vezes, as deslocavam. O monitor ficava lá inclusive conversando com as pessoas, a gente teve um feedback.

A questão de apresentar propostas de intervenção para o metrô de São Paulo eu, na verdade, eu não sei te dizer, porque eu nem sei como funciona isso, para quem que eu apresento, como fazer, como aqueles artistas que estão lá foram selecionados, eu não sei...

Pesquisadora: Está publicado no site os dois regulamentos: para obras temporárias e para obras permanentes. O artista é quem tem que conseguir patrocínio, ou ele banca tudo, ou ele consegue um patrocinador que vai atrás da Lei de Incentivo, e tudo mais, para que possa executar. No início o Metrô comprava as obras, agora parou de comprar.

Daniela Kutschat: É, eu imagino mesmo, a Tomie Ohtake... É uma questão mesmo de política orçamentária e política pública e cultural.

Daniela Kutschat: $O$ que acontece com a gente é justamente isso que você estava falando, o artista passa muito tempo elaborando projetos, fazendo a própria produção do projeto. Então, ele é na verdade, um executivo, ele tem que ser um empreendedor, ele tem que correr atrás dos editais, às vezes ele precisa do selo de algum órgão pra ele poder entrar com o projeto. Então, por exemplo, se você já tiver aprovado no MINC o seu projeto isso já te ajuda... Ele tem que, realmente, ser muito empreendedor, tem que desenvolver várias habilidades e qualidades bastante administrativas. Aquela visão de artista que idealiza e pronto, eu acho que não é assim. Não é isso que eu vejo com meus colegas, não é isso que eu vivo, e é complexo.

Eu acho uma pena que não exista essa visão, que é até uma visão estratégica, de se colocar a cultura lá dentro, de tornar a cultura mesmo, as artes, próximas do 
público, cada vez mais próximas do público, justamente nesses espaços, que são os espaços que são utilizados pelas pessoas.

Pesquisadora: Agora só uma pergunta, só voltando, nessa tecnologia que você e a Rejane desenvolveram, para uma obra que era para ser exposta temporariamente, você acha que é possível que ela seja utilizada para uma obra permanente, para uma estação?

Daniela Kutschat: $A$ gente procurou desenvolver uma tecnologia que era ligar 0 botão, deixar ligado, e aquilo funcionar sem problemas. E quando a gente foi pra Alemanha, eu acho que aquilo ficou quase 4 meses, e aquilo foi ligado apenas uma vez, nunca foi desligado. Então, a gente conseguiu realmente um estado da arte também no sentido de robustez do projeto que foi bem interessante. Agora, tem uma questão aí, que é como guardar esses trabalhos, como fazer a manutenção deles, porque as tecnologias também elas vão mudando, e se é pertinente atualizá-los tecnologicamente. Essas são questões mesmo que o pessoal da área de arte e tecnologia discute muito, e, inclusive, os museus também discutem. Por exemplo, esse museu que adquiriu a obra, a adquiriu pela questão de que a gente tinha desenvolvido software, que foi entregue junto, que a gente tinha desenvolvido toda a parte tecnológica, e que nos tínhamos uma possibilidade de manutenção que eles dominavam. Tudo isso foi pensando. Inclusive a elaboração desse contrato de venda foi uma coisa complexa, por que o que você está vendendo?

Pesquisadora: Autoria, não é?

Daniela Kutschat: $A$ autoria continua sendo sua, você continua sendo o autor. Mas você está vendendo software, você está vendendo a instalação, a tecnologia. Eles podem mudar de repente, daqui 5 anos eles poderiam dizer: "Ah, mas esses sensores estão desatualizados. Vamos trocar por uma tecnologia melhor?". O que aconteceu, o Itaú Cultural adquiriu uma obra anteriormente nossa, que era uma obra que necessitava de uma luva de dados. Eles iam participar de uma exposição e o volume de pessoas que iriam utilizar essa luva seria grande. Então eles entraram em contato com a gente e foi elaborada uma outra versão, uma atualização desse trabalho, onde a gente utilizou, ao invés da luva, o Kinect, o sensor de movimento. A gente deu uma atualizada no projeto fazendo essa troca. E com isso, o gesto da pessoa não era mais só na mão, eram os gestos mesmo no corpo. Dessa forma a gente mudou também um pouco a gramática de como que ia funcionar a interação. Agora, e no futuro, daqui 50 anos, 100 anos, que talvez a gente não esteja mais aqui, o que eles vão fazer? Esse problema é o que o pessoal do vídeo também tem, porque se você compra o vídeo você está comprando o quê? A cópia ou o original? O original vai durar um certo tempo, e pra você reproduzir a obra você precisa dos equipamentos também. Você tem que ter os equipamentos também, você não pode ter só o vídeo, você tem que ter o equipamento de projeção. Essas coisas são questões mesmo que são muito debatidas, o quanto os trabalhos já não podem ser vistos. Uma série de trabalhos que eu realizei na década de 90 que hoje não rodam mais, porque não é mais aquele sistema operacional, aquele computador, aquela porta de entrada. Então, cadê esses trabalhos? Eles só existem na documentação.

Pesquisadora: Seria possível aplicar essas tecnologias em obras permanentes no metrô? 
Daniela Kutschat: Sim. Até é se você pensar que você tem que ter um acervo e, no seu acervo você tem que ter $X$ dispositivos, que são daquela época, e eles têm que funcionar, pra você poder fazer com que o trabalho funcione, ou seja, você vai fazer quase que uma arqueologia de equipamento.

Pesquisadora: Para que sejam substituídos de tempos em tempos.

Daniela Kutschat: Ou talvez, até que não sejam substituídos, para que eles se mantenham originais. Aí, depende muito da política do museu, de como que o museu entende a obra. Por exemplo, o Itaú Cultural entendeu, e nós entendemos, que uma atualização de luva de dados para Kinect conceitualmente não iria interferir na nossa obra, achamos que era pertinente. Agora, pode existir uma instituição que diga: "Não, vocês estão mudando alguma coisa no trabalho, vocês estão trocando" $E$ aí o todo já não é mais aquele. Então, aí depende muito da política institucional. Eu lembro que há uns 10 anos atrás veio uma mulher do Centro Pompidou falar das instalações do Bill Viola, que são instalações videográficas. Ela falou de como eles têm que pensar a aquisição dessas obras e o que e como eles podem guardar essas obras para elas sobreviverem. Então, é aquele problema, existem os requisitos físicos que você pode construir, da instalação, mas existem os requisitos projetivos, que são na verdade, eles estão meio que fechados naquele período em que existia aquela tecnologia. Agora, a pergunta é: será que eles poderiam atualizar isso? Será que, eles digitalizando tudo, e mudando o sistema de projeção a obra seria a mesma? Existe essa discussão. Já existia essa discussão no vídeo, imagina hoje em que as tecnologias digitais que estão mudando assim, não é? Impressionante.

\section{Entrevista Regina Silveira}

Entrevista concedida via correio eletrônico

Data: 12 de julho de 2012

Pesquisadora: Parece-me que grande parte de seu trabalho se relaciona com o espaço, com o lugar. Espaços efêmeros são construídos com a sombra da luz. Intercepta luz com formas. Projeta luz sobre formas. Transforma o espaço em um ambiente através do uso de diversas técnicas e tecnologias atuais. O que pensa sobre o uso de tecnologias atuais (LED, célula fotovoltaica, mídia eletrônica, videoprojeções) em intervenções ambientais, não só temporárias mas também permanentes, para estações de metrô de São Paulo?

Regina Silveira: Possivelmente essas tecnologias atuais, que já estão na "família" daquelas utilizadas para a comunicação dentro das estações do metrô, poderiam até proporcionar uma implantação mais fácil de obras artísticas - permanentes ou não mais afinadas com as condições oferecidas pelo ambiente e pela situação de passagem e apreensão rápida, por parte dos usuários do Metrô. Talvez elas tenham mais capacidade, especialmente quando aplicadas a intervenções ambientais, de ocupar escalas maiores com menor fisicalidade e mesmo - considerada a comunicação onipresente - de se constituírem como ruído capaz de criar uma espécie de "pausa" ou mudança temporária - nas percepções banais do cotidiano. Mas tudo depende da qualidade da arte, como sempre... o uso das novas tecnologias por si só não assegura o estatuto da arte - que para ser arte tem que ficar na contramão e no avesso da comunicação... 
Há nuances... por exemplo: quando você aprecia o trabalho do Alex Flemming na Estação Sumaré, nem pensa que aquele conjunto de imagens fotográficas e poemas realizados sobre vidros está executado em versão atualizada (pelo simples uso de recursos fotomecânicos e da serigrafia) das técnicas mais tradicionais dos antigos vitrais...

Pesquisadora: Você tem trabalhado na curadoria das exposições Vitrines do MASP, teve a obra Descendo a Escada exibida na Exposição Arte Cibernética: Acervo Itaú Cultural, na Estação Brás. Pretende apresentar alguma proposta de intervenção para o metrô de São Paulo?

Regina Silveira: A pergunta se refere a três situações diferentes, na minha relação com o Metrô de São Paulo, que já dura muitos anos...

1- Assumi a curadoria das vitrines da estação Trianon-MASP, temporariamente, pouco mais de um ano atrás, na minha qualidade de membro do Conselho da Curadoria do MASP, com a intenção de dar uma orientação mais definida para o uso daquele equipamento em espaço público. Tudo na mais perfeita coordenação com as duas instituições envolvidas -o MASP e o Metrô -, e com o objetivo - também compartilhado - de promover o uso das vitrines para artistas que se dispusessem a tomar os espaços oferecidos como lugares para intervenções específicas - e não como vitrines convencionais, para apreciar quadros emoldurados....

2- Descendo a Escada fez parte da bela iniciativa do Itaú Cultural de exibir obras da sua coleção de arte e tecnologia dentro de estações do metrô - acho que foi um sucesso, a interatividade das obras colaborou para atrair o público - que muitas vezes pode gastar um pequeno tempo a mais dentro da estação. E os espaços mais escuros do percursos internos ganharam uma mágica que antes não tinham...

Foi temporária, ainda bem, porque assim a mostra guardou o máximo do seu poder de surpreender, sem muito desgaste de manutenção. Uma iniciativa para manter ou dar sequência, sem dúvida.

3- No momento, não tenho proposta para intervenção temporária em estações do metrô de São Paulo. Durante a Rio + 20, no evento Luz na Cidade, cuja realização foi caótica e cheia de dificuldades, eu tinha a proposta de projetar na rua a videoanimação "1001 Dias", com trilha sonora, sobre o elemento arquitetônico construído para a saída de ar do metrô no exterior da estação do Largo da Carioca, no centro do Rio de Janeiro. Antes de cancelar esta projeção, impossibilitada por diversas diversos impedimentos, ainda fui solicitada a investigar as possibilidades de uma projeção no interior da Estação Ipanema, onde também não se conseguiu realizar pelo excesso de iluminação do ambiente disponibilizado pelo Metro para o evento Luz na Cidade. Mas eu bem que fiquei gostando e pensando na estranheza e no interesse de projetar aquela sequência de dias e de noites nos interiores cavernosos das estações de metrô, como aberturas para um céu impossível...

Pesquisadora: O trabalho foi (será) concebido especificamente para o espaço da estação?

Regina Silveira: Minha proposta de obra permanente na Estação Vila Madalena que mesmo sendo especifica hesito em chamar de "intervenção", um termo muito mais adequado a obras efêmeras -, tem agora mais de 10 anos. Tenho o projeto pronto desde então, e do início ele foi aceito pelo Metrô - que ainda hoje, acredite se quiser, continua a querer que este projeto se realize. Mas sou eu quem tem que conseguir.... Uma longa história, com diversos proponentes nas inscrições para benefícios das leis de incentivo, muitas justificativas, muitas idas e voltas a Brasília e 
outras comissões, que um dia contarei em detalhes, se houver oportunidade e se este projeto for feito. Ele iniciou pouco antes do novo milênio, com minha vontade de aplicar a obra "Tropel", feita em 98 na fachada do edifício da Bienal de SP, como motivo gráfico para ocupar o paredão encima das catracas, por sua afinidade com os grafites tão celebrados da Vila Madalena. Anos depois, o projeto incluiu também a ocupação do túnel e com o tempo a realização técnica proposta, anteriormente em vinil adesivo, ficou muito mais enxuta e atualizada, pelas possibilidades abertas pelo uso de chapas de alumínio composto. recortadas a laser, para reproduzir um rebaixamento com resultados gráficos similares.

A estação foi medida e visitada mil vezes, para complementar a informação das plantas fornecidas pelo Metrô. Um dos últimos resultados deste estudo foi uma maquete de madeira, bastante detalhada, onde consegui por fim apreciar a possível nova visualidade que a estação iria adquirir.

Pesquisadora: Como foi (tem sido) o processo para apresentação e execução da proposta de intervenção?

Regina Silveira: Já respondi acima.

Pesquisadora: No processo de desenvolvimento de seu trabalho atuou (tem atuado) de forma integrada com o arquiteto que projetou a estação?

Regina Silveira: Até para a proposição da obra permanente (insisto em não querer chamar de intervenção) me associei ao arquiteto Ronald Monreal (que já executou inúmeras obras para mim, desde meados dos anos noventa). Ele esteve comigo em todas as reuniões com o metrô, ao longo dos anos - foi com ele que concebi as estratégias, materiais e técnicas de execução - e sempre tive em tudo o maior apoio técnico por parte do Metrô.

Pesquisadora: O que pensa sobre a atuação integrada (projeto interdisciplinar) no processo de desenvolvimento de propostas artísticas, arquitetônicas e de design para as estações?

Regina Silveira: Pode ser essencial, especialmente quando a proposta envolve o ambiente - há muitos conhecimentos e dados envolvidos que o artista sozinho não domina - a colaboração interdisciplinar é sempre um enriquecimento.

Pesquisadora: Até que ponto regras normativas influenciam no projeto e na forma de atuar do artista?

Regina Silveira: Eu mesma me sinto a vontade com limites e parâmetros - em qualquer projeto que envolva espaços públicos e ambientes com funções, eles não devem ser entendidos como barreiras restritivas, mas como balizas para a criação. Penso que as regras podem funcionar para compor a invenção do artista com uma espécie de charada a resolver - em muitos casos isto pode ser bem interessante, leva a imaginação para novos caminhos.

Pesquisadora: Como definiria o espaço das estações de metrô de São Paulo? Regina Silveira: Seco e limpo. Gosto bastante, também porque são passagens despersonalizadas, para transito rápido, olhares indiferentes. Tudo isto entendo como desafios para o artista.

Pesquisadora: Qual o significado da arte inserida nas estações de metrô de São Paulo? 
Regina Silveira: Um lugar para percepções inusitadas, olhar novo, suspensão da indiferença, beleza, e por aí vai...

Pesquisadora: A partir de dados colhidos em pesquisa foi possível observar que $40 \%$ das estações não possuem obras permanentes, enquanto em outras, há uma concentração de obras instaladas. Qual medida poderia ser tomada para mudar esta realidade?

Regina Silveira: Tanto quanto sei o Metrô não possui mais uma comissão regular para resolver a questão da Arte no Metrô, tem apenas consultores e não coloca verba para as realizações permanentes - elas podem ser propostas e aceitas, mas isto é tudo. Para que o projeto fique valendo mesmo é preciso que seja aprovado pelas leis de incentivo, que tenha um proponente, um produtor e um patrocinador. $O$ artista tem que chegar com tudo para a execução.

Não sei que comissão responde por algumas intervenções que vemos em estações de metrô - e também não sei como atua o Metrô para obras de arte efêmeras e intervenções - por convite? mas provavelmente age da mesma maneira como para obras permanentes - ou talvez como nas vitrinas da MASP, onde fornece apenas 0 suporte técnico para as diferentes montagens. Neste fornecimento tudo básico e lento, mas funciona.

Parece que a medida a tomar ou o caminho é este mesmo, não há lugar para amadorismo ou improvisações.

Pesquisadora: O tipo de tecnologia aplicada na obra Descendo a Escada, apresentada na Estação Brás, tem custo elevado? Considerando que nas estações de metrô estão presentes o efeito pistão (deslocamento de ar) e a trepidação, a obra exigiu manutenção frequente? Regina Silveira: Esta foi a resposta encaminhada por Marcos Cuzziol (do Itaú Cultural) que em sua mensagem disse que acompanhou a instalação da obra na Estação Brás, e sua manutenção, durante todo o período:

"...A tecnologia utilizada não tem custo especialmente elevado - a maior diferença de um PC de uso normal é a placa de vídeo com saídas independentes para os três projetores. As exigências de manutenção também não foram muito diferentes das de um ambiente mais controlado. Lembro apenas que foi necessário ajustar o sensor de presença algumas vezes, mas isso se deveu muito mais ao volume de público que ao ambiente em si. Entretanto, outras obras, que ficaram mais próximas às plataformas, apresentaram defeitos nos cabos de vídeo devido a vibração e exigiram estrutura reforçada nas telas de projeção para suportarem os constantes deslocamentos de ar."

\section{Entrevista Waldemar Zaidler}

Local: Faculdade de Arquitetura e Urbanismo da Universidade de São Paulo

Data: 15 de junho de 2012

Pesquisadora: Como parte do acervo permanente da Companhia do Metropolitano de São Paulo está a sua obra: Fiesta, instalada na Estação Sé. O trabalho foi concebido especificamente para o contexto, para o espaço da estação?

Waldemar Zaidler: Então, não foi. Esse trabalho foi feito para 18a Bienal Internacional de São Paulo, ao longo do ano de 1985. Na verdade, apesar de não ter 
sido especificamente pra um espaço do Metrô, pra aquele espaço específico, ele foi feito pra um espaço de circulação e de grande movimento de pessoas. É claro que são espaços de natureza totalmente diferentes, mas, na minha concepção daquela época, era o que menos importava porque, na realidade, o trabalho era uma síntese. Ele não se resumia ao painel. O painel sintetizava uma quantidade muito grande das mesmas imagens que estavam nele espalhadas pela cidade, convergindo para Bienal. Depois, não foi feito convergindo pra estação da Sé e como aliás, hoje, continua. Não vem convergindo pra lugar nenhum porque não existem mais. Essa efemeridade era um dado consciente, era uma coisa que estava ligada ao acontecimento da cidade como um reflexo desse acontecimento conscientemente separado.

Então, só acho que é uma coisa legal, que eu sei que você está estudando, não é? Na verdade, o que eu falei no começo, dele estar sintetizando uma série de coisas que estavam na cidade, isso, é uma coisa que diferencia um trabalho feito em ateliê e colocado, transposto. Acho importante fazer essa ressalva, porque o Metrô tem muita coisa que são obras de ateliê. Não, foi um trabalho produzido num contexto da cidade, num contexto público, com caráter de arte pública, relacionado com coisas que estavam acontecendo, e feitas por mim, com as mesmas imagens, com um sentido. Inclusive, eu tomei muito pito da Sheila Leirner que era curadora da Bienal porque o projeto era que as imagens vinham de vários pontos em direção ao edifício da Bienal, entrariam pela Bienal e seriam pichadas mesmo pela Bienal até chegar ao painel. Quando eu comecei esse pedaço, principalmente quando comecei colocar uns ratos espalhados por todas as colunas, a Sheila Leirner subiu nas tamancas, me puxou a orelha. Tá bom, não vou arrumar enrosco e o trabalho sofreu, eu acho que muito com isso. Não perdeu o significado mas perdeu uma das possibilidades, perdeu uma das possibilidades mesmo, mas enfim, essa ressalva é só para diferenciar, porque apesar de não ter sido feito pra aquele espaço específico, ele traz uma série de características da arte pública, da intervenção pública, da arte de intervenção propriamente dita que é o que diferencia esse trabalho de um mero, não que seja mero, desculpe, usei a palavra errada, mas de um trabalho feito num ateliê, concebido em ateliê e, simplesmente, transposto.

Pesquisadora: Como foi o processo para a apresentação e instalação do trabalho? Waldemar Zaidler: Foi uma coincidência que o Metrô tava iniciando o acervo. O trabalho, eu, particularmente, gostei. Um monte de gente gostou e eu achei uma judiação destruir aquilo, ia ser destruído, iam jogar fora simplesmente. Inclusive teve um episódio, uma anedota que quando já tava tudo certo com a Companhia do Metrô, que o Metrô queria ficar com o trabalho, eu fui à Bienal, já tinha terminado a exposição, comunicar que o painel iria para o Metrô. Eu falei com um sujeito que eu não lembro quem era, mas o cara me disse o seguinte: não, não pode, o painel é nosso. Falei, ué, mas vocês não tem acervo. Bienal não tem acervo. O quê que vocês vão fazer com isso? Não, não interessa: o painel é nosso. Mas, não tô entendendo. A resposta que eu ouvi foi a seguinte: a tinta é sua, o painel é nosso. Ele tava se referindo a um compensado de oitava categoria que eles tinham colocado lá, pregos, parafusos e caibros da estrutura, ele tava se referindo a isso. Ilustra bem para uma série de coisas assim que acontecem em nosso país, tanto que eu doei o painel pro Metrô, mas o Metrô teve que pagar pra Bienal a madeira, não é engraçado? Coisas de Brasil. É bem curioso isso, enfim, mas a história foi essa mesmo. Foi um trabalho que tava feito, que ia ser destruído e que tinha um desenvolvimento ali que parecia interessante pra mim e pra um monte de gente. Eu 
ofereci pro Metrô. O Metrô tava formando o acervo. Acho que, naquele momento, ainda não tava pra eles tão incorporada a ideia de site específico, de coisa assim. Gostaram do trabalho, acharam que iria bem, escolheram um lugar eles próprios, foram lá: ah! isso aqui vai cair muito bem naquele lugar que ele está até hoje e pronto, e foi assim a história dele.

Pesquisadora: O que pensa sobre a atuação integrada (projeto interdisciplinar) processo de desenvolvimento de propostas artísticas, arquitetônicas e de design para as estações? O que impede que esta forma de atuação aconteça de metrô de São Paulo?

Waldemar Zaidler: Eu acho maravilhoso, acho que é assim que deveria ser. Essas disciplinas todas não podem acontecer de modo separado, em momentos diferentes ou sob a batuta de algum maestro. Tenho uma visão totalmente humanista disso. Acho que sempre foi assim, teve um lapso modernista aí que interrompeu essa prática, mas que, na verdade, sempre foi assim antes e está voltando cada vez mais a ser. A diferença é que, antes, ia o Borromini, as pessoas que já concebiam o edifício com seus murais. Inclusive, o trompe l'oeil, vem de uma tradição muito próxima disso, de precisar fazer a cruz na nave da igreja e não ter espaço, então, faz-se a ilusão desse espaço. Enfim, é uma coisa que sempre foi concebida, pelo menos até onde eu sei, até onde eu pude estudar e perceber, de uma maneira única, integradíssima. O Vitrúvio, por exemplo, quando ele descreve os murais da antiguidade, fica claríssimo a preocupação que tem com a preservação, da boa preservação material da parede que era concebida pro resto da vida, à eternidade. As temáticas todas entram numa outra conversa, mas, de alguma maneira, o fato de se fazer, de se conceber um mural tinha suas funções estéticas e da época. Não, não vou entrar nisso, mas, tinha também o forte componente de estruturação da matéria. $O$ afresco realmente segura a parede por milênios e já é uma coisa que vem e que depois é retomada no Renascimento, vem toda a era moderna. No Modernismo é que blumba, dá essa quebrada, mas depois volta. Não tem como escapar disso aí, é mesmo no Modernismo, é uma coisa que já não dura pouco tempo e já um mundo de gente, de Rino Levi até outros tantos que já começam a incorporar novamente a questão do mural, tô falando do mural porque é uma coisa mais óbvia, mais fácil, mas isso se reflete em muitas outras coisas. Tem a Maria Bonomi, por exemplo, com os painéis de relevo, integradíssimos à arquitetura. Tem um monte de exemplos que faz essa coisa integrada. Quando se trata então da concepção moderna do espaço público, com toda dinâmica, com toda ambiência que isso envolve, pensar essas disciplinas separadamente me parece um absurdo total. Acho que a arquitetura, a arte, tem que sair realmente de uma concepção múltipla, polifônica, conversada, entrosada. Acho que é uma tendência que deveria caminhar pra existir.

Pesquisadora: Como você definiria o espaço das estações de Metrô de São Paulo? Waldemar Zaidler: Olha, tem estações e estações. Tem, inclusive, estações mais antigas e estações mais modernas, mais recentes. As estações mais antigas, elas têm, bom, eu não vou por este caminho do mais antigo e do mais recente não. Isso existe porque, principalmente, é uma coisa mais ligada a um encaminhamento político de como são feitas as coisas. Tem duas grandes vertentes que deve ser, eu não sei como, mas imagino que seja, uma briga boa dentro do Metrô na questão de arquitetura. Uma concepção de estação, de espaço interno da estação que privilegia, ou que procura privilegiar, a pessoa na questão do usuário não só do 
ponto de vista prático mas também do ponto de vista monumental. A estação do Metrô, no seu espaço interno, como uma coisa que agrega ao cotidiano da cidade um valor de uma monumentalidade, um valor de mudar mesmo, de tentar ser um lugar, de tentar ser um marco, considerando todos os não lugares que a gente já sabe, os Marc Augé do mundo, sem desprezar isso, mas é uma tentativa. Outro, é uma monumentalidade, por isso que eu falei um pouco sobre antes e depois, é uma monumentalidade externa, não também no sentido de um lugar que marca o ponto do Metrô. Aliás, é muito curioso porque o Metrô, num monte de lugar, no mundo inteiro, é da terra para baixo, você tem uma entradinha e pimba. Aqui, tá virando não consigo entender no sentido prático porque, mas está virando um negócio de edifícios, um do lado do outro. Você pega uma estação Fradique. Que é aquele prédio em cima da Fradique? Eu não sei, uma coisa de vai saber, manutenção, coisa técnica do Metrô. Tá, tudo bem, mas tem outro logo ali, são muito próximos, não dá pra entender o que que significa aquele, com o perdão da palavra, cagalhão que fizeram aqui perto da USP, na Vital Brasil. Para que um troço daquele tamanho para fora? Quer dizer, isso tem um significado. É um tipo de edificação que não dá pra entender o sentido, a necessidade, a não ser privilegiar politicamente uma relação externa, e nessas, a gente vê o espaço interno, na minha avaliação muito menos trabalhado do ponto de vista do usuário no que se refere aos materiais, no que se refere à própria arquitetura, ao desenho das peças, ao design dos equipamentos e tudo. Estações mais recentes, como essa que fizeram na Consolação, que chama Paulista e a que fica ao lado da Paulista que chamam Consolação, que tem na sua lateral uma vitrine da Casas Pernambucanas ou coisa que o valha. Ah! mas tudo bem, como é que chama isso, de lei, de legislação, de Cidade Limpa, só existe essa conversa porque levantaram aquela coisa com o revestimento que a mais pobre das padarias recusaria, com aquela pastilha hidráulica que sei lá que diabo, uma coisa primária, uma coisa demente, uma coisa assim sem nenhum cuidado: olha, é pro povo mesmo, puta, faz lá mesmo meu, tudo bem faz grandão que é pra todo mundo ver que fez, a sensação que eu tenho, não tô dizendo que seja isso, mas acho que a representação desses edifícios, desses espaços, dessas duas vertentes, uma delas representa isso. Outra delas, que se encontra nas estações mais antigas, e em algumas mais recentes também, como me agrada muito a do Alto do Ipiranga, por exemplo, é uma estação pra baixo, ela tem uma entrada arquitetonicamente concebida, com design bonito, uma estrutura legal. Parece um pudim, não sei se lembra como é. Uma estrutura de um pudim. Ali, uma coisa de luz, de claridade, ou seja, uma bela recepção, um ponto importante, mas que, simplesmente, recebe as pessoas, tem uma preocupação interessante. Lá dentro, tem espaços generosos abaixo da terra, espaços generosos com o usuário não só no sentido de caber o usuário, coisa que na Praça da Sé já não acontece, não cabe, o usuário não cabe lá dentro, isso é um horror mas daí também é uma questão de dimensionamento, de fazer outras opções. Não é o espaço em si, é simplesmente um espaço que ficou pra trás. É um monte de gente a mais pra nenhum espaço a mais, entupiu. Natural, isso não é culpa do espaço, é culpa de quem não fez mais espaço, outros espaços, outras alternativas com o crescimento da demanda da população, dos usuários, do número de usuários. Então, tem essas duas vertentes dos espaços internos do Metrô: uma que tenta tratar o usuário como gente, e eu acho que é essa a vertente que insiste, não importa de que maneira, se equivocada, se correta, se às vezes sim, às vezes não, mas insiste pra que tenha, por exemplo, a questão da arte que procura tratar a própria arquitetura como arte e, a outra vertente, que quer colocar lojinha, que quer colocar muambódromo oficial, que quer colocar o shopping center, 
que quer fazer coisas para fora, coisas que tudo bem, é prático juntar pontos de venda num lugar de grande circulação. Não sei, para muita gente não. Eu não sou urbanista, tem muito urbanista que fala que não, não sei, eu não entro no mérito, mas eu tendo a acreditar mais na Jane Jacobs. Jane Jacobs, por exemplo, fala que não tem nada que concentrar as coisas ali. Tem que diversificar, tem que deixar na rua mesmo. Tudo bem, pensamento lá de 1960, mas muito atual.

Pesquisadora: Você é considerado um dos precursores do Stencil Graffiti em São Paulo, mas também é pintor, cenógrafo, ilustrador, designer e é pesquisador de arte urbana. Parece-me que na sua obra Fiesta, fez uso da técnica do stencil para pintar uma ilustração, rica em elementos dispostos em layers, efeito muito presente em intervenções artísticas contemporâneas, possibilitado pelos recursos que as tecnologias atuais oferecem. O que pensa sobre o uso de tecnologias atuais (LED, célula fotovoltaica, mídia eletrônica, videoprojeções) em intervenções ambientais, não só temporárias mas também permanentes, para estações de metrô de São Paulo?

Waldemar Zaidler: Bom, eu acho que a questão da tecnologia é uma questão que responde à uma intenção do trabalho. Não sei te dizer se tecnologia $a, b$ ou c é adequada por si só. Eu não penso assim. A tecnologia é empregada na medida em que se tenha uma concepção no trabalho e, se usar uma tecnologia que favoreça essa concepção, ou seja, qualquer tecnologia é válida. Claro que nenhuma tecnologia prescinde de manutenção. Se for um afresco, a única coisa é a periodicidade da manutenção que varia, mas tudo, tudo precisa. A tecnologia não é uma prioridade. Não vejo a tecnologia como uma coisa que determina outra, pelo contrário, ela é determinada, ela é resultado. Claro que existe aí uma conversa que pode ser super rica, um diálogo entre a tecnologia e a conceituação, um intercâmbio de possibilidades e de desenvolvimentos que é super legal, mas não é isso que vai realmente determinar a coisa, por exemplo, é o fato de eu usar stencil nesse trabalho pro Metrô.

Pesquisadora: Foi isso mesmo? Você usou o stencil pra fazer uma ilustração?

Waldemar Zaidler: Não, eu não vejo aquele trabalho como um trabalho de ilustração. Ele é um trabalho que tem ali uma narrativa interna. Ele tem uma série de elementos que se articulam. Enfim, tem uma poética particular ali.

Pesquisadora: Parece uma cadeira, com uma luz sobre ela.

Waldemar Zaidler: Na verdade, a narrativa desse trabalho, pra mim, que pra cada um é uma coisa, é um universo composto por todas aquelas imagens. Inclusive, é uma coisa que, devido à iluminação, que não é lá grande coisa, pra não falar péssima, mas quando eu fiz o trabalho no espaço da Bienal, gozado como isso perde muita coisa nessa transferência de local e tudo, mas enfim, se olhar com atenção você vai ver que na parte mais escura do painel, ele também é super rico em imagens, só que não tão visíveis. De uma corneta sai uma luz, uma coisa completamente débil mental, não é assim que funciona. Dentro desse facho de luz, partes, algumas partes desses objetos representados são iluminados de maneira diferente. São realmente iluminados na medida em que eles revelam a cor, a luz. Não precisa falar mais nada. É nesse momento, naquela situação, essa é a narrativa naquela situação, o que foi iluminado dentro desse universo foi aquela figura. Fica por conta de cada um fazer esse truque dentro da própria cabeça e iluminar o que 
bem entender, na hora que bem quiser e, como depois, outros trabalhos, outros, é a continuação daquele trabalho. Eu fiz outros trabalhos naquela mesma linha, que trazem outros objetos, com outros elementos, mas sempre dentro da mesma ideia, inclusive, com mesmas cores, com o mesmo tipo de tratamento. Esse conjunto é importante. Ele, isoladamente, quer dizer quando se coloca. Vê, a sequência muda o entendimento também do trabalho, então, aí, o stencil ele simplesmente era uma tecnologia que favorecia, como eu disse, favorecia esse tipo de tratamento. Ficava mais fácil, ficava bem mais fácil, como da mesma maneira que você imagina aquele mundaréu de imagens. Não sei dizer quantas imagens tem ali aplicadas. Você imagina a prática do fazer daquilo lá? A questão, a vivência prática daquilo, que são estênceis grandes. Você tinha um espaço do tamanho deste salão caramelo aqui, onde nós estamos aqui. Salão caramelo não, desse ateliê. Um negócio enorme, tem doze metros, sei lá, dez, doze metros de comprimento e, as máscaras, os estênceis, são feitos em papel cartão duplex, com tamanho médio de meia folha e você não pode empilhar uma em cima da outra enquanto a tinta tá molhada porque gruda tudo. Então, você imagina a área que ocupa pra fazer isso aí 85. Quando em 87, eu me deparo com meu primeiro Macintoch, você imagina a maravilha, tecnologia. Como mudou a minha cabeça, as minhas possibilidades de trabalhar. Aproveitam essa articulação de imagens de uma maneira que se tenha uma terceira imagem, outras imagens, em função dessa articulação. E como essa tecnologia mudou meu trabalho. Claro, eu parei de usar stencil imediatamente, era muito mais fácil fazer no computador, muito mais imediato, podia explorar muitas outras coisas, ou seja, lógico, perde-se. Aí eu senti muito o que se perde em termos plásticos passando pra esse outro meio. Começa até dar uma certa, um outro tipo de avaliação. Aí sim, a tecnologia no sentido de percepção, no sentido de fruição, no sentido de proporcionar maneiras de se perceber diferentes, de proporcionar diferentes relações no ponto de vista de prazer, de proximidade, de tato, enfim, todas essas coisas que a gente sabe que tem. Nessa hora, começa a ter uma avaliação em relação à tecnologia. Hoje em dia, se eu tiver que fazer um painel nos mesmos moldes, se eu quiser fazer um painel, tiver oportunidade de fazer, certamente eu vou usar, dependendo claro, sempre, do espaço. Como eu tô te dizendo, a priori, não é a tecnologia, porque se for num espaço público, porém, interno, eu dificilmente usaria uma coisa, uma tecnologia dessas que você mencionou LED, uma coisa que pra mim, pra esse tipo de trabalho eu considero uma coisa mais fria Já num ambiente aberto, de grandes dimensões, talvez, eu preferisse isso, mas eu jamais usaria o computador e a impressão na plotagem como um truque, porque daí, pra esse caso eu tô falando, porque pra outros, eu inclusive já usei, eu não tenho nada contra. Então é assim, colocar tecnologia na frente do trabalho como a coisa que determina o trabalho é uma grande besteira, é uma bobagem, inclusive, é uma coisa que eu reparo. É pura falta de informação mesmo, falta de reflexão, para não falar uma puta de uma ignorância dos encomendadores dos trabalhos que colocam a questão da tecnologia na frente, tanto pra determinar o que eles querem, quanto pra determinar o que eles não querem. Se envolve determinado grau de manutenção, com uma periodicidade ou com um tipo específico então já não pode, ou seja, tá colocando a questão da tecnologia como um impeditivo pra fazer um trabalho que naquela tecnologia alcançaria a plenitude da sua linguagem. A tecnologia é consequência. Tecnologia, no meu entendimento, em qualquer área do conhecimento, é uma interface entre o conhecimento e a materialidade das coisas, só isso. No mundo real, só faz essa interface e só serve pra isso. Se você tira essa função de interface e coloca ela como um fim, tudo bem, pra quem gosta de tecnologia e quer estudar 
esse tal desenvolvimento, tecnologia, maravilhoso. Graças a Deus que existe gente que pensa assim, e que faz isso, mas não é arte, não se aproxima da arte, não tem picas a ver com a arte, a coisa em si, que fique claro.

Pesquisadora: Como definiria o espaço das estações de metrô de São Paulo? Considerando essas duas vertentes, principalmente considerando o usuário, você acha que esses espaços são espaços estritamente de passagem?

Waldemar Zaidler: Não, de jeito nenhum. Eu penso muito a respeito dos Marc Augé da vida aí. Acho super legal. É uma coisa que existe não-lugar, espaço de passagem assim, mas a questão do espaço não é uma questão inerente ao espaço. É uma troca e que envolve o ser vivente naquele espaço. A ontologia do espaço é dividida com o ser que nele vive. $O$ espaço de passagem tá muito mais ligado a uma questão da ambiência, que é revelada nesse espaço, e a ambiência depende de quem tá ali. Então, qualquer espaço é espaço de passagem e nenhum espaço é espaço de passagem. A gente não tem o Smitson andando lá no rio Passaic, aquela coisa maravilhosa eu acho que isso é uma situação, tem isso e tem um monte de, aquele George Simmel lá falando dos stimung, essa palavra alemã que remete à ambiência, que é uma coisa que existe na paisagem, nas considerações feitas sobre o entendimento da paisagem, que a paisagem só passa a existir quando rola esse tal de stimung, ou seja, é uma questão de percepção. Eu acho que toda consideração a respeito de paisagem desde aquela história linda lá do Mont Vertoux que sobe o Petrarca e, com todas as dúvidas, as angústias que ele revela naquele passeio, que é considerado por muita gente a inauguração da questão da paisagem no mundo ocidental, no nosso mundo, no século XIV já, século XIII, então é isso. Eu acho que os lugares não são ou deixam de ser, existe aí uma relação, por isso é importante a gente tratar da questão da arte pública, a questão dos ativadores desse espaço, e aí mais uma vez, a questão da tecnologia. Tecnologia voltando um pouco, a tecnologia não ativa coisa nenhuma. Ela é utilizada pra fazer com que uma ideia seja percebida, por quem tá ali passando e que possa detonar, possa ativar, possa funcionar como gatilho de uma percepção diferente daquele lugar que não é não-lugar, não é um lugar de passagem. Não sei, pra mim, eu funciono assim. Eu sou bem sincero e verdadeiro nessa coisa, sabe. Acho que existe essa concepção do não-lugar etc. etc., mas é uma coisa analítica, é uma coisa que sim, que deve ser considerada, deve ser pensada, na hora que se cai a ficha desse fenômeno, dessa possibilidade e aí você assume uma posição, uma postura política em relação à essa possibilidade e aí, como artista, como arquiteto, como seja lá o que for, performer, o diabo que for, você vai fazer ali algum tipo de intervenção porque, politicamente, você não quer que aquele espaço continue sendo um espaço. Você quer transformar ele num lugar e pra isso precisa um estímulo, só como uma ajudazinha porque o espaço pra virar lugar, ele prescinde desse estímulo, volto a falar do Robert Smithson, passeando lá em Passaic, é pessoal.

Pesquisadora: Qual o significado da arte inserida nas estações de metrô de São Paulo?

Waldemar Zaidler: Eu acho que antes de mais nada, bom, o significado da arte vamos começar a falar hoje e acabar... Eu não vejo o significado da arte no Metrô, diferentemente do que eu vejo em qualquer outro espaço público. Trata-se de espaço público e de arte pública. A arte pública tem duas funções básicas que são na verdade, inclusive, uma só. Eu, analiticamente, vejo dois grandes lados que é o lado digamos estético, filosófico, que é isso que eu acabei de falar, de fazer, de 
causar reflexões e convidar, eu vejo muito assim. Por exemplo, o meu trabalho no Metrô, eu fico satisfeito com isso. É uma coisa que tá ali convidando as pessoas a fazerem uma reflexão, um tipo de reflexão, não uma reflexão racional necessariamente, mas enfim, é algum tipo de movimento interno, ou seja, racional, nacional, sentimental, afetivo, o catso que for. É simplesmente um convite. Quer aceitar maravilha, não quer, maravilha também. Eu acho que a arte é assim, se tem repertório bateu, não bateu, paciência, ótimo outra coisa vai bater, alguma coisa, em algum momento, bate pra todo mundo, todo mundo. Essa é uma das... eu não gosto de falar função porque não é função, é um dos lados do fenômeno, e outro, é político. Acho que esse lado é um lado até mais objetivo, menos difícil de ser mais óbvio em relação ao outro que eu falei, ele é mais óbvio, ele é um lado que demonstra uma preocupação. É um tratamento de cidadãos como cidadãos. Cidadãos que merecem todo tipo de cuidado que a cidade possa oferecer, então, a arte é mais um deles, mais um desses cuidados fundamentais.

Pesquisadora: Pretende apresentar outra proposta de intervenção para o metrô de São Paulo? Fale sobre a proposta.

Waldemar Zaidler: Olha, nessas condições em que os trabalhos estão acontecendo no Metrô de São Paulo, nesse momento da minha vida e do Metrô, não pretendo fazer nada com eles, aliás, eu não pretendo nem andar de Metrô porque tá um saco, não é? Se possível, eu vou de táxi, entendeu, porque tá, a gente sempre tem que pegar Metrô, como todo bom cidadão, na hora do rush, porque é na hora do rush mesmo que a gente tem que fazer as coisas e, simplesmente, não dá, tá um saco, tá um porre, tá insuportável, não está funcionando legal, não está cumprindo o papel, ficou pra trás. O que eu acabei de falar, a cidade cresceu, o Metrô não. Não tá acompanhando proporcionalmente. Então, um serviço que num momento determinado foi interessante no ponto de vista prático já não tá sendo muito mais. Não quero nada com o Metrô no momento. Acho que a maneira que, volto a dizer, eu falei assim no momento, que não importa muito se equivocadamente ou não, é muito importante que se esteja sendo tratada por uma das vertentes porque eu sei que não é... Uma coisa é ponto pacífico dentro do pensamento da Companhia, mas é superimportante que tenha uma vertente tratando disso. Só que eu acho que há uma guerra na disputa entre as duas vertentes: a que não quer arte, a que acha que arte é uma coisa que não precisa, que é mais importante botar lojinha, e quando eu falo isso, eu falo com muita segurança porque eles colocam a lojinha na frente da obra de arte fisicamente encobrindo a obra de arte. Fizeram isso com meu painel, um negócio lá da Bauducco, uma empresa que assina tudo que faz, com a questão de responsabilidade social, com isso e aquilo e coloca uma lojinha, um stand mequetrefe, horroroso, sem design nenhum, na frente literalmente de uma obra de arte, provavelmente, porque pensa a mesma coisa da obra de arte que eu penso do stand deles: um painel mequetrefe aí, dane-se, então, tudo bem. É uma disputa que a lojinha tá ganhando. Isso faz com que a vertente que se preocupa com isso, escolha uma metodologia, um caminho, uma maneira de fazer as coisas, que a mim, neste momento da minha vida, não me interessa. Eu tentei, levei isso até um determinado ponto. Vi que os obstáculos extra-arte a serem transpostos eram, pro meu gosto, pra minha vontade nesse momento, intransponíveis. Não tô a fim, não quero, não tô a fim de pagar pra trabalhar. Em outras palavras, hoje, não me identifico politicamente com o Metrô como me identifiquei no passado. Naquele momento, pra doar alguma coisa pra essa Companhia, naquele momento político, já doei , eu doei, falei: Ô, tá vendo esse painel aqui? Bacana né?, Quer? Queremos. 
Maravilha, tó de presente pra você, só não tenho dinheiro pra pagar a madeira que a Bienal quer cobrar e também não tenho como transportar isso aí, nem instalar. Vocês fazem essa parte? Mas tá aí, pra mim foi uma maneira de garantir a manutenção do caráter público da obra, nesse sentido, acho que foi superimportante, mas essa facção que tava na em 1985, faz quanto tempo, faz a conta, eu sou ruim de conta, um tempo, né. Era um outro momento, era um momento de, realmente, uma Companhia que tava com intenções digamos, em relação à cidade, com pendências, claro. A disputa é uma coisa constante, tem que se lidar com isso, mas, naquele momento, dava pra perceber. O meu TGI, foi feito aqui na FAU, por isso que esse painel foi parar lá. Quando eu fiz o meu TGl, em 82, quer dizer, ao longo do ano de 81, o objeto de trabalho foram duas torres de respiração que tinha no Largo São Francisco, de fronte à Universidade, que hoje não existe mais, foi propor uma intervenção pra aquelas duas torres, e como era uma coisa que, na época, eu tava supermilhão por hora, fazendo já há uns dois, três anos e no ambiente da FAU, digo no ambiente acadêmico, não que eu pintasse, aliás, pintei muito aqui dentro, esse tipo de coisa que nós tamo olhando aqui, que é uma folha pichada aqui, na coisa nossa. Se não fui o primeiro, fui o segundo a fazer, acho que fui o primeiro a fazer aqui na FAU. Então, é inclusive aqui, no ambiente interno aqui da coisa, mas falando com um pensamento acadêmico, fazendo na cidade $e$ então eu me aproximei do Metrô nesse processo do TGI, porque eu queria de fato concretizar aquilo, queria fazer do ponto de vista acadêmico, e queria também como design. Eu comecei a ver um monte de gente, tive uma relação, uma abertura pra tratar desse assunto lá, e com pessoas, com um grau de envolvimento, de conhecimento, de informação, de sensibilidade muito diferente do que há hoje. Essas pessoas, não, nenhum julgamento de valor, mas é claro que essa diferença entre as pessoas que tratam desses assuntos, o poder que essas pessoas têm, detêm pra tratar esses assuntos, inclusive, muitas daquelas pessoas continuam lá, são pessoas ótimas, mas, simplesmente, com poder super reduzido em relação ao que tinha naquela época pra esses assuntos, ou seja, são esses conflitos que, ora vai assim, ora vai assado e isso é assim mesmo, em qualquer empresa, em qualquer instituição do planeta que seja regida por esse sistema que a gente vive. Nesse momento, com a balança pendendo mais pro lado que está pendendo, eu não quero, como falei, nem andar em Metrô.

Pesquisadora: Você falou que chegou a tentar, mas você chegou a apresentar alguma proposta?

Waldemar Zaidler: Sim, apresentei uma proposta para a estação Alto do Ipiranga, que é uma belíssima estação.

Pesquisadora: E você tinha pensado em usar que técnica para esse trabalho? Ou não tinha chegado nesse ponto?

Waldemar Zaidler: Não, tinha chegado sim. Está até esboçado. Era um grande ... o nome dele é engraçado: chama o Rizoma do Ipiranga. A ideia seria atarantar. Isso em função do espaço. Uma coisa bem ..., aí sim, total site específico, inclusive, inspirado na estrutura total daquele pudim, no posicionamento das escadas rolantes e tudo. Seria uma série de elementos, de barras atarantadas numa estrutura que ficaria na própria estrutura, inclusive, mimetizada com a estrutura da cobertura, seguindo a mesma linguagem, o mesmo padrão, o mesmo tudo. Essas barras seriam independentes, mas elas se tocariam fazendo com que houvesse um 
movimento rizomático mesmo. Todo mundo tocando em todo mundo e, cada um, fazendo seu movimento em função desses toques e tudo girando ao mesmo tempo. $E$ aí, ligando essas barras, que foi isso o que eles imputaram. Em alguns momentos, ligando a barra $A$ pendurada no ponto $A 1$, lá no teto, ligando com a barra $B$ pendurada no ponto B1, lá no teto. Até de uma maneira articulada teriam imagens que se remeteriam à ideia do Grito do Ipiranga. Daí de um ideário que eu tava compondo na época, e que, não o caso de apresentar esse ideário, mas que iria desde Almeida Junior até todo o outro lado da história, a caganeira do D. Pedro, ou seja, eu iria botar uma farra ali, mesmo. Alguma coisa com imagens recortadas em algum material $X$. Como é que chama isso? Rígido. Na verdade seriam os positivos dos estênceis.

Pesquisadora: Entendi. É uma máscara, não é? O stencil é a máscara e você fica com o miolo.

Waldemar Zaidler: Isso. Seriam os miolos interligando os miolos num universo representativo dessa temática do Grito do Ipiranga compondo e fazendo essa interligação entre algumas das barras e, eventualmente, projetando sombras. Eventualmente, não. Projetariam sombras nos espaços mais escuros que daí são aqueles espaços generosos que eu te falei, ou seja, uma coisa que ...) Sombra porquê é um espaço fisicamente iluminado, inclusive naturalmente iluminado. Mas, quando não pela luz do dia, com luz artificial e daria para fazer fotos. Enfim, daria para fazer com que o trabalho realmente se expandisse em termos de ambiência, para outros níveis da estrutura. Para outros andares da coisa. Provavelmente ...Eu achei assim ... gostaria muito de fazer. Eles gostaram também. É que daí começa com essas histórias ... Então vamos fazer o seguinte, vamos não fazer, que fica melhor pra todo mundo. Faz aí do jeito que vocês quiserem e eu faço outro. Ideia, graças a Deus, não é o que me falta e pronto. Não tem embaço. Pronto.

Pesquisadora: Puxa, que pena, seria um trabalho bem contemporâneo.

Waldemar Zaidler: Seria interessante, contemporâneo e com zero de tecnologia, de não dar dor de cabeça pra eles, o que é pior. Porque eu até bolei, sabe, um jeito que essa estrutura descia e tinha uma articulação que ficava ao alcance da mão pra fazer a limpeza das peças com uma vassoura, de seis em seis meses, pra tirar o pó. Não depende de nada. Não tem peso. Não depende de nada. Nada. É uma coisa que tem movimento, mas é um movimento iniciado pela corrente de ar ou por um desequilíbrio proposital de uma peça que fique ali, num pêndulo, ou até por um sensorzinho que quando o negócio para, dá uma empurradinha, sabe. Plim! Uma coisinha já é o suficiente pra detonar todo o movimento, questão sonora, questão de iluminação, som e um chamado para essa representação ainda que o Rizoma não esteja presente, ou seja, não seja representável, mas uma representação da ideia. Principalmente na época que eu fiz essa proposta eu estava tentando entender um pouquinho - não entendi até hoje e nunca vou entender, não faz mal, mas estava inspirado por essa coisa. Então, rolou desse jeito. Pois é, então, o trabalho que é o meu objeto de pesquisa no momento, o motor da minha pesquisa que é como você explorar artisticamente questões relativas à alteridade, à diversidade $e$ à interatividade sem reduzir, principalmente, a interatividade - que é um fenômeno que eu tenho notado - ao lado de consumo. Que é o famoso: aperta aqui acende ali. Faz micagem daqui, acontece micagem dali. Isso tem acontecido em inúmeras propostas artísticas que julgam, que se anunciam, como exploradoras da questão, por 
exemplo, da interatividade. Há uma redução de consumo. É uma redução consumista da interatividade porque acaba saindo, ficando numa interatividade de atitude e que escapa, acaba a interatividade de linguagem. E de despertar uma questão interativa interna no usuário - que eu acho que é isso que importa - para que essa interatividade internalizada resulte numa atitude, aí sim, interativa socialmente. Não que eu tenha alguma coisa contra apertar aqui e acender ali. Não. Eu acho o maior barato. Toda vez que eu acho um eu fico fazendo micagem. Eu fico aproveitando. Não tem problema nenhum. Inclusive eu tenho um monte de ideias de fazer trabalho que funciona nesse sentido, mas eu vejo que é como tudo, sempre, começa virar uma moda e que fulano chega lá na exposição. Eu vi crianças, testemunhei crianças na exposição, essa da Pinacoteca que ainda está lá, me foge o nome, do Giacometti, não é? Eu vi criança procurando onde é que apertava. Onde é que é para apertar? O que é que vai ..., ou seja, aquela um pouco de parque de diversão. Essa ... o que acho assim ... um viés de popularização da arte totalmente equivocado. Popularizar a arte não é fazer parque de diversão, não. Não é fazer apertá aqui, acendê ali. A popularização da arte passa pela outra parte da nossa conversa que é a questão das políticas públicas. Que é a questão de descentralização. Que é a questão de abertura de aceitação da diversidade, da alteridade no sentido de dar voz a propostas que são consideradas espúrias. Que são consideradas vândalas. Que são consideradas amorais. Que são consideradas inadequadas pelo estabelecido. Isso sim é popularizar a arte. Ir contra, mexer nessas questões é popularizar a arte. Transformar num parque de diversão é entrar no sistema e fazer com que alguém faça da arte uma maneira de cobrar ingresso. $O$ cinema é interessante como uma coisa que fica nesse limiar. E tem tantas obras tão interessantes. Cinema de arte mesmo. Profundíssimas, maravilhosas. E que não tem bilheteria. Às vezes tem. E nada de mais ter. Não tenho nada contra ter. Maravilhoso. Se todo mundo conhece o Giacometti, se todo mundo conhece o Picasso, se a exposição do Rodan a fila dá volta no quarteirão, é maravilhoso. Não tem nada demais. Só que, como artista eu acho que o papel da arte vai além do apertá aqui, acendê ali. Mais uma vez, acontece isso quando a tecnologia é colocada no primeiro plano. Coloca tecnologia em primeiro plano, acontece isso. Graças a Deus que tem gente assim fazendo isso, porque assim desenvolve a tecnologia. Mas isso não é arte, em minha opinião. Tem lá suas interseções, como tudo na vida, a sua aderência, parte comum, mas não sinto e não penso isso como arte.

Pesquisadora: Muito interessante. E essa proposta que não foi adiante no Metrô. Você chegou a esboçar alguma coisa?

Waldemar Zaidler: Sim. Desenhei.

Pesquisadora: E eu posso ter acesso?

Waldemar Zaidler: Pode, claro que pode. Total. O projeto completo. É um projeto super simples, que foi feito com caneta Bic, um croqui mesmo. Mas eu acho que dá para ter uma visualização mais do que suficiente para uma coisa que eu tenho que correr atrás. Não estou recebendo uma encomenda. Olha, faça assim e eu quero saber se você fez direito. Não. É assim: o espaço é meu, o trabalho é seu. Todo o trabalho é seu, então, que seja todo. Vai sair como eu quero independente de você gostar ou não. 
Pesquisadora: Até que ponto regras normativas influenciam no projeto e na forma de atuar do artista?

Waldemar Zaidler: Apresentei uma proposta que houve um pedido. Quando eu apresentei a proposta, eu não sabia, não sabia, que eu teria que, caso fosse aceita, correr atrás da realização disso, conseguir dinheiro, conseguir patrocínio, conseguir tudo, e ainda por cima, convencer uma coisa chamada manutenção das questões da tecnologia que é o seguinte: Ah! pode por, mas quem manda se o trabalho, a linguagem, quem manda na tecnologia é o departamento de manutenção. Olha que maravilha. Olha que casamento perfeito: arte com manutenção. Vá pro meio do inferno, não tem cabimento um negócio desse. Eu não sabia. Eu propus esse trabalho, o trabalho foi muito bem aceito, gostaram bastante, mas começaram a pedir um determinado tipo de detalhamento que indicava duas coisas: uma, a questão da manutenção que eu já falei e, outra, a questão de censura à palavra, e essa, eles queriam saber exatamente como seriam as imagens. Claro que, numa estação do Alto do Ipiranga, o tema Ipiranga paulistano estaria presente e isso foi explícito na proposta mas não desenhado. É uma proposta, não um trabalho definitivo. Queriam um detalhamento de como seriam essas imagens, ou seja, queriam saber exatamente qual abordagem seria dada a essas questões, que do ponto de vista, de alguém lá, ou de alguens, são questões delicadas. No meu ponto de vista, não tem nada de delicado, aliás, nem nessa, nem em nenhuma outra, não é? Então, em vista disso, pediram isso, me deram prazo pra fazer essa, digamos, retificação de projeto, esses esclarecimentos de projeto e eu pensei bem e falei: olha, puta, não vou esclarecer porcaria nenhuma dentro desse esquema porque não tô afim de negociar isso nesse momento, noutro momento, talvez, tivesse. Isso é da mesma maneira que um lugar não é passagem por si só. Uma Companhia, um freguês, também não é freguês por si só, sempre tem que ter aí uma ida e uma volta, então, mais por causa disso.

Pesquisadora: Porque não tinha um regulamento né. Esse ano que eles puseram regulamento no site pra obras permanentes que fala aí todas essas questões que você tá colocando.

Waldemar Zaidler: Olha, talvez até tivesse, talvez até tivesse esse regulamento e por falha minha não eu num tivesse visto, mas eu fui convidado. Quando me convida pra um jantar na sua casa, se você me convida pra um jantar na sua casa numa quintafeira eu, mais ou menos, sei que roupa que eu vou, sabe, não vou aparecer de terno e gravata e não vou aparecer de bermuda e boné, entendeu? Porque é um jantar na casa da Ewely, então, são coisas da prática social que envolve os negócios e as relações profissionais que, se daí eu chegar na quinta-feira à tarde e tiver mais dezoito pessoas todas de fraque, eu vou me sentir, falar: pô Ewely, você não me avisou, você me convidou o catso, fala que o negócio é assim, não é, ia ficar chateado com você, ia mesmo, como fiquei chateado com o Metrô, falei: pô, tudo bem que vocês tem publicado isso aí. Dane-se eu não vi ué. Eu não fiquei chateado, simplesmente falei: ó não dá, é, assim: desculpe hoje, só amanhã, não vai rolar, então não. Eu acho assim que essa parte da nossa conversa é uma parte da questão prática que entra no dia-a-dia, na coisa que tem muito pouco a ver com arte, pra não falar, nada a ver com arte. Eu gosto muito, são coisas assim, que fazem parte do fazer artístico, que possibilitam na verdade a concretização das obras de 
arte dentro de um determinado âmbito. Quando se trata de arte pública, é um âmbito muito restrito, principalmente depois de um movimento que começou já há uns quarenta anos atrás, cinquenta anos atrás, do qual eu fiz parte. Eu ainda faço, de uma certa maneira, que é ignorar esse tipo de encomendador e perceber que existem outros encomendadores pra questão da arte pública que não passam por essas coisas, então, da mesma maneira que existem outros circuitos de arte a serem explorados além das galerias, além dos museus, enfim, as coisas vão se multiplicando. Eu acho que esse fazer, num determinado momento, a sua intenção do trabalho, o trabalho tem sentido dentro daquele âmbito, daquela instância de encomenda, de instituição, enfim, que ocupa esse lugar determinado dentro do campo vastíssimo da arte pública, aí, não há esforços a serem medidos. Pra mim é assim, da mesma maneira que eu não tinha medo de polícia que me impedisse pichar, entendeu, é da mesma maneira que não tive medo de encarar um monte de careca de terno atrás duma mesa na hora de fazer um mundaréu de painéis que eu fiz em espaços, em instituições como o SESC ou coisas desse naipe, porque eu achava que, naquele momento, valia a pena fazer e então eu fui às últimas consequencias e fiz. São coisas do fazer. Eu gosto muito das histórias lá de Roma, das brigas entre o Borromini e o, ai, como é que chama, nossa, o cara mais importante dos estados, da cidade de Roma? Bernini. Bernini e Borromini brigando com influência da sobrinha do Papa, isso e aquilo, pra ver quem fazia a Fonte dos Cinco Rios. Daí, no fim das contas, ganha o Bernini e ele bota um deles lá, que eu não me lembro qual, olhando pro lado, cobrindo o rosto com lenço assim, que é pra ele não olhar o prédio do Borromini que tá no outro lado da rua. São coisas, anedotas interessantes. O pai do Bernini, não sei se você sabe disso, quem conta é aquele Simon Schama, era o cara em Roma correspondente à SABESP de hoje, aqui de São Paulo. Era o cara que manjava de todos os recursos hídricos, de todas as tranqueiras, por isso que o Bernini era tão craque em fazer fonte. É porque ele tinha um pai que ensinava tudo. Ele aprendeu um monte de coisa de água, de engenharia de água mesmo. Era o cara que cuidava da questão do saneamento, ou melhor, do abastecimento de água de Roma. Gozado esse negócio, que não são por acaso, ou seja, esse lado, voltando ao Metrô, esse lado do fazer, da burocracia do fazer, dos trâmites do fazer artístico, ele é superimportante, ele conta, ele influencia o trabalho, ele influencia a escolha de tecnologias, ele influencia um monte de coisa, mas não tem picas a ver com arte na minha opinião, entendeu? Aí é outra coisa, eu como artista, como arquiteto, como designer, como pesquisador, eu encaro essa tranqueirada toda se o trabalho tem a ver com a minha ideia artística, se a minha necessidade artística tem a ver com isso, se não, não quero. Agora, eu tô correndo atrás, por exemplo, por causa de uma bobagem que eu inventei aí. Eu tô correndo atrás de um treco que é o seguinte, aliás, se você tiver alguma ideia me ajuda, que é um negócio de acender fogo. Eu preciso de um negócio que acenda fogo em sequencia, como se fosse uma boca de fogão. Um fogareiro, sabe, aquele negócio que acende o aquecedor? O gás no aquecedor de gás, aquele piloto. Eu queria um negócio que fosse uma sequência de uns 150, 200 pilotos, um do lado e do outro, de maneira que, controlado por um sistema de automação pra que os foguinhos acendessem assim, assado. Eu tô falando com uma empresa de automação industrial japonesa, tô entrando em contato com o corpo de bombeiros, tô falando com o negócio de aquecimento de gás, esqueci o nome da empresa, esse que faz chuveiro, negócio de chuveiro que tem esse pilotinho, enfim, você percebe que eu junto um monte de tranqueiras de tecnologia, né, de automação de sensores, de acendedores e tudo que é uma coisa pra ninguém ver, é pra ficar tudo 
escondido. O que me interessa é acender um foguinho atrás do outro, então, eu vou atrás disso tudo, isso é pra alguém trabalho artístico.

Pesquisadora: Você atua como arquiteto também?

Waldemar Zaidler: Não como arquiteto. Eu sou designer. A prática do projeto de arquitetura tradicionalmente concebido não. Adoro, acho assim a concepção de espaço, de coisas, mas eu vou até o croqui $n^{\circ} 0$, assim, partido, daí pra frente eu chamo os universitários.

Pesquisadora: Só voltando um pouquinho nessa proposta que você tentou levar adiante no Metrô e que foi interrompida, no desenvolvimento dessa tua proposta, você chegou a ter algum contato com o arquiteto que projetou a estação?

Waldemar Zaidler: Não, não tive. Não chegou nesse ponto. Chegaria, quer dizer, eu não sei, é porque assim, o convite surgiu, na verdade, como continuação duma história em que havia a vontade de um determinado departamento do Metrô de realizar um projeto que eu tinha proposto como alternativa para um projeto que eles me convidaram para participar de uma concorrência. Então, foi assim: existia uma necessidade do Metrô, eles determinaram não sei por quais vias uma concepção de projeto, de solução pra aquela necessidade, chamaram alguns escritórios, os escritórios propuseram soluções, inclusive o meu, dentro do que eles tavam falando . Eu propus uma solução dentro do que eles tavam falando, e eu falei: ó isso aí que vocês tão pedindo, desse jeito, eu faço assim ó. É uma porcaria, não vai dar certo, é uma droga. Eu acho que devia ser feito assim ó, e aí, entra numa seara. Eles gostaram, eles concordaram comigo, falaram: puta, que legal, é isso mesmo que a gente queria, como a gente é burro, oba como você é legal. Eu fiquei super feliz, só que aí foi um tiro no pé porque como é uma coisa completamente burocratizada, teria que pegar o meu projeto e colocar como solução pra que pudesse ser feito novamente uma concorrência e aí eles não conseguiram separar o projeto que poderia simplesmente entrar num acordo com eles e falar olha, o projeto é esse, custa tanto e eu não participo da concorrência, tudo bem, vocês me compram o projeto e fazem com ele o que vocês, bota para construir quem vocês quiserem, com o desenvolvimento que cada um irá propor, maravilhoso, mais que bacana, pra isso que serve projeto, aliás. Não, não, essa possibilidade não existe. Então, criou-se um impasse, um impasse que durou mais ou menos uns dois anos, com reuniões trimestrais e, cada reunião desta, gerava uma emergência de apresentação de não sei o que, que me dava um puta dum trabalho pra segunda-feira que vem, essa reunião era na quinta de tarde, sabe, uma coisa assim. Eles realmente gostaram da coisa até que surgiu um determinado momento que eles falaram assim: puxa essa coisa que você tá fazendo podia virar uma intervenção artística propriamente dita, eu falei : puta, mas é isso mesmo, por isso que vocês gostaram, era pra mim tá muito mais, era pra tá resolvendo uma coisa, numa escala pequena mas que, na verdade, tá embutido aí dentro esse potencial. Ah então faz aí, tá, tá no momento certo, vai ter uma reunião agora de coisa, tal, faz aí uma proposta pra ser submetida nessa reunião, que é uma reunião de curadoria que seleciona os trabalhos para, é, pra se ferrar, (risos) pra ir atrás, fala ó legal, hein, seu trabalho é bacana, faz aí meu, tchau, desde que você não me mexa, obedeça a manutenção. Então aí, foi essa a história. Foi desse jeito, então eu rapidamente fiz essa proposta, pra mudar de patamar, sair daquele ambiente e passar pra outro. Foi pra essa comissão, essa comissão gostou, porém, pediu aquelas coisas que eu te contei. Pediu uma porção de coisas, por um lado técnicas, que botava a tecnologia na frente de tudo e, por 
outro lado, uma coisa que eu senti como uma censura, como uma possibilidade, não que fosse essa a intenção, não tô acusando ninguém de censor, nem de nada, mas, é, sabe, é uma coisa que já me causou um desconforto suficiente para, somado com ir atrás, me fizesse falar: ó, num, mais uma vez, insisto, acho que é um momento político da Companhia. Isso acontece em todas as Companhias. É normal. Em algumas, isso é revertido e fica um tempo assim, em outras não, fica assim, um século, aí, depois abre uma brechinha, ao contrário. É uma questão de momento, acho que é uma questão assim de política.

Pesquisadora: Gostaria que falasse um pouco sobre o seu Trabalho de Graduação.

Waldemar Zaidler: $O$ meu TGI foi um audiovisual que mostrava uma documentação ampla da questão das imagens espalhadas pela cidade explorando a questão das narrativas, como é que fazia isso. Detonava, explorava a ideia de narrativa visual. $E$ aí, a questão da proposta do tratamento daquele espaço específico do Metrô, dos respiradores do Metrô. Mostrava, daí sim, a questão da construção tecnológica que eu pretendia para aquela linguagem específica. Aí sim, aquela linguagem específica, com aquelas imagens específicas que eu entendia interessante para colocar naquele lugar. Aí sim, total ser específica. Eu me propunha usar uma tecnologia $X$ que era o stencil. Por quê? Eu estava super envolvido com isso e porquê, de fato, teve um avanço na questão estrutural de concepção da imagem feita com stencil. Um deslocamento mesmo do tipo de imagem, possibilitado pelo stencil, que eu achei interessante registrar. Então, nesse audiovisual, tinha passo a passo a construção de um stencil, fotografado passo a passo com os elementos que a gente tinha introduzido na linguagem em si. Que é uma puta de uma bobagem, mas uma bobagem tecnológica. Sabe qual a tecnologia que revolucionou? Dizer que eu revolucionei é um exagero, mas fez o deslocamento mesmo: grampo de grampeador, desse aqui que segura papel no canto. Grampo. A questão é a seguinte, a linguagem do stencil, que é um negócio mais velho do que andar para frente. No século XIX, era utilizada principalmente na arquitetura americana para fazer aqueles barrados de pintura nos quartos, uma coisa que meio que concorria com papel de parede, ou seja, uma coisa do século XIX total. Se bobear um pouco, até do XVIII, final do XVIII e de antes disso também. Está dentro da técnica de reprodução de silk screen etc. Era uma coisa, era uma estrutura vazada e autoestruturada enquanto objeto, ou seja, resultava num tipo de imagem que era composta por áreas e não por linhas. Então o que acontecia? Você tinha, por exemplo, essa folha que nós estamos olhando aqui, você vê que a linha não era uma linha contínua, o que obviamente era um dado de linguagem - acho até legal tirar uma foto mesmo. Se você continuar esse traço, essa parte aqui do meio cai fora. Então, o que faz com que a linguagem própria, histórica do stencil ,seja outro tipo de coisa. E que você tem o equilíbrio de claros e escuros fazendo o próprio desenho, ou seja, um desenho de contraste e não de linhas. E aí, quando você tem o grampinho, ele possibilita a continuidade da linha, ou seja, você tem uma nova possibilidade de desenho com a utilização do stencil. Tudo bem, aí fala assim: uma coisa que a gente pensava, mas aí deixa de ser stencil. Tudo bem, o que nos interessa não é o stencil em si ou a coisa em si. O que nos interessa é a mágica de fazer desenhos em segundos na cidade, tomar de assalto uma coisa, pichar mesmo. $E$ isso possibilita, leva a mágica a um departamento diferente que é a indagação: puxa vida, olha aquele desenho, como é que faz um desenho, que deve levar um tempão para fazer, que eram desenhos super complexos, nesse lugar que não pode fazer? Essa estranheza já era suficiente para causar uma percepção ontológica do 
espaço nas pessoas que encantava. Não o desenho em si. Eu sempre falo isso: $O$ grafite, pra mim, não é uma estética formal, é uma estética relacional. É outro papo. É a atitude envolvida nisso, todo o histórico envolvido nisso que as pessoas compram. Quando elas se apropriam de uma imagem, elas querem aquela imagem dentro do quarto, na parede da casa, na camiseta. Elas estão comprando o histórico. Aquela imagem é um sinal de atitude. Ela funciona como um rastro, uma marca da atitude. E é isso que é o barato. Então o stencil, mais uma vez, a tecnologia, em função de perseguir esse fato foi um puta de um barato. Por isso, no meu TGl, tem na construção essa coisa do grampinho, daí como é que é que faz. O que virou uma escola mesmo. Esse TGI ganhou trilha sonora e foi feita junto com o Carlos Matuck, com quem eu trabalhava normalmente. E o fotógrafo era o João Paulo Capobianco, esse que virou braço direito da ministra da Saúde, biólogo e fotógrafo. Ele já mexia com questões ecológicas desde a ECA e tudo. As fotografias eram dele. Esse material foi exposto com um sucesso totalmente inesperado na Galeria Fotoptica. E por conta desse evento, o Casimiro Xavier de Mendonça, que na época, logo depois disso faleceu, ele era o cara que cuidava das questões de arte na Veja, que na época, ainda era uma revista diferente do que é hoje - vamos dizer assim - que tinha um posicionamento político um pouco mais apurado, um pouco mais comprometido com algumas coisas ... Então, deu uma matéria de três páginas completas falando disso. Era uma coisa que já vinha vindo desde o Alex Valério, principalmente. Mas muito centrado na figura do Alex. Nessa época, o Alex viajou - ele estava fazendo um curso nos Estados Unidos. Eu acho que foi assim, o primeiro grande acontecimento de mídia, porque três páginas na Veja, naquela época não vinha sozinho. Era uma coisa, como eu disse, uma revista tinha um peso diferente do que tem hoje no cenário da imprensa. Isso, nos anos 80, comecinho de 82. Eu apresentei o TGI em 81, então já estava pronta. Era bem diferente. Então na rabeira disso veio televisão, veio jornal para caramba, veio um monte de coisa. E pela primeira vez, não centrada na figura do Alex, o que era um dado super importante para o desenvolvimento do fenômeno como um todo porque foi uma ampliação, aquela coisa que era ... ainda que ligada a ele. O nome dele aparecia, ele tinha participação. O fato de você ter outro foco significava abertura de diversidade de um fenômeno que tava centrado em um que sabia um pouco maior, mas que, de repente, a nível nacional, já não era mais um, eram grupos. Ficou no plural e, a partir daí, as coisas tomam um rumo bastante diferente. Então esse momento foi um momento muito importante, sem dúvida nenhuma. Foi um momento fundamental no desenvolvimento dessa novela aí. Uma coisa importante. E é isso.

Pesquisadora: A partir dos dados colhidos em pesquisa foi possível observar que $40 \%$ das estações não possuem obras permanentes, enquanto em outras, há uma concentração de obras instaladas. Qual medida poderia ser tomada para mudar esta realidade?

Waldemar Zaidler: Você já viu falar no el paredon, el paredon? (risos). Não? Aquela coisa que os cubanos botavam no paredão e metralhava todo mundo? Essa seria a medida, seria a medida mais sensata, eficaz, rápida e não vou dizer indolor, porquê ia doer um monte. É assim. É meu, isso é um reflexo. Tem uma coisa que eu li recentemente, que eu acho que é muito interessante, que responde isso de uma maneira sensacional, que é uma parte de um livro da Lucrécia Ferrara que se chama Estratégia dos Signos, que é a parte final que ela faz uma análise da questão da reforma da Praça da Sé, que sofreu a última etapa da reforma da Praça da Sé, que foi em função do Metrô e que comenta isso com uma lucidez sensacional. Isso 
mesmo, o que não é assim nesse país, o que não é concentração de renda, concentração de cultura, concentração de arte, é concentração, concentração, concentração, não é? E pronto. O que fazer em relação a isso, é paredão, revolução. Não tem o que fazer em relação a isso. O que tem que fazer é o seguinte: vamo estudar, vamo tê uma atuação política em relação a como é a exigência de criação, manutenção e evolução de políticas públicas que tratem da arte porquê, isso, não é uma questão do Metrô. O Metrô tá dentro de uma, aliás, dentro das políticas públicas o Metrô tá cinquenta anos à frente, é um exemplo. Com todos esses problemas que a gente sabe, pô, pegar uma cidade como São Paulo, as questões das políticas públicas em relação às questões visuais, particularmente a questão da arte na cidade de São Paulo, engatinham. É uma coisa, nossa, que beira à indigência. É exemplo a Cidade Limpa, que é um avanço. Na minha opinião, é um avanço, mas é um avanço totalmente desvinculado de qualquer tipo de conhecimento, qualquer tipo de pesquisa, qualquer tipo de reflexão mais aprofundada, é, puta, é completamente sem pé nem cabeça, não é? É uma medida que, praticamente, teve um reflexo interessante. Teve vários reflexos e tudo, mas não traz nela e é compreensível que não traga. Não é nenhuma acusação, não é nenhuma é, como que chama? Nenhum demérito. É uma coisa historicamente compreensível porquê é uma coisa que não existia, nunca existiu, como é que um negócio então já vai começar. É um primeiro passo pra falar: bom e agora? ah! Então, acho que a gente precisa tratar de uma política pública pra ver como é que fica esse negócio e eu fiz essa pergunta publicamente pra Regina Monteiro. Você sabe quem é? Numa palestra que ela fez no Instituto Maria Antonia, a respeito do Cidade Limpa. Eu tava na plateia. Perguntei publicamente essa questão das políticas públicas e ela falou: olha é tudo feito assim, um a um. Em relação às propostas, como é que faz pra encaminhar essas questões da arte na cidade? Resposta dela, literal: análises de projetos, um a um, com o chicotinho, repito gravador: chicotinho na mão. Essa foi a resposta literal da pessoa encarregada, supostamente, encarregada da manutenção do visual da cidade, ou seja, totalmente desvinculada, não existe a menor noção do que possa ser uma política pública nesse setor, na cabeça dessa pessoa e, por consequência, conheço várias pessoas daqui, pô muito bacana, hein, não tô falando mal deles não. É um momento em que fica cristalizada, fica visível, patente a ausência do pensamento da criação, da existência de qualquer tipo de política pública e é em relação ao visual, o que dirá então em relação à arte? Ou seja, a questão da concentração é um reflexo político de como as coisas são encaminhadas na cidade e o Metrô não foge à regra. $O$ Metrô poderia sim ter iniciativas como tem, por exemplo, centros culturais como o Banco do Brasil etc., até mesmo o Itaú, de criar mecanismos, de facilitar a intervenção artística, inclusive com coisas efêmeras, com eventos, com performances, com tudo isso que a gente sabe dessas possibilidades todas de maneira mais móvel, mais ágil, barata inclusive, não barata no sentido de pobre, barato no sentido de exequível, de dinâmico, de tornar uma coisa dinâmica, partindo de concepções, digamos, mais contemporâneas do que o mural, do que o painel, do que a escultura. Como inclusive existe aquela intervenção do piano lá, eu acho superbacana, não é? Bota um piano lá e vê o que acontece. Isso é uma coisa saudável, baratíssima, zero de custo. Um piano alugado, zero, e que poderia tá numa posição de lugar inclusive com outros tipos de instrumentos, com outros tipos de coisas, e até com oficinas de instrumentos. Pra se fazer ali bate-lata, enfim, 0 diabo que pudesse ser feito, mas você percebe como é uma coisa política e isso dependeria daquela tal vertente, ganhar uma força política, um poder que 
simplesmente tá subjugado à questão de lojinhas, à questão de farmácia popular, à questão de INSS, de serviços públicos que são importantes, farmácia popular até, também eu acho um negócio até simpático, não precisava ser tão feio só porque é popular, podia ser mais bonito, agora, ursinho de pelúcia, caixa de chocolate, ovo de páscoa, páscoa o negócio fica, meu Deus do céu, sabe. Isso sim é transformar as coisas. E fazer força pra transformar o lugar, o espaço num lugar de passagem, isso sim é fazer força, é dar todo estímulo pra que o lugar seja transformado num ponto de consumo, ou seja, a pessoa que tá ali, e que se utiliza daquilo, tenha olhos para aquele momento do consumo que não tem picas a ver com espaço, é a mesma coisa se ela tiver comprando aquele ovo de páscoa ali ou em qualquer outro lugar, em qualquer shopping Center. Tirando a questão de comodidade, que não sei se é cômodo, imagino às seis da tarde como é que chega em casa, naquela amassação de metrô, naquele calor lá dentro. Deve chegar um punhado de bosta o ovo, um ovo líquido deve ser, arc! Coisa nojenta! E pra quem não quer comprar ovo, puta, acabou completamente qualquer possibilidade de um interesse naquele espaço, ou seja, é fazer com que, é perpetuar. Deixasse o espaço nuzinho, concreto, cinza, não precisava nem luz: pronto, já existia possibilidades dele não ser um lugar de passagem, dele ser um lugar dependendo sempre da ambiência e da disponibilidade da pessoa que vai usar isso, como eu já falei, mas quando você faz esse tipo de coisa é pra capar qualquer possibilidade e isso é o que capa qualquer possibilidade de você colocar é, nesse $40 \%$ de estações que não tem nenhum tipo de coisa, pelo contrário, não só não tem nenhum tipo de coisa, como a arquitetura em si dá sinais de que não é pra ter mesmo. É notar aqueles ladrilhos que a gente falou. É fazer esses prédios pra cima. Questões externas, não é? Questões de marcar politicamente a existência do Metrô: olha como o Metrô está crescendo, olha como é bonito, olha como é, reflete, é feito de espelho, isso e aquilo, e lá dentro, as pessoas que nem sardinha em lata, passando por lojinhas. Então, eu acho que tá bem, é paredão, é uma coisa que passa por política pública, por um monte de questões que são totalmente externas à arte, à arquitetura. Qualquer tipo de coisa, inclusive eu, você sabe, que se você for fazer uma performance numa dessas estações e neguinho lá, o cara da manutenção achar, por alguma razão, que o quê você está fazendo é contrário aos bons costumes, ao pudor público, ele certamente tem o poder de decidir isso e chamar a segurança e falar: ó tira aquele maluco dali, o cara tá ficando pelado ó, não pode. Existe uma segurança, existe um código dizendo o que pode, o que não pode. Não sei, acho que se parar lá no meio e começar a cantar talvez não te tirem de lá, vão falar: ah! coitado é bobo, judiação, deixa o cara lá, mas se você começar a fazer uma performance um pouco mais estranha, uma dança do ventre, vão ó, ó, lá não, tá, prostituição, não pode. Então é assim, não é? É uma falta de clareza, é uma falta de discutir o que fazer com isso. Não é questão da arte. É questão de cultura, é questão do campo da cultura mesmo, questão política dentro do campo da cultura. 